
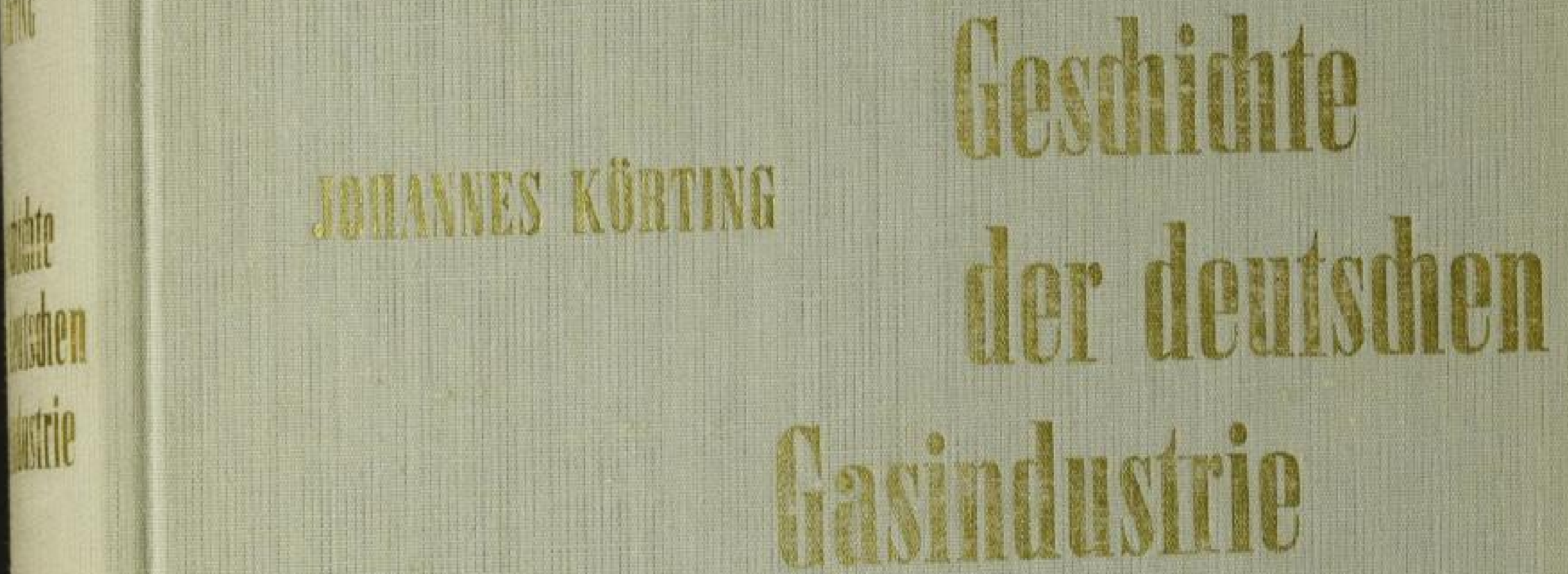

\title{
7 SLUB
}




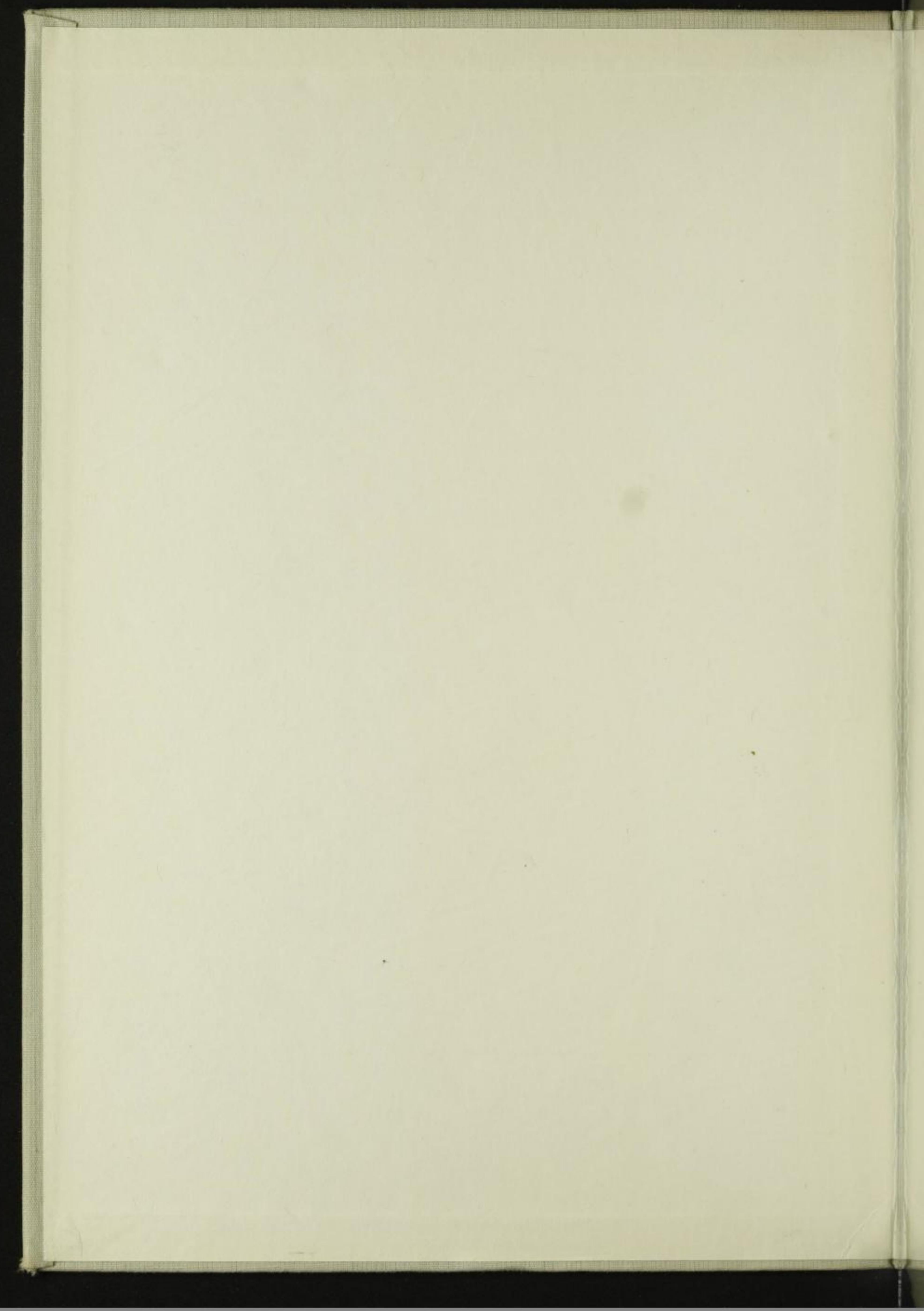

7 SLUB Wir führen Wissen. 

PROF. DIPL.-ING.

JOHANNES KORTING

\section{Geschichte der deutschen Gasindustrie}

Mit Vorgeschichte

und bestimmten Einflüssen des Auslandes

Die deutsche Gasindustrie stellt einen lebendigen und zukunftsträchtigen Faktor in unserer Energiewirtschaft dar, nicht nur auf Grund vielseitiger neuer Impulse, sondern auch kraft einer jahrzehntelangen systematischen Entwicklungsarbeit und einer über hundertjährigen Tradition. Der Verfasser hat die Entwicklung der Gaswirtschaft in ihrer ganzen Breite so intensiv miterlebt, wie dies kaum einem anderen Fachmann vergönnt war.

Die umfassende Arbeit zeichnet die geschichtliche Entwicklung des deutschen Gasfaches bis zu unserer Zeit in allen Einzelheiten auf. Der Verfasser zeigt in seinem Werk nicht nur den großen Anteil des deutschen Gasfaches an der allqemeinen technischen Entwicklung, sondern auch die vielen Impulse, die aus diesem Fachgebiet in die Breite gegangen sind und andere Industrien befruchtet haben. Die Lebensgeschichten entscheidender Persönlichkeiten des Gasfaches und ihre bahnbrechenden Leistungen stehen im Vordergrund. Gleichzeitig gibt das Buch dem Ingenieur-Nachwuchs Anregungen, welche Mittel und Wege es gibt, um die heute noch so zahlreichen ungelösten Aufgaben der Technik erfolgreich durchzuführen. Darüber hinaus ist es ein Buch für jeden Gasfachmann und Energiewirtschaftler.

\section{SLUB}


KÖRTING • GESCHICHTE DER DEUTSCHEN GASINDUSTRIE 


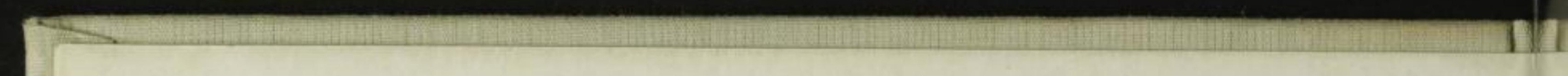




\section{Prof. em. Dipl.-Ing. Jobannes Körting}

\section{GESCHICHTE DER}

\section{DEUTSCHEN GASINDUSTRIE}

Mit Vorgescbicbte

und bestimmenden Einflüssen

des Auslandes

VULKAN-VERLAG DR. W. CLASSEN

ESSEN

\section{SLUB}




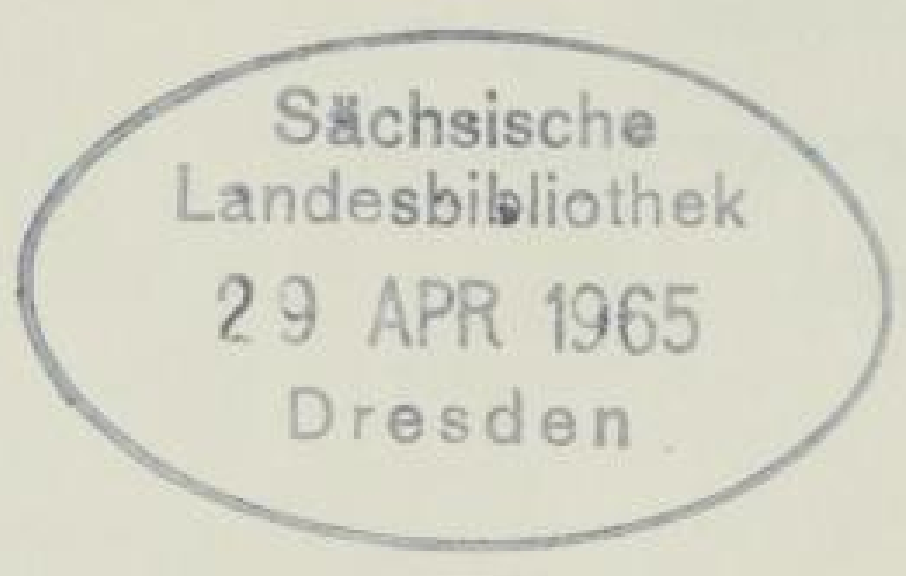

(C) Vulkan-Verlag Dr. W. Classen, Essen 1963

Alle Rechte, insbesondere das der Übersetzung in fremde Sprachen, vorbehalten.

Ohne ausdrückliche Genehmigung des Verlages ist es auch nicht gestattet, dieses Buch, einzelne Beiträge oder Teile daraus, auf photomechanischem Wege (Photokopie, Mikrokopie) zu vervielfältigen. Gesamtherstellung in Ungarn

\section{SLUB}




\section{ZUM GELEIT}

Die deutsche Gasindustrie stellt einen lebendigen und zukunftsträchtigen Faktor in unserer Energiewirtschaft dar, nicht nur auf Grund vielseitiger neuer Impulse, sondern auch kraft einer jahrzehntelangen systematischen Entwicklungsarbeit und einer über hundertjährigen Tradition. Ihr Wachsen vom ersten Keim bis zum starken, vielfach verzweigten Baum hat in dem vorliegenden Werk Herr Professor Dipl.-Ing. Johannes Körting mit feiner und liebevoller Feder gezeichnet. Er hat die Entwicklung der Gaswirtschaft in ihrer ganzen Breite so intensiv miterlebt, wie dies kaum einem anderen Fachmann vergönnt war. Wenn er sich aus innerer Berufung verpflichtet fühlte, der Fachwelt seine Erinnerungen und das Ergebnis langjähriger Studien in dieser Schilderung der deutschen Gaswirtschaft zur Kenntnis zu bringen, so gebührt ihm für diese verdienstvolle Arbeit der Dank des deutschen Gasfachs. Die Kenntnis der hier zusammengetragenen Probleme und Entwicklungen wird sicherlich auch zur Bewältigung der neuen grołen Aufgaben beitragen, vor denen die deutsche Gaswirtschaft heute steht.

Auch der Vulkan-Verlag hat mit der Herausgabe dieses Werkes Dank und Anerkennung verdient.

Berlin und Hamburg, im Sommer 1963

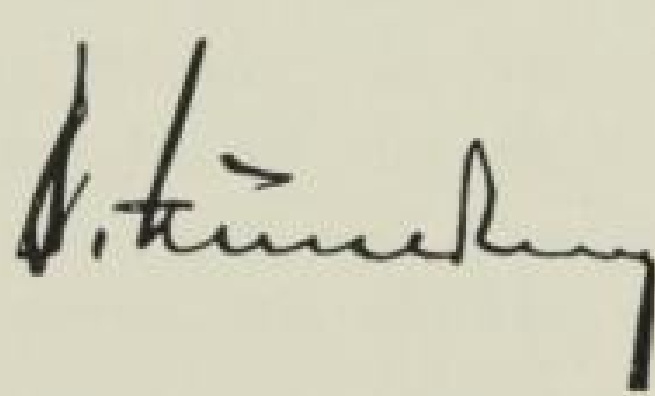

Professor De.-Ing. Hünerberg Präsident

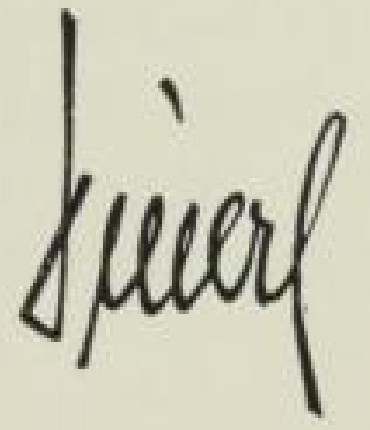

Direktor Dipl.-Ing. Düwel Vizepräsident

des Deutschen Vereins von Gas- und Wasserfachmännern

\section{SLUB}


Ts 


\section{VORWORT}

Der Verfasser hatte ursprünglich die Absicht, eine umfassende Darstellung der Weltgasgeschichte zu schreiben. Bei der Bearbeitung zeigten sich zwei deutliche Grenzen. Eine war der kaum mehr zu bewältigende Umfang, wenn wirklich für alle Länder ein Nachschlagewerk über geschichtliche Einzelheiten entstehen sollte. Dann aber auch kamen aus manchen Gasländern ungenügende und unvollständige Mitteilungen, so dał eine Ergänzung und Klärung von Zweifeln durch Briefwechsel kaum erreichbar erschien.

Dafy andere Länder in wertvollster Weise teils durch ihre Organisation, teils durch Vermittlung zu geschichtlich interessierten Einzelpersonen geholfen haben, wird im Texte des Buches klar. Ihnen sei hier der Dank des Verfassers ausgesprochen.

Die Darstellung in den einzelnen Abschnitten klammert sich nicht an ein strenges Skelett der Unterabteilungen. Das ist mit Absicht geschehen, weil je nach dem Zeitalter, der eine oder andere Gesichtspunkt gewichtiger wurde und deshalb breiter oder vorweg besprochen werden mufte oder umgekehrt fortfallen konnte.

Mit Schrifttumsnachweisen wurde nicht gespart. Trotz vereinzelter nicht zu überbrückender Lücken dürften die Bezeichnungen verständlich sein. Nur Nachweise aus dem deutschen Journal für Gasbeleuchtung und der Zeitschrift: Das Gas- und Wasserfach sind in den späteren Abschnitten nicht mehr mit dem immer wiederkehrenden Namen verzeichnet.

Buchstabenabkürzungen sind im Text für Vereine, Organisationen und Firmen vermieden, nur zusammengezogene Namen, wie etwa Bamag für Berlin-Anhaltische Maschinenfabrik Aktiengesellschaft, die ein Wort mit Begriff - auch in Verbindung mit anderen Firmennamen, wie etwa Pintsch-Bamag geworden sind, bilden für diesen Grundsatz wenige Ausnahmen.

Karlsruhe, im Sommer 1963

Jobannes Körting 
Thentin 
INHAL T

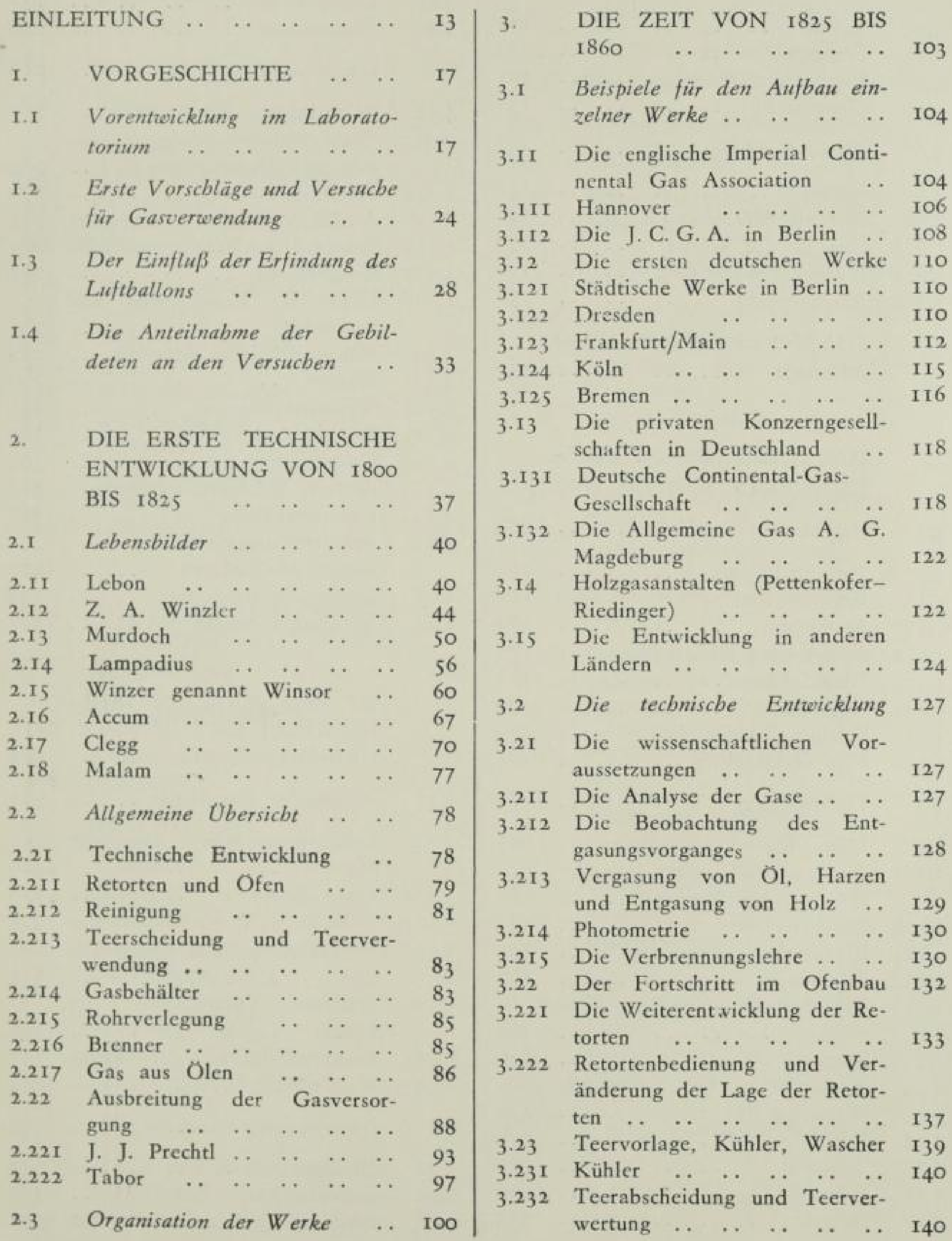


3.233 Schwefelwasserstoffreinigung.. $\quad \mathrm{I} 42$

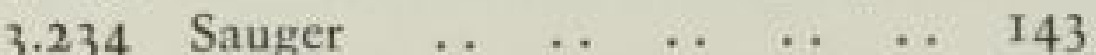

$\begin{array}{lllll}3.3 & \text { Die Gasbebälter .. } & \text {.. } & \text {.. } & 145\end{array}$

3.4 Erzeugungsanlagen für andere

$\begin{array}{llllll}\text { Gasarten } & \text {. } & \text {. . } & \text {.. } & \text {.. } & \text { I45 }\end{array}$

3.4I Öl- und Holzanlagen ... .. 145

3.42 Zusätze zur Verbesserung der

$\begin{array}{llllll}\text { Leuchtkraft } & \text {. } & \text {. } & \text {.. } & \text {. } & \text { I47 }\end{array}$

3.43

3.5

$3.5 \mathrm{I}$

3.52

3.53

3.54

3.6

$36 \mathrm{I}$

3.62

3.621

3.622

3.623

3.7

4.

DAS ENDE DES 19. JAHRHUNDERTS 1860 BIS I9C0 163

4.I

4. II

4.I 2

4.1 21

4.122

4. 123

4. 124

4.12

4.1 26

4.2

4.21

4.211

4.212

$4.2 I_{3}$

$4.2 \mathrm{I}$

4.215

4.216

4.22

4.23

4.24

4.25

4.26

4.27

$\begin{array}{lllll}\text { Persönlichkeiten } & \ldots & \ldots & \ldots & \text { I63 }\end{array}$ Konjunkturen und Wettbewerb 173

$\begin{array}{llllll}\text { Petroleum } & \ldots & \ldots & \ldots & \ldots & 173\end{array}$

Aufschwung nach $1871 \quad \ldots \quad 175$

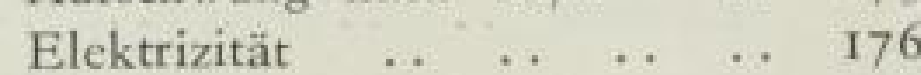

$\begin{array}{llllll}\text { Gasmotoren } & \ldots & \ldots & \ldots & \ldots & 179\end{array}$

Erneute Schwierigkeiten $\quad . \quad$ I79

Das Gasglühlicht .. $\quad . . \quad \ldots \quad I 82$

Gaserzeugung $\quad \ldots \quad \ldots \quad \ldots \quad$ I 84

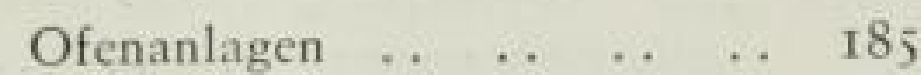

Generatorgasfeuerung mit

Wärmerückgewinnung . . . $\quad$ I86

$\begin{array}{lllll}\text { Lademaschinen } & \ldots & \ldots & \ldots & \text { I93 }\end{array}$

Einzelheiten zum Ofenbau .. 195

$\begin{array}{llllll}\text { Schornstein } & \text {.. } & \text {.. } & \text {.. } & \text {.. } & 197\end{array}$

Fördereinrichtungen im Gas$\begin{array}{lllllll}\text { werk } & \ldots & \ldots & \ldots & \ldots & \ldots & 197\end{array}$

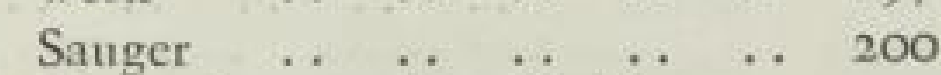

Karburierung für Kohlengase 202

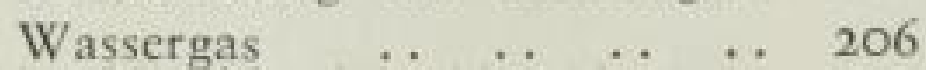

$\begin{array}{lllllll}\text { Olgas } & \ldots & \ldots & \ldots & \ldots & \ldots & 22 I\end{array}$

Azetylen $\quad \ldots \quad \ldots \quad \ldots \quad \ldots .222$

$\begin{array}{llllll}\text { Rohstoffe } & \ldots & \ldots & \ldots & \ldots & 226\end{array}$

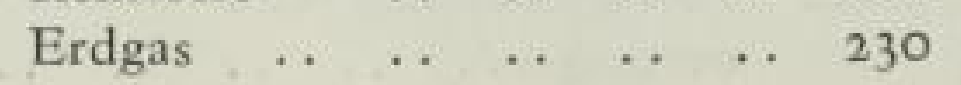

$4 \cdot 3$

4.31

$4 \cdot 32$

$4 \cdot 33$

$4 \cdot 34$

$4 \cdot 4$

4.41

4.42

4.43

$4 \cdot 5$

4.5I

4.5 II

4. 512

4. $5 I_{3}$

$4.5 \mathrm{I} 4$

4.515

4.516

4.52

4.521

4.522

4.523

4.524

4.525

4.61

4.62

Aufbereitung des Gases und

Wertstoffe $\ldots 2 . . .2 . .230$

Teergewinnung und -verwer-

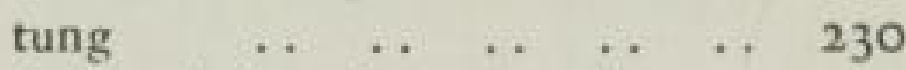

Ammoniakgewinnung und -ver-

$\begin{array}{llllll}\text { wertung } & \ldots & \ldots & \ldots & \ldots & 237\end{array}$

Schwefelreinigung $\ldots \quad \ldots \quad \ldots .245$

$\begin{array}{lllllll}\text { Koks } & \ldots & \ldots & \ldots & \ldots & \ldots & 249\end{array}$

$\begin{array}{lllll}\text { Gasverteilung } & \ldots & \ldots & \ldots & 253\end{array}$

Rohre und Rohrleitung .. 253

$\begin{array}{llllll}\text { Gasbehälter } & \ldots & \ldots & \ldots & \ldots & 257\end{array}$

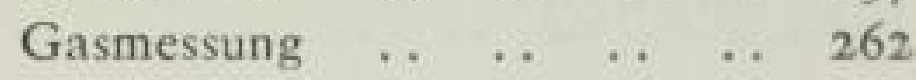

Gasverwendung $\quad \ldots \quad \ldots \quad \ldots \quad 269$

$\begin{array}{llllll}\text { Beleuchtung } & \ldots & \ldots & \ldots & \ldots & 269\end{array}$

Verbrennungsvorgänge, Theo-

rien und Untersuchungen .. 269

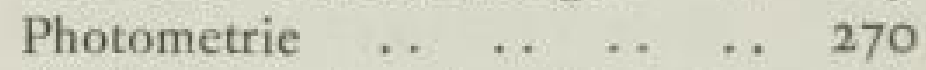

Ausführung der Leuchtbrenner 274

Sauerstoff als Verbrannungshilfe 28 I

$\begin{array}{llllll}\text { Gasglühlicht } & \ldots & \ldots & \ldots & \ldots & 282\end{array}$

Olgas für Eisenbahnen und

$\begin{array}{llllll}\text { Seezeichen } & \ldots & \ldots & \ldots & \ldots & 286\end{array}$

Wärmetechnische Arbeiten . 288

Kochen . . . . . . . . . . 290

Warmwasserheizer _. . 295

Raumheizung . . . . . . . . 30 I

$\begin{array}{llllll}\text { Gasmotoren } & \text {. . . . . } & \text {. } & 307\end{array}$

Andere Wärmeverbraucher .. 315

Únfallverhütung $\quad \ldots \quad \ldots \quad \ldots \quad 317$

Arbeitsschutzgesetze und

soziale Maßnahmen .. .. 320

4.63 Nachwuchsförderung .. .. 320

$\begin{array}{lllll}4.64 & \text { Vereinsgründungen } & \ldots & \ldots & 322\end{array}$

IM ZWANZIGSTEN JAHR-

HUNDERT BIS ZUM WELT-

$\begin{array}{lllll}\text { KRIEG I9OI-I9I4 } & \text {. } & \text {. } & 325\end{array}$

5.I Allgemeine Gescbicbte .. .. 325

5.II Lebensgeschichten führender

$\begin{array}{lllllllll}\text { Männer } & \ldots & \ldots & \ldots & \ldots & \ldots & 326\end{array}$

5.III Hans Bunte .. .. .. .. 326

5.112 Wilhelm v. Oechelhäuser .. 329

5.12 Veränderungen der Wirtschafts-

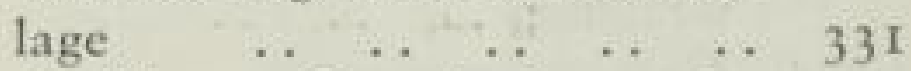

5.13 Straffere Organisation des

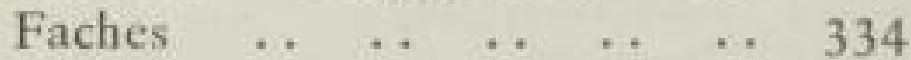

5.I3 I Besitzverhältnisse der Werke 337

$\begin{array}{lllllll}5.14 & \text { Wettbewerb } & \ldots & \ldots & \ldots & \ldots & 338\end{array}$

$\begin{array}{lllllll}5.2 & \text { Gaserzeugung } & \ldots & \ldots & & \end{array}$

$\begin{array}{lllllll}5.21 & \text { Ofenbau } & \ldots & \ldots & \ldots & \ldots & 342\end{array}$

$\begin{array}{llllll}5.22 & \text { Generatorgas .. } & \ldots & \ldots & \ldots & 353\end{array}$

5.23 Förderanlagen in den Werken 353 


\begin{tabular}{|c|c|c|c|c|c|}
\hline .24 & Wassergas & .. & & & \\
\hline .25 & Luftgas .. & . & . & & \\
\hline 26 & Flüssiggas & .. & .. & & \\
\hline & Erdgas $\quad \ldots$ & . & .. & & \\
\hline 28 & Kokereigas & . & .. & .. & \\
\hline & $\begin{array}{l}\text { Aufbereitung des } \\
\text { Nebenerzeugnisse . }\end{array}$ & & & $\begin{array}{r}\text { und } \\
\ldots\end{array}$ & \\
\hline $3 I$ & $\begin{array}{l}\text { Teergewinnung und } \\
\text { tung } \quad . \quad \ldots \text {. }\end{array}$ & $\begin{array}{l}\mathrm{d} \\
\ldots\end{array}$ & $\begin{array}{c}\text {-ver } \\
\ldots\end{array}$ & $\begin{array}{r}\text { wer- } \\
\ldots\end{array}$ & \\
\hline 32 & Ammoniakwirtschaft & & . & .. & \\
\hline 33 & Schwefelreinigung . & .. & $\cdots$ & .. & \\
\hline 34 & Koks $\quad \ldots \quad \ldots .$. & . & . & & \\
\hline 4 & Betriebskontrolle & .. & & & \\
\hline & Gasverteilung .. & . & 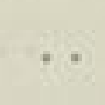 & .. & \\
\hline & Gasbehälter ... & W & & & \\
\hline & Rohre und Rohrleit & itun & & & \\
\hline 53 & Gasmessung $\quad \ldots$. & . & . & .. & \\
\hline .6 & Gasverwendung & $\cdots$ & $\cdots$ & .. & \\
\hline $6 \mathrm{I}$ & eigenschaften & & & . & \\
\hline 62 & Bcleuchtung ... & . & . & .. & \\
\hline 63 & Preise und Werbung & & . & . & \\
\hline 5.64 & Kochen ... . . & . & .. & . & \\
\hline 65 & Warmwasserbereiter & & .. & .. & \\
\hline 5.66 & Raumheizung ... & . . & .. & . & \\
\hline \multirow[t]{2}{*}{5.67} & che und & & dustr & & \\
\hline & endung . & .. & .. & .. & \\
\hline & .. $\quad$. & .. & . & .. & \\
\hline $0 / 2$ & Luftschiffahrt .. & . & . & .. & \\
\hline
\end{tabular}

6. DIE ZEIT VOM KRIEGS-

AUSBRUCH I9I4 BIS ZUM $\begin{array}{llllll}\text { JAHRE } & 1926 & \ldots & \ldots & \ldots & 417\end{array}$

6.I Allgemeine Gescbicbte .. .. 417

6.11 Organisation des Faches .. 427

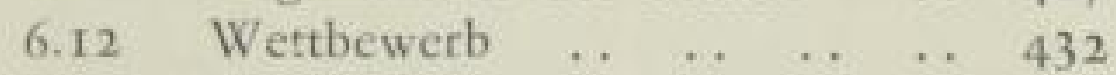

$\begin{array}{llllll}6.2 & \text { Gaserzeugung } & \ldots & \ldots & \ldots & 433\end{array}$

$\begin{array}{lllllll}6.21 & \text { Ofenbau } & \ldots & \ldots & \ldots & \ldots & 433\end{array}$

$\begin{array}{lllllll}6.22 & \text { Schwelung } & \ldots & \ldots & \ldots & \ldots & 437\end{array}$

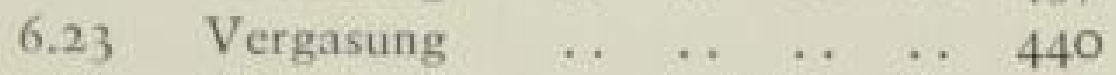

6.24 Andere Gase und Rohstoffe 444

6.25 Aufbereitung ..

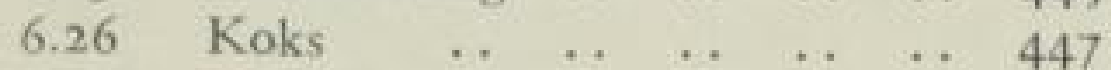

6.27 Heizwert und Brenneigen$\begin{array}{lllllll}\text { schaften } & \ldots & \ldots & \ldots & \ldots & . & 449\end{array}$

$\begin{array}{llllll}6.28 & \text { Betriebsaufsicht } & \ldots & \ldots & \ldots & 451\end{array}$

$\begin{array}{llllll}6.3 & \text { Gasverteilung } & \text {. } & \ldots & \ldots & 453\end{array}$

6.3I Rohre und Rohrleitungen .. 453

$\begin{array}{llllll}6.32 & \text { Gasbehälter } \ldots & \ldots & \ldots & \ldots & 457\end{array}$

$\begin{array}{lllllll}6.33 & \text { Gasmessung } \ldots & \ldots & \ldots & \ldots & 458\end{array}$ $\begin{array}{llllll}6.4 & \text { Gasverwendung } & \text {. } & \text {. } & \text {. } & 459\end{array}$

6.41 Werbung und Preise .. . . 459

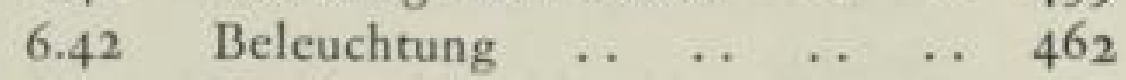

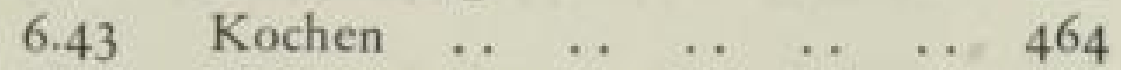

$\begin{array}{lllll}6.44 & \text { Warmwasserbereitung } & \ldots & \ldots & 466\end{array}$

$\begin{array}{lllllll}6.45 & \text { Raumheizung } \ldots & \ldots & \ldots & \ldots & 466\end{array}$

$\begin{array}{llllll}6.46 & \text { Gewerbliches Gas . . } & \ldots & \ldots & 468\end{array}$

7. DIE ZEIT VON I926 BIS

$\begin{array}{lllllll}1939 & \ldots & \ldots & \ldots & \ldots & \ldots & 471\end{array}$

7.I Allgemeine Gescbicbte des

Facbes $\quad$.

7.11 Organisation des Faches .. 479

7.2 Ausbau der Ferngasversorgung 488

$\begin{array}{llllll}7.3 & \text { Gaserzeugung } & \text {. } & \text {. . } & \text {. } & 499\end{array}$

7.3 I Gaswerksofenbau und -betrieb 50I

$\begin{array}{lllllll}7.32 & \text { Schwelung } & \ldots & \ldots & \ldots & \ldots & 505\end{array}$

7.32I Braunkohleneinsatz in Gas$\begin{array}{lllllll}\text { werken } & \ldots & \ldots & \ldots & \ldots & \ldots & 506\end{array}$

7.322 Erncute Arbeiten an der Stein-

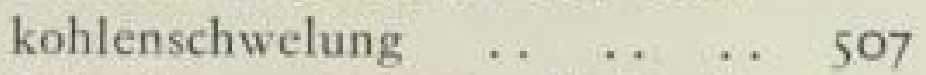

7.323 Schwelung anderer Rohstoffe 5 IO

$\begin{array}{lllllll}7.33 & \text { Vergasung } & \ldots & \ldots & \ldots & \ldots & 510\end{array}$

7.34 Andere Treibgase $\quad . . \quad \ldots \quad 513$

$\begin{array}{llllll}7.4 & \text { Gasaufbereitung } & \ldots & \ldots & \ldots & 517\end{array}$

7.41 Schwefelwasserstoffreinigung .. 518

$\begin{array}{llllll}7.42 & \text { Gastrocknung .. } & \text {. . . . . . } & 519\end{array}$

7.43 Kohlenmonoxydentfernung .. 519

7.44 Benzolgewinnnung $\quad . .552 \mathrm{I}$

$\begin{array}{llllll}7.5 & \text { Betriebsaufsicbt } & \ldots & \ldots & \ldots & 523\end{array}$

7.5I Beurteilung der Brenneigenschaften der Gase .. $\quad . . \quad \ldots \quad 524$

$\begin{array}{lllllll}7.52 & \text { Heizwert } & . . & \ldots & . & \ldots & 526\end{array}$

$\begin{array}{llllll}7.6 & \text { Gasverteilung . . . . . . } & \text {. } & 526\end{array}$

7.61 Behälter $\ldots \begin{array}{lllll}7 . & \ldots & \ldots & \ldots & 526\end{array}$

7.62 Rohre und Rohrnetze .. .. 530

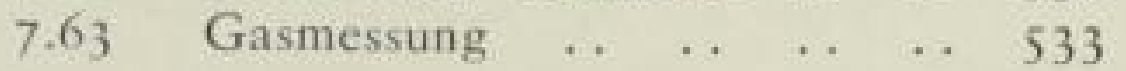

$\begin{array}{llllll}7.7 & \text { Gasverwendung } & \ldots & \ldots & \ldots & 535\end{array}$

$7.7 \mathrm{I}$ Wettbewerb $\ldots \begin{array}{llll}7.7 & \ldots & \ldots & 535\end{array}$

$\begin{array}{lllllll}7.72 & \text { Werbung } & \ldots & \ldots & \ldots & \ldots & 537\end{array}$

$\begin{array}{lllllll}7.73 & \text { Gaspreise } & \ldots & \ldots & \ldots & \ldots & 54 \mathrm{I}\end{array}$

$\begin{array}{lllllll}7.74 & \text { Beleuchtung } & \ldots & \ldots & \ldots & \ldots & 543\end{array}$

$\begin{array}{lllllll}7.75 & \text { Kochen } & \ldots & \ldots & \ldots & \ldots & 543\end{array}$

$\begin{array}{lllll}7.76 & \text { Warmwasserbereitung } & \ldots & \ldots & 544\end{array}$

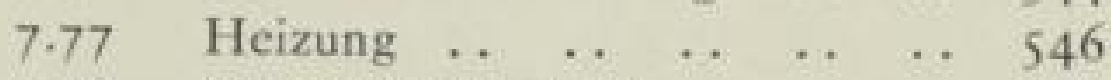

7.78 Gewerbliches Gas .. .. ... 549

7.79 Regler und Sicherheitseinrich-

$\begin{array}{lllllll}\text { tungen } & \ldots & \ldots & \ldots & \ldots & \ldots & 554\end{array}$

7.8 Bebordliche Eingriffe und Vorschriften $\quad \ldots \quad$. 
8. VON 1939 BIS 1960 .. $\quad$.. 559

8.I Die Zeit des zweiten Welt$\begin{array}{lllllll}\text { krieges } & \ldots & \ldots & \ldots & \ldots & \ldots & 559\end{array}$

8.2 Wiederaufbau nacb dem Kriege 562

8.3 Von der Währungsumstellung 1948 bis zur Koblenfülle, $1958 \quad 565$

8.31 Gaserzeugung aus Kohlen .. 573

8.32 Gaserzeugung aus Mineralölen und deren Produkten ... .. 577

8.33 Umwandlung von Raffinerierestgas (Raffgas) in Stadtgas 580

8.34 Erdgas und Grubengas ‥ 583

8.35 Gasaufbereitung insbesondere $\begin{array}{llll}\text { Schwefelreinigung } & \ldots & \ldots & 587\end{array}$

8.36 Gasverteilung- und -messung 589

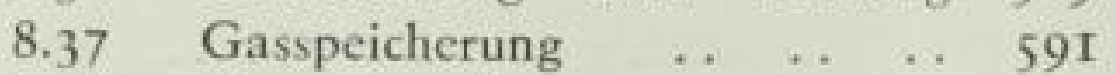

8.38 Gasverwendung $\quad \ldots \quad \ldots \quad \ldots .592$

8.38I Straßenbeleuchtung $\quad \ldots \quad \ldots \quad 592$

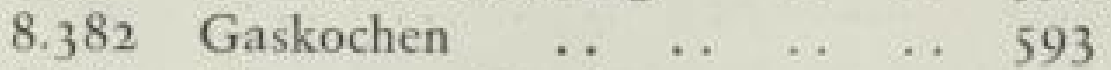

8.383 Warmwasserbereiter $\quad \ldots \quad \ldots \quad 593$

8.384 Gasraumheizung .. $\quad . .6 \quad \ldots \quad 594$

8.385 Gewerbe- und Industriegas$\begin{array}{lllllll}\text { absatz } & \text {. } & \text {.. } & \ldots & \ldots & \ldots & 595\end{array}$

8.385 I Eisen- und Stahlindustric .. 597

8.3852 Glasindustrie _... ... 601
8.3853 Keramische Industrie .. .. 601 8.3854 Metallindustrie $\quad . \quad \ldots 6.602$ 8.3855 Trocknung $\quad \ldots \quad \ldots \quad \ldots \quad \ldots 603$

8.39 Vereine, Zeitschriften und Organisation des Faches .. .. 604

\section{ZUSAMMENFASSUNG} UND AUSBLICK .. $\quad . . \quad \ldots \quad 611$

$\begin{array}{llllllll}\text { Anhang I } & \ldots & \ldots & \ldots & \ldots & \ldots & \ldots & 6 \mathrm{I} 4\end{array}$ $\begin{array}{llllllll}\text { Anhang } 2 & \ldots & \ldots & \ldots & \ldots & \ldots & \ldots & 616\end{array}$ $\begin{array}{llllllll}\text { Anhang } 3 & \ldots & \ldots & \ldots & \ldots & \ldots & \ldots & 617\end{array}$

$\begin{array}{llllllll}\text { Anhang } 4 & \ldots & \ldots & \ldots & \ldots & \ldots & \ldots & 618\end{array}$ $\begin{array}{llllllll}\text { Anhang } 5 & \ldots & \ldots & \ldots & \ldots & \ldots & \ldots & 621\end{array}$

$\begin{array}{llllllll}\text { Anhang } 6 & \ldots & \ldots & \ldots & \ldots & \ldots & \ldots & 622\end{array}$

$\begin{array}{llllllll}\text { Anhang } 7 & \ldots & \ldots & \ldots & \ldots & \ldots & \ldots & 624\end{array}$ $\begin{array}{llllllll}\text { Anhang } 8 & \ldots & \ldots & \ldots & \ldots & \ldots & \ldots & 632\end{array}$ $\begin{array}{llllllll}\text { Anhang } 9 & \ldots & \ldots & \ldots & \ldots & \ldots & \ldots & 639\end{array}$

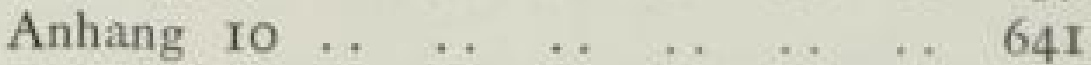

NAMENSVERZEICHNIS _. . . $65 \mathrm{I}$ $\begin{array}{lllllll}\text { ORTSLISTE } & \ldots & \ldots & \ldots & \ldots & \ldots & 672\end{array}$ SACHVERZEICHNIS $\quad \ldots \quad \ldots \quad \ldots \quad 68 \mathrm{I}$

\section{SLUB}




\section{EINLEITUNG}

Jede Darstellung der Kulturgeschichte oder der allgemeinen Weltgeschichte wird heute mit der technischen Revolution um die Wende des 18. zum 19. Jahrhundert eine Epoche festsetzen. Auffallend ist dabei, daf überwiegend die mechanisch begründete Maschinenindustrie betrachtet zu werden pflegt. Dabei wird mit Recht die Konstruktion der drehenden als Einheit in sich geschlossen gebauten Dampfmaschine durch James $W$ a $t$, im Jahre $178 \mathrm{I}$ als der Zeitpunkt der Epoche angesehen. Damit wird aber, wie immer bei der Festsetzung eines Datums für geschichtliche Perioden, der wirkliche Ablauf in unzulässiger Weise vereinfacht. Die Folge ist, dafy eine falsche Vorstellung von der Entwicklung zustandekommt. Nicht allein hat der Bau der Watt'schen Dampfmaschine eine lange Zeit geistiger Arbeit mit vielen Überlegungen und Versuchen zur Voraussetzung - I50 Jahre sind leicht zu beweisen -, viel wichtiger ist, daf̧ der Fortschritt der gesamten Wirtschaft ihr allmählich den Boden bereitete. Der Bergbau verlangte mit tiefergehender Teufung nach gröłeren Energien, die Manufaktur der Textilien und Kurzwaren drängte nach der fabrikmäf̧igen, mechanischen Fertigung. Der Partner Watts, der diesen zu seiner Konstruktion drängte, Matthew Boulton, hatte bereits eine Manufaktur zur Massenfertigung von Schnallen und Knöpfen mit 400 Arbeitern entwickelt, als er an Watts Arbeiten Anteil nahm.

Vergessen wird aber oft, dał die Chemie als Wissenschaft fast in der gleichen Zeit den Weg zur Technik beschritt.

N. Leblanc erhielt sein Patent auf die Sodaherstellung r79r.

Nimmt man allgemeiner als mit der äußerlichen Tatsache der Konstruktion der Dampfmaschine die Durchforschung der Eigenschaften des Dampfes durch J. $B l a c k$ als entscheidende Tat, so kann man dem die Arbeiten A. L. $L a v o i$ siers am Sauerstoff, die Entthronung der Phlogistontheorie und den Beginn der quantitativen Forschung in der Chemie (1789) gleichsetzen. J. B. Ricbters : Anfangsgründe der Stöchiometrie oder der Mef̧kunst chemischer Elemente sind $1793^{-1797}$ veröffentlicht worden.

Damit wurde tatsächlich der Weg zur chemischen Technik frei. Es ist nun auffallend, daf3 auch da wieder als Beginn der chemischen Industrie die anorganische Schwefelsäurefabrikation ( 1746 die ersten Bleikammern in Birmingham) und die Sodaherstellung so ausschlief̧lich beachtet werden, daf̧ die Bedeutung der organisch-chemischen Technik, und zwar die Gasindustrie als Schrittmacher, oft genug nicht erwähnt wird. Dabei liegen die entscheidenden Jahre 1792 und 1794 mit den ersten Versuchen Lebons, Murdocbs und Lampadius, die zur Technik führten, so nahe beim Stichtag der Dampfmaschine, daf3 allein 
diese Tatsache aufhellend über das weitgespannte umstürzlerische technische Geschehen - gleichzeitig mit der grołen politischen Revolution - ist.

Brachte die Dampfmaschine die energetische Entwicklung in Gang, deren Aufblühen aber auch als Anteil an den sozialen, wirtschaftlichen und politischen Krisen uns heute bewufyt ist, so gab die Gasbeleuchtung Sicherheit auf den Straß̧en und die Möglichkeit, in den Abendstunden ohne Uberanstrengung der Augen zu lesen und feine Arbeiten zur verrichten. Teure Anlagen mit Maschinen wurden durch die verlängerte Ausnützungszeit besser verzinst und schneller abgeschrieben. Das war allerdings nun auch die Veranlassung, dał zunächst die Arbeitszeit in einem Umfange ausgedehnt wurde, wie es bis dahin, durch das Tageslicht begrenzt, nur im Sommer möglich gewesen war. Auch das führte zu sozialen Krisen, an denen aber nicht die Technik, sondern deren sinnlose Anwendung schuldig war.

Das Gasfach wurde die erste große Schule für die organisch-chemische Technik. Für seine Zwecke wurden zuerst Laboratoriumsgeräte, Kühler, Wascher, Trennkolonnen, Gasbehälter u. s. w. ins Grołe übertragen. Viele seiner Ingenieure haben, über das Fach hinausgreifend, allgemeine technische Fortschritte ausgelöst.

Manche Gasfachingenieure haben indessen den Eindruck, als ob ihr Fach auch heute noch in der Öffentlichkeit nicht das Ansehen genösse, das ihm zukäme. Äuf̧erungen sind vornehmlich im europäischen Schrifttum zu finden. Der Grund für die Unterschätzung der Gasindustrie als Wärmelieferer und der Vielfalt ihrer chemischen und physikalischen Aufgaben samt ihrer technischen Durchführung mag daran liegen, dał die drei in ihr wirkenden $W$ issenschaftsgebiete, Chemie, Physik und Wirtschaft, heute stark spezialisiert sind, und die Zahl der Leute, die alle drei Aufgabenkreise voll übersehen können, gering ist. Aber selbst in Gasfachkreisen ist es wenig bekannt, welchen Anteil das Fach an der allgemeinen technischen Entwicklung gehabt hat, und wie oft Anregungen aus dem engeren Fachgebiet in die Breite gegangen sind und andere große Industrien befruchtet haben. Durch solche Eindrücke wurde der Verfasser angeregt, sich bei allgemein technisch-geschichtlichen Studien mit der des Gasfaches insbesondere zu befassen, und - einer Neigung folgend - legte er besonderen Wert darauf, die Lebensgeschichten der entscheidenden Persönlichkeiten zu erforschen. Aus der Charakterdarstellung dieser Männer geht hervor, dał vorwiegend eine universelle Bildung gepaart mit Spitzenleistungen auf einzelnen Gebieten einhergegangen ist. Damit wird eine Ausbildung bestätigt, die oftmals schon ganz allgemein für den Ingenieur, der in führende wirtschaftliche und technische Stellungen vorrücken möchte, als Ideal bezeichnet worden ist. Die Erfindungen sind meistens nicht plötzlich reif vor dem geistigen Auge eines Erfinders entstanden, wie man es heute als Lernender, der das Vorhandene als gegeben und selbstverständlich vor sich sieht, versucht ist zu glauben. Die Männer haben, wenn Neuland zu betreten war, gestützt auf vorhandene unvollkommene technische und wissenschaftliche Erkenntnisse durch schöpferische Genialität sich den Weg bahnen müssen, oft unter Entbehrungen und gegen böse Widerwärtigkeiten ankämpfend. Manche Namen von Pionieren sind verklungen; das Schicksal hat ihnen so mitgespielt, daf3 eine Verankerung in den Annalen nicht geschehen konnte. Diese unbekannten Soldaten der Technik, die auch auf einem Felde der 
Ehre gefallen sind, darf man nie vergessen. In einer Darstellung der Geschichte sind dafür die allgemein gehaltenen verbindenden Abschnitte über den technischen Fortschritt da.

So möge das Buch wie jedes erfreuliche Geschichtsbuch nicht einfach ermittelte und vorhandene Daten aufzeichnen und zum Auswendiglernen verführen, sondern es möge dazu dienen, der heranwachsenden Generation Anregungen zu geben, welche Mittel und Wege es gibt, um die auch heute noch zahlreichen ungelösten Aufgaben der Technik erfolgreich zu vollenden. Dabei kann an Gedanken von Werner von Siemens, Rudolf Diesel und Hugo Junkers erinnert werden, dał bei einer Erfindung die Genialität $5 \%$, der Fleiß die übrigen $95 \%$ ausmacht. Auch beim Konstruieren und bei der Entwicklung eines Unternehmens als einem selbständigen Wirtschaftskörper dürfte das Verhältnis von schöpferischem Geist und Fleił als Beitrag zum Vorwärtskommen das gleiche sein. Das dürfte wohl auf einen jungen Mann, der heute leicht unter der erdrückenden $\mathrm{W} /$ ucht einer hochgezüchteten Wissenschaft steht und bei seinem Eintritt in den Beruf von Minderwertigkeitsgefühlen beschlichen wird, ermutigend wirken. Ausdauer und Fleif haben einen so entscheidenden Anteil am endgültigen Erfolg, dał nicht nur die Höchstbegabten Aussicht auf besondere Erfolge in der Berufsarbeit haben.

Mit diesem Wunsche wird das Buch der Öffentlichkeit übergeben. 


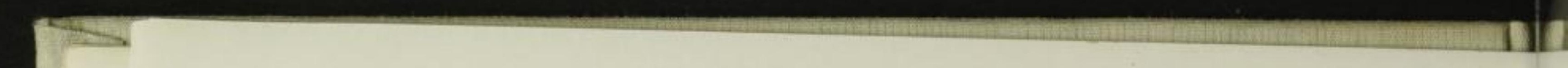




\title{
I. VORGESCHICHTE
}

\author{
I.I VORENTWICKLUNG IM LABORATORIUM
}

Wenn wir das Werden der Gasindustrie bis zu ihren Anfängen zurückverfolgen, so gelangen wir in die Epoche, in der das verblassende Mittelalter mit seiner religiös-kirchlich ausgerichteten Denkweise vom ersten Licht der wissenschaftlichen Naturerforschung angestrahlt wird.

Ein heute lebender Mensch, der von tausenderlei technischen Dingen umgeben in Gefahr schwebt, von ihnen in seinem Denken beherrscht zu werden, ist allzu sehr geneigt, diese äuf̧eren Verhältnisse als unentbehrliche Grundlage einer hohen Zivilisation, ja einer echten Kultur zu erachten. Er wird nur nach sehr eingehender Beschäftigung mit den Zuständen des ausgehenden Mittelalters ein klares Bild gewinnen und empfinden, dał gerade damals die Menschen sich ganz auf der Höhe der Zeit fühlten und sich mit Recht fühlen durften. Wohlhabenheit, ja Reichtum, waren damals bis in breite Bürgerkreise gedrungen und bildeten eine kulturfördernde Grundlage. Die staatliche Ordnung im Feudalismus und Zunftwesen war ausgeglichen, wenngleich natürlicherweise kleinere innere Krisen auch in dieser Organisation beobachtet werden können.

Das erste Massenerzeugnis, das Buch, wurde durch Johannes Guten bergs (I400-1467) Buchdruckverfahren lebensfähig. Der Drang, in fremde Länder zu gehen, sorgte für einen Verkehr von Volk zu Volk, dessen Einfluf auf den Gedankenaustausch man sich heute, wo er an Schnellverkehrsmittel und Nachrichtenwesen gebunden zu sein scheint, auch nicht leicht klar macht. Nicht nur der reiche Handelsmann reiste und hatte seine Frachtwagen unterwegs. Auch der Student war auf ausländischen Hohen Schulen zu finden; ein „Malermeister" Albrecht Dürer hielt sich drei Jahre in Venedig und zwei Jahre reisend in den Niederlanden auf; ein deutscher Haudegen Georg von Frundsberg tauchte in italienischen Kämpfen auf. Der Arzt Paracelsus, geboren im Jahre der Entdeckung Amerikas, kam aus der ewigen Wanderschaft sein ganzes Leben lang nicht heraus. Der bisher bekannte Raum Europas, Asiens und Afrikas reichte für den Tatendrang dieser Menschen nicht mehr aus, das Zeitalter der großen Entdeckungen war gekommen. Die methaphysische Grundlage des Christentums war noch nicht bezweifelt. Anteilnahme am künstlerischen Schaffen zu Hause und in der Fremde war ailgemein, ebenso die Beschäftigung der bürgerlichen Kreise mit der soeben geistig freigegebenen und gesellschaftsfähig gewordenen naturwissenschaftlichen Forschung.

Leider trieb, wohl als Bremse gegen eine zu freie Entfaltung des menschlichen Wohlseins, auch das Kriegswesen die üppigsten Blüten, so daf schlief̧lich der 
Wohlstand, zumindest in Mitteleuropa, nämlich Deutschland und Italien, in den Staub getreten wurde. Aber trotzdem konnte noch Kaiser Karl V. 30 Jahre erst nach der Entdeckung der neuen Welt die Errichtung eines christlichen Weltreiches, in dem die Sonne nicht untergeht, ins Auge fassen.

Unangefochten von den hiermit verbundenen fortdauernden und die Ruhe störenden Kriegsfahrten bleibt aber die Arbeit an der Erforschung der Natur im Blickpunkt aller Kreise. Die neuartige Geistigkeit hatte sich so tief aller denkenden Menschen bemächtigt, dał selbst diese Störungen der Bewegung nichts anhaben konnten. Dabei ist Wissenschaft noch nicht spezialisiert, und wie schon Leonardo da Vinci († I519) mit einer uns überraschenden Vielseitigkeit künstlerische, literarische, naturwissenschaftliche, technische, wirtschaftliche und politische Gedanken verarbeitete und schöpferisch weitertrieb, so sehen wir ganz allgemein Kunst, Geisteswissenschaft und Technik bei den führenden Köpfen das Denken beeinflussen.

Auch die Väter der gaswissenschaftlichen Forschung waren neben Naturwissenschaftlern: Fürsten, Priester und besonders häufig Mediziner und Pharmazeuten. Sie befaf̧ten sich in ihren der Alchimie entwachsenden Laboratorien mit den Wundern der gasförmigen Stoffe, und erst nach einer Inkubation von rund 200 Jahren kam der technisch besonders ausgebildete Ingenieur und der Handwerker, die Anregungen übernehmend, an die Arbeit und lieł̧ eine Gastechnik entstehen.

Selbstverständlich war bereits früher, ja seit dem Altertum, Gas beobachtet worden, vor allen Dingen die Entflammbarkeit des Erdgases. Die Irrlichter über den Sümpfen erregten, wenn sie gelegentlich durch einen Blitzschlag entzündet waren, Neugier oder Schrecken. Die Griechen kannten die Lagerstätten des Erdöles am Kaspischen Meer und berichteten, dał über ihnen ein Flammenmeer gelegen habe. Plutarcb erzählt, Alexander der Groß̧e sei bei seiner Eroberung Asiens in der Gegend von Ekbatana einer Feuerquelle begegnet, und Plinius erwähnt Orte, wo es genüge, mit brennenden Fackeln zu nahen, um Flammen entstehen zu lassen.

Bei dem Experimentieren der Alchimisten mit allen möglichen Stoffen mit besonderer Vorliebe über dem Feuer dürfte wohl hin und wieder auch Gas erzeugt und entflammt worden sein. In der Bücherei des Arsenals von Paris befindet sich eine Mitteilung, daf mitten im dunkelsten Mittelalter ein Rabbiner Ezecbiel, der unter dem beiligen Ludwig (1226-I270) gelebt habe, sich einer W/underlampe bedient habe, um seine Zauberbücher zu entziffern. Die Lampe habe ohne Docht und ohne Öl gebrannt. Aber eine wissenschaftliche oder technische Forschung konnte sich auf all diesen Beobachtungen und Versuchen nicht aufbauen. Der Rabbiner Ezechiel wurde jedenfalls kurzerhand als Zauberer verbrannt ${ }^{2.1}$ ).

Der erste, der die Herstellung eines brennbaren Gases festgehalten und beschrieben hat, ist T. B. Paracelsus (1492-154I). Er stellte Wasserstoff durch die Einwirkung von Säuren auf Metalle her, den er allerdings für gewöhnliche

1.1) R. Ellisen, Vortrag zum 75 jährigen Jubiläum der Ingenieurvereinigung der Spezialschule zu Loewen. Ferner: Dean Chandler und A. Douglas Lacey: The rise of the Gas Industry in Britain (Die Entwickelung der Gasindustric in Britannien) British Gas Council, London 1949.

18 
Luft hielt. Immerhin spricht er vom „spiritus silvester“, dem Waldgeist. Nach seiner Zeit wurde die Luft ganz allgemein mit dem griechischen yás be beichnet $\left.{ }^{1,2}\right)$. Der Arzt und Alchimist Johann Baptiste van $\mathrm{Helmont}$ zweigte die Bezeichnung ,gas" Ende des 17 . Jahrhunderts für die von der atmosphärischen Luft verschiedenen Luftarten $a b$. Das aspirierte holländische $G$ ist einem tonhaltigen $\chi$ so ähnlich, daf̧ die neue Schreibweise begreiflich ist.

Die Úbersetzung seines Werkes ${ }^{1.2}$ ), die aus dem Latein des Alchimisten und seinen Vorstellungen nicht ganz leicht ist, muß ungefähr folgendermał̧en lauten: Aber weil Wasser, im Dampf durch Kälte niedergeschlagen, in anderem $\mathrm{Zu}$ stande ist als Dampf, der durch Hitze hervorgebracht ist, deswegen habe ich als freie Bezeichnung des Seltsamen, wegen Mangels eines Namens, jenen Dunst Gas genannt, nicht weit vom Chaos der Alten entfernt. Es möge mir genügen zu wissen, dał Gas aus Dampf, Ruß und öligen Tropfen reichlich fein ist, obgleich gegen Luft vielmals dichter, und daf dem Stoff nach selbst Gas Wasser ist, durch Fermentation der festen Stoffe dazu entwickelt. - (Gas aus Wasser:) Gas und Blas sind neue Namen, von mir eingeführt, weil ihre Kenntnis den Alten unbekannt war. Aber dennoch nehmen Gas und Blas unter den natürlichen Urstoffen einen notwendigen Platz ein. Darum ist dieses Seltsame weiter zu untersuchen. Und zwar zunächst: Durch welche Ursache aus Wasser Gas wird und inwiefern es ein anderer Zustand von jenem ist, wodurch Hitze das Wasser zu Dampf erhebt. Ferner muf3 aus der Zerlegung des Wassers gewuft werden, inwiefern diese beiden zusammenhängen."

Man sieht daraus, wie van Helmont sich abquält, die neu gefundene Erscheinung mit der Anschauung von den vier Elementen des Altertums, deren eines das Wasser ist, in Einklang zu bringen.

\section{LEB E N S B I L}

Johann Baptiste van Helmont: als Arzt und Chemiker bedeutend, geboren 1577, gestorben 1644 zu Brüssel, hat die Chemie durch eine Reihe wichtiger Entdeckungen bereichert. Er betrachtete das Wasser als den Hauptbestandteil aller Stoffe und war überzeugt von seiner Umwandlung in erdige Substanzen. Dem Feuer sprach er jede stoffliche Natur ab, bezüglich der Luft ist zweifelhaft, ob er sie als Element betrachtete. Er lehrte das Weiterbestehen eines Körpers in seinen Verbindungen und hatte damit den Grundgedanken von der Erhaltung des Stoffes erfaf̧t.

Van Helmont steilte wichtige Untersuchungen über die Gase an und war der Begründer der Gas-Chemie ${ }^{1.4}$ ). Er kennzeichnete zuerst die luftförmigen Körper durch Ermittelung ihrer Eigenschaften als verschiedenartig. Er beschäftigte

\footnotetext{
1,4) Kluge: Etymologisches Wörterbuch dee deutschen Sprache, II. Auflage Berlin-Leipzig. De Gruyter \& Co. 1934

1.3) Johannis Baptiste van Helmont: Opera Omnia 1682. Ex Bibliopolio Hafriiensi, H. Ch. Paulli 1707 Progymnasma Meteori 29, Urtext GWF 79 (1936) S. 84

3.4) G. Lockemann, Geschichte dei Chemie I, S. 64. Sammlung Göschen Bd. 264 W. de Gruyter \& Co. Berlin 1950 
sich vor allem mit der Kohlensäure, zeigte ihre Entstehung aus Marmor oder Pottasche mit Säure (gas sylvester oder gas carboneum), aus brennender Kohle, bei der Wein- und Biergärung, bewies ihr Auftreten im Magen, in Mineralwässern und Erdhöhlen. Wasserstoff und Grubengas beschrieb er als eigentümliche Luftarten. - Trotz aller Kenntnisse betrieb und verteidigte er die Goldmacherei aus Quecksilber mit Hilfe des Steines der Weisen.

Zunächst wandte sich nunmehr ganz allgemein die Aufmerksamkeit allen gasförmigen Stoffen zu, deren eigenartiges Verhalten erst jetzt ins Bewuftsein kam. - Torriceili (1608-1647) baute im Jahre 1643 das erste Quecksilberbarometer. Er wies nach, daf absolutes Vakuum denkbar sei, und bestimmte das Gewicht der Luftsäule. - Otto von Guericke (1602-86) scheint, unabhängig von diesem Erfolg Torricellis, in Magdeburg den Luftdruck durch eine Wassersäule von rund 1o $\mathrm{m}$ festgestellt zu haben. Dieser blieb aber bei der wissenschaftlichen Feststellung nicht stehen, sondern ging zum ersten Mal in der Geschichte der Technik auf technische Versuchsführungen über und löste damit die Entwicklung aus, die über die atmosphärische Maschine zur Dampfmaschine geführt hat. Wahrscheinlich sind die meisten seiner Versuche zwischen 1657 und 1662 ausgeführt worden.

Das brennbare Gas blieb aber nunmehr auch nicht unbeachtet. Im Jahre 1618 veröffentlichte der französische Arzt Jean $T$ ardin eine Schrift über „La fontaine qui brusle près de Grenoble avec la recherche de ses causes et principes et ample traicté des feux souterrains ${ }^{41.5}{ }^{1.09}$ ). Van de Velde berichtet über den Forscher in der Anmerkung 16: „Nur in Jöchers Aligem. Gelehrten Lexikon Leipzig 1751 fand ich einige Angaben über Jean Tardin: Tardinus Johannes, ein französischer Medicus, von Tournon, lebte zu Anfang des 17. Seculi und schrieb Disquisitionem physiologicam de pilis, so zu Tournon 1619 gedruckt worden und in Dornavii Amphitheatro tom. I stehet. Von diesem Schreiber berichtet der "Catalog of printed books of the British Museum London 1897".

Jean Tardin erneuerte auch, so drückte er sich aus, die vor ihm beobachtete Erscheinung, indem er Kohle in geschlossenen Gefägen erhitzte und dabei die verbrennbare Verflüchtigung erhielt, die ihm erlaubte festzustellen, dał das Feuer der Kohle und das Feuer der Flamme von gleichem Wesen und Natur sind. Seine Veröffentlichung geriet indessen in Vergessenheit und ist erst später wieder entdeckt worden ${ }^{1.7}$ ).

Aus dem Jahre 1659 berichtete Thomas Sbirley 166r der Royal Society in London von Versuchen mit einem Gase, das einer Kohlengrube in der Nähe von Wigan entwich und bei der Annäherung eines Lichtes Feuer fing. ${ }^{1.5}$ ) Er schrieb: „Die Bevölkerung dieser Stadt behauptete ernstlich, daß das Wasser dieser Quelle wie Öl brenne, in welchen Irrtum sie wegen des Mangels einer gründlichen Nachprüfung der folgenden Einzelheiten verfielen. - Als wir zu der besagten Quelle kamen (wir waren 5 oder 6 Mann) und an die Oberfläche

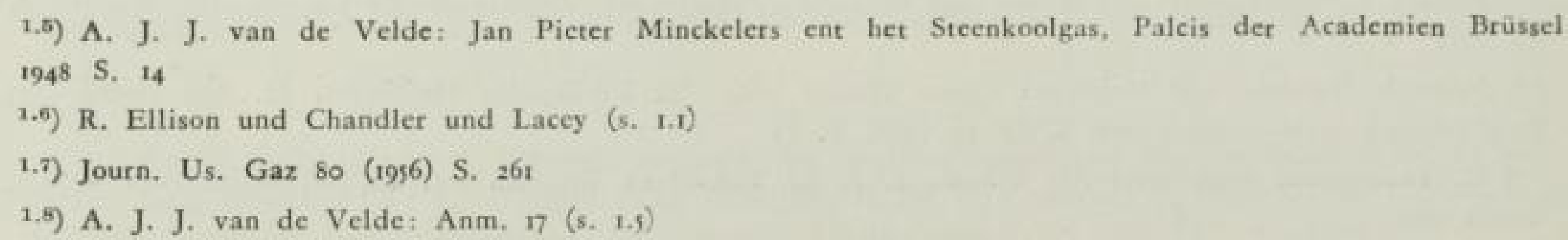


eine brennende Kerze hielten, wahrhaftig, da entstand plötzlich eine grołe Flamme, die lebhaft brannte. Bei diesem Anblick begannen sie alle, mich auszulachen, weil ich bestritten hatte, was sie mir versichert hatten. Ich aber, der ich mich widerlegt fühlte durch ein Gelächter, das auf eine Unachtsamkeit sich gründete, begann zu untersuchen, was ich sah. Als ich beobachtete, daf die Quelle am Fußze eines Baumes entsprang, der oben auf einem benachbarten Erdwall wuchs, und dał das Wasser einen Graben anfüllte.... hielt ich die Kerze an verschiedene Teile des W/assers in dem Graben und fand, wie ich erwartete, dał bei der Berührung der Kerze mit dem Wasser die Flamme erlosch. So ging sie auch aus, wenn ich ein Geschirr voll Wasser vom Brennplatze schöpfte und die brennende Kerze daranhielt. Indessen bemerkte ich, daf das Wasser am Brennplatze kochte und wogte wie Wasser in einem Topf auf dem Feuer, obwohl meine Hand hineingehalten, es nicht als warm empfand ${ }^{\text {“1, }, 9}$ ).

Thomas Sberley oder Sbirley wird in der Bibliotheca chemica von John Ferguson, Glasgow 1906 genannt. Geboren zu Westminster 1638 , studierte cr Hcilkunde in Frankreich, wurde Arzt Karls II. und starb 1678. Er hat die englische Übersetzung gefertigt von Johann Sigismund Elsboltz: Destillatoria curiosa - The curious Distillatory, written originally in Latin by Jo. Sigism. Elsholtz, put into English by. T.S. M-D. physician in ordinary to his majesty, London, printed by J. D. for Robert Boulter $1677^{1.19}$ ). Shirley bemerkt dazu, dafs der Ort etwa 30 bis $40 \mathrm{~m}$ von der Offnung einer Grube entfernt war und dafy Urgan, Asthon und das ganze Land mehrere Meilen darum voll sei von Kohlengruben. „Ich näherte meine Hand der brennenden Stelle und fühlte, daß von ihr ein ungestümer Zug ausging, als wenn es Wind wäre ${ }^{\text {ct.11 }}$ ). „Der Zusammenhang zwischen Steirkohle und brennbarem Gas", so meint van de Velde, „hier Kohlengrubengas oder Methan, war dadurch festgestellt.“ Indessen scieint Shirley üher die Feststellung hinaus, dafy die Luft, die in Blasen aufstieg, entzündbar war, nichts weiter untersucht zu haben.

Dagegen hat 1684 der hochwürdige Herr John Cla yto n, Dechant von Kildere, die Quelle bei Wigan nicht allein genauer untersucht ${ }^{1,12}$ ), er lief3 auch in der Quelle nach der Ursache für die Gase nachgraben und stieł auf Kohle. Er heobachtete, daf 3 mehrere Kohlengruben in der Umgebung gewesen waren. Deshalb beschaffte er sich etwas Kohle aus einer der nächstgelegenen Gruben und destillierte sie in einer Retorte über offenem Feuer. „Zuerst kam nur „Phlegm" (Rauch), dann schwarzes Öl und schlief̧lich „Spirit" (Geist oder Gas), den ich in keiner Weise kondensieren konnte. Er beschädigte meinen Kitt und zerbrach meine Gläser. Einmal, als er den Kitt aufrił, beobachtete ich beim Versuch, ihn wieder zu dichten, in die Nähe kommend, daf̧ der Geist

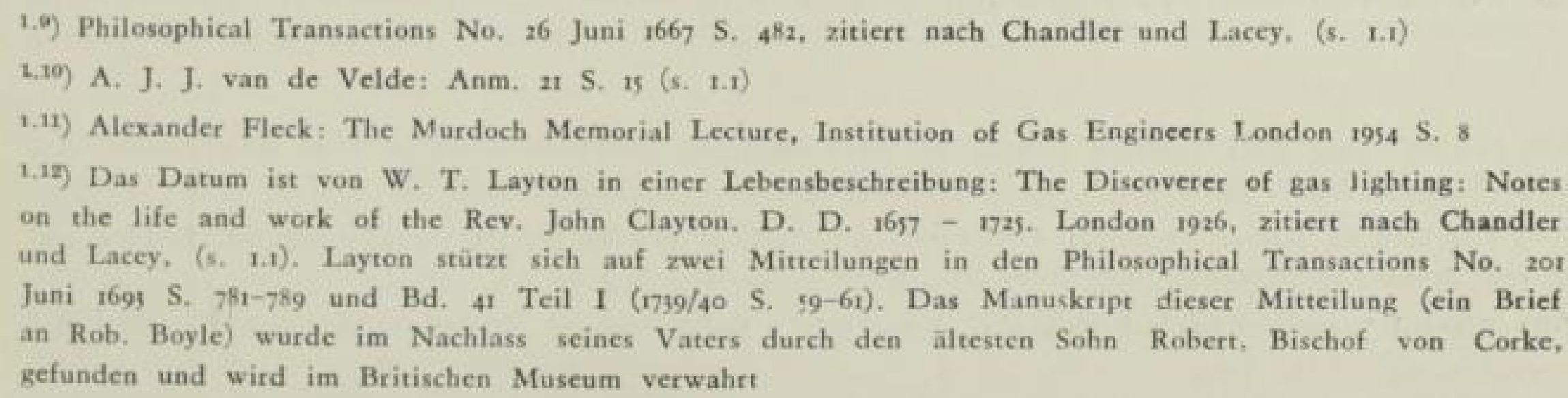


an einer Kerze Feuer gefangen hatte und kräftig brannte, sowie es in einem Strom austrat, den ich ausblies und wieder zündete, abwechselnd mehrere Male." Clayton fing dann das Gas in Schweinsbiasen auf, vergebens suchend, das Gas zu kondensieren. Er hat dann noch Besucher mit Versuchen erfreut, indem er eine Blase anstach und das Gas entzündete, das restlos verbrannte. Dazu sagte er: „Man muf3 diesen Geist in guten dicken Blasen halten, wie solche eines Ochsen. Wenn ich den Geist in Kalbsblasen füllte, verlor er in 24 Stunden seine Entflammbarkeit, ohne daf die Blase zusammenschrumpfte ${ }^{\text {(2..2a }}$ ).

Die weitreichenden Möglichkeiten technischer und wirtschaftlicher Art, die die Verwendung des Gases bieten konnte, hat Clayton offenbar nicht geahnt. Immerhin stellt er die drei Erzeugnisse der Steinkohlenentgasung ausdrücklich fest: Wasserdampf, Teer und Gas.

In den "Vegetable staticks" von S. Hales $1727^{1.14}$ ) findet man wichtige Beobachtungen über Versuche mit trockenem Erwärmen verschiedener organischer Stoffe mit einer ausführlichen Beschreibung der genommenen Proben. Stephen Hales, geboren zu Beekesbourn (Kent) 1677, gestorben zu Teddington $176 \mathrm{t}$ war Geistlicher; 1717 Mitglied der Royal Society und 1751 der Académie des Sciences zu Paris. In der Übersetzung von De Buffon 1735 Paris über die Arbeiten von Hales heif̧t es: „Um die Menge Luft, die aus irgend einem Körper durch Destillation oder durch Schmelzen austritt, kennenzulernen, warf ich zunächst den Stoff, den ich destillieren wollte, in eine kleine Retorte, an die ich einen Glasbehälter mit sehr grofem Fassungsvernögen ankittete." Hales untersuchte Blut, Fett, Holz, insbesondere Samen, Wachs, Zucker, Steinkohle und bestimmte die Menge des gewonnenen brennbaren Gases. Er stellte fest, daf rund $\mathrm{I} / 3$ des $\mathrm{Ge}$ wichtes der Newcastle-Kohle in Form von Gas und kondensierbaren Dämpfen ausgetrieben wurde. $\mathrm{Da}$ er eine Glasretorte benutzte, war er an verhältnismäßjig niedrige Temperaturen gebunden und ging über die erwähnten Feststellungen nicht hinaus. Vielmehr erneuerte R. W atson, Bischof von Llandaff, im Jahre ${ }_{1767}$ die Versuche von Hales $\left.{ }^{1.15}\right)$. Er untersuchte die Destillationserzeugnisse und fand als Bestandteile ein brennbares Gas, eine wäfrige Flüssigkeit von $1 / 8$ des Gesamtvolumens und, versetzt mit Ammoniak, ,ein dickes Öl, ähnlich dem Teer". Den verbliebenen Rest beschreibt er als leichte schwammige Masse, dem Aussehen nach und in der Qualität ein Erzeugnis aus Grubenkohle darstellend wie einen Handelsartikel, der gewöhnlich mit coke oder cinder (Koks oder Koksgrus) bezeichnet wird. Watson leitete auch die „Luft“ aus Grubenkohle durch Glasrohre und beobachtete, daf sie nach einem Durchgang durch Wasser entzündbar blieb und mit einem reineren Lichte verbrannte.

${ }^{1733}$ gab Sir James Lotber an die Royal Society ,einen Bericht über feuchte Luft (Grubengas) in einer Kohlengrube.... die innerhalb eines Bereiches von 20 Yards von der See betrieben wurde. Die lebhafte anschauliche Schilderung

\footnotetext{
1.13) Samuel Clegg jun.: Practical treatise of the manufacture and distribution of Coal Gas. London 1841 S. 2 (Bücherei der T. H. Aachen)

1.14) Dr. Stephen Hales: Vegetable Staticks or An Account of some statical experiments etc. London 1727 S. 176. zitiert nach Chandler und Lacey ( $5,1.1)$

1.15) Richard Watson, Chemical Essays 2. Ausg. Bd. 2 London 1782 S. 317-368, zitiert nach Chandler und L.acey (s, I.I)
} 
beschäftigt sich mit der „plötzlichen Entwicklung von Gas“ in einer ihm gehörenden Zeche nahe Whitehaven ${ }^{1,20}$ ).

Das Vorkommen von Sumpfgas im Bodenschlamm von Gewässern wurde 1775 von Alessandro $V$ olt a festgestellt ${ }^{1.17}$ ).

1777 hat François Cbaussier (Dijon 1746-1828) Lehrer der Heilkunde zu Paris, im Journal de Physique eine Mitteilung über die brennbare Luft veröffentlicht. Er erinnerte daran, daß die brennbare Luft nicht nur aus Metallen entsteht, sondern auch aus Steinkohle, aus mineralischen Substanzen, Pflanzen usw. In einer Beschreibung des Flugzeuges (Luftschiff (?)) von Dijon - erschienen 1784 zu Dijon unter Mitwirkung von Morveau und Bertrandwird erneut über die Eigenschaften des Gases gesprochen. Ein Jahr später gibt de la Metberie ein Buch über die Luftarten heraus, in dem ein Hauptteil der brennbaren Luft gewidmet ist ${ }^{1,19}$ ). Darin wird berichtet, daf3 allerlei tierische und pflanzliche Stoffe durch trockenes Beheizen Veranlassung gäben zu brennbarer Luft, ja selbst Steinkohle und fossile Harze (Bernsteine). Diese letzteren Stoffe seien Überreste von organischen Wesen, und die brennbaren Gase hätten immer ihren Ursprung in organischen Wesen. Etwa um 1780 begannen die Untersucher festzustellen, daf das brennbare Gas, das man durch trockene Destillation erhalte, nicht dasselbe Gas wie Wasserstoff sei, das durch die Einwirkung von Säuren auf Metalle entsteht.

De la Metherie bemerkt auch, dał das Gas aus organischen Stoffen, ebenso wie Gas aus Fäulnisprozessen und das Moorgas eine sichere Menge von Säuregasen $\left(\mathrm{CO}_{2}\right)$ enthalte, so dał das Kalkwasser Schwierigkeiten macht. So wird ein deutlicher Unterschied zwischen Wasserstoff und Steinkohlengas gemacht.

Bemerkenswert ist, daf̧ de la Metherie bereits von Wassergas spricht: „Die Kohle, die aller Luft durch ein heftiges Feuer beraubt ist, oder wenigstens keine mehr bei diesen Temperaturen abgibt, wird von neuem solches abgeben, wenn man sie durch W/asser gehen läß̧t. Diese Luft ist reine saure Luft und die brennbare Luft, die aus der Zersetzung des Wassers kommt."

In Deutschland wurde zuerst ein brennbares Gas, das zur Raumbeleuchtung herangezogen wurde, bei der trockenen Destillation von Knochen gewonnen, und zwar vom Geheimen Medizinalrat und Prof. der Chemie und Physik Dr. Johann Georg Pickel in Würzburg, der dort 1786 sein Laboratorium zur Gewinnung von Salmiak benutzte, dann 1790 von $E r \times l e b e n$ in Landskron. Eine weitere technische Entwicklung brachten diese Versuche aber nicht, ebenso wenig wie die Arbeiten von Henfrey in den Vereinigten Staaten von Nordamerika, der ohne Kenntnis früherer europäischer Arbeiten bei der Untersuchung von Steinkohlen auf ihren Bitumengehalt I80I ein Gas gewann, das sich zufällig an einer offenen Flamme entzündete und leuchtend brannte.

Damit ist die Reihe der rein experimentell, zwar mit wissenschaftlichem Interesse, aber noch mehr spielerisch arbeitenden Gelegenheitsforscher abgeschlossen.

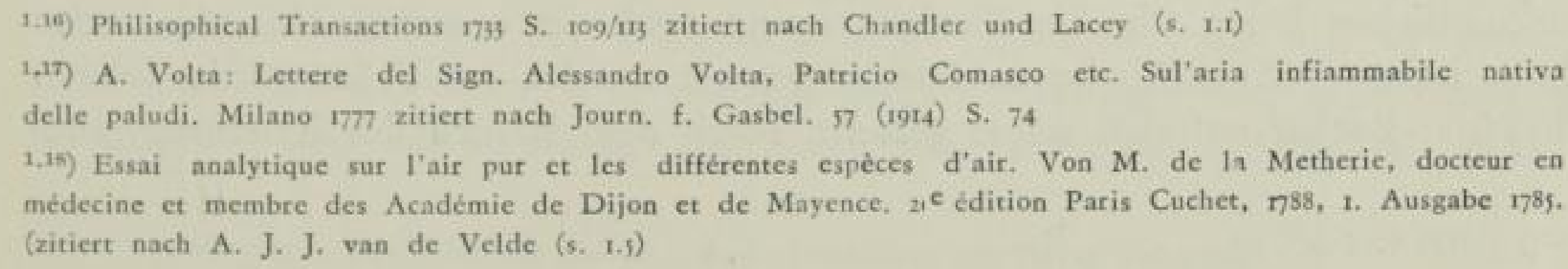


I.2 ERSTE VORSCHLÄGE UND VERSUCHE

FÜR GASVER W NDUNG

Nunmehr treten Beobachter und Erfinder heraus, die an die Verwendung des erzeugten Gases denken.

Einer der vielseitigen Geister, der auch chemische Experimente ausführte, war Dr. Johann Joachim Becher, geboren zu Speyer 1635. (Bild I) Gasmeister Ullricb. Speyer, hat folgendes Lebensbild zusammengestellt' ${ }^{1.19}$ ).

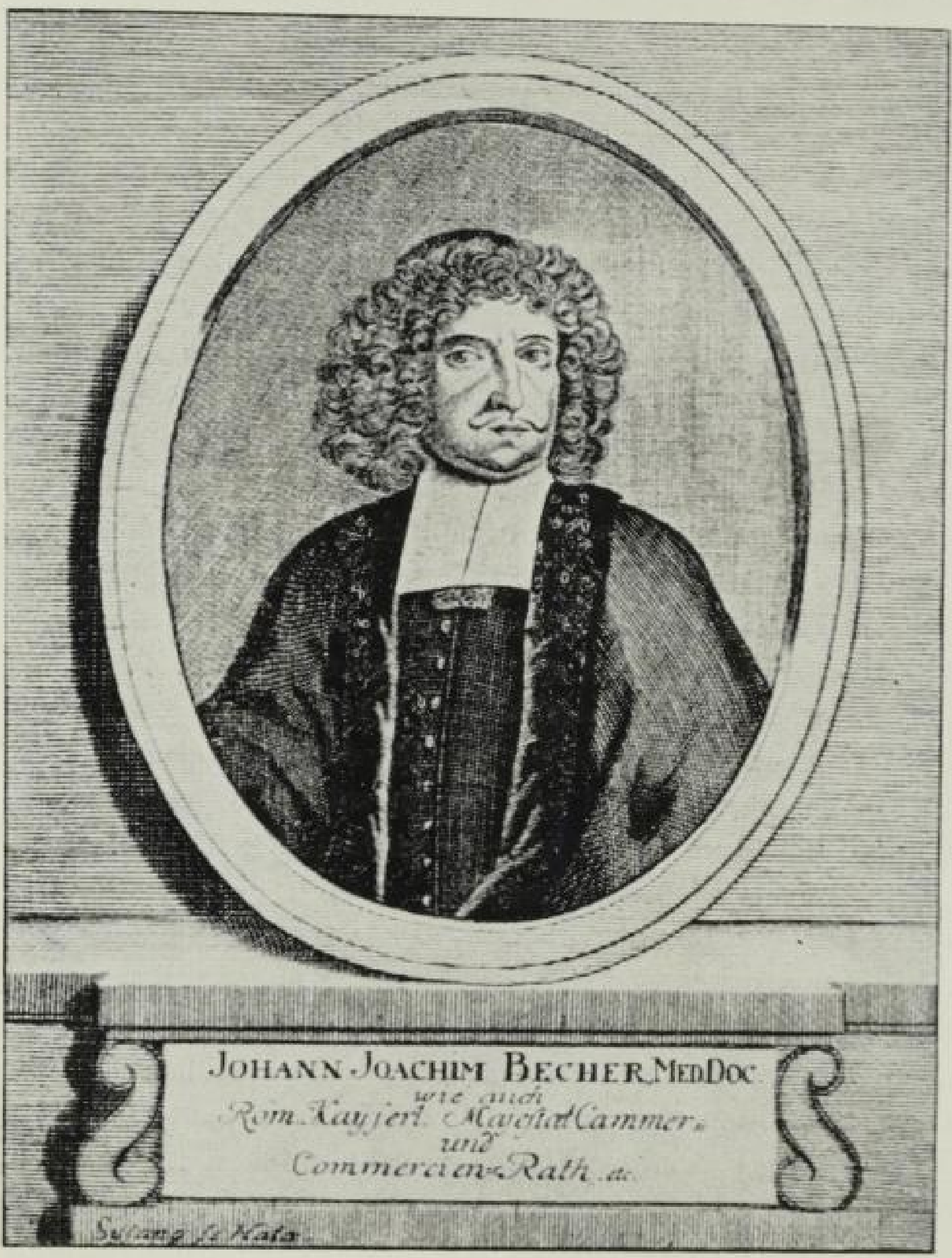

Bild 1

Dr. Johann

Joachim Becher

$1635-1682$

(GWF 78 [1935] S. 319)

\section{LE B E N S B I L D}

Johann Joachim Becher wurde in Speyer als Sohn des lutherischen Pfarrers Joachim Becher und seiner Ehefrau Anna Margaretha Gaufy geboren. Einen urkundlichen Beleg gibt die Taufeintragung, nach der er am 6. Mai I635 in der lutherischen Predigerkirche zu Speyer getauft worden ist. Früh wurde Johann Joachim Becher auf sich selbst gestellt. Nach dem Besuch des Retschergymna-

1.19) GWF. 78 (1935), 318

\section{SLUB}


siums in Speyer und der Liniversität in Mainz fand er seinen ersten Wirkungskreis als junger Doktor der Medizin am kurmainzischen Hofe. Er vermählte sich mit der Tochter des Hofrats von Hornigk und wurde Leibarzt des Kurfürsten und Erzbischofs Johann Philipp, Grafen von Schönborn, zugleich Professor an der Universität Mainz. Die Vielseitigkeit seiner Gaben und Interessen begann sich auszuwirken. Er erfand eine Universalsprache, laborierte in Chemie und Physik. Auch in praktischen Dingen zog man ihn zu Rate; so entwarf er eine Polizeiverordnung für Mainz und half an dem weitschauenden Plan eines Rhein-Donau-Kanales. Schon 1664 jedoch trat er in kurbayrische Dienste, und zwar als Leibarzt. Bald wurden ihm wieder wirtschaftliche Aufgaben übertragen: die Gründung einer Seidenmanufaktur, Unterhandlungen mit der holländisch-westindischen Kompanie und mit Österreich. In Wien faf̧te er festen Fußj. Auf seine Anregung hin wurde dort ein „Kommerzienrat" errichtet, dem er selbst angehörte. An der Gründung einer österreichischen Seidenmanufaktur war er beteiligt. Es beschäftigten ihn auch Pläne einer Exporthandelsgesellschaft. Ferner wurde er mit handelspolitischen Missionen in Holland betraut. Schwere Anfeindungen, vor allem der Hał des Grafen von S inzendorf, des Präsidenten im Kommerzienrat, vertrieben ihn aus Wien. Einen festen Wirkungskreis fand er nun nicht mehr. Er ging nach Holland, erfand eine neue Seidenhaspel und suchte durch das Schmelzen von Silber und aus Seesand Gold zu gewinnen. Von Holland setzte er über nach England. Dort wurde ihm die Unterstützung gelehrter Freunde zuteil. Er besuchte die Bergwerke von Schottland und Cornwallis und nahn das chemische Laboratorium wieder auf. In London ist er auch gestorben, und zwar wird hierfür der Oktober 1682 angegeben.

Becber war wohl beeinfluft von Paracelsus. Er war der Vorkämpfer der Verbrennungslehre nach der Phlogiston-Theorie. Dem Gasfach näherte er sich durch seine Anteilnahme an der Herstellung von Steinkohlenteer. Dieser wurde bereits 1660 im Eisenwerk Pontypool (Monmouthshire) benutzt ${ }^{1.50}$ ) und zwar, um Lacke für nachgeahmte Japanware herzustellen. Damals befand sich die englische Eisenindustrie wegen der mangelnden Holzkohle in einer schweren Krise. Nach der Restauration der Stuarts 1600 war der Einfluf industriefeindlicher Grofgrundbesitzer sehr gewachsen. Diese waren bestrebt, die Eisengewinnung ganz zu verbieten. 16-6 erwog die Regierung, die Staatswerke im Forest of Dean - eine der ältesten Hütten Grof̧britanniens - ganz stillzulegen. Solchen Absichten warf sich der "Cavalier", Prinz Ruprecht von der Pfalz, entgegen. Ruprecht war ein Sohn des Kurfürsten Friedrich V., des unglücklichen Winterkönigs. Er hatte als Verweser der Oberpfalz die volkswirtschaftliche Bedeutung der Eisenindustrie kennengelernt. Das Kriegsschicksal verschlug ihn nach England. Er hatte erkannt, dał die englische Krise vom Holzmangel ausging, und war wohl einer der Sucher, das Holz durch Steinkohle abzulösen, ein Beginnen, das durch den hohen Schwefelgehalt englischer Kohle und bei Benutzung der überlieferten Feuerungen für Holz ohne Roste erschwert war. Ob er seinen Landsmann Becher, der sich in Holland aufhielt, bewogen hat, nach England zu kommen, oder ob umgekehrt der durch ein wechselvolles Schicksal herum-

1.20) Otto Johannsen: Geschichte des Eisens 3. Aufl. Düsseldorf 1933 Verlag Stahleisen 
gestof̧ene Becher ihn aufsuchte, ist nicht mehr feststellbar. Jedenfalls ging Becher 1680 nach England und erhielt $168 \mathrm{I}$ ein Patent auf die Herstellung von Steinkohlenteer. Dieser Teer sollte den knapp gewordenen Holzteer für die Konservierung der Schiffe ablösen; mit dem Koks machte man Versuche, Eisen zu verarbeiten. Nach Beckmann ${ }^{1,2}$ ) hat auch König Karl 1I. die Verdienste Bechers gewürdigt und sich von seinen Erfolgen überzeugt. Beckmann schildert, als Volkswirt vorausschauend, die Bedeutung des Steinkohlengases, das von Becher abgefackelt wurde. Eine industrielle Verwendung des Gases, insbesondere zur Beleuchtung hat Becher wahrscheinlich in England nicht vorgenommen, wenn auch nach manchen Berichten bei der Entgasung von Torfen in den Niederlanden das Gas beachtet sein soll.

C. W. Tabor, ein sorgfältiger W'issenschaftler, Hof- und Regierungsrat des ehemaligen kurmainzischen Staates, mit Erfahrungen in verschiedenen ofentechnischen Verfahren, entwickelte allerdings im Jahre 1822 Gedanken, an denen man nicht vorübergehen kann $^{1.22}$ ). Er sagt: „Soviel mir bewuft ist, hat unser deutscher Landsmann, der bekannte Joh. Joachim Becher zuerst eine Anwendung des Steinkohlengases zu Schmelzprozessen gemacht. Er erzählt selbst in seiner ,närrischen Weisheit und weisen Narrheit ${ }^{\text {‘1.23 }}$, daf er schon vor dem Jahre 1685 (?) in Holland die Verkohlung des Torfes und in England die der Steinkohlen entdeckt habe, daf er aus beiden nicht nur sehr gute Kohlen erhalten habe, die nicht mehr rauchen noch stinken, sondern daf er auch mit den Flammen davon so stark zu schmelzen vermochte als mit Holz. Die Flamme von einem Schuh Kohlen sei io Fuf lang gewesen. Die Proben mit Steinkohlen habe er in Gegenwart des Herrn Boyle gemacht, auch in Windsor damit im Groß̧en abgetrieben. Er habe aus Steinkohlen Teer gemacht und gezeigt, daf3 entteerte Kohlen zum Gebrauch besser seien als vorher.

„Verstehe ich die Erzählung recht, so geht daraus hervor, dał Becher die Steinkohle einer wirklichen Destillation unterworfen hat, denn wie könnte er sonst Teer und verkohlte Steinkohle (d. i. Koks) erhalten haben? Hat er aber dieses getan, so konnte ihm die Existenz so wenig wie die Brennbarkeit des Gases unmöglich unbekannt bleiben, wie seine Erzählung auch ergibt. Die to Fuf̧ lange Flamme konnte nicht von einem Fu\} Kohlen (Koks) entstehen, und wenn die im freien Feuer selbst vor dem stärksten Gebläse gelegen hätten, weil Koks sehr starke Glühhitze, aber wenig Flamme geben, noch weniger konnte er damit abtreiben, was bekanntlich eine sehr starke Flamme erfordert, also muf beides von dem entzündeten Gas zu verstehen sein. ..... „Die Versuche Bechers wurden in England öffentlich genug bekannt gemacht, dał sie zu jedermanns Wissenschaft gelangen konnten....." Tabor meint, daf3 man nur wegen seiner Ausländereigenschaft sie verschwiegen habe. Sicherlich ist aber die kurze Dauer der Versuche schuld daran, daf sie in Vergessenheit gerieten. Boyle wurde auch, wie wir wissen, sehr stark mit solchen Vorträgen bedacht, daf3 es durchaus ver-

\footnotetext{
1.24) Johann Beckmann: Beiträge zur Geschichte der Erfindungen II. S. 192 Leipsig 1784 (erhalten in Bücherei Universität Tübingen)

1.22) zitiert ausführlich im Abschnitt 2,222

1.2x) Joh. Joachim Becher: Närrische Weisheit und weise Narrheit (entstanden 1680 in London) Frankfurt 1687 S. 67, zitiert in Beckmann (s. 1.m), erhalten in der Stadtbücherei Schaffhausen
} 
ständlich ist, wenn der das an sich bereits angewandte Verfahren nicht besonders registriert hat. Becher ist vielmehr zu schnell verstorben, um den praktischen Arbeiten den Nachdruck zu geben, der ihm Eingang in die englische Literatur verschafft hätte. Sein eigener Bericht ist ja erst nach seinem Tode in Deutschland veröffentlicht.

1764 hat M. Jar $s^{1.04}$ ) die Benutzung des Grubengases aus der Umgebung von Lyon zur Beleuchtung vorgeschlagen und sogar angeregt, das Gas durch Rohrleitungen in die benachbarten Städte zu leiten. Der Vorschlag wurde aber nicht ausgeführt. Im Jahre darauf scheint $S$ ped in $^{1.24}$ ), Direktor der Bergwerke von Whitehaven, begonnen zu haben, seine Arbeitsräume mit Grubengas zu beleuchten. Er fał̧te den Gedanken, das Gas in Fässer einzufüllen und der Stadtverwaltung anzubieten. Diese aber lehnte ab.

Im Jahre 1776 reichte François $C$ b a us sie $r^{1.24}$ ), Professor der Medizin zu Paris, der Akademie der Wissenschaften eine Denkschrift über die Verwendung von Gas ein und berichtete über eigene Versuche in Dijon. 1782 stellte Dr. S p i elma $n$ n, Professor der Medizin in Straf̧burg ${ }^{1.24}$ ), Versuche an. Im Jahre 1788 führte ein deutschen Wissenschaftler Diller ,philosophisches Feuerwerk" im Lyceum Theather zu London aus. Die genaue Art dieser Einrichtungen kennt man nicht. Sicherlich ist es aber nicht Steinkohlengas oder Wasserstoff gewesen. Im Jahre 1786 beobachtete Lord $D u n d o n$ ald die reiche Entwicklung der Gase in den Koksöfen, die er einige Jahre vorher hatte errichten lassen. Er faf̧te den Gedanken, die Gase durch einen Kühler zu schicken, um die leichten Teeröle zu kondensieren und zu gewinnen. Danach zündete er die Gase an, und so wurden die Räume für die Nachtarbeit erhelltt ${ }^{1.25}$ ). Er schēnt auch die Absicht gehabt zu haben, das Gas in geschlossenen Gefäłen in sein Landhaus zu bringen.

Inzwischen wurde die Gastechnik im Anschluß an die Verkokung der Kohle belebt, zumal die Marine beim Mangel an Holzteer sich mit dem Steinkohlenteer befafte. Bis dahin hatte man in Meilern nur hin und wieder den Teer gewonnen und das Gas abbrennen lassen.

Weit seiner Zeit vorauseilend und deshalb besonders anregend ist ein Patentgesuch J. Barbers aus Newneaton aus dem Jahre 1791. Barber dachte an die Krafterzeugung und schlug eine Druckgasfeuerung für metallurgische Zwecke vor $\left.^{1.30}\right)$. Er regte an „ein Metallgefäß zu benutzen, Retorte genannt, das so gebaut ist, dał (wenn es durch ein herumschlagendes Feuer erhitzt wird) Kohle, Holz, Öl oder jeder andere brennbare Stoff hineingelegt werden können und der Rauch oder Dampf, der sich darin bildet, durch ein dünnes Rohr herausgeführt werden kann und weiter in ein anderes Metallgefäf mit dem Namen Exploder geleitet wird, durch eine Luftpumpe und einen Verdichter oder regelnde Bälge. Dieses Rohr hat seine Öffnung gegenüber einem anderen ähnlichen Rohre, das in den Exploder eintritt (an der gegenüberliegenden Seite des

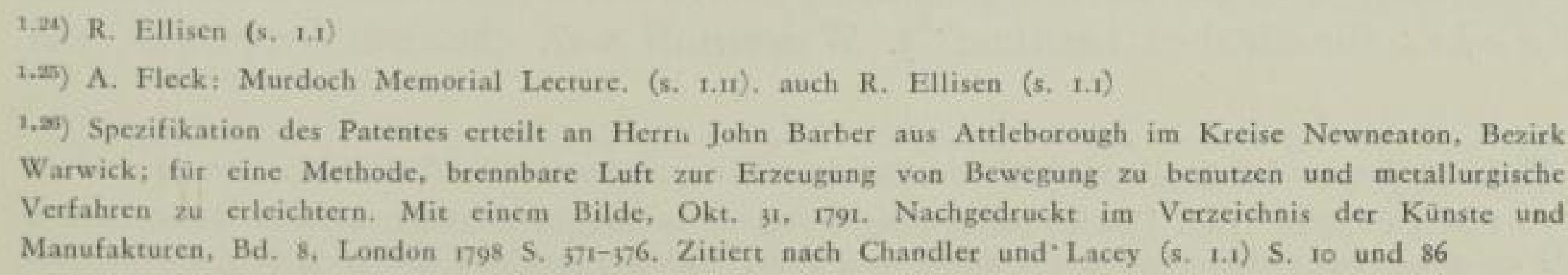


Rohres, das den brennbaren Dampf von der Retorte herbringt) und mit gleichen Mitteln eine angemessene Menge atmosphärischer oder gewöhnlicher Luft hineinwirft, wobei die beiden Lüfte gemischt werden, die, so gemischt, Feuer fangen werden nach Anwendung eines Zündspanes oder einer Kerze. Sie strömen dann aus mit grołer Geschwindigkeit in einem kontinuierlichen Strom, solange der Exploder mit angemessenen Mengen der beiden Lüfte bespeist wird."

Seiner Schrift war eine Zeichriung über eine Retorte beigelegt, übcr die er schrieb: „Ich benutze zwei Retorten, damit die Maschine mit deren einer am Laufen bleiben kann, während die andere gereinigt wird von Koks und Asche aus dem Stoff zur Erzeugung der brennbaren Luft. - Jede Art von Maschine nach diesen Prinzipien mag mit bescheidenen Kosten hergestellt, mit sehr wenig Brennstoff betrieben und mit geringer Mühe gesteuert werden, verglichen mit jeder Maschinenart, die bisher erfunden ist." - Mehr als zweifelhaft ist es, ob Barbers Maschine gearbeitet hat. Trotzdem dürfte dieser frühe Gedanke an die Verbrennungsmaschine geschichtlich bedeutsam sein.

\subsection{DER EINFLUSS DER ERFINDUNG DES LUFTBALLONS}

Einen grofen Auftrieb erfuhr die Anteilnahme am Gas durch die Erfindung der Brüder Montgolfier, des "Aerostaten“ (Luftballon) am 7. Juli 1783. Sie erhitzten die Luft durch ein Feuer unter dem Ballon ${ }^{1.27}$ ). Das Aufsehen dieser Erfindung war ungeheuerlich. Alle Welt beschäftigte sich mit dem Aerostaten, und in kurzer Zeit wurden an verschiedenen Orten, erst in Frankreich, dann auch in den anderen Ländern Europas, Ballone in die Luft entsendet. Aber man suchte nach einem leichteren Gas, das auch bei der Umgebungstemperatur seine Tragfähigkeit behielt, um die Ballone zu füllen. Zwei Brüder Robert bemühten sich sofort, die Versuche nachzuahmen. Ohne genaueres zu wissen, arbeiteten sie mit dem Physiker C barles zusammen, der Wasserstoff aus der Auflösung von Eisen in Schwefelsäure herstellte. Nach grołen Schwierigkeiten, die Hülle des Ballons einigermał̧en befriedigend zu dichten, ließ̧̧en sie am 28. August 1783 auf dem Marsfelde zu Paris einen Ballon aufsteigen. Am 2I. November 1782 stiegen Pilatre de Rosier und d'Arlande von la Muette mit einer heifluftgefüllten Montgolfiere als erste Menschen auf und landeten glücklich in la Butte aux Cailles. Charies und Robert erhoben sich in den Tuilerien am I. Dezember und kamen 9 Meilen von Paris wieder zur Erde. Die Begeisterung war allgemein. Aber auch Karikatur und satirische Gedichte trugen zur Verbreitung der Neuigkeit bei. Man sprach von einer wahrhaftigen Ballon-Epidemie, die sich nach Italien, Belgien, England ausbreitete.

Technisch aber war die Aufgabe noch keineswegs befriedigend gelöst; das Feuer unter dem Ballon war gefährlich. Davon hat d'Arlande an seinen Freund F a u jas Einzelheiten berichtet ${ }^{1.25}$ ). Wasserstoff war, chemisch hergestellt, viel

\footnotetext{
1.m) Lucien Bertin: Les premiers emplois du Gaz de Houille en Aérostation, Amiens, G. Stora 1912

1.2s) Faujas de Saint Frnd: Descriptions des expériences de la machine aćrostatique de M. Montgolfier et de celles auxquelles cette découverte a donné lieu, Paris, Cuchet, 1785 (zitiert nach 1.27) S. 15
} 
zu teuer und konnte nur so langsam entwickelt werden, daß̧ während der Füllzeit bereits ein groß̧er Teil des Gases durch die Hülle hinausdiffundierte.

Diese Lage veranlaf̧te im Herbst 1782 den Herzog Louis Engelbert von Aremberg, einen freigebigen Beschützer des physikalischen Instituts der Universität Loewen, drei Gelehrte mit Untersuchungen über die Gewinnung von brennbaren Gasen aus verschiedenen Grundstoffen zu beauftragen. Es sollte festgestellt werden, ob man nicht schnell nach einem einfachen Verfahren und mit geringen Kosten eine groß̧e Menge beständigen Gases von genügend geringer Wichte gewinnen könnte.

Unter diesen drei Gelehrten befand sich Johannes Petrus Minckelers, damals Professor in Loewen, der sich dieser Aufgabe mit systematischer Gründlichkeit widmete ${ }^{1.29}$ ).

\section{E B E N S B I L D}

Minckelers war ein Gelehrter von gröfter Vielseitigkeit, so wie sie damals vielfach z!ı finden waren. Er ist neben seinen allgemeinen Vorträgen über Physik und Chemie auch bekannt geworden als Forscher auf dem Gebiete der Versteinerungen und auf dem der Meteorologie. Es ist anzunehmen, daf Minckelers die eine oder andere Arbeit, vielleicht gerade die von Chaussier, die ja in einer anerkannten wissenschaftlichen Zeitung erschienen war, gelesen hat. Wahrscheinlich hatte er Versuche vor dieser Zeit nicht gemacht, ehe er den Auftrag auf eine Zweckforschung, wie wir heute sagen würden, übernahm.

Jan Pieter Minckelers (in der holländischen Namensform) stammt aus einer Bürgerfamilie in Maastricht, die dort schon seit 1499 ansässig war $\left.{ }^{1.30}\right)$. Sein Vater war Apotheker, der Groß̧vater Arzt. Er wurde geboren am 1. oder 2. Dezember $174^{8}$ zu Maastricht, das damals der Botmäfrigkeit des Fürstbischofs von Lüttich unterstand. Jan Pieter besuchte die humanistische Jesuitenschule seines Heimatortes mit dem Ziele, Priester zu werden. Er verpflichtete sich mit i6 Jahren dazu und erhielt symbolisch eine Tonsur. Sein Vater sandte ihn dann nach Loewen, damit er dort Theologie und Philosophie studiere. Mit 20 Jahren wurde er Baccalaureus und am 22. Dezember 1770 empfing er in Luik die Weihe als Subdiakon ${ }^{1.31}$ ). Dann aber fuhr er nach Loewen zurück, um Naturwissenschaft zu studieren. Seine Priesterschaft hat er wohl nicht autgegeben. Er wird auf allen Bildern, die seine Forschertätigkeit wiedergeben, im Gewand des Geistlichen dargestellt und in einem Kollegeauszug als ,venerabilis“ = ehrwürdig bezeichnet. An der Universität Loewen tat er sich so hervor, dał er bereits 1772 , also 24 Jahre alt, zum Professor der Philosophie ernannt wurde und den Lehrstuhl für Naturwissenschaften bekleiden durfte.

Hier erreichte ihn also der Forschungsauftrag des „blinden“ Herzogs im September 1783 , dem schon am 2I. November des gleichen Jahres ein Ballonaufstieg folgte.

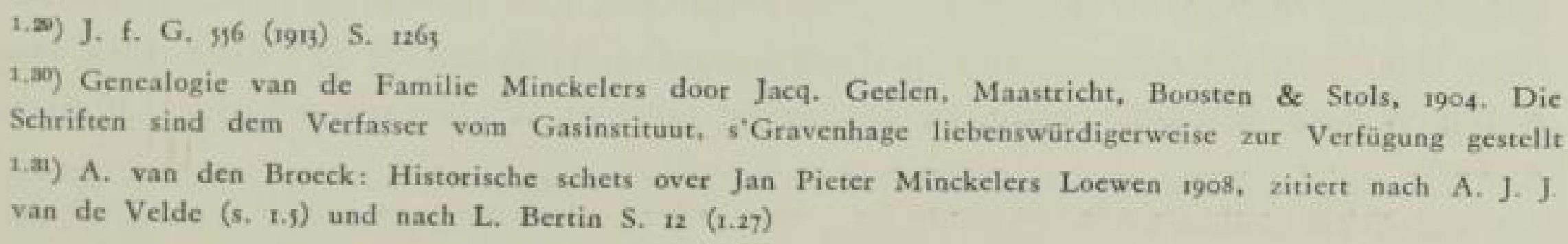


Minckelers ist im Jahre 1788 nach Maastricht zurückgekehrt, wo er die Apotheke seines Vaters übernahm. Sein Vater ist allerdings erst 1800 gestorben. Das Land war inzwischen unter französische Herrschaft gekommen. In der soeben gegründeten Zentralschule seiner Heimatstadt wurde Minckelers 1797 mit dem Unterricht der Chemie und der Physik betraut, den er 20 Jahre lang ausgeübt hat. Dabei blieb er bei wissenschaftlichen Dingen, er richtete ein Physikkabinett und ein chemisches Laboratorium ein. Am 3. Juli 1816 wurde Minckelers zum Mitglied der königlichen Akademie zu Brüssel gewählt. Es war ihm aber nicht vergönnt, an den Sitzungen teilzunehmen, da ihn ein Schlaganfall traf. So nahm seine Lebensarbeit im 68. Jahre ein Ende, er starb 75 Jahre alt am 14. Juli i 824.

Minckelers hat im Jahre ${ }_{178} 4$ einen Bericht über die Arbeiten abgefaf3t, von dem noch in der Universitätsbücherei eine Ausfertigung vorhanden ist: Mémoire sur l'air inflammable tiré des différentes substances, rédigé par M. Minckelers, professeur de philosophie au Collège du Faucon, Université de Louvain, Louvain 1784 .

Er lautet auszugsweise: Zunächst wurde das Gas gepruft, das durch Erwärmen von Stroh und Wolle in eisernen Gefäß̧en gewonnen war. Das Gewicht des Gases war $4^{8}$ für Stroh gegen 71 von Luft und 41 für Wolle gegen 64 von Luft. Das Gas war wirklich noch zu schwer und daraus konnte geschlossen werden, dał das Gas, das Montgolfier gebraucht hatte, von anderer Art gewesen sein muf3te.

So wurden weitere Proben genommen, und zwar mit Schafsknochen. Eichen- und Buchenholz, Holzkohle, Schornsteinrufy und Molybden ${ }^{1.42}$ ). Die so erhaltenen Gase waren schwerer als das Gas, das man aus Salzsäure und Schwefelsäure auf einwandfreien Metallen erzeugen konnte. Schwefel kann nicht gebraucht werden, weil er durch Erhitzung sublimiert. Hier werden Macquer, Baumé, Valmont de Bomare, Bertrand, Morant, Gensonne en Brockes angezogen. Brockes und van Bouchaute, die beiden mit Minckelers beauftragten Professoren, haben Steinkohle in Glasretorten trocken erhitzt und Flüchtiges festgestellt.

Da kam Minckelers auf den Gedanken, Steinkohle in einem geschlossenen eisernen Rohr in einem Schmiedefeuer zu erhitzen (also auf höhere Temperaturen und in gröf̧erem Maß̧stab als bisher). Dazu sagt er selbst: „Le succès a répondu à mon attente, car le $\mathrm{i}^{\text {er }}$ Octobre passé ayant mis de la houille en poudre dans un canon de fusil, j'ai obtenu de l'air inflammable en abondance et très promptement; 4 onces de houille me donnèrent un pied cubique, mesure de France, et cet air, lequel, ayant été pesé, fut trouvé 4 fois plus léger que l'air atmosphérique." - (Der Erfolg entsprach meiner Erwartung, denn am I. Oktober des vergangenen Jahres tat ich Kohlenstaub in einen Büchsenlauf und erhielt brennbare Luft in Fülle und sehr schnell, 4 Unzen Kohle gaben mir einen Kubikfuf3 (französisches Mał̧) dieser Luft, die beim Wiegen sich als viermal so leicht wie Luft erwies.)

Zuerst wurde fette Kohle erhitzt, durch die Schwellung verstopfte das Rohr, Magerkohle wurde für besser geeignet befunden. Die Messungen von Thysbaert über das Gewicht des erhaltenen Gases ergaben 15 gegen 64 für Luft. Gas, das durch Wasser geleitet wurde, behielt seine geringe Wichte unverändert. Weiter-

1.a9) unklar, was gemeint ist 
hin wurde der Einfluf starker Hitze auf Weingeist und Vitrioläther untersucht, die als Dampf durch stark erhitzte Rohre strömten. Es ergaben sich unbrennbare Gase, deren Volumen sich durch Behandlung mit Kalkwasser verminderte. Proben von allerlei Stoffen: Kampfer, Benzoeharz, Zucker, Pech, Harz, Terpentin, Jodpech, Bernstein, Torf, Horn, Tierfett, Wachs, Walöl, Kohlsamenöl, erbrachten brennbares Gas, das aber schwerer war als das Steinkohlengas. Die Vergleiche wurden durch Thysbaert mit dem Gas aus Metali und Säure angestellt, das auch durch Priestley als „,brennbare Luft“ (Wasserstoff von Cavendish) untersucht und viel leichter befunden worden war als das Kohlengas $4 / 64$ vom Luftgewicht.

Nach dem Auflassen eines Ballons auf dem Schlof3 Aremberg am 2I. II. 1783, der mit Kohlengas gefüllt war, wurde ein größzerer am 24. 2. 1784 zu Loewen und einen Tag zuvor in Antwerpen glücklich in die Luft geschickt. Die Ballons kamen einige Kilometer entfernt vom Aufstiegplatz wieder herunter.

Der Bericht ist von J. P. Minckelers gezeichnet. Eine Tafel der spezifischen Gewichte von J. F. T b y s b a ert, Direktor der Schule der Künste in der Universität Loewen ist beigefügt.

Die Schrift Minckelers hat den Charakter einer ernsten wissenschaftlichen Arbeit. Die Untersuchungen wurden in eisernen Rohren mit halbfetter Kohle mit groß̧er Hitze geführt. Um größjere Mengen und die Verstopfung der Rohre zu vermeiden, wurden Retorten verfertigt; aber leider wird über weitere Versuche nichts mitgeteilt. Minckelers war ein bescheidener Mann. Er hat ein kleines Gaswerk erbaut, die von ihm erzeugten Mengen, $17 \mathrm{~m}^{3}$ bei dem Ballon Februar 1784 , gingen über das Laboratoriumsausmaf hinaus.

Aus Briefen von Zeitgenossen geht hervor, dał beinahe ein halber Kubikmeter Gas nach Schlof, Aremberg in 3 Behältern aus blankem Eisen gesandt worden sind. Hiernach nimmt van de Velde den ersten Schritt aus dem Laboratorium in den technischen Versuch für Minckelers in Anspruch.

Minckelers hat mit dem Ballonfüllen seine Aufgabe offenbar als erfüllt angesehen. Er soll allerdings auch für das Universitätsgebäude eine Beleuchtung ausgeführt haben. Vielleicht ist auch die Verlagerung des Unterrichts von Loewen nach Brüssel durch die damals Belgien beherrschende österreichische Regierung im Jahre 1788 eine Ursache für die Unterlassung weiterer Versuche gewesen.

Ebenso angeregt, nach einem leichten Traggas für die Montgolfieren zu suchen, arbeitete vermutlich ohne Kenntnis des Auftrages an Minckelers in Amiens der Apotheker Alexandre Lapostolle.

\section{LE B E N S B I L D}

Lapostolle ist geboren zu Maubeuge am 21. Dezember $1749^{1.39}$ ). Nach Besuch einer guten Schule und zweijährigem Praktikum bei einem Apotheker bereitete er sich in Paris auf die Prüfungen vor. Seine Lehrer waren die besten Chemiker der Zeit: Cadet de Vaux, Roulle, Baumé, Sage.

\footnotetext{
1.si) L. Bertin (s. 1.27) auch: Poggendorff, Lexicon der Lebensbeschreibungen der Wissenschaftler. 2. Aufl. und: J. f. G. 96 (1913) S. 1263
} 
1744 lief $\mathrm{er}$ sich nach beendetem Studium in Amiens als Apotheker nieder. Seine Aufopferungsbereitschaft während einer Epidemie brachte ihm den Schutz des staatlichen Aufsehers Bruno d'Agay ein, dank dessen er obsiegte, als seine ortsansässigen Kollegen sich beklagten, daf̧ er nicht vor ihnen seine Prüfungen als Apotheker abgelegt habe.

Nach 1777 gab er mit d'Hervillez einen Lehrgang über Chemie und Naturgeschichte im Saal der Jacobiner und später bis zu seinem Tode unter dem Schutz der Akademic im Jardin du Roi. Bei der Gründung der Medizinschule wurde er Professor für pharmazeutische Chemie. Nach der Schaffung der Zentralschule der Somme las er dort gleichfalls Chemie. Als sehr tüchtiger Versuchsführer eröffnete er 1782 in seinem Privatlaboratorium einen Kursus für physikalische und chemische Vorführungen, den bedeutende Wissenschaftler besuchten. Der Einfluf Lapostolles auf die Entwicklung der wissenschaftlichen Studien war groß̧ und gut. Dank seiner Fähigkeiten als Vortragender, seiner Verbindlichkeit und seinem Eifer erlangte er einen hohen Ruf als Wissenschaftler, der durch viele Veröffentlichungen belegt wird.

Seine Mitbürger schätzten nunmehr seinen Rat über Fragen der Hygiene und Gesundheit. Er wurde Mitglied des Stadtrates, Verwalter der Krankenhäuser, Mitglied der Akademie von Amiens, korrespondierendes Mitglied der medizinischen Akademie, Präsident des Gesundheitsrates usw.

Die chemische Revolution Lavoisiers warf grausam die Theorien (Phlogiston als Körper betrachtet) über den Haufen, denen Lapostolle mit Treue anhing. Der Mann, der früher ein Neuerer war, war bis zu einem gewissen Grade durch die neuen Auffassungen überholt. Von diesem Augenblick an fühlte er, daf̧ seine Vorlesungen ein wenig zu grołe Anhänglichkeit an die Wissenschaften seiner alten Lehrer enthielten.

So vermachte er 1829 sein physikalisches Laboratorium der Stadt Amiens. Am 19. Dezember 1830 starb er, nachdem er die Zeugen seiner langen und grofen Arbeiten überlebt hatte. „Es ist dieses das Schicksal derer“, so sagt Dr. Barbier $\left.^{1,3}\right)$, „die der Himmel mit einem langen Greisenalter bedacht hat. Sie fallen umgeben von jungen Generationen, denen man auseinandersetzen muf, was sie für ihre Väter getan haben, und was das Vaterland ihnen schuldig ist."

Über seine Forschungen über das Gas gibt nur ein Brief an das Journal de Paris vom 7. Januar 1784 Auskunft ${ }^{1,25}$ ). Er bezieht sich auf Versuche der Brüder Montgolfier. „Mit Befriedigung habe ich in den ersten Berichten über diese Erfindung gelesen, dał die Wissenschaftler sich bemühen, diese Ausführung nützlicher und weniger kostspielig werden zu lassen, die einen, um sie lenkbar zu machen, die andern, um ein brennbares Gas zu erhalten, das mit einem billigen Preis die Leichtigkeit vereinigt, die das Gas aus der Auflösung des Eisens auszeichnet...." Am 23. November 1783 lief $L$ av o isier eine Sonderkommission für das Studium der machines aérostatiques gründen. In der Niederschrift der Aussprache vom 27. Dezember des folgenden Jahres heif̧t es: daf

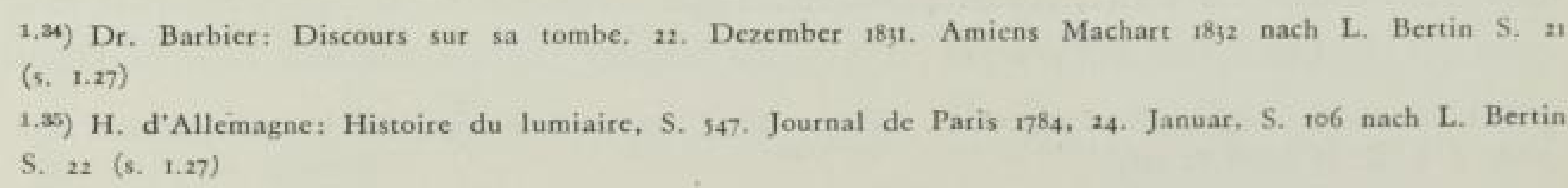


es sich gezeigt habe, dafy man eine beträchtliche Menge Gas aus fast allen tierischen und pflanzlichen Stoffen gewinnen kann. Der schwierige Punkt sei, einen gut geeigneten Apparat zu finden ${ }^{1.30}$ ).

In dem Brief heif̧t es nach einem Hinweis auf das Steinkohlengas weiter: „Bei den Versuchen, die wir mit mehreren Liebhabern angestellt haben, haben wir uns überzeugt, daß seine Entwicklung mit einer Schneiligkeit vor sich geht, die Vorsichtsmafnahmen erfordert, um es in den Ballon zu führen. Es entwickelt sich aus Steinkohle, die in ein luftdichtes Gefäß eingeschlossen ist. Dieses wird einem kräftigen Feuer ausgesetzt. Das Erzeugnis besteht aus zwei luftförmigen Flüssigkeiten, nämlich aus einem brennbaren Fluidum von hoher Flüchtigkeit und einer anderen, die als Grundlage ein Erdöl hat, aber im Zustand des Dampfes gehalten wird durch eine grołe Menge feurigen Fluidums. Im Augenblick der Gewinnung ist dieses Gemisch gut entzündbar, dagegen nicht mehr in gleicher Weise, wenn es längere Zeit in einem Ballon aufgehoben wird. Das Erzeugnis scheidet kondensierend auf den inneren Wänden des Ballons das Erdöl ab, und sein auflösendes Prinzip verändert die brennbare Luft in gewöhnliche atmosphärische. Dieser Vorgang findet nicht statt, wenn man das luftförmige Fluidum, bevor es in den Ballon gelassen wird, durch Wasser durchtreten läßzt, daß̧ das Erdöl von seinem Lösungsstoff trennt und sich dessen bemächtigt."

Es wird dann noch gesagt, dał das so gereinigte Gas von grołer Schönheit sei. Die Menge sei sehr grof und sei deshalb kaum zu messen. Zurückbleibt ein Brennstoff im Zustand des Kokses (der also schon ein bekannter Begriff war). Dann folgen Richtlinien zur Verbesserung des Ballonstoffes.

Weitere Nachrichten liegen nicht vor. Die Arbeiten sind wohl gegenüber den pharmazeutischen Interessen Lapostolles zurückgetreten.

\subsection{DIE ANTEILNAHME DER GEBILDETEN AN DEN VERSUCHEN}

So war also zu Ende des 18. Jahrhunderts an vielfachen Stellen die Untersuchung des Gases und der Nebenerzeugnisse der Entgasung geschehen. Eine reichhaltige, wenn auch stark verstreute Literatur war vorhanden, und die wissenschaftlichen Akademien waren mit Berichten über die Forschung wohl versehen. Dabei kann man wohl ohne weiteres annehmen, daf bei weitem det kleinste Teil von Äuf̧erungen auf uns überkommen ist. Aber charakteristisch für den Zustand ist, dał sich in der vorhergehenden Zeit allgemein wissenschaftlich interessierte Männer nur gelegentlich mit den Gasen beschäftigt hatten. Ihre wissenschaftliche Neugier war vielseitig und groł, die Freude an Experimentieren leitete sie, und mit den von ihnen gefundenen wissenschaftlichen Feststellungen waren sie meistens zufrieden. An eine technische grofzügige Verwer tung im Sinne des 19. Jahrhunderts hat keiner von ihnen gedacht. Viel weniger

1.30) A. L. Lavoisier: Oeuvres complites III. S. 742 nach L. Bertin (5, 1.27)

3 Geschichte der deutschen Gasindustrie 
hat irgend einer von den Forschern seine Lebensarbeit in der Auswertung der Kenntnisse des Gases gesehen.

Für viele andere mag von G. Licbtenberg, Professor der Physik und Chemie in Göttingen (1742-1799) berichtet werden. Dieser steckte tief in Versuchen mit der Elektrisiermaschine, mit Messungen der Luftelektrizität (durch Drachen), als er sich 1782 plötzlich den „verschiedenen Luftarten“ zuwandte. $\mathrm{Zu}$ nächst sind es Versuche mit Sauerstoff, dann Wasserstoff. Neben dem Hauptkolleg las er über das Thema: „Uber die Lehre von den mancherlei Gattungen der Luft, vom Feuer und von der Elektrizität und dem Magneten, ausführlicher als es in dem allgemeinen Kollegio geschehen kann."

1783 kam der Wasserstoff in den Vordergrund bei den Versuchen. Mit Freuden sah er eine Blase voll Wasserstoff an die Zimmerdecke emporsteigen. Er träumte von grof̧en Möglichkeiten. Ihm ist mit der Ausführung im Grof̧en Montgolfier zuvorgekommen. So schrieb er am I. Dezember 1783: „Es freut mich, daf allen Menschen der Versuch mif̧lingt. Mein Gothaischer Bruder, der mehr Louisdor auf Versuche zu verwenden hat, als ich Tropf Dreigroschenstücke, konnte nichts herausbringen. Bucholtz in Weimar wollte seinem Wertherschen Herzog, dem leidenden Werther selbst, Herder, Wieland den Versuch zeigen, ward mit allem ausgerüstet. Es ging aber nicht...... Der Herzog von Gotha hat mehrere Ballons aus Paris kommen lassen, sie taugten aber alle nicht, so niedlich sie auch gemacht waren."

In den Weihnachtsferien füllte er im ausgeräumten Auditorium seine aerostatische Maschine. Er schrieb vorher: Schon seit einigen Wochen ist meine grofe aerostatische Maschine fertig. Sie kostet mich am Ende über vierzig Taler. lch wäre der erste in Deutschland gewesen, der so etwas zustande gebracht hätte, allein ich habe hier kleinen Platz und mufte die Ferien abwarten, um mein Auditorium zum Füllen zu gebrauchen.

An den Aufstiegversuchen Blanchards nahm er lebhaften Anteil. Er selbst benutzte einen Ballon für seine Versuche mit Luftelektrizität und war froh, von dem unsicheren Drachen unabhängig geworden zu sein ${ }^{1.37}$ ).

Wie allgemein die Anteilnahme gewesen ist, beweist deutlich J. Mus ä $u s^{1.05}$ ). Er erwähnt in seiner launigen Weise, Zeitereignisse zu glossieren, mehrmals den Ärostaten, den gasgefüllten Luftballon, und zwar in den letzten drei Teilen seiner Märchen. Da diese in den Jahren 1782 bis 1786 herausgekommen sind, ist hiermit ein Beweis gegeben, wie stark die gebildete Welt von der neuen Technik beeindruckt gewesen ist. C. M. W i el an d, der 1803 die Musäusschen Märchen auf Wunsch der Witwe Musäus neu herausgegeben hat, fügt dem Text einige Anmerkungen an und widmet sich dabei wieder mit erfreulicher Aufmerksamkeit den Dingen, die vom Ärostaten handeln.

Auch Goet he hatte die Ballonluftfahrt von ihrem Beginn 1783 mit lebhafter Anteilnahme verfolgt. Er lief̧ in Weimar eine der ersten Montgolfieren $178_{4}$ aufsteigen. Vor allem fesselten Goethe die Berichte über die ersten Beobachtungen

\footnotetext{
1.37) Ernst Vincent: G. C. Lichtenberg, Tag und Dämmerung: Aphorismen, Schriften, Briefe, Tagebücher. Mit einem Lebensbild, Leipzig, Verlag Dieterich 1941 3. Aufl.

1,38) Johann August Musãus: Die deutschen Volksmärchen, München und Leipzig bei Georg Müller, Bd, z
} 
bei solchen Fahrten wegen seiner allgemeinen naturwissenschaftlichen Beschäftigungen $\left.{ }^{1,20}\right)$.

In Jena hatte sich der Kupferschmied $P f l u g$ mit Versuchen zur Gasherstellung befafyt. Karl August machte am 3. Oktober 1816 Goethe die Mitteilung, dał er bereit sei, für diese Versuche den Hof des Jenaischen Schlosses zur Verfügung zu stellen und mit deren Leitung den Professor v. Münchow zu beauftragen. Zwei Zentner Steinkohlen wurden zur Verabfolgung beim Kastellan Kirchner bereitgestellt. Zugleich sollten auch Versuche, aus Holz Leuchtgas zu gewinnen, angestellt werden. Auf Grund dieser Anregung erfolgte dann tatsächlich die versuchsweise Anlage einer Gasbeleuchtung ${ }^{1.40}$ ).

Goethe berichtet hierüber in den "Tag- und Jahresheiten 1816 " , „Zu sonstigen physikalischen Aufklärungen war der Versuch einer Gasbeleuchtung in Jena veranstaltet."

Dafy zunächst aber die Ballonfahrt Pate stand, geht daraus hervor, dafy schon ${ }_{18}{ }_{4}$ für das physikalische Kabinett in Jena Ballonhüllen angekauft wurden.

Karl August war auf̧erdem vom Professor der Physik J. W. Döbereiner in Jena auf das von F. Fontan a entdeckte Wassergas aufmerksam gemacht. Die Veröffentlichung stammt aus dem Jahre 1780. A. L. Lavoisier und Meusnier wiederholten die Versuche 1793 und bestätigten das Ergebnis ${ }^{1.41}$ ). Auch Goethe befafte sich nunmehr mit diesem Gase. Am 5. 12, 1816 schrieb er an Döbereiner ${ }^{1.42}$ ):

„Ew. Woblgeboren baben in einem Scbreiben an Serenissimus folgendes gemeldet: ,Ich babe gefunden, dab Koble und Wasser bei ibrer Wechselwirkung in bober Temperatur das woblfeilste und reinste Feuergas geben, und bätte ich das Geld, um diese Entdeckung durch Versucbe weiter fortzusetzen und sie zum Nutzen für das Leben ausarbeiten zu können, so würde ich vielleicht imstande sein, die Bereitung des Lichtgases (sic!) woblfeiler und einfacher auszufübren, als dies von den Engländern geschehen ist, durch) Benutzung ibrer Steinkoblen.' Ibre Königliche Hobeit wünschen über diesen Gegenstand vollkommen unterrichtet zu werden und zu vernebmen, wieviel auf diese Versuche verwendet werden müfte, um bedeutende Resultate berauszubringen."

Goethe sagte weiter in seinem Briefe dem Professor seine Unterstützung für die wichtigen Versuche zu.

Wenn man diese lebhafte Beschäftigung Goethes mit dem Gase kennenlernt, so ist anzunehmen, daf3 die oft zitierten Verse Goethes in der Sammlung "Sprichwörtlich“:

,Wüßgte nicbt, was sie besseres erfinden könnten, Als daf3 die Licbter obne Putzen brennten!"

\footnotetext{
1.30) Carl Diehm: Körpererzichung bei Goethe. Verlag Kramer Frankfurt/M., 1948. Diehm gibt eine umfassende Darstellung der Beschäftigung Goethes mit den Versuchen

1.40) J. Zeidler: Goethe Handbuch, Bd. 1, Stuttgart 1916, S. 182

1, e1) Ullmanns Encyklopädic d. techn. Chemie. 3. Aufl. 1953, Bd. 4 S. 651/55. Brenngase. Verfasser F. Schuster

1.45) Leipziger Neueste Nachrichten. 14. 3. $1912-\mathrm{Nr}, 74$ 
durchaus keiner seufzenden Sehnsucht entsprangen, so wie es meist dargestellt wird. Vielmehr sind sie wohl eher der Niederschlag einer sehr sorgfältigen Beschäftigung mit den Grundlagen und den vor ihm liegenden Möglichkeiten. Die Sammlung ist 1807 begonnen, 1812 gab sich Goethe dem Studium deutscher Sprichwörtersammlungen $\operatorname{hin}^{\mathrm{t} . t 3}$ ). Nach G. v. Loeper „Zu Goethes gereimten Sprüchen" gehören die Sprüche meist den Jahren $18 \mathrm{I}_{2}$ bis $18 \mathrm{I}_{4} \mathrm{an}^{1 .+4}$ ).

Damit mag die Periode der Vorbereitung als beendet angesehen werden. Wir sehen, daf̧ die Gasherstellung die weitesten Kreise als neue Erkenntnis fesselte. Das war der Boden, auf dem, natürlich in der Übergangszeit sich überschneidend, die Ingenieurarbeit zwangsläufig aufgenommen werden muf̧te.

1.43) J. Zeidler: Goethe Handbuch, Bd. 3. Stuttgart, 1918, S. 354

1.44) L. Geiger: Goethe-Jahrbuch, Bd. 5. Frankfurt, 1884, S. 289

\section{SLUB}




\section{DIE ERSTE TECHNISCHE ENTWICKLUNG VON I 800 BIS I 825}

Bis zur Wende des 19. Jahrhunderts darf man die Vorstufe der Gastechnik rechnen. Das allgemeine Interesse der Gebildeten war rege, aber es kam eigentlich nur zu Spielereien, die bald mehr oder weniger vergessen wurden. Darüber darf auch nicht hinwegtäuschen, daf manchmal technische und wirtschaftliche Wünsche als Triebkraft sichtbar werden. Darunter kann man die englischen Versuche, den zur Holzkonservierung notwendigen Teer aus Steinkohlen zu gewinnen, rechnen. Spielerischer Natur, wenn auch mit überraschend phantasievollen Erwartungen für eine technische Weiterentwicklung bleiben auch die Ballonversuche. Aber sie führten doch schon zu Aufträgen für die angewandte Forschung, die grundsätzlich den Weg aus dem Laboratorium hinaus in den technischen Małstab des Versuches weisen.

Ohne klaren Abbruch des bisherigen „Bastelns“ und ohne bewuften Anfang, etwa so, daf er im Schrifttum als solcher festgehalten wird, schaltete sich indessen gegen Ende des $x$ 8. Jahrhunderts der Ingenieur mit dem im Maschinenwesen um diese Zeit entwickelten Denken, dem Beginn des Konstruierens, ein.

Um den Vorgang gut zu verstehen, muf man zunächst die allgemeine Lage in den damaligen drei Kernländern - England, Frankreich und Deutschland - zu umreif̧en versuchen.

Das wissenschaffliche Interesse war in allen Landern rege, der Gedankenaustausch lebhaft, die Art der Arbeit aber verschieden. Die grołe Umwälzung in Frankreich seit 1789 bis zum Kaiserreich tötete die wissenschaftliche Arbeit nicht gänzlich. Lavoisier, der zuerst die Verbrennung als Oxydation erklärte und die neue Chemie (quantitative Messungen) begründete, endete zwar auf dem Schafott. Sadi Carnot aber, der Sohn eines 1815 verbannten Revolutionspolitikers, war bis zu seinem Tode als Wissenschaftler tätig. Die theoretische Ingenieurausbildung war gut, da Frankreich die Ingenieure für seine militärischen Zwecke, vor allem als Straßenbauer, brauchte. Der erste französische Gasingenieur $L e b a n$, ein Schüler der ersten auf streng wissenschaftlicher mathematischer und physikalischer Grundlage arbeitenden technischen Akademie, die 1747 gegründet worden war, war der Ausbildung nach Straf̧enbauer. Aber großje und Neues wagende technische Unternehmungen waren in den ungeordneten Zeiten unmöglich. - In Deutschland lebte der Wissenschaftler sehr bescheiden, zur technischen Entwicklung fehlte das Geld. Der 30-jährige Krieg hatte die technisch-kaufmännische Vorherrschaft Deutschlands (Eisenindustrie) zerstört. Der Wiederaufbau war immer wieder unterbrochen, zuletzt durch die friderizianischen Kriege. Auf den Krücken des Merkantilismus entwickelten sich nur, gestützt durch die Fürsten, einzelne Manufakturen in bescheidenem Umfange. 
Anders in England. Zwar war dort auch noch manches etwas chaotisch. Durch den jüngeren Pitt (Premierminister von ${ }_{17} 83$ bis $180 \mathrm{r}$ ) wurde der bis dahin wechselnde Kampf, ob der König über das Parlament hinweg oder das Parlament über den König das Volk regieren sollte, zugunsten der Demokratie entschieden. Aber die Verwicklung in die napoleonischen Kriege brachte Störungen im Aufbau. Der Mittelstand wurde mit den Kosten schwer belastet. Aber während der Kriege konnte England auf Kosten der Gegner - Frankreich und zeitweilig, durch Napoleon gezwungen, Holland - sein neues, durch den Verlust Nordamerikas verletztes Weltreich (Kap, Indien, Kanada, Australien) neu und glücklich aufbauen. Bei einer ungeheueren Vermehrung der Bevölkerung unter Ge org III. (1760-1820) von 7,5 auf über 14 Millionen Menschen $\left.{ }^{2.1}\right)$ wurde die Technik für die Volkswirtschaft wichtig. Im r8. Jahrhundert sind die Kanäle zum Transport der Kohlen ausgebaut worden, um die Jahrhundertwende folgen die festen Straf3en (Mac Adam) und danach die Eisenbahnen, die auch wegen der Kohlen als gröfter Fracht gebaut wurden. Die Kohlengewinnung aus immer tiefer gehenden Schächten machte die Mühen um die Dampfmaschine wirtschaftlich. Ein grofzügiger und erfahrener Geschäftsmann wurde zum Partner Watts. In seinen Fabriken ( 400 Menschen Belegschaft) wurde bereits vor Watt auf eine gewissenhafte Ausbildung der Lehrlinge in Schulklassen geachtet. $W$ a $t$ t fügte die wissenschaftlichen Grundlagen hinzu, schaffte Zeichenbüros und technische Rechner. (Der Rechenschieber in seiner noch heute üblichen Form ist eine Erfindung Watts.) In der Firma von Boulton und W at war $M u r d o c b$ Maschinenmeister, und unter seiner Anleitung reifte als Lehrling der erste grofje Konstrukteur der Gasversorgungstechnik $S$ a m u el C l e g g heran.

Der Zug vom Lande in die Städte war gewaltig. London insbesondere wuchs in einem Maß̧e, das das Erstaunen und den Schrecken der ganzen Welt auslöste. Der n e u e Mittelstand der Techniker häufte während der napoleonischen Kriege Reichtümer $a^{2.1}$ ) in London auch noch durch den Handel (Kriegsgewinne?). So waren zwei Vorbedingungen für die ganz neue T'echnik der Gaserzeugung günstig; 1. dał̧ Geld Anlage suchte, 2. dał Verständnis für die Anforderungen einer verläßlichen technischen Ausführung bereits erarbeitet und die ersten Könner zu ihrer Verwirklichung vorhanden waren.

So sind die Pioniere des Gasfaches geradezu typische Vertreter der gesamten Technik der drei Länder:

Pbilippe Lebon ist der mathematisch, physikalisch gut gebildete Ingenieur (Akademiker).

William Murdocb, der aus der Praxis und Erfahrung kommende bedächtige Konstrukteur (Techniker) und

Wilbelm August Lampadius der Hochschulprofessor mit guten Verbindungen zur Jndustrie, hochgebildet, mit klarem Blick für die Anforderungen der Technik und Wirtschaft.

Unter Würdigung dieser Verschiedenheiten ist der bekannte Prioritätsstreit über die Taten des Franzosen und Engländers für jeden Ingenieur sinnlos.

Lebon erhielt im Jahre 1799 auf das Gaserzeugungsverfahren ein Patent. Murdoch

2.1) George Macauley Trevelyan: Geschichte Englands 1947, 2. Bd. S. 687, 694/95. München Oldenbourg-Verlag

38 
hat hingegen keine Patente genommen. James Watt hatte schlechte Erfahrungen mit Patenten gesammelt und setzte ganz auf das Pferd der Geheimhaltung als Schutz der eigenen Arbeit. Im Jahre 1802 hatte Murdoch die Fabrik zur Feier des Friedens von Amiens mit einer Gasbeleuchtungsanlage illuminiert. Beide Erfinder haben sich aber schon vor ihren Veröffentlichungen in langdauernden Versuchen mit Gaserzeugung befaf̧t. Das genaue Datum des Beginns dieser Arbeiten ist nicht bekannt, und so ist der Prioritätsstreit doppelt sinnlos.

Die beiden Ingenieure zeigen uns ein Schulbeispiel für die Anwendung beider technischen Möglichkeiten. Lebon hatte Schulen besucht, er begann im Laboratorium und ging dann zur technischen Ausführung über. Murdoch war zunächst Handwerker - als Oberingenieur bei Boulton und Watt deswegen erfolgreich, weil er Schwächen der Dampfpumpen James Watts im Betrieb auszugleichen vermochte.

Wenn man nun noch hinzunimmt, daf̧ über das Gas selbst schon länger in Laboratorien und auch in Anlagen Versuche vorlagen, so können wir sicher sagen, dał jeder der beiden Männer, der Franzose und der Engländer, als Ingenieur zur Entwicklung seine eigenen Gedanken hinzugetan habe. Lebon beschränkte sich auf die Entgasung von Holz; er klärte dabei technische Fragen der Reinigung und wirtschaftliche der Verwertung der Nebenerzeugnisse. Murdoch nahm für seine Anlagen Steinkohle und wies damit den Weg, der, zunächst zögernd und unsicher begangen, die Größe der heutigen Gasindustrie herbeigeführt hat. Der Einfluł der Persönlichkeit war in dieser Frühzeit so groł, dał eine nüchterne, nur die technischen Einzelaufgaben in ihrer fortschreitend besseren Beantwortung behandelnde Darstellung für diese erste Spanne nicht erfreulich gelingen will. Das ist auch gar nicht verwunderlich. Die Anfänger muß̧ten, gestützt auf sehr lückenhafte Berichte, unklare, oft aus der Theorie heraus falsche Vorstellungen und Begriffe und über abergläubische Anweisungen sich ihren Weg suchen. Konstruktive Erfahrungen waren nur ganz allgemeiner Art vorhanden, so etwa mit den Baustoffen, den Steinen, dem Holz, Guf̧eisen und Schmiedeeisen und mit einigen Buntmetallen. Für den Gasapparate- und Rohrleitungsbau mufte man aus dem eben entwickelten Maschinenbau Vergleiche heranziehen. Verarbeitungsmöglichkeiten waren noci unvollkommen und hochwertige Handwerkskunst entscheidend für Erfolg und Haltbarkeit. Sie war äuferst schwer zu finden. So muf̧te der Konstrukteur viel aus sich selbst heraus überlegen, was er erwarten konnte. Mit hohem Wagemut und neuschöpferischer Erfindungskraft muf̧te er ins Unbekannte vorstołen und dann erlernen, die $\mathrm{Be}$ währung zu beobachten, zu messen und Fehler mit ihren Ursachen zu finden. Das brachte in jener Zeit die angeborene Veranlagung und die selbsterworbene Fertigkeit entscheidend ins Spiel. Danach ist es angemessen, zunächst einmal Leben, Ausbildung und Denken der Ersten zu beschreiben, und danach erst in einer Zusammenfassung die technische Entwicklung aufzuzeigen. So kommen ganz von selbst zunächst eine Reihe von Lebensbildern. 


\section{II Lebon (Bild 2)}

Philippe Lebon wurde am 29. Mai 1767 in dem gemütlichen Hause geboren, das sein Vater Jean François Lebon, ein angesehener Staatsbeamter, in dem kleinen Dorfe Brachay in dem Bezirk Obere Marne besaf $\left.3^{9.2}\right)$. Der aufgeweckte Knabe ist in dem damals gewerblich sehr regen Bezirk herumgestreift und hat wohl auch die Köhler bei der Arbeit beobachtet. Schon früh zeigte er eine Neigung zum Studieren. Daher schickte ihn sein Vater nach Châlons-sur-Marne, wo er Zeichnen, Mathematik und Geschichte lernte. Am ro. April 1787, also 20 Jahre alt, trat er in Paris in die Ecole des Ponts et Chaussées ein. Nach der Lehre

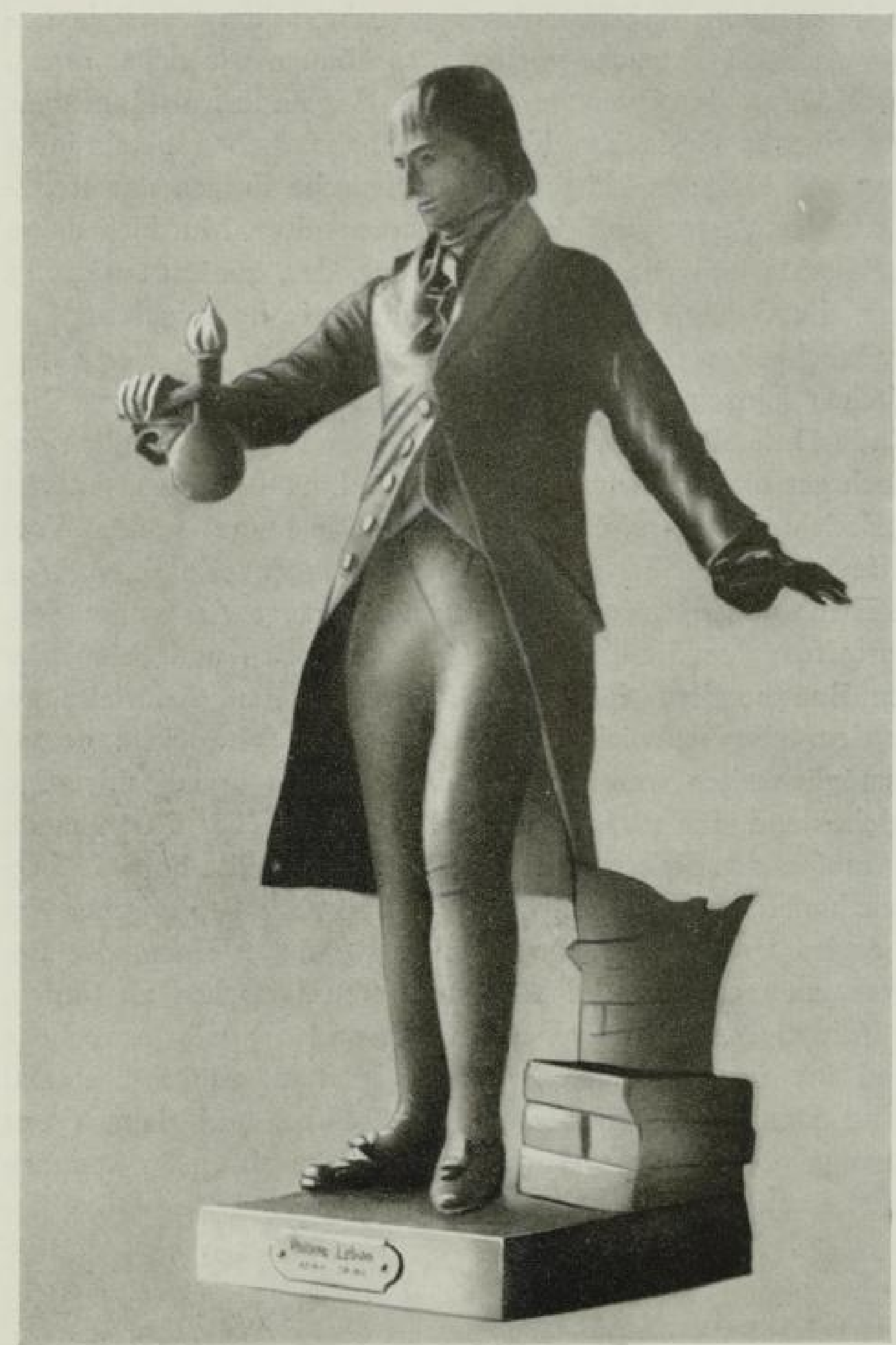

Bild 2

Philippe Lebon im Alter von 35 Jahren, 1767-1804 (Statue aus , Gaz de France Information " 15. Nov. 1954)

2.2) Gaz de France - Information 1954 No: 64, Notes documentaires. GWF 96 (r955), I4s

\section{SLUB}


wurde er sofort angestellt, nach und nach alle Wissenschaften zu lehren, die diese Schule pflegte. 1792 erhielt er im Wettbewerb einen Preis von 2000 Pfund, um begonnene Verbesserungen an der Dampfmaschine weiterzuführen.

Der „Ingenieur für Straßzen und Brücken" wurde in die Bezirksverwaltung von Angoulème versetzt, wo er sich, ein glückliches Leben vor Augen, verheiratete. Aber trotz der Ergebenheit seiner Frau begann ein Leben voller schwerer Erschütterungen. Zuerst waren es Schwierigkeiten mit dem Vorgesetzten, der nicht ohne Neid auf den begabten jungen Menschen sah. Dann kamen geldliche Verlegenheiten, weil die Wünsche die Einkünfte des Erfinders überstiegen. Längere Zeit beschäftigte Lebon die Wärmebehandlung von Holz in einem geschlossenen Gefäf, um ein Gas zu erzeugen, das für Beleuchtung und Heizung geeignet war. Bei einem kurzen Besuch um 1790 bei seinem Vater fand er pharmazeutische Glasblasen im Bodenraum, füllte sie mit Sägespänen und setzte sie in ein glühendes Kohlenbett. Er sah die dunklen Gase entweichen, verbrannte sich die Finger, als er die Glasblase anfassen wollte, umhüllte den Hals und die Öffnung mit einem nassen Lappen. Zu seiner Überraschung wurde der Gasstrom dabei klar und durchsichtig. Da zündete er ihn an und erhielt seinen ersten Gasbrenner.

Bei dieser Entdeckung blieb er nicht stehen. Er baute sofort in der Küche einen Ofen, fing das Gas unter Wasser auf und erhielt nunmehr eine stärker leuchtende Flamme. Nach längerer Zeit, während eines zweiten Besuches in der Heimat, nahm Lebon die Arbeiten mit einem vergröferten und verbesserten Gerät wieder auf. In einen Ofen aus Ziegeln setzte er eine metallische Muffel ein. (Bild 3) Er hatte, so sagt ein französischer Berichterstatter, das erste Gaswerk gebaut. Freudig sagte er zu den umstehenden Bauern: „Meine Freunde, ich werde Euch heizen und leuchten von Paris nach Brachay."

Indessen schien ihm seine Erfindung noch nicht vollendet zu sein. Er kam nicht von der Stelle, da seine Stellung als Ingenieur bei seiner Behörde gefährdet war. Eine Untersuchungskommission löste die Schwierigkeiten mit seinem Chef durch eine Versetzung. Sie sandte ihn nach Montargis nahe bei Paris, wo er die Unterstützung von Freunden fand. Er konnte eine bescheidenes Laboratorium für Versuche bauen und erhielt 1799 sein Patent, lautend auf ,neue Wege, um Brennstoffe besser auszunützen, sei es zur Wärmeerzeugung, sei es zur Beleuchtung. und dabei verschiedene Wertstoffe zu gewinnen". Sein Gerät nannte er Thermolampe, die er der Öffentlichkeit als Haushaltsgerät vorstellte, überzeugt, daf er eine technisch wertvolle Erfindung gemacht hatte, die einen wirtschaftlichen Kampf auslösen mußte.

Als entscheidend für die günstige Verwendung des Gases erkannte er dessen leichte Fortleitungsmöglichkeit, die Verteilbarkeit nach mehreren voneinander nach Größ̧e und Örtlichkeit unabhängigen Verbrauchsstellen und die Regelbarkeit.

In einer Niederschrift vom August 180I, die auch in Deutschland weit verbreitet wurde, sagte er: „Durch eine ebenfalls leicht herstellbare Verteilungsanlage kann ein einziger Ofen alle Feuerstätten eines Hauses beliefern." - Hier sind auch schon von Lebon die heute noch gebrauchten Werbeworte kurz zusammengefafit $\left.{ }^{2,4}\right)$.

a.7) Journ. des Usines a Gaz 78 (1994) Nr, 12 S. 441 


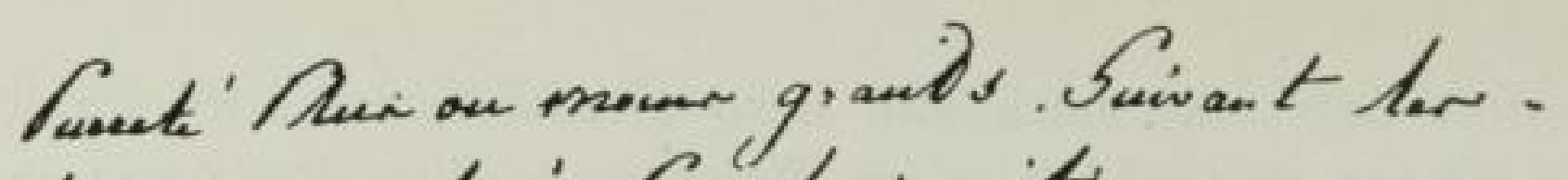
Mrymer emplayo' Kour a puifur

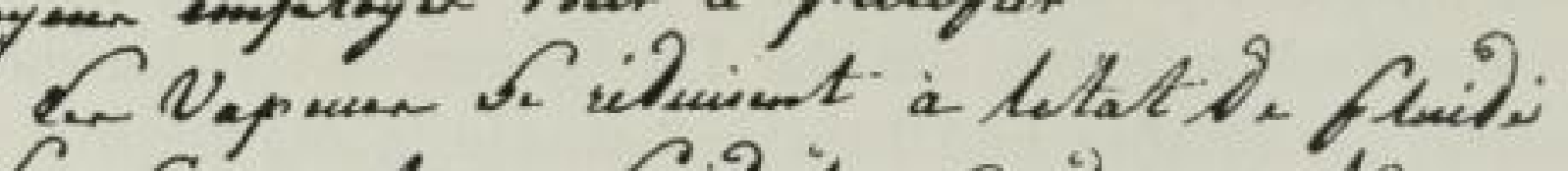

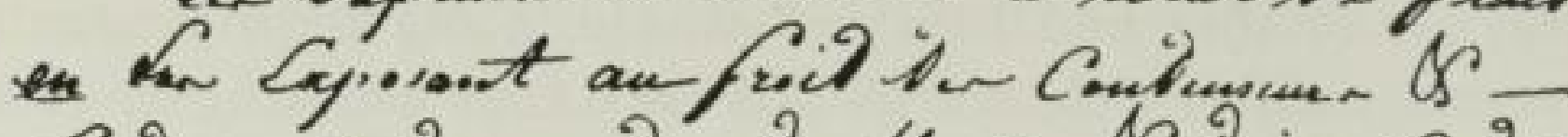

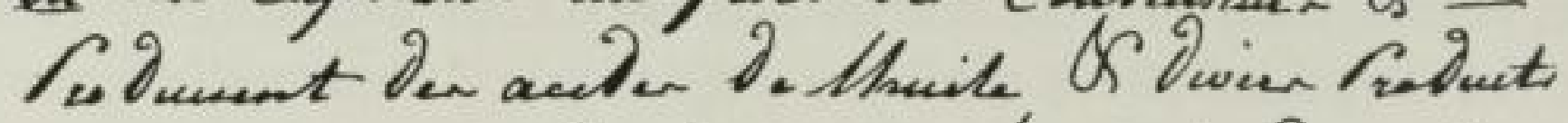
awaloguen aux Combuctibler emplay in Demente

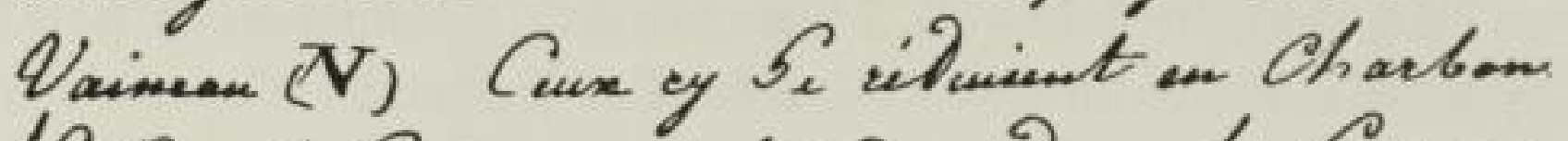

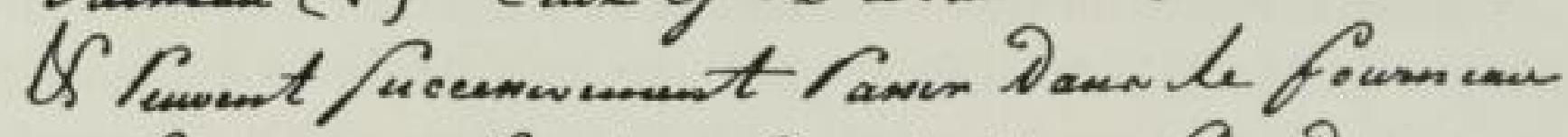
T. Vour opiner, Var huer Countuation. Suer D.

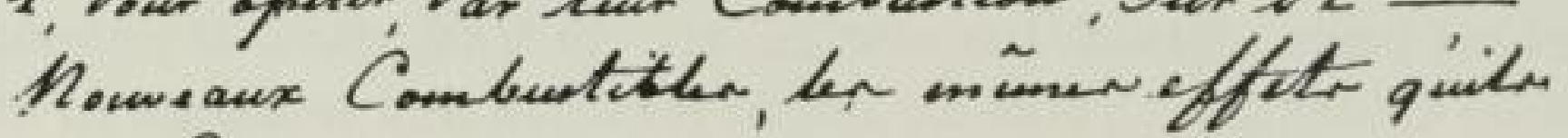

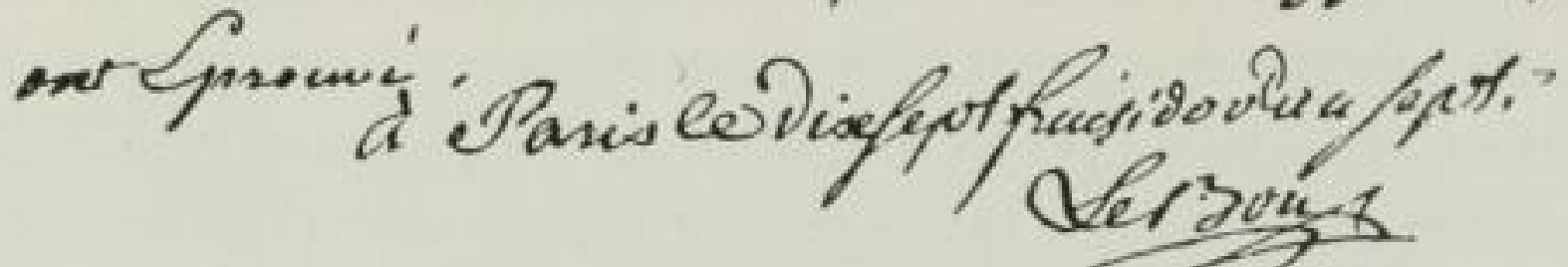

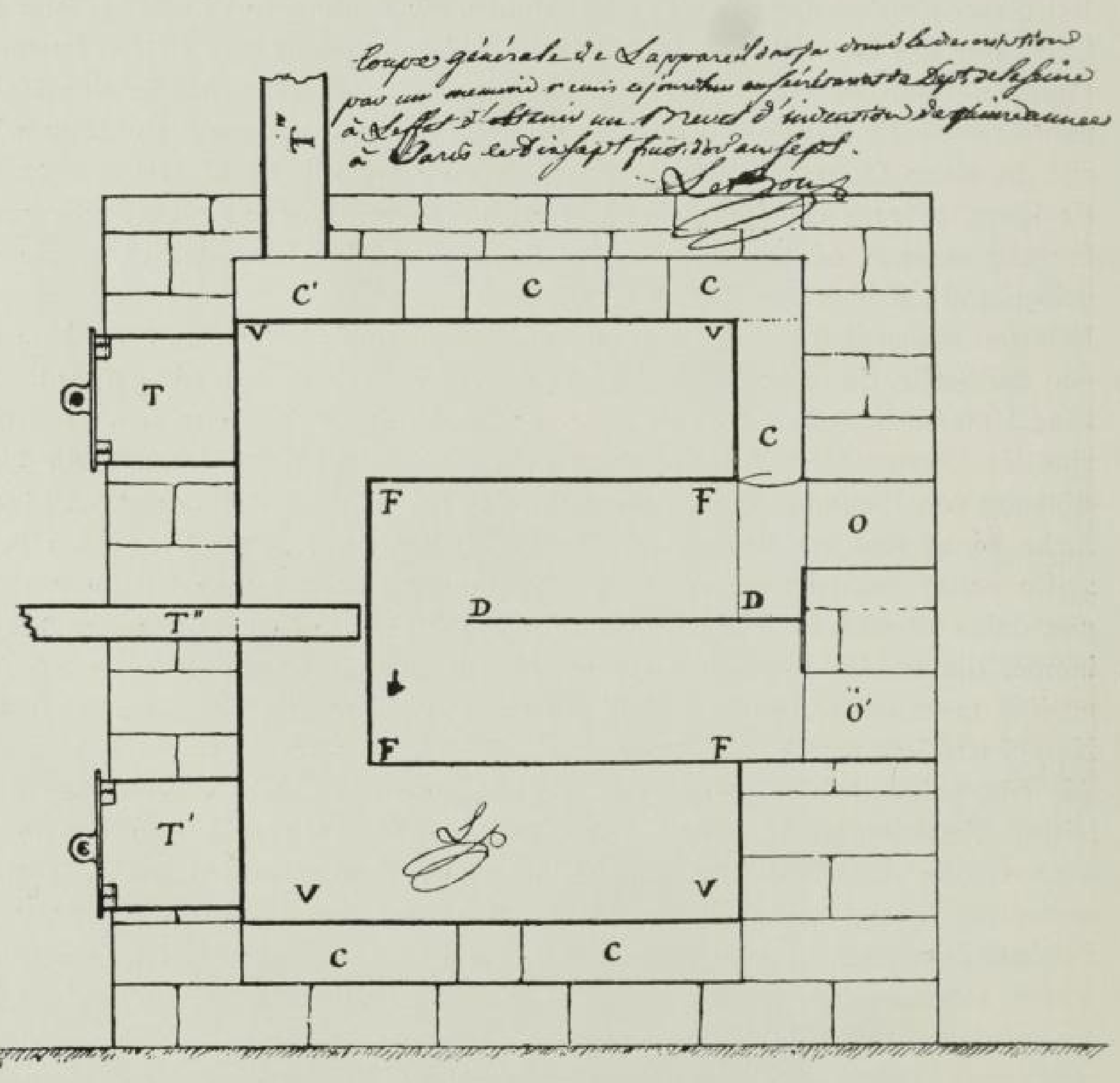

Bild 3 Zeichnung Lebons über die Thermolampe in der Patentschrift von 1799 mit U-förmig liegender Retorte F; Feuetraum V; Schüröffnung T; 'TI Schieber TII Gasabzug C TIII (Gaz de France Information 15. Nov. 1954)

SLUB 
Um den Beweis anzutreten, dał grołe Hausanlagen möglich seien, richtete er in einem vielbesuchten Gasthaus, dem Hôtel de Seignelay, eine groß̧e Anlage her und verteilte das Gas durch Leitungen im Treppenhaus und in den Gesellschaftsräumen. Der Erfolg war überraschend. Die Menge drängte sich, um das neue Licht zu sehen trotz eines Eintrittspreises von 3 frs.

Lebon wollte noch alles verbessern und die Verwendung ausbauen und hielt mit weiteren Anlagen zurück. Aber er griff zunächst nach dem wirtschaftlich günstigsten Teil, der Herstellung und Lieferung von dringend benötigtem Holzkohlenteer für die Konservierung von hölzernen Schiffen. Im Walde von Rouvray, nahe bei Rouen, errichtete er ein Holzentgasungswerk. Die Kriegsmarine nahm ihm den Teer ab, das Gas benutzte er zur Heizung der Öfen. Das Fabrikgebäude, eine kleine Holzfällerhütte, wurde jedoch durch einen Sturm des Daches beraubt, später fiel es einem Brand ganz zum Opfer. Lebon stand ohne Mittel da, aber er gab nicht auf, sondern verlegte seine Anlage nach Marlay in die Nähe von Paris. Dort arbeitete er wirtschaftlich und dachte daran, seine Familie zu sich zu nehmen.

Bisher wurde über das Ende Lebons eine sehr dramatische Schilderung gegeben. Er habe, so hief3 es, am 2. Dezember 1804 an den Feiern zur Salbung Napoleons zum Kaiser teilgenommen. Nach dem Feste sei er am nächsten Morgen, von 13 Dolchstichen getroffen, ermordet in den Champs-Elysées aufgefunden worden. Seine Wohnung sei anscheinend geplündert gewesen und kein Blatt seiner Arbeiten hätte sich vorgefunden. Aber nach Durchforschung der Dokumente über seinen Tod hat sich herausgestellt, daf Lebon am Morgen des 3. Dezember in seinem Quartier gestorben ist und zwar an Erschöpfung, als Opfer seiner unermüdlichen Arbeit bei Tag und Nacht ${ }^{2.4}$ ).

So endete viel zu früh das Leben des Forschers und Ingenieurs, der sich mit der notwendigen Beharrlichkeit die Aufgabe gestellt hatte, die Herstellung des Gases und die Verwendung ihrer Erzeugnisse technisch-wirtschaftlich auszuwerten. Hätte er länger gelebt, so wäre vielleicht von ihm aus in Frankreich unmittelbar die Entwicklung des Gasfachs in Gang gekommen. So aber war seine Bestattung die eines Armen - bezahlt wurde sie von einem Freund. Nach o Jahren konnten die Seinigen die Grabmiete nicht mehr aufbringen, und so wurde seine Grabstelle eingeebnet. Auf dem Friedhof, auf dem sich die Gedenktafeln für Marschall Ney, Murat und andere Grofe des Kaiserreiches befinden, gibt eine Pyramide Kunde von Winsor als dem Gründer der Stadtgasbeleuchtung von Paris. Nur dank dem Mute der Witwe Lebons, die in einer Zeit, als Frauen nicht berufstätig zu sein pflegten, als Chemiker, Ingenieur, Industrielle und Leiterin eines Gaswerkes das Werk des Verstorbenen fortführte und eine Veröffentlichung im Jahre $18 \mathrm{II}$ an die Société d'encouragement „Memoiren über die Holzdestillation" niedergeschrieben hat, ist das Werk Lebons dem Gedächtnis erhalten geblieben.

2.4) Journ, des Usines à Gaz 79 (1955) S. $8 / 10$ 
Indessen ist festzustellen, dał die Konstruktion der Thermolampe in Deutschland grofes Aufsehen erregt hat. Den Beweis liefert Zacharias Andreas W in zle r, der freien Künste und Weltweisheit Doktor, Eigentümer einer $k$. und $k$. authorisierten Salpeter-Plantage zu Znaim in Mähren in seinem Buche: „Die Thermolampe in Deutschland oder vollständige, sowohl theoretisch als praktische Anleitung, den ursprünglich in Frankreich erfundenen, nun aber auch in Deutschland entdeckten Universal-Leucht-, Heiz-, Koch-, Sud-, Destillier- und Sparofen zu errichten ${ }^{6.25}$ ). (Bild 4 )

Winzler ist sicher nicht derselbe Mensch, der sich Friedrich Albert Winzer und später Winsor nannte, wie es heute im englischen und französischen Schrifttum angenommen wird. Die Verwechslung tritt anscheinend zuerst auf in der Neuarbeitung des technischen Wörterbuches von KarmarschHeeren durch Friedrich Kick und Wilhelm Hintl ${ }^{2.0}$ ). Hier wird erzählt, wie Winzler an mehreren Orten Vorführungen gemacht habe und dann auch nach London gekommen sei. Von hier hat offenbar Brockhaus 1884 seine Informationen für das Conversations-Lexikon ${ }^{2.7}$ ) übernommen und zur Verbreitung beige$\left.\operatorname{tragen}^{2.5}\right)$. Karmarsch führte 1872 noch beide Männer getrennt aut ${ }^{2,5}$. .

Winzler, der, wie der Titel seines Buches sagt, Eigentümer der SalpeterPlantage in Znaim, also dort örtlich gebunden war, berichtet auf S. 20 seines Buches: „Nach Vorbereitungen deliberierte man über die Art, wie wir von dieser Vorrichtung (Thermolampe) öffentlichen Gebrauch machen sollten. Es in publiken Örtern, Hörsälen, Schauspielhäusern zu tun, würde unserer Bemühung, nützlich zu sein, einen Anstrich von Marktschreierei gegeben haben. Auch schien uns der rohere Teil des Publikums gar nicht dazu geeignet, weder Geschmack an der Sache zu finden, noch ihren Gehalt hinlänglich würdigen zu können. Wir wurden daher einig: blof̧ den gebildeten Teil des Publikums, vorzüglich aber Gelehrte, und den hohen Adel, sehen, prüfen und entscheiden zu lassen. Meine Wiener Freundic gingen nun voraus, um Zubereitungen zu machen, und ich folgte ihnen am 13 . April 1802 in Begleitung meines bekehrten Ungläubigen (einem Freund, der zunächst das gröfte Miftrauen gezeigt hatte) ebenfalls nach der Kaiserstadt, in welcher wir aus Gründen von Wichtigkeit zuerst die Experimente mit der Thermolampe machen wollten." Sie wurden dann in einem nur zum Teil bewohnten Hause eines Grafen v. F. ausgeführt. Eine Bekanntmachung erfolgte am 5. Mai 1802 in der Wiener Zeitung S. 1630.

F. A. Winsor dagegen sagt in einer ,Notice historique sur l'utilisation du gaz hydrogène pour leéclairage" vom Jahre 1816 , dał̧ er schon seit 1785 in London Entgasungsversuche angestellt habe. „Meine Geschäfte brachten mich I8O2 (von

\footnotetext{
9.5) Brünn 1803, bei Franz Karl Siedler. (Ein Original befindet sich in der Büchstei der T. H. Wien)

2.6) $84(1941), 698$; Karmarsch-Heeren, Technisches Worterbuch 3. Auf. Bd, 5. Prag 188x S, 421

2.7) Brockhaus Conversationslexikon 15. Ausg. Leipzig 1884, Abschnitt Gasbeleuchtung

2.5) Die geschichtlichen Daten der Uberarbeitung des. Worterbuches sind indessen nicht sehr vertrauens. wüdig. So wird im Gegensatz zur 1. Auflage des Buches auch die Tatigkeit Murdochs historisch falsch entwickelt. Er habe in Cornwall Versuche angestellt, derentwegen er mit Boulton \& Watt bekannt geworden sei, so dass er 1898 in diese Firma eingetreten sei. Die Dokumente, die Murdoch selbst geliefert hat, zeiger aber, dass er von Boulton \& Watt nach Cornwall entsandt war

9.9) Karmarsch, Geschichte der Technologie, Bd, 11, 1872, S. 852 (Bücherei der T. H. Hannover)
} 


\section{D ie \\ TEer molampe \\ in \\ $\mathfrak{D} \mathfrak{e} \mathfrak{t} \mathfrak{\mathfrak { d }} \mathfrak{I} \mathfrak{a} \mathfrak{n} \delta$ \\ Doer:}

vollftánbige, fownbl theoretifd) als praftiche Znleitung, ben ur(pringlid in granfreid) ets fundenen, nun aber aud) in Deut(d)lano entoeften

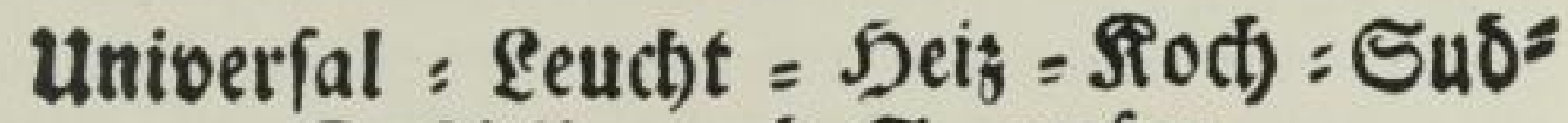
Deftillir = uno Sparofen ju erridten.

Mit vier Rupfertafeln.

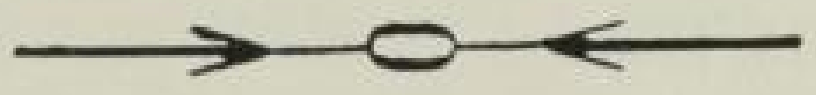

Entoedt und verfact

o o $n$

Zad). 2tndr. $\mathfrak{B}$ inzler,

Der frenen Rinfte und ber Beltweisbeit Doftor, au $\phi$

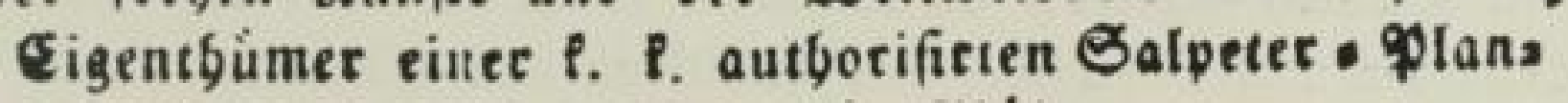
tage zи Suaim in Mábren.

Bild 4

Titelblatt der ersten deutschen Abhandlung über Gaserzeugungsanlagen

(Original in der

T. H. Wien)

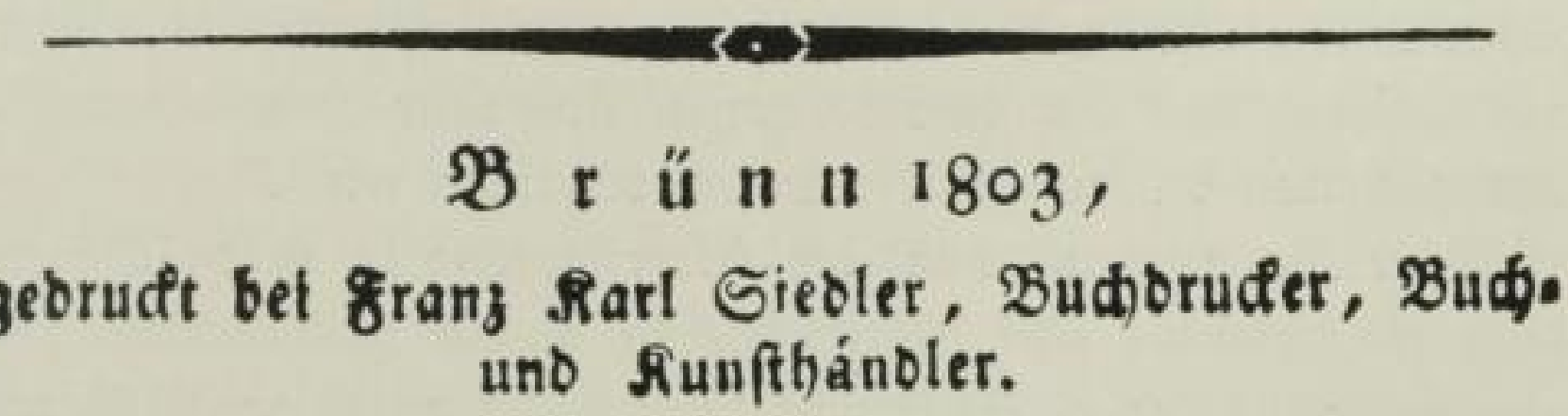
uno funfthánoler.

London) nach Paris zurück. Ich wurde in einen Raum geführt, der von Lebon mit Gas beleuchtet wurde. .... Am 3. April 1802 verlieł ich Paris. Einige Monate später indessen, in Braunschweig geschäftlich festgehalten, baute ich einen Beleuchtungsapparat, der die Anerkennung des verstorbenen Herzogs und 
seines ganzen Hofes fand. Mein erstes Flugblatt über diese Erfindung wurde mit seiner Genehmigung diesem Fürsten gewidmet."

Diese Terminangaben genügen wohl, aber da sich der Irrtum sehr tief eingefressen hat, sei noch bemerkt, dafy zwar beide Schriftsteiler davon sprechen, wie Freunde die Konstruktion nachgeprüft und sie mit der Lebons als gleiches Licht gebend bezw. gleich befunden hätten, Winzler aber benutzt sie, um Steinkohle zu „entschwefeln“, während Winzer ausdrücklich sagt, dał er 1802 wie Lebon Holz verwandt habe. Schlieflich ist es unwahrscheinlich, dafy ein Winzler bei der Anglisierung seines Namens das 1 fortgelassen und die Vornamen verändert hätte. Auch dał er den Dr-Titel später verschwiegen hätte, ist seiner ganzen Art nach unmöglich anzunehmen. Nachforschungen nach den Taten Winzers in Braunschweig sind leider erfolglos geblieben.

Für die Geschichte der Gastechnik ist die Klarstellung insoweit von Wichtigkeit, als man Winzler ein sehr sorgfältiges Bemühen um eine objektive technische Darstellung zubilligen muf, während Winsor mit seiner Werbung, wie wir später sehen werden, recht anfechtbare Behauptungen aufgestellt hat. Es wäre also nicht gut, die Ausführungen Winzlers mit den späteren Äuf̧erungen Winzers zu belasten. Winzler bringt auf S. 173/74 seines Buches eine Würdigung Lebons: „Es ist nicht die Arbeit eines mutwilligen Feuerkopfs, der seine Glut nur auf fremde Kosten unterhalten will. Daß ihn aber auch nicht Selbsttäuschung zu irgend einem leeren Phantom mit fortrif̧, dafür bürgt der ruhige, sachgewisse, durchaus systematische Gang seiner ganzen kleinen Abhandlung. Wie dankbar benimmt er sich gegen seine Lehrer! Wie liebenswürdig an der Seite eines Chaptals, Fourcroi's, Vauquelins? Wäre er in einem so hohen Grade Chemiker gewesen, wie diese grof̧en Männer, er würde mir selbst und anderen über die Thermolampe nichts mehr zu sagen übrig gelassen haben. Indes hat er über das Verbrennungsgeschäft in der Natur wirklich so viel Licht verbreitet und überhaupt der Nachwelt zur Vervollkommung des Heiz- und Beleuchtungssystems in einerr so hohen Grade vorgearbeitet, daf es nun ein leichtes werden muf, an diesem Leitfaden das grołe und wichtige Problem zu lösen, mit dem Entwicklungsgrundstoff von Wärme und Licht nach den Gesetzen der höchsten Sparsamkeit und Zweckmäß̧igkeit umzugehen. Endlich laß̧t uns doch, ihr Grübler, Kenner, Zweifler und Forscher, nur geradezu mit deutscher Aufrichtigkeit gestehen, dafy wir alle noch mit keiner Thermolampe vertraut geworden wären, hätte nicht Mutter Natur den Bürger Phil. Lebon dazu ausersehen, uns dieserhalb aus dem Schlummer von mehreren Jahrtausenden zu wecken - ein Geständnis, das ihn auf einmal und für immer gegen das sehr gewöhnliche Schicksal, von seinen Zeitgenossen verkannt zu werden, schützen wird."

Winzler hat noch 1802 in der Alserkaserne in Wien die erste Gaserzeugungsanlage eingerichtet und betrieben. In einem gemauerten Herd war eine Retorte eingebaut, in der er Holz und Steinkohle entgaste. Während der Herdbenutzung konnte gleichzeitig Gas erzeugt werden. Dieses wurde zur Reinigung in ein mit Kalkmilch gefülltes Gefäß̧ geleitet und in einem blasebalgartigen Behälter aufbewahrt oder, bei der gewerblichen Anwendung, unmittelbar durch Blechrohre den Verbrauchsstellen zugeführt ${ }^{2.10}$ ).

2.10) Z. d. Osterr. Gas und Wasserfachm. 71 (1931) S. 101 
Winzler ermöglicht uns auch einen Einblick in die lebhafte Beschäftigung der Deutschen mit Lebons Erfindung. Eine Kritik an den verschiedenen Arbeiten scheint diese in sachverständiger Weise zu würdigen. Lob und Tadel wechseln sich ab. Der Erscheinungsort ist jeweils genau angegeben. Zunächst stellt er fest, dafy die Veröffentlichung Lebons aus dem Jahre 1801 sehr viele Bearbeiter angesprochen habe $\left.{ }^{2.11}\right)$. Er gibt dann eine Auswahl der wichtigsten Werke: von Joh. B. Wenzler, Passau 1802. Giers $c b$ aus Harzgerode, Me inert, Prag, Rat Andre, D. F. Kretscbmer zu Sandersleben, Nordenscöld, Göttling, La mpadius, über den später berichtet werden muf, und F re n$z \mathrm{el}$. Zusammenfassend sagt er, man habe ihm zugeflüstert, daf̧ damals 200 Physiker damit beschäftigt gewesen seien, die Thermolampe nachzuerfinden. Sprinzl, Wien hat noch folgende Nacherbauer der Lebonschen Thermolampe ausfindig gemacht $^{219}$ ): Wagner, Salzburg, J. Jaf̧niger und Apotheker Moser, Wien, 1816 richtete der Ziegeleibezitzer J. G. $B i b l$ in seinem Hause Gasbeleuchtung ein. Sein Sohn Ernst führte die Gasbeleuchtung der Kesslerschen Maschinenfabrik Esslingen 1827 aus $^{5.12}$ ).

La mpadius hat bereits 1799 im Schlof zu Dresden dem Kurfürsten eine Thermolampe vorgefïhrt. Das war also noch vor der Zeit, als die Veröffentlichung Lebons die allgemeine Aufmerksamkeit wachgerufen hatte. 1802 wurden alles in allem bereits s solcher Lampen in Dresden an verschiedenen Stellen zur Schau gestellt. Aber immer noch wurden dort die Versuche, wenn auch nicht mehr als Spielerei, so aber doch als Jahrmarktsschauobjekt betrachtet, mit dem man sein Geld verdienen konnte ${ }^{2.13}$ ).

Winzler hat sich vor den Versuchen mit der Theorie auseinandergesetzt. Dieser Teil seines Werkes ist heute schwierig zu verstehen. Er faf̧t Wärme und Licht als Körper auf, die er dem Sauerstoff, Wasserstoff, Kohlenstoff (nicht unter den brennbaren Körpern genannt), Pflanzenlaugen, Kalkerde, Stickstoff, Phosphor, Minerallaugensalz, Schwefel, Metallstoff und dem allgemeinen primitiven Erdstoff gleichsetzt. War er auf der Höhe der chemischen Kenntnisse?

Angeregt durch eigene Versuche und eine Unterredung mit Priestley über dessen "dephlogistierte Luft" $=$ Sauerstoff, hatte Lavoisier am 25.4.1775 seinen umstürzenden Vortrag gehalten über „Über die Natur des Prinzipes, welches sich mit den Metallen bei ihrer Verkalkung verbindet und ihr Gewicht erhöht". Aber es hat noch Jahre gebraucht, ehe die Erscheinungen der Wärme und des Lichts von den überkommen Vorstellungen eines besonderen Wärmestoffes freigemacht wurden. Gegen Ende der achtziger Jahre konnte Lavoisier die alte Phlogistontheorie als völlig überwunden betrachten und seine Oxydationstheorie entwickeln. Aber selbst noch in seinem zweibändigen Lehrbuche aus dem Jahre 1789 „Traité élémentaire de Chymie, présenté dans un ordre nouveau et d'áprès découvertes modernes" brachte er unter den Elementen auch noch Licht und Wärme als gewichtslose Grundstoffe, die dem Sauerstoff zuge-

2.11) Eine ausführliche Würdigung der ersten Obersetzung der J. M. Daisenbergerschen Buchhandlung in Stadt am Hof bei Regensburg findet sich in N. H. Schilling. Geschichte der Gasbeleuchtung in Bayern (J. f. G. $30(1887)$ S. 383 )

2.12) $39(1896), 31$

2.12) Dr. G. C, Rudolf Blochmann, Rudolf Sigismund Blochmann VDI-Verlag Berlin NW 7 1939 (im Besitz der Bücherei der T. H. Darmstadt) 
ordnet sind. Aber nun ist alles umgekehrt: Trennung (von Phlogiston) war nun Vereinigung (mit Sauerstoff) und Vereinigung wurde Trennung. 1792 wurde Lavoisiers Werk von S. F. Hermbstädt (1760-1833), Hofapotheker und Professor der Pharmacie, der sich auch mit Lebons Thermolampe beschäftigt hat, ins Deutsche übersetzt. Indessen setzte sich die neue Anschauung nur langsam durch. Wir sahen bereits, wie Lapostolle an ihr im Alter zerbrach. Die letzten Phlogistiker wurden mit L. F. v. Crell (I816) und A. J. Retzius (182I) zu Grabe getragen ${ }^{2.14}$ ).

Man kann dem alten Praktiker Winzler keinen Vorwurf machen, daf er 1803 diese ganzen noch etwas schwierig zu verstehenden Theorien in dem Bemühen, sich volkstümlich auszudrücken, undeutlich gebracht hat.

Umso mehr aber fesseln uns heute noch Winzlers technische Urteile. Sein Interesse führte davon her, dał er in der Salpeterplantage seit Jahren ,unabgeschwefelte" Steinkohle hat verwenden lassen und die Abdünstungen sehr lästig dabei wurden.

Auffallend ist, daf er bei Betrachtung der Wirtschaftlichkeit der Thermolampe den Unterfeuerungsaufwand gar nicht erwähnt, offenbar weil cr sich die Retorte in einem Kachelofen zur Zimmerbeheizung eingesetzt vorstellte. Immerhin wird eine Wahrheit festgehalten, dał bei der Verbrennung roher Kohle im Rauch sehr nützliche Nebenprodukte verschwendet würden.

In einer etwas primitiven und deshalb nicht in allem verständlichen Zeichnung gibt er eine einfache Anlage wieder ohne Gasbehälter, offenbar seine erste Versuchsanlage für die Vorführungen. Denn in einer besseren und textlich erklärten Darstellung eine Anlage mit Retorte, Waschfał, Balgengasbehälter und Verbrennungsofen. (Bild 5) Über diese Einrichtungen verschiedenster Art folgt dann noch eine besondere Tafel.

Über die Anfertigung der Teile ist nichts gesagt. Dagegen beschreibt er die Sicherheitsanforderungen: Dichtheit der Rohre, Inbetriebsetzung mit Ausschluf der Bildung explosibler Gemische im Innern und ähnliche Maf̧nahmen. Auch über die Verbrennung im geschlossenen Raume mit Luftzuführung durch ein konzentrisch durch das Gasrohr gelegtes Rohr zur Vermeidung der „Knallgasbildung" zerbricht Winzler sich den Kopf.

Für Winzler ist das erzeugte Gas schlechthin Wasserstoff. Bei Vorschlägen zur Verbesserung spricht er indessen von der Möglichkeit, den Flammenglanz durch Kohlenstoff (Kunstname sei gekohlter Wasserstoff) zu erhöhen. Er weist auf die Wichtigkeit hin, den Brenner besser durchzubilden und lobt den Argandbrenner, wie er bei Öllampen bekannt war, als nachzuahmende Konstruktion (die in England bereits begonnen war).

Die Aufzählung der Vorteile der Entgasung ist etwas verwirrend. Fr glaubt, wegen der Reinheit des Gases für alle Gasfeuerungen ohne Abzug auskommen zu können. Er erwähnt die Beseitigung der Rauchplage und vor allem den Wert des Kokses als metallurgischen Brennstoff. Heute noch zeitgemäß ist im Abschnitt über die Nebenprodukte die Feststellung, daf Gas und Koks als Haupterzeugnisse zu werten seien. Ja, er spricht es aus, dafy das Ideal sei, eine Anlage für ganze Städte zu errichten. Mit diesem Gedanken ist er seiner Zeit weit voraus.

2.14) Georg Lockemann: Geschichte der Chemie, Sammlung Göschen Bd. 265a 1955, S. 8-11

$4^{8}$ 


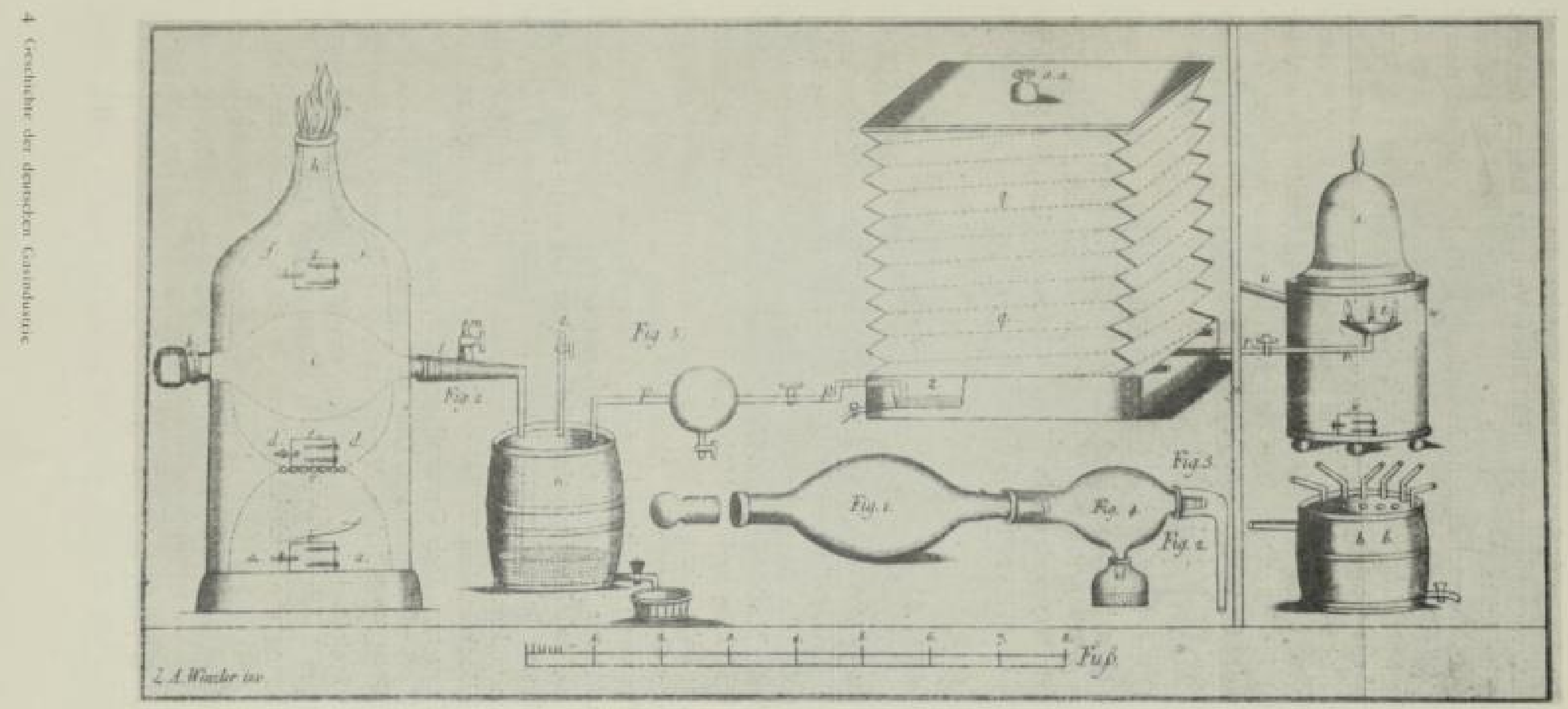

Bilds Z. A. Winzlers verbesscte Gasbercitungsanlage (Original in der T. H. Wien)

6

\section{ㄱ SLUB}

Wir fuhren Wissen. 
Die mit seinem Leucht- und Sparofen, wie Winzler die Thermolampe aut Deutsch genannt hat, vorgenommenen öfentlichen Vorträge fanden Anklang. Das veranlaf̧te ihn, im Jahre 1804 um die Verleihung eines Privilegii exclusivi zur Ausbeutung seiner Thermolampe nachzusuchen ${ }^{2.15}$ ). Es ist wohl gut darauf hinzuwcisen, daf solche Privilegien in der streng vom Staate im Rahmen des Schutzes der Zünfte beaufsichtigten Wirtschaft nicht die Bedeutung von Patenten hatten. Winzler hatte niemals verheimlicht, daf3 er den Gedanken von Lebon übernommen hatte. Er betonte auch in seinem Buche seine Befähigung, den Nachbau richtig vorzunehmen und hielt darum ein Bauprivileg (meist in einem beschränkten Gebiete) für berechtigt. Das Gas für die Beleuchtung der Deymschen Kunstgalerie, der Staatlichen Salmiakfabrik in Nußdorf, der Kattunfabrik in Kettenhof und einiger anderer Betriebe wurde mit seinen Apparaten erzeugt $\left.^{2.16}\right)$.

Wenn man diese Ubersicht über den Stand des Wissens gewonnen hat, muf man bedauern, daf einmal der so befruchtend wirksame $L e b o n$ durch seinen frühen Tod aus der Arbeit gerissen wurde und Winzler offenbar nach der Veröffentlichung das Interesse verloren hat. Vermutlich waren ihm die Schwierigkeiten bei der Ausführung zu groł und die weitere Verfolgung zu kostspielig ${ }^{2.17}$ ).

\section{I3 Murdocb (Bild 6)}

William Murdoc ${ }^{2.18}$ ) wurde 1754 in Ayrshire, Schottland, geboren, in einer romantisch gelegenen, einsamen Mühle, die sein Vater John betrieb. Schon der Vater zeigte technische Begabung. Er baute ein Rad mit Eisenzähnen für Dr. J. Ro eb u $c k$, der für 6 bis 7 Jahre Watts Versuche mit der Dampfmaschine finanzierte. Uber Erziehung und Ausbildung des Sohnes wissen wir nichts. Erzählungen gibt es, er habe schon als Kind in einem Teekessel Kohlen gebacken und das entwickelte Gas entzündet. Aber hier dürfte es sich wohl um eine freundlich nacherfundene Geschichte handeln, ebenso wie die, die den Knaben James W a $t$ an Mutters Teekessel die Kraft des Dampfes beobachten lassen will. Glaubhafter ist, daf3 Murdoch einen Selbstfahrer für seine Schulwege als erstes Dreirad gebastelt habe. Als ganz junger Mann hat er eine Brücke über den Nith entworfen und gebaut. Mit 23 Jahren machte er sich auf die Wanderschaft und bat bei Boulton, dem Teilhaber Watts, in Soho um eine Anstellung. Von diesem wurde er 1779 nach Cornwall geschickt, um die Pflege der Wattschen Dampfmaschinen zu übernehmen. Dort blieb er bis 1798. In seiner Freizeit beschäftigte er sich mit technischen Versuchen verschiedenster Art. Arbeiten an einer Dampfstraf3enlokomotive wurden ihm von Watt untersagt, weil dieser von den notwendigen hohen Drücken nichts wissen wollte. 1791 nahm er ein Patent auf die Röstung von pyritischen Erzen in einer geschlossenen Retorte 
Bild 6

William Murdoch

$1754^{-1839}$

(Gemälde aus

"Murdoch Centenary Lecture")

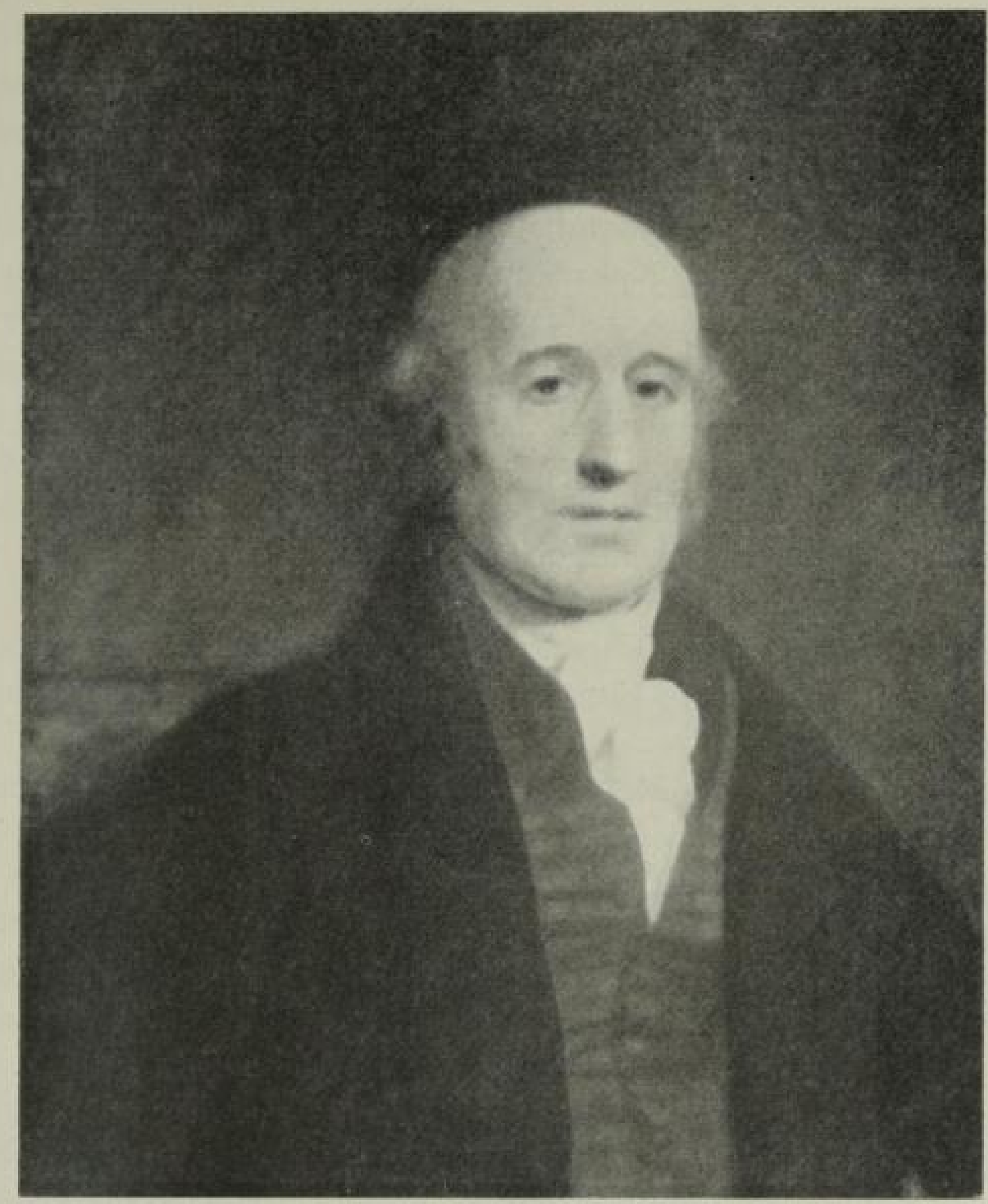

zur Erzeugung von Vitriol, Farbstoffen und Mitteln zum Schutze von Schiffsböden. Diese Arbeit hat ihn auch zur Entgasung von Kohlen geführt. Er soll sein Haus in Redruth im Jahre 1792 mit Gas beleuchtet haben, wahrscheinlich mit einer einzigen Flamme. Der Gaserzeugungsofen war auferhalb des Hauses aufgestellt und ein kurzes Rohr durch das Fenster in das Zimmer eingeführt. Ein Patent hat er hierfür nicht genommen. Seine Arbeit wurde zunächst nicht weiter verfolgt, da Watt gegen solche „Ablenkungen“ eingestellt war. Als Watt aber um 1800 ausscheiden wollte und Murdoch vorbereitend seit 1798 mit der technischen Verantwortung der gesamten Firma betreut wurde, nahm Murdoch die Arbeiten wieder auf. Während eines Besuches in Paris lernte Gilgory W a $t$, der älteste Sohn James Watts, im Jahre 1801 die Versuche Lebons mit Holzentgasung kennen. Sein Bericht hat James $W$ a $t$, den Jüngeren, veranlafyt, durch die Firma Boulton \& Watt die Kohlenentgasung verstärkt bearbeiten "u lassen $^{2.18}$ ).

Zunächst wurde die Gaserzeugungsanlage in Soho eingesetzt und aus Anlaf des Friedens von Amiens im Jahre 1802 die Fabrikanlage der Firma Boulton \& Watt illuminiert. Mit einer festlichen Außzenbeleuchtung trat die Firma zum

2.19) Zeugenaussage: J. Watts jun. im Streit gegen Winsor. Abgedruckt bei W. Matthews: An historical sketch of the Origin. Progress and Present State of Gas Lighting London Rowland Hunter 1827 Anhang D: S. 314

\section{SLUB}


ersten Male mit dem neugeschaffenen Geschäftszweig an die Offentlichkeit.

Nach alten Bildern ist die Retorte ein gröf̧erer guß̧eiserner Topf gewesen, der nach Art eines Tiegels in den gemauerten Ofen mit Planrostfeuerung eingesetzt war. (Bild 7) Die Ladung mit Kohle und die Entladung des Kokses geschah, wie bei einem Tiegel für Metalle, von oben. Daß̧ das trotz der vorgesehenen Winden mit dem glühenden Koks eine beschwerliche Arbeit war, ist ohne weiteres klar. Man kann vermuten, daf die Gasbereitung zunächst nicht dauernd betrieben wurde, sondern der Ofen nach jedem Einsatz etwas crkaltete. Trotzdem bleibt die. Arbeit schmutzig und schwierig. Der Aufbau war also gegen Le bon mit seiner waagerechten U-förmigen Retorte zunächst ein Rückschritt ${ }^{2.90}$ ).

Als zweite Form wurde eine flaschenartige gufyeiserne Retorte als Tiegel benutzt, die das Gasabgangsrohr oben unterhalb des Deckels und unten einen Stutzen zum Ziehen des Kokses hatte.

Dann folgte eine Schrägretorte mit $45^{\circ}$ Neigung, die wegen der dichten Lagerung der Kohlen in der Retorte bei fehlender Gasabsaugung keine guten Ergebnisse hatte.

Die nunmehr von Murdoch angegebene waagerechte Retorte hatte bereits die Gebrauchsform, die für hundert Jahre beibehalten worden ist. (Bild 8) Vor die Retorte war ein mit Schrauben festgezogener Kopf gesetzt, von dem senkrecht nach oben das Gasrohr abging und an der vorne ein Deckel mit einem Bügel festgezogen war. Auch der Querschnitt dieser Retorte vom kreisrunden zum elliptischen und nierenförmigen wurde von Murdoch entwickelt.

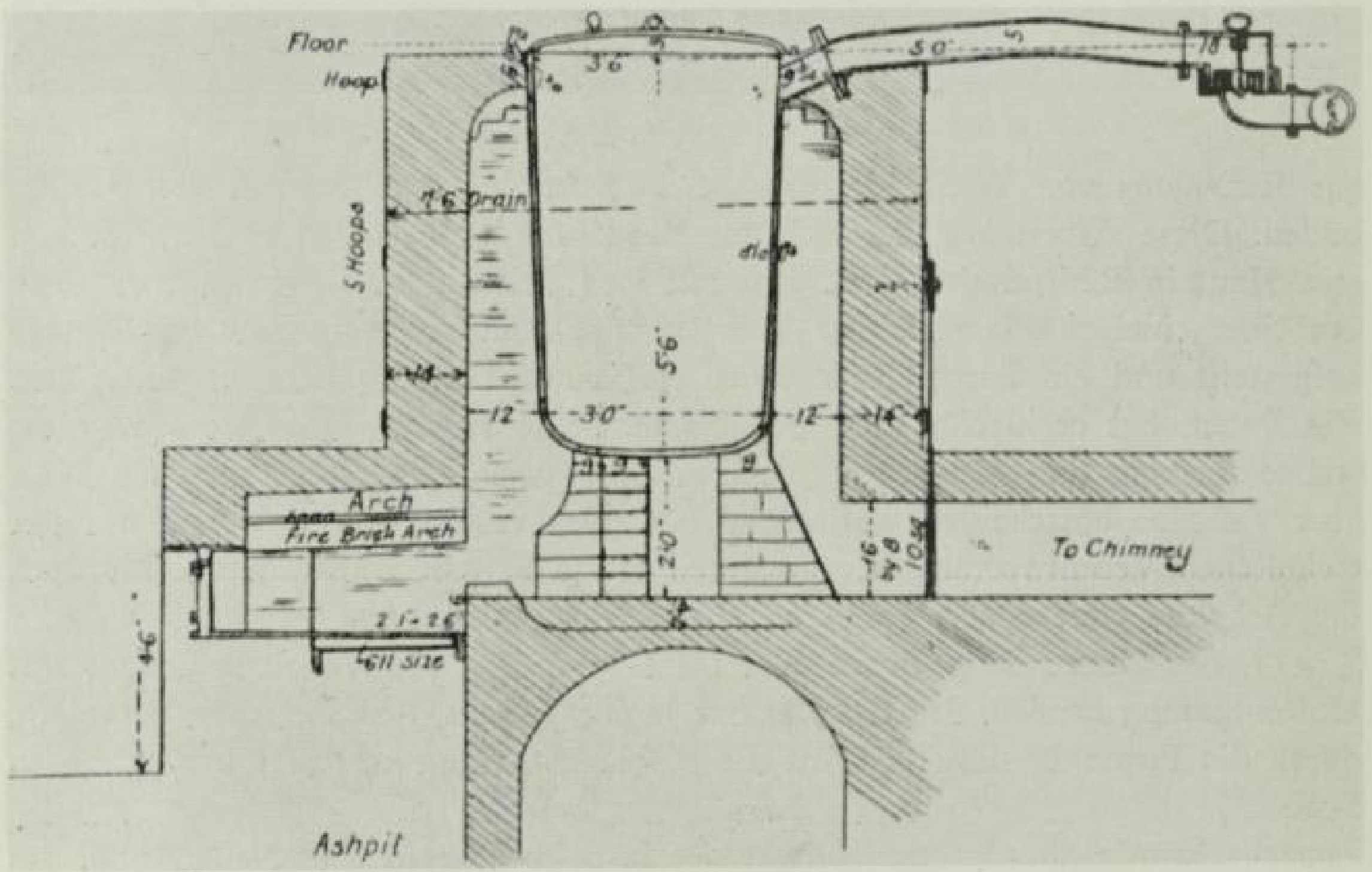

Bild 7 Erste Retorte Murdochs für einen Industriebetrieb (Phillips \& Lee) als Tiegel

(Aus „Murdoch Centenary Lecture")

2.90) Samuel Clegg jun. A Practical Treatise on the Manufacture and Distribution of Coal Gas, London, John Weale $184 \mathrm{I}$ 
Bild 8

Waagerechte Retorte

Murdochs

(Aus .,Chandler \& Lacey", British Gas Council 1949)

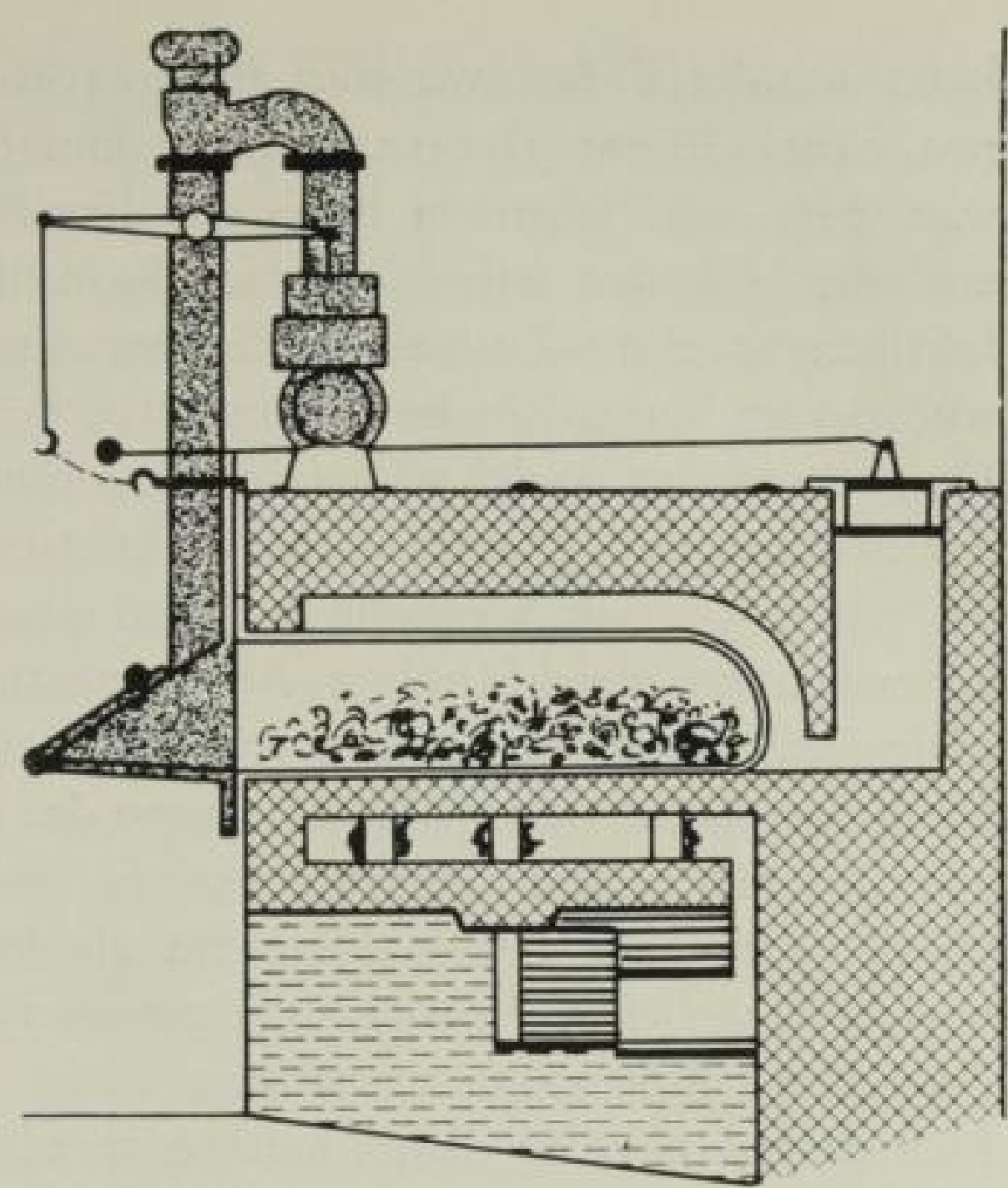

Creigbton, der Verfasser der ersten Supplements der Encyclopedia Britannica über Gaslicht, ein Bürger von Soho, bringt in seiner Darstellung das, was er in der Fabrik von Boulton \& Watt gesehen hat, und beschreibt auch die Retorten. $\left.{ }^{2.21}\right)$. Die Weiterentwickelung war in aller Stille weitergetrieben worden, so sagte James Watt, der Jüngere, aus $\left.{ }^{2,10}\right)$. Sie erstreckte sich auf die beste Form der Retorten, auf Baustoff und Einbau der Rohre, über die Größ̧e der Gasbehälter (bei dieser Gelegenheit spricht Watt zum ersten Male die Kritik aus, dał der Name Gasometer eine Entstellung sei, es handele sich um Gasspeicher), über die Wirtschaftlichkeit verschiedener Brennerarten. Alles in allem seien es sehr kostspielige Versuche gewesen, die mindestens 3000 bis 4000 \& gekostet hätten. Patente seien nicht genommen, weil die Verteidigung der Dampfmaschinenpatente sich als sehr kostspielig erwiesen hätte. (Das hängt mit dem englischen Patentrecht zusammen, weil die Neuheit nicht geprüft wird und deshalb der Inhaber eines Patents dauernd Nachahmer, die sein Patent verletzen, verfolgen muf3. Aufjerdem macht man die Öffentlichkeit vorzeitig auf eine neue Entwicklung aufmerksam.) Bei den Gaspatenten wäre auch ein Erfolg zweifelhaft gewesen, weil die Arbeiten Dundonalds und anderer als Vorwegnahme hätten angesehen werden können. Alle Geräte waren damals in Soho noch nicht voll befriedigend.

Nach der Illumination wurde die Gasbeleuchtung der Fabrikräume in Soho allgemeiner eingeführt. Der Baumwollindustrielle G. Lee, in der Firma Philipps \& Lee, Manchester, hatte den Wert der Gasbeleuchtung erfaf̧t. Er erteilte Watt den ersten Auftrag. Zunächst wurde das Wohnhaus mit Gasbeleuchtung versehen und, als sie sich nach Verbesserungen bewährte, die ganze Fabrik mit der neuen Beleuchtung ausgerüstet. Das war offenbar für die Spinnereien ein wirtschaftlich entscheidender Schritt nach vorne. Damals schon war eine Spinnerei wegen der Maschinen kapitalintensiv. Für die Arbeit und insbesondere die An-

2.21) W. Matthews, S. 24 (5, 2,19) 
knüpfung der Fäden war aber gutes Licht erforderlich. Die verbesserten Öllampen (Argandbrenner) heranzuziehen und die Zahl der Leuchten zu vermehren, war teuer, und trotzdem blieb das Ergebnis wegen des gelegentlichen Blakens einfacher Lampen unbefriedigend. So erklärt sich die Anteilnahme der Textilfabriken an einer Zentralbeleuchtungsanlage mit Gas. Die mögliche Arbeitszcit wurde vom Tageslicht unabhängig.

Daß̧ das zu den sozial scheuflichen Verhältnissen geführt hat, die allgemein aus der Frühzeit des „Manchestertums“ bekannt geworden sind, war aber kein Fehler der neuen Technik, vieimehr lag es an der mangelnden Erfahrung, was man dem Menschen an gleichförmiger Arbeit zumuten kann. S. Clegg jun, sagte: $:^{2.2 x^{\prime \prime}}$ ). „Die Einwohner können ihren verschiedenen Berufen nachgehen bei seinem erfreulichen Licht, wobei die Zeitspanne des Nutzens verlängert wird." Bislang war aber das mangelnde Licht eine soziale Wohltat gewesen, die die Natur im Winter den Menschen erwies. Nunmehr glaubte man aber, auf die Dauer den Menschen die täglichen Arbeitszeiten zumuten zu können, die bisher nur im Sommer gefordert waren. Das verbesserte Licht war an sich eine Wohltat; was der Mensch gedankenlos damit machte, wurde zur Plage. Immerhin war der Erfolg zunächst so überzeugend, daf Fabrikbeleuchtungszentralen als besonderes Arbeitsgebiet entstanden.

Zwei Berichte liegen von Murdoch selbst vor, die wegen ihrer nüchternen, technischen Klarheit und als Beispiel für die Kämpfe, die plötzlich zu bestehen waren, auszugsweise als Anlage 1 und 2 wiedergegeben sein mögen. Der erste ist ein Vortrag in der Royal Society (25. Februar 1808), der zweite ein Brief an ein Parlamentsmitglied I809. Beide entstanden, als Winsor, über dessen Wirken später zu berichten sein wird, sich um eine Konzession zur Gasbeleuchtung Londons bemühte.

Daf man bei Beleuchtungsanlagen für Fabrikbetriebe im Rahmen des allgemeinen Lieferprogrammes der Firma stehen blieb, ist aus dem vorsichtigen Geschäftsgebaren leicht erklärlich. Leider ist nicht festgehalten, wieviele solcher Anlagen Boulton \& Watt unter der Werksleitung Murdochs seit 1800 geliefert haben. J. W at $t$ jun. benannte, Anlagen und sagt dazu, daf noch eine Anzahl andercr errichtet und in Auftrag seien.

Vermutlich wurde durch die Verhandlungen vor dem Parlamentsausschuf klar, dał sich die Lieferung von Gasanlagen in der Zukunft nicht zu einem in sich abgerundeten Fabrikationszweig entwickeln würde. Die neuen Gesellschaften zeigten das Bestreben vieles selbst zu entwerfen und sich der Hilfe von beratenden Ingenieuren zu bedienen, die Einzelgeräte aber bei irgendwie geeigneten Werkstätten unter mehr oder weniger strenger Abnahmekontrolle zu kaufen. Der Aufbau einer überragenden Baufirma, die mit den Dampfmaschinen bei Boulton \& Watt gelungen war, war damit aussichtslos. Diese Möglichkeit kam erst um die Mitte des Jahrhunderts zustande. Eine der ältesten Firmen, die sich für Gaswerkslieferungen spezialisierte, Robert Dempster \& Sons Ltd, Elland near Halifax, nannte sich noch 1866 Robert Dempster, Consulting Gas Engineer $\left.^{2.22}\right)$. Murdoch zog sich um $18 \mathrm{ro}$ aus der Weiterbearbeitung des Gasfaches zurück. Ein Angebot Geschäftsteilhaber zu werden, lehnte er ab. Er blieb lieber

2.22) Festschrift Robert Dempster \& Sons Limited, Elland Yorks 1965 
Angestellter mit dem allerdings fürstlichen Gehalt von roou \& im Jahre. Hierbei wurde wohl ein Einfluł seines alten Meisters wirksam, der ja als etwas ganz ungewöhnliches in einer Maschinenfabrik der damaligen Zeit, das Arbeitsgebiet auf die Dampfmaschine beschränkt wissen wollte. Murdoch ging in die Werkstatt, vor allem als Betriebsleiter der Giesserei. Seine Erfindungsgabe wirkte sich in der stetigen Verbesserung der mechanischen Einrichtungen aus. Im Alter von 76 Jahren setzte er sich zur Ruhe (1830) und starb in Sycamore Hill im Jahre 1839. Einen schönen Beweis, daf̧ die angesehene Firma bewufyt ein Programm einhielt, liefern uns viele Nachahmer. Da wird J. Pemberton genannt, der Gas in geringem Umfange für Industriezwecke 1806 benutzt hat. Nach William Matthews ${ }^{2.25}$ ) war er der von James Watt jun. 1809 in seiner Zeugenaussage vor einem Parlamentsausschu\} erwähnte Fabrikant von Gasanlagen gewesen. Pemberton beleuchtete zuerst seine Fabrik, auch die Front der Gebäude, die in einer Hauptstrafe Birminghams lagen - eine erste Leuchtreklame. Pemberton brauchte das Gas nicht nur zur Beleuchtung, sondern auch zum Löten. Seine erste Licferung an Fremde ging an $S$ a unders, einen Knopffabrikanten, dann folgten noch mehrere Fabrikanlagen bei Birmingham, darunter auch eine bei B. Cook bei der besonders viel Lötarbeit zu erledigen war.

In Schottland war J. M. Pertb Schrittmacher, der 1813 eine Werbeschrift über die Vorzüge des Gases herausgegeben hat. - In Deutschland übernahm das gleiche Verfahren der Werksgasanstalten F. W. Harkort. Dieser hatte 1819 in Wetter an der Ruhr seine mechanische Werkstätte mit dem Ziele errichtet, den grof̧en Vorsprung, den England während der napoleonischen Kriege in Konstruktion und Fertigung gewonnen hatte, durch seine Musterwerkstätte einzuholen. Natïrlicherweise stand damals für Harkort der Bau von Damptmaschinen im Vordergrunde, aber er studierte und entwickelte auch die Textilmaschinen und, was uns hier besonders angeht, lieferte auch, ganz nach dem Vorbild von Boulton \& Watt zu den Textilfabriken dic Gasbeleuchtungsanlagen mit ${ }^{2.21}$ ). Harkort ging aber noch weiter. Er wandte sich an Regierungsstellen in Düsseldorf und Köln, wo neue Kasernen gebaut wurden, und warb dafür. dał für diese Gebäude Gaserleuchtungsanlagen hergestellt wurden. Mit dem Bauingenieur $A l t b$ ans hat er einen Briefwechsel geführt, in dem dieser anfragte, ob man denn nicht das Gas auch für Kochen und Heizen verwenden könne. Was Harkort geantwortet hat, ist nicht bekannt. Von ihm mag F. Dinnendabl in Essen, der nachweislich mit Harkort bekannt war, die Anregung erhalten haben, seine Fabrik mit Gasbeleuchtung zu versehen. Matschof schreibt allerdings, dał er hierzu durch den Apotheker Flassboff in Essen, der im Laboratorium Gas hergestellt hatte, veranlaf̧t worden wäre. Die Harkort nahestehende Zeitung "Hermann" vom 27. 3. I818 berichtete begeistert über den Erfolg der Beleuchtung. In den ersten 8 bis ro Tagen sei der Hof der Fabrik jeden Abend voll von $\mathrm{Zu}$ schauern gewesen, die Dinnendahl zujubelten, begeistert vom Anblick des schönen Lichtes $\left.{ }^{9.2}\right)$.

\footnotetext{
9.m) William Matthews: An historical sketch of the origin and progress of gas lighting. London, Rowland Hunter 1827 , 3. 43

2.34) Conrad Matschoss: Beiträge zur Geschichte der Technik und Industric, 10 (1920) S, 8-10

225) Conrad Matschoss: Grosse Ingenicure, Lehmanns Verlag München, 1937, 2. Aufl. S. 11. Auch Z. VDI 1903 S. 590 . JfG. $46(1903), 377$
} 
Auch Lampadius fing mit Kleinanlagen in Betrieben an. (Er erleuchtete zwar schon $I \delta_{I I}$ einen Teil der Fischergasse zu Freiberg mit Gas.) I816 richtete er das Gaslicht in den Amalgamierwerken ein. Lampadius gibt in den Anmerkungen zu seiner lbersetzung des Accum ${ }^{2.29}$ ) eine kleine Liste bestehender Kleinanlagen:

I) Hartmann Eisenwerk Zorge

2) Althaldensleben, Gut Natusius, legt Neubauer einen Gasapparat zur Erleuchtung einer Steingutfabrik an

3) Fabrik Cockerill, Berlin

4. Salomonsapotheke Leipzig und Chemiker Bornschein (Hausbeleuchtung)

5) Orgelbauer Uthe, Dresden.

Von besonderer Bedeutung ist die Anlage geworden, die sich R. S. $B l o c h-$ mann im Jahre r819 zur Beleuchtung seiner Werkstätte nachweislich auf englische Vorbilder hin in Dresden angelegt hat. Er brachte auch eine Laterne über dem Haupteingang an, die die Aufmerksamkeit der Öffentlichkeit stark anregte. So kam es dazu, dał ihm der Bau des ersten Gaswerkes für die öffentliche Hand angetragen wurde. Darüber wird im folgenden Abschnitte im Rahmen des Lebenslaufes Blochmanns noch zu berichten $\operatorname{sein}^{2.47}$ ).

J. J. Precbtl, Direktor des $18 \mathrm{is}$ gegründeten Polytechnikums in Wien, ließ́ das Gebäude der Schule mit Gaslicht versehen, worüber auch noch später zu berichten ist. Sicherlich waren Privatgasanstalten für Einzelbetriebe weiter verbreitet, als uns heute bekannt ist.

\subsection{Lampadius}

Wenn auch im allgemeinen die Arbeiten des Professors Wilhelm August $\mathrm{L}$ a mpadius an der Entwicklung der Gastechnik nicht in dem Maf̧e gewürdigt werden, wie die Lebons und Murdochs, so darf in einem deutschen Buche sein Anteil nicht fehlen. Lampadius hat mit seinen Arbeiten wenig später als $L e$ $b o n$ und $M u r d o c b$ begonnen, zunächst im Laboratorium und dann im technischen Maf̧stabe und hat danach Beleuchtungsanlagen hergestellt. Schlief3lich war sein Gutachten vom Jahre 1817 in Dresden mafggeblich für den sächsischen Staat, den Plan einer Gasbeleuchtung der Stadt voranzutreiben. Durch seine Veröffentlichungen und die Übersetzung des , $A c c u m^{\prime \prime}$, die mit Anmerkungen und Berichtigungen nach seinen eigenen Forschungen versehen ist, hat er viel zur Verbreitung des Wissens über die Gaserzeugung beigetragen.

\section{SLUB}




\section{LE B E N S B I L D}

Wilhelm August Lampadius ist in Hehlen a. d. Weser am 8. 8. 1772 als Sohn eines Offiziers, der in englischen Diensten stand, geboren. Sein Vater ging dienstlich nach Amerika und ist dort verschollen. So lag die Erziehung des Knaben allein in den Händen der Mutter und deren Schwager, des Pastors. Prössel zu Bofzen bei Fürstenberg. Die Liebe zu den Naturwissenschaften zeigte sich schon früh. Mit 12 Jahren konfirmiert, kam der Junge als Lehrling in die Ratsapotheke nach Göttingen. Aus Neujahrgeschenken, die er als Lehrling erhielt, und mit den Gaben einiger Verwandten hatte er während der Lehre 75 Taler erspart, mit denen er sein Studium begann. Er beschreibt es als einen der glücklichsten Augenblicke seines Lebens, wie er zum ersten Male, der harten Knechtschaft der Lehre entronnen, als ein freier Jüngling, ein Göttinger Bursch, in seiner Studentenbunde - sogar mit einem Sofa - gesessen hätte mit den schönsten Aussichten, die Natur und namentlich Meteorologie zu studieren.

Sein grof̧er Gönner wurde Professor Licbtenberg. Lichtenberg, Gmelin, Kästner, Murray, Blumenbach gaben ihm freien Zutritt zu den Kollegs, die er 1790 bis 1793 mit Eifer besucht hat. Vielleicht hat Lampadius von Lichtenberg ${ }^{2.5}$ ) den leichten Hang zur Satire - in Gestalt eines gutmütigen Humors angenommen. Möglicherweise hat Lampadius auch von Licbtenberg, der ja zu Weihnachten 1783 damit begann, Aerostaten-Versuche anzustellen, zuerst über das Gas gehört. Ohne Frage aber war es wohl Lichtenberg, der Betreuer der englischen Prinzen Ernst August (nachmals König von Hannover) und Georg, der ihm das Amt des Einpaukers der Prinzen vermittelte. Gegen Ende des dritten Studienjahres forderte ihn Graf v. Sternberg als Begleiter zu einer Reise durch Rufland nach China auf, die wegen der Ausweisung durch die Polizei aber in Moskau abgebrochen wurde. So kam Lampadius als Privatsekretär des Grafen nach Böhmen wo er sich der Chemie und deren praktischer Anwendung in den kleinen Industriebetrieben widmete. Von hier aus wurde er 1794 nach Freiberg zur Bergakademie zuerst als a. o. Professor berufen. In jahre darauf, also 23 Jahre alt, wurde er zum o. Professor für allgemeine Chemie ernannt. Er war sehr vielseitig mit der technischen Anwendung seiner chemischen Kenntnisse beschäftigt. Man kann nur die Hauptgebiete hier nennen: Agrikulturchemie, Düngesalze, Rübenzuckerfabrikation, wegen der ihn Napoleon I. und auch Carl August von Weimar zu Rate zog. Überhaupt war er stets bereit, in den Fabriken der Umgebung Ratschläge zu erteilen.

So kam er auch zum Hüttenwesen. Ab 1797 hielt er einen Kursus für Hüttenkunde. Er kam mit $F a b e r$ du $F a u r$ in Wasseralfingen zusammen, dem rührigen württembergischen Hüttenmann, der mit Gasgeneratoren und Heifwind im Hochofen arbeitete. Im Freiberger Bezirk führte Lampadius den Heifwind ein.

Berühmte Schüler waren Alexander von $H u m b o l d t$ und Henrik Steftens. Mit Berzelius und Mitscberlicb stand er in inniger Verbin-

\footnotetext{
2.25) Zusammengestellt nach Neuer Nekrolog der Deutschen 20 (1842) Weimat 1844 S. \$03 bis 314

2.2n) Carl Brinitzer: G. C. Lichtenberg, die Geschichte eines gescheiten Mannes. Tubingen, Wunderlich Verlag. 1996
} 
dung. Nach 48 Jahren erfolgreicher Tätigkeit in Freiberg verstarb er nach einem langen, aber nicht schmerzlichen Krankenlager am 13. 4. 1842.

So war der Mann beschaffen, der sich als erster Wissenschaftler an einer technischen Lehranstalt der Gaserzeugung zuwandte. Schon im Jahre 1798 begann er mit Entgasungsversuchen an einer Menge brennbarer Stoffe ${ }^{9.80}$ ) und veröffentlichte die Ergebnisse über Ausbeutezahlen und Aschengehalt in den Sammlungen chemischer Abhandlungen, 3. Band, 1800, Dresden bei Walther.

Bereits erwähnt ist, dał Lampadius dem Kurfürsten in seinem Schlof̧e in Dresden bereits 1799 eine Thermolampe vorgeführt hat. Sollte er damit erreicht haben, dał die Fürsten dieses Landes ihr Auge von der neuen Beleuchtungsart nicht abwandten und die Treiber wurden, daf̧ die spätere königliche Regierung die Stadtbeleuchtung in Dresden als erstem Unternehmen der öffentlichen Hand erbaut hat?

Andere technische Verkohlungsversuche im Groß̧en hat er in den „Erfahrungen im Gebiete der Chemie und Hüttenkunde“, Weimar, Sächs. Ind. Comptoir, I8ıs bekanntgegeben. Hier wird auch über Braunkohle, Erdkohle, Moorkohle berichtet.

1817 stellte er fest $\left.{ }^{2.31}\right)$, dał er seit 20 Jahren auf dem gräflich Bucquoischen Eisenwerke Gabrielenhütte Buchenholz zur Gewinnung von Teer und Essig verkohlt und das Gas zur Unterfeuerung benutzt habe.

Lampadius berührte das Dilemma bei der Holzverkohlung: $:^{2.85}$ ) Arbeitet man mit mäßjiger Temperatur, erhält man eine gute Holzkohle, aber wenig und schlecht leuchtendes Gas; bei hoher Temperatur ergibt sich aber mit einem besseren Gase eine schwammige Holzkohle. Er beansprucht für sich, den ersten Gedanken, das Gas in Hütten zu Heizzwecken heranzuziehen, gehabt zu haben.".as).

„Zur Ergänzung des Geschichtlichen über die Benützung der bei der Verkohlung der Brennmaterialien verlorengehenden Stoffe sei es mir erlaubt, hier anzuführen, daf̧ meine Versuche hierüber im Jahre 1797 begannen. In diesem Jahre röstete ich in dem hiesigen Henkelschen Laboratorium zuerst Kiese durch das brennende gekohlte Hydrogengas (ein Name, der in den alten Schriften immer wieder durcheinander für Kohlengas oder Methan gebraucht wurde), welches bei der Verkohlung des Holzes entweicht. .... Bei diesen Versuchen war mir der jetzige Salineninspektor, Herr Klemm, behilflich. Herr Murdock, dessen Versuche ich aber nicht kannte, und ich haben uns mithin in Hinsicht der Ansprüche auf die Entdeckung der Anwendung des gekohlten Hydrogengases zu teilen. Er gab das Licht und ich die Wärme. .... Die Steinkohlengasbeleuchtung fing ich hier zuerst an, nachdem dunkle Nachrichten über dieselbe während der traurigen Continentalsperre aus dem gewerbereichen England zu uns drangen. Die kriegerischen Unruhen und der Geldmangel haben uns in Sachsen bis jetzt von der weiteren Ausführung dieses neuen Industriezweiges abgehalten. .... Es war den 24. Januar 1816, an welchem ich das Steinkohlengaslicht (in Deutschland zuerst) auf dem kgl. Sächs. Amalgamierwerk in der Halsbrücke bei Freiberg anzünden konnte."

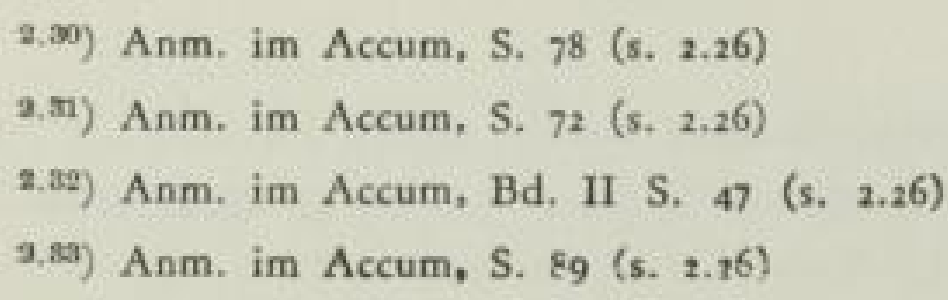


Nach dieser Aufzeichnung des Lampadius selbst könnte die Nachricht, er habe bereits $18 \mathrm{II}$ einen Teil der Fischergasse in Freiberg beleuchtet ${ }^{2.34}$ ), als widerspruchsvoll bezeichnet werden. Vermutlich hat aber Lampadius diese Anlage, die vier Wochen im Betriebe war, nur als Versuch gewertet, während die Beleuchtung im Amalgierwerk eine Dauereinrichtung war. Sie hat mit Erweiterungen im Jahre 1825 bis 1894 gearbeitet $^{2.35}$ ).

Lampadius hat sich mehr als alle wissenschaftlichen Forscher bis dahin in die Technik vertieft. Statt dem damals üblichen Schattenphotometer nach $R u m$ ford zum Vergleich der Leuchtkraft zweier Flammen benutzte er einen Tubus, in der trübe Hornglas- oder Beinglasscheiben eingesetzt wurden, bis das anvisierte Licht nicht mehr sichtbar war. Damit gewann er uach der Zahl der notwendigen Gläser eine Skala von Dunkelheit $=0^{\circ}$ bis zum hellsten Licht (Sauerstoff mit Phosphor $)=100^{\circ}$, z. B. Öllampe $=$ Vollmond $37^{\circ}$, Talglicht $30^{\circ}$, Probierofen $42^{\circ}$, Gaslicht $45^{\circ}$, Glasofen $62^{\circ}$, Sonnenlicht $85^{\circ}$ usw. Über die Mängel z. B. aus Ungenauigkeiten der Trübungen soll hier nicht gerechtet werden. Der Versuch, eine absolute Skala zu schaffen, ist aber zu bewundern ${ }^{2.30}$ ).

In der Gaserzeugung stellte er den Einfluß der wirksamen Gaskühlung gegenüber den unzureichenden englischen Kühlern - als Schlangen im Behälterwasser - fest. Daraufhin entwickelte er einen besonderen Vorkühler aus einer flachen Bleiblechblase.

Besonders hat sich Lampadius mit der Verwertung des Teeres befafyt. Er hielt ihn für eine gute Maschinenschmiere, beschrieb das Verfahren, ihn als Rostschutz für Eisen zu verwenden und gab ein Rezept mit Zuschlägen für die damals eine grof̧e Rolle spielenden Eisenkitte. Er beschrieb auch die Weiterverarbeitung des Teeres in Blasen zur Entfernung des Wassers und Gewinnung von Terpentinöl, mit dem er Versuche als Beleuchtungsöl angestellt hat. Der Rückstand sei ein sehr schönes schwarzes Pech.

Angeregt durch die Übersetzung des Accum und Nachrichten im Hermbstädt'schen Bulletin hat er sich nach 1817 auch mit der Zersetzung des Teeres zur Gaserzeugung befafjt. Er hat nach Vorbildern ein glühendes schrägliegendes Eisenrohr benutzt, in das der Teer eintropfte, wobei er auch sonst schlecht verwertbare Öle anderen Ursprungs ,thermisch krackte“. Der sich im Rohr absetzende Koks muf̧te von Hand entfernt werden. Lampadius hielt Leinölgas für Haushaltsanlagen wegen der geringen erforderlichen Hitze - das Rohr eingebaut in den Kochherd - für vorteilhaft.

Überhaupt machte sich Lampadius Gedanken, wie die Gasbeleuchtung gefördert werden könnte. Ihrer allgemeinen Einführung zur Straßenbeleuchtung stände die nach den napoleonischen Kriegen entstandene Geldknappheit entgegen. Man solle so beginnen, dafy man einzelne Hausbesitzer durch Subventionen ermutige, Hausanlagen in die Kachelöfen einzubauen, und diese verpflichte, als Gegenleistung einen Wandarm zur Straf̧enbeleuchtung auf̧erhalb des Hauses anzubringen. Später erklärte er, dał̧ mit Hilfe des Gasbehälters, den er erst 1815 kennen-

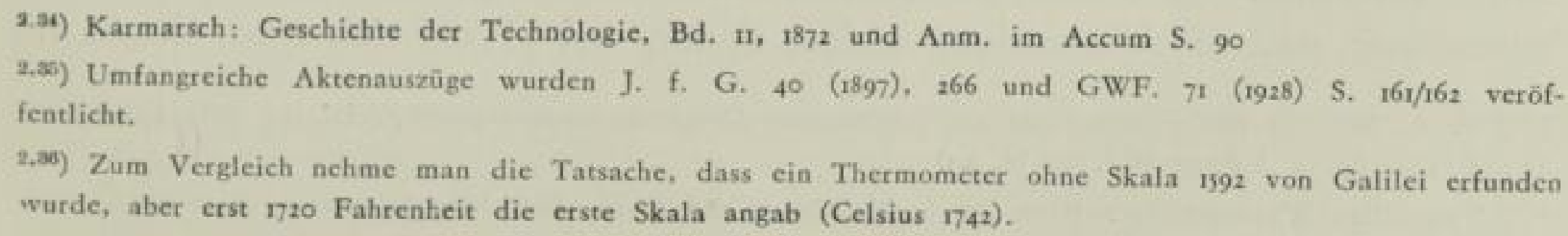


gelernt hat, die Straßjenbeleuchtung auch von einer Gasfabrik möglich würde. Man fühlt gerade aus diesen Anregungen, daf̧ hier am Wirtschaftlichen die Möglichkeiten des Professors ihr Ende fanden.

2.15 Winzer, genannt Winsor

Die wirtschaftlichen Grundlagen waren dagegen in England trotz der napoleonischen Kriege und der Kontinentalsperre gegeben. Diese nutzte der Deutsche Friedrich Albert Winzer, in England sich Winsor nennend, aus.

\section{E B E N S B I L D}

Uber W/insors Lebensweg ist nicht viel bekannt. Karmarsch sagt, er sei 1762 in Deutschland geboren, an anderen Stellen wird das Jahr 1763 und Braunschweig als Geburtsort genannt, jedoch läß̧t sich jetzt in Kirchenbüchern und Archiven dort nichts mehr feststellen.

In seiner ,Notice historique ${ }^{(\omega . .37}$ ) macht Winsor einige Angaben über sein Leben. Er sei als Kaufmann erzegen und tätig gewesen. Seine Neigungen aber führten ihn zu physikalischen Versuchen, für die er seine ersten Ersparnisse opferte. Beim ersten Ballonaufstieg in Paris im August 1784 (richtig August 1783 ) sei er zugegen gewesen und habe $L u n$ ard $i$ in London im September des folgenden Jahres erlebt. Das regte ihn an, kleine Ballons mit verdünnter Luft und Wasserstoffgas aufsteigen zu lassen. Das Gas stellte er aus Eisenfeilicht ${ }^{2.35}$ ) und Kohle in Tabakspfeifen, irdenen Töpfen und Digestoren her.

1802 kam Winsor in Geschäften von London nach Paris und sah dort die Raumbeleuchtung von $L e b o n$. Er wurde dadurch zu erneutem Nachdenken über die Möglichkeiten der Gasverwendung veranlaf̧t. Sein Versuch, eine Lebonsche Thermolampe zu kaufen, mif̧lang. Er wandte sich danach nach Braunschweig, wo er selbständig das gleiche zu konstruieren bestrebt war. Er fand die Anerkennung der Herzogs, dem er eine erste Schrift über die Erfindung widmete. Im Jahre 1803 kehrte er nach London zurück und widmete sich nun ganz der erfaß̧ten Aufgabe. - Er begann mit öffentlichen Vorträgen. Er hatte sich wohl den Deutschen Diller (s. S. 27) zum Vorbild gewählt; so wurde er mit seinen Experimenten zunächst nicht ernst genommen. Aber im Glauben an seine Mission veröffentlichte er mehrere Flugschriften, unbeschwert von seinem mangelhaften Englisch. So gelang es ihm zunächst, wenige Menschen zu überzeugen. I804 wurde eine .,Gesellschaft mit Mitteln für einen Ausschu\} zur Anstellung von Versuchen" - wir würden heute sagen: eine Gasforschungsgesellschaft - gegründet. Wegen der Sprachschwierigkeiten nahm er nunmehr einen Assistenten, E. Heard, der für ihn vorlas, während er selbst die Versuche vorführte. Mit diesem Assistenten hatte er kein grofes Glück. Er war unzuverlässig, und die Verbindung endete damit, dał Heard sich eines Tages mit

\footnotetext{
2.37) T, A. Winsor: Notice historique sur l'utilisation du gaz hydrogène pour l'ćclairage 1816 , zitiett aach Chandler \& Lacey Anhang II S. 132 (s. 1.1)

2.34) Vermutlich Wasserstoffherstellung durch Einbringen des Eisens in Schwefelsäure
}

60 
dem Manuskript davon machte und selbständig in der Provinz Vorträge hielt. In seinen Anpreisungen übernahm Winsor die Werbegedanken Lebons. Darüber hinaus behauptete er, dał „sein“ Gas geruchlos sei, ein helles Licht gäbe und öffentliche Straf̧en und Häuser billiger und besser beleuchtet werden könnten als mit Öllampen und Kerzen. Es könne zur Illumination der Gärten benutzt werden, habe besondere Eigenschaften als Heilmittel fur Asthma und Lungenleiden. Der Pflanzenwuchs könne beschleunigt und ein Leuchtturm besser beleuchtet werden. (Im Anhang 3 ist eine seiner Werbeschriften in der Übersetzung gegeben, die dic Schwätzerei dieses Mannes recht deutlich werden läft.) Auch „clean air" griff er auf. Winsor hat sogar an ein Gesetz gedacht, nur noch Gas und Koks zur Verfeuerung zuzulassen. Er wandte sich an die sich eben regenden Gefühle für menschlichere Einstellung kleinen Kindern gegenüber-2.39, Es sei nicht mehr nötig, die übelste Arbeit der Menschheit, nämlich die der Schornsteinfeger, fortzusetzen, die damals kleine Jungen in den Kaminen hinablieł̧en, um sie zu kehren. Schlieł̧lich versprach er märchenhafte Gewinne. 1807 war er so weit, daf̧ er aus ,nationalem Interesse“ eine National Light and Heat Company beim Parlament durchsetzen wollte mit einem Kapital von I Mic Pfund Sterling in 20000 Aktien zu je 50 Pfund Nennwert, von denen nur s Pfund einzuzahlen wären. Für diese s Pfund versprach er eine Rente von 570 Pfund im Jahr ${ }^{2.00}$ ). (Bild 9) Das Büro der Forschungs-Gesellschaft richtete er nunmehr in der vornehmen Pall Mall ein. Gleichzeitig wurde eine Beleuchtungsanlage auf der Rückseite des Carlton House Gardens öffentlich gezeigt und später ein Teil von Pall Mall mit Lampen, die mit dem Ofen durch Bleirohre verbunden waren, erleuchtet. Die Vorführungen in geschlossenen Räumen glückten allerdings nicht in gleicher Weise, da das ungereinigte Gas be: den Zuhörern Kopfschmerzen verursachte.

Jetzt erregte Winsor ungeheures Aufsehen. Trotz der wilden Flüge der Einbildung, die seine finanziellen Voraussagen umgaben, fand seine praktische $\mathrm{Ar}$ beit ernste Beachtung. Er gewann die Hilfe von S. Clegg, über dessen technische Taten noch getrennt zu sprechen sein wird, der nicht nur den Ofen verbesserte, sondern auch die Reinigung des Gases mit Kalkmilch vorschlug. Die Aktionäre waren aber klug genug, von sich aus einen Ausschufs zu bilden, um die Versprechungen Winsors nachzuprüfen. So wurde Winsor mehr der technische Ratgeber als der Geschäftsführer. Winsor war zwar enttäuscht, aber für die Entwicklung war es ein Glück, daß̧ in Geschäften erfahrene Männer die nun kommenden Kämpfe gegen Murdoch, Lord Dundonald und alle, die Explosionen und Vergiftungen fürchteten, führten.

Der Aktionärausschuł, der zum ersten Male im Gasthof „Krone und Anker" am 3./4. Juli 1807 zusammentrat, verfaf̧te eine Eingabe an den König um ein Privileg (Royal Charter), die weitgehende Vollmachten für ganz Engiand verlangte, aber keinen Erfolg brachte. Der Ausschu\} war dabei mit Gedanken vorgestof̧en, die später für die Entwicklung groß̧er Aktiengesellschaften vorbildlich wurden. In Anlehnung an die damals nur bei Gesellschaften mit dem

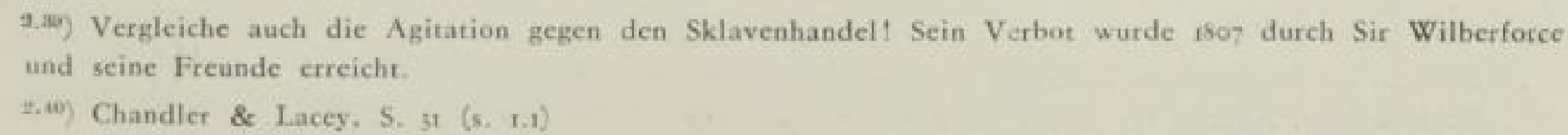




\section{aomifsion for}

To prevent the pressure of Crowd, by severat hundreds of Persons coming to one lecture, the Experiments, \&c. will be given twice every. Wednesday, viz. from 8 till half past 9; and from 10 till half past $110^{\prime}$ clock. This will sult the conveniency of early and late, of near and distant, Visitors.

Mr. Winsor, the Patentee, most respectfully invites all Memlers of Parliament to a constant free Admission, every Tuesday evening, during the present Session, to enable them to speak to Facts, whenever this important National Concern is brought lefore them as Legislators.

\section{NATIONAL}

\section{Light and Heat Company, No. 97, PALL-MALL, \\ TO BE ESTABLLSHED WITH}

\section{A MILLION of CAPIT $A L$ In 20,000 Fifty-pound Shares,}

At $\mathscr{L}^{5}$ deposit only, as the other $\mathscr{L} 15$ is to be made up from the Dividends.

To be under the Sanction of an Act of Parliament.

7 VHE Share Receipts of this lucrative Concern are now delivering at this Office, at the Banks of Messrs. Levarses and Co, 39, Pall Mall, and Sir Matrnew Bloxam and Co. 27, Gracecturet-Sirest, where Plans and Estimate Tables may be had gratis, as also at J 1 ord's and BaTsos's CoffeeHouses, Official Experiments uroved onc Chaldron of Coal to contain 23\%, $x_{x}$ in value; which gives above 242 Millions for the yearly consumption of the realm. The estimate savings are only rated at $114,845,294 /$. all costs of carbonising, Sic. deducted; and if the Company only realize 1-10th of this reduced Sum, each 5\% deposit will secure to the Subscribers 570\%, per Ann. Wonderful as this may appear, the Fatimates and Experiments will stand the test of the best calculators and clacmists. The whole is detailed in Mr. Winosr's Pampliet on the Natronal Light and Heat Compang.

M.un respectable Subscribers, seeing my experimests, have applied for an increase of Shares on the following scate of deponits, which I cheerfully submit to the Public

si the must Hattering testimony of the encouragement of my plasi.

Five Shares, to pay 31 deposit cach, and have 1 rour Firieen Shares, to pay $2 l .10$ s, deposit each, and tave 2 votes. Thirty share;, to pay 2 i. depout each, and have 3 votes. Sixiy Shares, to pay 1 l los depoit each, and bave 4 votes. One Hundred Shares and upwards. 1 l. each, and bave 5 voles. bicjuid which no vote allowable.

Bild 9

Faksimilie einer Einladung F. A. Winsors 1807

Zweck öffentlicher Wohlfahrt, wie Wasserversorgungsunternehmen, erlaubte beschränkte Haftung wurde auch für die Anteilseigner die Haftung nur bis zum Kapitalsanteil gefordert. Dann sollte das Recht, Straf̧en aufzureifen, allgemein gewährt werden.

Die Niederschriften über die Verhandlungen vor dem Parlamentsausschuf Murdoch gegen Winsor $\left.{ }^{2.41}\right)$ 1809 bieten eine Fülle von Aufschlüssen über den technischen Stand und die wissenschaftliche Einsicht in dieser Zeit.

Bei dem starken Widerspruch, dem diese Absichten begegneten, holte man als Gutachter Friedrich Accum heran, einen Chemiker, der im Bezirk Soho in London ein Laboratorium betrieb. So kam dieser tüchtige Mann mit dem Gasfach in Berührung.

2.41) W. Matthews, Anhang D, S. 266 (s, 2.25) 
Im folgenden Jabre wurde ein neuer Vorstoł beim Parlament unternommen mit wesentlich bescheideneren Ansprüchen. Das Kapital wurde auf 200000 Pfund, der Zweck der Gesellschaft auf die Beleuchtung der City von London beschränkt. Dieses Mal war der Ausschuł erfolgreich. Einige Auflagen muf̧ten in Kauf genommen werden. Das Alleinversorgungsrecht auch in dem bezeichneten Bezirke wurde entsprechend den herrschenden liberalen Grundsätzen ausdrücklich ausgeschlossen. Verboten wurde der Verkauf und die Installation von Geräten und Anlagen in Privathäusern. Die Gesellschaft war also auf Installateure als Unternehmer angewiesen, die erklärlicherweise keinerlei Erfahrungen mit Gasleitungen hatten und dann auch gerade bei grofen Anlagen wie Theaterbeleuchtungen so versagten, dał ernste Belästigungen und Gefahren auftraten und die Gesellschaft einzelne Anlagen völlig neu erstellen mufte. Das Wegerecht mufte von jedem Stadtbezirk (parish) und noch kleineren Verwaltungseinheiten getrennt erhandelt werden, was zu einer Unzahl von Schwierigkeiten führte. Insbesondere war es schlimm, wenn ein Bezirk, der Gasbeleuchtung eingerichtet haben wollte, nur durch einen anderen zu erreichen war, der sich dagegen sträubte.

Erst I812 waren alle Auflagen erfüllt und die Gas Light \& Coke Co wurde mit J. L. Grant als "Governor" gegründet. In das Direktorium trat $A c c u m$ ein, mit ihm neben anderen noch J. Hargreaves und J. Barlow. Diese drei konnten, wenn auch bislang nur als Amateure, etwas Kenntnisse über die Gasfabrikation ausweisen. Winsor stelite an die neue Gesellschaft hohe Forderungen - er war bemüht, seine Auslagen bei der Vorbereitung, die ihn tief in Schulden gebracht hatte, sofort ersetzt zu bekommen. So kam er zunächst nicht in das Direktorium, zu seiner grossen Enttäuschung.

Der Anlauf war schwer; überall zeigte sich, daf wirklich niemand in der Leitung der Gesellschaft ausreichende technische Kenntnisse hatte ${ }^{2.42}$ ).

Die technische Lage besserte sich erst, als man S. Ciegg im Dezember 1812 zunächst in untergeordneter Stellung gewann und ihm allmählich gröł̧ere Freiheit und Verantwortung übertrug. In einer Generalversammlung im Januar $\mathrm{I}_{13} 3$ beklagte sich Winsor, dafy seine Ansprüche aus der Entwicklungszeit nicht erfüllt seien. Die Versammlung beschloł, ihm ein Jahresgehalt von 600 Pfund vom Gründungstage an zu gewähren und ernannte ihn zum Direktionsmitglied ${ }^{2.28}$ ). Die Direktion aber bekümmerte sich um diesen Beschluf nicht. Es wurde Winsor geschrieben, daf̧ die frühere Gesellschaft, für die er Auslagen gehabt habe, eine völlig andere Rechtsperson als die jetzige gewesen sei. Nach abermaligen Klagen bei der Generalversammlung konnte Winsor am 6. Juli 1813 seinen Sitz im Direktorium einnehmen. Entschädigungen für seine früheren Auslagen erhielt er aber nicht.

Während dieser Zeit drängte eine Gruppe von Aktionären, die durch Winsor gewonnen waren, unter ihnen T. Lives e y, auf eine bessere Führung der Geschäfte. Die drei Direktoren Grant, Hargreaves und Accum schieden im De-

\footnotetext{
2.42) Für Einzelheiten aus dieser sehr zum Nachdenken reizenden ersten Zeit muss auf Stirling Everard, History of the Gas Light \& Coke Co, 1812-1949 London, 1949 Ernest Benn Led, verwiesen werden. Sie ist nach den Originaldokumenten der Gesellschaft zusammengestellt

2.4a) Es mag daran erinnert werden, dass die recheliche Stellung der Direktoren in England etwas anders gelagert ist als in Deutschland und in gewisser Weise nach der Rechtsstellung eines Aufsichtsrats hinneigt
} 
zember 1813 nach weiteren Auseinandersetzungen aus. Winsor hatte nun den gesuchten Einfluf. Indessen zeigte sich bei den nunmehr folgenden Untersuchungen, dał Winsor geschäftlich viele Fehler und Nachlässigkeiten begangen hatte. Viele Leute hatten an ihn ihre Gründeranteile gezahlt; die eingenommenen Gelder waren aber an die Gesellschaft nicht weitergegeben worden. Andere, deren Namen Winsor nicht einmal aufgeschrieben hatte, konnten sich nur bei ihm schadlos halten. In den als Folge dieser Verantwortungsiosigkeit entstandenen Finanznöten kam Winsor im Januar I8Is um einen Urlaub von zwei Monaten ein und verschwand nach Paris. Er war, was damals noch möglich war, seinen Gläubigern ausgerückt. In Paris rief er sofort eine Gasgesellschaft ins Leben, die aber 1819 zahlungsunfähig wurde. Um Winsor nicht in Not verkommen zu lassen, wurden ihm nunmehr von der Gesellschaft 200 Pfund jährlich gezahlt bis zu seinem Tode in Paris im Jahre 1830.

Über Winsors Charakter und Verdienste sind die verschiedensten Äuß̧erungen zu finden. Er war kein seriöser Kaufmann. Er scheute sich nicht, möglicherweise durch seine Phantasic verführt, in gutem Glauben, die Verdienste anderer herabzusetzen und sich desto mehr Bedeutung beizulegen. Ohne Zweifel ist er von Lebon angeregt worden, das gibt er ja auch zu. Er sagt aber, er sei 1802 nicht klüger aus Paris abgezogen, als er hingekommen wäre. Nach dem, was Z. A. W inzler 1803 über die Veröffentlichungen Lebons und ihre Aufnahme in Deutschland berichtet hat, ist das aber kaum glaubhaft. Das Mifztrauen gegen seinen Bericht ist umso berechtigter, als man andere Ungenauigkeiten nachweisen kann. Seine technischen Kenntnisse waren anfangs sicher sehr lückenhaft. Aber man darf ihm wohl glauben, dał er schwer, selbst mit den Händen zugreifend, gearbeitet hat, um die Lücken zu schlief̧en. (Bild ro)

Wenn man den Charakter Winsors heute beurteilen will, so darf man nicht vergessen, daf3 in der Zeit der napoleonischen Kriege aus dem in London zusammengefaf̧ten Welthandel grofe Gewinne einkamen, die das Geld leicht lockerten. Auch die allgemeine technische Entwicklung nahm ein stürmisches Tempo an. Wir kennen und bewundern heute sehr viele "Erfinder" der damaligen Zeit, die ohne wirklich tiefgreifende Kenntnisse grofe Leistungen hervorgebracht haben. Wieviele Unbekannte beim Sturmlauf um den technischen Erfolg unrühmlich liegengeblieben sind, wissen wir nicht. Daf3 der Typ dieser Unternehmer mit geringen Kenntnissen, aber hohem Selbstbewuf̧tsein eine gängige Erscheinung war und auch ernst genommen wurde, illustriert vielleicht am besten. C. Dikkens im David Copperfield mit Mr. Micawber.

Winsors Werbemethoden sind es, die am meisten Kritik hervorgerufen haben. Dabei ist es sehr fraglich, ob ohne den rednerischen Aufwand ein Erfolg, viel weniger noch ein so schneller Erfolg erzielt worden wäre. (Bild $\mathrm{nI}$ )

Es lohnt sich, in diesem Zusammenhange auf den heute als Pionier des deutschen Eisenbahnwesens anerkannten Volkswirt Friedrich List zu verweisen, der sehr ähnliche Methoden angewandt hat und zu seiner Zeit als nicht seriös angesehen wurde, obwohl er den entscheidenen Erfolg herbeigeführt hat. Franz Schnabel berichtet darüber, wie List vorgegangen ist. $\left.{ }^{2.44}\right)$. Er hat, als er den Bau der Bahn von Leipzig nach Dresden in Gang brachte, das Vorbild geschaffen,

9.44) Franz Schnabel: Deutsche Geschichte des 19. Jahrhunderts Bd. 3 Freiburg 1934, Herder \& Co. S. 37 
Bild 10

Karikatur auf Winsors Werbevorträge 1807 von S. W. Fores

(Gas Journal Centenary)

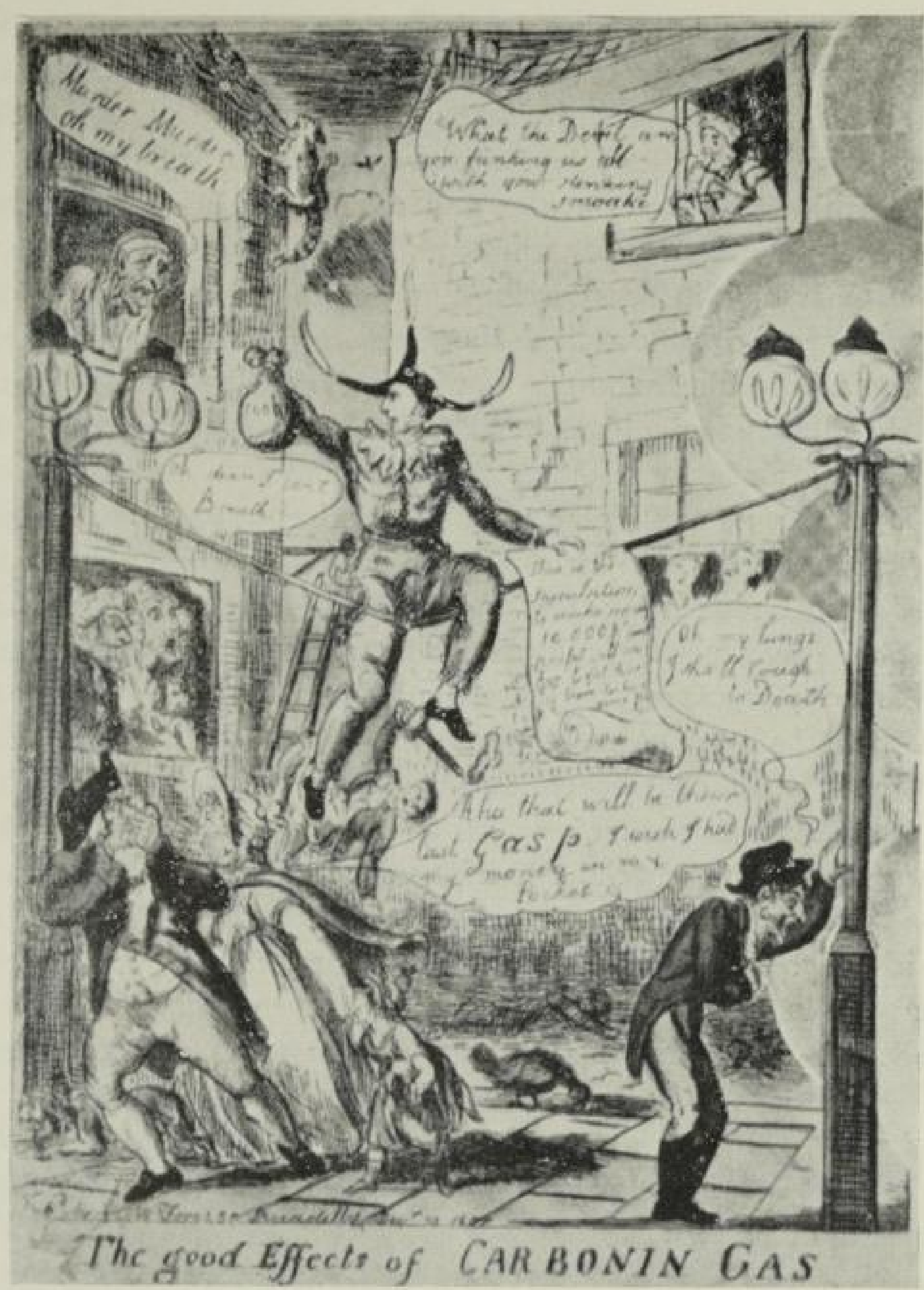

nach welchem man in Deutschland bei allen Bahnbauten verfahren ist. Er hat zunächst durch Schriften und Zeitungsartikel die Öffentlichkeit, das Publikum, aufgeklärt. Denn die Macht der öffentlichen Aufklärung hatte er in Amerika kennengelernt. Eine öffentliche Versammlung wurde einberufen und hier ein Komitee gewählt. Dieses stellte den Kostenvoranschlag und die Rentabilitätsberechnung auf und verhandelte dann mit der Regierung, von der man die Gewiłheit haben muß̧te, dał̧ sie die geplante Aktiengesellschaft genehmigte, später sich etwa meldende Gesellschaften für die gleiche Bahnstrecke ausschloß̧, daf sie ferner das für den Bau notwendige Enteignungsgesetz erlief̧ und womöglich Zinsgarantie gewährte oder die Gemeinden zur Zeichnung von Aktien ermächtigte. Erst wenn alles dieses geschehen war, wurde die Subskription aufgelegt und dann die Aktiengesellschaft gegründet.

Winsor, der vor der gleichen Aufgabe ohne Vorbild gestanden hat, ist fast ganz nach dem gleichen Verfahren vorgegangen, ehe er durch den Ausschuf den Royal Charter beantragen liefy.

Das Schicksal Lists und Winsors bei den Gründungen ist dann auch sehr ähnlich gewesen. List hat überall eingegriffen, hat die Gründung von Komitees veran- 
laf̧t, ... nnit unermüdlichem Eifer hat er für den Eisenbahngedanken geworben. In Leipzig war man mit ihm nicht einverstanden. Dort hatte er sich durch seinen Reichtum an schöpferischen Gedanken und als Mann der Propaganda grofartig bewährt, aber die Leipziger Kaufleute hielten ihn wegen seines leidenschaftlichen Temperamentes und seiner ,goldenen Rücksichtslosigkeit" nicht für geeignet zur Zusammenarbeit am gemeinsamen Werke. Er wurde weder in das Komitee noch in das Direktorium gewählt, und doch hatte er erwartet, daf̧ ihm als dem Schöpfer der Idee die Stellung des allgebietenden Direktors übertragen würde. Die Entfremdung wurde immer schlimmer, als List die einzelnen technischen Entscheidungen bemängelte. Man sollte an diese Dinge denken, wenn man Winsor heute leichthin aburteilt.

Ungeheuer ist natürlich der Unterschied zwischen der langsamen technischen Entwicklungsarbeit und dem geschäftlichen Vormarsch Murdochs und dem leichtsinnigen Drängen Winsors. Aber das Verdienst des fruchtbaren Gedankens, dafy e in Gasversorgungsunternehmen ganze Städte versorgen müsse, den zwar schon Winzler ausgesprochen hatte, und die Erkenntnis, daf dazu eine kapitalstarke Gesellschaft mit Aktien unter beschränkter Haftung von nöten sei, kann man Winsor nicht absprechen. Die begeisterten Werbeworte von Lebon lassen vielleicht ahnen, daf̧ auch er auf grofe Anlagen allmählich hinausgegangen wäre, wie man eine gleichartige Entwicklung aus den Einzelanlagen Murdochs als zwangsläufig kommend ansehen mag. Für den groł̧en Wurf aber, der das Gesicht der Gasindustrie so schnell formte, war tatsächlich der unvorsichtige Draufgänger im rechten Augenblick aufgetreten.

Die Überzeugung, dał Winsor grundsätzlich das Richtige erstrebt hatte, saf3

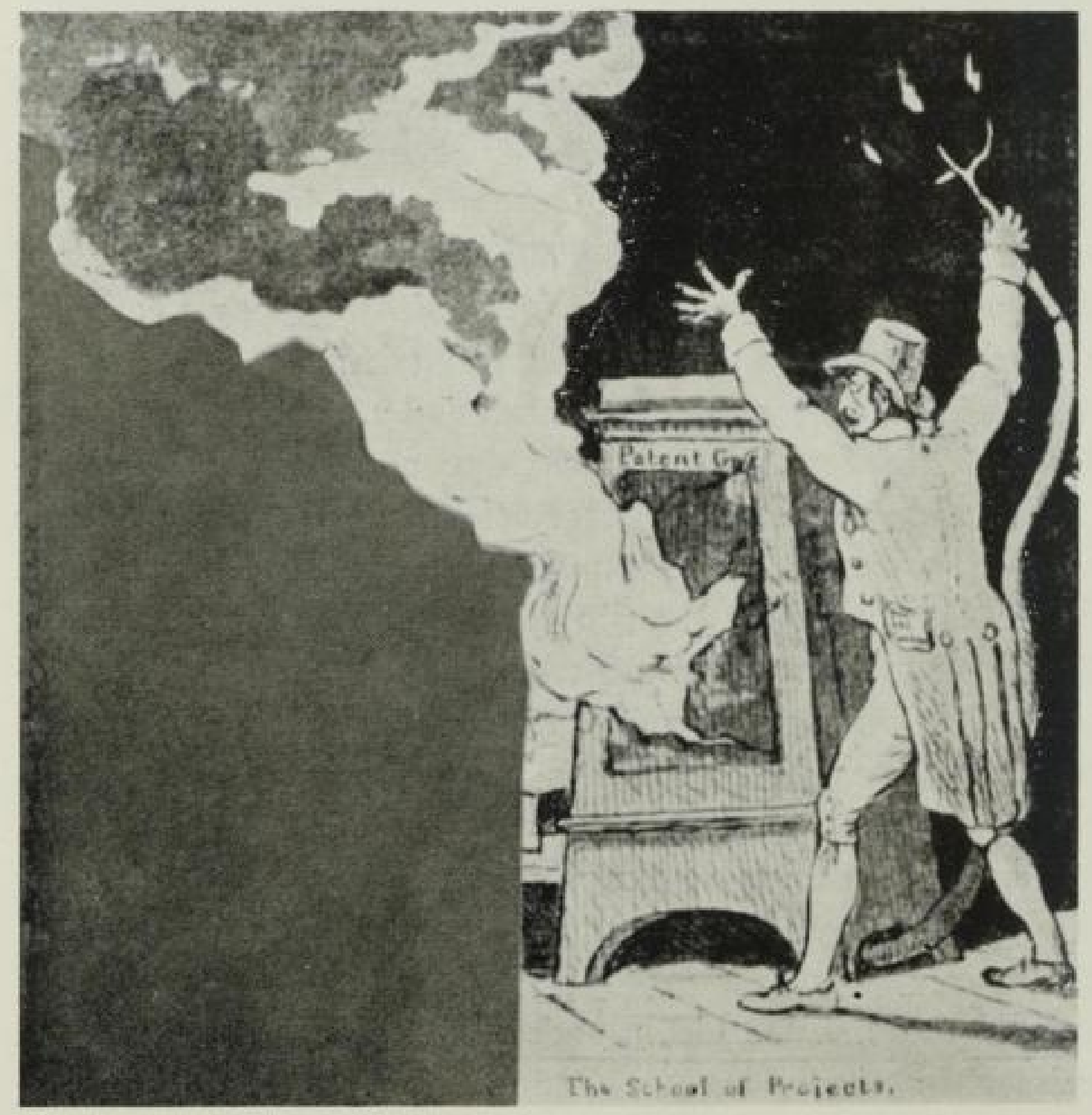

Bild It

Karikatur auf Winsors Werbevorträge 1807 von S. Tipper (Gas Journal Centenary) 
auch noch nicht einmal in den Köpfen der Gesellschafter fest. A c cum trat schon 1812 dem beginnenden Bau des ersten Werkes in Cannon Row mit dem Vorschlag, in Einzelhäusern Thermolampen jeweils einzubauen, entgegen. Er hatte sich allerdings wegen der dann notwendigen Baukosten gründlich getäuscht, was bei einer Nachprüfung durch das Direktorium klar wurde.

Immerhin war man mit gewissem Recht der Ansicht, dał Gas nur auf verhältnismäfjig kurze Entfernungen durch Straß̧en geleitet werden könne. Man benutzte nämlich als Treibkraft lediglich den Druck, der sich in der Retorte bilden kann. Er war mit 2" WS bei den Schwierigkeiten, die Deckel dicht zu bekommen, für die Retorte und die günstige Entgasung schon reichlich hoch, für den Abfluf des Gases sehr gering, da noch Vorlage und Reiniger und mit einem Druckunterschied beim Füllen und Leeren, der Gasbehälter durchflossen werden mu\}ten. Auf diese Weise muß̧ten auch bei einer Zentralversorgungsanlage im Gebiete von London gleich mehrere Gaswerke kleinen Ausmałes erbaut werden. So gab es viele Baustellen und Betriebe, die mit dem zunächst zur Verfügung stehenden Personal kaum beherrscht werden konnten. Da man nicht schneil genug den Wünschen nach Gasbeleuchtung nachkommen konnte, entstanden mehrere selbständige Gasgesellschaften im Wettbewerb mit der Gas Light \& Coke Co.

\subsection{Accu}

Auch Friedrich Christian Accum mufy man in die Reihe der Pioniere des Gasfaches einreihen. Er ist der erste Chemiker gewesen, der im Dienst einer Gasgesellschaft gestanden hat. Geboren ist er am 29. 3. 1769 in Bückeburg ${ }^{9.45}$ ). Sein Vater, der sich als Seifensieder betätigte, starb, als der Junge 3 Jahrc alt war. So wuchs er in engen Verhältnissen auf. Über seine Schulbildung wissen wir nicht viel, etwas Gymnasialbildung scheint er indessen genossen zu haben. Wahrscheinlich ist er bei einem Apotheker in der Lehre gewesen, von denen damals vor allem die praktische Chemie gepflegt wurde. So ist er vermutlich nach Hannover gekommen und von dort durch $\mathrm{Br}$ a n de nach London gebracht, der sowohl in Hannover als auch in London eine Drogen- und Chemikalienhandlung betrieben hat. In London besuchte Accum fleißjig die sich bietenden Vorträge, er fiel A. Carlisle und W. Nicbolson auf, von denen jener sich seiner Ausbildung unter Beschäftigung als Laborant annahm, dieser ihn zu: schriftstellerischen Arbeiten ermutigte. 1800 eröffnete Accum ein selbständiges Geschäft, ein Laboratorium zur Analyse und Prüfung von Handelsprodukten und eine Handlung für chemische Geräte und Chemikalien. Bald crteilte er auch Studenten Unterricht in Experimentalchemie. Er wurde ein sehr bekannter und gesuchter Chemiker, und wenn auch seine Hauptbeschäftigung auf dem Gebiets der Nahrungsmittelchemie gelegen hat, holte man ihn doch, wie erwähnt; als Gutachter über die Gasbereitung und -verwendung heran, als der Streit zwischen Winsor und Murdocb tobte $\left.{ }^{2.40}\right)$. Als Zeuge bei der Untersuchung vor

\footnotetext{
2.15) Heimatbläter, Beilage zur Schaumburg-Lippischen Landeszeitung Bückeburg $1952 . \mathrm{Nr}$. 10 und if

2.45) St. Everard, The History usw. London 1949 (s. 2.42)
} 
dem Unterhausausschuł 3 kam Accum in ein schwieriges Kreuzverhör, schwierig deswegen, weil, wie er dem Ausschuf freimütig sagte, er keine Lust habe, alle Karten über seine Versuchsmethoden, die seinen Lebensunterhalt gewährten, offen zu legen. Der gegnerische Anwalt stellte in seinem Plädoyer die Behauptung auf, dał Accum über das einfache geometrische Gesetz des mit dem Quadrat des Durchmessers wachsenden Flächeninhaltes des Kreises nicht Bescheid gewuf̧t habe, die sich auch heute noch als erwiesen in der Literatur findet ${ }^{2.47}$ ). Beim Lesen der Aussagen wird aber deutlich, daß er bei einer Flamme von doppelter Höhe bei Photometerversuchen nur die doppelte Lichtmenge festgestellt hatte. „Ich habe das nicht nach arithmetischen Verfahren ermittelt, sondern aus dem Ergebnis der wirklichen Messungen." Alles andere ist auch das Ergebnis sehr sonderbar formulierter Fragen gewesen, wie man es bei Kreuzverhören in technischen Dingen leider öfter erlebt.

Was Accum sonst insbesondere über die chemischen Dinge gesagt hat, konnte füglich nicht bezweifelt werden. Er hat sich mit der Herstellung von Salmiak und Ammoniumkarbonat aus Gaswasser beschäftigt, hat den Teer untersucht und fraktioniert die leichten Öle und Asphalt abgeschieden. Auch wenn er beim Koks feststellt, daf̧ der nahe am Feuer erzeugte für technische Zwecke, der weiter $a b$ schlecht entgaste für den Haushalt im offenen Feuer am besten geeignet sei, so sagt er die Wahrheit. Auffallend ist, daf3 er scheinbar dem Koks einen höheren Heizwert nachsagt als der Kohle, aber er beschreibt auch, daf er nur die gesamte Feuerung zur Verdampfung von Wasser und Schmelzen von Metallen betrieben habe. Dabei seien, wie immcr viele noch wertvolle Rauchschwaden aus der Kohle abgezogen.1.45).

Die Verbindung mit der ersten Gasgesellschaft führte 1812 zu seiner Aufnahme in den Court of Directors. Sein Einsatz zum Bau eines Gaswerkes war nicht glücklich, während sich $C l e g g$ im Werk Petersstreet erfolreich durchsetzte. führte Accums Arbeit zu einer Reihe von Unfällen, die auf seine geringe technische Begabung hindeuten. Ein von ihm aus Guf̧eisen entworfener Gasbehälter sackte bei der Ausführung in sich zusammen. Bereits im November 1813 trat Accum von seinem Posten zurück.

Sein Hauptverdienst liegt in den vielen wissenschaftlichen Veröffentlichungen. Neben vielen Einzelbeiträgen in Zeitschriften hat er allein 20 Bücher geschrieben, in denen immer wieder eigene Untersuchungen auftauchen. Im Jahre $18 \mathrm{rs}$ erschien sein Buch, das erste über den Gegenstand überhaupt, über das Gaslicht ${ }^{2.40}$ ). In diesem ersten Buche werden noch sehr viele Worte für die Erklärung des Wesens des Kohlengases und für seine Vorzüge gebracht, die nicht tief begründet erscheinen. Aber einige Abschnitte sind heute noch beherzigenswert. Die Verbrennung des Gases macht er durch den Vergleich mit der Kerze deutlich. Mit bescheidenen Ausdrücken spricht er die Vermutung aus, dał die Leuchtkraft des Gases jeweils von den Eigenschaften der Gasart herkomme. Darin wird er durch seinen übersetzenden Professor zurechtgewiesen. Dieser hängt offenbar noch an der Vorstellung Lavoisiers, daf̧ Licht und Wärme

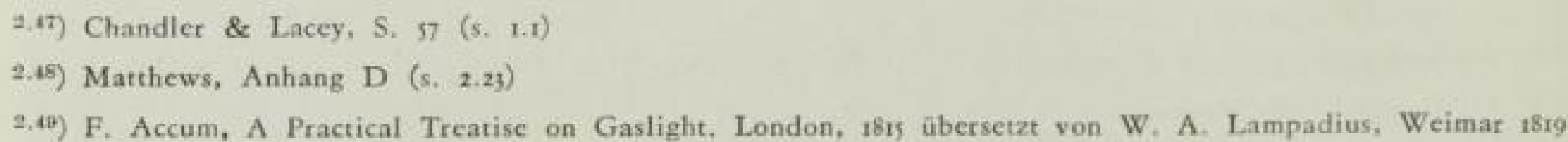


unwägbare Körper seien, die dem Sauerstoff zugeordnet wären. Lampadius sagt: „Daf3 die Farbe der Flamme nicht von eigener Lichtentwickelung herrühre, geht gerade daraus hervor, daf oft garnicht brennbare Körper die Flamme dennoch färben. Diese Verschiedenheit der Flammenfarben scheint wohl davon abzuhängen, wie die in der Flamme aufsteigenden Teilchen gewisser Körper das weiß̧e Licht des Sauerstoffes mehr oder weniger zerlegen." Accum aber sagt einige Zeilen weiter: „Was die durch Steinkohlen, Holz und andere Brennstoffe gefärbte Flamme und ihre Varietäten ins Rote und Purpurfarbene betrifft, so erscheint sie durch die der Flamme mehr oder weniger beigemischten Wasserdämpfe und Rauchteile, kurz durch solche Stoffe zu entstehen, die mit der Flamme unverbrannt aufsteigen." Accum scheint also C. L. Bertbollet zu folgen $^{2.50}$ ), der glaubte, daf bei den reagierenden Stoffen, nicht allein Sauerstoff (Wärme $=$ Calorie) zur Verbrennung beitrage. Der im gleichen Jahre von H. $D$ a $v$ y ausgesprochenen Ansicht, der eine Verdampfung der organischen Stoffe im Inneren der Flamme annahm und Kohle in fein verteilter Form als Lichtgeber ${ }^{2.51}$ ) benannte, kam Accum also näher als der Professor $L$ a mp a di us. Accum bringt dann noch viele technische Einzelheiten der Gaserzeugung und Gasverteilung, die, da sie Leistungen von Clegg und anderen beschreiben, an anderen Stellen dieser Darstellung berücksichtigt worden sind.

Die Neubearbeitung dieses Stoffes in seinem zweiten Werke ${ }^{2.57}$ ) ist dem gegenüber viel klarer und kürzer. Beim Lesen spürt man deutlich die Fortschritte, die der Verfasser in der Sicherheit der Erkenntnisse gemacht hat. Sein Englisch ist ausgezeichnet. Dieses Buch ist mit einem brauchbaren Schlagwortverzeichnis versehen.

Accum weist auf die Möglichkeit, mit Gas zu kochen, hin. „Bei der Raumheizung mit Gas könnte in Lagerräumen, Bildergalerien, Büchereien eine gleichmäfjige Temperatur gehalten werden.“ „Jede leuchtende Verbrennung, ob Kerze oder Gaslicht, geht über den Weg des Kohlenwasserstoffgases."

Am packendsten ist aber vielleicht sein scharfer Angriff gegen den Unfug, die stark riechende, ausgebrauchte Kalkmilch der Gasreiniger einfach in die Kanäle und Vorfluter abzulassen. Er geht soweit, Auflagen des Gesetzgebers dagegen zu verlangen. Hier kommt wohl seine Lebensaufgabe zu Worte. Er hatte sich nämlich damals gegen die Verfälschung und Vergiftung der Lebensmittel, die er ja laufend zu untersuchen hatte, gewandt und so sagt er: „Das gesunde Wasser ist für uns von eben solchen Folgen, wie irgend eine bessere Beschaffenheit oder Kostenersparnis in der Beleuchtung sein kann. Wir müssen besorgt sein, daf3 wir bei Benutzung von Verbesserungen, die Wissenschaft und Kunst entdeckt hat, nicht etwa die natürlichen Segnungen, die wir der Freigebigkeit der Natur verdanken, unnötigerweise entwerten."

Accum ist schon sehr früh vorgeworfen worden, dał er sich für kaum ausführbare Entwürfe von Erfindern - meistens ist das Cleg $g$ - ohne Kritik zu sehr ein-

\footnotetext{
2.50) Essai de Statique Chimie 180;

2.5i) H. Davy, Philosophical Transactions, Royal Society 1819, I, S, 75 nach Muspratts theoretische, praktische und analytische Chemie, Encyclopadisches Handbuch der Technischen Chemie von F. Stohmann und Brum. Kerl. Leuchtstoffe 1894 S. 89

2.52) F. Accum, Description of the Process of Manufacturing Coal Gas 2. Auf1. London 1820
} 
gesetzt habe, aber andererseits kann man selbst heute noch verstehen, daf3 er von Cleggs Erfindergedanken besessen war.

Im Jahre 1820 kam Accum mit einer Schrift über die vielen Verfälschungen der Lebensmittel heraus, die er im Laufe seines Lebens festgestellt hatte $\left.{ }^{2.58}\right)$. Er fügte den zwei ersten Auflagen dieses Buches eine Liste der in letzten Jahren ergangenen Gerichtsurteile bei mit Nennung der Namen der Betrüger. Er hatte sich wohl nicht vorgestellt, wie mächtig diese Herren trotz ihres „Dreckes am Stecken “ waren. Seinen Gegnern kam zu passe, dał auch Accum einen bösen Fehler begangen hatte. Er hatte nämlich in den aus der Royal Society geliehenen Büchern Seiten, die er für seine Arbeiten brauchte, einfach herausgerissen. Nun wurde er unter Anklage wegen Diebstahls gestellt.

Accum sah sich nach einer Zeit grołartiger Erfolge plötzlich angefeindet und verlassen von allen Freunden. Er wurde vor Scham und Schande kopflos. Zum Gerichtstermin erschien er nicht, seine Kaution lief er verfallen und, obwohl ein Freispruch erfolgte, verlief er in aller Stille London.

Nach einer längeren Erholungsreise wandte er sich nach Berlin, wo er als korrespondierendes Mitglied der Kgl. Akademie der Wissenschaften aufgenommen wurde. Bei der Gründung des Gewerbeinstituts 1827 wurde er Professor der Technischen Chemie und der Mineralogie, an der Bauakademie Professor für Chemie, Physik und Mineralogie.

Den Schlag aber, den ihm die öffentliche Anklage in London versetzt hatte, hat er nicht mehr verwunden. An der Entwicklung der Chemie hat er nicht mehr mitgearbeitet. Er hielt sich still zurück. Seine wenigen weiteren Veröffentlichungen erschienen anonym oder mit dem Anagramm Mucca. Am 29. 6. 1838 ist Accum verstorben ${ }^{2.54}$ ).

\subsection{Clegg}

Wo immer man die technische Entwicklung der für einen störungsfreien Betrieb notwendigen Geräte und Apparate verfolgt, tritt uns Samuel Clegg als der bewundernswerte, phantasicbegabte Ingenieur mit erfolgreichen Lösungen entgegen.

\section{E B E N S B I L D}

Clegg ist am 2. März ${ }_{1781}$ in Manchester geboren ${ }^{2.25}$ ). Erzogen wurde er von Dr. Dalton, dem Physiker und Chemiker, dessen Name noch heute wegen der Daltonschen Gesetze und der chemischen Atomtheorie jedem Schüler bekannt wird. Mit 24 Jahren, also wohl nach gründlicher theoretischer Ausbildung. wurde er bei Boulton \& Watt als Lehrling angenommen. Dabei war er Zeuge

5.53) F. Accum: A Treatise on the Adulterations of Food and Culinary Poisons, London 1820 (Die Mehrzahl der Werke ist als Original vom Altertumsverein Bückeburg gesammelt.)

2.54) Ausführliche Letensbeschreibung: GWF, 99 (1958), $\$ 16$

2.55) J. f. G. 4 (1861), 305. Chandler \& Lacey S. 47 (s. 1.1) Nach: A Practical Treatise on the Manufacture and Distribution of Coal Gas. S. Clegg jun.: 1841. S Auflagen bis 1868 
mancher Versuche Murdochs und wurde vor allem mit der Erstellung von Gasanlagen (für Fabriken) beauftragt. Schon als Lehrling richtete er die Beleuchtung der Baumwollspinnerei von H. Lodge, Halifax, ein. Er war ${ }_{4}$ Tage vor Murdoch mit dessen Anlage bei Philipps \& Lee fertig, weil er seinen Meister in freundschaftlicher Weise übertrumpfen wollte und mit Überstunden hatte arbeiten lassen. Die Verunreinigungen des Gases verursachten Kopfschmerzen und reizten die Lungen. Deshalb setzte er zur Reinigung in die Behältertassen Kalkmilch ein, die er mit einem Rührwerk in Bewegung hielt.

Das Verfahren hat anscheinend im Laboratorium zuerst W. Henry aus Manchester angewandt $\left.{ }^{2,50}\right)$. 1804 hat Henry in einer Vortragsreihe über Chemie in Manchester über die Verwendung von Kohlengas gesprochen (Nicholson Journal 180 s und Phil. Transactions $1808,1820,1824)$. Er hat Gase analysiert und stellte den Kohlenstoff als die Quelle des Leuchtens fest.

Die Schwierigkeiten, die übelriechende ausgebrauchte Milch aus der Tasse zu entfernen, veranlaf̧ten Clegg $1807 / 08$ an der Gasanlage einer Römisch-katholischen Schule in Stonyhurst, Lancashire, zum ersten Male eine vom Behälter getrennte Schwefelwasserstoffreinigung mit Kalkmilch vorzusehen. 1809 hielt er einen Vortrag über Gasanlagen für Fabriken in der Royal Society of Arts und erhielt deren silberne Medaille. Bekannt wurde er aber durch die Gasanlage beim Buchhändler Ackermann, Ior Strand, im Jahre 1812, von der Accum eine perspektivische Zeichnung bringt. (Bild I2) Sie bestand aus zwei Horizontalretorten, einer gut ausgebildeten Teervorlage, einem rechteckigen Gasbehälter mit entlasteter Tauchglocke, Gaskühlung im Behälterwasser, Teerscheider und Kalkmilchreiniger besonderer Bauart ${ }^{2.57}$ ).

Danach trat er im November 1812 zur Gas Light \& Coke Co. über und widmete sich umfangreichen Verbesserungen in deren Werk Peters Street, Westminster, die für die gesunde Entwicklung der Gesellschaft wesentlich waren. Zunächst muß̧te das Rohrnetz an vielen Stellen überholt und verstärkt werden. Die Rohrdurchmesser wurden lediglich nach den gemachten Erfahrungen bemessen. Vorschriften für die Installation möchte man „TVR 1819 “ nennen. Sie sind als Anhang 4 nach Accum gegeben und geben als Beispiel ein eindrucksvoiles Bild vom Stande der Technik, wie sie unter Clegg entwickelt ist.

Clegg hatte auch einen grof̧en Teil der Voreingenommenheiten gegen das Gas zu beseitigen. Als im Dezember 1813 die Gaslampen auf der Westminsterbrücke angezündet werden sollten, verweigerten die Laternenanzünder, eine geschlossene Zunft oder Gewerkschaft aus der Zeit der Ölbeleuchtung stammend, die Arbeit. Clegg steckte die neuen Lampen mehrere Nächte lang persönlich an und hat sicherlich auch die Verständigung mit der Zunft herbeigeführt ${ }^{2.55}$ ). Im Oktober 1813 kam es zu einer Explosion im Werke, die natürlich grofes Aufsehen erregte. Infolge Unachtsamkeit beim Wechsel des Kalkwassers war Gas aus dem Reiniger ausgetreten und hatte sich an den Retorten entzündet. Clegg wurde als einziger mit Verbrennungen verletzt und muf̧te I4 Tage das Bett hüten. Er traf sofort Änderungen, um Wiederholungen zu vermeiden. Er versah die Reiniger mit

2.5n) Matthews, S. $37 / 38$ (s. 2,25), Vergl. auch Abschnitt 2.12: Winzlers Anwendung von Kalkmilch

2.07) S. Clegg jun, S, 13 (s, 2.20)

3.5s) S. Clegg jun, S. 19 (s, 2.20) 


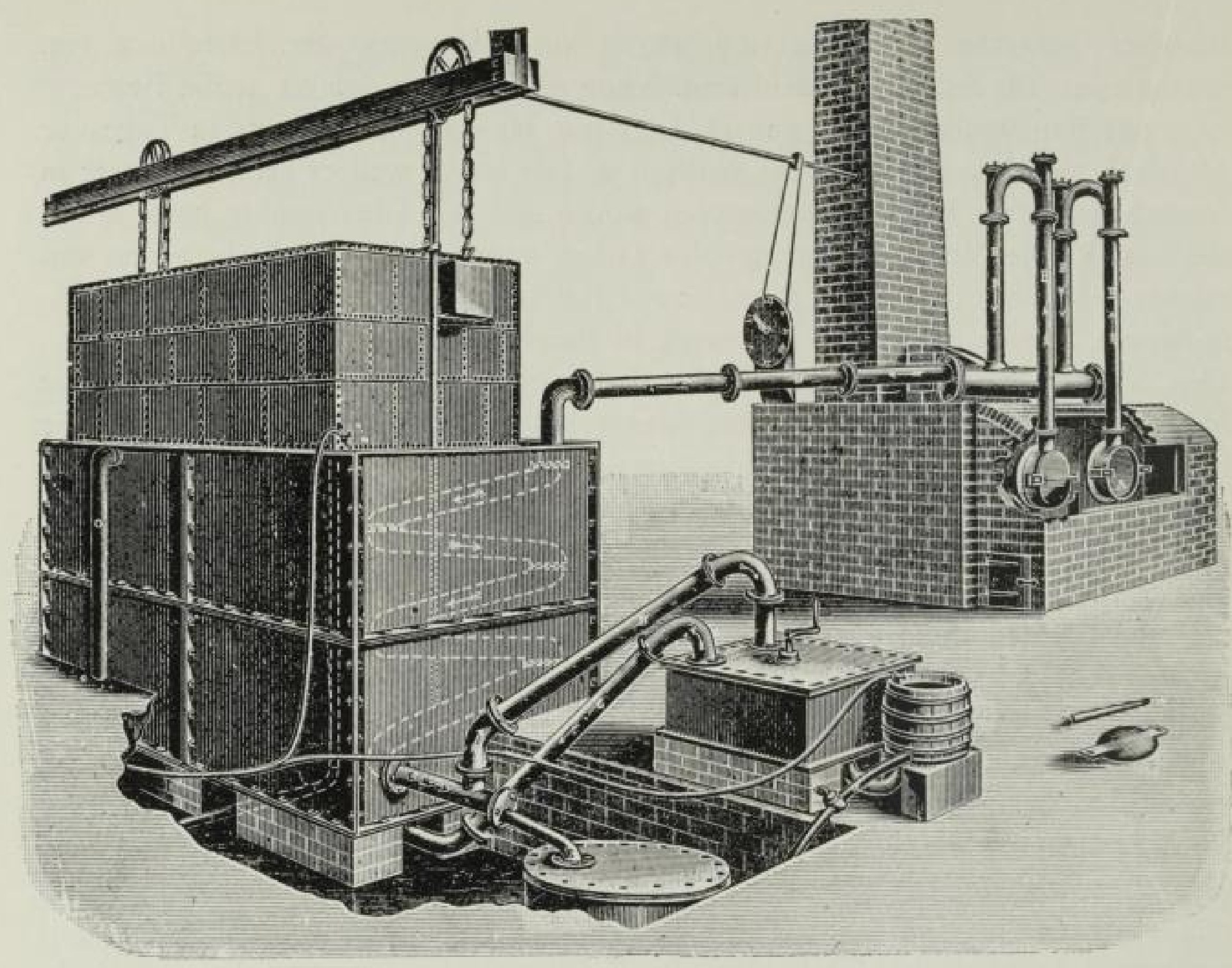

Bild 12 Cleggs Anlage beim Buchhändler Ackermann, Strand, London 1812

einem Tauchverschluf am Ablał des Kalkwassers und lieł die Ausgleichsgewichte am Behäiter fort, so daf̧ dieser mit Sicherheit unter Überdruck stand. Dafür entwickelte er den Druckregler für den Ausgang in die Stadt.

Der „Home Secretary“ lief̧ einen Ausschuf der Kgl. Gesellschaft unter dessen Präsidenten Sir. J. Banks zusammenrufen, der den Vorfall zu untersuchen hatte. In diesen Ausschuf hatte man auch Sir W. Congreve als „einen Fachmann auf dem Gebiete der Explosionen" gewählt, der damit mit der Gastechnik bekannt geworden ist, ein Umstand, der für die Entwicklung der Industrie vor allem auch in Deutschland von entscheidender Bedeutung werden sollte (Vgl. Abschnitt 3.II).

Clegg erklärte freimütig, was geschehen war, und was er getan hatte, um gleiche Unfälle für die Zukunft zu vermeiden. Drastisch überzeugte er den Ausschuf,, daf̧ ein nur mit Gas gefüllter Behälter nicht explodieren könne, indem er mit der Axt ein Loch schlug und das ausströmende Gas entzündete. Er gewann durch seine Art den Ausschuf für sich und besonders Congreve zum besonderen Freund des Gases.

1817 konnte Brande im Journal of Science and the Arts ${ }^{2.59}$ ) feststellen, dafy bis dahin nur 6 Unfälle kleineren Ausmaß̧es vorgekommen wären, obwohl nächtlich viele tausend Lampe brannten, die noch dazu im allgemeinen sehr sorglos behandelt würden.

2.50) Chandler \& Lacey, S, SI (5. 1.1)

72 
Kleinere Arbeiten Cleggs waren es, die Gieß̧ereien zur richtigen dichten Herstellung von Rohren zu zwingen, Absperrhähne und Brenner zu verbessern u. a. Nach den Feststellungen der Gasgesellschaft hat die "Chartered" Gas Light and Coke Co. von Anbeginn an Schmetterlingsbrenner verwandt. Clegg jun. schreibt sie einem Arbeiter Winsors namens Stone zu, während andere Berichte sie als eine Erfindung des Schotten J. B. Neilson in Glasgow, der aber erst 1817 ins Gasfach eintrat, bezeichnen. Selbst in solchen kleinen Dingen gibt es also Prioritätsstreitigkeiten, die man heute aber kaum mehr klären kann.

Viel wichtiger war die Konstruktion eines Gasbehailters, mit der sich Clegg recht geplagt hat. Die Tauchglocke war aus den Laboratorien bekannt, wo sie als Gasometer zur Speicherung und Messung kleiner Gasmengen verwandt wurde (vgl. S. 84). Im technischen Małsstabe wurde aber die grofe Wassertasse ein schwierig beherrschbares Element. Mit den zur Verführung stehenden Bauerfahrungen und Baustoffen war sie nicht dicht zu bekommen. Vor allem aber stand das Werk Petersstreet auf sumpfigem Grund, der früher von der Themse überflutet worden war. Darum verlangte das Gewicht des Wassers nach schweren Fundamenten und Pfahlgründungen. So versuchte Clegg, die Wassertauchung durch eine Lederdichtung zu ersetzen, wie man sich denken kann, ohne guten Erfolg. Nun kam eine kinematisch geniale Konstruktion aus Blechtafeln, die an den Rändern mit Lederfalzen gedichtet werden sollten. Auch das ging nicht. Danach folgte ein Versuch in Anlehnung an den nassen Gasmesser, einen drehbaren nassen Behälter zu bauen, der mit seiner Kammer einer grołen Ringwaage ähnlich sieht. Da alles unvollkommen war, wurde der nasse Gasbehälter mit schmiedeeiserner Glocke weiter entwickelt.

Sehr wichtig wurde Cleggs Gasdruckregler, den er zuerst für den Gasbehälterausgang entwickelt hat, dann aber auch in kleinerer Ausführung als Einzelregler für Leuchten und als Wohnungsdruckregler auf den Gasmesser aufgebaut verwenden wollte.

Cleggs Beitrag zur Entwicklung der Schwefelwasserstoffreiniger ist im Zusammenhange mit anderen Arbeiten unter 2.2I2 abgehandelt. Andere Reinigungsverfahren von auswärtigen Erfindern lehnte Clegg brüsk ab. Genannt werden Koning aus Alkmaar (vgl. S. 91.) und Kretscbmar aus Dessau, der ohne Kalk arbeiten wollte. (Möglicherweise handelt es sich um den von Winzler erwähnten Kretschmer aus Sandersleben. Das kann leider nicht mehr festgestellt werden.)

Aufregend aber ist geradezu die Konzeption einer flachen drehbaren Retorte, die aus Schmiedeeisenblechen zusammengenietet war. Zu ihrer Empfehlung sprach Clegg Gedanken aus, die auch heute noch für einen Drehtischherd im Industriebetriebe gepriesen werden. Er hat nicht nur fast kontinuierlichen Einund Austrag im Auge, sondern auch Vorwärmung und Abkühlung vor und nach der Zone höchster Hitze, die ein Drittel der Kreisfläche umfaß̧t, zur verbesserten Wärmeausnützung. Dabei erhielt er in der Aufwärmzone Schwelteere, die er aber sofort im Steigrohr kondensierte und in das Kohlenbett zurückfallen lief, um sie in der Heizzone zu zersetzen. Vor allem wollte er die Kohle in flachen Mulden lagern, die mit durch den Ofen gehen, um den Koks zu schonen, der dann auch in den offenen Feuern Londons besonders gut gebrannt haben soll. Accum schrieb in heller Begeisterung über die in der Königlichen Münze von 
Clegg nach seinem Ausscheiden aus der Gas Light and Coke Company errichtete Einzelanlage (Bild ${ }_{13}$ ). Über die Steigerung der Ausbeutezahlen aus einer Tonne Kohle gab er fast nicht glaubwürdige Zahlen an. Indessen hat sich die Retorte nur in wenigen Anlagen eingeführt. Sie war wohl den Beanspruchungen durch Wärme nicht gewachsen. Auch der Antrieb gibt, wie er gezeichnet ist, kein allzu grof̧es Vertrauen. Aber noch 1827 ist Matthews des Lobes für diese Anordnung voll.

Als grofe Erfindung Cleggs wird man seine „Maschine zum Messen und Verzeichnen der Menge des verbrauchten Gases in der Abwesenheit des Beobachters", kurz den Gaszähler bewerten. Zuerst als Stationsgasmesser, zur Verfolgung der Erzeugung geschaffen, lenkte er die Aufmerksamkeit auf den hohen Verbrauch der Abnehmer, der mit den vertraglich vereinbarten Pauschalsummen nicht im Einklang stand, und führte zu geeigneten kleinen Zählern.

Die erste Bauart bestand aus zwei grofen tierischen Blasen, die abwechselnd mit Gas gefüllt wurden und in einem Weiß̧blechgehäuse untergebracht waren. Es war also ein trockener Gasmesser. Die Steuerung geschah durch Tauchung in Quecksilber. Die Blasen waren bald durch das Gas zerstört. Leder und andere

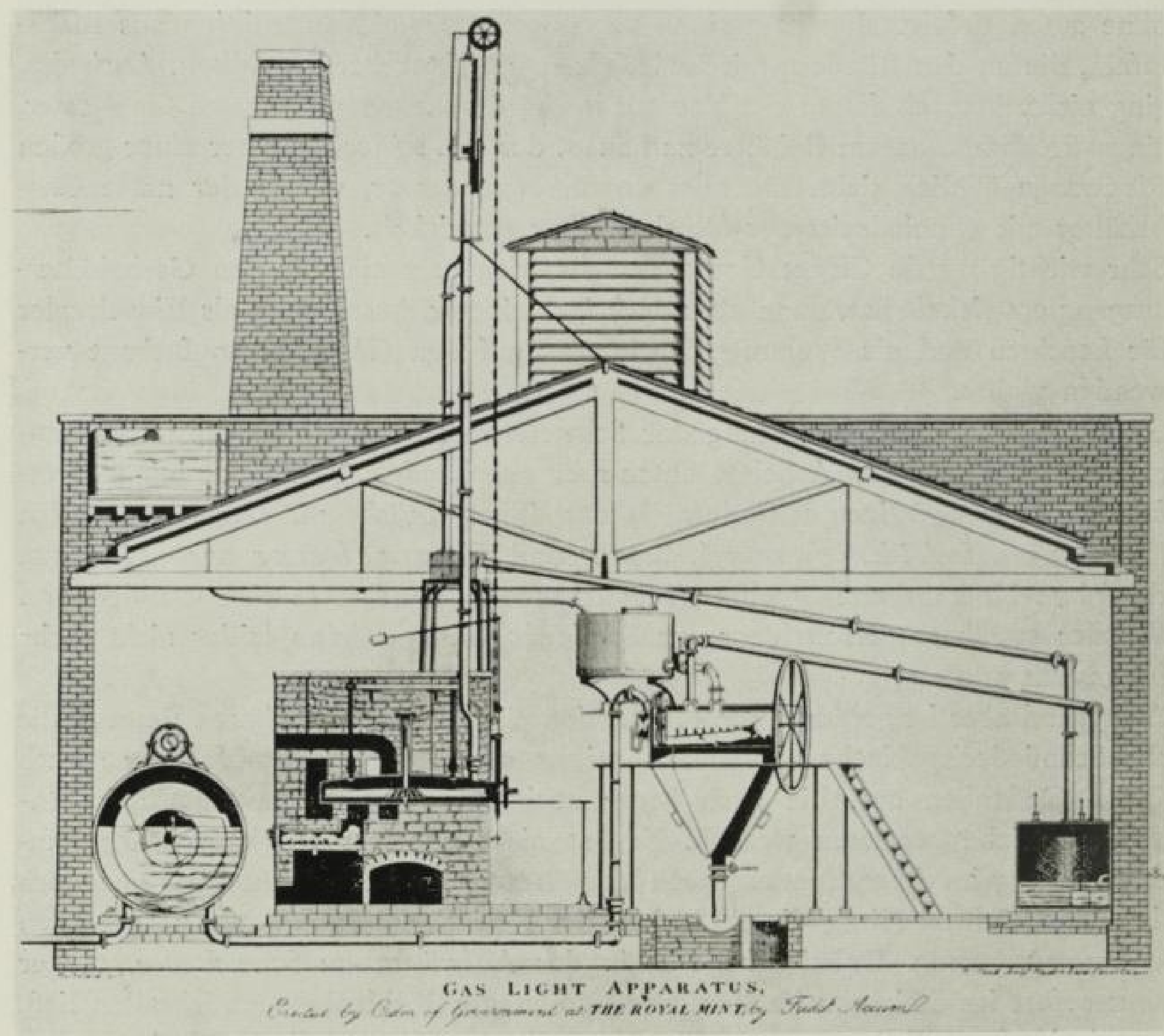

Bild ${ }_{13}$ Die Gaserzeugungsanlage in der Kgl. Münze zu London, entworfen durch S. Clegg und gebaut von Accum mit der flachen Drehretorte und dem drehbsren Kalkmilchreiniger (Chandler \& Lacey) 
Membranstoffe, mit Firnis oder Goldhaut belegt, wurden hart. Danach wurden zwei kleine Gasbehälter genommen, die wie die Blasen gesteuert wurden. Davon wurde ein Zähler bei Ackermann aufgestellt. Schlief̧lich wurde der erste Trommelgaszähler entwickelt, über den Clegg mit seinem Assistenten $M$ a l a m. der die Trommel verbessert hatte, später wegen der Prioritätsrechte in Streit geriet. Nach dem Urteil der Society of Arts hatte der Malamsche Messer nichts Gemeinsames mit dem Cleggschen, obwohl beide die drehende Bewegung hat ten. Schon der Cleggsche Messer zeigte aber die Fähigkeit des Konstrukteurs, sich den Ablauf der Tauchung räumlich vorzustellen $\left.{ }^{2,20}\right)$. Die Grundgedanken, wie auch der Aufbau des Zählwerkes sind über hundert Jahre nicht geändert worden.

Ganz besonders aber dürfte die Flammensicherung am Brenner heute fesseln, zu der ihn Auseinandersetzungen mit den Feuerversicherungen geführt haben. Sie ist schon $\mathrm{r} 8 \mathrm{r}$ entwickelt worden. Für die allgemeine Verwendung war sie zu kostspielig, sie sollte aber in geschlossenen Räumen und Gewölben vorgesehen werden. Die gedachte Wirkungsweise mit einem sich schwächer dehnenden Eisenstab in einem Messinggehäuse ist nach der Zeichnung ohne weiteres verständlich. (Bild $\mathrm{I}_{4}$ ). Die Einführung dürfte nicht nur an dem Preise, sondern auch an der hinderlichen grofen Speicherwärme mit ihren Verzögerungen gescheitert sein.

Trotz seiner Regsamkeit, vielleicht sogar gerade deswegen, wurde Clegg allmählich den Direktoren der Gesellschaft unbequem.

Naheliegend ist der Gedanke, dał die vielfachen Versuche, die bei ungenügenden Erfahrungen im Gaswesen notwendig waren, um gelegentlich einen Treffer zu haben, den Herren, die für die Wirtschaft verantwortlich waren, starke Sorgen bereiteten. In den Chroniken sind natürlicherweise fast nur die bewährten Konstruktionen zu finden, manchmal die grofen Fehlschläge. Was aber an dauernden kleinen Fehlern vorgekommen ist, Unkosten verursachte, aber schnell beseitigt werden konnte, ist nicht bekannt. Clegg wai da in einer Lage, die manchem Ingenieur innerhalb einer Firma Aufregung und Ärger bereitet. Heute aber, in einer ausgereiften Technik, ist die persönliche Verantwortung leichter als beim Beginn eines neuen technischen Verfahrens.

Hinzu kam noch, dał Clegg ein lebhafter Draufgänger war. Er fühlte sich durchaus sicher auf seinem Gebiete und war mit der Kritik der Arbeit anderer Leute schnell und scharf.

Immerhin stieg die Verärgerung Cleggs mit dem Direktorium. 1816 wurden ihm die Auslagen für seine Experimente, die er ohne Genehmigung durchgeführt hatte, vom Direktorium vorgehalten. Er antwortete stolz und selbstbewuft, wenn man einen Besseren hätte, würde er gern zurücktreten. Ja, er forderte ausschlief̧lich für sich persönlich das Recht, seine Erfindungen auszubeuten. Er nahm außjerhalb seines Vertrages mit der Gasgesellschaft den Auftrag als Berater beim Bau einer Gaserzeugungsanlage in der königlichen Münze an, wie er überhaupt als Zivilingenieur von vielen Seiten in Anspruch genommen wurde. Das mag uns heute noch viel erstaunlicher sein als seinen Direktoren. Denn nach englischem Recht sind gerade diese Direktoren für solche Nebenaufgaben frei. 


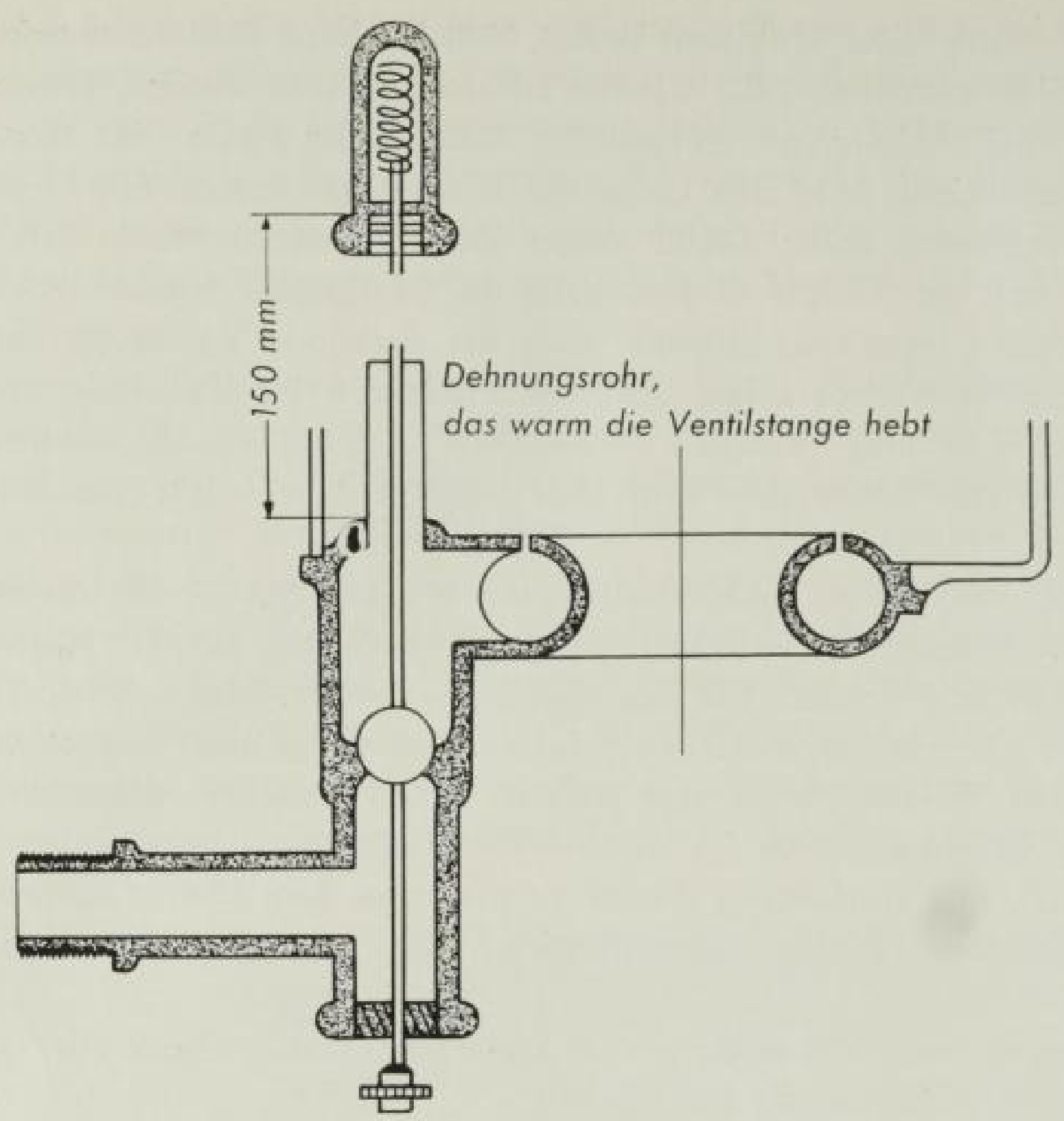

Bild 14

Brenner mit Flammensicherung

(nach Clegg jun. 184r)

Clegg war aber kein Direktor, sondern Angestellter mit einem Aufgabenkreis, der kaum zu bewältigen war. Man kam dann zwar zu einem neuen Anstellungsvertrage, bei dem Cleggs Arbeitskreis nach seinen Wünschen eingeschränkt war. Aber bald kamen neue Auseinandersetzungen. Er beklagte sich über den erbärmlichen Zustand der ihm anvertrauten Anlagen: „Keine der Retorten wird mehr länger als einen Monat halten“". Das Direktorium war böse, und am I. April 1817 legte Clegg sein Amt nieder.

Er hat sich zunächst noch weiter mit der Gastechnik beschäftigt. Sein Sohn berichtet $^{2.81}$ ), daß Clegg im Jahre 1817 durch vielfache Versuche bestätigt fand, daf̧ sich die Leuchtkraft des Gases proportional mit dem Dichteverhältnis verändere. Sehr viel später, 1940 , stellte $\mathrm{H}$. S a inte Claire-Deville die Behauptung auf, daß3 der Heizwert des Gases einen Maßstab für die Lichtleistung gäbe. Solchen Beziehungen traten erst E. Terres und H. Straube I92I entgegen ${ }^{2.02}$.

Clegg erhielt noch ein oder zwei Aufträge der Gasgesellschaft auf ihm patentierte Anlagen. Er arbeitete mit Crossley an der Verbesserung des Gasmessers, bekam aber Verbindung mit inzwischen gegründeten konkurrierenden Gasunternehmen. Dann wandte er sich vom Gasfach ab, ging als Ingenieur in portugiesischen Staatsdienst, beteiligte sich dann an der Entwicklung der Drucklufteisenbahn von $S$ a muda, die ein Fehlschlag wurde.

2.61) S. Clegg jun., S. 43 (5. 2.20)

2,63) J. f. Gasbel. 64 (1921), 321 
Die englische Regierung holt ihn aber als Inspektor heran, wobei er Ermittlungen zur Vorbereitung neuer Gasgesetze anstellte. In seiner Freizeit half er seinem Sohn bei der Bearbeitung von dessen Lehrbuch: A practical treatise on the manufacture of gas lighting, London $184 \mathrm{I}$, das $\mathrm{I} 868$ seine 5. Auflage erlebte. Er starb in der angesehenen Stellung als government inspector am 8. Januar 186r.

\section{$2.18 \mathrm{Malam}$}

Ein Zeitgenosse von Clegg war John M a la m. Er wird als Zeichner im Gaswerk Petersstrafje, das Clegg unterstand, genannt. Auch er war ein befähigter Ingenieur und ist für manche Verbesserungen verantwortlich. Daf es mit Clegg zu einer Auseinandersetzung über die Erfindung des Gaszählers gekommen ist, wurde bereits erwähnt. Malam führte seinen Zähler 1819 in der Society of Arts vor. Das Urteil lautete, daß der verbesserte Zähler mit dem Clegg patentierten auf̧er dem Gehäuse und der Drehbewegung nichts gemein habe. Malam wurde die goldene Isis-Medaille verliehen.

Malam wird wahrscheinlich zu Unrecht ${ }^{2.39}$ ) die Einführung der liegend-ovalen Retorte zugeschrieben. T. S. Peckston, der viele Versuche über Gasausbeute im Rahmen der Gas Light \& Coke Co. durchgeführt hat, schrieb ihre Erhöhung dieser Form $\left.\mathrm{zu}^{2.04}\right)$. Die Beobachtung, daf die niedrige Schichtung das Gas leichter austreten lief̧ und der beschränkte freie Raum über der Kohle die Zersetzung der Kohlenwasserstoffe minderte (Leuchtkraft), dürfte richtig sein, wenn auch die 50\% Erhöhung der Gasausbeute wegen der Form der Retorte Peckston nicht geglaubt werden kann. Ein deutscher Wissenschaftler, C. W. T $a b o r$, auf dessen Abhandlung noch zurückgekommen werden muf, steht 1822 offenbar unter dem Eindruck, dał in der Rivalität von Clegg und Malam Peckston sich einseitig für Malam eingesetzt und Clegg Unrecht zugefügt hat. Matthews berichtete 1827 , daß Malam und Peckston verschwägert waren $\left.^{2, \infty}\right)$.

Auch in die Schwefelreinigung hat sich Malam verbessernd eingeschaltet. Man war dazu gekommen, zur besseren Ausnutzung der Kalkmilch mehrere Wäscher hintereinander zu schalten, die viel Platz beanspruchten. Malam konstruierte die ersten Turmreiniger, indem er in einem Gehäuse drei Tauchwäscher übereinander setzte. Auch für Reinigerkästen mit trockenem Kalk gab er Verbesserungen in der Schaltung an, vornehmlich durch den Entwurf einer Verteilungsglocke auf vier Kästen, ähnlich den Umsteuerventilen bei Siemens-Martin-Öfen ${ }^{2.96}$ ).

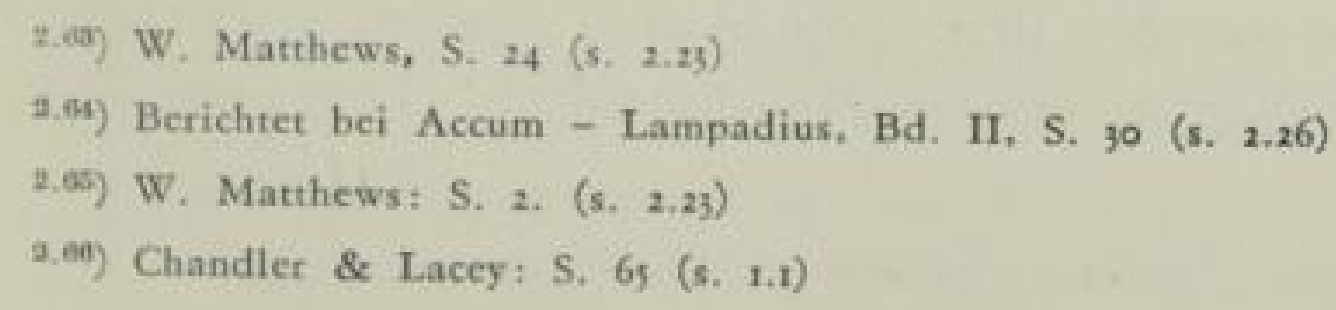




\subsection{A LLGEMEINE ÜBERSICHT}

Die Kohlenentgasung wurde zunächst in London durch den Koksabsatz wirtschaftlich sehr begünstigt. Das geht aus einer nur nebenbei zu findenden Tatsache hervor. Accum gibt für seine Rechnungen über Ausbeute und Aufwand fast immer und in erster Linie den für die Unterfeuerung notwendigen Kohlenaufwand an. Nur hin und wieder wird auch der Verbrauch von Koks erwähnt. Man kann sich das damit erklären, dał, wie Accum es auch erwähnt, die Kohlen im Einzelhandel Londons teuer waren. Das ist insofern verwunderlich, weil die Kohlen auf dem Seewege herankamen, man nannte Steinkohle in London geradezu Seacoal, d. h. Seekohle. Aber die Segelschiffahrt um die Küste war nicht ungefährlich. Zum Kohlentransport wurden die ältesten Schiffe, die sich nicht mehr auf den Ozean wagen konnten, benutzt. Darüber sind in der Geschichte der Gas Light and Coke Company an vielen Stellen Anmerkungen enthalten. So war der Handel vom Wetter abhängig und die Lieferung sehr ungleichmäfjig. Das ergab wieder Preisschwankungen und ganz offenbar grołe Händleraufschläge. Auch darüber berichtet diese Geschichte, indem sie die Bemühungen der Gasgesellschaft im einzelnen beschreibt, sich vom Zwischenhandel nach Möglichkeit unabhängig zu machen. Der Transport innerhaib der Stadt vom Themseufer her war auch keineswegs für den kleinen Abnehmer günstig. Demgegenüber erhielten die Gaswerke mit ihren groß̧en Abschlüssen und geregelten Fuhrverhältnissen die Kohlen doch erheblich billiger. Kleine Seitenkanäle für Schuten sind auch wohl ausgenützt worden.

Der Koks fiel hingegen in den verschiedenen Gaswerken oft mitten in der Stadt an. Es war ja auch eine überraschend grołe Zahl von Einzelwerken vorhanden, da diese nicht zu grofy werden sollien, und die Fortleitung des Gases nur auf geringe Entfernungen möglich war. So fand der Koks gerade in London in den Bezirken um die Werke herum einen guten Absatz im Kleinverkauf. Mancher Abnehmer war auch froh, von den Kohlen ganz verschiedener Art, die ihm der Kleinhandel durcheinander anbot und die oft sehr gasreich waren, loszukommen. Koks war in guß̧eisernen Retorten bei niedriger Temperatur entgast, in den offenen Feuerstellen gut und mit etwas züngelnden Flammen verwertbar. Der Preis war, selbst wenn der Einzelhandelspreis für Kohlen im Stadtbezirk unterboten wurde, für das Werk immer noch günstig.

Diese Verhältnisse trafen aber nur für die grofe Stadt London, die sich zudem gerade in dieser Zeit gewaltig ausdehnte, zu. In den Landstädten lagen die Verhältnisse anders, besonders in den Kohlenrevieren selbst.

2.2I Tecbniscbe Entwicklung

Die erste schwierige Aufgabe, das Gaserzeugungsverfahren in die Technik zu übertragen, war durch $C l e g g$ und $M$ a l a m erfolgreich gelöst. Die notwendige Sicherheit war durch konstruktive Lösungen und nach der Einarbeitung von Fachkräften erreicht. Der Betrieb war bei den erreichbaren Preisen wirtschaftlich möglich. Noch 1860 sagte Schilling in seinem Handbuch $\left.{ }^{2.77}\right)$ : „Der erste Er- 
finder (Murdoch) gelangte also im Laufe weniger Jahre auf den Stand, den wir irn Groß̧en und Ganzen noch heutigen Tages als Grundlage für unsere Konstruktionen festhalten."

Nunmehr galt es, das Verfahren zu verbessern. Gute, gleichmäß̧ige Leuchtkraft mufte mit immer geringerem Aufwande erzielt werden. Das kam in dem betrachteten Zeitabschnitt lebhaft in Gang, war aber nunmehr, wie immer, weniger das Werk von Einzelnen, sondern ergab sich aus der Zusammenarbeit mehrerer. Der Beweis wird dadurch gegeben, daf3 in manchen Dingen grundsätzliche Meinungsunterschiede ganzer Schulen festgestellt werden können. Das ist der richtige Abschnitt, um eine Gesamtübersicht über das weitere Geschehen zu geben.

\section{2ri Retorten und Ófen}

Ganz natürlicher Weise wandte sich die Aufmerksamkeit der İngenieure zuerst der Verbesserung der Öfen und der Form der Retorten zu. Man beobachtete, daf verschiedenartige Kohlen auch andere Behandlung, zumindest andere Temperaturen verlangten. Ganz allgemein wufte man, dał hohe Temperaturen die beste Gasausbeute, aber auch einen hohen Verschleif an Retorten bringen. Accum fafyte 1820 die Erfahrungen der Londoner Gesellschaften dahin zusammen, dał, wo die Kohlen teuer, die Retorten preiswert seien, mit hohen Temperaturen gefahren werden sollte; wo aber die Kohlen billig, Löhne dagegen hoch seien, müsse man zur Schonung der Retorten bei niedrigen Temperaturen arbeiten $^{3.05}$ ). Als guter Mittelwert wurde Hellrotglühen (a bright cherry redness) angegeben. Auffallend ist, dał bei all solchen Betrachtungen Accum die Leuchtkraft des Gases nicht bewertet, wie überhaupt die Zersetzung der Kohlenwasserstoffe in den freien Räumen oberhalb des Kohlenhaufens nicht ausdrücklich erwähnt wird, und nur tastend dieses Ergebnis vermieden wird. Dabei widmete gerade Accum schon frühzeitig der Messung der Leuchtkraft mit dem Schattenphotometer von $R u m f o r d$ seine Aufmerksamkeit und entwickelte eigene Kontrollverfahren mit durchscheinenden blinden Gläsern.

Nicht von $A c c u m$ begründet, damals also auch nicht bekannt, ersieht man aus den Konstruktionen die Schwierigkeiten, die Retorten und ihren Inhalt mit den einfachen Planrosten gleichmäßjig zu beheizen. Da die Kohle an den Seiten der kreisrunden Retorten viel eher völlig entgast ist als in der starken Lage der Mitte, wurde eine flache rechteckige Querschnittsform versucht - (I8I2 bei Gas Light and Coke Co. $)^{2.30}$ ). Diese hielt aber die Wärmespannungen nicht aus. Besser in dieser Hinsicht war ein Halbkreis mit flachem Boden und die elliptische Retorte 20 \ 10 bis $25 \times 10$ Zoll $(500 \times 250 \mathrm{~m} / \mathrm{m}$ bis $625 \times 250 \mathrm{~m} / \mathrm{m}$ ) in Querschnitt und etwa $1800 \mathrm{~m} / \mathrm{m}$ bis $2100 \mathrm{~m} / \mathrm{m}$ lang. Der Unterfeuerungsaufwand an Kohle betrug 30 bis 36 v. H. der entgasten Kohle ${ }^{3,70}$ ). Eine nierenförmige Retorte versuchte $M u r d o c b$ bereits $1805^{2,109}$ ). Sie entsprang dem Wunsch, in den aufgebauschten, von zwei Seiten erwärmten Ecken eine größere Kohlenmenge zu haben ${ }^{2.71}$ ).

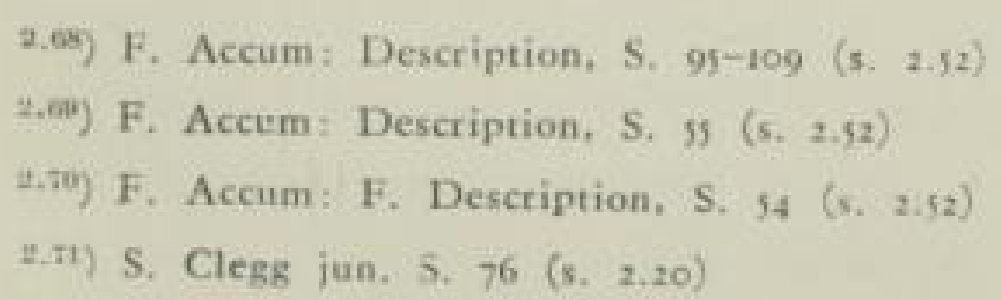


A ccu $\mathrm{m}$ beschrieb 1820 als im neuesten Ofen eingebaut wieder zylindrische Retorten (nach $R a c k b o u s e$ ), die zusammen mit dem Ofen Peckston untersucht hat; während Clegg noch $184 \mathrm{I}$ den Querschnitt eines liegenden D mit an der unteren Fläche stark abgerundeten Ecken bevorzugte.

Viel schwieriger aber stellte sich die gleichmäfige Beheizung in der Längsachse und vor allem die mehrerer Retorten in einem Ofenraum. Anfänglich beschränkte man sich darauf, über einem Rost zwei Retorten übereinander einzubauen und nahm in Kauf, daf die obere Retorte nachhinkte. Um Bedienung zu sparen, versuchte man, mehrere Retorten bis zu fünf einzubauen (drei in der unteren Reihe, zwei darüberliegend). Es zeigte sich aber, daf3 der Unterfeuerungsverbrauch anstieg. Den Grund dafür hat schon sehr frühzeitig (1822) der Deutsche $T a b$ or erkannt $^{2.7 z}$ ). Die Engländer hätten sich zu sehr an die Erfahrungen mit Dampfkesse!n gehalten. Wie bei eingebauten Walzenkesseln wurden die Kanäle eng gehalten, also sicher, ohne die Einwirkungen genau zu kennen, auf konvektiven Wärmeübergang hin gebaut. Die Gase wurden mit möglichst guter Schornsteinwirkung nach oben aus dem Ofen hinausgefuhrt. Dabei mufiten sie natürlich längs des Weges abkühien -und gegen Ende die Entgasung langsamer werden als am Anfang. Tabor schlug einen freien Ofenraum vor, dessen Abzug zum Stauen der heif̧en Gase nach unten zu führen sei. Dieser Vorschlag wurde aber offenbar nicht beachtet. Noch ${ }_{18} 43$ führt $K a r m a r s c b$-Heeren ${ }^{2.73}$ ) unter den Ofenbildern als neu nur den B arlow schen Ofen an, der dem Gedanken Tabors gemäß gebaut ist.

Zunächst versuchte man, den Einfluf der Strahlung vom Rost durch flache Steineinbauten unter den ersten Teil der Retorte zu mindern. Dann brachte man mehrere Feuerstellen, zunächst zwei unter dem Ofenraum mit fünf Retorten an. Für $A c c u m$ ist die neueste Ausführung die freitragende Retorte von $R a c k b o u s e$ in einem ,air furnace“. Was er mit gerade diesem Ausdruck gemeint hat, wird nicht ganz klar; er spricht von einem Ofen mit stark erhitzter Luft, aber darin kann man keinen Unterschied von früheren Ausführungen sehen, es sei denn, daf ảer Luftüberschufł geringer als fruher war. Indessen sind hier drei Feuerstellen im 5-Retortenofen vorgesehen. Die drei Retorten der unteren Reihe ruhen auf Stühlen, die zwei oberen sind durch das Gewölbemauerwerk aufgehängt, alle Retorten ohne einen Strahlungsschutz. Die Abzüge sind auffallend eng gezeichnet, mit Einzelschiebern im waagrechten Teil versehen, so dał hier zum ersten Mal ein Stau der Abgase vorgesehen ist. Der Ofenraum selbst wird durch ein abgeflachtes Gewölbe überdeckt. Rackhouse kommt offenbar auf diese andere Weise, wie es $T a b$ or später will, zur strahlenden Wärmeübertragung, ,wobei die Retorten der von allen Seiten einwirkenden Hitze ausgesprochen gut standgehalten haben“. „Das Feuer geht frei und gleichmäßjig um alle Retorten herum und die ganze Höhlung des Ofens erreicht eine gleiche Temperatur, die sie behält, wenn der Heizer dafür sorgt, so wenig Luft wie möglich hinzuzulassen." Dieser letzte Satz trifft wohl den entscheidenden Fortschritt gegenüber der ailgemeinen Ansicht, dał die Feuerung mit reichlicher Luft freiweg brennen sollte.

2.72) H. W. Tabor: Vollstandiges Handbuch, Frankfurt/Main, S. 195/97 (s. 2.115)

2.73) Karmarsch-Hecren, S. 822 (s. 2.6)

80 
Über die Drehherdretorte Cleggs, die sich nicht allgemein einführen konnte, ist in seinem Lebenslauf ausführlich berichtet worden.

Die Entwicklung der Tonretorten, die 1820 beginnt, mag geschlossen im dritten Hauptabschnitt dieses Buches beschrieben werden.

Den Ofenbauern mögen noch einige Einzelheiten über die Ausführung der Öfen willkommen sein. Verankerungen gab es nicht. Deshalb ist das Mauerwerk aufjerordentlich schwer und vorzugsweise sind Halbkreisgewölbe verwendet. Unter den Öfen wird oft, geschützt durch schwere Gewölbe, der Koks sofort gelagert. Cleg g kämpft um die schnelle Beseitigung des Kokses zum Schutze der Arbeiter gegen die Strahlung des glühenden Kokses. Sicherlich hat man aber bei manchen der gezeichneten Kokskeller mit Wassergasbildung und Explosion zu tun gehabt.

Steigrohre von den Retortenköpfen mit Teervorlage sind schon recht bald genormt in der Ausführung, wie sie sich im Grundsatz erhalten hat, solange Waagegungsmethode mitgeteilt.

\subsection{Reinigung}

In den Lebensbildern wurde bereits erwähnt, daf schon Minckelers 1784 Gase durch Wasser und Kalkmilch geleitet hatte, und daf auch Lebon an eine Waschung des Gases gedacht hat. Winzler nahm Kalkmilch; technisch entwickelt, hat $C l e g g$ die Kalkmilchreinigung. Dieser hat auch wohl bei der Hilfsstellung, die er kurze Zeit Winsor gegeben hat, diesem die Reinigungsmethode mitgeteilt.

E. He ard, der Winsor bei seinen Werbevorlesungen geholfen hat, erhielt 1806 ein Patent auf die Reinigung von Gasen bei hoher Temperatur ${ }^{2.74}$ ), um das Gas ohne unangenehmen Geruch verbrennen zu können. Kalk sollte entweder mit den Kohlen in die Retorten eingetragen oder das Gas in einem besonderen Apparate über erhitzten Kalk geleitet werden. Auch könne man sowohl Alkalien oder alkalische Erden, wenn sie von Kohlendioxyd befreit sind, als auch Metalle und deren Oxyde, wie Eisen, Mangan, Zink, Kupfer oder Blei zur Reinigung verwenden. Hier findet man also schon die ganze Fülle von Möglichkeiten der Gasreinigung samt Anwendung des Eisenoxyds vertreten, und auch die Erhitzung von Kalk zur Entfernung des Schwefelkohlenstoffes, auf die Bowditch 1862 ein Patent erhielt ${ }^{2.2 \pi}$ ).

Die Kalkmilchreinigung befriedigte jedenfalls keineswegs. Sie brauchte viel Wasser, und die Abführung der ausgebrauchten Milch führte zu Beschwerden der Kanalverwaltung im Werke Peters-street. Die Speicherung in Behältern konnte nur ein Notbehelf sein. April ${ }_{1814}$ berichtete $C l e g g$, daf̧ alle Behälter angefüllt seien. So überlegte man die Verlegung des Werkes an eine andere Stelle, wo ein Abflufggraben vorhanden war $^{2.70}$ ). Schlief̧lich kam man mit dem Ausschuf für die Themseschiffahrt überein, gegen eine jährliche "Strafe" durch

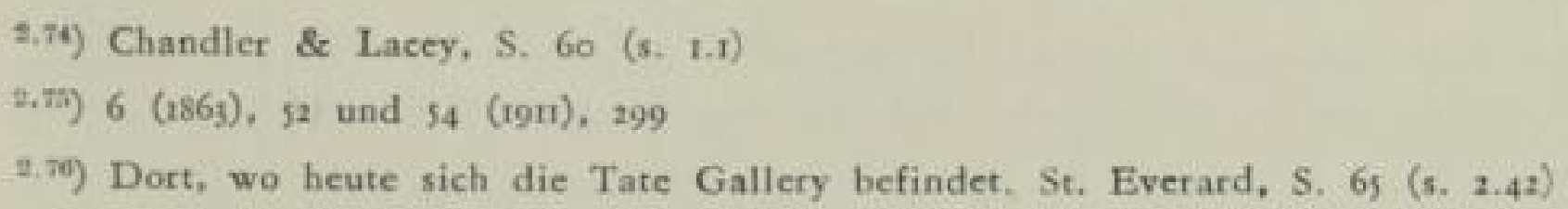


ein besonderes Rohr das Kalkwasser einfach in den Fluß zu lassen. Dort hat es ja sicher damals, wenn man den Beschreibungen von C. Dickens folgt, nach Teer, Tran und Fischen genug gerochen; aber eine wirkliche Lösung war auch das nicht.

Clegg versuchte, mit weniger Wasser auszukommen. Die Anwendung trockenen Kalkes bei Ackermanns Privatgasanlage war ein Fehlschlag gewesen. Ein steifer Brei setzte aber dem Gasstrom zuviel Widerstand entgegen. Der Widerstand war ein schweres Hindernis, weil ja Gassauger noch unbekannt waren. A c c um spricht von Gasdrücken bis $100 \mathrm{~m} / \mathrm{m}$ in den Retorten mit Schwierigkeiten, die Köpfe dicht zu halten. Clegg hat mehrere Konstruktionen versucht, um mit beweglichen Zuführungsrohren, Kratzern und dergleichen, die Widerstände erträglich zu halten. Für den Antrieb der Welle benutzte er den Stationsgasmesser. Um die Tauchtiefe im einzelnen Wascher zu vermindern, wurden drei Gefäł̧e hintereinander gesetzt, die $M$ a l a $m$ zuerst übereinander angeordnet hat, wobei er auch darauf hinwies, dał eine grof̧e Oberfläche die bessere Ausnutzung des sehr reichlich mit Wasser versetzten Kalkes ermögliche, und damit die eingesetzte Menge verringerte $\left.{ }^{2, \pi}\right)$. A c $u m$ allerdings ist der kaum verständlichen Meinung, dał besonders viel Flüssigkeit damit notwendig werde $\left.^{2.75}\right)$. Clegg hat dann nach seinem Ausscheiden aus der Gasgesellschaft eine neue Bauart eines Reinigers für seine Anlage in der königlichen Münze erbaut und sich patentieren lassen. Diese Bauart hat aber keine Verbreitung gefunden ${ }^{2.70}$ ). Allmählich nahm man Dampfmaschinen zum Antrieb der eingebauten Rührwerke. Das Verfahren lief̧ trotz sorgfältiger Vorschriften über die Herrichtung einer gleichmäßjig dünnen Kalkmilch ${ }^{2.0}$ ) noch sehr viel zu wünschen übrig. Der Gedanke, das viele Wasser loszuwerden, glückte erst R. P billipps in Exeter. Sein Patent von 1817 sagt aus: .,Ich setzte dem zu Pulver zerfallenen gebrannten Kalk nur soviel Wasser zu, dafy die Kalkmilchteilchen eben aneinander haften, aber nicht so dicht, daf̧ das Gas nicht mehr durchtreten kann." Die Anweisung für die richtige Herstellung des gerade richtig feuchten gleichmäf̧ig verteilten Kalkes liest sich wie ein Rezept für ein Preisstück der Kochkunst ${ }^{2.51}$ ). Dieser Kalk wurde auf Horden in $150 \mathrm{~m} / \mathrm{m}$ Höhe aufgelegt. Phillipps machte auf die Notwendigkeit aufmerksam, der Gasmenge entsprechend u. U. mehrere Reiniger nebeneinander zu schalten. An die Verfolgung seines Patents knüpft sich eine böse Erzählung. Die Gaswerke, die die Erfindung benutzten, gründeten eine Interessengemeinschaft. Da nach englischem Recht die Neuheit nicht geprüft wird, muß der Erfinder im Prozeł̧wege seine Ansprüche durchsetzen, wenn die Benutzer nicht von selbst dazu bereit sind. Als nun Phillipps klagte, stief er auf die grołe Abwehrfront und mufzte aus finanziellen Gründen die weitere Verfolgung aussetzen. Er starb infolge der Aufregungen ${ }^{9.62}$ ). Im grof̧en Maß\}-

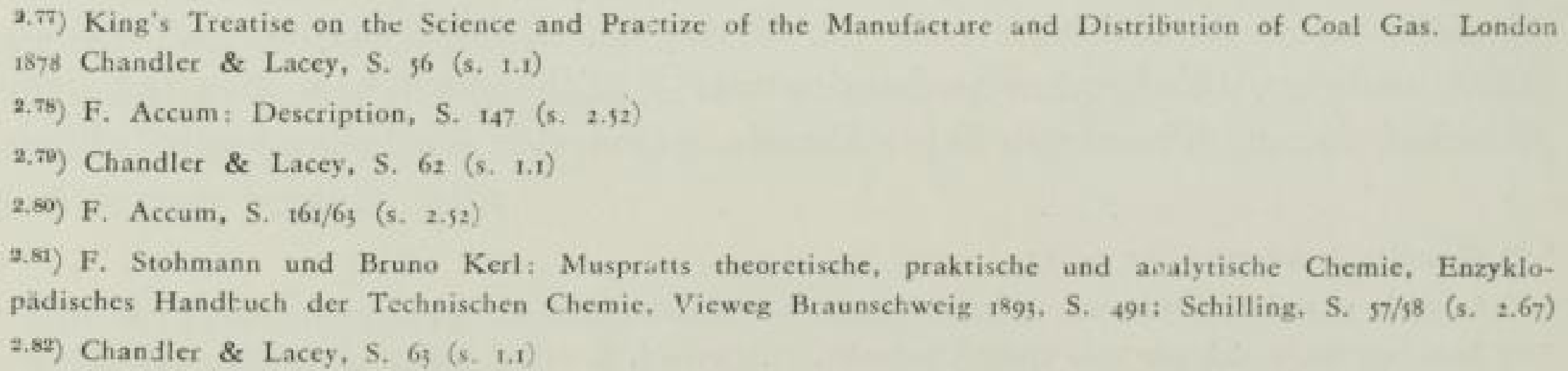


stabe aber ging man auf Phillipps Verfahren erst 1870 und allgemein 1890 über. Inzwischen verbesserte $M$ al a m die Anordnung der Reinigerkästen. Er führte durch eine Umschaltvorrichtung mit unterteilter Tauchglocke die wechselweise Hintereinanderschaltung der Reinigungskästen, wie sie später auch bei der trokkenen Eisenhydroxydreinigung üblich geblieben ist, $1817 \operatorname{ein}^{2.58}$ ).

$\mathrm{Zu}$ beachten ist, dał mit Kalk auch Kohlendioxyd gebunden wurde, was der Leuchtkraft des Gases zugute kam. $C l e g g$ konstruierte noch ein Prüfgerät für den Schwefelwasserstoffgehalt des Gases, in dem er Bleiacetat und BariumWasser (für den Kohiendioxydnachweis) verwandte ${ }^{2.81}$ ).

\subsection{Teerscheidung und Teerverwendung}

Der Teerscheidung wurde zunächst wenig Aufmerksamkeit zuteil, was kondensierte und sich durch Schwerkraft an Teer und Ammoniakwasser abschied, wurde aufgefangen. $C l e g g$ verwahrte sich ausdrücklich dagegen, daf̧ die Sorge um die Nebenerzeugnisse zu seinen Aufgaben als Ingenieur gehöre ${ }^{2.55}$ ). Gewiß meldeten sich Interessenten für die Ausbeutung des Teeres, ja, nachdem Clegg ausgeschieden war, versuchte die Gas Light \& Coke Co. I818 die Aufbereitung, lief̧ sie aber später (1833) als unwirtschaftlich wieder fallen. Diese Anlage hatte die Aufmerksamkeit I. D altons gewonnen. Er konnte mehrere Erzeugnisse aus dem Teer vorweisen. Über die verschiedenen kurzlebigen Versuche, den Teer zur Vergasung heranzuziehen, ist in den Lebensläufen der Erfinder berichtet. Man verbrauchte den Teer, so gut man konnte, als Eisenanstrich (Gasbehälter) und machte auch die ersten Versuche, ihn zu verbrennen, ohne auch damit zu befriedigenden Verfahren zu kommen. Die chemische Industrie nahm gewisse Mengen ab. Die üblichen Verfahren der Destillation zur Gewinnung von Gasöl und Pech beschreibt Accum sehr eingehend, ebenso wie die Aufarbeitung des Gaswassers zu Salmiak und Ammonsulfate ${ }^{2,5 n}$ ).

\section{$2.214 \mathrm{G}$ as behäler}

Die ersten Gasanlagen waren ohne Behälter gebaut worden. Das Gas sollte in dem Maf̧e verbraucht werden, wie es erzeugt wurde. Das stellte sich bald als unmöglich heraus. Der nasse Gasbehälter mit einer Tauchglocke war aus den alten Laboratorien bekannt. Lange Zeit hielt man A. L. Lavo isier für den Erfinder der Gastauchglocke im Laboratorium. W. Le ybold zitiert aus dem Buche Lavoisiers: Traité élémentaire de chimie, Paris 1789 , den Anspruch, den dieser selbst ausgesprochen hat: „Ich habe den Namen ,Gazomètre einem Instrument gegeben, das ich erfunden habe und das ich ausführen lief\}, um ein Gebläse zu haben, das einen dauernden und gleichmäb̂igen Strom von Sauerstoff für Schmelzversuche liefern sollte." Die Glocke ist an einem Waagebalken aufgehängt mit Gegengewichtsschale.

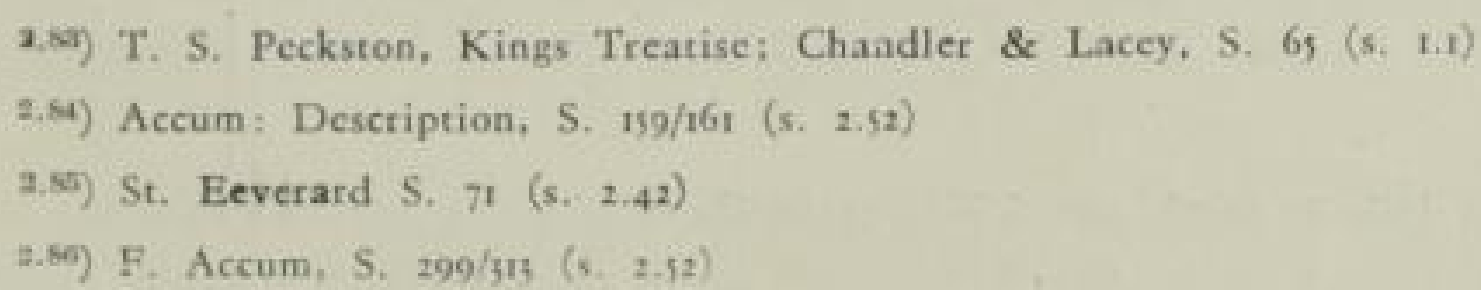


F. M. Feldbaus hat aber entdeckt, daf Huyghens schon 1687 die Tauchglocke im Laboratorium verwandt hat. Deshalb braucht aber auch die Angabe Lavoisiers nicht falsch zu sein, wenn er seine Erfindung auf die $\mathrm{Zu}$ ordnung des Waagebalkens zur Druckveränderung bezieht.

A c cu m hat die Lavoisiersche Glocke vereinfacht, indem er auf die Kalotte einen langen Stab lotrecht setzte, an dem mit einem Bügel die Glockenhöhe abgelesen werden konnte. Le ybold vermutet, daf Accum den Gedanken eines Gasspeichers an $\mathrm{Cleg} g$ weitergegeben habe ${ }^{2.57}$ ).

Die Ubertragung ins Grołe war jedenfalls eine gute Ingenieurleistung, die zunächst viele Schwierigkeiten bereitet hat. Vor allen waren es die Wassermengen, die die Konstrukteure aufregten. Die in den Boden eingelassenen Tassen waren nur schwer zu dichten. In London kam bei den nahe der Themse gelegenen Werken noch der schiechte Boden hinzu. Clegg entwarf trockene Gasbehälter (s. S. 73), die sich aber nicht bewährten.

Um einen gleichmäß̧igen Druck für die Verteilung zu haben, wurde die Glocke an Gegengewichten aufgehängt. Die Kette war so bemessen, dał sie den Gewichtszuwachs der aufsteigenden Glocke im abfallenden Trumm aufwog. Die ersten Bücher enthalten sehr eingehende Berechnungen, die zeigen, dał den damaligen Konstrukteuren die Behandlung der Aufgabe nicht leicht gefallen ist. Ein Vorzug war es, daf bei dieser Bauart der Gegendruck des Gases bis zu den Retorten gering gehalten werden konnte. Man kam auch bald darauf, dał man zur Verteilung Gewichte auf die Glocke auflegen konnte, um Mängel im Rohrnetz zu überwinden, andererseits aber auch Gewichte auf das Gegengewicht zum "Saugen“" aus den Retorten, wo vielleicht die Reiniger verstopft waren, was ja bei den Kalkreinigern leicht vorkam. Das war natürlich Handarbeit, die schwer vom Ingenieur beaufsichtigt werden konnte. So kam es dazu, daß in einen Behälter auch Luft eingesaugt werden konnte, wenn etwa die Reiniger gesäubert wurden ${ }^{2,55}$ ). Eine Explosion $18 \mathrm{iz}$ führte zu einer Besichtigung der Anlagen durch einen Ausschuf. (s. S. 7I) Der Bericht des Ausschusses war beruhigend, wurde aber nicht veröffentlicht. Er brachte aber unangenehme Auflagen: I. dał die Luft aus den Behältern nicht mit Gas verdrängt werden dürfe. Wie das anders geschehen konnte, war nicht gesagt. 2. daf3 die Behälter nicht mehr als $6000 \mathrm{cft}$, d. s. $160 \mathrm{~m}^{3}$ fassen dürften. Das war böse, wo man schon Behälter hatte, die mehr als doppelt so grof̧ waren. 3. dał die Behälter umbaut werden müßten, um sie gegen Winddruck zu schützen. Diese Vorschrift war insofern berechtigt, als die an den Gegengewichten aufgehängten Glocken keinerlei weitere Führung hatten, die Glocken also sehr leicht gegen die Tassenwandungen gedrückt werden konnten.

Clegg ging an die grundsätzliche Beseitigung der Gefahren. Er lieł̧ die aufhängung an Gegengewichte fort, gab den Glocken seitliche Radialführungen (aus Holzbalken) und konstruierte den nassen Regler für die Ausgangsleitung nach dem Prinzip, wie er noch heute gebaut wird. Clegg lief̧ also das ganze Gewicht der Glocke auf die Retorten wirken, was entschieden ein Nachteil war, aber er hatte das Gas im Behälter sicher unter Überdruck. Samuel Clegg jun. be-

\footnotetext{
12.57) Z. f. angew. Chemie (1918) S. 164; JfG. 61 (1918), 573; GWF. 79 (1936), 84

2.89) St. Everard, S. $59($ s. 2.42)
}

$8_{4}$ 
richtet 184I, daf3 oft genug bei unzureichenden Rohrweiten die Behälter - für die Abgabezeit - mit Zusatzgewichten belastet werden muften. Blieben sie beim Füllen der Behälter liegen, so war wenigstens keine Gefahr vorhanden. Die Umbauung konnte fortbleiben. Daß das beabsichtigt war, zeigte ein Preisvergleich der Baukosten, den S. Cle g g jun. aufgestellt hat.

In Schottland (Glasgow) folgte man den Gedanken Cleggs nicht. J. B. N e il so n, ein als Konstrukteur und später als Wärmetechniker bekannter Mann, hielt mit Rücksicht auf die Retorten an der Aufhängung fest. In Cleggs Journal ist darüber eine Auseinandersetzung erfolgt, die S. Clegg jun. noch $184 \mathrm{I}$ an das Tageslicht ziebt. Damals war man sich also offenbar immer noch nicht einig über diesen Punkt. Karmarsch-Heeren halten noch 184I die Bauart mit Ausgleichgewichten für aligemein üblich und geben auch ihrerseits die Berechnung der bei grofen Behältern recht schweren Ketten. Sie empfehlen dabei jedenfalls, die Gegengewichte wegen der unbestimmbaren Teerschichten, die an den Glokken haften, auszutarieren ${ }^{2.08}$ ).

Die Teleskopierung war ursprünglich ein Gedanke von $T$ a it 1824 , der ihn in der Mile End Oil Gas Company verwirklichte. In Leeds wurde 1826 ein fertiger Behälter besichtigt. Die allgemeine Aufnahme liegt erst in späterer Zeit ${ }^{2.00}$ ).

\subsection{Rohrverlegung}

Über die Rohrverlegung wird am besten $A c c u m s$, Übersicht" angezogen, die als Anlage 4 im Auszuge beigefügt ist.

\subsection{B renner}

Das Erste war natürlich, einfach das Gas am Ende eines Rohres anzuzünden. Das gab einen flackernden Brand. So entstanden geschlossene Rohre mit kleinen düsenartigen Löchern. Aber schon $M u r d o c b$ hat bei Phillipps and Lee sich auf zwei Brennerarten beschränkt. Die eine war der Hahnensporn- (Cocspur)brenner, ein senkrecht geführtes Rohrende, aus dessen Spitze das Gas durch ein enges $(0,8 \mathrm{~mm} \varnothing)$ Loch austrat und der auf̧erdem auf jeder Seite ein weiteres Loch hatte. Die seitlich auftretenden Flammen wurden durch den Auftrieb nach oben gebogen. So entstand ein Bild, das man mit der Bourbonischen Lilie oder zwei Hahnensporen verglich. Der Andere war aber schon ein nach dem Argandölbrenner entwickelter Beleuchtungskörper. Das Gasrohr endete in einem Ringe mit einer Vielzahl enger Löcher. Die Luft konnte von auß̧en sowohl wie von innen an den sich bildenden Flammenzylinder herantreten. (Bild 14) Die Flamme war bereits - wohl auch nach dem Vorbilde der Ollampen dieser Art - mit einem mehr oder weniger bauchigen Glaszylinder geschützt. Das Grundprinzip dieses Brenners ist bis zur Ablösung durch den Auerbrenner für hohe Ansprüche beibehalten worden, nur an der Luftzuführung mit Einregelmöglichkeiten ist vielerlei „erfunden“" worden.

\footnotetext{
4.46) Karmarsch-Hecen S. 828 (s. 2.6)

2.00) St. Everard S. $156 \quad(8.2,42)$
} 
W in sor hat bei seinen Vorführungen offensichtlich den Cocspurbrenner bevorzugt. In den vielen aus seiner Zeit erhaltenen Karikaturen über ihn ist vorwiegend dieser Brenner zu sehen. (Bild io und II.) Der Hahnenspornbrenner wurde durch den Fledermausflügelbrenner abgelöst (Batswingburner). Das ist der Schnittbrenner, der noch heute in Geräten mit Leuchtflammen benutzt wird. Um seinen Ursprung ist etwas Dunkel. Die Einen behaupten, er sei von Anfang an bei der Gas Light and Coke Company benutzt worden, andere, er sei zuerst in Glasgow etwa 1817 verwandt. Jedenfalls war auch hier die Grundform sehr früh gefunden. Verbesserungen haben sich mehr auf die Wahl des Baustoffes und auf die Anordnung der Kanäle im Innern des Mundstückes bezogen.

Der Ausführung der Leuchtkörper nahm sich offenbar die gestaltende Phantasie sofort an. Technischer Art sind die vielfachen Bauarten beweglicher Beleuchtungskörper mit Gelenken und Stopfbüchsen. Auffallend ist die sorglose Anwendung offener Tauchtassen mit Quecksilberfüllung bei grofen Kronleuchtern in geschlossenen Räumen.

\section{$2.217 \mathrm{G}$ as aus Ölen}

Einige mutige Männer wandten sich der Herstellung des Gases aus Öl zu. Gewił war das OI der Brennstoff, der auch bislang für die Beleuchtung verwendet wurde. Er war also da.

Besondere Aufnerksamkeit wird den Versuchen von J. und P. Taylor, aus Ölen ein hervorragend leuchtkräftiges Gas herzustellen, in den aiten Schriften gewidmet $^{2, \cdot 1}$ ). Ein Patent wurde $18 \mathrm{Is}$ an J. Gosling und J. Taylor erteilt. Als Rohstoff konne ein wohlfeiles und schlechtes Öl, das nicht einmal für Lampen geeignet sei, dienen. Die Anlage werde wegen der hohen Leuchtkraft des Gases kleiner als eine solche für Kohlengas. Die Retorte war ein gekrümmtes, rotglühendes Gufjeisenrohr, in das Öl eingetröpfelt wurde. Mit der Tropfgeschwindigkeit konnte man die Gaserzeugung regeln. Da das Gas unter allen Umständen schwefelfrei wäre, so könnte man Reinigungsapparate einsparen.

Von diesen Vorzügen wurden viele Engländer beeinflufzt, zumal die Gesellschaft Taylor and Martineau auch noch sehr günstige Ertragsrechnungen vorlegte. Unter anderen zeigte sich bei den Verhandlungen vor dem Unterhaus wegen eines Olgasgesetzes der damalige Inspektor of the Gasworks, Sir W. Congreve als sehr vertrauensselig. Er glaubte vor allem an eine geringere Explosionsgefahr, da ja die Mengen bei gleicher Leuchtkraft geringer wären. Vor dem Ausschu\} ist über all diese Gesichtspunkte viel an Erfahrungen und Theorien vorgetragen worden.

Ein Erzeuger zum Kracken wurde zu London in der Halle der Apotheker zur Beleuchtung dieses Hauses aufgestellt und kurz darauf wurde das Covent Garden Theater und die Hauptpost mit Ölgas versorgt. Gesellschaften zur Ausbeutung des Verfahrens wurden in vielen Städten gegründet, so in Edinburg, Liverpool,

2m) Accum-Lampadius Bd. II S. 169/170 (gibt Auszug aus Journal of Sciences and the Arts Bd. 6 S. 108)

(s. 2.26): Tabor Bd. II (s. 2.115): Accum, Description; S. 289 ff. (s. 2.52) 
Bristol und Hull. Edinburg wurde 1824 in Betrieb genommen und 1827 auf Kohlengas umgestellt. Chairman der Gesellschaft wär Sir W. $\left.S \cot t^{2.02}\right)$. Der berühmte Schriftsteller hatte ganz im Anfang in einem Briefe das Gas lächerlich gemacht. Er schricb an einen Freund in Schottland, daf in London „ein Verrückter vorschlägt, London mit - Nun, was meinst Du? - Ja; mit Rauch zu erleuchten $^{2.08}$ ). Die Entwicklung vom schnellen Kritiker zum Aufsichtsratsvorsitzenden einer Gasgesellschaft zeigt besser als viele Einzelheiten, was in 20 Jahren an Technik und Vertrauen errungen war.

Wirtschaftlich aber konnten sich die Ölgasgesellschaften nicht halten. Den günstigen Voraussagen hatte man vermutlich Spitzenleistungen bei genauester Führung der Vergasung zugrunde gelegt, die im rauhen Betriebe nicht annährend erzielt werden konnten. Offenbar war bei dem ganz guten Gas auch einfach ein grofer Teil des Öles als Dampf unzersetzt mit in das Gas übergegangen, der sich aber bei langen Straf̧enleitungen wieder niedergeschlagen hat. Diese Beobachtungen hatten die Unternehmer bei der Werbung neuer Ortschaften verschwiegen, ebenso, wie sie nicht davon gesprochen hatten, daf bei der thermischen Krakkung sich Koks in den Retorten bildete. Ja es scheint sogar, daf dieser Koks in der Bilanz des ersten Werkes im ersten Betriebsjahre als Wert aktiviert worden war. In Colchester war der Unternehmer stillschweigend zum Zusatz und nachher zur alleinigen Verwendung von Kohlengas übergegangen. Er war aber immer noch bereit, den Patentinhabern die besten Auskünfte als Referenz zur Verfügung zu stellen. Die Begründung für die Umstellung ist aber von Wert. Zunächst kam er mit dem Ölpreis nicht zurecht. Dann erzeugte er soviel Kohlengas, dał er den für die Füllung der Ölretorten notwendigen Koks selbst herstellen konnte, und schlieflich nahm er allein Kohlen, weil er beim Mischgas mit den Schwankungen in der Ölgaserzeugung nicht fertig wurde und daher dauernd verschiedenes Gas erhielt. Genau dasselbe ist später noch anderen Erfindern von Mischgasanlagen zugestoßen.

Ein wenig vorausgreifend mögen noch einige technische Anregungen erwähnt sein, die aus dem Ölgasbetrieb sich hergeleitet haben. 1862 erhielt E. Le s co m$b e$, der Direktor der Ölgasfabriken in Bristol und Norwich ein Patent für dic Herstellung des Gases aus aufgelöstem Harz. $D$ a n i e ll erhielt ein Patent über "Vergasung des Harzes in flüchtigen Ölen, einem Rückstand der Ölvergasung". Schließ̧lich hat J. H. I b betson Wassergas mit Dampf über heił̧en Koks erzeugt und die Teerkrackung über dem heif̧en Koks versucht. Über dessen Erfolge ist aber nichts verlautet.

Der Umstand, daf̧ die Leuchten an die Rohrleitungen gebunden und fest an den Wänden angebracht waren, mufte manchem als Nachteil gegenüber den leicht beweglichen Öllampen erscheinen.

So beschrieb schon $A c c u m$ in seinem ersten Buch von 1816 eine Kleinanlage, bei der der Retortenofen "tragbar" sei und die Leuchten unmittelbar auf dem Gasbehälter angebracht sind (Tafel II der Übersetzung). Nach der Zeichnung kann die Ortsbeweglichkeit nur beschränkt gewesen sein.

La mpadius bediente sich eines Holzfasses von 8 Leipz. Cubikfuf $={ }_{18}{ }_{4} 1$

2.120) E. F. Armstrong: Murdoch Centenary Lecture. Publ. No. 207 Institution of Gas Eng. 1939 S. 17

a, ay) Chandler \& Lacey, S. I (s, , 1.1) 
Inhalt (Tafel IX der Übersetzung), das er nach der Art eines Aspirators durch Auslaufen von Wasser im Laboratorium füllte und im Betrieb aus einem zweiten Faf mit Wasser langsam wieder vollaufen lief $\left.3^{2.44}\right)$.

1819 erhielt D. Gordon ein Patent, verdichtetes Gas in geeignete Behälter zu drücken, das zur Gründung der „London Portable Gas Co.“ führte (Portativgas). Deren Behälter aus Kupfer hatten ungefähr $2 \mathrm{cft}$. $={ }_{56} 1$ Inhalt mit 30 atü Druck.

Die Gesellschaft versorgte zeitweilig eine ganze Reihe von Abnehmern, deren berühmtester wohl die Royal Institution war. Der Beschluß dieser erlauchten Gesellschaft: ,.zu überlegen, ob die Beleuchtung des Hauses mit Gas statt Öl angebracht sei“", stammt vom 7. 12. 1818. Aber erst 1828 wurden wirklich Bücherei und Vorstellungsraum mit Traggas erleuchtet.

Mit den Kondensaten, die bei der Verdichtung des Gases gefunden wurden, wird die Entdeckung des Benzoles durch $F$ ar a d a $y$ im Jahre 1825 in Zusammenhang gebracht ${ }^{2.05}$ ). Auß̧erdem stellte er zuerst Butylen und das „ölbildende Gas" Äthylen in den Rückständen fest.

\subsection{Ausbreitung der Gasversorgung}

„Die Zahl der in London brennenden Gaslichter betrug (1819) s1 ooo. Die Länge der Hauptröhren war 188 Meilen $(300 \mathrm{~km})$. Anlagen fanden sich in Edinburg, Glasgow, Liverpool, Bristol, Bath, Cheltenham, Birmingham, Leeds, Manchester, Exeter, Chester, Manlesfield, Preston, Kidderminster und vielen anderen Städten und Ortschaften Grof̧britanniens. - Der beste Beweis für die Sicherheit der neuen Beleuchtungsart ist es, daf $\ldots . .$. man von keinem durch sie veranlaf̧ten unangenehmen Zufall gehört hat, während Klagen genug über die Wirkung der Funken gewöhnlicher Lichter oder über die Nachteile, durch Sorglosigkeit eines schlechten Putzens derselben veranlaf3t, lautbar werden. - Manufakturen und öffentliche Gebäude, durch Gas erleuchtet, werden geringer versichert als solche, die auf andere Weise erleuchtet sind. - Von der Wärme, welche das brennende Steinkohlengas entwickelt, sind ebenfalls schon mannigfaltige Anwendungen gemacht worden. Man braucht sie, um Speisen in den Küchen warm zu halten, Wasser zu sieden und Vorratshäuser, Bildergalerien und Buchhandlungen in gleicher Temperatur zu halten. Kupferdrucker erwärmen ihre Platten, und Goldschmiede und andere Künstler löten durch die Gasflamme ${ }^{\text {(2.2.00 }}$ ).

Schon in dieser Frühzeit tauchte auch der Gedanke auf, das Gas nicht innerhalb der Großstädte sondern in der Nähe der Zechen zu erzeugen und mit Rohren nach London zu leiten.

S. B. Rogers, Nantyglo, ein Mann, der weit vorausschauend dem Ingenieurwesen grołzügige Ziele vor Augen hielt (transkontinentale Eisenbahnen), schrieb

\footnotetext{
2.94) Accum, Bd. I S. 253 (s. 2.26)

2.25) Georg Lockemann: Geschichte der Chemie, Bd. II, Sammlung Göschen Walter de Gruyter, Verlag Berlin, 1955 S. 37: Murdoch Centenary Lecture, S. 18 (s. 2.92)

a.ne) Accum-Lampadius, siehe 2.26 
schon vor 1825 einen offenen Brief, man moge in Newport und Cardiff grofe Gaswerke errichten und deren Erzeugnis durch Rohre von geeigneten Abmessungen über Gloucester nach London leiten, um sowohl diese Metropole, wie auch durch Zweigleitungen andere, am Wege liegende volkreiche Städte, die Eisenbahngesellschaften usw. mit Gas zu beliefern. „Es fallen bei den Gruben nicht weniger als 800 Tonnen minderwertiger Kohle als unverkäufliche Rückstände an, die sich in ihrer Gesamtheit sehr wohl in Gas und Koks umwandeln lieł̧en." Uber die Möglichkeit, eine so grołe Aufgabe technisch mit den damaligen Mitteln und Erfahrungen zu bewältigen, hat Rogers allerdings nichts geschrieben $\left.{ }^{2.07}\right)$.

C. W. T $a b$ or, Frankfurt, schrieb, 1822 über die Lage ${ }^{2.09}$ ): „In Frankreich will die Sache nicht recht voranschreiten, obgleich man alle Hilfsmittel dazu in reichem Maß̧e in der Hand hat. Wie man hört, so hat sie öftentlich Widerspruch gefunden, dem ungeachtet sollen doch einige Manufakturenbesitzer davon Gebrauch gemacht haben. In Paris hat im Palais Luxembourg ein Deutscher, der einsichtsvolle Herr Pre $u$ F 3 aus Hannover, mit Beifall eine solche Beleuchtung errichtet. Auch soll daselbst ein Engländer, dessen Name mir entfallen ist (es handelt sich offenbar um Winsor), eine Aktiengesellschaft zusammengebracht, sehr bedeutende Summen verwandt, aber bis zur Stunde noch nichts zustande gebracht haben." (Paris erhielt das erste erfolgreiche Gaswerk $182 \mathrm{I}$ von $P$ a uwels $)^{2.00}$ ).

„In den Niederlanden, die ohnehin reich an Steinkohlen sind (einschlief̧lich des heutigen Belgien), hat man größere Fortschritte gemacht. So sind in Brüssel schon ganze Straß̧en und viele Privathäuser erleuchtet. In Amsterdam und Rotterdam befinden sich aus England verschriebene Apparate. Aachen und Lüttich haben ebenfalls angefangen."

In Brüssel ist 1817 eine Gasgesellschaft von dem Bürger P.J. Me eus-V an der $M$ a el e $n$ gegründet worden, die am 4. 8. 1818 eine 20-jährige Konzession erhielt. Die Erzeugungsanlagen wurden in schon vorhandene Gebäude eingebaut. Ungefähr ein Jahr später wurde die Beleuchtung mit 72 Laternen aufgenommen $\left.^{2.100}\right)$.

Úberall war wohl, wie es $L$ a mpadius für Deutschland erwähnt, die Armut nach den napoleonischen Kriegen der Hauptgrund, der gegen grofe Anlagen sprach. Außerdem kann auch die in der vor-napoleonischen Zeit unter dem Merkantilsystem geweckte Einstellung, vom Staate die Initiative bei gewerblichen Risiken zu erwarten, mitgespielt haben. Zwar hatten $S$ te in und $H$ ardenberg Bürgerstolz und Unternehmergeist zu fördern gesucht; dał es indessen damit langsam ging, zeigen die vielfachen Bemühungen in allen deutschen Ländern zur Förderung des Gewerbefleif̧es in der ersten Hälfte des 19. Jahrhunderts.

Nun war ja auch tatsächlich die Erleuchtung der Strafen ein Anliegen der Städte und ihrer Polizeiverwaltungen. Wie diese mit der Aufgabe und den

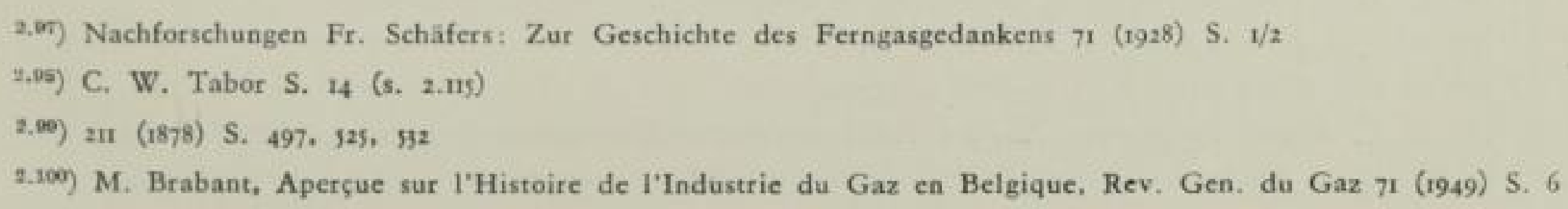


Kosten rangen, geht am besten aus der Vorgeschichte der Gasbeleuchtung hervor, von der hier ein Weniges gesagt sein mag.

Eine regelmäfjige Beleuchtung hatte als erste Stadt des Kontinents Paris 1617. Gegen Ende des Jahrhunderts folgen dann mehrere Städte: Amsterdam 1669 . Den Haag 1673, Hamburg 1675, Berlin 1682, Wien 1687, Leipzig 1701 und London $\left.176^{2.100}\right)$. Daf3 die öffentliche Sicherheit der Hauptgrund für die Neuerungen war, geht am besten aus Forderungen von zeitweiligen Besatzungsheeren hervor. In Bremen verlangte während des siebenjährigen Krieges der französische General 1758 die allgemeine Beleuchtung. 1778 brannten dann auch 284 Tranlampen in dieser $\left.\mathrm{Stadt}^{2.102}\right)$. Auch in Köln forderte 1759 der französische General die allgemeine Beleuchtung, die der Magistrat allerdings der hohen Kosten wegen ablehnte $\left.{ }^{2,108}\right)$. Aber als die französischen Revolutionsheere einmarschierten, erzwangen sie die Beleuchtung von 7 Uhr abends bis 7 Uhr morgens unter der Androhung, die Behörden der Stadt sonst vor das Straf- und Revolutionstribunal als Feinde des öffentlichen Interesses zu bringen.

Aus vielen anderen solchen Berichten kann man entnehmen, daf dem Wunsche nach Sicherheit durch Licht die knappe Kasse der Städte entgegengehalten wurde. In München und in Dresden beschäftigten sich aber nach den Freiheitskriegen die Könige, also die Landesregierung, damit, die Beleuchtung ihrer Hauptstädte nach dem englischen Vorbilde zu verbessern.

Der König von Sachsen erteilte durch ein Rescript vom 16. 6. 1816 dem königlichen Polizeikollegium den Auftrag, Vorschläge für einen im Groß̧en anzustellenden Versuch zu machen, die Dresdener Straf̧en durch Gaslicht zu erleuchten. In đ̆esem Lande war ja schon einige Pionierarbeit geleistet worden, wie bereits erwähnt ist $\left.{ }^{2.104}\right)$. Die Polizei konnte daher gründliche Arbeit leisten. Sie konnte bereits in dieser Frühzeit Angebote von vier Seiten einholen, von Mechanikern und Chemikern, die sich mit der Gasherstellung schon beschäftigt hatten. Begutachtet wurden die Angebote durch Lampadius. Die Gesandten in London, Paris und Wien berichteten über die dortigen Anlagen. Die Landesregierung empfahl einen Versuch, woraufhin der König anordnete, die Plätze um das Theater, die katholische Kirche und das Schlof zu beleuchten. Das war am 16. 12. 1820 .

Inzwischen hatte man sich auch in München mit der Gasbeleuchtung befaf̧t. Der Bergrat J. v. B a a der war ein vielseitig begabter und interessierter Mann, allerdings nicht gerade angenehm in seinem Auftreten ${ }^{2.105}$ ). Dieser hatte England häufig besucht und dabei auch die Gasbeleuchtung kennengelernt. Er errichtete in München ein solches Werk, das aber nicht zum Dauerbetrieb kam. Der König beauftragte vielmehr den ebenso vielseitigen G. F. Reicben $b a c b$ mit einem vollständigen Plan für die Gasbeleuchtung Münchens, den dieser I8I8 angefertigt hat. Georg Friedrich Reichenbach ist einer der erfolgreichsten Pioniere der technischen Frühzeit gewesen. Geboren am 24. 8. 1771 zu Durlach, wuchs er in Mannheim auf. Er besuchte dort die Militärschule, die nach ihrem französischen Vor-

\footnotetext{
2.10r) Zahlen nach Karmarsch-Heeren. Technisches Worterbuch, Leuchrstoffe, Prag 188r

2.102) Hundert Jahre Gasversorgung in Bremen, 1954 S. 13

2.103) Wasser Gas Elektrizität, Köln 1950 S. 29 (s. 3.22)

2.10i) Dr. G. C. Rudolf Blochmana: Aus der Frühgeschichte der Gastechnik Oldenbourg München 1942

2.105) C. Matschoss: Grosse Ingenieure, Lehmann München, 2. Aufl. 1938 S. 21
} 
bilde die Mathematik besonders pflegte. Seine ersten grofen Konstruktionen hat Reichenbach als wissenschaftlicher Feinmechaniker geschaffen (Teilmaschine). Die Berührung mit Utzschneider und später mit dem „Glaserlehrling“" Fraunbofer lief̧ hochangesehene Werkstätten in München und Benediktbeuren entstehen. Eine besondere Tat im Grofmaschinenbau sind die Wassersäulenmaschinen gewesen, deren eine in Reichenhall von $18 \mathrm{r}$; bis 1927 , also по Jahre lang, unermüdlich gearbeitet hat. Reichenbach hat Baader nach England begleitet und kam dadurch seinerseits an das Gasfach heran.

Seine groł̧en Pläne sind nicht ausgeführt worden. 1826 sollten aber wenigstens die Arkaden des Hofgartens mit Gas beleuchtet werden. Aber die „Akademie“ wollte davon nichts wissen. München erhielt seine Gasbeleuchtung erst 1850.

Da Reichenbach auch in Wien mit Ertl ein mathematisch-mechanisches Institut betrieb und mit J. J. Prechtl bekannt geworden ist ${ }^{2,100}$ ), so ist als sicher anzunehmen, daf̧ hier gerade über die Gasbereitung Anregungen hin- und hergegangen sind. Jedenfalls fielen seine Arbeiten indirekt auf fruchtbaren Boden. R. S. Blochmann, über dessen Leben im Anhang 7 ausführlich berichtet wird, war als Feinmechaniker von Ruf von Dresden nach München geholt worden und arbeitete bei Reichenbach. Die Beschäftigung mit dem Gase blieb nicht aus. Die ersten Versuche hat Blochmann in Benediktbeuren angestellt in den Jahren 1816 und 1817 . Entwürfe für die Tabaksfabrik von P. P. v. Maffe $i$ in München und das königliche Theater folgten. Die Anlagen wurden indessen nicht ausgeführt, weil Blochmann nach seiner Vaterstadt Dresden zurückgerufen wurde ${ }^{y .105}$ ). Dort nun baute er in seine mechanische Werkstatt im Jahre 1819 eine eigene Gasbeleuchtungsanlage ein, mit der er auch eine Lampe am Eingang des Hauses betrieb. Diese Leuchte fiel natürlich in der Öffentlichkeit auf. Das Polizeikollegium, das ja noch auf der Suche nach einem geeigneten Mechaniker zum Bau der befohlenen Anlage beim Theater war, wurde auf ihn aufmerksam, verlangte am 3. Februar cin Angebot. Leider statb der rührige Leiter des Kollegiums plötzlich. Eine Unterbrechung der Verhandlungen war die Folge. Erst ein von auf̧en kommender Anlał brachte sie wieder in Gang.

Einen Beweis für die Anteilnahme der Gebildeten an der neuen Technik liefern die Arbeiten des holländischen Pastors B. Koning, die dieser 1809 begann. Sieben Jahre später trat er mit seinem Buche „Noodig Berigt voor den Nederlander" an die Öffentlichkeit, in dem er lebhaft für die Gasbeleuchtung eintrat. Er sprach von kohlenstoffhaltigem Wasserstoffgas. Da er mit Dampfeinblasen in die Retorten arbeitete, kam er auf $500 \mathrm{~m}^{3}$ Gas je Tonne Steinkohlen von unbekannter Leuchtkraft. Er stellte auch Vergleiche mit dem englischen Gase an. Die Reinigung sei leichter möglich. Auf die Möglichkeit der Verwendung der Wertstoffe wies er hin. Für seinen Gasmotor „Hydrophor" erhielt er eine staatliche Anerkennung von 1000 Gulden $^{2.100}$ ).

In Hamburg bemühte sich Johann Georg $\mathrm{He}$ is e, der 1817 in seinem Hause Güssingerstr. 49 eine Thermolampe eingebaut hatte, um die Erlaubnis einer allgemeinen Beleuchtung, für die er eine Aktiengesellschaft gründen wollte. Trotz

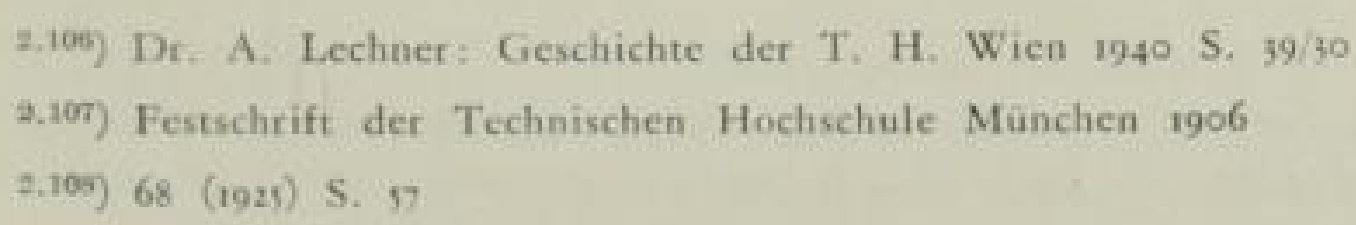


seiner Berechnungen und Anschläge vertraute ihm der Senat nicht, da er kein Fachmann sei. Diese in Gestalt des Oberspritzenmeisters und eines Bürgermeisters hatten vielerlei Bedenken. Man lieł das Angebot unerwidert. 1834 erneuerte Heise seine "Supplik“, wieder ohne Erfolg. Erst nach dem grofyen Brande 1844 schrieb man die Erbauung eines Gaswerkes aus ${ }^{2.100}$ ).

So ganz einfach war das Ringen der ersten Mechaniker in Deutschland nicht. Natürlich kosteten die Anlagen Geld, das wirklich oder auch nur angeblich nicht vorhanden war. Es gab auch Vorurteile, die anscheinend durch handfeste Händlerinteressen genährt wurden. Es fällt nämlich beim Studium dieser Zeit auf, dał gerade die Städte, die an den Wasserstrał̧en die groł̧en Umschlagplätze für das Leuchtöl, Walöl und Tran beherrscht haben, besonders zögernd vorgegangen sind.

Vielleicht tut man den Kölnern kein Unrecht, wenn man die so allgemein bekannte Äuf3erung einer dortigen Zeitung aus dem Jahre I8ı9 als möglicherweise in diesen Zusammenhängen entstanden betrachtet. Sie lehnte bekanntlich die Beleuchtung $a b^{2.110}$ ).

I. Aus theologischen Gründen; weil sie als ein Eingriff in Gottes Ordnung erscheint. Nach dieser ist die Nacht zur Finsternis eingesetzt, die nur zu gewissen Zeiten vom Mondlicht unterbrochen wird. Dagegen dürfen wir uns nicht auflehnen, den Weltplan nicht hofmeistern, die Nacht nicht in Tag verkehren wollen; -

2. Aus juristischen Gründen; weil die Kosten dieser Beleuchtung durch eine indirekte Besteuerung aufgebracht werden sollen. Warum soll dieser und jener für eine Einrichtung zahlen, die ihm gleichgültig ist, da sie ihm keinen Nutzen bringt oder ihn gar in manchen Verrichtungen stört? -

3. Aus medizinischen Gründen; die Gasausdünstung wirkt nachteilig auf die $\mathrm{Ge}$ sundheit schwachleidiger und zartnerviger Personen, und legt auch dadurch zu vielen Krankheiten den Stoff, weil sie den Leuten das nächtliche Verweilen auf den Straf̧en leichter und bequemer macht und ihnen Schnupfen, Husten und Erkältung auf den Hals zieht. -

4. Aus philosophisch-moralischen Gründen; die Sittlichkeit wird durch Gassenbeleuchtung verschlimmert. Die künstliche Helle verscheucht den Gemütern das Grauen vor der Finsternis, das die Schwachen von mancher Sünde abhält. Die Helle macht den Trinker sicher, daf er in den Zechstuben bis in die Nacht hinein schwelgt, und sie verkuppelt verliebte Paare. -

5. Aus polizeilichen Gründen; sie macht die Pferde scheu und die Diebe kühn. -

6. Aus Staatswirtschaftlichen Gründen; für den Leuchtstoff, Öl oder Steinkohlen, geht jährlich eine bedeutende Summe ins Ausland, wodurch der Nationalreichtum geschwächt wird. -

7. Aus volkstümlichen Gründen; öffentliche Feste haben den Zweck, das Nationalgefühl zu erwecken, Illuminationen sind hierzu vorzüglich geschickt. Dieser Eindruck wird aber geschwächt, wenn derselbe durch allnächtliche Quasi-Illumi-

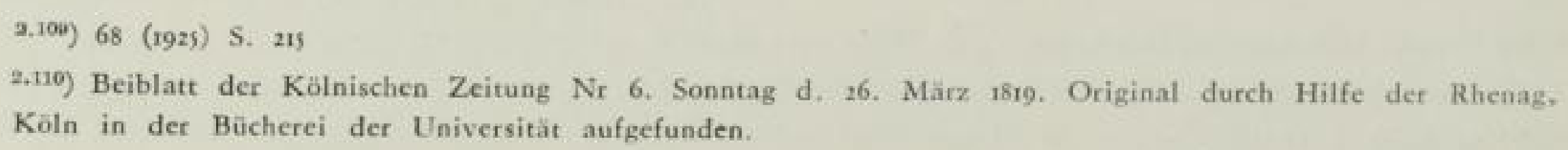


nationen abgestumpft wird. Daher gafft sich der Landmann toller in dem Lichtglanz als der lichtgesättigte Großhändler.

Der Gründe sind reichlich viel. Man hat sie damit meistens als lächerliche Urteilslosigkeit aufgenommen.

Die Kölnische Zeitung hat aber auch die Sätze aus einer anderen Zeitung, leider nicht mit Quellenangabe entnommen. Sie sagt selbst etwas humorvoll: „Diese allerdings wichtigen Gründe, die unsere Leser vielleicht für Scherz zu nchmen geneigt wären, scheinen an manchen Orten, nach dem dortigen Beleuchtungswesen zu schliefyen, schon ernsthafte Beherzigung gefunden zu haben."

Wenn man aber dann die Gegenreden eines Winsor und $A c c u m$ liest, wird ganz klar, dafy ähnliche Vorstellungen im Munde der Leute nicht ohne Erfolg weitergegeben worden sind.

Ganz im Gegensatz dazu steht das Verhalten der deutschen Wissenschaftler. Sie entzogen sich nicht den ingenieurmäßjigen Aufgaben, sondern suchten sie mit den wissenschaftlichen Kenntnissen zu heben. Wir hatten das bei Lampadius schon sehr deutlich gesehen.

2.22I J. J. Precht 1

Noch mehr Ingenieur und Konstrukteur auf wissenschaftlicher Grundlage war der Direktor des ersten deutschen (österreichischen) Polytechnikums in Wien, J. J. Precbtl.

\section{LEB E N S B I L D}

Johann Joseph Precbtl wurde in Bischofsheim in der Rhön als Sohn des Vorstandes des Eisenhüttenwerkes in Oberbach am 16. II. 1778 geboren ${ }^{\text {?.M1 }}$ ). Er studierte in Würzburg die Rechte und Naturwissenschaft, war zuerst Jurist beim Reichskammergericht in Wetzlar, bald aber Erzieher in Brünn. I804 erschien sein erstes Werk: „Über die Fehler in der Erziehung, vorzüglich in Hinsicht auf die gesellschaftlichen Übel" bei F. Vieweg in Braunschweig. I80s wurde seine Abhandlung „Über die Physik des Feuers“ preisgekrönt. I809 betraute ihn die österreichische Regierung mit der Organisation der zu errichtenden Real- und Navigationsschule in Triest. I8ro wurde er Professor der Physik und Chemie an der Realakademie in Wien. Dort wurde er mit dem Entwurf des Planes zur Errichtung eines polytechnischen Institutes in Wien beauftragt. Er stellte die Schulung grundsätzlich auf die akademische Lehrmethode ein: Freiheit vom Schulzwang im Unterschied zum Vorbild der Ecole polytechnique ${ }^{2.12}$ ). Freiheit in der Wahl der Lehrfächer, aber wie bei jener, starke Betonung der theoretischen Fächer Physik, Chemie, Mathematik, auf der anderen Seite darüber hinaus: Konstruktion und Werkstatt (in der Schule) und schließlich amtliche Gutachten

\footnotetext{
2.113) J. Neuwirth: Die K. K. Technische Hochschule in Wien 1815-1915 Wien 1915 Verlag der T. H.

2.112) Die Ecole polytechnique ist in Paris im Jahre 1794 gegrũndet worden (Franz Schnabel, Deutsche Gerchichte im Neunzehnten Jahrhundert, Herder Freiburg 1934, Bd. 3, S, 305)
} 
der Schule über Erfindungen, über durch die Wissenschatten erreichbare Förderung der Industrie, Laboratoriumsversuche. Damit schuf er die Grundlagen, die im Laufe des Jahrhunderts zur vollberechtigten Technischen Hochschule geführt haben. Infolge der Revolution 1848 und der Reaktion trat er nach einem arbeitsreichen Leben unter Verleihung des Leopoldsordens und unter Erhebung in den Adelsstand am 4. Juni von seiner Tätigkeit zurück. Er starb am 28. 10. 1854 nach kurzer Krankheit in Wien.

Prechtl baute in das grołe Gebäude des Polytechnikums eine Gasteleuchtungsanlage ein, die er zur Ausnutzung der Abgase mit einer Dampfheizungsanlage verband. Darüber gibt er eine Beschreibung in der ,Anleitung zur zweckmäf̧igen Einrichtung der Apparate zur Beleuchtung mit Steinkohlengas ${ }^{\text {iaia }}$ ). In der Einleitung kritisiert er Accums erstes Buch als eine im Groß̧en ausgeführte Ankündigung zur Empfehlung des Gaslichtes. Sie habe weniger den Charakter einer instruktiven Anleitung. Er erwähnt J. J. Becber, Murdocb, Lebon und $W$ in zle $r$, denen er freundlich gerecht wird.

Am fesselndsten ist seine Angabe der Zusammensetzung des Kohlengases: I) Wasserstoff, 2) Kohlenwasserstoffgas (womit Methan bezeichnet wird), 3) ölbildendes Gas (Aethylen), 4) Schwefelwasserstoffgas, 5) Kohlenoxydgas. Es folgen im einzelnen Wichte und Verbrennlichkeit des Gases. Ein kurzer Auszug über die Verbrennung der Gase möge hier folgen:

„Auch das reine Wasserstoffgas kann auf dieselbe Art, mit einer stark leuchtenden Flamme verbrennen, wenn ihm feste Teile beigemengt werden, welche während seines Verbrennens ins Glühen kommen, und dadurch seiner auf̧erdem schwachen Flamme die nötige Färbung geben. Wenn man so Wasserstoffgas durch eine dünne Röhre strömen läßt, in welcher sich feingepulverter Zink befindet, so dafy dieser von dem Gas mit fortgerissen wird, so brennt es, an dem andern Ende der Rohre entzündet, mit einer starken weiß̧en Flamme, weil die Zinkteile glühend werden und sich im Verbrennen in glühendes Zinkoxyd verwandeln. Was hier die mechanisch beigemengten Zinkteile bewirken, leisten bei dem Verbrennen des Kohlenwasserstoffgases die durcb die Hitze aus demselben abgesetzten Koblenteile.

Wenn daher das kohlenhaltige Wasserstoffgas als solches und unzersetzt verbrennt, so brennt es ebenso mit schwachem, bläulichem Lichte, als die übrigen brennbaren Gasarten, z. B. Wasserstoffgas und Kohlenoxydgas, bei welchen durch das Verbrennen keine festen glühenden Teile sich absetzen, indem nur gasförmige Produkte, nämlich Wasserdampf und Kohlensảure sich bilden. Dieses ist der Fall, wenn das brennende Kohlenwasserstoffgas in allen Teilen mit Sauerstoffgas oder atmosphärischer Luft in Berührung kommt, wodurch seine schnelle Verbrennung bewirkt wird, ohne dał eine Absetzung von Kohle aus demselben möglich wird. Durch diese schnelle Verbrerinung wird aber zugleich eine starke Hitze erzeugt, welche, verhältnismäßjig zu der brennenden Gasmenge, gröf̧er ist als hei der stark leuchtenden Flamme, weil hier ein 'Teil der Hitze des brennenden Wasserstoffgases auf die Erhitzung der abgesetzten Kohle verwendet wird. Wenn man mitten durch eine stark leuchtende Flamme von Kohlenwasserstoffgas mit dem Lötrohr Luft bläst, so dał̧ alle Teile der Flamme mit

2.113) Wien 1817, bei Carl Gerold. (Dieses Werk besitzt die Bibliothek der 'T. H. Wien)

94 
der Luft in Berührung kommen können, so brennt sie mit einer blauen Flamme, weil hier das Gas unzersetzt verbrennt. Dasselbe ist der Fall, wenn man das Gas in einer argandischen Vorrichtung mit einem übermä̧̧igen starken Luftzuge verbrennt: ebenso, wenn man das Gas mit atmospbärischer Luft vermischt und es aus einer engen Öffnung ausströmen läft; seine Flamme ist in diesem Fall völlig blau und wenig leuchtend, ob sie gleich auch bei geringer Masse eine sehr starke Hitze verbreitet, welche jene der stark leuchtenden Flamme bedeutend übertrifft.* Läßt man im Gegenteil durch eine Kohlenwasserstoffgasflamme nur einen geritigen Luftzug hindurchstreichen, so kommen dadurch die abgesetzten Kohlenteile derselben in ein lebhafteres weif̧eres Glühen und Verbrennen, und die Flamme, welche auf̧erdem eine gelblichweiß̧e Farbe hat, nimmt dadurch eine weiß̧e glänzende an.

Da demnach bei dem leuchtenden Verbrennen des kohlenhaltigen Wasserstoffgases immer ein Teil dieses Gases unzersetzt verbrennen muf, um den inneren und übrigen Teil des Gases zu crhitzen und zur Absetzung der Kohlenteile zu nötigen, so folgt von selbst daraus, dał jede Kohlenwasserstoffgasflamme am unteren Teile eine blaue Farbe haben müsse. Je geringer im allgemeinen derselbe ist, desto leuchtender ist die Flamme und umgekehrt, da der blaue Grund der Flamme einen Teil des Kohlenwasserstoffgases ohne Absetzung des leuchtenden Kohlenstoffs, folglich auf Kosten der leuchtenden Kraft verzehrt. Die Größ̧e dieses blauen Teiles hängt von folgenden Umständen ab:

Der blaue Teil ist bei einer Flamme von ölbildendem Gas bedeutend kleiner als jener des reinen Kohlenwasserstoffgases. Der Grund davon licgt darin, weil das ölbildende Gas bei seinem Übermafł an Kohlenstoff einer geringeren Erhitzung bedarf, um sogleich einen Teil seines Kohlenstoffs abzusetzen, als das Kohlenwasserstoffgas; je geringer aber diese Hitze ist, desto schneller und tiefer am Grunde der Flamme wird der blaue Teil durch Absetzung von glühendem Kohlenstoff weif, gefärbt, und desto dünner und kürzer ist dic unsichtbare blaue Hülle, welche die Flamme umgibt."

Die Phlogistontheorie ist bei ihm überwunden. Der Sauerstoffbedarf zur theoretischen Verbrennung wird angegeben, z. B. bei Methan auf roo Maf̧e Gas 200 Małe Sauerstoff.

Prechtl kennzeichnet die Bedingungen zur besten Darstellung des Steinkohlengases für die Beleuchtung:

i) Natur der Steinkohle selbst,

2) Die Feuerung und der Grad der Hitze,

3) Die Form und Behandlung der Retorte,

4) Die Dauer der Operation,

5) Reinigung des Gases,

6) Seine Verbesserung und Bereicherung durch Zusatz von „ölbildendem Gas“, das er durch Teerzersetzung gewinnt.

\footnotetext{
- Auf solche Art werden durch das sogenannte Newman'sche Geblase, in welchem aus einer sehr engen Röhre cine aus reinem Wasserstoffgas und Sauerstoffgas gebildete Knalluft ausstrōmt, die grössten Hitzergrade hervorgebracht, obgleich das sich sn der Spitze der Röhre zeigende blaue Fläminchen bei Tage kaum sichtbar ist. (FuBnote Prechtls)
} 


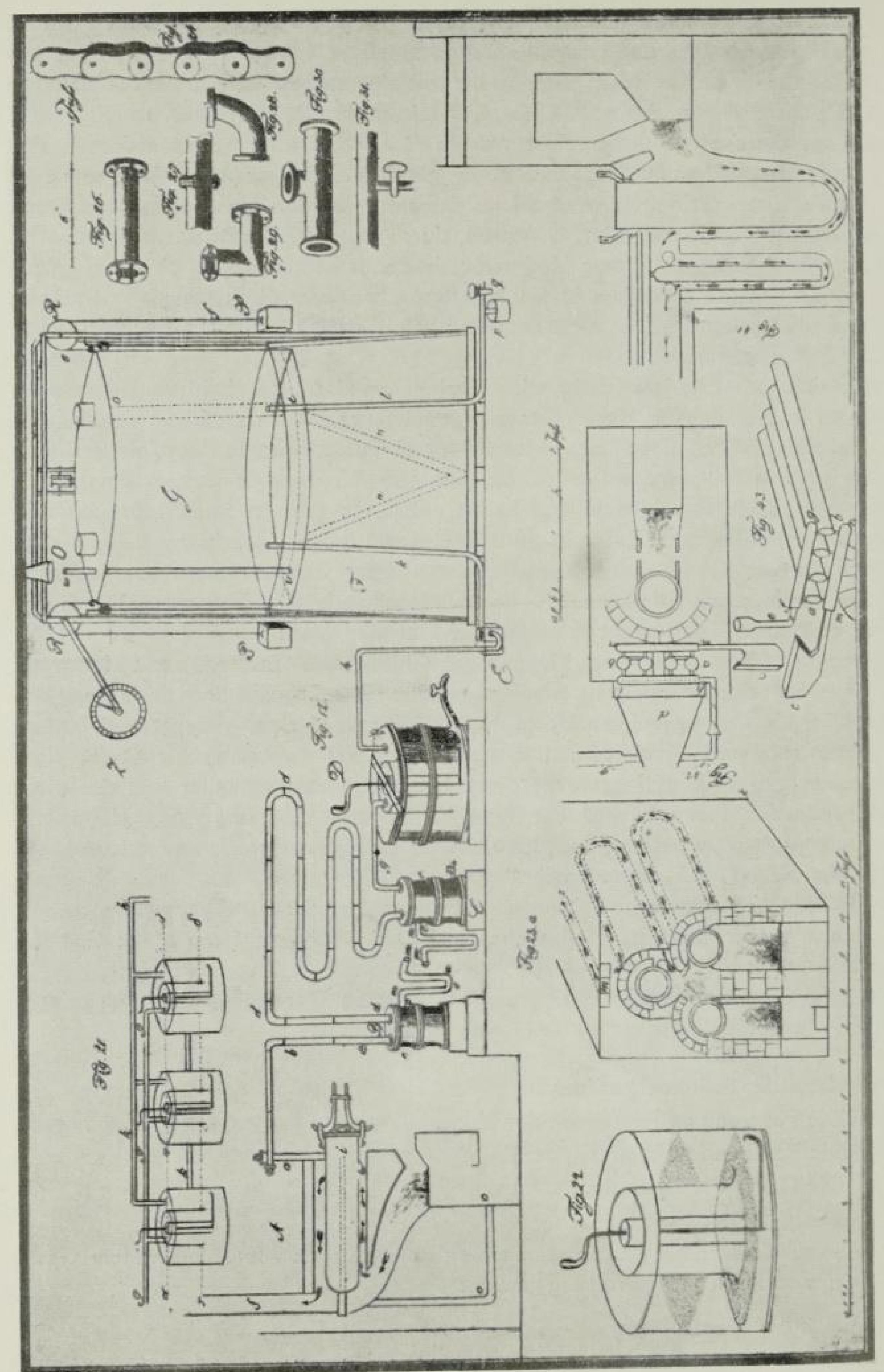

Bild is Einrichtung eines Beleuchtungsapparates von J. J. Prechtl, Wien 
Die Zeichnung Prechtls über die Anlage zeigt einmal die sorgfältige Hin- und Rückführung der Heizgase um die Retorte mit Abdeckung der Strahlung aus dem Feuerbett, um eine gleichmäßjige Aufheizung der Retorte zu bekommen. Die Führung der Gasrohre zur Kühlung durch und um die Behältertassen lehnte Prechtl ab. Am Gasbehälter ist links das „Gasoskop“, der Inhaltsanzeiger, angebracht. (Bild is)

Die Anlage war aber doch wohl zu anfällig geraten und ist nach wenigen Jahren wieder entfernt worden. Eine öffentliche Straf̧enbeleuchtung ist in der Walfisch- und Krugerstraf̧e am 8. Juli 1818 in Wien von Prechtl in Betrieb gesetzt. Die Gaserzeugungsanlage stand in der Polizeiwache am Kärntnertor. Sie war durch 4 Monate in Betrieb ${ }^{\text {s.ru }}$ ).

\subsection{2 $\mathrm{T}$ a bor}

Der dritte Deutsche, der die Gastechnik mit guten wissenschaftlichen Grundlagen und Erfahrungen im Feuerungsbetriebe behandelt hat, ist der bereits angezogene Carl Wigand $\left.T a b o r^{2.115}\right)$.

In der Vorrede gibt Tabor an, wie er dazu kommt, sich mit der Gastechnik zu befassen. Die Pensionierung 1803 (Länderverteilung $=$ Säkularisation) verpflichtete ihn zu wissenschaftlichen Veröffentlichungen. Liebe zur Naturwissenschaft als Grundlage, technologische Erfahrungen und das seit 25 Jahren bestehende grołe Aufsehen, die Verbesserung der Technik in den letzten ro Jahren, veranlaß̧ten ihn, die Anwendung der Erfindungen zu empfehlen.

Verarbeitet sind: Accum-Lampadius, Prechtl und Peckston.

Aus dem vielerlei seiner zustimmenden und ablehnenden Kritik seien nur einige eigene Gedanken herausgegriffen. Sehr eingehend befaß̧t sich Tabor mit der Rohrberechnung. Die reinen Erfahrungszahlen über die anzuwendenden Durchmesser, noch dazu ohne Rücksicht auf die Rohrlänge, insbesondere bei Accum, genügen ihm nicht. Er macht darauf aufmerksam, dał $P$ a z $i o t$, Dorpat, beim Strömen durch Rohre eine festanliegende, aber sehr dünne Grenzschicht annehme, so dał nur die innere Reibung der Gasteile als Widerstand bedeutend sei und eine einfache Formel zur Berechnung genügen müsse. $S \mathrm{cbmidt}$, Gief̧en, fand (1820) den Einfluf der Wurzel aus der Dichte des Gases. So geht Tabor daran, aus der Ausfluffformel die notwendige Druckhöhe zu errechnen. wobei allerdings die Beiwerte nicht ganz klar werden.

J. J. Precbtl $l^{\text {.11" }}$ gab eine Formel, die auf einer Erfahrungszahl über den Aus-

fluf̧ aus einem Rohr von $\mathrm{I}^{\prime \prime}$ Durchmesser aufbaut und mit $\mathrm{Q}=\frac{D^{2}}{\sqrt{L}}$ annähernd die Bezichung der Poleschen Formel (s. Potenz von D) trifft. In der endgültigen

\footnotetext{
2.14) Im technischen Museum in Wien steht ein Modell dieses Gaswerks

2.115) Vollständiges Handbuch der Gasbeleuchtungstechnik. Nach den neucsten Erfindungen und Erfahrungen bearbeiter von Carl Wigand Tabor, Hof- und Regierungstat des ehemaligen Mainzischen Kurstaates, korrespondierendes Mitglied der Wetterauischen Gesellschaft für die gesamte Naturkunde, Frankfurt/M. Andraisthe Buchhardlung, 1822

2.115) Joh. Jos. Prechtl, Technologische Enzyklopãdie oder Alphabetisches Handbuch der Technologie, der technischen Chemie und des Maschinenwesens, Bd, 6. Stuttgart, Cotta, 18ı
} 
für $L$ enthalten: $D=\sqrt{\frac{\text { el } L}{455000}}$

Geschichtliche Daten über die Forschung an Rohren bringt ein Aufsatz: H. Ricbter, Freiberg Sa.: Rohrhydraulik - 200 Jahre Forschung ${ }^{2 \cdot 17}$ ).

Sehr eingehend beschäftigt sich Tabor mit den vielen Fehlschlägen der Engländer, mehrere Retorten in einer Feuerungsanlage gleichmäßjig zu erhitzen ${ }^{2.115}$ ). Grundsätzlich sei der Fehler, daß̧ die Erfahrungen beim Dampfkessel auf die Anordnung der Rauchzüge angewandt würden. Bei der Erwärmung trockener Körper müsse eine gleichmäf̧igere Wärmeeinwirkung erreicht werden. Er fährt dann fort $\left.^{2,110}\right)$ :

"Wenn es erlaubt ist, nach der Analogie von anderen Ófen zu schlief̧en, wo es ebenfalls darauf ankommt, einem gegebenen Raum eine gewisse Temperatur zu verschaffen, so scheint es hier nicht vorteilhaft zu sein, dafy die Öffnung, durch welche Rauch und überhaupt die entweichende Hitze abgeführt werden soll, in dem oberen Teil des Ofens angebracht ist und dał überhaupt die untere Mündung des Schornsteins höher als der obere Teil des Ofens liegt. Da hier die Luftsäule, welche durch das Aschenloch und den Rost auf das Brennmaterial wirkt, bedeutend höher ist als die Luftsäule, welche auf die Öffnung im oberen Teil des Gewölbes drückt, hat jene ein beträchtliches Übergewicht über diese, es entsteht also ein heftiger Luftzug zwischen dem Rost und der Öffnung, die Bewegung der erhitzten Luft wird, da ihr in dem Ofenraum fast nichts widersteht, der kürzesten Richtung folgen, sie wird den Wärmestoff mit Gewalt fortreifen, ehe er noch Zeit gehabt hat, auf den übrigen Raum des Ofens und auf die Retorte zu wirken, daher wird die Temperatur im Ofen nicht gleich sein und also einer der Hauptzwecke dieser Einrichtung größtenteils verlorengehen; überdies kommt die erhitzte Luft früher, als sie den gröften Teil ihres Wärmestoffes hat absetzen können, in den Schornstein, erhöht hier die Temperatur bedeutend, macht also, daf3 der Schornstein noch luftleerer wird, und dadurch erhält die unter den Rost drückende Luftsäule noch ein größgeres Übergewicht und die Geschwindigkeit der im Ofen stattfindenden Bewegung, folglich das Entweichen der Hitze, vermehret sich immer mehr. Wird hingegen die Ausfluföffnung in den unteren Teilen des Ofens angebracht, so steigen Flamme und Hitze vermöge ihrer Natur erst senkrecht in die Höhe, sie stołen oben wider das Gewölbe, werden von diesem teils zurückgeworfen, teils gezwungen, sich längs dem Gewölbe bis an die hintere Wand fortzubewegen, dann herunterzusteigen und da die Ausfluf̧öffnung zu suchen. So wirkt die Hitze nach allen Seiten hin, ihre Bewegung ist langsamer, sie hat Zeit, sich den im Weg stehenden Körpern mitzuteilen, und so wird sie weit mehr abgekühlt in den Schornstein gelangen, als bei der oben beschriebenen Einrichtung."

Tabor predigte also Dinge über den Vorteil des unteren Abzuges, die auch

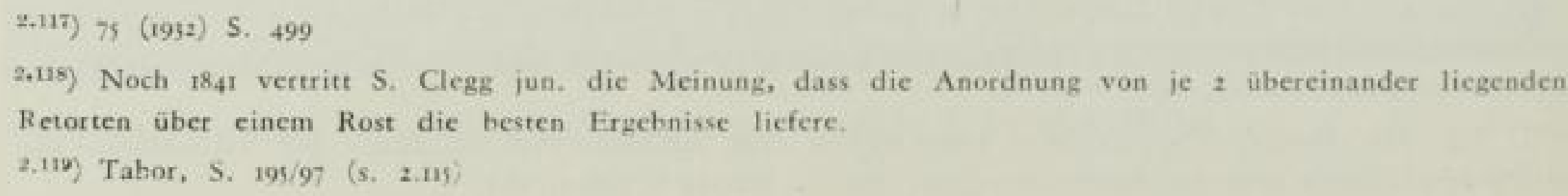


heute noch die Ofenkonstrukteure beschäftigen ${ }^{2.120}$ ), und nur langsam mehr Anerkennung erreichen.

Wegen der Kühlung der Gase verweist er auf Lampadius und Precbtl, die eine lebhafte Kühlung empfehlen, letzterer mit dem Vorschlag, die Oberflächen berieseln zu lassen. Wichtig sei das für die Abscheidung des Ammoniakwassers vom Teere $\left(S_{.324}\right)$. Er beschreibt dann aber auch den Röhrenkühler von Perks mit senkrechten Rohren.

Zur Gasreinigung empfiehlt er neben der Kalkmilch mit ihrem unangenehmen Geruch die Durchleitung des Gases durch Rohre die mit Blechabschnitten gefüllt sind. Dafy damit die organischen Schwefelverbindungen, an denen die englischen Kohlen reich sind, im Gase verbleiben, erwähnt er nicht.

Aufreizend ist seine Meinung, dał die Rohre im Erdreich kaum Druck bekämen, also unnötig dick gemacht würden. Die Hauptrohre waren aber gegossen und damit ergab sich bei den einfachen Eisensorten eine grof̧e Wandstärke. Tabor verweist deshalb auch auf die Spezialeisensorten aus der „Beckischen, jetzt Buderus'schen Hürte am Vogelsberg zu Herzenhalm". Rohre aus geschmiedetem Eisen seien nicht dicht zu bekommen. Für Hausanschlüsse seien alte Flintenläufe gut, die nach der Abrüstung viel am Markt waren und in England den Namen „barrels" für Hausanschlüsse veranlaf̧t haben. Die Empfehlung, für Innenleitungen gelötetes Weifblech zu nehmen, auch Kupferrohre, ja, wo „keine Gefahr des Bruches", Glas, Papier und Leder zu nehmen, beweist nur die Verlegenheit, in der die Gasfachleute sich befanden, ehe das geschweifrte Eisenrohr zur Verfügung stand.

Ein Schlaglicht darauf, wie langsam aber doch beharrlich die Gasbeleuchtung vorankam, gibt der folgende Lagebericht Tabors ${ }^{2,121}$ ).

„Vorzügliche Verdienste um die Gasbeleuchtungskunst aber sammelte sich $\mathrm{Hr}$. $P r e c b t l$ durch Herausgabe seiner äufjerst faf̧lichen Anleitung zur Beleuchtung mit Steinkohlengas, durch diese wurde auch mancher weniger Unterrichtete in Stand gesetzt, etwas in der Sache zu tun. Endlich war er es auch, der auf kaiserlichen Befehl den Versuch machte, einige Straf̧en der Stadt Wien mit Gas zu erleuchten, welches allgemeinen Beifall fand. Durch diese Vorgänge aufgemuntert, wurden nun in Dresden, Berlin, Leipzig, Hamburg, Hessen-Kassel, Koblenz größere und kleinere Anlagen gemacht, meistens um Manufakturgebäude und öffentliche Häuser zu beleuchten. Vorzüglich verdienen die von dem $\mathrm{Hr}$. C. Becker in Mannbeim herrührenden Anlagen, die mit besonderer Einsicht und Dauerhaftigkeit ausgeführt sind, angeführt zu werden. Die erste Anlage machte er in einem Caféhaus in Mannheim, die zweite, weit bedeutendere, führte er in Oberrad bei Frankfurt am Main aus, wo er bei Hr. Claus ein ganzes Gasthaus mit einem grofen herrlich beleuchteten Tanzsaal so mit Gaslicht versah, daf3 es die Wirkung von I6o Unschlittlichtern, 8 auf I Pfund, hervorbrachte. Die dritte Hauptanlage von ihm ist zu Seelbach bei Lahr im Breisgau, unweit von Straf̧burg, wo eine grof̧e Baumwollenzeug-Manufaktur nicht blofł erleuchtet, sondern auch durch Wasserdämpfe erwärmt wird. So weit ist man bis

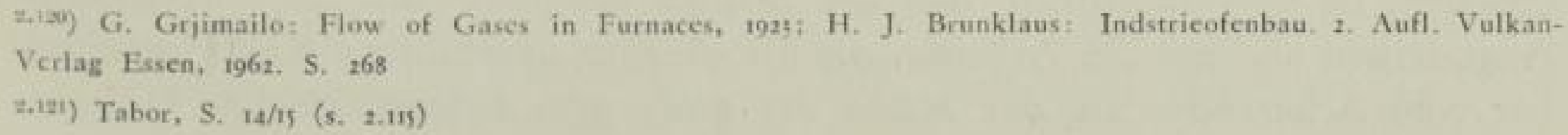


jetzt in Deutschland gekommen, und es wird noch weit besser vorangehen, wenn man erst genauer mit dem Einzelnen wird bekannt sein und die Apparate wohlfeiler wie bis jetzt liefern kann, wo Habsucht, Unkunde und Ungeschicklichkeit in der meistens ungewöhnlichen Arbeit die Sache so verteuerten, dał viele abgeschreckt wurden."

Diese Auslese beweist aber die Gründlichkeit der ganzen Arbeit, mit der Tabor dazu beitragen will, dafy endlich auch in Deutschland eine allgemeine Gasversorgung in den Städten zustandbekommt. Das ist aber erst 3 Jahre später durch die englische Imperial Continental Gas Association geschehen.

\subsection{O R G A N IS A T J O N DER WERKE}

Der Bericht über die Entfaltung der Organisation der Gaswerke muß notwendigerweise kurz gehalten werden, obwohl gerade er kulturgeschichtlich in der Ausführlichkeit, wie ihn die Gas Light and Coke Co. zusammengestellt hat, für den Forscher besonders wertvoll ist.

Der äuf̧ere Rahmen war durch die Form einer Kapitalgesellschaft mit einer beschränkten Haftung für grołe Unternehmen zwar glücklich gewählt, aber dieser Rahmen war noch mit lebendigen Menschen, die vor ganz neuen Aufgaben standen, auszufüllen. Schon in der geschilderten technischen Entwicklung fällt auf, wie schnell die leitenden Köpfe wechselten. Das mag bei den Technikern mit ihrem Seltenheitswert bei der hastigen Entwicklung erklärt werden. Bei den Geschäftsführern mit Verwaltungsaufgaben ist es aber nicht anders. Auch sie mögen einfach zu Anfang vor zu groß̧e Aufgaben gestellt worden sein. Indessen fällt doch auf, daf Streitsucht und Rechthaberei, Eigenschaften, die man heute in England im Geschäftsleben seltener als bei anderen Völkern trifft, und sogar ein mangelnder Begriff über die notwendige Ehrlichkeit vielfach offenbar werden. Man kann wohl annehmen, daf̧ die bis dahin ganz auf das Individuum abgestellte geschäftliche Tätigkeit sich im Rahmen der beschränkten Haftung nicht zurechtfand. Mit der grofyen Verantwortung bis zur persönlichen Haftung mit dem letzten Pfennig des Eigentums und dem Schuldgefängnis selbst nur bei Zahlungsverzögerungen auf der einen Seite, der geringen steuerlichen und allgemein moralischen Verantwortung, bis zur Möglichkeit, sich durch eine Reise ins Ausland den Gläubigern heimlich zu entziehen, auf der anderen, war das Wagnis damals ungewöhnlich groł auf beiden Seiten. So entstanden die Kämpfe der Aktionäre mit dem Vorstande mit Kampfgruppenbildungen nach dem Vorbilde politischer Parteien, die manchmal in wenigen Jahren, in einem Falle erst nach 20-jährigem Kampfe, einen Vorstand oder stellvertretenden Vorstand der Gesellschaft in der Dunkelheit verschwinden lassen.

Irgendwelche Sorgen, dał überhöhte Gewinne die Wettbewerber hochziehen müssen, den Umfang des Geschäftes abdrosseln oder gar bei einem öffentlichen Versorgungsunternehmen unmoralisch sein könnten, kommen gar nicht auf.

Wenn diese Dinge bereits bei den höchsten Beamten der Gesellschaften vorkommen, ist es verständlich, daf die richtige Eingliederung der untergebenen Angestellten und gar der Arbeiter, die als gänzlich unerfahrene Kräfte unmittelbar vom Acker oder aus der Masse der grof- oder hafenstädtischen Gelegen- 
heitsarbeiter herangezogen wurden, zunächst noch viel weniger Verständnis fand. Natürlich ist das bei den einzelnen Gasgesellschaften je nach dem Charakter des Leiters sehr verschieden. Manche Gesellschaften sind sogar ihren Abnehmern gegenüber unbekümmert hart. Wenn es ruchbar wurde, daf̧ ein Abnehmer wegen einer verzögerten Gasrechnung in den Schuldturm wandern kann, und damit ihm womöglich die Erwerbsmöglichkeit für sich und seine Familie abgeschnitten wird, so kann man sich vorstellen, daf Kundenwerbung eine schwierige Sache ist. Andererseits sind die Berichte über Unterschlagungen beim Einzug der Gelder und Veruntreuungen der Buchhalter ebenso häufig wie die Überschreitungen der vereinbarten Brennzeiten durch die Abnehmer. Angestellte konnten schlief\}lich nur gegen eine Bürgschaft von Leuten, die einen ausreichenden Besitz und einen besonders vertrauenswerten Ruf besaf̧en, hereingenommen werden.

So zeichnet sich das Bild ganz im Anfang. Indessen muß festgestellt werden, daß in der betrachteten Zeit deutliche Zeichen sichtbar werden, diese Beziehungen zu verbessern. 1824 wurden dann zum ersten Male nasse Gaszähler gegen einen Preisnachlaf̧ von $10 \%$ auf die den Verträgen zugrundeliegenden Gasmengen angeboten; zunächst also auf freiwilliger Grundlage, wobei derjenige, der sparsam wirtschaften wolite, noch besondere Vorteile erzielen konnte. Von den ersten Unterstützungen der Arbeiter bei Unfällen oder plötzlich durch Krankheit auftretender Not allerdings auf ganz freiwilliger Grundlage und nach Beschluf̧ des Direktoriums finden sich auch Berichte.

Will man diese ganze Periode in wenigen Sätzen zusammenfassen, so mag folgendes gelten: Technisch wurde entschieden, dał das über ein Stadtgebiet sich ausdehnende Versorgungsunternehmen und nicht die Einzelanlage die dem Gase angemessene Form darstellt. Die Aktiengesellschaft mit groł̧em Kapital ist dafür Voraussetzung. Die Apparate und Ofenanlagen wurden bis zu einer befriedigenden Sicherheit entwickelt. Die Erkenntnis, dał nur Ehrlichkeit und Menschlichkeit solche großjen Gemeinschaften erhalten können, reifte. 


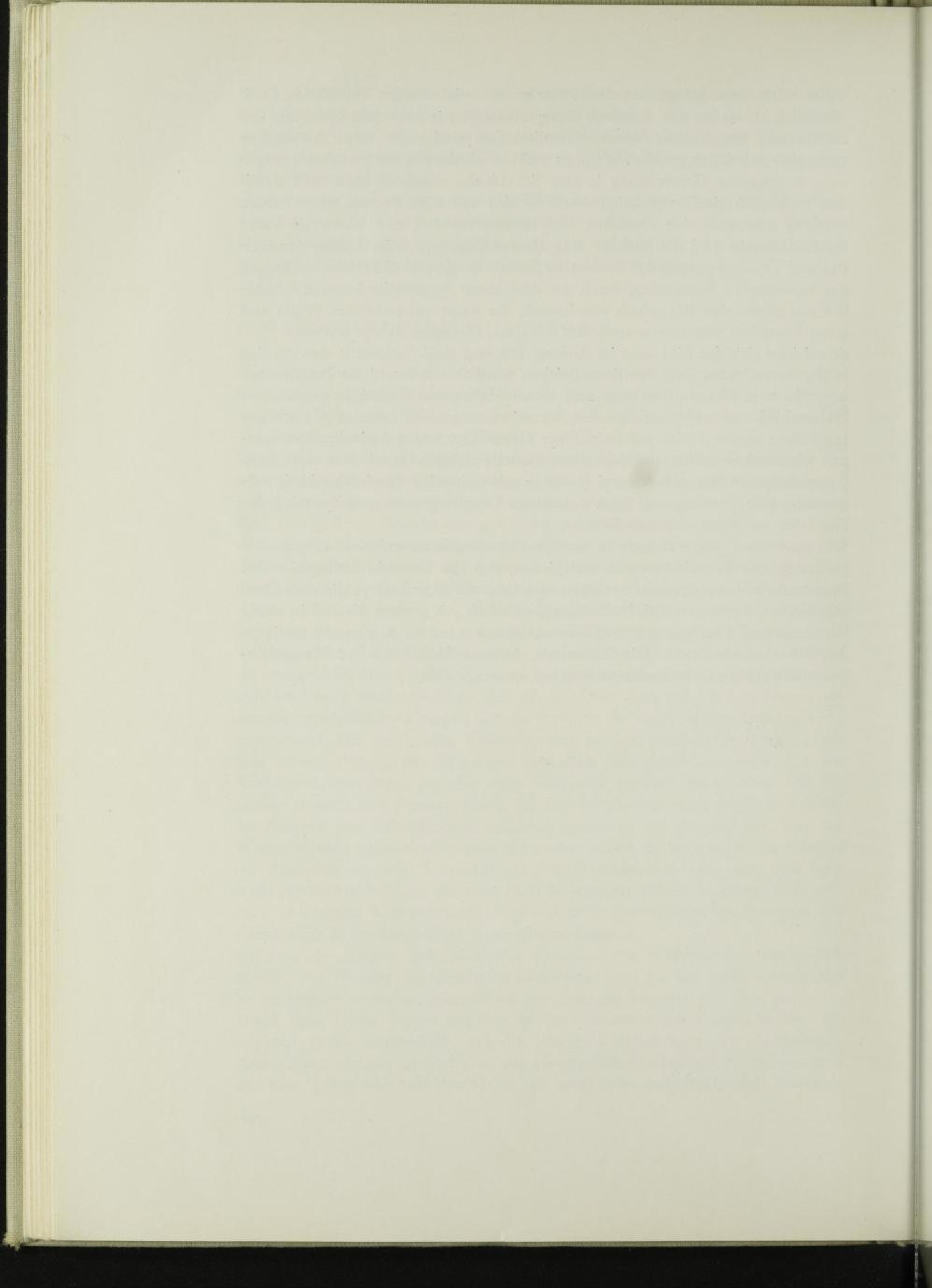
그 Sirfohren Wissen. $^{\text {SLUB }}$ 
Eine Wahl geschichtlicher Abschnitte ist nicht gerade leicht, weil in der Entwicklung oft längere Übergangszeiten zu entstehen pflegen. Andererseits würde aber das Gesamtbild unübersichtlich, wenn nicht in Abschnitten Zusammenfassungen erfolgten. Bei einer Darstellung technischer Dinge muf dann aber der Vorstellung entgegengetreten werden, dał etwa in den betonten Zeitpunkten mit einem Male in allen Einzelheiten gänzlich neue Verfahren anlaufen. Den jeweils in einer solchen Epoche Lebenden ist jedenfalls die Umstellung selten deutlich und bewufyt. Deshalb wird es gut sein, eine Begründung für die Wahl des eine Epoche bildenden Jahres zu geben.

Das Jahr 1825 ist für die Geschichte des deutschen Gasfaches allerdings ein ganz klarer Abschnitt, weil in ihm die ersten grołen Werke zur Beleuchtung ganzer Städte aufgebaut wurden, nachdem die Genehmigungen erteilt und die Gesellschaften gegründet worden waren.

Der Umschwung aber im Jahre 186c liegt tiefer. Zwar läßt sich zunächst aussagen, daf̧ in den fünfziger Jahren dic letzten Grołstädte Deutschlands eine Gasbeleuchtungsanstalt erhielten. Am hartnäckigsten hatte wohl Bremen die Ölbeleuchtung für ausreichend gehalten. Am 23. 9. I854 kam aber auch dort ein allgemeines Gaswerk in den Betrieb.

Wenn man die geistige Regsamkeit des Bürgertums richtig bewerten will, geht man vielleicht am besten auf die Revolutionsjahre 1848 und 49 zurück. Damals begeisterte sich das Bürgertum für zwei Dinge:

1. Die Gründung eines deutschen Bundes zur Erfassung aller Deutschen in einer politischen Gemeinschaft,

2. Die Errichtung der Demokratie, oder zum mindesten einer konstitutionellen Verfassung, in der das Bürgertum sich eine führende Stellung zudachte.

In der Paulskirche kamen die besten Köpfe der Zeit aus dem wirtschaftlichen Leben und der Wissenschaft zusammen. Trotz der hochfliegenden Ziele scheiterte die Bewegung im Alltag. Die Reaktion wurde spürbar. Das Bürgertum war entmündigt, nicht aber die in ihm treibende Kraft. Von der Revolution kam man zur Evolution. An den einfachsten Grundlagen wurde angepackt. In dieser Zeit arbeitete der Eisenhüttenmann F. Steinbeis als Staatsbeamter mit der Begünstigung seines Landesfürsten an der Erstarkung des Mittelstandes. Durch die Organisatiton und Erziehung der Gewerbetreibenden legte er den Grund zu der glücklichen wirtschaftlichen Struktur des Landes Württemberg, die sich noch heute auswirkt. Im Jahre 1365 folgte das Grof̧herzogtum Baden mit der Gründung der Landesgewerbehalle unter der Leitung des später auch für das Gasfach bedeutungsvollen Prof. H. Meidinger dem gegebenen Beispiel. 
Deutschsein - vor der Gründung des Bismarckschen Reiches, von der Maas bis an die Memel, von der Etsch bis an den Belt, also auch Österreich und die Deutschen im Baltikum gesinnungsmäf̧ig erfassend - Können und Wissen waren die Grundzüge des Voranstrebens. Hiervon wurde auch das Gasfach belebt. Um diese Zeit herum fand vor allem die vorwiegend empirische und stark auf handwerkliche Erfahrung gestützte Arbeitsweise ihr Ende. Die wissenschaftliche Durchforschung des ganzen Faches und mit ihr der freimütige Gedankenaustausch im Gegensatz zur Geheimniskrämerei setzte sich durch. Diese Umstellung beschränkte sich keineswegs auf das Gasfach allein, sie ist sogar auf andern technischen Gebieten deutlicher zu sehen. Der Verein deutscher Ingenieure mit dem ausgesprochenen Ziel wissenschaftlicher Arbeit und freien Gedankenaustausches wurde am 12.;. 18;6 gegründet. Das Ingenieur-Taschenbuch „Hütte erschien im gleichen Jahre zum ersten Male. Die Zeitschrift des Vereins deutscher Ingenieure wurde $\mathrm{ab} 1857$ herausgebracht. Im gleichen Jahre wurde F. $R$ e d t e n$b a c b e r$, den der Verein deutscher Ingenieure als Begründer des Maschinenbaues als Wissenschaft gewürdigt hat, zum Direktor des Karlsruher Polytechnikums ernannt. Er fügte nach seinen schon lange verkündeten Gedanken die allgemeinbildenden Fächer zur Erziehung ganzer Menschen dem fachtechnischen Studium hinzu. 1860 traten die Eisenhüttenleute zum Verein deutscher Eisenhüttenleute zusammen.

I858 kam als erstes auf das Gasfach begrenztes Blatt in Deutschland Schillings Journal für Gasbeleuchtung als wissenschaftlich ausgerichtete Zeitschrift heraus. Im Jahre darauf wurde der Verein der Gasfachmänner Deutschlands gegründet, und 1860 erschien als erste umfassende deutsche Darstellung der Gastechnik seit 1820, wo es auf dem Kontinente noch gar kein Gaswerk gegeben hat, $S$ c billing $s$ Handbuch für Steinkohlengasbeleuchtung. In der Zwischenzeit gab es nur gelegentliche Einzeldarstellungen.

Damit wurde ab 1860 die Arbeitsweise vollkommen anders, und daher dürfte auch dieses Jahr als Epoche mit Recht gewählt sein.

3.I BEISPIELE FÜR DEN AUFBAU EINZELNER WERKE

3.II Die engliscbe Imperial Continental

Gas Association

Die in Deutschland erwünschte Belebung in der Errichtung von Beleuchtungsanstalten kam im Jahre 1825 durch die Regsamkeit der Engländer. Nachdem im eigenen Lande Gaswerke in einem beachtlichen Umfange errichtet waren und befriedigend arbeiteten, versuchten die Briten, ihr Kapital unter Einsatz der Erfahrungen in fremden Ländern gewinnbringend anzulegen. Diese Tat ist nicht immer freundlich gewürdigt worden. Dabei ist es doch in der freien Weitwirtschaft gang und gäbe, daß ein Unternehmen besondere technische Erfahrungen und Konstruktionen durch Ausfuhr, und wo diese behindert ist, durch Tochterfirmen im Auslande wirtschaftlich ausnutzt.

104 
Deutschland war in den Jahren von 1812 bis 1825 mehr als andere Länder in der Gastechnik zurückgeblieben. Wie ungeheuerlich es an Kapital gefehlt hat, ist man sich auch wohl ein Jahrhundert später nicht mehr bewuft gewesen. Die Bescheidenheit des Biedermeier verwischt das Bild. Damals bestand Deutschland auch nach der grof̧en Bereinigung, die Napoleon vorgenommen hatte, aus 39 selbständigen und mit Zollgrenzen umgebenen Kleinstaaten. Während aus Preuf̧ens Ostgebieten Lebensmittel nach England über See exportiert wurden, verhungerten in den Jahren nach den Freiheitskriegen die Menschen im Westen und vor allem im Südwesten. Baden, Württemberg und die Pfalz verlief̧en alljährlich Auswandererscharen, über die 5- bis 6-stellige Zahlen errechnet worden sind. Ein so trostlos organisiertes deutsches Vaterland konnte für irgendwelche Fabrikunternehmen kein fremdes Kapital, wie es dringend nötig gewesen wäre, zur Entwicklung gewinnen. Beispielsweise haben die Gebrüder Remy auf dem Rasselstein bei Neuwiea, deren Werke dort auf wertvollen Eisenvorkommen und Wasserkräften aufgebaut waren, von Cockerill zwar gute Ratschläge, aber keine Kapitalunterstützung bekommen. Ja selbst seine Empfehlung bei holländischen Bankleuten half gar nichts. Eine Rente schien bei den wirtschaftlichen Behinderungen nicht gesichert.

So war es für die Volkswirtschaft ein beachtlicher Zufluf an Aufbaukapital, wenn über die bei einem Gasversorgungsunternehmen voraussehbare Rente ausländisches Kapital hereingeholt werden konnte. Die volkswirtschaftlichen $\mathrm{Zu}$ sammenhänge sind uns heute geläufig. Damals kannte man sie wenig und muf̧te nach der augenblicklichen Empfindung tastend vorgehen.

In den ersten Tagen des Dezember 1824 wurde in London die Imperial Continental Gas Association gegründet. Geistiger Vater war Generalmajor Sir William Congreve (1772-1828), eine auffallende Persönlichkeit, deren Lebenslauf bei den Erfolgen seiner Gesellschaften für die Ausbreitung des Gases hier nicht übergangen werden darf.

\section{LE B E N S B I L D}

Congreve, am 20. 5. 1772 in Staffordshire als Sohn des Leiters des Kgl. Laboratoriums zu Woolwich geboren, war als Soldat Controller of the Royal Laboratory and Superintendant of Military Machines, wobei er bemerkenswerte wissenschaftliche Leistungen zeigen konnte. $\mathrm{Er}$ ist es, der zu allererst Raketen als Kampfmittel konstruierte, die auch in der Schlacht von Leipzig eingesetzt wurden. Hierüber hat er bereits 1807 ein Lehrbuch verfaf3t, das 1827 in vierter Auflage eine Erweiterung erfuhr.

Im Jahre 1813 war bei der Gas Light and Coke Co. ein Zerknall vorgekommen (vgl. S. 71). Die Öffentlichkeit war aufs äuß̧erste aufgeregt. Der Home Secretary fühlte die Verantwortung, die die Behörde durch die Erteilung der Lizenz hatte, und so wurde ein Ausschuf der Kgl. Gesellschaft berufen, um den Unfall zu untersuchen. Fachleute und alle Einzelheiten kennende Wissenschaftler waren aber damals aufjerhalb der Gasgesellschaft kaum zu finden. So wurde Congreve in den Ausschuł berufen, weil er ja „Fachmann auf dem Gebiete der 
Explosionen “ war $\left.^{3.1}\right)$. Damals demonstrierte Clegg die Harmlosigkeit eines richtig betriebenen Behälters. Congreve war für Gas gewonnen, wenn auch ihm später ein Brand einer aus Holz gefertigten Pagode, die zur Feier des Sieges über Napoleon im Rahmen eines Feuerwerks mit Gas erleuchtet werden sollte, zur Last gelegt wurde. Er hatte nämlich gegen den Rat Cleggs zunächst das Feuerwerk abbrennen lassen, das die Pagode entzündete. Die Gasinstallation hielt aber stand. Mit der Beleuchtung war es allerdings nichts.

Congreve erfand auch einen Gaszähler, bemühte sich um die Verbesserung der Retorten und wurde bald als Autorität in Gasangelegenheiten angesehen ${ }^{3.2}$ ). Am 22. 2. 1822 wurde er zum Inspector of Gasworks in the Metropolis seitens der Home Office ernannt ${ }^{3.3}$ ). Er bemühte sich, durch Abgrenzung der Versorgungsgebiete dem bereits entbrannten wilden Wettbewerb der verschiedenen Gasgesellschaften Einhalt zu gebieten. Mit anderen Fachleuten verlangte er, zus Sicherheit und zum Schutz gegen Wettereinflüsse, vor allem Wind, die Behälter mit Mauerwerk zu umgeben (Vgl. S. 84). Zeitweilig trat er für die Ölgasgesellschaft mit ihrem leuchtkräftigeren Gase $\left.\operatorname{ein}^{3.4}\right)$. Schon ${ }_{1814}$ hatte Congreve den Erzherzog Johann von Österreich für das Gas einzunehmen versucht. 1824 setzte er nun seine ganze Person für den Erfolg der Imperial Continental Gas Association ein. Seine Freundschaft mit König Georg $I V$. brachte den „Ritter“ am Hofe in Berührung mit den Vertretern fremder Länder. Im Kopf des Gesellschaftsprospektes tauchen deren Namen auf. Er verhandelte mit den Geldleuten und besuchte dann die für die Beleuchtung entscheidenden Behörden in Amsterdam, Hannover und Berlin. Als Mitarbeiter gewann er Da niell (den Physiker, der durch das Daniellsche Element später berühmt geworden ist) und als Ingenieur J. Perks (Erbauer des Gaswerks in Berlin). Von Januar bis Mai 1825 wurden Gent, Antwerpen, Amsterdam, Den Haag, Rotterdam, Hannover, Berlin, Dresden, Leipzig, Frankfurt/Main und Weimar besucht. Nach den ersten Abschlüssen in Hannover und Berlin, über die später zu berichten ist, kam es 1826 zu einer Auseinandersetzung zwischen Congreve und dem Direktorium. Congreve zog sich aus den Geschäften zurück. Er starb $1828^{3.5}$ ).

Den ersten Elfolg hatte die Gesellschaft in Gent. Sie setzte damit ihren Fuf nach Belgien, wo noch heute die englische Gesellschaft an der Gasversorgung, allerdings von den Zechenkokereien aus, beteiligt ist.

3.III Hannover

In Deutschland kam die Gesellschaft zuerst in Hannover zum Zuge, wobei die Beziehungen des Königshauses erleichternd gewirkt haben mögen. Am 21. 12. 1824 wurde von der Regierung Congreve ein persönliches Privileg zur Erleuchtung der Residenzstadt Hannover mit Gaslicht auf 20 Jahre erteilt unter der Bedin-

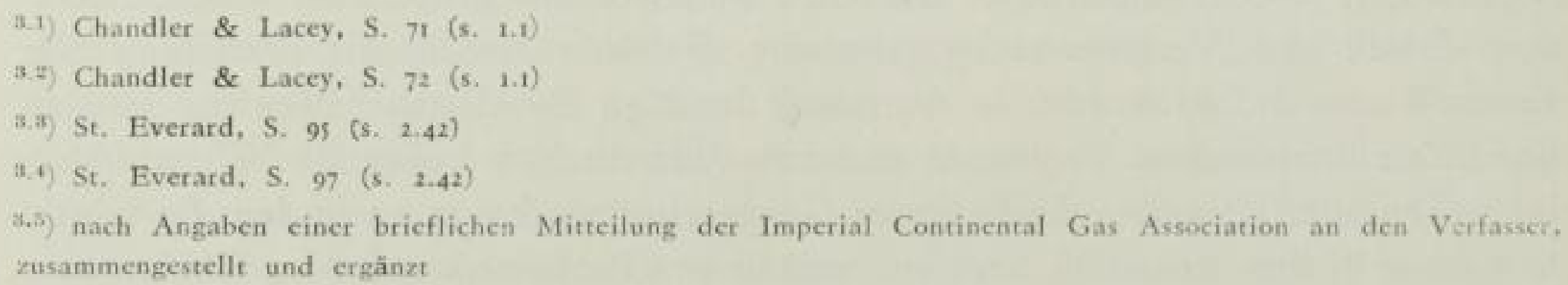


gung, dał er wegen der öffentlichen Straf̧eabeleuchtung den mit dem Magistrat verabredeten Vertrag vollziehen und erfüllen werde ${ }^{3 .}$ ). Mit dem Privileg wurde ihm ein ausschliefliches Recht der Beleuchtung erteilt. Irgendwelche Vereinigungen von Privatleuten zur gemeinschaftlichen Gaserleuchtung waren danach unzulässig, indessen war die Aufstellung einer Beleuchtungsanlage für eigene Rechnung frei. Der Beleuchtungsvertrag mit der Stadt ist am 14. Jan. 1825 zwischen der Gesellschaft und dem Magistrat abgeschlossen worden ${ }^{3.7}$ ). Am 12. 8. 1826, dem Geburtstage des Königs, brannten zum ersten Male die Gaslampen. Das „Hannoversche Magazin" hat 1836 nachstehenden auf dicse Zeit zurückschauenden Beticht gebracht:

„Die Anzündung der neuen Laternen lockte die ganze Bevölkerung aus den Wohnungen; Jubel und Freudenrufe begrüßten das schöne reine Licht, durch welches die Strał̧en wie mit einer festlichen Illumination gefüllt erschienen. Bis in die Nacht dauerte diese allgemeine Pilgerfahrt; die Augen konnten sich nicht sättigen an diesem Fest der Lichter, und man sah besonders die zufällig anwesenden Landleute eine solche Laterne stundenlang umstehen und starr das dreizackige helle Flämmchen betrachten, welches ohne Öl und Docht wie ein zauberischer Feuerquell ohne Ende leuchtend hervorsprudelte. Die düsteren Winkel und Schattenstellen sind nun wie durch Feerei verschwunden, vielleicht gegen den Wunsch mancher Nachtwandler, Schatzgräber und abendlicher Jäger und Botaniker, doch sicher zum Ruhme der Stadt und zum allgemeinen Besten ${ }^{\text {c3. }}$ ).

Man spürt, wie der Leitartikel sich in die Poesie versteigt, um alles anschaulich zu schildern. Das ist insofern beachtenswert, als in den nunmehr zu behandelnden Streitigkeiten zwischen Stadt und Gesellschaft I833, also drei Jahre vorher, eine Art Frieden geschlossen war, Streitigkeiten, in die das erwähnte „Magazin“ scharf und verdienstvoll aufklärend eingegriffen hatte.

Der Grundsatz dieser Verträge der ersten Zeit war einfach: Die Gesellschaft übernahm die Beleuchtung zu den Kosten, die für die bisherige Ölbeleuchtung (in Hannover bei einem Pachtvertrag mit einem örtlichen Unternehmer) aufgewendet werden mufsten, sicherte aber eine verbesserte Beleuchtung zu (in Hannover die zweifache Lichtmenge). Die Gesellschaft errichtete Gaswerk und Rohrnetz auf ihre Kosten. Viele Unstimmigkeiten erwuchsen aber aus Nebenbestimmungen: Benutzung und Pflege der vorhandenen stadteigenen Laternenpfähle, Erledigung von Beschwerden, Staub- und Dämpfefreiheit der Anlagen u. ä. Eine Vielzahl von zur Kritik berechtigten Behörden auf der einen Seite, eine Hartnäckigkeit des zunächst mit einer Unterbilanz beginnenden Ingenieurs auf der anderen, liefsen dramatische Spitzen entstehen. Gleich im ersten Winter 1826/27 froren die Leitungen, insbesondere die Laternenanschlüsse, ein. Es wurde festgestellt, dał im deutschen Klima die Verlegung in 45 bis $60 \mathrm{~cm}$ Tiefe jeden normalen Frost an die Rohre kommen lief̧. Die Zuleitungsrohre der Straf̧enlampen waren dazu noch ohne Schutz auß̧en an den Holzpfählen hochgeführt. Streitigkeiten um Entschädigung veranlaf̧ten den Direktor Lennard D rory.

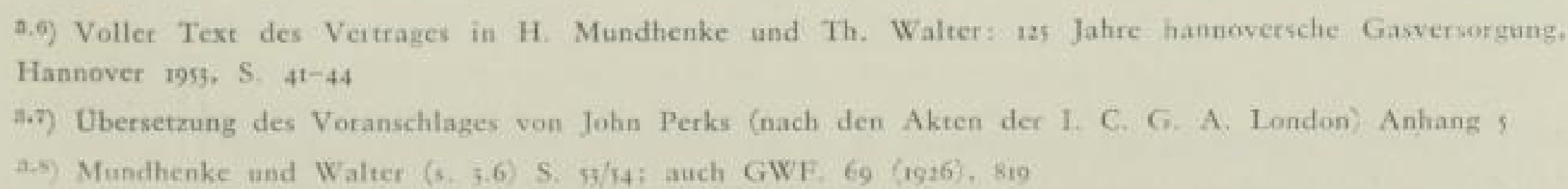


am 19. 10. 1827 die ganze Beleuchtung einfach abzustellen, wobei dann auch die an sich am Streit unbeteiligten Privatabnehmer in Mitleidenschaft gezogen wurden ${ }^{3.9}$ ). Die Stadt verlangte daraufhin unter anderem die Abberufung des Direktors. Am I4. I. 1833 kündigte die Gesellschaft den Beleuchtungsvertrag mit der Stadt in der Absicht, die privaten Abnehmer weiter zu beliefern. Die Behörden beantworteten die Kündigung mit dem Hinweis, daf mit dem Beleuchtungsvertrag auch das Privileg hinfäliig würde. Die Stadt drohte am I5. 4. 1833, die Rohre herausreifen zu lassen, und die Stadt verhandelte bereits mit den früheren Ölbeleuchtungsunternehmer wegen Herstellung des alten Zustandes. Jetzt lenkte die Gesellschaft ein, L. Drory wurde nach Berlin versetzt. Als erster deutscher Gaswerksadministrator der Gesellschaft trat Ernst Körting in die Dienste der I.C.G.A. Von da ab beruhigte sich das Verhältnis. Man hatte offenbar endlich gelernt richtig abzuschätzen, was man gegenseitig voneinander verlangen und erwarten konnte. Erst am 12. Januar 1918 ging als Folge des Wirtschaftskrieges im Weltkriege das Gaswerk in den Besitz der Stadt über.

3.112 Die I.C.G.A. in Berlin

Am 27. März 1826 konnte Congreve auch für Berlin mit dem Ministerium des Inneren einen Vertrag auf das ausschließ̧liche Beleuchtungsrecht der Stadt für 2I Jahre abschliefzen. Von ihm sagt die Gesellschaft ${ }^{3.19}$ ): „So begann eine Verbindung mit der Stadt Berlin, die über 93 Jahre (ebenfalls bis 1918) währte und sich als das beste Geschäft erwies, das die Gesellschaft jemals besessen hat." Die Bedingungen waren ähnlich wie in Hannover. Von der Pflicht zur Gasbeleuchtung wurden schmale Gassen und weitabliegende unbedeutende Strafjen ausgenommen, die die I.C.G.A. mit Öllampen erhellen sollte. Die Gesellschaft verpflichtete sich, die gesamte Anlage bis zum I. I. 1829, die "Linden“ und das königliche Schlof aber innerhalb von 9 Monaten zu erleuchten. Um die Herstellung der Werke zu beschleunigen, durften zunächst gewisse Apparate, Rohre usw. zollfrei aus England eingeführt werden, später aber war alles in Preuß̧en zu kaufen, was nicht billiger - einschlieflich Zoll - von England bezogen werden konnte. (Bild I6)

Ein gewisser Fortschritt zu Gunsten der Gesellschaft gegenüber dem hannoverschen Vertrag bildeten die klaren Bestimmungen für die Fortsetzung nach 21 Jahren. Die Stadt hatte das Recht, den Vertrag zu gleichen oder im Einverständnis mit der Gesellschaft abgeänderten Bedingungen zu erneuern. Sie war aber auch berechtigt, jede andere Beleuchtungsart einzuführen, wobei die Gesellschaft das Recht aut Versorgung von privaten Kunden auf immer behalten sollte. Die Gesellschaft wurde sogar unter den besonderen Schutz der Regierung gestellt. Diese empfahl die Gesellschaft auch in allen gröferen Städten des Landes, vornehmlich in Breslau, Danzig und Königsberg. Hier in Berlin wurde auch sofort ein Ortsansässiger zum Vertreter der Gesellschaft ernannt, dessen Hauptaufgabe es war, gute Beziehungen mit den Behörden aufrecht zu halten und dafür zu sorgen, dał̧ das Geschäft ohne Störung lief.

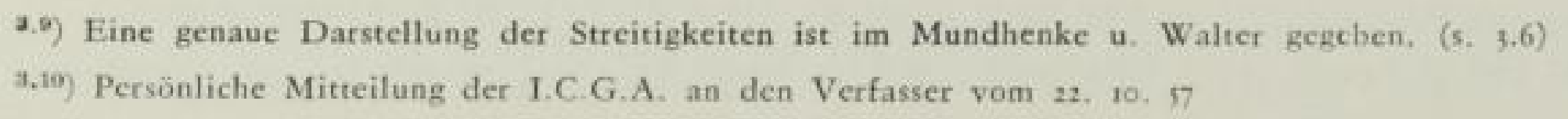




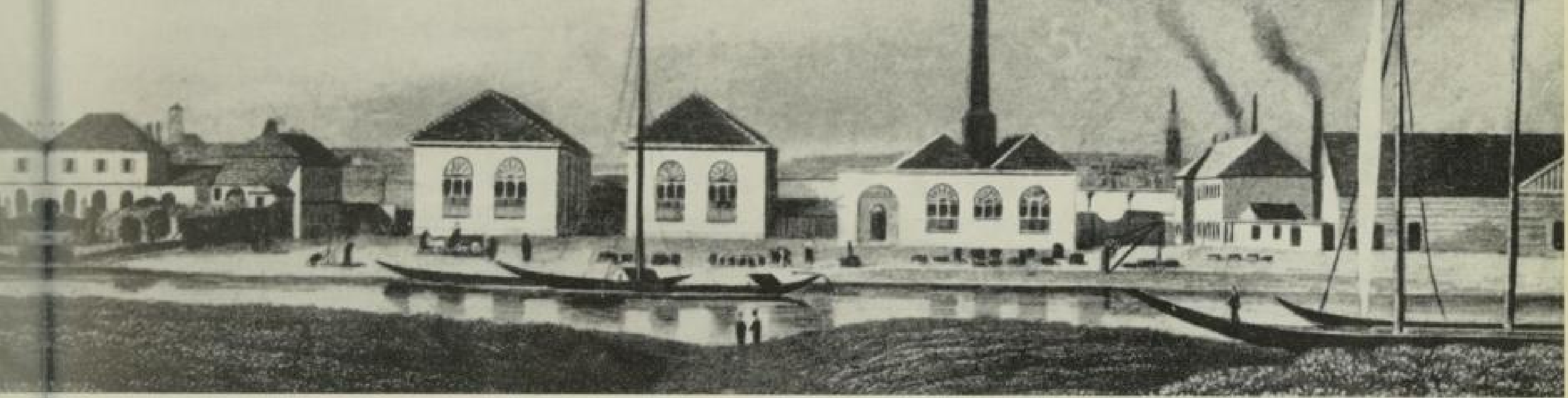

Bild 16 Berlins erste ,Gas-Erleuchtungsanstalt" in der heutigen Gitschinerstrafye yom gegenüberliegenden Ufer aus

Leider erwiesen sich gerade diese Hoffnungen auch in Berlin als trügerisch. Mit dem Magistrat, über dessen Kopf hinweg die Landesregierung den Vertrag geschlossen hatte, kam es zu Streitigkeiten über die Ausdehnung der Beleuchtung und über zu zeitiges Verlöschen oder Nichtanzünden von Laternen $\left.{ }^{3.11}\right)$. Dieser zog bereits 1836 als erfahrenen Fachingenieur den Leiter der städtischen Werke in Dresden und Leipzig, R. S. Blochmann, als Berater heran, und weil die Verhandlungen mit der englischen Gesellschaft nicht recht vom Flecke kamen, wurde dieser veranlaf̧t, Pläne gleich für zwei stadteigene Gaswerke, je eines auf jedem Ufer der Spree, einzureichen. Aus diesen Planungen wird es deutlich, wie unzureichend die vorhandene Beleuchtung empfunden wurde. Die englische Gesellschaft unterhieit bei 8000 Privatflammen, 1842 Strafenlampen. Blochmann schätzte die Erfordernisse für eine ausreichende Beleuchtung auf s140 Straf̧enleuchten und stellte das Projekt auf 25000 gesamte Flammen ein, sodał noch I9 860 Privatabnehmer versorgt werden konnten ${ }^{3.12}$ ).

Den Ernst der Lage hat wohl die englische Gesellschaft damals nicht gesehen. Tatsächlich war sich auch Biochmann bewuf̧t, dał der Anlauf des städtischen Werkes im Wettbewerb mit dem englischen, dem ja das Recht, die privaten Abnehmer weiter $\mathrm{zu}$ bedienen, nicht genommen werden konnte, recht schwierig sein würde. Dabei waren zwei Umstände besonders bedenklich. Der Aufbau der städtischen Werke sollte mit den ortsansässigen Maschinenbaufirmen geschehen,

3.11) G. M. S. Blochmann: J. f. G. $36(1893), 423$

3.12) Rudolf Sigismund Blochmann ist nicht nur fur das deutsche Gasfach sondern auch als vielseitiger Ingenieur für die technische Entwicklung in Deutschland von so grosser Bedeutung, dass sein Lebenslauf als Anhang 7 geschlessen beigefuge is. Damit ergeben sich zwar Wiederholungen der hier im laufenden Text aufgefuhrten Geschehnisse, Das Bild aber zur Kürzung zu zerreißen, erscheint nicht angāngig zu sein 
die aber erst die Ofen und Apparaturen kennenlernen muß̧ten. Hier waren Zeichnungen zu fertigen und Probegeräte herzustellen, ehe an die laufende Lieferung gedacht werden konnte, während die Engländer alles bereits in etwa genormt in ihrer Heimat einkaufen konnten. Auch das Bedienungspersonal, Arbeiter, Meister und Ingenieure, muf̧te im Betrieb geschult werden. Blocbman $n$ war auf̧erstande, die notwendigen Kräfte etwa aus Dresden oder Leipzig heranzuziehen, da beide Werke sehr klein waren und selbst sich ausdehnen muften.

Anhang 6 enthält eine Aufstellung der Werke der I.C.G.A.

\section{I2 Die erstendeutscben Werke \\ 3.12I Städtische Werke in Berlin}

Trotzdem beschloł am I5. IO. 1844 die Stadtverordnetenversammlung, die Straf̧enbeleuchtung ab I. Jan. 1847 in eigene Regie zu nehmen. Am I. Juli 1845 begann die Stadt mit der Verlegung der Leitungen. Jetzt wurde die englische Gesellschaft aufgeschreckt, um in letzter Minute den drohenden Kampf in seinen Folgen zu kennzeichnen, setzte sie den Gaspreis für Privatabnehmer auf die Hälfte des bisherigen herab.

Aber nun war es zu spät. Die vorhandenen Industriellen: Eggels, Freund, Wöhlert in Berlin, das Gräfl. Einsiedelsche Eisenwerk Lauchhammer und die königliche Gief̧erei hatten auch wohl schon zuviel Vorarbeit in die auf sie zukommende Arbeit hineingesteckt. Man darf auch nicht vergessen, dał die 40-er Jahre in Deutschland ganz allgemein sehr schwierig waren, so daf3 die genannten Fabriken, die auf dem Maschinenbau ihre ersten guten Jahre hinter sich hatten, um Arbeit verlegen waren, und dementsprechend in der Stadtverwaltung ihren Einflufy geltend gemacht haben dürften. Am 9. 12. 1846 wird das eine, I4 Tage später das andere Gaswerk noch rechtzeitig fertig, um am I. 1. 1847 die Beleuchtung der Stadt zu übernehmen.

Die englische Gesellschaft mufte nicht nur in Berlin einen schweren wirtschaftlichen Schlag entgegennehmen, vielmehr hatten nunmehr auch die Maschinenbaufirmen Berlins gelernt, Öfen und Apparate zu bauen. Sie belieferten alsbald auch die an anderen Orten entstehenden Gaswerke mit Apparaten, Gaszählern und Gasleuchten, sie suchten auch, diesen Absatz systematisch zu entwickeln, und to Jahre nach der Einrichtung des städtischen Berliner Werkes wurde auf ihr Betreiben die Deutsche Continental-Gas-Gesellschaft errichtet, von deren Namen schon deutlich wird, dał sie gegen die englische Imperial Continental Gas Association auftreten sollte. Doch davon wird später berichtet.

3.122 Dresden

Zunächst müssen wir uns noch einmal Dresden zuwenden. Auch dort hatte ja Congreve 1824 einen Besuch abgestattet, um einen Beleuchtungsvertrag mit der Regierung abzuschlief̧en. Dort aber hatten sich, wie erwähnt, die Landesregierung und in ihrem Auftrage das Polizeikollegium sehr eingehend mit Entwürfen 
beschäftigt. Man hatte auch in R. Blochmann einen urteilsfähigen und vertrauenerregenden Ingenieur am Orte. So wurde die Kritik des englischen Angebotes sehr klar und selbstbewufyt. Am 29. I2. I824 schrieb das Stadt-Polizeikollegium an die Landesregierung ${ }^{4.13}$ ): ,..... Diese Bedingungen scheinen auf den ersten Blick höchst vorteilhaft, indem die Stadt ohne einen Aufwand für die Anlage und ohne Vermehrung der jährlichen Unterhaltungskosten dreimal besser, als jetzt beleuchtet werden würde, sowie dann auch die vieljährigen Erfahrungen, die man in England über die Gasbeleuchtung gemacht hat, und der rühmlichst bekannte Namen des Vorstehers dieser Gesellschaft für die Solidität des Anerbietens Bürgschaft zu leisten scheinen.

Bei näherer Betrachtung desselben scheint jedoch, dał es höchst schwierig fallen dürfte, sich wegen Erfüllung der gegebenen Zusicherungen allenthalben sicherzustellen. Daf3 die Gasbeleuchtungsgesellschaft nicht willens zu sein scheint, sich die Hände allzu sehr binden zu lassen, dürfte aus den wegen der Straß̧enbeleuchtung Berlins unter dem 30. Okt. 1824 geschlossenen Bedingungen erhellen, in denen so manche Einschaltungen enthalten sind, die die Gesellschaft ziemlich frei und unabhängig erscheinen lassen. Es ist wohl auch nicht zu verkennen, daf3 das Anerbieten in pekuniärer Hinsicht nur scheinbar vorteilhaft ist, indem nach Verlauf des Kontraktes entweder es sich nötig machen würde, der Gesellschaft den ganzen Apparat abzukaufen oder einen neuen selbst anzulegen, wo dann in der Zwischenzeit auch noch der Gewinn, der aus diesem Unternehmen zu erwarten steht, für die Beleuchtungskasse verlorengegangen sein würde. Wenn es nun überdies höchst unpopulär und für die vaterländische Industrie sehr niederschlagend erscheint, von Ausländern ein Werk ausführen zu lassen, dem die inländischen Mechanici unter Benutzung der seither mit der Gasbeleuchtung im Auslande vielfach gemachten Erfahrungen wohl ebenfalls gewachsen sein dürften, und es für Handel und Gewerbe im allgemeinen sehr bedenklich sein möchte, einer Gesellschaft englischer Kapitalisten einen festen Platz in den größeren Städten des Kontinents einzuräumen, so können wir nicht anders, als nach unserer innigsten Überzeugung unser ohnmaßggebliches Gutachten dahin auszusprechen, das es nicht rätlich erscheint, die Beleuchtung hiesiger Residenz mit Gas mehrberegter Gesellschaft in Entreprise zu übergeben, wenn auch einem längst gefühlten Bedürfnis einer besseren Straf̧enbeleuchtung hierdurch auf dem kürzesten Wege sollte abgeholfen werden können."

Im Dezember 1826 kam Congreve noch einmal nach Dresden und besuchte manche Kreise der Stadt und am Hofe. Vom Minister Graf Einsie del veranlafyt, suchte er $B l o c \dot{b} m a n n$ auf und bot ihm die Direktion eines gedachten englischen Werkes an. Aber Blochmann lehnte ab.

Unter der Zusicherung staatlicher Unterstützung ging R. Blochmann ans Werk, die Versuche im kleinen fortzusetzen und den Versuch im grofen vorzubereiten. Man experimentierte, man rechnete, man zeichnete und trat in Verbindung mit den Stellen, die als Lieferer in Aussicht zu nehmen waren. Die Schwierigkeiten blieben nicht aus, aber sie wurden überwunden. Blochmann verstand es, die Unternehmer und Handwerker anzuweisen. Was im Schrifttum greifbar war,

3.13) Dr. G. C. Rudolf Blochmann: Aus der Frühgeschichte der Gastechnik. Verlag Oldenbourg. München 1942 S. $24 / 23$ 
wurde von ihm ausgewertet. Die besonders schwierige Aufgabe, gasdichte eiserne Rohre zu gief̧en, wurde beim Lauchhammerwerk gelöst. Im Herbst 1827 waren die Bauten der Gasbereitungsanstalt an der Bastei "Sol" innerhalb der alten Stadtbefestigung vollendet. Die Verlegung der Rohre und das Aufstellen der Kandelaber dauerte, im Winter ausgeführt, bis ins Frühjahr 1828. Am 27. 4. 1828 brannten die Gasflammen auf den zunächst aufgestellten 36 Kandelabern. Dresden besaf̧ damit die erste deutsche, mit Steinkohlengas betriebene Strafenbeleuchtungsanlage in öffentlicher Hand. Bis 1833 wurde die Verwaltung des Betriebes durch den Staat geführt. Unter dem Einfluf der Verfassungsänderungen 1830/31 gingen die Anlagen ohne Entschädigung in den Besitz der Stadt über, die damit die Eigentümerin des ältesten deutschen kommunalen Gaswerkes wurde ${ }^{2.1 y}$ ). Damit war eine Entwicklung eingeleitet, die von dem englischen Vorbilde stark abwich. Dort sind vor der Verstaatlichung der Gaswerke (1948/49) etwa $1 / 3 \mathrm{im}$ Besitze von Gemeinden gewesen, mit $2 / 3$ überwog, die Privatwirtschaft. In Deutschland war das Verhältnis lange Zeit umgekehrt, allmählich gingen dic städtischen Versorgungen immer mehr in die Hände der Städte über, zum mindesten aber in gemischtwirtschaftliche Unternehmungen, bei denen die Städte hohe Beteiligungen hatten.

3.123 Frankfurt/Main

Ganz andere Wege ging die Entwicklung in der Stadt Frankfurt a. M. In Hannover ${ }^{3,25}$ ), Preuf̧en und Sachsen wollte man sich auf ,inländische" Kohlen stützen. In der reichsfreien Stadt muf̧te aber jeder Rohstoff ",aus dem Auslande" kommen. Zwar begann die Gasverwendung r8r9 auch auf Steinkohlengrundlage mit einer Hausanlage im Senkenbergischen Stift, an die auch die Beleuchtung der Eschenheimerstrafye angeschiossen wurde ${ }^{\text {s.th }}$ ). Die Saarkohle aus St. Ingbert befriedigte aber nicht (mit Gufsretorten niedrige Temperaturen), und das Gutachten des Stiftes forderte Ölgas, das ja eine höhere Leuchtkraft hatte. Vielleicht spielten aber auch Rücksichten auf die Kaufmannschaft, die bisher das Beleuchtungsöl geliefert hatte, in dieser Stadt des Handels eine Rolle.

1826 wurde mit der englischen I.C.G.A. ohne Erfolg verhandelt. 1827 erwarben indessen die Frankfurter Bürger J. F. Knobla $u c b$ und J. G. R. Scbiele (geb. 1795, gest. 15. 2. 1865) ${ }^{3.17}$ ) ein Privileg auf eine Ölgasfabrik. (Bild 17) Schiele war zu dieser Technik durch Tabor angeregt worden ${ }^{3.25}$ ). Tabor übernahm zwar aus Accum die sehr grołen Zweifel an der Wirtschaftlichkeit der Ölgasbereitung. Er schrieb ${ }^{3.19}$ ), für Frankfurt komme in erster Linie St. Ingberter Saarkohle in Betracht, denn auch die in der Nähe gefundene Braunkohle liefere ein schlechtes Gas. Ölgas sei zwar gut, aber teuer. Die Umwandlung in Leuchtgas bringe

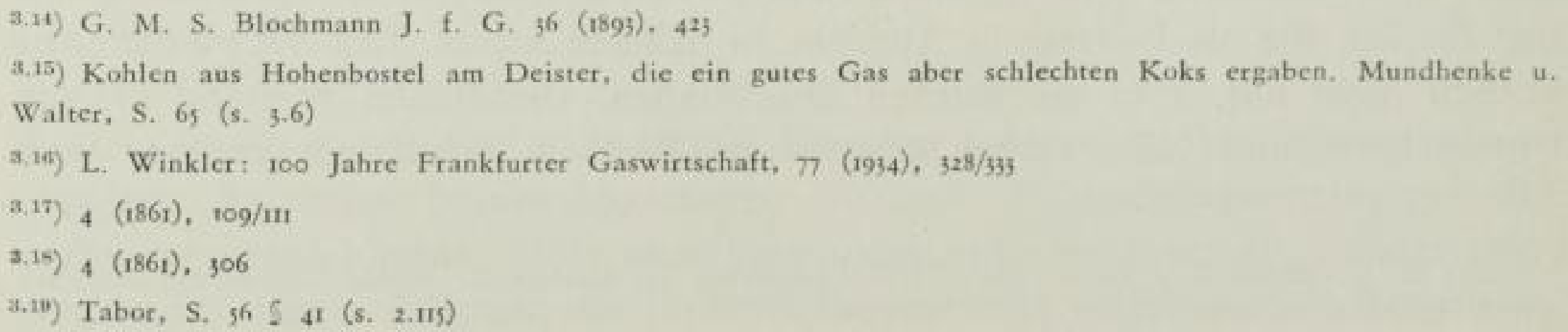




\section{Frantfurtersơntount.}

Nro. 236

Freitag, Den 24. 2uguft

1827

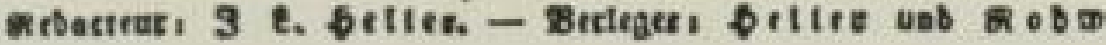

Tithidtofalenbet oer Dorsett.

य०० 0 it

24.

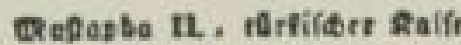
II a f ap ba II. tom im Jabe 169 nre Xitets fut Regirrung; $a$ mat be Goba, unb bat fid burd feine rrio grmadt. Dit genctianr natymen oet geglerung bie reld, 3n/et Ec im folgenben Sabre rouber entrifin

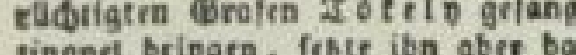
inoph bringre in

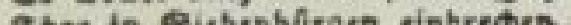
gor in Eirbrabrara rintrean.

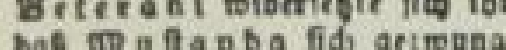
bah ers a bie wittiat Reftung zifiof op bie witctige freftung difofi ab boe fle unter ynfabruag o von Badifa burto ria bluti: wen tiarm obremoligen Sinf ise fatbet is feinten rigrace wis ut a ob a mit riner $x_{r m}$ fen, wurbe aber bei 3eat! gen init rines taum balb Gigteu tajer angestiffon o. frait lager 20.000 *t' $\$$ ' Sjanittidarea. $Z_{g} g$ unt ta Itersi bas pange aut ben Sábra ber engldedilose Errigni griebea hu etrittin ouf 25 Jabre mit eqiges Z̈ricsen, colgea grime, grtriten mos butts getlung Pepante. joriffbrigen 280 aी lo fre wurbes bod jotstorigen Eg $\mathrm{r}^{2}$ fitute oes 8 . Viflider estriben oem orution ungaril(ten tharuben nidit to mirdern atfouviel Envalt ia bartern tiet, bap

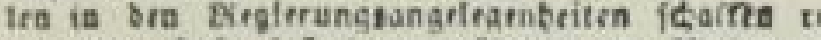

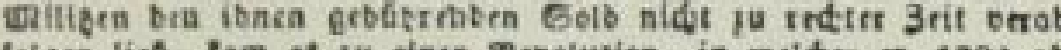

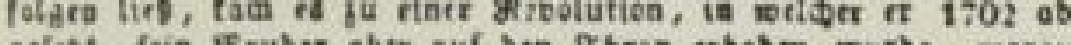

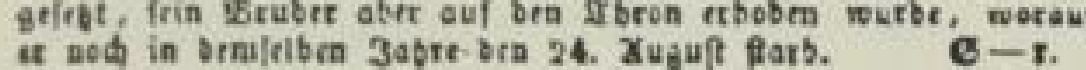
$\mathrm{DaS}_{\mathrm{B}}^{\left(1 \mathrm{SO}_{3}\right)}$

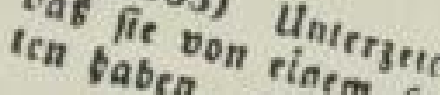

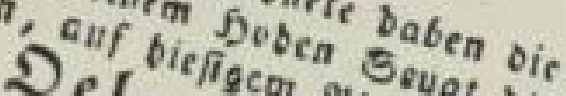

S क w

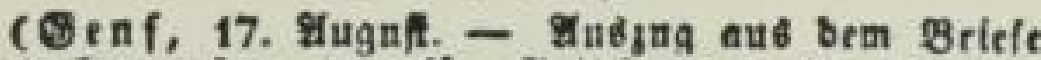
rined franjofen, ber fùr (Eriedenlanb faupft.) 3ebt, ba bie grofien Beftrebungen ber Briedien 3 Ercberung tbrer lumabbángigfeit nabe baran finb, bom Erfolge gefront gu merbes; jest, ba fie auf ben Puntte Erfolge gefront gu werbes; jegt, ba fie auf bem Yunfte

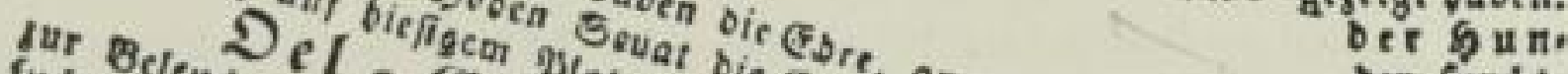

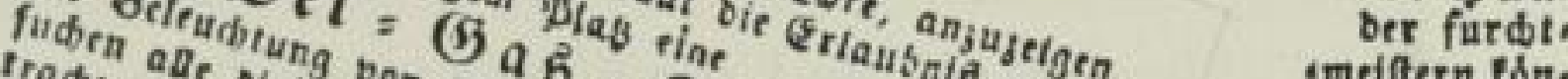

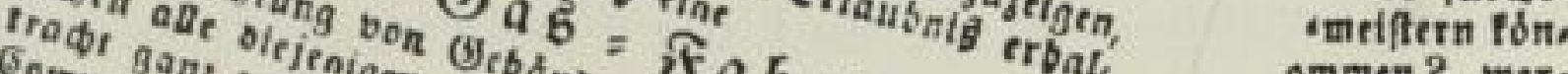

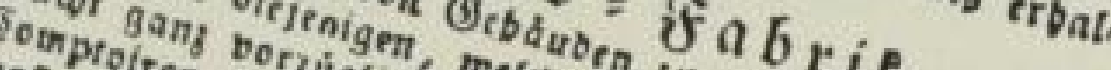

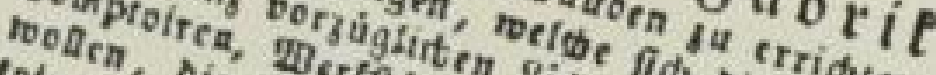

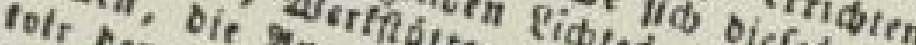

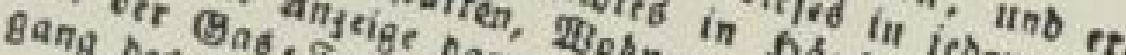

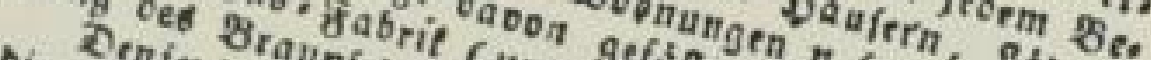
oie Rofenigen

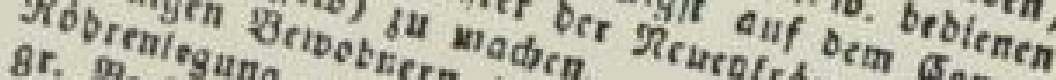

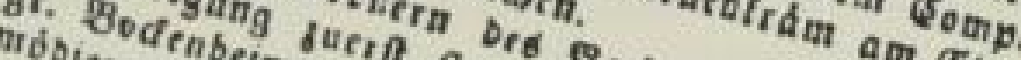
3eil,

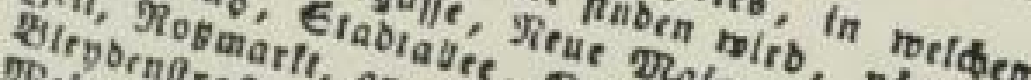

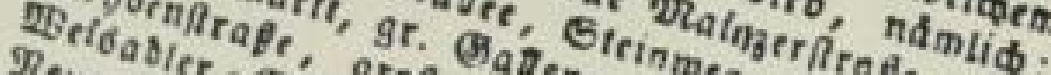

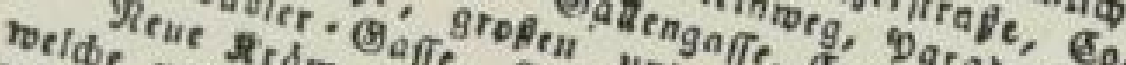

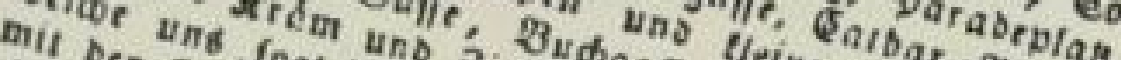

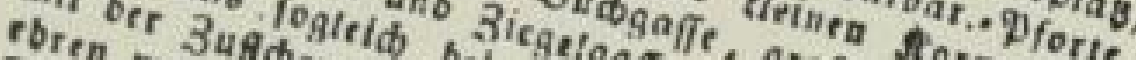

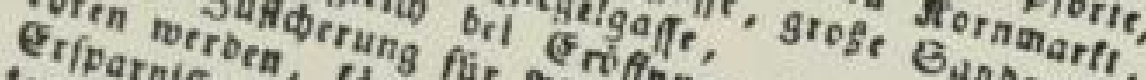

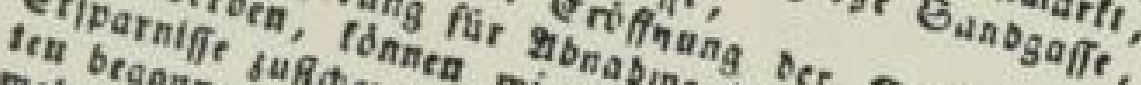

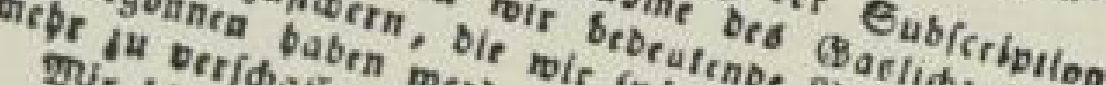

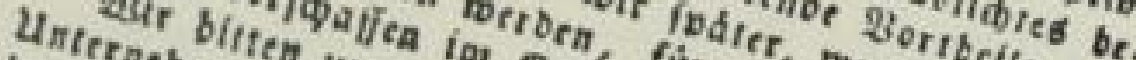

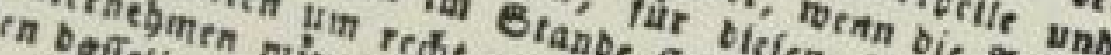

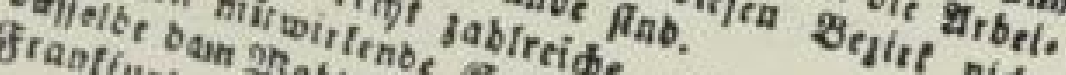

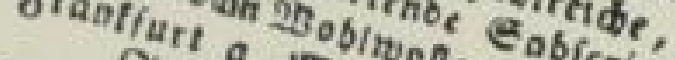

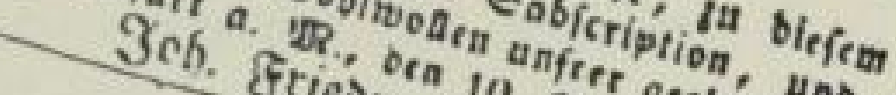

$$
n i \phi t
$$

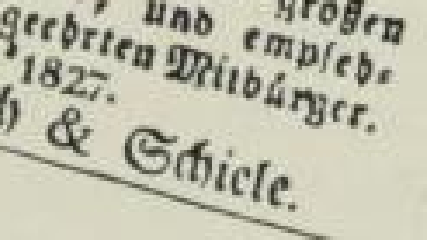

varuber . ommen? wer. unb enempfind. reine baben, es radi, aber ba. ranter aber ba. marnten git nit unarnomiuen baben, mit ibren Sulfos. jonbs find ungenut urfaiffe zu befriebi. feben, aber niat bee.

bat fiळ bargeboten; meflidie Dienfte Ieti. $c$ vernadlafigt. 2Bit ber Briedenfreunbe a. Durd eine f́arf. Then unb planuen. Stof. jelungen, jult, balt, unb unter bequener dangenebue, griunbe, fadr.

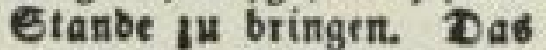
b, bas Sr. Bimbernat nur Sous bie Portion berechnet. an einen $Z_{a g}$ lang gu ndubern soe fid nur barum banbrin, nos cine IRanufactur ju er. twiebad in Eroben zu verfer. on if biergu in (Benf aur bem oon Senf erỏffnet, wo man

alen meiteren $r i a d w e i f u n g e n$ gefest witr.

De य

(शR An $\phi$ en, 19. Yug.) Die in (8) redentarb ge. wefesen bairifoen Dffigiere unb Unteroffigiere find nun

Bild 17 Faksimile der Ankündigung der Franfurter Gaswerke (GWF 77 [1934] S. 328)

nach der Schattenphotometrie Verluste gegenüber der Leuchtkraft bei der unmittelbaren Verbrennung des Öles.

Knoblauch und Schiele, die miteinander befreundet waren, hatten in den Jahren 1825 bis 1827 Versuche zur Erzeugung eines brauchbaren Ölgases in Niederrad, damals einem Orte noch aufjerhalb Frankfurts, angestellt. Als sie nunmehr als erste deutsche Privatunternehmer mit dem Bau eines Werkes in Frankfurt begannen, wählten sie Ol als Ausgangsstoff, weil die Anlagen - ohne teure und 
übelriechende Schwefelwasserstoffreinigung und mit kleinen Behältern und Rohrweiten bei einer bestimmten Lichtmenge - mit weniger Kapital hergestellt werden konnten. Hatte doch auch der kluge Talior über J. und P. Taylor gesagt, sie werden sich ein bleibendes Verdienst um die Gasbeleuchtungskunst erwerben, wenn sie noch Mittel finden, dieses Gas wohlfeiler zu liefern. Tabor glaubte also offenbar an die Möglichkeit, im Verfahren eine so weitgehende Verbesserung zu erreichen. Daf dem durch den Aufbau und Preis des Rohstoffes natürliche Grenzen gesetzt sein könnten, hat er auch wohl noch nicht ganz klar gesehen.

Ausserdem hatte in München in diesen Jahren das Ölgas besondere Aufmerksamkeit erregt. Dem Angebot der I.C.G.A. in München eine Beleuchtungsanstalt zu erbauen, trat die gutachtlich befragte kgi. Akademie der Wissenschaften entgegen. J. v. Y elin behauptete, das Ölgas habe eine totale Revolution im Beleuchtungswesen bewirkt ${ }^{3.39}$ ) und den Sieg über das Steinkohlengas davongetragen. Ölgas gäbe das schönste Licht und könne auch das allerbilligste liefern, wenn das Öl erst einmal eigentliches Marktgut werde und aus den Luxusartikeln heraustrete. Man beachtete in München, dał man nahe der Stadt keine geeigneten Kohlen besäß̧e und die Förderungskosten „ausländischer Kohle“ sehr teuer würden - (1824 ohne Eisenbahn). Demgegenüber aber könne die Landwirtschaft auf Ölfruchtbau sicherlich mit Erfolg gebracht werden.

Diese wirtschaftlichen Umstände waren unter den damaligen Verkehrsmöglichkeiten und den in Betracht kommenden Mengen für München sicherlich nicht ganz falsch gesehen. In Frankfurt an der Wasserstraß̧e waren die Voraussetzungen allerdings ganz andere. Die Anlagen wurden gröf̧tenteils aus England bezogen. Eiserne Retorten wurden mit Koks geladen, glühend geheizt und Rohöl gemäß dem Gasbedarf eingetropft. Das Gas wurde in Kalkwasser gekühlt, eine Schwefelwasserstoffreinigung war bei Ölgas nicht notwendig. Der Heizwert lag bei $10-12000 \mathrm{kcal} / \mathrm{m}^{3}$. Das Werk kam am 18. 9. I828 mit einer Abgabe von 3000 $\mathrm{cft}=84 \mathrm{~m}^{3} /$ Tag als Höchstmenge in Betrieb. Die Abgabe gegen Pauschale ohne Gasmesser, dazu auch die hohen Gasverluste im Rohrnetz aus dünnwandigem Guß̧eisen mit Holzscheiten und Pech gedichtet führten dazu, dał nur etwa die Hälfte des abgegebenen Gases bezahlt wurde. So muf̧te das Werk wegen der Verluste wieder stillgelegt werden. Die Inhaber entwickelten aber eine echte unternehmerische Zähigkeit. Sie setzen sich mit der I.C.G.A. in Verbindung, die ihre Erfahrungen gegen Lizenz und Gewinnbeteiligung zur Verfügung stellte. Es wurden nunmehr als Rohstoff Harze, die in Spiritus gelöst waren, verwandt, wobei die wechselnde Gasbeschaffenheit viel Sorgen bereitete. Die Hilfe, die Daniell geben konnte, war nicht ausreichend. Es entstanden gerichtliche Streitigkeiten, die Daniell verlor. Schiele muß̧te seibständig vorgehend die Mängel des ihm zur Verfügung gestellten Verfahrens beseitigen. Nun entschloł man sich zur Abgabe des Gases in fahrbaren Druck-Behältern, mit denen man bis Wiesbaden lieferte. Der Gasabsatz stieg von $23500 \mathrm{~m}^{3}$ auf $53500 \mathrm{~m}^{3}$ im Jahre 1837. Die Strałenbeleuchtung war zunächst nur versuchsweise betrieben. Um ihr gerecht werden zu können, wurde 1838 mit der Gründung der Frankfurter Gasbereitungsgesellschaft auf Aktien die Kapitalgrundlage (500000 Gulden) verstärkt. Auf Grund einer Ausschreibung erreichte die I.C.G.A. am I. 5. 1844 auf 25 Jahre das

3.20) $30(1887), 411$

$I I 4$ 
alleinige Recht auf Steinkohlengasbeleuchtung. Im Konkurrenzkampf wurde nunmehr die Lage der alten Gesellschaft schwierig. Zwar hatte ein Gutachten des Physikalischen Institutes in Frankfurt die höhere Leuchtkraft des Ölgases nachgewiesen, aber im Urteil des Abnehmers spielt die Größje der sichtbaren Flamme auch eine Rolle und die war bei Kohlengas für den gleichen Preis gröłzer. Als neuer Rohstoff wurden Bogheadkohlen bei der Olgasgesellschaft verwandt. Das erzeugte Gas wurde mit Hoizgas und heimlich auch mit Steinkohlengas versetzt. Natürlich kam es nun zu Streitigkeiten wegen des Rechtes der I.C.G.A., trotzdem genehmigte der Magistrat 1860 die zusätzliche Kohlengasherstellung mit der Auflage, ein neues Werk zu bauen, nachdem die englische Gesellschaft gegen andere Zugeständnisse auf das Monopol der Kohlengasherstellung verzichtet hatte. Hier mag der Bericht zunächst einmal abschlieł̧en, denn mit dem Sohne des J. G. R. Schiele, Simon Schiele, als Erbauer des Werkes in der Gutleutstraf̧e und als Leiter der „Neuen Frankfurter Gasgesellschaft" trat ein für unser Fach so erfolgreicher Ingenieur auf, daf schon aus diesem Grunde die weitere Entwicklung besser später geschlossen dargestellt wird. Er begann sein Lebenswerk bei der scharfen Wettbewerbslage unter den schwierigsten Voraussetzungen und hat sie gemeistert.

Es kann nun nicht die Aufgabe dieser geschichtlichen Darstellung sein, über jedes einzelne neue Gaswerk, seine begeisterte Aufnahme oder seine Schwierigkeiten bei der Vorbereitung und in den ersten Jahren des Betriebes zu erzählen. Vielmehr sind mit den vier Beispielen die Geschehnisse, wie sie mehr oder weniger überall zu beobachten sind, hinreichend geschildert. Doch mögen noch die grołstädtischen Werke erwähnt werden, die besonders spät errichtet worden sind, damit nicht der Eindruck entsteht, als ob im groß̧en und ganzen alles recht schnell und glatt gegangen sei. Vorweg mag erwähnt werden, daf̧ natürlicherweise diejenigen Städte zögerten, die eine gute Ölbeleuchtung der Straf̧en hat$\left.\operatorname{ten}^{3.21}\right)$.

$3.124 \mathrm{~K} \ddot{\mathrm{O}} \mathrm{ln}$

In Köln war die Beleuchtung in den Jahren 1824 bis 1830 an eine holländische Gesellschaft verpachtet, die neue Öldochte, vermutlich Argandbrenner mit Luftzuführung auch im Inneren des ringförmigen Dochtes, einführte, die für eine bessere Strafjenbeleuchtung sorgten $\left.{ }^{3.22}\right)$. Schon als man von der Gasbeleuchtung in England zuerst gehört hatte, war in Köln Interesse vorhanden gewesen. Die Stellungnahme der Kölner Zeitung vom Jahre 1819 ist bereits erwähnt worden. Aber es blieb nicht bei der Ablehnung. 1836 baute die Firma C. J. S t o of eine Gasfabrik, in der aus Ölrückständen und Harz Leuchtgas hergestellt wurde und als Portativgas in festen Behältern (Vgl. S. 88 und 114 ) in die Häuser geliefert wurde. 1837 wurde so das Schauspielhaus beleuchtet. Die Zahl der Kun-

\footnotetext{
a,at) $\mathrm{M}$. H. Schilling hat als Altersarbeit im J. f. G, 1887 und 1888 eine ausführliche Geschichte det Gasbeleuchtung in Bayern veröffentlicht, die nach den damals noch zugänglichen Aktenunterlagen die besonderen Schwierigkeiten des weitab von der Kohle liegenden Landes schildert.

a. 22) Wasser, Gas, Elektrizitat. Herausgegeben zur 1000-Jahr-Feier der Stadt Köln. Kön 1990
} 
den war erheblich. Daneben bot 1836 die I.C.G.A. eine Gasbeleuchtungsanlage auf Steinkohlengrundlage an; die Stadtverwaltung nahm das Angebot nach einigem Zögern, gedrängt durch die Regierung, auf 25 Jahre für 725 Flammen an. Am 10. 8. 184I brannten zum ersten Male die neuen Leuchten, aber erst 1845 wurde die vorgesehene Laternenzahl erreicht. Druck und Qualität des Gases, verglichen mit dem Ölgas verständlich, wurden als schlecht befunden. Es kam zu Reibercien zwischen der Stadt und der Gesellschaft. Als diese 1854 den Vor. schlag machte, die Konzession auf 20 Jahre gegen Herabsetzung des Preises zu verlängern, lehnte die Stadt ab. Vielmehr lief3 die Stadt bereits i858 die Anlagen wegen eines Ankaufes abschätzen. Aber auch damit kam man nicht zum Ziele, ja es kam in den nächsten is Jahren zu zahlreichen Prozessen, wobei die Gasbezieher die Leidtragenden waren ${ }^{3.2 m}$ ).

3.125 Breme n ${ }^{1.24}$ )

Auch in Bremen hat man besonders lange gezögert, obwohl dort bereits 1817 im Hause der "Gesellschaft Museum zur Förderung des geistigen Lebens" eine Hausanlage errichtet war, mit der Vortrags- und Gesellschaftssaal und der Hauseingang beleuchtet wurden. Congreve hatte die Stadt 1824 bereits angesprochen, kurz darauf bot sich eine zweite, englische Gesellschaft, I844 Barlow \& Co. an. Aber die Bürgerschaft hatte Bedenken gegen die Verträge und gegen die Technik, wobei Feuersgefahr, Explosionsgefahr und andere Unfälle vermutet wurden. Auf̧erdem entspräche aber die Ölbeleuchtung allen billigen Ansprüchen. Io Jahre später war ein Handelsherr in England vom Gesehenen so beeindruckt, daf̧ er ein neues Angebot der I.C.G.A. vermittelte, das aber erneut auf Bedenken stieł. Schliefylich aber wurden die Bürger ungeduldig. Man wollte wenigstens Portativgas haben. Aber selbst gegen dieses wandte sich ein Senator energisch. Dem Unternehmer Eblers wurde mit der Konzession zur Errichtung einer Portativgasanstalt die Herstellung des Gases aus Stcinkohle verboten. Er muß̧te Öl und Tran verwenden, für die wohl Bremen ein wichtiger Umschlagplatz gewesen ist. 1842 kam die Lieferung des Portativgases für Häuser und Büroräume in Gang, aber gegen eine selbst nur versuchsweise Beleuchtung der Straf̧en wandte sich die Finanzdeputation. Ehlers kam im ganzen gut ins Geschäft, aber er mufte viele Klagen über Ruf̧en seiner Fabrik hören, ja 1846 kam einmal wieder ein Gesuch, Ehlers die Konzession zu entziehen. Aber nunmehr kam von der Bürgerschaft die Anregung zu prüfen, ob es an der Zeit sei, eine Gasbeleuchtung der Strał̧en und Plätze einzuführen. Ein neunköpfiger Ausschuf des Senates und der Bürgerschaft bearbeitete die Fragen gründlich und kam zum Schluf, daf3 die Stadt in eigener Regie ein Gaswerk bauen sollte. Man rief als Ratgeber R. S. Blocbmann hinzu, der als Direktor der Berliner Gaswerke bezeichnet wurde, aber auch in Stettin das Gaswerk gerade erbaut hatte. Blochmann riet, sogleich mit der Beleuchtung des Bahnhofes, der gerade vollendet wurde, den Anfang zu machen. Die Bürgerschaft war nunmehr dafür, daß̧ auch die Bahnhof-

3.23) $8(186 y) 20 / 36$

9.24) 100 Jahre Gasversorgung Bremen, Stadtwerke, Bremen A.-G. 1954. 
und Georgsstraf̧e (heute Bürgermeister Smidstr.) angeschlossen werden sollte. Das kleine Gaswerk kam rechtzeitig mit der Eröffnung der Eisenbahn nach Wunstorf am 12. 12.47 in Betrieb. Der Eindruck der Beleuchtung war so, dał man nach Vergröf̧erung rief, aber das war mit der kleinen Anlage im Bahnhof nur beschränkt möglich. Ein grołzzügiges Projekt verzögerte sich aus Geldmangel - Bremen hatte gerade die Hafenanlagen von Bremerhaven schaffen müssen und mufte auch sonst in den Ausbau der Weser viel investieren.

Erst 1852 regte nunmehr der Senat an, dem Bau eines Werkes näherzutreten. Ein Ausschufł lief̧ sich außzer von Blochmann auch von dem belgischen Ingenieut Leprince ein Angebot ausarbeiten. Dieser hatte in Belgien, Düsseldorf und Braunschweig nach einem ihm patentierten Verfahren Steinkohlengas mit $\mathrm{Zu}^{-}$ sätzen von Ölgas, zu dem er den gewonnenen Teer restlos benutzte, von besonders guter Leuchtkraft hergestellt. Er unterbot Blochmann erheblich, vor allem, weil er mit dem hochwertigen Gas kleinere Gasbehälter, auf deren Ummauerung er verzichtete, vorgesehen hatte. Vor allem aber entschied die Tatsache, daf er den gewonnenen Koks restlos zur Unterfeuerung, auch der Ölretorten, verwerten konnte. Die Deputation hatte nämlich aus Stettin und anderen Städten erfahren, dał der Absatz von Koks sehr schwierig wäre. Das Gaswerk wurde gebaut, die Finanzierung war nicht einfach, die Straßenbeleuchtung zwang zur Erhebung einer Gassenreinigungs- und Erleuchtungssteuer. Der Preis für Einzelabnehmer von 4 Rth je $1000 \mathrm{cf}=$ etwa $43 \mathrm{Pfg} / \mathrm{m}^{3}$ wurde trotz der hohen Leuchtkraft als hoch empfunden. Im September 1854 wurde das Gaswerk in Betrieb genommen. Die Zahl der Privatanschlüsse übertraf, obwohl die Anschluf̧kosten vom Abnehmer zu tragen waren, alle Erwartungen. Nach zwei Jahren muf̧te das Werk erweitert werden. Wegen des hohen Preises und der Verluste, die trotz der Steuer die Straf̧enbeleuchtung verursachte, wurde ${ }_{1859} \mathrm{~W}$. Oecbelbäuser, der Direktor der Deutschen Continental-Gas-Gesellschaft als Sachverständiger herangezogen. Is Jahre lang war er betatender Ingenieur. Nach seinen Angaben wurden Öfen und Apparate umgebaut, statt Harz und Teer wurde neben westfälischer Kohle englische Newcastle- und Bogheadkohle entgast. Das Ergebnis, offenbar zunächst ohne Beanstandung der Leuchtkraft, die mit 60 bis $70 \%$ über dem normalen angegeben wird, war so erfreulich, dał am I. I. I86I ein Gaspreis von $34 \mathrm{Pf} / \mathrm{m}^{3}$ und ein Jahr später von $24 \mathrm{Pfg}$. ausreichte. Oechelhäuser, der sich mit $5 \%$ an der Herabsetzung der Selbstkosten für seine Mühen entlohnen lieł, sagte in seinen Lebenserinnerungen, dał er freiwillig auf die volle Höhe verzichtet hätte, weil der so aufkommende Ertrag weit über das Gedachte hinausging und nunmehr mit maximal 3000 Thalern festgesetzt noch um 500 Thaler über dem Gehalt eines Bürgermeisters lag. Die Geschichte bis zum ordnungsmäßjigen Betriebe des Gaswerkes in Bremen ist langwierig. 30 Jahre hat es vom ersten Angebot der englischen Gesellschaft bis zur Inbetriebnahme des Gaswerks gedauert, und weitere 6 Jahre, bis das Werk mit ausreichenden Preisen verdienen konnte. Man muł aber die Geschichte im einzelnen lesen, um zu erkennen, mit welcher Umsicht und Sorgfalt die Behörden und Ausschüsse vorgegangen sind. Kaum mehr zu erkennen ist aber der Einfluf\} der besonderen wirtschaftlichen Lage der Stadt, die in erster Linie mit allen verfügbaren Mitteln um den weiteren freien Zugang zum Meere mit den größer werdenden Schiffen gerade in diesen Jahren gerungen hat. 
Allmählich fanden sich nun auch einzelne mutige Menschen, die cinen Gaswerksbetrieb als offene Handelsgesellschaft gründeten. Beispiele bietet die berichtete Geschichte der Werke in Frankfurt/Main und Bremen. Wo das Kapital knapp war, griff man zum Portativgas, aber auch Berohrungen wurden ausgeführt. I85o zählte man 35 Gasanstalten. Dann beschleunigte sich die Gründertätigkeit. In den folgenden to Jahren werden 176 neue Werke errichtet ${ }^{3.25}$ ). Der Wunsch war aber viel größzer als die Zahl der Kapitalisten. So kam der Bankpräsident L. $N u l$ a $n d t$ auf den Gedanken, eine großze private Kapitalgesellschaft nach dem Muster der englischen Imperial Continental Gas Association zu gründen. Als vertrauenswerter Fachmann bot sich ihm der preufische Baurat a. D. H. V. v. $U n r u b$ an, der das Gaswerk in Magdeburg erbaut hatte.

\section{E B E N S B I L D}

Hans Viktor v. $U n r u b$ war am 28. März 1806 in Tilsit geboren. Er besuchte die Bauakademie in Berlin, wurde 1826 Straf̧enbauinspektor in Breslau, 1839 Regierungs- und Baurat in Gumbinnen. 1843 nach Potsdam versetzt, lief er sich 1844 beurlauben, um den Bau der Potsdam-Magdeburger Eisenbahn zu übernehmen. Von Magdeburg aus baute er auch die Bahn nach Wittenberge (1846-

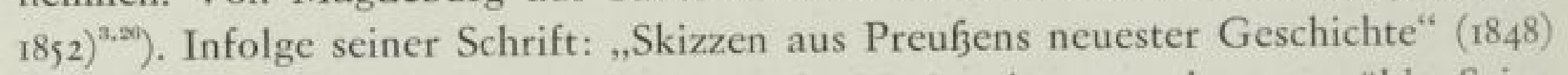
wurde er für Magdeburg in die preuf̧ische Nationalversammlung gewählt. Seine politische Laufbahn, die ihn später auch als liberalen Abgeordneten der zweiten Kammer in die Opposition führte, zog ihm die unversöhnliche Feindschaft des preufyischen Ministers von det Heydt zu, der ihn zwang, aus der Leitung der Bahngesellschaft auszuscheiden. ${ }^{\text {s.27) }}$ v. Unruh bereitete dann im Jahre 185I den Bau eines Gaswerkes in Magdeburg unter Heranziehung R. S. Bloc bmanns für die Planungen vor und gründete dazu eine Gesellschaft, die auch an anderen Orten Gaswerke bauen sollte. Obwohl es sich um ein rein privatwirtschaftliches Unternehmen handelte, fand der Minister auch dort Möglichkeiten, v. Unruh und damit der Gesellschaft das Dasein zu erschweren. Die Konzession aus Berlin kam und kam nicht. Diese Verfolgungen waren der Grund dafür, dafy die erstrebte Gasgesellschaft nicht nach Magdeburg sondern nach Dessau kam. v. Unruh war der unentbehrliche Fachmann, technisch und wirtschaftlich, denn damals gab es keine großze Auswahl. Er hatte auch schon alles vorbedacht. Der Herzog Leopold Friedrich hatte keine Voreingenommenheit gegen den Barrikadenkämpfer, und so nahm v. Unruh das Angebot, nach Dessau zu kommen, an. In der konstituierenden Generalversammlung am 7. 5. 1857 wurde Nulandt erster

\footnotetext{
8.25) Celle, Gas nach roo Jahren

5.26) Nach Meyers Konversationslexikon ;. Aut1. Bd. is Leipzig 1878

s.:T) 100 Jahte Deutsche Continental-Gas-Gesellschaft, Disseldorf 
Vorsitzender der neuen Aktiengesellschaft, v. Unruh deren zweiter. V. v. Unruh behielt die Leitung der Deutschen Continental-Gas-Gesellschaft nur etwas mehr als ein Jahr, in dem er die grundlegenden Verträge mit einer Reihe von Städten abgeschlossen hat. Im Grunde befriedigte ihn aber die "Gaskocherei“" nicht. Aufserdem hatte er Ursache, das Finanzgebaren des ersten Vorsitzenden mit Vorbehalt zu betrachten. So übernahm v. Unruh zu Ende des Jahres 1856 die Leitung der Pflugschen Waggonbauanstalt, die zur Aktiengesellschaft für Eisenbahnbedarf umgewandelt wurde, in Berlin. Er kehrte schlief̧lich in die Politik zurück, wurde einer der Mitbegründer der Fortschrittspartei in Preufen und Abgeordneter im deutschen Reichstag. Der Gasgesellschaft blieb er indessen als Vorsitzender des Aufsichtsrates bis zu seinem Tode im Jahre 1886 verbunden. Schon der Name der Deutschen Continental-Gas-Gesellschaft zu Dessau deutete darauf hin, daf3 die englische Gesellschaft Vorbild gewesen war; die Gesellschaft sollte in die Weite wirken. Ihr Gründungskapital tetrug 3 Mio Thaler, die nach dem Baufortschritt aufgerufen werden sollten. Geldgeber sollen vor allem auch die Berliner Fabrikanten gewesen sein, die durch Blochmann an das Gasfach herangeführt waren. Jedoch haben sich darüber Belege nicht finden lassen. Es ist aber verständlich, dał man die grof̧en Arbeiten, die sich als kommend abzeichneten, im Inlande verrichten wollte, zumal da nach dem Verklingen des Uimsturzes nach 1848 das Wirtschaftsleben neue Antriebe erhalten hatte. v. Unruh gelang es schnell, in bestehende Verträge über die Einführung von Gasbeleuchtung einzutreten und zwar mit den preufischen Städten Frankfurt/ Oder, Mülheim/Ruhr, Mönchenglabdach, Rheydt und Potsdam und neue Abschlüsse mit Hagen, Luckenwalde, Nordhausen, Erfurt und Dessau zu erreichen. Der Andrang der Städte war so groł, dał bis zum Mai 1857 bereits über hundert Anträge von Städten auf Abschluß̧ von Gasverträgen abgelehnt waren. Im Ausiande gewann man die Verträge mit Lemberg, Krakau und später noch Warschau. In Gaiizien kam man in Wettbewerb mit der Österreichischen Aktiengesellschaft für Gasbeleuchtung in Wien, die 1855 gegründet war. Aber statt eines verderblichen Streites führte dieser Wettbewerb zu einer Beteiligung, die 1858 auf $662 / 3 \%$ ethöht wurde. In Warschau konnte man in die Abkommen, die G. M. S. Blochmann (der Sohn) 1853 abgeschlossen hatte, eintreten, für die bereits in Köthen eine Kapitalgesellschaft gegründet war. Die ausländischen Regierungen begünstigten die Bemühungen der neuen Gesellschaft. Das ist kennzeichnend für die zweite Hälfte des 19. Jahrhunderts, in dem zwar der nationale Gedanke immer mehr in den Völkern gepflegt wurde, aber nicht davon abhielt, im Sinne des liberalen Verkehrs der Nationalstaaten untereinander auch miteinander zu arbeiten. Mit Stolz konnte v. Unruh im ersten Jahresbericht darauf hinweisen, dał die Gesellschaft in einem Jahre sieben Werke erbaut hätte, davon das westlichste in Mönchengladbach, das östlichste in Lemberg.

Bei den Verhandlungen mit der Stadt Mülheim/Ruhr hatte v. Unruh mit dem Bürgermeister der Stadt Oecbelbäuser schwer zu ringen. Das Technische sofort überschauend, das Wirtschaftliche meisternd, verstand der Bürgermeister, einen für die Stadt äuf̧erst günstigen Vertrag zu erhandeln, und als v. Unruh sich klar wurde, daf ihm die Leitung der Gesellschaft nicht völlig lag, machte et Oechelhäuser das Angebot, in das Direktorium einzutreten. Oechelhäuser nahm an und übernahm den Dienst am I4. II. I856. 


\section{E B E N S B I L D ${ }^{3.25}$ )}

Wilhelm Oecbelbäuser, der Ältere, ist am 26. 8. 1820 in der Papiermühle seines Vaters in Siegen in der "Leimbach" geboren. Der Vater war ein angesehener Bürger seiner Stadt, I834 westfälischer Landtagsabgeordneter, Stadtrat, Synodalvertreter. Als Fabrikant von Papier konnte er einen Zug zu erfinderischen Verbesserungen der Maschinen nicht unterdrücken. Die "Werkstatt" wurde eine kleine Fabrik, die auch ins Ausland lieferte. Aber mit 14 Kindern aus zwei Ehen waren die Lebensverhàltnisse beschränkt. Sorgen waren immer vorhanden. „Am Ende des 19. Jahrhunderts lebte kein Fabrikarbeiter in einfacheren und dürftigeren Verhältnissen als damals die Familie des Vaters."

W. Oechelhäuser kam bereits mit 4 Jahren in die Volksschule, mit 8 Jahren in die höchste örtliche Lehranstalt, die Lateinschule, die er mit I4 Jahren verlief̧, um bei seinem Vater als Lehrling in den Werkstätten aufgenommen zu werden. Oechelhäuser gibt kulturpolitisch höchst aufschlufyreiche Einzelheiten über den Unterricht in beiden Schulen in seinen Lebenserinnerungen, die hier leider nicht gebracht werden können. Gelehrt wurde jedenfalls nicht gerade viel, und es gab eine sehr einseitige Auswahl des Stoffes.

Gelernt aber hat Wilhelm desto mehr. Da ihn Mathematik anzog, bezwang er sie im Selbststudium. Auch die Freizeit in der Lehre nutzte er gut aus, angeregt sich um die kaufmännischen Dinge kümmernd. Nach dreijähriger Lehre gab es Wanderjahre, auch ins Ausland. Die technischen Fähigkeiten förderte er so weit, daf̧ er als Konstrukteur in der mechanischen Werkstätte beschäftigt wurde. Die Prüfung zum „Einjährigen“ mit Erfolg bestanden, gründete sich ganz auf Selbststudium. Während der Dienstzeit in Königsberg fand er noch Gelegenheit, Vorlesungen an der Universität (Psychologie, Physik und Chemie) zu hören. In Königsberg wurde auch sonst seine Aufnahmefähigkeit für große volkswirtschaftliche und politische Zusammenhänge und Aufgaben offenbar.

Das Jahr I848 mit dem durch die Revolution gestörten Wirtschaftsleben brachte die väterliche Fabrik zum Zusammenbruch. Erst zwei Jahre später wurde sie von den Brüdern Adolf und Heinrich aufs neue begonnen. Sie entwickelte sich zum Grofkraftmaschinenbau, lieferte um die Jahrhundertwende auch Grofgasmaschinen, Bauart Körting, und ist eines der Stammwerke der Siegener Maschinenfabrik A. G. geworden.

Wilhelm aber mußzte wandern. Er wandte sich nach Frankfurt, wo das Parlament in der Paulskirche tagte. Er wurde Zeitungsberichterstatter, obwohl et die Lücken seiner unmethodischen Ausbildung selbst bitter empfand. Von grofer Bedeutung auch für später wurde eine Empfehlung beim Reichshandelsminister vom Jahre 1848 , dem Bremer Grofkaufmann A. Duckwitz. Dieser führte ihn an die große Periode seiner wirtschaftlichen und handelspolitischen Schriftstellerei heran, wodurch er schlieł̧lich zum Geschäftsführer des Vereins der zollvereinsländischen Eisenindustrie in Berlin wurde. Wieder kamen aus seiner Feder vielbeachtete Berichte aller Art. 1852 wurde ihm, der nun bekannt war, der Posten des Bürgermeisters in Mülheim/Ruhr angeboten. Er hat für diese Stadt viel Gutes geschaffen: Im Schulwesen, Baupolizei, Feuerlöschwesen und

\footnotetext{
3.25) Zusammengestellt nach dem Lebensbild, das sein Enkel, Wolfgang v. Oechelhäeuser niedergeschrieben hat. Dieses Werk ist leider nur noch in wenigen Handschriften vorhanden.
} 
Verkehr. Er erreichte es, dał die Bahn von Dortmund nach Duisburg trotz der schwierigen Geländeverhältnisse Mülheim nicht umging (gegen den Willen des preuffischen Handelsministers v. d. Heydt). Er gtündete auch die Mülheimer Dampfschleppschiffahrtsgesellschaft, die die Kohlenhändler von der Ruhrorter Schiffahrt unabhängig machte.

In den Verhandlungen mit der Deutschen Continental-Gas-Gesellschaft erreichte er einen besonders günstigen Vertrag. Als man ihm den Eintritt in das Direktorium der Gesellschaft anbot, nahm er an. Es siegte, so sagt er selbst, die alte Anhänglichkeit an das kaufmännische und technische Fach. Seine Wanderjahre sind 1856 beendet. Am 15. 3 . 1858 wurde er zum Generaldirektor mit alleiniger Zeichnungsvollmacht berufen. 33 Jahre war er Leiter der Gesellschaft. In energischer, zielbewuf̧ter, das ganze technische und kaufmännische Gebiet umfassender Arbeit gelang es ihm, der Gesellschaft einen als mustergültig angesehenen und immer mehr vervollkommneten inneren Aufbau zu geben, und sie auch in den technischen Fortschritten auf der Höhe der Zeit zu erhalten. Er diente damit nicht nur den Aktionären sondern auch den Gasabnehmern. Einen ausgezeichneten zuverläfigen Beamtenstab wuß̧te er heranzubilden. Seine Berufsgenossen im Deutschen Verein von Gas- und Wasserfachmännern bezeichneteı ihn im Nachruf als den letzten der Männer, an deren Namen die Entwicklungsgeschichte und der Aufschwung der deutschen Gasindustrie in technischer und wirtschaftlicher Beziehung anknüpft. Am I. Januar 1890 trat Oechelhäuser als Generaldirektor zurück; bis zu seinem Tode am 25. September 1902 war er Vorsitzender des Aufsichtsrates.

Dieser Mann, der unendlich viel auf Reisen war, hatte aber neben der Berufstätigkeit noch Spannkraft genug, um im Parlament mitzuwirken und dabei soziale Fragen und Kolonialpolitik mit dem ganzen Schwung seines Denkens zu bearbeiten. Bebel nannte ihn einmal den "Vater der Arbeiterausschüsse“. Er beriet auch noch technisch und wirtschaftlich viele andere Unternehmungen. Durch Duckwit z nach Bremen gerufen, leitete er die Reorganisation des dortigen Gaswerkes.

Besonders aber ist bewundernswert, dał trotz aller dieser Dinge der Sinn füi Kunst und Literatur nicht verblich. Oechelhäuser war Anreger, Gründer und lange Jahre Vorsitzer der deutschen Shakespeare-Gesellschaft, selbst auf diesem Gebiete forschend und sogar Dramen für die deutschen Bühnen bearbeitend. Für diese Tätigkeit verlieh ihm die Universität Würzburg den Dr. phil. h. c., eine Ehrung, die ihm immer besonders wertvoll gewesen ist.

Die Entwicklung der Gasgesellschaft wurde durch Oechelhäuser in gesunde Bahnen gelenkt. Als dieser nach Dessau kam, stand Nulandt ,inmitten einer schmeichlerischen, schmarotzenden Umgebung wie eine Art Halbgott da". Durch den übereilten Ausbau der Werke mit Überschreitungen der Anschläge, die auch durch Erweiterungen nötig wurden, hatte die Gesellschaft nach dem Einzug der 2 Mio Thaler Kapital noch ein ungedecktes Konto von 600 oco Thalern. Hinzu kam eine vom Hamburg 1857 , ausgehende Handels- und Finanzkrise, die auch dic von $N u l a n d i$ geleiteten Unternehmen einschließ̧lich der Dessauer Landesbank in den Grundfesten erschütterte. Auch der Vertrag mit der Österreichischen A. G. für Gasbeleuchtung brachte Sorgen, die Oechelhäuser nur durch Abgabe eines ausgezeichneten Oberingenieurs, $F$ a e $b n d r i c b$, meistern konnte. Nulandts 
Stellung war 1858 so erschüttert, daf̧ er im Frühjjahr 1858 sich von der Gesellschaft zurückziehen muf̧te. Oechelhäuser übernahm nach eigenem Vorschlage die gcsamte Verantwortung als Generaldirektor am 15.3. 1858.

Die Hauptaufgabe war, die Verträge mit den Städten zu verbessern, die von der falschen Voraussetzung ausgingen, dał nach ihrem Ausbau der Absatz gleich bleiben würde und einen kostenlosen Anfall der Werke an die Städte nach 45 bis so Jahren vorsahen. In der sicheren Ahnung, dał das eben auftretende Petroleum einmal ein schwerer Wettbewerber werden würde und die Gaspreise drücken würde, arbeitete Oechelhäuser neue Vertragsformen aus, bei denen die kostenlose Überlassung fortfiel. Schmackhaft machte er den Städten diese Verträge durch das Angebot bedeutend ermäfigter Gaspreise. Er kam bei seinen Verhandlungen auch durch bis auf die Stadt Mülheim/Ruhr, wo der Bürgermeister, er selbst, in seinem Vertrage diese Möglichkeit bereits vorweggenommen hatte. Die geldliche Lage meisterte Oechelhäuser durch die Hilfe alter Freunde auf Grund seines persönlichen Kredites bei der Berliner Handelsgesellschaft, der Gothaer und Leipziger Bank und bei dem Schaffhausenschen Bankverein in Köln. I859 konnte er mit $6 \%$ die erste Dividende auszahlen. I861 wurde der Parikurs der Aktien überschritten. Durch energisches Zugreifen und eine klare Darstellung der Lage war die Gesellschaft in Ordnung gebracht.

3.132 Die A 11 gemeine Gas-A. G. Magdeburg

Inzwischen hatte auch die Magdeburger Gesellschaft als Allgemeine Gas-Aktiengesellschaft ihre Konzession erhalten. Sie mußte sich aber, da sie als zweite Gesellschaft im gleichen Raume kam, mit kleineren Anlagen begnügen.

3.I4 Holzgasanstalten (Pettenkofer-Riedinger)

Eine heute kaum mehr verständliche Belebung in der Errichtung kleiner Gaswerke brachten die Arbeiten des als Hygieniker berühmten Universitätsprofessors Dr. Max Pettenkofer in der Verwendung des Holzes zur Beleuchtung von 1848-1849. Ganz im Anfange hatte ja schon Lebon sein Gas aus Holz hergestellt. Auch Lampadius beschäftigte sich damit. Er fand, dafz wenn man eine schöne Holzkohle haben wolle, bei niedriger Temperatur die Leuchtkraft des Gases schwach sei. Es bestand in der Hauptsache aus Methan, Kohlenmonoxyd und viel Kohlendioxyd; es fehlten also die Träger der Leuchtstoffe, die schweren Kohlenwasserstoffe. Ging Lampadius zu höheren Entgasungstemperaturen über, so ergab das Verfahren unbrauchbare Holzkohle. Pettenkofer überwand die Schwierigkeiten (Vgl. S. 130). Die erste Holzgasanlage war die zur Beleuchtung des Münchener Hauptbahnhofes 1850. Die Ausführung und weitere Auswertung wurde L. A. Rieding er überlassen.

\section{E B E N S B I L D}

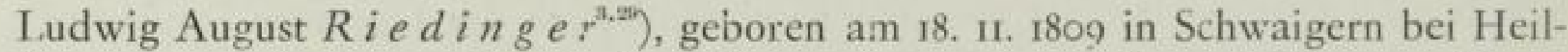
bronn, war als Sohn unbemittelter Eltern schon mit I4 Jahren Vollwaise. Er er-

3.av) Dr. F. Hassler, Geschichte der L. A. Riedinger, Maschinen- und Bronzewarenfabrik A. G. Augsburg, 1928 
lernte das Schreinerhandwerk bei einem tüchtigen Meister, nachdem er dem ersten Meister, der sich wenig um den Lehrling gekümmert hatte, nach 3 Wochen entlaufen war. Als Modellschreiner in einer Baumwollspinnerei beschäftigte er sich mit der Verbesserung der Maschinen und wurde mit 21 Jahren Werkmeister. 1842 war er nach fleifigem Selbststudium in Augsburg bereits technischer Direktor einer grof̧en Spinnerei und Weberei. 1850 wurde er als Mensch, der seine Belegschaft glänzend führte, dem König bei einem Besuch der Fabrik vorgestellt. Aber nun regte sich der Neid der Kollegen. Die Tätigkeit wurde Riedinger verleidet. Schweren Herzens trennte er sich von der Firma. Da trat Pettenkofer an ihn heran. Am 24. I. 185 I wurde Riedinger mit $25 \%$ an der Holzgasgesellschaft beteiligt. Er setzte sich durch und überwand die ersten technischeri Schwierigkeiten.

Für Riedingers geschäftlichen Anstand ist eine Äuß̧erung kennzeichnend. Er hatte beobachtet, dał andiere Gaswerksgründer freiweg hohe Dividenden versprachen, die dann aber jahrelang nicht eintraten. Der Unternehmer hatte beim Bau gut verdient. Dazu sagte Riedinger: „Ich hielt das für Unrecht und kam auf den Gedanken, wenn ich Gaswerke, vielleicht 20, baue und keinen Bankier oder Associé nehme, kein Geld in Form von Aktien suche, sondern auf eigene Rechnung baue, wenn die Fabrik im Betrieb ist, dann erst Aktien ausgebe in der Höhe, wie das Erträgnis zu $5 \%$ aus dem Betrieb sich herausstellt, ich die $5 \%$ garantiere, so ist das ein ehrliches Geschäft." Erstaunlich ist, daf3 er wegen der guten Meinung, die man von ihm hatte, das notwendige Geld tatsächlich auf persönlichen Kredit hin „ohne jedes Pfand“ bekam.

Nach Ablauf von 4 Jahren, als er 8 Städte mit Gas beleuchtet hatte (Bayreuth, Darmstadt 1854, Würzburg, Gief̧en, Bamberg 1855, Zürich, St. Gallen, Ulm 1856) fand er, daf die fremden Zulieferungen an Maschinen und Apparaten seinen Ansprüchen an Güte nicht entsprachen, und er entschloß̧ sich, die Bestandteile zur Gasfabrikation und zur Beleuchtung selbst zu fertigen. So entstand die Miaschinen- und Bronzewarenfabrik L, A. Riedinger. Die Konzession wurde nach einigen schwierigen Verhandlungen am 9. 4. 1857 erteilt, zunächst für eine mechanische Werkstätte, I859 auch für die fabrikmäßige Herstellung von Gasapparaten, 1865 für Gasmesser.

Die noch immer lebhafte Mitarbeit Riedingers bei der Gründung von Textilfabriken kann hier nicht im einzelnen erwähnt werden, wohl aber, daf̧ dieser einfache Mann gtoßes Kunstverständnis besaf und viel zur Verschönerung von Augsburg beigetragen hat (Umbau des Hotels Drei Mohren). Im April r879 ereilte den fast 70-jährigen, noch unermüdlich Tätigen ein Schlaganfall, und wenige Tage später bewahrte ihn am 20. 4. I879 der Tod vor dem Schicksale langen Siechtums.

Der Erfolg Riedingers lag sicherlich in der sorgfältigen Ausführung, die der geborene Schwabe allen seinen Anlagen zuteil werden liefz, dann aber auch an seinem Finanzierungssystem, das den kleinen Gemeinden jecies Wagnis abnahm, andererseits aber das fertige und mit feststellbarer Rente arbeitende Werk den örtlichen Kapitalgebern oder Gemeinden überantwortete. Langfristige Bindungen wurden erst nötig, wenn Klarheit gewonnen war, und dann jedenfalls nicht unbedingt mit Riedinger. 
Wirtschaftlich waren gerade die kleinen Werke gesund. Holz war ja in Süddeutschland noch als Brennstoff bevorzugt. Holzkohle hatte dort einen guten Markt. Sie wurde als Schmiedekohle fast ausschlief̧lich benutzt. Die kleinen Hüttenwerke Süddeutschlands waren stolz auf das reine Holzkohleneisen. (In großen Werken gelang es F. Steinbeis 1844 , bei Stumm, Neunkirchen ein brauchbares Roheisen mit Koks zu erschmelzen. Römheld hatte 1847 in Mülheim/Ruhr den ersten Erfolg mit Ruhrkoks.) Die ungeregelten Eisenbahntarife der privaten Eisenbahngesellschaften, die noch nicht die Möglichkeiten von Preisnachlässen bei schnell umschlagbaren, regelmäßjig bezogenen Massengütern crprobt hatten, lief̧en die Kohle im allgemeinen teuer sein. Indessen war Riedinger auch kein Dogmatiker, und sein viertes Gaswerk Gießjen wurde gleich auf Kohlengrundlage gebaut. Die Lage wurde allerdings auch verändert, als der Umsatz im einzelnen Werke größ̧er wurde und er aus dem Rahmen: Angebotenes Holz - verlangte Holzkohle örtlich herauswuchs; aber auch, wenn dann, um mit dem Transport beauftragt zu werden, die Eisenbahnen im Tarif entgegenkamen. So wurde allmählich ein Werk nach dem andern auf Kohlen umgestellt.

Bis 1860 hat die Firma Riedinger 25 Werke erbaut. 1871 wurden in einer Aufstellung der Firma 6o Werke ausgewiesen, die fast alle mit Kohlengas arbeiteten.

Eine Zusammenstellung der im Jahre I859 betriebenen Gaswerke mit ihren Eigentümern und Erbauern ist im Anhange 8 beigefügt.

\section{I5 Die Entwicklung in anderen Ländern}

Da die Entwicklung in anderen Ländern sehr ähnlich wie die in Deutschland verlaufen ist, so genügt eine allgemeine Übersicht.

England ging durch eine Zeit, in der sich die Liberalen (Whigs) mit kurzen Unterbrechungen gegen die Konservativen in der Führung des Landes durchsetzen muften. So wurde der freie Wettbewerb selbst auf dem Gebiete der Gasversorgung mit allen Mitteln erzwungen. Gas war teuer und die Dividenden der Gesellschaften gering, bis der Wettbewerb untragbar wurde. Es war nichts ungewöhnliches, dał drei, vier oder gar fünf grołe Gesellschaften ihre Hauptleitungen in denselben Straß̧en liegen hatten, oft genug auf beiden Seiten..... Die Straf̧en wurden dauernd aufgerissen, denn die Abnehmer wechselten ihre Versorgungsgesellschaft ${ }^{3.30}$ ).

Die Täuschung, dał eine Vielzahl von Gasgesellschaften die Preise drücken würde, wurde 1849 durch T. G. B arlow in einem Flugblatt sorgfältig aufgeklärt $\left.^{3.31}\right)$. I8 53 wurde in Südlondon ein Abkommen der Gasgesellschaften über die Bezirke erzielt; 1860 folgte der Norden der Stadt.

Ein ausführlicher Bericht über die vorhandenen Wirkungen des Wettbewerbes auch auf die Geschäftsmoral ist von N. H. Schilling an Hand der schiedsgerichtlichen Verhandlungen zwischen der Great Central Gas Consumers Com-

3.so) G. Livesey: The inception and development of Gas Lighting J. of Gaslighting 1894,5646
3.31) A Letter.... on the cost and supply of Gas in the Metropolis 1849, Chandler \& Iacey, S. 74 (s. 1.1) 
pany in London und A. A. Croll im Auszuge und mit kritischen Zusätzen veröffentlicht worden $\left.{ }^{\text {a.sz }}\right)$. Croll war einerseits ein tüchtiger Ingenieur, der dem Fache viele Anregungen vermittelt hat, andererseits nahm er mit Erfolg Stellung gegen überhöhte Preise. Die Gaspreise betrugen vor $\mathrm{I}_{4} 48$ is $\mathrm{Sh} / \mathrm{ro00} \mathrm{cft}$. $=53,5$ $\mathrm{Pfg} . \mathrm{m}^{3}$. Im Wettbewerb sanken sie auf $2 \mathrm{I}, 4 \mathrm{Pfg}$. Nach einem zweiten Aufsatze: ,Die Gaserleuchtung in London ${ }^{\text {(a.3.an) }}$ ) wurden im Jahre 1858 2 Sh. 6 d füt $1000 \mathrm{cft}={ }_{16} \mathrm{Pfg} . \mathrm{m}^{3}$ gefordert. Damals wurden von $\mathrm{I}_{3}$ Gasgesellschaften nach $L o w e$ in einem Jahre in London 84000 t Kohle entgast und 220 Mio $\mathrm{m}^{3}$ Gas abgegeben. Croll hatte angeboten, das Gas ab Werk zum Preise von $7,15 \mathrm{Pfg} . / \mathrm{m}^{3}$ zu liefern. Die neue Great Central, die nur Verteilungsgesellschaft sein sollte, müsse dann vom Abnehmer $14.3 \mathrm{Pfg} . \mathrm{m}^{3}$ fordern. Dieses Verteilungsgeschäft wurde aber so nachlässig geführt und durch weitere Verträge wurden dem Gaserzeugungswerk die Verluste angelastet, dał ein groß̧er Streit entstand, den Schilling im einzelnen erzählt. Dieser Streit hat dann zur staatlichen Regelung 1860 geführt. Durch einen Erlał (Metropolis Gas Act 1860) billigte die Regierung nunmehr die Absprachen der Werke untereinander. Der wilde Wettbewerb hörte im ganzen Königreiche auf, obwohl er in einzelnen Fällen sehr heilsam gegen die rücksichtslose Ausnützung eines Monopoles gewesen war.

Die Gasgesellschaften muften indessen zum ersten Male eine allgemeine Regierungsaufsicht auf sich nehmen, die allerdings gemessen an den heute herrschenden Verhältnissen sehr milde festgesetzt war ${ }^{3.24}$ ). Die höchste Dividende wurde auf $10 \%$ festgesetzt, ferner der Gaspreis, die Reinheit und die Leuchtkraft des Gases. Auf̧erdem wurde eine Lieferpflicht an alle Bewerber, die in $45 \mathrm{~m}$ Entfernung vom Rohrnetz wohnten, auferlegt.

In England war um die Mitte des Jahrhunderts jede größzere Stadt mit Gas versorgt.

Frankreich ging langsamer vor. W ins ors Gründung in Paris 1816 war bereits 1819 zahlungsunfähig. Von Bestand waren die folgenden Gründungen: 1820 Comp. Française, 182I Comp. Marguerite I834 Comp. de Belleville, Comp. de Leconièrc und Comp. de l'Ouest, 1836 Comp. Parisienne, 1839 wurden 6 Versorgungsbezirke nach lebhaftem Wettbewerb eingeteilt. Zeitweilig bestanden ro verschiedene Gasgesellschaften, die aber ${ }_{18} 83$ in der Compagnie Parisienne de Gaz aufgingen ${ }^{3.55}$ ). Aus der Provinz werden die Städte Lyon, Marseille, Bordeaux, Nantes, Caën, Boulogne, Amiens erwähnt.

Ein wesentlicher Unterschicd mit den Arbeitsbedingungen deutscher Unternehmer bestand darin, daf die Vertragsdauer im allgemeinen unbegrenzt war. Deshalb konnten die Abschreibungen nach der voraussichtlichen Lebensdauer der Anlagen bemessen werden. Sie waren im allgemeinen niedriger als in Deutschland. Ferner wurde das Gas für die öffentliche Beleuchtung zu normalen Preisen abgegeben, während in Deutschland das Gas zu einem geringeren Preise, manchmal unter den Gestehungskosten geliefert werden mufte. Das lief auf eine indirekte Besteuerung der privaten Gasabnehmer hinaus.

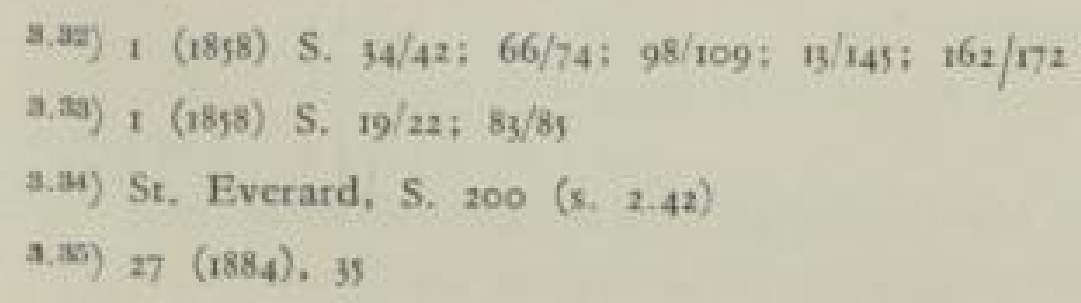


In Belgien wurde die private Gesellschaft von Meeus - van der Ma elen 1844 durch die Imperial Continental Gas Association übernommen; 1846 Gent.

Schweden erhielt in Gotenburg $1845 / 46$ das erste öfentliche Gaswerk, das eine Reihe von kleinen Privatanstalten ablöste. I852 folgte Stockholm ${ }^{4.50}$ ), I854 Malmö ${ }^{3.37}$ ), 1860 Helsingborg ${ }^{3.35}$ ).

Dänemark wurde von der Danish Gascompany, einer englischen Kapitalgesellschaft, gegründet 14. 6. 1853 in London, erschlossen. Diese übernahm die ein Jahr vorher in Odense gegründete Gesellschaft, baute das Gaswerk in Flensburg 1853 und bis $1858 / 59$ sieben weitere Werke; Kopenhagen-Friedrichsberg folgte 1857 . Kopenhagen-Strandvey $1893^{\text {2.37 }}$ ).

In den Niederlanden wurde die erste Konzession für eine Gasfabrik in Rotterdam am 30. Juli 1825 erteilt $^{3.35}$ ).

In Rußland wurde die erste Konzession für St. Petersburg in Jahre 1859 gegeben und zwar an eine englische Gesellschaft. Der Bau ging sehr langsam vonstatten. In Nordamerika fałte die neue Technik im Jahre 1816 Fuf. Eì Künstler, R. Peale, hatte in Baltimore ein Museum erleuchtet. Er erhielt die Erlaubnis Gas herzustellen, Rohre in die Straß̧en zu legen und schlof̧ cinen Beleuchtungsvertrag mit der Stadt ab.

Die New York Gas Light Co. wurde 1823 gegründet, eine zweite Gesellschaft, die Manhatten Gas Light Co. I830. Im Stadtteil Harlem arbeitete ab 1855 die Harlem Gas Light Co. und seit 1858 war auch die Metropolitain Gas Light Co. in der Gasversorgung tätig. Diese Gesellschaften verteilten Kohlengas aus der Entgasung. Später wurde die Herstellung von karburiertem Wassergas vorgezogen.

Die in Nordamerika besonders gepflegten Ansichten, daf der völlig freie Wettbewerb die Grundlage eines gesunden wirtschaftlichen Lebens sei, hat den Werken sicherlich manche Nachteile gebracht. Auch in New York waren viele Strałjen von mehreren Gesellschaften berohrt. Als auffallende Tatsache wurde in Deutschland oft berichtet, daf̧ die Stadtverwaltung ihre Beleuchtungsverträge jeweils nur für ein Jahr mit dem billigsten Bieter abzuschlief̧en pflegte ${ }^{3.40}$ ). Aber allmählich scheinen sich auch dort die alten Gasgesellschaften verständigt zu haben. Aus dem Jahre $187 \mathrm{I}$ wird von gleichen Preisen berichtet, die mit $4 \mathrm{I}$ Pfg. $/ \mathrm{mi}^{5}$ sicher nicht schlecht waren und nach der Kaufkraft des Dollars den europäischen Gaspreisen in etwa entsprechend gewesen sind.

Im Jahre 1853 sollen bereits in den Vereinigten Staaten 300 Gasgesellschaften bestanden haben, die s Mio Kunden versorgten. In einer Übersicht vom Jahre $1859^{3.42}$ ) werden in 17 Staaten und 89 Städten Gaswerke genannt, die 80 Mio $\mathrm{m}^{3} /$ Jahr erzeugt haben.

Das erste Erdgas wurde 1821 in Fredonia (N. Y.) in nur 80 Meter Tiefe gefunden. Erst 1858 wurde dort die erste Erdgasgesellschaft gegründet.

Australien hatte 1837 sein erstes Gaswerk.

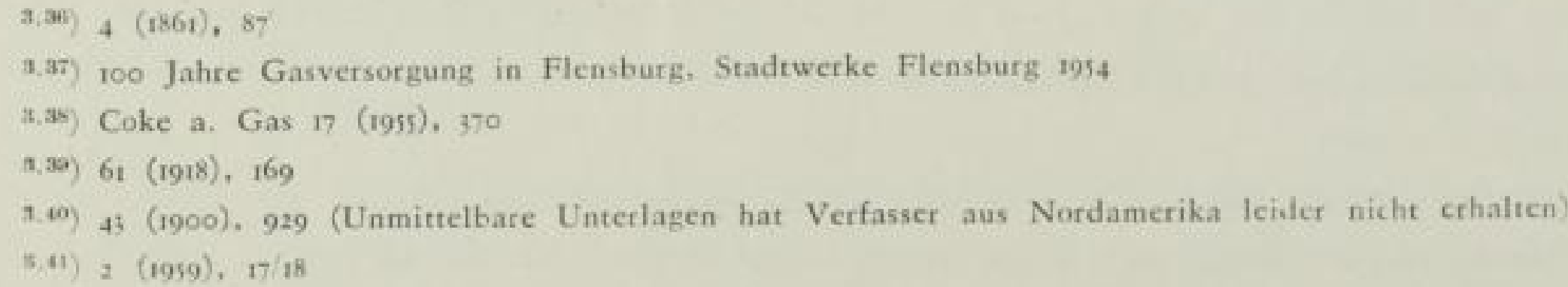


In Südamerika wurde das erste Werk im Norden ganz in der Einsamkeit einer Wüste errichtet. Dort herrschte, nachdem der Wert des Salpeters erkannt war, wirtschaftlich reges Leben. 1853 folgte Valparaiso, 1856 Buenos Aires und 1860 Rio de Janciro. Alle Einrichtungen kamen aus England, dazu auch noch die notwendigen Facharbeiter ${ }^{\text {tat }}$ ).

\subsection{DIE TECHNISCHE ENTWICKLUNG}

3.21 Die wissenscbaftlicben Voraussetzungen

Es wäre eine wissenschaftlich anregende Aufgabe, die Entwicklung der chemischen Erkenntnisse und üblichen Analysenverfahren an Hand der alten Bücher zu verfolgen und das, was von den Grofen des Faches: Dalton, Davy, Faraday, Liebig, Bunsen, Runge, Perkin und Hofmann die Gastechnik befruchtend berichtet wird, durch eine Darstellung der Kleinarbeit in den Laboratorien der Gaswerke zu ergänzen. Das müßte aber ein vielseitiger Chemiker, der auch wichtige Angaben durch Versuche nachzuprüfen im Stande ist, in die Hand nehmen. Für den Zweck dieser Arbeit ginge das zu weit. Wir müssen uns auf Einzelheiten beschränken.

3.2II Die Analyse des Gases

Im grofjen scheint es, daf̧ die chemisch wissenschaftlichen Anschauungen noch bei dem stehen geblieben sind, was $P r e c b t l$ bereits 1817 verkündet hat. $C l e g g$ jun. nennt $\left.184 \mathrm{I}^{3,43}\right)$ für die Bestandteile des Gases neben Wasserstoff: Kohlenmon- und -dioxyd, Methan und für alle Kohlenwasserstoffe nur das ölbildende Gas Elayi (Aethylen). Es mag sich dabei aber nur um eine Vereinfachung der Ingenieure handeln und durchaus ein tieferes Wissen vorhanden gewesen sein. Karmarscb-Heeren führten zwei Jahre später die gleichen Einzelgase auf ${ }^{\text {.4 }}$ ), obwohl sie einige Abschnitte danach aut Untersuchungen Faradays an Kondensaten verdichteten Ölgases zu sprechen kommen, bei denen dieser drei verschiedene Kohlenwasserstoffe, unter diesen zum ersten Male Benzol, festgestellr hatte. Uberraschend ist die Behauptung von Karmarsch, daf die Gase Kohlenexyd, Kohlendioxyd, Wasserstoff. Stickstoff und Schwefelwasserstoff nur in sehr untergeordneter Menge im Gase vorhanden seien. Das ist umso erstaunlicher, als schon Precbtl und ihm folgend Tabor als ersten und wichtigsten Teil den Wasserstoff erwähnt haben. Auf diese Weise ist es wohl auch zu verstehen, daf selbst 1860 Scbilling ${ }^{n .25}$ ) nur drei schwere Kohlenwasserstoffe unterschied. 1. Elayl (Aethylen) 2. Propylen und 3. Ditretyl (Butylen). Es sind das die Einzelgase, mit denen sich $B u n$ sen in den 1857 herausgegebenen gasometrischen

3.42) Schmidt-Hebbel: Neue Deliwa-Ztg, (1957), 275

8. 4s) Clegg jun., S, 29 (s. 2.20)

3.44) Karmarsch-Heeren. Technisches Worterbuch 1843 S. 818

a.45) N. H. Schilling: Handbuch für Steinkohlengasbeleuchtung - Verlag R, Oldenbourg München 1860 S, 30 
Methoden $^{\text {s.te }}$ ) beschäftigte. (Bunsen bespricht auch noch die Bestimmung von „Aethyl“, womit er nach der Volumenformel zu urteilen aber n-Butan bezeichnet.) Bunsens Arbeiten, die zur Ausbildung der Untersuchungsmethoden mit dem Eudiometer geführt haben, fanden an Eisenhochöfen und Kupferschieferöfen bereits 1838 und 1840 statt; Berichte finden sich in dieser Zeit in Poggendorffs Annalen. Sc bill ing läßt es klar werden, dał 1860 groß̧e Fortschritte in der Analytik gemacht worden waren, indem er beim Teer ro Kohlenwasserstoffe und II mit ihnen gebildete Säuren und Basen benennt. Indessen lag die analytische Bestimmung noch im Argen. Er sagte: „Die schweren Kohlenwasserstoffgase nebst den Kohlenwasserstoffdämpfen, die wir unter der Bezeichnung „höhere Kohlenwasserstoffe" zusammenfassen wollen, sind die eigentlichen Träger der Leuchtkraft im Gase und ihre qualitative Bedeutung steht zu ihrem Kohlenstoffgehalt in geradem Verhältnis. Eine quantitative Gasanalyse würde offenbar das radikalste Verfahren sein, um den Wert eines Leuchtgases zu ermitteln. Die Ausführung einer derartigen Analyse gehört jedoch bis jetzt noch in das Reich der frommen Wünsche.... Aushilfsweise ist man darauf bedacht gewesen, den quantitativen Wert der lichtgebenden Bestandteile im Gase wenigstens summarisch dadurch zu ermitteln, dał man den Gehalt an Kohlenstoff bestimmt hat."

\subsection{Die Beobachtung des Entgasungsvorganges}

In der Beobachtung des Entgasungsvorganges wurden grofe Fortschritte getan. Wir sahen bereits, dał $A c c u m$ nur die erzeugte Menge über die Vergasungszeit und ferner die Gesamtabgabe aus verschiedenen Kohlen bei hohen und niedrigen Temperaturen beobachtet hatte. Úber die unterschiedliche Leuchtkraft der nacheinander ausgetriebenen Gasmischungen gab er sich dabei keine Rechenschaft. Auch bei seiner Empfehlung, Kohle in dünnen Lagen von etwa $50 \mathrm{~m} / \mathrm{m}$ zu entgasen, ging er nur auf die Gasmenge und die wärmetechnischen Vorteile ein. Ganz anders beschrieb $C l e g g$ jun. 184I den Entgasungsvorgang. Er betonte, wie verwickelt der Vorgang sei, weil sich die Einzelgase gleich wieder zu anderen Stoffen vereinigen. Als Beispiel nennt er Wasserstoff, der sich mit Kohlenstoff verbände, ferner mit Schwefel und mit Stickstoff in Ammoniak. Er betontc auch, dał man die Kohle in dünnen Schichten entgasen und das Gas schnell abziehen müsse, weil das ölbildende Gas sich an den heif̧en Flächen des freien Retortenraumes zersetze. Das Gas habe danach eine schwache Leuchtkraft, sei aber (wohl kalorisch betrachtet) nicht schlecht zu nennen.

Zur Verdeutlichung zog er einen Brief J. Daltons an seinen Vater vom Januar 1815 heran, in dem jener annimmt, dafy bei der Entgasung kein Aethylen entstehe. Das habe erst W. Henry festgestellt ${ }^{\text {s.ur }}$ ). Die englischen Kohlensorten sind von $\mathrm{Cl}$ leg $g$ einer systematischen Probeentgasung in einer flachen Retorte von $\mathrm{r}, 20 \mathrm{~m}$ Länge und $30 \mathrm{~cm}$ Breite unterworfen worden. Bestimmt wurdc dabei die Leuchtkraft mit dem Schattenphotometer von $R u m f o r d$, die Menge der schweren Kohlenwasserstoffe und des Schwefelwasserstoffes, die Menge des

3.45) Robert Bunsen: Gasometrische Methoden. Vicweg Braunschweig 1857

3.47) Clegg jun., S. $44(5,2.20)$

128 
Teeres und Ammoniakwassers. Die Kohlenmenge konnte in der Proberetorte nicht festgestellt werden (was nicht recht verständlich ist). Dr. Henry leitete die zu erwartende Leuchtkraft aus dem Sauerstoffbedarf und dem entstehenden $\mathrm{CO}_{2}$ bei der Verbrennung ab, also in etwa vom Heizwert. Die Richtigkeit bestreitet Clegg unter Hinweis auf den Einfluß der Kohlenart und der Entgasungstemperatur.

Professor W. Stein, Dresden ${ }^{\text {s.t }}$ ) vertrat bei seinen Versuchen an sächsischen Steinkohlen die Meinung, dał das Dichteverhältnis ein ausreichender Małstab für die Leuchtkraft des Gases sei, so dał er auf die schwierige Photometrie verzichtete. Das Dichteverhältnis bestimmte er in roher Weise durch Ausströmungsuntersuchung aus einem Kubizierapparat.

Scbilling ging $1860^{\text {a.te }}$ ) auf die Schwierigkeit ein, durch Kleinversuche die Betriebsergebnisse vorauszusagen. Er betonte den Einfluf der Schichthöhe. Vor allem seien die Kleinversuche meist mit zu niedriger Temperatur vorgenommen, weil guß̧eiserne Retorten verwendet wurden. W. Stein gäbe als Skala der Temperatur das Schmelzverhalten einer Kupfer-Zinnlegierung an, also zwischen 600 und $700^{\circ} \mathrm{C}$, während man im Betriebe $1000^{\circ} \mathrm{C}$ anwende (bei keramischen Retorten).

Karmarscb-Heeren ( 1843 ) brachten die erste Systematik über Kohlen in der deutschen Literatur. Sie unterschieden Backkohlen, Sandkohlen und dazwischen Sinterkohlen. Das beste Gas liefere die Cannelkohle, doch würden meistens die wohlfeileren Newcastle-Kohlen, zur Varietät der Schiefer- und Glanzkohlen gehörig, angewandt. ,Anthrazit (Kohlenblende) wird nicht selten mit Steinkohle verwechselt." Sc billing schlief̧t sich der Einteilung nach Back-, Sinter- und Sandkohlen an, unterscheidet aber auch Pech, Schiefer-, Cannel-, Grob- (mit viel Erde), Ruß̧kohle (staubförmig). Er teilt Analysen über preuß̧ische Kohlen (W. Heintz) und sächsische (W. Stein) mit ${ }^{3.30}$ ). Der Einfluf der Sauerstoffgehaltes wurde mit vielfachen Hypothesen erörtert. Ob der Schwefel organisch in den Kohlen gebunden sei, sei eine offene Frage. „Es ist nicht gesagt, daf3 die schwcfelreichste Kohie auch das schwefelreichste Gas gibt."

3.213 Vergasung von Öl, Harzen und Entgasung von Holz

Mit Walöl, Rüböl und Harzen als Rohstoff lief̧ sich ein besonders leuchtkräftiges Gas bereiten. Bei Dunkelrotglut lieferten die meisten Ölsorten ein Gas, das der Schwefelreinigung nicht bedurfte. Das reizte auch in Deutschland zu immer erneuten Versuchen, irgendwie wirtschaftlich durchzukommen. Besonders gern wurde der Versuch mit tragbarem Gas gemacht, wo man glaubte, den Kapitalaufwand für das Rohrnetz einsparen zu können, und wo die hohe Leuchtkraft mit geringeren Mengen, also kleineren Behältern durchzukommen versprach. Ol aber stieg sofort im Preise und wohl jede Ölgasanstalt ist unwirtschaftlich geworden. Als Ersatz wurden Harze versucht, die man durch Wärme verflüssigte oder mit Spiritus auflöste. Aber auch hier blieb der Gewinn aus.

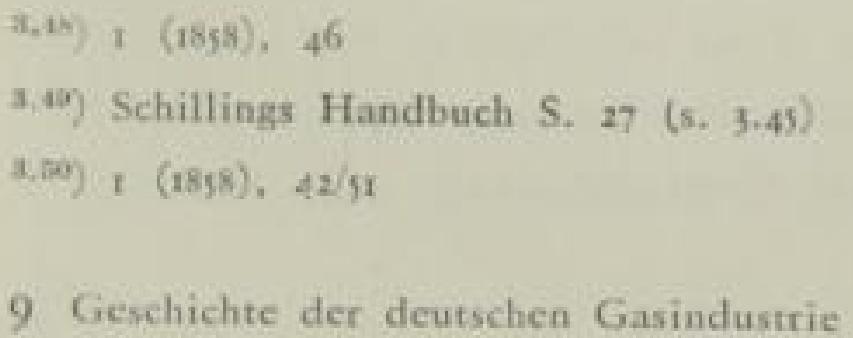


M. v. Pettenkofer griff die Verwertung des Holzes wieder auf (Vgl. S. 122). Er benutzte zur Entgasung niedrige Temperaturen, wobei er eine gute Holzkohle erzielte. Dann aber leitete er die Gase, die sich aus Methan, Kohlenmon- und -dioxyd zusammensetzten, durch Rohre von sehr hoher Temperatur. Dabei zersetzte er einen Teil des mitgerissenen Teeres und erhielt befriedigende Leuchtkraft. Das Kohlendioxyd wusch er mit Kalkmilch aus. So war das Verfahren verwickelter als die Kohlenentgasung. Auch Zerkleinerung, Trocknung und Behandilung des Holzes beim Füllen der Retorten waren umständlich und kostspielig, was aber bei kleinen Werken wenig auffiel. Schilling erwähnt noch I860 kurz Holz als Rohstoff. Es sei nur örtlich hinreichend niedrig im Preise, zumal die Reinigungskosten (offenbar von $\mathrm{CO}_{2}$ ) höher seien. Torf liefere dagegen geringwertige Nebenprodukte. Braunkohle sei nicht über den Versuch hinausgekommen.

\subsection{I4 Photometrie}

Einen grofen Fortschritt machte die Photometrie durch R. W. Bunse $n^{3.51}$ ). In einer Veröffentlichung über Bunsens Zink-Kohle Batterie ${ }^{3.52}$ ) beschrieb Bunsens Freund J. Re is et auch das Photometer. Es bestand damals aus einer Scheibe durchscheinenden Papiers, in deren Mitte eine zweite noch lichtdurchlässigere Fläche angebracht war. Nur wenn die Lichtstärke auf beiden Seiten der Scheibe gleich ist, erscheinen beide Flächen gleich hell. Später wurde von Bunsen statt des doppelten Papiers in der Mitte ein Fettfleck angebracht.

Der Vorteil gegenüber dem bis dahin gebrauchten Rumfordschen Schattenphotometer lag in der leichteren Vergleichsmöglichkeit der Helligkeit der aneinandergrenzenden Flächen gegenüber den drei Tönungen des Schattenphotometers. Die subjektiven Fehler wurden damit verringert. Ferner war die achsiale Anordnung der Leuchten bequemer als die auf einer Fläche verteilten Lichtquellen der alten Photometer.

3.215 Die Verbrennunglehre

Schon zu Beginn des 19. Jahrhunderts sind Zweifel an der Brauchbarkeit der Lavoisierschen stofflichen Theorie der an den Sauerstoff gebundenen Wärme aufgetreten. $R u m$ ford und $D a v y$ zeigten ungefähr gleichzeitig die Bedeutung der Reibungswärme auf, Rumford bei Kanonenbohrversuchen, Davy (I9 Jahre alt), indem er Eisstücke aufeinander rieb und zum Schmelzen brachte.

In der deutschen Literatur werden die Unterschiede in der Auffassung nicht so deutlich, weil die Calorie (der Wärmestoff) von Lavoisier mit Wärme übersetzt ist. Infolgedessen können die Berichte über die Wärme auch mit Vorsteliungen, wie wir sic heute haben, recht weit verstanden werden. Im Englischen aber heißzt der Stoff: Caloric, die physikalische Erscheinung aber: Heat. Das erleich-

\footnotetext{
3.51) G. Lockemann: Robert Wilhelm Bunsen. Stuttgart 1949. Wissenschaftliche Verlagsgesellschaft, S. 82

3.52) Ann. de Chimie et de Physique 1842, ref. in Poggendorfs Ann. 60 (1843), 402

130
} 
tert die Einsicht, was jeweils gemeint ist und läf̧t die Ungereimtheiten der Theorie dem heutigen Leser noch deutlich werden.

Die ersten, wenn auch ganz groben kalorimetrischen Messungen spricht man D alto $n$ zu, der unter einem Kessel mit bestimmter Wassermenge verschiedene Gase verbrannt hat. Er sprach aus, dał die Wärme und auch das Licht möglicherweise vom Sauerstoff und vom brennbaren Körper herkommen könnte $\left.{ }^{t 0.59}\right) . D a v y$ machte gleichartige Versuche, indem er Ol erwärmte und damit die Kondensation des Wasserdampfes im Heizgas bei den höheren Temperaturen vermeiden konnte.

Für die Engländer ist $J o$ ule der Vater des mechanischen Wärmeäquivalents, weil er die Gleichheit der chemischen, elektrischen und mechanischen Energie in einer Vorlesung von $184 \mathrm{I}$ ausgesprochen hätte. $\mathrm{H}$. H. $\mathrm{Hef}^{3.5 \mathrm{I}}$ ) kam bereits $184^{\circ}$ zur Erkenntnis, dał die bei einem chemischen Vorgang entwickelte Wärme unabhängig von den durchlaufenen Zwischenstufen ist. Robert $\left.M a y e r^{3.55}\right)$ sprach 1842 mit dem ,Gesetz von der Erhaltung der Energie“ den ersten Hauptsatz der mechanischen Wärmetheorie aus. Da er kein Gelehrter vom Fach war, hat es lange gedauert, bis seine Tat allgemeine Anerkennung fand. 1847 wurde von Joule ein Vortrag vor der Manchester Literary and Philosophical Society gehalten: „Wenn immer lebendige Kraft zerstört wird, so wird eine exakt gleichwertige Wärmemenge wieder hergestellt.“

Mit einem verbesserten Kalorimeter stellten $1848-1852$ P. A. F a v re, (1813-1880, Professor in Marseille) und J. Th. Silbermann (1806-1863), Professor in Paris) die Verbrennungswärmen organischer Verbindungen fest, auf denen $185 \%$ $B$ unsen bei der Berechnung der Verbrennungswärmen von Gasgemischen weiter aufbaute.

189. hat William Thomson (Lord Kelvin) einen Aufsatz über die „dynamische Wärmetheoric" mit Zahlenwerten über das Wärmeäquivalent verfafft. Von 1892 ab bestimmte julius $T$ bo msen (1826-1909, Professor in Kopenhagen) Wärmetönungen bei den verschiedensten chemischen Reaktionen. 1859 schrieb W. Rankine ein Buch über die Thermodynamik der Dampfmaschinen und 1863 veröffentlichte J. T ynd a ll Vorlesungen über „Wärme - eine Art Bewegung“. Damit erst war die stoffliche Auffassung der Wärme und ein ernstliches Hemmnis der Erforschung auch der Brennstoffe und der Verbrennung endgültig beseitigt. 1857 untersuchte Bunsen die Explosionswellen verschiedener Einzelgase. Die Beobachtung der Reaktionen wurden in Wöhler und Liebigs Annalen von ihm 1866 bekannt gemacht. Fast gleichzeitig arbeiteten $M$ a ll a rd und H. Le Cbatelier. Die hier notwendigerweise nur stichwortartig beschriebene Untersuchung aller Erscheinungsformen der Wärme war also in der ganzen wissenschaftlichen Welt auf das lebhafteste in Gang gekommen. Sie stand im Mittelpunkt des Interesses.

Trotzdem ist es aber nicht verwunderlich, dał der Ingenieur S. Cle g g jun., der noch dazu stark unter dem Einfluf seines alternden Vaters schreibt, diesem hastigen Treiben nicht hat nachkommen kỏnnen. Er schrieb, $184 \mathrm{I}$ noch ganz im

\footnotetext{
3.an) J. Inst. Fuel 90 (1957) Nr. 200 S. 499/505

3.54) G. Lockemann, Geschichte der Chemic, Sammlung Göschen Bd, 269a S. 92

3.65) Robert Julius Mayer (1814-1878) Arzt in Heilbronn
} 
Sinne der Stofftheorie der Wärme. Ja, sogar die Encyclopaedia Brittanica, die in den Jahren 1853 bis 1860 in der 8 . Auflage erschienen ist, war bezüglich der Wärme noch völlig unklar. Scbilling dagegen ging 1860 auf die Theorie der Wärme gar nicht ein, umso mehr Gedanken aber widmete er im theoretischen Teile der Wirkung der Einzelgase auf die Verbrennung. Er unterschied im Kohlengas, wie seine Vorgänger: I. lichtgebende Gase (schwere Kohlenwasserstoffe), 2. verdünnende Gase (Methan, Wasserstoff und Kohlenmonoxyd), 3. verunreinigende Gase (Schwefelwasserstoff, Kohlendioxyd und Ammoniak). Er besprach wohl zum ersten Male die Verbrennungseigenschaften und legte etwas deutlich fest, was noch heute manchmal in Erinnerung gebracht werden muf, mit den Worten: „Hätte man unter übrigens gleichen Umständen die Wahl zwischen verschiedenen Gasen, so würde das vorzuziehen sein, das den meisten Wasserstoff enthält." (E. Frankland hatte damals im Stcinkohlengas den Wasserstoffgehalt mit 10-50\% schwankend festgestellt). Damit hob Sibilling auf die eben bekannt gewordenen Versuche Bunsens über die verschiedene Flammengeschwindigkeit ab. Kohlendioxyd im Abgas und deshalb auch Monoxyd und Methan im Brenngase bezeichnete Schilling als sehr nachteilig für die Leuchtkraft. Die Analyse schrieb er mit den Eudiometer von Pettenkofer vor. Dic Lichtentwicklung wird von ihm eindeutig dem in der Flamme ausgeschiedenen Kohlenstoff zugeschrieben ${ }^{3.5 i}$ ). So gelangte er auch zu einer Bewertung der Dicke der Flamme, wegen der teilweisen Abschirmung der Strahlen durch benachbarte Kohlenstoffteilchen. „Je reicher das Gas an Kohlenstoff ist, oder je geringer das spezifische Gewicht ist, desto kleiner soll die Ausfluß̧öffnung sein."

\section{3,22 Der Fortscbritt im Ofenbau}

Schon an anderer Stelle (S. 79) wurde die Feststellung Schillings erwähnt, dał\} sich in den betrachteten 35 Jahren am grundsätzlichen Aufbau der Öfen nichts mehr geändert hätte. Man doktorte, wie man zu sagen pflegt, an den Symptomen der Kinderkrankheiten herum, ohne dał̧ jedenfalls für Öfen und liegende Retorten grundlegende Änderungen gefunden wurden. Es lohnt sich daher auch nicht, die einzelnen konstruktiven Maf̧nahmen zu beschreiben. KarmarscbHeeren zeigen (1843) mehrere genaue Zeichnungen von Ófen mit bis zu 5 gemeinsamen Retorten in einem grof̧en Flammenraum mit oberem Abzuge. Die Haltbarkeit wird mit $8-9$ Monaten angegeben, ist also immer noch in der Gröfsenordnung, die schon $A c c u m$ nennt.

Nur einer der gezeigten Öfen, den cr, wahrscheinlich fälschlicherweise $B$ ar lo $w^{3.57}$ ) zuschreibt, hat die für den grofen offenen Raum richtige Führung der Gase nach unten. Vom Feuerraum wird in einem senkrechten Kanale das Heiz-

\footnotetext{
9. 56) Schillings Handbuch, S. 62 (s. 3.45)

3.57) Es gibt drei Barlows, die in Frage kämen: James Barlow, einer der ersten Direktoren der Gas Light and Coke Company $(1812-1822)$, seinen Bruder George, der das erste Fachblatt: The Gas Gavette and Monthly Advertiser gründete, aber wegen einer schweren Augenkrankheit im gleichen Jahre aufgab, und den Solnn von James, einen beratenden Ingenieut Thoams Greaves B., 1811-1872, der 1849 das Journal of Gas Lighting. das heutige Gas Journal, begründet hat. Thomas hatte vielfache Interessen im Fach, ist aber nicht als Konstrukteur bekannt.
} 
gas bis unter die oberste Retorte geführt und dann zu beiden Seiten dieses flachen schornsteinartigen Kanales an je zwci Retorten vorbei nach unten. Die gezeichneten Retorten haben wieder die alte schon von Clegg versuchte Nierenform.

Scbilling beweist 1860 durch die vielfachen Zeichnungen, daf dic Kanalführung immer verwickelter wurde. So suchte man, der Gleichmäßigkeit der Beheizung zu dienen.

Manchmal sind die Verbindungskanäle vom Feuerraum etwas länger geführt, in einem Falle gibt es auch eine Vorwärmung der Verbrennungsluft in sicherlich völlig ungenügenden Wärmeaustauschern. Unter dem Handrost konnte man wegen der Schlacken jedenfalls keine wirksame Luftvorwärmung anwenden. Der untere Abzug ist nunmehr allgemein zu finden. Die Feuerung wird mit $100 \%$ Luftüberschuf betrieben, bei Kohlen wurde auch ein Teil als Oberluft zugeführt. Bei Koks wird auf die Verdampfung von Ammoniak-Wasser unter dem Rost Wert gelegt.

Für die Feuerraumgrößze werden nur Erfahrungswerte ohne einen Ansatz zur Berechnung genannt. Verbessert sind gegen früher die Feuerraumtüren (mit Steinauskleidung). Die Schieber sind, ausdrücklich begründet mit der erleicherten Bewegung, gut durch Gegengewichte entlastet. Da die Ófen jetzt zwar Längsaber keine Queranker aufweisen, sind die Gewölbe immer noch halbkreisförmig oder mit groß̧en Formsteindecken ausgeführt.

Während Clegg für den Schornstein noch keinerlei theoretische Unterlagen gab, hat Schilling bereits die Formel für den Treibdruck richtig gebracht. Die Strömungseinflüsse sind aber noch ungewif̧. Das ist auch insofern kein Wunder, als die grundlegenden Arbeiten über Strömung und Strömungswiderstände von Weisbacb aus dem Jahre 1855 stammen. So sind Angaben über die beste Strömungsgeschwindigkeit in Schornsteinen bei Karmarscb-Heeren mit $1,5 \mathrm{~m} / \mathrm{s}$ und anderen mit dem doppelten Werte verständlich.

Wie immer zu einer Zeit unfertiger Durchforschung, muß die Proportionalkonstruktion, das Verhältnis von Schornsteinquerschnitt zur Rostfläche, „nach Erfahrung" als Wissenschaftsersatz dienen. Wenn nun schon, wie erwähnt, die Rostfläche einfach gegriffen war, so kann man sich die weitere Abweichung von den bestmöglichen Werten beim Schornstein leicht vorstellen. Indessen ist erstaunlich, wie nahe im allgemeinen durch den Vergleich vieler - allerdings ähnlicher - Anlagen der Bestwert ermittelt zu werden pflegte; so wie ihn die später möglich gewordene Berechnung bestätigte.

\subsection{Die Wetterentwicklung der Retorten}

Überraschend sind die Versuche, mit zwei hintereinander geschalteten Retorten zu arbeiten, weil bei ihnen der leitende Gedanke nicht ganz klar ist. Während die grofe Linie dahin geht, das erzeugte Gas an der gleichmäfjig scharf beheizten Retorte möglichst schnell und durch enge freie Räume aus der Retorte herauszuführen, wird hier plötzlich von Lowe eine Retorte von doppelter Länge mit zwei Köpfen, die im Halbzeitwechsel einmal von der einen, das andere Mal von der anderen Seite geladen wird, angewendet. Das Gas aus der frisch beladenen Hälfte der Retorte wird über den halb ausgegarten glühen- 
den Koks der anderen Hälfte hinweggeführt, also sicher kräftig zersetzt ${ }^{7,30}$ ). Der Grund für diesen Versuch mag in der allgemein zu niedrigen Temperatui der Retorten za suchen sein, wodurch Schwelteerdämpfe entstanden, die in der anderen Hälfte zersetzt werden sollten. Von der Einführung berichtet die $\mathrm{Ge}$ schichte der Gas Light \& Coke Co., bei der Lowe beschäftigt war, nichts, dagegen erwähnte Oechelbäuser in einem Reisebericht.". ${ }^{35}$ ) dafy die durchgehende Retorte mit zwei Köpfen bei grofjen Werken vorherrschend sei. An anderer Stelle wurde ein weiterer Versuch unternommen, zwei nebeneinanderliegende Retorten zu verbinden. Dazu muften aber Steuerventile eingebaut werden, die, von Hand betätigt, eine stete Gefahr brachten, daf̧ versehentlich eine Retorte ganz geschlossen blieb. Lowe hatte diese Gefahr durch verschieden tiefe Tauchung in der Teervorlage vermieden.

Es war bereits mehrfach erwähnt worden, welchen Wert die ersten Ingenieure auf eine flache Lagerung der Kohle in den Retorten gelegt haben. Wohl aus solchen Erwägungen kommt es zum Bau einer breiten, flachen Retorte mit Bandförderung $\left.{ }^{3.00}\right)$. In der Beschreibung des Erfinders, die $\mathrm{Cleg} g$ offenbar ohne Kritik übernommen hat, werden die Schwierigkeiten des mechanischen Teiles in der Hitze sicherlich unterschätzt. Für solche Konstruktionen waren die Zeiten noch nicht reif.

Dagegen konnte die flache Retorte von F. J. Grafton, Edinburg, aus Ton statt Guf̧eisen 1820 mit Erfolg gebaut werden. Der Körper glich einem liegenden $\mathrm{D}$ von 2,5 m Länge, 1,50 Breite und etwa 30-35 cm Höhe. Der Boden der Retorte ist leicht nach oben gewölbt. Die Retorte ist aus sechs einzelnen Schüssen der Länge nach zusammengesetzt. Grafton erfuhr in den ersten sieben Jahren viele Angriffe. Es kamen in den Werken sogar Sabotageakte vor. Die längere Haltbarkeit erwies sich bald. Die grofe Wärmespeicherung wirkte günstig auf den Temperaturabfall beim Be- und Entladen. Die Dichtheit war selbst in den Stoßstellen der einzelnen Schüsse gut. Durch die höhere Entgasungstemperatur sank die Leuchtkraft des Gases. Die starke Graphitausscheidung veranlafte Grafton zu Versuchen, den Ursachen nachzugehen. Die Veränderung der Retortenlänge hatte keinen Einfluf̧. Als er beobachtete, daf̧ das Zusetzen zuerst am geschlossenen Ende auftrat, brachte er je einen Kopf vorn und hinten an, erhielt weniger Graphitansätze, aber oben unter dem Dach doch noch die gleiche Menge. Die Beobachtung, daf im Sommer bei geringerem Druck in der Retorte die Ansätze kleiner wurden, führte zu gründlichen Versuchen über den Einfluf̧ des Druckes und dann zur Einführung der Absaugung.

T. Spinney erbaute 1832 Retorten von ähnlichen Ausmaßzen aus einzelnen Steinen und Platten aus verschiedenen Schamottequalitäten. Die Steine waren mit Nuten und Federn versehen. Der Unterfeuerungsbedarf war hoch $(50 \%$ der eingesetzten Kohle und $75 \%$ des erzeugten Kokses). Man schob das auf die unnötige Dicke der Steine, wahrscheinlich war aber der schlechte Einbau mehr schuld. Immerhin ergab sich wegen der gesteigerten Gasausbeute nur ein gering gesteigerter Betriebsaufwand gegenüber Guf̧eisen.

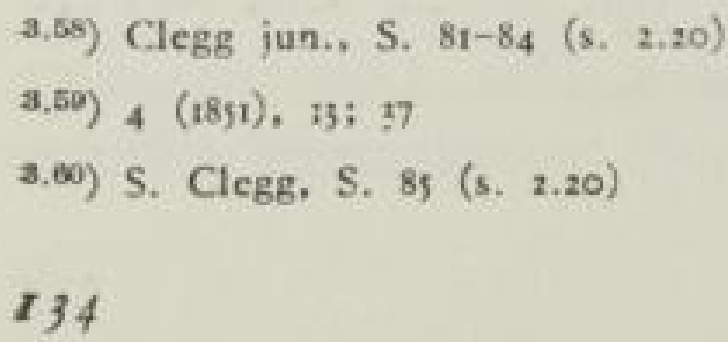


Die ersten, aus einem Stück gefertigten Retorten zeigten Joseph Cowen \& Co. auf der berühmten Weltausstellung in London 185 r. Zwei Jahre später erfolgte ihr Einbau im Hauptwerk der Gas Light \& Coke Co. Im folgenden Jahre folgten umfangreiche Bestellungen, die Benutzung von Guf̧eisen wurde mehr und mehr verlassen.

In Deutschland wandte sich F. F. Didier 1834 der Erzeugung feuerfester Steine und bald darauf der Herstellung von Schamotte-Retorten $\mathrm{zu}^{\text {s.ai }}$ ).

\section{LEB E N S B I L D}

Friedrich Ferdinand Didier wurde am 5. Januar 1801 in Stettin geboren. Er war Abkomme von Hugenotten, sein Urgrof̧vater hatte wegen der Ansiedelung der Flüchtlinge mit dem groł̧en Kurfürsten verhandelt. F. F. Didier wurde als Kaufmann ausgebildet und lernte mehrere Gewerbe kennen. Was ihn veranlaß̧te, mit den Mitteln der Eltern 1822 eine Ziegelei bei Rostock anzukaufen, ist nicht bekannt. I834 erwarb er in Podejuch bei Stettin einen anderen Ziegeleibetrieb, dem eine Kalkbrennerei angegliedert war. Der dort bisher verarbeitete Lehm war restlos abgebaut; man muß annehmen, dał Didier den Wert des darunter liegenden eisen- und kalkfreien mit Ton gemischten Quarzsandes als Rohstoff für feuerfeste Steine kannte. Damit schlug er nach 10-jähriger anstrengender Arbeit die ausländischen Wettbewerber, die zunächst den deutschen Markt beherrscht hatten. Daß̧ er sich in lang andauernden Versuchen mit der Herstellung von Retorten befaf̧t hat, beweisen Funde von alten Brocken, die seine Arbeiten in die 4 oer Jahre verlegen lassen. Einen fähigen technischen Partner fand er in Wilhelm Kornbardt, einem Schüler Blocbmanns, der 1847 - 26 Jahre alt - die Direktion des neu gebauten Stettiner Gaswerks übernahm. 1865 w wrde Kornhardt Teilhaber bei seinem 20 Jahre älteren Freunde Didier. Zwei Jahre später war das arbeitsreiche Leben Didiers beendet.

Über den Zeitpunkt der ersten Lieferungen wird nichts berichtet. Bekannt ist, dafy die städtischen Werke in Berlin in den Jahren $1850-1856$ Schamotte-Retorten eingebaut haben, daf diese aber von Stettin geliefert wurden, ist nicht erwiesen. Sicher ist vielmehr, daf, gegen Ende der hier betrachteten Pcriode eine ganze Reihe von Schamottefabriken mit Angeboten auf Retorten hervortreten. Ihre Bewährung bildete einen Hauptberatungsgegenstand in den Hauptversammlungen des 1858 gegründeten Vereins der Gasfachmänner Deutschlands. Zunächst wurden die belgischen Erzeugnisse als besser angesehen. Die Firma F. S. Oests Wittwe \& Co., Berlin, von der die Ablichtung einer Anzeige im Journ. f. Gasb. gezeigt ist, wurde aber bereits als ebenbürtig von mehreren Gaswerken, u. a. auch Berlin bezeichnet. (Bild 18)

I824 fertigte Christian Ludwig O est, Berlin, aufjer Waren aus Steingut und Majolika auch feuerfeste Steine. Unter der Witwe seines Sohnes lieferte die Firma: F. S. Oest Wwe. \& Co. Berlin, Schönhauser Allee 128, die SchamotteRetorten, die insbesondere $K \ddot{u} b n$ ell, Berlin, 1859 als besonders vorzüglich bezeichnet hat. Durch Tochtergesellschaften im In- und Auslande wurde sie unter- 


\section{Journal für Gasbeleuchtung} und

\section{verwandte Beleuchtungsarten.}

\section{Monatschrift}

redigirt von

\begin{tabular}{|c|c|}
\hline 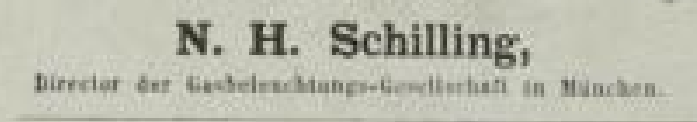 & 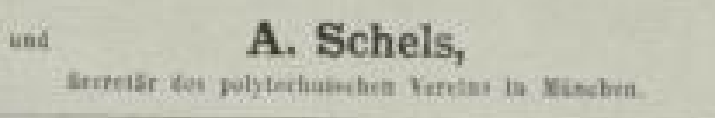 \\
\hline 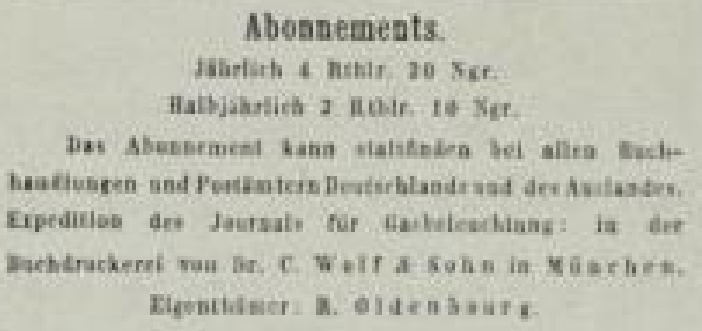 & 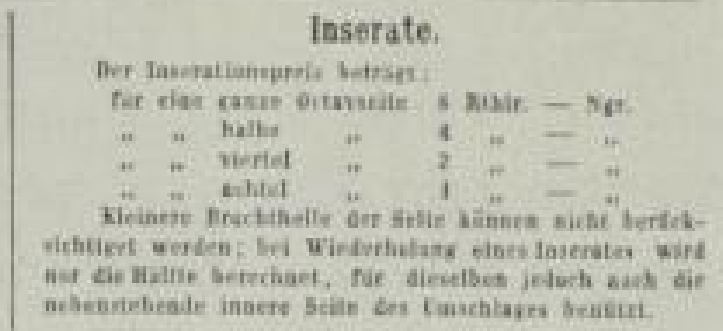 \\
\hline
\end{tabular}

Die Chamott-Retorten- und Stein-Fabrik

$$
\text { von F. S. Oest's Wittwe u. Comp. Berlin, }
$$

erlaubt sich ilire Fabrikate, als Chanotr-Reterten zur Gas and Mineralb1-Bereitung so wie Chamottateine in jeder beliebigen Form und Grüsse zir empfeblom, Von den gang.

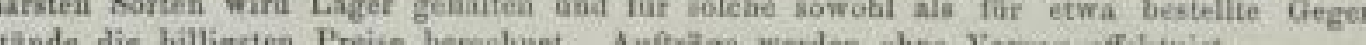
(a)

stadtischen

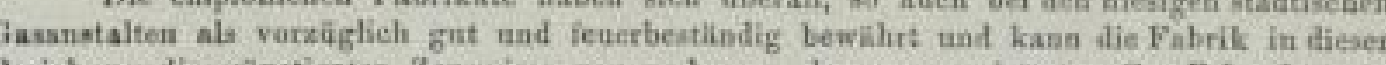

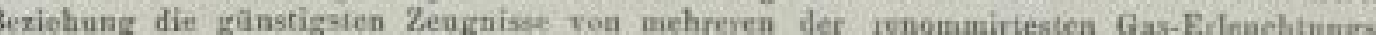
Anstallen uod anderen Etablisaeinents vorlegen (beibringan)

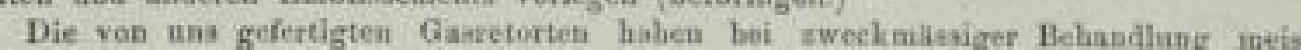
$21 \%$ bis 3 Jahre in Betriebe bein starksten Feuer ansgehalten und die von uns geis the

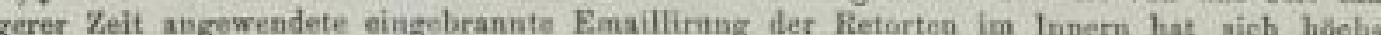
nutulich erwieaen, indean dio Entfornung des Graphits bedeutend erleichtert wird.

\section{ASCHEMANN \& FRICKE} in Berlin

Fabrik für Gasbeleuchtungs-Gegenstände und Bronzewaaren, empfoblen fili Gas-Anatalten ihr Lager, resp. Anfertigung, ron Fittings, Kandelabern, La-

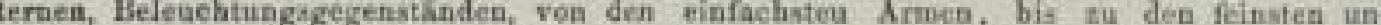

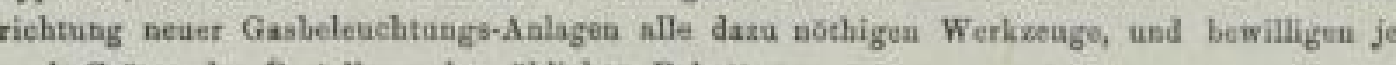
ach Grumo der Bestellang dea thlichen Rabatt.

stützt $\left.{ }^{300}\right)$. Dabei war mati inzwischen auch in England von den besonderen Formen und Abmessungen der Steinretorten abgekommen. Sie glichen den bisher verwandten gufeisernen Retorten. Von Kornbardt stammen elliptische Querschnitte. Schilling bestätigt, dał die Schamotteretorten erst in der Mitte der 5o-er Jahre aufgekommen seien, sich dann aber schnell durchgesetzt hätten.

Scbilling erörtert den Umstand, daf̧ trotz der erhöhten Temperaturen und Gasausbeuten in den Tonretorten die Güte des Gases gleich der aus den kirschrotglühenden Guf̧eisenretorten sei. Er schrieb das auf die Wärmedämmung im 
Ton, dürfte damit aber nicht ganz den richtigen Sachverhalt treffen. Denn für die Wärmeaufnahme ist die geringe Wärmeleitfähigkeit der Kohlen nach der Trocknung der Hauptwiderstand. Die Zersetzung dürfte vielmehr eben durch die gröf̧eren Gasmengen, die schnell aus dem nunmehr eng gehaltenen freien Raum über der Kohle abgesaugt wurden, vermindert worden sein. Daneben spielte die Verringerung der Entgasungszeiten von 6 auf 4 und 3 Stunden eine wichtige Rolle.

\subsection{Retortenbedienung und Veränderung der Lageder Retorten}

Laden und Entleeren der Retorten war eine schwere Arbeit, die zu erleichtern sich die Ingenieure bemuhten. Wir crwähnten bereits, daf3 man wenigstens den glühenden Koks gleich zu entfernen versuchte, Löschen mit Wasser vor den offenen Türen war ja eine mif̧liche Sache und allzu lange durften die Retorten auch nicht offenstehen und auskühlen. Die gewöhnlichen Schaufeln wurden durch eine Lademulde ersetzt, bei der aber 3 Mann, gut aufeinander eingearbeitet, angreifen mufjten.

1828 machte J. Brunton (West Bromwich) Versuche mit einem Vorschubkolben $^{\text {anas }}$. Er baute eine kontinuierliche, etwa einmal stündlich geladene horizontale stark konische Retorte mit geschlossenem Kopfe, ähnlich einer Unterschubfeuerung und einem Daueraustrag in einem Wasserverschluf. Er behauptete, durch das Hinwegstreichen des vorne erzeugten Teeres über den fast ausgegarten Koks $35 \%$ mehr Gasausbeute zu erreichen ${ }^{3.64}$ ). Im J. f. G. 1 (1858) S. 4 ist in einem schönen Stich, Tafel I, eine ganz ähnliche Retorte gezeigt, bei der lediglich der

Bild 19

Kontinuierliche Retorte mit Schnecke (J. f. G. I [1858] S. 4.)

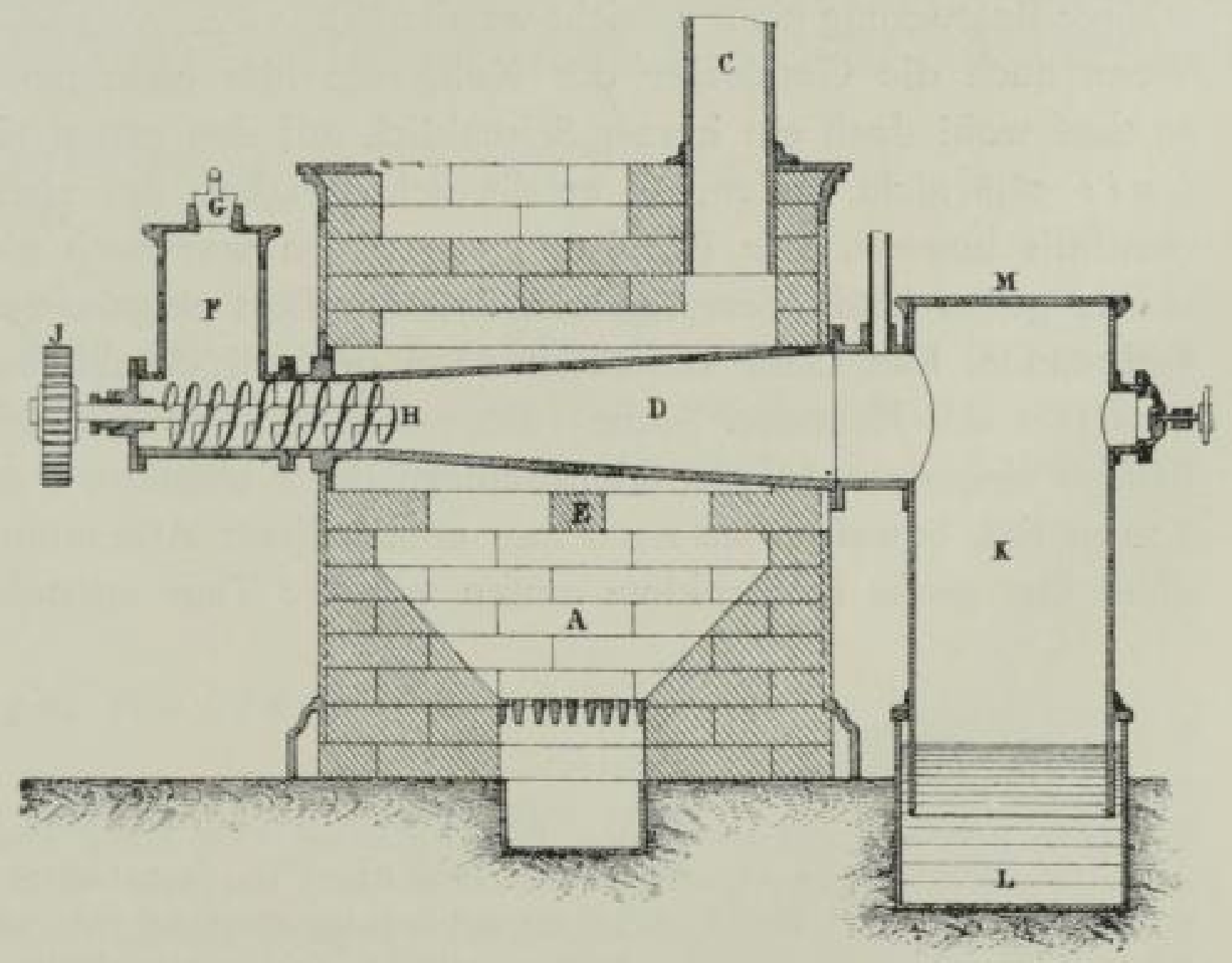

a,ai) E. F. Armstrong. Murdoch Centenary Lecture, Inst, of Gas Eng. Publ. Nr, 207, London 1939

a.6r) S. Clegg jun., S. T7 (s. 2,20) 
Stofkolben durch eine Schnecke ersetzt ist. (Bild 19) Die Retorte war für eine Einzelanlage kleinsten Ausmaf̧es gedacht.

Später kam Brunto n auf den Gedanken, die Retorten - wie einst Murdoch - senkrecht zu stellen. Eine solche Anlage wurde auch gebaut, aber es dauerte noch so Jahre, ehe die Bauart reif wurde (als man gelernt hatte, die hohen Räume gleichmäßjig zu beheizen und das Glühlicht keine Ansprüche an den hohen Gehalt an Kohlenwasserstoffen mehr stellte).

Aus Berlin wird berichtet, daf die ersten Öfen der englischen Gasgesellschaft I826 mit senkrechten Retorten gebaut worden seien. Im Werkmuseum in Mariendorf findet man auch noch alte Retorten, deren Verschleif auf einc solche Anordnung schlief̧en läß3t $\left.{ }^{3.05}\right)$. Aktenunterlagen darüber sind leider weder in Berlin noch in London vorhanden. Nähere Nachforschungen lassen jedoch die stehende Anordnung als unwahrscheinlich erscheinen. Der den Bau ausführende Ingenieur J. Perks hatte vorher das Werk Dorset Street der City Gas Company erneuert. Dort hatte er verschiedene Retortensysteme erprobt, war abet nur bei den Formen von Rackbouse, die im $A c c u m$ genau beschrieben sind, erfolgreich $\left.{ }^{9,66}\right) \cdot 1817 / 18$ hat er andere Formen patentieren lassen, aber wieder mit waagerechten Retocten. (Bild 2C) Kings Treatise bemerkt, dał Perks diese seine für Dorset Street entwickelte Bauart auch in Berlin angewandt hat ${ }^{3,6 \pi}$ ). Auf̧erdem liegt ein ausführlicher Prüfungsbericht von $G$. Lowe über die Werke in Hannover und Berlin aus dem Jahı 1828 vor, der mit vielerlei Beanstandungen sicherlich die damals ganz ungewöhnliche Anordnung senkrecht oder im Kreise angeordneter Retorten nicht unerwähnt gelassen hätte.

So dürfte wohl der erste Versuch, senkrechte Retorten in normalen Gaswerksöfen einzubauen, soweit man von der ersten Anordnung $M u r d o c h s$ absieht, $W$ in $s$ or jun. zugesprochen werden müssen. Dieser baute sie 1836 in Brick Lane Works ein, hatte aber einen bösen Miß̧erfolg. Vermutlich konnte eine gleichmäßjige Befeuerung nicht erreicht werden ${ }^{\text {s.an }}$ ).

Wenn auch die Geschichte der Kokereien hier nicht gebracht werden soll. ${ }^{3.0 \%}$, so darf wohl doch ein kurzer Seitenblick auf den ersten Kammerofen von Jose $L u$ is 1858 nicht fehlen, da er die Schwierigkeit der gleichmäfjigen Beheizung ebenfalls beweist. Die Beheizung von aufzen war noch nicht gut gelungen. So wurde gegen Ende der Ausstehzeit unten Luft eingelassen, um etwas Koks zu verbrennen. Die Gase verkokten dann den zurückgebliebenen oberen Teil des Einsatzes der Kammer. Schon 1860 waren in Paris Koksöfen in den Gaswerksbetrieb eingesetzt. In den Abmessungen der Kammern, $2 \mathrm{~m}$ weit, $\mathrm{I} \mathrm{m}$ hoch und $7,20 \mathrm{~m}$ tief, beweisen sie noch ihre unmittelbare Abstammung vom Bienenkorbofen. Der grof̧e Kohlenklotz muf̧te mehrere Tage ausstehen. Den Fabrikanten

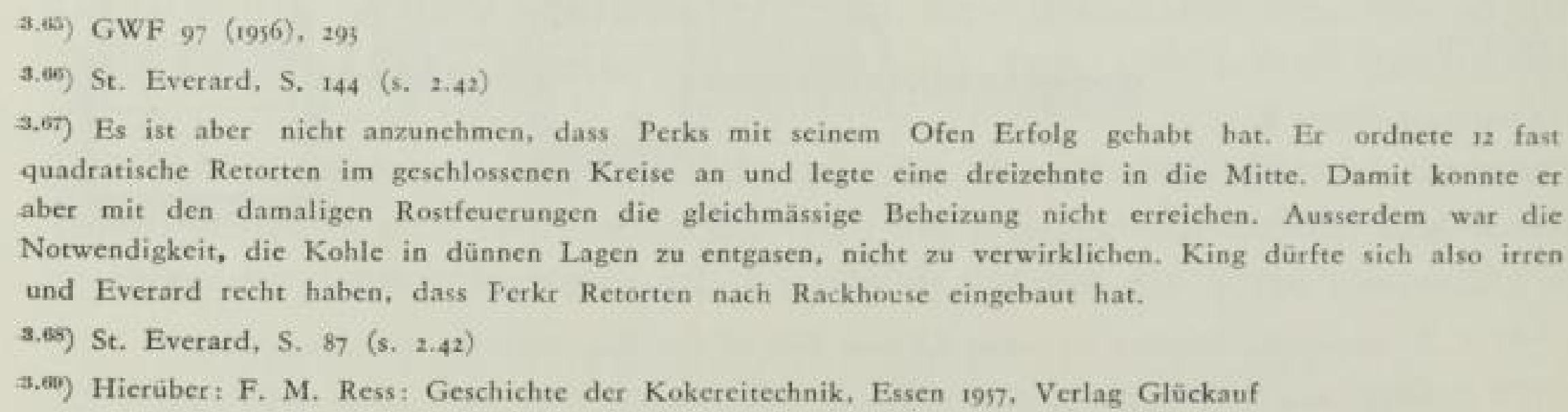



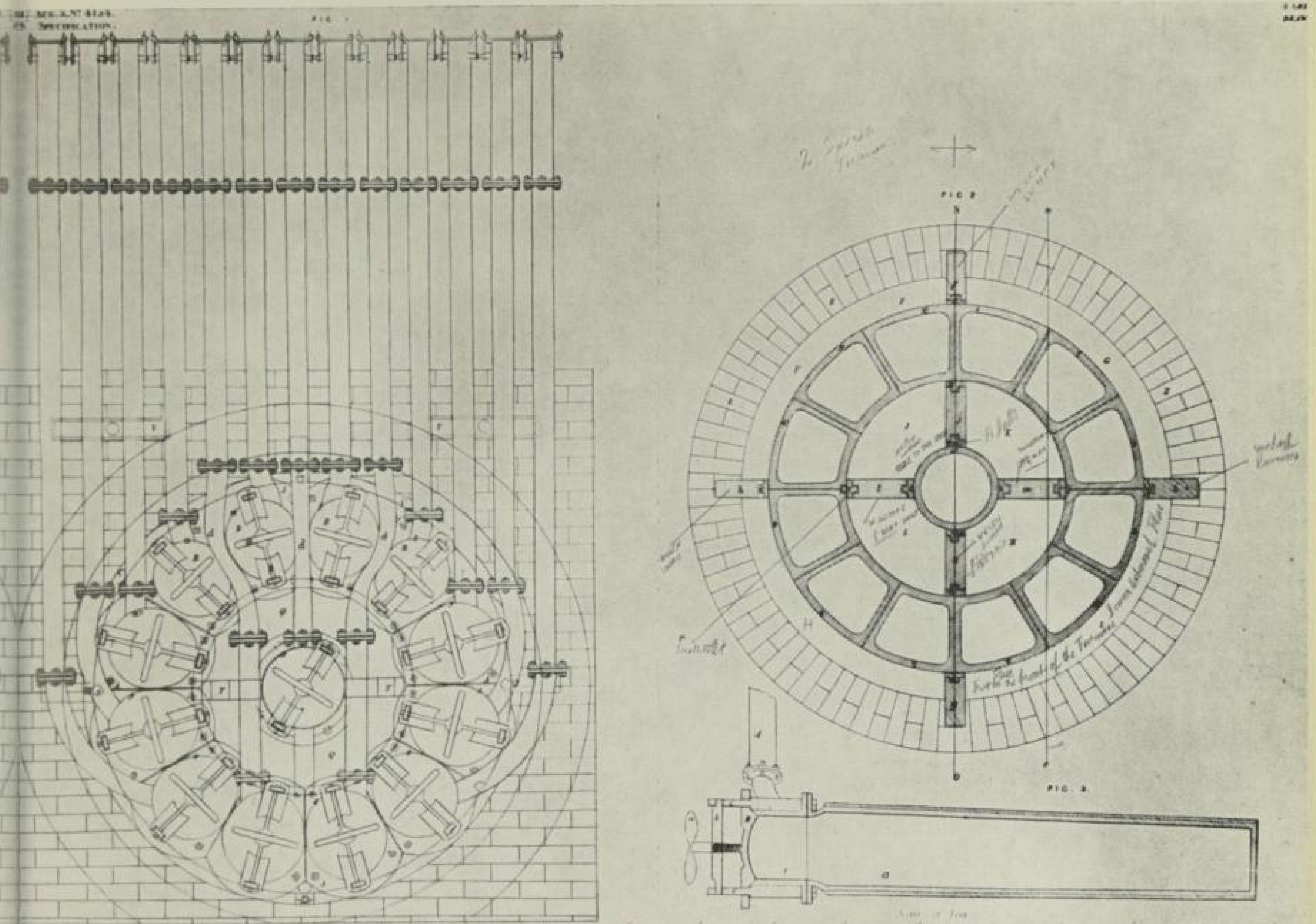

Bild 20 J. Perks Neunretortenofen nach einer Patentanmeldung von 1817

Pauwels und Dubochet kam es aber auch bei dem Pariser Bedarf an Koks mehr auf den erstklassigen Koks als auf die Gasausbeute an. Die Öfen hatten auch keine Teervorlagen, chargiert wurde alle drei Tage. Während aber sonst für die Tonne Gaswerkskoks 20 frs. erzielt wurden, betrug der Preis des Hüttenkokses $35 \mathrm{frs}^{3.70}{ }^{3.0}$ ).

3.23 Teervorlage, Kübler, Wascber

Die Teervorlage der Retortenöfen blieb zunächst gegen $C l e g g$ sen. unverändert. Runde Rohre waren noch 1860 vielfach zu finden, so sagte Scbilling, wenn auch erkannt war, daf ein Trog mit flachem abnehmbarem Deckel wegen der Reinigung besser sei.

3.70) J. f. G. $4(1861), 19 / 27 ; 37 / 61$

\section{SLUB}


$3.231 \mathrm{~K} u ̈ h l e r$

Der Kühler wurde zunächst als Rohrkühler in einem Becken ausgeführt. J. Perks hat den ganzen Kühlapparat eng gebaut in einen gußzeisernen Wasserbehälter eingesetzt (englisches Patent Nr. $4 \mathrm{I5} 4$ vom 4. 2. 18r8). (Bild 21)

Lange ist eine Meinungsverschiedenheit aufgetreten, ob man das Gas lange Zeit mit Teer in Berührung lassen solle, damit es Leuchtstoffe aufnehmen könne, oder ob im Gegenteil der Teer leichte Kohlenwasserstoffe aufnehme. So kam man zeitweilig zu mäf̧iger Kühlung auf $50-90^{\circ} \mathrm{C}$. Um die Mitte des Jahrhunderts wurde augenscheinlich die Luftkühlung bevorzugt. 3-6 m hohe senkrechte Rohre von $300 \mathrm{~mm}$ und mehr Durchmesser wurden zu je zweien durch Umkehrstücke verbunden; unten taucht das eine in den Teer des Autfangbehälters ein, das Rohr für den aufsteigenden Gasstrom endet oberhalb des Teerspiegels. Unten sind diese beiden Rohrenden durch eine Tauchwand im gufeisernen Kasten getrennt, das absteigende Rohr dagegen mit dem nächsten aufsteigenden in einem Raume, so daf̧ das Gas mehrmals auf- und abflief̧en muf̧. Diese Luftkühler wurden dann auch von auf̧en berieselt. Der Luftkühler von Kirk $b$ a m bestand aus einem Doppelzylinder aus Blechen. Im Ringraum wurde das Gas von oben nach unten gedrückt, die Luft streicht im Gegenstrom innen und aufzen nach oben. W. Kornbardt, Stettin, rüstete die Rohire mit dachartigen Schaufeln aus, um das Gas an die Wände zu drücken. Aus all den Anordnungen erkennt man die Unsicherheit über den Weg, den die Wärme geht. In den alten stehenden Rohrkühlern war mindestens im ersten Teile die Strahlung wirksamer, die engen Ringkanäle konnten aber nur konvektiv die Wärme abgeben. Soweit man also auch bereits mit der strahlenden Wärmeabgabe bei Flammen und glühenden Flächen war, so wenig Sicheres war noch über die Gasstrahlung bekannt oder auch nur erahnt. Wie weit die Erkenntnis damals gegangen ist, sieht man deutlicher als an den Kühlern an den ersten "Lokomobil-Kesseln“ von F a r c o t, Weltausstellung London 1862 und Paris 1867 , bis dann ein Feuerraum mit groß̧em Durchmesser die Gase in einen Rauchröhrenkessel entlä (3t ${ }^{3.71}$ ). Im Jahre 1850 hatte sich in Brüssel eine verbesserte Ammoniakwassergewinnung mit Bottichen voller Sägespäne, die mit kaltem Wasser vollgesaugt waren, durchgesetzt. An den Arbeiten, Schwefelammonium zur Fabrikation von Alaun herauszuziehen und besondere Düngestoffe zu gewinnen, arbeitete E. Solv a y (I8381922). Sein Verfahren zur direkten Herstellung von Soda ist im Laboratorium des Gaswerks Brüssel zuerst erdacht worden ${ }^{3.72}$ ). Solvay hatte nur vergebliche Versuche anderer in dieser Richtung vor Augen ${ }^{3.2 \pi}$ ). Das Patent erhielt Solvay 186I, die erste Ammoniak-Sodafabrik richtete er 1863 ein, brauchte allerdings noch to Jahre, bis alle technischen Schwierigkeiten überwunden waren.

3.232 Teerabscheidung und Teerverwertung

Die einfache, sich selbst überlassene Abscheidung des Teeres (und Gaswassers) aus dem Gase suchte man zu verbessern. Hierzu wurden „Skrubber“ als Prall-

a.71) C. Matschoss: Geschichte der Dampfmaschine, Berlin 1908 Bd. II S. 451

3.72) M. Brabant: Aperçu sur 1'histoire du Gaz en Belgique. Rewue générale du gaz 71 (1949), \&

3.73) F. M. Ress: Geschichte der Kokereitechnik, Essen 1957 S, 231

140 

bot Schwierigkeiten, wobei es dann zu unangenehmen Ruß̧bildungen kam. W. Hor $n$, Bremen, der mit Oechelhäuser eng zusammengearbeitet hat, lief̧ deshalb den Teer auf die glühende Platte nur tropfenweise fallen und führte seitlich Zweitluft in die Flammen. Klagen aber über den unregelmäfigen Gang sind über beide Einrichtungen geführt. Es war sehr schwer, den Zufluf des Teeres zu regeln.

In diese Zeit fällt aber der Ansatz zur vollkommen veränderten Bewertung des schwarzen Abfalles der Gaswerke. K. v. Reicbenbacb entdeckte 1830 das Paraffin, J. Y o ung gelang 1850 dessen industrielle Verwertung $\left.{ }^{n, 4}\right)$. Schon F. F. Runge (1795-1867) isolierte 1833 wertvolle Stoffe aus dem Teer. Im folgenden Jahre hatte er in der chemischen Fabrik Oranienburg aus Anilin einen blauen und schwarzen Farbstoff hergestellt ${ }^{t+5}$ ). Da aber der Inhaber der Fabrik, die preuf̧ische Staatsbank (Seehandlung), für Experimente nicht zu haben war, unterblieb die Übertragung in die Fabrikation. Diese gelang dem r9-jährigen W. H. Perkin (1838-x907) in London 1857 in einer eigenen Fabrik. Natürlicherweise reichte die Zeit bis zum Ende des betrachteten Abschnittes nicht aus, um die wirtschaftliche Unwälzung auf dem Teermarkt wirksam werden zu lassen. In der Destillation wurden nur gewonnen: leichtes Teeröl (in Camphinlampen verbrannt), schweres Teeröl, Asphalt, Benzol und Benzin (zur Kleiderreinigung 1860 noch neuartiges $\mathrm{Mittel})^{3,74}$ ).

3.233 Schwefelwasserstoffreinigung

Dieses Feld wurde noch fast ganz, wie gleich im Anfang, vom Kalkmilch- und Ätzkalkreiniger beherrscht, wobei die Bevorzugung des einen oder anderen Verfahrens von der Geschicklichkeit der Betriebsleitung und der Möglichkeit, die übelriechende ausgebrauchte Milch irgendwie loszuwerden, abhing. Die vielen verschiedenen kleinen, aber nie grundsätzlichen Änderungen an der "Maschine“ könnten ein Buch füllen, sind aber heute nur noch von geringem Werte (vgl. Abschnitt 2.2I2).

Erwähnt mag die Anordnung von Creig bton in Glasgow werden, der nicht das Gas durch die Kalkmilch, sondern die Milch durch das Gas als Wascher gehen lief̧. In einem schrägliegenden Trog mit mehreren Scheidewänden lag eine Welle mit Schöpfrädern.

$d^{\prime}$ A r cet nahm (etwa $\mathbf{1 8 2 0}$, das genaue Datum ist nicht festzustellen) eine archimedische Spirale, mit der er das Gas nach unten in die Milch mechanisch pumpte und damit auch die Retorten vom Druck entlastete. Die Anpassung an die Erzeugungsmenge sollte durch Veränderung der Umdrehung der antreibenden Dampfmaschine und bei geringen Leistungen durch einen Umgang von der Druck- nach der Saugseite geschehen. Der Fühler dieses einfachen Regelkreises ist ein Manometer vor dem Reiniger. Das Zwischenglied ist aber det beobachtende Mensch, der in die Dampfmaschinensteuerung eingreift, mit all seinen Unvollkommenheiten in der Aufmerksamkeit ${ }^{3.70}$ ).

3.74) Schilling: Handbuch, 1860 (s, 4.45)

3.75) 100 Jahre Teerfarbenindustrie G. W. F. 98 (1957), 1086 mit weiteren Schrifttumsaachweisen

3.76) Karmarsch-Heeren: Technisches Wörterbuch 18.43, Schilling: Handbuch 3. Aufl. S. 363 
Weitgreifender war der Versuch, die Reinigung durch glühende Eisenrohre, die mit Eisenfeilicht gefüllt waren oder auch leer blieben, zu erreichen. H. P a lmer regte schon 1818 ein Verfahren an. Er schrieb: „Abfälle von Eisenblech oder verzinnten Eisenplatten, irgend ein Eisenoxyd auf der niedrigsten Stufe der Oxydation, Toneisenstein, Frisch-schlacken oder schwarzes Eisenoxyd sollen auf Rotglut erhitzt und das Gas hindurch und dann noch durch eine Zysterne mit kaltem Wasser geleitet werden. Nach Erschöpfung wird der Stoff durch Öffnen von Klappen der plötzlichen Einwirkung der Luft ausgesetzt und, da es rotglühend gehalten wird, wieder regeneriert, bevor ein zweiter Apparat völlig ausgenutzt ist $^{\text {a.TiT }}$ ). Zwar wurde der Schwefelwasserstoff entfernt, aber gleichzeitig wurden auch die Kohlenwasserstoffe zersetzt. Das Gas war kein Leuchtgas mehr. Setzte man Holzkohle in die Rohre ein, so entstand Kohlenmonoxyd und Wasserstoff. Brande, vermutlich der Chemiker, der später in Hannover als sachverständiger Kritiker am ersten Betrieb des Gaswerkes aufgetreten ist, behandelte die Fragen in den Transactions of the Royal Society ${ }^{3.78}$ ).

Die Reinigung mit Oxyden von Metallen, vornehmlich Eisen, begann mit H. Muizon 1835. Er nahm Eisenvitriol, das durch Vermittlung von Schwefelkiesen hergestellt wurde. Im gleichen Jahre schlug Pbillipps Eisenoxyd $\left.\operatorname{vor}^{n, 70}\right)$. Erfolgreich war das von Laming vorgeschlagene Eisenchlorür vermischt mit Ätzkalk und Kreide und später ein Gemisch von Eisenoxyd mit einem Kalksalze. Auf den Kalk glaubte man wegen der Bindung des Kohlendioxyds und einiger Schwefelkohlenstoffe, nicht verzichten zu können. F. C. Hills führte das Eisenoxyd 1849 ein. Es kam zu einem Prozef um sein Patent mit den Gasgesellschaften, die sein Verfahren ohne Hemmungen anwandten, 1858. Laming widersprach Hills Patentansprüchen, wurde aber abgewiesen, weil er ja ein Gemisch angewandt hatte. So kam Laming um seine eigenen Patentrechte. Die Berliner städtischen Werke führten die Lamingsche Masse I857 zunächst versuchsweise, I861 allgemein ein. Noch 1360 vertrat $S$ c billing $g^{3.80}$ ) die Ansicht, dał eine Reinigung mit reinem Eisenoxyd unbedingt die nachträgliche Durchleitung durch Kalk erforderlich mache, um Kohlendioxyd zu entfernen (Leuchtkraft).

Anregend ist auch die Tatsache, daf̧ A. Croll schon frühzeitig $\left.{ }^{n .51}\right)$ um 1840 die nasse Reinigung in der Vereinigung von Salmiakgewinnung und Schwefelwasserstoffreinigung sich patentieren lię̧. Er führte Zinkchlorid in einen der üblichen Reinigungsbehälter ein und erhielt ein unlösliches Zinksulfat und Salmiak

$3.234 \mathrm{~S}$ a uger

Als Grafton 1839 den Vorteil der Absaugung auf die Graphitbildung entdeckt hatte, konstruierte er einen umlaufenden Sauger nach Art eines nassen

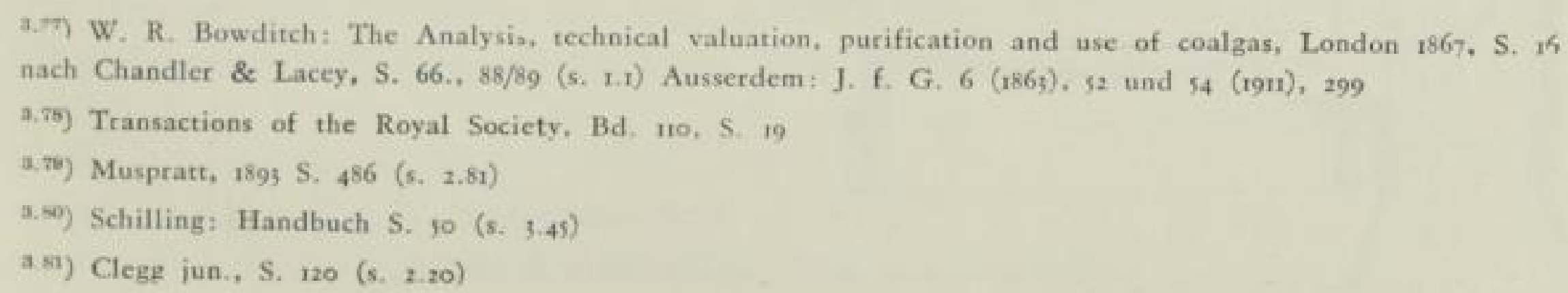




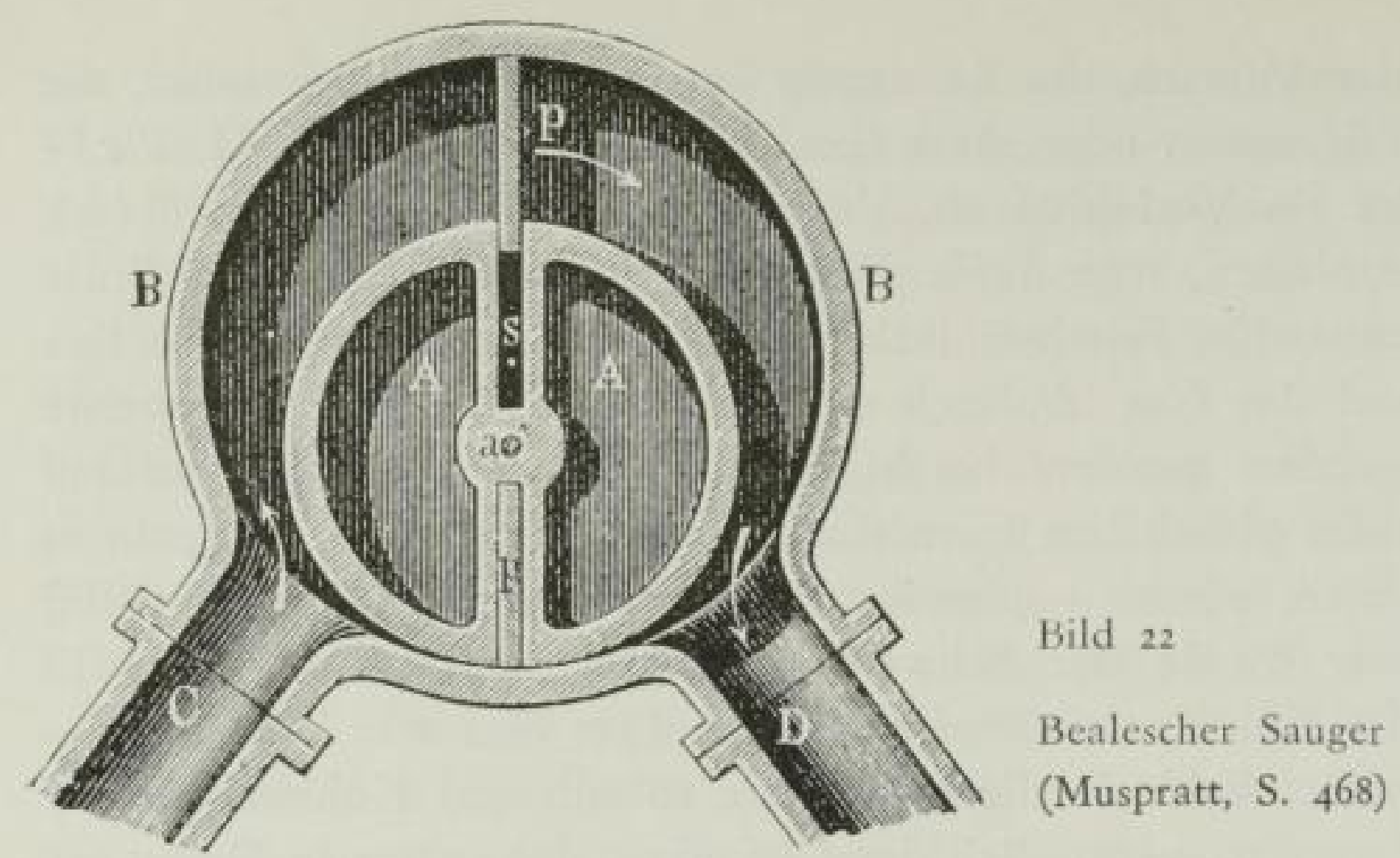

Gasmessers. Dann aber wandte man sich nach dem Vorbilde von J. Metbven 1848 den Glockenexhaustoren zu. Gasbehälterglocken wurden von einer darüber liegenden Antriebswelle mit äuferer Kraft auf- und abgesenkt. Einen der ersten Sauger dieser Art baute v. $U n r u b$ in Magdeburg ein. Dieser enthielt zwei in Wasser tauchende Glocken mit sinnreicher Tauchwechseleinrichtung. Man war also zum allerersten Gasmesser Cleggs zurückgegangen und kam zu sehr umfangreichen Maschinen. Es gab deren mehrere Bauarten (Pauwels \& Dubochet. Paris).

Der erste umlaufende Sauger, ein Vorläufer des heutigen Rotationssaugers, ist von Beale gebaut worden und führte sich schnell ein (Bild 22). Daneben wurden auch Kolbenexhaustoren angewandt, die dem Dampfmaschinenzylinder mit Schiebersteuerung ähneln (Bild 23.). In Berlin wurden mit einer Balancierdampfmaschine je zwei solcher Zylinder verbunden. Der gröfte Vorteil des Saugers war die Entlastung der Retorten vom Überdruck, der durch den Widerstand der Leitungen und Wascher hervorgerufen wurde. Er drückte das Gas auch durch die Schwefelreinigung in den Gasbehalter.

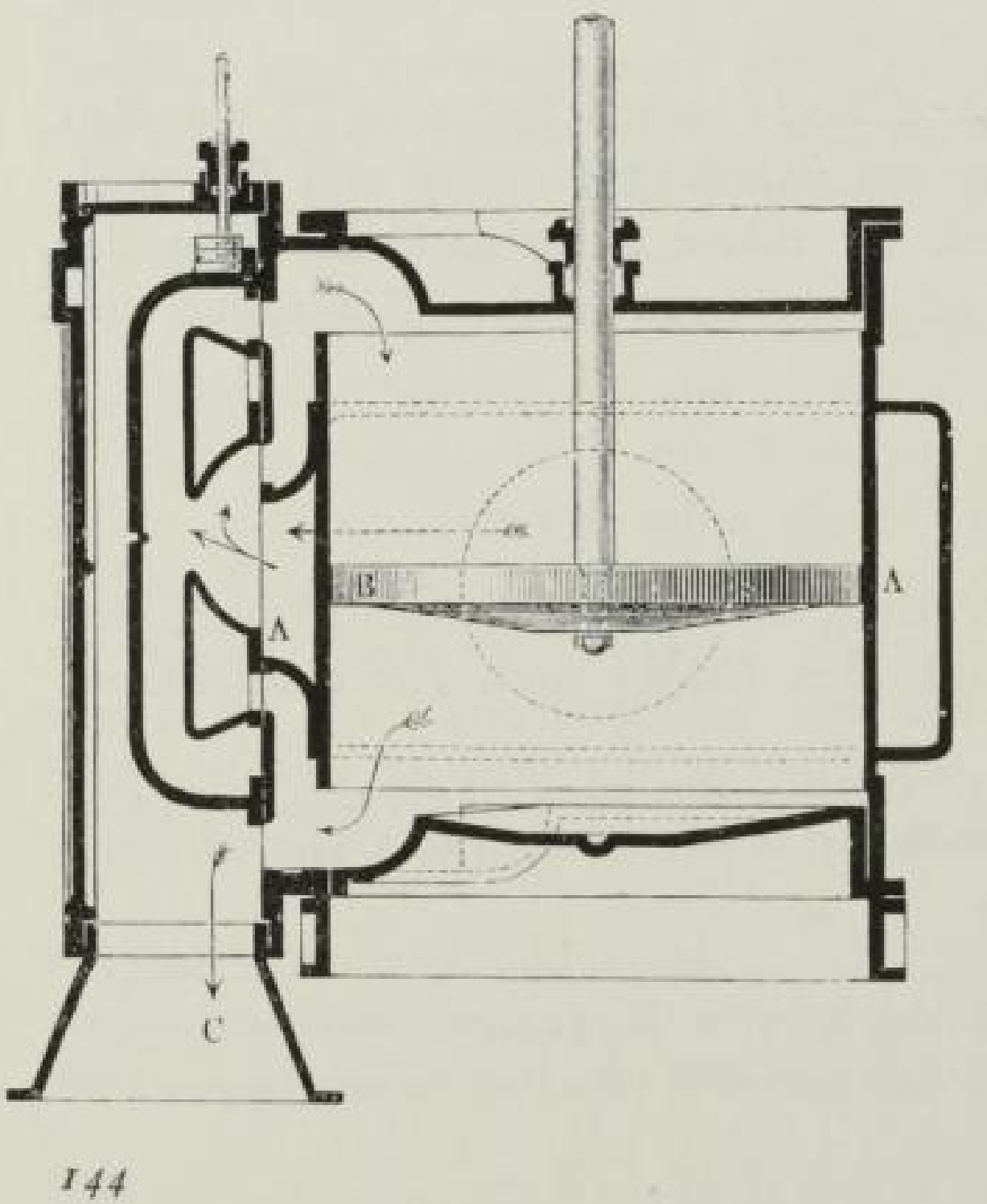

Bild 23

Kolbenexhaustor

(Muspratt, S. 467)

\section{SLUB}


Der Aufbau der Gasbehälter wurde grundsätzlich in der Zeitspanne von I8251860 nicht geändert. Die Meinungsverschiedenheiten über den Vorzug der Entlastung der Glocke (Glasgow) und den der Führung durch feste Gerüste (Clegg 1841) blieb bestehen. Auch Karmarscb-Heeren meinen noch ${ }_{18} 43$, dafł die Glocke mit Ausgleichsgewichten allgemein üblich sei. Nur bei teleskopierten Behältern komme man um eine Führung nicht herum. Bei ihnen sei nur die oberste Glocke entlastet. Karmarsch handelt theoretisch ab, wie das Gegengewicht berechnet werden könne. Es sei aher nötig, die Auswiegung trotzdem an der Baustelle vorzunehmen wegen der Unzuverlässigkeit der Blechstärken und des Anklebens der als Rostschutz angebrachten Teerschicht in verschiedener Stärke.

Die Möglichkeit der Teleskopierung wurde zuerst von $T$ a it 1824 ausgesprochen. Dieser war bei der Mile End Oil-Gas Co, tätig. In Leeds konnte I826 ein teleskopierter Behälter besichtigt werden. 1834 griff als erste Londoner Gasgesellschaft die City of London Gas Co., diese Bauart auf. Sie stief auf ein Patent von S. Hutchinson vom Jahre ${ }^{18} 33$, das aber, beanstandet, nicht aufrechterhalten wurde ${ }^{n, z}$ ). So lief $\mathrm{G}$. Lowe bei der Gas Light and Coke Company 1836 auch einen Behälter teleskopieren ${ }^{3.57}$ ). Dabei wurde die bis dahin verlangte Umbauung mit einem steinernen Hause fortgelassen.

Die ersten deutschen Gasbehälter hatten alle noch Umbauungen, gleichgültig, ob sie von der englischen Gasgesellschaft oder von $B l o c b m a n n$ ausgeführt wurden. Der erste deutsche Behälter mit Teleskop ist 1846 von Blochmann in Berlin gebaut worden. Dieser war aber umbaut. Die Geschichte der Berliner Gaswerke $^{3.44}$ ) gibt ein anschauliches Bild, wie die Schwierigkeiten bei der Vergrößzerung der Behälter wegen der Umbauung anstiegen, bis in die So-er Jahre. Anderseits war für Bremen der Zuschlag an Leprince dadurch entschieden worden, dał dieser auf die Umbauung schon damals verzichtet hatte und damit wesentlich billiger sein konnte als Blochmann. Daf wegen des abgeschlossenen Luftraumes die Gefahr der Bildung eines explosiblen Gemisches herbeigeführt wurde, ist damals offenbar nicht im Streite erörtert worden. Wohl aber, dafy an Heizungskosten gespart werden konnte. Für die ersten Behälterheizungen wurde Dampf benutzt.

\subsection{ERZEUGUNGSANLAGEN FÜR ANDERE GASARTEN}

3.4I Ol- und Holzanlagen

Zur Ölgasherstellung benutzte man zunächst die auch für Steinkohlen entwickelten Anlagenteile. Solange man nur schwefelfreie Öle verwandte, konnte die Schwefelwasserstoffreinigung entfallen. Die Formen der immer gufjeisernen Re-

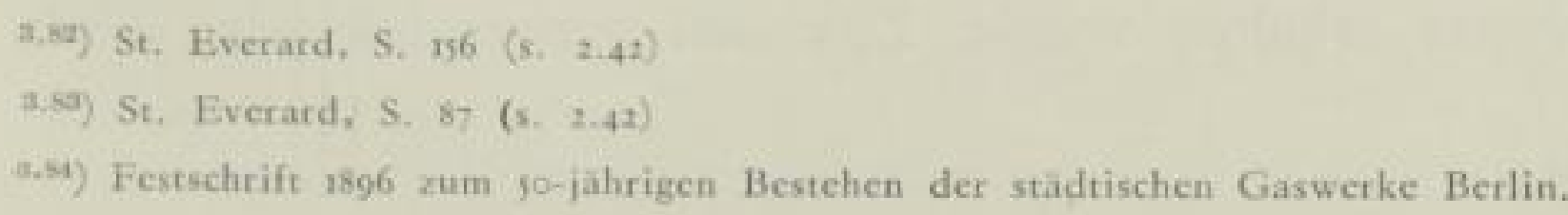




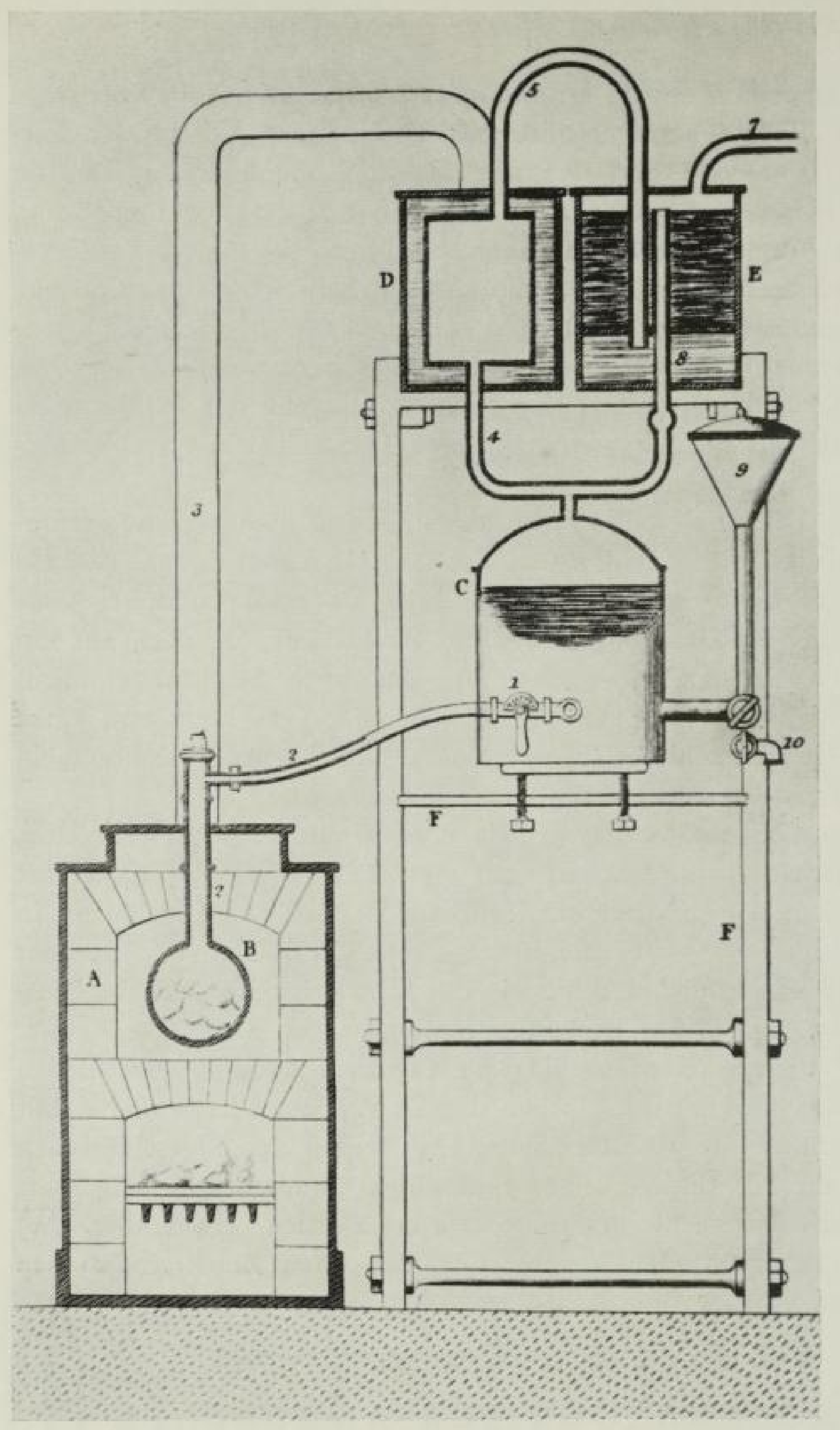

Bild 24

Einfache Ölgasanlage nach Matthews I84I

torten wurden vielfach abgewandelt, (Bild 24) auch mit Zwischenwänden versehen $^{3.55}$ ).

Bei der Holzgasherstellung wurde das von Pettenkofer entwickelte Verfahren, bei niedriger Temperatur zu entgasen und danach in $18 \mathrm{~m}$ langen Rohren das Methan zu spalten, später aufgegeben. Die groł gewählten Retorten wurden nur zu einem Drittel gefüllt, so dał eine hinreichende Fläche zur Zerlegung der Teerdämpfe in der Retorte erhalten wurde. Zuweilen verwendete man noch

3.S5) Muspratt 1893 S. 667 (s. 2.81) 
ein unter der Retorte liegendes rotglühendes Rohr, durch das das Gas zur Reinigung abgeführt wurde.

Die Einrichtungen einer solchen Holzgasanstalt wurden in dem Gutachten über die erste Anlage der Holzgasfabrik in St. Gallen ${ }^{3.50}$ ) beschrieben. Es sind vier Öfen mit je drei Retorten. Erwähnenswert ist das gesonderte Essighaus gleich neben dem Retortenhaus, in dem der erzeugte Holzessig mit Kalk gebunden wird. Dann kommen Kondensationskühler, Wäscher, Sauger, Reinigungsanlagen mit drei Kästen. Eine bemerkenswerte Einzelheit ist es, dał die dort verwandten schmiedeeisernen Rohre teurer seien als sonst übliche Bleirohre.

\subsection{Zusätze zur Verbesserung der Leucbtkraft}

Ursprünglich waren verständlicherweise die Vorschriften über die einzuhaltende Leuchtkraft des Gases sehr ungenau festgesetzt worden. Die Bedingungen, die ja von den Gasfachleuten vorgeschlagen wurden, waren unter den gewählten Kohlensorten und Entgasungsverfahren auch leicht zu erfüllen.

Man setzte oft auf lange Jahre hinaus lediglich fest, daf3 die Leuchtkraft das Doppelte der vorhandenen Ölbeleuchtung sein solle, ohne über die Art und Weise der Feststellung dieser Leuchtkraft genaue Anweisungen in den Verträgen zu verankern.

Allmählich wurden die Abnehmer anspruchsvoller. Kritiken, die Beleuchtung sei unzureichend, waren billig. Zwei gleichzeitig abgefaf̧te Reiseberichte mit der Behauptung, die Beleuchtung in London sei besser als in Paris und umgekehrt, kamen in den 40-er Jahren in die Presse. Im Wettbewerb vor allem in London trieben die Gasgesellschaften ihre Versprechungen in die Höhe, Spitzenleistungen mit bestgeeigneter Kohle wurden als Dauerwerte festgelegt. In den Kohlenanlieferungen und auch durch längere Lagerung gab es aber Verschlechterungen, und so versuchte man schon recht früh, die Leuchtkraft des Gases durch Zusätze zu erhöhen.

Die Versuche, Teer in besonderen Retorten zu vergasen, rührten daher. Gewisse Erfolge wurden erzielt, solange dic Kohlen mit niedrigen Temperaturen entgast wurden und der Teer damit reich an leicht siedenden Ölen war. Verfahren, die die Aufgabe bestens lösen soliten, sind immer wieder erfunden worden, auch als bereits mit Tonretorten die Temperaturen so hoch getrieben waren, dał der Teer keine nennenswerten Mengen leuchtender Kohlenwasserstoffe mehr enthielt. Noch 1889 gab das Patent von J. Dinsmore, Liverpool ${ }^{3.57}$ ) Veranlassung zu neuen umfangreichen Erörterungen in England.

G. Lowe versuchte $184 \mathrm{I}$, hohen Anforderungen an die Leuchtkraft gerecht zu werden, indem er im Hause des Abnehmers oder gar erst an der Lampe Naphthaverdampfer anordnete. Das war offenbar zur Abwehr der reinen Ölgasbeleuchtung gedacht, aber ein recht unvollkommener Ausweg, weil er ja bis zu einem gewissen Grade die Rückkehr zur Öllampe oder Hausanlage darstellte. Man rühmte aber das ,weił̧e“ Licht mit verminderter Wärmeabgabe und geringeren

\footnotetext{
a.50) 1 (1898), $10 / 18$

a.57) $\$ 2$ (1889), 10,36
} 
Kosten (offenbar gegenüber Ölgas) ${ }^{3,4}$ ). Als erster griff der Reformclub danach. Es folgten das Athenäum- und das Parthenontheater und eine Brauerei. 1842 wurde der Buckinghampalast so eingerichtet. Auch mit dieser Einrichtung wurde ein Gedanke in die Tat umgesetzt, der noch viele Erfinder beschäftigen sollte, die - wie so oft - nicht davon loskamen, daf3 die Bauart des „Karburators“ entscheidend für den Erfolg sein könne, der immer ausblieb.

Seit 1844 aber griff man zum Zusatz von Cannelkohle zur üblichen Gaskohle. Cannelkohle war damals schon teuer, und da sie nur in verhältnismäł̧ig kieinen Nestern gefunden wurde, stieg ihr Preis mit der wachsenden Verwendung. Aber selbst deutsche Gaswerke an der Küste glaubten lange Zeit, ohne sie nicht auskommen zu können. Darüber muf im folgenden Hauptabschnitt noch berichtet werden.

Wenn nun schon das Kohlengas durch Karburatoren oder Ölgase aufgebessert wurde, so konnte der Gedanke reifen, als Trägergas Wassergas zu benutzen. Um die hartnäckigen Versuche zu verstehen, diesen Weg zu gehen, muł man sich vergegenwärtigen, dał die Verwertung des Kokses in vielen Fällen schwierig war. Dał man den Koks verbessern könne, ist erst um 1870 allgemeiner erkannt worden. Selbst eine Ausgabelung wurde nur hin und wieder vorgenommen. Als zeitweilig die staatlichen Harzer Hütten sich weigerten, den hannoverschen Koks abzunehmen, hatte das Werk grołe Verluste. Stettin hatte noch in den so-er Jahren kaum einen Koksverkauf. Für Bremen war das Angebot von Leprince, den Koks restlos zu verwerten, entscheidend für den Zuschlag an ihn.

Das Wassergasverfahren war an sich schon früh versucht worden. Lavo isier hatte etwa 1784 an seine erfolgreichen Versuche, Wasserdampf durch Überleitung über glühendes Eisenpulver zu zersetzen, angeknüpft ${ }^{3+3}$ ) und die Rohre mit Holzkohle gefüllt. Dabei erhielt er mehr brennbares Gas als vorher, dessen abweichende Eigenschaften er festgestellt hat $\left.{ }^{5.00}\right)$. Das war wohl die erste Darstellung von Wassergas. Gengembre, Vater und Sohn, erhielten am 26. 4 . 1867 ein Patent über ein Verfahren mit Wasserdampf und Holzkohle. 1824 leitete J. H. I b betson in England Dampf über gluhende Kohlen.

$183 \mathrm{I}$ lief sich G. Lowe, Ingenieur bei der Gas Light and Coke Company den Wassergasprozefy patentieren. Der heiłe Koks aus einer Retorte wurde unmittelbar in einen Generator gestofyen und dann zeitweilig mit natürlichem Zug aufgeheizt, zeitweilig mit Dampf zur Wassergasbildung beschickt. Lowe regte bereits an, das Gas mit den Dämpfen aus leicht flüchtigen Olen oder anderen lichtgebenden Stoffen zur Beleuchtung geeignet zu machen ${ }^{*-{ }^{\prime \prime}}$ ).

Ein Jahr später erbaute M. Jobard aus Brüssel Anlagen zur Versorgung von Dijon, Strałburg und Antwerpen und auch eines Teiles von Paris mit karburiertem Wassergas ${ }^{3.12}$ ). Scine Ergebnisse wurden von Sellig t:e verwertet. Dieser leitete den Wasserdampf durch zwei mit Kohlen gefüllte Retorten und

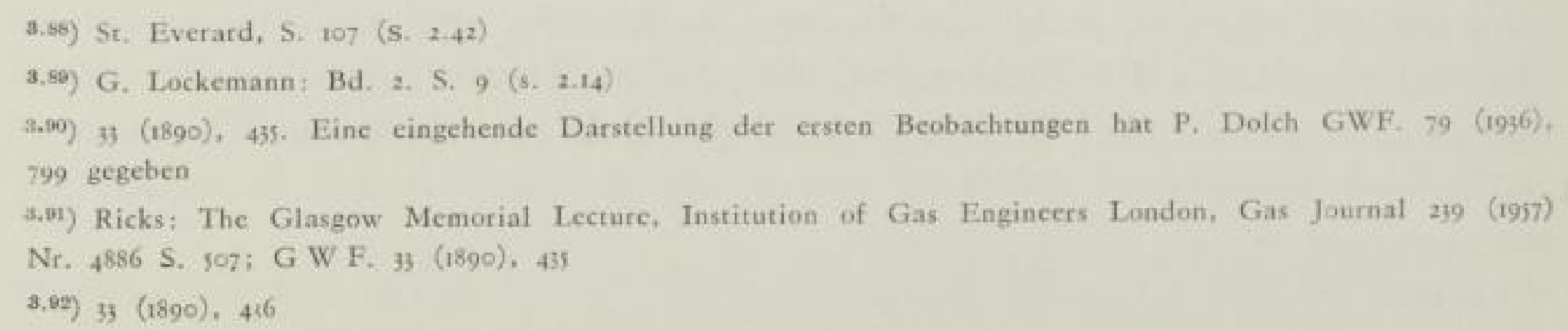


das erzeugte Wassergas durch eine dritte glühende Retorte, in der anfangs Gasöl, später Schieferöl vergast wurde $\left.{ }^{3.09}\right)$. S. W bite änderte das Verfahren dahin ab, dafy er ein Gemisch aus Wasserdampf und Wassergas durch Retorten leitete, worin anfangs Öl und Harz, später Cannel- oder Bogheadkohlen der trockenen Entgasung unterworfen wurden ${ }^{3.04}$ ).

Alle diese Finrichtungen konnten sich aber nicht durchsetzen. Die Schwierigkeiten lagen in einem erhöhten Unterfeuerungsverbrauch und in der Unvollkommenheit der Regelung. Schwankungen in den Temperaturen, Ungenauigkeiten in der Wasserdampfzersetzung und in der Entgasung beeinfluften die Zusammensetzung des Gases sehr.

Unter diesen Mängeln litten auch die Bauarten von Leprince et frères in Luik (Belgien). Dieser hat in Belgien Anlagen in der Simonisschen Tuchfabrik zu Verviers, auf einer Zinkhütte der Vieille Montagne ${ }^{n .05}$ ) und bei Cockerill in Seraing eingerichtet. Eine gewisse Bedeutung hat sein Mischgas in Deutschland gehabt, weil er bei seiner Werbung geltend machte, dał kein lästiger Koks aufkomme $\left.{ }^{a, a v}\right)$. Sein Verfahren ist in Braunschweig, Bremen und Düsseldorf angewandt worden. In Düsseldorf arbeitete die Privatfirma Sinzig \& Co. von 1845 ab bis 1865 , nach seinem Verfahren ${ }^{3.17}$ ). Das ist belegt durch einen Bericht von E. C. Ferrari aus dem Jahre 1853 , der sich im Stadtarchiv von Maastricht befindet, aut Grund dessen die Firma Leprince et frères zu Luik am 26. 2. 1857 einen Vertrag mit der Stadt Maastricht erhalten hat.

Leprince stützte sich auf den Hydrocarbonprozeß von W bite (I850). Die Wassergasretorten wurden mit Koks, Kohlenklein und Sägespänen gefüllt und bis zur Rotglut erhitzt. Dann wurde in ein eingebautes Eisenrohr Wasser eingespritzt, das verdampft den ganzen Raum erfüllte. Leprince nahm in die Wassergasretorten fette Steinkohlen ${ }^{3.05}$ ). In Düsseldorf waren fünf Öfen mit je fünf Eisenretorten zur Entwicklung von Steinkohlen-(Wasser)gas vorhanden und drei Öfen für eine davon getrennte Erzeugung von Harzgas. Auffallend ist in dem Bericht Ferraris, daf, die Leuchtkraft nicht dem gewöhnlichen Steinkohlengas entspräche ( $1: 9 / \mathrm{ro})$, während von Sinzig \& Co, eine höhere Leuchtkraft behauptet wird und diese in Bremen auch festgestellt wurde. Indessen scheint die Zusammensetzung des Mischgases stark geschwankt zu haben. Die richtige Einstellung der Wassermenge und des Zusatzes von Harzgas gelang wohl nicht. So kam es zu Streitigkeiten und in den beiden Fällen nach Ablauf der Verträge zur Umstellung auf Steinkohlengas.

\subsection{Koksmarkt}

Die Absatzmöglichkeit des erzeugten Kokses war sehr unterschiedlich gut. Das lag an örtlichen Verhältnissen und an den schlechten Verkehrsmöglichkeiten.

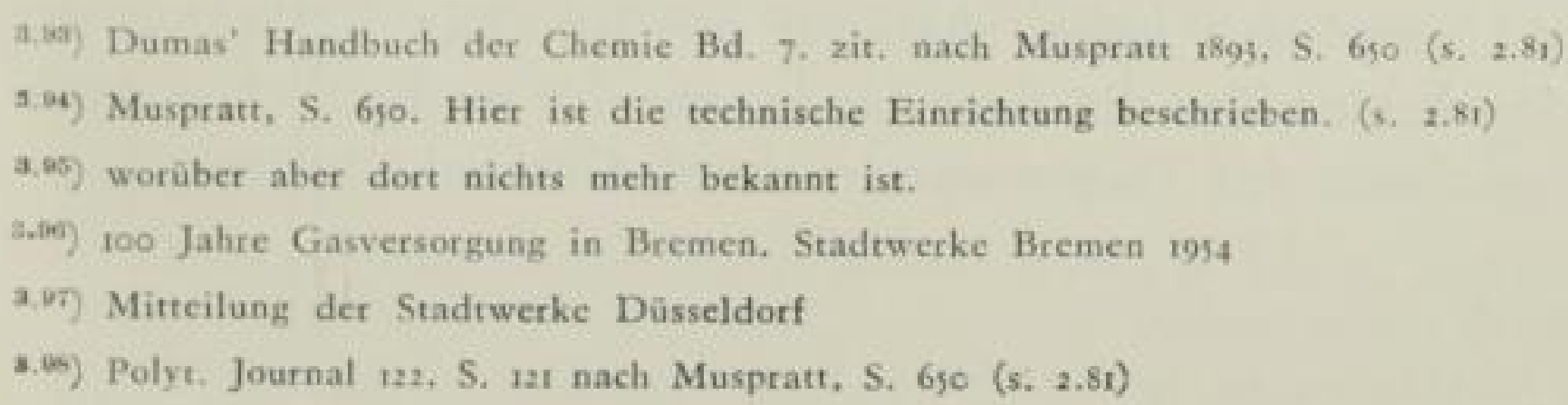


Wie sich das in London ausgewirkt hat, ist bereits im Abschnitt 2.2; S. 78 berichtet worden. In Hannover wurde die Königliche Harzbergbauverwaltung unter leichtem Druck der Zentralstellen veranlaf3t, den gesamten Koks abzunehmen. In Berlin wurde der Koks leicht untergebracht. In Leipzig war zwar die Zwickauer Kohle, auf der Achse angefahren, doppelt so teuer, wie die in Dresden verwendete Kohle, dafür aber auch der Erlös für den Koks doppelt so hoch.

\subsection{Robre}

Auch in der Kunst, Rohrleitungen zu bauen, sind in der betrachteten Zeit keine grundsätzlichen Änderungen vorgenommen. Für Hauptstränge beherrschte Gufeisen die Technik. Es waren noch liegend gegossene, deshalb kurze Rohre, die mit Muffen, Werg und Bleidichtung ineinander gesetzt wurden. In den Anschluf̧rohren herrschte Schmiedeeisen längsgeschweif̧t vor.

Indessen gab es auch Abweichungen von diesem Brauch. Aus Belgien wird berichtet $^{3.09}$, daf selbst Rohre aus Steinzeug, Holz und Sandstein verlegt wurden, von denen sich in Löwen 1878 noch $3 \mathrm{~km}$ vorgefunden haben. In Nordamerika wurden die ersten Rohrleitungen für Erdgas ausschließ̧lich aus Holz hergerichtet. Nachgewiesen ist eine Holzleitung von $\mathrm{I}$ km Länge, die 1826 ein Bohrloch mit dem Leuchtturm von Barcelonahafen (N. Y.) verbunden hat ${ }^{3.100}$ ). Verbleite Blechrohre (Tuyaux Chameroy), die in mit Sand gefüllte Kästen oder Holzschalen verlegt wurden, sind nur in Frankreich angewandt worden.

\subsection{Ferngaspläne}

In seinen Studien ,Zur Geschichte des Ferngas-Gedankens“ ist Fr. Schäfer, Dessau, einer Mitteilung G. M. S. Blochmanns in den Beiträgen zur Geschichte der Gasbeleuchtung nachgegangen, daf bereits 1828 ein Projekt aufgetaucht sei, das Gas auf den Kohlengruben in Staffordshire zu erzeugen und durch eine fast 200 km lange Rohrleitung nach London zu schicken. (Vgl. S. 89)

Es handelte sich um eine Aufforderung zur Zeichnung von 8000 so £.-Aktien einer „Universal Gas Company in London“. Das Gas in Staffordshire erzeugt, sollte durch Rohre entlang der grofen Heerstrafye nach London geleitet werden und teils aus eigenen Behältern der Gesellschaft durch Rohrnetze oder als tragbares Gas an Kleinverbraucher abgegeben, teils an Londoner Gasgesellschaften verkauft werden. Kohlen und Löhne würden billiger sein als in London, Koks könne sicherlich in dem angrenzenden lndustriebezirk, wo sich bereits ein guter Markt entwickelt habe, abgesetzt werden. Die Verlegung der Erzeugung aus London heraus löse die Beanstandungen der medizinischen Autoritäten über die Verseuchung des Themsewassers durch Gaswerksabwässer.

\footnotetext{
3.90) M. Brabant, Rev. Gén. du Gaz 71 (1949), 8

3.100) Am. Gas. Ass. Public Inf. Bureau Nr. 34 
Wirtschaftlich war der Zusammenhang wohl richtig erkannt. Die technische Ausführbarkeit mit den zur Verfügung stehenden technischen Mitteln wurde schon durch einen Zeitgenossen bezweifelt ${ }^{\text {s.101 }}$ ).

\subsection{Robrnetzberecbnung}

Für Rohrnetze, die höher gelegene Gebiete versorgen, verlangte S. Clegg I84I Druckregler, um zu hohe Gasverbräuche der Pauschalabnehmer und Strałenbeleuchtung zu vermeiden. Sonst sei eine unangezapfte Hauptleitung zu einem Verteilungspunkte zu verlegen, an dem $12 \mathrm{~m} / \mathrm{m}$ Druck erreicht werden müf̧ten. Dort sei ein Speicherzylinder angebracht. Im übrigen brachte er mehrere Seiten mit Tafeln über Gasmenge, Durchmesser und Länge der Rohre, die nach Versuchen und mit Umrechnungen vervollständigt zusammengestellt waren. Auß̧er diesen Umrechnungsformeln wurden keine theoretischen Grundlagen gegeben.

Die noch heute Rohrberechnungen zu Grunde gelegten Formeln sind von J. Weisbach um 1845 aufgestellt. Zahlen für den Reibungsbeiwert wurden 1855 veröffentlicht ${ }^{3.100 x}$.

Die sehr einfache Formel von $P$ ole wurde $I_{5}{ }_{5}$ angegeben und 1852 im Journal of Gaslighting veröffentlicht. Schilling stützte sich r86o auf diese Formel.

\subsection{Gasmessung}

Die Normalform des grof̧en nassen Stationsgaszählers war bereits vor I825 durchentwickelt. Dic kleinen Fortschritte im Aufbau und durch Zutaten sind kaum mehr feststellbar. Selbst der Stil der Ausschmückung wurde einander nachgemacht und wirkt als Normalie.

Festhalten soll man indessen als wertvolle Einzelheit die Konstruktion von Lowe (seit I82r bei der Gas Light and Coke Company), um die Leistung der Arbeiter besonders während der Nachtzeiten aufzuzeichnen. Lowe verband einen auf einem runden Blatt geführten Bleistift mit dem Zeiger einer über dem Zählwerk angeordneten Zeituhr. Die sinusartigen Kurven wurden durch die wechselnde Geschwindigkeit der Umdrehung des Gaszählers mehr oder weniger auseinandergezogen $^{3.109}$ ) und gaben einen Anhalt für die in der Zeiteinheit erzeugte Menge.

Auch die nassen Gaszähler für Abnehmer waren fertig. Heute kann man sich kaum mehr vorstellen, dał sie keineswegs begeistert aufgenommen wurden. Sie gaben vielmehr zu Áuseinandersetzungen mit den Kunden Anlał. Der Pauschaltarif wurde für die Leuchtflammen als ausreichend angesehen, und im Wettbewerb der Gasgesellschaften untereinander wurde der "grołzzügige“ Pauschaltarif gegen die ,kleinliche“ Messung oft genug ausgespielt. Auch die ersten Gas-

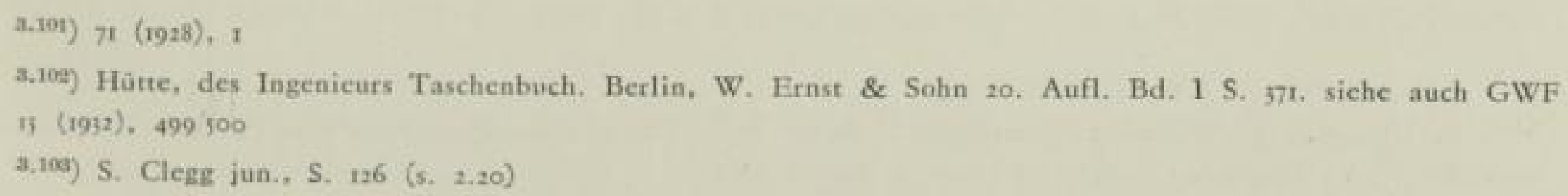


werke der englischen Gesellschaft in Deutschland verwendeten keine Gasmesser. In der Geschichte der Frankfurter Gasversorgung wurde bereits die tödliche Wirkung der Zeittarife erwähnt.

Die Bemühungen, das frostgefährdete Wasser im Messer zu vermeiden, sind verständlich. Als erster scheint A. Croll, ein sehr rühriger und vielseitiger Fachmann, den alten Gedanken wieder aufgegriffen zu haben (um 1850 in London). Aber Erfolg hatte erst Thomas Glover, ursprünglich Ingenieur und Gelbgief̧er in Leith, als er Schieber mit Kurbelantrieb einführte (I844). Er hatte einige Jahre mit Croll (und Richards) zusammen gearbeitet, trennte sich dann aber von ihm. Mit den runden Balgen, die die zwei Kammern in zwei Mef\}räume aufteilen, war auch die Form gegeben, die bei vielen Messern, insbesondere in Nordamerika noch heute unverändert üblich ist. Trotz der hohen Vollkommenheit, die damit erreicht war, setzten sich diese Art Messer erst langsam durch. In Frankreich waren sie noch 1870 durch einen Erlał der Präfekten (arrêté préfectoral) verboten ${ }^{3.100}$ ). Hauptschwierigkeit machte die Auswahl des Leders und seiner Imprägnierung, die erst langsam in mühseliger Arbeit verbessert wurde. 1847 gründete C. Turner die Diaphragm and General Leather Co. Ltd. Er führte ostindische Schafleder als Membranstoff ein.

\subsection{G A S V E R W EN D U N G}

3.6r Brenner

Die Leuchtbrenner entsprechen in ihren Grundanordnungen noch um 1860 den Formen, die bereits in den ersten Jahren der Gastechnik entwickelt worden waren. Neu war der Fischschwanzbrenner mit zwei unter einem Winkel gebohrten Öffnungen, so dał die Gasstrahlen sich unmittelbar oberhalb der Austrittstellen treffen. Die Flammenfläche steht dann senkrecht zur Ebene der beiden Strahlen. Sie sind unempfindlicher gegen Druckschwankungen als flache Schmetterlingsbrenner, weil ein Teil der Ausströmungsenergie vernichtet wird.

Mit den ersten Erwägungen, das Gas als Wärmespender zu verwenden, gingen auch Gedanken einher, die Brenner dem jeweiligen Zwecke anzupassen. Schon 1824 haben die Aetna Iron Works in Liverpool an den Schwenkbrenner gedacht. Das Kochgerät bestand aus einem alten Flintenlauf mit vielen Löchern der Länge nach. Wenn etwas gebraten werden sollte, wurden die Flammen waagrecht geführt, sollte dagegen geröstet werden (gegrillt), so wurden sie senkrecht gestellt. ein Zinnblech wurde als Spiegel hinter die Flammen gebracht.

Auch die Entwicklung des Bunsenbrenners fällt in diesen Abschnitt. Schon Prechtl war es, wie erwähnt, bekannt, daß̧ die Zufuhr von Luft zum Gas vor der Verbrennung eine heife, kurze entleuchtete Flamme ergab. (S. 94/95)

M. F a raday hat in den ,Chemischen Manipulationen oder das eigentlich Praktische der sicheren Ausführung chemischer Arbeiten und Experimente ${ }^{(4.105}$ ) einen 
Brenner beschrieben. An dem Brennerrohr ist ein Konus aus Messing- und Kupferblech an drei bis vier Armen so befestigt, dał er auf- und abwärts geschoben werden kann. Das obere Loch ist etwas gröfzer als das Brennerrohrende. Schiebt man den Konus nach unten, hat man eine leuchtende Flamme. Hebt man ihn an, so erhält man eine Entleuchtung. Eine entsprechende Einrichtung ist auch für Argandbrenner beschrieben. Von einem den Konus abschlief̧enden Drahtgewebe ist keine Rede. Das erste Patent auf einen Heizbrenner mit Luftzufuhr durch ein Gebläse wurde an $M$ a ll e $t$ 1833 erteilt ${ }^{3,100}$ ). Zwei Jahre später wurde von Robinson in Edinburg ein Kochbrenner herausgebracht, bei dem ohne ein Gebläse eine Zumischung von Luft zum Gase vor der Verbrennung erfolgte: Ein unten offener, oben durch ein engmaschiges Drahtgeflecht abgeschlossener Hohlkegel aus Blech stand auf drei niedrigen Füßzen und umfaß̧te ein in etwa einem Drittel der Höhe frei endendes Gaszuführungsrohr. Das Gas strömte frei in den nach oben sich verjüngenden Hohlraum, mischte sich mit der von unten hinzutretenden Luft und verbrannte oberhalb des Drahtgeflechtes mit blauer, nicht rufender Flamme. Der Brenner ist also nur eine besondere Form des von Faraday angegebenen. Da die Luft nur durch das austretende Gas mitgerissen und von unten zutreten konnte, so war damit, was den Mischvorgang betrifft, der Bunsenbrenner angegeben. Allerdings fehlte die Ansaugewirkung des Strahles.

Der Brenner von Robinson war nach und nach in England sehr verbreitet. Er wurde 1848 durch R. W. Elsner Berlin, in etwas veränderter Gestalt (mit mehreren Gasdüsen) und in verschiedenen Größzen und Formen auf den Markt gebracht.

Im Jahre I849 lief̧ sich D. O. Edwards einen Brenner aus einer hohlen Tonkugel, in deren Wandung Löcher gebohrt waren, patentieren. Das Gas wurde in die Kugel eingeführt, erhielt seine Verbrennungsluft durch die unteren Öffnungen, und das Gemisch verbrannte an der Oberfläche des oberen Teiles der Kugel mit einer dünnen gelben Flamme. Edwards beanspruchte für seine „Atmopyre" die Brauchbarkeit in Heizöfen und Kochkammern oder für die Aussendung von Wärmestrahlung. Der Brenner fand eine gewisse Aufmerksamkeit. ein grofjes Gaswerk stellte sogar mit dem Einbau mehrerer Brenner in einem Dampfkessel Versuche an, in der Hoffnung, besonders preiswert Dampf erzeugen zu können ${ }^{\text {a.107 }}$ ). Die Erstluftansaugung ist aber wohl unbedeutend gewesen, wie die Erwähnung der gelben Flamme vermuten läft. Offenbar spielte bei den Versuchen der Glaube eine Rolle, daß̧ man durch geschickte Einrichtungen mehr aus dem Gase an Wärme herausholen könne als mit der offenen Flamme. Der Begriff eines dem Gasgemisch eigentümlichen Heizwertes war dem Erfinder offenbar noch nicht bekannt.

Im Herbst des Jahres 1852 kam R. W. Bunsen als Professor nach Heidelberg. Ihm war der Neubau eines chemischen Institutes bei der Berufung zugesagt worden. $\mathrm{Da}$ in Heidelberg ein Gaswerk vorhanden war, so wollte er seine Laboratorien auf Gasfeuerung umstellen. Das Handbuch für Gastechnik (1916 Bd. 8 S. 3) glaubt, daf3 Bunsen den Elsnerschen Brenner gekannt haben müsse,

9. 105) Hardbuch der Gastechnik Bd. \& S. 2, 1916 Oldenbourg München

a.10n) Gas Journal Centenary 1949 S. 19 
weil er 1854 dem Mechaniker Des a g a Anleitung und Auftrag gab, einen Brenner zu konstruieren, welcher ohne Anwendung von Drahtnetzen imstande sei, das Gas mit atmosphärischer Luft gemischt „zur Verbrennung zu bringen, um dadurch eine vollkommen ruffreie Verbrennung zu erzielen ${ }^{4.3,109}$ ).

Ebenso viel Wahrscheinlichkeit hat aber auch die Behauptung von Bilt $z$, daf er aus England, wohin Bunsen lebhafte Beziehungen hatte, einen Argandbrenner, wie ihn Faraday 1828 für Laboratoriumszwecke beschrieben hat, oder auch einen Brenner von Edwards erhalten hat. Von diesem kann man ohne weiteres glauben, was Lockemann ${ }^{3,100}$ ) weiter schreibt: „Er gab zwar eine nicht leuchtende Flamme, aber diese war unstetig, sehr groł und nicht zu regeln. Durch die starke Mischung des Gases mit Luft (hohem Luftüberschuf, insbesondere bei Kleinstellung) war die Flammentemperatur sehr niedrig."

So kam der Auftrag an Desaga zustande. „Nach vielen Versuchen gelang es endlich, einen Brenner zu konstruieren, welcher den Anforderungen entsprach, und zu Ostern 1855 war das...... Laboratorium...... mit 50 solchen Brennern versehen. Ende des Jahres war bereits eine grołe Anzahl ,nach allen Richtungen " verkauft."

Nach diesem Bericht ist oft gesagt worden, der eigentliche Erfinder des Brenners sei Desaga gewesen. Wenn man sich aber mit der Person Bunsens beschäftigt und seine Leidenschaft kennenlernt, immer wieder die Apparaturen in seinem Laboratorium besser brauchbar und einfacher herzustellen, wird man ihm den Hauptanteil des Gedankens nicht ernstlich streitig machen wollen - nämlich die gute Strahlpumpe mit immerhin 10\% Wirkungsgrad herzustellen, damit eine ausreichende Gemischaustrittsgeschwindigkeit zu erhalten und auferdem den Erstluftzutritt bis zur Leuchtflamme zu regeln. Am ersten Modell befand sich unten die Strahlpumpe in einem hohlen Würfel mit vier waagerechten Bohrungen, die zugestopft werdien muften. Die zylindrische Ausführung mit Schieber ist erst später ausgebildet.

Ebenso wird auch die Vermutung des Handbuches für Gastechnik ${ }^{9,110}$ ), Bunsen habe die gewaltige Tragweite seiner Erfindung für die Heizung mit Gas nicht vollauf gewürdigt, weil er weder Patente noch sich an der weiteren Ausgestaltung beteiligte, dem Charakter Bunsens nicht gerecht. Bunsen hat überhaupt keine Patente genommen, auch nicht auf seine chemischen Verfahren. Als wissenschaftlicher Forscher fühlte sich Bunsen durch den Erfolg seiner Arbeit auf den jeweiligen Forschungsgebieten voll entlohnt. Durch manchmal allerdings lange hinausgeschobene Veröffentlichungen machte er sie ohne Vorbehalt allgemein bekannt.

Jedenfalls war die Freiheit, die Bunsen der Ausbeutung der Erfindung ließ̧, ein Geschenk für die Gasindustrie. Nicht nur Desaga, auch Elsner, der den Fortschritt schnell für seine Geräte übernahm, entwickelte den Brenner zu vielgestaltigen Formen weiter. Das taten auch Pettit \& Smith, London 1856 und später andere Firmen.

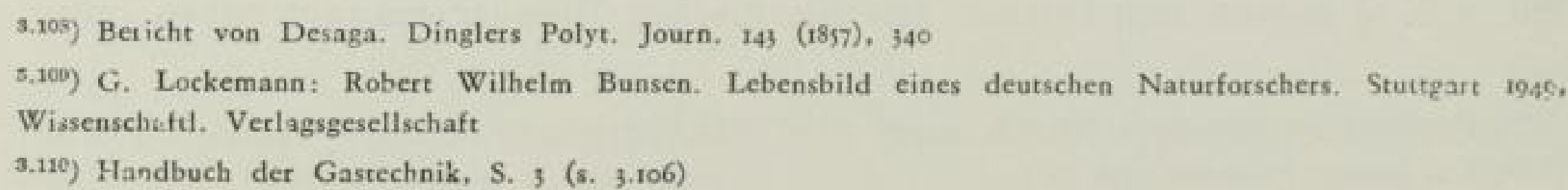




\section{LE B E N S B I L D}

Robert Wilhelm Bunsen (I8II-1899) ${ }^{3.11}$ ) als Sohn eines Universitätsprofessors und Bibliothekars (dessen Vater und Groß̧vater Münzmeister gewesen waren) am 30. März 18II in Göttingen geboren, besuchte Bunsen das Gymnasium in Göttingen und in Holzminden und studierte von Ostern 1828 ab in seiner Vaterstadt Chemie (bei F. Stromeyer), Physik, Mineralogie, Geologie und andere naturwissenschaftliche Fächer und promovierte als Zwanzigiähriger zum Dr. phil. Er machte dann $1832-1833$ eine anderthalbjährige Studienreise durch Deutschland (bis Berlin), Frankreich (mit längerem Aufenthalt in Paris), die Schweiz, Tirol und Österreich (bis Wien), auf der er als rüstiger Wanderer weite Strecken zu Fuß zurücklegte, viele technische Anlagen besichtigte und mit einer grofen Zahl bedeutender Persönlichkeiten in nähere Berührung kam. Nachdem er sich dann I834 in Göttingen als Privatdozent der Chemie habilitiert hatte, übernahm er nach dem Tode seines Lehrers Stromeyer (gestorben 18. August 1835) vertretungsweise dessen Vorlesung und die Leitung des Laboratoriums. Im folgenden Frühjahr (I836) wurde er bei der Berufung W ö blers nach Göttingen dessen Nachfolger an der Höheren Gewerbeschule in Kassel. Durch eine Explosion beim Arbeiten mit der "Cadetschen Flüssigkeit" zog er sich (am 9. Nov. 1836) eine schwere Schädigung des rechten Auges zu, was ihn aher nicht hindern konnte, die äuf̧erst beschwerliche und gefahrvolle Arbeit zu Ende zu führen. Weiter hat er sich auf dem Gebiete der organischen Chemie nicht betätigt. Sein ganzes Interesse galt den mit Mał, Zahl und Gewicht zu verfolgenden Vorgängen. Wir haben in ihm einen Hauptbegründer der physikalischen Chemie zu sehen. Im Herbst 1839 an die Universität Marburg berufen, beteiligte er sich im Jahre 1846 an einer von der dänischen Regierung veranlaf̧ten geognostischen Forschungsreise nach Island. Nachdem er dann noch drei Semester an der Universität Breslau gewirkt hatte, folgte er im Herbst 1852 einem wiederholt an ihn ergangenen Ruf nach Heidelberg, und dort ist er als eine der gröften Zierden der Ruperto-Carola bis an sein Lebensende (IG. August 1809) geblieben. In Heidelberg ist ihm auch 1908 ein grofjes würdiges Denkmal errichtet worden. In der „Deutschen Bunsen-Gesellschaft für angewandte physikalische Chemie“ ist dem großen Forscher eine lebendige wissenschaftliche Ehrung zuteil geworden.

Von seinen überaus zahlreichen wissenschaftlichen Arbeiten seien hier nur diejenigen erwähnt, die das Gasfach mittelbar oder unmittelbar betreffen. Der Hauptteil der Arbeiten dieses Forschers lag aber auf dem Gebiete der Anorganischen Chemie.

Die Untersuchung von Eisen- und Kupferhochöfen 1838 und 1840 führte zu den gasanalytischen neuen Verfahren. Die gasometrischen Methoden, Braunschweig 1857, enthielten neben der eigentlichen Analyse auch die Bestimmung des spez. Gew. (Dichte) durch Ausströmungsvergleiche, die der Absorption und Diffusionsvorgänge durch poröse Körper, der Verbrennungswärme, Berechnung der Temperaturen und Entzündungstemperaturen von Gasgemischen. 1866 wurden

2.m, Ithernommen nit Finwilligung des Verfassers aus: G. Lockemann, Geschichte der Chemie. Sammlung Göschen Bd. 265 a S. 52/53. Für eine ausführliche Darstellung wird verwiesen auf G. Lockemann, Robert Wilheim Bunsen: Lebensbild eines deutschen Naturforschers, Stutrgart 1949. Wissenschaftliche Verlagsgesellschaft 
die Arbeiten über die Flammenreaktionen (Zündgeschwindigkeit) veröffentlicht. Das Photometer wurde 1842 beschrieben, der Bunsenbrenner 1855 zuerst angegeben.

3.62 Gas als Wärmespender

Obwohl schon Lebon, Winsor und Lampadius von der Möglichkeit, die bei der Gasverbrennung fühlbare Wärme auszunützen, sprachen, und obwohl Accum einige Anwendungen durch Handwerker erwähnt, ist diese Art der Gasverwendung nicht über Versuche hinausgegangen.

3.62I Gas in der Küche

Am zahlreichsten sind die Anläufe, Gas zum Braten, Backen und Kochen zu benützen. Der Brenner der Aetna-Werke aus dem Jahre 1824, der zum Rösten und Braten dienen sollte, wurde schon erwähnt (S. I52). Er war nicht viel mehr als ein offener Brenner. Chandler \& Lacey ${ }^{3.112}$ ) haben viele Hinweise auf erste Ausführungen solcher Geräte zusammengetragen. Ein berühmter französischer Küchenchef A. So yer benutzte Gas in der Küche des Reform Club, Pall Mall im Jahre 184r. Dieser prägte das heute noch richtige Werbewort: „Ein Gasherd strebt nach größerer Wirtschaftlichkeit, weil die Flamme erst dann entzündet. wird, wenn sie gebraucht wird. Er liefert genau die Menge, die verlangt wird, und kann gelöscht werden, sobald die Arbeit fertig ist." Soyer hat auch öffentlich geworben bei einer Grołbrataktion eines $200 \mathrm{~kg}$ schweren Rindstückes in einem nur für diesen Zweck hergestellten mit Gas beheizten Ofen von $2 X_{\mathrm{I}} \mathrm{m}$ Fläche. Das Beef wurde, nachdem es in 8 Stunden durchgebraten war, im Triumphzug durch die Stadt Exeter getragen. $18 ; 2$ benutzte er Gas wieder in einer Volksküche, die der Wohltätigkeit diente.

Die erste Durchkonstruktion von Herden elfolgte aber erst Ende der 40-er Jahre durch die Ingenicure A. King, J. S b arp. und E. God d ard. Der Herd Kings ist deshalb besonders anregend, weil er im A.ufbau und den Abmessungen den noch heute in England üblichen Herden schon sehr nahekommt (Bild 25). Wie aber die Brenner eingerichtet waren, weiß man nicht mehr.

I851 wurde sogar mit vielen verschiedenen Fabrikaten, die zum Teil auch in Lizenz Kings gebaut zu sein scheinen, eine Gasgeräteausstellung im Polytechnischen Institut in London veranstaltet. Veranlassung dazu war, daf̧ in der Weltausstellung im Kristallpalast die Vorführung der Gasgeräte im Betrieb untersagt worden war.

Obwohl die Anwendung des Bunsenbrenners 1856 (Patente von Pettit und Smith) neue Möglichkeiten boten, haben aber alle diese Bemühungen keinen dauernd fühlbaren Erfolg gehabt. Grund dafür war der noch zu hohe Gaspreis. In der Beleuchtung erzielte man im Wettbewerb von Ollampen und Kerzen leicht einen hohen Preis. Rückwirkend beschränkte aber auch der Preis die absetzbare Menge, 


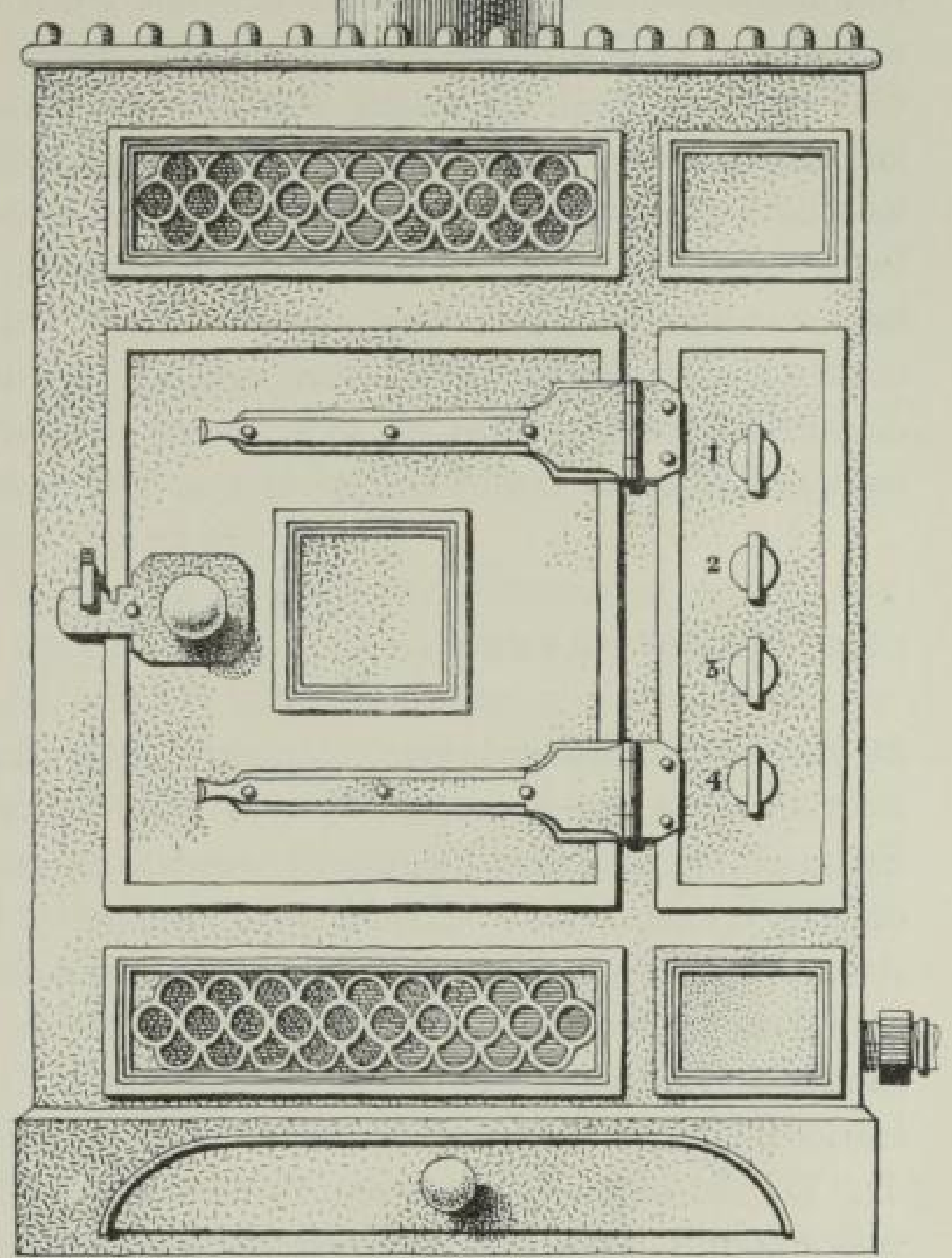

sodaß die Unkostenaufschläge verhältnismäßjig hoch waren. Hinzu kam noch eine deutliche Voreingenommenheit der Bevölkerung gegen neue Kochweisen und gegen Gas. 1833 bezog sich J.O.N. R utt er auf einen Aufsatz im Athenaeum: „Wenige Familicn werden geneigt sein, den schrecklichsten aller Mißbräuche zu dulden, nämlich ein Gasrohr im Hause nur für gelegentliche Benutzung, wie sie beim Hickschen Röstapparat gegeben ist,“ 1846 schreibt derselbe Ingenieur des Gaswerks Brighton ${ }^{\text {s.th }}$ ): „,Für cine lange Zeit, nachdem Gas in allen wichtigen Stadten eingeführt war, wurde der Brennstoff nur für geeignet gehalten, Straf̧en. Läden, Stapelhäuser, Fabriken und öffentliche Gebäude zu beleuchten. Seinc Anwendung in der Eintrittshalle oder dem Treppenhause eines gut ausgestatteten Hauses wurde als verwegener Versuch angesehen. Als Gas trotzdem weiter in das Innere vordrang, in bewohnte Gänge und häusliche Arbeitsräume, da schüttelten manche altmodischen Leute den Kopf, blickten ernst in die Welt und sagten schreckliche Folgen voraus. Diese Befürchtungen und Vorhersagen sind verschwunden. Wo noch in dunklen Winkeln solche Gedanken leben, zusammen mit dem Grauen vor Eisenbahnen, Dampfschiffen und elektrischen Telegraphen, sind das Ausnahmen gegenüber dem Vertrauen und der Befriedi- 
gung, die ganz allgemein vorherrschen, wo das Gaslicht einer anständigen Erprobung (fair trial) zugeführt wurde."

Ein bemerkenswerter Umstand der mit dem Vormarsch des Gaslichts zusammenhängt, ist der folgende: „Von den vielen Tausenden von Menschen, die das Gas nahmen, weil sie es für ihr Geschäft als unentbehrlich sahen, hat bis vor kurzem nur ein kleiner Teil es für gleichermaß̧en notwendig für die Bequemlichkeit und das Behagen ihrer Familien angesehen."

In den andern Ländern, insbesondere auch in Deutschland, ist die Entwicklung kaum anders gewesen. Bei der Entwicklung der Brenner ist Elsner bereits erwähnt. Er scheint, Heizgeräte jeglicher Art ausgeführt zu haben. Auch unter den Privilegien in Wien ist sein Name genannt. Es ist aber leider nicht festzustellen, wie diese ersten Geräte nun in Wirklichkeit ausgeführt wurden.

3.622 W a r m wasserbereitung

Mit der Warmwasserbereitung ging man noch langsamer voran. In der ersten Zeit scheinen nur gelegentlich, rein handwerklich, einzelne Erhitzer von festen Brennstoffen auf Gas umgestellt worden zu sein. Das Bad im Hause war auch in der ersten Hälfte des Jahrhunderts kein Bedürfnis. Eine kennzeichnende Anmerkung findet sich 1842 im Magasin of Science and School of Arts ${ }^{3.114}$ ), daf, man Baderäume nunmebr als ein Bedürfnis in allen neuzeitlichen Häusern von gewisser Größje ansehen müsse, wie auch in Clubräumen, Hotels und Krankenhäusern. Dabei wird auch erwähnt, daf man neuerdings dazu überginge, neben der Wanne einen gesonderten Ofen aufzustellen, dessen Wasser in freier Umwälzung mit dem Bad in Verbindung stände. Wenn die richtige Temperatur erreicht war, mußte das Feuer gelöscht werden.

1850 behauptet $D$ efries, daf3 er mit seinem „Magic“-heizer mit Gas in $6 \mathrm{Mi}$ nuten ein Bad für 2 Penny herstellen könne, eine Leistung, die allerdings keineswegs geglaubt werden kann. Der Brenner war mit Leuchtflammen einfach unter die Badewanne gesetzt. Von seiner Bewährung ist nichts bekannt.

3.623 Raumheizung

Die Raumheizung konnte sich bei den üblichen Gaspreisen ebenfalls nicht durchsetzen, obwohl schon sehr frühzeitig erfindungsreiche Köpfe an der Aufgabe arbeiteten. Luftheizer, meist mit einem inneren Luftzylinder, der von auf̧en mit Gas beheizt wurde, sind 1832 (R. B arnes), 1838 ( $H$ a d d e $n$ \& Jobnson) und später noch $C$ rossley patentiert worden. Der unter Brennern erwähnte Tonkörper von Edwards sollte nach dem Willen des Konstrukteurs strahlend auch zur Raumheizung benützt werden. Ab 1850 gingen Bemühungen, die offenen Kohlenfeuer durch aufgeheizte Brocken feuerfesten Stoffes nachzuahmen. Drei Jahre später kam die Firma Smith \& Phillips, von denen gesagt wird, sie seien wohl die ersten guten Konstrukteure gewesen, mit gläsernen Glühkörpern heraus.

s.116) Gas Journal Centenary 1949 S. 120

158

\section{SLUB}


Die Aufnahme dieser Nachahmungen des Kohlenfeuers war aber wenig freundlich, weil mit Leuchtflammen die Verbrennung unvollkommen war und bei schlechten oder ganz fehlenden Abzügen der Geruch die Leute belästigte ${ }^{\text {a.11" }}$ ). Der bereits mehrfach erwähnte $E l$ s ner, Berlin, hatte die Domkirche in Berlin mit abzugslosen Gasheizöfen ausgerüstet, die den Raum bei $-2^{\circ}$ Réaumur auf Io- $\mathrm{II}^{\circ}$ R. zu erwärmen vermochte ${ }^{3.110}$ ). „Der Geruch des verbrannten Gases war beim Eintritt in die Kirche bemerkbar, fiel jedoch bei längerem Aufenthalt in derselben nicht mehr auf und veranlafjte nicht einmal Husten während des Gottesdienstes. Anfänglich schlug sich der durch Verbrennen des Gases und das Ausatmen der cirka 2000 Personen starken Gemeinde gebildete Wasserdunst an den Fenstern nieder, später war selbiger an Wänden und Säulen bemerklich, welches sich jedoch nicht bis zum Herabtropfen steigerte. An den Goldverzierungen war kein nachteiliger Einfluł bemerkbar."

Auf Grund dieser damals als befriedigend angesehenen Ergebnisse wurde 1857 die St. Katharinenkirche in Hamburg ebenfalls mit Elsnerschen Ofen ausgerüstet. Uber den Ofen heif̧t es: „Das Gas wird in einen Behälter geleitet, wo es sich mit Luft vermischt und dann über einem Drahtsieb verbrennt. Das Verbrennen geschieht ohne Rauch, Ruf̧, mit nichtleuchtender Flamme und möglichst starker Hitzeentwickelung. Hierfür forderte Elsner 170 Rthr. das Stück."

Noch weniger als bei diesen ersten Geräten kann man für gewerbliche Verwendungszwecke von einer sich entwickelnden Industrie sprechen. Eine Ausnahme kann die Berliner Firma R. W. Elsner, die bereits erwähnt wurde, gewesen sein. Eine Anzeige dieser Firma mit ihrem grofen Arbeitsprogramm wird als Faksimile beigefügt (Bild 26). Elsner hat sich aber nicht durchsetzen können ${ }^{3.117}$ ). Er hat wenig Absatz gefunden. Ein Schlauchbügeleisen wird gerühmt ${ }^{3.19}$ ), das aber kaum vollkommene Verbrennung erzielt haben dürfte. Noch immer stand fast nur die Beleuchtung im Mittelpunkt der Anteilnahme der Fachleute. Die mehrfach angezogenen Fachbücher jener Zeit, Clegg und Schillings Fiandbuch behandeln ausschlief̧lich dieses Gebiet der Gasverwendung.

\subsection{SCHLUSSBETRACHTUNG FÜR DIESEN A B S CHNIT T}

Wir trafen schon darauf, wie die Klcinstaaterei mit ihren schlechten Verkehrsverbindungen und Zöllen, die wirtschaftliche Ausnützung der neuen Beleuchtungstechnik erschwert hatte. (vergl. Abschnitt 3.I4). Dazu kam noch das Durcheinander mit Maß̧en und Gewichten und mit den Währungen, das den Handelsverkehr und den Gedankenaustausch der Techniker behindert hat.

Erhalten sind zwei Gutachten ${ }^{3.10}$ ) George Lo we über die Werke in Hannover und Berlin aus dem Jahre 1828. Lowe bekennt, dał er einen Vergleich mit den

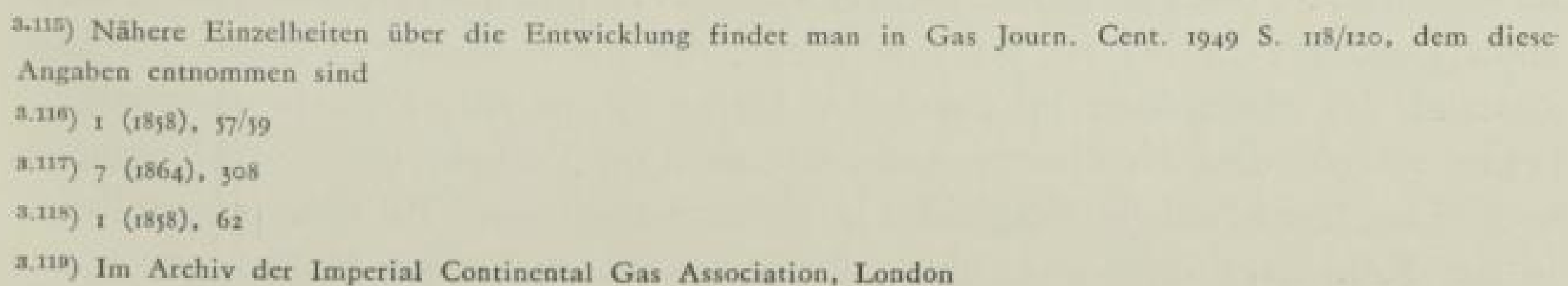




\section{Journal für Gasbeleuchtung} und

verwandte Beleuchtungsarten.

\begin{tabular}{|c|c|}
\hline \multicolumn{2}{|c|}{$\begin{array}{l}\text { Monatschrift } \\
\text { redigirt von }\end{array}$} \\
\hline 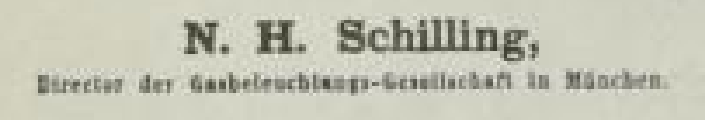 & 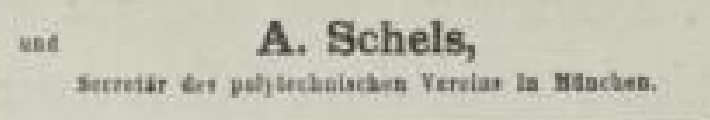 \\
\hline 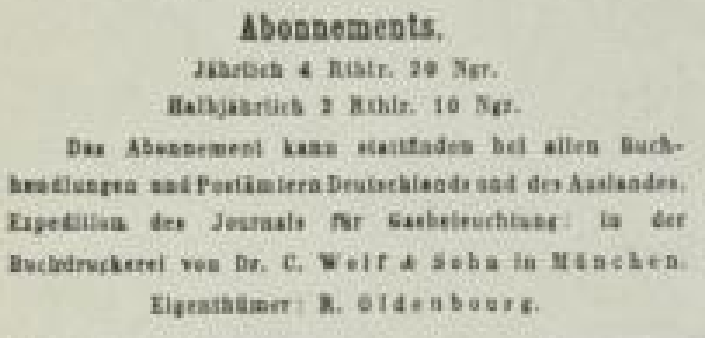 & 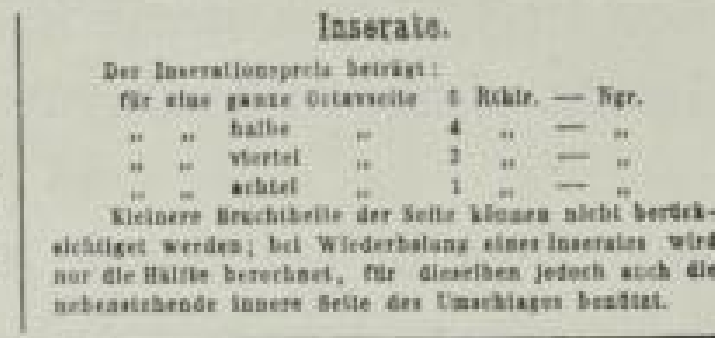 \\
\hline
\end{tabular}

Das Institut

zur allgemeinsten Anwendung brennbarer Gase für den Haushalt, für die Technik wie für die Fabrikation

\section{Th. W. E I s mer \\ Berlin}

Zimmerstrasse $\mathrm{Nr}, \mathbf{7 8}$, empfiehlt sein Lager

Tranaportabler Gas-Koch-Apparate der verachiedensten Construction und Gruase, is Blech, Measing und Gusseisen, einfach und elegant lackirt und broncirt, Platesus und Aufatze mit mehreren Bremeern, Rechanda und Thee-Comforts in gtösster Auswibi. Gas-, Koch-, Back- und Brat-Heerde in allen Grössen, fit einen Have and von 10 bis 50 Persogen, mit Vorrichtangon zum Kaffenbronnen, Erhitzen der Platteisen, Spiegal- und Planuesbratifen.

Gas-Heiz-Oefen und Kamine in einfachen und eleganten Formen, zur Heizung kleiser und grossor Wohns, Schlar. und Garcerobenximmer, Corridors, Salonn, Conceriall- und Versammlungsale, insbegondate aber fur Kirdeben jeder Grosso:

Ktrchen-Heiz-Kamine, nach eigener Erfindang, welche die Fabrik bisher einxis and allein gefertigt, und, nuf dem Continent zar praktisctien Anwendung gebracht hat. Gasspparate aller Art fur Gewerbtreibende, zum Erhituen der Platt, Bagel. and Brenneisen, fär Hausfrauen, Sehneider, Hutancher, Frisedrs, Blumivnfabrikanien, Buch-

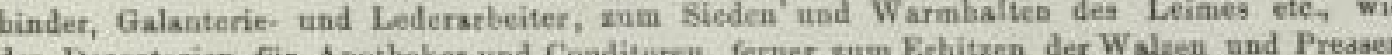

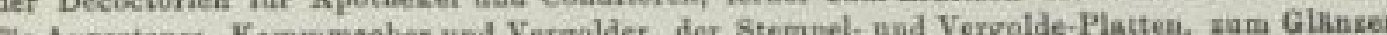

Gello

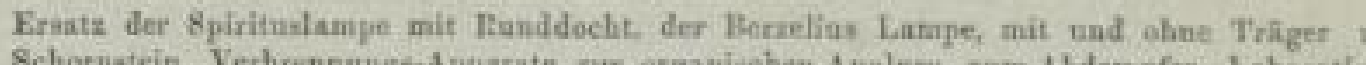

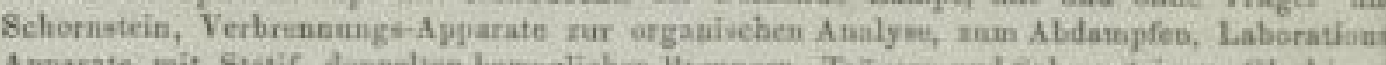

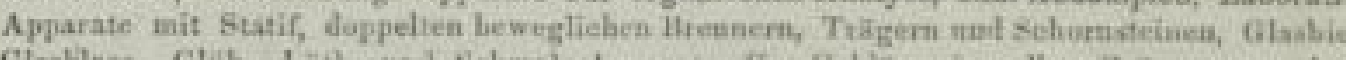

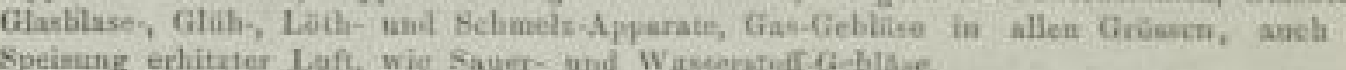
Luft-, Warm-Wasser-, Dampf-, Douche-, B

Brause-, Sitz - und Reise-

Wärm-Schranice mit Gasheizung, zum Warnhalien van gpeisen, xur Erwit-

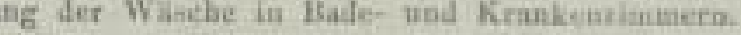

Desinfections-Schränke mit Gasheizung, fïr Strafonataftrin Aduits- und Kroun-

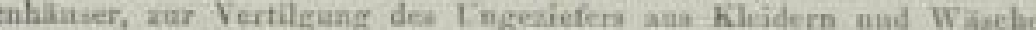

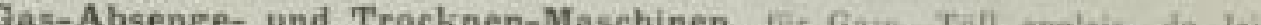

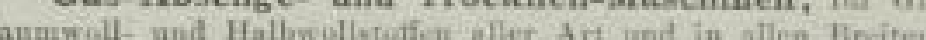

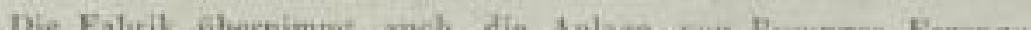

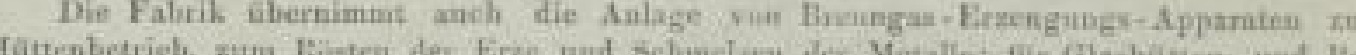

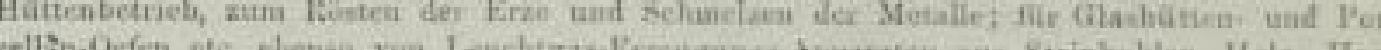

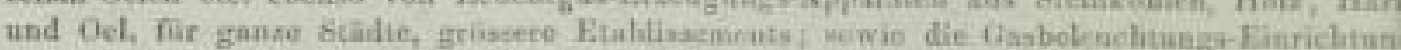

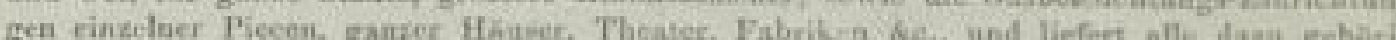

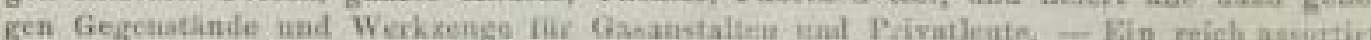

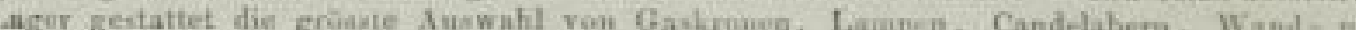

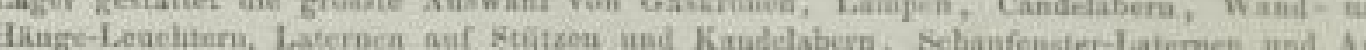

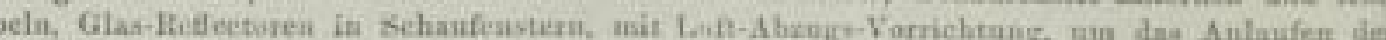

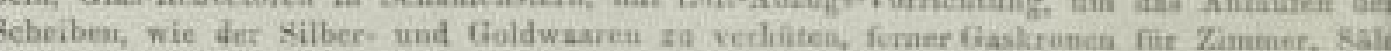
and Theater, mit Ventilatione-Vorrichtang, una die Wirne und verdurbeee Laft als salchep

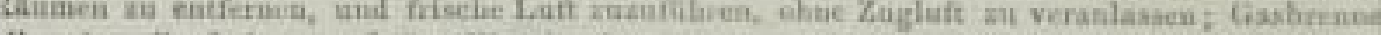

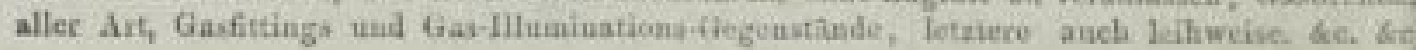

Die Fabrik für Gasbelenchtungs - und Wasser-Anlagen

SCHÄFFER \& W A LCKER in BERLIN

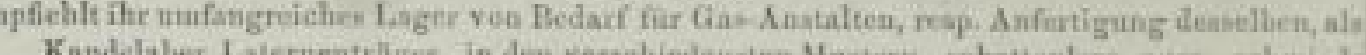

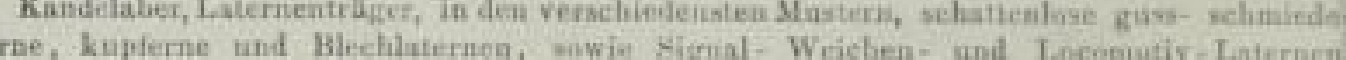

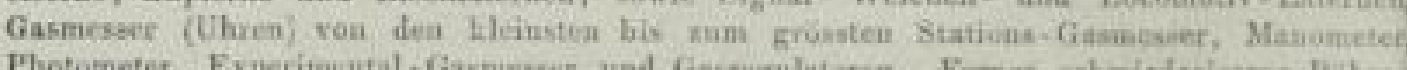

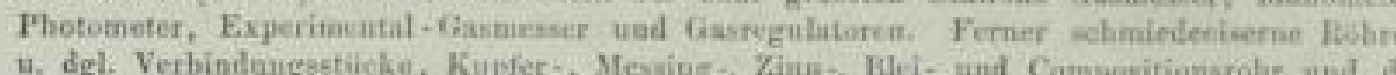

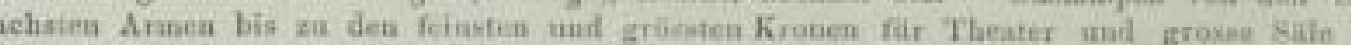

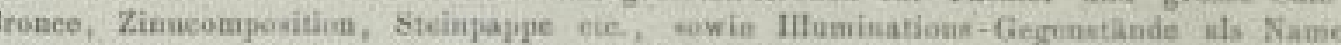

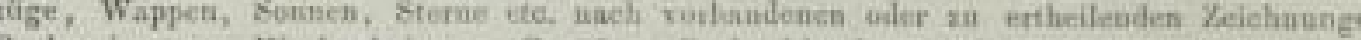

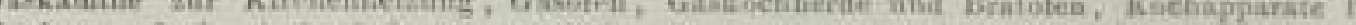

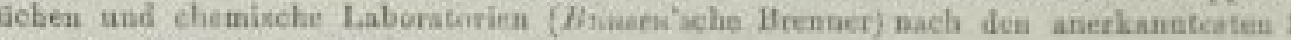

\section{Argand'schen Porzellan-Brenner}

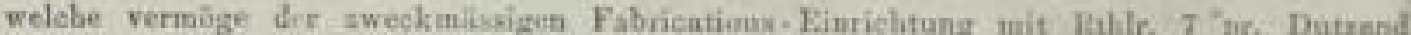

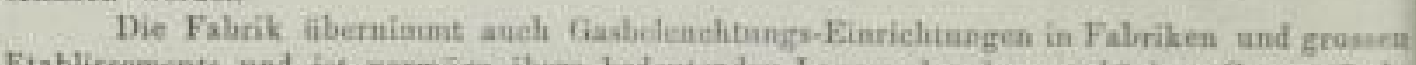

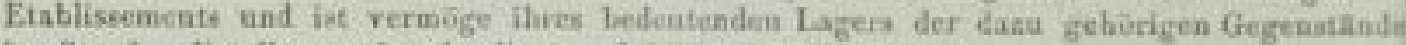

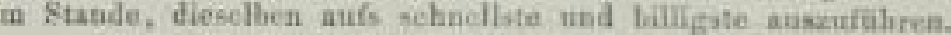

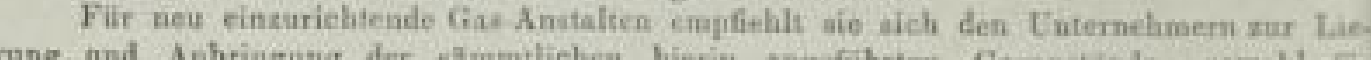

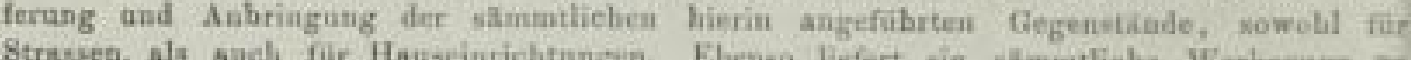

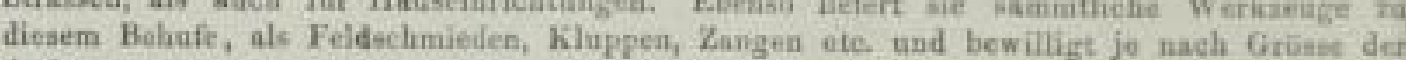

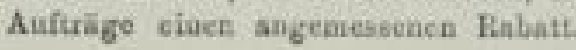

Bild 26 Anzeige der Firmen R. W. Elsner Berlin und Schäffer \& Waicker

(J. f. G. 2 [1859] 209/210

Ergebnissen englischer Werke nicht befriedigend aufstellen könnte. Die Behauptung der Betriebsleitung, daf das in Hannover gebrauchte Mafł eines „balgon", das sonst nicht bekannt ist, dem englischen ,bushel" gleich sei, mufzte er nach den überraschend guten Ergebnissen unter Einsatz dieser Annahme ernstlich bezweifeln. Dabei fällt uns als unerklärlich auf, dał er den Wert des Bushel im Flächenmał (area of square inches) angibt...,W Wie groł eigentlich die Flächc eines Londoner bushel ist, ist eine Frage, die nicht leicht zu lösen ist. Der Zustand der Mef̧größzen im Londoner Hafen ist so schurkenhaft unerfreulich, beides sowohl dem Nennwerte nach, wie auch im Verkehr, dafy es vollkommen nutzlos ist, irgendwelche Vergleiche in Festsetzungen oder Tabellen anzustellen." In der Kohleneinfuhr wurde aber sehr viel nach englischen Maßjen gehandelt.

\section{SLUB}


In Deutschland hatte dazu noch um 1860 jedes Land seine eigenen Maßje. Das Journal für Gasbeleuchtung vom Jahre 1859 bringt eine Tafel für Io verschiedene Cubikfuf̧. Zur Erhöhung der Verwirrung rechneten aber die Gaswerke wegen der von England bezogenen Zähler mit englischen Cubikfuß, ja, in Hannover wurde sogar das englische Mafy in der Eichordnung vorgeschrieben, das vom landeshoheitlichen Maßs nicht wenig abwich. So trifft man denn auch im Schrifttum immer wieder auf Zweifel, welches Landesmał bei eincr Mitteilung gemeint sein könnte.

Die verantwortlichen Ingenieure und Wirtschaftler litten unter diesen Zuständen; man kann sich die Sehnsucht nach der Vereinheitlichung vorstellen, die besonders auf Frankreichs metrisches System schaute.

Hinzu kam die Zersplitterung des Eisenbahnwesens. Wenn etwa der Weg de: Saarkohle durch Baden oder die Pfalz nach dem übrigen Süddeutschland ging, so gab es auf den kurzen Weg besondere Frachtaufschläge, die wie einst in Mittelalter, die Zölle am Rhein, die Frachten so in die Höhe trieben, daf̧ die Kohle wirtschaftlich unverwendbar wurde.

Solche Erfahrungen gaben dem nationalen Sehnen einen sehr nüchternen aber nützlichen Boden. Das äuß̧erte sich darin, dał der I859 gegründete Verein der Gasfachmänner Deutschlands ganz selbstverständlich alle Teile Grołdeutschlands als sein Arbeitsgebiet betrachtete, einschliełlich der mit Österreichs Krone verbundenen Magyarischen und Slavischen Länder. Eine Lösung dieser schweren wirtschaftlichen Behinderung wurde aber bis 1860 noch nicht gefunden. Dagegen deuten zwei Ereignisse darauf hin, daß technisch und wirtschaftlich eine große Umwälzung bevorstand:

1859 wurde in Titusville im Staate Pennsylvania die erste Ölbohrung fündig und die Umarbeitung auf Leuchtpetroleum vorgenommen. Wir erwähnten schon, dał Oechelbäuser sehr früh den billigen Wettbewerber kommen sah und darum, die Entwicklung vorwegnehmend, die Gaspreise senkte. Das war wohl der erste Schritt zur Ausbreitung der Gasverwendung, sofern man nicht die billigen Preise, die in Berlin wegen des Wettbewerbs der englischen und städtischen Gaswerke aufkamen, als den entscheidenden Wendepunkt betrachten will.

Das zweite Ereignis fiel in das Jahr 1860. Es gelang dem Belgier Le no ir am 24. Januar, den ersten Gasmotor, der sich wirklich drehte, als doppelt wirkende waagerecht liegende Maschine zu erbauen. Gewił hatten sich bereits eine Reihe Erfinder mit dem Gedanken abgegeben, aber keinem war bisher ein Dauererfolg beschieden gewesen. Lenoirs Maschine war noch sehr unvollkommen, sie verbrauchte viel Gas für kleine Leistungen. Immerhin war sie eine technisch brauchbare Lösung einer Aufgabe, die damals viele Köpfe bewegt hat, dem Kleinbetrieb, insbesondere dem Handwerk eine Antriebsmaschine zur Verfügung zu stellen, die den gefahrvollen und darum ständiger Wartung bedürfenden Dampfkessel vermeidet. Die Maschine Lenoirs regte aber zu den Versuchen zur Verbesserung an, die vor allem andern dann auch Nikolaus August $O t t o$ gelungen ist. 


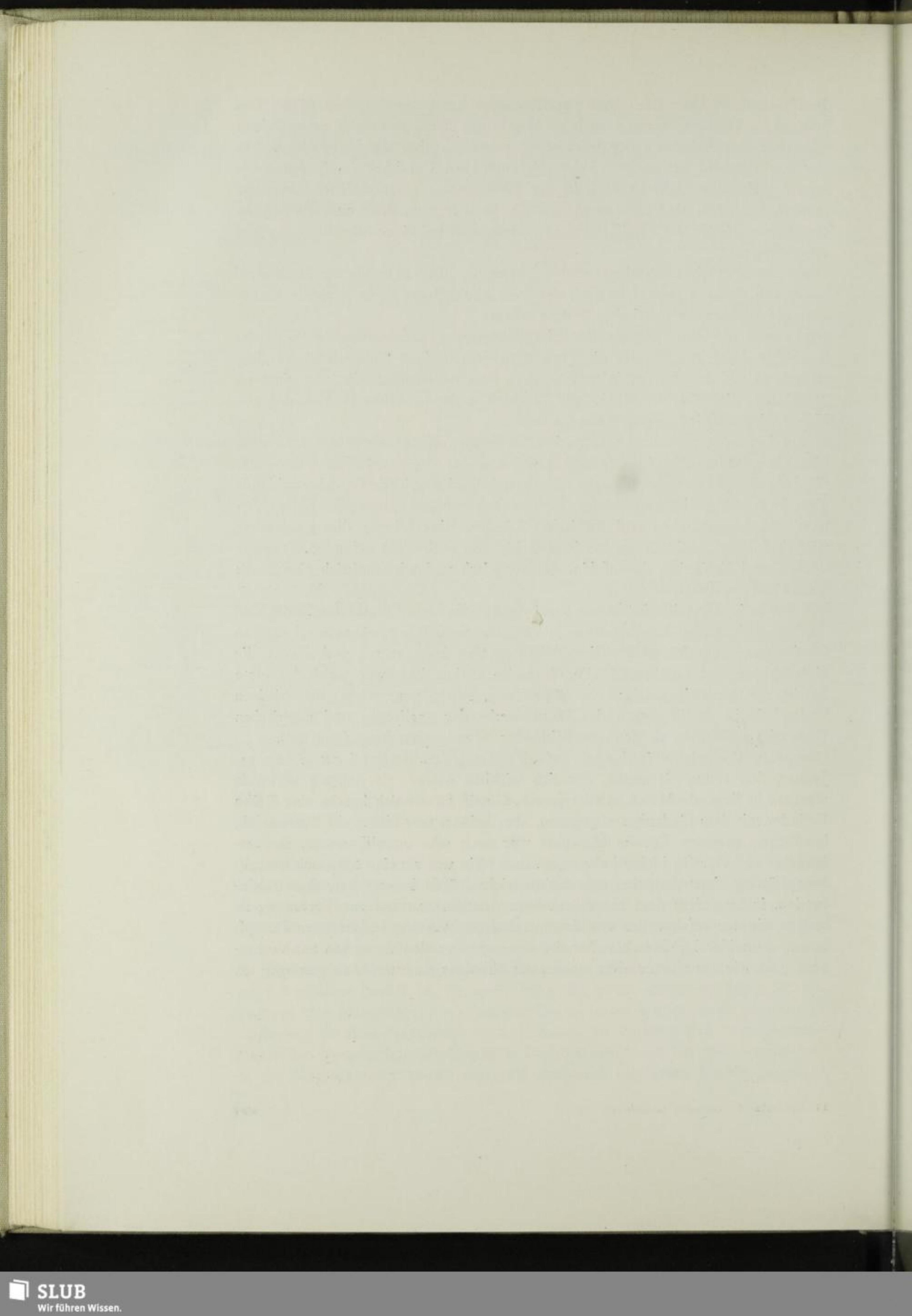




\section{DAS ENDE DES I 9. JAHRHUNDERTS I 860 BIS I 900}

\section{I ALLGEMEINE GESCHICHTE}

Die Begrenzung dieses Abschnittes mit der Jahrhundertwende mag auf den ersten Blick als ein Zugeständnis an eine recht äuferliche Einteilung erscheinen. Sie ist indessen für das Gasfach berechtigt. Denn um diese Zeit begann eine ganz neuartige Bewertung des Gases durch die Einführung des Auerschen Gasglühlichtes. Für die offene Flamme war seine Leuchtkraft, der Gehalt an schweren Kohlenwasserstoffen, małggebend. Dieser gab sehr deutliche Bedingungen für die Auswahl der Kohlen, die Entgasung in kleinen Mengen, die Temperatur des Ofens, die Ausstehzeit und für die Aufbereitung des Rohgases. Gegen Ende des Jahrhunderts wurde mehr und mehr der Heizwert des Gases entscheidend. Es kam darauf an, aus der Kohle eine hohe Heizwertzahl aus Gasmenge mal Heizwert herauszuholen. Die dadurch gegebene Möglichkeit zu wirtschaftlich vorteilhaften Verfahren der Gasherstellung wurde erst in den letzten Jahren des Jahrhunderts erkannt und im 20. Jahrhundert entwickelt. Alles, was bis zur Wende geschehen ist, darf als Vorstufe betrachtet werden.

Schon zu Anfang des vorigen Abschnittes stellten wir fest, dafy um das Jahr 1860 herum die Wissenschaft in der Technik eine bislang nicht erkannte Bedeutung gewann. Jetzt waren auch die Ingenieure da, die überhaupt fähig waren, die Anregungen der Wissenschaft aufzunehmen und in der technischen Entwicklung zu verwerten.

Ganz auffallend ist dabei der Einfluf̧ einzelner Persönlichkeiten. „Teamwork und Masseneinflüsse sind ganz in den ersten Anfängen. Das ist der Grund, warum mehr als in den anderen Abschnitten eine Reihe von Lebensbildern gegeben werden mufy, wenn man die geistige Grundlage dieser Epoche begreifbar machen möchte.

4.II Persönlicbkeiten

Eine Bewertung der einzelnen Männer gegeneinander kann nicht versucht werden. Es ist aber wohl berechtigt, für diese Zeit N. H. Sc billing als ersten zu nennen.

\section{E B E N S B I L D}

Nikolaus Heinrich $S c$ billing $g^{4.1}$ ) (Bild 27) ist geboren am 12. 8. 1826 als Sohn eines Schullehrers in Holstein. Er besuchte vom 12. bis zum 16. Lebensjahr das

4.1) $37(1894), 467$

II* 


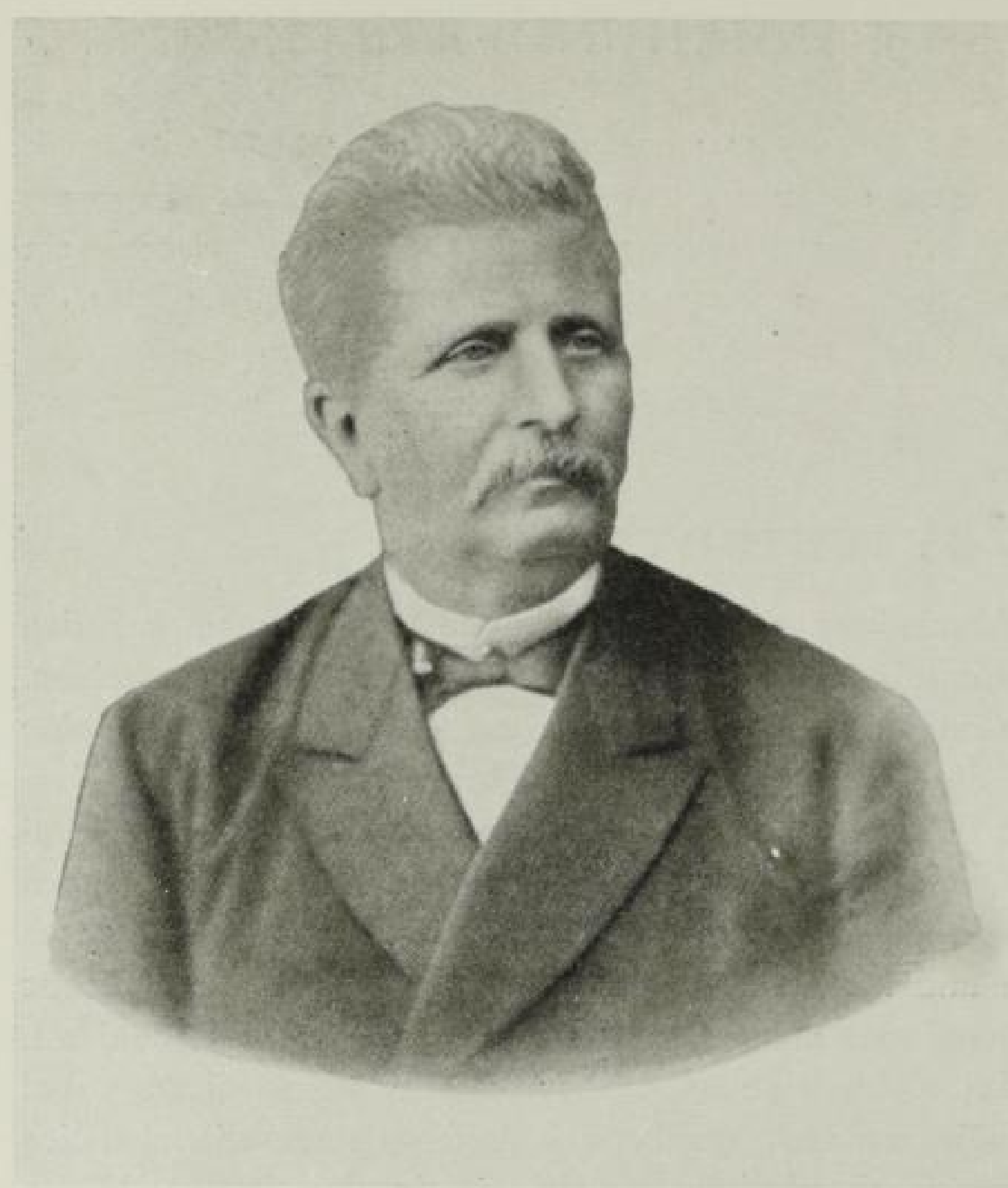

Bild 27

Nikolaus Heinrich Schilling

(Aus ,so Jahre DVGW")

Gymnasium zu Glückstadt. Infolge einer Erkrankung wurde er bis 1843 als Hilfslehrer tätig. Aber diese Aufgabe füllte ihn nicht aus, eine Ausbildung als Geometer vertiefte seinen Sinn für Mathematik. Glücklich war er als ihm sein Vater im Jahre 1844 gestattete das Polytechnikum in München zu besuchen, das er nach vier Jahren mit dem Abschluß̧urteil: „In allen Fächern vorzüglich" verlief. Schilling betätigte sich zunächst als Bauingenieur an Ausbaggerungen und im Eisenbahnbau. 1850 wurde er von der privaten, von Engländern betriebenen Gasgesellschaft in Hamburg als Inspektor für Gasbeleuchtung eingestellt. Diese Aufgaben genügten Schilling offenbar nicht, aber sein Gesuch in der Gasbereitung beschäftigt zu werden, wurde vom englischen Direktor abgeschlagen. Indessen wurde ihm 1856 eine Studienreise nach London bewilligt und bald finden wir ihn als städtischen Beleuchtungsinspektor. Bei dieser Tätigkeit hatte Schilling Zeit und Gelegenheit auch andere Werke zu beraten. Er entwarf die Behälterführung in Itzehoe, beriet Güstrow im Auftrage des Besitzers und war 1857 beratender Ingenieur für den Bau des Werkes in Oldesloe. In dieser Zeit brach seine Neigung zur Schriftstellerei durch. Er bearbeitete ein Beiblatt der Hamburger Nachrichten (Technische und Technologische Bläter) und schrieb auch für Dinglers Polytechnisches Journal. Dadurch reifte bei ihm der Gedanke, daß̧ das Gasfach eine eigene technische Zeitschrift haben müsse. Er schrieb an Professor Kayser in Münschen, der kurz nach Erhalt des Briefes zufällig auch von R. Oldenbourg um Rat gefragt wurde. Professor Pettenko$f e r$ hatte seinerseits Oldenbourg gegenüber geäufert, dał eine Gasfachzeitschrift notwendig sei. Kayser konnte Oldenbourg den Brief Schillings zeigen. 
Dieser war so anregend, dał Oldenbourg nach Hamburg reiste um Schilling zu sprechen. Beide wurden schnell einig und am I. Juli 1858 kam aus Schillings Feder und als R. Oldenbourgs erstem selbständigen Verlagswerk die erste Nummer des Journal für Gasbeleuchtung heraus. Im gleichen Jahre noch wurde Schilling als Direktor der Münchener Gasgesellschaft nach München berufen. Die gründliche Neuorganisation des Werkes brachte zwar viel Arbeit, aber trotzdem hat Schilling sein Journal als Schriftleiter sorgsam betreut. Die ersten Aufsätze sind überwiegend von seiner Hand geschrieben worden. Sie fallen dadurch auf, wie frei und unbekümmert Schilling schreibt. Er nennt ohne Scheu die Dinge, wo auch sein Wissen nicht ausreicht und ist mit der Kritik anderer Beiträge keineswegs zurückhaltend. Aber dadurch erreichte er sein Ziel, eine lebhafte Beteiligung der Fachgenossen zu wecken.

Daß̧ Schilling neben diesen Arbeiten und seiner Anteilnahme an der Gründung des Vereines der Gasfachmänner Deutschlands auch noch im Jahre I860 die erste Ausgabe seines Handbuches herausbringen konnte, mag damit erklärt werden, dafy der Stoff schon lange Zeit systematisch zusammengetragen worden war. Aber selbst unter dieser Voraussetzung muf man Arbeitslust und -kraft dieses damals 34-jährigen Mannes bewundern. Schilling war aber nicht nur Schriftsteller, sondern durchforschte selbst sein Fach nach den verschiedensten Seiten hin. 1863 machte er bekannt, was er in der von ihm eingerichteten anscheinend ersten - Versuchsanstalt in München an Kohlenuntersuchungen geleistet hatte. Nach fünf Jahren, in der Zeit, in der Schilling auch die vielen Freundschaften innerhalb des Vereins anknüpfte und liebevoll pflegte, kam die stark umgearbeitete zweite Auflage seines Werkes auf deutsch und französisch heraus. Es hatte allgemeine Anerkennung gefunden. In diesem Jahre betretite er noch dazu den Bau eines Gaswerkes in Eger. Aber schwer traf ihn der frühe Tod seiner Frau und fast gleichzeitig der von dreien seiner Kinder, so daf es still um ihn und mit ihm wurde. Erst nach zwei Jahren, als er sich zum zweiten Male verheiratet hatte, kam die alte Kraft wieder. 1874 entdeckte er H. Bunte und zog ihn zu seiner Entlastung in die Schriftleitung des Journals. I877 kam die erweiterte dritte Auflage des Handbuches, die heute noch als besonders wertvolles Zeugnis der damaligen Technik dient, heraus. Es folgte der Neubau des Gaswerkes II in München bis 1883. Danach erkrankte Schilling $188_{4}$ schwer. Er trat in den Ruhestand. Sein Sohn Eugen Scbilling war in die Fufstapfen des Vaters getreten. Aber noch war der Vater zwischendurch an der Arbeit. 1887 und 1888 erschien in sechs Folgen die Geschichte der Gasbeleuchtung in Bayern im Journal. In ihr sind mit der Schilling eigenen Genauigkeit die Archive der Städte Bayerns ausgewertet. Die alten Verträge finden ihre sachverständige Würdigung auf Vorzüge und Schwächen. Riedingers und Pettenkofers Arbeit am Holzgas wurde mit Originalberichten in ebenfalls sechs Folgen im Journal von 1888 gebracht. N. H. Schilling erlitt mehrere Schlaganfälle. Selbst als der Verein 1890 in München seine Hauptversammlung abhielt, konnte Schilling nicht teilnehmen. Seine Arbeit über die Entwicklung der Gasindustrie mufte verlesen werden.

Am 5. Juli 1894 wurde Schilling von seinen Leiden durch den Tod erlöst.

Neben Schilling stand in dieser Zeit Simon $S c b$ i el $e^{t .2}$ ).

$4.2) \quad 38(1895), 577$ 


\section{E B E N S B I L D}

Simon $S$ c biele (Bild 28 ) wurde am 2I. Juni 1822 als eines von neun Geschwistern geboren. Sein Vater J.G.R. Schiele wurde bereits im Abschnitt 3.I23 (S. II2) als der erste deutsche Gasunternehmer aus eigener Kraft erwähnt. Simon besuchte das Gymnasıum in Frankfurt/M. und ging zum Studium in die Schweiz. Danach trat er zur praktischen Lehre in das väterliche Gaswerk ein. Nebenher gab er sich mit Gaswerksplanungen ab. I849/50 leitete er den Umbau des Werkes

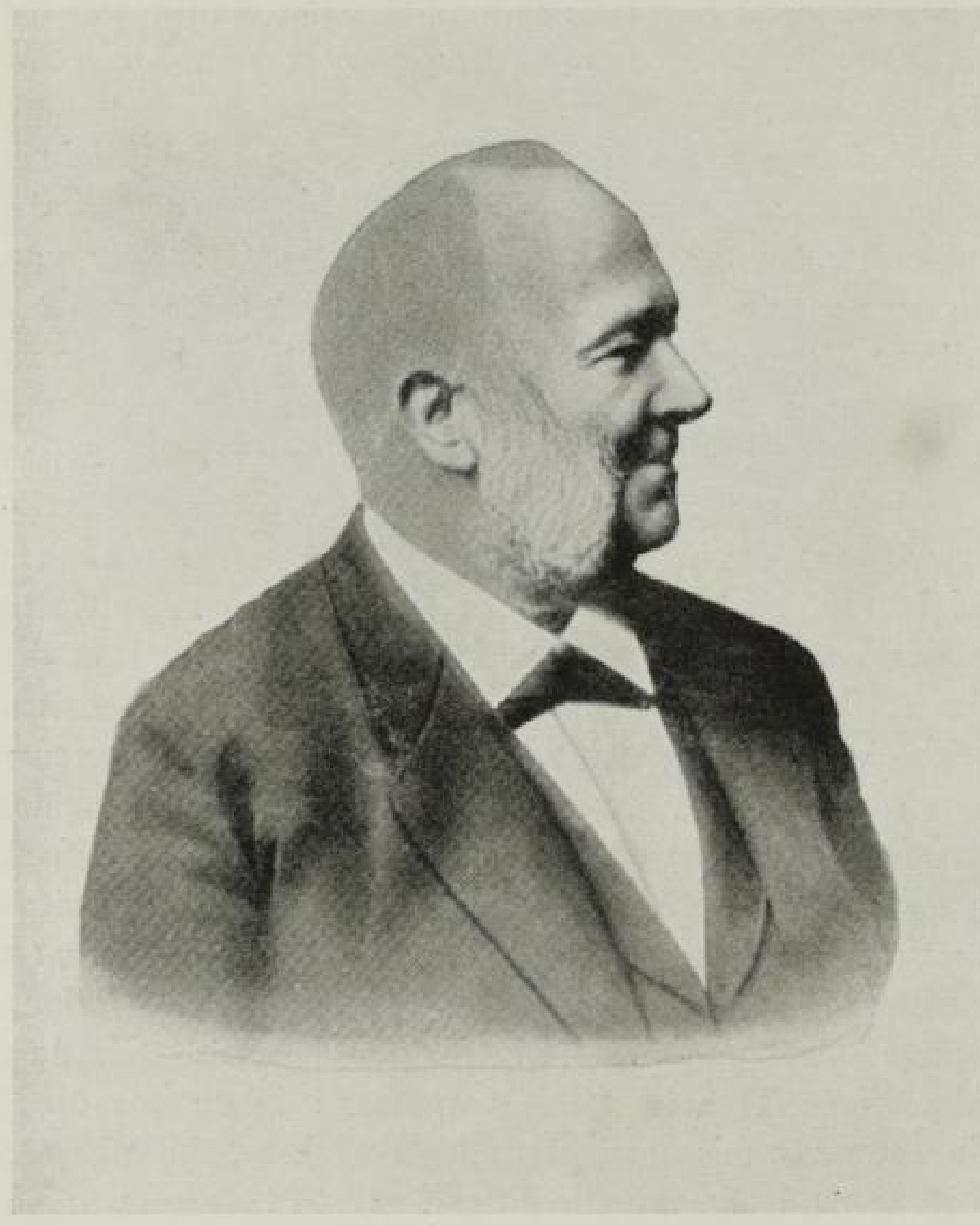

Bild 28

Simon Schiele

(Aus , so Jahre DVGW“)

in Hanau, das H. F. Z i e gler gekauft hatte. Für die Gesellschaft Puricelli entwarf er das Gaswerk Krefeld, leitete dessen Bau und wurde dort I854 Direktor. Während dieser Zeit zeigte er sein weitgehendes Mitleben mit der allgemeinen Technik, weshalb er auch 1859 dem Verein deutscher Ingenieure beitrat. Für das Gasfach besonders wertvoll war es, dał er die Ruhrkohlensorten zu laufenden Versuchen heranzog. Ihm ist die Entdeckung mancher besonders guter Gaskohlenzechen zu verdanken. Als 1860 die neue Frankfurter Gasgesellschaft ein neues Werk bauen sollte, beteiligte er sich am Wettbewerb. Sein Entwurf wurde als besonders klar ausgezcichnet. Er selbst kam $186 \mathrm{r}$ in seine Heimatstadt zurück und übernahm die Leitung der Gesellschaft. Diese Aufgabe war wegen der hohen Leuchtkraft, die die Frankfurter Gesellschaft gewährleistet hatte, besonders schwierig, nachdem die Boghead-Kohlen abgebaut

\section{SLUB}


waren. Dabei war der Wettbewerb mit der Imperial Continental Gas Association, die ein weniger leuchtkräftiges Gas liefern durfte, sehr schwer. Aus dieser Aufgabe heraus erwuchsen zwei Schwergewichte in seiner technischen Arbeit, einmal die Anteilnahme an einer genauen Lichtmessung. Schiele wurde schon 1865 von F. Sonntag nach Mainz zu Hilfe gerufen, als dieser Auseinandersetzungen mit der Stadt bewältigen muf̧te. Als 1868 der Verein die bis dahin auf freier Zusammenarbeit geführten Arbeiten übernahm, wurde Schiele Vorsitzender der Lichtmesskommission. Er hat diesen Vorsitz fast 30 Jahre innegehabt und ihm ist es zu verdanken, dafy das deutsche Fach auf diesem Gebiete durch die sorgfältige Arbeit der vielen Forscher, die es stellte, allmählich die internationale Führung errungen hat. Die andere Aufgabe ergab sich aus seinen laufenden Versuchen, die Erhöhung der Leuchtkraft des Gases in möglichst wirtschaftlicher Weise zu erreichen. Schiele hat darüber mehrere Aufsätze geschrieben, die neue Wege wiesen und alle Fachleute aufklärten. Schiele gehört auch zu den Gründern des Deutschen Vereins. Er war von 1859 bis 1882 Vorstandsmitglied und 14 mal je ein Jahr Vorsitzender. I882 ernannte ihn der Verein zum Ehrenvorsitzenden. Schiele beschränkte sich aber durchaus nicht auf das Gasfach. Im Verein deutscher Ingenieure war er $7 \mathrm{mal}$ Vorsitzender. Als Mitbegründer des Frankfurter Bezirksvereins wurde er I89o zum Ehrenmitglied des V.d.I. ernannt. Als Stadtverordneter und 1867 als Landtagsabgeordneter gab er auch der Politik (Fortschrittspartei) seinen Arbeitsanteil. 1873 arbeitete er an der Schaffung der Frankfurter Quellwasserleitung mit. 188I war er Vorsitzender der Patentausstellung in Frankfurt, die damals grofjes Aufsehen erregt hat. Als Bürger war er Gründer des Turnvereins und des Mittelrheinischen Fabrikantenvereins. Bei all dieser Arbeit fand er noch die Zeit, ein reiches und schönes Familienleben zu führen. Naturwissenschaften und Musik wurden gepflegt. Am 15. Juli 1895 raffte ihn plötzlich eine akute Lungenentzündung aus dem tätigen Leben.

Als drittes und viertes ausführliches Lebensbild mag hier noch das der „Fabrikanten" S. Elster und J. Pintscb vorweg genommen sein.

\section{E B E N S B I L D}

Siegmar Elster wurde zu Braunschweig am 27 . Mai 1823 geboren $^{43}$ ). Er besuchte Gymnasium und Gewerbeschule und kam bereits $1837 / 38$ zu R. Blochmann. Beim Bau des Berliner städtischen Gaswerkes am Strahlauer Platz war er mit beschäftigt. Schon ${ }^{2} 84^{8}$ gab er sich mit dem Bau von Gasmessern ab, bearbeitete aber noch die Entwürfe für Dir. C. A. Kü $b$ nell (Berliner Gaswerke) für das Gaswerk Königsberg. I8ৎı besał er die erste kleine Werkstatt in der Spandauerstraf̧e, der 1856 eine neue Fabrik in der Königsstraf̧e folgte. Sein Arbeitsprogramm blieb aber nicht auf Gasmesser beschränkt, im Gegenteil, die Vielheit der aufgegriffenen Aufgaben ist genau gar nicht zu beschreiben. Hervorgehoben seien: Sauger und Umlaufregler, selbstätige Stadtdruckregler, Druckmesser und Druckschreiber, Apparate zur Untersuchung des Gases auf Verunreinigungen und zur Lichtmessung. In der Lichtmef̧kommission hat Elster 
eifrig mitgearbeitet und hartnäckig für seine Ansichten, wohin die Entwicklung gehen müfte, mit durch Versuche belegten Feststellungen gestritten. Sein von ihm weiterentwickeltes Bunsenphotometer wird später als das meistverwendete Gerät bezeichnet. Für die Beurteilung der Intensivlampen mit ihren großen Lichtmengen entwickelte er das Winkelphotometer. Elster hat immer wieder die Entwicklung einer internationalen Lichteinheit angeregt und war dabei ein Gegner der deutschen Vereinskerze mit gut belegten Einwendungen.

Ein ganz anderes Gebiet betrat er mit der Fertigung genauer Normalhohlmafe, die er auch für Brasilien geliefert hat. Er fertigte Kronleuchter und Lampen mit der damals gewünschten reichen Verzierung, studierte zu diesem Zwecke die Metallegierungen, wobei er eine ,antike Bronce“ für Kunstgegenstände erfand. Ganze Beleuchtungsanlagen wurden für das Winterpalais in Petersburg, für Schlof̧ Babelsberg, für das Rathaus Berlin und für die Theater in Magdeburg und Riga (eine besonders entwickelte anspruchsvolle Technik) geliefert. Rein künstlerischen Interessen entsprang seine Anstalt für Glasmosaik (1877). Anderen gewerblichen Künstlern half er gerne. Der Kunstemaillefertigung von Ravené wurde in seiner Werkstatt ein Platz zugewiesen. 1880 errichtete er die Zweigfabrik in Mainz. Sein Bestreben bei allen Arbeiten und auch mit Geldopfern dem allgemeinen Nutzen zu dienen, wird besonders erwähnt. Elster starb am 21. März 189I.

\section{LE B E N S B I L D}

Karl Friedrich Julius Pintscb (Bild 29) wurde am 6. I. I8Is in Berlin als Sohn des Bollenhändlers (= Zwiebel, Gemüse) Johann C bristian Pintsch geboren. Die Familie stammte aus dem Spreewald, von wo Christian zugewandert war, um die heimischen Erzeugnisse in der Grołstadt von nahezu 200000 Einwohnern zu vertreiben $\left.{ }^{4.4}\right)$. Julius erhielt eine möglichst gute Erziehung und Ausbildung; nach der Volksschule besuchte er die Gewerbeschule (einer Bildungsanstalt, die in der Weiterentwicklung zur Techn. Universität führte) und das Gymnasium zum Grauen Kloster. Ara I. April I829, also mit I4 Jahren kam er auf seinen Wunsch in die Lehre als Klempner, die er nach 4 Jahren als Geselle beendete.

Auf der Wanderschaft, wobei er sich $3 \mathrm{I} / 2$ Jahre in Dresden aufhielt, lernte er seine spätere Frau Amalie Lenk kennen. Ab Juli 1838 arbeitete er in Berlin als Klempner in einer Lampenfabrik. I843 machte er sich als Meister selbständig. Seine Werkstatt am Strahlauerplatz 4 lag in unmittelbarer Nachbarschaft des neuen städtischen Gaswerkes, dessen Bau 1844 beschlossen, aber wohl schon vorher erörtert worden war. Damit war es natürlich, daß3 der in der Lampenfertigung besonders tätige junge Handwerker zu Lieferungen herangezogen wurde. Eine Unfallanzcige vom März 1844, nach der Pintsch beim Bau der Gasanstalt beschäftigt, mit dem Hammer in der Hand abgestürzt sein soll (F. M. Feldhaus) ist nicht verständlich, weil der Bau der Gasanstalt erst im November des Jahres

4.4) A. Boetticher: Julius Pintsch (Berlin 1815-1884), seine berlin-lausitzischen Vorfahren und seine Abkömmlinge: Görlitz, C. A. Starke als Handschrift gedruckt. Ferner: F. M. Feldhaus: Carl Friedrich Julius Pintsch 1940 u. derselbe: Julius Pintsch; Ein Berliner Klempnermeister, Bahnbrecher des Fortschritts, Installateur und Klempnerzeitung 3 S. 673. Sämtlich im Besitze der Firma Pintsch-Bamag, Butzhach/Hessen. 


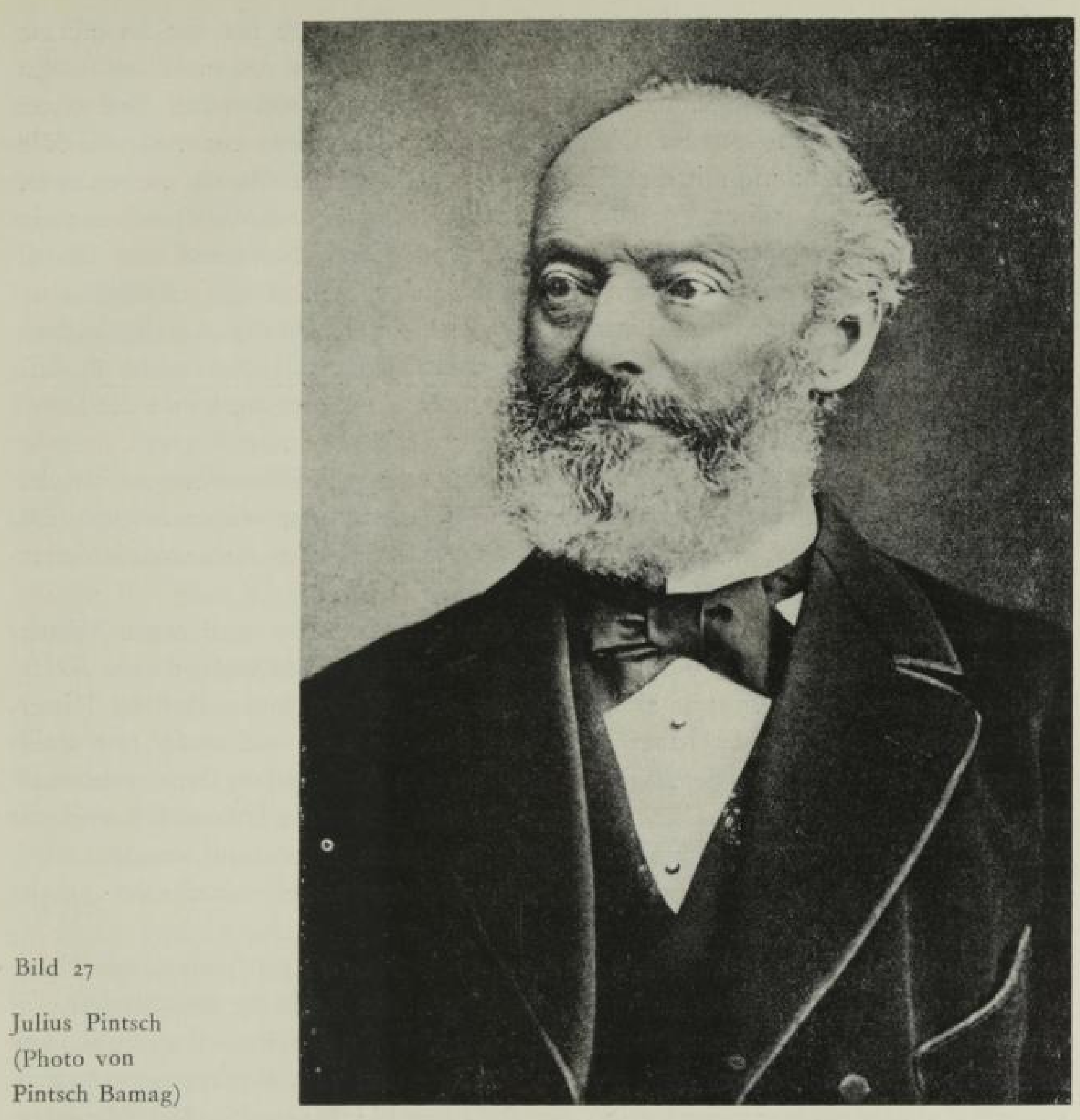

in der Stadtverordnetenversammlung beschlossen wurde. Sicher aber ist, dafy Pintsch gar bald zur Instandsetzung von Gasmessern, Rohren und Apparaten, die beim Versand beschädigt waren, herangezogen wurde. Er muf̧te seine Werkstätten 1845 von der Wohnung entlasten und sie 1848 bereits durch Zukauf erweitern. 1847 baute Pintsch zuerst einen neuen Messer, wahrscheinlich als erster in Deutschland. Um die Anerkenung des Wertes muf̧te er ringen, aber am 20. 2. I851 erhielt er den ersten Auftrag für 20 Messer. Damit war der Schritt von der handwerklichen Instandsetzungswerkstätte zum Fabrikanten vollzogen. 1854 nahm Pintsch seinen älteren Sohn Richard in die Werkstatt auf, der sich so gut einarbeitete, dafy er schon mit 18 Jahren den Vater entlasten konnte, so dał̧ dieser eine technisch werbende Tätigkeit aufnehmen konnte. 1863 zwang der wachsende Umfang der Fabrikation zum Neubau einer Werkstätte in der Andreasstr. 72/74. 1868 kam die Verbindung mit der Niederschlesisch-Märkischen Eisenbahn wegen der Schaffung eines Gasbeleuchtungssystems für Eisenbahnwagen zustande. Der Vater und drei tüchtige Söhne arbeiteten mühsam an der Konstruktion - wahrscheinlich, wie damals noch meist geübt - mit Blechschere 
und Lötkolben. I870 kam Richard auf den Gedanken, dał für die Bewährung der Pref̧gasbeleuchtung ein guter Druckregler entscheidend wäre. Damit muf̧te die Firma zur Feinwerktechnik übergehen, die im Gasmesserbau ihre ersten Ansätze hatte machen können. Die Olgasbeleuchtung wurde ein voller Erfolg. Die Geschäftsverbindung mit den Eisenbahnverwaltungen führte zu immer neuen Aufgaben: Ein sehr früher Vorschlag wollte mit Olgas auch die Beheizung der Wagen ausführen. Später entwickelte die Firma Dampfheizungs- und Warmwasserheizungen für Eisenbahnwagen. Durch eine Anregung während einer Reise in Rufland kam Julius Pintsch auf die Gasbeleuchtung von Seezeichen. Eine Zweigfabrik in Fürstenwalde wurde 1872 erbaut. Als sich nach 1870 die trockenen Gasmesser in Deutschland immer mehr durchsetzten, baute die Firma I878 auch diese Messer.

Julius Pintsch erhielt den Titel eines kgl. preufischen Kommerzienrates im gleichen Jahre. Im nächsten Jahre überlief̧ er die Arbeit ganz seinen Söhnen und verzog nach Fürstenwalde. Am 20. Januar 1884 starb er nach mehreren Schlaganfällen.

Man könnte die Reihe der Lebensbilder ähnlicher begabter und reger Männer noch vielfach fortsetzen. Jedes einzelne würde zum Gesamtbilde dieser Kräfte in der Hauptentwicklungszeit des Aufbaues der Werke einen Beitrag leisten. Leider würde aber die Häufung doch ermüden. Es mögen deshalb nur einige Namen erwähnt sein von denen, die vor allem die Ausbreitung der Gasbeleuchtung um diese Zeit durch Entwürfe und Bauten gefördert haben. Da sind die Schüler Blochmanns, deren Namen bereits in dessen Lebenslauf erwähnt sind. $\mathrm{Da}$ ist Lie gel in Stralsund, dessen Hauptlebenswerk die Verbesserung der Retortenöfen gewesen ist.

In Karlsruhe sind die Familien $S p r e n g$ und $S o n n t a g^{4.5}$ ) als Gaswerkserbauer in zwei Generationen tätig. Sie gründeten die Badische Gesellschaft für Gasbeleuchtung in Karlsruhe, wo sie das von den Engländern Barlow und $M a n b$ y 1846 gebaute und später vernachlässigte und zum Konkurs gekommene Gaswerk zuerst pachteten und dann mit Puricelli kauften $\left.{ }^{4.5}\right)$. Mit MaierKapferer zusammen kauften sie das zunächst gepachtete Werk Nürnberg. Die Familien bauten und betrieben zum großen Teile selbst etwa 20 Gaswerke darunter Mannheim, Mainz, Freiburg i. Br. ${ }^{4.7}$ ).

Emil Spreng war einer der ersten, der die wachsende Bedeutung der Teerverwertung erkannt hat. Er studierte die Anilinfarben und gründete eine Teerproduktenfabrik in Nürnberg, die er aber nach zwei Jahren wieder abstief, um sich ganz dem Gasfach widmen zu können. Sonntag hat das Gaswerk Mainz für die Stadt gebaut und dann gepachtet. Nach Auseinandersetzungen mit der Stadt über die Leuchtkraft des Gases gab er Veranlassung zur eingehenden Beschäftigung mit der Lichtmessung. Er rief die besten Fachleute des Faches, der Städte und der Hochschulen zur ersten Aussprache zusammen. In Mainz betrieb er eine Gasgerätefabrik und in den 6o-er Jahren gründete er eine Bronzefabrik in Höchst.

4.5) Nachruf F. Sonntag: 13 (1870), 231

4.6) J. N. Spreng: , (1862), 5, $16(1873)$, 110/41

4.7) Nachruf C. L. E. Spreng: 7 (1864), 194 
A. Spreng, der für die Familie das Gaswerk Freiburg betreute, erblindete früh, arbeitete aber weiter für die Gasindustrie. Er ist einer der Gründer des Deutschen Vereins ${ }^{4.5}$ ).

Nicht so umfangreich haben sich die Karlsruher H. Ra upp und L. Dölling betätigt, die das Gaswerk Karlsruhe nach Spreng besessen haben. Aber auch hier waren zwei Generationen im Gasfach tätig. Sie erbauten etwa to Werke. Durch den Bau des Gaswerkes Schaffhausen (1860) bekam A. Raupp jun. Beziehungen zu der 186r gegründeten Schweizerischen Gas Gesellschaft, für die Dölling das Gaswerk Pisa erbaut hat. A. Raupp wurde als Leiter des Gaswerkes Konstanz (seit 1864 ) ein Opfer der Tragik im Ingenieurberuf. Ein neuer Gasbehälter war ungenügend fundiert, er versackte und Raupp ertränkte sich im Wasser dieses Behälters ${ }^{4.7}$ ).

Im Rheinisch-Westfälischen Bereich waren besonders lebhaft tätig: W. Ritter , (Iserlohn, Langenberg, Solingen) ${ }^{4.19}$ ). W. Fr a nke, Dortmund ${ }^{4.11}$ ) (etwa 12 Werke und mehrere Betriebsberatungen städtischer Werke) und O. Kellner (Is Werke $\left.)^{+.12}\right)$. Man könnte noch mehrere solcher Namen anführen. Aber die Zahl genügt schon, um zu belegen, wie sehr nocb die Erbauung der Gaswerke die höchst persönliche Arbeit einzelner gewesen ist, und dał gerade in den 6oer Jahren eine grołe Zahl fähiger Männer am Werke gewesen ist.

Daß3 die Arbeit der selbstgebildeten, aus der Betriebstätigkeit erwachsenen Fachleute, ihre großen Gefahren gehabt hat, ist unbestreitbar, zumal jeder einseitig auf das angewiesen war, was er selbst kennen gelernt hatte und andere Verhältnisse immer nur mangelhaft beurteilen konnte. Hierfür stehen gleich im Anfang des betrachteten Abschnittes zwei Belege zur Verfügung und zwar in in Halle und Leipzig.

In Halle war ein neues Gaswerk erbaut worden und statt der Fortschritte gegen früher war eine $\mathrm{W} /$ irtschaftlichkeit nicht zu erzielen. Nun wurde als Gutachter der Direktor des Gaswerkes Chemnitz H. B or $n$ hinzugezogen, der wegen der guten Leistung von ihm entwickelter Öfen in Chemnitz, jedenfalls später, eine gewisse Berühmtheit erlangt hat. Aber in Halle traf er ganz andere Öfen an, und er bezeichnete die groß̧en zur Auswirkung der Strahlen eingebauten Ofenräume als schädliche Räume. Er meinte, die Verluste entständen dadurch, daß im zu groß̧en Rauminhalt „,kalte Luft mitgeglüht" werden müsse. Zwar gab er zu, daf3 durch Drosselung der Abgasschieber viel gespart werden könnte, widersprach sich aber gleich danach selbst mit der Behauptung, daf der grołe schädliche Raum eine übermäß̧ig groł̧e Offnung der Schieber verlange. Bor $n$ stellte den schnellen Verschleif der Retoren fest, der auf Verwürgungen zurückzuführen war, weil die Steigrohre ohne Ausdehnungsmöglichkeit zwischen Köpfen und Vorlage angebracht waren. Daf er aber auch gerade mit der falschen Feuerführung und infolgedessen ungleichmäf̧igen Erwärmung zusammenhing, bemerkte er nicht. Richtig sagte Born, daß̧ der Betrieb des Gaswerkes nicht durch die vielen wissenschaftlich gebildeten Beamten ohne Erfahrungen geordnet werden

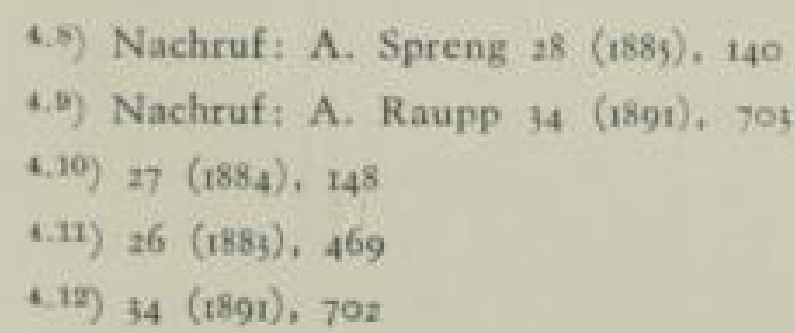


könne, er empfahl vielmehr vor allen Dingen einen Gasmeister, der dann auch wirklich nach wenigen Monaten das Werk wirtschaftlich betrieben hat $\left.{ }^{4.13}\right)$. Vor allem konnte der Rohrverlust von $25 \%$ auf $10 \%$ gemindert werden.

In Leipzig löste eine Verzögerung im Ausbau des Werkes den Zorn der Bevölkerung aus. Der Verwalter hatte bereits im Jahre $1856^{4.14}$ ) einen Antrag gestellt für das völlig herabgewirtschaftete und unzureichende Gaswerk ein neues an günstiger Stelle zur Entlastung des bestehenden aufzuführen. Dazu wurde auch ein Gutachten Drorys (welcher Drory das gewesen ist, ist nicht gesagt) hinzugezogen und R. S. Blocbmann arbeitete das Projekt aus. Irgendwelche Bedenken müssen ein Gutachten Kornbardts herbeigeführt haben ${ }^{4.15}$ ), der die Ergebnisse in Leipzig mit dem von ihm verwalteten gleichgrofen Stettiner Gaswerk verglich. Er bemängelte die Verwendung eiserner Retoren. Er selbst war ja beteiligt an den Arbeiten der Stettiner Schamottefabrik und kam zu dem Schluł, dał bei richtiger Führung das alte Gaswerk noch ausreichen müß̧te. Dic Verwaltung hatte gleichzeitig einen Gutachten von Prof. O. L. Er $d m$ a $n n$ heran gezogen $\left.{ }^{4.16}\right)$, das besonders scharf „gegen das unwissenschaftliche Gebaren und Handeln des Gasfaches“ zu Felde zog. Seine bösartigen Auf̧̧erungen führteı sofort zu einer Äuf̧erung des Journals, das nun wiederum an Beispielen bewies, wieviel Unheil von Männern der abstrakten Wissenschaft durch Hineinreden angerichtet würde. Erdmann im besonderen wurde vorgeworfen, dał er nur die vorhandene Anlage und Betriebsweise für seine Versuche benutzt habe, ohne die Leistungen anderer Betriebe und Öfen zu vergleichen. Dabei käme er natürlich zum Ergebnis, daf̧ das Gaswerk nicht mehr ausreiche. Die Billigung des viel zu kleinen Behälterraums wurde besonders gebrandmarkt. Im übrigen aber ist das Gutachten, wenn man die damals erreichten wissenschaftlichen Ansichten kennen lernen will, durchaus lesenswert. Um diesen Streit zu beenden, wurde nunmehr als Fünfter noch Prof. Pettenkofer in München als unparteiisch in Anspruch genommen. Pettenkofer, der sich auf Riedinger gestützt hat, verfolgte ganz offensichtlich den Wunsch, durch vorsichtige Darstellungen zwischen den kämpfenden Geistern zu vermitteln. Er kam aber schlief̧lich zu dem gleichen Ergebnis wie Kornhardt, daf̧ es zunächst genüge, das bestehende Gaswerk herzurichten, verlangte aber, daf es mit reichlicherem Behälterraum ausgestattet würde, um die bisher dort üblichen Schwankungen zwischen Tagund Abenderzeugung auszuschalten. Immerhin waren durch diesen Streit drei wertvolle Jahre verloren worden, in denen die Versorgungslage immer schwieriger wurde. Mehrere Jahre lang hatte das Gaswerk keinerlei Anträge auf Beleuchtungsanlagen Privater entgegennehmen können.

Aber nicht immer waren die Unternehmer glücklich. Daf̧ die englische Gesellschaft, die 1846 das Karlsruher Gaswerk erbaut hatte, in Konkurs ging, ist schon angedeutet. Der Besitzer des Gaswerkes Cannstatt, gegr. 1852, mußte 1858 das Werk an seine Gläubiger abtreten ${ }^{4.1}$. In Salzburg erbaute P. Gräser aus Darmstadt das Werk, das am I6. I. $\$ 9$ in Betrieb gesetzt wurde. Die Gasausströ-

\footnotetext{
4.13) 2 (1859)+302-314

4.14) $3(1860), 214$

4.15) 3 (1860), 189

4.16) 3 (1860), 151

4.17) 2 (1859), 295
} 
mungen aus dem Rohrnetz waren so zahlreich und groß̧, dał um Leben und Gesundheit der Einwohner zu schützen am Ende des Monates das Werk auf Befehl der Regierung wieder stillgelegt wurde. Dic Gesellschaft wandte sich an Riedinger, der sich verpflichtete das Werk in Ordnung zu bringen und zu betreiben ${ }^{4.15}$ ).

Besonders gedacht werden möge der Gründung der Thüringer Gasgesellschaft in Gotha mit Urkunde des Herzogs vom 2. Juni $\left.1864^{4.10}\right)$. War ihr Arbeitsbereich auch zunächst gedacht, das Gas in die Städte Thüringens zu bringen, so dehnte sich doch sehr bald der Wirkungskreis auf ganz Deutschland aus. 1874 ist der Sitz bereits Leipzig. Die Entwicklung der Gesellschaft im Wettbewerb mit der Deutschen Continental-Gas-Gesellschaft ist für das deutsche Gasfach von entscheidender Belebung gewesen. Heute vertritt sie noch als das im Betrieb von Einzelgaswerken gröfte privatwirtschaftliche Unternehmen der Bundesrepublik - neben anderen Energieversorgungsunternehmen - den Gedanken, det, die 1872 immerhin is Werke ihr eigen nannte. Sie stand in freundschaftlichen lichen Betrieben zur Führung zu verhelfen ${ }^{4.20}$ ).

Um 1866 wurden in Berlin auch die „Neue Gasgesellschaft Nolte \& Co. gegründet, die 1872 immerhin is Werke ihr eigen nannte. Sie stand in freundschaftlichen Beziehungen zur Deutschen Continental-Gas-Gesellschaft ${ }^{4,21}$ ).

\section{I2 Konjunkturen und Wettbewerb}

Durch den vorstehenden Abschnitt wird bereits deutlich, daf̧ das Gasgeschäft auch damals schon keine unter allen Umständen sichere Verzinsung abwarf. Wenn Riedinger mit dem in seinem Lebenslauf wiedergegebenen Ausspruch nach dem Einlaufen eines Werkes sichere Renten vorauszusagen vermochte, so war jedenfalls die Grundlage dafür sein technisches Können und sein wirtschaftliches Gefühl.

\subsection{Petrole u m}

Alsbald aber wurde das „Monopol“ auf dem Gebiete guter Beleuchtung angefochten. Bisher waren Mitbewerber das Photogen und Solaröl, die beide aus der Schwelerei im Sächsisch-thüringischer Braunkohle stammten, also gewisse nicht unterschreitbare Erzeugungskosten hatten. 1863 kamen die ersten Nachrichten über die Erdölfunde in Pennsylvanien ${ }^{4.22}$ ). Unter dem Namen Naphtha oder Petroleum erregte das "merkwürdige Produkt" die Aufmerksamkeit der Fachleute. In England T. G. B arlow, in Deutschland S. Elster, Karmarscb \& Heeren, N. H. Scbilling und andere mehr untersuchten das neue Leuchtmittel. Auf der einen Seite herrschte eine optimistische Freude, auf der andern Ablehnung, besonders wegen der Feuergefährlichkeit der zunächst vor dem Ver-

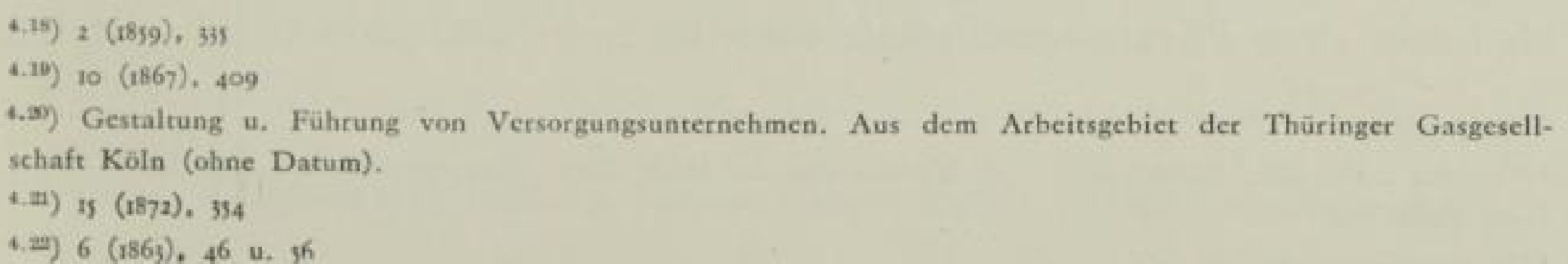


sand nicht genügend abgetriebenen, sehr leicht flüchtigen Bestandteile. Auch die Hoffnung, dał̧ die Fundstellen bald erschöpft sein könnten, wurde von der alten Industrie geäufert.

Hinzu kamen noch seit 1866, besonders im Badener Lande laute Anpreisungen im Kampf um den Markt mit unsachlichen Erörterungen über die Geschäftsführung der Gaswerke. Wenn auch die bestehenden Gaswerke im laufenden Absatz noch nicht gestört wurden, so machte sich dennoch eine Kritik an den Verträgen mit den Gasgesellschaften bemerkbar. Erschwert wurde die Lage für viele private Gaswerke dadurch, daf gerade in dem kritischen Augenblick, den der neue Wettbewerber verursachte, eine grofe Zahl der vor 25 und 30 Jahren abgeschlossenen Verträge ablief. Das muf̧te natürlich zur Überprüfung führen, wie eine Stadt mit ihrer Gasgesellschaft gefahren war, ob Eigenbetrieb oder ein Wechsel mit dem Unternehmer für die Zukunft angebracht wären. Je nach dem Geschick der verantwortlichen Leiter mit den Partnern der Städte (Beleuchtungsausschüssen, einzelnen Beamten usw.) auszukommen, waren die Auseinandersetzungen sachlich und freundlich, oder gehässig und mit falschen Voraussetzungen belastet zu führen. In den städtischen Parlamenten wurden oft von Laien politische oder auch aus politischen Uberzeugungen störende und die Verhandlungen der Verwaltungen erschwerende Äußzerungen getan. ${ }^{4.25}$ ).

r865 beklagte ein Leitartikel des Journals die Tendenz der Städte, den bestehenden Gesellschaften Wettbewerber zu schaffen. Bisher bestand ein solcher Wettbewerb in Deutschland nur in den verhältnismäfjig groß̧en Absatzgebieten in Berlin und Frankfurt, in dieser Stadt dazu noch mit zwei verschiedenen Gassorten, so dał der Bürger zwischen hoher Leuchtkraft oder billigem Preise die Wahl hatte. Allerdings müßten, so sagte der Leitartikler (vermutlich $S$ c b i l l i n g) die Verträge und die photometrische Arbeit genau festgelegt sein. Daran hätte es vielfach gefehlt. Streitigkeiten in Köln mit der englischen Gesellschaft wurden als Beispiel erwähnt ${ }^{4.21}$ ).

Der Jahresbericht der Deutschen Continental-Gas-Gesellschaft über das Jahr 1867 ging auf die Wettbewerbslage mit dem sehr billigen Petroleum ein. Der wirtschaftlich weitblickende W. Oecbelbäuser sah für die privaten Gaswerke keine ernsthaften Gefahren, ebenso wenig wie man durch werkseigene Gaswerke in den Fabriken ernstlich behindert worden sei. Allerdings dürfe man keine überhöhten Gewinne erwarten, und um zu billigen Preisen zu kommen, müsse man die Konzessionsdauer verlängern. Denn mit der Verbilligung müsse ein Mehrabsatz kommen, der zu Neuanlagen zwinge, für die nun wieder eine ausreichende Abschreibungszeit notwendig würde. Mit der Zubilligung sehr weitgehender Preisminderungen ist der geschickte Verhändler auch bei allen Städten durchgekommen. Sc billing veröffentlichte $\mathrm{r}^{8}\left(9^{4.5}\right)$ mehrere Aufsätze, in der er die Lage durch eine sachliche Aufklärung zu bereinigen versuchte. An Beispielen in Leipzig und Dresden, wo durch die Sparsamkeit der Deputationen, Verzögerungen im Ausbau der Werke zu ernstlichen Notlagen geführt hatten, besprach er, als Leiter einer Privatgasgesellschaft sicherlich nicht ganz unparteiisch, die Be-

4.23) $19(1876), 6$

4.24) siche auch: Gas, Elektrizitäts- und Wasserwerke der Stadt Köln. Herausgegeben zur rooo Jahrfeier der

Stadt Köln 1950.

4.25) $12(1869), 55,16 \mathrm{r}, 222,336$ 
hinderung der städtischen Werkleiter sich der Entwicklung schnell, und oft mit einem Wagnis, anzupassen. Die Drohung, eine städtische Anstalt zum Wettbewerb mit den bestehenden Privatwerken zu schaffen, wurde in Karlsruhe durch den Ankauf der $\mathrm{Werke}^{4 .{ }^{*}}$ ), in Stuttgart durch Verlängerung des Vertrages wirtschaftlich sinnvoll gelöst ${ }^{t \cdot 2 \pi}$ ).

Gewił gab es unter den Gasfachleuten auch Schwarzseher, die unter dem lauten Geschrei der Petroleumvertreiber und dem Verlangen nach billigen Preisen das Ende der Gaswirtschaft kommen sahen. Aber es überwog doch eine kraftvolle Selbstbesinnung der führenden Männer. Ausschau wurde gehalten nach glücklichen Entwicklungen im Auslande. Berichte über Kochen mit Gas in England und Frankreich tauchten auf. Man begann über eine Verbesserung der Feuerung nachzudenken, obwohl es vorerst nicht zu baulichen Neuerungen kam (vgl. Abschnitt 4.2II). Schneller zu verwirklichen waren Maf̧nahmen zur Verbesserung des Koksabsatzes. Der Koksfüllofen wurde durch ein Preisausschreiben (vgl. Abschnitt 4.34) als Lösung bekannt ${ }^{4.53}$ ).

In Karlsruhe entstand die erste Koksaufbereitungsanlage. Altona und Bremen konnten bald den zerkleinerten und abgesiebten Koks sogar mit einem Preisaufschlag absetzen $\left.{ }^{4.3}\right)$.

4.122 Aufschwung nach 187 I und dessen Ende 1873

Diese mehr in den Gemütern sich zeigende Krise wurde plötzlich durch den Sieg von $187 \mathrm{r}$ abgelöst. Der allgemeine wirtschaftliche Aufschwung überdeckte die Sorgen um den Wettbewerb. In deutschen Geschichtsbüchern wird fast immer dieser Aufschwung rein materialistisch mit dem Einflief̧en der Kriegsentschädigungsmilliarden erklärt. Aus den Annalen der Gaswirtschaft ist aber deutlich zu sehen, dafs dieses wirtschaftliche Vorwärtsdrängen nicht allein in Deutschland, sondern auch in England ${ }^{4.30}$ ) und auch im unterlegenen Frankreich eingetreten ist. Ein Leitaufsatz im Journal der gleich nach Beendigung des Krieges geschrieben wurde, erwartete den wirtschaftlichen Aufschwung, weil die Spannungen der drohenden Kriege $1864,1866,1870 / 71$ ausgeglichen seien, und weil man nunmehr eine, wie die Geschichte später auch erwiesen hat, berechtigte Hoffnung auf eine lange, friedliche Arbeit der europäischen Großmächte miteinander hegen könnte. Die unternehmerische Freudigkeit war also auch stark psychologisch begründet. Für die Gaswirtschaft brachte aber der Aufschwung neue Sorgen mit sich: Kohlenknappheit und stark steigende Preise. Die Gaspreise konnten nur langsam und nicht in gleichem Ausmał̧e folgen. Bei privaten Werken hinderten die langfristigen Verträge, bei den Städten politische Bedenken. Trotzdem kam es $1872 / 73$ zu vielfachen Erhöhungen der Preise $\left.{ }^{t .31}\right)$. Andererseits machte man aber auch die Erfahrung, daßz die Mengenkonjunktur bei verhältnismäßjig zurückbleibenden

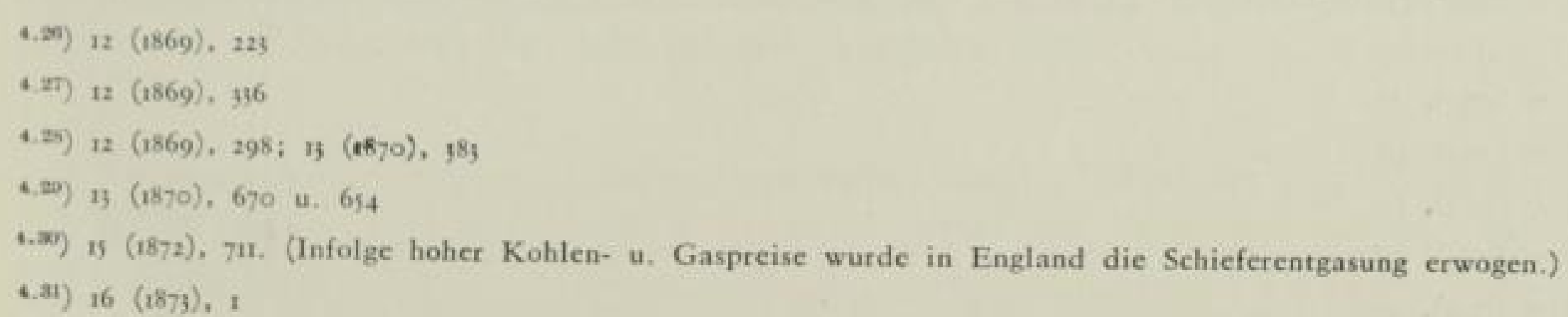


Preisen einen beachtlichen Beitrag zum wirtschaftlichen Erfolg zu leisten vermag. Es schadete auch nichts, dał die Petroleumeinfuhr bei billigen Preisen in Hamburg in einem Jahre um $70 \%$ gestiegen war. Das Erdöl diente vorzüglich zur Befriedigung des Wunsches nach besserer Beleuchtung in Arbeiterkreisen und auf dem Lande, wo Gas noch nicht benutzt wurde ${ }^{4.122}$ ).

Schon bald gegen Ende des Jahres 1873 brach die Konjunktur zusammen. Die Gaswerke standen einem Kohlenüberfluf bei sinkenden Kuhlenpreisen aber noch steigenden Löhnen gegenüber $\left.{ }^{4.35}\right)$. Das Ringen um die Kommunalisierung wurde nun sehr heftig. Einzelne Fachleute sind dabei besonders hervorgetreten. Auffallend ist z. B. das Auftreten von C. A. Kübnell, Berlin mit seinen Projekten, die besonders verlockende Ergebnisse für stadteigene Werke versprachen ${ }^{6.34}$ ).

Ein Schlaglicht darauf, daf aber auch die Stadtwerke in diesen Jahren einer überhitzten Konjunktur und danach eines schweren Zusammenbruches sich in keiner leichten Lage befanden, liefert ein Bericht aus Köln $\left.{ }^{4.35}\right)$. Das Werk hatte am I. 5. 1873 das heruntergewirtschaftete Netz der englischen Gesellschaft übernommen. Acht Jahre unerfreulicher Streitereien vor der Verwaltung und den Gerichten, in denen die Gesellschaft alle irgendwie vermeidbaren Aufwendungen unterlassen hatte, waren vorausgegangen. Die Arbeitsdisziplin am Umschlagpunkte der Konjunktur war schlecht. Die Löhne muf̧ten sofort um $25 \%$ erhöht werden. „Die auß̧erordentlich schwierige Stellung der Verwaltung und speziell der Direktion im ersten Jahre hatte ein Gutes für die Zukunft des Geschäftes: Weil jedermann an dem dauernd glücklichen Erfolge zweifelte und Verantwortlichkeit von sich abzuhalten bemüht war, erlangte die Verwaltung die notwendige Selbständigkeit, die Krise zu überwinden." An eine Preisherabsetzung, die die Gasabnehmer nach Außzerungen während der Kämpfe mit der privaten Gesellschaft erwartet hatten, war nicht zu denken. So kam es zu einer Eingabe mehrerer Bürger bei der Regierung gegen eine Gaspreiserhöhung, die mit Kosten der Beleuchtungs- und Rohrnetzerneuerungen begründet worden war ${ }^{4.25}$ ).

\subsection{Elektrizität}

$\mathrm{Zu}$ all den Beunruhigungen kam nun noch die Elektrotechnik, die sich anschickte, vor allem die Beleuchtung an sich zu ziehen, während das Petroleum nach wie vor um Vergröß̧erung des Absatzes rang. Im Dezember 1867 hatte Werner Sieme $n s$ das ,dynamo-elektrische Prinzip“ entdeckt, und aus seiner Weiterentwicklung entstanden die ersten Starkstrommaschinen für hohe Stromstärken. Nunmehr hatten die Beleuchtungstechniker, die schon seit langem mit Batteriestrom elektrische Leuchten konstruiert hatten, die sichere Quelle, die auch preiswert den Strom zu schaffen versprach.

Insbesondere in Frankreich wurde die neue Technik vielfach aufgegriffen, und man war dabei etwas lärmend. In Deutschland wurde das Neue entschieden

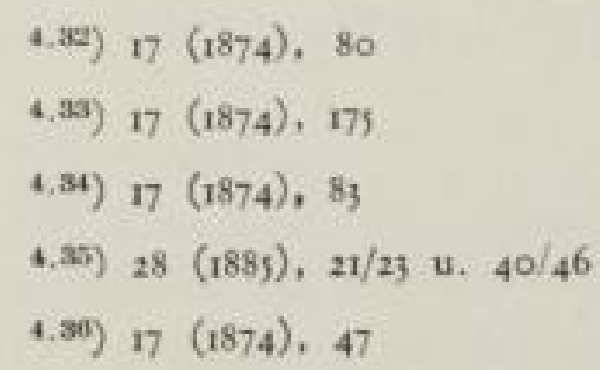


ruhiger beurteilt, vor allem wohl, weil W. v. Siemens, der es ja wohl am besten beurteilen konnte, sehr genau die technischen Möglichkciten im Augenblick und für die Zukunft überprüfte. Siemens war nun kein Mann überschwenglicher Spekulation; er kannte die Schwierigkeiten bei allen Erfindungen $\left.{ }^{4.37}\right)$. Immerhin waren die Gasfachleute erneut beunruhigt.

Darum sprach wohl $1877 \mathrm{~W}$. Oecbelbäuser, der ja Siemens gut kannte, im Jahresbericht seiner Gesellschaft für 1876 über den Ausgleich der Konjunktur im Gasfach; jetzt sei bei einem Rückgang des Absatzes doch Gewinn möglich, weil die Kohle billig, der Koks aber im Preise geblieben sei, während das Petroleum sogar noch teurer geworden sei. Die elektrische Strafjenbeleuchtung (nur diese kam, solange man nur die Bogenlampe kannte, zunächst in Betracht) könne den Gaswerken nicht lebensgefährlich werden, weil diese im Durchschnitt nur $13 \%$ der Gasabgabe ausmache. Schlieflich könnten die Gaswerke auch die elektrische Beleuchtung in ihren Arbeitsplan aufnehmen.

Im Jahre darauf war aber der Niedergang auch bei den Gaswerken spürbar. Die Industrie mit verkürzten Arbeitszeiten nahm weniger Gas ab, auch die Eisenbahnen sparten und die Kokspreise gaben nach $\left.{ }^{4.35}\right)$. Dafür war die Elektrotechnik rege und hatte vor allem auf der Ausstellung in Paris 1878 einen grołen Erfolg. Hier trat zum ersten Male die Bogenlampe von Jablochkoff auf, die nachher vielfach für Strafyenbeleuchtungsversuche eingesetzt wurde. Noch aber waren die Anlagen sehr teuer. Der Strom lief̧ sich nicht „teilen“ d. h. jede Bogenlampe brauchte ihre eigene Dynamomaschine. Die Parallelschaltung versagte mit dem ungeregelten, schwankenden Lichtbogen. Erst später wurden fünf Jablochkofflampen hintereinander geschaltet. Immerhin bewirkte der Eindruck der Pariser Ausstellung einen Kurseinbruch bei Gaswerken. Am 21. II. 1878 hatte die Deutsche Continental-Gas-Gesellschaft mit ${ }_{12} 3 \%$ ihren niedrigsten Kurs des Jahres. Sie faf̧te den Entschluf, ihren Wirkungskreis auch auf Einrichtung und Betrieb der elektrischen Beleuchtung auszudehnen. Die Satzungen wurden in der Hauptversammlung am I2. März 1879 entsprechend geändert. Da aber kamen geheimnisvolle Nachrichten, T. A. Edison sei die Aufgabe den Strom zu teilen gelungen. Phantasien, nunmehr könne man bereits die Stadt New York mit Strom, der am Niagarafall erzeugt sei, beleuchten, wurden verbreitet und geglaubt. An der Londoner Börse kam es zu einem Kurssturz der Gasaktien. Der Jahrgang 1878 des Journals für Gasbeleuchtung, das bereits 4 I Aufsätze den Berichten über die Elektrizität widmete, spiegelt die Aufregung auch in Deutschland wieder.

Mit welchen Mitteln der neue Wettbewerber gefördert wurde, mag eine Ankündigung von Edisons Erfindung im New York Sun belegen $\left.{ }^{4.35}\right)$ : „Heureka, ich habe es gefunden" soll Edison in seinem Laboratorium in Menlo-Park voller Aufregung ausgerufen haben, den Griff einer Rolle von Ritchies Leitungsdraht in seinen Händen drehend, und sonderbarerweise durch ein ganz anderes Verfahren, als dasjenige, mittels dessen bisher die Männer der Wissenschaft dieses Ziel zu erreichen gedachten. Sie alle hatten sich in seine Sackgasse verrannt, und wenn sie erfahren werden, wie ich die Aufgabe gelöst habe, so wird jeder sich

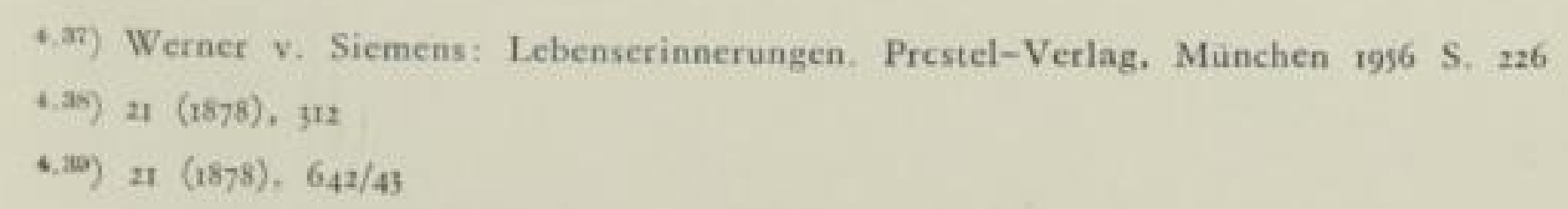


wundern, daf er selbst nicht auf den Gedanken gekommen ist, so einfach ist er. Zehn Lichter mit einer einzigen Maschine zu erzeugen, hat man als einen grołen Triumpf der technischen Wissenschaft betrachtet. Mit meinem soeben erfundenen Verfahren, kann ich mittels einer Maschine 1000, nein to 000 oder vielmehr eine unbegrenzte Zahl von Lichtern erzeugen.

„Sobald die Pracht und Billigkeit meiner elektrischen Beleuchtung bekannt werden wird, voraussichtlich in einigen Wochen, und zwar sobald ich meine Verfahren habe patentieren lassen, wird die bisherige Gasbeleuchtung ihrem Ende nahe sein. Mit is bis 20 der neuerdings vervollkommneten Dynamo-elektrischen Maschinen des M. Wallace kann ich den ganzen unteren Teil von New York City erleuchten und gebrauche hierzu nur eine einzige Maschine von soo PS. ... Die im Gebrauch befindlichen Gasbrenner und Kronen kann ich für meine Beleuchtung nutzbar machen. In jedes Haus kann ich einen Lichtmesser stellen, von welchem aus die Drähte durch das Haus geleitet werden... Alsdann können die Hauseigentümer ihr Gas abschaffen und ihre Gasmesser den Gesellschaften zurücksenden... So oft alsdann ein Lichtstrahl begehrt wird, hat man nur nötig, an einer kleinen Feder in der Mitte des Brenners zu drücken. Streichhölzer werden überflüssig."

Man möchte annehmen, dał Edison als Konstrukteur eine auf weite Zukunft gerichtete Aufzerung getan hat, aber sich nicht im unklaren war, wie viel Arbeit noch alle Einzelheiten bereiten würden, und daß̧ lediglich der Reporter mit dem Zeitraffer die Sensation zu schaffen versucht hat.

Das Geheimnis wurde alsbald im Scientific American gelüftet ${ }^{4, t}$ ). In die Mittelachse einer auf Weifglut gebrachten Platinspirale war als Wärmeregler eine Dehnungsstange eingesetzt, die die Spirale vor dem Schmelzen bewahren sollte. Im Jahre darauf war es klar, daß̧ Edison mit dieser Bauart gescheitert war ${ }^{4.11}$ ). Der Regler war unzuverlässig, die Drähte aus Platin-Iridium zerschmolzen.

Die Probeanlagen mit den ersten Bogenlampen in Paris und London mit ihren lichtstarken Einheiten veranlaf̧ten die Gasgesellschaften Grof̧brenner bis 400 Kerzen verschiedenen Systems [W. T. $S u g g$, Mehrfachring-Argandbrenner. Fr. Siemens Regenerativlampen (vgl. Abschnitt 4,5)] unabhängig von dem vorgeschriebenen und bezahlten Gesamtlichtstrom der üblichen Lampen auf eigene Kosten aufzuhängen und zu betreiben. Sie konnten das Ergebnis einer langen Reihe von Versuchs- und Entwicklungsarbeiten, die auch auf manche Irrwege geführt hatten, nunmehr einsetzen und zunächst einmal beweisen, dał gleich groł̧e Lichtmengen mit Gas immer noch billiger zu erreichen wären, als mit den damaligen elektrischen Anlagen.

Unbestreitbar war indessen, daf die von Siemens und Hefner-Alteneck inzwischen konstruierte Differentialbogenlampe einen sichtbaren Fortschritt der Elektrotechnik bedeutete $\left.{ }^{4 . t 2}\right)$. Man sah, daf die elektrische Beleuchtung als Wettbewerber bleiben würde ${ }^{4.45}$ ). Das gab den Anstof ein ganz neues Absatzgebiet mit allen Mitteln zu suchen die Küche. Gewif̧ waren schen hin und wieder Schritte

\footnotetext{
4.40) $21 \quad(1878), 685$

4.41) 22 (1879), 223

4.42) $23(1880), 2$ u. 36

$4+3) 24(1881), 3$ u. 36

178
} 
in dieser Richtung getan. Als das Petroleum auftrat, gingen die Ingenieure als Hersteller von Geräten an die Arbeit. Io Jahre der Entwicklung hatten die Kocherbauweise soweit verbessert, daf man nun auch vertrauensvoll die allgemeine Einführung ins Auge fassen konnte (vgl. 4.52I).

In Dänemark hatten die Gaswerke es gewagt, durch stark herabgesetzte Preise in die Küche einzudringen. Die Abnehmerschaft hatte Verständnis dafür be wiesen, daf̧ das Tagesgas zum Ausgleich der Belastungen, billiger abgegeben würde als das Leuchtgas. Der Erfolg blieb auch nicht aus. Gerade in den kleinen Orten gab man 1880 schon $92 \%$, ja in dem besten $200 \%$ der Leuchtgasmenge als Kochgas ab und fuhr wirtschaftlich sehr gut dabei. In Paris hatte man es im gleichen Jahre ohne Preisnachlał, aber durch kostenfreie Verlegung der Steigleitungen, für die man 7,7 Mio frs verauslagt hatte, auf $25 \%$ gebracht

4.124 Gasmotoren

Da kam endlich in der Mitte des Jahres 1880 dem Gasfach eine allgemeine Wiederbelebung der Wirtschaft zu Hilfe. Paris verzeichnete 1880 den größten Zuwachs, den es bis dahin je erlebt hatte $\left.{ }^{4.4}\right)$. Auch die deutschen Gesellschaften: Allgemeine Gas A. G. Magdeburg, Deutsche Continental-Gas-Ges. ${ }^{4+t^{5}}$ ) und Thüringer Gasges. ${ }^{4.49}$ ) berichteten, dafy der Absatz wieder stiege.

Dabei wirkten sich die schon länger vorbereiteten Arbeiten an der Entwicklung der Gasmotoren aus. Gegenüber der Lenoirschen Gasmaschine war schon Ottos atmosphärische Maschine 1867 ein grofer Fortschritt. Es gelang den Werken, diese Maschine in handwerklichen Betrieben unterzubringen. Die technische Vollkommenheit aber wurde erst 1876 mit dem Viertaktmotor von $O$ t to erreicht, der um 1880 bis 8 PS Gröłze ausgeführt wurde. Durch verbilligte Abgabe des Kraftgases erreichten die Werke eine beachtliche Absatzsteigerung. Alles war wieder in hoffnungsvollem Aufblühen.

4.125 Erneute Schwierigkeiten

Da ereignete sich ein furchtbares Unglück, das dem Gasfach erneut schweren Schaden zufügte. Im Jahıre 1882 brannte das Wiener Ringtheater ab. 384 Menschen kamen dabei ums Leben. Die Ursache war, dał vorschriftswidrig eine Gassoffittenlampe mit elektrischer Fernzündung in Betrieb gesetzt werden sollte ${ }^{4.47}$ ). Diese Soffittenlampen hatten einen geschlossenen gläsernen Verbrennungsraum. Alles ging gut, wenn der elektrische Funke sofort zündete. Für den Fall, daf diese Zündung versagte, bestand eine Vorschrift, die Lampe von der Decke herunterzuziehen, zu öffnen und von Hand zu zünden. Das unterlieł der Beleuchtungswärter, vielmehr versuchte er nachträglich mit einem zweiten elektrischen Funken zu zünden, was eine Explosion hervorrief, die sofort die in der Nähe angehäuften Bühnendekorationsstoffe entzündete. Das Gerichtsverfahren hat ein-

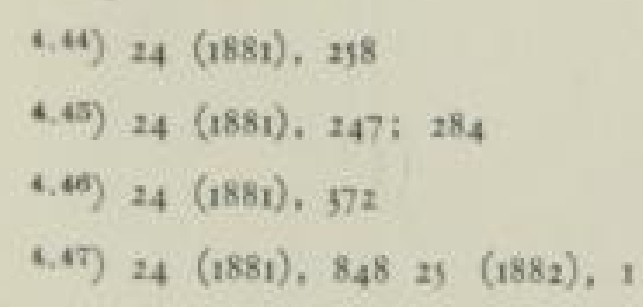


wandfrei ergeben, dał̧ die Größ̧e des Unglücks auf einen völligen Mangel an Schulung des Personals zurückzuführen gewesen ist ${ }^{t .49}$ ). Aber solche Feststellungen vermögen gegen die Schäden des panischen Schreckens bei den ersten Nachrichten nichts gut zu machen.

Anderseits konnten die Fortschritte der $E$ di s on-Glühlampe nicht mehr geleugnet werden ${ }^{4.49}$ ).

Nachdem er zunächst mit Papierkohlenfäden eine an sich ältere Sache aufgegriffen hatte, hatte Edison inzwischen den Kohlenfaden aus Bambusfaser, der sich bestens bewährte, gefunden. Nun aber zeigte sich in der Geisteshaltung der aufsteigenden Konjunktur, dafy die elektrische Beleuchtung dem Gas keinen Abbruch tat, weil sie ganz allgemein zur Steigerung des Lichtbedürfnisses führte ${ }^{4.50}$ ). Nunmehr griffen die Gaswerke ernstlich den Gedanken auf, die Elektrizität mit Gasmotoren zu erzeugen. Das schien zunächst recht günstig zu sein, besonders da die Verteilung des Stromes mit den niedrigen Spannungen auf weite Entfernungen nicht möglich war und deshalb kleine Zentralen gebaut wurden. Das Gaswerk Amsterdam richtete für seine Büros einen Gasmotor, der $4^{8}$ Glühlampen speiste, ein $\left.{ }^{t, 31}\right)$. Schiele mahnte auf der Hauptversammlung die Gaswerke, die elektrische Beleuchtung ihrerseits in die Hand zu nehmen. Eine erste Versuchsanlage zur Beleuchtung der Potsdamer Strafe und des Leipziger Platzes in Berlin mit 36 Differential-Bogenlampen wurde in einem von der Stadt zur Verfügung gestellten Gebäude mit ${ }_{4}$ Gasmotoren von je 12 PS errichtet und Mitte September 1882 in Betrieb genommen ${ }^{4.52}$ ).

Mit besonderem Mut ging die kleine Stadt Temesvár in Ungarn I883 vor, die mit der Brush-Gesellschaft einen Vertrag über ausschließ̧lich elektrische Beleuchtung der Stadt abschlofy. Sie verletzte dabei die bestehenden Verträge mit dem Gaswerk, muf̧te dann aber, als die Installation sich keineswegs bewährte, darum bitten, die Beleuchtung vorerst fortzusetzen. Das Gaswerk Temesvár hat noch viele Jahre mit Erfolg gearbeitet $\left.{ }^{4.53}\right)$.

Im gleichen Jahre wurde in Berlin die Deutsche Edison-Gesellschaft gegrün$\operatorname{det}^{t^{4.5}}$ ), aus der sich die Allgemeine Elektrizitätsgesellschaft entwickelt hat. Indessen waren nicht alle Gründungen zur Ausbeutung der elektrischen Erfindungen gleich glücklich. Die Gründertätigkeit überschlug sich besonders in England. Eine Gesellschaft im Besitze von irgendwelchen Patenten vergab die Lizenzen an Untergesellschaften und diese wieder an weitere kleine Unternehmen. Damit wurde zwar viel Kapital flüssig gemacht, aber Anlagen wurden nicht geschaffen. Im High Holborn in London wurde die Zentrale geschlossen $\left.{ }^{4.55}\right)$. C b a m b er la i n, der Vater des elektrischen Beleuchtungsgesetzes Englands von 1882, stellte als Präsident des Board of Trade fest, dał 120 Konzessionen nachgesucht seien,

\footnotetext{
4.45) $25(1882), 19 ; 282 ; 317$

4.49) $25(1882), 75$

$4,50) 25(1882), 106,201,236,269$

4.51) $25(1882), 459$

4.52) $25(1882), 639$ und 655

4.53) $26(1883), 78 / 79$

4.54) $26(1883), 287 ; 304$

4.65) $27(1884), 33$
} 
73 erteilt, aber keine ausgeführt waren $\left.{ }^{4.56}\right)$. Selbst in der Society of Arts wandte sich ein Vortrag, der die technischen Fortschritte als gesund und anerkennenswert bezeichnete, scharf gegen die Ubertreibungen bei der Gründung von Gesellschaften in der Zeit von $188 \mathrm{I}$ und $\left.1882^{4.57}\right)$. Indessen fielen unter diesen Eindrücken selbst in Deutschland die Kurse der Gasgesellschaften. Die Gründung der Aktiengesellschaft der Städt. Elektrizitätswerke Berlin im Jahre I884 war sicher gesünder als die Mehrzahl der englischen Gründungen. Die Gesellschaft errichtete mit der Deutschen E.dison-Gesellschaft die erste Blockstation in der Friedrichstraf̧e für 2000 Glüh- und 18 Bogenlampen ${ }^{4.55}$ ). Die Dampfkessel und Maschinen wurden in den Kellern aufgestellt.

Der Gasabsatz aber stieg in Deutschland noch immer, wenngleich nun ein neuer Schlag die Gasindustrie traf. Die Preise der Nebenerzeugnisse, des Teeres, für den ein so grofer Markt nicht vorhanden war und insbesondere des Ammoniaks, sanken beträchtlich. Durch den Krieg zwischen Peru und Chile fiel das Salpetermonopol Perus, und Chile war gezwungen, nach dem Kriege mit allen Mitteln Salpeter auszuführen $\left.{ }^{4.50}\right)$. Durch eine geschickte Werbung sank der Preis für Ammonsulfat sogar am Stickstoffgehalt gemessen unter den des Salpeters. C. H. Söbren in Bonn regte I 886 den unmittelbaren Verkauf des Ammoniaks an die Landwirtschaft $\left.a^{4.60}\right)$. Dazu wurde im Bezirksverein Rheinland und Westfalen in der Versammlung in Köln am 21. 2. 1886 die Errichtung eines Verkaufssyndikats für die Nebenprodukte beschlossen. (Vgl. S. 24j)

Nun sank auch wieder der Gasabsatz und zwar als Ausfluf3 einer politischen Beunruhigung, die an den Namen Boulanger geknüpft ist. Die Elektrizität war dabei anerkanntermafjen nicht schädlich. Vielmehr beantragte die englische Gas-Gesellschaft in Wien die Genehmigung zur Verlegung eines elektrischen Kabels zur Beleuchtung des Hoftheaters und ihres Hauptbüros in Wien $\left.{ }^{4.61}\right)$. In Dessau wurde von der Deutschen Continental-Gas-Gesellschaft die zweite elektrische Zentrale Deutschlands für Beleuchtung des Theaters, des Schlosses und der Büros der Gesellschaft, und zwar mit Gasmotoren, in Betrieb gesetzt. Das Gaswerk München hatte auf Anregung der Edison-Gesellschaft Pläne, das Haus Salvatorstraf̧e 20 mit elektrischem Licht durch einen Gasmotor zu erleuchten ${ }^{4.63}$ ). Trotz des bereits wahrnehmbaren Zuges, grołe Räume elektrisch zu beleuchten, wurde auf Kosten der Gasgesellschaft das Odeon in München im Rahmen einer Neuausstattung mit einer guten Belüftungsanlage für Gaslicht vorgesehen $\left.{ }^{4 . a 3}\right)$. Eine Untersuchungskommission stellte im folgenden Jahre fest, daß diese Anlage sehr befriedigend $\left.\operatorname{sei}^{4 . .4}\right)$. Trotzdem aber wurde zwei Jahre später die elektrische Beleuchtung eingeführt.

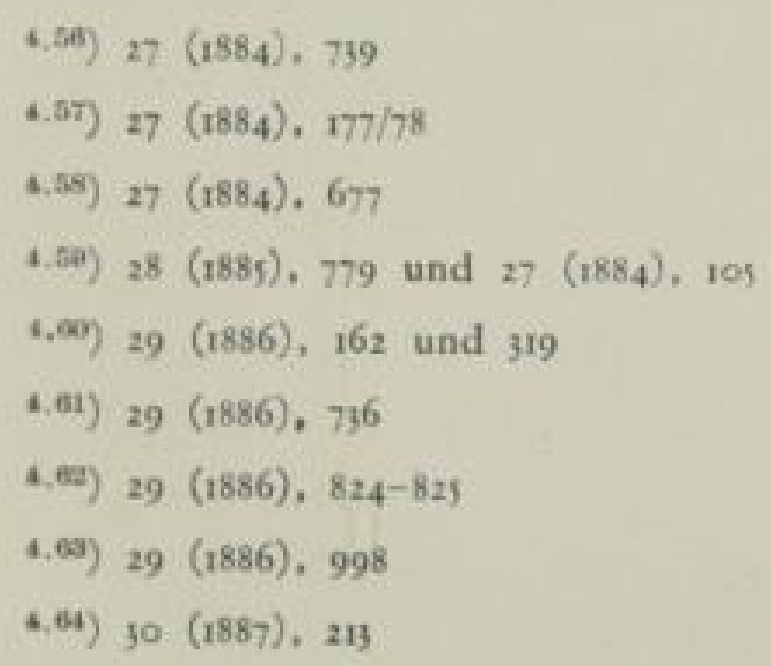


Viel schlimmer waren die allgemeinen wirtschaftlichen Krankheitserscheinungen, die sich durch die Zuckerkrise, die Ertragslosigkeit der Landwirtschaft und eine Uberproduktion der Industrie kund taten. Erst im folgenden Jahre konnte wieder eine Steigerung des Gasabsatzes festgestellt werden. Interessant ist eine Feststellung der Thüringer Gasgesellschaft über den Anstieg des Gasabsatzes. 4,4 \% Privatbeleuchtung, $15,35 \%$ Straß̧enbeleuchtung und $87,36 \%$ Industriegasbeleuchtung $\left.{ }^{4.45}\right)$. Nunmehr wurden die Gaspreise für das Kochen an vielen Orten wesentlich herabgesetzt.

Mit der lebhafteren wirtschaftlichen Betätigung stieg nun auch die Anwendung der elektrischen Beleuchtung. Werner Siemens stellte 1888 fest, daf3 sie im Vorjahre wie noch nie zuvor gestiegen sei, und dafy vor allen Dingen der Bau von Zentralen in Gang gekommen sei $\left.{ }^{i-n_{n}}\right)$. Dagegen waren durch den neu auftretenden Wettbewerb des Petroleums aus Baku die Petroleumpreise so gedrückt, wie man es seit den 6oer Jahren in Deutschland nicht erlebt hatte.

Durch die Entwicklung der Regenerativlampen, die viele Nachahmungen ins Feld ricfen, trug F. Siemens sehr zur weiteren Ausbreitung der Starklichtbeleuchtung bei. Dem Gasmotor erwuchsen Wettbewerber durch die Errichtung von Druckluftanlagen, die das Kleingewerbe versorgen sollten ${ }^{4.07}$ ); in London wurde für den gleichen Zweck seit 1887 Druckwasser verwendet ${ }^{1.65}$ ). Trotz groß̧er Werbung waren solche Anlagen aber wirtschaftlich den Gasmotoren nicht gleichwertig. Es ist wohl das erste Mal gewesen, als in London C ro mp to n, der Vorsitzende des Elektrizitätsvereins, 1895 den Totalitätsanspruch für Kochen und Heizen mit Elektrizität aussprach ${ }^{4 . a v}$ ). Er meinte mit der elektrischen Heizung könne in Kabaretts ein erträglicher Aufenthalt während der Kälteperiode geschaffen werden.

4.I26 Das Gasglühlicht

Jetzt kam Auer v. Welsbach mit seiner Erfindung des Glühstrumpfes im rechten Augenblick dem Gasfach zu Hilfe. Die erste Nachricht im Jahre $1886^{4.50}$ ) wurde zwar mit groß̧er Skepsis entgegengenommen. Die ersten Glühstrümpfe waren auch noch aufjerordentlich empfindlich, aber im Jahre 1892 hatte Auer seine Strümpfe schon so weit verbessert, daf Faehndrich, Wien, von einem Sieg des Auerbrenners sprechen konnte $\left.{ }^{t .77}\right)$. In Wien waren in neun Monaten 90000 Brenner geliefert. In Deutschland zur gleichen Zeit 20000 , davon die Hälfte nach: Berlin. Faehndrich wies darauf hin, welche grołe Bedeutung diese Erfindung nicht allein wegen der besseren Ausnützung des Gases im Brenner hätte; vor allem sei die Leuchtkraft des Gases nicht mehr von gleicher Bedeutung wie früher und damit würden ganz neue Wege für eine verbilligte Gaserzeugung in groß̧en Ofeneinheiten ohne Karburationszusätze erschlossen.

4.65) 31 (1888), 309

4.66) 31 (1888), 1093

4.07) 34 (1891), 369

4.68) 3) (1894), 110

(.6) $38(1893), 114$

4.70) $29(1886), 65 / 66$

4.7) $35(1892), 345$ u. 57 
Die allgemeine Wirtschaftslage belebte sich aber erst wieder im Frühjahr $1894^{4.77}$ ) und entwickelte sich dann besonders lebhaft. So endete das Jahrhundert in einer freundlichen wirtschaftlichen Atmosphäre und mit glücklichen Aussichten auf die Zukunft.

Die Gaswerke haben im Jahre 1899 I,2 $\mathrm{Mia} \mathrm{m}^{3}$ Gas $\left(\mathrm{H}_{0}=5500\right)$ erzeugt. Ein volles Drittel davon diente zum Kochen, Heizen und Motorenbetrieb. 2I Mio Einwohnern von so Mio insgesamt im Deutschen Reiche ist das Gas zugänglich geworden. I Privatflamme kam auf $1,8 \mathrm{i}$ Einwohner und zwar in Grofstädten I : 1,54 , in Kleinstädten $\left.I: 2,9^{4.73}\right)$. Der Gasverbrauch je Kopf und Jahr betrug in Großstädten $54 \mathrm{~m}^{3}$ in Kleinstädten $26,6 \mathrm{~m}^{3}$, I Gasmotor kam auf $8 \mathrm{I} 4$ versorgte Einwohner; I PS auf 190. 26000 Motore entwickelten no 000 PS, also im Durchschnitt war die Stärke eines Motors 4,3 PS.

Als Beispiel dafür, was als der beste Ofen angesehen wurde, wurde auf der Weltausstellung in Paris ein Schrägretortenofen nach A. Coze gezeigt ${ }^{4.74}$ ).

Die Dinge, um die sich das Sinnen und Trachten des Faches drehte, behandelte H. B unte in seinem Vortrage: „Zur Mischgasfrage" auf der Hauptversammlung des Vereins ${ }^{4.75}$ ) und über "Gasglühlicht" auf dem ersten internationalen Gaskongref in Paris $\left.{ }^{4.76}\right)$. Durch das Verfahren von J.Fleiscber und C. Dell$w i c k$ sei in der Wassergasherstellung $(70 \%$ thermischen Wirkungsgrad gegen $50 \%$ vordem) ein solcher Fortschritt geschehen, daf man sich die Frage vorlegen müsse, ob die günstige Aufnahme des Wassergasverfahrens nur eine vorübergehende Erscheinung sei, oder ob im 20. Jahrhundert die alte Kohlenentgasung zu den überwundenen Verfahren gehören würde. Die Karburierung mit Ol sei in Deutschland nur durch den möglicherweise schaell beseitigten hohen Zoll auf Erdölerzeugnisse behindert. Die kalte Karburierung mit Benzol, die bereits vielfach ausgeübt wurde, sei dann wirtschaftlich, wenn die Zechen als Haupterzeuger die Auswaschung im entsprechenden Maf̧e steigerten. Die Ölkarburierung sei aber vorteilhafter, weil vorwiegend Aethylen entstände, das nicht wie Benzol bei Kälte ausfalle. P. Mabler habe zwar in seiner „Contribution à l'étude des combustibles ${ }^{\text {(4...7\%}}$ ) den Entgasungswirkungsgrad unter Berücksichtigung des Wärmewertes aller Wertstoffe auf $96 \%$ errechnet, aber möglicherweise könne man in Zukunft die Wassergasumsetzung statt bisher nach der Umsetzung $\mathrm{H}_{2} \mathrm{O}+\mathrm{C}=\mathrm{CO}+\mathrm{H}_{2}$ auch nach $2 \mathrm{H}_{2} \mathrm{O}+\mathrm{C}=\mathrm{CO}_{2}+{ }_{2} \mathrm{H}_{2}$ erstreben. Denn der $\mathrm{CO}_{2}-$ Gehalt, der bisher wegen der Beeinflussung der Leuchtkraft nicht auftreten durfte, schade beim Auerbrenner nicht mehr in gleichem Maßje.

Dieser Brenner war nun soweit entwickelt, dał bei $30 \mathrm{~mm}$ Druck während 300 Stunden durchschnittlich mit $1201 / \mathrm{h} 70 \mathrm{HK}$ erzeugt oder $1,7 \mathrm{l} / \mathrm{HK}$ gebraucht wurden. Noch 1895 ging die Mehrzahl der I4 verschiedenen Glühkörpersorten nach $300 \mathrm{~h}$ Brenndauer auf $40 \mathrm{HK}$ zurück $\left.{ }^{4.75}\right)$. Bei Pref̧gas und Pref̧luftlampen wurden I $1 / \mathrm{HK}$ erreicht. Vergleichsversuche mit den Gasen von Berlin, Charlot-

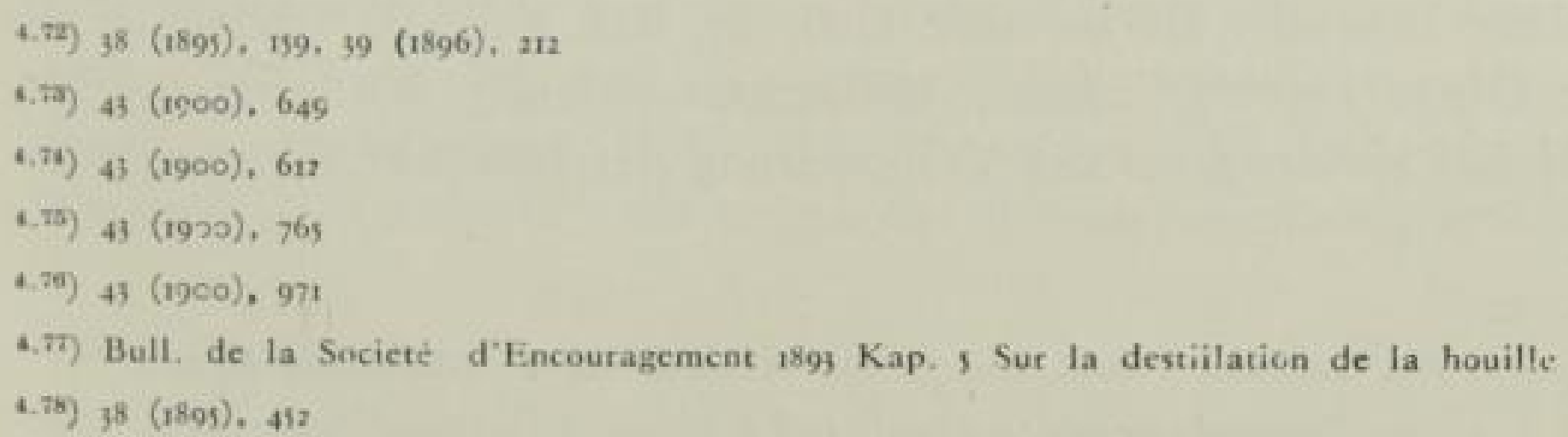


tenburg, Dessau und Karlsruhe zeigten, daf bei den Heizwerten von 5130; 5022; 5242 und $5003 \mathrm{kcal} / \mathrm{m}^{3}$ die Leuchtkraft im Schnittbrenner zwar 9,4; 8,8; II,6; u. I2,4 HK ergab, indessen im Auerbrenner gleich war. Untersuchungen mit verschiedenen Zusätzen zum Leuchtgas zeigten die Brauchbarkeit solcher Zusätze im Auerlicht.

Damit sei, so sagte $B u n t e$, eine neue Freiheit in der Gaserzeugung gewonnen, die in vielfacher Hinsicht ausgebeutet werden könne. Wahrscheinlich komme in der Zukunft die Verwendung groß̧er Kammern nach dem Vorbilde der Kokereien mit ihren vielmals billigeren Verfahren. Als Vorsitzender des Deutschen Vereines aber sprach W. v. Oecbelbaeuser d. J. auf der Hauptversammlung zu seinen Fachgenossen von den grof̧en Anliegen des Ingenieurs ${ }^{4,70}$ ).

I). Der Bewältigung der sozialen Aufgaben des Ingenieurs als Folge der neuen Rechte der Hochschulen (Gleichschaltung mit den Universitäten und Promotionsrecht).

2). Der Vorbildungsfragen der höheren Schulen.

3). Der Sorge um den allgemeinen Stand der technischen Intelligenz.

Die ideelle Auffassung der Fachgenossen über ihr Fach hatte er bereits 1892 zur 100-Jahrfeier des Gasfaches formuliert $\left.{ }^{4.50}\right)$ : „Wir verwahren uns ausdriicklich dagegen als wollten wir die Generalpächter von Licht-, Wärme- und Kraftverteilung sein. Der Himmel bewahre uns vor einer solchen Riesenaufgabe. Wir stimmen vielmehr ganz mit den besonnenen Führern der elektrotechnischen $\mathrm{Be}$ wegung und unseren Freunden in dieser Industrie überein, welche wiederholt die Ansicht vertreten haben, dał Petroleum, Gas und Elektrizität auch in Zukunft nebeneinander ihre volle wirtschaftliche Berechtigung und jede dieser Industrien ihr charakteristisches Absatzgebiet behalten werden können. Allein gegenüber jenen Heißsspornen und Hellsehern, die nicht müde werden können, unserer Leuchtgasindustrie eine baldige Götterdämmerung zu prophezeien, stellen wir fest, dafy die Gasindustrie nicht nur auf zwei sondern sogar auf drei kerngesunden Beinen steht: nämlich

Licht, Wärme und Kraft" .

Das stimmte auch noch für den Abschlu\} des Jahrhunderts. „Der Wettbewerb hatte das Gasfach eher gefördert als der Entwicklung geschadet ${ }^{\text {(4t.51)}}$.

\subsection{G A E R ZEUGUNG}

Beherrschend blieb für den ganzen Zeitabschnitt die Entgasung der Kohlen in Retorten, die anfangs durchweg liegend angeordnet waren. Durch das Vorgehen von A. Coze, Reims fanden aber ab Mitte der 8o-er Jahre schrägliegende Retorten immer mehr Freunde. Es ist aber nicht so, dafy sich dic Fachleute mit dem Stand der Dinge beruhigt hätten. Wassergaserzeugung, Karburierung des Wassergases und des Kohlengases zur Verbesserung der Leuchtkraft wurden im-

\footnotetext{
4.Rv) $43(1900), 477$ u. 493

6.80) W, v, Oechelhaeuser: Aus deutschet Technik und Kultur, München 1921 R. Oldenbourg S, 120

4.81) Leitartikel des J. f. G. zur Jahrhundertwende 43 (1900), I
}

184 
mer wieder vorgeschlagen, versucht und erörtert, schon weil in Nordamerika dieses Gas bald einen überragenden Anteil an der Versorgung bekam.

In den goer Jahren gingen dann englische Werke zur Zumischung von karburiertem Wassergas zum Kohlengas über und von da ab wurde auch in Deutschland sehr lebhaft an der Entwicklung weitergearbeitet.

Ölgas gewann ein besonderes Absatzgebiet für die Beleuchtung von Eisenbahnwagen und von Seezeichen. Azetylen trat ab 1895 als Wettbewerber auf, als es gelungen war, Kalziumkarbid im Lichtbogenofen preiswerter als je zuvor herzustellen. Aber auch diese Gasart fand bald ganz bestimmte Absatzgebiete, für die es sich als besonders geeignet erwiesen hat.

So war auch diese Zeit keine Spanne behaglicher Ruhe, zumal auch der Ofenbau entscheidende Wandlungen erfuhr.

\subsection{Ofenanlagen}

Über den Stand der Technik um 1860 gibt ein Reisebericht W. Oecbel bäusers einen ausgezeichneten Überblick ${ }^{4.52}$ ). In England fand Oechelhäuser manche sehr veralteten Werke vor. Er schob das auf die gesetzliche Dividendenbeschränkung von $10 \%$, die den Reiz zu größerer Wirtschaftlichkeit nähme. Der grofe Absatz hatte auch großje Ofeneinheiten nach sich gezogen. Vor allem fielen die $6 \mathrm{~m}$ langen durchgehenden Retorten mit zwei Köpfen auf. In der Regel waren diese Ofen stark verankert. Normalerweise waren 7 Retorten in einem Feuerraume. Die Flammen gingen bis zum Gewölbe hoch und wurden dann nach unten abgezogen. Tabors alte Anregung war also zur Norm geworden. Ein Ofen von Croll in den Surrey und Great Central Gasworks hatte im oberen Teile 6 bis 7 Tonretorten und im unteren die gleiche Zahl eiserne. Die freitragenden Retorten ohne Zwischenauflagen waren allgemein vorgezogen. Thr Vorteil war die leichte Wärmeaufnahme, der Nachteil, dał sie leicht brachen. G. Livesey der South Metropolitan Gas Co. bevorzugte aus Ziegeln zusammengesetzte Retorten. Hierzu wurden Dinassteine benutzt $\left.{ }^{1.83}\right)$. Als Unterfeuerungsaufwand wurden angegeben: als Bestwert in Liverpool 22,5\% bezogen auf Kohlengewicht $=\mathrm{I} / 3$ des erzeugten Kokses. Im Durchschnitt aber brauchte man 24 bis $26 \%$, während Deutschland auf 20 bis $21 \mathrm{~kg}$ Koks $/ 100 \mathrm{~kg}$ Kohle gekommen wäre. Chargierung geschah mit der groß̧en von drei Leuten bedienten Handmulde. Ausstehzeit betrug in England 6 Stunden, in Deutschland nur 3. Damit war bei uns der Verlust an Leuchtkraft, der durch höhere Temperaturen entstand, wieder eingeholt. Die Leistung ist also in Deutschland höher gewesen, die aus der Kohle entgaste Gasmenge dagegen in England.

Die in Paris angetroffenen Ofen von Pauwels \& Dubochet mit Kammern von $2 \mathrm{~m}$ Weite, $1 \mathrm{~m}$ Höhe und 7,20 m Tiefe, die nur alle drei Tage geladen wurden, sind echte Koksöfen, wie sie damals üblich waren. Sie gaben wenig Gas, aber einen ausgezeichneten Koks. (Vgl. S. 138/139.) Es gab also damals in Paris die erste „Gaskokerei“, die neben der Retortenentgasung betrieben wurde.

\footnotetext{
6.52) $4(1861), 13 / 25: 37 / 6 \mathrm{t}$

4.83) 5 (1862), 417; Muspratt, S, 485 (5. 2.81)
} 
Die bessere Ausnützung der Unterfeuerung wurde gerade in Betracht gezogen. 186I berichtete man aus Kopenhagen (Englische Gesellschaft), daf3 Gas- und Luftkanäle im Mauerwerk zum Wärmeaustausch nebeneinander geführt wur$\left.\operatorname{den}^{4{ }^{* 1}}\right)$. Näheres ist leider aus dieser anregenden Mitteilung nicht zu ersehen. Oechelhäuser hatte festgestellt, daf̧ er die Ausnützung verbesserte, wenn er die üblicherweise beim 7-Retortenofen unmittelbar über dem Rost liegende Retorte fortlief, also aus dem 7er Ofen einen 6er Ofen machte. Grund war offenbar die bessere Entfaltung der frei brennenden Flamme ${ }^{4.55}$ ).

4.2II Generatorgasfeuerung mit Wärmerückgewinnung

Eine Umwälzung im Gaswerksofenbau brachten aber, wenn auch langsam, die Arbeiten von Friedrich Siemens am Industrieofen. Dieser hatte sich bekanntlich, sozusagen als technischer Lehrling bei seinem Bruder Wilhelm Siemens mit der Heifluftmaschine mit Regenerator nach dem Vorbilde J. Erics sons abgemüht, die mit einem Wärmeaustauscher arbeitete. Dabei zündete bei ihm der Gedanke, da\} der „Regenerator “ im Ofenbetrieb von ganz besonderem Werte sein würde, überall da, wo die Abgase mit hohen Temperaturen in den Schornstein entlassen wurden. Bei den ersten Arbeiten mit Vorwärmung der Luft aus den Abgasen aus dem Jahre $\left.1856^{4.80}\right)$ versuchte er es mit dem Planrost. Aber er sah bald ein, daf̧ der ungleichmäßjige Betrieb dieser Roste und die mangelhafte Rostkühlung die Aufgabe erschwerten. So erfand er für sich von neuem den an sich schon bekannten Gasgenerator, bei dem er die Zweitluft sehr heif zuführen konnte. Siemens hatte voll damit zu tun seine Einrichtung für Flammöfen zu entwickeln. Bei den Stahlöfen wurde nicht nur Wärme gespart, sondern auch das Martinsche Einschmelzverfahren erst ermöglicht.

Das Gasfach nahm von seinen Arbeiten zum ersten Male I862 Kenntnis ${ }^{4.57}$ ). Was sie in sich bargen, ahnte man noch nicht. Das Urteil lautete vielmehr: „wichtig für Unterfeuerung mit minderwertigen Brennstoffen, um Koks abgeben zu können". Bei der Gas Light \& Coke Co. und in Paris wurden im gleichen Jahre die ersten Ofen mit Treppenrostgenerator erbaut. Im Bericht darüber ${ }^{4.85}$ ) war man wegen des Bauaufwandes skeptisch, da ja der metallurgische Erfolg fü: Retorten keine Bedeutung habe. In London habe man die Öfen 12 Monate lang ohne wirtschaftlichen Erfolg betrieben, in Paris sähe man noch nicht klar. Immerhin wurde verzeichnet ${ }^{4.85}$ ), dał der Versuch am ersten Ofen günstig ausfiel und 16 Ofen mit 8 Retorten umgebaut wurden. Noch ro Jahre später schob man den wirtschaftlichen Erfolg der Pariser Öfen darauf, dał diese aus Platzmangel zweistöckig gebaut waren $\left.{ }^{4.00}\right)$. Jedenfalls hielten aber infolge der gleichmäßjigen Beheizung die Retorten länger. In Frankreich hatte man aber auch ein-

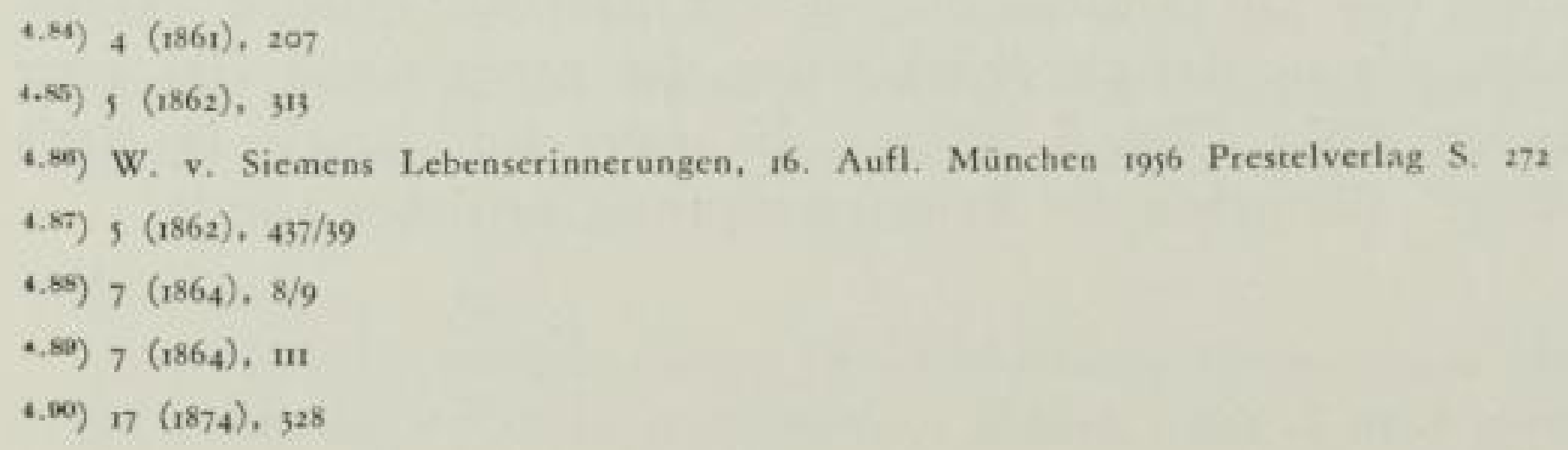




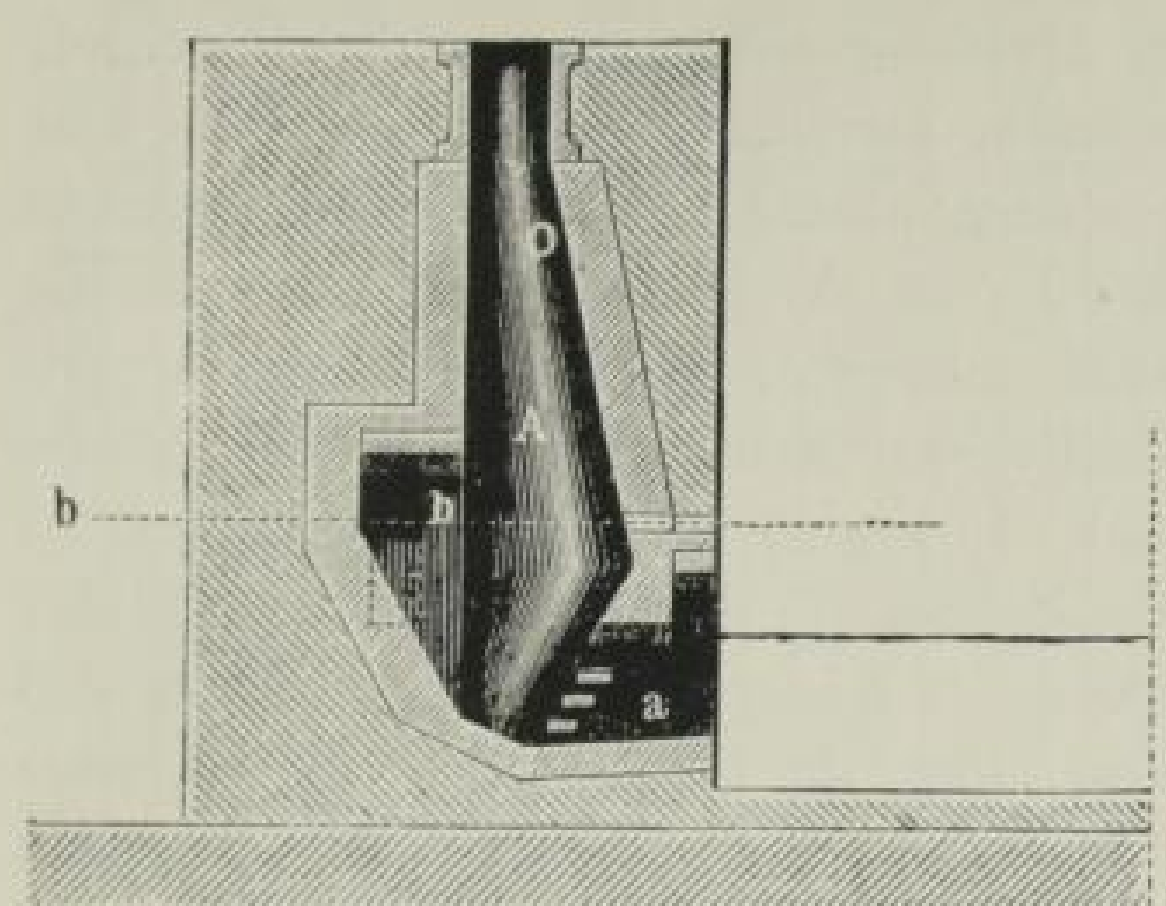

Bild 30

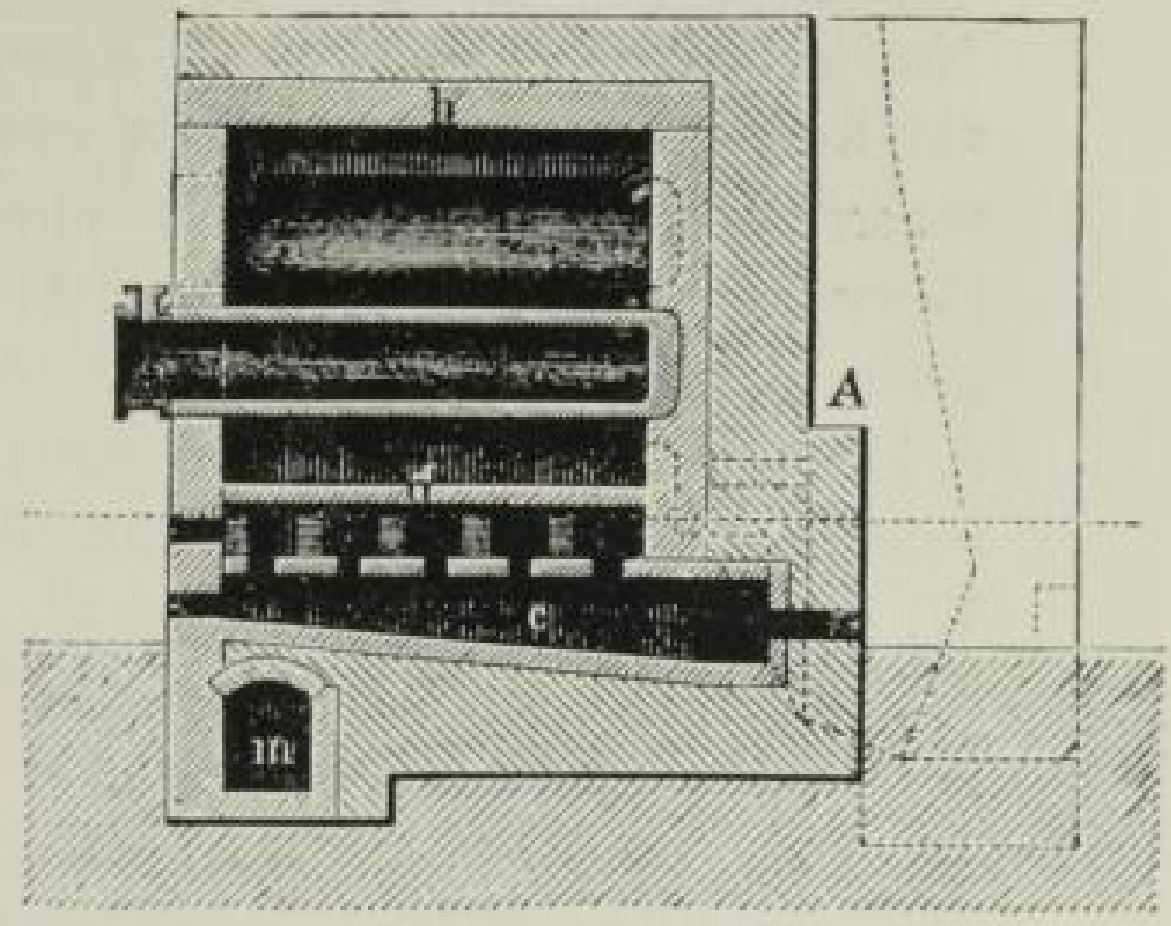

Bild 31

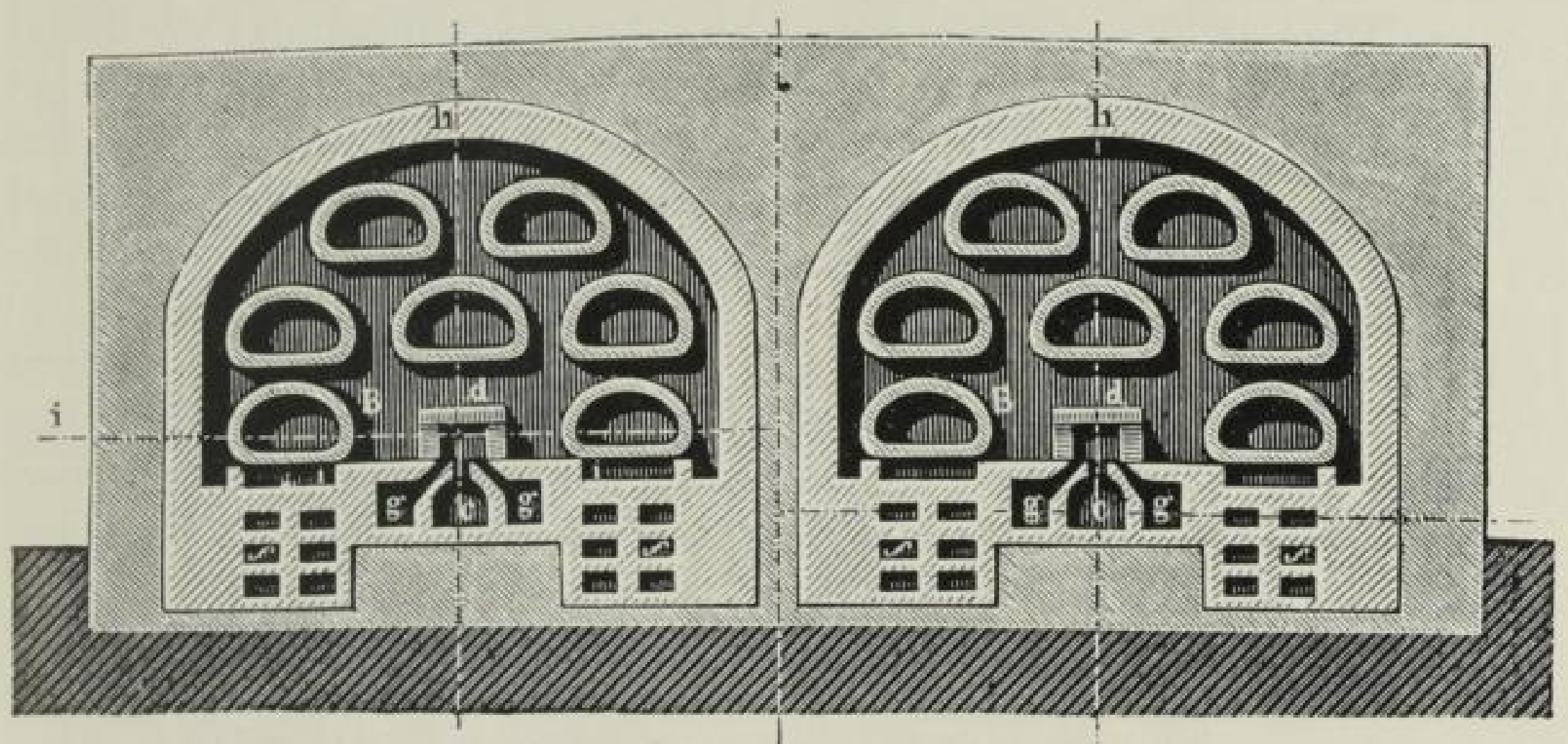

Bild 30 bis 32 Öfen von Müller und Eichelbrenner (Muspratt, S. 405/6)

fachere Bauarten versucht. Ponsard nahm Rekuperatoren, die aber durch Undichtigkeiten litten. Lencaucbez erzielte größere Ersparnisse, weil er mit nur 2,5\% $\mathrm{O}_{2}$ im Abgas feuern konnte. Der Chefingenieur des Pariser Gaswerkes schlug vor, zur besseren Feuerführung mit Gas die Retorten senkrecht zu stel$\left.\operatorname{len}^{4 \cdot 11}\right)$. Die besten Schrittmacher aber waren Müller \& Eichelbrenner, die in der Provinz mehrere Gasgeneratoren unter gewöhnlichen Retortenöfen eingebaut hatten. Sie lieferten sowohl Treppenrostgeneratoren als auch Zentralgencratoranlagen mit Rekuperatoren ${ }^{4 * 2}$ ) (Bilder 30 bis $3^{2}$ ). Beim Einzelgenerator wärmten sie lediglich die Luft vor, aber nicht durch die Abgase sondern in Kanälen unter dem Ofen. Das war ein Fehler, da ja diese Wärme dem Ofen nun entzogen wurde.

Jetzt aber hatte der Gedanke in Deutschland gezündet. Schon $1876^{4 . v a}$ ) schrieb die Deutsche Continental-Gas-Gesellschaft einen Brief an das Journal für Gasbeleuchtung, nachdem sich die Generatorfeuerung seit Frühjahr 1875 bewährt habe, würde sie bei ihren Werken allgemein eingeführt werden.

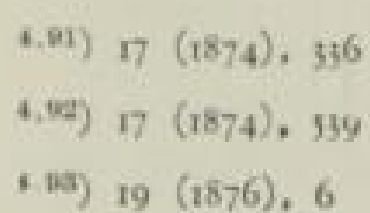


Nun erhob sich ein lebhafter Kampf der Meinungen. Der eine wollte Zweitluft am Rost vorwärmen und hielt vom Generator gar nichts. ${ }^{4.94}$ ), der andere bewies theoretisch, dafs die Luftvorwärmung wenig ausmache ${ }^{4.05}$ ). Die Priorität in Deutschland wurde W. Oecbelbäuser von A. Hegener, Köln streitig gemacht, der sie G. Liegel, Stralsund zusprach, während umgekehrt A. $K l o ̈ n n e$ Liegel angtiff, er habe tatsächlich gar keinen Generator $\left.{ }^{4.00}\right)$. Beliebt wurden die Generatoren ohne Rost mit flüssigem Aschenabzug (Liegel ${ }^{4,37}$ ); W. Bäcker, Budweis ${ }^{4.95}$ ) und W. Hor $n$, Bremen ${ }^{4.09}$ ). Ein vollständiges Bild der aufeinanderprallenden Meinungen zu geben, ist leider unmöglich. Es kam 1876 zu einer allgemeinen Aussprache $e^{4.100}$ ). Von allen, die Erfahrungen hatten, wurden die günstigen Wirkungen zusammengetragen. Es war das nicht allein die rückgewonnene Wärme, sondern auch der gleichmäf̧ige Abbrand, Schonung der Retorten, Erhöhung der Retortenzahl im gleichen Ofenraum, Möglichkeit mit geringem Überdruck im Feuerraum zu fahren. Dresden gab an, dał der Koksverbrauch je $100 \mathrm{~kg}$ Kohle auf $\mathrm{I} 6$ bis $17 \mathrm{~kg}$ Koks bei 6-8\% $\mathrm{CO}_{2}$ im Abgas gesunken sei. Ein Ausschuf mit H. Bunte wurde beauftragt, den Einfluf des Zuges auf den Generator zu untersuchen. Den Bau des Generators übernahm das Gaswerk München. Ein Unterwindgebläse wurde von Gebr. Körting, Hannover gestiftet. $\left.{ }^{4.101}\right)$.

Bunte hat diesen Auftrag viel umfassender angefaß̧t, als er ursprünglich gelautet hatte. Schon bald nach der Sitzung veröffentlichte er die klare Theorie des Generators. Aus gesammelten Erfahrungen hielt er die Nachteile fest, die das etwa doppelte Luftvolumen der Abgase bei Rostfeuerung gegenüber der Generatorgasfeuerung mit sich brächte $\left.{ }^{t .102}\right)$. Er entwickelte die Anregungen Bunsens bei seinen berühmten Versuchen an Öfen der Eisen- und Kupferhütten zu einer genauen chemischen Feuerungskontrolle in allen Zwischenstufen. Dabei schuf er seine Bürette. Der Schluß̧bericht des Ausschußzes hob die grołe Bedeutung des Wasserdampfzusatzes unter dem Koksgeneratorrost hervor ${ }^{\text {t.103 }}$ ). Im Jahr 1909 feierte der Bericht des Vorsitzenden des Vereins, diese Untersuchung als die „erlösende Tat" zur wissenschaftlichen Arbeit im Fach" $\left.{ }^{4.12}\right)$. Der Münchner Retortenofen für Gasfeuerung mit Luftvorwärmung war ein Ergebnis der Arbeiten $^{4.105}$ ) (Bilder 33 und 34).

Als Beweis, dafy die neue Entwicklung in der Gastechnik weite Kreise beschäftigt hat, mag ein ausgezeichneter Aufsatz eines Auf̧enseiters, des Gewerbeschullehrers C. Ha upt. Brieg ${ }^{4.100}$ ) festgehalten werden, der sich mit der

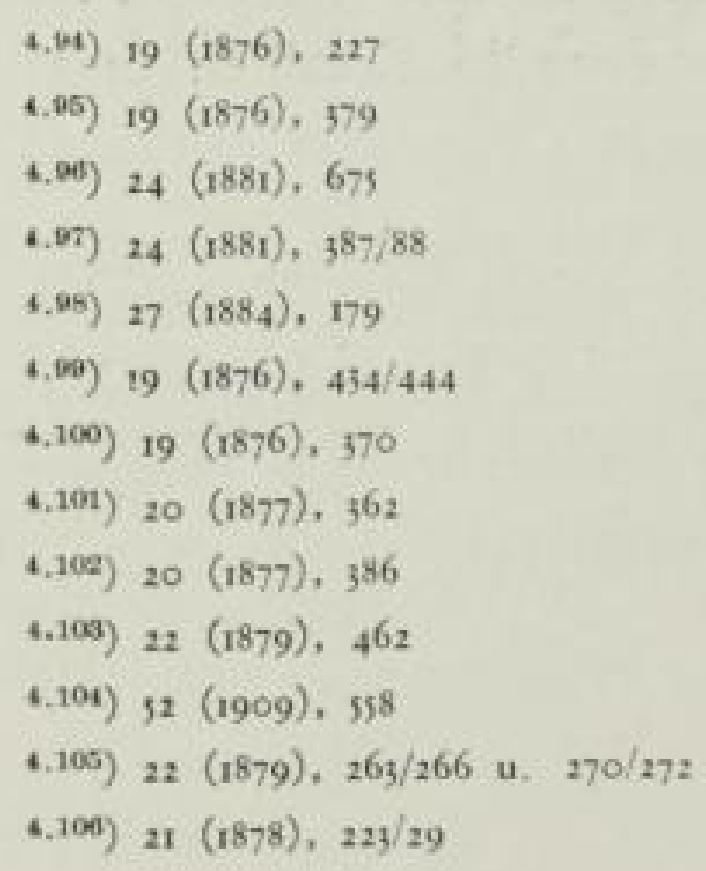




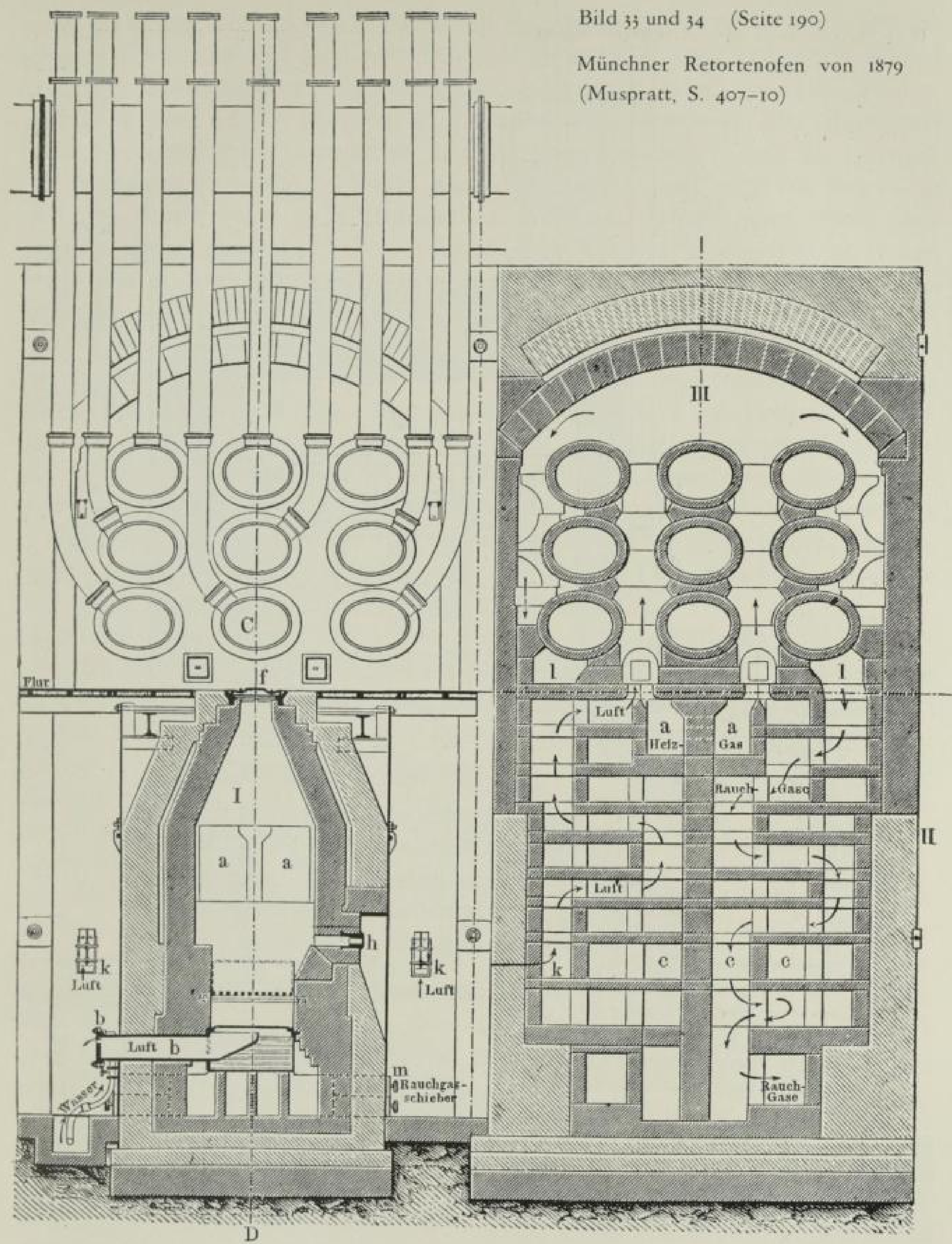

Flammenentwicklung bei Generatorgasfeuerungen auseinandersetzt, die erhebliche Vereinfachungen im Ofenbau zur Folge hätte. Im gleichen Jahre zeigten auch Müller \& Fichet auf der Pariser Ausstellung zwei verschiedene Typen für Ofenbrenner, die eine mit kurzer Flamme und Abdeckung der deutschen Bauweise entsprechend, die andere mit besonders langgezogener gieichmäßjiger Flam$\left.\mathrm{me}^{t .10 \%}\right)$. Einzelne Schwierigkeiten z. B. mit Dickteerbildung in den Steigrohren 


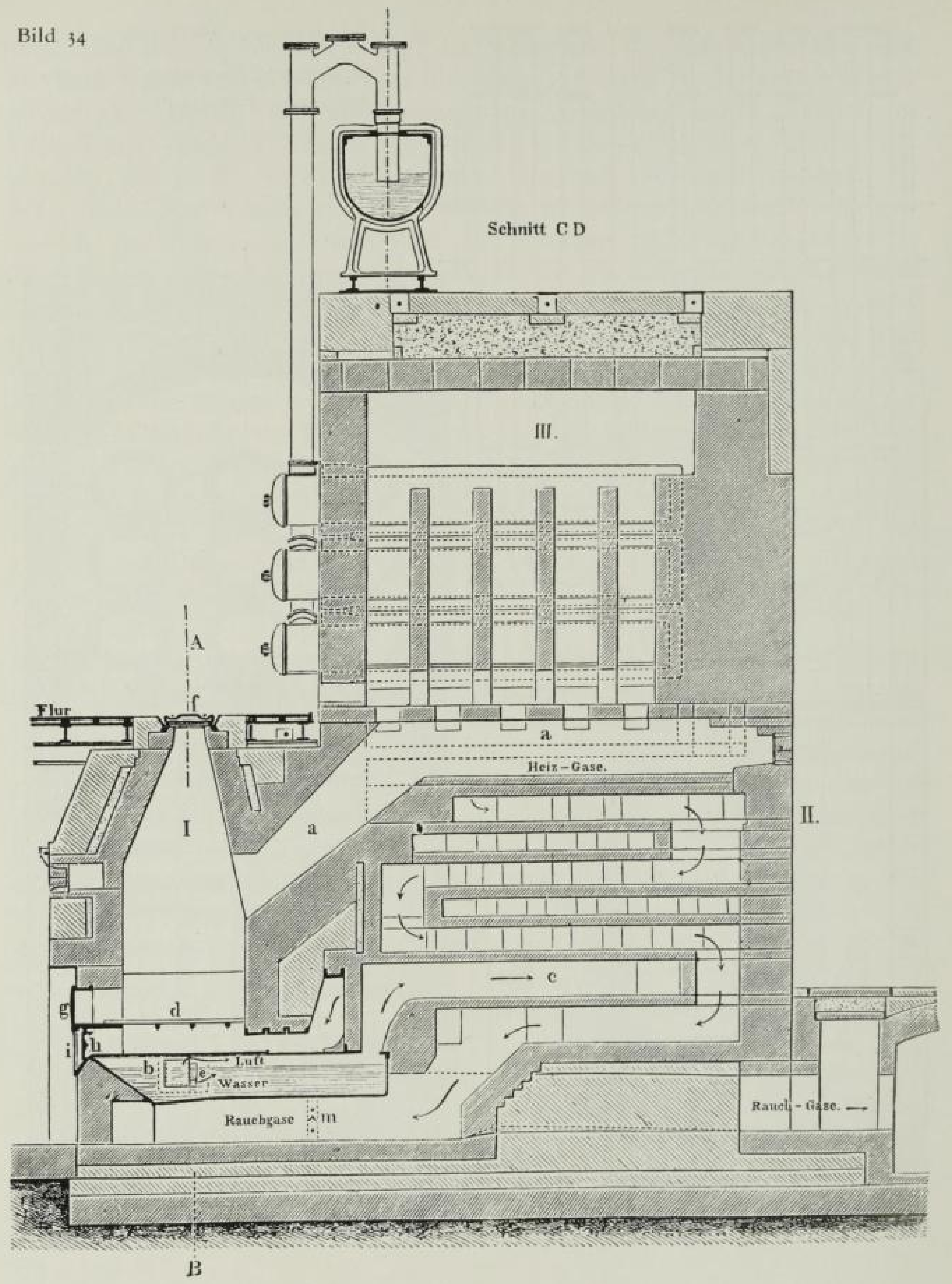

wurden bald überwunden. Freudig konnte auf der Hauptversammlung des Vereins festgestellt werden, daß bezüglich der Generatorgasfeuerung Deutschland allen Ländern vorausgeeilt war $\left.{ }^{4.105}\right)$. Das wurde nun auch in England 1884 bestätigt, wo man auf Brennstoffersparnis nicht den gleichen Wert gelegt hatte, die Anregungen aber nunmehr aufnahm ${ }^{4.100}$ ).

4.108) 22 (1879), 433

(.109) $27\left(188_{4}\right), 48 \mathrm{t}$

\section{SLUB}


Der Wert der Gasfeuerung ist aber wohl erst dann voll eingesehen worden, als r884 A. Coze auf den Gedanken kam, nunmehr die Retorten mit einem Winkel von $30^{\circ}$ schräg zu legen. Solche Versuche waren mehrfach gemacht worden, sicherlich öfter als uns berichtet ist. Es lag ja auch allzu nahe, die Schwerkraft zum Kohlentransport auszunutzen und die beschwerlichste Arbeit im Gaswerk loszuwerden. Aber alle Versuche waren gescheitert, weil man die Beheizung mit der Rostfeuerung nicht genügend in der Hand gehabt hatte. Wenn aber ungleichmäßjig geheizt und entgast wurde, vor allem über die Zeit gerechnet, dann war es nicht möglich die Retorte nach Programm in dem Augenblick zu entleeren, an dem der Koks willig herausrutschte.

A. Coze erhielt sein Patent Nr. 33959 in Deutschland am 28. 3. I885. Die Ersparnis an Arbeitskräften war zunächst nicht so grof̧, wie man erwarten sollte. Für zwei Öfen waren in Reims 4 Mann statt vorher 6 Mann zur Bedienung erforderlich. Den Arbeitern war zwar die Arbeit erleichtert, aber die Wirtschaftlichkeit für den teueren und in der Haltbarkeit ungewissen neuen Ofen zu errechnen, war nicht leicht. Es mufjte zudem der Neigungswinkel der Retorte der Kohlenart angepafjt werden, denn wenn nicht die Aethylene zersetzt werden sollten, mufte die Kohlenschicht ganz flach in den Ofen rutschen und durfte sich nicht stauen oder unten stopfen.

Zum ersten Male in der Geschichte des Gaswerkbaues trat nunmehr der Fall ein, dał eine Lieferfirma, die Stettiner Schamottefabrik, in ihrem Betriebe einen Probeofen herstellte. Sie nahm dazu, um an Kosten zu sparen, Rostfeuerung und erntete sofort die Erkenntnis, dafy der Ofen mit dieser Feuerung nicht zu betreiben war. Bald aber wurden auch in Berlin und Dresden Öfen gebaut ${ }^{. .110}$ ). Wichtig erwies sich die Ausgestaltung der Fülleinrichtung in Deutschland mit einem löffelartigen Trichter, der der Hitze des oberen Kopfes möglichst entzogen ist, damit sich nicht bei Wartezeiten die Kohlen im Kopf erwärmen könnten. Die Engländer, die ebenfalls 1889 in Brentford und 1890 in Kensal Green größzere Anlagen gebaut hatten, versuchten einen senkrechten Einfüllschacht mit schlanken Bogen zur Schräglage. Noch viele tastende Änderungen wurden bekannt, aber verhältnismäßjig schnell hat sich die Einrichtung nach Bild 35 mit nach der Kohlensorte und Feuchtigkeit wechselnder Neigung in der Schütte und Stau am unteren Ende der Retorte als beste durchgesetzt. 1896 wurde ein Ausschuf\} beauftragt, die Erfahrungen zusammenzustellen $\left.{ }^{4.111}\right)$. Damals standen bereits solche Ofen in Altona, Berlin, Chemnitz, Dresden, Kassel und Wien. Zwei Jahre später waren in Deutschland 885 Retorten im Betrieb, 630 im Einbau, in Österreich 193 und 1620 (neues Gaswerk Wien), im übrigen Festlande 315 und $405^{\text {(.112) }}$.

Ein Bericht des Gaswerkes Esslingen aus dem Jahre $1899^{4.113}$ ) stellte fest, daf Cozeöfen auch für kleine Werke wirtschaftlich wären. Als bemerkenswerte Einzelheiten möge festgehalten werden, daf der eifrige und viclscitige W. Fo uli s

\footnotetext{
6.110) $35(1892), 505 / 912$

4.111) $39(1896), 466$

(.112) $41(1898), 368$

4.113) $42(1899), 141$
} 


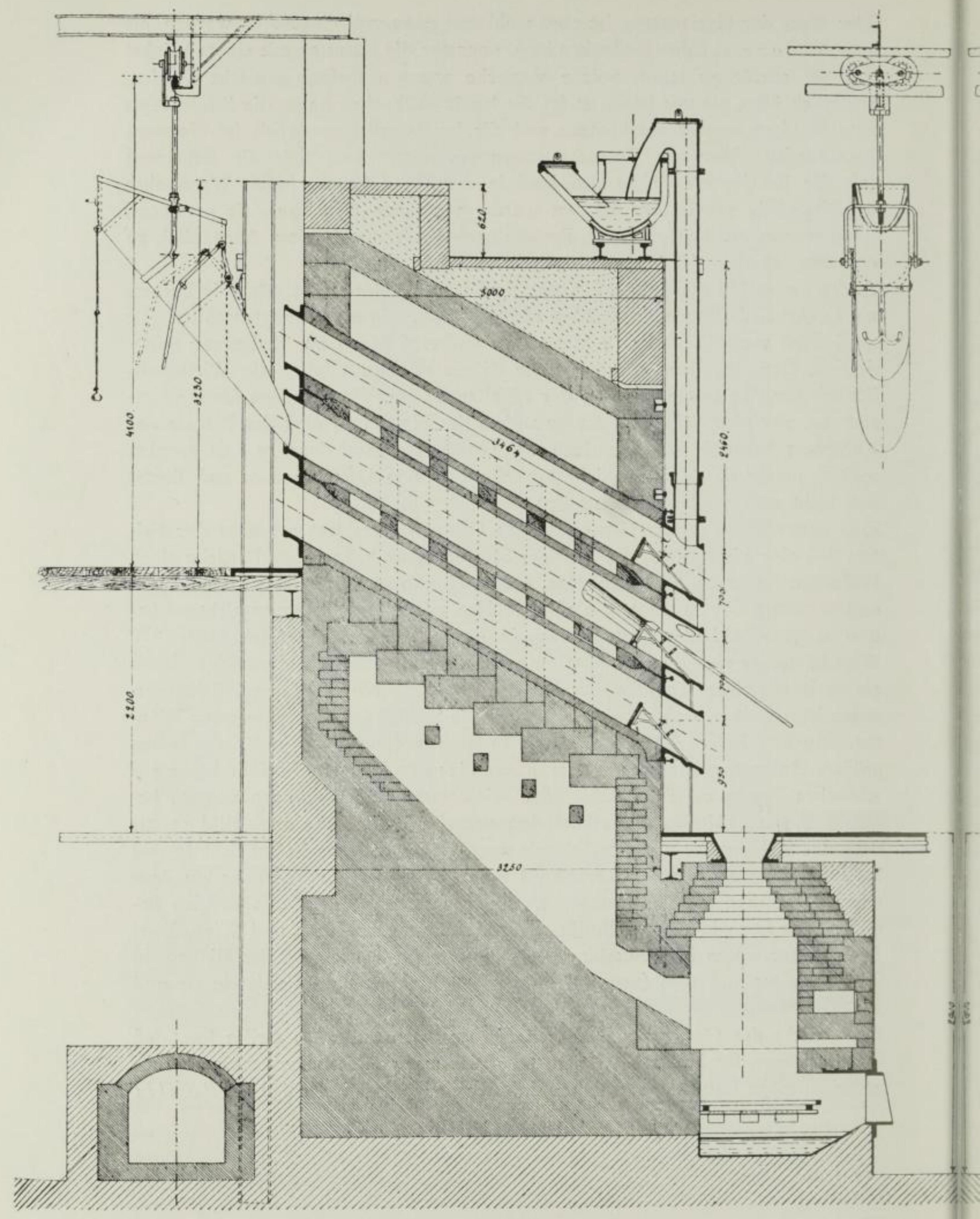

Bild 35 Coze-Ofen mit deutscher Füllmulde 1893 (Muspratt, S. 421/22) 
in England 1897 eine Lanze für Zentralgeneratoren brach ${ }^{t+14}$ ), während $K l \ddot{~} n n$ e in seinem Retortenofen von 1899 mit freier Flammenentfaltung erneut ,mit dem Prinzip der zwangsweisen Führung der Feuergase" brach.

4.212 Lademaschinen

Mit dem Cozeofen war die Aufmerksamkeit ganz allgemein auf die Aufgabe gelenkt, die schwere Handarbeit beim Laden und Entleeren der Retorten zu erleichtern. Die Bemühungen darum sind aber auch schon recht alt gewesen. In den Kokereien hatte man schon ab 1850 verschiedene Arten von Ausdrückmaschinen entwickelt $\left.{ }^{t+115}\right)$. In Dublin wurden seit $\left.1865 / 66^{\text {t.116 }}\right)$ für grof̧e Retorten von $6 \mathrm{~m}$ Länge und $450 \mathrm{~mm}$ Durchmesser Dampflademaschinen verwendet. Dabei wurde, nicht mit gutem Erfolge, versucht, drei Retorten übereinander mit einem gemeinsamen schweren Deckel zu verschliefzen $\left.{ }^{4.117}\right)$. Die Lademaschinen waren wegen des aufgebauten Dampfkessels sehr schwer beweglich und anfällig, so daf̧ zwei Reservemaschinen notwendig waren. Uberhaupt hat der Antrieb grofe Mühen bereitet. Versucht wurde Preßluft, Preß̧wasser und schließ̧lich Transmission von einer langen Welle her, die vor den Öfen lag. A. Heg ener baute in Köln einen hydraulischen Stoker ein $\left.{ }^{t .115}\right)$. Zur dauernden Benutzung kam aber zunächst nur die einfache Handlademaschine von E. $G r a b n$ in Essen, die die bisher durch Umdrehen auszuleerenden großen Schaufeln vermied ${ }^{4.49}$ ). Bild 36 zeigt den beweglichen Schieber, den er anwandte und den Umklapphaken zum Ausziehen. Eine gewisse Aufmerksamkeit erregte der Dampfstrahllader des Amerikaners A. Q. Ross, der die anfällige Mechanik vermeiden wollte ${ }^{4.139}$ ). Io Jahre lang hat man aber in Deutschland Grahn allein gelassen. Erst 1892 wurden in Charlottenburg durch die Bamag handbediente Lademaschinen nach $R u n g e$ eingebaut $\left.{ }^{t .121}\right)$. Aber nun wandten sich auch andere Maschinenfabriken der Aufgabe zu, vor allem Schumann \& Küchler, Erfurt ${ }^{4,129}$ ) und C. Eitle in Stuttgart $^{4.123}$, der seine Lademaschine an einer Laufikatze aufgehängt hat. Ob Cozeofen oder Lademaschine das bessere sei, war zu „einer hart umstrittenen Frage“ geworden $\left.{ }^{4.123}\right)$.

Zum Löschen und Abführen des Kokses wurden Rinnen in langer Arbeit entwickelt.

Vom 6. März 1867 stammt ein Patent von R. Breckon und R. Dixon, die ein Förderband aus gelenkig verbundenen Blechwangenkästen erbauten. $\mathrm{H}$. $H a c k$ und F. Ley schufen ein flaches Band aus Einzelblechen, auf denen der

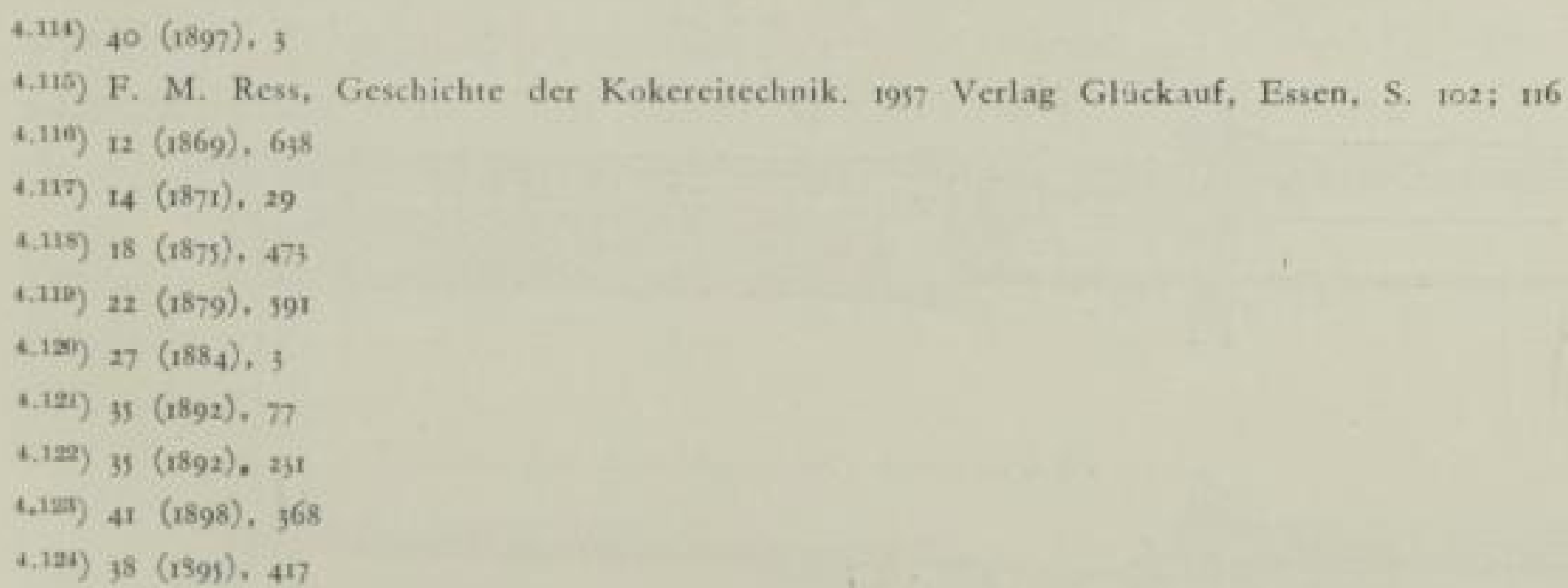



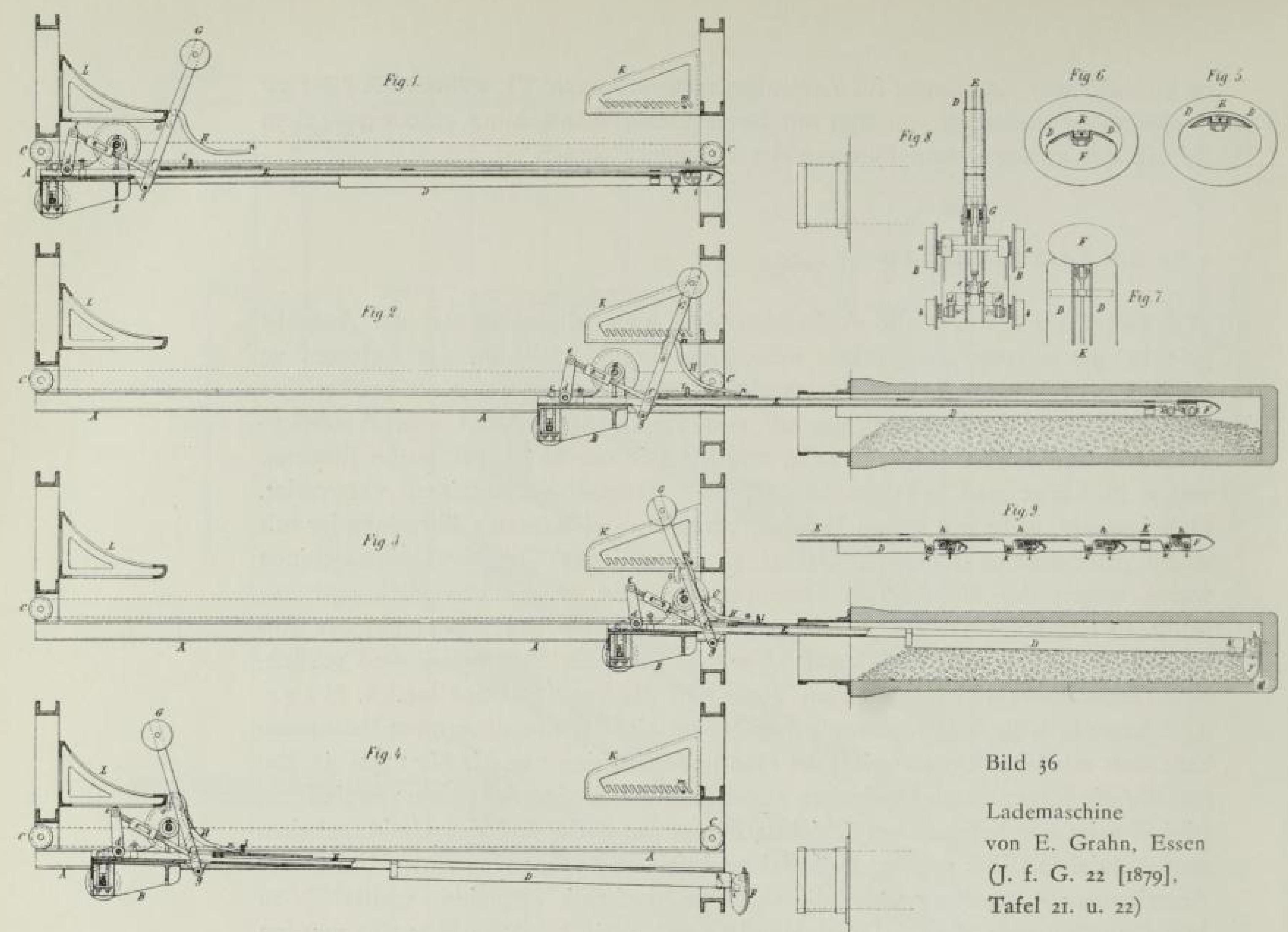

Bild 36

Lademaschine

von E. Grahn, Essen (J. f. G. 22 [1879],

Tafel 21. u. 22)
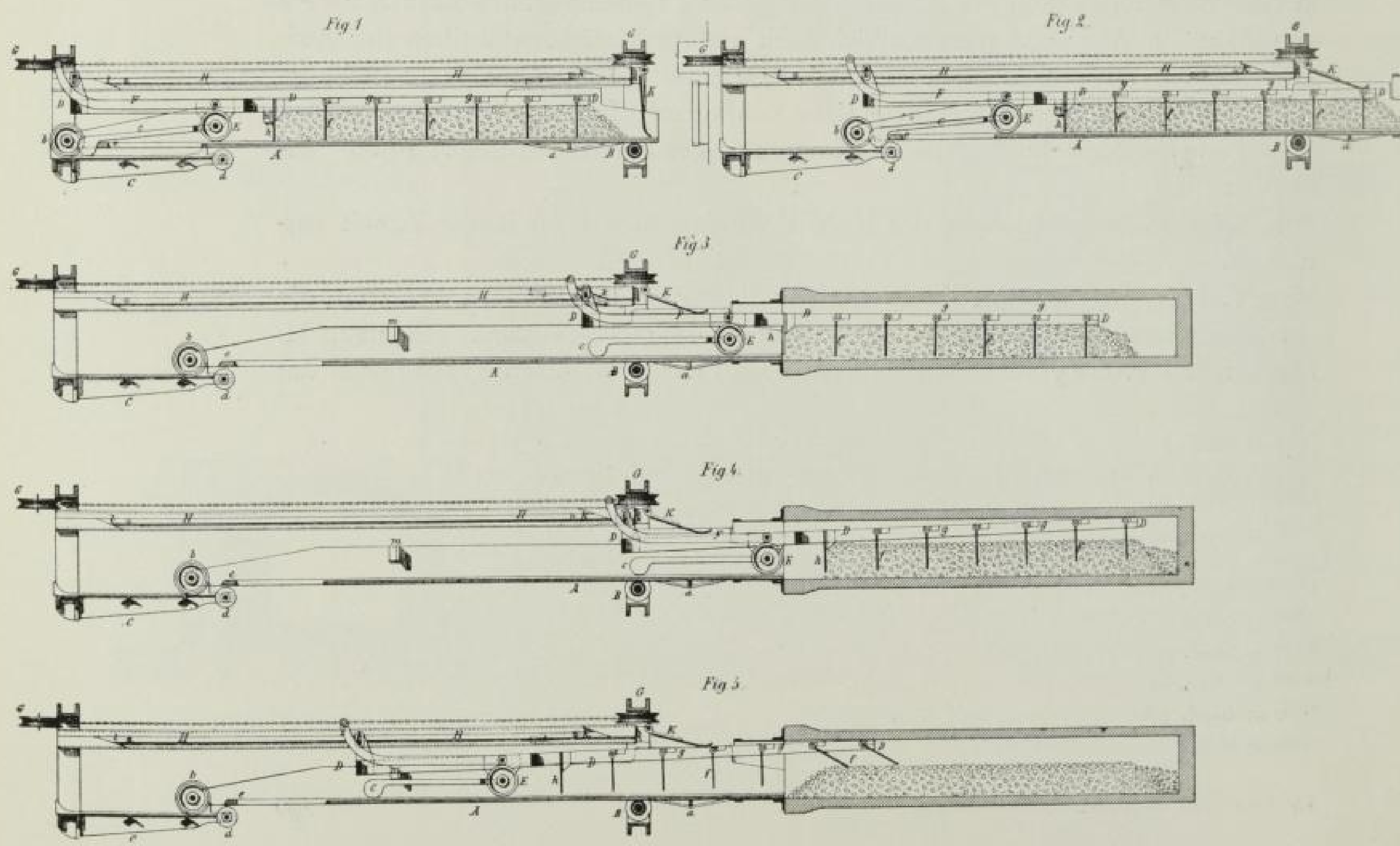

\section{SLUB}

Wir führen Wissen. 
Koks nur durch Besprengen mit Wasser gelöscht werden sollte. Beschwerden ergaben sich mit dem Rücktrum, das in den sich unten absetzenden Koksschlamm zu liegen kam. Das änderte am 3. April 1890 G. W aller. Das Rücktrum lag nicht mehr im Wasser, aber nun ging sehr viel Wasser verloren.

Eine befriedigende Lösung brachte am 3. Dez. I895 de Brouwer, der eine grołgliedrige Kette auf einer Blechbahn laufen lief, die er außzerhalb des Ofenhauses so hoch führte, dał kein Wasser ausgeschöpft wurde, sondern in den Trog zurücklief $\left.{ }^{4.2 z}\right)$. In Rouen setzte sie de Brouwer in Betrieb. Die Kette wurde gleich sehr günstig beurteilt und vielfach eingebaut ${ }^{4.125}$ ). Man achtete zunächst weniger darauf, dał der Koks zerrieben wurde. Vielmehr begrüßte man die Erleichterung der Arbeit im Ofenhaus, wo strahlende Hitze und Dampfwolken verringert wurden. Nur eine ablehnende Äuß̧erung kam aus Hannover, dał die Rinne im Betriebe zu teuer würde $\left.{ }^{4.177}\right)$. Klön ne saugte das überschüssige Wasser am Ende der Rinne ab und brachte es wieder nach vorne (D. R. P. 124395 v. 12. 8. 1900). Bamag löschte erst aufzerhalb des Ofenhauses ab. Das hochgehende Trum wurde zum schornsteinartigen Dunstabzug eingekapselt (D. R. P. II8 290 v. 26. II. 1899$\left.)^{4.125}\right)$.

An der Wende des Jahrhunderts war der Ofen einer sehr kritischen Betrachtung unterworfen und in lebhafter Entwicklung. Die ganz neue Beurteilung des Gases nach Heizwert und nicht mehr nach der Leuchtkraft ließ̧en neue Möglichkeiten erscheinen, die bereits vorbereitend zu neuen Schritten erwogen wurden.

\subsection{Einzelheiten zum Ofenbau}

Im Laufe der Zeit haben sich die Fachleute mit einem erstaunlichen Aufwand an Konstruktionsgedanken bemüht, schrittweise Verbesserungen in den Ergebnissen oder auch Erleichterungen der Arbeit zu erreichen. Das alles aus den reichlich vorhandenen Berichten festzustellen, ist schier unmöglich. Es müssen die wichtigsten Neuerungen genügen.

In den 6oer Jahren machte die Fertigung der Retorten große Fortschritte. Während anfangs englische und bald darauf belgische Retorten die besseren waren, holten viele deutsche Hersteller alsbald den Vorsprung ein. Im Jahrgang 186I des Journals fällt besonders der Anstieg in der Zahl der Tonretorten anbietenden Firmen auf. Als ein Beispiel für viele mag die Tätigkeit des später so erfolgreichen Dr. C. O t to als jungem Ingenieur bei H. J. Vygen \& Co., Duisburg ab I860 dienen ${ }^{4.125}$ ). I862 trat er als mafgebender Berichterstatter über Tonerprobung auf $\left.{ }^{4.120}\right)$. Innerhalb der I2 Jahre, die Otto in Duisburg tätig war, stieg die Firma, deren Betriebsdirektor er bald wurde, zu einem der führenden Unternehmen Deutschlands auf. Schon 1863 wurde vom Verein ein Ausschuf zur Vereinheitlichung der Retorten eingesetzt $\left.{ }^{(.130}\right)$. Als erstes Ergebnis kounte dieser Aus-

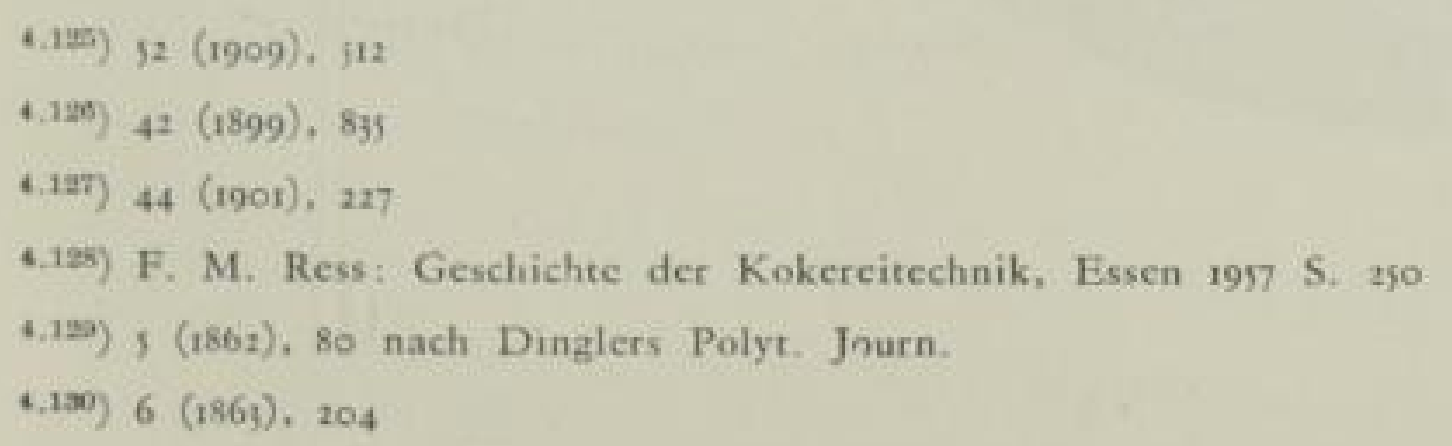


schuf 1865 berichten, daf̧ unter 50 Retortenformen nur zwei übereinstimmend waren $\left.{ }^{4.23 x}\right)$. Die Empfehlung des Ausschusses, die er zwei Jahre später aussprach $^{4.12 a}$ ), sah vier ovale Retorten und 4 mit abgeflachtem Boden als Norm vor. 1876 erhielt W. D. Cliff in England ein Patent über mechanisches Ziehen der Retortenkörper $\left.{ }^{4.139}\right)$. Natürlich meldeten sich die üblichen Bedenken, aber bald kamen anerkennende Nachrichten über die Gleichmäßjigkeit der erzeugten Hohlkörper. Eine zwar nur eine Einzelheit berührende Verbesserung, die aber in der vielfachen Wiederholung der Arbeit dennoch einen wirtschaftlichen Fortschritt darstellte, war der Ersatz der Retortendeckel Bild 37 mit Lehm- oder Kittverschmierung durch den selbstdichtenden Verschluf̧ mit einer Klapptür nach $\mathrm{H}$. Morto $\left.n\left({ }_{1860}\right)^{4.134}\right)$, der dann vielfach verbessert wurde (Bild $\left.{ }^{8} 8\right)$. G. Li e g el beseitigte 1882 die immerhin noch bei Morton notwendigen drei Bewegungen durch
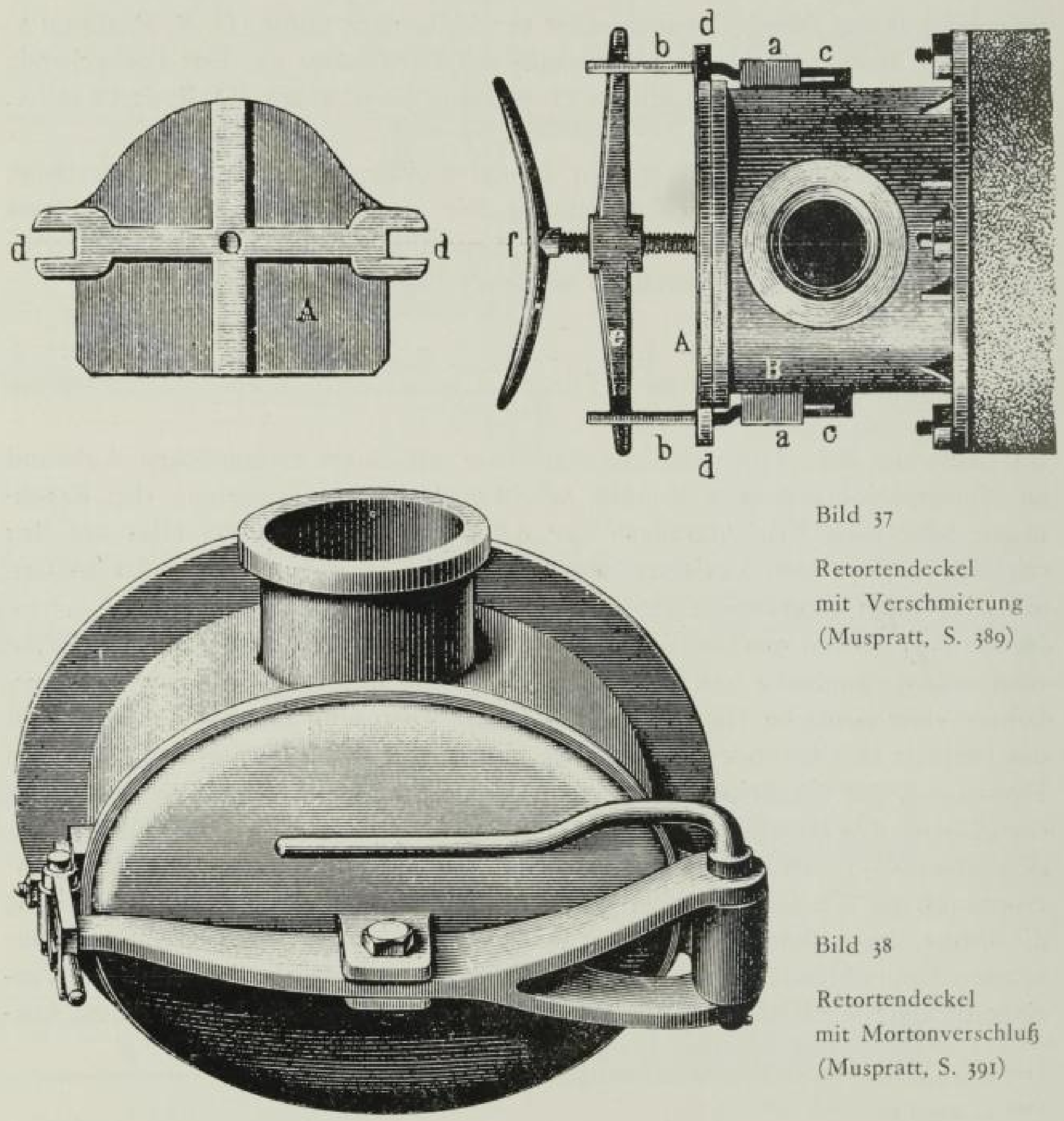

Bild 37

Retortendeckel mit Verschmierung (Muspratt, S. 389)

Bild $3^{8}$

Retortendeckel mit Mortonverschlufy (Muspratt, S. 391)

4.135) $8(1869), 220$

4.135) $10(1867), 234$

4.123) $19(1876), 86$

4.134) Muspratt S, 590 (s. 2.81) 
eine Einhandexcenterbewegung $\left.{ }^{4 \cdot 15}\right)$. Er sah sich einem bösen Angriff $K l \ddot{o} n$ nes alsbald ausgesetzt. Aber seine Anordnung lag sicher in der Richtung der Spanntechnik. Sie wurde von der Bamag übernommen.

\subsection{Schornstein}

Dem Schornstein wandte man wenig Aufmerksamkeit zu. Manchmal geriet er zu hoch. Dann wurde die überflüssige Energie abgeschiebert oder Kaltluft am Fuf̧e zugelassen. H. Brebm, Pforzheim wandte sich gegen dieses Vorgehen. Man solle dann vielmehr die freie Rostfläche verkleinern und den Koks móglichst hochpacken. Er selbst hat damit beträchtliche Brennstoffersparnisse erzielt $\left.^{t .135}\right)$. In den meisten Fällen fand aber Brehm, dał die Schornsteine zu klein ausgeführt waren, besonders im Querschnitt. Er forderte Einzelschornsteine für jeden Ofen. Brehm hatte sich sehr eingehend mit den Fragen beschäftigt und sich Rat bei Prof. F. Grasbof in Karlsruhe wegen der Berechnung geholt ${ }^{t .12 \pi}$ ).

\subsection{Fördereinrichtungen im Gaswerk}

Verhältnismäf̧ig spät wurde man auf die Unkosten der Förderung der Kohlenund Koksmengen aufmerksam. Mit Karren und allenfalls auf schmalspurigen Werkbahnen wurde alles mit Menschenkraft bewegt. Dublin scheint das erste Werk zu sein, das in dieser Hinsicht, mit der maschinellen Kohlenladung auch die Kohlen mechanisch zu fördern sich anschickte $\left.{ }^{4.125}\right)$. In Hannover ergab sich eine besondere Lage, als in Linden eine neuer Bahnhof in der Nähe des Gaswerkes, aber getrennt durch einen Fluł und eine belebte Straß̧e eingerichtet wurde. Es wurde eine Drahtseilbahn zur Anförderung der Kohlen gebaut ${ }^{t .130}$ ). Die Anlage litt unter vielfachen Störungen und wurde durch ein Anschlufggleis mit einer Brücke ersetzt ${ }^{4.149}$ ). 1890 nach den Arbeiterunruhen in England, tauchten wieder Berichte über diese Aufgaben auf. J. West machte in einem Vor$\left.\operatorname{trag}^{4.111}\right)$ auf die Vorteile der mechanischen Förderung aufmerksam, die er als Bauunternehmer bereits entwickelt hatte. Er sprach vom Auskippen der Waggons in der Längsrichtung, vom Hochbringen der Kohlen mit Kränen oder festen Aufzügen. Zwei Jahre darauf wurde das Charlottenburger Werk durch die Bamag mit vielfachen mechanischen Einrichtungen neu erbaut $\left.{ }^{4.112}\right)$. Gewif war die Lösung des Antriebes mit Dampf, Druckwasser und Druckluft damals noch sehr schwierig und deshalb auch der Betrieb teuer. Man beachte die im Bild 39 gezeigte Zuführung des Druckwassers zu den Lademaschinen mit ihren

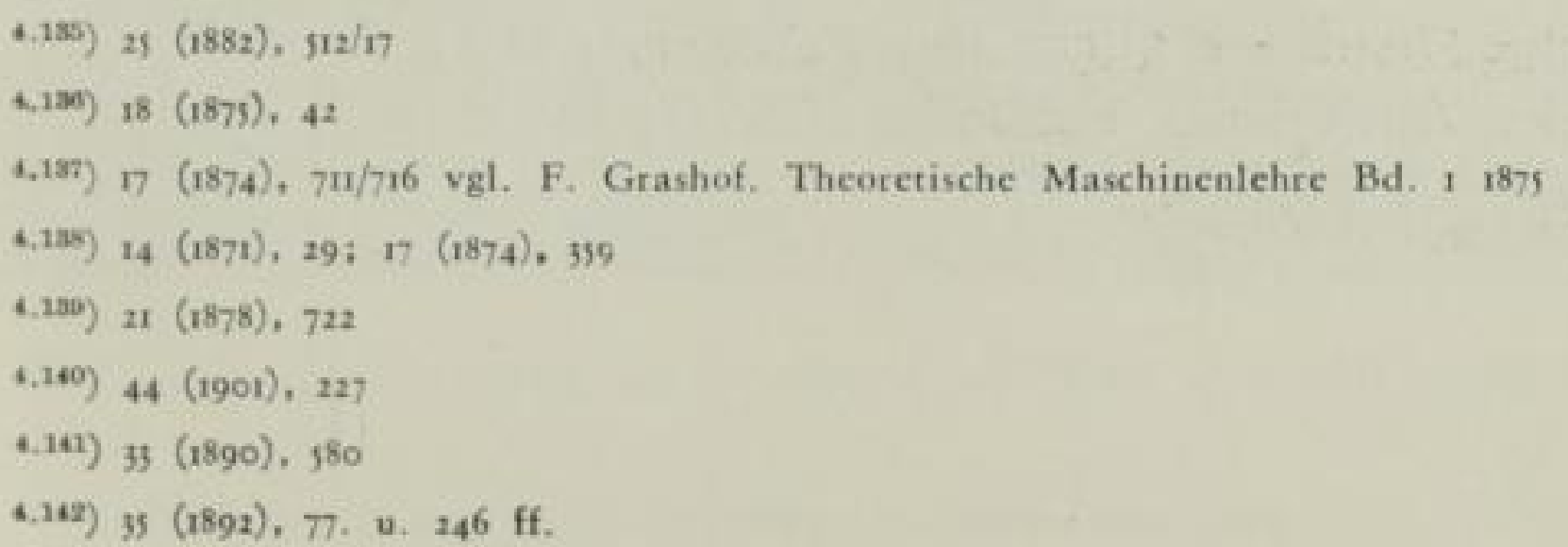




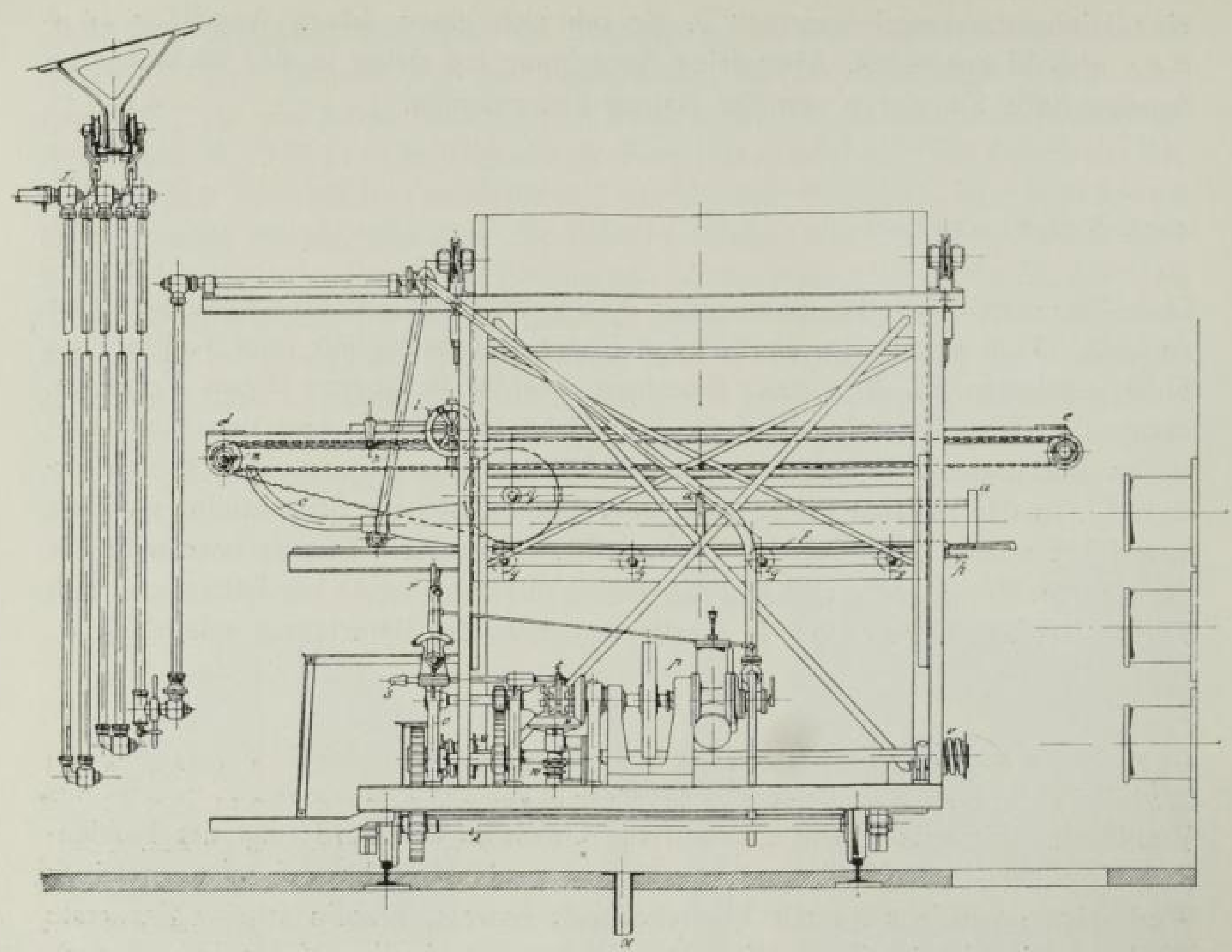

Bild 39 Lademaschine mit Druckwassererantricb (J. f. G. S [1862] S. 248)

vielen, sicherlich undicht werdenden Gelenken, die der Zeitgenosse als "äufjerst sinnreich" bezeichnet hat. Becherwerke und auch schon Förderrinnen wurden in den 9oer Jahren versucht. Amerikaner benutzten ${ }^{4.149}$ ) Förderketten aus Temperguf in Rinnen der Link Belt Co., Hunts Elevator, einen einfachen Seilaufzug mit Dampfmaschine, einen Kettengreifer und Becherketten. W. Foulis, sagte zwei Jahre später ${ }^{4.14}$ ): Die Erkenntnis sei eingetreten, daf3 man die Massengüter mechanisch fordern müsse. Niemand zweifle mehr an dem Vorteil, wenn die Handarbeit eingeschränkt würde. Oft handelte es sich allerdings dabei nur um eine Hängebahn, deren Wagen von Hand verschoben wurden ${ }^{\text {t.15 }}$ ). Im neuen Gaswerk Kiel wurden zwei Dampfkräne zum Löschen der Schiffe von Hand zur Ladestelle verschoben. Von ihnen ging eine Drahtseil- und Hängebahn zum Werke $\left.{ }^{4.1 .66}\right)$. Sehr weitgehend waren die Einrichtungen in Zürich ${ }^{4.17}$ ). „Trotzdem sind die Anlagen, die die Menschenarbeit ganz vermeiden, sehr selten". Tatsächlich waren auch noch Transportbänder, Ketten, Becherwerke usw. so anfällig, dał bei größ̧eren Mengen und vor allem Entfernungen, der Lokomotivbetrieb besser befunden wurde. Auch beim Füllen der Schrägretorte solle man eine

\footnotetext{
4.143) $38(1895), 593$

4.144) $40(1897), ;$

4.145) $43(1900), 441$

$4.145) 43(1900), 573$

4.147) $43(1900), 725$
}

198

\section{SLUB}


volle Automatik fortlassen. Wegen der wechselnden Kohlenbeschaffenheit könnte man die Aufsicht an dieser Stelle nicht entbehren.

In der Druckschrift über den Bau des am 31. 10. 1899 in Betrieb genommenen städtischen Gaswerks Wien ${ }^{4.146}$ ), das für eine Erzeugung von $500000 \mathrm{~m}^{3} /$ Tag und roo Mio $\mathrm{m}^{\mathrm{n}} / \mathrm{J}$ ahr ausgelegt war, findet man bezeichnenderweise keinen zusammenfassenden Abschnitt über die Förderanlagen. Immerhin sind $6 \mathrm{~km}$ Vollbahngeleise im Werke verlegt, aber ,von maschinellen Einrichtungen zur Beförderung des Kokses und der Kohle wurde Abstand genommen, um den Umfang der Anforderungen kennen zu lernen, welche an die definitiven einschlägigen Einrichtungen und die maschinelle Beförderung von Koks und Kohle zu stellen sind; eine Vorsicht, welche sich schon durch den kurzen Betrieb des Werkes als eine wohlbegründete erwies“. Nur von der Kohlenförderung im Ofenhause zu den Cozeöfen wird ein anschauliches Bild gegeben. (Bild 40) „Die Beschickung der Retorten geschieht mit Hilfe von Füllgefäßen, welche auf einer Hängebahn längs der Ofenblöcke verschoben werden"

Gerade diese Darstellungen zeigen deutlich, wie die Aufgabe, die Fördermenge und Auslegung richtig zu treffen, erkannt, erstrebt aber keineswegs gelöst war.

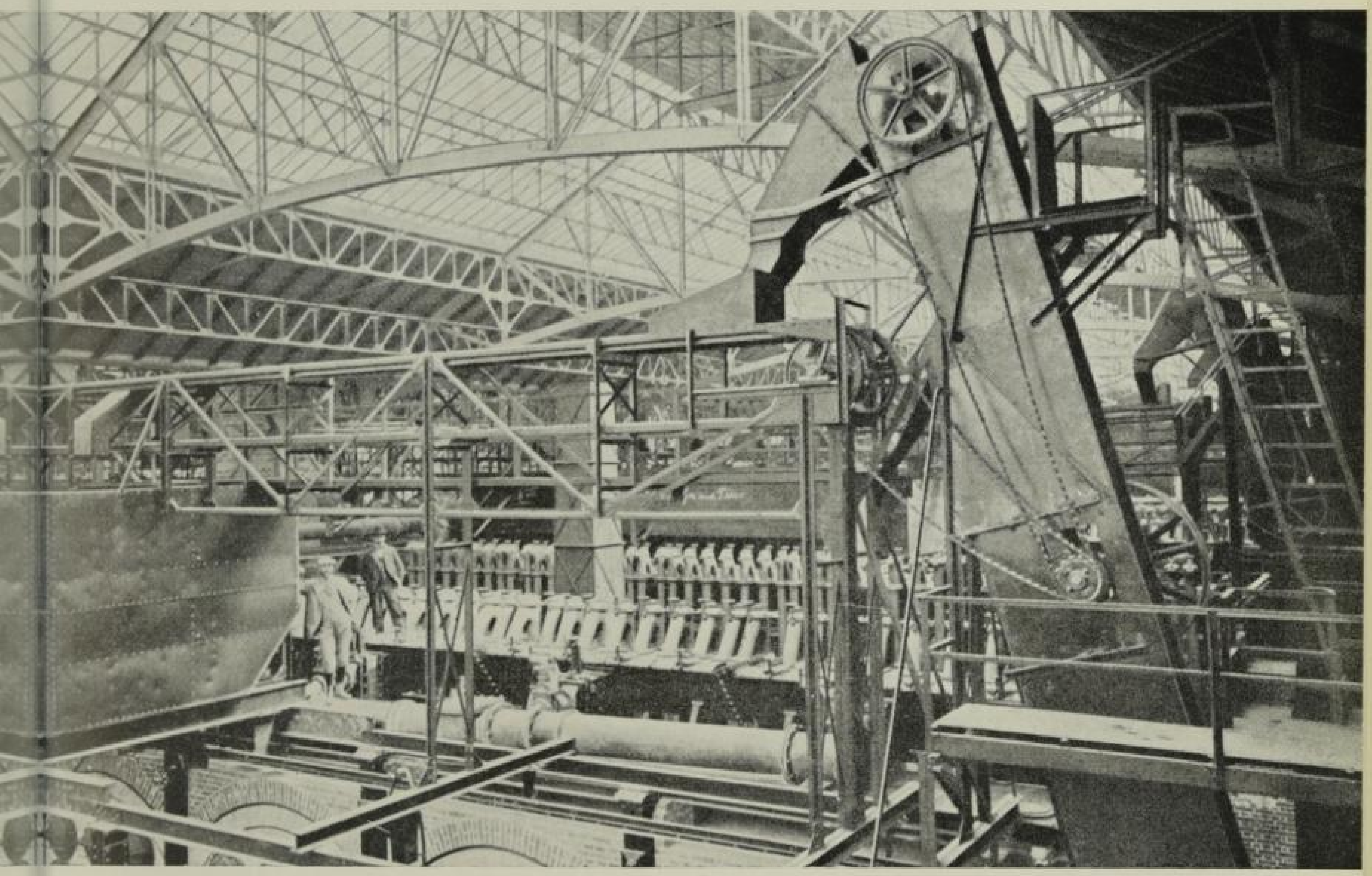

Bild 40 Kohlenförderung im Ofenhause zu Wien 190 t (Erbauung des Wiener städt. Gaswerks)

4.145) Die Erbauung des Wiener stadtischen Gaswerks, Wien 1901 
Auf der ersten internationalen Gastagung zu Paris $19 \mathrm{co}$ war die Förderung Gegenstand der allgemeinen Aussprache. Sie war aber Beweis, wie in allen Ländern die Lage gleich unsicher war. Über die Koksabfuhr und Löschung mir Brouwerrinnen ist bereits im vorhergehenden Abschnitt gesprochen.

\section{$4.216 \mathrm{~S}$ a uger}

Im Rahmen der Fördereinrichtungen mag auch der Sauger, oder wie er damals vielfach genannt wurde, Exhaustor, als Gasförderer abgehandelt werden. (Vgl. Abschnitt 3.234).

In der ersten Hauptversammlung des Vereins spielte der Streit, ob man einen Sauger verwenden solle oder nicht, eine grofe Rolle, der sich seitens E. B el o we auch gegen Tonretorten überhaupt wandte $\left.{ }^{4.140}\right)$. So ganz vollkommen waren auch die Einrichtungen nicht. Beim Bealeschen Förderer beanstandete man, dał er nur $2 / 3$ der berechneten Menge liefere $\left.{ }^{t .150}\right)$. Daf3 das lediglich ein volumetrischer Wirkungsgrad mit entsprechend herabgesetztem Energieaufwand wäre, erfaßte man bei der Schwierigkeit, den mechanischen Aufwand zu bestimmen, nicht. Die Kolbenpumpen aber, die vor allem G. $K u b n$, Stuttgart befürwortete, hatten zu viele Ventile und durch sie Störungen $\left.{ }^{4.151}\right)$. Man ging zu Schiebern über ${ }^{4.150}$ ) (Bild 23 ). Recht wenig befriedigend war die Druckregelung von den Retorten her, in denen in England $25 \mathrm{~mm}$ Uberdruck gehalten wurden. Mit Drosselklappen griff man in die Dampfzufuhr ein, womit die Umdrehungszahl des Saugers geändert wurde, oder aber in das Zuleitungsrohr des Gases, was bei Kolbenmaschinen allerdings etwas barbarisch war $\left.{ }^{0.15 \pi}\right)$. A. $P$ a $u$ wels steuerte gleich beide Ströme durch Klappen. W. Oecbelbáuser hielt den Umlaufregler trotz des Energieverlustes für die beste Lösung.

Uberraschend ist ein Vorschlag in den Jahresberichten der Landwirtschafts- und Gewerbeschule zu Ansbach von J. G. Munker $\left.1860 / 6 \mathrm{1}^{t .154}\right)$. Aus hygienischen Gründen war der Schornstein für die Ofen des Werkes überhoch ausgeführt. Man mufte den Unterdruck durch Kaltluft mindern. In diesen Strom wurde nun eine Luftturbine eingesetzt, die eine Pumpe antrieb, aber auf den Sauger geschaltet werden sollte. Die Einrichtung war aber nicht lange im Betriebe $\left.{ }^{t .155}\right)$. Im Gaswerk Johnston bei Glasgow wurde die „Gasturbine“ gleich in den Fuchs zum Schornstein eingebaut. Anderenorts pumpte man Wasser hoch und trieb den Sauger mit einem Wasserrade an.

C. Scbiele, Frankfurt, der Bruder von Simon Schiele, baute 1865 ein gasdichtes Kreiselgebläse $\left.{ }^{t .14}\right)$, von dem es damals hieł, es bewähre sich als Sauger. Jedenfalls war bei ihm eine Drosselsteuerung im Gasstrom angebracht. Heil-

\footnotetext{
4.149) \& (1860), 95; 113

$6.150)_{3}(1860), 320$

6.151) 4 (1861), 238

4.152) Muspratt S. 466 (s. 2.81)

$.153)_{4}(186 \mathrm{r}), 49$

4.104) $4(1861), 384 / 388$

4.155) 8 (1865), 224

4.156) $8(1865), 284$
} 
bronn bemerkte dazu, dał̧ es aus besonderen Gründen Kreiselgebläse anderer Bauart schon seit drei Jahren zur Gasförderung benutze ${ }^{4.157}$ ). 1867 glaubte N. H. Schilling die Streitfrage, ob Sauger oder nicht, dahin beantworten zu können, dał sie wegen des Energieverbrauches und der erforderlichen Aufsicht nur für Werke mit einer Jahresabgabe über 140000 bis $280000 \mathrm{~m}^{3}$ wirtschaftlich seien $\left.{ }^{4.139}\right)$.

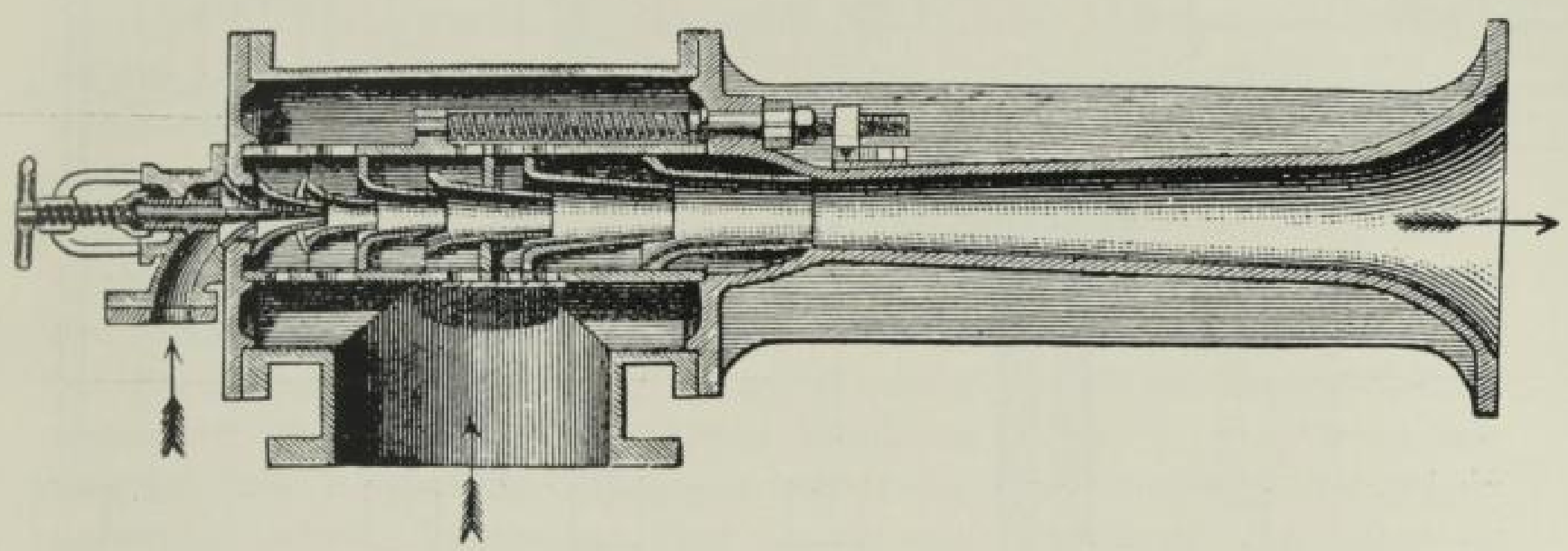

Bild 4 I Dampfstrahlsauger von E. Körting (Muspratt, S. 471)

1872 baute Ernst Körting einen Dampfstrahlexhaustor Bild $4 \mathrm{I}$ der den Dampfaufwand nach dem Druck in der Gasleitung selbstätig regelte $\left.{ }^{4.150}\right)$. In der Anwendung zeigte sich, dał trotz des schlechten Wirkungsgrades aller Strahlpumpen der Dampfverbrauch geringer war als bei den damaligen Dampfmaschinen mit Kolbensauger $\left.{ }^{\text {t.kno }}\right)$. Dieser Sauger wurde häufiger, auch bei kleinen Werken verwandt, obwohl wegen der Dampfzufuhr ihm die Vermehrung der Naphthalinausscheidung zur Last gelegt wurde, die nur durch gröłere Kühlanlagen und sorgfältige Beschränkung des Dampfverbrauches auf das eben ausreichende, behoben werden konnte $\left.{ }^{t .161}\right)$. J. Gareis entwickelte noch bei der kölnischen Maschinenbauanstalt einen Kolbenexhaustor, der neben der hin- und hergehenden Bewegung des Kolbens diesem auch noch zur Steuerung eine drehende erteilte, womit die Ventile unnötig wurden $\left.{ }^{1.402}\right)$.

Am meisten dürfte aber der Bealesche Sauger (Bild 22) benutzt worden sein, den die Bamag mit drei im inneren Kolben verschiebbaren Platten ausrüstete, um die störenden Druckschwankungen zu vermindern (Bild 42).

Das von den Amerikanern F. M. und P. H. R o o t $s$ zu Connersville entwickelte Gebläse wurde seit 1868 von der Aerzener Maschinenfabrik Adolf Meyer, Aerzen bei Hameln gebaut ${ }^{\text {t.ees }}$ ). Im Journal ist es nicht erwähnt. Für Gaswerke hat es sich wohl erst nach der Jahrhundertwende eingeführt.

(.157) $8(1865), 389$

4.158) $10(1867), 317 / 326$

4.150) is $(1872), 671$

$4.100), 16(1873), 313$

4.161) 30 (1887), 1008

$4.102) 23(1880), 252$

f.16a) Ress, S. 319 (s. 4.115 ) 

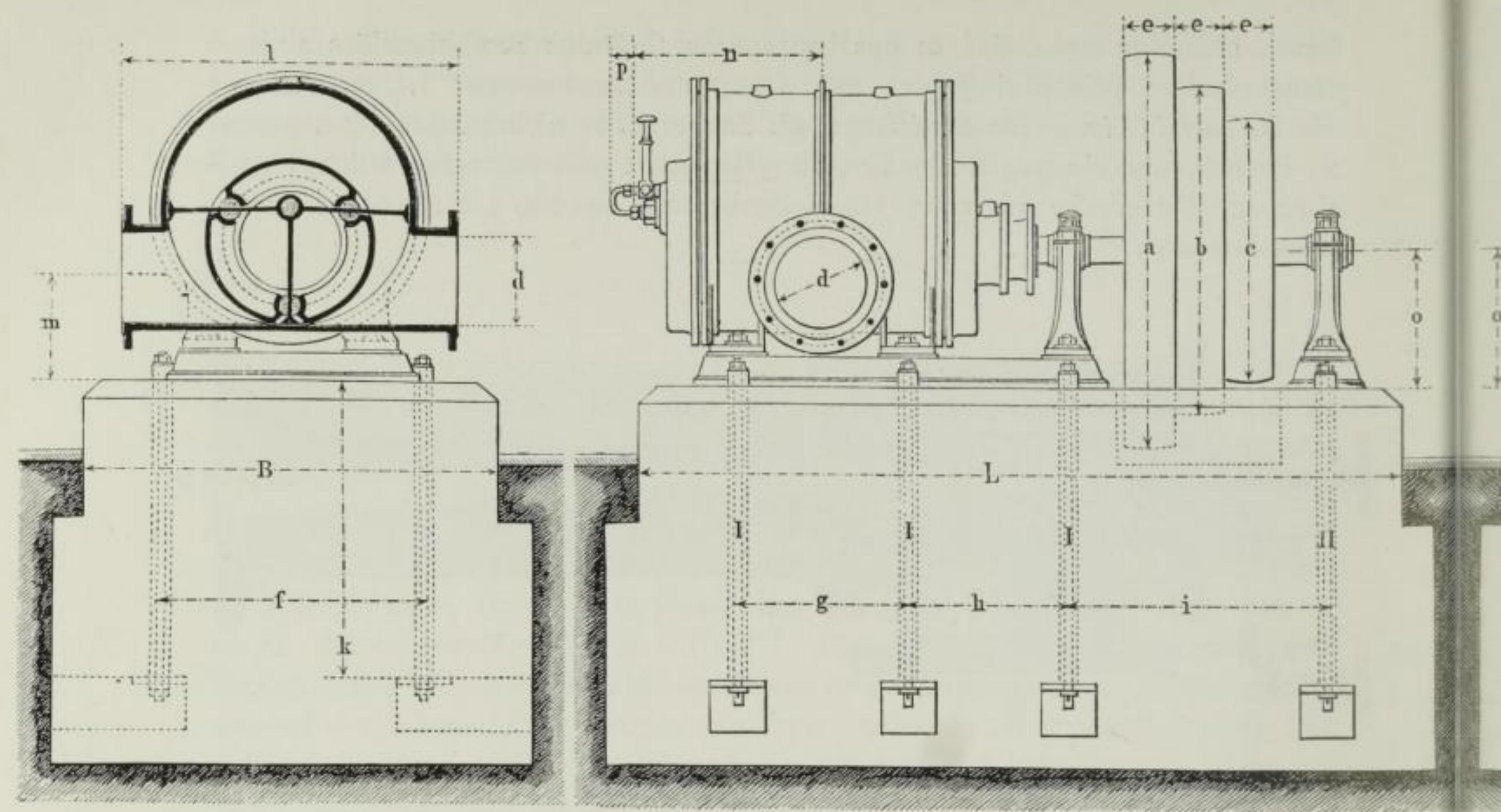

Bild 42 Bamag-Sauger (Muspratt, S. 468/69)

\subsection{Karburierung für Kobiengase}

Um das Jahr I860 waren Bemühungen der Erfinder, ein besseres oder billigeres Gas herzustellen, lebhaft im Gange ${ }^{4.164}$ ).

Das schon von Lowe versuchte Verfahren Leuchtgas an der Verwendungsstelle zu karburieren, wurde in immer neuen Abwandlungen angeboten. 1862 waren in Paris 1700 Karburateure eingebaut ${ }^{t .105}$ ), die meist Naphthalin verarbeiteten. Fünf Jahre später $\left.{ }^{4.100}\right)$ wurde von einem Steckenpferd der Franzosen gesprochen. Erwähnt wurden M. Muller in Champignole und viele andere.

Auch Luftgasanlagen wurden immer wieder mit den verschiedensten Anordnungen, die die Schwierigkeit der fraktionellen Abdestillation der verschiedenen Anteile der Karburierungsmittel bannen sollten, zurecht gebaut. In Philadelphia wurde vor 1864 Luftgas verteilt $\left.{ }^{4.107}\right)$. A. Mongruel trat in Paris um 1867 auf. G. Kromschröder, Osnabrück kämpfte im Anfang seiner geschäftlıchen Tätigkeit lebhaft für ein englisches Luftgasverfahren ${ }^{\text {t.10 }}$ ). Der vielgeschäftige Erfinder S. Marcus in Wien erfand 1860 seinen ersten Luftgasapparat. 1865 und 1866 nahm er je ein „Privileg“ auf deren Herstellung ${ }^{4.120}$ ). I874 aber wurde

4.104) $3(1860), 10$

4.105) , (1862), 162

4.100) ro $(1867), 497$

4.167) $7(1864), 222$

4.165) $16(1873), 23$

4.160) Siegfried Marcus Lebensbild 2. Auft. Wien 1956 S. 7

\section{SLUB}


die groß̧aufgezogene Luftgasgesellschaft in London liquidiert. Ein Kapital von 2,2 Mio M war verloren ${ }^{1.170}$ ).

Bei kurzen Vorführungen erzielten die Erfinder leicht ein weif̧es Licht. Sie verschwiegen aber, dał aus den Gemischen von flüssigen Kohlenwasserstoffen, die damals vorwiegend aus der Braunkohlenschwelung gewonnen wurden, die leichten Fraktionen reichlich vorweg verdampften, danach aber die Menge der brauchbaren Kohlenwasserstoffe stark absank und schliȩ̧lich ein unverwertbarer Rückstand blieb. Uberraschend ist, dał selbst W. Oecbelbäuser in Bremen, als das Leprincesche Mischgas durch Kohlengas abgelöst wurde, darauf hinwies, daf̧ man besondere Anforderungen an die Leuchtkraft mit Karburateuren an der Verbrauchsstelle leicht erfüllen könne.

Der erfolgreiche frühere Oberingenieur der Deutschen Continental-Gas-Gesellschaft, Faebndrich der die Wiener Gas-Industriegesellschaft aus dauernden wirtschaftlichen Schwierigkeiten herausgeführt hatte, erwärmte sich noch 1879 für die Karburierung an der Lampe mit Naphthalin, weil mit diesem Kohlenwasserstoff die fraktionelle Destillation vermieden wurde $\left.{ }^{t .171}\right)$. Als Albocarbonlicht hat diese Einrichtung in England und Deutschland zeitweilig eine gewisse Bedeutung gehabt. Sie brannte aber nur an zugfreien Orten einwandfrei, in Windfängen ${ }^{4.172}$ ) und als Straf̧enbeleuchtung rufzte die Flamme sehr leicht ${ }^{4.173}$ ). Ein Nachteil war, dał nach dem Anzünden eine Stunde verging, ehe die Naphthalinverdampfung (bei $70-90^{\circ} \mathrm{C}$ ) im notwendigen Ausmaf̧ in Gang kam.

Auch die "heif̧e" Karburierung wurde in vielerlei Weise versucht, teils als Zusatz zum Kohlengas, teils mit Wassergas. Dabei konnte man entweder hochwertige feste Brennstoffe oder auch Ole den Kohlen gleich in der Retorte zusetzen oder die Vergasung des Oles getrennt vornehmen. Alles finden wir in den Patentbeschreibungen dieser Zeit in vielfacher Weise bunt durcheinander. Der immer fühlbarer werdende Mangel an Cannelkohlen führte dazu, die böhmischen Plattenkohlen und Falkenauer Braunkohlen zuzusetzen $\left.{ }^{4 \cdot 17}\right)$. St. $M a$ c a d a m, Edinburg machte schon 1870 den Vorschlag, stark verschiedene Kohlen wie die üblichen Gaskohlen und Cannelkohlen nicht getrennt zu verarbeiten, sondern beide Kohlen vorher zu mischen und dann gemeinsam zu entgasen ${ }^{4.178}$ ). Später ${ }^{4.170}$ ) wies S. Schiele darauf hin, daf viele der Zusatzstoffe keincn brennfähigen Rückstand gäben. Boghead, Cannel, Australische Kerosene Shale mit den anderen Kohle zusammenverarbeitet, erhöhten den Aschengehalt des Kokses. Das gleiche sei auch bei Plattenkohlen aus Böhmen der Fall ${ }^{4.177}$ ).

Sicherlich die richtige Entwicklung störend waren die immer erneuten Versuche, auch Teer zu vergasen und dadurch die Leuchtkraft zu erhöhen. Gegenüber den vielen Versuchen die Vergasung in einer Retorte auszuführen, mag ein tech-

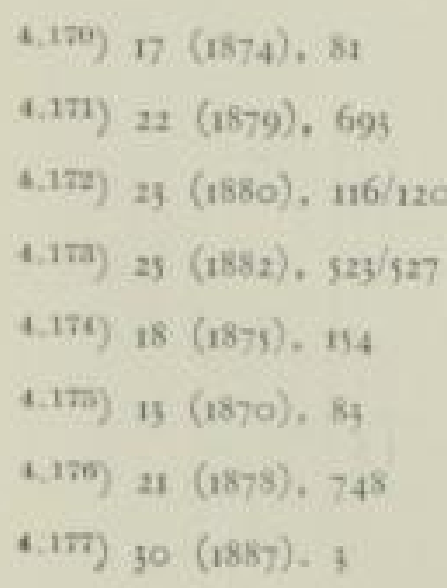


nologisch anregenden Vorschlag aus dem Jahre 1860 genannt werden ${ }^{\text {t.17 }}$ ). Empfohlen wurde Dampf von 6-7 at, der womöglich in einer Rohrspirale überhitzt werden sollte. An der Austrittsdüse wurde er mit dem Teer in Berührung gebracht. Daraus sollte ein Gas mit hoher Leuchtkraft entstehen. Der Berichterstatter, Le Roux, bemerkte aber, dał das entstandene Gas durch einen Wäscher, der mit einem flüchtigen Kohlenwasserstoff angefüllt sei, geschickt würde und sich vermutlich erst dort anreichere. Zu befürchten sei, daf der Überhitzer, der $1000-1200^{\circ} \mathrm{C}$ warm würde, durch Stöße der Speisepumpe zerstört würde.

Angesichts der immer neuen Vorschläge von Apparaten zur Teerentgasung faß̧te N. H. Schilling in einem Leitartikel ${ }^{4.12 \pi}$ ) seine Meinung wie folgt zusammen: „Eine Gasfabrik, die aus ihrem Teer noch mit Vorteil Gas produziert, beweist nur, dał sie schlecht betrieben wird, denn sie läß̧t bei zu niedriger Temperatur ihrer Öfen einen Teil des Gases im Teer sitzen".

Trotzdem wurden die Vorschläge immer wieder sehr ernst genommen. Besondere Beachtung fand ein Patent von J. Dins more, Liverpool, den Teer zu entgasen $\left.{ }^{4.180}\right)$. Auch in Deutschland besprach ein phantasievoller Berichterstatter, G. Schimming, dieses Verfahren ${ }^{41}{ }^{181}$ ), bei dem angenommen wurde, dafy in einer rotglühenden Zersetzungskammer der Wasserstoff des mit dem „potentiellen " Teerdampf eintretenden Gases sich mit den Leichtölen des Teeres zu aromatischen Kohlenwasserstoffen vereinige und gasförmige Produkte der Acetylen- und Olefinreihe bilde. Wenige Monate darauf konnte aber festgestellt werden, dafy auch mit diesem Verfahren nicht mehr erreicht werde, als sich mit der gewöhnlichen, richtig geführten Entgasung auch erzielen lieł̧. Den Beweis lieferten zwei grof̧ angelegte Parallelversuche ${ }^{4.152}$ ).

Trotzdem vertrat aber Prof. He mpel abweichend von Bunte und $K r \ddot{a}$ mer noch 1893 die Meinung, dał die Teerentgasung möglich und zweckmäfjig sein müsse. In Gegenwart von Wasserstoff (im Gase) würden sich Olefine und aromatische Kohlenwasserstoffe in Paraffine umwandeln lassen ${ }^{4.185}$ ).

Erfolgreicher konnten die erneuten Vorschläge Öle zu vergasen sein. Schäffer \& Walcker in Berlin, damals eine führende Firma im Gasgerätebau, bemühten sich, ein Gasbereitungsverfahren von A. Prince (Engl. Patent v. 4. 6. 6I) in Deutschland einzuführen. Eine waagerechte Retorte wurde mit 4 bis $6 \mathrm{Pfd}$ Holzkohle gefüllt, in diese Holzkohle tauchten drei Rohre ein, eines für Dampf und zwei für Öleinträufelung. Auffallend ist dann aber, dał als Aufwand 30 bis $40 \mathrm{Pfd} T$ e e $r$, 50 bis $60 \mathrm{Pfd}$ Wasser und 4 bis 6 Pfd Holzkohle genannt werden $\left.{ }^{4.18 s}\right)$. J. J. T a y $l$ or , Manchester wollte einen Ölvergasungsofen durch Abhitzeverwertung wirtschaftlich machen. Er dachte an die Kupplung mit einer Warmwasserheizung oder Brat- und Backräumen samt Warmwasserheizung,

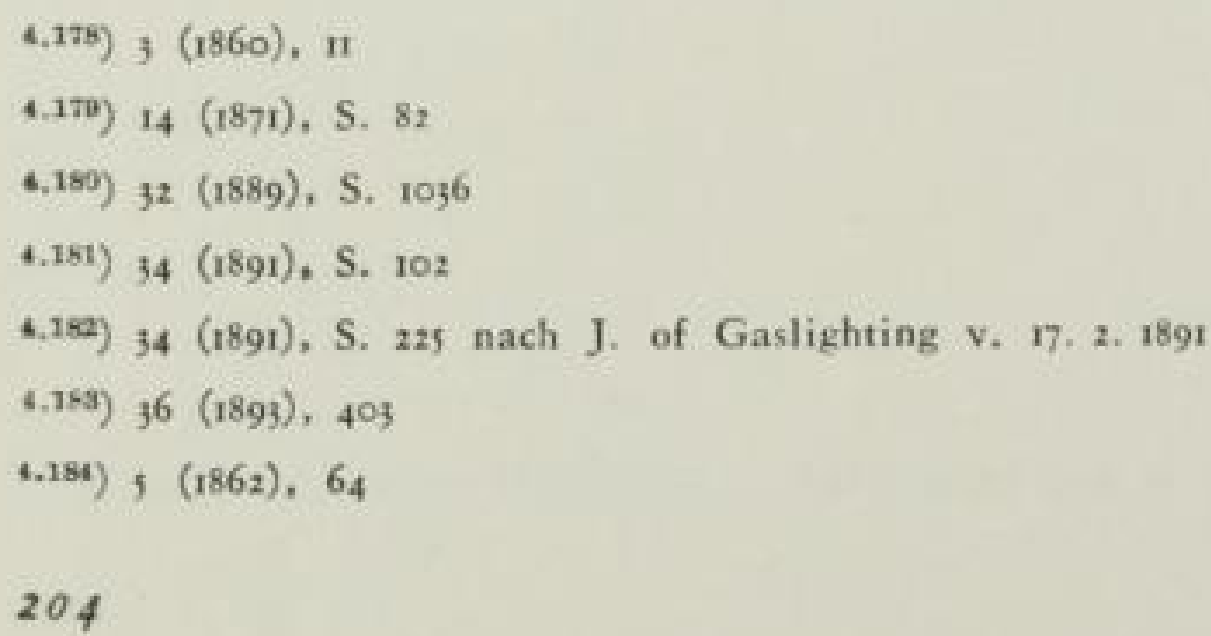


wollte also zu den Größjen der alten Thermolampe zurückkehren ${ }^{4,15}$ ). Noch immer wurden aber auch an anderen Orten Kleinanlagen „für Dienstmädchenbedienung" zur Fettgasherstellung gebaut und empfohlen ${ }^{4.136}$ ).

Die Entdeckung und der Vertrieb des Erdöles gaben diesen Bestrebungen einen neuen groß̧en Auftrieb. In der Maschinenfabrik G. v. Kranss in München wurde eine Vergasungsanlage für Petroleumrückstände eingerichtet. Sie ergab ein gutes Gas, über die Menge und Art der Rückstände wurde nicht berichtet $^{1.197}$ ).

Besonders in Schottland wurde angesichts der Erdölpreise viel von der Ölvergasung gesprochen. Schon $\mathrm{I}_{54} 4$ hatte dort $D$ ir $n s d$ a $l e$ ein Patent auf künstliche Kohle zur Vergasung erhalten. Er prefte gemahlene Kohle mit Harz und Öl, stellte also Briketts her. S e ur tränkte zum gleichen Zwecke Torf und Sägemehl mit Öl, und 1865 verband Mackenzie eine bituminöse Feinkohle mit Schieferöl und später Petroleum. J. Ha milt on, Glasgow versuchte Feinkohle mit schwerem Öl und Naphthalin zu verwenden ${ }^{4.155}$ )

Einen ähnlichen Vorschlag machte r881 A. Riebeck in Halle, um bei den durch den Erdölwettbewerb gesunkenen Preisen dem aus der Braunkohlenschwelung erhaltenen Paraffinöl einen neuen Absatz zu erschlief̧en ${ }^{4,190}$ ): Die Kohle wurde abgesiebt und das Kohlenfein mit $20 \%$ Paraffinöl getränkt; mit der Stückkohle wurde die Retorte bis zur Hälfte gefüllt und dann der Kohlenölkuchen sorgfältig in die Mitte so aufgelegt, dał keine Berührung mit den Wänden der Retorte erfolgte. Die Leuchtkraft wurde bis zu einem Höchstmał an Öl von 10\% gesteigert, indessen genügten bereits $\mathrm{I}$ bis $3 \%$ O $\mathrm{Ol}$ auf den gesamten Einsatz bezogen, um die Flamme des Gases weif̧er zu färben. Nach diesem Verfahren wurde dann auch I880 in Halle/Saale gearbeitet ${ }^{1.190}$ ).

Der sehr sorgfältige und in der Kritik zurückhaltende $\mathrm{S}$. $S c$ biele meinte vom Riebeckschen Verfahren, es sei wegen der Zerkleinerung der Kohle und dem schwierigen Einbringen zu teuer. Es würde auch leicht gestört und sei nicht ungefährlich $\left.{ }^{4.101}\right)$.

Eine heutigentags besonders auffallende Nachricht enthält ein allgemeiner Bericht über die weitgetriebenen mechanischen Einrichtungen des Gaswerkes Dublin. Dort wurden schon im Jahre I870 Kohlen gemahlen und gemischt. „In der Mühle werden die Kohlen nach Mackenzies Patent mit Öl vermischt ${ }^{\text {(4.107 }}$ ). Angesichts der niedrigen Preise des Paraffinöles wurde aber auch die Ölvergasung für kleine Werke als wirtschaftlich angesehen. Kücbler, Weifenfels warnte vor der Mischung, da der Teer sich verschlechtere $\left.{ }^{4.195}\right)$. Auf Grund seiner langjährigen Erfahrungen äuf̧erte sich $1878 \mathrm{~S}$. Scbiele, Frankfurt grundsätzlich

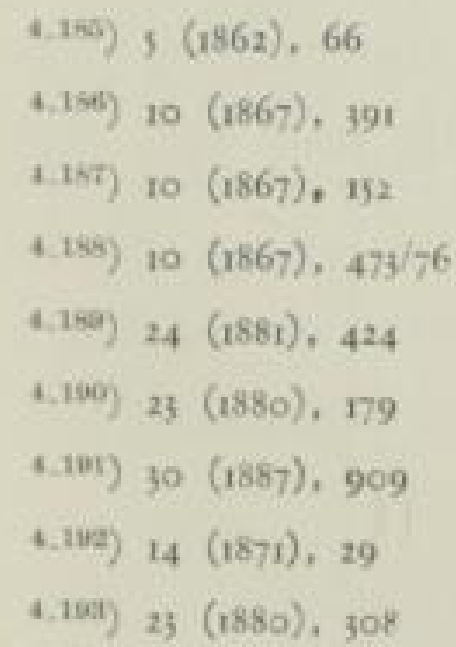


über die Aufbesserung Ǵes Leuchtgases durch reichere Rohstoffe $\left.{ }^{4,121}\right)$. Soweit diese permanente Gase liefern, entstünden keine Schwierigkeiten, Dämpfe aber kondensierten in Rohrleitungen und verdampften wieder recht willkürlich nach der Temperatur, so daf3 starke Schwankungen in der Leuchtkraft aufträten. Das sei vor allem bei den Ölen aus bituminösen Schiefern der Fall. Das Dichteverhältnis der getrennt erzeugten Zusatzgase solle vom normalen Gase nicht zu stark abweichen, deshalb eigneten sich für Norddeutschland Cannelkohlen, für Süddeutschland böhmische Platten- und Braunkohlen und im Südwesten auch französische Boghead d'Autun am besten. Noch 1883 setzte Hanau australische Bogheadkohlen $\left.\mathrm{zu}^{\mathrm{t}}{ }^{105}\right)$. Aus dem Jahresbericht für 1892 des Gaswerkes Kaiserslautern ersieht man. daf auch damals noch neben 6,ז Mio kg Saarkohlen 425000 kg Braunkohle aus Falkenau entgast wurden ${ }^{4.100}$ ) und im Jahre 1896 verarbeitete das neue Gaswerk in Harburg englische und westfälische Kohlen mit io bis I2 \% Cannelkohlen um I8 HK Leuchtkraft (für den iso I Schnittbrenner) zu erreichen $\left.{ }^{4,197}\right)$. Das darf man aber als Folge übertriebener Anforderungen an das Leuchtvermögen, die verteuernd wirkten, ansprechen.

Dagegen wurden in Rheinland-Westfalen schon seit den soer Jahren keine $\mathrm{Zu}$ satzkohlen zur Ruhrkohle mehr verwandt $\left.{ }^{4.195}\right)$. Wegen der Leuchtkraft war man auf grubenfrische Kohlen angewiesen.

\subsection{W assergas}

Die Verfahren zur Erzeugung von Wassergas und seine Verwendung nach der Karburierung zur Beleuchtung wurden besonders in Nordamerika entwickelt. Dort waren die Voraussetzungen insofern günstig, als einerseits reichlich und preiswert Anthrazit angeboten wurde, und ein leuchtkräftiges Gas gebende Gaskohlen knapp waren, andererseits die junge Petroleumindustrie, die für den Versand gefährlichen sehr leicht flüchtigen Kohlenwasserstoffe, die vor dem Export aus dem Brennöl herausgenommen werden muf̧ten, zur kalten Karburierung anbot und später die schweren Rückstände der Aufbereitung Verwendung suchten. Eine ausgezeichnete Übersicht der vielen verschiedenen Einrichtungen gibt ein Autsatz von Fr. H. C belto $\left.{ }^{t .290}\right)$. Kürzer gefafst ist Muspratt (Leuchtstoffe) 1893 S. 649/662. Hier können nur einige wenige Anlagen besprochen werden, an die sich die übrigen mit geringen Abweichungen in der Ausführung anlehnen. Man kann zwei grundsätzlich verschiedene Arbeitsarten unterscheiden. Die Erzeugung in Retorten und die in Generatoren.

Allgemeine Anteilnahme erweckte der "American Hydrocarbon Prozess" von Gwynne und Harris. W. A. Gwynne erhielt 1863 mehrere Patente und richtete seine erste Anlage in Elizabeth N. Y. ein, die mehrere Jahre im Betrieb blieb. Hier wurden im Gaswerk zwei der vorhandenen Retortenöfen umgebaut. Es gingen jeweils zwei Retorten mit bituminöser Steinkohle und cine mit

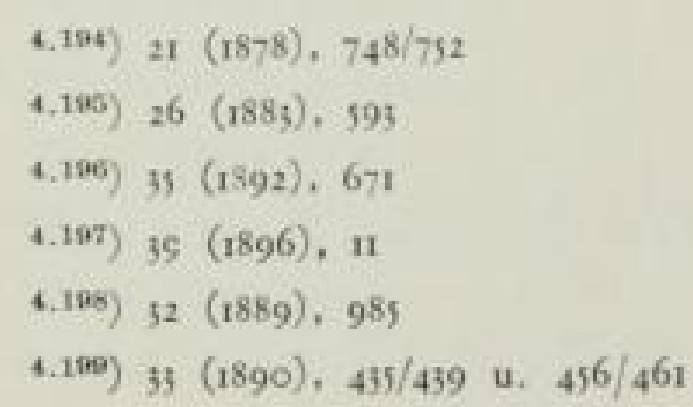



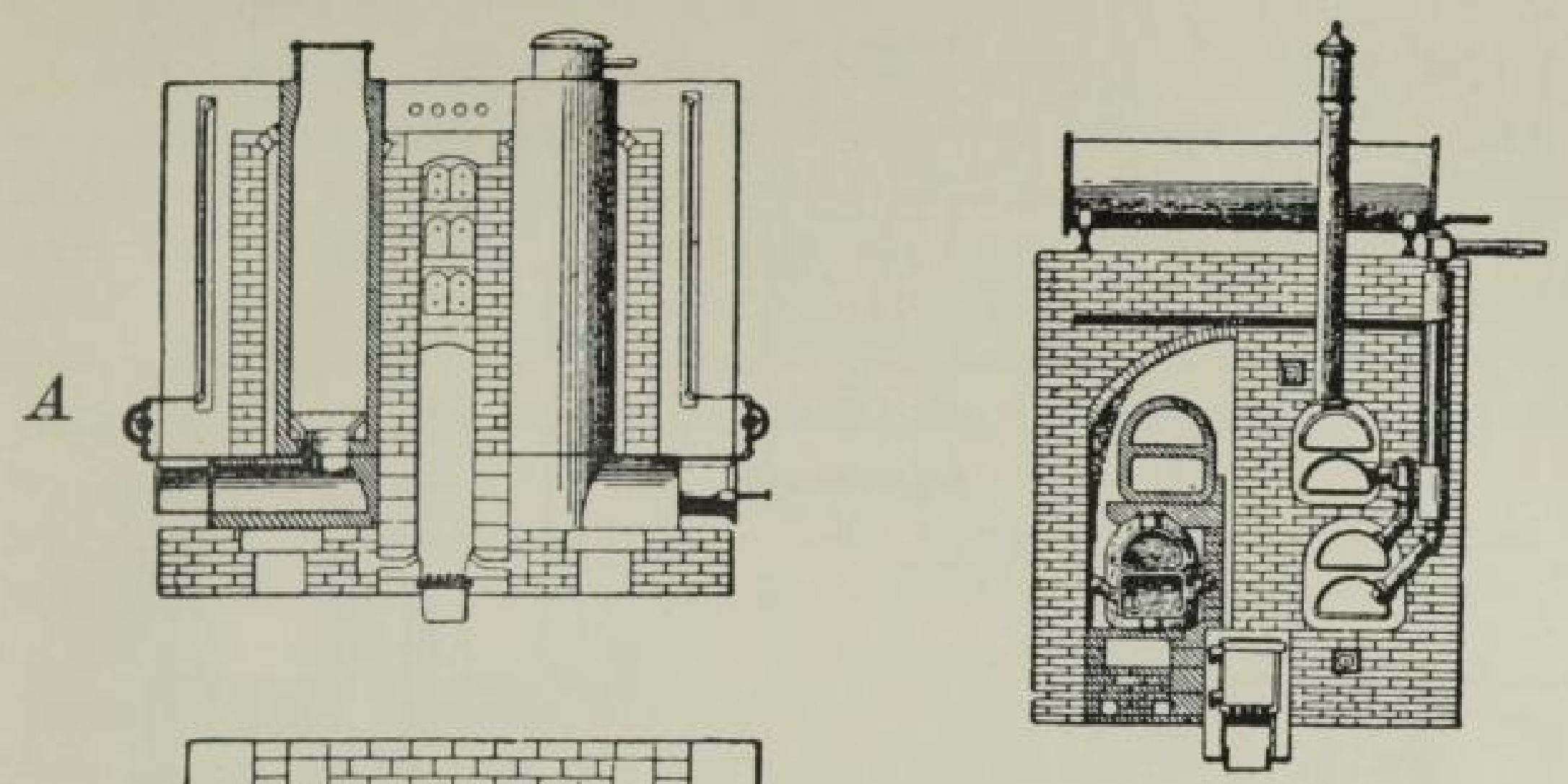

Bild 43

Wassergasanlage mit Retorten

(J. f. G. 30 [1890] S. 436 )

Anthrazit für Wassergas $\left.{ }^{4.200}\right)$. Grundsätzlich also war es das gleiche Verfahren, wie es Wbyte und Leprince angewandt hatten (S. I49). Hiermit war ein wirtschaftlicher Fortschritt noch nicht erreicht.

Gwynne verband sich in einer Gesellschaft mit G. W. Harris, der ebenfalls Wassergaspatente besafy. Sie errichteten 1368 gemeinsam die erste Anlage in Fair Haven bei New Haven, Conn. als Gwynne-Harris System. Nach dem Tode von Gwynne wurde mit H. P. und A. L. Alle n die "National Coal Gas Co" gegründet, dic dem Verfahren den Namen Allen-Harris gaben. Es war das einzige, was unter den von $1868-1875$ erscheinenden Retortenverfahren allgemeine Anteilnahme fand. Anlagen wurden in Utica, Brooklyn, Westchester und Newark (N. Y.) errichtet. Nach Verbesserungen entstanden die Betriebe in Roudout u. Poughkeepsie (N. Y.) $\left.{ }^{t .501}\right)$. Bild 43.

Links ist A ein Ofen mit senkrechten Retorten aus feuerfestem Ton. Die Retorten sind mit Kohlen angefüllt. Der Dampf wurde an der Vorderseite durch fein verteilte Röhrchen eingeblasen. Er zersetzte sich in den senkrechten Retorten. Das Gas ging dann durch den Ofen rechts mit waagerechten Retorten, in denen Öl zerlegt und fixiert (d. h. in permanente Gase umgewandelt) wurde. Der Weg durch diese Retorten ist etwa II $\mathrm{m}$ lang bei immer steigender Temperatur.

Bei den Generatorprozessen kann man wieder zwei Arten unterscheiden. Die einen erzeugen im Generator das Wassergas und karburieren es nachher in einem besonderen Apparat mit eigener Feuerung. Die andern stellen in einem Arbeitsgange das Gas im Generator her, karburieren und fixieren es sofort.

4.500) $7(4864), 227$

4.201) 33 (1890), 455 


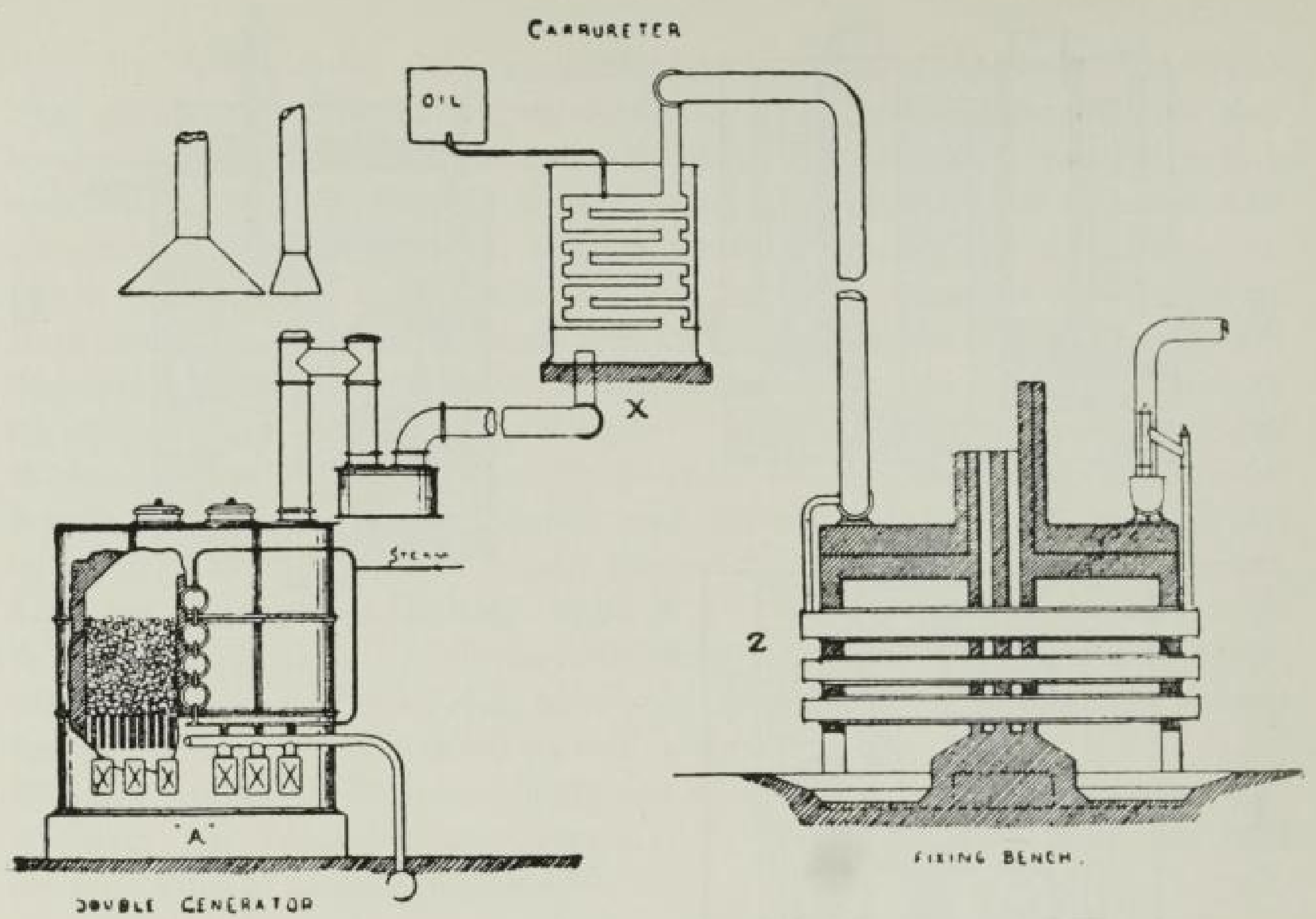

Bild ${ }_{44}$ Wassergasanlage nach Tessié du Motay (J. f. G. ;o [1890] S. 437)

Unter den ersteren ist die Anlage des französischen Chemikers Tessié $d u$ Mo t a y erwähnenswert. Tessié du Motay hatte sich ursprünglich die Verbesserung der leuchtenden Verbrennung des Gases durch Sauerstoff zur Aufgabe gemacht, worüber im Abschnitt 4,5I mehr gesagt werden wird. Er erkannte, daf3 er zur vollen Wirkung ein an Kohlenwasserstoffen reicheres Gas benötigte, als es das Pariser Stadtgas war. So kann er zur Entwicklung seiner Aniage. Tessié du Motay arbeitete in Paris von 1867 bis 1870 . Seine Anlagen sind in Amerika etwas abgewandelt worden und arbeiteten in den joer Jahren wie folgt (Bild 44). In einem einfachen Generator wurde Kohle mit Gebläseluft und Wasserdampf vergast. Das Heißblasegas wurde ungenutzt abgeführt. Wenn der Generator heif war, wurde periodisch Dampf eingeblasen. Das nunmehr erzeugte Gas wurde im Karburateur angereichert, der Naphtha in flachen Schalen oder Pfannen enthielt und von aufen mit Dampf geheizt wurde. In den nachgeschalteten waagerechten Retorten wurden die Dämpfe fixicrt. Die erste Anlage wurde in New York ${ }_{1} 876$ in Betrieb genommen, weitere sind in der Umgebung New Yorks benutzt worden ${ }^{4.30}$ ).

Wie man sieht, wurde auf eine gute Ausnützung der Wärme geringer Wert gelegt. Sicherlich ist es das Verdienst des Prof. T. S. C. Low $c$, Norristown (Pa), hierin grundsätzlich einen Wandel geschaffen zu haben.

Lowe war im Bürgerkriege Chef der Luftschifferabteilung der Potomacarmee. Er beschäftigte sich mit der Gasfabrikation für die Ballons. So kam er nach den Kriege ins Gasfach. 1872 nahm er das erste Patent, das bereits die Hauptzüge seines Verfahrens enthielt. Ein zweites Patent 1875 bildete die Grundlage aller heute üblichen Wassergasanlagen. Lowe benutzte die beim Heif̧blasen ent- 
stehenden Gase zur Aufheizung des Úberhitzers, womit er die Grundgedanken der Siemensschen Regeneration verwertete. Dem Wassergas wurden oben im Generator Öle oder andere Karburierungsmittel zugeführt, die im Überhitzer fixiert wurden. Bei nicht karburiertem Wassergas wurde der Úberhitzer für Dampf eingesetzt. Seine erste Anlage errichtete Lowe 1873 in Phönixville. Zwei weitere von ihm selbst erbaute folgten. Auß́erdem wurden noch mehrere durch Lizenznehmer geschaffen bis 1882 die United Gas Improvement Co. in Philadelphia alle Rechte erwarb.

Bild 45 zeigt die ursprüngliche Anordnung: A ist der Generator, gefüllt mit Koks oder Anthrazit, der mit Gebläseluft auf Glühhitze gebracht wurde. Der Dampf kann seitlich in $1 / 3$ Höhe des Bettes, das Öl oben eintreten. B ist der Überhitzer, gefüllt mit feuerfesten Steinen. Unter dessen Gewölbe unten tritt Zweitluft zur Verbesserung der Blasegase. Durch den geöffneten Deckel gehen die Abgase ins Freie. Nach hoher Aufheizung des Generators wird Dampf und Öl gegeben. Die Gase gehen nunmehr vom Überhitzer zur Wasservorlage und dem Skrubber. Da die Wasservorlage neben der Waschung auch einen Teil der lichtgebenden Bestandteile entfernte, wurde sie später fortgelassen. Bei dem in den goer Jahren ausgeführten Apparat fällt das geordnete Gitterwerk auf, das den Regeneratoren der Industrieöfen gleich ausgebildet ist. Vor dem Überhitzer steht der Karburator, in den nunmehr von oben das Ö - dieses kann nunmehr Schweröl sein, - eingebracht wird. Die lange Säule nach dem Überhitzer ist der Ölvorwärmer (Bild 46 ).

$H u m p h r e y s$ verbesserte die Anlagen. Er bekämpfte vor allem die Ruß̧bildung bei Verwendung der schweren Öle durch grołe Regeneratorflächen. Er setzte zwei Reihen von Apparaten parallel. Beide wurden gleichzeitig heif\}geblasen. Beim Gasmachen wurde in dem einen der Überhitzer der Dampf erhitzt, im anderen das karburierte Gas fixiert. Beim nächsten „Run“ wurden die Überhitzer bezgl. Dampf und Gas vertauscht. Erstrebt war mit den großen Uberhitzerflächen das Gas bei niedrigen Temperaturen zu fixieren und dadurch den Ruf̧ und Naphtalinabsatz zu vermeiden.

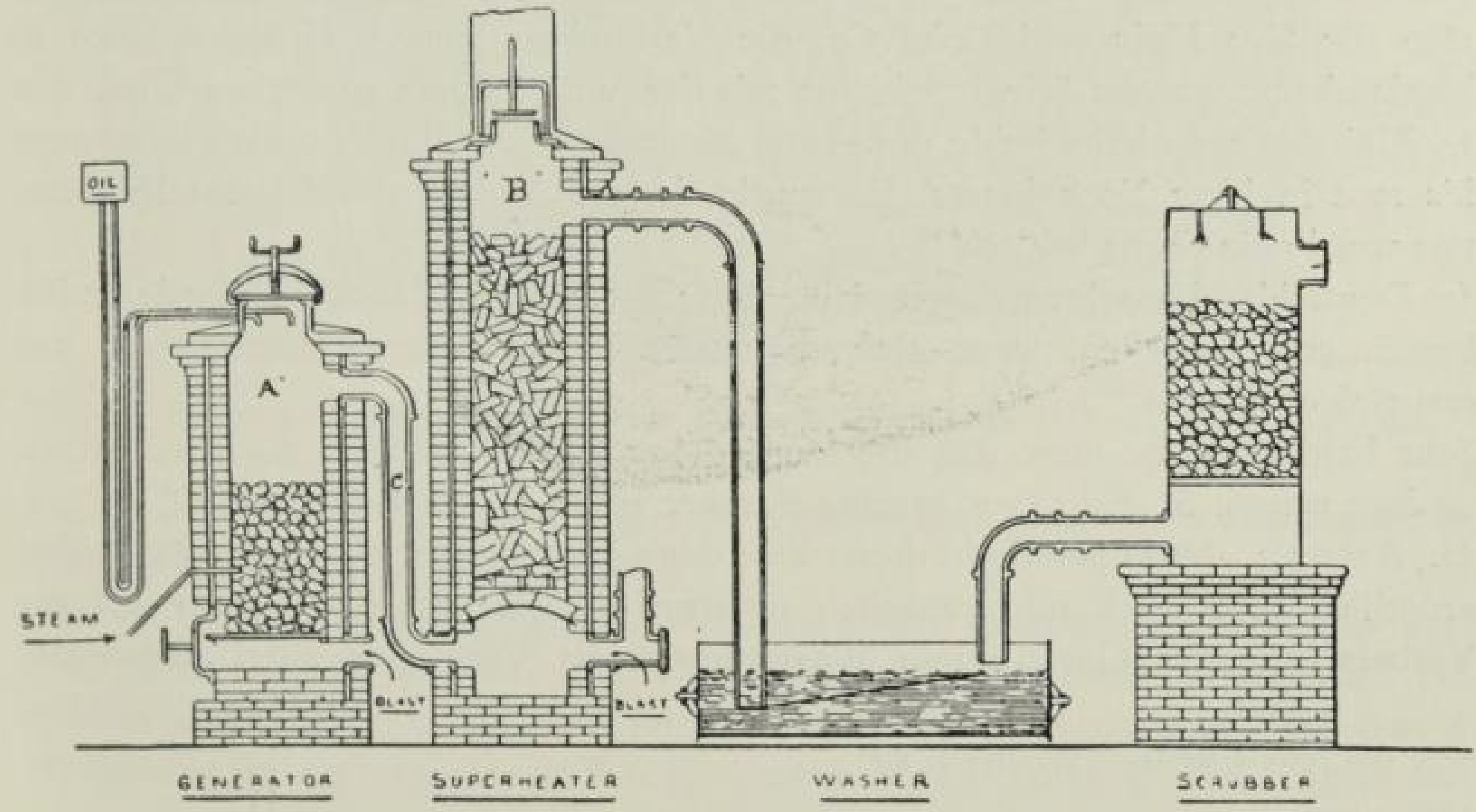

Bild 45 Wassergasanlage nach Lowe, Philadelphia Pa (J. f. G. 30 [1890] S. 456)

I4 Geschichte der deutschen Gasindustric 


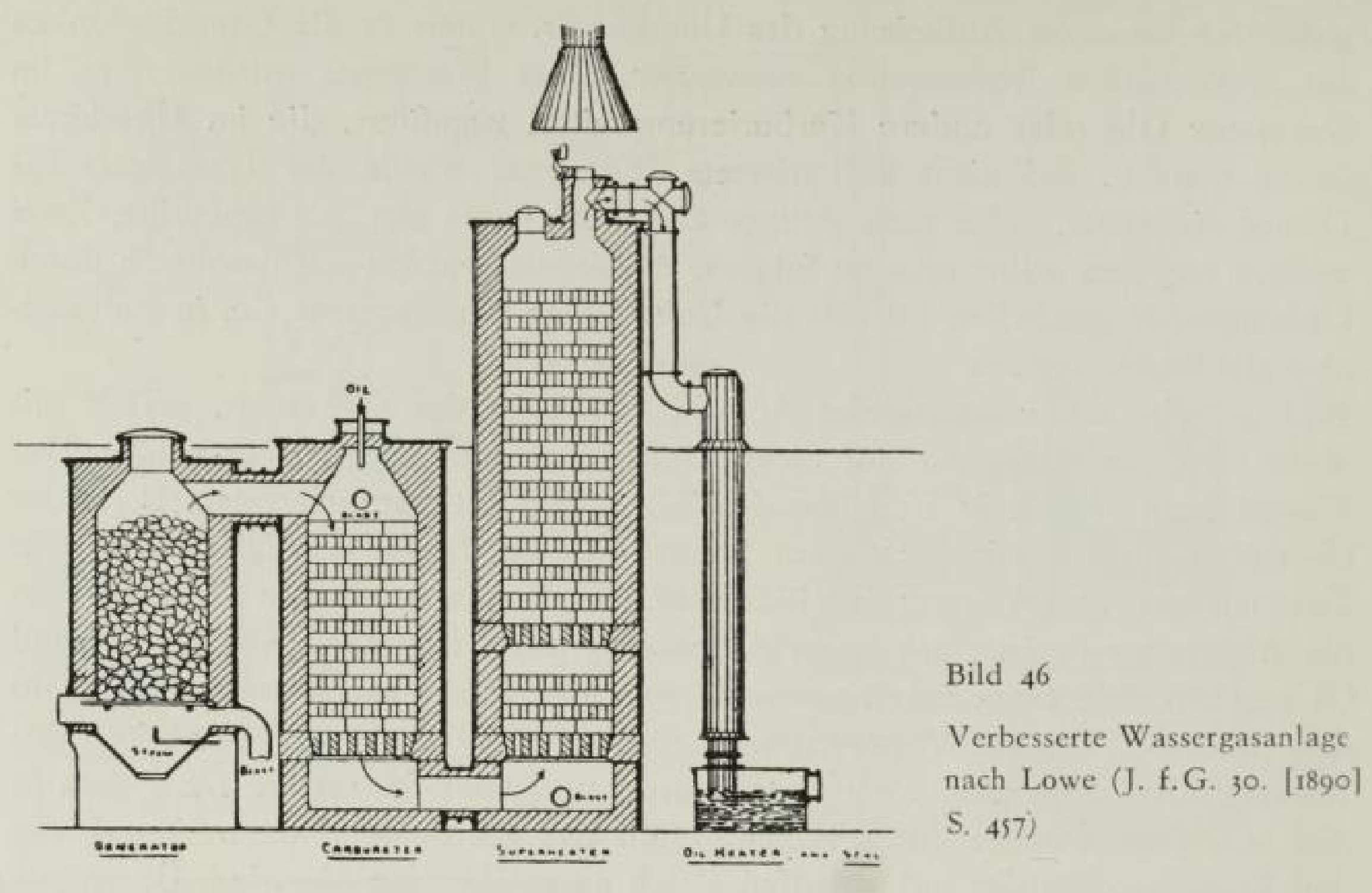

LE B E N S B I L D

Alexander Crombie $H u m p b r e y s$ hatte einen wechselvollen Lebensweg. Geboren I85I zu Edinburg kam er mit 8 Jahren nach Boston (Mass). Er besuchte die Marineakademie und ging mit 26 Jahren in die Gaswerkspraxis. Während dieser Zeit studierte er an zwei Tagen in der Woche am Stevens Inst. of Technologie. Er verfaffte eine theoretis he Studienarbeit über Wassergas. 1877 war er bei der Pintsch Gas Lighting Co. in New York tätig, seit 1885 bei der United Gas Improvement $\mathrm{Co}$, die 40 Gaswerke betrieb. Hier zog er Glas gow an sich, der später die Einführung der Wassergaserzeugung in England übernahm, als 1890 die Gas Light and Coke Co. die Verbindung suchte. Glasgow hatte in England unerwartete Schwierigkeiten mit der Verarbeitung russischen Öles. Am 12. Mai 1892 gründeten beide die Firma Humphreys \& Glasgow, die Humphreys bis 1902 in New York leitete. Er wurde dann Präsident des Stevens Institute. 1912 wurde die Firma britisch ${ }^{4.202}$ ).

In Deutschland machten die Berichte über diese Entwicklung in Nordamerika berechtigtes Aufsehen, wenn auch die ersten ausführlicheren Mitteilungen uns erst 1876 erreichten ${ }^{4.204}$ ).

Sehr bald erkannte man, dał die Vorbedingungen in Amerika doch wesentlich andere waren. S. Elster brachte darüber einen klaren Reisebericht ${ }^{4.95}$ ).

H. Bunte, der ja gerade in dieser Zeit den Generatorbetrieb für Gaswerksöfen gründlich theoretisch und praktisch untersucht hatte und dabei auch auf die Verbesserung des Gases durch Wasserdampf als Vergasungsmittel neben der

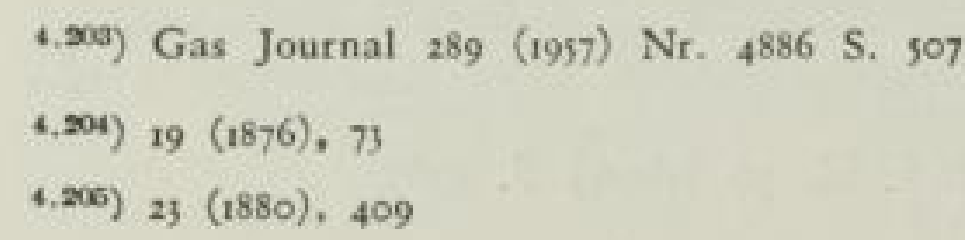



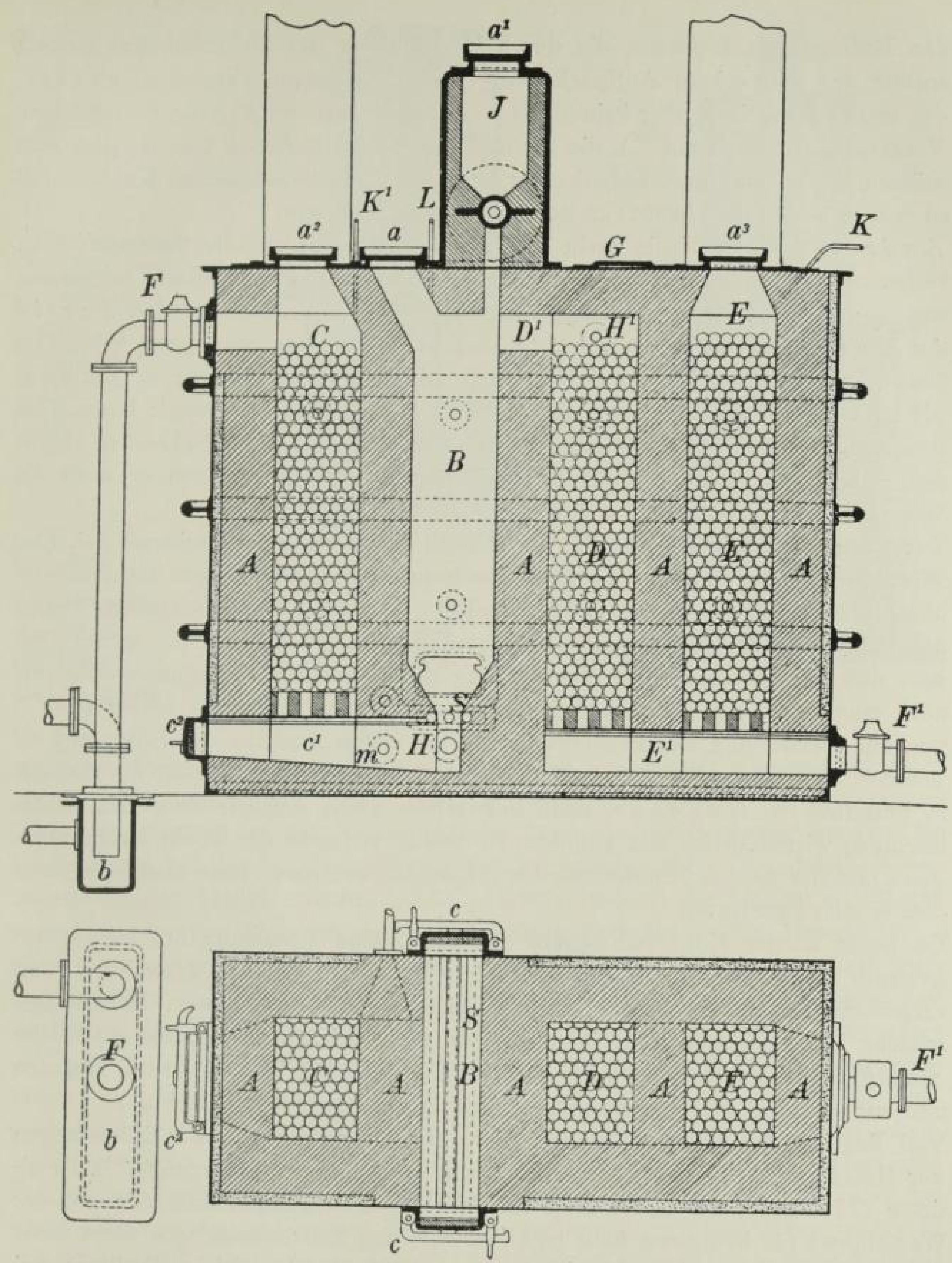

Bild 47 Wassergasanlage der Europäischen Wassergasgesellschaft (J. f. G. 23 [1880] S. 338)

Luft gestofen war, war in der Lage, die Theorie und praktischen Ergebnisse der Wassergaserzeugung abzuhandeln $\left.{ }^{4.000}\right)$.

Die Europäische Wassergasgesellschaft, deren Sitz in Schweden war, trat auch in Deutschland auf. Für diese Gesellschaft, aber mit durchaus selbständigen Gedanken kamen J. v. Quaglio und G. S. Dwight mit einem Verfahren in Anlehnung an Strong und T.S.C. Lowe heraus. (Bild 47.) Sie mufyten sich 
den Bedingungen anpassen, die durch Verwendung des aschenhaltigen Kokses anstatt des sehr reinen Anthrazites in Amerika gegeben wurden. Quaglio, der zwar optimistisch, aber keinesfalls phantastisch war, zeigte neun verschiedene Vergasungsverfahren auf ${ }^{4.207}$ ), die für reines und ölkarburiertes Gas möglich sein müssen. Dabei mag der Gedanke das Wassergas aus eingeblasenen Kohlenstaub zu erzeugen historisch heute von besonderem Interesse sein.

Andrea e, Wien, der in recht sachlicher Weise sich um die Sauerstoff-Gasverbrennung bemüht hatte und auch zu vorübergehenden Erfolgen gekommen war, griff 1884 in einem Vortrage die Frage auf $\left.{ }^{4.205}\right)$. Er betonte, daf̧ T es sié du Mota y das Verfahren von Strong bereits vorweg genommen habe. Die Umstellung von Leuchtgas auf Wassergas sei in Amerika viel weiter gediehen, als man in Europa ahne, was er bei einer Studienreise festgestellt hatte. Das Retortengas werde dort bald das Feld räumen müssen. Zu den bekannten Gründen - billigem Anthrazit und Karburierungsmitteln -, benannte er noch als wesentlich die Ersparnis an in Amerika teueren Arbeitskräften.

Zur Unruhe trug nicht wenig die Suche nach einem billigeren Heizgase bei. Der Wettbewerb des Petroleums in der Beleuchtung hatte Bemühungen um den Gasabsatz für Heizzwecke aller Art ausgelöst. Die neuen Konstruktionen ließ̧en die Hoffnung auf einen vollen Erfolg aufkommen. F. S i e mens sprach 1880 aus, dał die ausschlief̧liche Verwendung des Gases für Raumheizzwecke nur noch eine Frage der Zeit sei. Sein Bruder Wilheim Siemens schlug 1881 $^{4.200}$ ) vor, zur Herstellung des Leuchtgases nur die ersten Stunden der Entgasung zu nehmen, dann aber umzuschalten und das schwächere Gas getrennt als Heizgas zu verteilen. A. Heg en er, Köln bezweifelte zwar, daß̧ die doppelten Rohrleitungen wirtschaftlich sein könnten. Er wollte vielmehr die wenig leuchtkräftigen Gase der letzten Stunden zur Unterfeuerung benutzen. Den Gedanken meldete er zum Patente an.

$\mathrm{Da}$ heute wieder Kohlenschwelung und nachherige Vergasung mit Erfolg angewandt werden, darf ein Patent von Altwill und F a r mer, New York nicht vergessen werden. Sie bauten einen Generator mit übergebautem Entgasungsschacht. Das Leuchtgas sollte in der halben Höhe seitlich durch retortenähnliche Stutzen abgezogen werden. Ein Teil des entstehenden Kokses ist zu vergasen und zur Heizung des Entgasungsschachtes zu verwenden ${ }^{4.210}$ ). (Bild 48.)

Viel Begeisterung brachte Prof. A. Naumann auf in seinen „Erörterungen zur Heizungsfrage mit besonderer Rücksicht auf Wassergaserzeugung ${ }^{\text {(4.and }}$ ). Er zitierte Giersen, der auf Grund theoretischer Erwägungen das Monopol des Wassergases für kommend hielt und forderte, daf̧ Leuchtgasanlagen nicht mehr aufgestellt werden sollten. Vorsichtiger war Prof. C. W inkler, Freiberg, bei aller Würdigung des Wassergases zur Verwertung minderwertiger Kohlen. Er hielt den Lärm um Strong für ungerechtfertigt laut ${ }^{4.212}$ ).

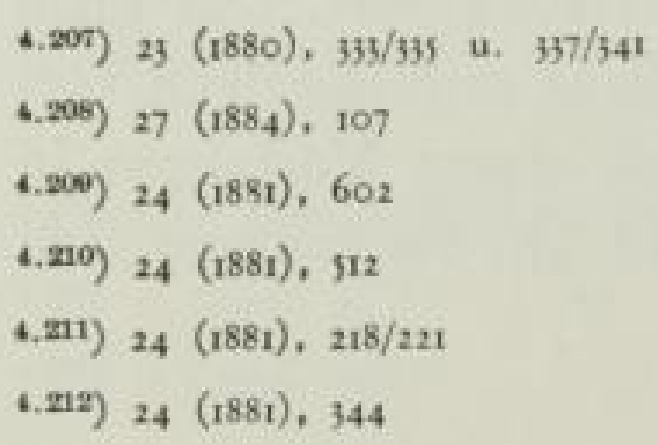




\section{Bild $4^{8}$}

Schwelvergaser

von Altvill

und Farmer

U. f. G. 24 [1881] S. 512 )
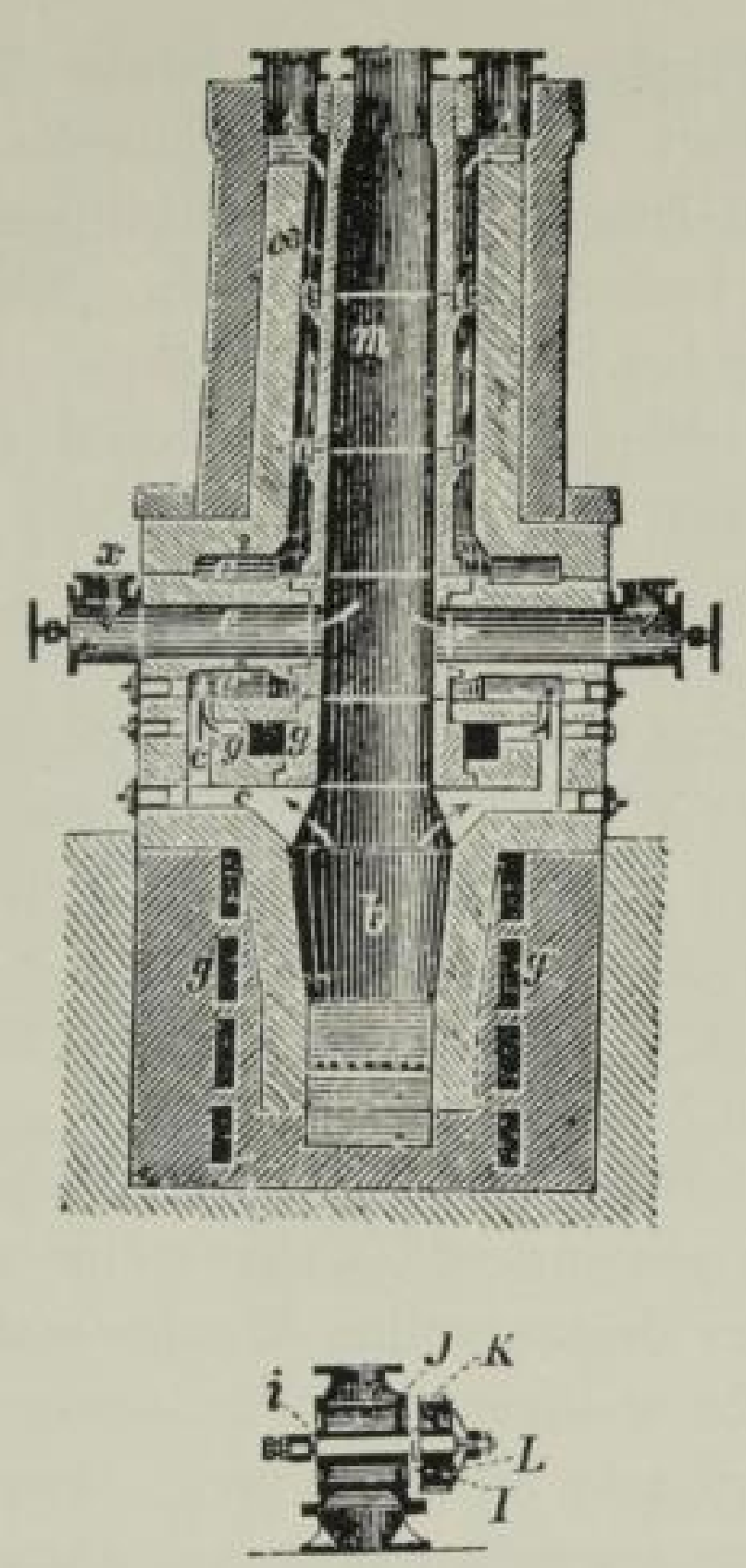

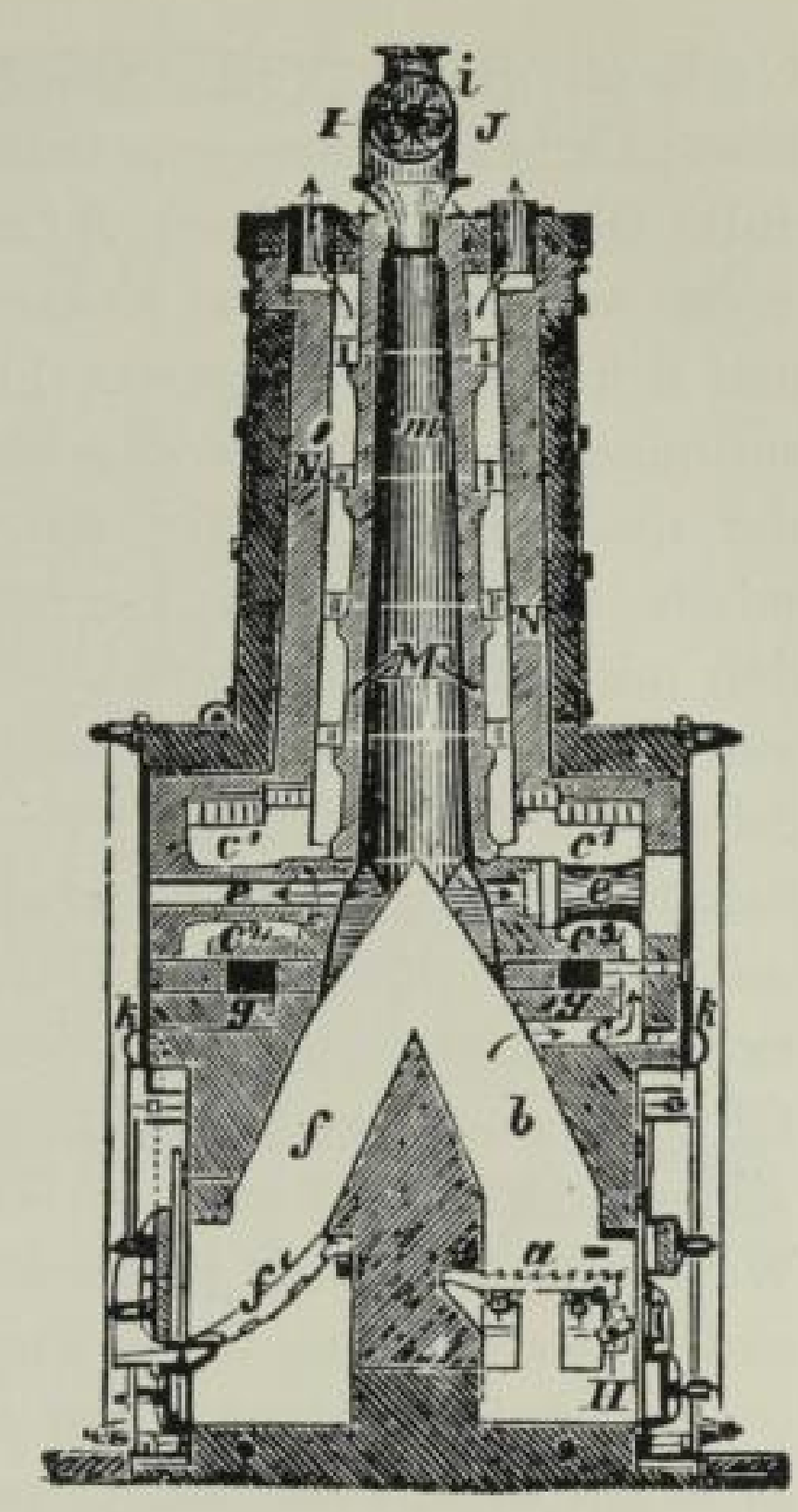

An einer Probeanlage, die $Q u a g l$ io für die Frankfurter Gasgesellschaft in Auftrag genommen hatte, stellte $B u n t e$ eingehende Versuche an. Die genaue Zersetzungstemperatur des Wasserdampfes konnte nicht bestimmt werden. Sie lag ungefähr bei $600^{\circ} \mathrm{C}$. Der Einfluf der Ternperatur auf $\mathrm{CO}$ und $\mathrm{CO}_{2}$-Anteil wurde verfolgt. Mafggebend für die $\mathrm{CO}_{2}$-Entwicklung sei der Mangel an Wärme im ganzen System. So ergab sich als günstigste Periode: 6 Min. Heizen und 4 Min. Gasen. Vergasungswirkungsgrad: $48,9 \%$. Als zum Teil vermeidbare Verluste wurden festgestellt: I. Die hohe Abgangstemperatur des Heizgases von $660^{\circ} \mathrm{C}$, 2. die des Wassergases von $500^{\circ} \mathrm{C}$, 3. die hohe Aufenwandtemperatur von $140^{\circ}$ C. 4. Betriebsverluste beim Schlacken, Abbrand beim Füllen, Undichtigkeiten. Der Versuch durch Zusatz von Paraffinöl, die in der Frankfurter Gasgesellschaft durch Vertrag besonders hochgehaltene Leuchtkraft zu erreichen, scheiterte wegen des hohen, bei der Verbrennung entleuchtend wirkenden Kohlendioxydgehaltes. $(7,3 \%$ im Mittel). Bunte sagte bessere Ergebnisse bei einer gröłeren Anlage voraus. Quaglio erkannte an, dafy bisher weder in Amerika noch im Stammhause seiner Gesellschaft in Schweden annähernd gleichwertige wissenschaftliche Feststeliungen gemacht seien. Er dachte für die Zukunft daran, den Ofen zu isolieren und einen Abhitzekessel anzubauen.

Von England ( $T$ ownsend und Woodall) kam der Vorschlag, die getrennte Verteilung von Wassergas für Heizzwecke dadurch wirtschaftlich vorzubereiten, daf man zunächst Stadtgas zu besonders billigen Preisen abgäbe ${ }^{4.213}$ ). Wenn dann ein ausreichender Konsum erreicht sei, könne die besondere Leitung verlegt werden. 
Nach all diesen Vorbereitungen wurde die erste grofe Wassergasanlage der Europäischen Wassergasgesellschaft in Essen bei Schulz-Knaudt ein voller Erfolg. Hierüber berichtete $B l a F_{3}$-Essen ${ }^{1,21}$ ) 1886. Als billiger Brennstoff wurden nicht nur aschenreiche Koksrückstände, sondern auch „Schröben” aus Puddelund Schweiß̈öfen eingesetzt. Die besondere Schwierigkeit der Aschenaustragung sei nunmehr befriedigend geiöst. Blał setzte sich auch dafür ein - ein Gedanke, der später immer wieder auftaucht (Dowson-Gas) - Blase- und Wassergas gemischt für industrielle Heizzwecke zu verwenden, worauf $B u n t e$ erwiderte, daf̧ mit dem Generatorbetrieb mit Dampfzusatz in ununterbrochenem Betriebe ein Gas gleicher Zusammensetzung wie das Mischgas erzielt werden könne. Bei Schulz-Knaudt muf̧te aber reines Wassergas zur Rohrschweif̧ung und zur Glühlichtbeleuchtung erzeugt werden. Die dort nach anfänglichen Schwierigkeiten mit Verpuffungen in den Leitungen eingesetzte Steuerwelle mit Nocken für den richtigen Einsatz der Perioden ist ein entscheidender Fortschritt geworden. Der Ofen wurde zu einer verläßlichen Maschine.

Ein Jahr später ist auch in Witkowitz eine Wassergasanlage der Europäischen Wassergasgesellschaft in Betrieb gekommen ${ }^{4.25}$ ), deren Gas auch zur Beleuchtung und Beheizung von Wohnräumen dienen sollte. Wieder meldeten sich Professoren von hohem Ansehen mit sehr weitgehenden Forderungen. G. L unge blieb in einem langen Aufsatz ${ }^{1.21}$ ) noch sehr nüchtern, meint aber dann, daf3 die Verteilung in besonderen Rohrnetzen geschehen solle, vor allem weil Wassergas als Heizgas ohne Ruß̧ brennend verwendet werden könne.

Schärfer waren die Forderungen W. Hempels in Dresden, Wassergas als Heizgas zu verteilen, unter dem Eindruck der Rauchgasbelästigung durch die dort im Hausbrand verwendeten Steinkohlen der nahegelegenen Fundorte ${ }^{4.277}$ ). Die Verschmutzung der Luft hatte in Dresden bereits zu behördlichen Auflagen geführt. Einwände wegen der Gefahren des hohen Kohlenmonoxyd-Gehaltes bei der Verteilung des Wassergases in die Häuser, führten zu Untersuchungen der Professoren Lunge und W yss, Zürich zusammen mit dem Gaswerksleiter in Bern, die aber nur einen Tatsachenbericht herausbrachten ${ }^{4.25}$ ). Offenbar meinten viele Ingenieure, dał Wassergas auch über den Heizwert gerechnet sehr viel billiger als Kohlengas hergestellt werden könne. Unter diesem Gesichtspunkte ist auch die günstige Aufnahme des Dowesongases zu verstehen, die durch einen Vortrag im Verein deutscher Ingenieure ${ }^{t .2 n}$ ) ausgelöst wurde. Optimisten glaubten, daß̧ nunmehr die „umständiliche und gefährliche Dampfmaschinenlage“ verschwinden würde und dem Gasmotor weichen müsse. Das Dowsongas war ein Gemisch von Blase- und Wassergas, die aus Anthrazit oder Koks hergestellt wurden $\left.{ }^{4.20}\right)$. Mit $57^{\circ} \%$ Inerten hatte es einen Heizwert von $1600 \mathrm{kcal} / \mathrm{m}^{2}$ und war dem Münchner Halbwassergas nicht unähnlich" ${ }^{\text {t.ㄹ' }}$ )

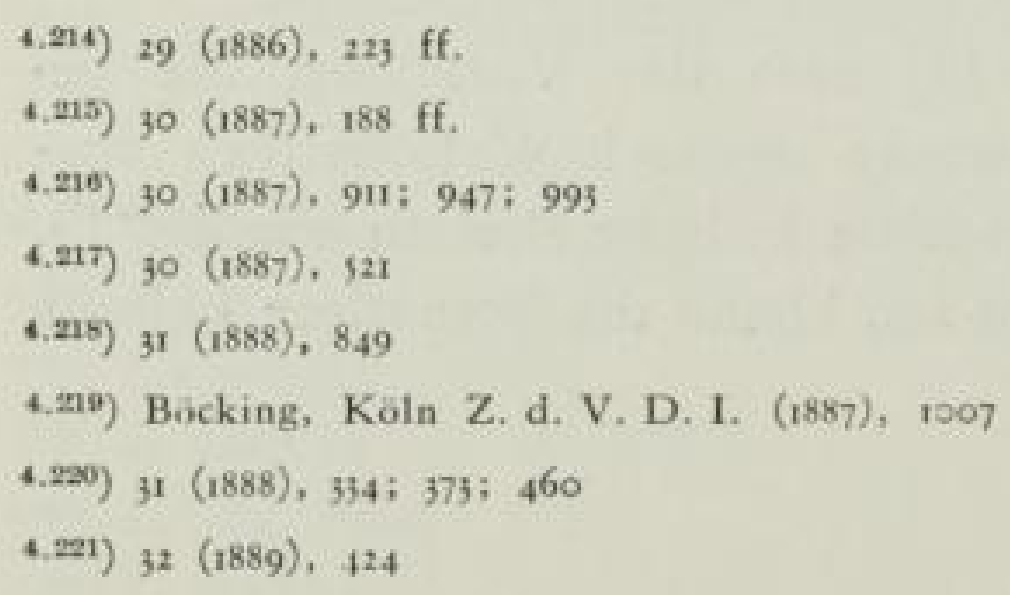




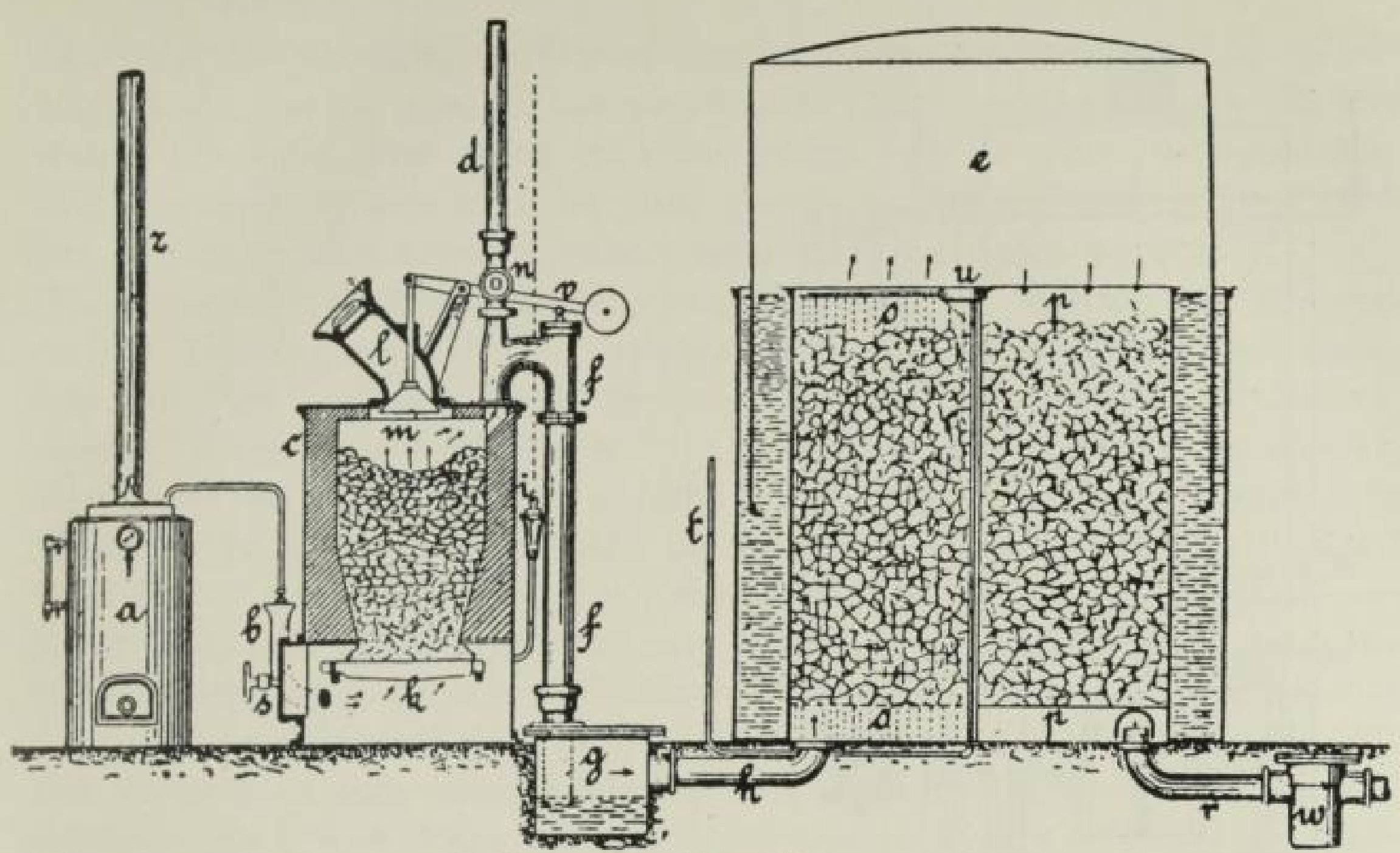

Bild 49 Dowson-Gaserzeuger (J. f. G. 31 [1888] S. 460)

Die technische Haupttat von J. Dow son war die konstruktive Vereinfachung und gedrängte Bauart seines Generators (Bild 49).

Die Skrubber waren im Innern des Gasbehälters eingebaut. Diese Anlagen konnten auch einfachen ungelernten Maschinisten in die Hand gegeben werden, später sind die kaum zugänglichen Skrubber nicht mehr verwendet worden.

L. Mond aus Kassel, der in England die Einführung des Solvayschen Verfahrens zur Sodaerzeugung übernommen hatte, bildete dort 1889 den Wassergasprozeł auf möglichst grołe Ausbeute an Ammoniak durch reichlichen Dampfzusatz aus. Er nahm auch minderwertige Kohlen, die er im Generatoroberteil entgasen lieł. Die Schwelgase mußten nach unten in den heif̧en Kokskuchen treten und wurden dann seitlich abgeführt. Er gewann das vierfache an Ammonsulfat aus der Kohle wie bei der Entgasung (Bild 50). Im Jahre rgor erhielt Mond eine Konzession auf Verteilung seines Gases von mindestens 1 roo $\mathrm{kcal} / \mathrm{m}^{3}$ in Southstaffordshire und East Worcestershire nur für Kraftwerke. Er belieferte ein Gebiet von $34 \mathrm{rm}^{2}$. Die Messung der Gasmengen geschah durch Teilstrommesser. Der Kohlenmonoxydgehalt des Gases betrug $14 \%$. Der Verteilungsdruck 0,5 atü ${ }^{1=m}$ ). W. Young war 1904 der Meinung, daß̧ beim Mondgasverfahren allein die Ammoniakausbeute die Verfahrenskosten decke. 1913 wurde indessen festgestellt, daf nach verlustreichen 6 Jahren das Unternehmen in England, obwohl es technisch einwandfrei arbeitete, zum ersten Male einen Gewinn abgeworfen hatte ${ }^{4.0 m}$ ).

Einen bleibenden Platz in der europäischen Gasindustrie erhielt das Wassergas indessen durch das Vorgehen der Gas Light \& Coke Co. in London. Diese hatte mehr als andere Werke mit plötzlich grofen Abgaben zu rechnen, nämlich dann, wenn die schwarzen Nebel über die Stadt kamen und das Licht während der

(1.221) $44(1901), 901$

4.215) 77 (1014), 305/306 


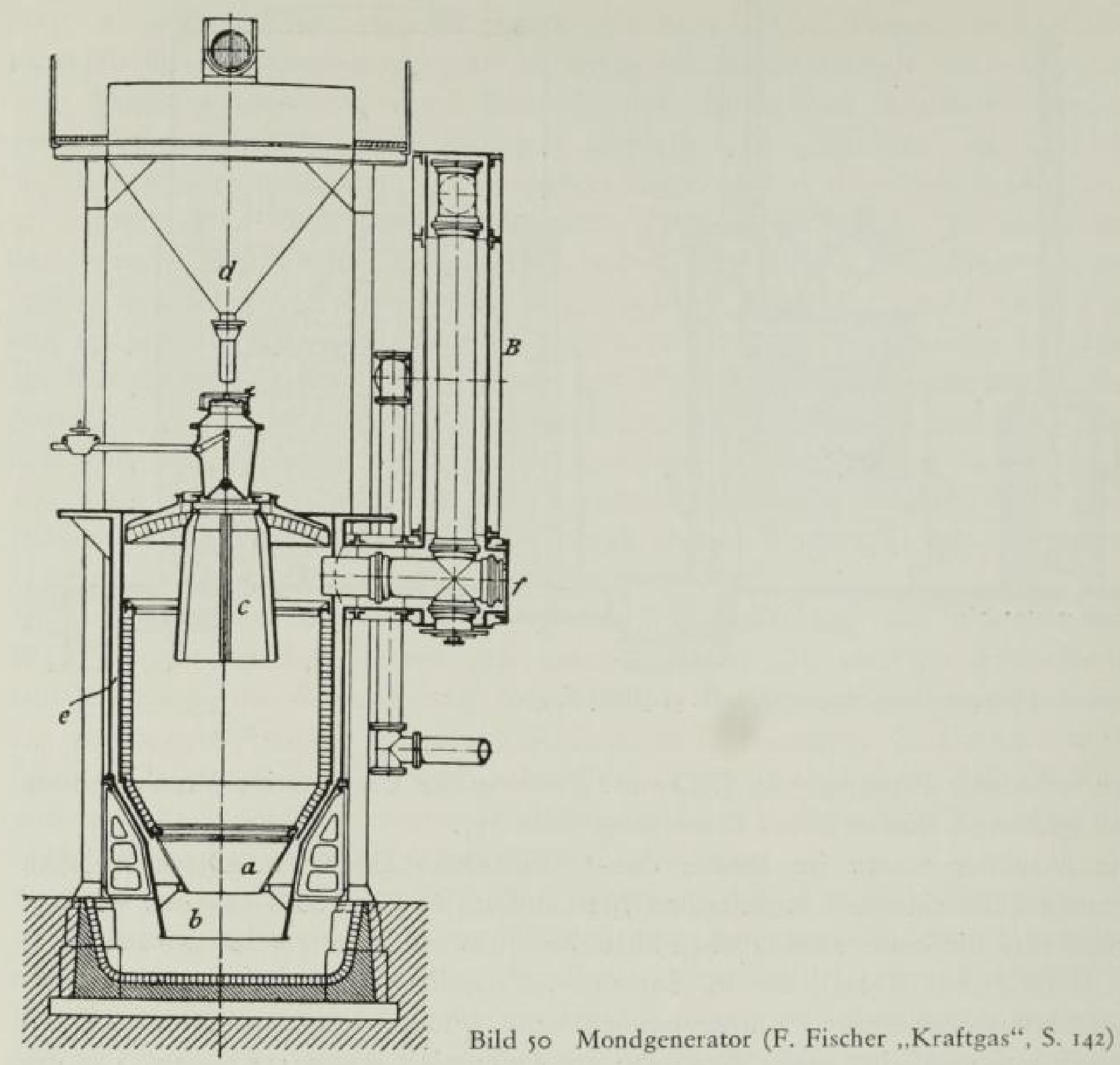

gesamten Tageszeit brennen mufte. Auß̧erdem war die Arbeiterschaft in diesen Jahren beeinflufyt durch den Versuch der Gewerkschaften, schnell an Macht zu gewinnen, äuß̧erst unruhig ${ }^{4.227}$ ). In der Südiondoner Gesellschaft war 1890 ein schwieriger Streik entbrannt, weil die Gewerkschaft die Gewinnbeteiligung der Arbeiter glaubte ablehnen zu müssen. In Leeds konnte auch das städtische Gaswerk einen Ausstand mit Unruhen nicht vermeiden ${ }^{4.25}$ ). Da die Schwerarbeiter an den Öfen immer zuerst zu streiken geneigt waren, so verlockte der leichtere Generatorenbetrieb die Werksleitung zu Versuchen. Schlieł̧lich spielte aber, zunächst nicht ausgesprochen, auch die Notwendigkeit eine Rolle, die Leuchtkraft des Gases zu erhöhen. Durch die besseren photometrischen Verfahren ergab sich die Klarheit, dał bis dahin die zugesicherte Leuchtkraft im Kohlengas nicht erreicht war. Die zusätzlich nötigen Cannelkohlen waren aber knapp und teuer geworden. Mit Wassergas als Trägergas schien die Erhöhung der Leuchtkraft sicherer möglich zu sein als bei Karburierung des an sich schon hochwertigen Lenchtgases. Darüber wurde zwar heftig gestritten. ${ }^{4=0}$ ), nicht erwähnt wurde aber dabei, daß̧ der notwendige Gehalt an Aethylen leichter erreicht und mit

\footnotetext{
4.224) $33(1890), 609$

4.295) $33(1890), 414 ; 467 ; 676$

4.226) $34(1891), 245 / 4^{8}$
} 
Sicherheit der günstigste Grenzwert eingehalten werden konnte, wenn ein verhältnismäf̧ig um ein weniges leuchtkräftigeres Gas in grołen Mengen zugesetzt wurde. Die kalte Karburation etwa mit Benzol, wie sie später in Deutschland vorübergehend Eingang fand, war aber damals in England nicht möglich, da in den Kokereien nennenswerte Benzolmengen nicht gewonnen wurden.

Die ersten Schwierigkeiten mit dem neuen Verfahren ${ }^{4.2 m}$ wurden bald überwunden $^{4.25}$. Nun breitete sich das Verfahren in England schnell aus. 1898 bestanden $8-9 \%$ der Gasabgabe des Landes aus Wassergas. Die Gas Light \& Coke Co. erzeugte allein $463000 \mathrm{~m}^{8}$ täglich, $\left.{ }^{4.29}\right)$. Deutschland, das zwar die Entwicklung in England beobachtete, folgte bedächtig. Der hohe Kohlenmonoxydgehalt im Wassergas gab zu Bedenken Anlał. Solche Stimmen kamen auch aus England. Prof. V. B. Le we s schlug dort vor, reinen Wasserstoff durch Herausnahme des Kohlenmonoxyds zu erzeugen. Im einem mit Eisenspänen gefüllten in die Kokskammer eingebauten Schacht sollte durch wechselnde Reduktion und Oxydation des Eisens im Rhythmus des Prozesses das Kohlenmonoxyd entfernt werden ${ }^{4.230}$ ). Die Versuche an sich verliefen günstig. Schwierigkeiten durch den im Gas mitgeführten Staub und Schmelzen des Eisenoxyduls wurden überwunden. Aber Lewes sagte selbst, daf die Aufbewahrung des Wasserstoffes wegen seiner Diffusionsfreudigkeit grołe Verluste bringen würde, und dał das Gas wegen der weiten Zündgrenzen sehr gefährlich sei. Ein Gas mit mehr als 50\% Wasserstoff sei nicht brauchbar.

Immerhin nahm nunmehr die technische Entwicklung der Wassergaserzeugung so stark an Breite und Tiefe zu, dafy sie im einzelnen unmöglich dargestellt werden kann. Erwähnt aber seien als Treiber: Prof. H. Stracbe, Wien und C. Dellwick. Stracbe war darauf aus, das Wassergas im neu erfundenen Glühstrumpf unmittelbar zu verbrennen. Er beschäftigte sich mit der Entfernung der Eisenkarbonyle, denen er die Verminderung der Leuchtkraft des Glühkörpers beim Betriebe mit Wassergas zuschrieb ${ }^{4.321}$ ). Strache hielt dessen Verwendung für billiger als die des Leuchtgases ${ }^{4, \text { ana }}$ ), fand aber gerade in diesem Punkte ernste Gegner. ${ }^{43 a g}$ ). Besonders für seinen Generator mit Kohlenfüllung (Bild 5I) bei dem im Aufstrom aufgeheizt, im Abwärtsstrom gegast werden sollte, gab er eine erstaunlich günstige Ertragsrechnung ${ }^{4.234}$ ).

C. Dellwick brachte durch seine Arbeiten einen gewaltigen Fortschritt im thermischen Wirkungsgrad. Er suchte beim Blasen durch eine geringe Schichthöhe des Kokses (1,20 m) Engl. Patent Nr. 29863 v. 28. 12. $\left.96^{1.255}\right)$ und durch Verkürzung der gesamten Heif̧blasezeit von bisher 45 auf is Minuten in der Stunde die CO-Bildung beim Blasen möglichst zu vermeiden. Dagegen verlängerte er umgekehrt die Gasezeit von etwa is auf 45 Minuten in der Stunde. Der Erfolg

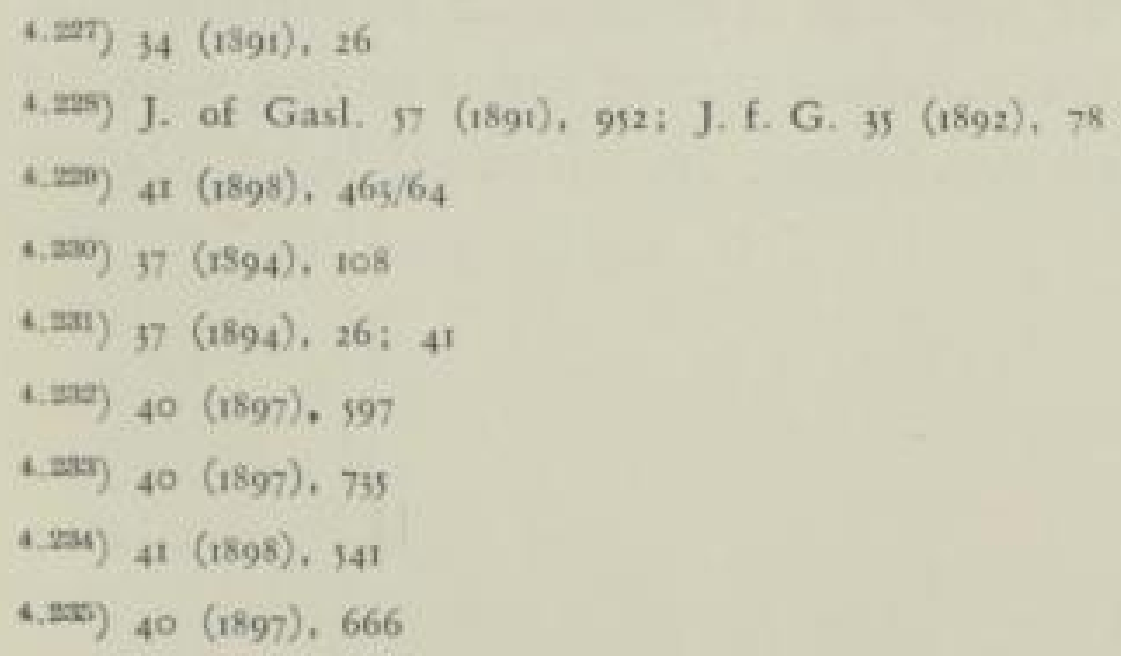




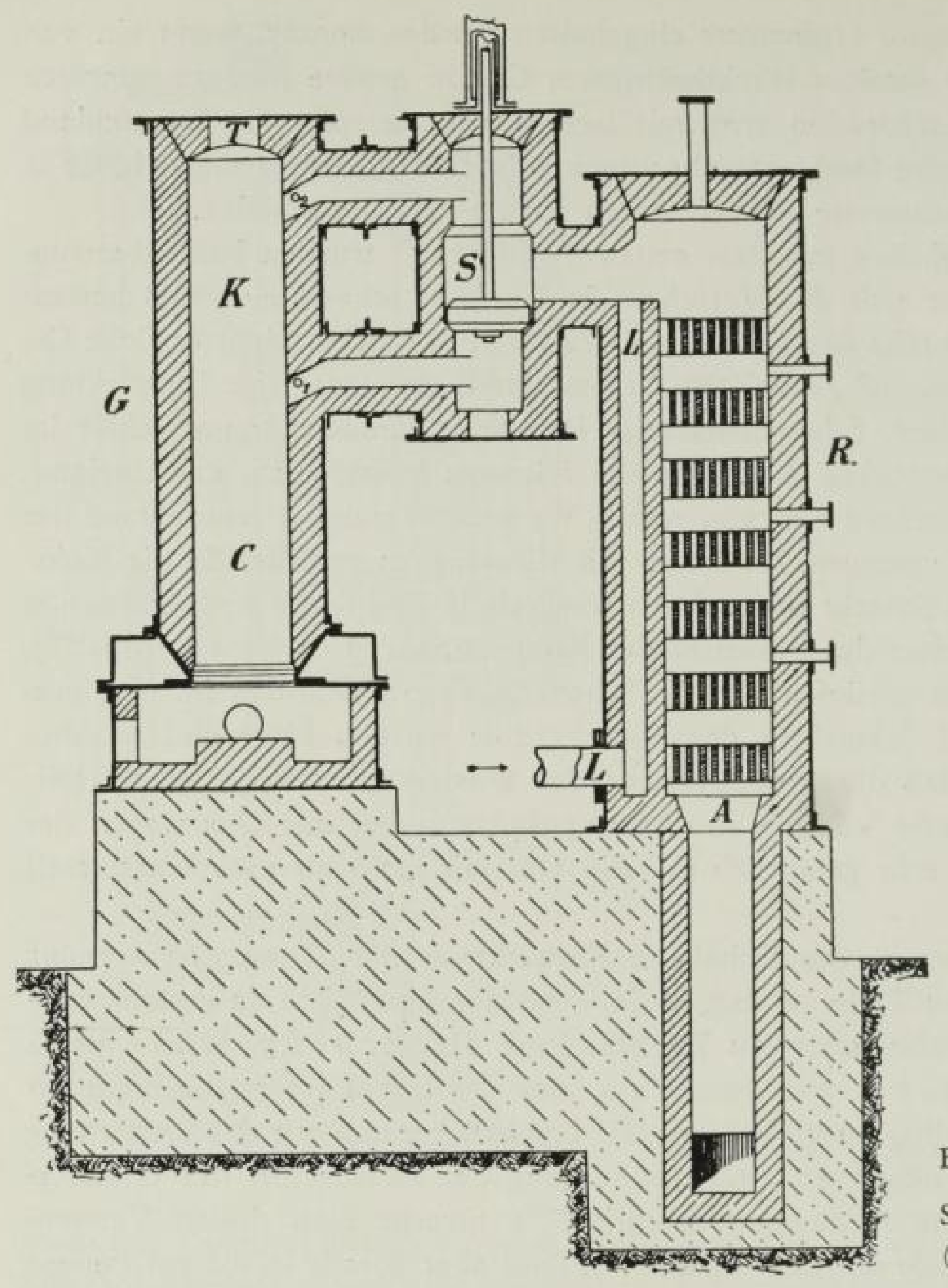

Bild 5I

Strachegenerator

(J. f. G. 4 i $[1898]$ S. 542 )

war, dał der Wirkungsgrad der beim Strongschen Apparat in Frankfurt/Main durch Bunte mit $50 \%$ festgestellt war und von Glasgow auf $57 \%$ erhöht wurde ${ }^{4.200}$ ), nunmehr bei $\left.70 \% \mathrm{lag}^{4.2 \pi}\right)$. J. Fle iscber erhöhte im ersten Generator auf der Warsteiner Hütte den Winddruck von $150 \mathrm{~mm}$ auf $300 \mathrm{~mm}$, was G. Lung e für einen entscheidenden Schritt zum Erfolge hielt. Eine wahre Invasion von Professoren und Sachker:nern in Warstcin war die Folge (Bunte, Lewes, Leybold, Lunge) ${ }^{4.235}$ ), die die Angaben der Werke bestätigt fanden. Aber gleich kam auch Widerspruch. Strache bestritt die Zweckmäfjigkeit des hohen Winddruckes. Nur die bei der kurzen Blasezeit sich ergebende niedrige Temperatur begünstige die Kohlendioxydbildung $\left.{ }^{4.29}\right)$. Die Dampfgeschwindigkeit müsse sogar gering sein bis dahin, wo die konstant bleibenden Wandwärmeverluste die wirtschaftliche Grenze setzten.

\footnotetext{
4.230) $37(1894), 81$

4.237) 43 (1900), $769 ; 971$

4.235) $42(1899), 593$

4.230) $43(1900), 354 ; 373$

218
} 
Das sagten auch die Versuchsergebnisse von. O. Bo udouard aus ${ }^{1.20}$ ), der seinen ersten Bericht über das $\mathrm{CO}_{2}+\mathrm{C}={ }_{2} \mathrm{CO}-$ Gleichgewicht bis $650^{\circ}$ am 27.3. 1899 in der Academie des sciences vorgetragen hatte. Die Untersuchungen über das Wassergasgleichgewicht wurden von Boudouard im Jahre 1900 auf dem internationalen Chemikerkongreł in Paris bekannt ${ }^{4.2 t}$ ).

Beide Forscher Stracbe und Dellwick konnten aber mit der Auswirkung ihrer Arbeit zufrieden sein. Im Jahre I899 wurden sowohl die: Société International du Gaz d'Eau, Brevèts Strache mit 1,I Mio frs., erhöhbar auf 1,5 Mio frs, ${ }^{4.22 z}$ ), als auch in Essen die Deutsche Wassergasgesellschaft Dellwick-Fleischer von Warsteiner Hüttenwerken, Bamag, Stettiner Schamotte und Frankfurter Wassergas-Syndikat System Dellwick-Fleischer ${ }^{4.213}$ ) gegründet. Die Gesellschaft wurde I906 klanglos wieder aufgelöst. $\left.{ }^{4,24}\right)$. Die małggeblichen Patente wurden auf Grund einer Klage der Firma Julius Pintsch, Berlin in den Jahren 1907 und 1909 für nichtig erklärt ${ }^{t .25}$ ).

Das erste deutsche Gaswerk, das eine Wassergasanlage neben die Entgasungsöfen stellte, war Bremen (von Humphreys \& Glasgow ${ }^{4.2 n}$ ). Hier sprach für die Entscheidung mit, daf̧ der bedächtige Bürgerschaftsausschuf den Umschwung von 1895 ab in der Geschaftsausweitung nicht recht ernst genommen und die Erweiterung des Werkes zu lange hinausgeschoben hatte. Da konnte die Wassergasanlage schneller fertig sein, als neue Retortenofen. Ganz ähnlich lag es in Königsberg im folgenden Jahre, wo sich Krieger und Kobbert gezwungen sahen, schnell eine anpassungsfähige Gasbereitungsanlage zu schaffen. Der von Kobbert vorgefundene Behälterraum betrug nur $30 \%$ der höchsten Tagesabgabe des vorhergehenden Winters. Durch die Wassergasanlagen mit Karburation wurde nicht nur der Engpafy in der Erzeugung beseitigt, sondern auch der Behälterraum entlastet $\left.{ }^{4.27}\right)$. Im Jahre 1899 waren schon Erfurt, Hamburg, Posen, Remscheid und Iscrlohn hinzugekommen ${ }^{4,259}$. Überall diente die Wassergasanlage lediglich zur Verstärkung der vorhandenen Ofenlieferfähigkeit.

Als bemerkenswerte Anregung mag noch die Anregung $\mathrm{Hempels}$ vermerkt werden, den Sauerstoff der neuentwickelten Lindeanlagen für die Generatorerzeugung zu benutzen ${ }^{4.210}$ ). Hempel glaubte, daf damit auch das Schwelgas in Gasmotoren geeignet würde, verkannte aber wohl, da\} in den Motoren arme Gase wegen der entsprechend geringen Verbrennungsluftmenge und leichteren Mischung durchaus wirtschaftlich zu verwerten waren. Fr. $K r u p p$ hatte damals bereits einen Motor für Schwelgas an Grube Emma in Weił̧enfels geliefert und von guten Ergebnissen berichten können ${ }^{4.3 i a g}$ ) (vgl. S. 3i5).

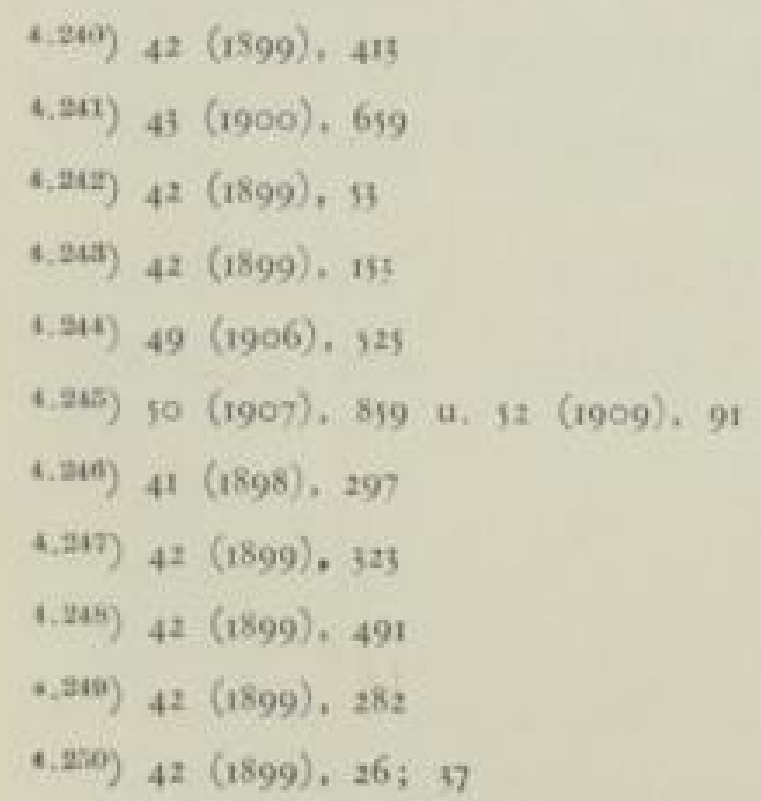


Die kalte Karburierung, so oft versucht und wieder aufgegeben, weil das preiswerte, gleichmäßjige Zusatzmittel nicht zu finden war, versprach in dem Augenblicke einen Erfolg als die Kokereien zur Wertstoffgewinnung aus ihren Gasen übergingen. Neben dem Teer, dem Ammoniak und dem Schwefelwasserstoft hielt man auch das Benzol im Ölwaschverfahren fest.

Benzol und seine Verwandten wurden von der chemischen Industrie gesucht. Es wurde aber bisher nur aus dem Gasteer ausgezogen. Nun konnten ungewohnt große Mengen und noch dazu auf billige Weise gewonnen werden. Der Erfolg war ein geringer Preis.

Andererseits hatte sich $B u n t e$ schon 1892 eingehend mit dem Benzolgehalt des Gases, den Sättigungsgrenzen und den Temperaturbedingungen für die Ausscheidung im Zusammenhang mit der Bekämpfung der Napthalinstörungen im Rohrnetz beschäftigt ${ }^{1.25}$ ). Im Jahre 1894 machte er den Vorschlag, das Steinkohlengas mit Benzol aufzubessern ${ }^{4.223}$ ). Er hatte das Bewufysein, daf3 auch die in Deutschland üblichen Leuchtstärken der Entwicklung billiger Herstellungsverfahren im Wege standen, als da waren: der Zwang in kleinen Räumen in dünner Lage zu entgasen, dazu besonders ausgewählte "Gas"-kohlen zu benutzen, die Temperaturen oder die Ausstehzeiten weise zu beschränken, also auf die volle Gasausbeute aus einer gegebenen Kohlensorte zu verzichten. Seine Versuche, Kohlengas bei $\mathrm{II}^{\circ} \mathrm{C}$ mit Benzol zu karburieren, ergaben eine Leuchtkraft am $1501 / \mathrm{h}$-Schnittbrenner von so HK statt der meist vertraglich geforderten 16 u. 17 HK. Aber dieser hohe Benzolgehalt schied sich natürlich, da es sich um Dämpfe handelt, bei Abkühlung wieder aus. Als einfachstes Verfahren schlug er vor, einen Teilstrom des Gases zu karburieren und diesen dann dem Hauptstrom wieder zuzusetzen. Nach Wiedervereinigung der beiden Ströme sei keine Auskondensation mehr zu befürchten. Benzol scheine reichlich genug vorhanden zu sein. Immer mehr Kokereien hätten auch Veranlassung, Öfen für Nebenstoffgewinnung zu bauen. Mit einer Zuschrift bestätigte $\Lambda$. Hü ssener, Essen ${ }^{4.253}$ ), dafy die von Bunte angegebene erzeugte Benzolmenge richtig geschätzt sei. Die Steigerungsmöglichkeit wäre aber noch viel größzer. Am Ende des Jahres trug E. Scbilling, München vor. $\left.{ }^{1.3 n}\right)$, daf $B u n t e$ durchaus richtig gesehen hätte. Die Karburierung mit Benzol bewähre sich ausgezeichnet. Selbst mit der noch unentwickelten Technik der Mischung zweier Gasströme war die Einhaltung einer gewünschten Leuchtkraft möglich. Aber schon scheinen die Benzolpreise angezogen zu haben. Ein Aufsatz des Journals für Gasbeleuchtung, der die allgemeine Einführung der Benzolkarburierung als voraussehbar bezeichnete, mahnte zu langsamen Vorgehen "wegen des Benzolsyndikates“. Tieferer Grund war wohl, dał die Kokereien ja die bestehenden alten Öfen nicht einfach durch neue ersetzen konnten, so daf̧ die ausgewaschene Benzolmenge nur schrittweise größer werden konnte.

Die Deutsche Continental-Gas-Gesellschaft hatte in 4 Werken die Karburierung eingeführt $\left.{ }^{4.25}\right)$. Nun waren schon drei verschiedene Verfahren des Bensolzu-

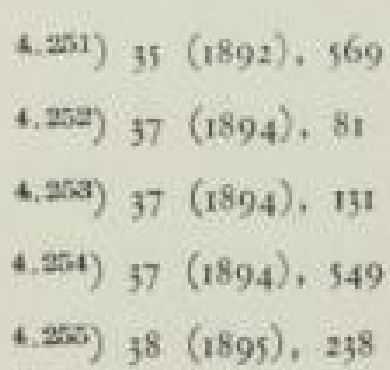


satzes im Gebrauch. In Gleiwitz erwärmte man das Benzol zur Verdampfung durch Wasserdampf und hatte mit dessen Regelung auch die Benzoldampfmenge in der Hand. Man sparte die Einrichtung für den „Münchner“ Teilstrom. Zimmermann \& Jansen, Düren wandten einen dem Skrubber ähnlichen Topf an, durch den das Benzol geregelt flof $\left.{ }^{1,20}\right)$. 1896 hatte die einsetzende Benzolkarburierung die Preise bereits um 100\% hochgetrieben ${ }^{4.27}$ ). Die Deutsche Continental-Gas-Gesellschaft sah sich gezwungen, auf Zusatzkohlen zurückzugehen". ${ }^{4: 5}$ ). Schon erwog man die Ölkarburierung aufzunehmen. Erörterungen, wie man gegen die hohen Zölle auf Erdöle vorgehen könne, kamen in Gang $\left.{ }^{1.250}\right)$. In England hatte man inzwischen die Einspritzung von (Petroleum-) Benzin von der Wichte $=0,680$ als billig und erfolgreich vorgenommen ${ }^{4.500}$ ). Da kamen, wie bereits berichtet, die ersten Wassergasanlagen zur Einrichtung, die über die Karburierung hinaus, auch noch den Spitzendienst erleichterten und schon kamen die ersten Äuß̧erungen, der Leuchtkraft des Gases nicht mehr die entscheidende Bedeutung beizumessen. Die ganze Frage der Karburierung wurde damit mit Rücksicht auf die neuen Möglichkeiten zurückstellbar. Der Umschwung bereitete sich vor.

\subsection{4 Ölgas}

Die Ölgaserzeugung hatte für städtische Werke neben der Kohlenentgasung keine bedeutende Rolle gespielt, aber niemals ist sie ganz aus den Augen gelassen worden. Rohstoffe Deutschlands waren Schieferöle aus bituminösen Schiefern und die Paraffinöle, die bei der Braunkohlenschwelteer-Aufarbeitung gewonnen wurden. Erdöl ais Kohöl oder Petroleum und Naphtha waren wegen der hohen Zölle in Deutschland kaum verwendbar. In den Goer Jahren machte die Schieferölfabrik bei Reutlingen besondere Anstrengungen, die hohe Leuchtkraft des Gases anerkannt zu sehen $\left.{ }^{1.51}\right)$. Verlockend war, dał die Reinigungsanlagen einfacher sein konnten, als bei Steinkohlengasen ${ }^{4,212}$ ). Wirklich mafgeblich durchgesetzt hat sich das Olgas in der betrachteten Zeitspanne nur zur Beleuchtung von Eisenbahnwagen und Seezeichen. Die Ölgasbereitung mag daher kurz abgehandelt werden.

Man konnte zwei grundsätzlich verschiedene Vergasungsverfahren unterscheiden. Einmal die Erhitzung durch Wärmeeinstrahlung bei niedrigen Temperaturen $\left(500-600^{\circ}\right)$ in weiten gußeisernen Retorten, von denen das von W. Yo ung und A. Bell, Peebles in Schottland (mit 40 Anlagen) als Peebles Verfahren von sich reden machte. $\left.{ }^{4.03}\right)$ Dworkowitsch nahm auf $800-1000^{\circ}$ erhitzte enge Rohre und fixierte die Gase in einer zweiten Rohrschlange. Es wurden dabei zunächst einfache gesättigte Kohlenwasserstoffdämpfe erzeugt, an den heif̧en Wänden

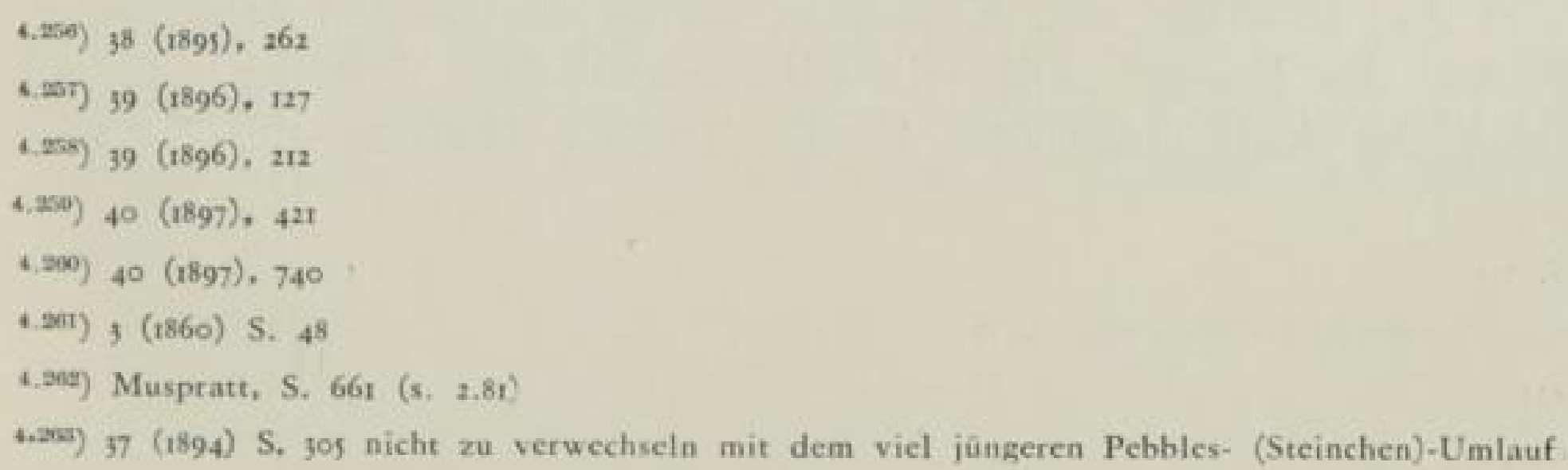




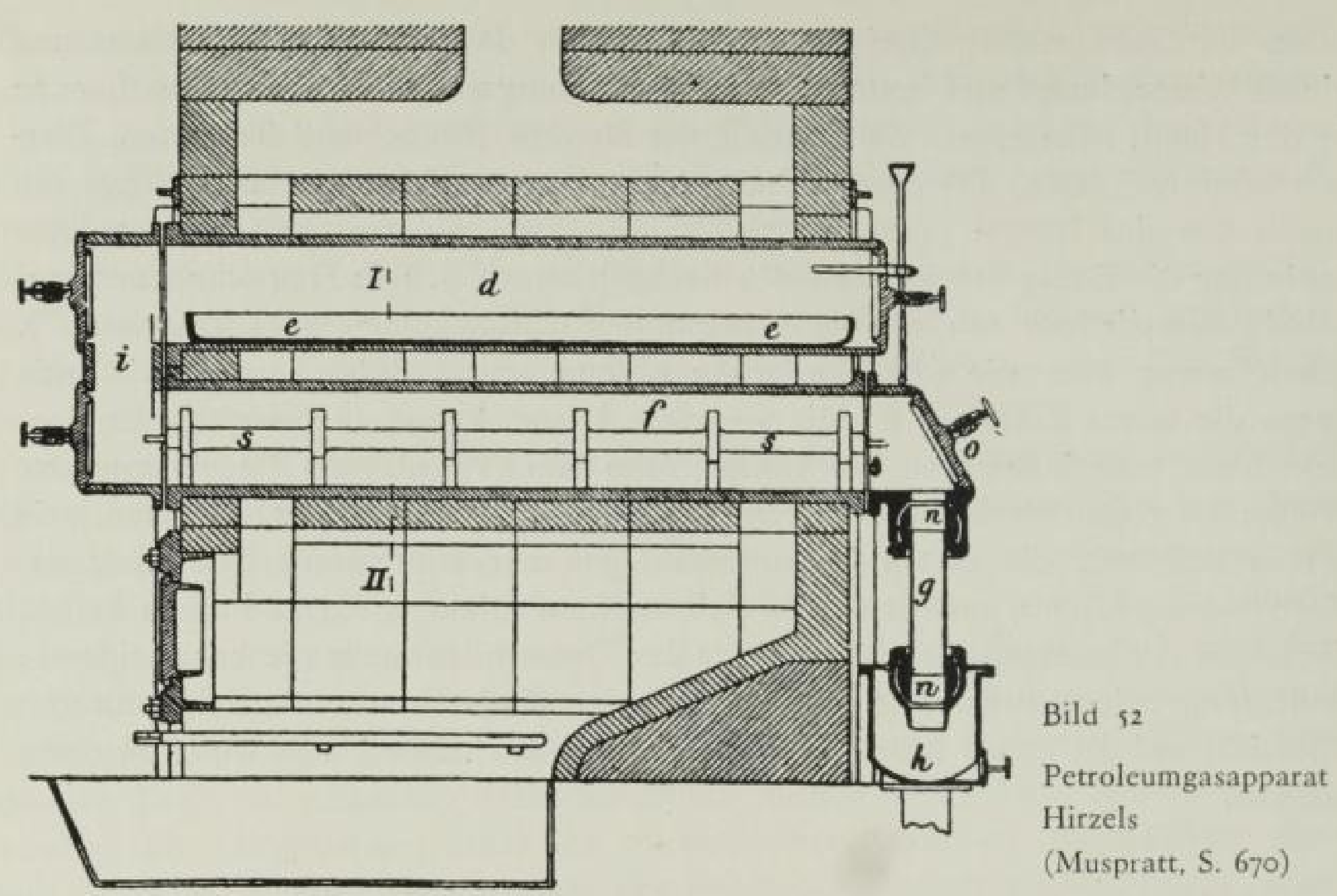

aber auch Clefine gebildet. Das erste Verfahren nahmen in Deutschland $W$ a $g$ ner vorm. Drescber in Chemnitz zum Vorbild, das zweite Schumann \& Küchler in Erfurt $\left.{ }^{4.25}\right)$. Küchler hat wertvolle Versuchsergebnisse veröffentlicht $\left.{ }^{4.255}\right)$. Hirzel, Leipzig hat in Deutschland die ersten Olgaswerke erbaut ${ }^{4.204}$ ). Bild 52 zeigt eine Anlage aus dem Jahre 1866. In der Retorte d wurden die Dämpfe aus der Schale e entwickelt, die vor allem dazu dienen sollte, die Retorte auf einfache Weise von Rückständen rein zu halten. In $f$ wurden die Dämpfe zu Gasen umgewandelt, was das Einsatzstück s aus Ton oder Eisen erleichtern sollte. Im Jahre I871 gelang es Julius $P$ intsch bei der niederschlesisch-märkischen Eisenbahn mit der Ölgasbeleuchtung festen Fuf zu fassen ${ }^{4.300}$ ). Die Vergasungsanlage von Pintsch zeigt Bild 53. Die Teile sind. Der mit Abgasen gewärmte Rohö!behälter $A$, in den eine mit dem Uhrwerk b angetriebene Pumpe a eingebaut ist. Diese soll das Öl ganz langsam und tropfenweise in die Retorte B drücken. C ist die Vorlage, D der mit Backsteinen gefüllte Kondensator zur Ausscheidung von Teeren.

\subsection{Azetylen}

Mit einem ungeheuren Aufwand optimistischer Lobreden wurde das Azetylen gerühmt, als es 1894 gelungen war, Kalziumkarbid im Elektroofen zu erschmelzen. I895 meldete das Journal „Die rein wissenschaftlichen Versuche sind mit der Herstellung des Kalziumkarbides in die Technik übertragen ${ }^{4 \cdot 2 i n}$ ). " Diese

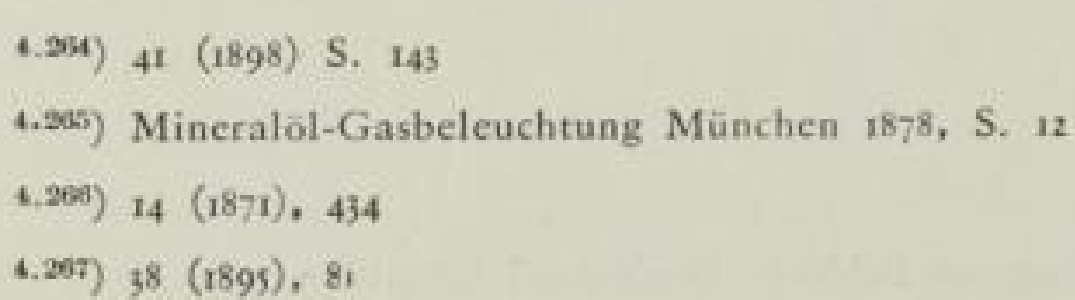

\section{SLUB}


und Stärke. Als Zeugen führte er W. v. Siemens an, der auf einer Versammlung der Naturforscher und Ärzte in Berlin gesagt hatte: „Es wird einmal gelingen, Naturstoffe chemisch herzustellen."

Indessen aber forderte die Aluminium-Industrie in Neuhausen beinahe das ro-fache des Frankschen Preises mit so Pf́g/kg. Eine nüchterne Nachrechnung E. Scbillings, München ergab, dał mit den Unkosten im Betrieb, Vertrieb und Verteilverlusten das Azetylen in der Karburation Benzol nicht verdrängen könne $\left.{ }^{4.271}\right)$. Prof. Lewes stellte 1894 seine vielbeachtete Theorie über die Bildung und den Zerfall von Azetylen in jeder Flamme auf $\left.{ }^{1.972}\right)$. Er war damit wohl für die Anschauungen über den Einfluf\} der Radikale ein Wegbereiter, obwohl H. Bunte entgegenhalten mufte, daf, der Nachweis vom Auftreten des Azetylens nicht gelungen sei.

I 896 stellte M. Bertbelot den exothermen Zerfall des Azetylens nach einem Druckstoł fest. Da er aber zur Auslösung den heftigen Zerknall von Knallquecksilber benötigte, hielt er nach weiteren Versuchen mit $V$ ie ill le normale Stößje für ungefährlich ${ }^{4.273}$ ). Immerhin beunruhigte die Häufigkeit der Explosionen ${ }^{4.274}$ ). Viele und lange Versuche wurden angestellt, um die geringe Gefahr zu bewei$\left.\operatorname{sen}^{4.255}\right)$. Der in polizeilichen Sicherheitsbestimmungen erfolgten Einreihung in die Gruppe der Sprengstoffe wurde von Te ic bman $n$ entgegengetreten ${ }^{4,270}$ ). Berdenicb, Budapest, der sehr viel für die Einführung des Azetylens zur Beleuchtung getan hat (Franzensplatz bei der Wiener Hofburg ${ }^{4.2 m i}$ ), Städtchen Weszprém ${ }^{4.25}$ ), Kaffeehäuser, Badeorte, Fabriken, Bahnhöfe ${ }^{4.270}$ ) gelang es in einem sachlichen und offenen Berichte, darzulegen, daf̧ die bekanntgewordenen Unfälle auf Unachtsamkeit und Nichtbeachtung der Vorschriften zurückgeführt werden könnten ${ }^{4.289}$ ). Ein beim Leuchtgase selten auftretender Gefahrenzustand entstand durch die Unterbrechung der Gasherstellung am Entwickler. Oft genug wurde das Verlöschen der Belcuchtung vom Entwickler herbeigeführt. Die Hähne blieben offen. Luft trat in die Leitungen ein. Bei der Wiederinbetriebnahme am nächsten Tag spielte Ungeduld eine grofe Rolle. In einem Falle konnte nachgewiesen werden, dał ein Beleuchtungswärter den engdüsigen Brenner abgeschraubt hatte, um das Gas schneller „kommen“ zu lassen. Mit einem brennenden Streichholz hatte er das Gas erwartet. Die Flamme schlug bis zum Gasmesser durch, der zertrümmert wurde.

Sicherlich waren aber auch viele Azetylenentwickler nicht sachlich hergestellt. Auf dieses Geschäft warfen sich Hunderte von „Blechschustern“. Bis 1899 waren 700 Patentanmeldungen und 1000 Musterschutze beim Patentamt eingetragen ${ }^{4.51}$ ).

\footnotetext{
$4.271) 38(1895), 202$

(.252) $38(1895), 562$

4.273) $39(1896), 797$

4.274) $39(1896), 843$

4.255) $40(1897), 197$ u. 213

(.256) $40(1897), 252$

4.277) ${ }_{41}(1898), 146$

4.278) 41 (1898), 146

c.270) 41 (1898), 164

4.280) 4t (1898), 290

เ.281) 42 (1899), 263

224
} 
Dabei gab es eigentlich nur drei Arten des Entwicklers: I. mit Tropfwasser in das Karbid, der sich für tragbare Lampen lange gehalten hat. 2. Mit aufsteigendem Wasser in einen Behälter der mit durchlöchertem Boden das Karbid enthält. Bei diesem konnte das Wasser nur höher steigen, wenn Gas verbraucht wurde und damit der Druck sank. Dieser Entwickler war als selbsttätiges Gerät in seiner Einfachheit unübertrefflich und 3. Körner von Karbid in Wasser fallend. $\left.{ }^{4.25}\right)$, $\left.{ }^{4.20}\right)$. Die beiden ersten Ausführungsarten bargen die Gefahr, daf durch zu schnellen Wasserzutritt die Temperaturen im Entwickler gefähriich hoch stiegen, die dritte war sehr schwer dem Verbrauch anzupassan, am wenigsten, wenn einfache Einschüttung mit der Hand gewählt worden war.

Nach der ersten überschwenglichen Begeisterungswelle wurde festgestellt, dał im allgemeinen Azetylen nur die Petroleumbeleuchtung verdrängte $\left.{ }^{1,2,5}\right)$. F. $S c b a ̈ f e r$, Dessau konnte zugunsten sehr kleiner Stadtwerke geltend machen, dał die inzwischen ausgebreitete Verwendung des Gases zum Kochen und Motorbetrieb vom Azetylen nicht erfüllt werden konnte ${ }^{t .25}$ ).

Bild $\$ 4$

Hutbrenner von Schwarz

(J. f. G. 43 [1900] S. и.)

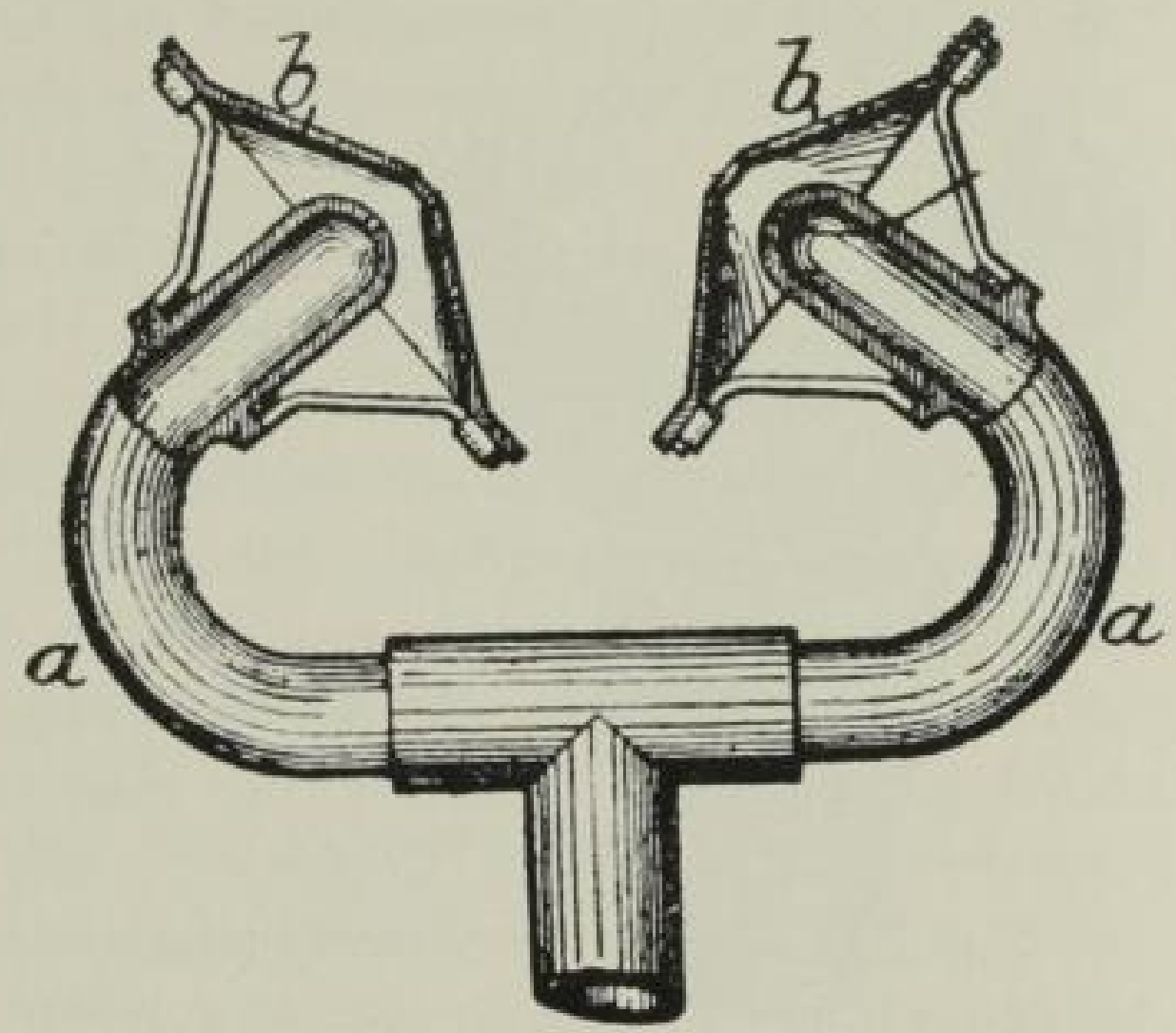

Um dem Selbstzerfall des Azetylens entgegenzutreten, wurden Reinigungsanlagen zur Entfernung des bei der Herstellung auftretenden Silizium- und Phosphorwasserstoffes vorgeschlagen ${ }^{4.250}$ ), besonders aber vor der Verdichtung zum Versand in Stahlflaschen, wofür R. Pictet auch vorherige Tiefkühlung emp-

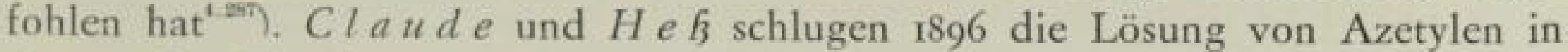
Azeton für Flaschengas vor, ein Verfahren, von dessen Grundgedanken auch C. Engler die Beseitigung von Gefahren erwartet hat $\left.{ }^{4.25 s}\right)$. Bert belot und Vieille lief̧en das Azeton in der Flasche vom spez. leichten Kieselgur auf-

\footnotetext{
4.252) 41 (1898), 495

4. 1585) 42 (1899), 263

4. 234) 42 (1899), 263

4.255) 42 (1899), 396; 409

4.256) 43 (1900), 48

(..287) $40(1897), 153$

4.256) 41 (1898), 372
} 
saugen $\left.{ }^{4.25}\right)$ und dann Azetylen einpressen. Zur technischen Entwicklung des Verfahrens wurde 1897 die Compagnie Francaise de l'Acétylène dissous in Paris gegründet. Das Gas wurde sorgfältig gereinigt, getrocknet und dann mit aller Vorsicht verdichtet $\left.{ }^{t .300}\right)$. Die Entwicklung von geeigneten Brennern hatte ihre Schwierigkeiten wegen der Ruß̧bildung. J. v. $S c b w a r z$, Nürnberg, nahm zuerst Bilwillersche Brenner mit flachem Hute (Bild 54) und später die sich allgemein einführende Doppeldüse mit gegeneinander gerichteten Strahlen (Bild 55$)^{4.901}$ ).

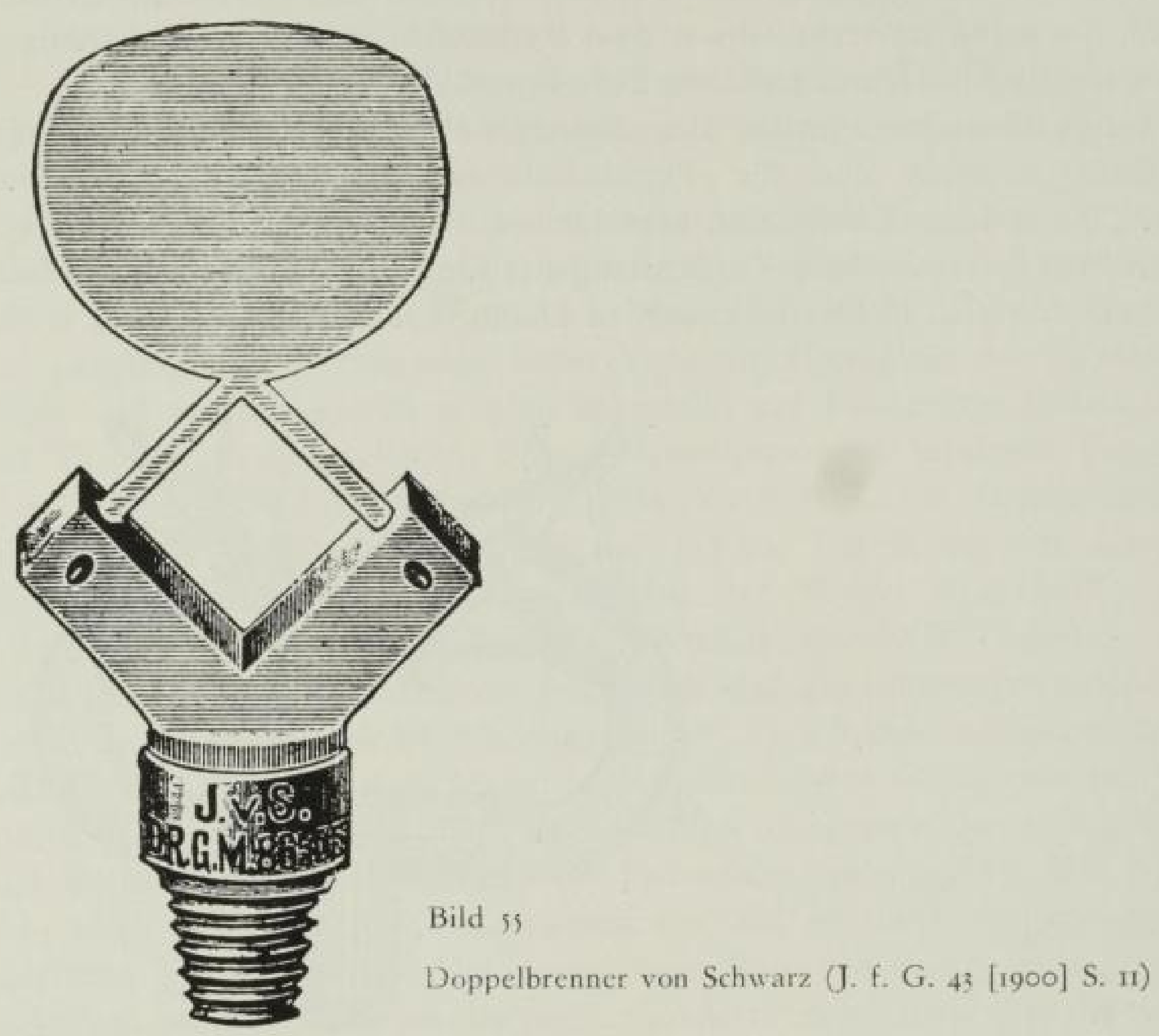

Azetylen wurde zeitweilig zur Aufbesserung des Ölgases bei Eisenbahnen benutzt. Der große Wurf, das Azetylen-Sauerstoffgebläse, war noch nicht getan. Immerhin bestanden gegen Ende des Jahrhundert zwölf Karbidfabriken ${ }^{1.29}$.

\subsection{Robstofle}

Das Leuchtgas wurde in der zweiten Hälfte des 19 . Jahrhundert im weit uberwiegenden Mafze aus Steinkohlen durch Entgasung gewonnen. Mit dieser Feststellung allein würden aber die technischen und wirtschaftlichen Sorgen der Gasfachmänner jener Zeit keineswegs in ihrer richtigen Größje erscheinen.

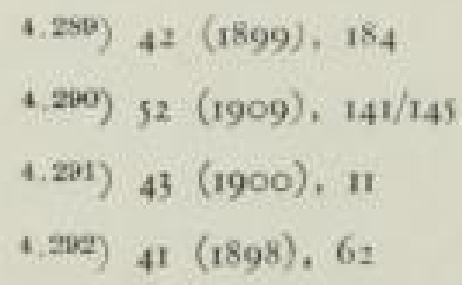

\section{SLUB}


Die sonderbarsten Rohstoffe wurden für die Gaserzeugung versucht und angewandt. Maikäfer und deren Larven wurden entgast. In der Pfalz wurde Weintrester in Retorten verarbeitet. ${ }^{4.20}$ ?. Jahrelang erhielt man daraus ein „besonders schönes" Gas $^{4.201}$ ). I869 wurde ein Projekt bearbeitet, in Fürstenwalde aus Braunkohle ein Heizgas zu erzeugen und nach Berlin zu liefern $\left.{ }^{4.25}\right)$. (Vgl. S. 257). Am auffallendsten sind aber die Jauche- und Kotvergasungen, die Hickey in Indien eingeführt hatte und auch für London vorschlug.2007). In Breslau richtete ein „Erfinder" gegen die Stadtverwaltung die schwersten Vorwürfe, dał sie sich solchen Piänen gegenüber wegen der schwierigen Sammlung des Rohstoffes ablehnend zeigte $\left.{ }^{4.207}\right)$. In Australien wurden die Blätter des Gummibaumes getrocknet und als Rohstoff in ${ }_{4}$ Städtchen ausgenutzt $\left.{ }^{1.25}\right)$. $S \mathrm{c} \mathrm{bil}$ lings Statistik von 1868 wies bei 530 deutschen und 82 ausländischen Werken nach: 58I benutzten Steinkohlen; 4 Braunkohlen; 2 Torf; 24 Holz und Petroleumrückstände, I8 Braunkohlenteer; 2 Braunkohlenteerfette; 6 Wollabfälle (Seifen), 3 Bogheadkohlen; s Swinter; (fetthaltige Abfälle, Seifenwasser, Ölkuchen, Knochen u. ä.) 3 Kreosot; je eines Schieferteer und Ölkuchen ${ }^{4.2 m}$ ).

Kohlen waren anfangs noch in den von den Gewinnungsstätten entfernten Gebieten durch die hohen Frachten unverhältnismäßjig teuer, was durch die Kokspreise bei hohem Unterfeuerungsbedarf nicht voll ausgeglichen wurde. So blieb tesonders in Bayern, als ungünstigstem Bezirk die Entwicklung gegen die übrigen deutschen Länder zurück. Zwar war inzwischen das Eisenbahnnetz einigermafjen vollkommen ausgebaut, aber es gab besonders in Deutschland eine Vielzahl kleiner Gesellschaften oder Staatsbahnbetriebe, die den Verkehr über lange Strecken erschwerten und verteuerten. So muf̧ten häufig irgendwelche in der Nähe gewonnenen Kohlen vorgezogen werden, obwohl sie einen Bestwert an Gasausbeute und Leuchtkraft nicht ergaben. Das führte oft genug zu Kritiken an den Preisen des Gases und der Leitung der Werke. Darauf war es wohl zurückzuführen, daf der Kampf um den Pfennigtarif ( $\mathrm{r}$ Pfg. je Centner und Meile) vom Deutschen Verein mit besonderem Nachdruck wieder aufgegriffen wurde $\left.{ }^{4,300}\right)$. Er brachte auch andere Kohlenverbraucher dazu, sich der Bewegung anzuschlieffen. In Norddeutschland hatte sich der Tarif zuerst durchgesetzt.

Der Beschluf des norddeutschen Eisenbahnverbandes vom 13. I. 60 bewilligte diesen Satz für geschlossene Kohlenzüge $\left.{ }^{t .301}\right)$. Es wurde versucht, die allgemeine Einführung durch Bundesgesetze zu fördern $\left.{ }^{4.202}\right)$. Erst vier Jahre später war der Pfennigtarif für Kohlenmassentransporte auch in Süddeutschland, auf̧er Bayern, allgemein durchgeführt ${ }^{\text {anom }}$ ). Dort schwebten noch Verhandlungen.

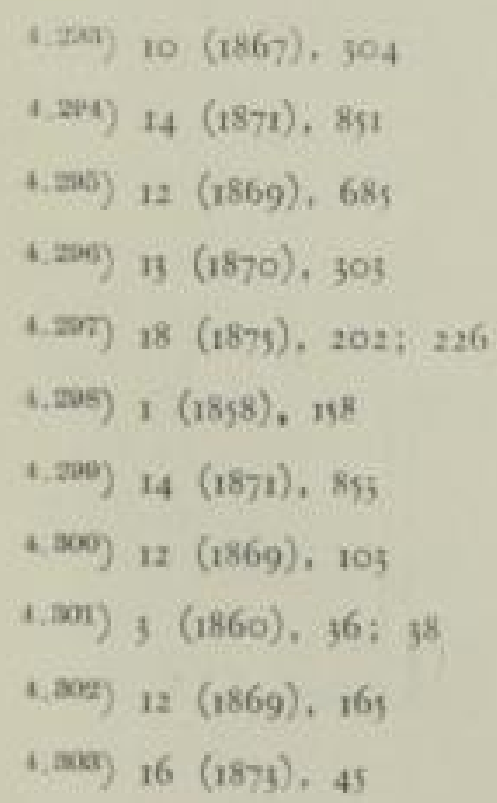


Über die Eignung der verschiedenen Kohlen hatten wohl jeweils die einzelnen Werke einen Begriff, aber ein allgemeiner Austausch von Erfahrungen und systematische Versuche fehlten noch. Die wenigen Mitteilungen S. Scbie$\left.l e s^{4.304}\right)$ und die nach 1863 von N. H. Scbilling in seiner Versuchsanlage erforschten Werte konnten den Mangel nicht beseitigen. Auch die Untersuchungen von $G a s c b$ über Saarkohlen ${ }^{4.205}$ ) und von $F l e c k$, Dresden ${ }^{4.509}$ ) über die Backfähigkeit oberschlesischer Kohle waren ein bescheidener Anfang. Auf Prof. Flecks Versuche, die Kohlen zu klassifizieren, geht der Begriff des „disponiblen Wasserstoffes" zurück (Steinkohlen Deutschlands von Geinitz, Fleck u. Hastig. München 1865). Sainte Claire-Deville, der Leiter der 186r eingerichteten Versuchsanstalt der Société du Gaz de Paris, und H. B unte betonten dagegen den entscheidenden Einfluß\} des Sauerstoffgehaltes auf das Verhalten der Kohlen $\left.^{4.305}\right)$. Französische Versuche machten darauf aufmerksam, daf3 zwischen der chemischen Analyse der Kohle und der Eignung zur Leuchtgasherstellung ein Zusammenhang bestünde $\left.{ }^{4.305}\right)$. St. Claire-Deville stellte dann mehr über den Einfluß der Zusammensetzung der Kohle auf das erzeugte Gas fest ${ }^{4.30 \%}$. Dabei ging seine Verallgemeinerung reichlich weit, wenn er sagte: „Das Gewicht an aromatischen Kohlenwasserstoffen in einem Kubikmeter Gas ist für alle Kohlensorten nahezu gleich. Dasjenige der ärmeren Gase enthält etwas mehr reines Benzol und folglich weniger Toluol, Xylol usw. Die reichen Gassorten enthalten alle mehr schwere Kolhenwasserstoffe (Azetylen, Propylen, Aethylen) und weniger Wasserstoff". H. Bunte hatte mit Hilfe der Heizversuchsstation des Polytechnischen Vereins in München den Heizwert vieler Kohlen genau bestimmt ${ }^{4.319}$ ). Unter seiner Anleitung untersuchte auch Eugen Scbilling die Ausbeute an Ammoniak in der Gaswerksversuchsstation $\left.{ }^{4.31}\right)$. Bertbelots Bombe $\left.^{4.312}\right)$ wurde von diesem in den 8oer Jahren entwickelt und zu Heizwertbestimmungen benutzt. Die $M a b l e r$ sche Bombe war eine Fortentwicklung dieser Einrichtung $\left.{ }^{\text {t.313 }}\right)^{\text {4.311 }}$ ) im Jahre I892.4.35).

Grofe Sorgen bcreiteten zwei Zeitabschnitte ausgesprochenen Kohlenmangels. Der erste um 1865 trat bereits in einer Zeit ein, in der durch die militärische Unruhe die Wirtschaft an sich schon gestört war. I5o kohlenverbrauchende Firmen, darunter sehr lebhaft die Gaswerke traten am 6. II. I865 in Frankfurt/Main zusammen, um über die mangelnde Versorgung Mittel- und Süddeutschlands

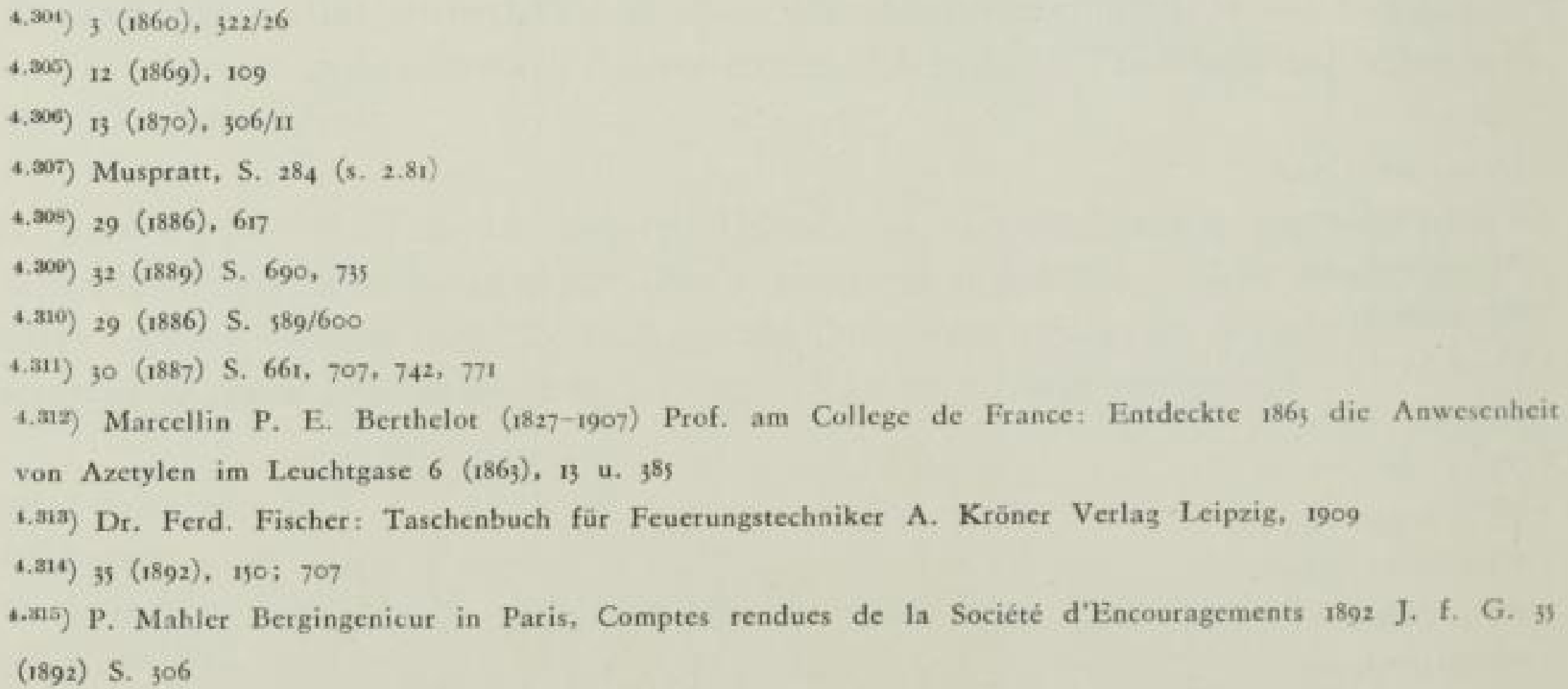


zu beraten. Die Notlage entstand nicht allein aus der zu geringen Förderung, sondern auch aus der unzureichenden Wagengestellung, die schon in den Sommermonaten fühlbar war. Während des Krieges mit Frankreich waren es die Truppenverschiebungen, die einen besonderen Notstand hervorbrachten. Im Journal für Gasbeleuchtung findet man eingehende Darstellungen, welche Mühen mit Verhandlungen und Reisen die Werksleiter auf sich nehmen muften, um Kohlen heranzuschaffen. Nach dem Kriege wurde es nicht besser. Auch ein zweiter Kohlentag in Düsseldorf konnte daran nichts ändern ${ }^{\text {t.316 }}$ ). Die Kohlenpreise stiegen, nicht nur im siegreichen Deutschland, sondern auch in England um $100 \%{ }^{4.317}$ ), bis dann im Winter $1873 / 74$ der Zusammenbruch der „Gründerzeit" erfolgte.

Die andere Knappheitszeit wurde durch die sich überstürzende Entwicklung der gesamten Technik gegen Ende des Jahrhunderts hervorgerufen $\left.{ }^{4.315}\right)$. Infolge des gesteigerten Kohlenverbrauches und, weil beim Kohlenmangel der Winterbedarf bereits im Sommer gekauft werden sollte, muf̧ten die Vorräte an Kohlen vielmals größzer werden als bisher. Das führte zu zwei neuen Sorgen: r.) Die Entwertung der Kohlen auf den Lägern ${ }^{\text {4.319}}$ ), 2.) die Selbstentzündung, über die 1900 in der Hauptversammlung des Vereins von C. H. Söbren, Bonn gesprochen wurde ${ }^{4.300}$ ).

Über die Zusatzstoffe zu den einfachen Steinkohlen ist im Zusammenhange mit der Aufbesserung des Leuchtgases bereits berichtet worden (Abschn. 3.42). Um die Mengenverhältnisse zu kennzeichnen, die üblich waren, mag eine Mitteilung der Allgemeinen Gas-Aktien-Gesellschaft Magdeburg, festgehalten werden. Der Konzern verbrauchte $188, \quad 15,1 \%$ englische, $62,6 \%$ westfälische, $5,8 \%$ oberschlesische, $14,6 \%$ niederschlesische und $\mathrm{r}, 8 \%$ ausgesprochene Zusatzkohlen. Bemerkt wird, daf der Anteil der englischen Kohlen wegen günstiger Preise höher war als sonst ${ }^{\text {t.an }}$.

Im Anfang des Zeitabschnitts mühte man sich auch noch weiter um Holz und Torfgas ab, wobei die erwähnte Frachtlage eigentlich immer entscheidend war. Dr. W. Re issig. Darmstadt, hat sich damals mit dem relativen Wert verschiedener Holzsorten, bis zum Kienapfel und Tannensamen beschäftigt $\left.{ }^{t .3 m}\right)$. Torf wurde teils mit Erfolg, teils mit völligem Mißerfolg in Retorten geschwelt im Gegensatz zu Schottland, wo man Schachtöfen benutzte ${ }^{\text {t.azzaz }}$ ). Das kleine Werk Sondershausen ( 5560 Einwohner der Stadt) wurde 1862 mit gutem wirtschaftlichem Erfolg von Steinkohlenbetrieb auf Holzgas umgestellt. Es lag damais aber auch $50 \mathrm{~km}$ von der nächsten Bahnstation entfernt und $30 \mathrm{~km}$ von der sicherlich nur mit kleinen Kähnen schiffbaren Unstrut ${ }^{4.921}$ ). Noch 1878 ging Meran mit Vorteil zu Holzgas über $\left.{ }^{4,325}\right)$.

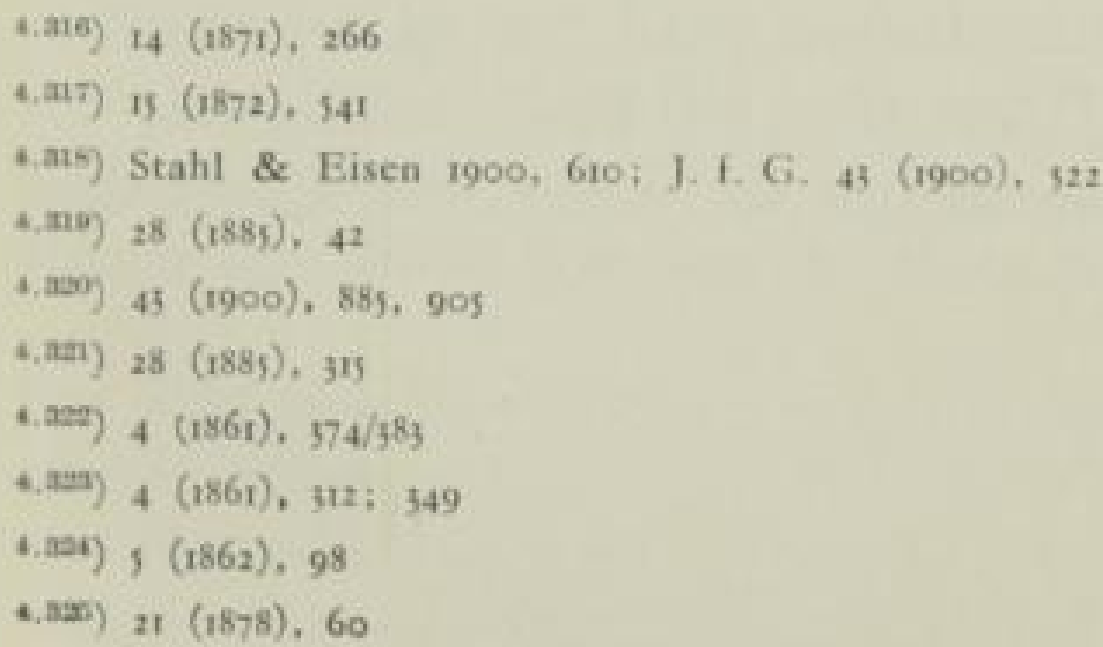


Bei der heute so groß̧en Bedeutung der Erdgasverteilung mögen auch noch die wenigen Berichte darüber aus dieser Zeit verzeichnet werden. 1877 wurde von groß̧en Mengen, die in Pennsylvanien bei der Ölsuche gefunden wurden, gesprochen. Die Ausnützung stecke aber noch in den Kinderschuhen $\left.{ }^{4.325}\right)$. Nach 7 Jahren aber mufte man bereits die grołartige Verwendung in Pittsburg und Umgebung feststellen: In der Eisenindustrie, zur Ruf̧fabrikation und mit vorzüglichen Ergebnissen wegen der Reinheit des Gases in der Glasfabrikation ${ }^{4.327}$ ). 1896 wurden $15,6 \mathrm{Mio}^{\mathrm{m}}$ in Amerika verbraucht ${ }^{4,32}$ ). Bald wurde sogar, teilweise durch Erschöpfung der Brunnen, teilweise aber auch wegen der stark gestiegenen Nachfrage, die Versorgung wieder knapp. Es muften Kürzungen vorgenommen und eiligst Ersatz mit ,gewöhnlichem Leuchtgas“ geschaffen werden. Im Jahre 1900 betrug der Wert der gewonnenen rund 4,2 Mio $\mathrm{m}^{3}$ Erdgas 99 Mio M. Das Gas wurde bis auf $2 \%$ in den Appalachischen und Lima-Indianafeldern gewonnen und durch rund $30000 \mathrm{~km}$ Leitungen verteilt. Die erste Rohrleitung von beträchtlicher Ausdehnung wurde r 882 mit $200 \mathrm{~mm}$ Durchmesser und $3 \mathrm{~km}$ Länge verlegt. Pittshurg erhielt nach Erschöpfung der Brunnen in der Nähe sein Gas aus Doddrige County aus mehr als $160 \mathrm{~km}$ Entfernung. Man zählte 10000 Rohrbrunnen mit Tiefen von 100 bis $1000 \mathrm{~m}^{3.39}$ ).

In kleinen Mengen wurde bei Brunnenbauten auch schon in den Niederlanden Erdgas gefunden und zur Beleuchtung benutzt ${ }^{4, \text { ano }}$ ).

\subsection{AUFBEREITUNG DES GASES \\ UND WERTSTOFFE}

\subsection{Teergewinnung und Verwertung}

Ein groß̧er Teil des Teeres wird in der Vorlage abgeschieden. Im Grundsatz war diese noch unverändert so, wie sie S. Cle g g angegeben hatte (vgl. S. 71,139). Die Tauchhöhe, die anfangs bis $100 \mathrm{~m} / \mathrm{m}$ betragen hatte, hatte man nach Einführung des Saugers herabgesetzt. Um trotzdem bei plötzlichem Stillstand des Saugers eine Sperre gegen das Gas bei einer geöffneten Retorte zu erhalten, machte man den Querschnitt des Vorlagengefäfjes vieifach größger als den der Rohre.

Grofe Sorge bereitete die Entstehung von Dickteer, die infolge der bei Tonretorten gesteigerten Temperatur eintrat. Die Vorschläge sie zu vermeiden, sind verwirrend, zumal die Ansichten über ihre Ursachen noch keineswegs geklärt waren. Bei Einführung der Gasbeheizung der Retorten mit ihrer dauernd hohen Temperatur stiegen die Schwierigkeiten. J. Th. Hasse, Berlin schlug 1880 die Verwendung von Schmiedeeisen für die Steigrohre vor, wobei der Querschnitt

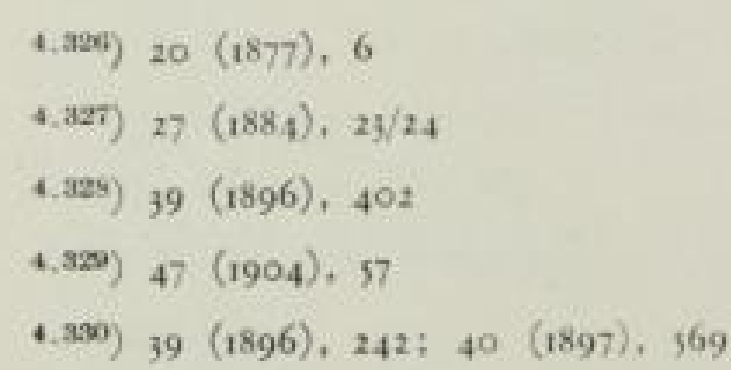


weit gehalten werden konnte $\left.{ }^{4,381}\right)$, dazu eine Isolierung der Steigrohre gegen die Wärmeeinstrahlung vom Ofen her. Die Vorlage versah er mit einer leicht zugänglichen Reinigungsöffnung (Bild 56). Andere ha!fen sich damit, die Steigrohre von aufyen mit Wasser zu berieseln. Das wurde zwar als Aushilfsmaf̧nahme gewertet, aber 1900 bei der Halberger Hütte wieder aufgegriffen, als auch bei den Koksöfen mit erhöhten Temperaturen Dickteer beobachtet wurde. An der Dehnungsmuffe sollte auch Wasser in das Rohr treten und verdampfen. Der Vorschlag begegnete Zweifeln über die Durchführbarkeit im Betriebe.

Bild 56

Vorlage nach Hasse (Muspratt, S, 433)

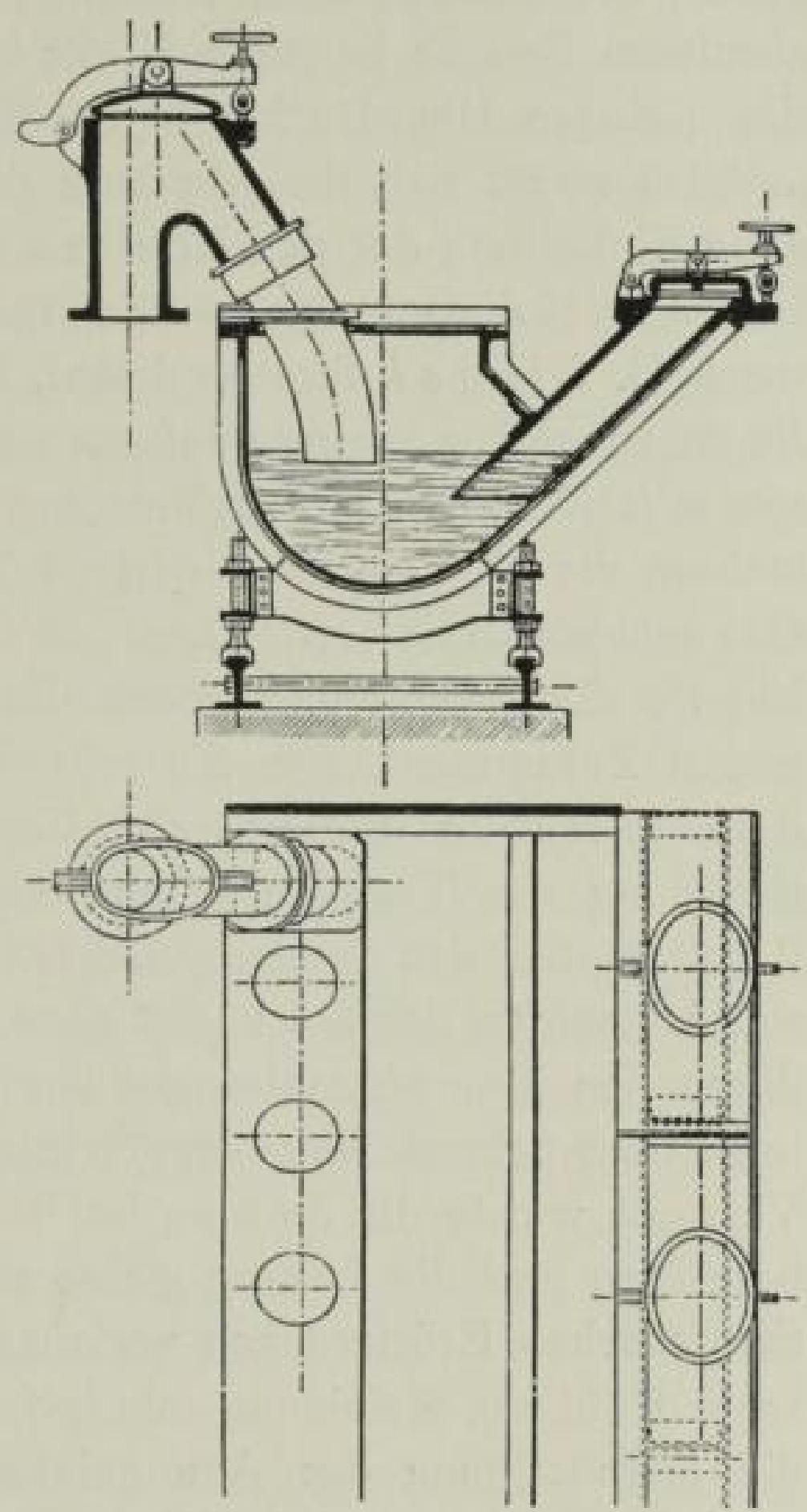

Mala $\mathrm{m}$ hatte schon 1874 in das isolierte Steigrohr von oben einen Wasserstrahl gerichtet ${ }^{4.32}$, als er die Retortenköpfe mit Koks und Steinen füllte, um die Teerdämpfe zu zersetzen, und einen sehr schweren Teer bewältigen muf̧te. Sehr viel Versuche wurden mit der Aufhebung der Tauchung während der Entgasungsarbeit angestelli. Damit wollte man auch dem Dickteer begegnen. Merkens, Insterburg stellte 1883 fest, dał er 430 Bauarten der Druckentlastung kennen gelernt habe, die aber alle von zweifelhaftem Werte seien $\left.{ }^{4.3 x 5}\right)$. Ein günstiges Urteil hatte sich dagegen F. $L u x$, Ludwigshafen gebildet, der dann auch die wichtigsten Einrichtungen ausführlich beschrieben hat ${ }^{4, x 4}$ ), darunter hatten die Vorschläge von A. Naumann viel Aufmerksamkeit gefunden. Et-

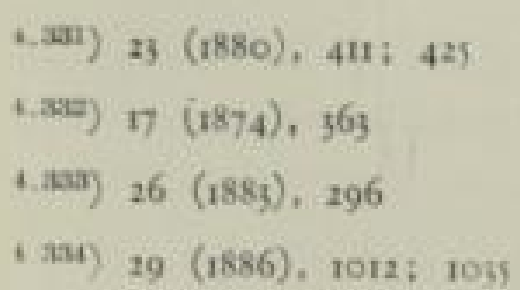


was sarkastisch fragte W. Oechelhäuser in der Aussprache, wie viele der Vorschläge ausgeführt seien, ob sie sich etwa nur beim Erfinder bewährt hätten und welche bereits wieder verworfen seien. L. Körting, Hannover berichtete dazu, daf3 er lediglich die Steigrohre sehr hoch gezogen habe und den Dickteer vermieden habe. Seine eigene Bauart habe er nicht auf die Dauer angewandt. E. Kunat $b$, Danzig empfahl bei guter Absaugung möglichst volle Retorten. Er lieł̧ also Gase und Dämpfe möglichst kurze Zeit im oberen freien Teil der Retorte. Bei vorübergehender Halblast solle man einzelne Retorten überstehen lassen, die anderen aber vollfüllen $\left.{ }^{4.315}\right)$. Unter Abwägung der Veränderung der absoluten Drücke leugnete E. Scbilling. München den schädlichen Einfluf̧ des geringen Uberdruckes in der Retorte auf den Entgasungsvorgang $\left.{ }^{4 a n a}\right)$. Allmählich setzte sich die Meinung durch, dał man den Dickteer nur durch genaue Einhaltung der den Kohlen angemessenen Temperaturen vermeiden könne. Englische Kohlen verlangten geringere Temperaturen als Ruhrkohlen. Das unterstrich G. Li e g el, Stralsund 1899, indem er seine jahrelangen Bemühungen und die daraus sich ergebende äuß̧erst vorsichtige Betriebsweise mit einer Ausbeute von $300 \mathrm{~m}^{3} / \mathrm{t}$ Kohle in einem Vortrage schilderte ${ }^{4.377}$ ). Auch W. Foulis, Glasgow mahnte die Kohlen bei niedrigen Temperaturen zu entgasen und das erzeugte Gas nachher zu fixieren ${ }^{4.353}$ ).

Mit der Teergewinnung stehen die Beschwerden der Naphthalinverstopfung in engem Zusammenhange. Sie mögen deshalb hier eingeschaltet sein. Die ersten Berichte tauchten um 1862 auf. Vermutlich bestand ein Zusammenhang mit der Erhöhung der Temperatur und Gasausbeute bei Aufnahme der keramischen Retorten und des Saugerbetriebes. N. H. Sc billing bekannte, dał das $\mathrm{Zu}^{-}$ standekommen der Störungen ganz ungeklärt sei $\left.{ }^{i, 3 a x}\right)$. Erhöhte Störungen wurden durch den Dampfstrahlsauger hervorgerufen. Man hielt es nun für notwendig nach dem Schwefelwasserstoffreiniger noch einen zweiten Kühler zu setzen ${ }^{\text {4.ม9 }}$ ). Versucht wurde die Störung im Werke mit kochendem Wasser oder Dampf zu beseitigen und die Lösung gleich aus den Wassertöpfen auszupumpen $\left.{ }^{4.31}\right)$. Nach theoretischen Erörterungen verlangte F. T ieftrunck, Berlin vor allem langsame Kühlung, Reinigung mindestens im letzten Kasten mit frischer Masse und die Herabsetzung des Ammoniakgehaltes ${ }^{4.3 i}$ ). In diesen Erörterungen tauchte zum ersten Male der Begriff der Dissoziation und des chemischen Gleichgewichtes bei einem Gaswerkchemiker auf ${ }^{4.33}$ ). Damals verbreitete sich die Auffassung, dał Ammoniak das Naphthalin löse $\left.{ }^{4,3 u}\right)$. (Friedleben), was Tieftrunck zu

\footnotetext{
1.345) 28 (1885), 910

4.356) 34 (1891), 452

4.337) 42 (1899), 521

4.398) $40(1897), 3$

4.239) 7 (1864), 292/95

4.340) 18 (1875), so

4.81) 18 (1875), 8 ;

4.342) 20 (1877). 509

4.33) Das Massenwirkungsgesetz war 1867 von Guldberg und Waage aufgestellt. Die theoretischen Grundlagen der chemischen Kinetik sind erst von J. H. van't Hoff 1884 entwickelt und die physikalische Chemie von W. Ostwald 1887 als Lehrgebiet in Leipzig aufgenommen

232 
der Äuß̧erung veranlaf̧te: „Ammoniakentfernung ist gleich Naphthalinentfernung ${ }^{\text {(4..3ss }}$ ). Richtig war indessen die betriebliche Beobachtung, daf̧ die Kühlung mit der Naphthalinentfernung im Zusammenhang stand. W. Young verlangte, daf̧ die schweren dampfförmigen Kohlenwasserstoffe warm $\left(80^{\circ} \mathrm{C}\right)$ abgeschieden werden sollten und danach eine ganz langsame Kühlung stattfinde $\left.{ }^{4.34}\right)$. Zur Beseitigung des Naphthalins wurde die Einspritzung von Kohlennaphtha, später Petroleum-Benzin bzw. Gasolin empfohlen. So wurde von J. Fleiscber, Frankfurt/M. ein Naphthalinwäscher bestehend aus einem Schacht, der mit Schlackenwolle oder Koks gefüllt und mit Petroleumnaphtha berieselt wurde, gebaut $\left.^{t, u a}\right)$. 1892 nahm H. B unte Stellung: Die Entstehung von Naphthalin sei bei hoher Temperatur stärker. Das Naphthalin gehe in Lösung, wenn gleichzeitig mit dem Naphthalin bei fortschreitender Abkühlung ein flüssiges Kondensationsprodukt niedergeschlagen würde. Das seien die Zwischenglieder zwischen Benzol und Naphthalin: Toluol, Xylol, Cumol usw. und die sauerstoffhaltigen Abkömmlinge: Phenol, Kresol usw. Diese seien nur in den ersten Stunden der Entgasung reichlich da. Daher sei die Verlängerung der Ausstehzeit im Frühjahr und Herbst schädlich. Als Gegenmittel empfahl er einen regelmäßjigen Turnus in der Füllung der Retorten und weiterhin ausreichende Kühlung.

E. u. C. F. Botle y versuchten 1897 das Naphthalin durch Einnebelung von Petroleum mit Streudüsen zu bekämpfen. Das Petroleum schied sich nunmehr aber an den Brennerdruckreglern $\mathrm{ab}^{4.3{ }^{4.7}}$ ).

J. B и e b, Dessau, führte in einen Skrubber (vgl. S. 140,238) Steinkohlenteeröl mit 3\% Benzol ein, machte aber danach die Entdeckung, dał dieses Verfahren in England an Young patentiert war. So kam er darauf, im Standardwäscher unmittelbar nach dem Teerscheider in der ersten Abteilung gesättigtes Teeröl zu verwenden $\left.{ }^{4.35}\right)$. P. Eitner, Karlsruhe untersuchte die möglichen Einspritzmittel nach ihrer Tension und Lösungsfähigkeit für Naphthalin. Er fand das Xylol als am besten passend ${ }^{t, 310}$ ).

Im Vorstehenden sind Teerscheider und Standardwäscher erwähnt, die erst im folgenden näher erklärt werden. Es erschien aber besser, auf diese Weise eine geschlossene Darstellung zu geben.

Zunächst aber möge die Teergewinnung weiter verfolgt werden. Über den Zweck und Stand der Kühltechnik im Jahre 1860 wurde unter $3.23 \mathrm{I}$ berichtet. $\mathrm{Da}$ sie im übrigen vorzugsweise der Ammoniakausscheidung diente und der Teer in den koksgefüllten Skrubbern eher lästig als willkommen war, so möge nur kurz erwähnt werden, dał eine völlige Befreiung des Gases von den Teernebeln in diesen Geräten trotz der langen Verweilzeiten des Gases nicht erreicht wurde.

D. Colla do $n^{4.850}$ ) hatte zuerst den Gedanken, die feinen Teerbläschen durch Verteilung des Gases in feine Ströme und den Anprall gegen feste Flächen zu

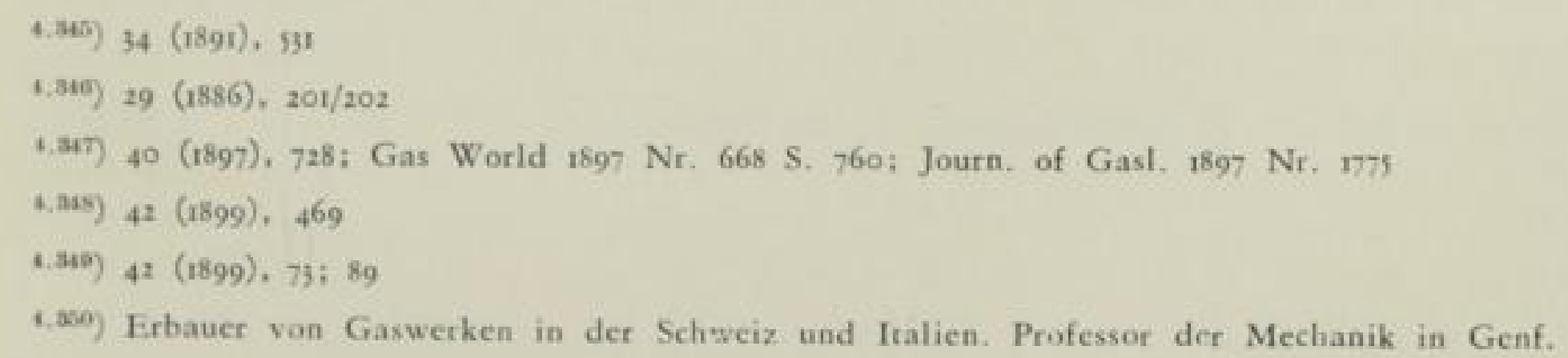


gröł̧eren Tropfen zu vereinigen und dann abzuscheiden $\left.{ }^{4.35}\right)$. E. Pelo uze, Administrator der Compagnie Parisienne und P. A uduin entwickelten daraufhin ihren Teerscheider so, wie er noch heute in Gaswerken verwandt wird, so daf3 auf eine genaue Beschreibung wohl verzichtet werden darf (Bild 57). Er wurde in Wien auf der Hauptversammlung des Vereins ausgestellt. „Wenn die Wirkung ... sich bestätigt ... so wäre die Ausdehnung. welche die Skrubber in unseren Fabriken künftig einzunehmen haben, auf ein fast lächerlich kleines Maf̧ beschränkt $\left.{ }^{4.2 a z}\right)^{\text {". }}$. Ganz aber wurde diese Hoffnung nicht erfüllt, weil mit dem „Pelouze“ die erwartete Ammoniakwasserabscheidung nur zu 30 bis $40 \%$ gelang $\left.{ }^{4.353}\right)$. Immerhin war die Teerentfernung in einem kleinen Apparat in befriedigender Weise gelungen.

C. Reutter als Direktor des Gaswerkes Mainz im Platze sehr beengt, baute auch den Kühler mit waagerecht wasserdurchflossenen Rohren auf kleiner Grundfläche auf. Das bewährte sich sofort in Mainz und Kassel (I895). Damit aber Teer und Naphthalin langsam ausgeschieden würden, wurde ein Luftkühler vorgeschaltet. Damit blieb tatsächlich der Teer flüssiger und die anfänglichen Störungen fielen fort $\left.{ }^{4,34}\right)$. Der Bamagkühler, bei dem zwar in der Hauptrichtung Gegenstrom von Wasser und Gas gewahrt blieb, aber in den einzelnen Stufen Gleichstrom eingeschaltet war, (D. R. P. I04 639 v. $4.8 .9^{8}$ ) vermied bereits auf diese Weise festen Teer ${ }^{4.355}$ ).

Bei den Nebenerzeugnissen der Gaswerke zeigt sich noch deutlicher als bei den Hauptrohstoffen, wie in der zweiten Hälfte des Jahrhunderts die Aufwärtsentwicklung in Sprüngen vor sich gegangen ist. Neue Erfindungen wurden mit grołen Hoffnungen aufgegriffen, mit lautem Lärm angepriesen und spekulativ eine Sonderkonjunktur erzeugt, dann wurde mit gleichem Überschwang nach der Baisse gedrückt. Dem Ruhe verlangenden Ingenieur blieb die Aufgabe sich technisch schnell anzupassen, und zwar möglichst so, daf ein nicht allzu grof̧er Aufwand an Kapital notwendig wurde und die Rente des Betriebes möglichst gleichmäfig gewahrt werden konnte. Dem Gasfach ist das, wie W. Oecbelbä us er mehrfach betont hat, im grofen und ganzen besser gelungen als andern Industrien. Insolvenzen sind kaum zu verzeichnen gewesen, wo die technische Führung aufmerksam war.

Noch 1859 ,vergrößjerten sich täglich die Teervorräte infolge der Geschäftsstokkung ${ }^{\text {(4.3.so }}$ ), obwohl Perkin die Entdeckung der Ànilinfarben ausgewertet hatte. Aber ein Jahr darauf stürzte sich eine grof̧e Zahl von Chemikern auf die rein empirische Suche nach neuen Farbstoffen ${ }^{1.35 \pi}$ ), wobei man um den Preis, die schönste Farbe gefunden zu haben, haderte.

Der Londoner Drogenbericht vom Dezember 1857 betonte, daf, sich infolge dieser neuen Entwicklung ein auß̧ergewöhnlicher Begehr nach Anilin eingestellt habe.

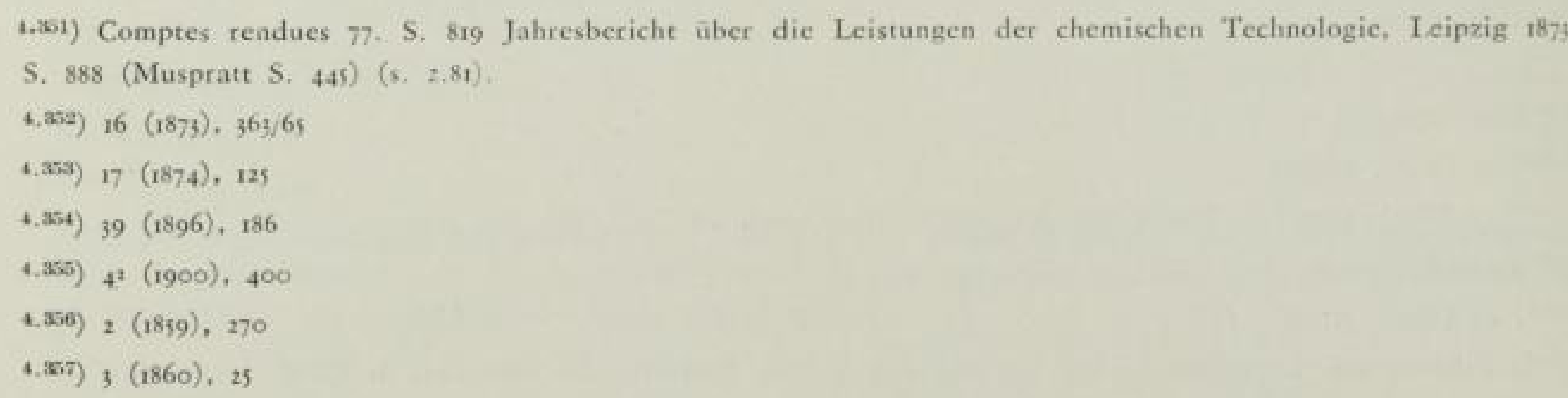

\section{SLUB}


Bild 57

Teerscheider von Pelouze

und Audiun

(Muspratt, S. 444).

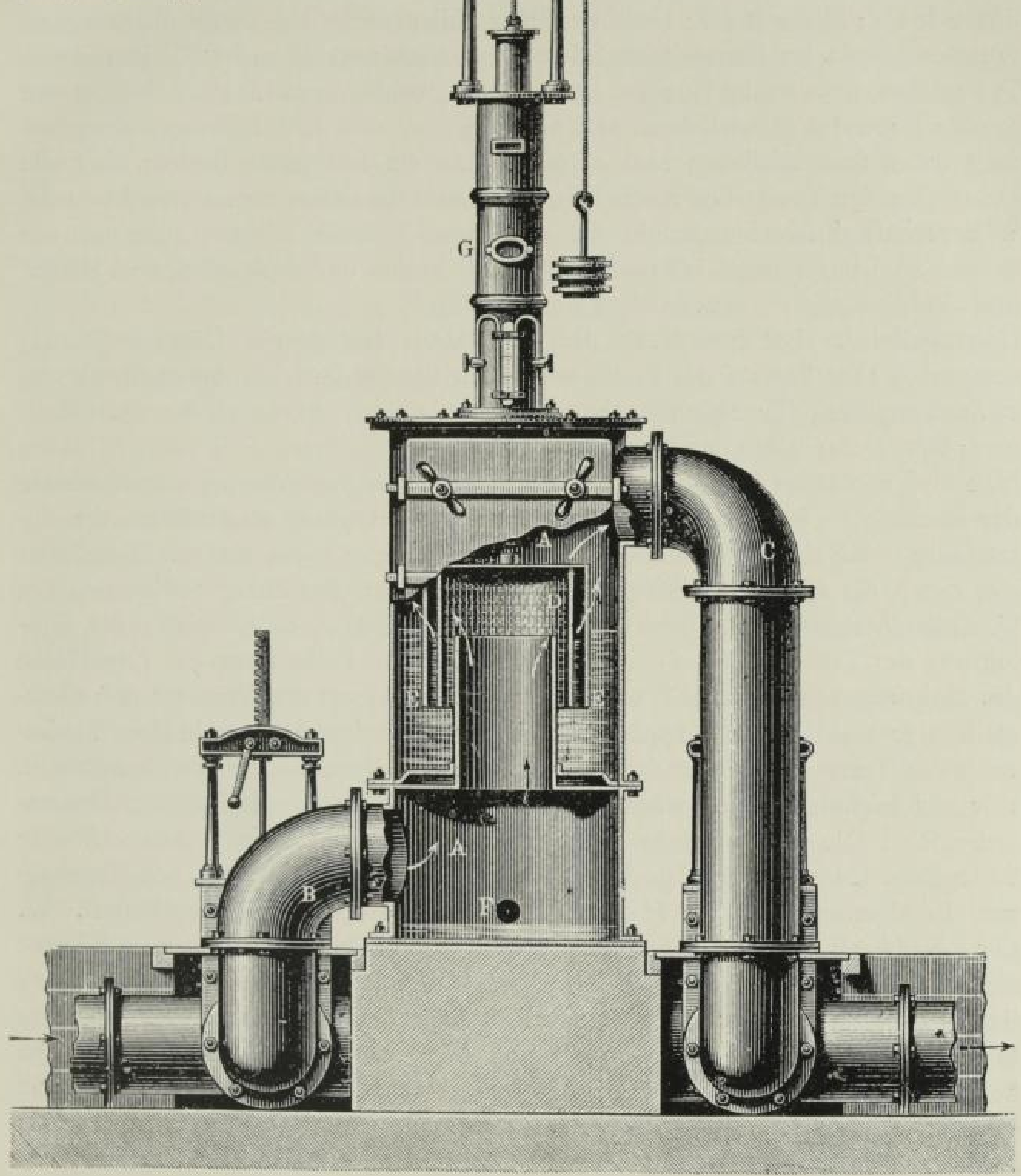

Der Preis war in kurzer Zeit von 10 auf 12 und dann gar auf 2I Sh. gestiegen. „Er ist in der Tat nur nominell und ist kein Anilin zu haben”. Die Fabrikation sei allerdings frei, aber der Gasteer sämtlich aufgekauft.

1860 erschienen die englischen Patente von Perkin, R. A. Brooman, J. T. Beale und Th. Kirkbam; R. D. Kay $\left.y^{4.35}\right)$, von D. Price u. C. H. Willi a $\left.m s^{4.350}\right)$. Über die Anilinfarbstoffe berichteten H. Kopp u. H. W ill $l^{t .300}$ )

\footnotetext{
4. a5s) $3(1860), 83$

4.xiक) ; $(1860), 136$

4.3007) $4(1861), 389: 411$
} 
und als bester Kenner A. W. Hof $\left.m \geq n n^{4,301}\right)$. Ob Teervergasung ${ }^{4.309}$ ) oder Verfeuerung ${ }^{4.983}$ ) noch wirtschaftlich seinen, wurde erörtert $\left.{ }^{4.904}\right)$. Namen, die heute noch bekannt sind, tauchten als Farbenerzeuger auf: Badische Anilin- u. Sodafabrik, I860 Mannheim, später Ludwigshafen; Meister, Lucius \& Co.; Weiler \& Co.; Bayer \& Co.; Kalle \& Co.; Dollfuss. Steinkohlenteer als Heilmittel für brandige Wunden wurde im französischen Heer (Italienfeldzug) versucht ${ }^{4.055}$ ). Die ersten Teerstraf̧en wurden in England gebaut ${ }^{t .36}$ ), wobei grundsätzlich bereits die heutige Bauweise entwickelt wurde, nur dał man auch Koksklein zwischen dem Split dabei unterzubringen suchte. 1883 wurde ein fesselnder Bericht über die Geschichte der Teerfarben geschrieben ${ }^{4.377}$ ). „,Mit ihr drang zum ersten Male die Wissenschaft durchschlagend in die empirische Technik mit gut ausgestatteten industriellen Forschungslaboratorien ein. Bad. Anilin- und Sodafabrik und Höchst sind Etablissements von gewaltiger Ausdehnung."

Ganz plötzlich aber brach 1885 die Konjunktur infolge der Überentwicklung zusammen. Der Verlauf der Preise wurde mit Schaudern wie folgt in M/rooo kg zusammengestellt $\left.{ }^{4.305}\right): \quad 1869 / 70 \quad 23,20 ; 73 / 74 \quad 29,03 ; 74 / 75 \quad 40,26 ; 77 / 78 \quad 22,88 ; 80 / 81$ 35,$29 ; 82 / 83 \quad 47,44 ; 83 / 8454,37 ; 8$; 12,00 .

Nun hief̧ es wieder für die Gaswerke den überflüssigen Teer als Unterfeuerung der Retorten zu beseitigen. Die alten Einrichtungen waren aber nicht mehr einsatzfähig, weil sie der Koksrostfeuerung angepałt gewesen waren. Diese aber war durch die Generatorgasfeuerung ersetzt worden. Brauchbar erwies sich der Dampfstrahlzerstäuberbrenner von Gebr. Körting, Hannover, ebenso die Einführung des Teeres in den Generator in etwa $40 \mathrm{~cm}$ Höhe unter der Oberfläche des Koksbettes mit Dampf ${ }^{4-350}$ ). Die Hauptversammlung des Vereines gab Gelegenheit zu eingehender Aussprache. L. Körting berichtete, wie der Wettbewerb des Teeres gegenüber der Rostfeuerung mit ihren hohen Luftüberschüssen sehr viel leichter gewesen wäre, als bei dem nunmehr genau geführten Generatorbetriebe. Die Regelmäßjigkeit des Teerzuflusses war jetzt von entscheidender Bedeutung. Dazu gab es viele Behelfsmittel, vor allem Teerdüsen mit eingebautem Reinigungsstößel. W. Hor $n$ hatte seine Tropfapparate verbessert. W. Oechelbäuser verbrannte den Teer aufjerhalb des Generators und führte die Abgase zur Reduktion des Kohlendioxyds durch den Generator. G. L i e g el lief̧ den Teer aus grołer Höhe auf das Koksbett träufeln ${ }^{\text {t.x }}$ ). Im folgenden Jahre konnte man feststellen, daf̧ alle die so schnell entwickelten Teerbrenner sich bewährt hatten $\left.{ }^{4.371}\right)$. Gegen Ende des Jahres war die Krise überwunden. Die Teerpreise hatten angezogen, wenn sie auch keineswegs den Spitzen von $188_{3} / 84$

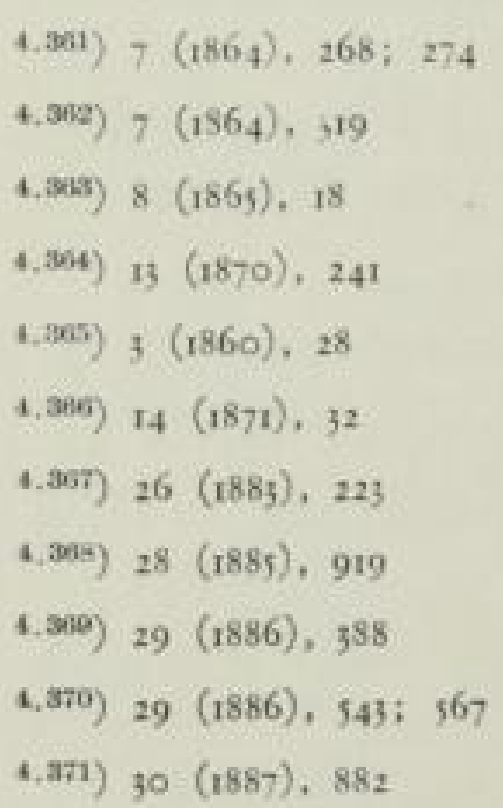


mehr entsprachen. Immerhin war Teer mit besserem Nutzen verkauft als verfeuert. Aber nun kam auch Teer von den Zechen, die auf die Gewinnung der Wertstoffe sich einrichteten. Trotzdem hielt sich die Preisechöhung $\left.{ }^{4.22}\right)$.

Den ersten Anstof, dazu hatte die Erfindung C. Fablbergs, Saccharin aus Teer zu gewinnen, gegeben $\left.{ }^{4.37 z}\right)$. Sie wurde mit dem damals üblichen frohen Hoffnungen bekannt gegeben. Wollte Fahlberg doch den Rübenzucker durch Stärkezucker aus Getreide mit Saccharin-Zusatz ersetzen. In grofen Mengen wurde dann auch Teerpech verbraucht, um aus Feinkohle Briketts zu fertigen ${ }^{4.374}$ ). In Deutschland mit der aufblühenden chemischen Industrie wurde im Gegensatz zu England Teer nur noch in bescheidenem Małe verbrannt. Besonders Benzol, das ja damals nur aus dem Teer gewonnen werden konnte, da es im Leuchtgas verbleiben mußte, war sehr begehrt $\left.{ }^{4 . a 55}\right)$. Aber nun begannen die Zechen auch das Benzol aus dem Gase auszuwaschen, die Teerkonjunktur versackte wieder gegen Ende des Jahres 1891, Benzol verlor die Hälfte seines Wertes ${ }^{4.376}$ ). 1894 wurde festgestellt, daß̧ trotz des Bedarfes der chemischen Fabriken eine Übererzeugung von Teer dauernd vorhanden sei. Denn die Ausbildung der Feuerungen für Staubkohle liefs die Brikettierung verringern ${ }^{4.37}$ ). Die Eisenbahnen, die $1883,57 \%$ der Kohle als Brikett bezogen hatten, brauchten 1890 nur noch $32 \%$. Wie die Schwankungen im Benzolpreise sich fortsetzten, ist bereits unter dem Gesichtspunkte der kalten Karburierung besprochen. Aber der Teer blieb unter dem Druck der Kokereien $\left.{ }^{4.375}\right)$. Auch daf3 1893 W. He mpel noch einmal für die Vergasung von Teer eintrat (im Augenblick der beendeten Konjunktur), ist bereits geschildert.

Zusammenfassend kann man sagen, dał gerade der Teerabsatz den heftigsten und schnellsten Schwankungen unterworfen war. Die Gaswerke haben sich mit grołer Wendigkeit der jeweiligen Lage angepaß̧t und so mit ihren technischen Mitteln dazu beigetragen, die wilden Erscheinungen der Spekulation abzuschwächen.

\subsection{Ammoniakgewinnung und-verwertung}

Der Gasfachmann heute, der durch den Wettbewerb der Stickstoffsynthese kaum mehr in der Lage ist, wirtschaftlich sein Ammoniakwasser zu verwerten, ist leicht geneigt, die alten Zeiten als "goldene“ zu betrachten. Aber das war durchaus nicht der Fall, denn auch schon damals gab es vielfache Einflüsse, die Sorgen und Umstellungen erzwangen.

Am ruligsten scheinen noch die ersten Is Jahre des hier betrachteten Zeitabschnittes gewesen zu sein. Vorwiegend wurden noch die langen fast ganz mit Wasser gefüllten Kästen benutzt, in deren unterem Teile ein Siebboden zur Verteilung des darunter aus durchlöcherten Rohren austretenden Gases angebracht war. Selbst wenn zwei dieser Kästen nacheinander geschaltet waren, er-

4.aT2) Jahresbericht der Thür. Gasges. 3r (1888), 308

4.379) 29 (เ886), 86!

4.57\%; 32 (1889), 113

4.375) 34 ( $(1891), 185$

4.376) $35(1892), 265$

(.3im) $37(1894), 308$

4.an5) $40(1897), 407$ 
reichte man nur eine geringe Anreicherung des Wassers an Ammoniak. Am störendsten war der grołe Widerstand im Gastrom ${ }^{\text {*a: }}$ ). Auch die Wäscher von Fleiscbbauer mit senkrechten Stofylatten, die zur Teerabscheidung geeignet waren, wurden zur Ammoniakauswaschung benutzt ${ }^{t .350}$ ), ebenso Chevalets Wascher mit einem Siebboden mit Löchern von I bis $3 \mathrm{~mm}$ Durchmesser, durch die das Gas von unten gegen das herabtropfende Wasser geführt wurde, wie $\left.\operatorname{sie}^{4.2 \times 1}\right) \mathrm{S}$. Elster weiterentwickelt hatte.

Um die hohen Druckverluste im Gasstrom zu vermeiden, wurden die Skrubber erbaut. Es war aber eine Kunst, das Wasser gleichmäfyig in feinen Strahlen oder Gerinnen über den ganzen Querschnitt zu verteilen. Das hat zu mannigfaltigen Bauarten geführt, die unmöglich alle beschrieben werden können. Die Skrubber waren grołe Apparate, die entsprechend teuer waren. 186r äuferte sich W. Oechelbäuser, daf Skrubber in Deutschland nicht genug ausgenützt würden $\left.^{4.555}\right)$. Die grołgen stehenden Kessel von $6 \mathrm{~m}$ Durchmesser und $9 \mathrm{~m}$ Höhe ${ }^{+.255}$ ) waren mit Füllkörpern, zunächst Koks ${ }^{4.351}$ ), dann mit Drainageröhren (Zylinder) angefüllt worden. A. K $\iota \ddot{o} n n e$ hatte den Skrubber mit grobem Kies gefülltt ${ }^{t .35}$ ), nachdem er genau die Wirksamkeit von Kühler und Skrubber untersucht hatte $\left.{ }^{t+1 \times x}\right)$. Als gut wirksam wurde der Wäscher von $K i n g$, London begrüfyt, der lediglich durchlochte Böden in $60 \mathrm{~cm}$ Abstand, aher mit viel weiteren Löchern als sie Chevalet verwendet hatte, nämlich konisch mit Durchmesser von $25 \mathrm{~mm}$ oben auf $12 \mathrm{~mm}$ Durchmesser unten eingesetzt hatte $\left.{ }^{4.357}\right)$. Es handelte sich also um einen Berieselungsskrubber, der auch die Teerabscheidung verbesserte. Als die Streudüse erfunden war, glaubte man mit ihrer Vernebelung des Wassers ohne jede Einlage auskommen zu können $\left.{ }^{4.355}\right)$. Gebr. Körting, Hannover entwickelten auch ihren Dampfstrahlexhauster zum Skrubber weiter, indem ein Kasten mit Sägespänen, also die ganz alte Einrichtung, nachgeschaltet und zum Schluf\} noch ein Nachkühler angebracht wurde $\left.{ }^{t .389}\right)$.

Der Kolonnenwascher von A. $K l \ddot{o} n n e$ nach dem Vorbild der Rektifizierböden gebaut, war eine Rückkehr zum Prinzipe Gas durch das W/asser zu leiten ${ }^{t .300}$ ) (Bild 58). Zscbocke, Kaiserslautern, baute 1892 einen Hordenwascher mit grofen Flächen ${ }^{\text {t.5n }}$ ) aus Holz. Der Plattenwascher der Bamag (Bild 59) aus Stahtblechen arbeitete nach dem gleichen Gedanken $\left.{ }^{4.309}\right)$. Beide Bauarten wurden lange Zeit angewandt.

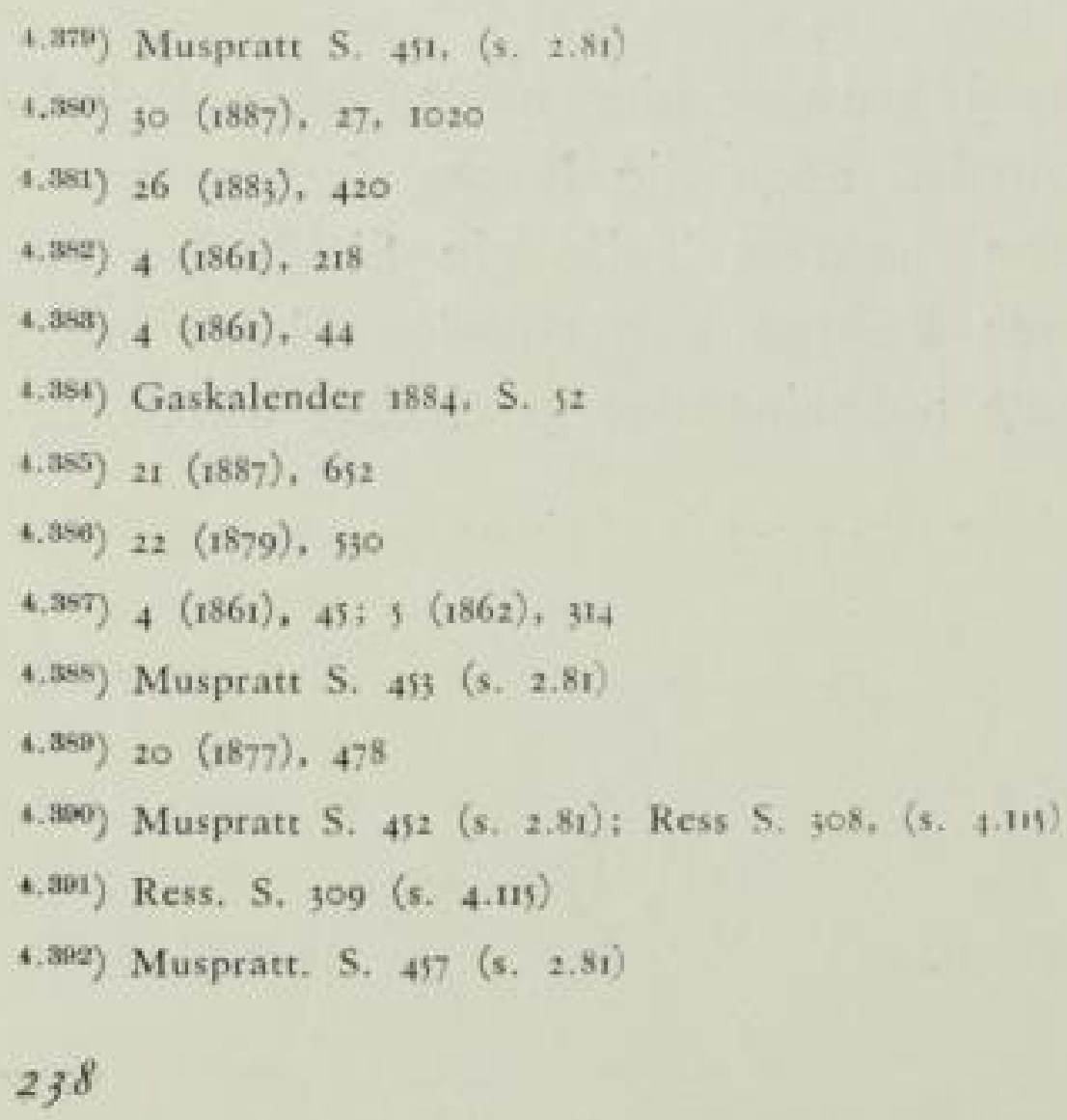




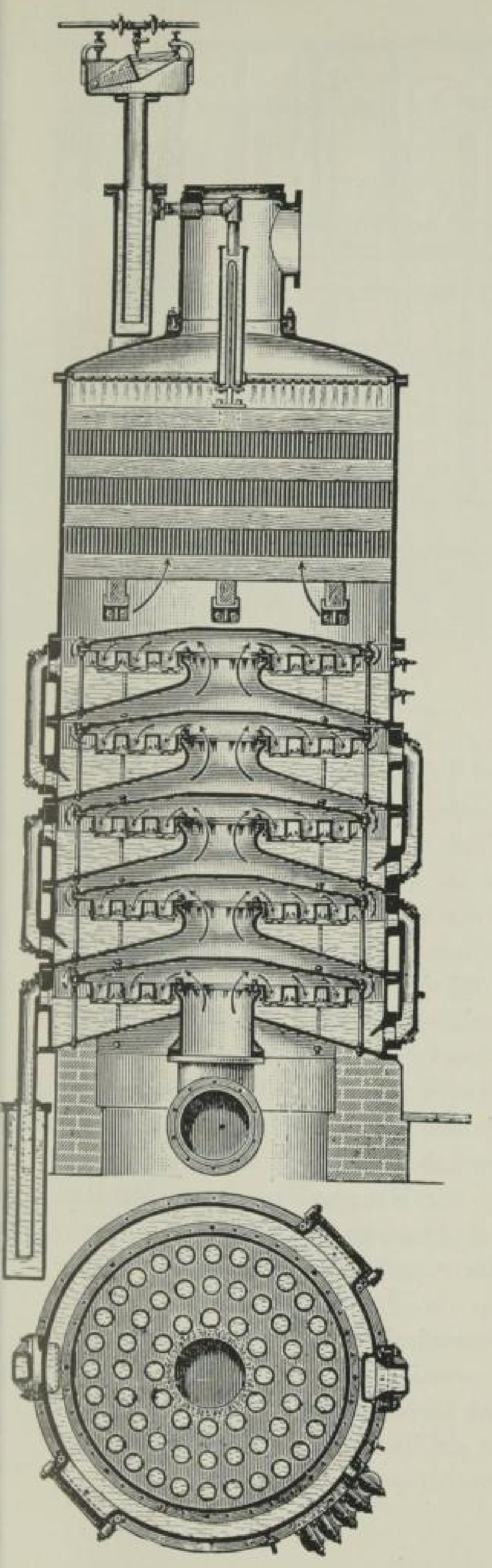

Bild 58

Wascher von Klönne (Muspratt, S. 452)
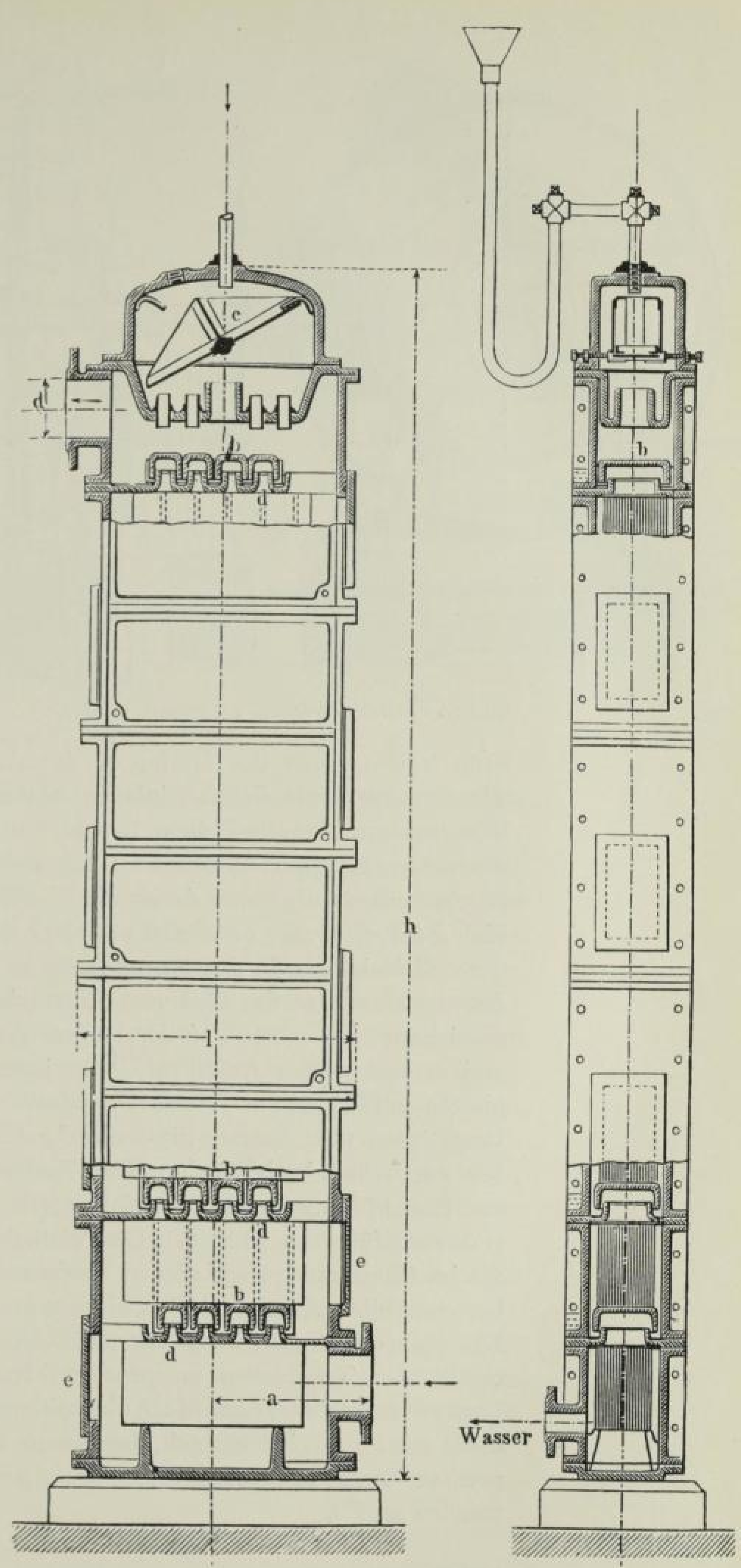

Bild 59

Plattenwascher der Bamag

(Muspratt, S. 457) 

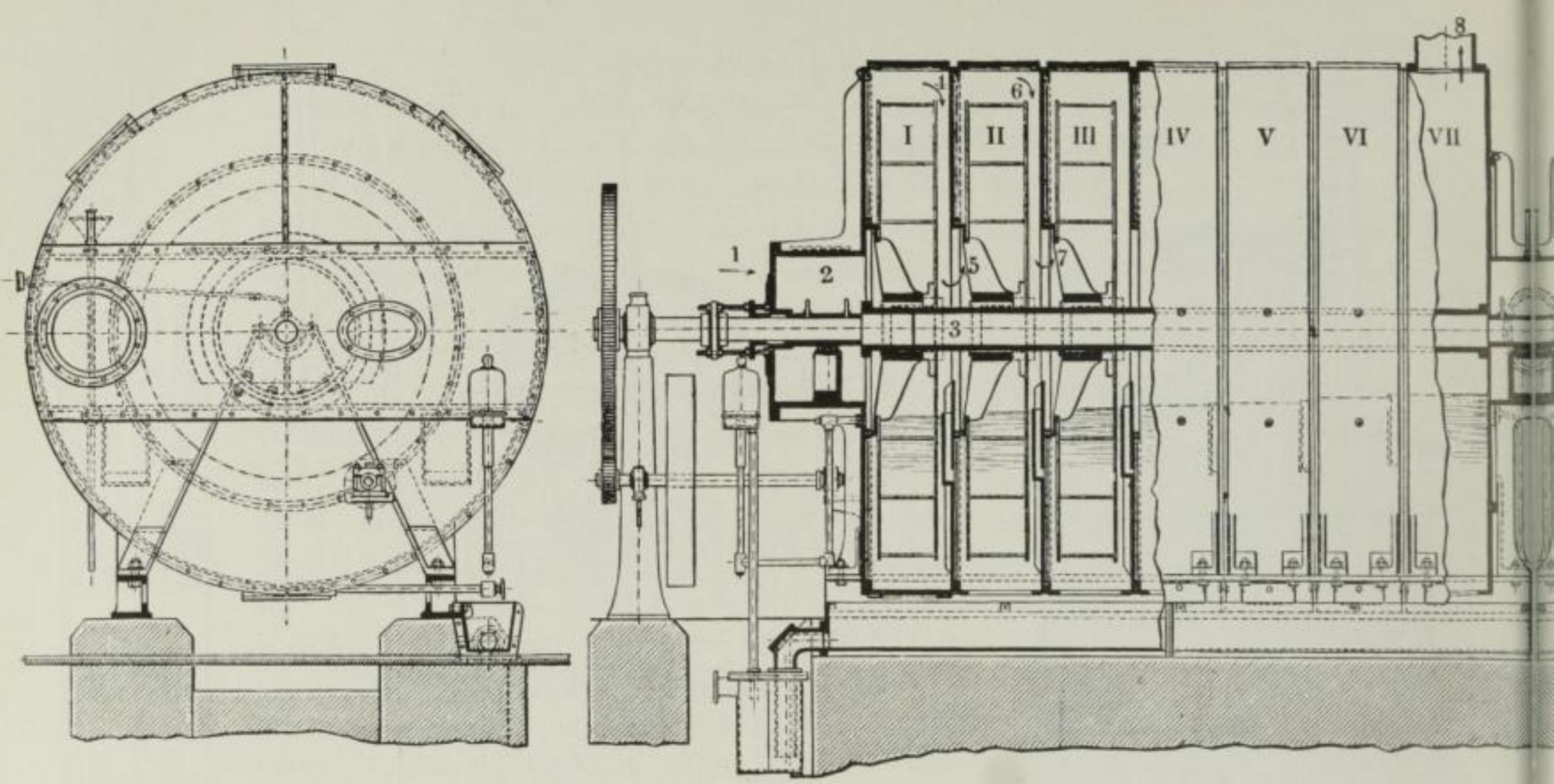

Bild 60 Standardwascher (Muspratt, S. 459/60)

Eine Verringerung des Umfanges der Anlagen erstrebten und erreichten die Wascher mit beweglichen Einlagen. Colladon ${ }^{4.309}$ ) benutzte einen oscillierenden Waschapparat, Paddon einen langen horizontalen Kasten, der zur Hälfte mit Wasser gefüllt war. Auf eine lange sich drehende Welle waren durchlochte Blechscheiben aufgesetzt, durch die oberhalb des Wassers das Gas durchstrich. Kirkbam. Hulett u. Cbandler verbesserten 1876 diesen Wascher ganz wesentlich, indem sie den langen Trog in 7 Kammern unterteilten (Bild 60), in denen stufenweise das Gas vom Ammoniak befreit wurde und das Wasser sich anreicherte. Er wurde auf der Pariser Ausstellung von 1878 im Modell gezeigt und erregte grof̧es Aufsehen $\left.{ }^{4.29}\right)$. In jeder Kammer waren to kreisrunde Bleiplatten untergebracht. Dieser „Standard“-Wascher fand schnell große Verbreitung. Schon 1880 ersetzte die Deutsche Continental-Gas-Gesellschaft alle Skrubber durch Standard-Wäscher. Der Zschockewascher von 1898 als Drehtrommel mit Kugelfuillung wurde in Zeichnungen auf der Hauptversammlung des Vereins vorgeführt ${ }^{\text {t.sm }}$ ) (Bild 6r). Die Vielheit der Apparateformen und noch mehr die im Grundsatz verschiedenen Verfahren der Auswaschung, die nebeneinander bestehen blieben, zeigt, dał es nicht gelungen war, dem Ideal nahe zu kommen. Die Konzentrationen im Wasser, die dem theoretischen Gleichgewicht bei einer bestimmten Temperatur entsprochen hätten, wurden nicht annähernd erreicht. Das verteuerte natürlich die Aufarbeitung des Gaswassers. Damit, dał das Gas noch 5 bis ro $\mathrm{gr} / \mathrm{m}^{3}$ enthielt, fand man sich $\mathrm{ab}$, in der Überzeugung, daf̧ ein gewisser Ammoniakgehalt der nachfolgenden Schwefelwasserstoffreinigung zuträglich sei $\left.{ }^{4,300}\right)$.

\footnotetext{
4.303) Muspratt. S. 458 (s. 2.81)

4.394) $21(1878), 532$

4.305) $4 \mathrm{I}(1898),{ }_{4}^{62}$

6.395) Muspratt. S. 463 (s. 2.81) 
gasgenerator geführt $\left.{ }^{t .405}\right)$, der um die Jahrhundertwende vollendet war. $\left.{ }^{4.401}\right)$. Er schickte sehr viel Wasserdampf durch den Generator. Bei seinen Arbeiten mit $\mathrm{K}$. Langer, Gase von Kohlenmonoxyd und Kohlenwasserstoffen unter Gewinnung von Wasserstoff zu befreien, griff er zu Nickel und Kobalt als Katalysatoren. Er verwandte Stücke, aber auch Massen (Bimsstein) mit Nickel imprägniert und überzogen $\left.{ }^{4 \cdot(105}\right)$. Dieses dürfte wohl die erste Anwendung von Katalysatoren in der Gastechnik gewesen sein. Auch W. Foulis empfahl I897 reichlich Dampf durch den fertigen Koks zu blasen, um den Stickstoff als Ammoniak zu gewinnen $\left.{ }^{4.406}\right)$.

Die Entwicklung der Aufbereitungsverfahren des Ammoniakwassers ist so stark von der schwankenden Marktfähigkeit der verschiedenen Ammoniaksalze abhängig, dał sie am besten mit dieser gleichzeitig abgehandelt wird. Wenn auch schon sehr frühzeitig die beiden Haupterzeugnisse (Ammonsulfat und Salmiak) bekannt waren, so scheint doch lange Zeit die Salmiakerzeugung den gröfzeren Umfang gehabt zu haben. Erst um I875 wurde spürbar, daf3 die Nachfrage von Ammonsulfat für die Landwirtschaft stieg und die Salmiakerzeugung zurückging $\left.^{4.40^{\circ}}\right)$. Dresden baute zwar eine Sulfatfabrik auf Werkskosten, verpachtete aber den Betrieb $\left.{ }^{t .405}\right)$. G. Th. Gerlacb schlug vor, die Sodafabrikation in Gaswerken aufzunehmen, stieł̧ aber auf Bedenken wegen der unverhältnismäßjig starken Aufsicht, die ein solcher Teilbetrieb erfordern würde $\left.{ }^{4.400}\right)$. Vielmehr wurde den kleinen Werken der unmittelbare Absatz des Ammoniakwassers zu Düngezwekken angelegentlich empfohlen.

Ganz neuartig war die trockene Reinigung des Ammoniaiss mit Superphosphat von Bolton und Wanklyn, die bei der South Metropolitan Gas Company in London aufgenommen wurde $\left.{ }^{t \cdot 10}\right)$. H. Bunte äußserte sich nach eingehenden Untersuchungen recht günstig über das Verfahren, weil der Umweg über das Wasser vermieden würde $\left.{ }^{t . t 11}\right)$. Die Kosten der Austragung hatte er aber nicht in die Rechnung eingestellt. In München wurde eine Anlage gebaut. Die Absorption war nur im Anfang einigermałen befriedigend, mit zunehmender Sättigung lief3 sie nach. Der Schwefelwasserstoffreiniger wurde mehr als sonst belastet. Nach einigen Jahren wurde das Verfahren aufgegeben ${ }^{4.12}$ ). Der Vorschlag von Heinke, Petersburg, die trockene Reinigung mit Schwefelsäure in Infusorienerde zu erreichen, traf auf lebhafte Ablehnung $\left.K l o ̈ n n e s^{t+113}\right)$. Inzwischen war der Preis für Stickstoffdünger stark gefallen. Die Ursache war der „Salpeterkrieg” zwischen Peru und Chile.

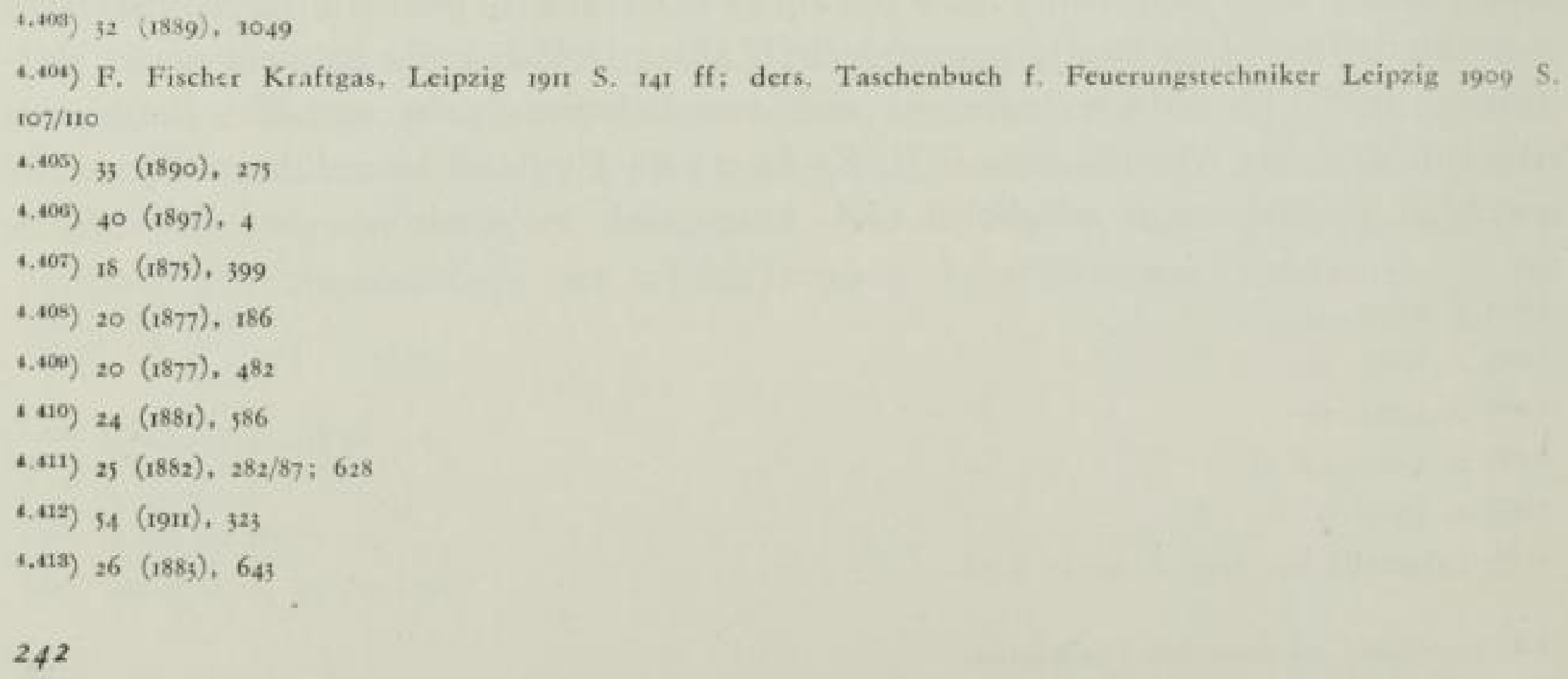

\section{SLUB}


Peru im Besitze der groł̧en südamerikanischen Salpeterläger, hatte die Preise hochgehalten und zu dem Zwecke IS73 den Privatbesitz enteignet. Von den Betroffenen waren 3/4 Chilenen, die nunmehr neue Läger aufspürten. Die Reibereien führten 1879 zum Kriege, der 1884 durch Friedensvertrag beendet wurde. An Chile wurden alle Lagerstätten von Peru abgetreten. Das Land gab volle Handelsfreiheit, begünstigte den Verkauf in Mengen, um durch Steuern die durch den Krieg geleerte Staatskasse zu füllen ${ }^{4.414}$ ). Schlimmer war, daß die Händler in Deutschland neben der Preisherabsetzung auch eine starke Aufklärungsarbeit über die Salpeterdüngung leisteten. Der Preis des Stickstoffes sank infolgedessen im Ammonsulfat nech unter den des Stickstoffes im Salpeter ${ }^{4.115}$ ). Auf den Markt kamen 1888 in Deutschland 33500 t Ammonsulfateinfuhr aus England; 225000 t Salpeter (das war etwa die Hälfte der Erzeugung Chiles), 9000 t Ammonsulfat eigener Erzeugung. Den Gaswerken wurde empfohlen, auf Salmiakgeisterzeugung auszuweichen ${ }^{t .10}$ ) oder Ammoniakwasser unmittelbar an die Landwirtschaft abzugeben.

Im Rahmen des Vereins der Gasfachmänner Rheinlands und Westfalens regte C. H. Söbren, Bonn am 21. 2. 1886 die Gründung eines Syndikats für Nebenprodukte an, aus der sich allmählich durch Zutritt von Gaswerken in ganz Deutschland die wirtschaftliche Vereinigung deutscher Gaswerke entwickelt hat. Dr. C. Otto empfahl durch Versuche über die Düngeverfahren bei verschiedenen Bodenarten den Bestwert zu ermitteln und auf diese Weise eine anregende und fruchtbare Werbung zu treiben ${ }^{4.42}$ ). Das preussische Landwirtschaftsministerium stand diesen Absichten günstig gegenüber. Eine Anzahl Werke verpflichtete sich zu einer freiwilligen Umlage von I Pf je verarbeiteter Tonne Kohlen $\left.{ }^{4.65}\right)$. Die Versuche zogen sich auf den Feldern über mehrere Jahre hin, da sie auch durch die Witterung beeinfluft wurden. Prof. P. W a $g$ $n$ er. Darmstadt stellte fest, dafy der Natrongehalt des Salpeters diesen besonders wirkungsvoll werden lasse $\left.{ }^{4.119}\right)$. Bei kalkhaltigen Böden erwies sich das Ammonsulfat als ausgezeichnet, auf anderen Böden wurde Kalkzugabe angeraten oder gleichzeitige Kalidüngung. Seit 1890 wandte sich die Landwirtschaft dem deutschen Stickstoffdünger wieder zu. Die Preise sind im Schaubila (Bild 62) dargestellt. Schlieflich wurde der Stickstoff im Sulfat besser bewertet als im Salpeter. Das war ein grofer Erfolg der Ammoniak-Verkaufs-Vereinigung $\left.{ }^{4.620}\right)$.

In München wurde durch H. Ries, wie erwähnt eine anfangs lohnende Superphosphatanlage betrieben ${ }^{4.421}$; ${ }^{4.20}$ ), Augsburg fertigte Salmiakgeist, Hof und Würzburg Ammonsulfat ${ }^{t .15}$ ). F. Tieftrunck empfahl für kleine Werke die

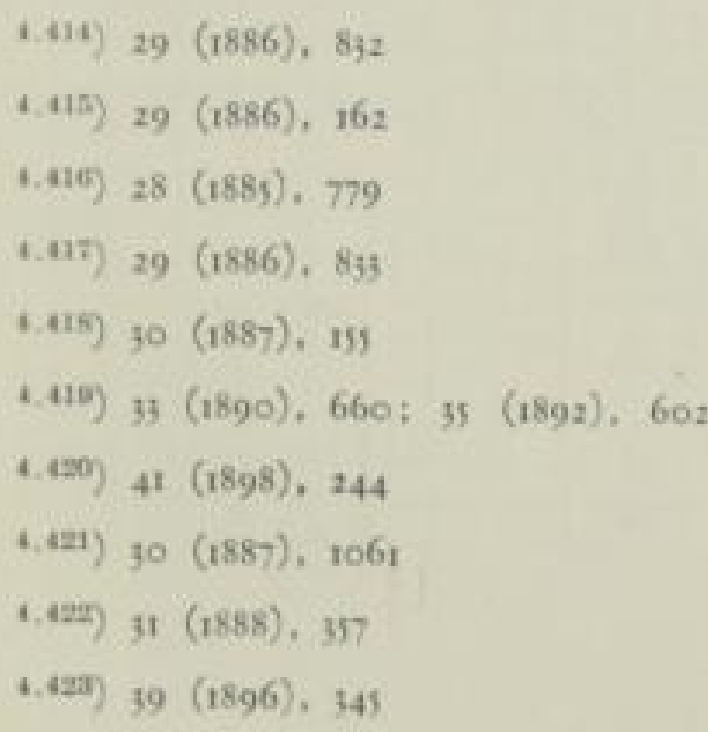




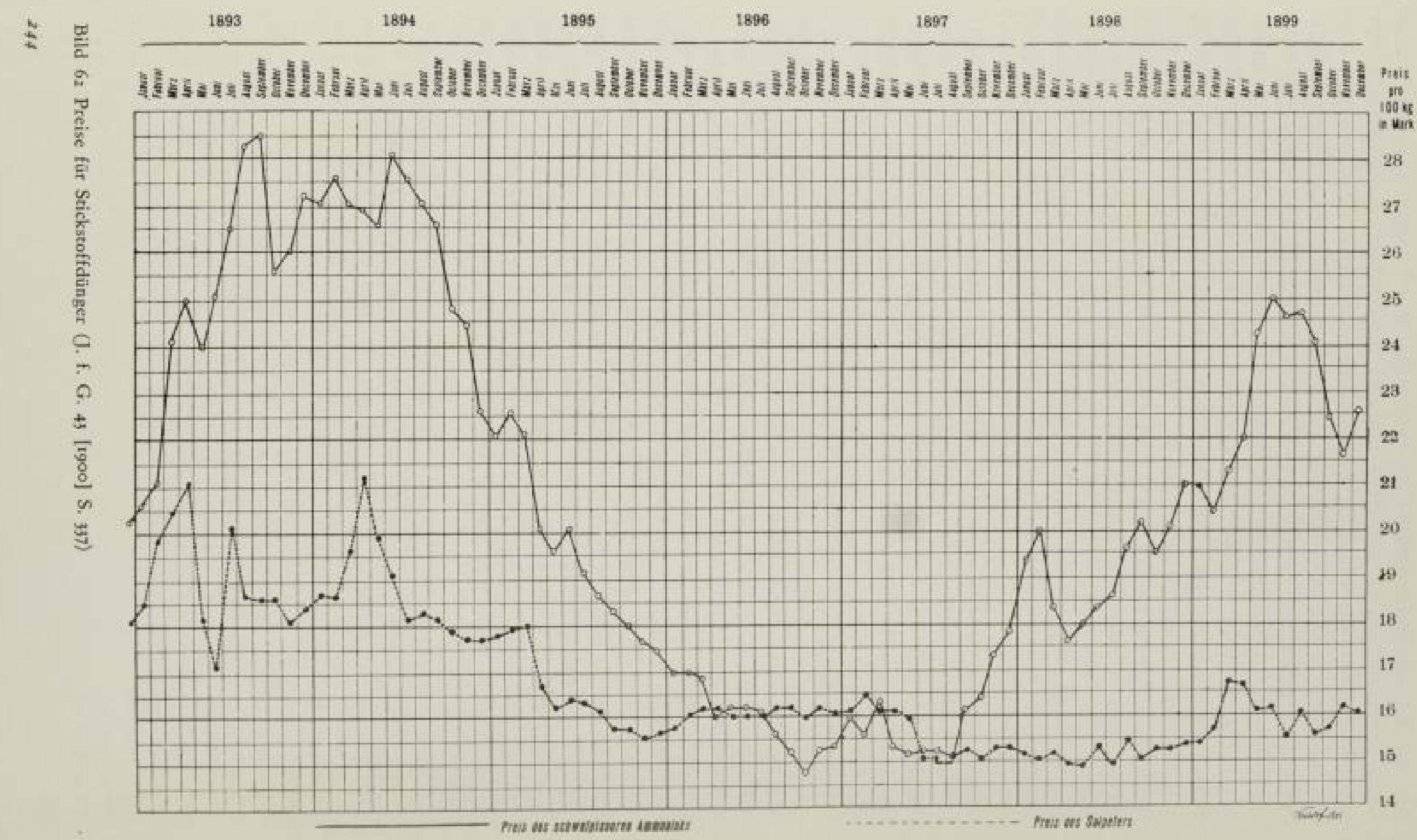

\section{SLUB}

Wir fuhren Wissen. 
Konzentration des Gaswassers von 2 auf $\left.{ }_{15} \% \mathrm{NH}_{3}{ }^{4 \cdot+24}\right)$. Hierfür herrsche Nachfrage bei Ammoniaksodafabriken und in der Kälteindustrie. Nicht ohne Einflu\} auf den Ertrag blieb die Entwicklung geschlossener Apparaturen zur Aufarbeitung des Wassers entweder auf konzentriertes Ammoniakwasser oder schwefelsaures Ammoniak, deren erste von Vorster und Grüneberg, Kalk bei Köln entwickelt worden ist $\left.{ }^{t, 42}\right)$. Die Vielheit der Erzeugnisse zeigt deutlich das Ringen der Werke um das jeweils beste Verfahren.

Auch noch andere Schwierigkeiten muften allmählich von den Gaswerken überwunden werden. Das war die Genehmigung von Aufbereitungsanlagen durch die Behörden. Die Gaswerke standen vielfach, allmählich von den Häusern eingeschlossen, im Wohngebiet der Städte. Der Geruch des Ammoniaks war lästig. Während viele gröłere Werke Verarbeitungsanlagen auf dem Werksgelände betrieben, andere die Aufarbeitung an Unternehmer abgegeben hatten, stief̧en manche auf unbedingten Widerstand. Nicht ohne Reiz ist die Tatsache, daf in Nürnberg die Errichtung der Anlage durch die Polizei verboten wurde, dann aber im Beschwerdeverfahren von der Regierung genehmigt wurde, während gleichzeitig in München umgekehrt die Polizei ein. verstanden war und die Regierung die Genehmigung versagte. Das Ammoniakwasser flof̧ zeitweilig unverändert in die Isar. Die ungewöhnliche Aufarbeitung mit Superphosphat in München war mit auf die festgefahrene Lage zurückzuführen $\left.{ }^{\text {t.tes }}\right)$.

\subsection{Scbwefelreinigung (vgl. 3.233)}

Die Reinigung des Gases von Schwefelverbindungen (Schwefelkohlenstoffen und Schwefelwasserstoff) hat wohl den Gaswerksleitern die meisten Kopfzerbrechen bereitet. Sie wurden noch für Deutschland unnötigerweise vermehrt, weil man stark auf das englische Vorbild sah. Dort aber ist der Schwefelkohlenstoffgehalt des Rohgases wegen der Kohlensorten viel höher als in deutschen Gasen. Auch die oft umstrittene Frage, wie stark der Kohlendioxydgehalt des Gases die Leuchtkraft beeinträchtigte ${ }^{t .27}$ ), spielte in die Erörterungen hinein.

W. Oecbelbäuser berichtete 186I, daf3 in England vier Jahre vorher noch elf verschiedene Reinigungsverfahren angewandt wurden, daf aber 1860 dic Lamingsche Masse gesiegt habe $\left.{ }^{4.429}\right)$. Nach dänischen Vorbildern wurden 1862 dic ersten Versuche von C. A. Kübnell, Berlin mit Raseneisenerz als Reinigungsmasse ausgeführt $\left.{ }^{\text {t.t2o }}\right)$. Die Ergebnisse waren, verglichen mit der Lamingschen Masse, günstig ${ }^{430}$ ). W. C l e l a nd, Liverpool berichtete über die Aufarbeitung der Reinigungsmasse. Der Verkauf des Schwefels deckte die Kosten des Verfahrens $\left.{ }^{\text {t.tat }}\right)$. Auch in England hegte man die Hoffnung, den übelriechenden Kalk

4.121) $24(1881), 614 ; 27(1884), 644$ : Patente: 21897 v. 8.8 .82 u. 25466 v. n. 5.83

4.425) $8(1869), 376$

4.126) $8(1865), 376$

(.42) $4(1861), 45 \mathrm{ff}, ; 79$

4.425) $4(186 \mathrm{r}), 46$

4.420) 5 (1862), 357

1.430) $6(1863), 270$

4.48) $6(1863), 383$ 
vermeiden zu können ${ }^{4 \cdot \text { ang }^{2}}$ ), was jedoch wegen der scharfen Bestimmungen des Gasgesetzes über den Gesamtschwefelgehalt des Gases nicht möglich war ${ }^{1.433}$ ). Als das grołe Gaswerk Beckton von der Gas Light \& Coke Co. in London erbaut wurde, hatte man die Reinigungsanlage besonders reichlich bemessen; trotzdem und trotz sehr guter und erfahrener Chemiker zur Betriebsaufsicht kam es zu einem völligen Fehlschlag. Man hatte die Eisenhydroxydkästen vor die Kalkreiniger gesetzt. Der Kalk ist aber nur in der Lage Schwefelkohlenstoff in dem Małe aufzunehmen, wie durch den Schwefelwasserstoff Schwefelkalzium gebildet worden ist. Da nun das Eisenerz den Schwefelwasserstoff aus dem Gase herausnahm, so konnte im Kalk Schwefelkohlenstoff nicht gebunden werden. Auß̧erdem wurden die Kühler als zu milde wirkend für fehlerhaft befunden. Die Skrubber reicherten nicht genügend Ammoniak an, um den üblichen Teil Schwefelwasserstoff und Kohlendioxyd mitzunehmen. Das Kohlendioxyd wurde nun vorweg im Kalk gebunden und damit dieser in steigendem Maf3e wertlos ${ }^{\text {t.ait }}$ ). Dieses Nachlassen des Kalkes blieb also zunächst bestehen auch als die Kalkreinigung vor die Reinigung mit Eisenoxyd gesetzt wurde. Über die zum Schluf äuß̧erst umfangreiche Einrichtung mit 9 bis 12 Reinigungskästen hintereinander berichtete W. Leybold, Frankfurt ${ }^{t .455}$ ). Wenn die Italiener dafür eintraten. dak der Kalkreiniger dem Eisenoxyd folgen soll, so ersieht man daraus, daf ihnen die Schwefelkohlenstoffe genau so wenig Sorge machten wie den Deutschen. Ihnen lag es nur an der Kohlendioxydbeseitigung zur Erhóhung der Leuchtkraft $\left.{ }^{4.130}\right)$. In England aber war die Lage durch das Gesetz ganz verfahren. Entweder muf̧ten die Werke wegen des ausgebrauchten Kalkes hin und wieder $50 \mathrm{~L}$ Strafe wegen Geruchsbelästigung oder aber $100 \mathrm{~L}$ wegen ungenügender Gasreinigung zahlen. Das führte zu einem schwierigen Prozeł, von dem der Ingenieurberichterstatter sagt: „Zum Schluß war durch die Zeugen, Sachver ständigen und Juristen alles völlig verwirrt." Das Urteil war aber wahrhaft salomonisch: Abweisung der Klage der Werke mit der Begründung, der Schaden, den die Gaswerke erlitten, sei nicht nachgewiesen ${ }^{4.47}$ ).

Die Schwefelkohlenstoffe waren auch die Veranlassung, dał die nasse Rcinigung sehr frühzeitig in England nach allen Richtungen ausgeprobt wurde. Mit Ammoniakwasser lief̧en sich sowohl Schwefelwasserstoff, Schwefelkohlenstoff und Kohlendioxyd entfernen. Nur reichte die im ersten Durchgange entstehende Ammoniakmenge nicht aus $\left.{ }^{4.135}\right)$. Die Versuche gingen also dahin, durch Erwärmung die aufgenommenen Gase abzutreiben, das Ammoniak wieder aufnehmen und dann das Wasser noch einmal umlaufen zu lassen. Live se y lief̧ durch einen Skrubber Abgase ziehen, damit ging aber auch das Ammoniak verloren $\left.^{4.43}\right)$. Hills Patent kochte mit Dampfmantel. Damit gelang es grundsätzlich, das Ammoniak vorzugsweise aus den abgehenden Dämpfen auszuwa-

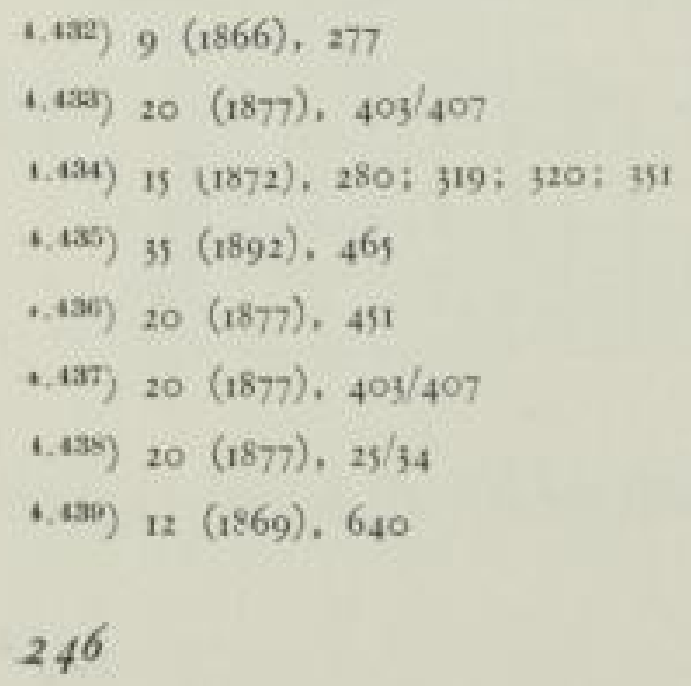


schen. Die Vetluste waren immer noch grof $\left.{ }^{4.40}\right)$. Bei einer mäf̧igen Erwärmung des Wassers auf $85^{\circ} \mathrm{C}$ gelang es, im Wasser freies Ammoniak zurückzubehal-

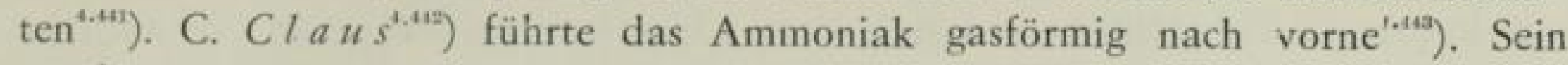
Verfahren wurde in Belfast, nach Versuchen in Birmingham, mehrere Jahre angewandt. Reiner Schwefel wurde gewonnen. Die genaue Beschreibung der reichlich verwickelten Anlage findet man bei $\left.M u s p r a t t^{t . u u}\right)$. Nach 8 Jahren hatte das Verfahren aber zu einem vollständigen Miß̧erfolg in Belfast geführt. Die Gründe lagen im häufigen Versagen der vielen Pumpen, in Verstopfungen von Rohren und Apparaten und in Undichtheiten ${ }^{4.45}$ ). Der Reinigungsgrad lag um $50 \%$ und ein Kalkreiniger könnte nicht entbehrt werden. Die Verfahren wurden mit vielfachen Abwandlungen immer wieder versucht ${ }^{+.46}$ ).

In Deutschland versuchte man mit allen Mitteln die trockene Reinigung zu verbessern. N. H. Schilling stellte 1866 fest, dał man mit der Lamingschen Masse das dreifache an Schwefel ausscheiden konnte, als nach der damals anerkannten Theorie möglich gewesen wäre ${ }^{t .4 \pi}$ ). Das führte zu einer Anregung, Untersuchungsverfahren zu vereinbaren ${ }^{4.45}$ ) und die Reinigungsmassen genau $\mathrm{zu}$ untersuchen ${ }^{\text {tan }}$ ). Im Ausschuß stellte man fest, dał die Theorie falsch war. Nur das Eisenoxyd der Lamingschen Masse bewirkte die Reinigung $\left.{ }^{1.40}\right)$. Diese Feststellung brach der reinen Eisenoxydreinigung den freien Weg ${ }^{4+1 \times n}$ ). Uber dic Theorie und die Ausführung der Reinigung folgten nunmehr eine ganze Reihe von Aufsätzen in den Jahren 1869 und 1870 . Unmöglich ist es, das alles festzuhalten. Eine geschichtliche Darstellung mit allen Erläuterungen der chemischen Vorgänge findet man in Musprat $t^{t .51}$ ). I881 veröffentlichte G. Perissini eine Berechnung der Größe der Gasreiniger ${ }^{4.4 i z}$ ). I88; sprach O. K $n u b l a u c b$ uber Gasreinigung und Ammoniakgewinnung. Er schlof̧ mit einer Mahnung, die chemische Betriebskontrolle auch in kleineren Gaswerken nicht zu unterlas$\operatorname{sen}^{4.45}$ ). Ein Jahr vorher hatte F. $L u x$ seine alkalisierte Reinigungsmasse bekannt gemacht $\left.{ }^{1.43}\right)$. Sie sei leicht zu regenerieren und nähme wohl auch Schwefelkohlenstoffe auf, was aber noch nicht erwiesen sei. Die Deickesche Masse $\left.{ }^{t .455}\right)$ hatte sich auf die Dauer nicht bewährt. Um die Raseneisenerze der Fellinghauser Gruben tobte zeitweilig ein bitterer Streit, weil das Gaswerk Oberursel als Zwischenhändler angegriffen wurde $\left.{ }^{4.45}\right)$.

$4.400) 14(187 x)$, 31: $17(1874), 573$

6.411) 18 (1875). 99 u. Muspratt S. 463 (5. 2.81)

1.442) Einige Angaben zum Leben von C. F. Claus (1828-1900) findet man in Ress S. 35s (s. 4-115)

4.443) $27(1884), 172 ; 29(1886), 918 ; 30(1887), 1033 ; 1140 ; 35(1892), 468$

4.444) Muspratt S. 464 (5. 2.81)

(.45) $40(1897), 739$

1.446) 54 (1911), 323/24

(.447) $10(1867), 328$

4.445) $10(1867) \cdot 9$

4.407) is (1888), 284

4. 450$) 21(1878), 36$

4.45i) Muspratt S. $4^{81 / 499}$ (s. 2.81 )

(.452) 24 (188i), 11

(.458) $26(1883), 440 / 448$

4.45) $25(2882), 45,589,824$

4.450) $8(1865), 227,249$

4.45e) $15(1872), 209$ 
Um die schwietige Arbeit der Austragung der Reinigungsmassen zur Regenerierung auszuschalten, versuchte man die Regeneration im Kasten. E. Grabn, war begeistert über die Anwendung eines Dampfstrahlgebläses, wie es auch in Düsseldorf gebraucht wurde $\left.{ }^{4,47}\right)$. F. $L u x$ berichtete von dem Verfahren $C o n$ duriers in Lens zur Regeneration im Kasten einen Luftschacht aufzusetzen, der von den Öfen von auf̧en angewärmt wurde ${ }^{4.155}$ ). Indessen bildeten sich in der zusammensackenden Masse allmählich Kanälchen, durch die das Gas hauptsächlich hindurchging. Eine Umschaufelung war also nicht vermeidbar. In England ging man zuerst zur Regeneration im laufenden Betriebe durch Zusatz von $I^{\%} \%$ Luft über $\left.{ }^{4.450}\right)$. Man sprach aber nicht davon, um die Abnehmer nicht wegen der Luft im Gase zu beunruhigen $\left.{ }^{4000}\right)$. Natürlich gab es Bedenken wegen der Minderung der Leuchtkraft durch den Stickstoff dieser beigegebenen Luft. W. A. Valon schlug den Zusatz von reinem Sauerstoff vor, jedoch lagen bereits vielfache Versuche von Percy F. Frankland (nicht zu verwechseln mit Edward Frankland, dem Schüler Bunsens und Freund Kolbes) vor, hatten aber erwiesen, daf̧ der Einfluf\} des Stickstoffes gering war. $\left.\left.{ }^{\text {t.tui }}\right),{ }^{\text {4.tea }}\right)$. H. $D$ r e $b$ $s c b m i d t$ stellte im Muspratt 1893 noch fest, daf das Verfahren in Deutschland nicht erprobt wurde $\left.{ }^{\text {t.45 }}\right)$. Fünf Jahre später hatte es aber Karlsruhe eingeführt und war sehr zufrieden $\left.{ }^{4.48}\right)$.

H. Tormin, St. Johann (Saar) hatte dagegen die Regeneration im Kasten durch Anschluf an den Schornstein vorgezogen, weil er mit der laufenden Luftansaugung eine wesentliche Leuchtkraftverminderung erlebt hatte $\left.{ }^{t .45}\right)$. Vielleicht war es ihm bei den damals gegebenen Regelmöglichkeiten nicht immer gelungen, die geringen Luftzusatzmengen wirklich einzuhalten. Eine mechanische Einrichtung zum Wenden der Reinigungsmasse hat ${ }^{8} 894$ Charlottenburg eingeführt ${ }^{4.60}$ ). Zeitweilig grołe Beachtung fand die direkte Gewinnung von Zyanwasserstoff aus dem Gase.

Vorarbeiten von V. Harcourt tha $)$ lagen schon aus dem Jahre 1875 vor. Harcourt behandelte das ammoniakhaltige Gas mit einer wässerigen Lösung von Eisenoxydhydrat. Der Etfolg blieb aus, weil die erforderliche Reduktion nur langsam und unvollständig vor sich geht. Andere Arbeiten mit Eisenoxydulhydrat führten zu einer fabrikmäfigen Ausbeutung. 1886 schlug O. $K n u b l a u c b$ (D.R.P. 41930 ${ }^{4.45}$ ) diese Methode mit Abänderungen zur Gewinnung von Cyanwasserstoff aus Leuchtgas vor. Auch hier kam es nicht zur Anwendung, weil man das Absorptionsmittel nicht genügend vor vorheriger Oxydation schützte. So erhielt man neben den löslichen stets auch unlösliche Salze, die die

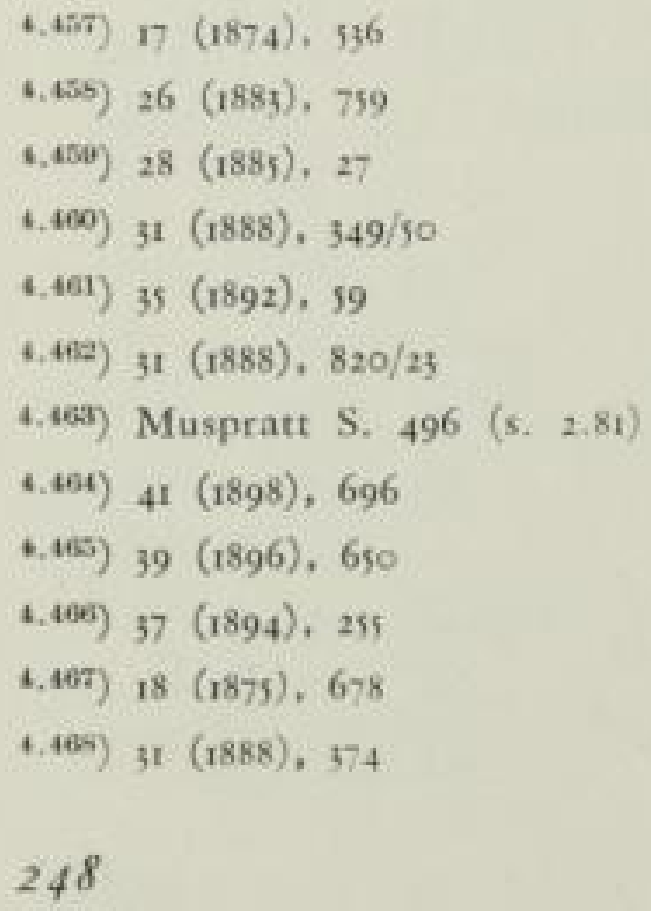


Verarbeitung erschwerten. 1892 führte W. Foulis ein geändertes Verfahren $e^{4 n^{4.400}}$ ), über dessen Anwendung im Den Haag J. Rutte $n^{4.470}$ ) später berichtet hat ${ }^{\left({ }^{2 i 1}\right)}$. Auf Grund einer Anregung von Martin, Mühlheim (Rhein) nahm $O$. Knublaucb seine Arbeiten zur Bestimmung des Ferrozyanes in der Reinigungsmasse auf $\left.{ }^{\text {tat }}\right)$. Zyan wurde zur Herstellung vom Berliner Blau und Blutlaugensalz sehr gesucht $\left.{ }^{\text {titz }}\right)$. Es erreichte den 8-fachen Stickstoffpreis wie im Ammoniak $\left.{ }^{4.4 i}\right)$. Neben $\mathrm{O}$. Knublauch, der sein Bestimmungsverfahren 1889 veröf-

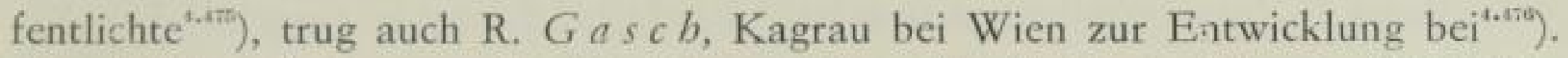
Eine höchste Steigerung der Nachfrage führte die Goldextraktion in Südafrika herbei $\left.{ }^{4 t \pi}\right)$. H. B unte aber machte darauf aufmerksam, dał die Preise eine neue Industrie zur Gewinnung von Cyan hervorgerufen habe und deshalb die Preishöhe nicht gesichert sei. In der Tat hatte J. $B u e b$, Dessau die Melasse der dortigen Zuckerfabrik mit Hilfe des Ammoniaks auf Cyan verarbeitet, dabei aber auch sein Verfahren Cyan aus Gas zu gewinnen entwickelt, das 1899 in 5 Werken der Deutschen Continental-Gas-Gesellschaft eingeführt war ${ }^{\text {tais }}$ ).

Die Waschung des rohen mit Ammoniak und Schwefelwasserstoff beladenen Gases erfolgte mit einer Eisenvitriollösung. $B u e b$ erreichte durch angemessene Verhältnisse der Wassermenge und der Eisenmenge eine Ausscheidung des Cyanwasserstoffes in Form einer unlöslichen Ammoniumferrocyanverbindung $\left.{ }^{4 \cdot 4{ }^{2}}\right)$. Das Verfahren fand wegen schwieriger Betriebsführung bald Gegner, obwohl Bueb genaue Anweisungen herausgegeben hatte.

Einige wenige Worte mögen noch dem Cooper-Verfahren von 1882, durch Kalkzusatz zur Kohle die Reinigung zu entlasten, gewidmet $\operatorname{sein}^{4.40^{\circ}}$ ). R. T. Spice behauptete, dafy der Schwefelkohlenstoffgehalt des Gases auf $\mathrm{I} / 3$ des früheren Wertes zurückgegangen sei. Der Berichterstatter im Journal für Gasbeleuchtung war etwas ungläubig und machte vor allem auf die Verschlechterung des Kokses durch den Kalk aufmerksam $\left.{ }^{4.451}\right)$. Im übrigen hatte aber schon 1859 O. Kellner, Mühlheim Kalk zur Kohle zugesetzt, weil damals die Reinigungsanlage zu klein gewesen war (vgl. S. 8i E. Heard).

\subsection{Koks}

Gaskoks war um r860 noch Neben-, man darf sogar sagen Abfallerzeugnis. Wenn schon frühzeitig vom Mahlen und Mischen der Kohle berichtet werden kann, (vgl. S. 203) so muf man dennoch im Unterschied zur heutigen Lage beachten,

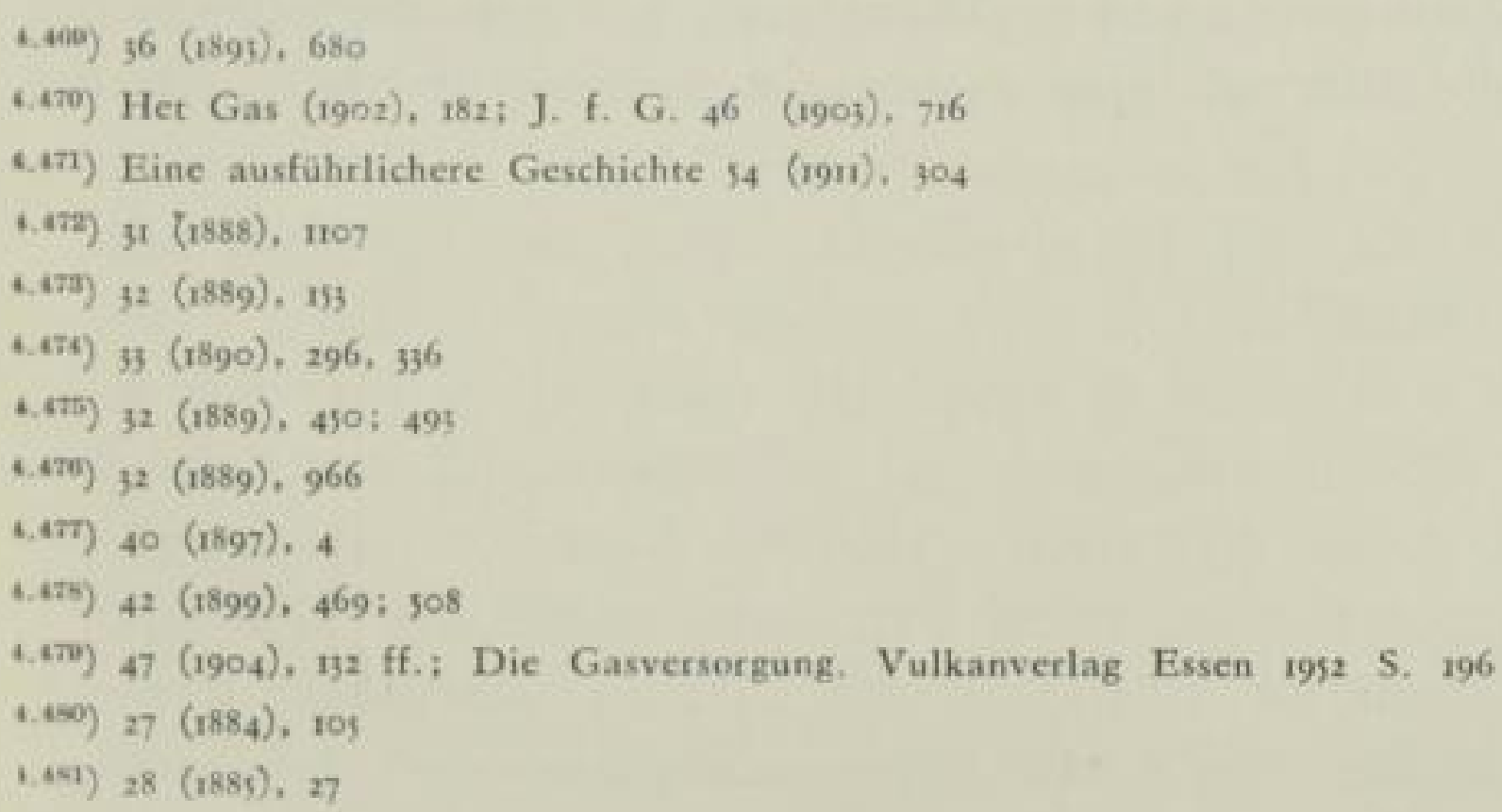


daf3 dabei nur die bessere Leuchtkraft des Gases oder mindestens die grofe Ausbeute der Kohle nach Menge und Leuchtkraft des erzielten Gases entscheidend abgewogen wurde. So wurde also der Koks, so wie er anfiel, mit mehr oder weniger Erfolg abgesetzt. Erst nachdem schon im Fachverein die Aussprache über Gasfragen to Jahre lang im Gange gewesen war, wandte man seine Gedanken dem Koksabsatz zu. 1869 stellte der Verein eine Preisaufgabe zur Erlangung der zweckmäßjigsten Konstruktion eines Zimmerheizofens für Gaskoks. Wie dieses Preisausschreiben ausgestattet wurde, und was es ausgelöst hat, liefert das beste Bild über den Stand des Wissens $\left.{ }^{4.452}\right)$. Verlangt wurde vor allem ein Wärmespeichervermögen, um den Wettbewerb mit den üblichen Kachelöfen bestehen zu können. Der beste Ofen müsse auch unbedingt in vorhandene Öfen eingesetzt werden können. Das Preisausschreiben wurde völlig mił̧verstanden. Im ersten Jahre wurden nur Zeichnungen der im Handel üblichen Bauarten eingereicht. Ein gewisser Erfolg war, dał die Hersteller, die Anteilnahme der Gaswerke erahnend, nun mit Anzeigen sich bekannt zu machen suchten ${ }^{4.45}$ ). Das Preisausschreiben wurde nach dem Mif3erfolge 1870 erneut erlassen $\left.{ }^{4.42}\right)$. Gegen das Urteil des Ausschusses ging als erster Wolpert, Kaiserslautern mit scharfen Worten und Forderungen an. Er rügte das unsinnige Verlangen nach Speicherung, da gerade die beste Eigenschaft des Kokses, im gleichmäßjigen Dauerbrand und steuerbar zu verbrennen, herabgesetzt würde $\left.{ }^{4.45}\right)$. Der Ausschuß̧bericht $\left.^{4.450}\right)$ stützte sich vor allem auf Untersuchungen, die A. $B u b e$, Dessau ausgeführt hatte $\left.e^{t-157}\right)$. Buhe gab dem Ofen mit ,unterem Abbrand“ den Vorzug, wegen der Kohlenmonoxydgefahr bei oberem Abbrande. Voraussetzung für den guten Betrieb wäre die Zerkleinerung des Kokses, die in Bremen und Altona mit Erfolg eingeführt war $\left.{ }^{4.45}\right)$. Altona erzielte sogar höhere Preise für den Kleinkoks. Diesem Vorgehen stimmte H. Meiding er, Professor am Polytechnikum Karlsruhe, bei mit den Worten: „Wollen Sie das Publikum für den Coke, diesen meiner Meinung nach vorzüglichsten aller Brennstoffe gewinnen, so müssen Sie ihn in der richtigen Form liefern, zerkleinert durch Maschinen, erbsen- bis wallnußggrof ${ }^{\text {(4.4.4so })}$.

\section{LEB ENSB I L D}

Johann Heinrich Meidinger, ist geboren am 29. I. 1831 als Sohn des Pfarrers Johannes Meidinger und seiner Frau Antoinette, geb. Buff (der Tochter des jüngsten Bruders von Werthers Lotte) in Frankfurt $\left.{ }^{\text {t.to }}\right)$. Nach dem Tode des Vaters, der inzwischen die Pfarrstelle in Niederrad innegehabt hatte, zog die

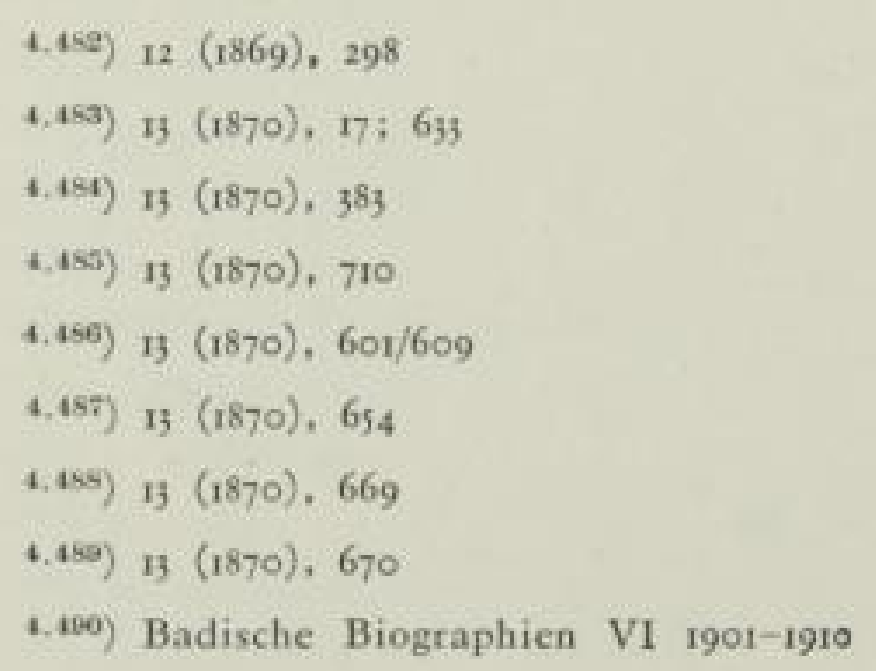

\section{SLUB}


Familie 1843 nach Frankfurt zurück. Dort besuchte Meidinger das Gymnasium, anschlief̧end studierte er ab 1849 in Gief̧en Naturwissenschaften, insbesondere Physik. Die Promotion auf dem Gebiete der Elektrizitätslehre lag auf seinem Lieblingsgebiete. Anschlief̧end aber hörte er noch in Heidelberg bei Bunsen Chemie über das hinaus, was er bei Liebig in Giefzen schon gehört hatte. Die Besuche der Weltausstellungen 1851 in London, 1855 in Paris beeinflufzen ihn, sich der Technik zuzuwenden. Je ein Jahr in Paris und London benutzte er neben den Sprachen zu technologischen Studien. Neben die mechanische und chemische Technologie wollte er die physikalische stellen. Er habilitierte sich 1857 in Heidelberg für Technologie mit der ersten deutschen elektrotechnischen Vorlesung: „Die Elektrizität in ihren technischen Anwendungen." Leicht verständliche Vorträge hielt er häufig im „Gewerbeverein“, darunter „die Geschichte der Dampfmaschine". Um eine aus Paris mitgebrachte elektrische Uhr langdauernd betreiben zu können, entwickelte er das Meidingerelement mit Trennung der beiden im Daniellschen Elemente verwandten Flüssigkeiten durch die Wichteverschiedenheit. Dieses Element herrschte bekanntlich in der Telegraphie, Telephonie, für Hausklingeln vor, bis es durch Trockenelemente und Transformator abgelöst wurde.

I86s wurde in Karlsruhe nach Württemberger Vorbild die Landesgewerbehalle begründet. Meidinger wurde ihr Vorstand und kam so an die Aufgaben der handwerklichen Bildung heran, worunter die Konstruktion des Dauerbrandofens für die Koldeweysche Polarexpedition 1869 hervorragte. Im gleichen Jahre übernahm er an der Hochschule Karisruhe einen Lehrauftrag für technische Anwendungen der Elektrizität und für Heizung und Ventilation. I874 wurde er ordentlicher Professor. Seine Forschungsarbeiten veröffentlichte er in der badischen Gewerbezeitung. Die Vielseitigkeit seiner Interessen und die Gründlichkeit seiner Arbeiten machen es unmöglich hierüber ein Bild zu geben. Meisterhaft sind seine Untersuchungen an Hauskaminen, die zur genauen Angabe der Meidingerscheibe, als einfachstem aber wirksamsten Schornsteinaufsatz geführt haben. Meidinger wanderte viel, war eifriger Schlittschuhläufer und hat so seine Gesundheit gestärkt. Er starb nach kurzer Krankheit am II. IO. I905.

Auf Meidingers Veranlassung führte das Gaswerk Karlsruhe zuerst eine Koksabsiebung und Zerkleinerung aus. Meidinger hatte seinen Füllofen nach vielen Überlegungen und Versuchen erbaut. Er bestand aus einem guß̧eisernen Innenzylinder mit doppeltem Blechluftmantel. Diesen hatte er gewählt, um die, wir würden heute sagen, infrarote Strahlung abzuschirmen. Die Heizflächen waren senkrecht gehalten, um der Meidinger bekannten Staubverschwelung entgegen zu wirken. Besondere Aufmerksamkeit war der Ofentür als aufgeschliffener Fallklappe gewidmet, da Meidinger darum wuß̧te, dał beim nächtlichen Brand hier alles gut dicht sein mufte. Oberhalb der Tür, die durch seitliches Verschieben genau geöffnet werden konnte, war eine halbmondförmige Platte angebracht, um die Luft in die Mitte des Ofens zu leiten. Die Regelung wurde unterstützt durch einen Zugunterbrecher im Abgasstutzen mit Schlitzschieber. Der Ofen hatte oberen Abbrand. Meidinger hatte sich durch Versuche vergewissert, daf, auch beim Nachfüllen von oben keine nennenswerten Mengen von Kohlenmonoxyd entwickelt wurden. Als Brennstoff verlangte er abgesiebten Kleinkoks. Aber der Preiskommission gefiel der Ofen nicht. Der Ofen fand auch die 
größte Verbreitung in Österreich, wo ihn ein Händler $\mathrm{Hei} m$ in Wien vertrieben hat.

Wie unzureichend noch die Kenntnisse der Gasfachleute auf diesem Gebiete waren, zeigt ein unwidersprochener Vortrag von C. Knoblaucb (nicht zu verwechseln mit F. J. Knoblauch, Frankfurt, dem Teilhaber J. H. Schieles, der schon Ende der zoer Jahre gestorben ist). Er verlangte Auf3enbeheizung der Koksheizöfen, da die Entnahme der Verbrennungsluft aus dem Zimmer den Sauerstoff vermindere. Die glühenden Flächen auch in den Luftkanälen erzeugten eine schwüle Luft im Zimmer, während Meidinger durchaus die Staubverschwelung als Ursache erkannt hatte. Den Koks müsse man kleinschlagen, aber der Grus störe die Verbrennung nicht ${ }^{4.412}$ ).

Auch Belgien förderte durch ein Preisausschreiben den Kokszimmerofenbau, wobei 9 Bilder damaliger Bauarten veröffentlicht worden $\operatorname{sind}^{4.402}$ ).

Fast ebenso wichtig wie der Bau geeigneter Ofen erwies sich die Erleichterung des Koksabsatzes im Kleinverkauf. In den Aussprachen, vornehmlich in den Zweigvereinen, wurden die umständlichen Aufsichtsmaßnnahmen gerügt, die mit Herumschicken des Kunden und Wartezeiten den bestwilligen Käufer abschreckten. Der Vorschlag, Koks nicht nach Hohlmaß̧en, sondern Gewicht zu verkaufen, stief̧ auf eine lebhafte Gegnerschaft. Die Wägearbeit sei bei größzeren Werken nicht zu bewältigen. Außzerdem schwanke der Koks sehr im Gewicht je nach Wassergehalt $\left.{ }^{t+4 x}\right)$. H. B unte stellte allerdings noch 1897 fest, daf der Heizwert der Kokse wenig bekannt sei. 12 untersuchte Proben zeigten Abweichungen von 3,7 bis zu $\pi, 6 \%$ im Aschengehalt. Die Heizwerte schwankten zwischen 7618 und $\left.80 \mathrm{II} \mathrm{kcal} / \mathrm{kg}^{\mathrm{t}}{ }^{\text {tat }}\right)$. Immerhin hatte München durch Aufklärung über den Füllofen den Kleinabsatz von Koks von $100 \mathrm{t}$ im Jahre 1882 auf $3900 \mathrm{t} 1888$ gesteigert $^{4.405}$ ). Der beträchtliche Kleinverkauf in Berlin in $1 / 4,1 / 2$ und $\mathrm{r} / \mathrm{r}$ Hektoliterbehältern wurde 1897 besonders hervorgehoben $\left.{ }^{4+400}\right)$. Dort kam es sogar zu einer Beschwerde in der Stadtverordnetenversammlung durch P. Singer, als plötzlich nicht genügend Koks vorhanden war. Der Vorgang war folgender gewesen: In den letzten zwei Jahren hatten sich die erzeugten Mengen nicht völlig absetzen lassen. Darum setzten Bemühungen ein, den Koks in Heizungsanlagen städtischer Gebäude und der Industrie unterzubringen. Da trat plötzlich infolge der sich steigernden allgemeinen Konjunktur eine Kohlenknappheit ein und alles nahm zum Koks Zuflucht ${ }^{\text {s.ten }}$ ).

Koksverwendung für Kesselfeuerung auch, wie ganz im Anfang allgemein, für Lokomotiven wurde lebhaft gefordert $\left.{ }^{4.485}\right)$. Für Zentralheizungen hatte er sich eingeführt.

Der Koksgrusverfeuerung wurde seit 1886 Aufmerksamkeit zuteil. Man nahm Planroste mit engen Schlitzen, verwendete Dampfstrahlunterwindgebläse oder

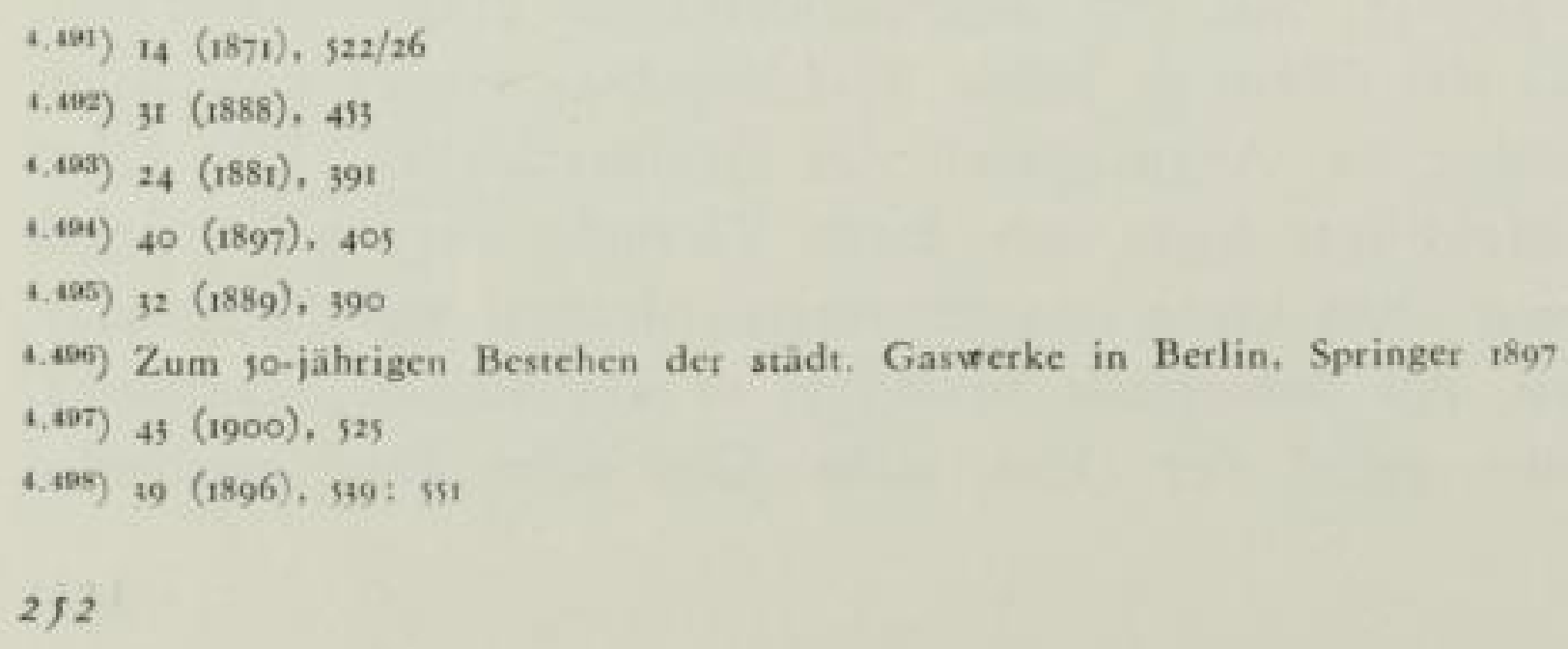


benutzte Treppenroste ${ }^{4+109}$. Kudličz ${ }^{4.500}$ ) und Perretroste ${ }^{t .501}$ ) waren damals sehr bekannt. Wie unvollkommen aber die Aufbereitung des Kokses noch manchmal war, erweist ein Vortrag von F. Froitzbeim, Köln über die Verwertung des Koksabfalles. Der Hausbrandkoks wurde beim Verladen lediglich ausgegabelt. Empfohlen wurden 30 bis $80 \mathrm{~mm}$ für Hausbrand, was sicherlich eine zu grofe Spanne war. Der Abfall von $30-0 \mathrm{~mm}$ wurde auf Rosten verfeuert ${ }^{1.3 m}$ ). Den Grus, der durch ein $5 \mathrm{~mm}$ Sieb fiel, etwa 20-25\% des gesamten Kokses ausmachend, versuchte man mit Sulfitablauge zu Briketts zu pressen, die sich aber nicht als haltbar erwiesen. So blieb noch viel zu tun übrig, um den Koksabsatz zu guten Preisen zu sichern.

\subsection{G ASVERTEIL UNG \\ 4.4I Robre und Robrleitung}

Die Rohrleitungstechnik machte nur kleine Fortschritte, diese aber stetig. Gufeisen war für Hauptrohre vorherrschend, zunächst noch liegend gegossen und daher mit dicken Wandungen und begrenzten Längen. Eine Anzeige der Tangerhütte im Jahre 1869 zeigte den stehenden Guf̧ der Rohre an $\left.{ }^{\text {4.5an }}\right)$. Dieses Werk dürfte das erste gewesen sein, das die neue Technik aufgenommen hat. Eine wichtige Tat war die Verwirklichung des in Gasfachkreisen herangereiften Gedankens der Normung von Rohren, Rohrmuffen, Flanschen, Schiebern und Fittings $1874 / 1875^{4.501}$ ) zusammen mit dem Verein deutscher Ingenieure (V.d.I.) Sie lieferte den Beweis, daf̧ sich bei gutem Willen, trotz Liberalismus, die Normen auch durchsetzen. Vorbilder aus dem Auslande waren nicht vorhanden. Eine Umarbeitung nach Jahren ging ebenfalls mit dem V. d. I. schnell vonstatten ${ }^{4.005}$ ). Die in Frankreich entwickelten Rohre von Chameroy, die bereits im vorigen Hauptabschnitt erwähnt sind (S. 150), haben sich in Deutschland nicht eingeführt, wenn nicht die Blechrohre mit Goudroneinfüllung die seit $188_{4}$ in Hannover benutzt wurden $\left.{ }^{4.500}\right)$ und die heiłasphaltierten Rohre in Köln eine Fortbildung der Chameroyrohre gewesen sind. Auch die auf der Pariser Ausstellung von 1867 gezeigten $^{4.300}$ ), schon 1858 bekannt gewordenen Rohre aus getecrter Pappe ${ }^{4.505}$ ) haben trotz der in Hamburg zeitweilig tätigen Asphaltröhrengesellschaft in Deutschland keine Freunde gefunden. Anders war es mit den von Schulz, Knaudt \& Co., Essen geschweiß̧ten Muffenrohren aus Eisenblech für Durchmesser über $600 \mathrm{~mm}$. Diese waren mit einem Hartlack überzogen. Sie sind wenigstens versuchsweise eingebaut worden $\left.{ }^{4.000}\right)$. In der Nacht vom 2r./22. Aug. I886 gelang es

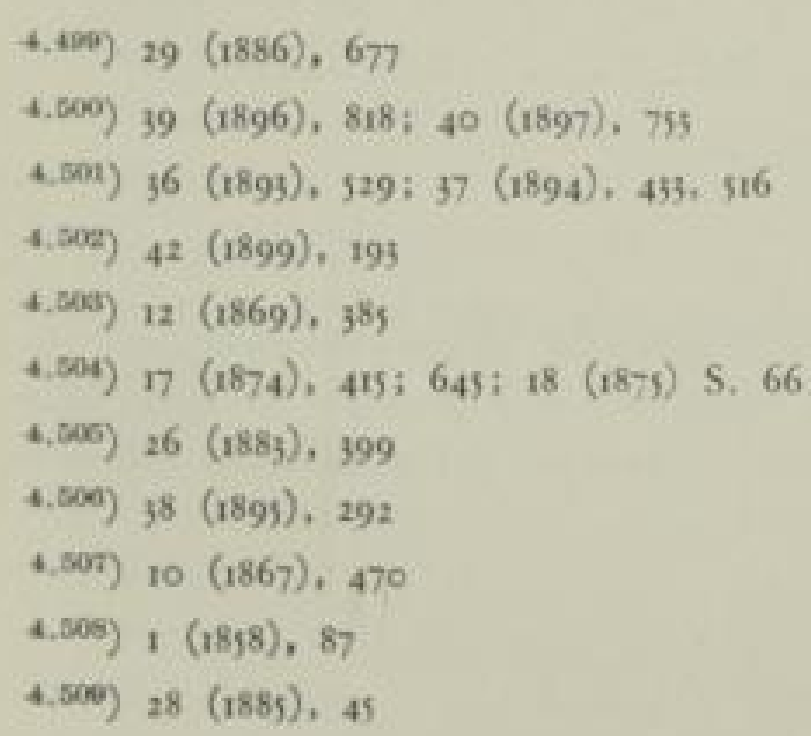


R. und M. Mannesmann erstmalig einen dickwandigen Hohlkörper nach dem Schrägwalzverfahren herzustellen. F. Siemens berichtete im Deutschen Verein den Gasfachleuten 1888 über das Mannesmannverfahren $\left.{ }^{4.510}\right)$. Das bestehende Syndikat wollte den Neuankömmling nicht aufnehmen. Im mittelrheinischen Verein kam es zu einer lebhaften Aussprache über die Zweckmäßjigkeit von Guf, Schmiedeeisen oder Blei (erwogen von A. $\left.K l \ddot{o} n n e)^{4.54}\right)$. Drei Jahre später muf sich bereits der deutsche Vertreter Le ykauff der Deutsch-österreichischen Mannesmannröhrenwerke wegen Verzögerungen in den Lieferterminen entschuldigen. Nicht Walzschwierigkeiten seien schuld, sondern Verzögerungen in der Lieferung von Maschinen zur Fertigung. München und Nürnberg hatten bereits sehr erfreulich verlaufene Versuche mit Biegen der Rohre und Aufweiten der Enden angestellt $\left.{ }^{t .312}\right)$. Muspratt erwähnte sie aber 1893 noch nicht. 1895 hatte dic Deutsche Continental-Gas-Gesellschaft Mannesmannrohre, mit imprägniertem Werg umwickelt, versuchsweise eingebaut ${ }^{4.513}$ ).

Die Mannesmann-Patente konnten die Gelsenkirchener Bergwerks A.-G. (Phoenix, Düsseldorf) erfolgreich umgehen, indem sie vorgestanzte Blöcke als Ausgangsstück für die Walzung benutzte. Das Pilgerschrittverfahren von Max Mannesmann stammte aus dem Jahre $1890^{4.514}$ ).

Hausanschlüsse wurden im allgemeinen aus Schmiedeeisen mit Teerstrick hergestellt. Nach französischem Vorbilde benutzte man auch einfache verzinkte Rohre in Stuttgart $1865^{4.515}$ ) und Düsseldorf $\left.{ }^{4.519}\right)$, Kupfer und Blei nur noch für kurze Laternenanschlüsse $\left.{ }^{4.517}\right)$. Von den ersten Anbohrmaschinen, die bei der Arbeit Gasverluste vermieden, wurde 1869 aus England berichtett.5is).

Als Dichtung der Muffenrohre herrschte der Teerstrick mit Bleiverguß vor. Kork als Dichtung wurde 1863 als sehr vertrauenswert angesehen ${ }^{4.519}$ ), hat sich aber nicht eingeführt. Zur gleichen Zeit etwa begann man sich mit Gummidichtungen abzugeben. Das führte fünf Jahre später zu einem Preisausschreiben ${ }^{4.320}$ ) das aber ergebnislos verlief $\left.{ }^{4,591}\right)$. Immerhin blieben die Meinungen geteilt. Insbesondere H. F. Ziegler, Hanau (1826-1882), aber auch I. R. Geith, Koburg ${ }^{4}$ ) traten für Gummidichtungen ein $\left.{ }^{4.529}\right)$, $\left.{ }^{4.354}\right)$. Ziegler wandte Gummi seit 1850 an $\left.{ }^{4.527}\right)$. Zuerst eingeführt wurde die Gummidichtung von Macintosh \& Co., Lon-

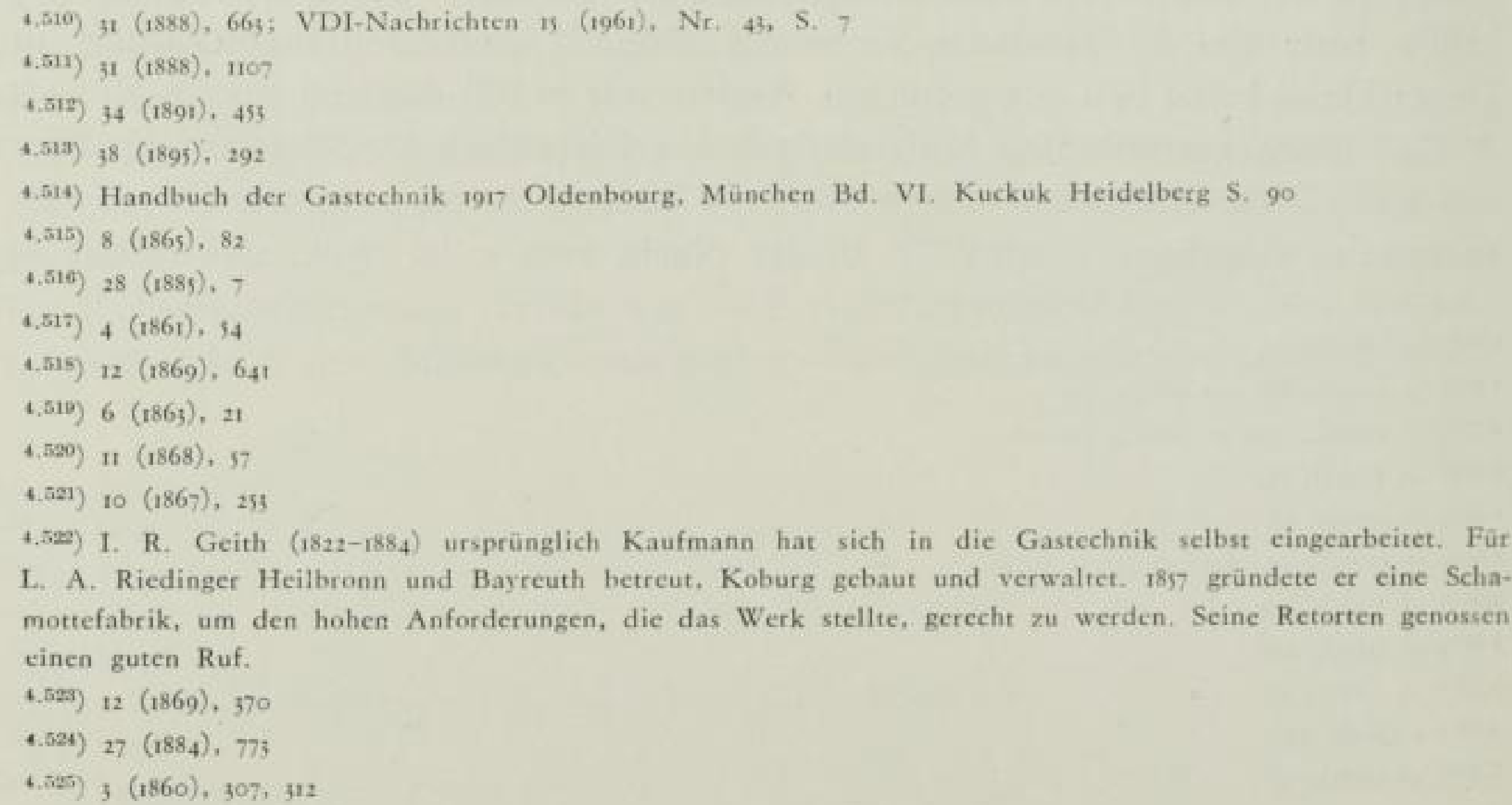

\section{SLUB}


don, der Firma, die dem Gummiregenmantel seinen englischen Namen abgegeben hat. In Frankreich und Belgien versuchte man immer wieder Verbesserungen ${ }^{4.520}$ ). Es blieb dabei, daf̧ nur ganz besonders ausgewählte Gummisorten auf die Dauer befriedigten, und diese schwer mit Sicherheit zu erhalten waren $\left.{ }^{4.62 \pi}\right)$. In England wurden die Rohre auch mit abgedrehten Konen ausgeführt und mit Farbe oder Mennige gedichtet $\left.{ }^{4.595}\right)$.

Die Haltbarkeit der Gasrohrleitungen wurde durch die Erdarbeiten ernstlich gefährdet, als die Städte tiefliegende Kanäle in die Straß̧en einbauten $\left.{ }^{4.55}\right)^{5}$. In Köln wurde besonders erschwerend empfunden, dał in neuen Baubezirken die Straf̧en oftmals lose aufgeschüttet waren u. a. auch mit Hausmüll $\left.{ }^{\text {t.5so }}\right)$. Bei Durchbruchsstraf̧en in der Altstadt waren oft alte Hausfundamente nur oberflächlich beseitigt, Hohlräume und Grundmauern wechselten ab ${ }^{4.521}$ ). Pfahl- und Holmunterbauten unter die Rohre wurden in solchen Fällen für notwendig erachtet. Dresden unterlegte die Rohre mit Steinen, was W. Hor $n$ lebhaft abgelehnt hat. Neue Sorgen kamen auf, als Blitzableiter zur Erdung an die Gasrohre angeschlossen wurden. Die Zweckmäf̧igkeit wurde von Gaswerken, Elektrotechnikern, Architekten- und Ingenieurvereinen völlig verschieden beurteilt ${ }^{4,52}$ ). Mit den ersten elektrischen Straß̧enbahnen traten auch noch die Sorgen mit Streuströmen auf. In einer Aussprache im baltischen Verein stand man 1892 nocí den ersten Lochfraferscheinungen hilflos gegenüber. Vermutet wurden immer wieder Einflüsse der Bodenbeschaffenheit $\left.{ }^{4.5 x a 3}\right)$. Drei Jahre später aber war der neue Feind erkannt $\left.{ }^{t . a s}\right)$. G. R a sc b. Karlsruhe, stellte die Vorgänge zum ersten Male ausführlich dar $\left.{ }^{4.350}\right)$. Mit dem Verband deutscher Elektrotechniker wurde eine gemeinsame Kommission 1897 gebildet; die aber nur langsam die Arbeit aufgenommen hat.

Um Einfrierungen der Gasleitungen zu beseitigen, hatte man schon seit alters her Spiritus eingegossen. In den goer Jahren versuchte man es auch mit Tiefkühlung des Gases, was besonders im baltischen Verein besprochen wurde. Man baute besondere Luftkühler, die im Winter bei hohen Kältegraden wirksam wurden. Das Verfahren hatte den Nachteil, dał die Leuchtkraft, ebenso wie bcim Waschen mit Schwefelsäure, geschwächt wurde, aujerdem immer noch fast reines Benzol einfror. J. B ue b, Dessau, führte im Gaswerkausgang bei aufkommender Kälte dampfförmig Spiritus ein $\left.{ }^{4.530}\right)$. Sein Patent wurde heftig angegriffen ${ }^{4.357}$ ). Wichtig war, daß schon ehe Eisverstopfungen vorkamen, also bei $-2^{\circ}$ bis $-3^{\circ} \mathrm{C}$ mit dem Verdampfen begonnen wurde ${ }^{t .35}$ ) .

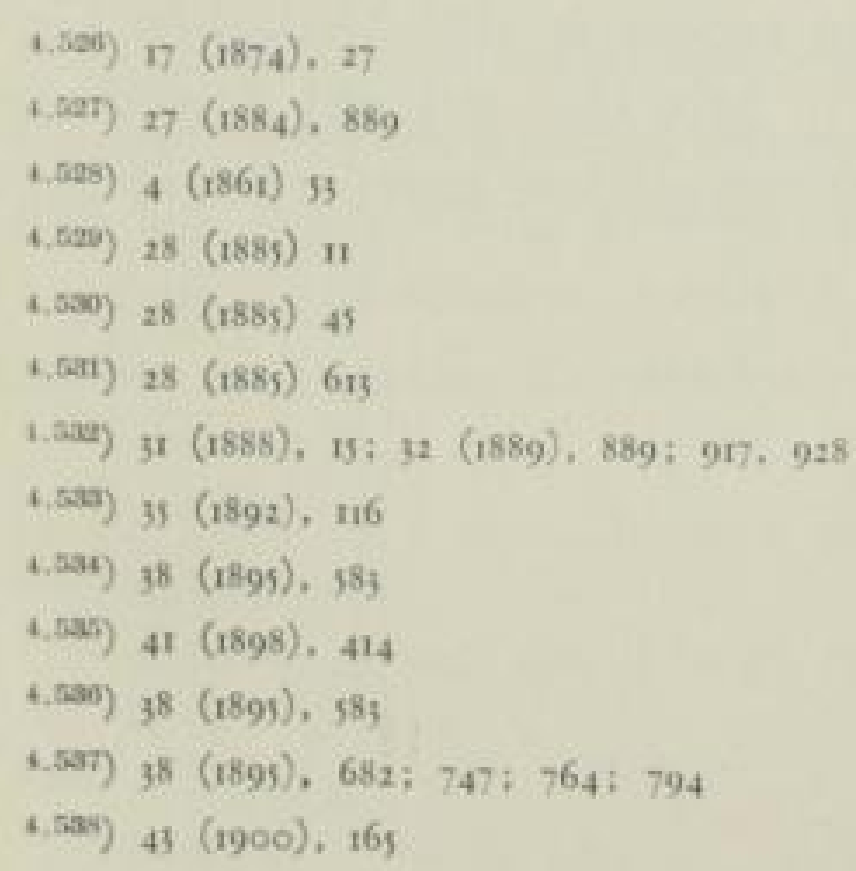


Die Leistungsfähigkeit der Rohrleitungen durch Druckerhöhungen zu steigern, wurde ohne viel Lärm zunächst rein praktisch versucht. Heilbronn stand 1866 vor der Aufgabe, kurz vor der Übergabe des Werkes an die Stadt mit der Hauptzuleitung mehr zu leisten und setzte ein Kreiselgebläse ein $\left.{ }^{4.539}\right)$. $1875 / 76$ hat das Kruppsche Gaswerk dasselbe getan. W. Oecbelbäuser empfahl bereits anfangs der 7oer Jahre ein überlagertes Mitteldruckspeisenetz. Darüber hattc er 1876 gesprochen ${ }^{4.689}$ ). Jm folgenden Jahre erschien im Journal eine Druckschrift eines ungenannten Verfassers (Oechelhäuser?), die empfahl einen höheren Druck bis $\mathrm{I} / \mathrm{Is}$ atü $=700 \mathrm{~mm}$ WS anzuwenden und aus dem überlagerten Netz in das Niederdrucknetz einzuspeisen. Als die Druckförderung vom Gaswerk Beckton in die Stadtmitte von London ( $15 \mathrm{~km}$ ) mit Hilfe eines Bealeschen Saugers bekannt wurde, erhob sich ein Prioritätstreit, weil dasselbe bereits vom Gaswerk Linacre nach Mitte Birmingham eingerichtet war $\left.{ }^{4.511}\right)$.

Besondere Bauten waren die ersten Düker unter Flußläufen, in Küstengebieten, aber auch in Berlin vor $\mathbf{1 8 6 2}$, später wurden dort die Leitungen in die Brücken verlegt $\left.^{4.542}\right)$.

In Nordamerika wurde durch die Erdgasversorgungsunternehmen eine Fernleirungstechnik entwickelt. Als die Bohrungen in der Nähe der Verbrauchsorte versiegten, muf̧te das Gas aus immer weiterer Entfernung herangeführt werden. Um die üblichen Bleidichtungen wurden noch Gummidichtungen mit Eisenklammern angepresst. So kam man zu Betriebsdrücken bis zu 20 at. Einzelne Rohrleitungen bis $160 \mathrm{~km}$ Länge mit $200 \mathrm{~mm}$ Durchmesser entstanden zur Jahrhundertwende. Mit $30000 \mathrm{~km}$ in Hauptleitungen und $15000 \mathrm{~km}$ in den Verteilungsnetzen hatte man 1900 rund $45000 \mathrm{~km}$ Rohrnetze mit hohen Betriebsdrücken im Gebrauch $\left.{ }^{4.515}\right)$. M. Flürschei $m$, Gaggenau berichtete über Pläne, in Nordamerika Gaswerke auf Kohlengruben zu errichten und durch Fernleitungen das Gas in die Städte zu bringen $\left.{ }^{4.54}\right)$. Schon früher war Wilhelm S i e me ns wieder auf Gedanken der Gaserzeugung zurückgekommen. In einem Vortrag in Bradford am 30. September 1873 über die Schachtofengaserzeuger sagte $\left.\mathrm{er}^{4.545}\right)$ :

„Einer meiner Lieblingspläne, zu dessen Ausführung ich noch nicht gelangt bin, besteht darin, solche Gaserzeuger auf dem Grunde (d. h. in der Tiefe) der Kohlengruben zu erstellen. Das Gas würde dann einen solchen Auftrieb bekommen, dał es mehrere Meilen weit bis zu den Fabriken oder sonstigen Verbrauchstätten gefördert werden könnte. Wir würden dadurch in der Stand gesetzt werden, jene enormen Mengen von Kleinkohlen nutzbar zu machen, die jetzt ungenutzt in den Gruben liegen bleiben."

Wilhelm Siemens sprach 1882 diesen Gedanken erneut in der britischen Gesellschaft zur Förderung der Wissenschaften aus ${ }^{4.540}$ ). Mit Hinweis auf den Wert der Nebenprodukte, die damals auf Zechen nicht gewonnen wurden, trat das

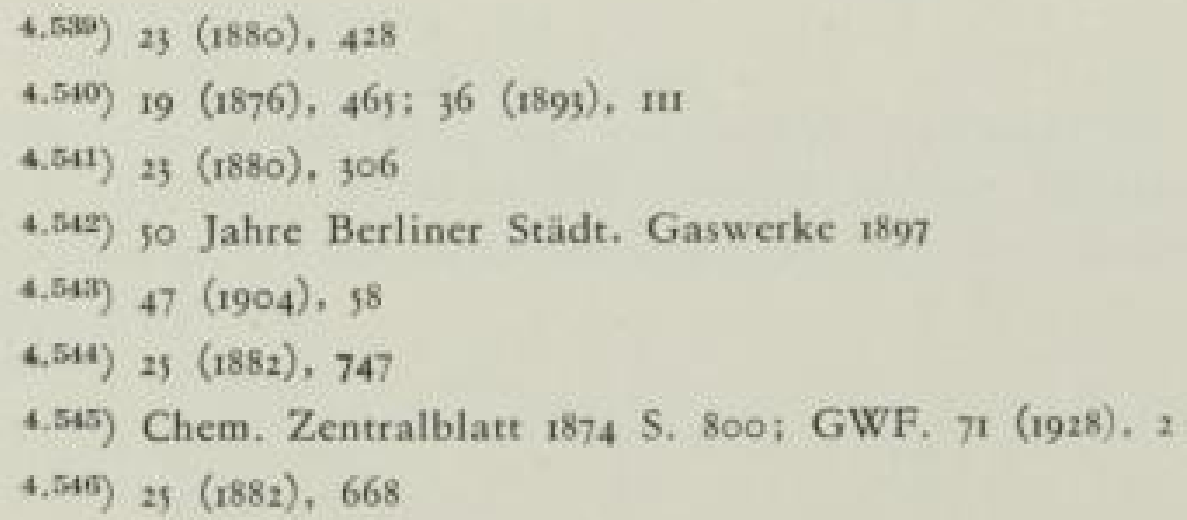


Journal diesem Gedanken entgegen ${ }^{4.567}$ ). Wahrscheinlich muf3 man es als einen Schaden ansehen, dał W. Siemens seinen Gedanken nicht weiter verfolgt hat, als die Rohrleitungstechnik und die Entwicklung der Gebläse schon so weit getrieben war, dał die technische Möglichkeit nicht zu bezweifeln war. Bei anderen schwierigen Ingenieuraufgaben hat Siemens soviel Können, Kraft und Zähigkeit bewiesen, daß man wohl glauben kann, er hätte auch auf dem Gebiete der Zechengasversorgung einen Erfolg erringen und damit eine ruhige Entwicklung frühzeitig einleiten können.

In London wurde eine Rohrleitung von $1828 \mathrm{~mm}$ Durchmesser und $45 \mathrm{~km}$ Länge verlegt $^{\text {t.5. }}$ ).

Um dieselbe Zeit tauchte auch in Deutschland ein Projekt auf, Gas auferhalb der Stadt zu erzeugen und mit einer Fernleitung nach Berlin zu schaffen. Es war das der Vorschlag von A. P ü $t s c b^{4,510}$ ), aus Braunkohle bei Fürstenwalde das Gas herzustellen, um es in Berlin zu verwenden (Vgl. S. 227).

Pütsch behauptete bereits um 1870 mit $Z i u r e k$ und Westphal ein solches Projekt bearbeitet zu haben. Es sollte ein Schachtofen mit Brand von oben nach unten nach schwedischem Vorbilde zur Vergasung dienen. Es sei auch ein Versuchsofen mit ro lotrechten Retorten mit schrägen Einfüll- und Abzapfstutzen betrieben worden. Das Gas sollte auf oberirdisch verlegten Leitungen von I250 $\mathrm{mm}$ Durchmesser mit $\mathrm{I} / 2$ atü nach Berlin gedrückt werden. In Berlin sollten grołe Behälter die gleichmäfjige Förderung möglich machen. Den Energiebedarf hatte Pütsch errechnet.

Die ersten deutschen nahtlosen Stahlflaschen für Hochdruckgase wurden von Mannesmann, Phönix und Rheinische Metallwarenfabrik für militärische Luftschiffahrt hergestellt ${ }^{4}$ ). $)$. Ähnliche Flaschen waren schon $\mathrm{I} 885$ im englischen Ägyptenfeldzuge und 1887 von Italien in Massaua verwendet worden.

\subsection{Gasbebälter}

Vorherrschend waren im ganzen Zeitabschnitt einfache oder teleskopierte nasse Behälter mit seitlichen Führungsgerüsten. $\mathrm{Ob}$ die Behälter durch Steinhäuser geschützt werden sollten oder frei stehen könnten, war eine Streitfrage, die in den ganzen Jahren nicht entschieden worden ist. Als 1896 der Entwurf für das große städtische Gaswerk in Wien von Sachverständigen begutachtet wurde, sprachen sich deren zwei für die Ummauerung, einer für freistehende Behälter aus. Je größzer die Behälter waren, umso mehr scheint man der Umbauung zugeneigt gewesen zu sein, um die ungewissen Winddrücke und die Schneebelastung aus der Berechnung auszuschalten. Man wollte nicht allein das Wasser vor dem Einfrieren bewahren, sondern auch die starke Abkühlung des Gases vermeiden, damit sich keine Kohlenwasserstoffe abschieden und die Leuchtkraft sank ${ }^{4.551}$ ).

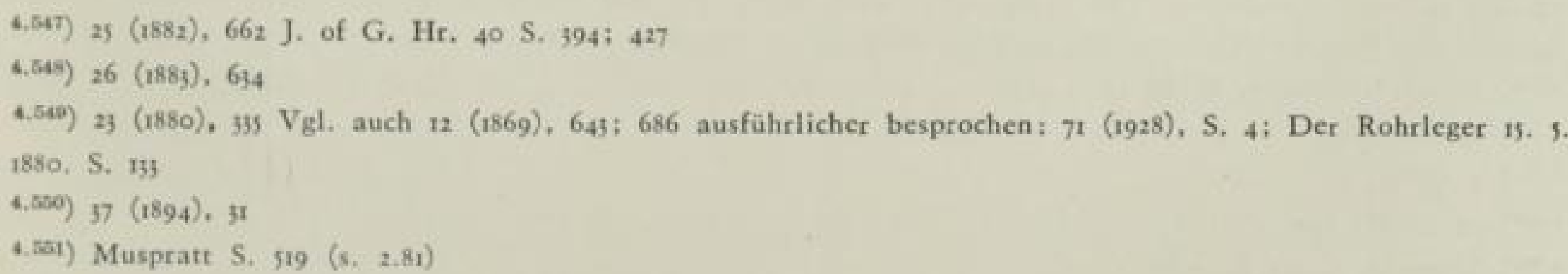


Die Warmwasserschwerkraftheizung für einen Behälter in Neuf wurde 1864 besonders vermerkt $\left.{ }^{4.552}\right)$. Dampfrohre nahe der Oberfläche des Wassers waren wohl allgemeiner angewandt.

Eine stetig fortschreitende, schöne Ingenieurarbeit ist die Vergrößzerung des einzelnen Behälters. I860 erbaute die Imperial Continental Gas Association in Ehrenfeld „ein leistungsfähiges Gaswerk“ für das die Kölnische Maschinenbau A. G. Köln-Bayenthal den Gasbehälter lieferte. Er faß̧te $\left.5500 \mathrm{~m}^{3}{ }^{3.53}\right)$.

I86r berichtete W. Oecbelbäuser aus England, dał die Behälter im Durchschnitt für ${ }_{14}$ bis $17000 \mathrm{~m}^{3}$ mit 34 bis $45 \mathrm{~m}$ Durchmesser teleskopiert gebaut seien. Der größte Behälter in England fałte damals $70000 \mathrm{~m}^{3}$ bei $60 \mathrm{~m}$ Durchmesser und $24 \mathrm{~m}$ Höhe. F. A. Ne um a n, Eschweiler zeigte 1867 an, dał er I30 Behälter und einzelne bis $36 \mathrm{~m}$ Durchmesser erbaut habe $\left.\mathrm{s}^{4.3 \mathrm{~A}}\right)$. 1869 wurde der Bau des damals und auch wohl heute noch größzten Einzelgaswerkes von Governor Be $c k$, Gas Light \& Coke Co., London, begonnen, das den Namen BecktonWerke erhielt $\left.{ }^{4.555}\right)$. Es erhielt ${ }_{4}$ Behälter von je $28000 \mathrm{~m}^{3}, 48 \mathrm{~m}$ Durchmesser, $18 \mathrm{~m}$ Höhe. Zusammen mit den bestehenden Behältern in den alten zum Teil stillgesetzten Werken hatte man $308000 \mathrm{~m}^{3}$ Speicherraum. Das waren $10 \%$ über die Erzeugungsmöglichkeit von $\left.280000 \mathrm{~m}^{3} / \mathrm{d}^{4,300}\right)$. Wegen der plötzlich eintretenden völlig dunklen Nebeltage wurden $100 \%$ der höchsten Tagesabgabe in London als Gesamtspeicherraum für notwendig gehalten. In Deutschland nahm man damals nur $\left.50 \% 0^{4.57}\right)$.

1886 wurde von der Imperial Continental Gas Association in Wien im Gaswerk Erdberg ein Behälter von $100600 \mathrm{~m}^{3}$ Inhalt erbaut. Er war der gröfte auf dem Kontinent. In England war man damals schon auf $234000 \mathrm{~m}^{3}$ gekommen $^{4.555}$ ).

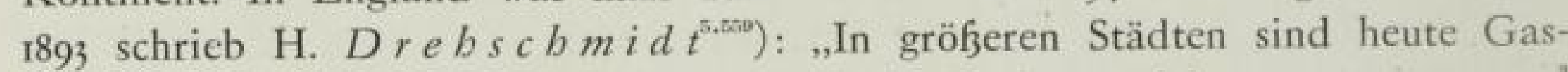
behälter von $30000 \mathrm{~m}^{3}$ gebräuchlich, in Berlin neuerdings solche von $80-90000 \mathrm{~m}^{n}$ und in Greenwich (South Metr. Gas Comp.) ist ein sechsteiliger Teleskopbehälter gebaut worden, der 91 $\mathrm{m}$ Durchmesser, $9 \mathrm{~m}$ Tiefe und $340000 \mathrm{~m}^{3}$ Inhalt hat." Beim Neubau des städtischen Gaswerkes Simmering in Wien wurden 4 Behälter mit doppelter Teleskopierung von je $90000 \mathrm{~m}^{3}$ mit $60 \mathrm{~m}$ Durchmesser, 33,6 m Höhe gewählt. Erbauer waren mit Jg. Gridl, Wien als Hauptunternehmer; R. Th. W a agner, Wien; Bamag, Berlin; Kölnische Maschinenbau A. G. Köln-Bayenthal; Dampfkessel und Gasometerfabrik vorm. A. Wilke \& Co., Braunschweig und F. A. Neuman, Eschweiler. Die Gesamptspeichermenge von

\footnotetext{
4.525) $7(1864), 318$

4.559) Die Kölnische Maschinenbau A. G. wurde 1855 auf Betreiben des Industriellen Gustav Mevissen als Leiter der Rheinischen Eisenbahn gegründet. Mit W. Oechelhäuser und der Deutschen Continental- GasGesellschaft wurden von ihe Behalter und Apparate für den Gasanstaltsbetrieb entwickelt, 1900 nahm dic Gesellschaft Fuhlung mir der Bamag. 1909 erfolgte die Fusion beider Gesellschaften. (100 Jahre Bamag KölnBasenthal: Pintsch-Bamag A.-G. (ohne Datum und Ort) S, 10-11 und Gas-Elektrizitats- unc Wasserwerke der Stadt Koln. Zur 1900 Jahrfeier der Stadt Kön. S. 33.)

4.jus Die Firma F, A. Neuman war 1833 als Kupferschmiede gegründet. Sie lieferte ihren ersten Gasbehälter an die Imperial Continental Gas Association nach Köln. Ab 1867 wurde durch die zweite Generation der Besitzer der Behälterbau besonders gepflegt (Anzeige in Leipziger Illustrierte t912 ",100 Jahre Gas").

4.505) Everard, Stirling. S. 235 (s. 2.42)

4.556) 14 (1871), 198

$4.557)_{4}(1861), 31$

4.55is) 29 (1886), 692

4. 359) Muspratt S. 519 (s. 2.81 )

258
}

\section{SLUB}


$360000 \mathrm{~m}^{\mathrm{A}}$ entsprach $72 \%$ der höchsten Erzeugung von $\left.500000 \mathrm{~m}^{34+500}\right)$. I905 erhielt der größte Behälter in Berlin-Mariendorf $150000 \mathrm{~m}^{3 \text { t.5an }}$ ) (Erbauer: Bamag, Berlin. Der Behälter wurde ohne Ummauerung ausgeführt), I912 erhielt Hamburg einen Behälter von $200000 \mathrm{~m}^{3}$ Inhalt, den F. A. Neuman, Eschweiler gebaut hat $\left.{ }^{\text {t.nen }}\right)$.

Für den Ingenieur besonders anregend sind die Beschreibungen über die Ausführung der Ummauerung mit gleichzeitigem Hochwinden der vorher fertiggestellten Kuppel, nach dem Verfahren von $S c b w e d l e r$, Berlin. Sie finden sich in: so Jahre Berliner städtische Gaswerke für das Jahr 1888 und auch in der Druckschrift über die Erbauung der Wiener städtischen Werke, to Jahre später. In beiden Fällen war Zeitmangel besonders drückend und dem wurde das Verfahren gerecht.

Die Behältertassen wurden meist aus Ziegelmauerwerk mit rauhen gut gebrannten Steinen und Zement ausgeführt. Kleinere führte man auch aus Schmiedeeisenblech oder gar noch Guß̧eisen aus. Das Gewicht der grof̧en Wassermenge, die Uberschwemmungsgefahr bei Bauten oberhalb des Bodens und die Dichtigkeit machten oft große Sorgen. Die Tragik beim Tode des Konstanzer Gaswerksleiters Raupp wurde bereits erwähnt (S. 171). Trotzdem entbehrt in der Rückschau dic wütende Pressefehde über die statische Berechnung zwischen A. $M o b r$, Dessau und F. Le b m a n n. Breslau im Jahre 1867 , die sich durch den ganzen Band des Journals für Gasbeleuchtung hinzieht, nicht eines humorvollen Einschlages. Es war wirklich frisches Draufgängertum der damaligen Ingenieure, wenn sie sich um sachliche Fragen persönlich so scharf in die Haare bekamen. Reizvoll ist dabei noch, dafz 25 Jahre später, wie wir noch sehen werden, um die Behälterführungen erneut ein ähnlicher persönlicher Krieg entbrannte.

Betontassen sind zuerst in England bei der South Metropolitan Gas Co. und in Beckton von der Gas Light \& Coke Co. ausgeführt worden $\left.{ }^{4.5 a i}\right)$. Bis 1893 sind sie aber nur bei Behältern mittlerer Größje angewandt worden $\left.{ }^{4.5 a t}\right)$. Eine eigenartige Form und deshalb viel erörtert, besaf̧ der von Prof. O. Intze, Aachen entwickelte Blechbehälter, den dieser vor allem bei Wasserwerken angewandt hat. Ausschaltung horizontaler Kraftkomponenten auf das Fundament, der schmale Ring als Fundamentlinie und der freie Raum unterhalb der Tasse, der als Speicher benutzt werden kann, wurden als Hauptvorzug geltend gemacht. Die Bauart stammte aus dem Jahre $1884^{4.505}$ ). Der größzte Behälter dieser Art ist in dem Gaswerk von Friedr. Krupp in Essen mit $37000 \mathrm{~m}^{\text {s }}$ Inhalt erbaut worden $\left.^{4.500}\right)$. Das Patent wurde durch andere Konstruktionen umgangen. A. $K l \ddot{o} n$ ne baute die Jenaer Form. Ein Prozeł gegen Bamag ging für Intze verloren ${ }^{4.507}$ ) In einem Vortrage regte Servier $\left.r^{\text {t.ses }}\right)$ damals schon den Bau von Hochdruck-

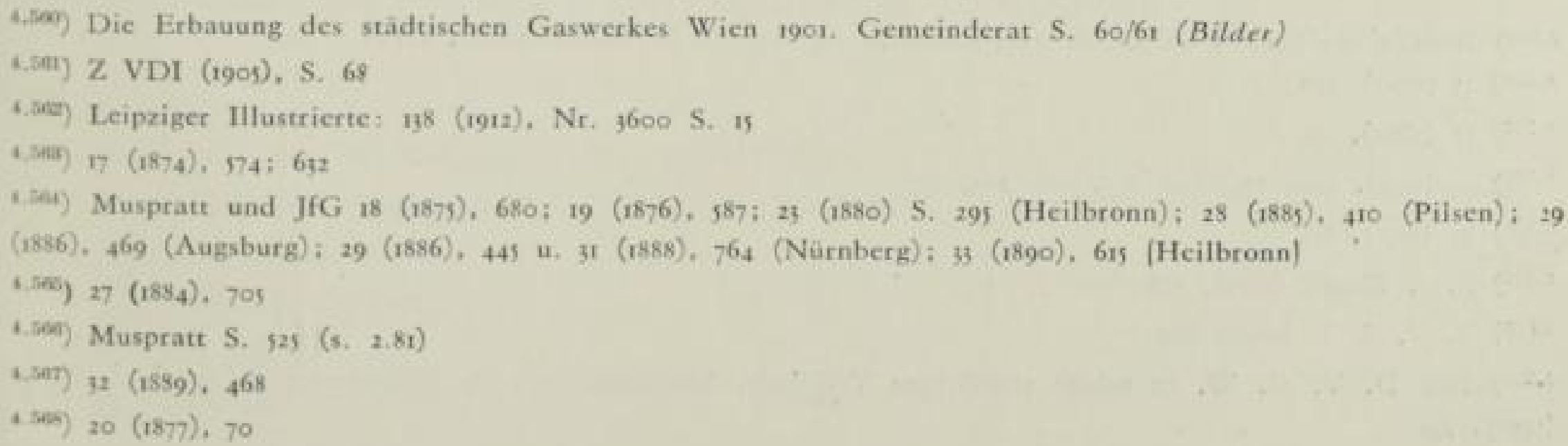


behältern für Spitzen an, wobei ein hoher Druck die Leistungsfähigkeit der Rohrleitungen günstig steigern könne.

$\mathrm{Zu}$ den ursprünglich nur radialen Führungen der Glocken traten ab 1877 auch tangentiale $\left.{ }^{4.56 e}\right)$. Nach Anregungen von Re is sn e r, städt. Gaswerk Müllerstr., Berlin und Angaben von Schwedler aus dem Jahre 1887, hat die Bamag den ersten Behälter mit tangentialer Führung 1888 erbaut. 1890 wurde ein gleicher für Gaswerk Halle geliefert $\left.{ }^{4.570}\right)$. Uber die Zweckmäfigkeit der tangentialen Führung kam es zu einem heftigen Streit zwischen M. N i e mann, Dessau und Prof. P. Pfeifer, Braunschweig, der sich auch unter Hinweis auf die Winterkälte in Chicago, wo freie Behälter standen, gegen die Umbauung aussprach ${ }^{4.571}$ ). In einer langen Aufsatzreihe $\left.{ }^{4.572}\right)$ zur Gasbehälterbauweise sagte Niemann: In früheren Jahren hätte man sich damit begnügt, an freistehenden Behältern eine kleine Anzahl von hölzernen und guf̧eisernen Böcken aufzustellen. Eine Verbindung oben wäre selten gewesen. An den Böcken wären Eisenbahnschienen befestigt gewesen, auf denen die Rollen liefen. Es wäre allgemein üblich gewesen, Spielräume bis zu 25 , ja $40 \mathrm{~mm}$ zu geben. Glocken hätten oft nur oben Rollen, unten lediglich Schleifen zur Gleitführung gehabt. Die Rollen wären oft nur am dünnen Mantel befestigt gewesen. Die Einteilung des Stützpolygons des Deckels, der Mantelstützen und Führungsschienen sei oft nicht die gleiche gewesen. Man hätte nicht die Kräfte von Wind und Schneelast geahnt. Daher wären oft Entgleisungen als etwas Selbstverständliches hingenommen worden. (Hase) ${ }^{1.573}$ ). Einen grundsätzlichen Umschwung hätten Erfahrungen mit Teleskopen gebracht. Bei gleicher Höhe der Schüsse steige das Windmoment etwa mit dem Quadrate der Schufzzahl. Selbst im Handbuche der Gastechnik von Schilling 3. Auflage sei keine statische Berechnung gegeben. Diese hätten zuerst Prof. Mela $\left.n^{4.55 t}\right)$ und ein Jahr später Prof. Intz $\left.e^{4.575}\right)$ ausgearbeitet und neuerdings Prof. $P$ feifer. Aber es herrschte noch sehr viel Unklarheit über die wirkliche Lastverteilung. Versuche an Modellen mit gegengeschleudertem Sand, Zugkräften usw, seien alle unvollkommen, da die wirklichen Verhältnisse nicht getroffen würden. Die Verspannungen seien nicht genau bekannt. Niemann gab dann seine eigenen Gedanken bekannt und sprach sich noch einmal für die Radialführung aus. Er lehne die Tangentialführung nicht ab, aber sie sei meist unnötig.

Der neugegründete Verein deutscher Gasbehälterfabrikanten regte die Aufstellung von gemeinsamen Grundlagen oder Vorschriften für die technische Ausführung und Lieferung von Gasbehältern $\left.a^{4.578}\right)$. Die Forderungen würden oft bei Anfragen unnötig hochgeschraubt. Unter gleichen Lagebedingungen wäre nicht unmöglich, dał die zugrunde gelegten Windgeschwindigkeiten um $100 \%$

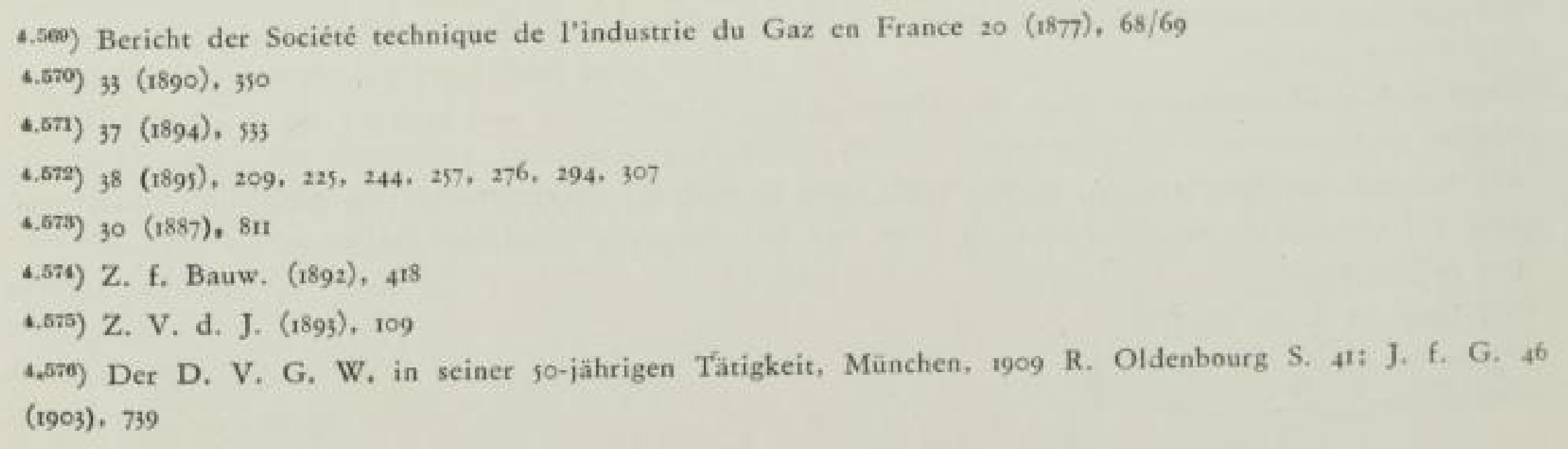


verschieden seien $\left.{ }^{4.377}\right)$. Ab 1898 bearbeitete ein Vereinsausschuí diese Fragen mit dem Gasbehältervercin. Seine Vorschläge wurden auf der Hauptversammlung 1903 in Zürich genehmigt und den Mitgliedern als Grundlagen empfohlen ${ }^{4.670}$ ).

Der erste spiralgeführte Behälter mit um $45^{\circ}$ geneigten Schienen an der Tassenwand ist 1888 von $G$ add und $M$ a so $n^{4.575}$ ), Northwich in Chester aufgestellt worden. An ihm brachen 1897 einige Nieten der Führungsschienen. Diese wurden dann auf ein $300 \mathrm{~mm}$ bereites Verstärkungsband im Mantel gesetzt.

Um die schwierig zu erfassenden Verspannungskräfte ganz auszuschalten, verbesserte O. Intze die Patente von E. L. Pe as $e^{4.577}$ ) in England, der 1887 die Glocke in Seilen aufgehängt hatte ${ }^{4.500}$ ) (Bild 63). Das blieb ebenso wenig erfolgreich, wie die Behälter mit Mittelführung ${ }^{4.051}$ ) oder der Gasbehältereingang und Ausgang von Pauwels (Bild 64).

Bild 63

Seilgeführte

Behälterglocke von Intze

(Muspratt, S. 532)

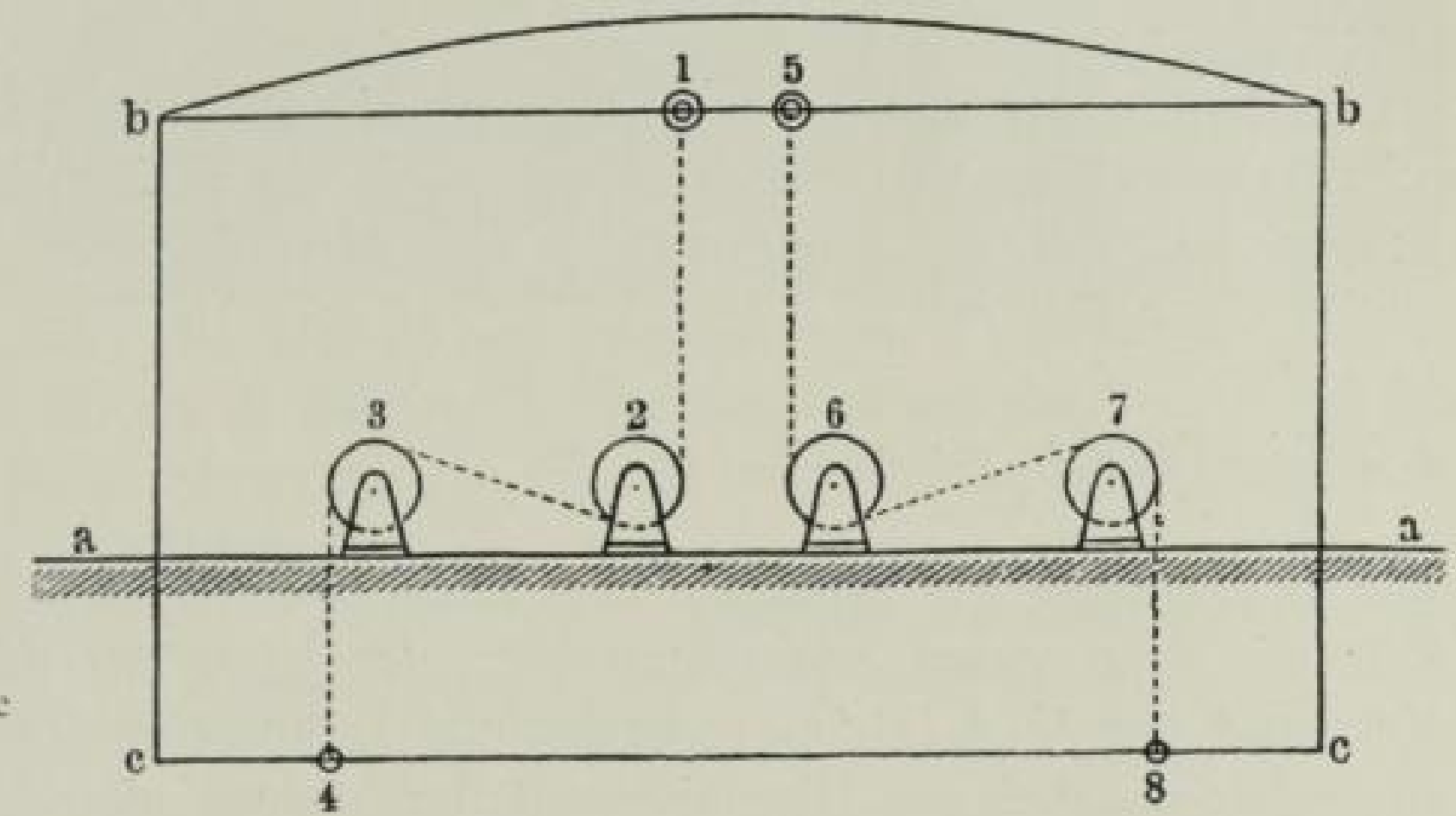

Die Aufstellung von Gasbehältern in Brennpunkten des Rohrnetzes ergab sich von selbst mit der Stillegung veralteter und im inzwischen herumgewachsenen Stadtgebiete störender Werke. Dabei kamen auch die ersten nicht von Abnehmern angezapften Verbindungsleitungen mit einem Druck von mehreren $100 \mathrm{~mm}$ WS auf.

Als Ersterscheinung auf dem wirtschaftlich wichtigen Gebiete mag noch die Studie über die Anpassung der Behältergrößze beim Bau an die jährliche Wachstumziffer festgehalten werden.589), schon weil gerade solche "Marktanalysen“" heute vielfach als etwas ganz neues herausgestrichen werden.

Auch die Tatsache, daf schon 1886 Horn, Regensburg, ein rühriger Fachmann, die Mängel des üblichen Teeranstriches von Behältern kennzeichnete, sollte nicht vergessen werden. Horn wies auf die Erhärtung des Teeres mit Brüchen und Korrosionen in den Rissen hin, aber auch auf die starke Wärmeaufnahme durch Sonnenstrahlen. Er empfahl teure Platinfarben vorzuziehen ${ }^{4.58}$ ).

(..57) $40(1897), 332$

4.675) Z. V. D. I. 1893 Nr. 38 u. 39; J. f. G. $33(1890), 604$

c.570) 33 (1890), 288; 36 (1893), 560

$4.650) 36(1893) 184 ; 291 ; 362$

4.5ea) Polyt. Centralblatt (1866), 73

4.689) $30(1887), 346$

(.685) 29 (1886), 443 


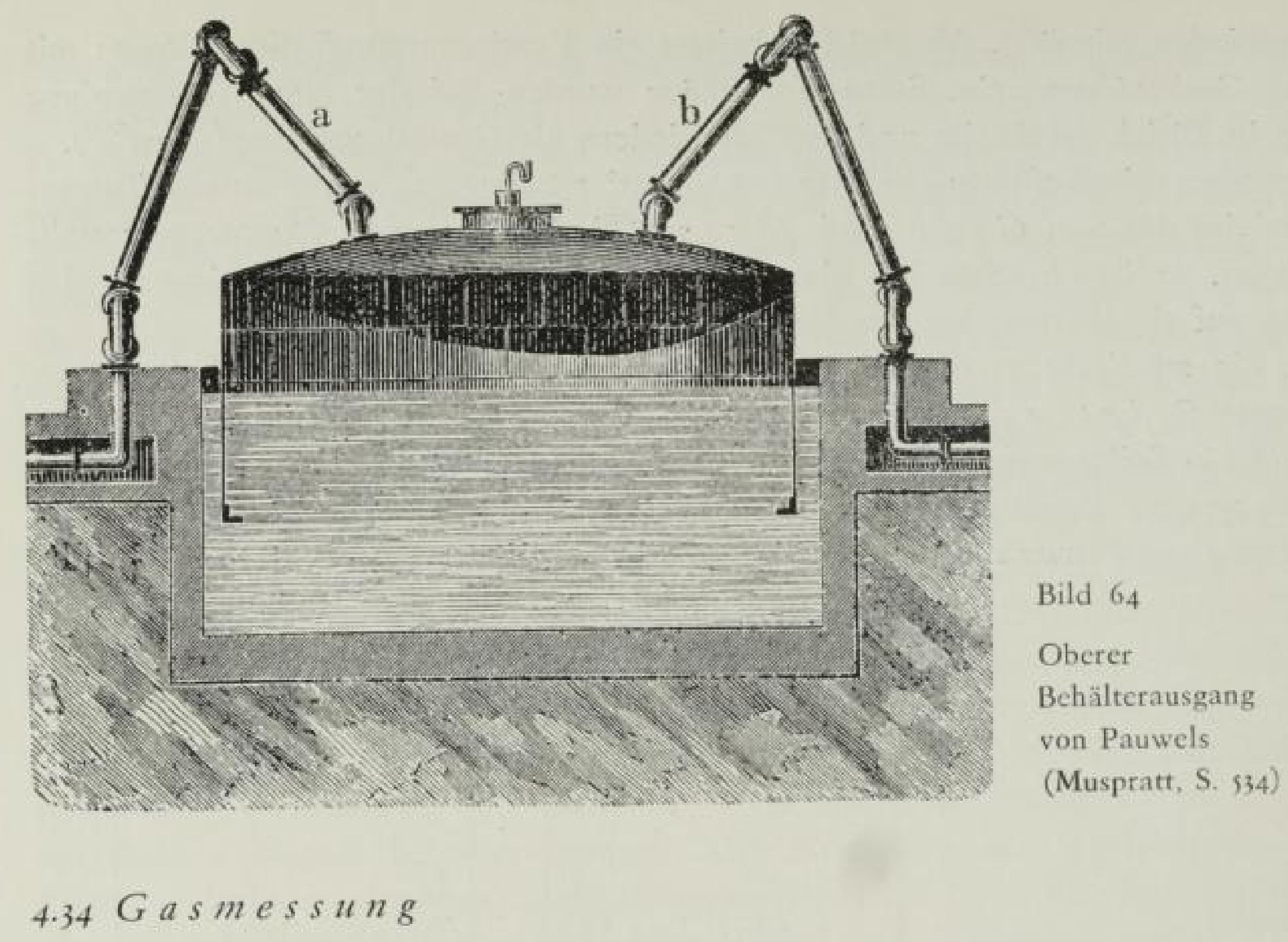

Die Bestimmung der erzeugten Gasmenge geschah in der ganzen betrachteten Zeit mit dem nassen Stationsgaszähler, der kaum verändert worden ist. Der Vorschlag von G. Live sey wechselnde Temperaturen am Gaszähler dadurch auszugleichen, dał das Überlaufventil durch einen wärmeempfindlichen Regler in der Höhe verschoben wurde, hat keine allgemeine Bedeutung erlangt ${ }^{4.44}$ ).

Bei Hausgaszählern war ein lebhafter Wettbewerb zwischen dem nassen und trockenen Messer, der mit steigender Zuverlässigkeit immer mehr Freunde gewann. In den ersten Eichordnungen, die überall fast gleichzeitig um 1860 herum erlassen wurden, waren zunächst nur nasse Zähler zugelassen.

Die preussische Verfügung Betr. Prüfung und Stempelung von Mał̧en u. Gewichten vom 13. 5. 1840 wurde 1893 auf Gasmesser ausgedehnt. Die Zählung in preussischen Kubikfuß wurde vorgeschrieben, die Eichgrenzen $\pm 2 \%$. Die Ordnung enthielt auch eine Anleitung zum Verfahren mit dem Kubizierapparat und dessen genaue Beschreibung $\left.{ }^{4.555}\right)$. Die englische Eichordnung vom 13. 8. 1859 erlaubte als Grenzen $\left.+2-3^{4.589}\right)$. Mit den sächsischen Eichgesetzen wurden nur sächs. Kubikfuf zugelassen. Für trockene Messer blieben Bestimmungen vorbehalten ${ }^{4.557}$ ). Die allgemeine Instruktion (Ausführungsanleitung) folgte erst $\left.1860^{4,558}\right)$ mit Eichgrenzen von $+1-2 \%$.

In Belgien stellte eine Präambel (1o. 5. 1859) fest, daf̧ die Mehrzahl der Messer aus Deutschland stamme und in (engl.) Kubikfuf messe. Die Imperial Continental Gas Co. gäbe nur solche Messer heraus und nur wenige Abnehmer seien in

\footnotetext{
4.584) $40(1897), 253$

$4.585)=(1859), 276 ; 285$

$4.556)=(1859), 344$

4.587) $3(1860), 8$

4.588) $3(1860), 83$
} 
der Lage, sich die Menge vorzustellen. Sie verlangte daher das metrische System. Der Kubizierapparat zur Prüfung wird danach allerdings in einem Rückfall in Altgewohntes mit is Kubikfuß̧ Inhalt angegeben. Die Genauigkeit, mit $\pm 1 \%$ verlangt, kann man auch wohl als unverständig scharf ansehen $\left.{ }^{4.505}\right)$. In Hannover zählten gemäf̧ Eichordinung von $1860^{4.500}$ ) die Messer in englischen Mafzen, während das Land sonst einen um etwa $10 \%$ höheren Kubikfuß benutzt hat. Genauigkeit $2 \%$. In Bayern schlof die Eichordnung von $183^{4.591}$ ) trockene Messer aus. Das war also ein Spiegelbild der Kleinstaaterei, die den Werksvergleich, der schon damals versucht worden ist, keineswegs erleichtert hat. Das im Norddeutschen Bunde 1868 aufgenommene metrische System brachte zunächst keine Besserung $\left.{ }^{4.000}\right)$.

Die Füllung der nassen Zähler war Anlał zu Freuden und Leiden. Zahlreich waren die Patente über Gasmesser mit konstantem Wasserstand $\left.{ }^{4.5 n g}\right)$. Die Mehrzahl der Bauarten zeichnete sich durch arg verwickelte Anordnungen aus $\left.{ }^{4 \mathrm{sin}}\right)$. Mit der „schwimmenden Trommel ${ }^{4,45}$ ) hat sich G. Kromscbröder den Beginn des Gaszählerbaues nach englischen Vorbildern trotz seiner sauberen Arbeit in Deutschland recht erschwert ${ }^{\text {t.timit }}$ ). Seine neue Bauart mit vergrößzertem Schwimmer erfüllte „fast” die gesetzlichen Bestimmungen ${ }^{\text {t.s7 }}$ ). Günstig beurteilt wurde der Zähler von Cowan \& Warner ${ }^{4,5 a 9}$ ). Bei ihm war auf der Trommelwelle eine zweite kleinere Trommel angebracht, die das bei zu geringem Wasserstande zuviel geförderte Gas zurückbeförderte.

Um Einfrierungen zu vermeiden, wurde die Glyzerinfüllung aufgenommen ${ }^{4.5 n o n}$ ). Es war aber schwierig, im Handel reines Glyzerin zu erhalten. Unrein griff es Britanniametalltrommeln an. In Görlitz verwandte man daher einfaches Weifblech für die Trommeln, das bei Wasser wegen Verrostung ausgeschaltet gewesen war $\left.{ }^{\text {t.000 }}\right)$. Seit 1877 versuchte man Chlormagnesiumlauge, die anfangs sehr gut beurteilt wurde $\left.{ }^{4, \text { s.11 }}\right)$. Die Deutsche Continental Gas-Gesellschaft stellte zeitweilig alle Zähler auf diese Flüssigkeit um. Es stellte sich aber heraus, dał die Lauge bei vielen Gassorten nicht brauchbar war. ${ }^{4.00 \%}$ ), vor allem, wenn das Gas schlecht gereinigt und ammoniakhaltig war. $\left.{ }^{4.000}\right)$.

Alle diese Schwierigkeiten vermieden die trockenen Gaszähler. Ihre Schwäche lag weniger in dem Aufbau, der 1860 schon ausgereift war, als in der Auswahl

4.550) $2(1859)$. S. 292

$4.600),(1860), 8 \mathrm{I}$

(.601) 6 (1863). 355

(..502) In (1868), 3/2

$4.583) 4(1861), 289 / 93$

(.689) 4 (1861), 36

t.ans) Die schwimmende Trommel hatte schon Clegg angewandt, aber auch er hatte mechanische Schwierigkeiten 1 (1888) S. 86; Schilling Handbuch für Steinkohlengasbeleuchtung München 186c R. Oldenbourg.

4.006) 9 (1866), 303/309:374

(.507) $9(1866), 463$

4.695) 18 (1875), 494: Muspratt S. 579 (s. 2.8t) ; J. f. G. 36 (1893) 672

. 1.000) 3 (1860), 33; n (1868) S. 441

$(.600) 8(1867), 112 ; 226$

(.001) 27 (1884), 107:34 (1891), 359

(.602) 38 (1895), 663

(..000) Drehschmidt im Muspratt S. 578 (s. 2.81) 
der Leder und dem Metall der Schieber. So ist ein Urteil Scbilling $\left.s^{4.004}\right)$ zu verstehen: „Wenn in England noch trockene Uhren in ausgedehntem Mafze in Gebrauch sein sollten, so werden sie wahrscheinlich nach und nach wieder verschwinden". Aber er selbst schwächte sein Urteil to Zeilen weiter wieder ab: „Ihre Konstruktion ist ohne Zweifel äußerst sinnreich, und es ist durchaus nicht gesagt, daf̧ nicht die Zukunft imstande sein werde, die gegenwärtigen Schwierigkeiten zu überwinden". Auch W. Oecbelbäuser drückte sich in seinem Reiseberichte vorsichtig aus: „Trockene Zähler von Glover wurden nicht ganz verworfen $\left.{ }^{(4.000}\right)$. Bei Dauerbetrieb befriedigten sie schon in Schottland, aber bei längeren Unterbrechungen gab es trockene Balgen und Absetzungen auf den Schieberflächen. Man stellte Gebrauchsfehler von $25-30 \%$ fest $\left.{ }^{4,005}\right)$. Auch in England meinte J. $R o b b$ aus Haddington noch 1868 , daf trockene Messer auf die Dauer nicht zuverlässig seien $\left.{ }^{4.60 m}\right)$. In diesem Jahre aber bot Thomas $G$ lo ve r seine Messer in Deutschland an $\left.{ }^{4.005}\right)$. G. Kromscbröder klärte die deutschen Fachleute auf, indem er über Gasmesserleder und die Anforderungen 1867 sprach $\left.^{4.000}\right)$. Ihm war es 1870 gelungen, die trockenen Messer als eichfähig durchzusetzen $\left.{ }^{4.610}\right)$. Thorn, das von einem sehr kritischen Ingenieur geleitet wurde, kaufte 1879 nur noch trockene Messer dieser Firma ${ }^{4.61}$ ). In den Jahren 1888/1890 wurden zunächst von 6 Werken Dauerversuche vorgenommen ${ }^{4,612}$ ), die von 4 Werken zu Ende geführt wurden. Die Auswertung der Versuche ist leider nicht veröffentlicht worden, sie hat wohl die Gasmesserkommission und die NormalEichungskommission beschäftigt. Noch immer kam es zur Schrumpfung der Leder, die auf schlechte Tränkung zurückgeführt wurde. Vorsichtige Fühler, ob man die Fehlergrenzen der trockenen Messer als Ausnahme erweitern sollte, wurden abgelehnt ${ }^{\text {. }}{ }^{\text {is }}$ ). Über den Stand aller Zählerkonstruktionen hat Dr. Ho m a $n$ n von der Normal-Eichungskommission ein anschauliches Bild 1893 gegeben, der leider seines Umfanges wegen hier nicht aufgenommen werden kann. Homann billigte dem trockenen Zähler besondere Vorzüge $\mathrm{zu}^{4.614}$ ). Das neue Gaswerk in Harburg, das 1896 gebaut wurde, sah fast ausschlieflich trockene Zähler vor. 1897 nahm die Gasmesserfabrik Mainz, Elster \& Co., die Firma Haas in sich auf und baute nun auch trockene Zähler in Mainz und in Berlin.

Eichzahlen sind 1895 veröffentlicht worden und geben ein gutes Bild über die Verteilung (Tafel I).

Aufyerhalb Berlins wurden also gegen Ende des Jahrhunderts mehr trockene als nasse Zähler geeicht. Man muf dabei beachten, dał die Imperial Continental Gas Association ihre eigene Gasmesserfabrik hatte, die nasse Messer herstellte.

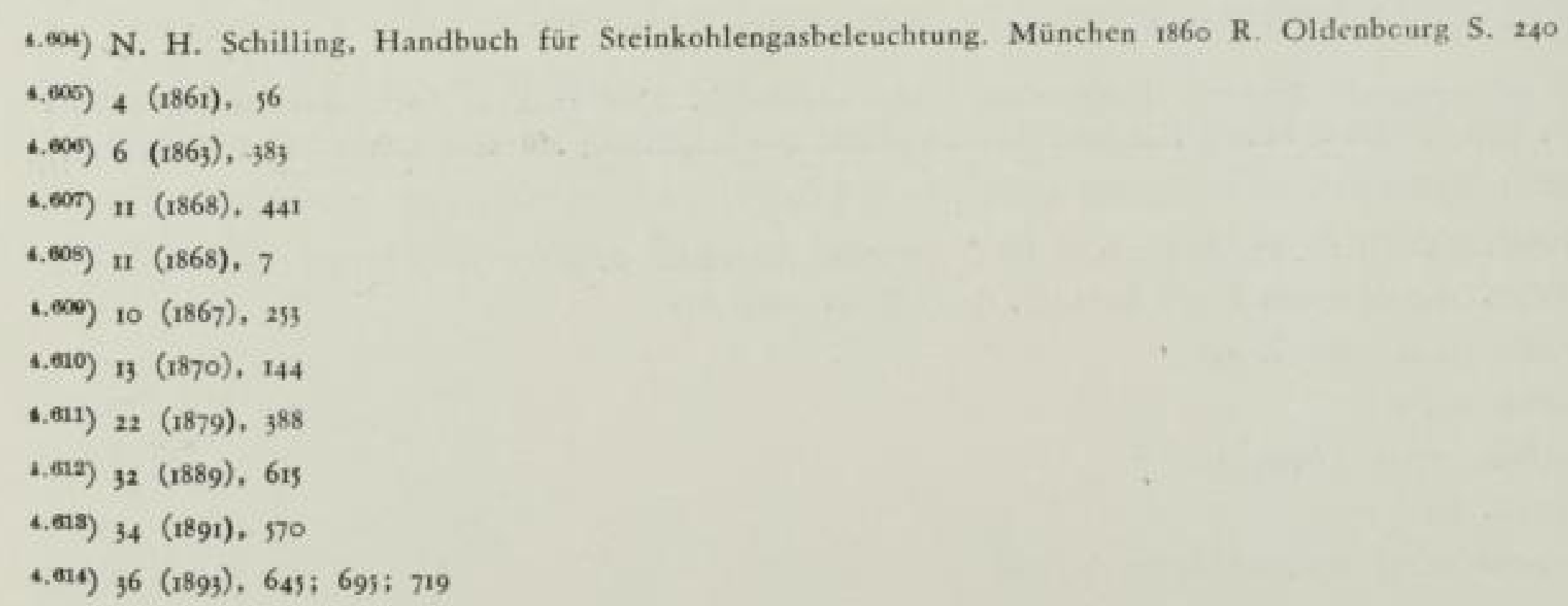


Tafel 1: Zahl der Eichungen für 1885-1895 in 1000 Stück jährlich

\begin{tabular}{|c|c|r|r|r|}
\hline \multicolumn{3}{|c|}{ Insgesame in Deutschland } & \multicolumn{2}{|c|}{ in Berlin } \\
\hline & nasse Zahler & trockene Zihler & nasse Zihler & trockene Zahler \\
\hline 1885 & 20,5 & 9,4 & 9,4 & 0,3 \\
1892 & 36,1 & 17,2 & 17,5 & 0,9 \\
1893 & 43 & 23 & 22,6 & 1,1 \\
1894 & 43,9 & 27,4 & 23,3 & 1,5 \\
1895 & 64,8 & 38 & 39,7 & 2,0 \\
\hline
\end{tabular}

Eine Sonderbauart, die zunächst mit viel Freude aufgenommen wurde, stellten die Zähler mit Doppelzählwerk dar. Der Wunsch, das Heiz-, Koch- und Kraftgas verbilligt abzugeben, hatte I88० P. W y $b a u w$, Brüssel zu dieser Bauart geführt ${ }^{\text {t.015}}$ ). Die Umschaltung der Zählwerke geschah auf zweierlei Weise. Am meisten wurden Druckwellen benutzt, am Abend die "natürliche“ Druckerhöhung zur Befriedigung der Leuchtgasbelastung, am Morgen eine echte Druckwelle. Das Tageszählwerk lief durch, die Nachtgaszählung wurde mit einem zweiten Zählwerk zugeschaltet. Der Preis war für Tagesgas auf ro cts, für Nachtgas auf 20 cts festgesetzt, wodurch sich mit dem einfachen Verhältnis von 1 : 2, gleiche Zählwerke ergaben. (Bild 65)

Eine andere Bauart für Netze, wo Druckwellen unmöglich waren, hatte zwei Abgänge, so dał Kochgas und Leuchtgas getrennt gemessen wurde. In Brüssel standen 1886 an solchen Zählern 2840 Stück ${ }^{4.016}$ ). Die eichamtliche Zulassung bereitete keine Schwierigkeiten. Eine Umgehung der Wybauwschen Bauart war der Zwillingsmesser von Guillaume \& Co., Köln. Eine eingehende Beschreibung des Umschaltwerkes findet man im Journal ${ }^{4,{ }^{a n 1}}$ ). Sämtliche Berliner Gaswerke lehnten indessen die Doppelzäh/werksmesser ab, einmal aus Bedenken gegen die Bauart, dann aber auch weil man die Gasverbilligung nicht von der Tageszeit abhängig machen wollte. Kochgas wurde dort auch abends verbraucht. Die Verbindung des Doppelzählwerkes mit einer Schaltuhr hat sich nur in Quedlinburg ${ }^{4.615}$ eingeführt.

Sehr lebhafte Auseinandersetzungen riefen die Automaten, auch Gasmesser mit Vorausbezahlung oder in Holland gleich zu Anfang Münzgaszähler genannt, hervor. Das erste Patent in England 1887 haben W. E. Price und R. W. Brownbill genommen. 1892 wurde ein Patent von $Z$ abrtmann, Kopenhagen leider schlecht erklärt, als selbsttätiger Gasverkäufer beschrieben ${ }^{4.619}$ ). Erfolgsnachrichten kamen aus England: In Liverpool hatte man I890 100 Automaten, I892 4000; I895 12000 . Die South Metropolitan Gas Co. hatte bis 18936000 Stück aufgestellt $\left.{ }^{1.00}\right)$. 1896 standen in England 250000 Atomaten. „Die grofartige Vermehrung der Abnehmerzahl war aber noch lange nicht abgeschlossen $\left.{ }^{4, \ldots+6 z}\right)$. Von

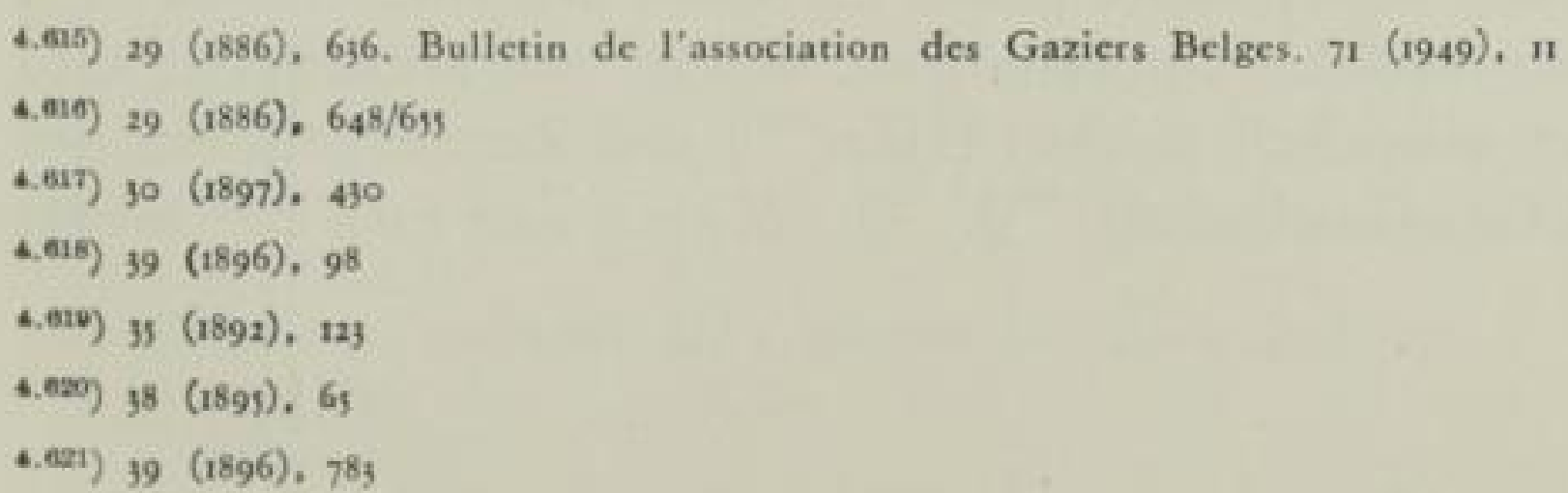




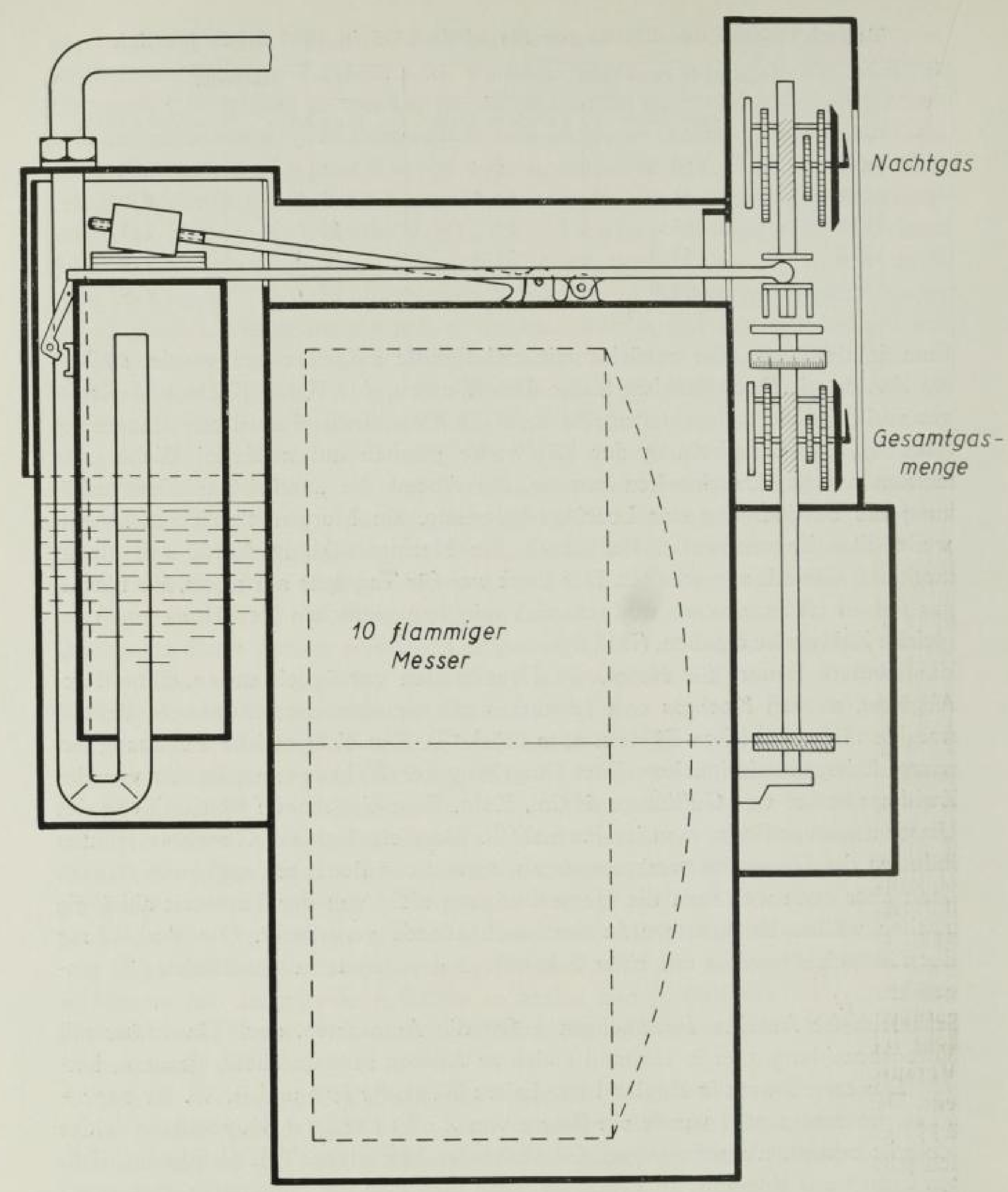

Bild 6s Doppelzählwerk von Pierre Wybaux

einem ungenannten Engländer wurde gesagt: „Der Vorauszahlungsmesser hat

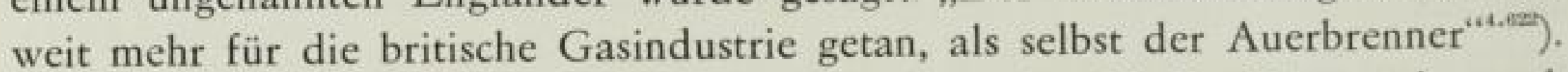
In Deutschland war man zunächst zurückhaltend, obwohl dic Münzwerke auch hier von den Herstellern entwickelt wurden [Haas ${ }^{4.025}$ ) und Zentralwerkstatt der Deutschen Continental-Gas-Gesellschaft $\left.\left.{ }^{t, 024}\right)\right]$. G. Kromschröder erwar-

$4.622) 40(1897), 233$

(.029) 38 (1895), 473

4. (29) 38 (1895), 648 
tete zunächst viele Störungen und Streitfälle $\left.{ }^{t * s}\right)$. M. Bessin, damals bei S. Elster, sprach vorsichtig abwägend, aber keineswegs ablehnend $\left.{ }^{4-50}\right)$. Er stellte fest, dał Süddeutschland sehr dafür eingenommen sei, Mitteldeutschland dagegen und der baltische Verein geteilter Meinung ${ }^{4.627}$ ). Dabei spielte die Koppelung der Münzgaszähleraufstellung mit den vorgelegten und im Gaspreise abzuzahlenden Installationskosten eine besondere Rolle. Die deutsche Arbeiterschaft wechselte ihre Wohnungen öfter als die englische. Aber gerade sie wollte F. Reicbard, Karlsruhe, erfassen, weil er feststellte, dafy Gas bisher in Wohnungen bis zu 300 M Jahresmiete keinen Eingang fand ${ }^{4005}$ ). Als die Imperial Continental Gas Association die Automaten in Berlin einführen wollte, erhoben die städtischen Werke Einspruch wegen Verletzung des Preisabikommens ${ }^{402}$ ). Während die Eichbehörden in Frankreich, Italien, Belgien und Holland keine Schwierigkeiten machten, überlegte und prüfte die deutsche Behörde sehr lange und lief̧ erst 1896 einige Ausführungen zunächst probeweise $\left.z^{4{ }^{4.39}}\right)$. Zwei Jahre später waren in Deutschland bereits elf verschiedene Bauarten am Markte ${ }^{4, \mathrm{san}}$ ). Am meisten wurde der bei der Deutschen Continental-Gas-Gesellschaft entwickelte Münzgasmesser verwendet. W. v. Oechelbaeuser betonte aber, dał̧ die Verzögerung durch die Eichbehörde keinen Schaden angerichtet habe, weil damit die ersten unvollkommenen Bauarten nicht benutzt worden seien ${ }^{4.620}$ ). Immerhin kam man nach der Zulassung zunächst nur langsam mit der Ausbreitung voran, da die inzwischen eingetretene gute Wirtschaftslage schon im üblichen Anschlußggeschäft alle Kräfte in Anspruch nahm ${ }^{4.003}$ ).

Das springende Zählwerk wurde nach mehrjährigen Ermittlungen 1893 zur Eichung zugelassen $\left.{ }^{4.834}\right)$. Es ist von $E d g e \mathbf{1} 842$ entworfen. Noch 1917 meinte aber das Handbuch der Gastechnik ${ }^{4, a x}$ ), das schleichende Zählwerk von C ros sle y sei nicht zu übertreffen. Man müsse zum mindesten auf den Paß̧schluf mit Maltheserkreuz verzichten umd zum Kraftschluf mit Federn greifen.

Zwei neue Mef̧verfahren mögen noch der geschichtlichen Daten wegen erwähnt sein: M. Flürscheim, baute den ersten Schwimmermesser $\left.1883^{4.53}\right)$. Er gab dem zylindrischen Rohrquerschnitt eine Ausbuchtung, in die die notwendige Erweiterung von unten nach oben verlegt war. Der Venturimesser wurde 1892 als Bourdou-Anemometer beschrieben $\left.{ }^{4,6 \pi}\right)$. Bourdou war durch die Diffusoren an Pumpen ( 1869 Nagel \& Co., Hamburg) und an der Fournesonturbine (Ulrich A. Boyden) angeregt worden. Die Schwierigkeit, den Druck genau zu bestimmen und die Störung der Messung durch die Stöß̧e der Kolbenpumpen wurden sofort erkannt (Bild 66).

4.625) $38(1895), 647$

4.620) 38 (1895), 645

4.627) 38 (1895), 648; S. 609 ;

4.655) $40(1897), 561$

(.120) $41(1897), 391$

4.600) 39 (1896), 33 .

(. asi) 41 (1898), $762: 78$ i

(. asaz) $40(1897), 563$

4.659) $42(1899), 145$

4. 634) $36(1893), 244$.

4. essi) Handbuch der Gastechnik Bd. 8. München 1917 Oldenbourg S. 218

4. (aso) 26 (1883), 799.

4.67) 35 (1892), 96 


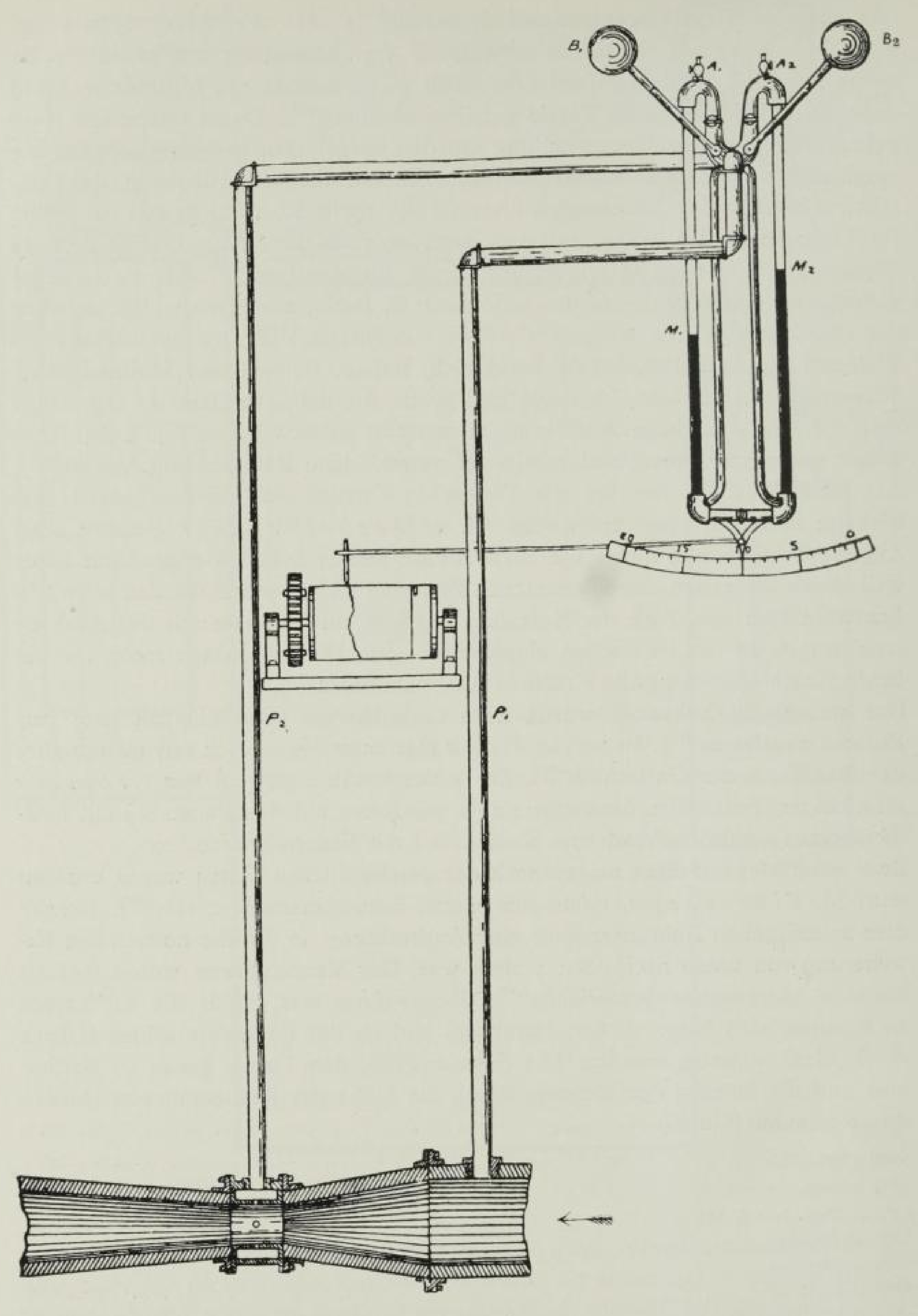

Bild 66 Venturimesser 1892 (J.f. G. 35 [1892] S. 100)

\section{SLUB}

Wir führen Wissen. 


\subsection{Beleucbiung}

Obwohl in den 7oer Jahren die Werbung für Koch- und Kraftgas in immer steigendem Maf̧e stattfand und in den 9oer Jahren Gasglühlicht von Auer sich durchsetzte, lag das Schwergewicht der Technik noch bis zum Ende des Jahrhunderts im Bemühen, ein leuchtkräftiges Gas zu liefern und in geeigneten Brennern mit offener Flamme zu verbrennen.

So richteten sich die Anstrengungen der Fachleute darauf:

I. die Zusammensetzung des Gases immer genauer zu bestimmen, und die gegenseitige Beeinflussung der einzelnen Bestandlteile zu erkennen,

2. die Verbrennungsbedingungen für die höchste Leuchtkraft zu erforschen,

3. die Leuchtkraft immer besser durch die Photometrie zu bestimmen.

Es wäre sicher sinnvoll, die vielen Arbeiten in den Laboratorien genau zu verfolgen, die nach den Veröffentlichungen aufkommenden kritischen Äuf̧erungen festzuhalten, und dabei auch zu berichten, wie durch diese Auseinandersetzungen Schritt für Schritt in mühsamer Arbeit immer bessere Verfahren im Laboratorium entwickelt worden sind. Allein eine solche Darstellung würde nicht mehr in den Rahmen der geschichtlichen Entwicklung der ganzen Industrie einbringbar sein. Es genügt wohl ein Hinweis darauf, daf̧ allein im Muspratt den Einflüssen auf die Entgasung 55 Seiten und der Beurteilung des Leuchtgases weitere 37 Seiten gewidmet sind $\left.{ }^{4.155}\right)$. Diese Darstellung müfte aber noch durch Auszüge und Besprechungen der Auf̧erungen im Journal und aus anderen Quellen ergänzt werden. Es muf daher, um nicht durch Weitschweifigkeit den Überblick über die grołe Entwicklung zu verlieren, genügen, die aufkommenden und verworfenen Verbrennungstheorien ganz kurz zu erwähnen und danach die Photometrie ein wenig ausführlicher zu behandeln, allein schon weil auf diesem Gebiete die deutsche Industrie einen besonderen Beitrag geleistet hat.

4.5II Verbrennungsvorgänge, Theorien und Untersuchungen

$D a v y$ hatte, wie bereits früher erwähnt, die Leuchterscheinung auf das Glühen der sich in der Flamme abscheidenden Kohlenteilchen zurückgeführt ${ }^{4.385}$ ). Auf dieser Annahme hatte man weiter gearbeitet und war sehr vertrauensvoll, eines Tages aus der Analyse des Gases auf die Leuchtkraft schliefzen zu können. In einem sehr lesenswerten Aufsatz über die Natur des Leuchtens der Flammen sagte O. Kersten $n^{4.049}$ ): „Wenn man noch einige weitere Kenntnisse von der Flamme haben wird, dann wird es möglich sein, eine Formel zur Berechnung der theoretischen Leuchtkraft eines Gases zu finden, so ähnlich wie man eine theoretische Heizkraft hat. Man wird aus einer Analyse ersehen können, wieviel Licht

4.639) Muspratt S. 282-337: S. $337-374$ (s. 2.81)

4.eas) Philos. Transactions of the Royal Society 1819

4.640 ) \& $(1862), 84 / 98 ; 123 / 131$ 
sich aus einer Menge eines Gases erhalten lä̧t, und wieviel der eine oder andere Brenner an Nutzeffekt gibt. Im Laboratorium des Herrn Blocbman $n^{4.6 r^{\prime}}$ ) sind weitere Arbeiten jetzt im Gange, um zu einer solchen Formel zu gelangen." Daß dieses Streben aussichtslos war, hat man heute allgemein begriffen.

Da trat E. Frankland mit der Theorie auf ${ }^{\text {ser }}$ ), daf in der Flamme keine festen Kohlenstoffteilchen vorhanden seien, wohl aber unter hohem Druck die Kohlenwasserstoffe an sich leuchteten. Seine Veröffentlichung verursachte mehrere Arbeiten von H. Wibel, Hamburg, $\left.{ }^{4.43}\right)$, W. Ste i $\left.n^{\text {t.aut }}\right)$, R. Blocb$m a n n^{465}$ ) und K. Heumann, Darmstadt ${ }^{4.600}$ ). Man blieb vorwiegend bei der Theorie von Davy. 1870 veröffentlichte Robert $v$. Hel mboltz als Erster in der Reihe von Forschern seine Untersuchungen über Licht- und Wärmestrahlen der Gase mit dem Hinweis auf den Unterschied der noch reagierenden und ausreagierten Gase (Strahlung von $\mathrm{CO}_{2}, \mathrm{H}_{2} \mathrm{O}$ und $\mathrm{C}^{\mathrm{n}} \mathrm{H}^{\mathrm{m}}$ als Chemoluminiscens erklärt $)^{4.617}$ ). Seine stark vereinfachten Gesetze wirkten für einige Jahre verwirrend. P. F. Frankland untersuchte das Leuchtvermögen einer Reihe reiner Kohlenwasscrstoffe ${ }^{4.65}$ ). Edward Frankland hat über den Einfluf̧ des Umgebungsdruckes auf die Leuchtkraft gearbeitet $\left.{ }^{4 a^{9}}\right)$. Auch Werner Siemens beschäftigte sich mit der Leuchtkraft der Flammen und Gase. Er vermutete Ähnlichkeiten mit der Geisslerschen Röhre ${ }^{t .55}$ ) bestätigte damit die Auffassung, dał Chemoluminiscens wesentlicher als Wärmestrahlung sei. Lewes entwikkelte 1892 eine Theorie, daß̧ der Zerfall sämtlicher Kohlenwasserstoffe über Azetylen als Zwischenstufe stattfände ${ }^{\text {t.5i }}$ ). Er hat damit wohl die Bedeutung der Radikale in der Flamme geahnt, in der konkreten Formulierung fand er aber keine Anhänger. Eine zusammenfassende Darstellung findet man im Muspratt. S. 83 bis Ior (s. $2,8 \mathrm{I}$ ).

In den 8oer Jahren arbeiteten $M$ all ard und Le Cbatelier ferner Berthelot und Vieille über Zündgrenzen von Gasluftgemischen, Zündgeschwindigkeiten und Explosionswellen, Anderungen der spezifischen Wärme und Dissociation. R. Dixon und H. Bunte schalteten sich zu Anfang der goer Jahre ein.

\subsection{Photometrie}

Der richtige Aufbau eines Photometers (Lichtmessers) und seine Handhabung ist eine schwierige Kunst, deren wissenschaftliche Grundlagen im Laufe der zweiten Hälfte des 19. Jahrhunderts in mühseliger Arbeit erarbeitet worden sind.

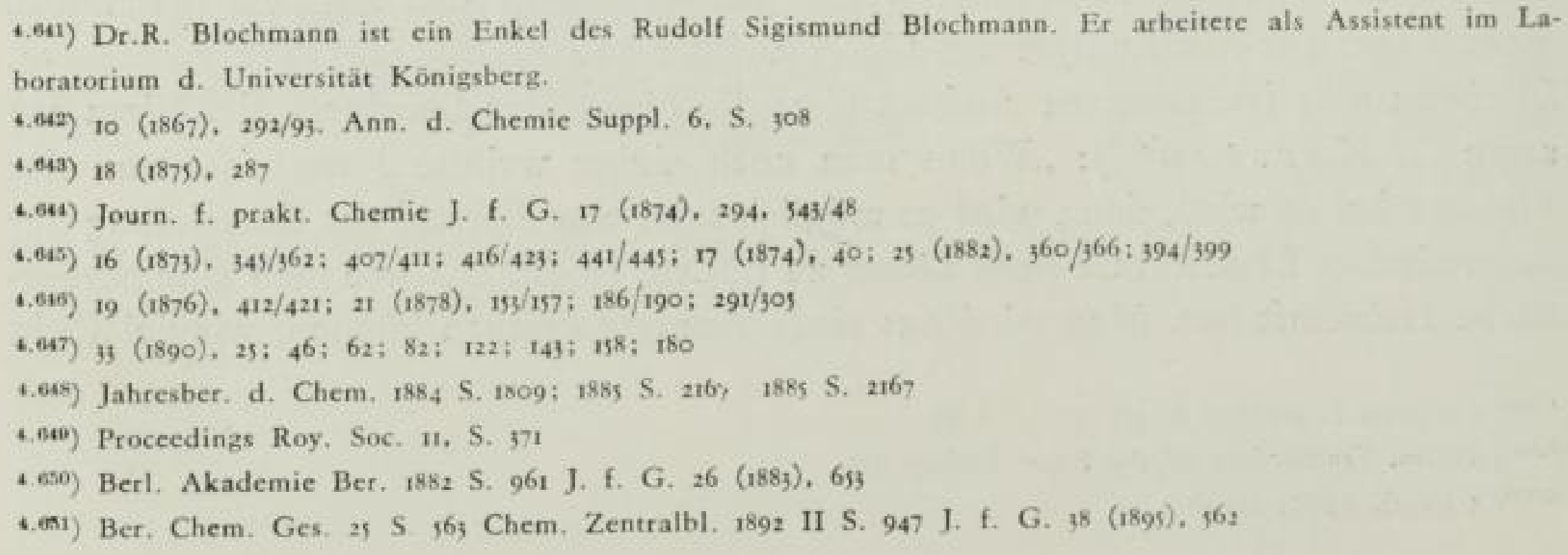


Für das Ergebnis ist vor allem die Vergleichslichtquelle mafggebend, die in genau reproduzierbarer Weise herzustellen, jahrzehntelange Bemühungen erforderte. Die Größzenabmessungen des Gerätes, der Schwärzegrad des umgebenden Raumes müssen berücksichtigt werden. Vor allem aber ist die auf den einzelnen Wellenlängen verschiedene Lichtempfindlichkeit des Auges eine Fehlerquelle. Die Augen einzelner Menschen sind auch verschicden. Aus allen diesen Umständen entstand eine Spanne der Unsicherheit, die mit dem verschärften Wettbewerb und mit steigenden Ansprüchen an die Leistung einer Leuchte immer mehr eingeschränkt werden mufte. Erst nach langen, noch im 20. Jahrhundert fortgesetzten Versuchsreihen gelang es, die Beobachtung mit dem Auge fortzulassen.

Die Messung durch Vergleich unter Berücksichtigung des "Abstandsgesetzes" ist zwar, wie wir bereits sahen, beim $R u m f$ ordschen Schattenphotometer angewandt. Bezeichnend aber ist, daß̧ schon $A c c u m$ 1810 zur Nachprüfung eigene Verfahren ersonnen hat, die er leider nicht bekannt gemacht hat.

Den noch rohen Verfahren entsprechend, waren die Vertragsbestimmungen noch viel oberflächlicher gehalten. In Hannover wurde 1825 festgelegt, „dał die Gesellschaft der Stadt ein Licht liefere, welches sich zu der bisherigen Beleuchtung mindestens wie 2 zu I verhalte“. Irgendwelche Vereinbarungen über das Mef̧verfahren, die Art und genauen Abmessungen der zu beurteilenden Leuchte und der Vergleichskerze wurden nicht getroffen. Diese Mängel in den Verträgen veranlafłten vielfach die unerfreulichen Auseinandersetzungen zwischen den Städten und den Gesellschaften. Hierauf konnte Sibilling noch 1870 in mehreren Aufsätzen hinweisen.

Um die Betriebsaufsicht zu vereinfachen, suchte man nach anderen Maßstäben für die Leuchtkraft. Lowe beobachtete die Flammenhöhe eines einfachen Lochbrenners, den er später mit einem Druckregler ausrüstete $\left.{ }^{4.05 i}\right)$. Nach dem gleichen Gedanken entwarf H. Giroud, ein angesehener Konstrukteur von Reglern, einen Gasprüfer. N. H. Scbilling hielt ihn für würdig, so eingehend untersucht zu werden, dał der Erfinder sagte, Schilling habe mehr herausgeholt, als er selbst erreichen wollte $\left.{ }^{t, a=9}\right)$. Immerhin ergab sich, daß die Flammenhöhe nur in engen Grenzen der Leuchtkraft proportional sei, also nur für sehr ähnliche Gassorten benutzt werden konnte (Nippolt) ${ }^{\text {t.esit }}$ ). Auch der Erdmannsche Gasprüfer ${ }^{4.55}$ ), der an einem Bunsenbrenner die am Entleuchtungspunkt notwendige Luftmenge ermittelte, gab unzuverlässige Ergebnisse. Nicht anders war Elsters Luftmischungsphotometer. $\left.{ }^{4.53}\right)$. Vielfach waren die Versuche, aus der Dichte des Gases auf die Leuchtkraft mit Hilfe mathematischer Beziehungen zu schlief̧en. Klarheit, dał auch das unmöglich ist, brachte P. F. Franklands Gegenüberstellung des Aethans (mit dem Molekular-Gew. 30,50) mit dem fast doppelt so leuchtkräittigen Aethylen (mit dem Molek-Gew. 28,03 ${ }^{4.557}$ ). Daf3 O. Kersten und R. Blocbman $n$ auf eine Errechnung der Leuchtkraft aus der Analyse hofften, wurde bereits S. 269 erwähnt.

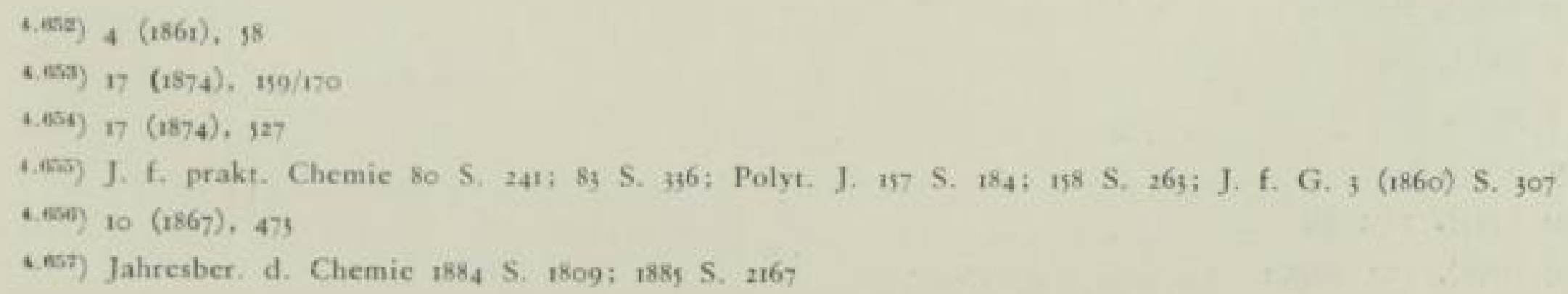


Schon frühzeitig wurde versucht, die Leuchtkraft objektiv zu messen, wobei das für des Sehen bei Licht notwendige Auge ausgeschaltet wurde. Werner Siemens schlug cine Selenzelle vor. Es erwies sich aber, dafy Selen nicht genügend gleichartig geliefert werden konnte $\left.{ }^{4.65}\right)$. Abwegig waren auch Bestrebungen, mit Hilfe eines Bolometers oder Radiometers die Gesamtstrahlung zu bestimmen und als Małsstab für die Leuchtkraft zu wählen. Das wäre nur bei ungestörter schwarzer Strahlung aller vergleichbaren Lichtquellen angängig gewesen, die aber bei Gasflammen nicht gegeben ist. So sind wohl die 1880 nicht verstandenen $\mathrm{Ab}$ weichungen erklärbar $\left.{ }^{4.055}\right)$. Auch photographisch arbeitende registrierende Messer wurden versucht (T. G. B arlow ${ }^{4.600}$ ? .

Diese vielfachen Ungewif̧heiten und Schwierigkeiten erklären die Absicht des neugegründeten Vereines von Gasfachmännern Deutschlands, 1859 Untersuchungen und Versuche auf dem Gebiete der Photometrie ausführen zu lassen. Die Arbeit hat ungewöhnlich große Etfolge gehabt, dank der Zähigkeit eines S. Schiele, der ab 186s dreiß̧ig Jahre lang den Vorsitz im Ausschuf geführt hat, und dank der Mitarbeit ausgezeichneter Wissenschaftler, von denen man Dr. H. Krüss, Hamburg, F. v. Hefner-Alteneck, Berlin (1845-1904) und H. Bunte, Karlsruhe, besonders hervorheben muf.

Zunächst fehlte es allerdings trotz des Vereinsbeschlusses an den Männern, die die gemeinsame Arbeit persönlich übernahmen, obwohl man feststellen kann, dał sich viele Werke und selbst kleine, wie Güstrow in Mecklenburg ${ }^{4.861}$ ) mit den Fragen der Photometrie sehr eingehend befaf̧t haben. Da veranlaften Streitigkeiten zwischen Werk und Stadt Mainz F. S o n nt a g im Jahre 1865, ihm bekannte Fachgenossen samt Wissenschaftlern zur Aussprache mit Vertretern verschiedener Städte zusammenzurufen. Den Vorsitz übernahm S. Scbiele. Es bildete sich ein Ausschuf, der die in der Sitzung anerkannten Unzulänglichkeiten beseitigen sollte ${ }^{4,1005}$ ).

Zunächst suchte man nach einer genau herstellbaren Vergleichskerze. Die bisher nach Gewicht dem Handel entnommenen Kerzen waren zu ungleichmäfig, insbesondere auch die aus England bezogenen Spermaceti-(Walrat)-kerzen. Stearinkerzen, in der Fertigung auch bezüglich des Dochtes von Scbilling überwacht, fielen trotz aller Sorgfalt nicht gleichmäßjig aus $\left.{ }^{4003}\right)$. Der freie Ausschuf kam in Geldverlegenheiten, die städtischen Behörden beteiligten sich nicht an der Arbeit. Daher übernahma der Verein I868 die Arbeiten.

Der Ausschuf wandte sich den Paraffinkerzen zu, gegen die vor allem S. Elster Bedenken äuf̧erte $\left.{ }^{4.66 t}\right)$, die aber dann Bemühungen, reines Paraffin zu erhalten, auslösten. 1872 konnten die ersten Normen für Photometrie beschlossen werden. Sie waren in den Hauptsätzen mehrere Jahrzehnte maf̧gebend. Vorsichtigerweise vermied man den Ausdruck Normalkerze und wählte dafür den

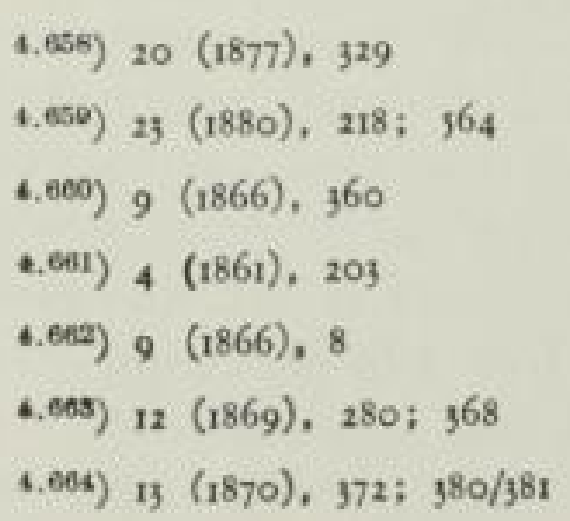

\section{SLUB}


Namen „Vereinskerze“. Ihre Herstellung überwachte der Ausschuf $\}^{4.015}$ ). Daraus erwuchsen Beschwerden, da bei stark wachsendem Bedarf nicht immer Vereinskerzen zu erhalten waren. In Frankreich benutzte man die Bec Carcel, die von Carcel als Öllampe, bei der das Öl durch ein Uhrwerk dem Dochte zugeführt wurde, schon 1800 entwickelt war. J. Met bven schlug vor, um die Form und Höhe der Normalflamme auszuschaiten, diese mit einem geschlitzten Mantel zu versehen und nur den Ausschnitt zu beobachten. Den Gedanken hatte auch Fr. $R \ddot{u} d o r f f$ bereits gehabt. Er fand zunächst eine freundliche Aufnahme besonders in England, mufte aber nach eingehenden Untersuchungen in Deutschland abgelehnt werden $\left.{ }^{4000}\right)$. Die Elektrotechnik strebte nach einer genaueren Lichteinheit. J. Violle schlug auf dem Elektrikerkongress von $188 \mathrm{I}$ diejenige Lichtmenge als Einheit vor, die von $\mathrm{I} \mathrm{cm}^{2}$ Platin bei seiner Erstarrungstemperatur in senkrechter Richtung ausgestrahlt wurde ${ }^{4.607}$ ). 1885 nahm ein erneuter Kongref̧ diesen Vorschlag an, obwohl die Einheit besonders teuer und umständlich in aer Herstellung war. Untersuchungen von Gasfachleuten und Elektroingenieuren bewiesen, dafy der Schmelzpunkt des Platins durchaus nicht gleich bleibt ${ }^{+\infty}$ ) . Wichtig war die Arbeit von $K r \ddot{u} s s$ über die unterschiedliche Empfindlichkeit des Auges in den einzelnen Farbenwellenbereichen ${ }^{4000}$ ). Gleichzeitig arbeitete v. Hefner-Alteneck bei Siemens \& Halske daran, zu einer überall allein nach Zeichnungen und schriftlichen Anwersungen gleich herstellbaren Leuchte und einem eindeutigen Brennstoff zu kommen. Dem ersten Bericht über seine Absichten ${ }^{\text {t.679) }}$ ) folgte alsbald (Okt. 1883) die Bekanntgabe des Amylazetates $\left.{ }^{4.071}\right)$. H. B unte prüfte diesen Vorschlag sofort nach und wurde danach zum lebhaften Befürworter ${ }^{\text {tain }}$ ). Ab, 1894 wurde der Brennstoff bei der Chem.-Techn. Prüfungs- und Versuchsanstalt, Karlsruhe, amtlich geprüft und abgegeben ${ }^{4.372}$. Nach weiteren gründlichen und vielseitigen Versuchen konnte der Verein die Phys.-Techn. Reichsanstalt bitten, die Beglaubigung der nunmehr mit Hefnerlampe bezeichneten Geräte zu übernehmen. Als Einheit der Lichtsstärke wurde zunächst Hefnerlicht Hfl. geprägt $\left.{ }^{4.174}\right)$. 1892 waren die Vorschriften ausgearbeitet, und die Reichsanstalt übernahm nunmehr die Beglaubigungen ${ }^{4,1755}$ ).

Aus geschichtlichen Gründen ist es wohl angebracht, den Hergang noch einmal zu beleuchten. In der Zeit des ersten, erfolgreichen Vorstofes der Elektrotechnik in das Gebiet der Gasbeleuchtung wurde in der in Deutschland damals unbestritten führenden Firma für physikalische und besonders elektrotechnische Arbeiten ein Vorschlag ausgearbeitet, den die Gasfachmänner mit Freuden aufnehmen konnten. Im Geiste der liberaien Weltauffassung wurde dann Hand in

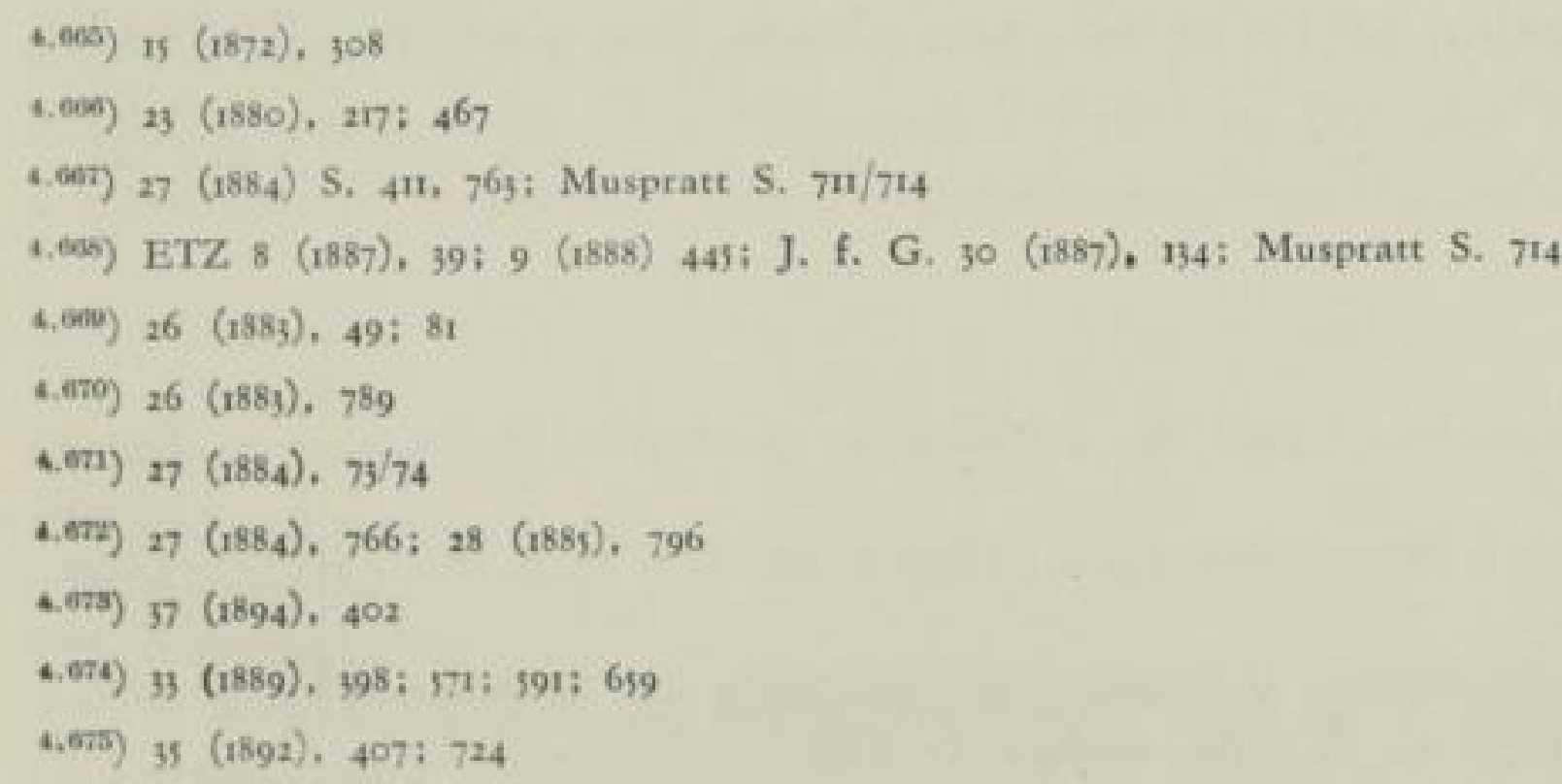


Hand gearbeitet, unter Hintansetzung dieses Geistes die Hilfe der staatlichen Anstalt in Anspruch genommen, und auf dicse Weise etwas so Gutes geschaffen, dafy der deutsche elektrotechnische Verein beim internationalen elektrotechnischen Kongref3 1893 beantragen konnte, das Hefnerlicht als internationales Einheitsmał einzuführen ${ }^{4.670}$ ).

Natürlich gelang das nicht sofort. Die Einwände der anderen Länder zugunsten der bei ihnen ausgearbeiteten Verfahren haben aber historisch keine Bedeutung. Die daneben herlaufenden Arbeiten an der Mef̧einrichtung, die Vereinbarung der Einzelbedingungen bei ihrer Anwendung mag wohl die Mitarbeiter und Erfinder alles in allem noch mehr beschäftigt haben als die Schaffung der Einheitskerze. Es handelt sich aber dabei mehr um die Arbeit der Physiker als der Gasingenieure. Aufjerdem würde wieder einmal eine ausführliche Darstellung den Überblick gefährden. So mögen nur zwei die Lage kennzeichnende Äuß̧erungen des H. Krüss, Hamburg, festgehalten werden: Zum Einfluf\} der Länge der Photometerbank auf die Ergebnisse sagte er: „Auf kaum einem anderen Gebiete herrscht eine solche Zerfahrenheit und Unzuverlässigkeit ${ }^{\text {tan7 }}$ )". Im folgenden Jahre begann er seinen Vortrag in der Hauptversammlung des Vereins mit den Worten: „Schon wieder ein neues Photometer! ${ }^{[4.076}$ ).

Kiüss war es dann wieder, der in Deutschland die Allgemeinheit auf den Unterschied der verhältnismäf̧ig einfachen Messung der Lichtstärke und die der Beleuchtungsstärke hinwies ${ }^{4.675}$. Er beschrieb die Arbeiten von P. W $y b a u x^{4.050}$ ), der statt der bisher üblichen Einheit Meterkerze ${ }^{t .6 \times 1}$ ) den Namen Lux vorschlug und für die mathematisch richtige Berechnung der Beleuchtungsstärke nach $\mathrm{F}$. Up p e $n$ b or $n$ I 880 (Z, f. Elektrizitätslehre 2 S. 384 ) eintrat.

In voller Übereinstimmung mit den Vertretern der Elektrotechnik wurden $\left.1897^{4.065}\right)$ die heute noch gebräuchlichen lichttechnischen Grundbegriffe durch den Verein genehmigt: Lichtstärke $\mathrm{J}$ (damals durch $\mathrm{HK}=$ Hefnerkerze gemessen, inzwischen durch $\mathrm{cd}=$ candela ersetzt); Lichtstrom $\Phi$ (Lumen $1 \mathrm{~m})$; Beleuchtungsstärke (Lux $1 \mathrm{x}$ ) und Lichtabgabe $\mathrm{Q}: \mathrm{lm} \cdot \mathrm{h}$ (heute Lichtmenge) ${ }^{\text {t.axs }}$ ).

\subsection{Ausführung der Leuchtbrenner}

Im Jahre 1860 verfügte man noch ausschlieflich über den einfachen Lochbrenner, den Schlitzbrenner und für hohe Ansprüche den Argandbrenner. Die Bemühungen, an den Straß̧enleuchten die vereinbarte Leistung mit einer möglichst geringen Gasmenge zu erreichen, waren lebhaft im Gange. Gesund war der Gedanke, das mit einem Doppelhahn zu erreichen, von denen der eine zur dauernden

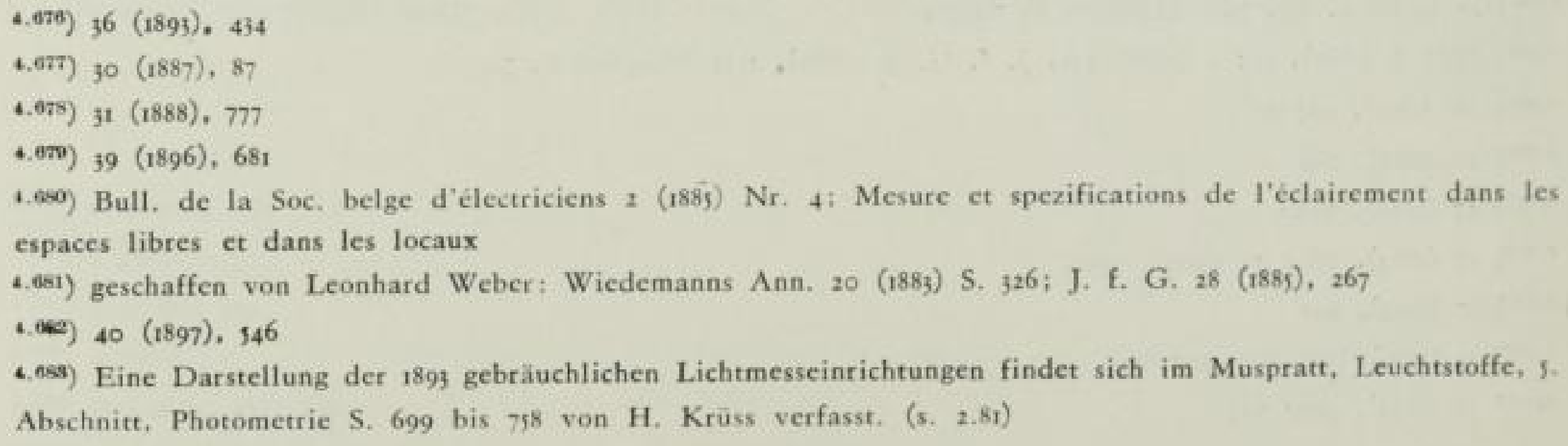


Einstellung nach den örtlichen wechselnden Druckhöhen, der andere zum Öffnen und Löschen dienen sollte $\left.{ }^{4,45}\right)$. Ausgedehnte Versuche von Reg n a ult und $D u m a s$ (berichtet von Auduin und Berard in den Ann. de Chemie et de Physique $3 \mathrm{Nr}$. 55) bestätigten nur die alte Regel: „Weite Brenner, schwacher Druck, gibt dem Licht den wahren Schmuck ${ }^{\text {(4.05) }}$ ). Aus dieser Erkenntnis entwickelte sich ein richtiger Sparbrennerschwindel, indem zur Druckvernichtung Watteeinlagen, Drahtspiralen, Leinen, Seide, Haare, Pflanzenfasern in das Rohr gestopft wurden $\left.{ }^{4,6 e g}\right)$. Damals schon traten Unberufene als Gutachter auf, und diese Gutachten wurden in den Anpreisungen verbreitet. Besonders hartnäckig war ein Erfinder T. Brönner, der mit C. F. A. Jabn, Dresden, einen richtigen Anzeigenkrieg führte.

Druckregler wurden nun allgemeiner eingeführt. Dem Regler von $S u g g$ wurde von G. Livesey (Ingenieur der South Metropolitan Gas Co.) ausdrücklich die Bewährung bescheinigt $\left.{ }^{4.057}\right)$. Er wurde auch bei allen Werken der Deutschen Continental-Gas-Geselischaft für Laternen in der Nähe des Werkes eingeführt. 1869 sind bereits bei ihr 1200 Stück im Gebrauch $\left.{ }^{t .0 n}\right)$ gewesen. Der Regler von SuggFriedlebe $n^{4(55}$ ) und von S. Elster (Bild 67) sind Mengenregler, ebenso der von M. Flürscbeim und von F. $\left.L u x^{4.007}\right)$.

Bild 67

Mengenregler von Elster (Muspratt. S. 590)

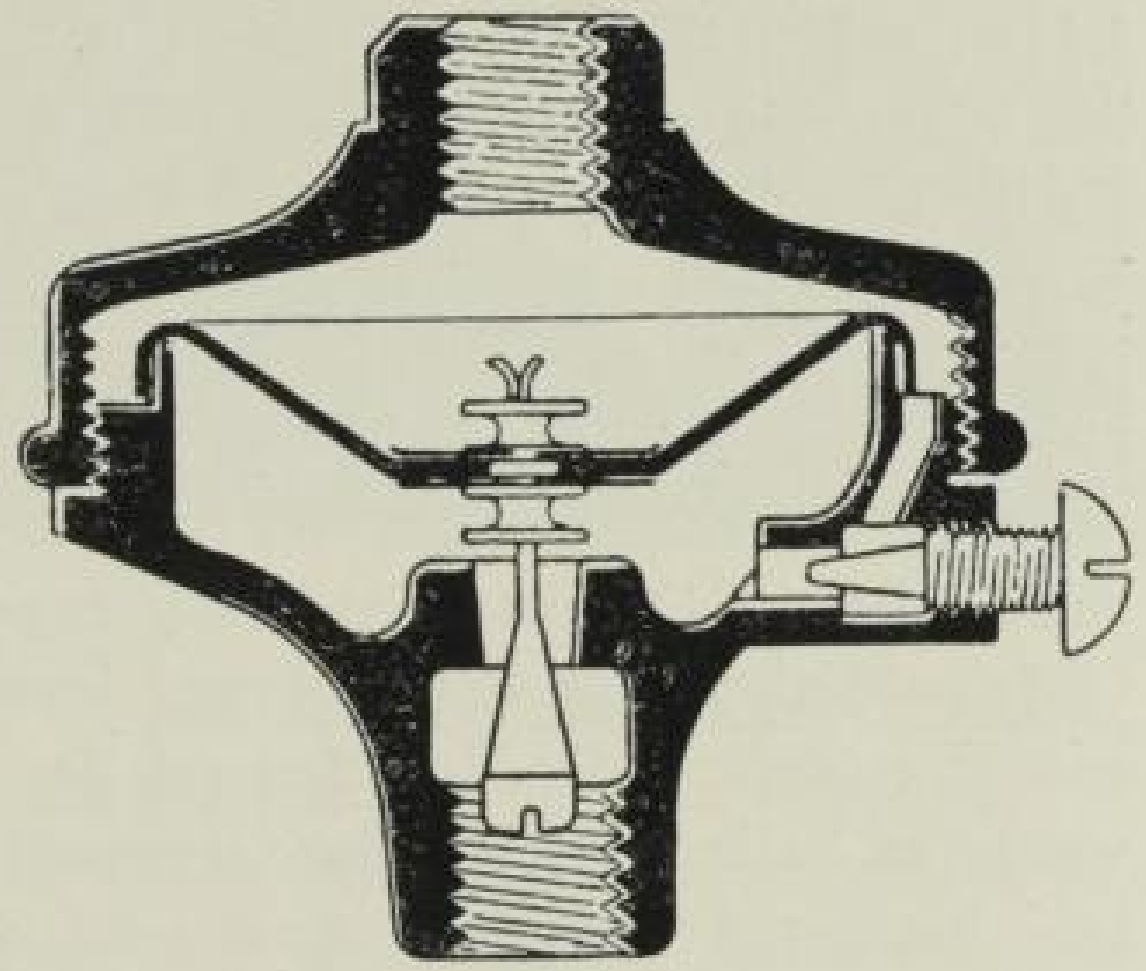

Die vielen Bauarten, die durch genaue Ausführung, durch genaue Bemessung von Zuluftkanälen, insbesondere bei Argandbrennern, und mit Brennerscheiben zur Stauung und Ausbreitung der Flamme arbeiten, mögen übergangen werden. Im allgemeinen waren die Erhöhungen der Wirkungsgrade nur gering. Der erhöhte Aufwand lohnte sich kaum.

Anders war es mit der Luftvorwärnung, obwohl gerade bei ihr manche Brenner einen erstaunlich verwickeiten Aufbau zeigten. Sie brachten immerhin merkbare Verminderungen im Gasverbrauch verglichen mit der Lichtfülle. Der Luftvorwärmung zur Erhöhung der Flammentemperatur wandte sich, nach den Erfol-

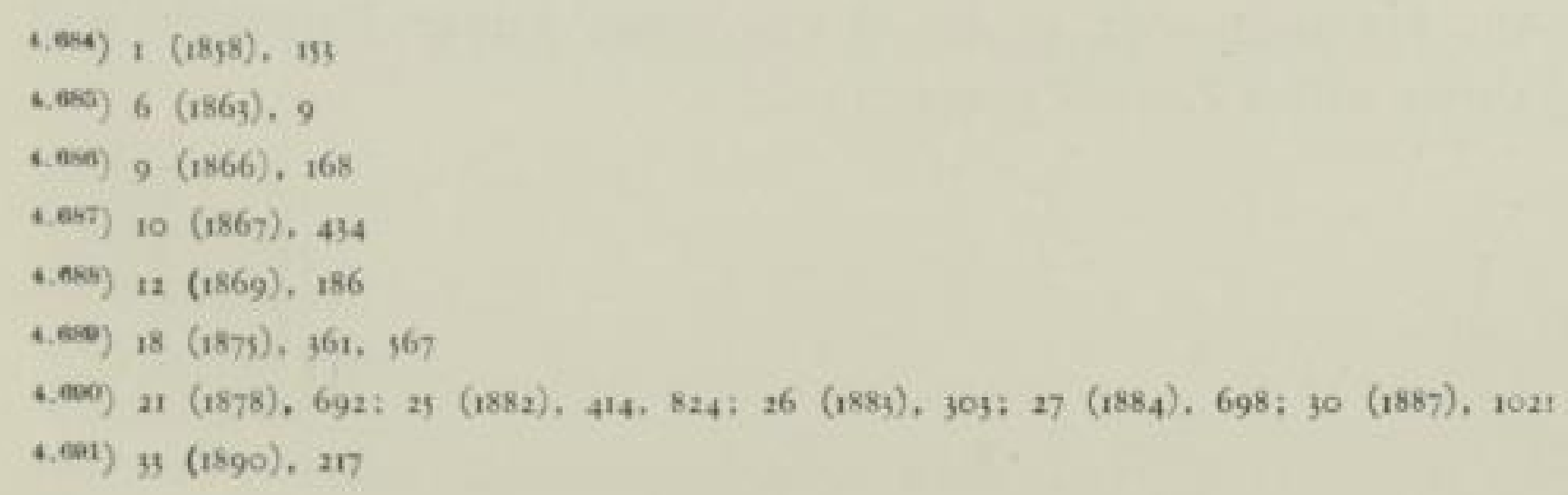


gen bei der Gaswerks-Ofenbeheizung erhöhte Aufmerksamkeit zu. Schon 1854 hatte W. R. Bowdit $c b$ einen Argandbrenner mit einem Doppelzylinder gebaut. In dem Ringraum wurde die Luft warm $\left.{ }^{4, \text { ang }}\right)$. Prof. E. Frankland verbesserte die Lampe. Er stellte Luftvorwärmung auf $260-300^{\circ} \mathrm{C}$ und bei hochwertigem Gas aus Cannelkohle eine Verbesserung der Leuchtkraft um $67^{0} \%^{\text {(6) }}$, fest. C b a ussenot und $M u c b$ all wandten $1880 / 81$ das gleiche Prinzip an ${ }^{4.69}$ ). Dieser hatte zunächst eine Lampe mit Hilfsheizung zur Luftvorwärmung erdacht. Mit der ihm eigenen Gründlichkeit ging etwa gleichzeitig F. Si emens an die Aufgabe heran. Er brachte seine Erfahrungen aus dem Bau von Ofenregeneratoren ein, betonte z. B. die Notwendigkeit, sich erwärmende Gase aufsteigen und umgekehrt kühler werdende Gase abfallen zu lassen $\left.{ }^{4.005}\right)$. Er hat seine Regenerator-Lampe in jahrelanger Arbeit verbessert und die verwickelte Bauart allmählich vereinfacht $\left.{ }^{4.000}\right)$.

\section{LE B E N S B I L D}

Friedrich Siemen s (Bild 68) ist als Bruder des Werner Siemens im Jahre 1826 in Mecklenburg geboren. Nach dem Tode seiner Eltern hatte er sich mit Is Jahren als Schiffsjunge auf eigene Füfe gestellt. Nach drei Jahren (I844) holte ihn Werner in die Heimat zurück und bestimmte ihn, sich autodidaktisch technisch auszubilden. Beim Lernen begann er sofort sein erfinderisches Schaffen. Werner urteilte: „Durch Friedrichs unzählige Projekte hat er wenigstens sich gründlich in die Sache hineinstudiert". In den soer Jahren finden wir ihn beim älteren Bruder Wilhelm in. London. Für diesen arbeitete er an der Heifluftmaschine. Er erkannte, daf der bei dieser Maschine übliche regenerative Wärmeaustauscher im Ofenbau viel besser angewendet werden könnte. Die notwendige Gleichmäfjigkeit der Feuerführung konnte er nur mit einer hohen Brennstoffschicht erreichen, die Vorwärmung der Luft nur im Bereiche der Zweitluft. So wurde er Erfinder eines Gas-Generators. Mit seinem Bruder Wilhelm hatte er kein leichtes Arbeiten, da diesem an der Metallurgie mehr lag als an der Feuerungstechnik allein. So kehrte Friedrich 1864 nach Berlin zurück und führte seinen Ofen in die Glasindustrie ein. Er wurce der Erfinder des Glaswannenofens und zahlreicher anderer Verbesserungen in der Glastechnik. Durch die Übertragung der Regeneration (heute würden wir Rekuperation sagen) auf Gaslampe und Gasheizofen wurde er Vater einer Gasgerätefabrik, deren österreichische Zweigfirma noch heute seinen Namen trägt. F. Si e mens war hoch angesehen. 1884 wurde er vom Gas-Institute (dem englischen Fachverein) durch die Birmingham Medal geehrt als ,originator of the regenerative system alike as applied to gas firing and to gas burners for illumination". Er ist der erste Doktor-Ingenieur ehrenhalber Deutschlands (Dresden). 1888 hat er sich von den Geschäften zurückgezogen, bis 1901 war er im Aufsichtsrat seiner Fabriken und starb 1904 nach drei Jahren stiller Zurückgezogenheit.

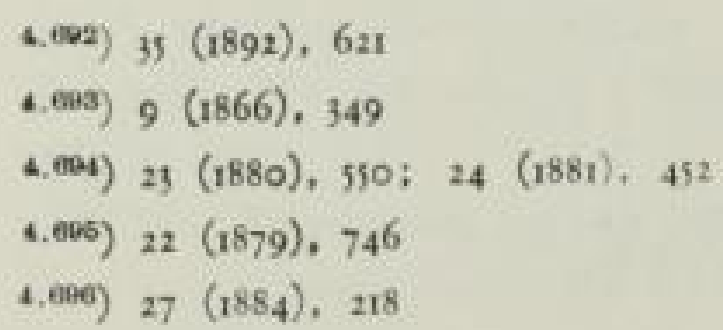




\section{Bild 68}

Friedrich Siemens (Siemens ,Lebenserinnerungen", S. 255)

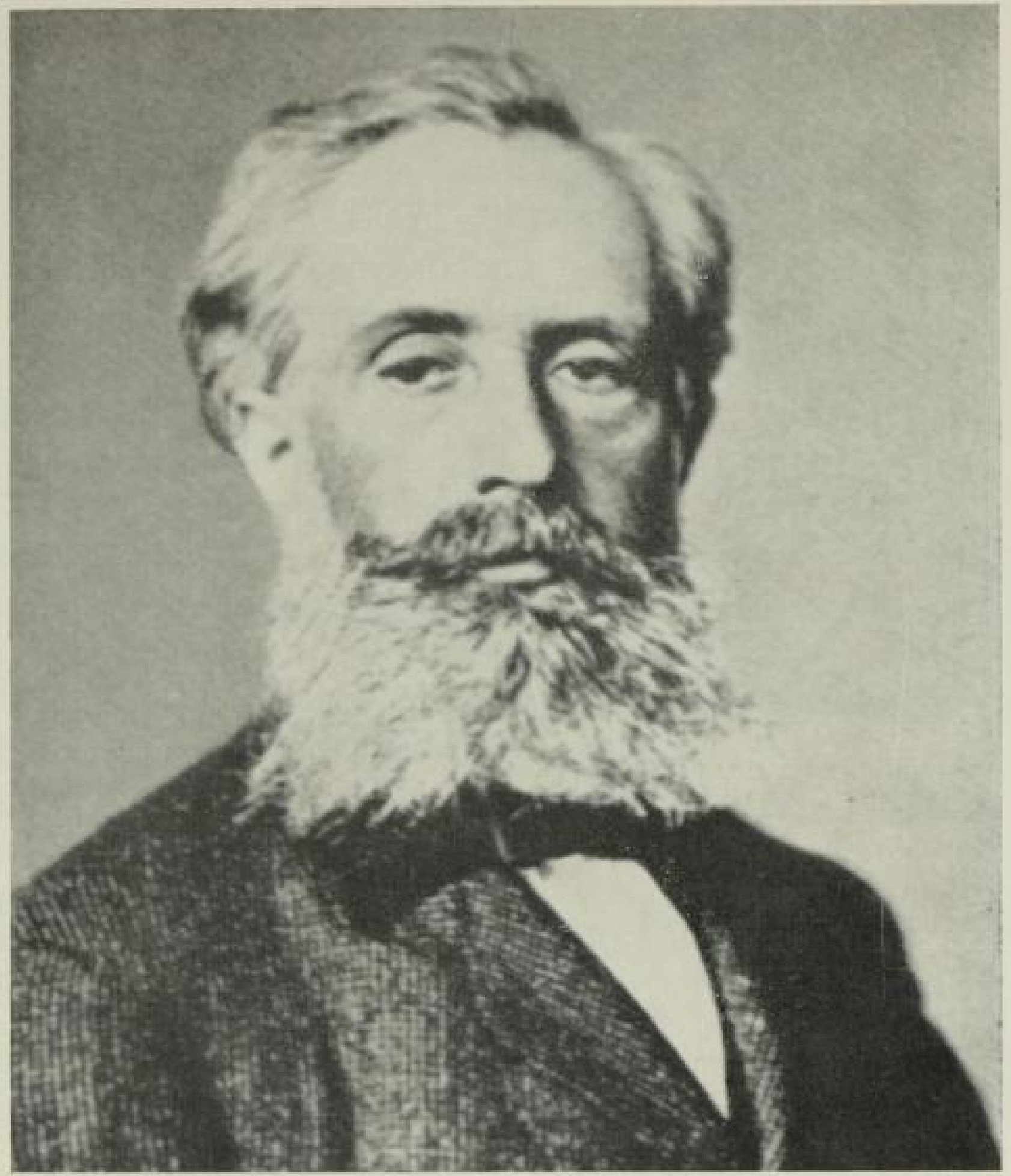

Die einfacher gebaute Wenham-Lampe ${ }^{4.007}$ ) mit dem flachliegenden Sternbrenner hatte anfänglich die meiste Verbreitung gefunden. In dem Gasabzug der geschlossen gebauten Lampe wurde zum ersten Mal eine Rückstromsicherung wohl begründet eingebaut $\left.{ }^{4,609}\right)$. Man klagte über die schlechte Ausführung insbesondere des Reglers, dessen gute Arbeit eine unbedingte Voraussetzung der Regenerativlampen war. $\left.{ }^{4, a x}\right)$. Siemens-Lampen waren dagegen „bei einigermafen aufmerksamer Bedienung“ gut. So wurde auch der „invertierte“ Regenerativbrenner ${ }^{4.00}$ ) und der Flachbrenner ${ }^{4 . \pi 19}$ ) (D.R.P. 42 I2I) aufgenommen. H. Bunte stellte in einem Hörsaal der Technischen Hochschule Karlsruhe Vergleiche zwischen einem großjen Argandbrenner und dem Regenerativbrenner an. Bei gleicher Flächenhelle brauchte jener 5,8 dieser nur $2,6 \mathrm{~m}^{3} / \mathrm{h}$. F. S i e m e $n s$ war, da der Wettbewerb der elektrischen Bogenlampen die Anregungen gab, auf die Entwicklung grofyer Lampen aus. Werner Siemens sagte dazu $\left.{ }^{4.709}\right)$. „Er hat den Sieg des elektrischen Lichtes über die Gasbeleuchtung bedeutend erschwert, was unserer brüderlichen Eintracht aber keinen Abbruch tat." Eine Lampe für nor-

4.607) $27(1884), 732 ; 30(1887), 549$

4. 1045) 51 (1888), 155

4.600) $30(1587), 317$

4.700) $30(1887), 181$

4.701) 30 (1887), 737

4.702) W. v. Siemens, Lebenserinnerunger: S. 272 (s. 4.86)

\section{SLUB}




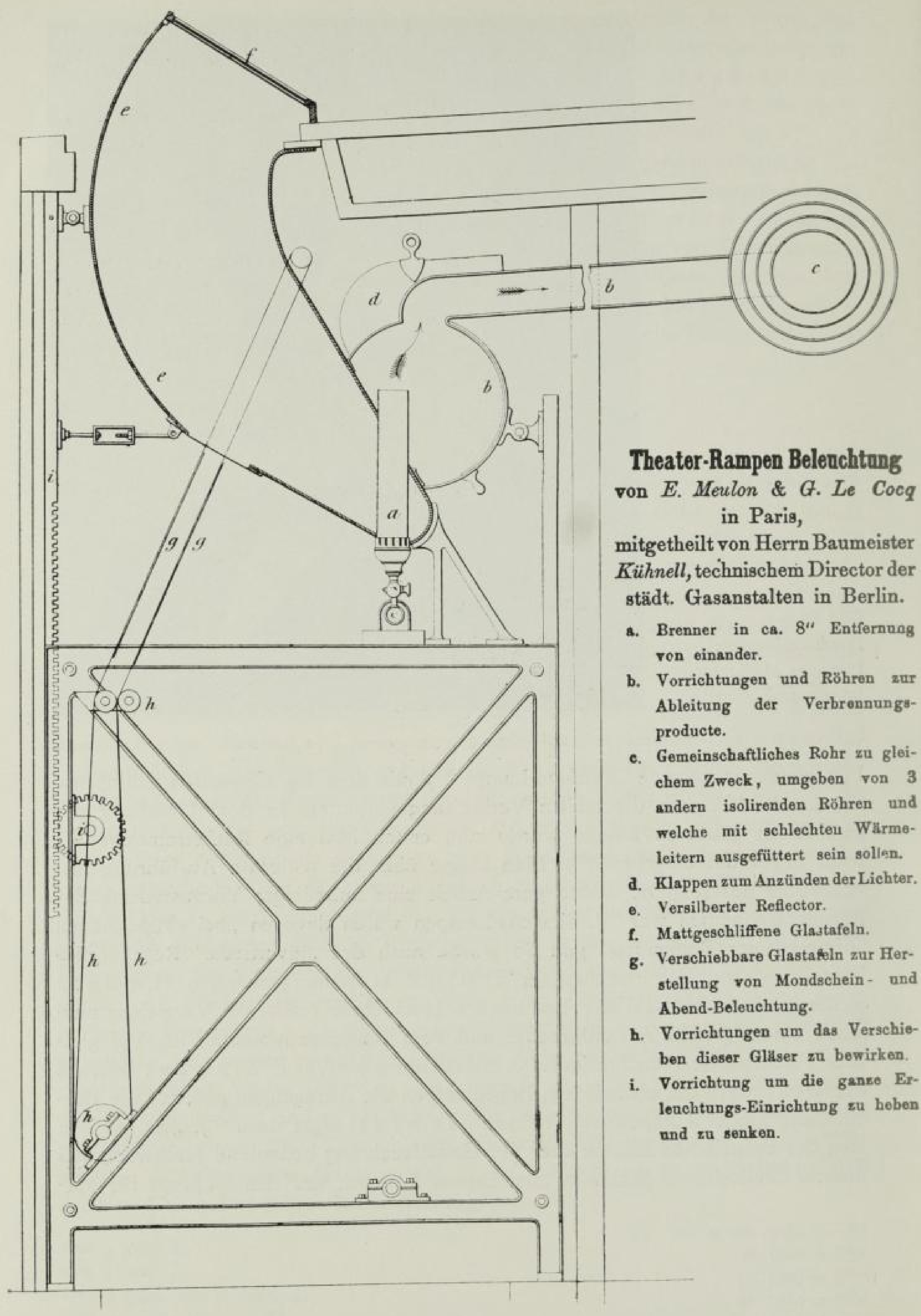

Bild 69. Geschlossenes Gaslicht für Bühnen (J.f. G. 5 [1862] Tafel 5) 
male Lichtstärken mit $50 \%$ Gasersparnis wurde in der belgischen Gaso-Multiplexlampe von $B$ and se $p t$ geschaffen $\left.{ }^{t .700}\right)$. Sie wurde bald durch das Auersche Gasglühlicht überholt.

Sehr viel Gedankenarbeit löste die Aufgabe, Theater, insbesondere Bühnen, zu beleuchten, aus. Es galt, die Flammen in einem geschlossenen Raume zu entfalten und die Abgase abzuführen, was zuerst in Paris ausgeführt worden ist. ${ }^{4.704}$ ) (Bild 69). Fünf Jahre später erregten Riedingers Bühnenbeleuchtungen in Augsburg und Darmstadt grofes Aufsehen ${ }^{400}$ ). I 870 sind sie in München, Berlin, Opernhaus und Schauspielhaus nachgewiesen $\left.{ }^{4.200}\right)$. Das Bild 70 zeigt die Beleuchtung des Saales der Postanstalt in Berlin, Bild 71 die indirekte Soffittenbeleuchtung der Pariser Theater. Die Scala in Mailand war damals ebenfalls mit Gas beleuchtet. Danach wird kein Aufhebens mehr von diesen Einrichtungen gemacht. Der schon erwähnte Brand von 1882 im Wiener Burgtheater führte trotz der für das Gas nicht ungünstigen Aufklärung der Gerichte und der vorsichtigen Äuf̧erungen der Feuerschutzbehörden zu einer schnellen Einführung elektrischer Beleuchtungseinrichtungen für Theater.

Eine indirekte Beleuchtung durch Deckenbestrahlung sollte der Elstersche Blendscheinwerfer ermöglichen ${ }^{4,707}$ ).

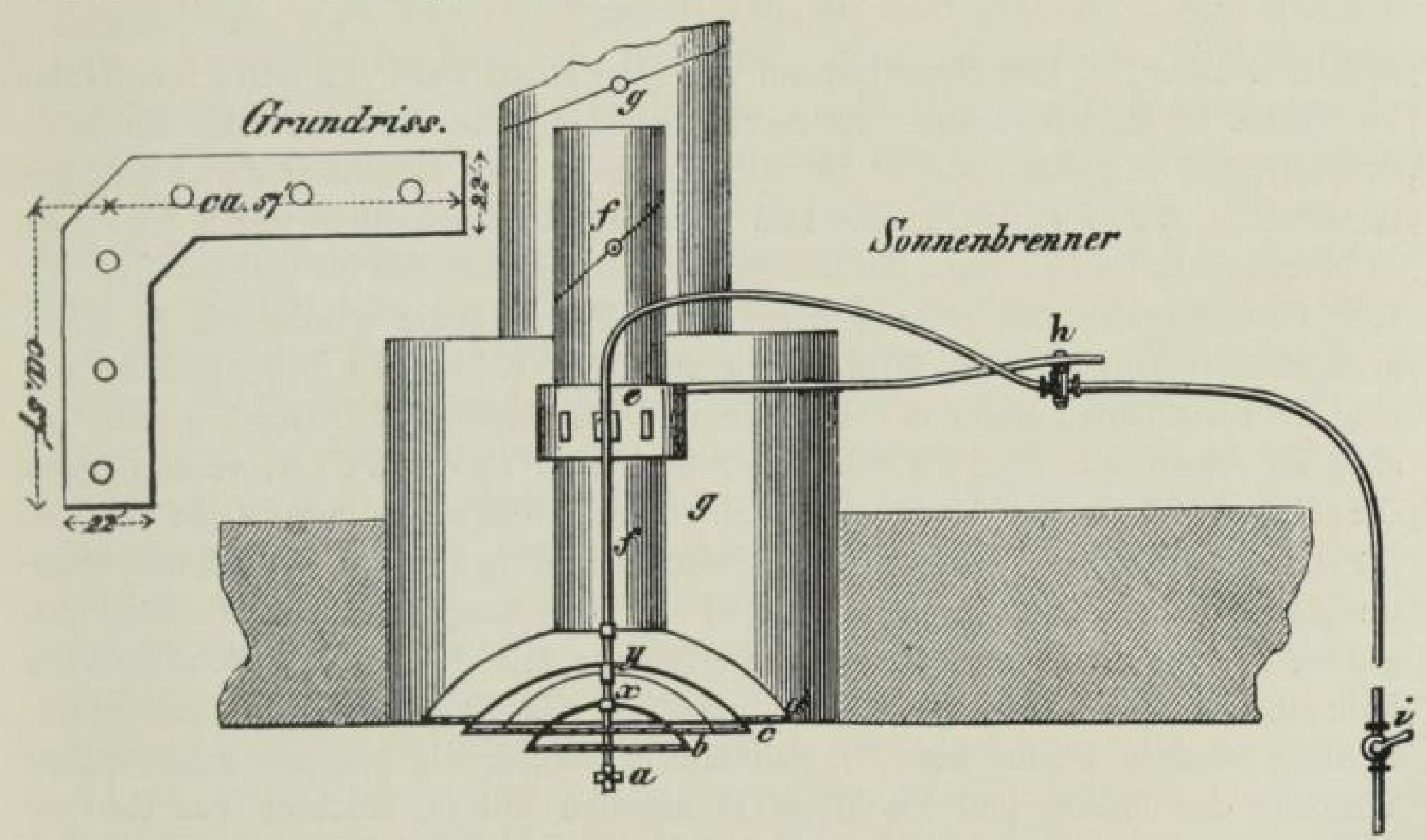

Bild 70 Beleuchtungsanlage in der Post in Berlin (J. f. G. 13 [1870] S. 92)

Schon früzzeitig suchte die Gasindustrie nach Mitteln, die Zündung ohne offene Flamme zu betätigen. Sehr weit ausgreifend waren die ersten englischen Vorschläge, mit dem Strom einer elektrischen Batterie zu zünden. Durch Stromstöß̧e sollte der Hahn langsam geöffnet, durch Glühen eines Platindrahtes das Gas ge-

\footnotetext{
4.709) $33(1890), 44$

4.704) $,(1862), 82$

(..205) $10(1867), 99$

4. 205$)$ 13 $(1870), 22$

4.705) ${ }_{54}(1891), 268 / 271$
} 


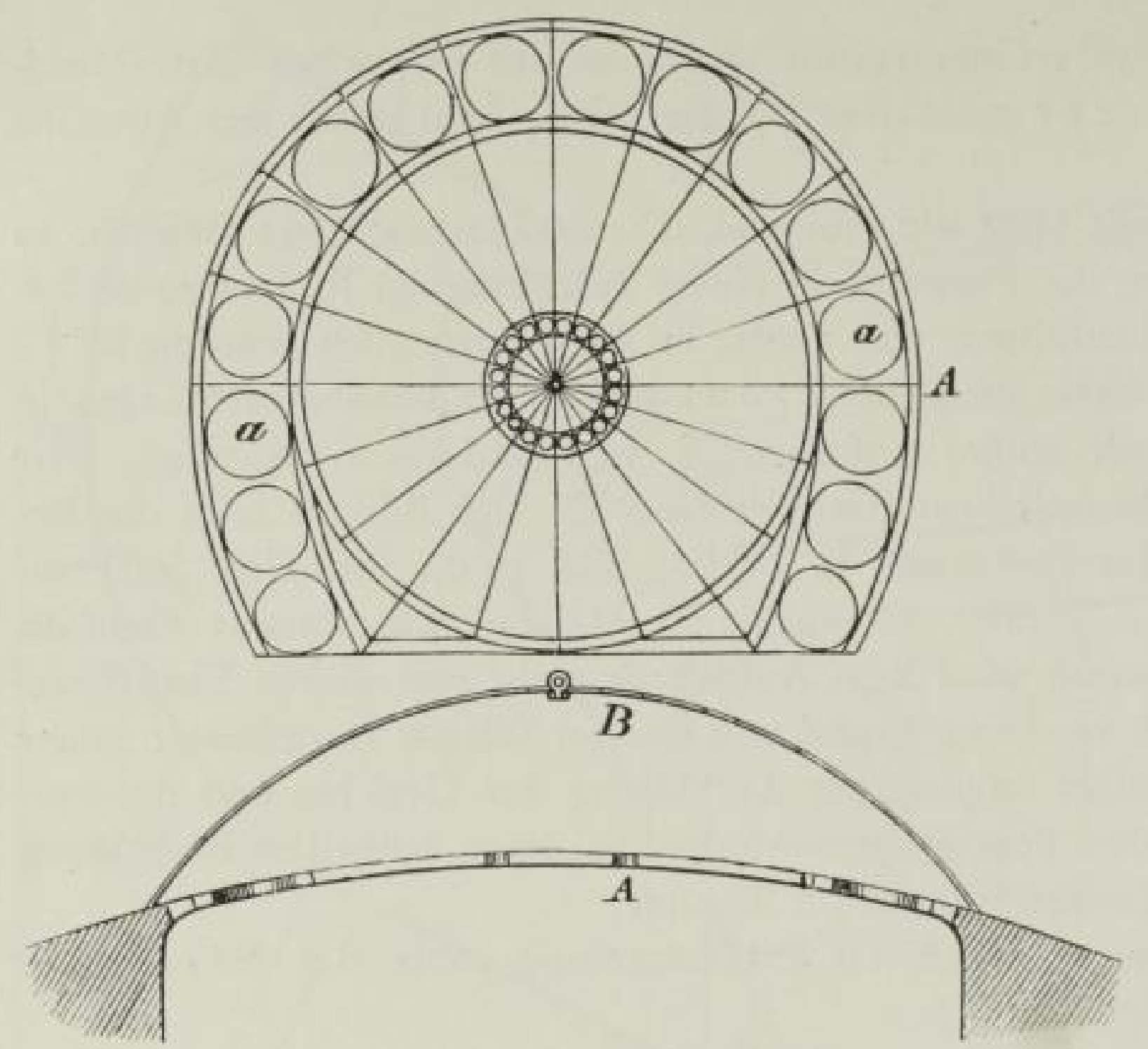

Bild 71

Soffitenbeleuchtung der Pariser Theater (J. f. G. 13 [1870] S. 94)

zündet werden $\left.{ }^{4.70 s}\right)$. Der Batteriestrom war aber zu schwach, um sicher den Hahn zu öffnen. H. Raupp verlegte die Achse des Hahnes in die Senkrechte. In Saarbrücken und St. Johann war er 1857 , in Pforzheim Aug. Benckiser damit sehr zufrieden. $\left.{ }^{400}\right)$. B a r low berichtete 1868 über eine Uhrenzündung von T in Norwich. L. Price regte die Benutzung von Druckwellen im Gasstrom an ${ }^{4.510}$ ). Der Gasverbrauch der ständig brennenden Zündflamme wurde mit 84 1/Tag angegeben, betrug aber in Wirklichkeit mehr $^{4.711}$ ). Klinkerfues brachte 1871 eine Druckwellenzündung mit Batterie und Platinglühdrat heraus ${ }^{4.712}$ ). Sie war aber zu verwickelt. L. Ba umeister und M. Flürscbeim, vereinfachten die Konstruktion. Sie kamen in Heidelberg probeweise zum Zuge ${ }^{4.7 i 3}$ ). $\mathrm{Ph}$. Lenze, Düren (der Vater von 4 Gasfachleuten) hatte eine Druckluftfernzündung für so auf $3,5 \mathrm{~km}$ verteilte Laternen mit einer besonderen Steuerleitung aufgebaut $^{4.74}$ ); Emmerich hat sich des Verfahrens mit dem Erfolg beträchtlicher Lohneinsparungen bedient ${ }^{4.715}$ ). Eine besondere Gas-Selbst- und Fernzünderausstellung fand in Berlin statt $\left.{ }^{4.70}\right)$. Zündeinrichtungen, die mit der katalytischen Wirkung des Platins und Platinmohres arbeiten sollten, tauchten von Zeit zu Zeit auf und verschwanden ebenso schnell wieder, weil sie keineswegs dauerhaft waren $^{4.717}$ ).

-.705) $2(1859), 120 / 121$

$4.700)=(1859), 293$

4.710) II (1868), 388; $12(1869), 640$

4.711) $12(1869), 640$

4.72) eingehend beschrieben in Muspratt. S. 633 (5. 2.81)

4.73) 17 (1874), 10; $646 ; 775 / 779 ; 18$ (1875), 5; 20 (1877), 668

4.74) $42(1899)$, 301

4.715) $43(1900), 427$

(.776) $42(1899), 737$

4.717) $10(1867), 499 ; 40(1897), 297$

280

\section{SLUB}


Vielfach sind die Versuche gewesen, mit „,billigem" Sauerstoff die Verbrennungstemperatur und dadurch die Leuchtkraft der Lampen zu erhöhen. Ausgelöst wurden die Absichten durch den Fehler vieler Erfinder, die Herstellungskosten im Laboratorium oder in einer Versuchsanlage allein zu betrachten, ohne die im technischen Mafsstabe notwendigerweise auftretenden Unvollkommenheiten, Sammel- und Verteilungskosten und Verluste zu berücksichtigen.

Statt einer vollständigen Darstellung mögen nur zwei der Erfinder genannt werden, die wenigstens bis zu Versuchsanlagen im Grołen gekommen sind:

Mit grołem Werbegeschrei wurde Tessié du Mot a y, Paris, begrüft. Nach einem Patent gemeinsam mit $M$ arécbal, Metz, wollte er sauerstoffangereicherte Luft durch abwechselnde Oxydation und Desoxydation von saurem und übermangansaurem Kali und Natron herstellen. Ein Kubikmeter Sauerstoff sollte nur 65 cts kosten. Allerdings wäre eine zweite Gasleitung zu den Leuchten notwendig gewesen, deren gasdichte Ausfuhrung damals nicht zu lösen war. Trotzdem wurde die wilde Werbung in Gang gesetzt. An der Börse hieł es: „Die Aktionäre der Gasgesellschaft sind sehr beunruhigt wegen des neuen Beleuchtungsstoffes“. „Die Pariser Gasgesellschaft hat dem Erfinder 2 Mio frcs geboten; er gibt aber seine Erfindung nicht her“. „Man spricht davon, daf die Pariser Gasgesellschaft sich mit der Gesellschaft, welche die neue Erfindung ausnützen will, zu vereinigen gedenkt $\left.{ }^{a+.75}\right)$. Eine Anlage wurde auch in Paris ausgeführt. Sie hat eine ganze Entwicklung durchgemacht, beginnend vom Versuch mit Glühkörpern bis zum angereicherten Ölgas. Ihre Erprobung wurde aber durch den Krieg 1870/71 gestört und danach fehlte die Protektion von ",höchster Stelle“. Im übrigen war Tessié du Motay ein ernster Konstrukteur. In Wien wurde sein Sauerstoff-Ölgaslicht durch die Creditanstait aufgegriffen, die sich ein Privileg geben lief $\left.\}^{t .10}\right)$. Der Bahnhof der Kaiserin-Elisabeth-Bahn wurde so beleuchtet, wobei ein vereinfachter Brenner benutzt wurde, bei dem die Flamme durch einen Mantel sauerstoffreicher Luft eingehüllt wurde $\left.{ }^{4.720}\right)$. Man äufjerte sich sehr befriedigt, auch noch $1873^{4.72}$ ). Ganz plötzlich kam die gegenteilige Nachricht. Die Anlage sei als unwirtschaftlich stillgelegt. Die Spekulanten, die hinter dem Unternehmen standen, hätten mehr erwartet ${ }^{4}$ ). Sehr ähnlich wie die T e s sié $d u$ Motays müssen die Bestrebungen von J. Pbilipps in Köln gewesen sein, der ein besonderes, in der Zusammensetzung geheimgehaltenes Gemisch von Kohlenwasserstoffen mit Sauerstoff, der über Kupferchlorür hergestellt wurde, verbrannte $\left.^{t^{t a z}}\right)$. Tessié du Motays Arbeit war auch so nicht ganz verloren, weil er erkannt hatte, daf̧ ein sehr leuchtkräftiges Gas für die Wirkung des Sauerstoffes Voraussetzung sei und er infolgedessen, wie auf S. 208 erwähnt worden ist, die Wassergaserzeugung mit Karburierung so entwickelte, dafy sein Verfahren die Grundlage für weitere Arbeiten wurde.

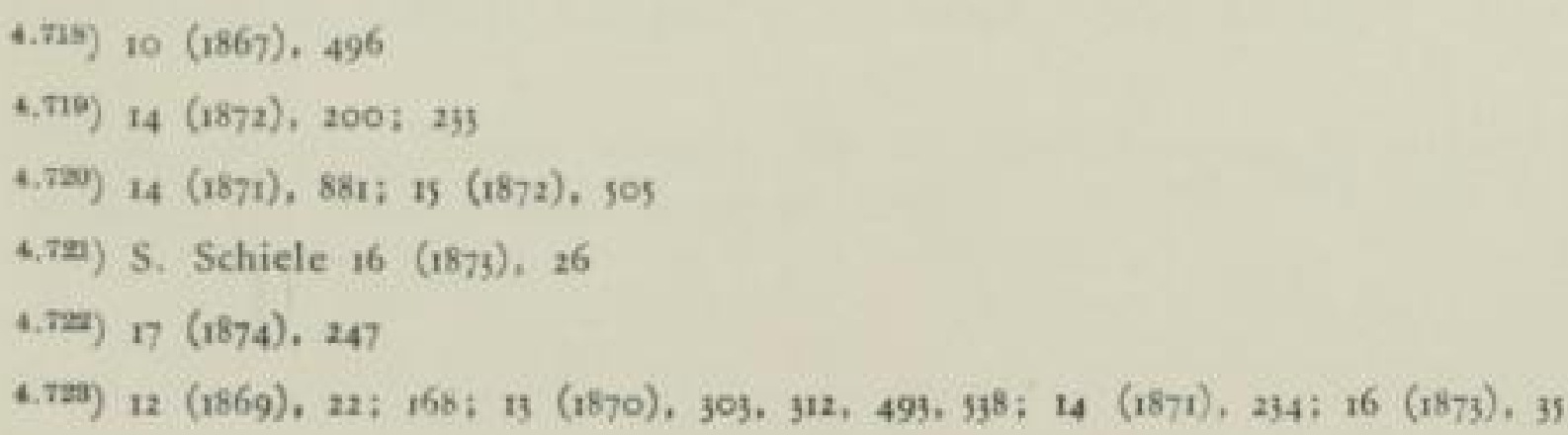


20 Jahre später glaubte H. Kaßn $n$ r, Sauerstoff über orthobleisauren Kalk billig herstellen zu können $\left.{ }^{4 . z z}\right)$. Er griff das bereits eingeführte Brinsche Verfahren über Bariumoxyd als zu teuer an, auch weil er wieder seine Laboratoriumsergebnisse den üblichen Handelspreisen gegenüberstellte ${ }^{4,75}$ ). Unter dem Namen Oxyölgas wurde ein Patentverfahren empfohlen, in einer Retorte ein sehr schweres Ölgas, das mit Luft verbrannt sehr leicht rußjt, mit Sauerstoff zu verbrennen ${ }^{4.22 n}$ ). Das war also nur eine Wiederholung der Gedanken von Tessié du Mota y.

\subsection{I5 G a sglühlicht}

Das Gasglühlicht hat eine lange Geschichte. Immer wieder wurde versucht, mit der Gasflamme keramische oder metallische Körper zu erhitzen, die ihrerseits Licht ausstrahlen sollten. Der erste Versuch war das Drummondsche Kalklicht 1826, das auch ein wenn auch kleines, so doch ganz bestimmtes Anwendungsgebiet fand. Úberall da, wo ein sehr weiłes Licht hoher Intensität benutzt werden mufte, in Leuchttürmen, bei der Photographie zur Anfertigung von Vergrößerungen, für Projektionslampen griff man auf das Kalklicht zurück. Zur Erhitzung diente Knallgas oder ein Leuchtgassauerstoffgemisch. Später wurde statt des sich rasch abnützenden Kalkstiftes Magnesia oder Zirkonerde benutzt. Auch Tessié du Motay begann damit seine Versuche. J. P. Gillard lief̧ Wassergas, das durch Uberleiten über glühende Holzkohle aus $94 \%$ Wasserstoff bestand, in einem $\Lambda$ rgandbrenner Platinnetze zum Glühen bringen (Patent v. 22. II. 49.) I861 wandte Fages in Narbonne das Verfahren mit einigen Verbesserungen an. Er war anfangs sehr zuversichtlich $\left.{ }^{4.727}\right)$, 1865 ging man aber zu Kohlengas über. Andere Platinbrenner waren Bauarten von $\mathrm{Hog} g, V i a l$ und $L e$ w is $\left.(1884)^{6.725}\right)$. C $\mathrm{l}$ a $m$ ond in England (D. R. P. 16640 v. 1881) nahm das Kalklicht wieder auf, arbeitete aber statt mit Sauerstoff mit Luftvorwärmung, machte sich also die Erfahrungen am Regenerativbrenner zunutze, allerdings benutzte er zur Aufheizung der Luft eine Hilfsflamme. Sein hängender Glühkörper war ein festes Geflecht aus Magnesia von 40 Stunden Brenndauer ${ }^{4{ }^{4}}$ ). Der Warmluftbrenner von $P \circ P D$ hatte ein durchlöchertes Hütchen aus feuerfestem Stoff und cinem Gewebe aus Platin $^{4.7 \times 0}$ ). (Bild 72). (Patent 23408 v. 30. 9. $82 ; 27$ (1884) S. 444.) In Paris machte er sich die in den Straß̧en verlegte Pref̧luftverteilung zunutze. Das Ganze war also wohl die erste Oberflächenverbrennung mit theoretischem Gemisch. Ein Glühkörper kostete 40 bis $70 \mathrm{M}$. Damit wurde dieses Licht zu teuer. Kaum zu unterscheiden ist der Brenner von $S$ o mzée, Brüssel, D. R. P. 27484 v. 9.9 .83 und $26988^{4.731}$ ).

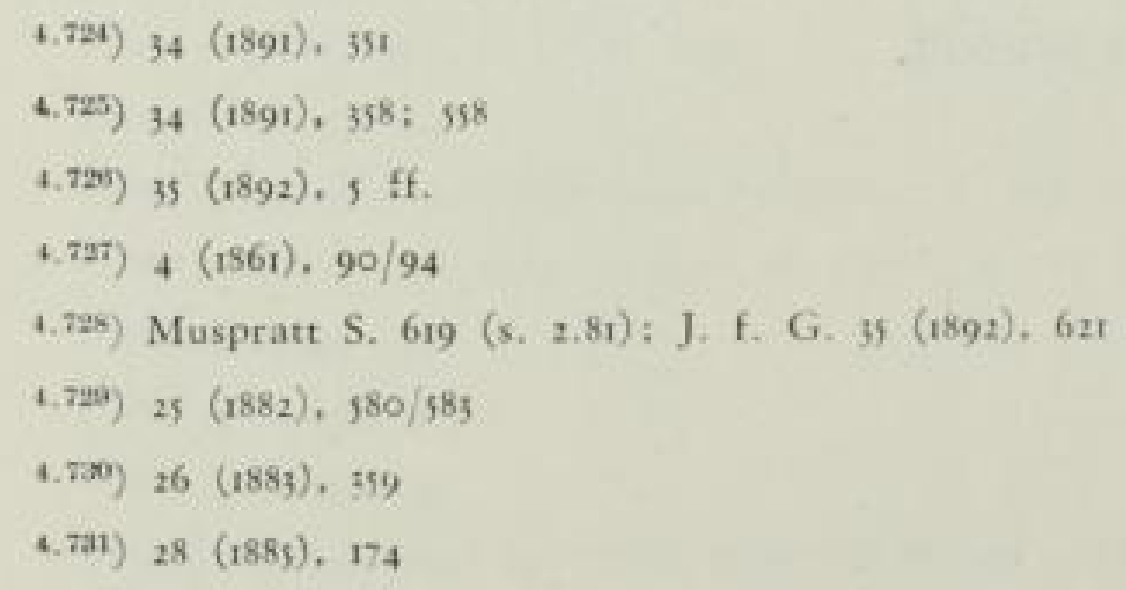




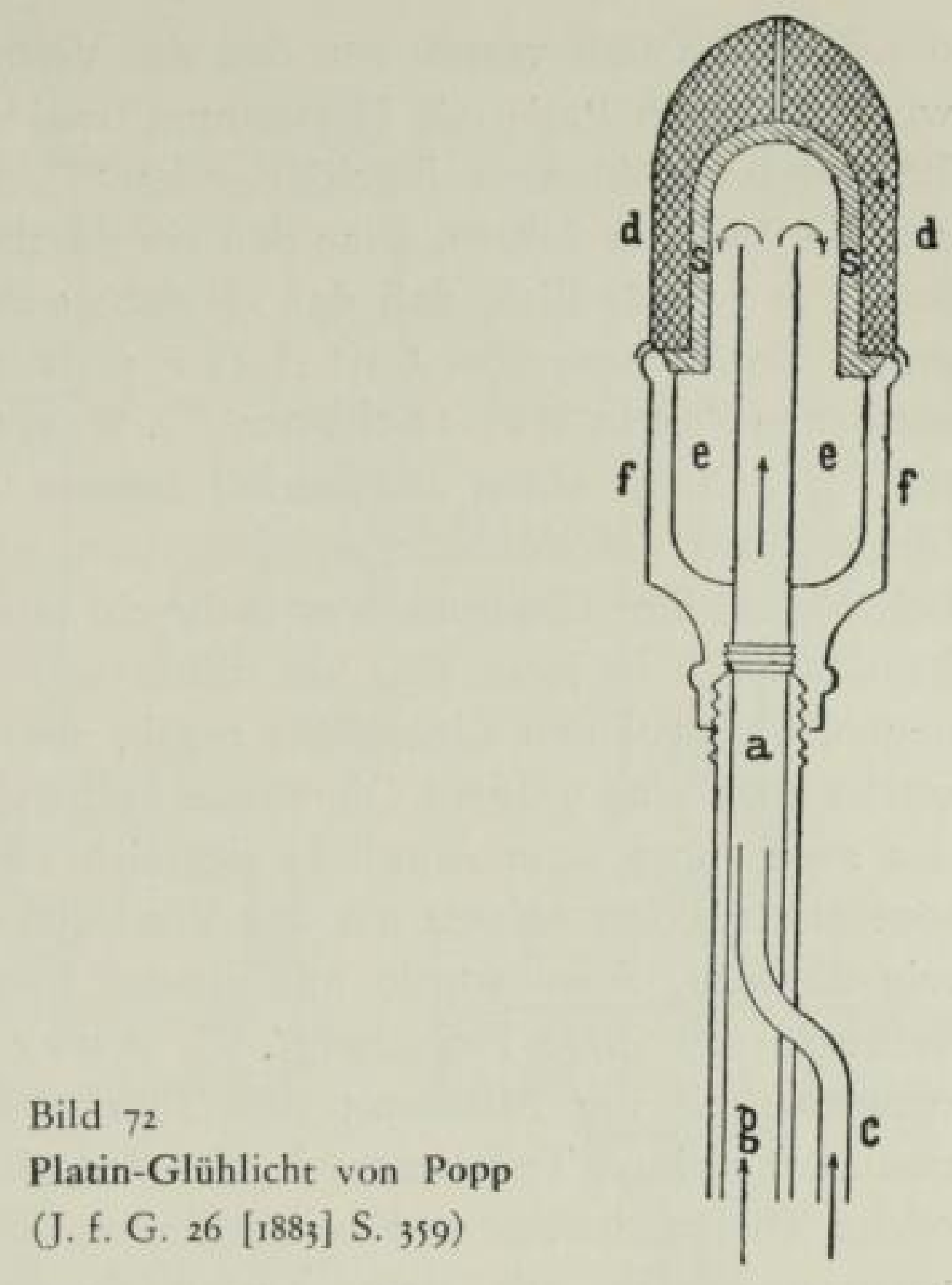

Als J. v. Quaglio im Dienste der europäischen Wassergasgesellschaft in Stockholm mit Erfolg dieses Gas bei Schulz-Knaudt in Essen zum Schweiłen von Rohren eingeführt hatte, dachte er auch an die Beleuchtung ${ }^{\text {t.tag }}$ ). Er sagte: „Ich glaube, daf̧ gerade die Zukunft der Beleuchtung...... in der Herstellung ganz mächtiger Incandescenzlichter mit Gas bestehen wird". Er muf3te in seinem Vortrag einen so ausgezeichneten Fachmann wie A. Hegener, Köln über die Unabhängigkeit der Verbrennungstemperatur vom Heizwert belehren. Die Verwirk-

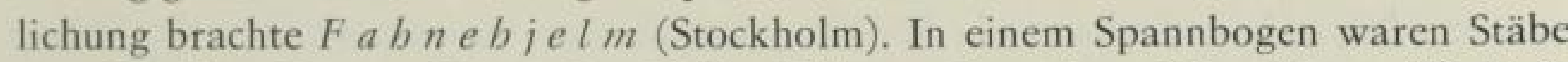
aus Kaolin, Quarz, Magnesia, Kaik, Zirkonerde oder Kieselsäure (D. R. P. $2949^{4, \pi a}$ ) über der Wassergasflamme aufgehängt. Später nach Bekanntwerden des Auerlichtes hat Fahnehjelm auch Metaligemische mit seltenen Erden als Überzug des Grundkörpers benutzt $\left.{ }^{t .73}\right)$. Ein Dauererfolg war auch dieser Beleuchtung nicht beschieden, obwohl sich in Deutschland J. Pintscb dem Vertrieb gewidmet hat.

Selbst der Aufbau Auers hatte Vorläufer, die aber A ue r nicht als Vorbild gedient haben. Bekannt geworden ist der Gedanke $T$ albots, Calciumchlorid auf Papier aufzutragen, das nach Abbrennen ein Aschenskelett ergab (1855) $\left.{ }^{4.75}\right)$. Cruiksbank benutzte ein Platinnetz. Sein Versuch, das Netz mit Erden zu überziehen, scheiterte wegen der Absplitterung der Massen vom Netz (1849). Frankenstein trug fertige Oxyde auf ein Gazenetz auf für Lunar- und Solarlampen (1862). Es gab aber noch viele andere, unbekannt gebliebene Erfin-

4.Tag) $26(1883)$, 608 Quaglio ging um 1885 ins Hüttenfach, wo er mehrere neue Verfahren einführte (Ress. Geschichte der Kokereitechnik S. 397 (5, 4,115)

4.7ai) $28(1885), 277 ; 326$

1.74M) 36 (1893), 416

4.735) $40(1897), 18 z$ 
der. Durch Zufall wissen wir, daf der Vater Rudolf Die sels, ein Lederhandwerker, sich in Paris mit Herstellung und Vertrieb von Messingglühkörpern für Leuchtflammenbrenner beschättigt hat $\left.{ }^{1,30}\right)$. Die Suche war gewaltig, besonders auch in den 8oer Jahren, ohne dał ein durchschlagender Erfolg erreicht wurde.

So ist es verständlich, daß̧ das Gasfach sich sehr skeptisch äuß̧erte, als 1886 die ersten Nachrichten über Carl Auerv. Welsb a cbs Arbeiten in der Pharmazeutischen Post in Wien erschienen ${ }^{437}$ ). W. v. Oecbel b a e u ser $r$ hat 19:9 berichtet $\left.^{4.735}\right)$ : „Durch einen Reisezufall konnte ich im Jahre 1885 der ersten Vorführung des Gasglühlichtes durch Auer im Universitätslaboratorium zu Wien beiwohnen. Der Eindruck war mehr ein interessanter als verblüffender; denn es handelte sich in jener Zeit um die erste Form des Auerlichtes, die zwar einen neuen, ungewohnten Lichteffekt ergab, aber zunächst weder eine gröf̧ere Lichtstärke noch eine gröłere Ökonomie herbeiführte. Erst 6 Jahre später (189t) kam das sogenannte neue Auerlicht siegreich zur allgemeinen Einführung, indem es jene ältere Form nahezu um das Vierfache an absoluter Helligkeit und Ökonomie übertraf. Auer wurde mit diesem Erfolg der gröłte Wohltäter der Gasindustrie seit ihrer Erfindung“. C. A uer hatte inzwischen in fleifiger Forschungsarbeit die Mischung des Thoriumoxydes (99. v. H.) mit einem überraschend kleinen Teil Ceroxyd gefunden, die die beste Leuchtkraft ergab. Zahlreiche Wissenschaftler und auch Männer, die die Patente übertreffen wollten, beschäftigten sich mit dem Zustandekommen der Wirkung ${ }^{4,730}$ ). Ricbard $P$ in $t s c b$ berichtete vor dem Verein über die sonstigen Verbesserungen: Trägerstange in der Achse des Glühkörpers, statt wie früher störend seitlich; festeres Aschengewebe (durch Tauchung in Kollodiumlösung); Aufhängung an Asbestschnur statt Platindraht ${ }^{4.70}$ ). Er führte auch eben neu entstandene Druckluft- und Prefluftbrenner vor. Pintsch wurde Aufsichtsratsvorsitzender der Deutschen Gasglühlicht-Gesellschaft Berlin, die die Auerpatente übernommen hatte. Nach England waren die Patente schon 1886 an ein Konsortium für I Mio Gulden verkauft worden $\left.{ }^{4.74}\right)$. G. F a e bndricb, Wien, sprach 1892 von einem Sieg des Auerbrenners. In Österreich seien in 9 Monaten 90000 Stuck geliefert, in Deutschland 20000 , die Hälfte davon nach Berlin $\left.{ }^{4,74}\right)$. Er verglich den Gasverbrauch je HK: Argandbrenner io 1, Siemens 6 bis 3,7 1, alter Auerbrenner 5,4 1, neuer Auerbrenner 2 bis 1,51 . Für einen Brenner mit allem Zubehör wurden in Österreich 5,25 bis 7,00 Gulden gleich 8,80 bis 12 Mark gefordert, in Deutschland (Stuttgart) dagegen 17,50 bis 21 Mark $\left.{ }^{4.74}\right)$. Das verschnupfte nicht nur die Abnehmer, sondern mufte auch die Brennerfirmen veranlassen, sehr eifrig nach Lücken im Patente und nach besseren Brennerbauarten zu suchen. So kam es zu umfangreichen und kostspieligen Prozessen $\left.{ }^{4.74}\right)$, aus denen die Gasglühlichtgesellschaft

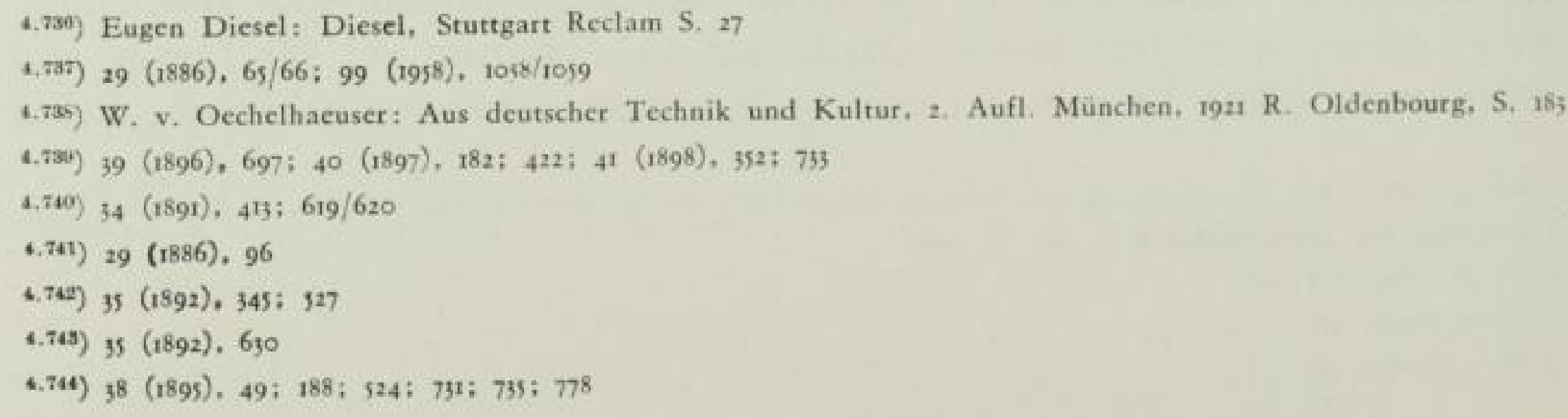


Bild 73

Denayrouzebrenner

(J. f. G. 38 [1895] S. 716)

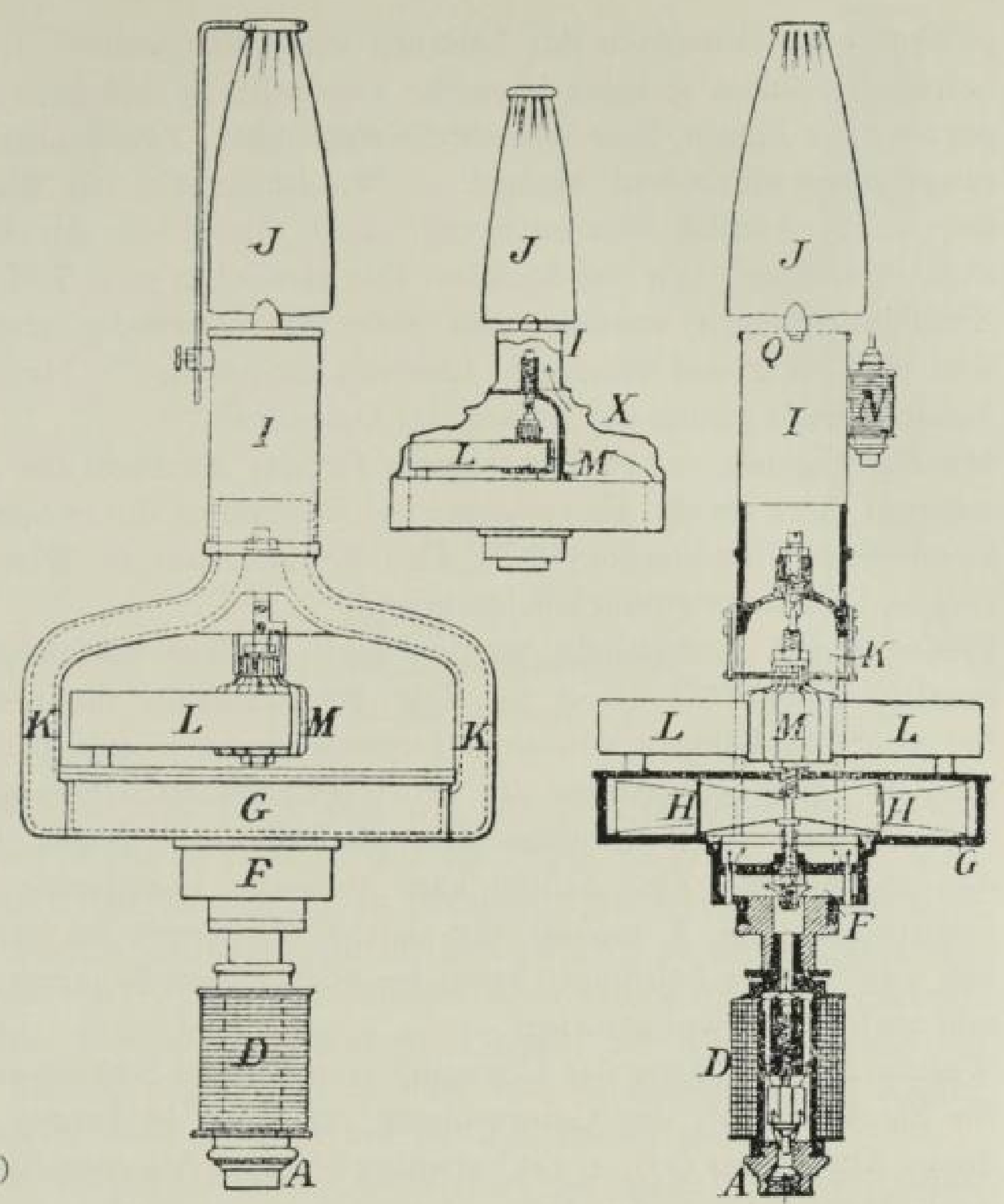

nicht ungerupft hervorging ${ }^{4.25}$ ). Im Jahre 1896 wurden 78 Giühlichtfabrikanten benannt, wie weit diese Lizenznehmer waren, geht aus der Mitteilung nicht hervor $\left.^{4.74}\right)$. M. L. De n a y ro uze, Neully s. Seine, versuchte die Mischung im zum Auerlicht notwendigen Bunsenbrenner durch ein kleines Motorgebläse zu verbessern $^{4.7 \pi}$ ). Die Vermutung von Prof. V. B. Lewes, daf3 wahrscheinlich durch den höheren Druck des Gases im Bunsenmischer mehr Luft angesaugt würde, wurde von $\mathrm{F}$. $\mathrm{Haber}$ bestätigt $\left.{ }^{4,745}\right)$. Denayrouze wandte auch Luftvorwärmungen an (Bild 73), lieł aber das Gebläse fort, als er durch einen Diffusor fast die theoretische Luftmenge erreichte ${ }^{1.7 u}$ ). Die Gesellschaft für Beleuchtungswesen schuf eine Regenerativ-Glühlichtlampe $\left.{ }^{4.750}\right)$. Andere versuchten es mit einem Wirbelkörper im Gasteil ${ }^{\text {(.751) }}$ ).

Die Straf̧enbeleuchtung ging langsamer auf Auerlicht über, da der Wind den Glühkörpern gefährlich wurde. Voran ging Wiesbaden, wo C. W. Muc b all eine besondere Zündvorrichtung geschaffen hatte, mit der er die lästige Ver-

4.745) $39(1896), 42: 659 ; 608 ; 40(1897), 445$

4.746) $39(1896), 585$

4.747) 38 (1895), 716

4.745) 38 (1895), 453: 39 (1896), 49

4.749) 40 (1897), 566; 49 (1900), 100

$4.750) 43(1900), 859$

C.781) $41(1898), 380$

\section{SLUB}


puffung beim Anstecken der Laternen vermeiden wollte ${ }^{4.759}$ ). 1897 haben von 262 befragten Städten 17 keine Versuche angestellt, 27 sind ganz auf Glühlicht übergegangen, 2 klagen über schlechte Erfahrungen, Zerstörungen durch Erschütterungen, Mutwillen und Mangel an Windsicherheit, 169 Werke wollen weitergehen. 2I, $5 \%$ aller Straf3enlaternen sind Auerlichte mit einer durchschnittlichen Brenndauer von 500 Stunden. Die vielfachen zum Teil teueren besonderen Zündeinrichtungen wurden nicht mehr für notwendig erachtet, ${ }^{\text {t.75s }}$ ). In Berlin sind 1898 mit 27000 Stück alle Laternen umgestellt $\left.{ }^{t, \pi}\right)$. Hamburg war zur Jahrhundertwende gerade am Anfang des Umbaues ${ }^{4.755}$ ).

Mit der Eignung reinen Wassergases für das Auerlicht hat sich H. Stracbe, mehrere Jahre befaf3t. Er verlangte die Entfernung des in Spuren im Rohgas vorkommenden Eisenkarbonyls $\left.{ }^{4.75}\right)$. Das Krankenhaus in Wien erhielt eine Strachesche Wassergasglühlichtbeleuchtung ${ }^{4, \ldots \pi}$ ).

Preß̧luft- und Prefggaslicht wurden auch vielfach „erfunden“, d. h. irgendwie zusammengebaut ${ }^{4.255}$ ) (Bild 7.4). Die Schwierigkeit, die wechseinde Menge bei mehreren Lampen von einer Luftzentrale her - mit gleichem Druck zu liefern, war grof3 und brachte arg verwickelte Bauarten hervor ${ }^{4.55}$ ). Wasserkolbenmotoren und Wasserstrahlgebläse, Heifluftmotorpumpen jeglicher Art wurden angewendet. Zum Schlu\} kam noch die Lucaslampe mit einem hohen Schornstein, (Vgl. S. 392/393), die gleiche Wirkungen hervorrief, allerdings häflich war $\left.{ }^{4.7 \times}\right)$. Die Leistungen lagen bei allen diesen Bauarten bei i 1/HK, manchmal auch noch etwas günstiger.

Welche Auswirkungen der Übergang vom offenen Schnittbrenner zum Glühlicht für die Wirtschaft der Gaserzeugung versprach, ist bereits in dem ersten Teil dieses Abschnittes (vgl. 4. 126) erwähnt worden. Als erstes Werk stellte das Gaswerk Magdeburg einen Antrag auf Herabsetzung der Leuchtkraft im iso 1 Schnittbrenner von ${ }^{14} \mathrm{HK}$ auf to und später $\left.8 \mathrm{HK}^{+.3 i+}\right)$. Demgegenüber stellte A. Samtleben fest, da\} Benzol, Aethylen und Azetylen bei guter Vormischung die Leuchtkraft des Auerbrenners zu erböhen vermöchten ${ }^{4002}$ ).

4.5I6 Olgas für Eisenbahnen und Seezeichen

Das Ölgas, dessen Erzeugung vor allem durch H. Hirzel in Deutschland verbessert worden war, sollte sich für Eisenbahnwagen als durchgreifende Neuerung bewähren. Mit diesem lichtstarken Gase konnten die Behälter kleiner gehalten

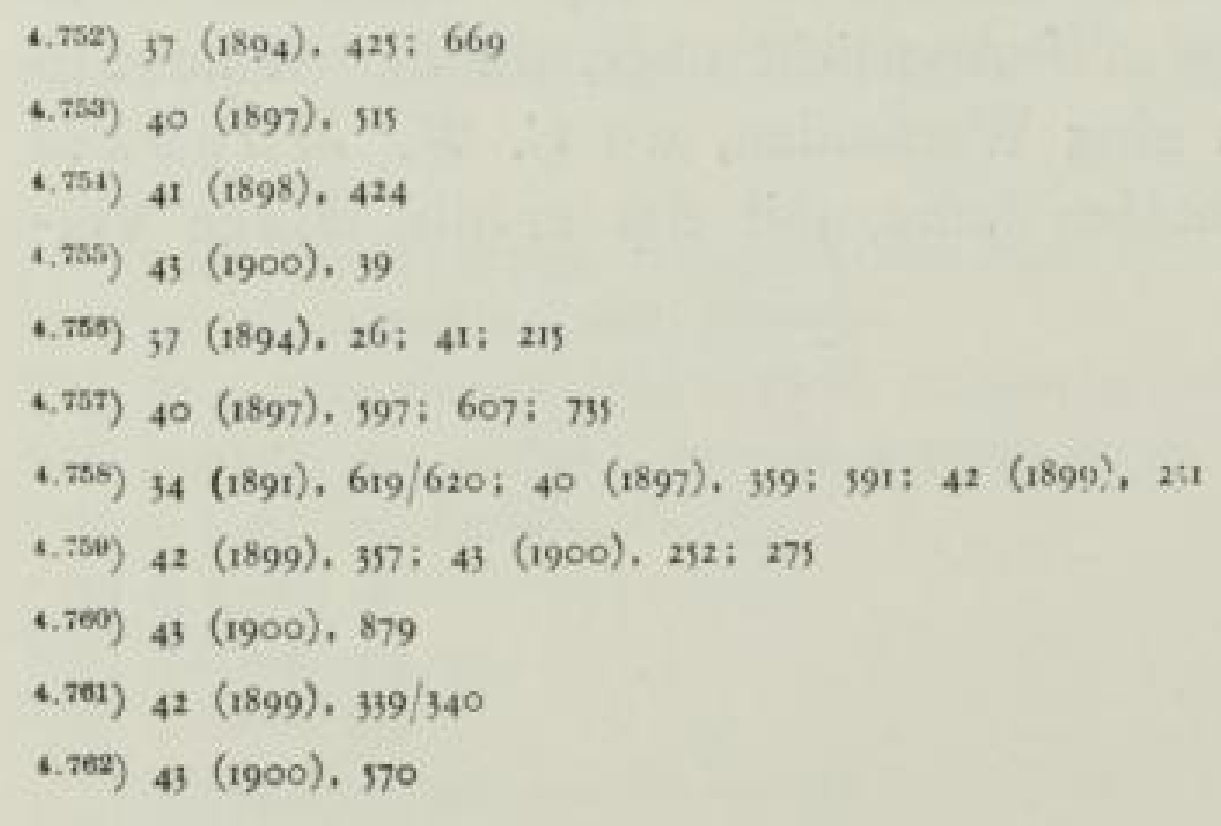




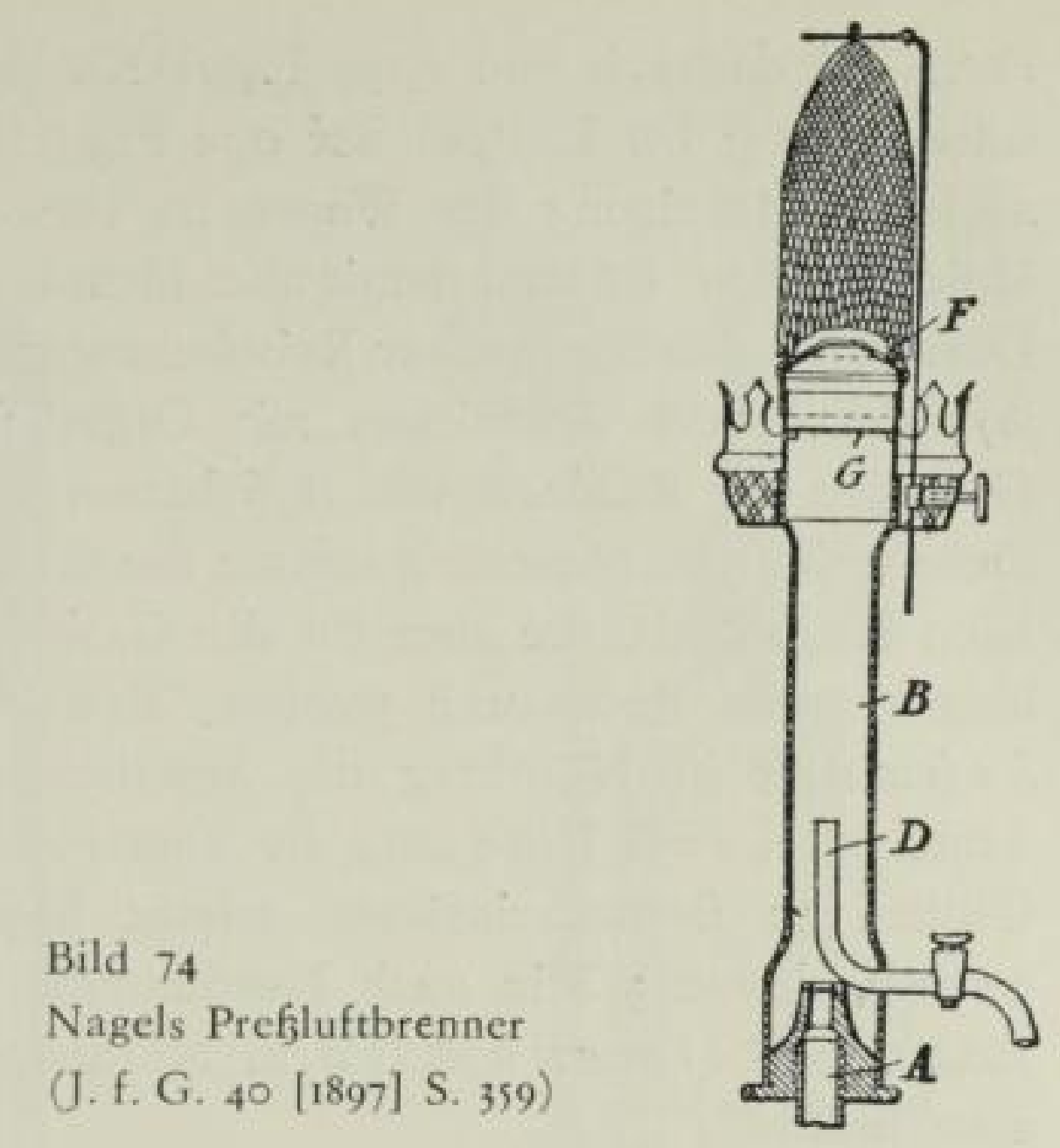

werden als bei Kohlengas. Im Jahre 1868 trat die Niederschlesisch-märkische Eisenbahn an Julius Pintscb heran mit der Frage, ob er gute Lampen für die Personenwagen anfertigen könnte ${ }^{4.76)}$. In Frankreich hatte man Ölgasbeleuchtung seit 1859 mit geringem Erfolge versucht. Pintsch ging an die Entwicklung. Ein Probezug lief 1870 von Berlin nach Breslau. Aber Niederdruckgas flackerte sehr unter den Stöfzen. Deshalb ging Richard Pintsch, der diese Arbeiten vor allem betreute, zur Speicherung mit 8,5 at über und entwickelte einen Regler, dessen gute Arbeitsweise wohl entscheidend für den Erfolg wurde $\left.{ }^{4.744}\right)$.

Das darf insofern festgehalten werden, als hierbei die gute Werkmannsarbeit Voraussetzung war. Die Firma hatte in der Feinwerktechnik, wie so oft im Kriege, besondere Erfahrungen gesammelt mit Torpedolieferungen, die ihr nun zugute kamen. Die Einrichtung eines Wagens (mit vermutlich 4 oder 5 Abteilen) kostete 200 Thlr gegen $4 \mathrm{I}$ Thlr bei Olbeleuchtung. Der Betrieb war aber soviel billiger, dał die Mehrkosten in 7 Monaten herauskamen. Io Jahre später war Pintsch-Ölgas allgemein im Gebrauch. In England hatte man zwar noch karburiertes Niederdruckkohlengas von $S u g g$ und in Amerika das Albokarbonlicht mit Benutzung der Druckluft der Westinghousebremse $\left.{ }^{4.7 \pi 5}\right)$. Aber Pintsch mit Tochterfirmen im Auslande setzte sich gegen sie durch. Die Einzellampen hatten aber eine so geringe Größje $\left(33 \mathrm{dm}^{3} / \mathrm{h}\right)$, dał noch $1895 \mathrm{Hom}$ a $n$ n vor der Normal-Eichungskommission sich äuß̧erte: „Es ist zwar nicht zu leugnen, dafy die Beleuchtung in den Eisenbahnwagen zum Lesen nicht ausreicht - es hat sogar seine Schwierigkeiten, wenn man bei des Lämpchens mildem Schein nur etwa im Kursbuche nachsehen will, wann der Zug auf der nächsten Station ankommen wird ${ }^{\text {at. }}$ ). 1898 beschlossen die Preufischen Staatsbahnen, dem Olgas $20 \%$ Azetylen zuzusetzen, wodurch die Leuchtkraft verbessert wurde $\left.{ }^{4.705}\right)$. Der

\footnotetext{
4.7e9) Installateur- und Klempnerzeitung 3 (?) S. 675, im Besitze der Pintsch-Bamag, Butzbach (Hessen)

4.706) $14(1871), 434$

4.7n5) $24(1881)$, 3

$4.7 \times 0), 38(1895), 65$

4.7ง7) $41(1898), 30$
} 
Preis fiel dadurch von $0,197 \mathrm{Pfg}$. $\mathrm{HKh}$ (bei reinem Ölgas mit $11-12$ HK Lichtstärke der $33 \mathrm{l} / \mathrm{h}$ Lampe) auf $0,12 \mathrm{Pfg} / \mathrm{HKh}$. 1886 regte $P$ in $t s c b$ an, Prefggas auch zur Beheizung der Wagen zu verwenden wegen der Mängel der damals üblichen Öfen. Er kam damit aber nicht durch ${ }^{4,708}$ ).

Durch eine Anregung einer Reisebekanntschaft in Rußland kam Julius $P$ in $t s c b$ I872 dazu, auch Seezeichen mit Ölgaslicht zu entwickeln. Die ersten grofen Gasbojen für Ruf̧land von 1876 hatten einen Vorrat für 3 bis 6 Monate. Auch diese technische Neuerung konnte die Firma über die ganze Welt verbreiten.

Eine Kleinigkeit, die aber für die Gasbeleuchtung insbesondere aber für Azetylengas grołe Bedeutung gewann, sind die Specksteinköpfe. 1856 erwarb J. v. $S c b w a r z$ in Nürnberg die Staatlichen Specksteingruben im Fichtelgebirge, nachdem er zwei Jahre lang die Verarbeitung des Specksteines durch Fräsen und Glühen zu Brennereinsätzen erlernt hatte. I 888 wurden 7 Mio Brenner hergestellt, davon 3 Mio nach Nordamerika ausgeführt ${ }^{\text {t.7eo }}$ ). I872 wurde die Firma Jean Stadelmann \& Co in Nürnberg gegründet, die die gleichen Erzeugnisse herstellte ${ }^{t, \pi 0}$ ).

\subsection{Wärmetecbniscbe Arbeiten}

Als sich die Gasindustrie der Gasanwendung für Koch-, Heiz- und Energiezwecke zuwandte, wurde die Bestimmung des Heizwertes eine Notwendigkeit. Das erste Durchlaufkalorimeter wurde von F. W. Hartley, dem Leiter der Fa. Alexander Wright \& Co. Ltd, London für die Untersuchung der im Kristallpalast zu London $1882 / 83$ zur Schau gestellten Heiz- und Kochgeräte 1884 gebaut $^{4.71}$ ) (Bild 75). A. W it $z$ (Ann. d. Chemie \& Physique 188, Bd. 6) hatte Versuche mit der Berthelotschen Bombe angestellt, die an sich nur für feste Brennstoffe gedacht war. Uberraschend ist, dał Witz volle Verbrennung erst mit $6 \%$ Luftüberschuf erreicht hat, und bezeichnend für die allgemeinen Kenntnisse der Leserschaft des Journals ist die Fuf̧note, in der die Kilokalorie genau erklärt wird $\left.{ }^{4772}\right)$. Die vielfachen Abwandlungen der Bombe mögen übergangen sein, da heute von ihnen wohl nur noch die von Mabler (Bergingenieur in Paris) Bedeutung hat. Sie wurde 1892 bekannt ${ }^{\prime: 17 z}$ ). A. S $l a b$ y stützte sich bei der Untersuchung von Motoren auf die Analyse. Er glaubte, die Schwierigkeit, die bei einfachen Analysen in der Bestimmung der Kohlenwasserstoffarten liegt, dadurch zu überwinden, daf er dieser Gruppe proportional mit dem Dichteverhältnis bestimmte Werte zuteilte $\left.{ }^{+, n \pi 4}\right)$. Hugo Junkers, der für O e c belb a e user die Maschinenuntersuchungen ausführte, empfand diesen Weg als zu zeitraubend und ungewif̧. Er entwickelte sein auch heute noch bekanntes Durchflußjkalori-

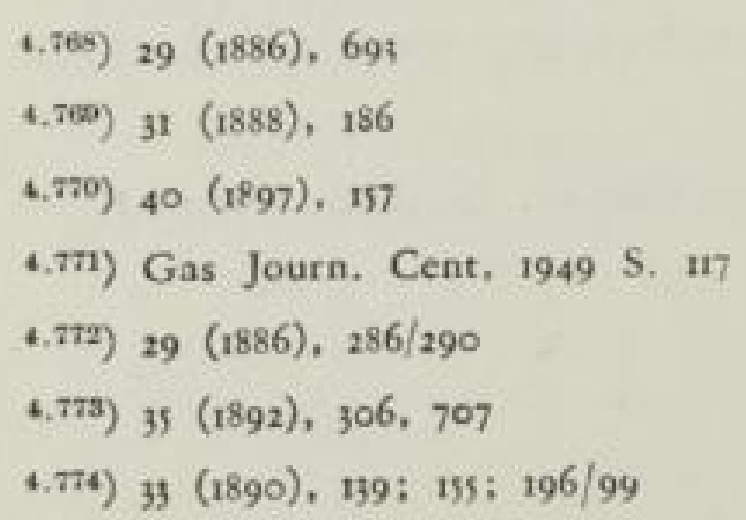

288 


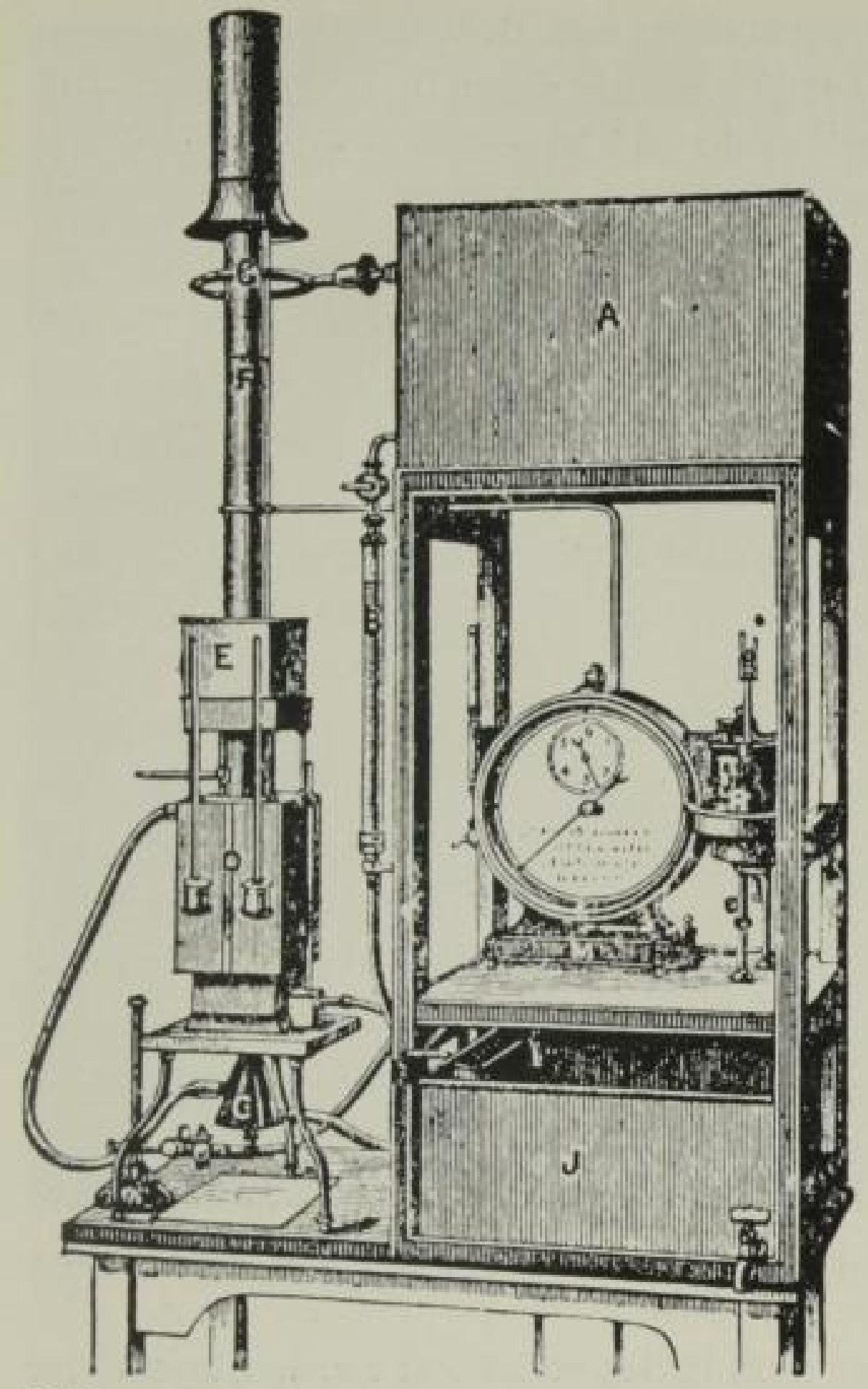

Bild 75

Durchlaufkalorimeter von Hartley

(Gas-Journ. Cent. [1949] S. I5)

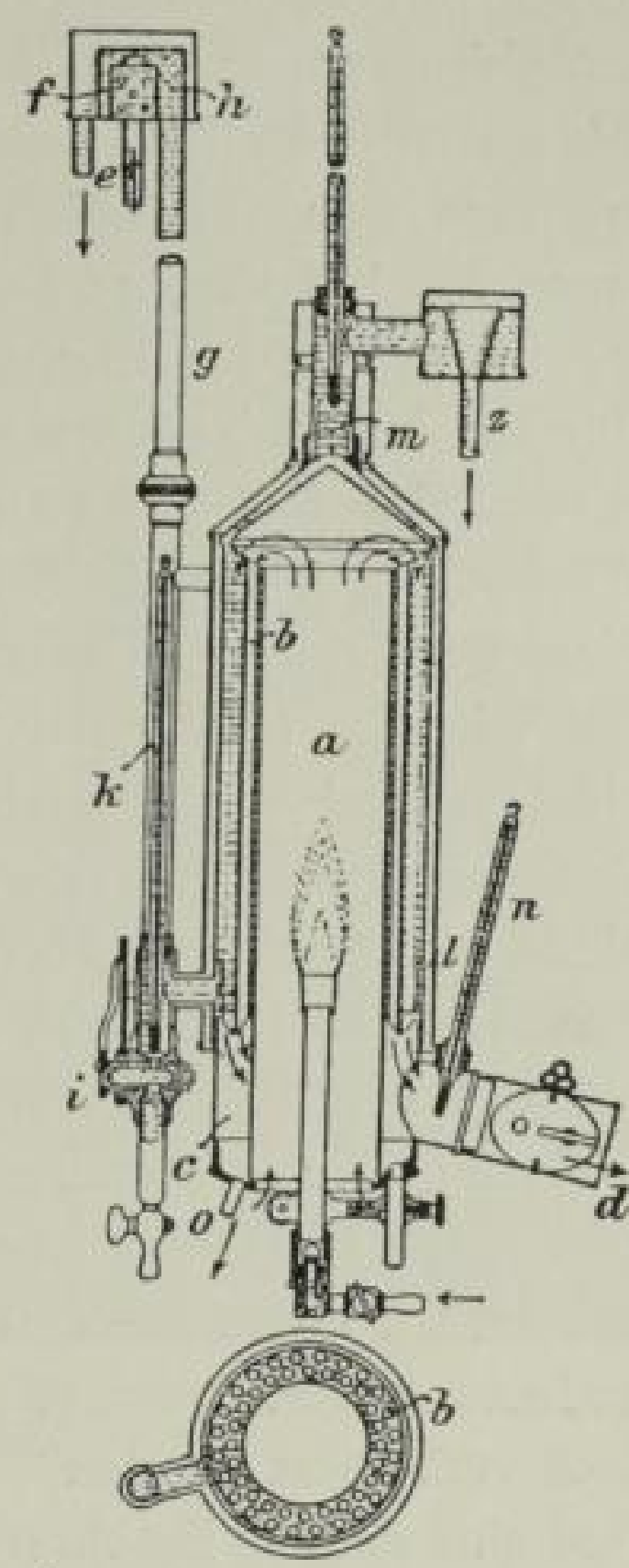

Bild 76

Durchlaufkalorimeter von Junkers (F. Fischer „Kraftgas", S. 15)

meter (D. R. Patent 71 73I vom 9. 6. 92), das J. B $u e b$, Dessau, 1892 bekannt gemacht hat $\left.{ }^{\prime, 755}\right)$. (Bild 76).

Über die Messung hoher Temperaturen hatten Karmarsch-Heeren $\left.1843^{4, \pi i n}\right)$ gesagt: „Die Pyrometrie gehört zur Zeit noch zu den schwachen Seiten der Physik, und keiner der vielen schon erfundenen Pyrometer (We $\mathrm{gew}$ o od und $D a$ n ie (l) ist imstande, sehr hohe Temperaturen mit einiger Genauigkeit anzugeben." - So war es 1860 auch noch. Noch $188_{4}$ berichtet das Journal über Versuche L. T. Wrigbts über die Abhängigkeit der Leuchtkraft des erzeugten Gases von der Temperatur, die er genauer verfolgt hat, aber ohne pyrometrische Messungen, weil nach der Natur der Vorgänge jede Temperatur-Messung illusorisch gewesen wäre $\left.{ }^{t .7 \pi}\right)$. A. He intz, Gaswerksleiter in Saarau, hat dann, um die Temperatur im Innern der Retorten zu prüfen, die Anregungen zu den keramischen Segerkegeln gegeben $\left.{ }^{* 7 \hbar}\right)$. Heintz war überrascht, wie niedrig die Temperaturen im Inneren der Kohle waren $\left.{ }^{4.79}\right)$.

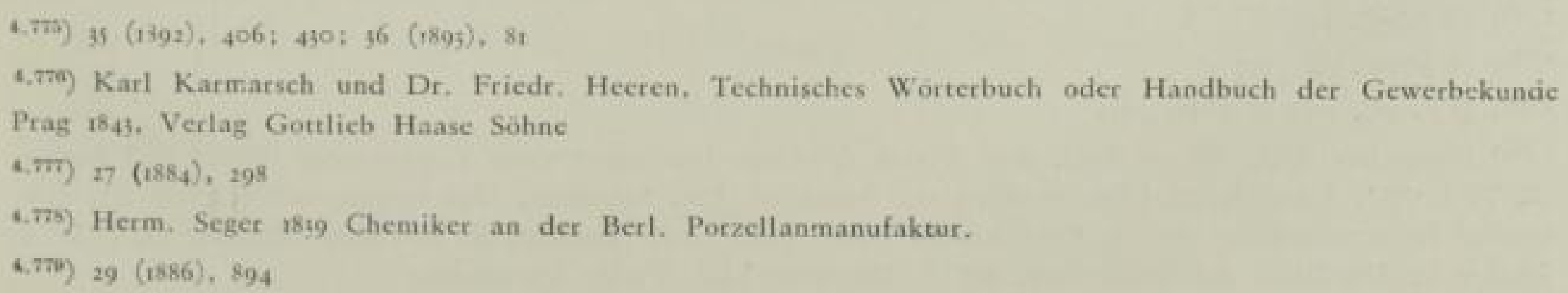


Der andere Weg führt vom Hitzdrahtpyrometer mit Brückenschaltung, zuerst dem Gasfach erläutert von W. Re is si g, Darmstadt $\left.1869^{4.750}\right)$, Widerstandspyrometer von Wilhelm Siemens aus Platindraht auf Porzellan gewickelt ${ }^{1.53}$ ) zum Graphitpyrometer von Steinle und Hartung, Quedlinburg ${ }^{4.752}$ ).

Als gut verwendbar, insbesondere auch zur Messung von Flammentemperaturen, erwiesen sich allmählich die Thermoelemente. Mit den physikalischen Grundlagen machte $C$. $S c b i n z$ das Fach 1866 bekannt $^{t .759}$ ). Verglichen mit Gasthermometern wurden Platin-Palladium von E. Becquerel und Platin-Eisen ${ }^{4.78}$ ). Für die hohen Temperaturen, die bei der Verbrennung von Gasen vorkommen, entwickelte $L$ e Cbatelier 1887 das Platin-Platinrhodiumelement $\left.{ }^{4.785}\right)$. Die Ausbildung nach W. W ien lag der Fertigung von C. W. Heräus, Hanau und Kaiser \& Schmidt, Berlin ${ }^{4.8 \pi}$ ) zugrunde.

Als wichtige Helfer bei feuerungstechnischen Messungen haben sich der Orsatapparat und die Buntebürette erwiesen. Man trifft häufig die Meinung, die Buntebürette sei ein Vorläufer des Orsatgerätes gewesen. Sie sind aber nebeneinander entwickelt worden, ja das Orsatgerät dürfte älter sein. Das Patent des französischen Ingenieurs L. H. O r s at stammt aus dem Jahre $1873^{4.757}$ ). Das 1876 gefertigte Bild des Gerätes zeigt bereits grundsätzlich die noch heute übliche Anordnung. Die Buntesche Bürette ist im Zusammenhang mit dem Generatoruntersuchungen (Zugkommission ron 1877 ) entwickelt und bekanntgegeben ${ }^{4.858}$ ).

Schlief̧lich möge noch der Gaswaage (Baräometer) von F. $L u x$, Ludwigshafen, gedacht werden, die 1885 bekannt wurde $\left.{ }^{t .750}\right)$. Sie ist im Laufe der Zeit mehrfach verbessert worden ${ }^{4.730}$ ).

Auf eine genaue Beschreibung der Geräte muf leider verzichtet werden, zumal die grundsätzlichen Anordnungen auch in neuzeitlichen Lehrbüchern zu finden sind.

4.52I Kochen

Die Eroberung der Küche ging in deutlich wahrnehmbaren Wellen vor sich, deren erste in den soer Jahren, vor allem in England, bald wieder verebbte. Die lebhafte Förderungsarbeit der Gaswerke und Gaswerksleiter lieł nach, wenn auch einige Hersteller mit Muße ihre Einrichtungen weiter entwickelten. Nur gelegentlich nahm das Fach in Deutschland Anteil an dem Erreichten $\left.{ }^{1.751}\right)$. 1862

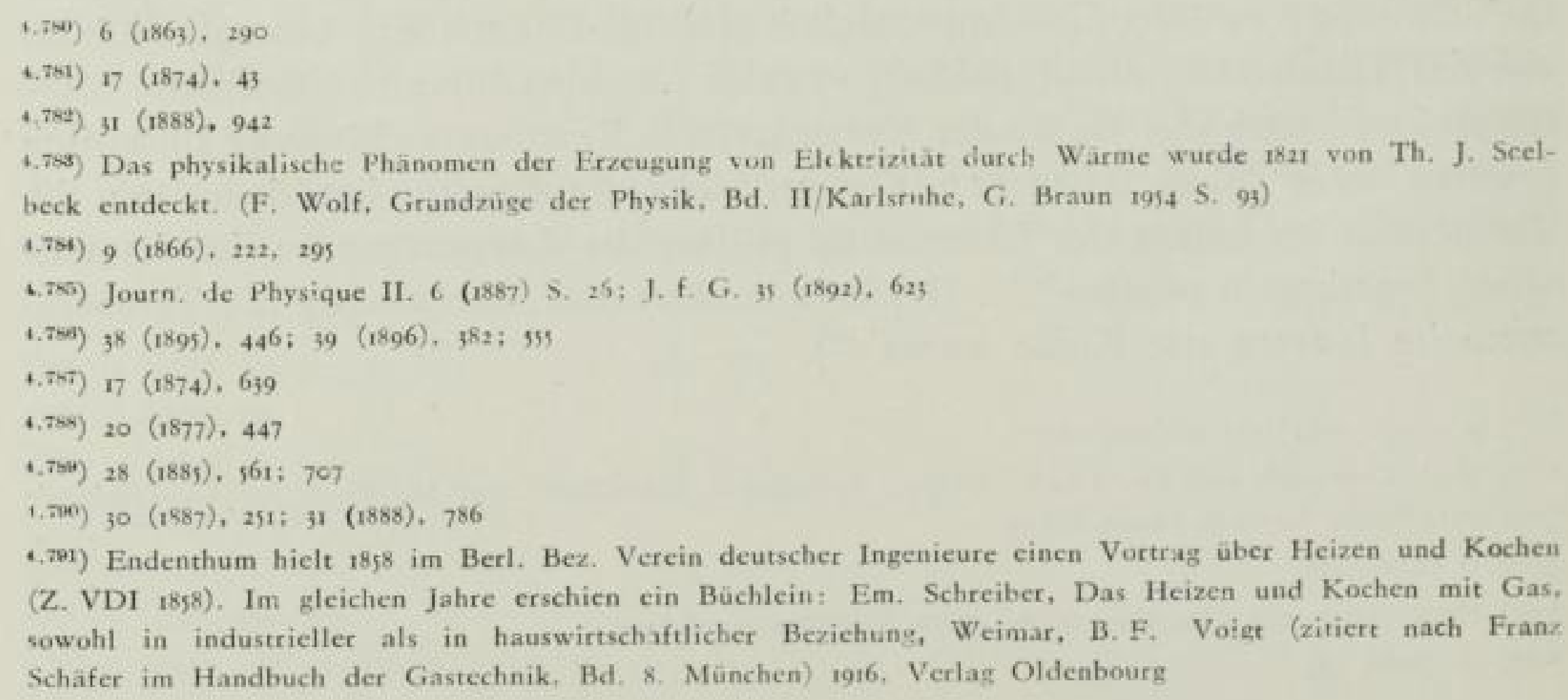




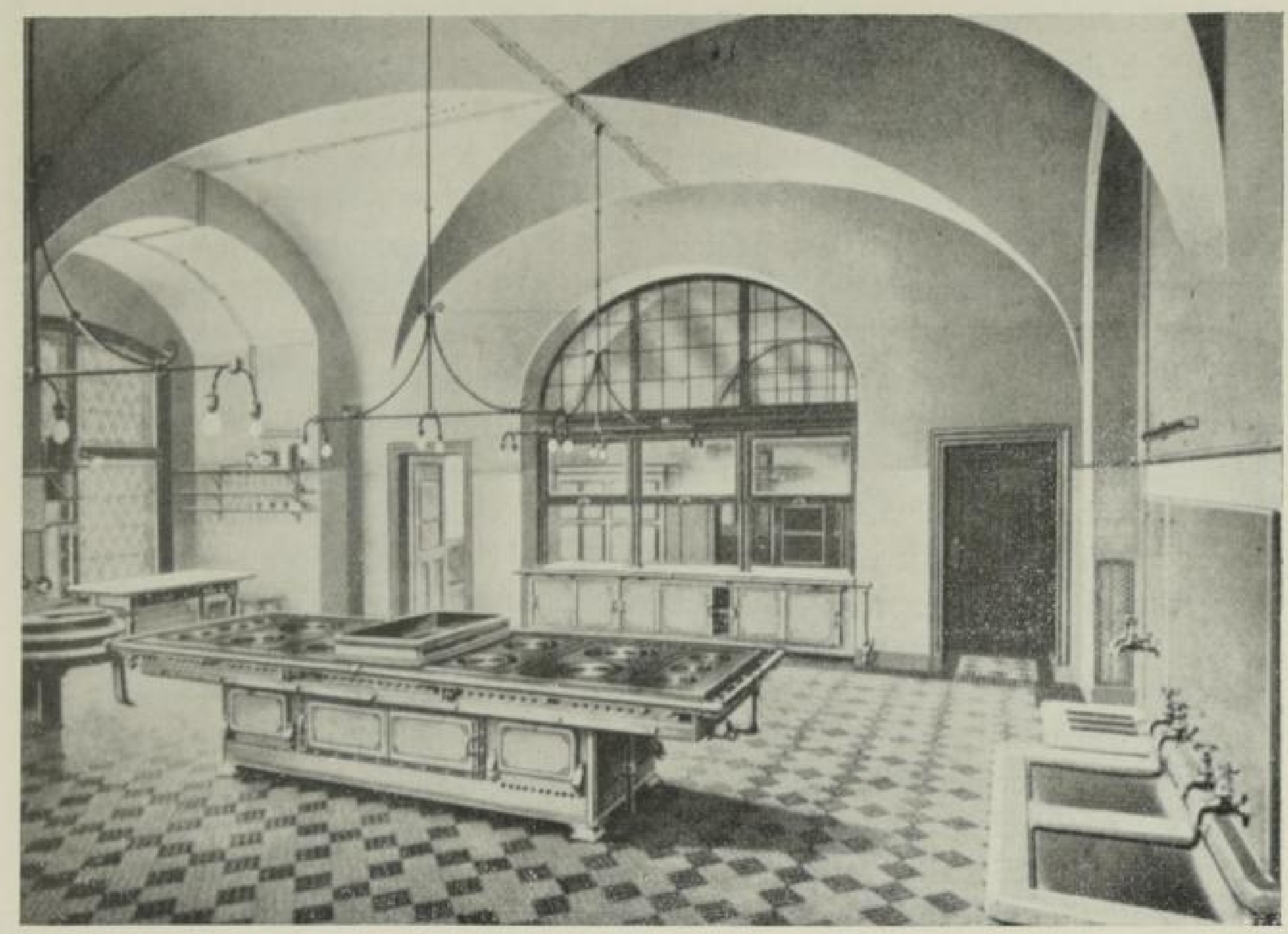

Bild 77 Grof̧küche im Reichstagsgebäude (Senkingwerke. Hildesheim)

bildete die Besichtigung der ersten deutschen Gas-Grołküche im Lindenhotel zu Berlin einen Teil der Veranstaltungen der Jahresversammlung des Vereins ${ }^{4.707}$ ). (Bild 77) Im gleichen Jahre gab die Deutsche Continental-Gas-Gesellschaft is$20 \%$ Rabatt für Heiz- und Kochgas, was aber als allgemeiner Anreiz nicht ausreichte.

Eine neue Welle löste die Entdeckung des Petroleums als Leuchtstoff aus. 1867 erschien im Journal die erste Übersicht uiber verfügbare Geräte von J. W illi a ms, P bilipps, Benham \& Sohn in England; St. Denis, Bengel \& Listard in Frankreich; Schäffer \& Walcker in Deutschland. Noch wurden neben den Bunsenbrennern auch für Kocher Leuchtflammen in „Ring"-brennern angewandt $\left.{ }^{\text {t.7ese }}\right)$.

Die Pariser Ausstellung des gleichen Jahres war reich mit Kochern und Heizöfen beschickt. 1870 wurde in Glasgow P. \& A. Main Ltd gegründet ${ }^{1 . * 14}$ ), John Wright \& Co. die 1866 ihre Firma gegründet haben, wandten sich 1873 dem Gaskocherbau zu. F. W. Hartley, London, hielt auf der Hauptversammlung des englischen Gasfachvereines einen Vortrag über die Einwände gegen das Gaskochen: Die Abgase würden als schädlich bezcichnet, sie verdürben die Speisen. Die Kosten seien zu hoch. Statt Debatten sei man als Gegenbeweis mit Gasküchen in Krankenhäuser und Clubs eingedrungen ${ }^{4.706}$ ). Im Groß̧en sei Gas aber zur

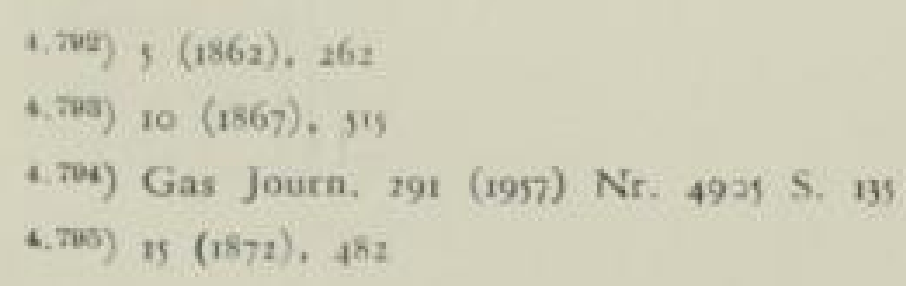


Wärmeverwendung einschlieflich Kochen ungeeignet $\left.{ }^{4 \text { tave }}\right)$. In Deutschland wurde erst nach dem Zusammenbruch der Gründerzeit die neue Welle spürbar. Man erzählte sich in Vorträgen und Berichten, was in anderen Ländern geschähe ${ }^{4.75}$ ), und führte bezirksweise Ausstellungen durch ${ }^{4.79}$ ). Kochlehrkurse scheinen zuerst in New York eingerichtet worden zu sein $\left.{ }^{4.700}\right)$. C. Voss, Krakau, hat in dieser Zeit unermüdlich bei den Gasfachleuten selbst erst einmal für den Gedanken, billiges Kochgas abzugeben, geworben. Auf der Hauptversammlung des englischen Vereins 1880 wurde zum ersten Male - im Hauptvortrag - ausgesprochen, dał die Zukunft des Gases beim Kochen und Heizen liege $\left.{ }^{4.50}\right)$. Aus Dänemark kam die Nachricht, daß̧ bei kleinen Werken (die meist von der englischen Danisch Gas Company betrieben wurden) der Kochgasabsatz bis $66 \%$ der Leuchtgasabsatzes ausmache. Bald folgten noch viel erstaunlichere Zahlen, darunter $200 \%$ beim meist vorgeschrittenen Werke $\left.{ }^{t .50}\right)$. Hans Bunte schrieb 1880 über die Anforderungen an Gaskochgeräte. Er verlangte Doppelbrenner zum sparsamen Fortkochen, verwarf die wasserummantelten Brenner, die das Abwaschwasser "kostenlos" miterwärmen sollten, berichtete über Versuche mit Turmkochen und trat für frei beheizte Bratöfen ein. Ein Ausschufbericht stellte fest, dał allgemeine, aufklärende Schriften über das Kochen notwendig seien. Sehr viele schlechte Geräte seien im Handel. Die Gaswerke müften die Güte beaufsichtigen. Einheitliche Untersuchungsverfahren seien zu vereinbaren. Durch die Installationsabteilung des Werkes München sei erreicht, dał wo immer eine Leuchte in der Küche sei, auch ein Kocher aufgestellt würde. Im Auslande lege man für Kochgas die Leitungen kostenfrei oder verbilligt. Man finanziere die Abzahlung oder Miete: Die South Metropolitan Gas Co. in London je roo M 2,50 M im Quartal. Paris gewähre beim vollen Gaspreise von $30 \mathrm{cts} / \mathrm{m}^{3}$ freie Steigleitungen und habe damit $25 \%$ des Absatzes als Kochlast erreicht. Wo für Leuchtgas 24 bis $20 \mathrm{Pfg} / \mathrm{m}^{\prime \prime}$ gefordert würden, könne man mit Kochgas ohne sonstige Exleichterungen - nur bis $16 \mathrm{Pfg} . / \mathrm{m}^{3}$ Erfolge erwarten. Motorengas müsse zu 13-12,5 Pfg. $/ \mathrm{m}^{3}$ abgegeben werden. In Dänemark sei man für Kochgas auf $12 \mathrm{Pfg}$. heruntergegangen, ein Preis, der auch in Këln gewährt wurde. Für Berlin wurde eine Kochgasabgabe von $19,7 \%$ ermittelt $^{+.502}$ ). Osnabrück gab Kochgas für ${ }_{14} \mathrm{Pfg} / \mathrm{m}^{3}$ ab. Zur Erleichterung des Entschlusses wurde die Kochgasinstallation zunächst probeweise kostenfrei ausgeführt. Erst wenn der Entschluł des Abnehmers endgültig war, wurde der zweite Messer gesetzt und es wurden die Selbstkosten der Installation berechnet ${ }^{4.503}$ ). Eine Geräteausstellung im Gaswerk diente der Werlung. Nach 4 Jahren meldete Osnabrück grof̧e Erfolge: Bei 648 Leuchtgasmessern hatte man 270 Kochgasmesser $\left.{ }^{4.504}\right)$. Die Deutsche Continental-Gas-Gesellschaft stellte $188_{4}$ fest, dał trotz der Bemühungen erst

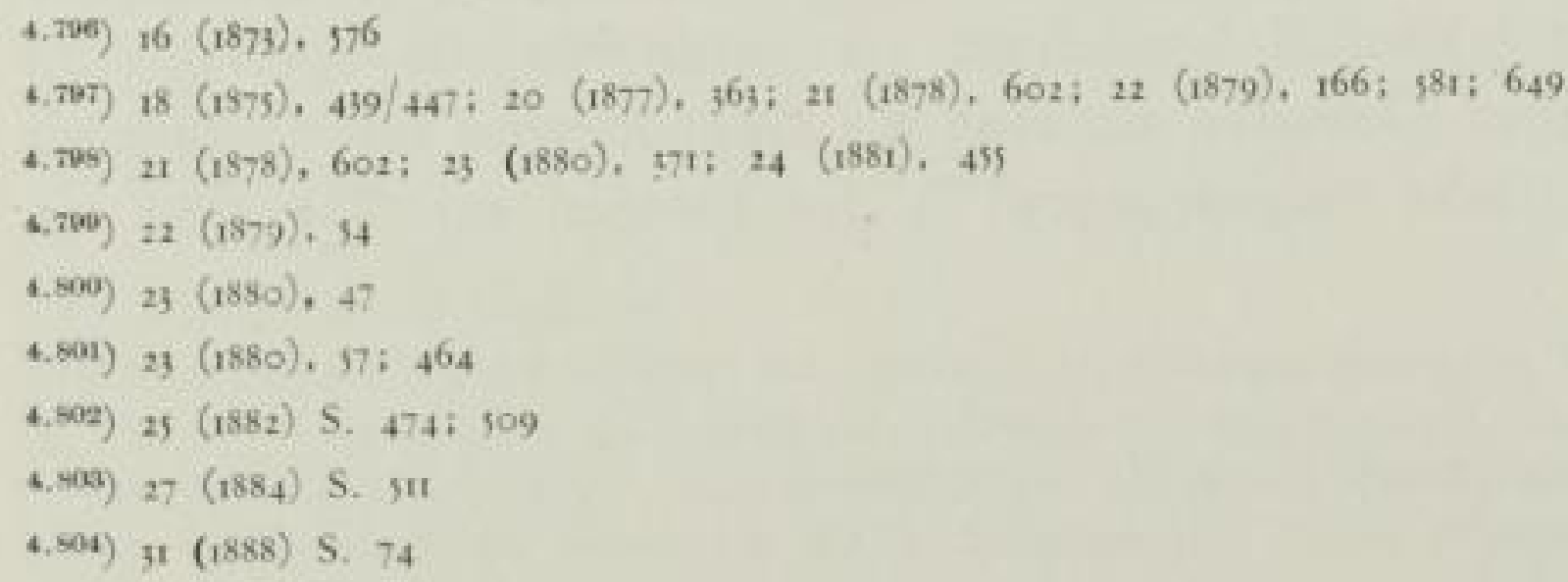


3.7\% des Gasabsatzes Koch- und Kraftgas sei $\left.{ }^{4+\infty}\right)$. Zwei Jahre später waren in Rheydt 100 Herde abgesetzt. Dort war die Werbung leichter als im übrigen Deutschland, wo der Herd dem Hauswirt gehörte ${ }^{t .800}$ ). So war die Werbung mit stark verbilligtem Kochgas úberall lebhaft in Gang gekommen. F. Reich ard. berichtete dem Verein von einer Umfrage, auf die 63 Werke ausführlich geantwortet hatten und grofe Fortschritte meldeten. Aber nur wenige Werke haben wirklich eine gröfere Zahl Herde abgesetzt. Nur zwei Werke mit mehr als 100000 Einwohnern hatten geantwortet; dort standen 149 und 95 Herde.

Bezüglich des Wirkungsgrades der Kocher waren die Erwartungen zunächst weit übertrieben. G. Wobbe, damals in Troppau bezeichnete als vollkommenes Modell eines Heizofens einen solchen der aus $\mathrm{I}^{3}{ }^{3}$ Gas $44 \mathrm{I} \mathrm{gr}$ Wasser kondensiere und vom oberen Heizwert gerechnet 99,4\% Wirkungsgrad habe. Auch für Kochgeräte forderte er, daf3 I 1 Wasser von 8 auf $100^{\circ} \mathrm{C}$ mit 17,21 Gas gebracht würden. Es sind also $92 \mathrm{kcal}$ im Wasser, 17,2 - 5,32 kcal aus dem Gas gleichgesetzt. Das wäre bei einer Verbrennungswärme von $5500 \mathrm{kcal} / \mathrm{m}^{3} 92 \%$. Er habe aber bei Untersuchungen Gasverbräuche von 53,$9 ; 43 ; 28 ; 221$ und damit nur 31,5; 39,5; 60,7; $77,3 \%$ des berechneten ,,möglichen "Wirkungsgrades erhalten. Er selbst hätte einen Regenerativ-Gaskocher konstruiert, der 221 verbrauchte. Er sagte aber selbst: „Leider dürfte sich dieser Apparat wegen der komplizierten, teuren Konstruktion kaum einführen. Es kam nur darauf an festzustellen, wie weit derartige Konstruktionen ausführbar sind ${ }^{\text {(4.007 }}$ ). Wobbe hat dann selbst einen Gasherd erbaut, der dem Kohlenherd möglichst gleich sein sollte, mit 3 verschieden grołen Brennern von 130 , 210 und 500 1/h Gasverbrauch, zwei Bratröhren übereinander mit einem Brenner dazwischen und mit oben aufgesetztem Wasserschiff. Die Öfen waren mit Schlackenwolle isoliert, die Kochplatte mit Schmutzfangblech versehen ${ }^{4.50}$ ),

F. Reichard, verlangte den Einbau von Druckreglern an jedem Kochherd, um der Verschwendung entgegenzutreten ${ }^{4.500}$ ). 1890 waren mehrere anerkannt gute Geräte auf dem Markt. Schulz \& Sackur, Schäffer \& Walcker, Wassbein und Deutsche Continental-Gas-Gescllschaft (Zentralwerkstatt) wurden genannt $\left.{ }^{t . s i g}\right)$. H. Bunte betonte die Notwendigkeit der freien Flammenentfaltung. Er forderte die feste Rippenplatte, die erst 40 Jahre später durch Hermann $M \ddot{u} l l e r$. Hamburg, allgemein erzwungen worden ist. Bunte verlangte auch einen Abzug am Bratofen und erorterte die Notwendigkeit der Ober- und Unterhitze, die er durch Einschieben einer schweren Eisenplatte erreichen wollte. Wasserschiffe am Gasherd lehnte er endgültig ab. Epple n, München, sagte dazu: „Wir haben an der Seite des Herdes einen Schnellwasserwärmer angebracht, der sofort heif̧es Wasser gibt. Es ist ein Schlangenrohr aus Kupfer, durch das Wasser direkt aus der Lcitung läuft. Der Apparat könnte auch an der Wand angebracht werden ${ }^{\text {"t.s11 }}$ ). Bei dieser Münchner Anregung darf man wohl

\footnotetext{
6.965) 27 (1884) S. 204

$1.906) 29$ (1886) S. 946

6.805) $26\left(188 y^{\circ}\right), 638 / 643$

1.508) $27(1884), 742$

$4.9007)$ 31 (1858), 368

$(-.910) 34(1891), 418$

4.511) $34(1891), 418$
} 
erwähnen, dał der Zapfhahnerhitzer, der sich über die ganze Welt verbreitet hat, auch einer Münchner Anregung (B. $L u d w i g$ ) $1927 \mathrm{zu}$ verdanken ist. F. $\mathrm{Haber}$ untersuchte die Kocherbrenner auf CO-Entwicklung. Bei französischen Herden stellte er $0,4 \%$ CO fest, deutsche Herde hatten diesen Fehler nicht $\left.^{t}{ }^{112}\right)$. Jetzt war der Herd im Grundsatz richtig entwickelt. Es mögen nur noch einige beachtenswerte Prioritäten festgehalten werden. F. Siemens, sagte: „An den Einlochkocher gehört ein Hahn n u r bei festem Anschluf “. Er brachte den Brenner mit drei übereinanderliegenden Schlitzenn ${ }^{4.153}$ ) (I895 Fig. 6I). Schäffer \& Walcker beschricben den Bratofenschwenkbrenner für Ober- und Unterhitze $\left.{ }^{4.64}\right)$. Die Werbung wurde immer mehr im Vereine besprochen. Richard Goebde, Mitarbeiter der Imperial Continental Gas Association, Berlin, prägte das bald allgemein aufgenommene Schlagwort: „Koche mit Gas!“. Das Flugblatt dieses Namens wurde 1894 im „Markischen Verein“" geschaffen ${ }^{4.515}$ ). Als erste Gaswerberin wurde nach englischem Vorbilde durch den Heizausschuf (L. Körting) Frl $\mathrm{Hobtmann}$, Hannover als Wanderrednerin für alle Werke 1893 verpflichtet $\left.{ }^{1 \cdot 16}\right)$. Zur Jahrhundertwende war sie immer noch mit anerkannten Erfolgen tätig $\left.{ }^{4.817}\right)$. Der erste Ingenieur, der Kochvorträge hielt, war D. We in berg, der nach Königslutter von Grimme, Natalis \& Co., Braunschweig entsandt wurde. (Bild 78 ).

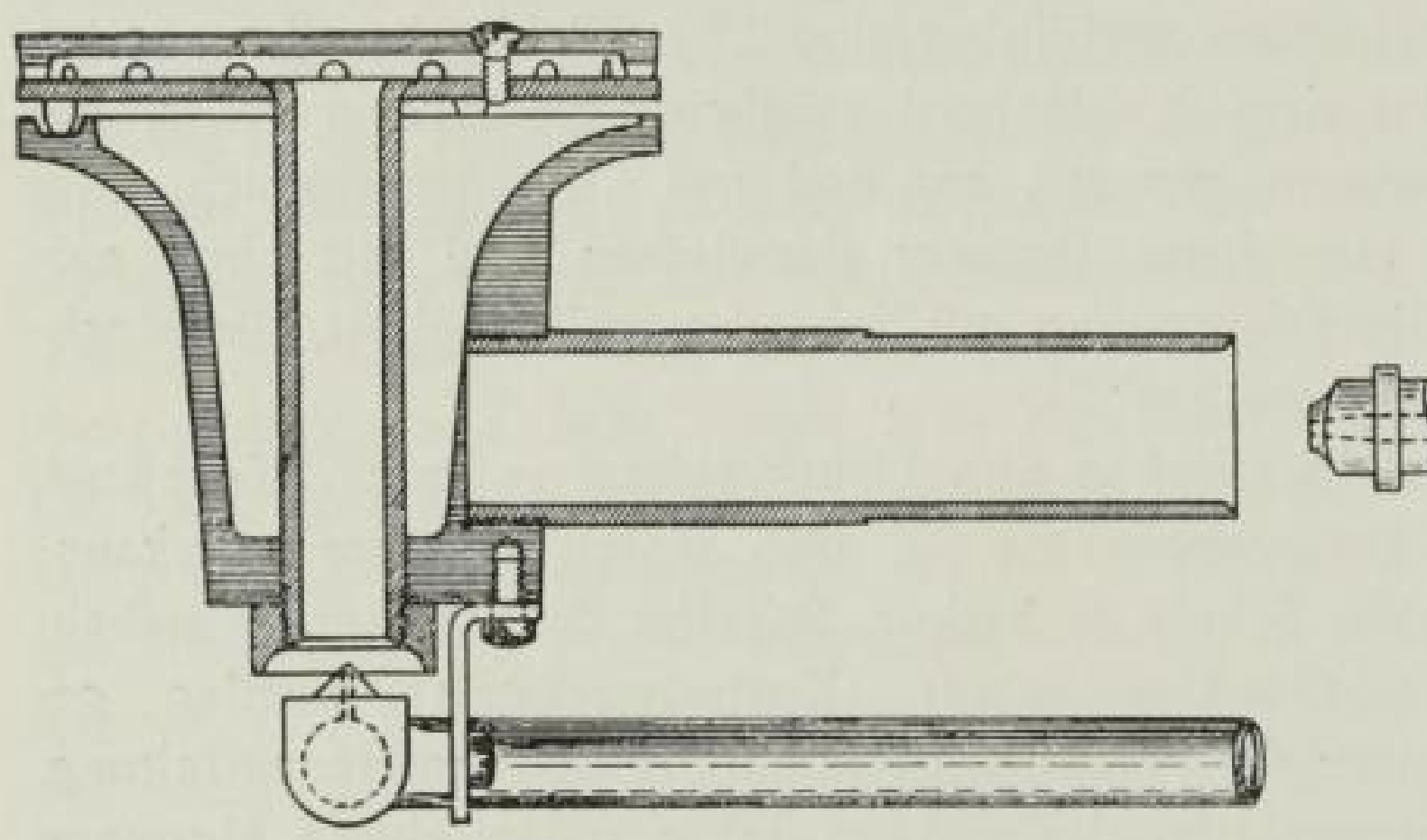

Bild 78

Junker und Ruh - Kocher 1897

(J. f. G. $39[1896]$ S. 100)

Der Widerstand gegen getrennte Leucht- und Kochgaszähler stieg merklich $\left.\mathrm{an}^{4.515}\right)$. Quedlinburg hat mit besonders gutem Erfolge mehr als to Jahre lang Sommergas billiger als Wintergas im gleichen Zähler abgegeben ${ }^{4 .+19}$ ). Kaiserslautern stellte fest, daf̧ das Verhältnis von Winter- zu Sommerlast durch die Werbung auf 1,93: I gekommen sei, während sonst noch 3 : I als guter Erfolg angesehen würde $\left.{ }^{4,650}\right)$. Die Kochmöglichkeit war inzwischen ein wichtiger Vorzug des

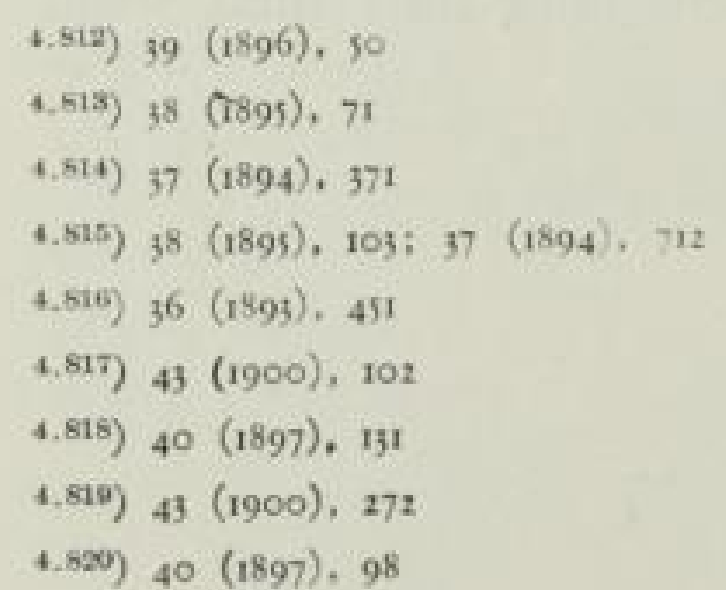


Gases geworden. Franz $S c b a ̈ f e r$ sagte im Kampfe gegen das Azetylen mit Beweisen: „Auch wo man elektrisches Licht hat, werden Gasanstalten gerade deshalb gebaut, um den Bewohnern die Annehmlichkeit des Kochens bieten zu können ${ }^{\text {(4t. } .21)}$ ).

4.522 W a r m wasserheizer

Langsamer noch als für Kochen, konnte Absatz für Warmwasserbereitung gefunden werden. Hindernd stand im Wege: 1.) Das ailgemein geringe Verlangen nach Badeeinrichtungen im Hause, 2.) die Meinung, daf3 das Abgas ohne Gefahr im Baderaum verbleiben könne, 3.) Schwierigkeiten mit dem Wärmeübergang aus dem $\mathrm{Gas}$ an die Wandungen im Badeofen.

Am frühesten kam auch diese Anwendung des Gases in England. 1867 erhielt das „Journal of Gaslighting“ eine Zuschrift von einem Bos. Pig er, der erzählte, wie er zwei befreundete Hexenmeister herbeigerufen habe, um eine Gasfeuerung nahe bei dem Badewasserbehälter aufzubauen, um die Erwärmung aus dem Küchenherd zu unterstützen ${ }^{4.60}$ ). Der „Nachwärmer“ ist also eine der ältesten Anwendungsarten im Warmwasserdienst. Aber „sobald der Erhitzer entzündet war, stank das ganze Haus vom Keller zum Boden nach halbverbranntem Gas, und es bildete sich eine ganze Menge Ruf3, der in die Ummantelung des Boilers fiel". 1874 wurde in der Royal Society of Literature ein Warmwasserbereiter von W. Ma $u g b a m$ vorgeführt, der vom Erbauer den Namen „Geyser" erhalten hatte. Auch dic Fa. Ewart \& Son beansprucht, zur gleichen Zeit einen schnellwirkenden Wasserheizer entwickelt zu haben $\left.{ }^{1.52 y}\right)$.

Eine Belebung brachte die Londoner Ausstellung von 1882. J. W rig bt kam erneut mit einer unmittelbar beheizten Metallwanne heraus. Sein Brenner hatte $2,8 \mathrm{~m}^{3}$ Belastung, womit er $3601 \mathrm{~W}$ asser um $33^{\circ} \mathrm{C}$ erwärmen konnte. Das entspräche bei $5000 \mathrm{kcal} / \mathrm{m}^{3}$ Heizwert einem Wirkungsgrade von $7 \mathrm{x} \%$. Ein Durchlauferhitzer, entworfen von V. Harcourt wurde von Sugg hergestellt und Kochstromtherme (Boiling Stream Therma) benannt.

In Deutschland stellte ein Ausschuß 1882 fest, dał wo Wasserleitung vorhanden sei, Badeöfen mit Gasheizung einige Liebhaber gefunden hätten ${ }^{1.20}$ ), als die verbilligten Preise für "Kochgas“ gewährt wurden. Wie und von wem diese gebaut waren, wurde nicht berichtet. Drei Jahre darauf aber kam J. G. H o u be n, Aachen, mit einem offenen Durchlaufgerät nach Patent 27876 heraus, bei dem also das ablaufende Wasser in unmittclbare Berührung mit den Abgasen kam. Für die Brause war ein besonderer geschlossener Behälter eingebaut ${ }^{4.521}$ ) (Bild 79). Wie bei lángerer Zapfdauer ohne Benutzung der Brause der Kochpunkt des Wassers in der Blase vermieden wurde, bleibt ein Geheimnis des Erfinders. Der Ofen bedürfte, so heiłzt es, keines Abzuges. Die Öfen wurden in 7 Größzen angeboten, von denen der besprochene 160 I Wasser in 9 Minuten von 12,5 auf $35^{\circ} \mathrm{C}$, also um $22,5^{\circ} \mathrm{C}$ mit $0,750 \mathrm{~m}^{3} \mathrm{Gas}$ aufwärmen konnte. Danach berechnet sich bei einer angenommenen Verbrennungswärme von $5500 \mathrm{kcal} / \mathrm{m}^{3}$ ein Wirkungsgrad von $88 \%$ bezogen auf diese. Die stündliche Belastung ist $5 \mathrm{~m}^{3} \mathrm{Gas}$.

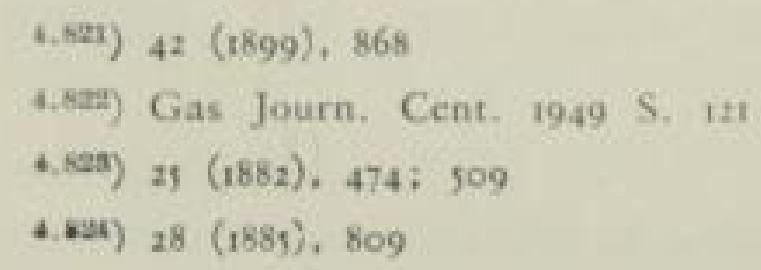




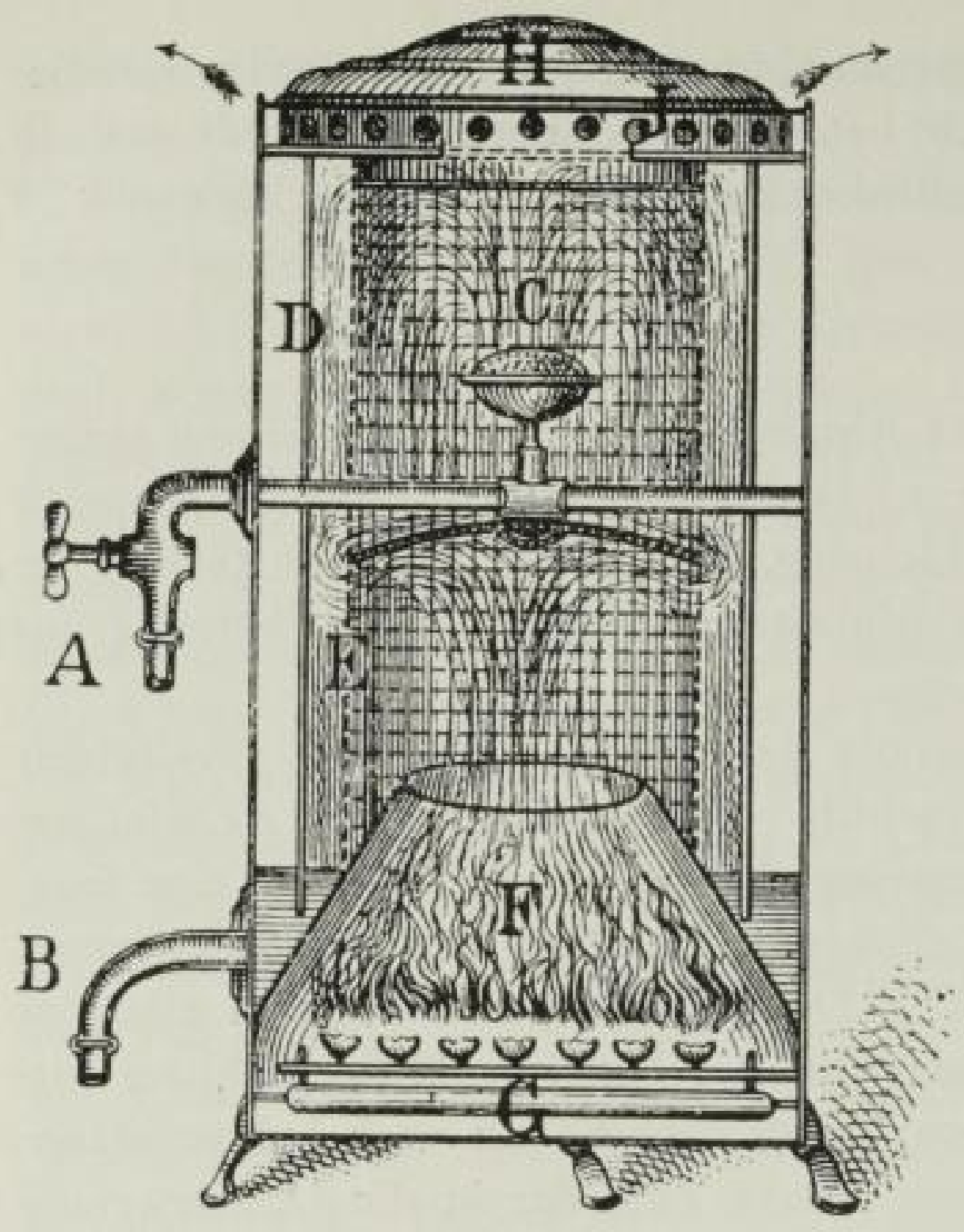

Bild 79

Houbens-Gasbadeofen 1885 (J.f. G. 28 [1885] S. 810 )

Das Patent von Escbebacb \& Haussner, Dresden (43656) über einen Badeofen mit parallelen Rohrschlangen dürfte den ersten geschlossenen Badeofen in Deutschland darstelien ${ }^{4.55}$ ). In gleichen Jahre konnte Eisele, Karlsruhe, über mehrere Schulbrausebäder mit Houbenschen Durchlauferhitzern berichten $^{4 * 20}$ ). (In Karlsruhe war auch die Gasraumheizung in Schulen zuerst eingerichtet worden (s. S. 305). F. Reic b'ard stellte durch eine Umfrage fest, $\mathrm{daB}$ in einzelnen Städten 80 , ja roo Houbensche Badeöfen zu finden seien ${ }^{4.257}$ ). Der Eschebachofen von 1890 hatte schmiedeeiserne Rohre, eine Leistung von IO $800 \mathrm{kcal} / \mathrm{h}=180 \mathrm{kcal} / \mathrm{min}$ bei einer Belastung von $3,150 \mathrm{~m}^{3} / \mathrm{h}$, so daf sich mit einem Heizwert von $5000 \mathrm{kcal} / \mathrm{m}^{3}$ ein Wirkungsgrad von $68 \%$ errechnen läft. Der Brenner war zum bequemen Anzünden ausschwenkbar. Der Houbensche Ofen (Houben Sohn, Carl, Aachen) hatte bereits eine angemessene Gröłze. Leistung: $340 \mathrm{kcal} / \mathrm{min}$ mit $950 \mathrm{dm}^{3}$ Gasverbrauch in II Minuten, was bei $\mathrm{Hu}$ von $5000 \mathrm{kcal} / \mathrm{m}^{3}$ einen Wirkungsgrad von $81 \%$ ergab ${ }^{4 * 5}$ ).

Im Jahre 1885 baute Johann $V$ a ill a nt in Remscheid eine Fabrik für Badeöfen. Er hatte sich dort auf der handwerklichen Wanderschaft als selbständiger Kupferschmied, Pumpenmacher und Heizungsinstallateur niedergelassen, I892 brachte er sein "geschlossenes System des Gasbadeofens" heraus und erhielt alsbald ein Patent auf die Bauart ${ }^{4 \times 2}$ ).

Die Firma entwickelte sich rasch auch unter der Leitung der Nachkommen und spezialisierte sich lange Jahre auf Gasbadeöfen. Schutzmarke „Osterhase" und der Name Geyser für dic Erzeugnisse sind im In- und Auslande bekannt. Es ist

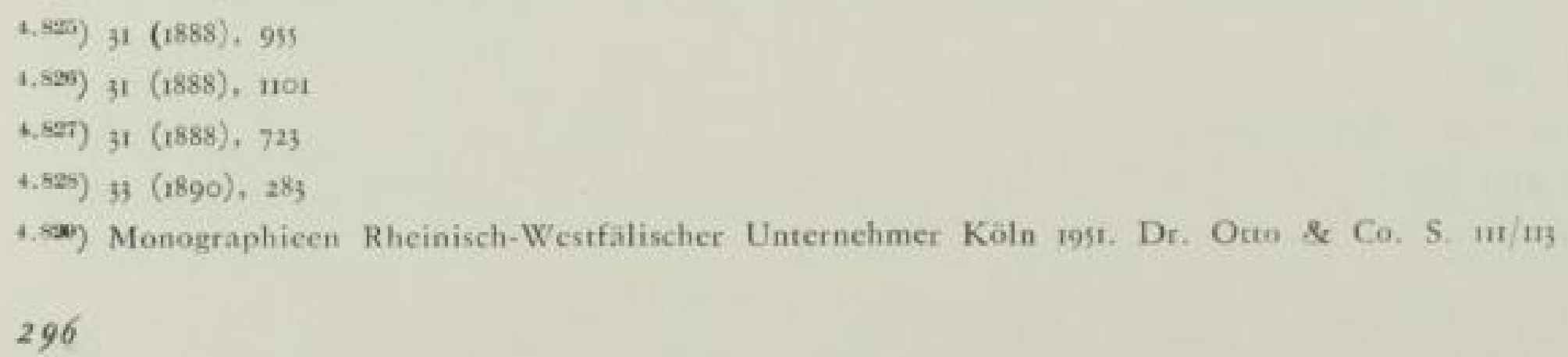


eine historisch anregende Tatsache, daß̧ unter den sich ändernden Verhältnissen in neuster Zeit (Vgl. S. 595) im Durchlaufgaswasserheizer mit Pumpe für Kleinzentralheizungen die Verbindung der Arbeitsgebiete des Gründers wiederauferstanden ist.

Das Ringen der Konstrukteure der ersten Zeit, die für den trägen Wärmeübergang des Gases an die Heizflächen genügende Größe der Flächen unterzubringen, wird besser als durch Worte durch einige Bilder gezeigt. (Bild $80,81,82,83)$. Schon im Abschnitt Kochen wurde berichtet, daf3 in München

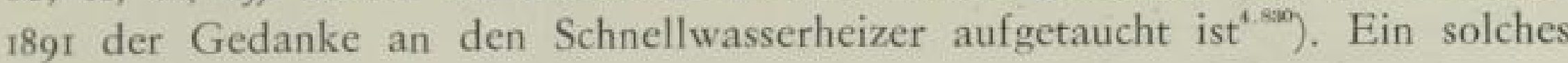

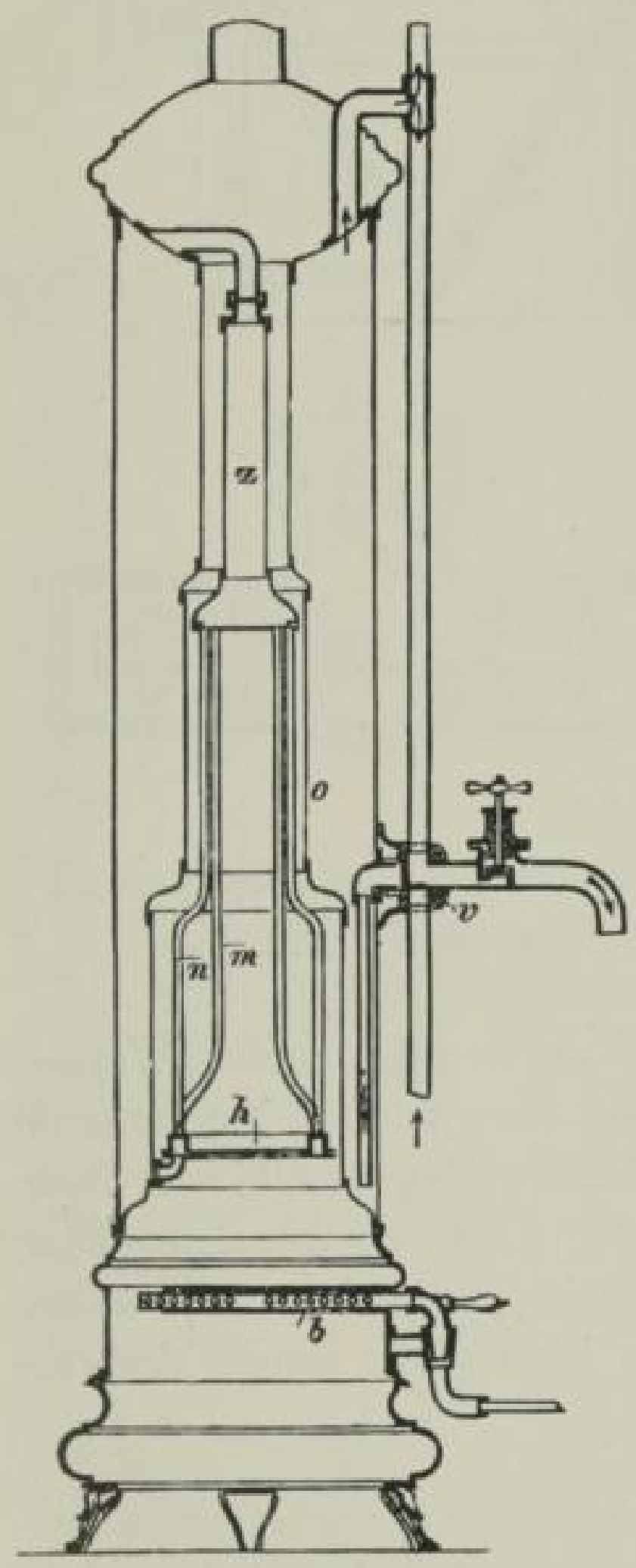

Bild 80

Zinkbadeofen von Blank, Heidelberg 1890

(J. f. G. 33 [1890] S. 392)

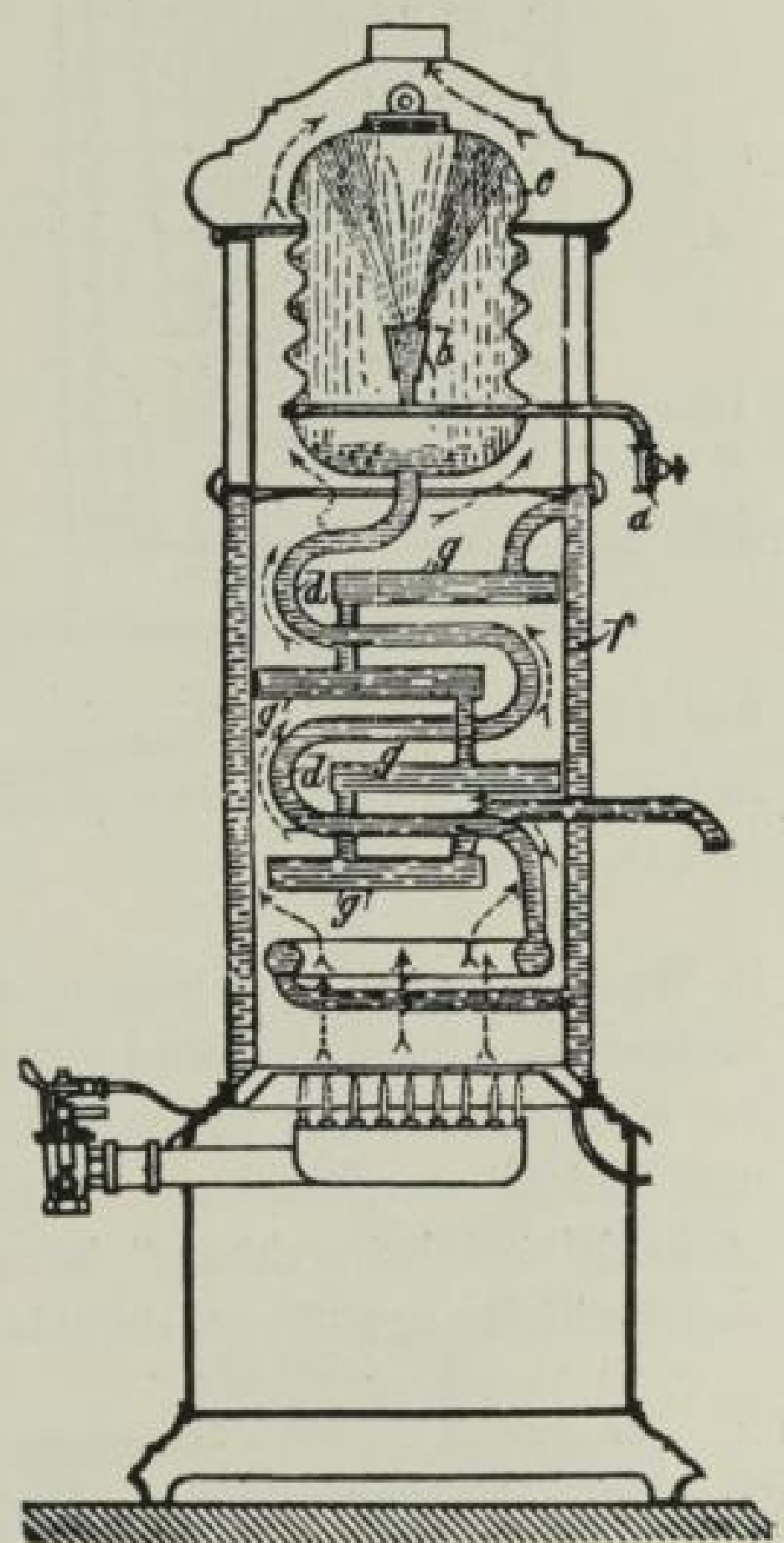

Bild $8 \mathrm{I}$

Badeofen von Theisejahns, Krefeld 1895

(J. f. G. $3^{8}[1895]$ S. 11)

liegendes Gerät hatte in England ein Jahr zuvor Th. Fletcber herausgebracht $\left.{ }^{4.3 n}\right)$. (Bild 84 ). Die Firma nannte ihn einen ,instantaneous heater for lavatories" (noch heute heif̧t in England der Durchlauferhitzer instantaneous heater). Sie sagte: „Es ist sehr wirtschaftlich, kleine getrennte Schnellheizer 


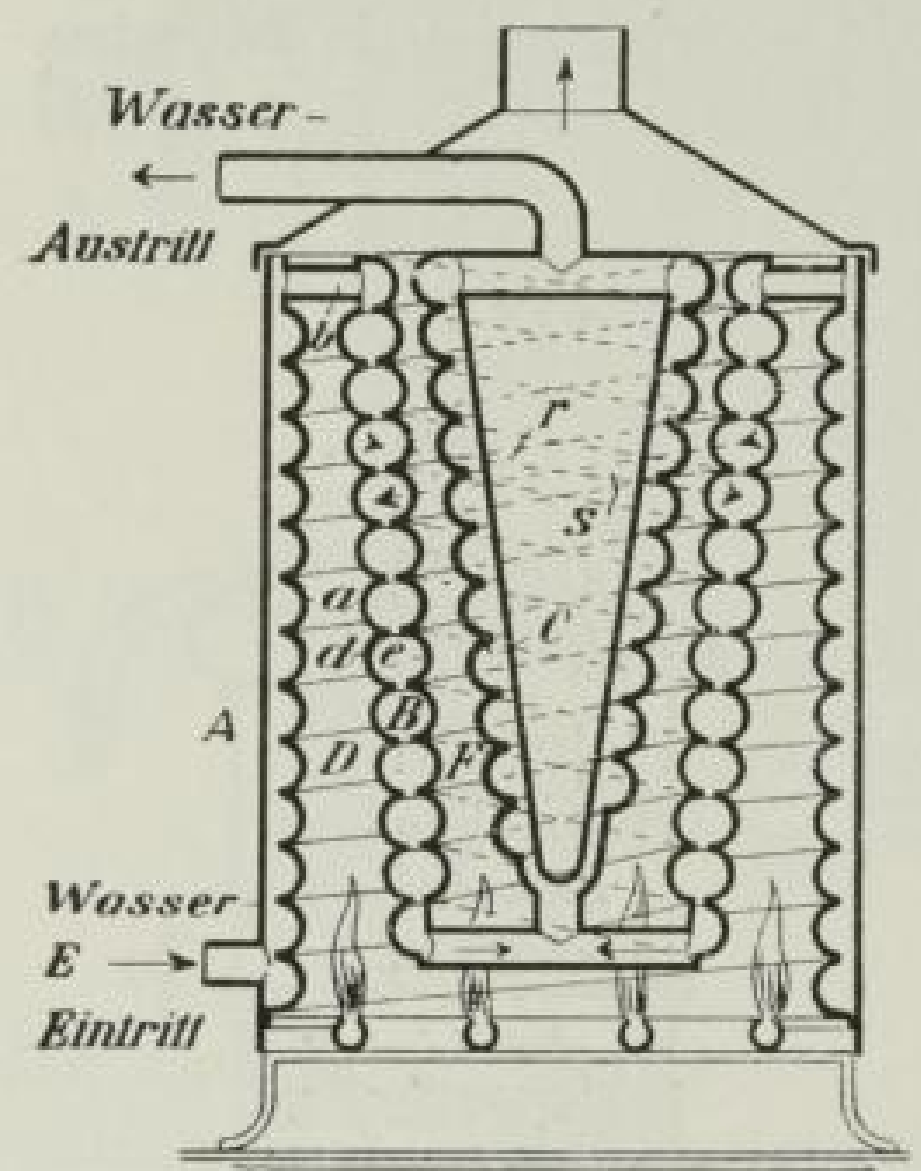

Bild 82

Badeofen von Gentsch, Charlottenburg 1895 (J. f. G. $3^{8}$ [1895] S. 122)
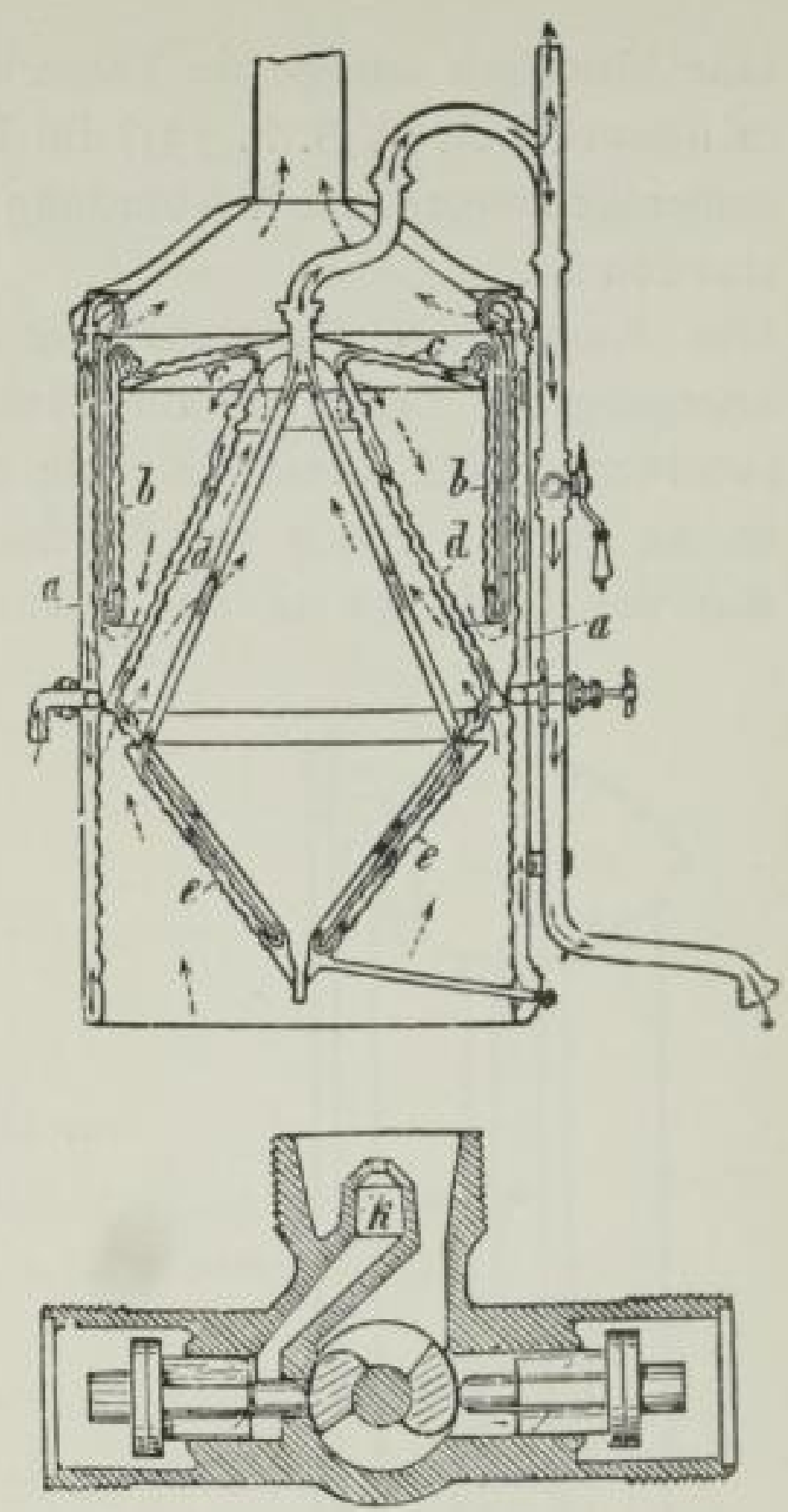

Bild 83

Badeofen von Eschebach, Dresden (J. f. G. 38 [1895] S. 317)

in Waschräumen, Anrichten u. s. w. zu haben, weil sie den dauernden Wärmeverlust vermeiden. Sie sind sicher genau so billig mit Gas, wie ein Vorratsgerät am Küchenherd. Sie haben dabei den Vorzug, jederzeit, Tag und Nacht, Sommer und Winter, arbeitsbereit zu sein". 1897 kam H. J $\| n k$ ers mit dem ersten "Schnellflüssigkeitserhitzer" heraus. Dieser zeigt bereits einige heute als selbstverständlich angesehene, damals neue Einzelheiten: Eine grofe runde Verbren-

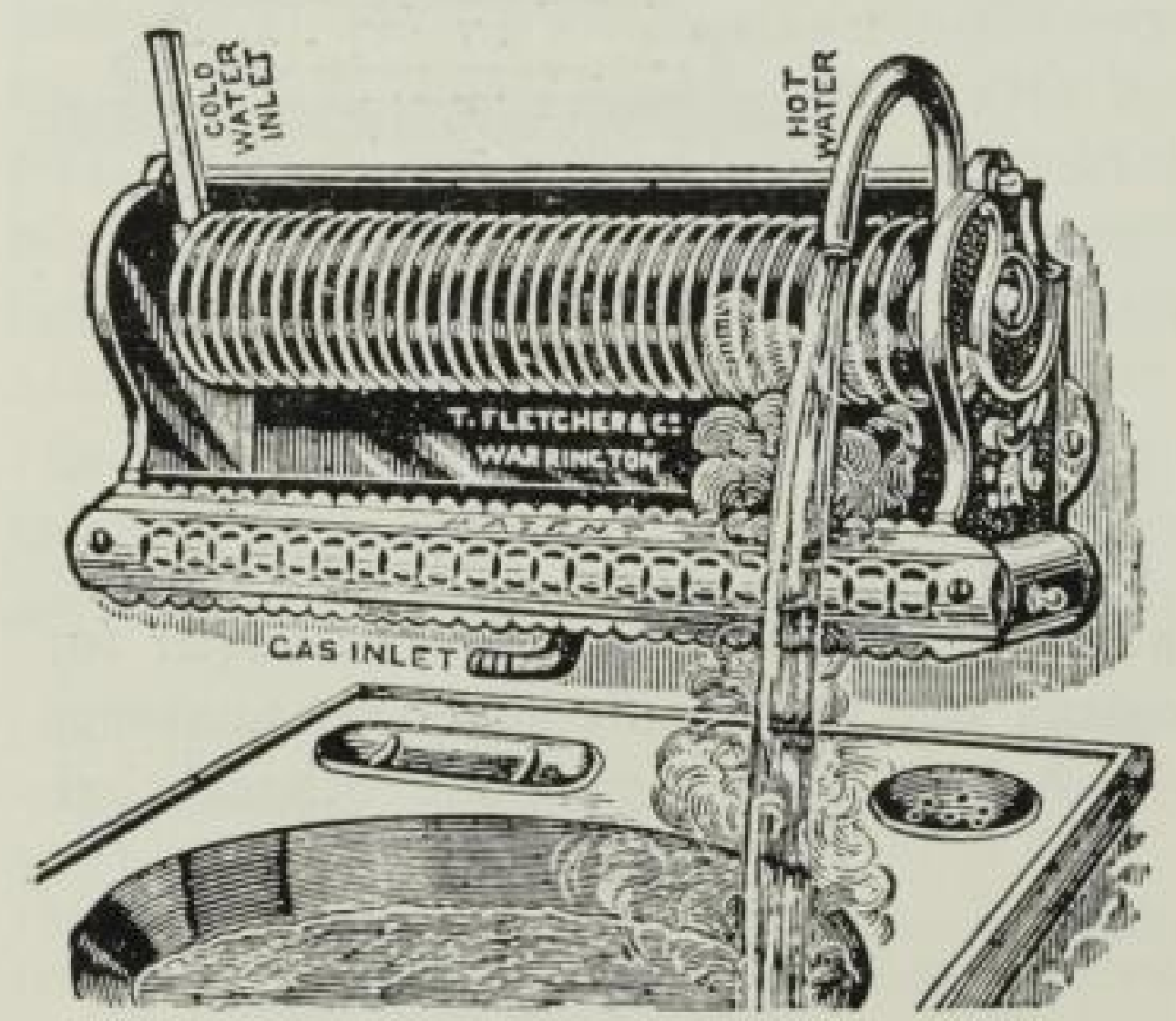

298
Bild 84

Schnellwasserheizer von Fletcher (Gas-Journ. Cent. [1949] S. 122)

\section{SLUB}


nungskammer. In ringsum angeordneten fallenden Zügen aus flachen Rohren mit engen Zwischenräumen im Wasserkörper bis zu $1 / 3$ der Gesamthöhe war ein Wärmeaustauscher gebildet (Bild 85). Alles war aus Kupferblech hartgelötet hergestellt. Das Wasser stand unter Leitungsdruck ${ }^{4.53}$ ).

Die erste Wassermangelsicherung wurde in cinem Patent von Houben Nr. 95 222 vom 21. 4. 97 beschrieben ${ }^{4.859}$ ). Ein weiteres Patent $\mathrm{Nr}$. $1073 \mathrm{II}$ vom 27. I. 99 schützte einen recht verwickelten Bunsenbrenner, der in eine hohe Verbrennungskammer eingesetzt werden sollte $\left.{ }^{4.54}\right)$. Das war aber sicher eine mif̧verstandene Bauweise.

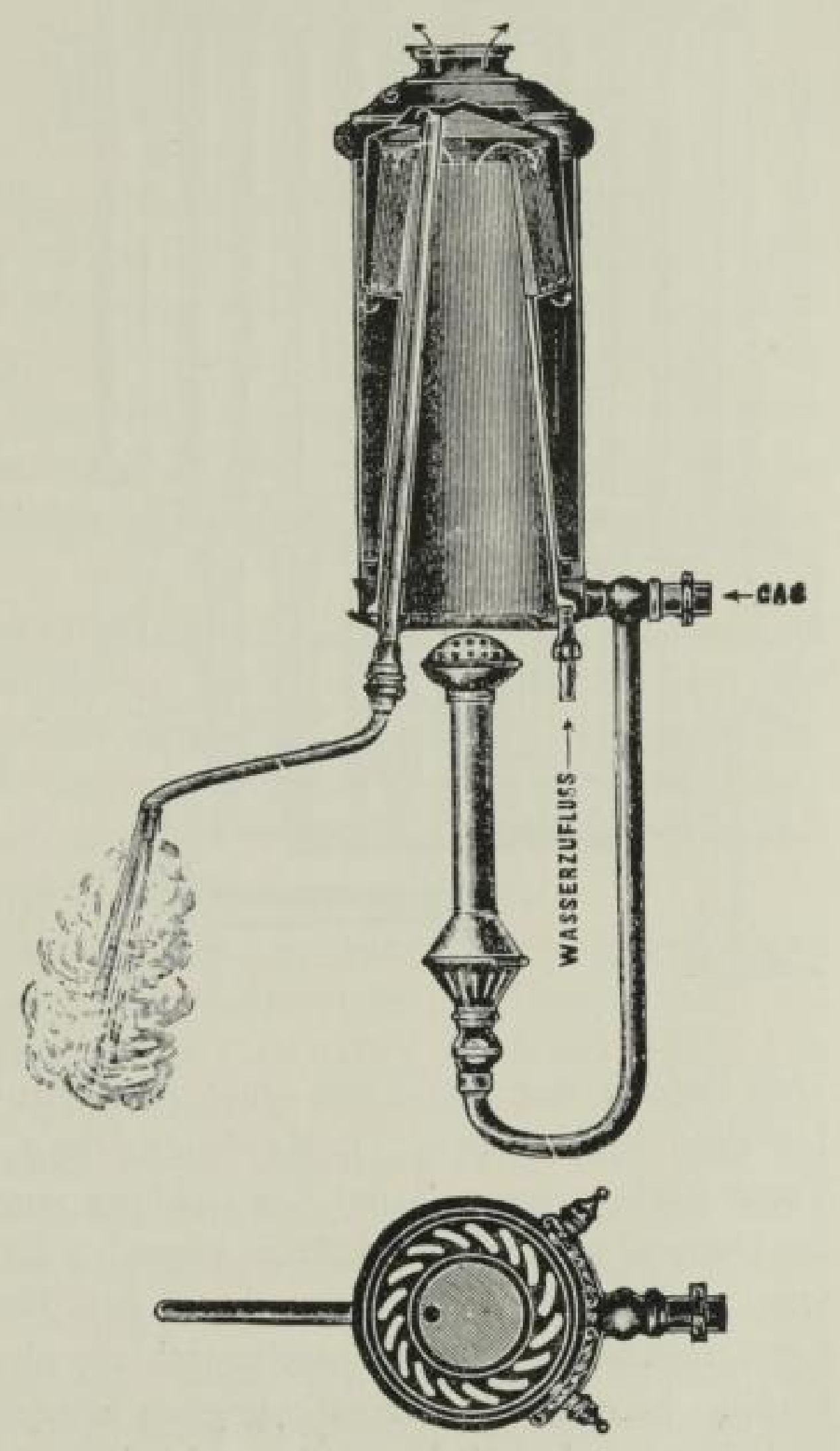

Junkers Badeofen 1897

J. f. G. 4 ० [1897] S. 801)

Nach Untersuchungen an Heizöfen kam Dr. med. R. Knor vom hygienischen Institut in München zur Überzeugung, dał bei Kohlen die Gefahr der Kohlenmonoxydbildung größzer sei als bei Gasöfen. Dał der Austritt der riechenden und beif̧enden Abgase bei Kohlenöfen leichter bemerkt wird als bei Gasöfen, erwähnte er aber nicht. Nach Beobachtungen an abzugslosen Badeöfen verlangte er indessen, hierfür Abzüge vorzuschreiben ${ }^{4,535}$ ).

(.832) $40(1897), 801$

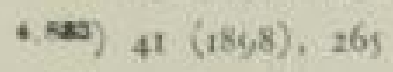

436) $43(1900), 800$

(.525) $\$ 4(1891), 15$

200

SLUB

Wir führen Wissen. 


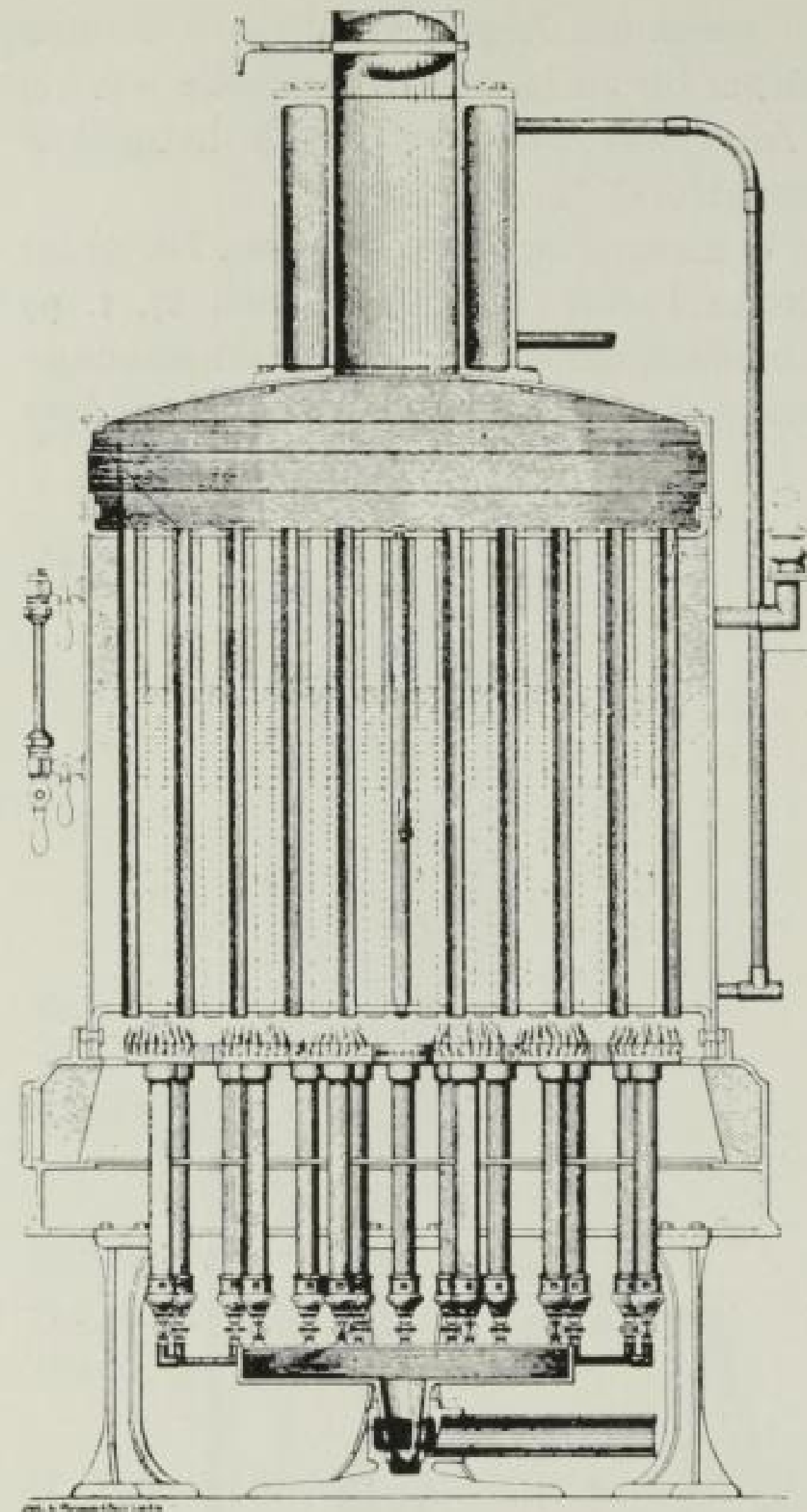

\section{Bild 86}

Jacksons Dampfkessel 1870 (Gas-Journ. Cent. [1949] S. 122)

Der Betrieb der Badeöfen ohne Abzug führte dann auch 1899 zu den ersten Unfällen in Hamburg ${ }^{4.59}$ ). Kohlenmonoxyd wurde als Todesursache an den Toten nachgewiesen. Seine Entwicklung wurde fälschlicherweise mit Rückschlag im Bunsenbrenner zu erklären versucht. Die Hamburger Polizei (Amtsblatt 44 vom 2I. III. 99) verbot kurzerhand den Betrieb jedes Gasgerätes über $5001 / \mathrm{h}$ Gasverbrauch ohne Schornstcinanschluf, obwohl das mit der Untersuchung der Unfälle betraute Medizinalkollegium ausdrücklich bestätigt hatte, daf̧ Kocher und Herde ohne Schornsteinanschluł ungefährlich seien $\left.{ }^{1.877}\right)$. Eine persönliche erboste Erwiderung seitens J. $H$ ud l e r, Glauchau, beweist alleidings, daf auch er den Einfluf\} mit Abgasen angereicherter Luft auf die Verbrennung im Badeofen nicht erfafgt hatte. Auch der Leiter des Hygienischen Institutes in Jena, A. Gärtner, der sich mit der Kohlenmonoxydvergiftung bei Zimmeröfen und Badeöfen befałte, gewann keine volle Klarheit. Er berichtete, daf̧ die Brenner frei im Laboratorium brennend auch nach langer Zeit kein Kohlenmonoxyd unverbrannt ließ̧en. Den Hauptfehler der Geräte sah er daher im Stau im Geräte

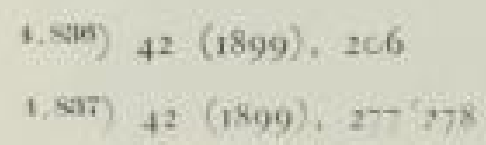

\section{SLUB}


selbst. Immerhin besprach er auch die Kohlendioxydanreicherung in der Luft. Die beste Warnung sei eine brennende Kerze, deren Flamme sich deutlich in die Länge zöge. Die einfache Prüfung sei zuverlässiger als chemische Untersuchungen $\left.^{4.555}\right)$.

Überraschend für jeden Gasfachmann dürfte es sein, daf3 das erste auf den ersten Blick ausgereifte Gerät auf diesem Gebiete ein gasgefeuerter Dampfkessel mit aufgesetztem, sicherlich nicht sehr wirksamem Speisewasservorwärmer war. Jackson brachte ihn 1870 auf den Markt ${ }^{4 \times 5}$ ). (Bild 86).

4.523 Raumheizung

Die Raumheizung mit Gas ist auffallend langsam in Gang gekommen. Das ist angesichts, zahlreicher überaus zuversichtlicher Äuf̧erungen vielleicht überraschend. Die Erfinder verschiedener Wassergasverfahren wollten, wie wir sahen, sogar gesonderte Heizgasnetze neben der Leuchtgasverteilung aufbauen. Am auffallendsten bleibt aber die Äufzerung des im allgemeinen recht nüchternen F. Siemens, als er seinen "Regenerativ"-Heizofen entwickelt hatte, daf dic Zeit kommen werde, in der ausschliefjlich Gas zur Heizung benützt werden würde.

Der Grund für die unberechtigt zukunftsfreudigen Gedanken dürfte darin zu suchen sein, daf̧ der Aufbau einwandfreier Öfen, die Erkenntnisse über die Notwendigkeiten der Heiztechnik und der Abgasführung viel schwieriger zu bearbeiten waren, als sich die Dränger dachten, und dał sie die wirtschaftlichen Zusammenhänge nicht richtig erkannten. Selbst in Gasfachkreisen wurde gelegentlich geäuf̧ert, daf das Fach träge, sogar schuldhaft gehandelt habe.

Dabei hätte man kaum ein anderes Vorangehen ins Auge fassen können, wenn man diese neuartige Technik im Voraus hätte planen wollen. Immer wird ein vorsichtiger Unternehmer beim Aufbau eines Geschäftes zunächst solche Lieferungen vorwegnehmen, bei denen er die besten Preise erzielt. Er hat dann zwar zuerst einen bescheidenen Umfang seines Umsatzes, kann aber auch die Entwicklungskosten für erweiterte Geschäfte herausverdienen und hält vor allem das Wagnis, das jede technische Neuerung in Form von Beanstandungen, kostspieligen Verbesserungen und Entschädigungen enthält, in tragbaren Grenzen. Genau das hat aber das Gasfach getan, indem es zunächst die Beleuchtung pflegte und erst, unter dem drohend werdenden Wettbewerb, für die erweiterten Gebiete Geld und Kraft für Entwicklung und Werbung einsetzte.

Daf3 dabei das Kochen und die Warmwasserbereitung in die Vorhand kam, ist verständlich, weil das hierfür gelieferte Gas die Ungleichmäßjigkeit der Abnahme im Sommer und Winter, die die Beleuchtung an sich hatte ( $I: 4$ bis $1: 5$ ) ausgleichen konnte. Vielfach blieb ja noch der Kohlenherd im Winter im Betriebe und Gas wurde im Sommer gern benutzt. Erst als das Kochgas das Leuchtgas überrundete, vor allem die Beleuchtung im Hause verloren ging, konnte das Heizgas neue Freunde gewinnen. Dabei blieb aber noch die ungleiche Abnahme,

\footnotetext{
(. Aas) $43(1900), 268 ; 294 ; 332$

4.k0) Gas Journ. Cent. (1949) S. 122
} 
abhängig von der Wetterlage, und das unangenehme Gefühl, dał man auch dem Koksabsatz schaden würde. Diese Lage aber war vor der Jahrhundertwende keineswegs erreicht.

In London standen die Gasfachleute mit vollem Herzen hinter einer „Smoke Abatement Exhibition“, einer Ausstellung mit dem Thema „Beiseitigung des Rauches, durch cine Schaustellung über Kochen und Heizen mit Gas“. Resigniert wurde festgestellt, dał es undurchführbar sei, das Rauchen der Hausschornsteine gesetzlich zu verbieten $\left.{ }^{4.40}\right)$. So alt ist das Bemühen, das erst 1957 in der clean air act - Reinluftverordnung in England - seinen Abschluf gefunden haben könnte, wenn nicht immer noch die Möglichkeit, den Hauptsünder mit seinen offenen Feuern von gasreichen Kohlen wirklich auf Koks und Schwelkoks umzustellen, Zweifein begegnete. Wilhelm Siemens zeigte damals schon eine „Lösung": Das offene Koksfeuer mit durchzüngelnder Stadtgasflamme. 1899 wurde die Rauchbekämpfungsbewegung in England durch einen besonderen Verein fester in die Hand genommen, der eine lange Geschichte hat $\left.{ }^{4.311}\right)$.

Auch in Deutschland (und Österreich) beschäftigte man sich mit der Rauch- und Rufsplage. In Hannover wurde die gasreiche Deisterkohle verbrannt mit dem Erfolge, daf, man dort besonders stark unter den Rufflocken in der Luft zu leiden hatte. So wurde die Bekämpfung auf Antrag des Hannoverschen Architekten- und Ingenieurvereines 1888 in den Arbeitsplan des Verbandes dieser Vereine aufgenommen. Eine Denkschrift wurde vom Verbandsvorstand im Jahre 1893 herausgegeben $\left.{ }^{4.812}\right)$. Sie betont, daf 3 der Hauptschaden nicht etwa durch die damals noch vielen Fabrikschornsteine, sondern durch die häuslichen Feuerstätten entstehe. Sie gibt Richtlinien für die Schornsteinbauten und regt gesetzliche Mafnahmen für eine wirksame Bau- und Betriebsaufsicht an, ohne die Schwierigkeiten zu verkennen, die diesem Vorhaben entgegenstehen. Koks und Gas werden empfohlen, auf Wassergas, Generatorgas, Dowsongas werden Hoffnungen auch zur Krafterzeugung gesetzt, ohne daf̧ allerdings die Kosten näher betrachtet werden.

Elsners abzugslose Öfen in der Katharinenkirche in Hamburg (vgl. 3.623) mufften nach s Jahren wieder als zu teuer entfernt werden ${ }^{1.813}$ ).

Von der Anwendung wenig wirtschaftlich gebauter Heizöfen für Konvektion und für Strahlung wurde bereits gesprochen (vgl. S. I59). Eine Belebung brachte der einfache Reflektorofen von Jac quet $\mathrm{I}_{864^{4}}{ }^{\mathrm{si4}}$ ) (Bild 87). Einen englischen Ofen aus dem Jahre 1873 mit reichen Verzierungen zeigt Bild 88. Der Jacquetsche Ofen wurde 1878 von Schäffer \& Walcker in Deutschland eingeführt. Aus dem Jahre ${ }^{2} 884$ stammte der Konvektionsofen von R. Kutscher mit quergelegten Lufterwärmungsrohren und einem Stabrost, un die Strahlung der Flamme nicht auf die Rohre wirken zu lassen. (Bild 89). Eine regelbare Schornsteinklappe gekuppelt mit dem Hahn ist eine Bauweise, die noch öfter hier und da aufgetreten ist $\left.{ }^{4.45}\right)$. G. Wob be war damals sehr fleif̧ig im Heizungsausschuf, er

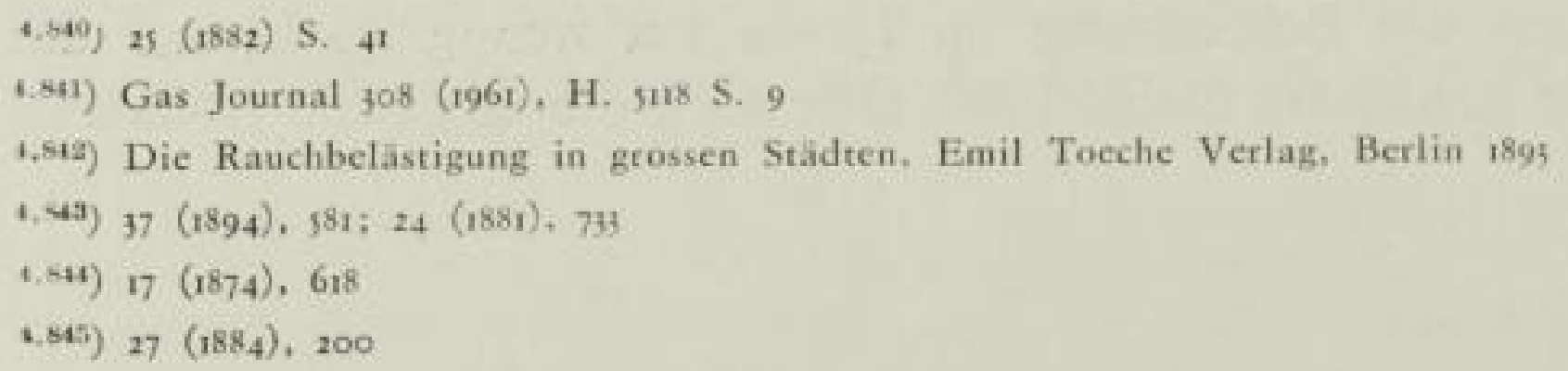




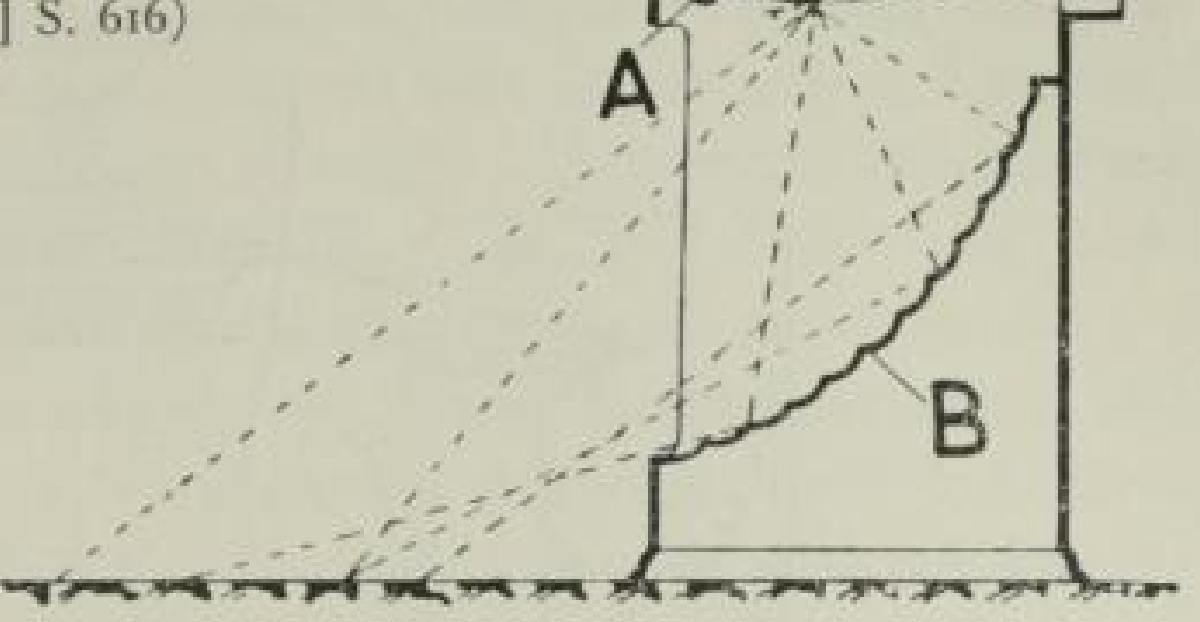

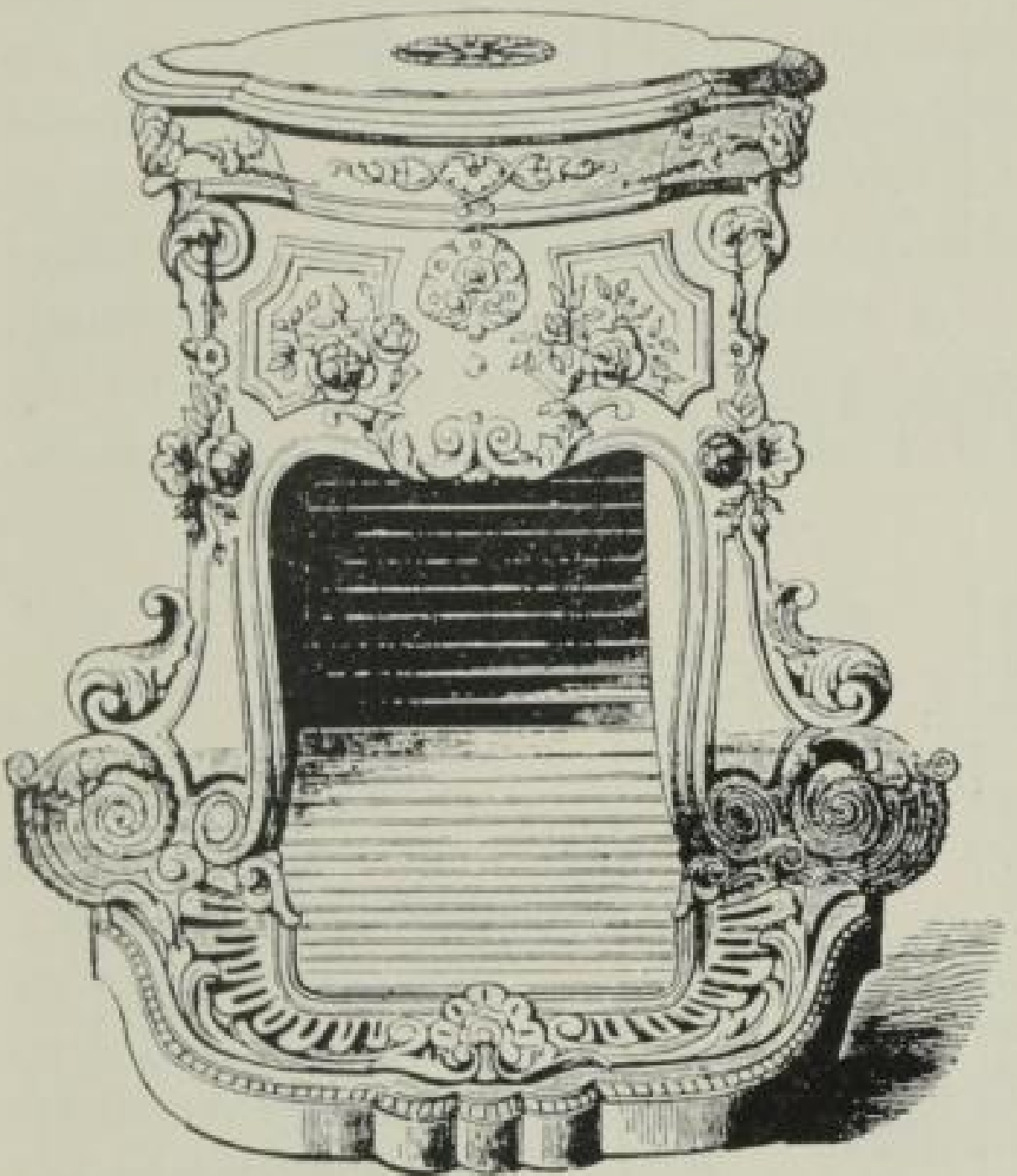

Bild 88

John Wrights Reflektorofen 1873 (Gas-Journ. Cent, [1949] S. 120)

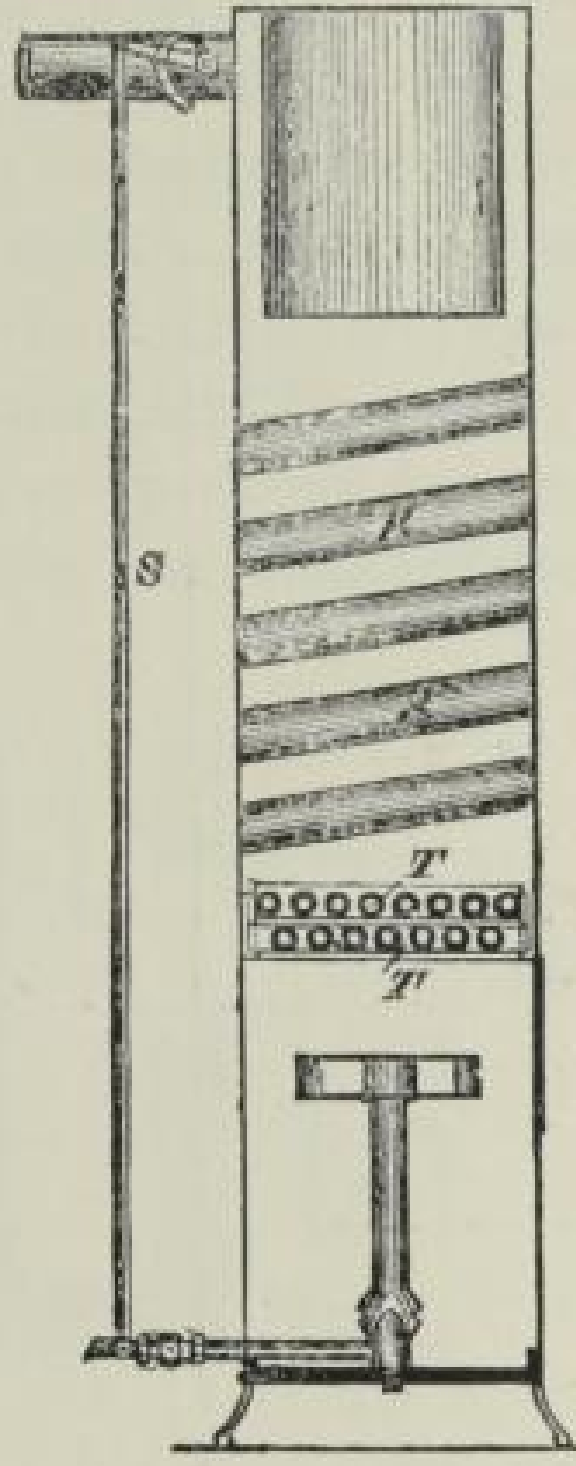

Bild 89

Konvektionsofen von

Kutscher

(J.f. G. $27[1884]$ S. 200)

verfał̧te auch eine Aufklärungsschrift. Seine Baumuster sind indessen überzüchtet und äuß̧erlich nicht gerade ansprechend $\left.{ }^{4.56}\right)$. Der „Regenerator" P. W y $b a u x$ I 887 soll nach den Untersuchungen in Brüssel $84 \%$ Wirkungsgrad erreicht haben, was nach den Zeichnungen kaum glaubhaft erscheint ${ }^{4.847}$ ). $\mathrm{Hou}$ be $n$ fertigte diese Öfen ,in jedem Stil und zu vorhandenen Tapeten und Vorhängen passend lackiert" an+sts $)$. E. Sc billing stellte fest, dał der WybauxOfen tatsächlich verglichen mit dem Kutscherschen Ofen durch die Strahlung des Reflektors eine erstaunlich hohe Fuß̧bodentemperatur erzeuge ${ }^{\text {t.sig }}$ ). Auch F. Siemens baute einen Reflektorofen (Patent von 1885 ), den er wegen der

4..40) 27 (1884), 586; 740; 742

$4.847)$ 30 (1887), 612: 31 (1888), 1003

1.849) 31 (1888), 1141

(.519) $32(1889), 459$

\section{SLUB}




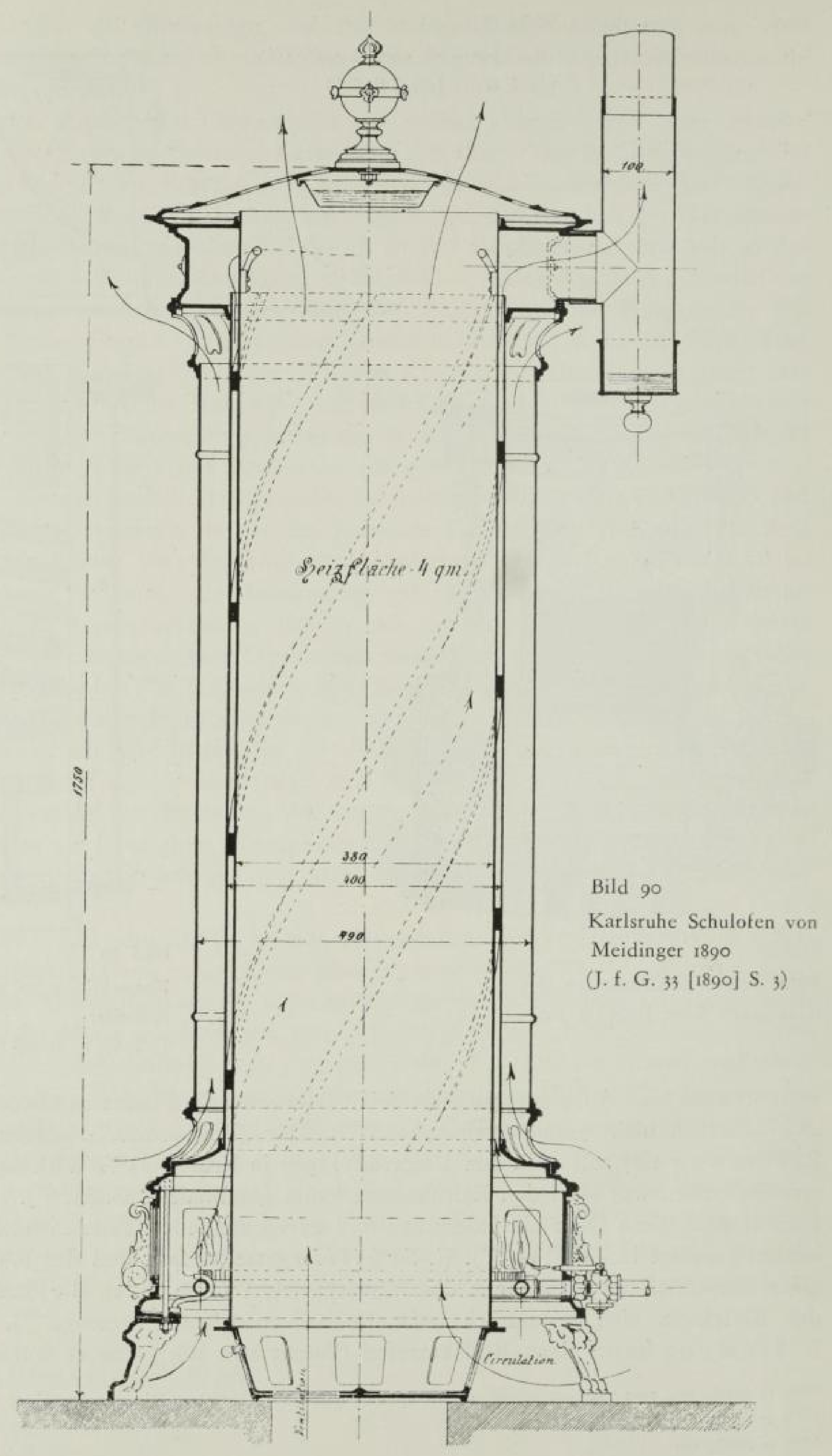

\section{SLUB}

Wir führen Wissen. 
Luftvorwärmung mit Regenerativofen bezeichnet hat. Wegen dieser Bezeichnung Regenerativofen oder gar Doppeltregenerativofen (Schäffer \& Walcker) ergab sich ein erbitterter Streit, weil die Vorwärmung in keinem Falle aus der $\mathrm{Ab}$ hitze, sondern der Flamme entnommen war. Siemens verteidigte seinen Anspruch wegen der durch die Vorwärmung erhöhten Strahlung $\left.{ }^{4.850}\right)$. Alle diese Öfen wiesen freihändig zusammengebaute konvektive Lufterhitzer auf, von denen die Fortbildung des Wybauxofens von Houben mit Ringkanälen nicht zu verstehen ist.

Zur gleichen Zeit entwickelte H. Meidinger seinen Konvektionsofen, der später als Karlsruher Schulofen gröfere Verbreitung gefunden hat. $\left.{ }^{4.61}\right)$. Er war I,7 $\mathrm{m}$ hoch und bestand aus drei Zylindern von 380, 400 und $490 \mathrm{~mm}$ Durchmesser. In den engen Kanälen zwischen den inneren beiden Zylindern befand sich eine Wendel, durch die die Gase nach oben geleitet wurden (Bild 90). Meidinger hat zum ersten Male das Prinzip verfolgt, die Widerstände in diesen engen Kanälen so hoch zu setzen, dał̧ ohne Stauvorrichtung oder fallende Züge, die er der Sicherheit wegen vermied, der Leuchtbrenner die gerade angemessene Luftmenge erhielt. Der Zündflammenhahn war durch Kreissektoren mit dem Haupthahn verriegelt, eine Anordnung, die danach bis heutzutage gern angewendet wird. Die Zündflamme sollte dauernd durchbrennen, damit Spielereien der Schüler nicht gefährlich werden. Die Luft, die durch den inneren Zylinder

Bild 91

Rückstromsicherung von

Meidinger 1894

Links große Offnung bei a, verstehendes Stück bei b.

rechts Staustück

sichelförmig bei $\mathrm{d}$

(J. f. G. $37[1894]$ S. 560)
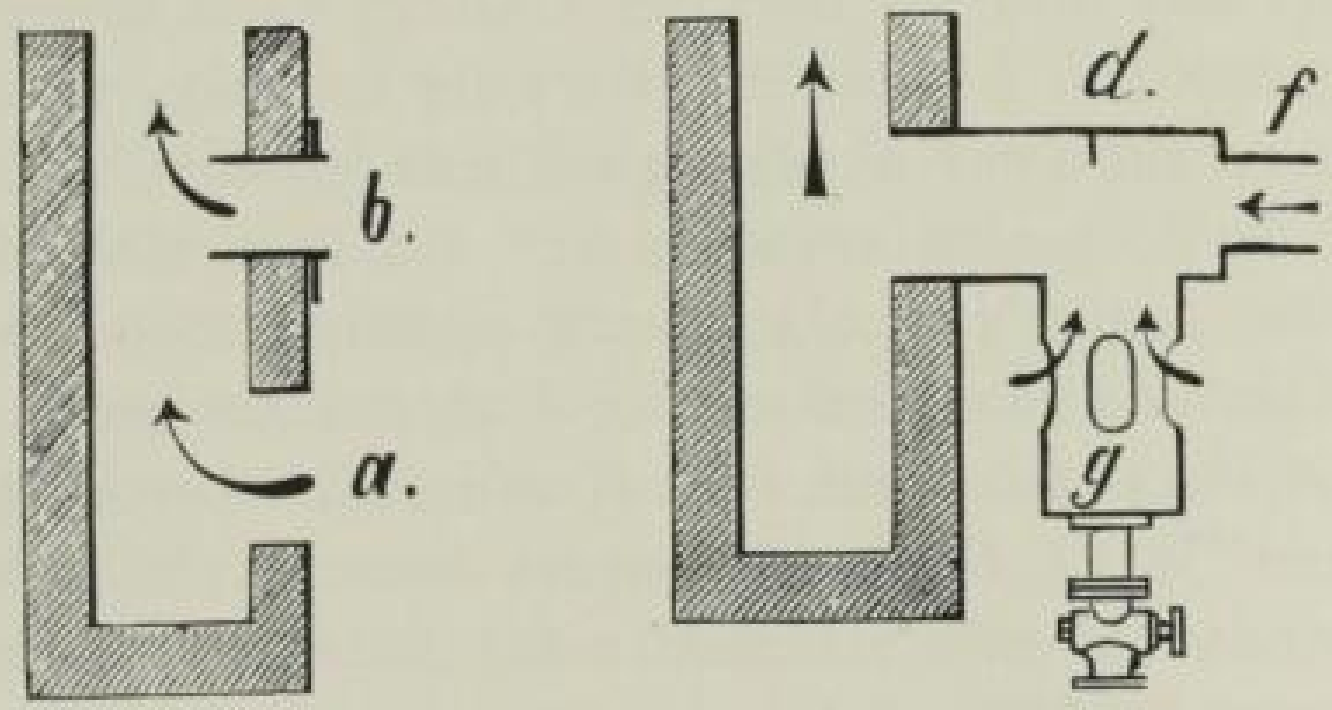

aufsteigt, konnte auf Umwälz- oder Frischluftbetrieb umgeschaltet werden, so dał eine Belüftung des Raumes möglich war. Der äuß̧ere Luftmantel, der vor allem die lästige (infrarote) Strahlung der mittleren Zylinderfläche abfangen sollte, war immer auf Umluft geschaltet. Zunächst wurden im Winter i887/88 zwei Versuchsöfen aufgestellt und als die Wirtschaftlichkeit erwiesen war, wurden nacheinander vier Karlsruher Schulen auf Gasheizung umgestellt. Meidinger hat seine konstruktiven Gedanken samt einer scharfen aber treffenden Kritik aller vorhandenen Systeme 1894 bekannt gemacht. Der Aufsatz ist heute noch für Ofenbauer lesenswert ${ }^{4.5 z}$ ). Meidinger gab dabei auch Richtlinien für den Bau von Rückstromsicherungen (Bild 9r). Er bezog sich auf seine Versuche mit einem Zugapparat ${ }^{1, k y}$ ) mit denen er auch wohl zum ersten Male bewies, dafy Gasabzüge über den Dachfirst hochgezogen werden müssen. Auch die genauen Ab-

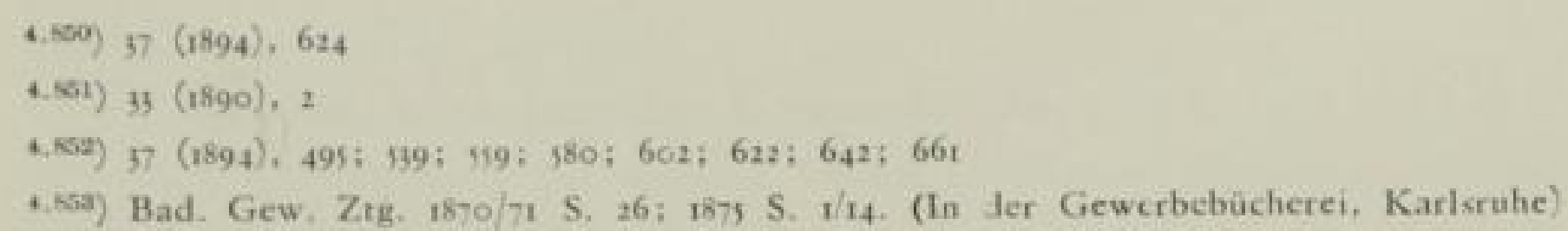


messungen der Meidingerscheibe begründete er schon damals. Den Wirkungsgrad bestimmte er nicht allein aus dem Abgasverlust, sondern er stellte daneben den Raumheizwirkungsgrad. Gasöfen sollen, so forderte er, ohne Kaminanschluf einwandfre: brennen. Ein Wirkungsgrad von $80 \%$ auf den Heizwert $(\mathrm{Hu})$ bezogen müsse genügen. Drosselklappen im Abgasrohr seien verwerflich. Auch Caglievina, Wien, trat gegen die Überbewertung von Bunsenbrennern bei Heizöten auf $\left.{ }^{t .5 \pi i}\right)$.

Das Preisausschreiben in Brüssel 1886, das zum Lobe des Wybauxofens führte, zwang dazu, einen gerechten Vergleich zu ziehen. Die Ofen wurden untersucht: auf vollkommene Verbrennung nach Geruch und auf Wirkung a) mit der Wärmemenge, die dem $R$ a ume je Kubikmeter Gas zugeführt wurde, b) nach der Aufheizgeschwindigkeit des Zimmers und c) der Wärmeverteilung im Zimmer bei Dauerheizung. Der Abgasverlust wurde über die chemische Zusammensetzung des Brennstoffes und der Abgase bestimmt nebst deren Temperatur. Es wurde schon damals festgestellt, dafy die Gasbelastung im allgemeinen, zum Nachteil der Wirkung, viel zu klein angenommen wird $\left.{ }^{4.855}\right)$. Auch $\mathrm{H}$. Bunte hat damals viele Heizöfen untersucht. Er stellte fest, dał in den meisten Fällen Abgase nicht mehr austraten und keine Kondensate mehr ausgeschieden wurden. Sein Versuchsverfahren berücksichtigte den Abgasverlust im Wasserdampf $\left.{ }^{4,5 i s}\right)$.

So war also um 1890 der Gasofen nach langer Arbeit ein einwandfreies Gerät geworden. Als nun die Werbung einsetzte, wurde sie aber auch gleich mit Rücksicht auf den Koksabsatz heftig angegriffen ${ }^{4 \cdot \text { sin }^{-}}$).

Sehr frühzeitig wandten sich die Ingenieure der Raumtemperaturregelung zu. Ein erster Vorschlag baute unmittelbar auf dem Quecksilberthermometer auf. Das in einem senkrechten Rohre aufsteigende Quecksilber sollte einen Schlitz in Form eines auf dem Kopfe stehenden $\mathrm{V}$ in dem Gaszuleitungsrohr absper$\mathrm{ren}^{4.65}$ ). O. $B \ddot{o b ~ m}$, Stuttgart, baute in Anlehnung an das Spiralrohrmanometer einen selbsttätigen Regler für Raumtemperaturen, der eine gewisse Anerkennung fand ${ }^{4.55}$ ). F. Si e me n s benutzte eine wassergefüllte Gummiblase (Bild 92), deren Bauch durch einen Gürtel aus Metall mehr oder weniger gequetscht wurde $\left.{ }^{t .580}\right)$. 1892 kamen Porges-Kutscher mit einer geschlossenen Verdampiungskapsel heraus, die mit veränderlichem Federdruck ihre Solleinsteilung erhielt ${ }^{4.8 \pi}$ ). Grundsätzlich war zum Ende des Jahrhunderts erkannt, daf die Gasheizung für gelegentliche Heizanforderungen an ehesten wirtschaftlich war, dał die Regelmöglichkeit des Gasstromes zur Einhaltung einer gewollten Höchsttemperatur im Raume grofe Ersparnisse brachte, dał Gasheizöfen im Nennwert verbältnismäß̧ig leistungsfähiger sein müssen als Kohlenöfen und dał sie, wie diese, einen Abzug haben müssen (wenigstens für deutsche Klimabedingungen).

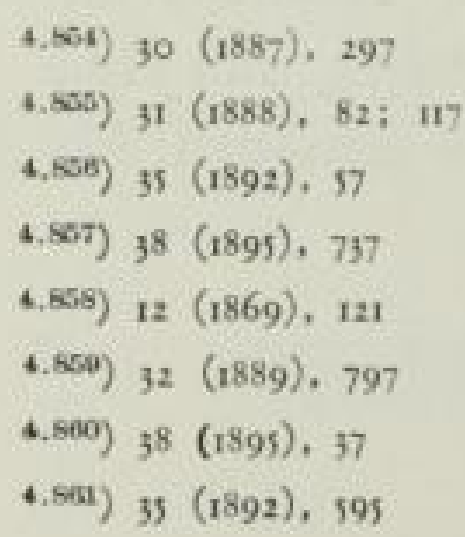


Bild 92

Raumtemperaturregler von F. Siemens (J. f. G. 38 [1895] S. $3^{8}$ )

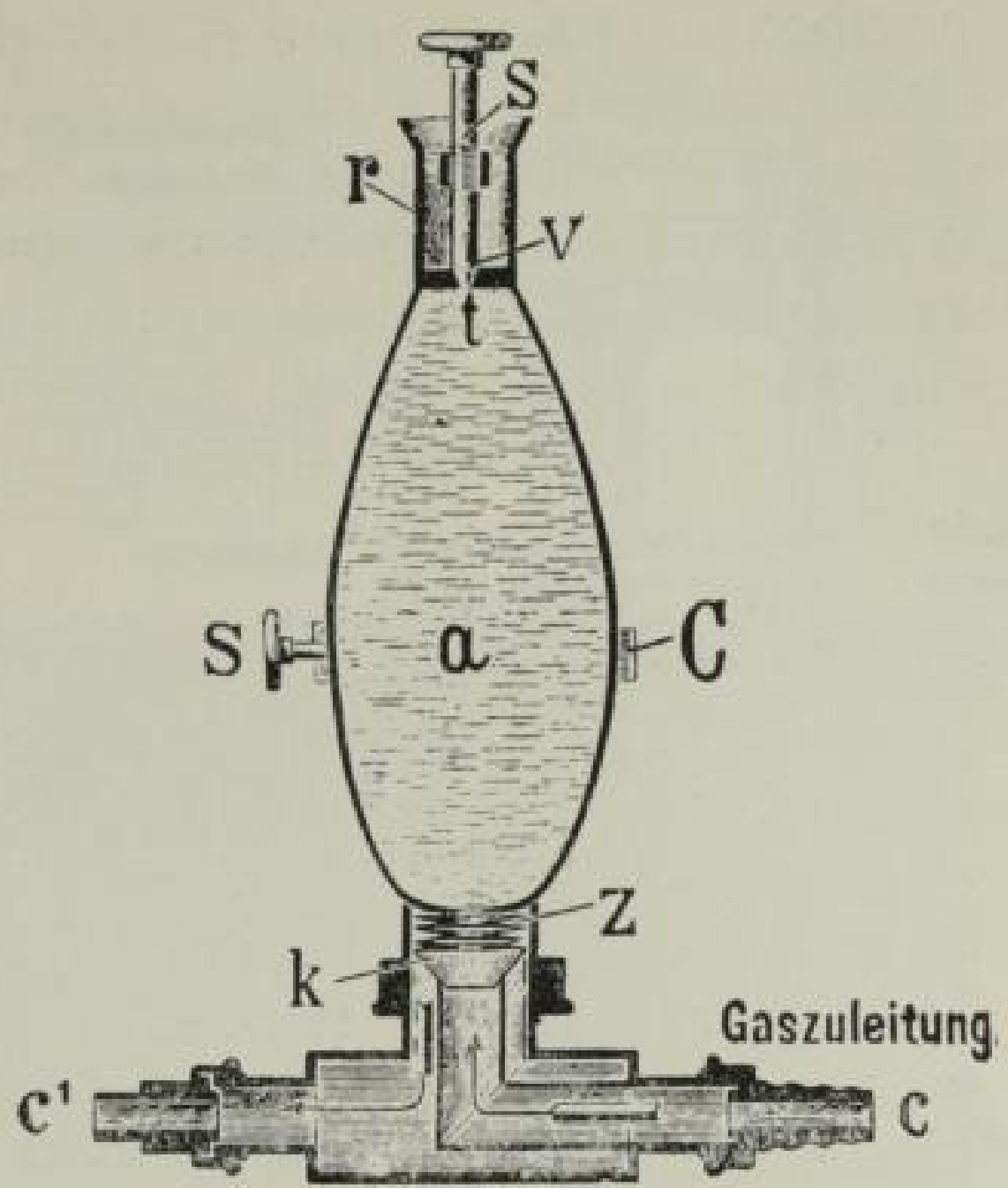

\section{$4.524 \mathrm{G}$ as motoren}

Die Verbrennungsmaschine erlebte in Gestalt des Gasmotors in der Zeit von 1860 bis 1900 ihre großze Entwicklung. Gewif hatten schon von Anfang an, als das Leuchtgas erzeugt wurde, mehrere erfindungsreiche Köpfe an solche Maschinen gedacht, aber erst im Jahre 1860 gelang es Lenoir, eine Maschine, die betriebsfähig war, zu bauen. Le no ir, der seine Erfolge in Paris errang, wird im allgemeinen als Franzose angesprochen. Er ist indessen in Mussy-la-Ville in der Nähe von Virton in Belgien geboren ${ }^{4.562}$ ) (Bild 93). Die Maschine, die das angesaugte Gasluftgemisch nach einem Drittel bis zur Hälfte des Zylinderhubes zündete, konnte nur $4,5 \%$ der im Gas vorhandenen Wärme ausnützen. Trotzdem wurde, wie schon bei anderen französischen Erfindungen zur Zeit des zweiten Kaiserreiches berichtet werden konnte, sehr laut und viel von der neuen Maschine gesprochen. Damals sicher nicht erreichte Leistungen von 450 bis $500 \mathrm{dm}^{3} \mathrm{Gas}$ je PSh wurden bchauptet ${ }^{4.903}$ ) $T$ res $k a$ stellte dagegen ${ }^{186} \mathrm{I}$ einen Gasverbrauch von $3,5 \mathrm{~m}^{3}$ PSh fest $\left.{ }^{1.54}\right)$. Die Wirtschaft hatte auch ein offenes Ohr, denn seit Jahren bemühte man sich um eine Antriebsmaschine für den im Maschinenzeitalter benachteiligten Handwerksbetrieb. Dampfmaschinen mit Kessel waren zu teuer und zu schwierig in der Wartung. Heifluftmaschinen wurden aber schwer und grof. Der Werberummel um Le noir hatte aber auch das Gute, daß allgemein die Aufgabe angefafist wurde. Vermutlich wurde N. A. Otto durch die Nachrichten aus Paris bewogen sich mit dem Gasmotor zu beschäftigen ${ }^{4, m i 3}$ ).

6.8ea) Revue gènérale du gaz 71 (1949), 9

4. Mas) C. Matschoss, Grosse Ingenieure, Lehmann München 2. Aufl. (1938) S. 250/251

4.8n) W. v. Oechelhacuser, Aus deutscher Technik und Kultur, München 1921, R. Oldenbourg S. 100 s. a. 16 (1873), 262 

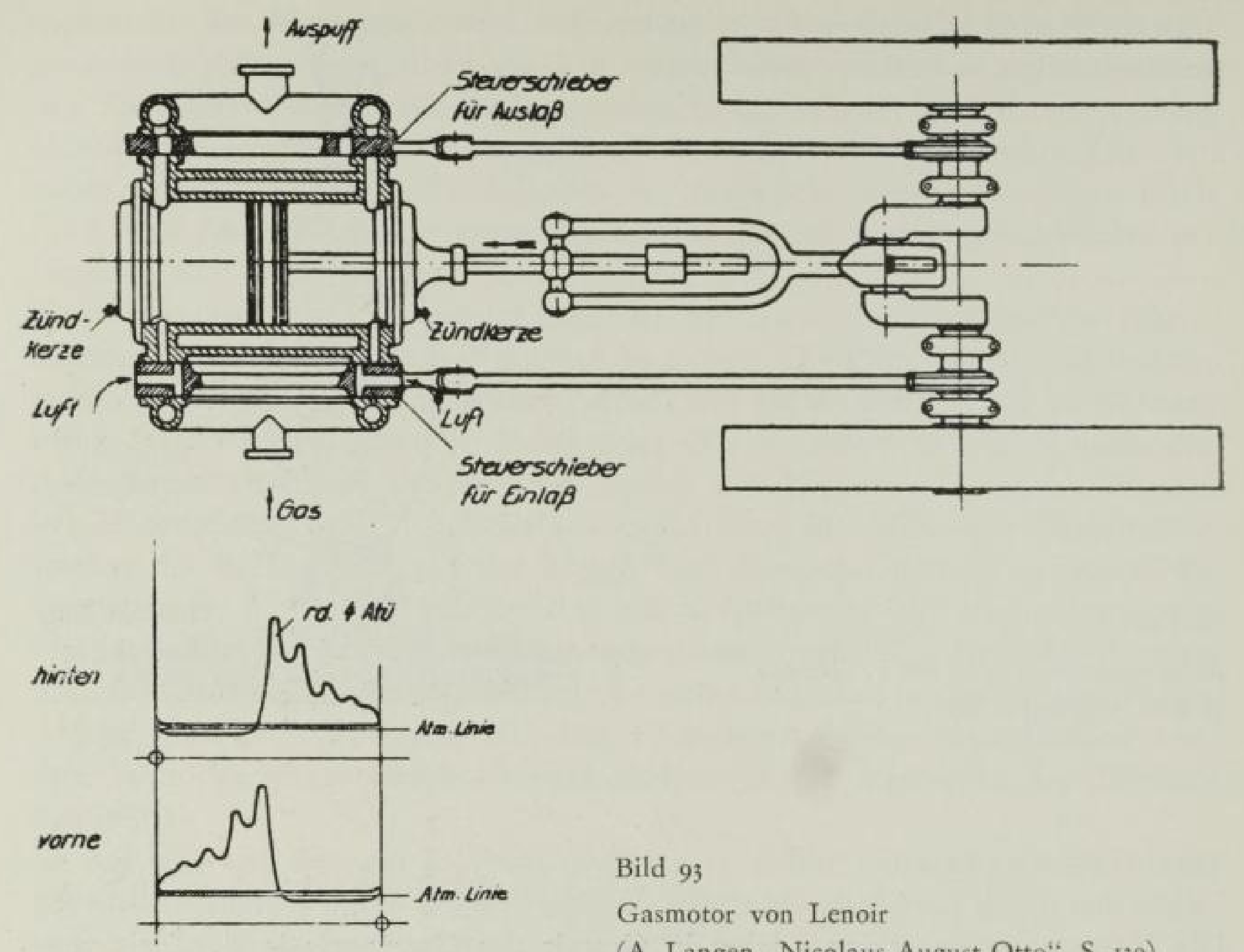

Bild 93

Gasmotor von Lenoir

(A. Langen „Nicolaus August Otto", S, 139)

\section{LE B E N S B I L D}

Nikolaus August O tto (Bild 94) wurde am 14. 6. 1832 in Holzhausen (Nassau) als Sohn eines Landwirtes und Posthalters geboren. Wenige Monate danach starb der Vater. Die Erziehung lag ganz in den Händen der tatkräftigen Mutter und des sehr viel älteren Schwagers. Nach der Volksschule besuchte Otto noch zwei Jahre die Realschule in Langenschwalbach als einer der besten Schüler. Dann kam er in die kaufmännische Lehre. Als Handelsreisender verdiente er sich sauer sein Brot. Befriedigung fand er bei seinen geistigen Anlagen dabei nicht. Seit 1858 verlobt, wollte er mit aller Macht eine unabhängige Stellung erarbeiten. In der Tatsache, daf̧ er sich ohne jede technische Vorbildung der Entwicklung der auf lange Sicht aussichtsreichen Gasmaschine verschrieb, wird heute vielfach ein Griff des Schicksals gesehen. Jedenfalls entwarf Otto nach längerem Basteln IS6I eine Vierzylinder-Maschine, bei der er die später entscheidend gewordenen 4 Arbeitstakte anwendete. Er hatte ohne theoretische Kenntnisse rein aus der Anschauung erkannt, dał die Schwäche der Lenoir-Maschine in der Zündung auf halbem Kolbenwege lag. Ottos Maschine wurde bei einem Mechaniker gebaut, sie lief 1862, war aber im gleichen Jahre schon verschlissen $\left.{ }^{\text {t.sog }}\right)$. Was möglicherweise Entwurfsfehler waren, schob Otto

4.805) A. Langen: Nicolaus August Otto, Stuttgart, Franksche Verlagsbuchhandlung 1949 S. 28 
auf die Wirkung der festen Kupplung mit der für ihn später üheraus nachteilig gewordenen Ansicht, dafy die Explosionsstöfye gemildert werden müf̧ten. Darum baute er in mühevoller Entwicklungsarbeit eine ,atmosphärische" Maschine mit freifliegendem Kolben im senkrechten Zylinder. Der wiederabsinkende Kolben wurde mit der Welle gekuppelt und gab die Drehbewegung her. Damals gewann er als Partner in der Firma N. A. Otto \& Co. den technisch befähigten und wirtschaftlich klaren, energiegeladenen Eugen $L$ ang $\mathrm{en} .1867$ wurde die

Bild 94

Nicolaus August Otto

(Matschoł

"Grofe Ingenieure",

S. 250)

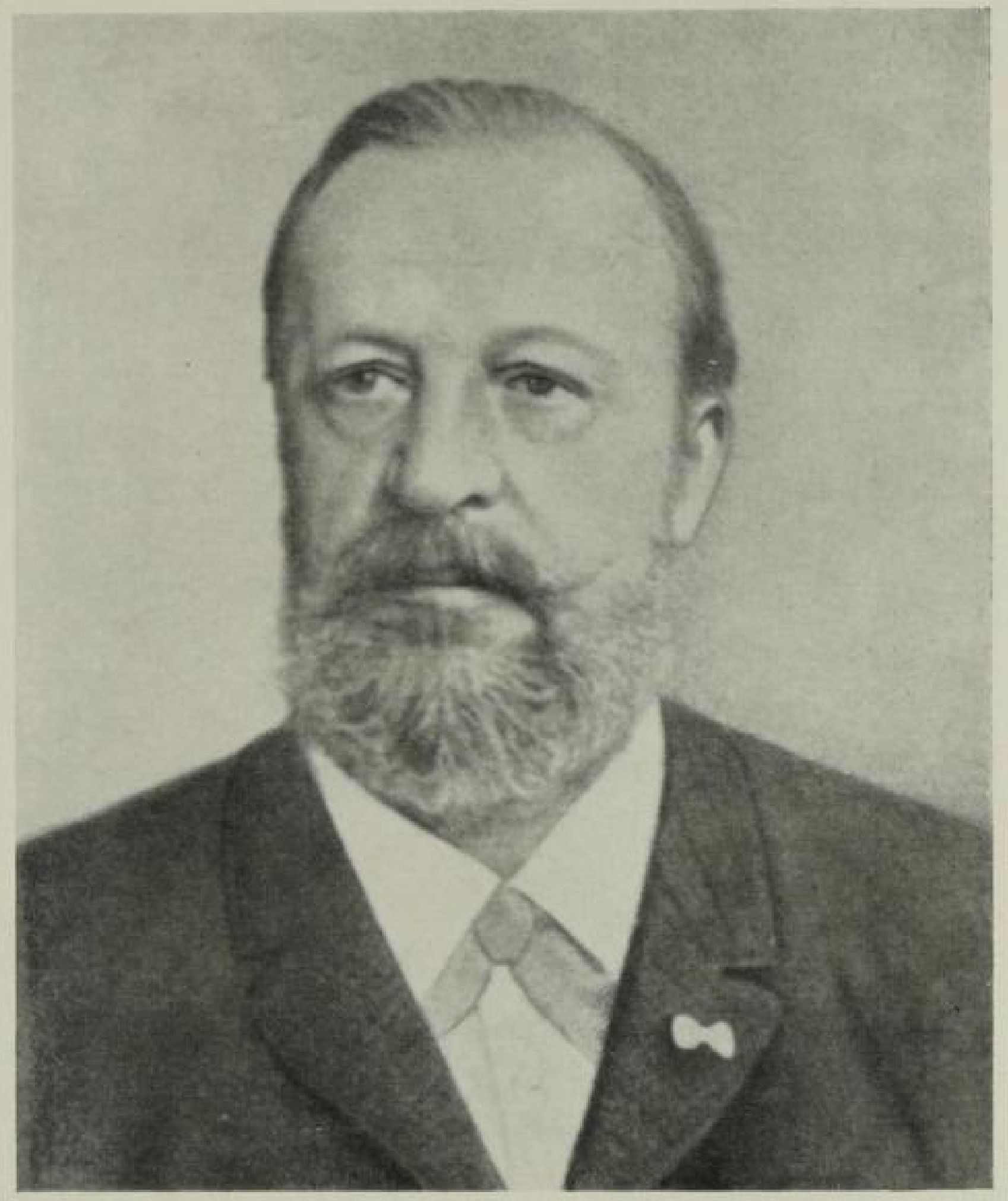

Maschine (Bild 95) aut der Pariser Ausstellung gezeigt. Eine genaue Untersuchung, die erst auf Verlangen des amtlichen Vertreters Preufens in der Jury ausgeführt wurde, zeigte, dał die Maschine nur die Hälfte an Gas verbrauchte wie die anderen Maschinen. Es waren dort 14 andere Gasmaschinentypen ausgestellt. Otto erhielt die goldene Medaille. Trotz der technischen Ancrkennung machte die Geldbeschaffung zum Anlauf der Fabrikation grofye Sorgen. Nach einer Zwischengründung, bei der Otto grołe Konzessionen machen mułte, wurde 1872 die Gasmotorenfabrik Deutz gegründet. Damals holte Langen den Schwaben G. Daimler als in der Konstruktion und Fertigung erfahrenen Ingenieur heran. Io Jahre hat Otto, der organisatorisch von der technischen Mitarbeit arg zurückgedrängt war, neben dem nicht leicht zu behandelnden Daimler geschafft. Allmählich schien es so, daf der Gasmotor von der weiteren Entwicklung der 


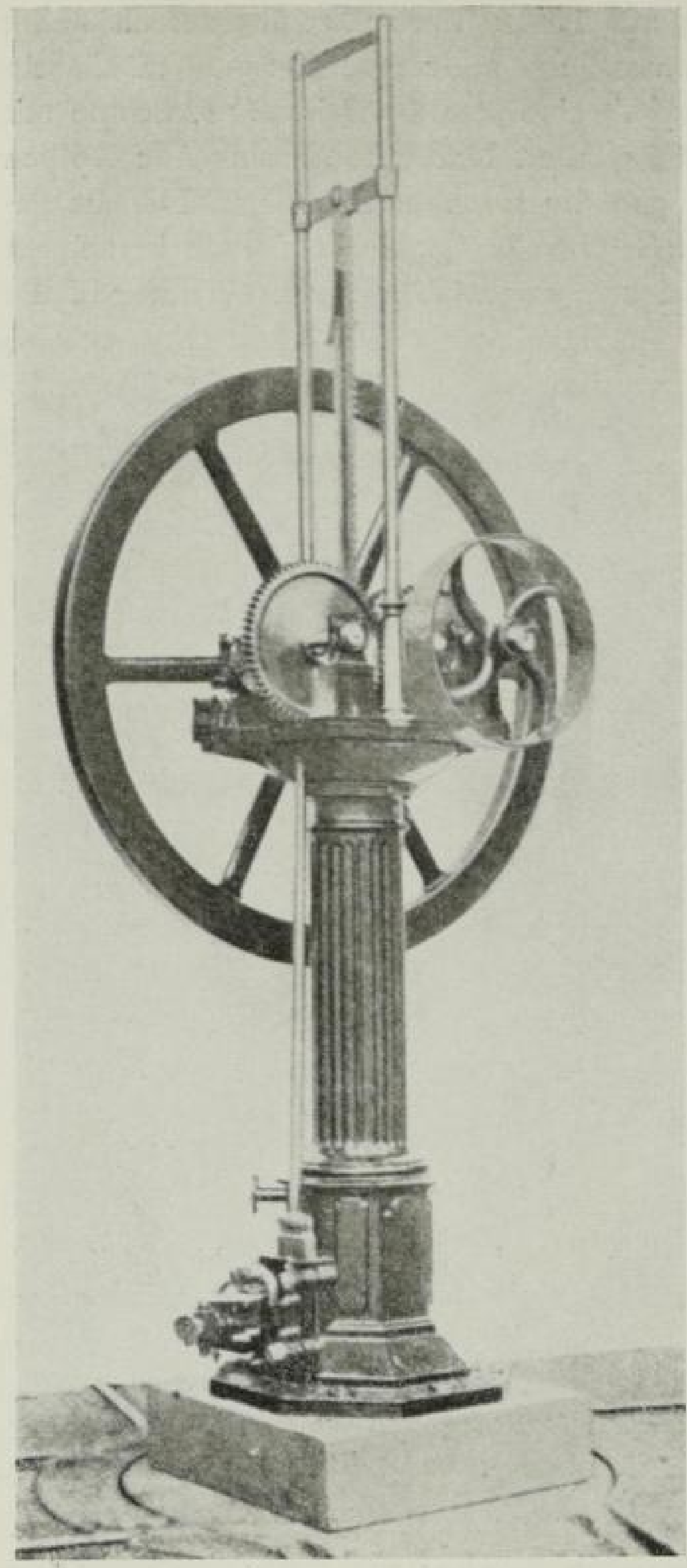

Bild 95

Atmosphärische Maschine von Otto und Langen

(A. Langen „Nicolaus August Otto", S. $3^{8)}$

Heiß̧luftmaschine überrundet würde. Otto griff nun seine alten Gedanken der mit dem festen Kurbeltrieb arbeitenden Viertaktmaschine wieder auf. Der nunmehr gut eingearbeiteten Firma gelang es nach 3/4-jähriger Arbeit am 6. 7.1876 die erste Ausführung von Ottos neuem Motor, in Betrieb zu setzen. Damit war das Verfahren gefunden, nach dem heute die überwiegende Zahl aller Verbrennungsmaschinen arbeitet. Die öffentliche Anerkennung der erfinderischen Leistung blieb nicht aus. Die philosophische Fakultät der Universität Würzburg verlieh Otto den Dr. phil. h. c.

Trotzdem begann nun die Tragik im Leben Ottos. Es waren ja auch andere Erfinder am Gasmotor am Werke. Meist bemühten sie sich, das Patent 532, das den Anspruch auf den Viertakt im vicrten Teil enthielt, durch einen Zweitakt-

\section{SLUB}

Wir führen Wissen. 
motor mit Hilfspumpe zu umgehen. Die Gasmotorenfabrik Deutz versuchte auf Grund des Patentes und anderer Patente, deren Rechte sie erworben hatte, den Bau von Gasmotoren ganz zu verhindern. So kam es zu einem grofen Prozef vor allem mit Gebr. Körting, der mit aller, sich immer mehr steigernder Schärfe geführt wurde, und schlieł̧lich mit einer Nichtigkeitserklärung vor dem Reichsgericht am 6. I. 1886 endete. Otto war schwer getroffen. Er war sich bewuf3t, der Erfinder des Viertaktes gewesen zu sein, vor allem aber, ihn in jahrzehntelanger Arbeit im spröden Stoff verwirklicht zu haben. Er mußte auch noch viele weitere Prozesse (allein 7 Zivilverfahren hingen an dem einen Urteil) zu Ende führen. Die Kräfte versagten ihm bei diesen Streitereien. Ein Herzleiden nahm unaufhaltsam seinen Fortgang. Am 27. Januar 189I erlag er den Anstrengungen.

Die Wogen, die der Prozeł, wie es im Kampfe verständlich ist, aufwühlte, sind leider heute noch nicht beruhigt. Immer wieder ist versucht worden, den Prozefgegnern unlautere Motive nachzuweisen ${ }^{4.00}$ ). Der Hauptgegner, Ernst $K \ddot{o} r t$ in $g$. ist aber seinerseits durch seine eigenen, auf sachlich technische Entwicklungen getichteten Arbeiten und durch zahlreiche allgemein das menschliche berührende Veröffentlichungen auch so bekannt geworden, dał̧ es besser wäre, diese Dinge ruhen zu lassen. E. Körting hat es als Ingenteur bedauert, dał die Prozesse schlief̧lich zur Vernichtung der Patente geführt haben ${ }^{4.417}$ ).

Bis zur Ausstellung I867 war auch in Deutschland die Lenoirmaschine hin und wieder benutzt worden. In Paris liefen 1865200 Maschinen. Sie wurden in Paris von Gautier \& Cie in Gröfyen von $1 / 2, \mathrm{I}, 2$ und 3 PS hergestellt ${ }^{4.60}$ ) und in Deutschland durch Moltrecht \& Co. Hamburg lebhaft empfohlen. Die kalorische Maschine (Heif'uftmas hine) sei geschlagen ${ }^{4 \cdot 5 i}$ ). N. A. O t to erzielte mit der atmosphärischen Maschine Leistungen von $\mathrm{I} \mathrm{m}^{3} \mathrm{Gas} / \mathrm{PSh}^{4.500}$ ) für den neuen Motor würder 750 1/PSh angegeben ${ }^{4,4}$ ). 1880 wurde dieser Motor bis zu einer Gröłe von 8 PS ausgeführt $\left.{ }^{\text {thiz }}\right)$.

Auf der Ausstellung von Paris 1879 waren neben Ottos Motor auch noch Maschinen von Lenoir, Hugon, Bisscbop, S. Simon (England) zu sehen. Simon benutzte die Abhitze zur Dampferzeugung. Den Dampf wollte er zur Verstärkung der Nutzleistung heranziehen $\left.{ }^{4.373}\right)$. Er behauptete, günstiger als Otto zu arbeiten. Bisschop hatte seine Kleinmaschine mit seitlicher Schubkurbel ausgestellt. Die wundersame Kinematik dieser Maschine zeigte den Abstand mit dem nunmehr so schlichten Motor von Deutz. Drei Jahre später in Altona auf einer internationalen Ausstellung von Kraft- und Arbeitsmaschinen für das Kleingewerbe zeigte sich aber ein hoher Gasverbrauch. Nun sollte die Maschine von

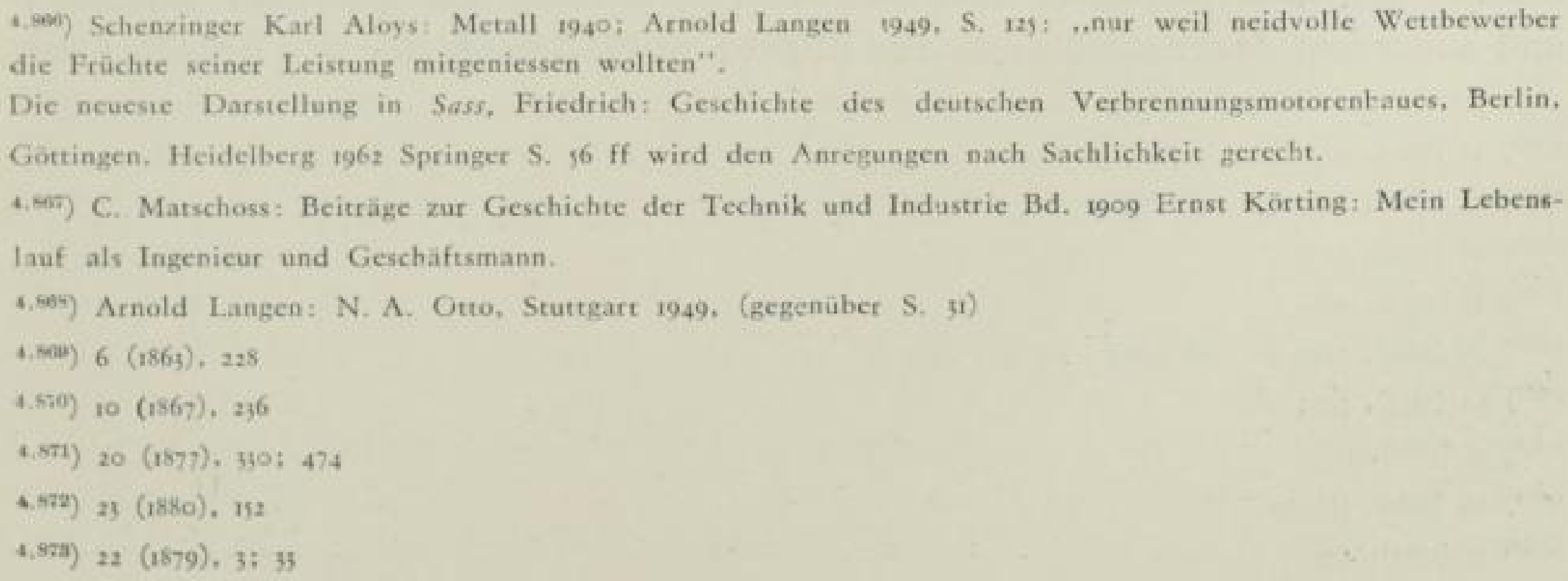


1/2 PS nur für zeitweilige Benützung im Handwerksbetrieb gelten, weil sie billig sei. Als Zweitaktmotoren waren ausgestellt: Körting-Lieckfeld, Hannover, die ein Jahr zuvor die gemeinsame Arbeit aufgenommen hatten; Egestorff (Hanomag), Linden bei Hannover; Buss, Sombart, Magdeburg; Wittig \& Hees $\left.{ }^{4.5 i}\right)$. Später wurden noch einzelne neue Motoren erwähnt, die aber nicht mehr alle genannt werden können, besonders nachdem durch den Patentprozefz DeutzKörting der Motorenbau frei geworden war $\left.{ }^{4.575}\right)$. Herausgegriffen sein mag aber ein phantasievolles Patent einer rotierenden Gasmaschine mit Wassereinspritzung. gebaut wie ein Bealescher Sauger mit 3 Flügeln, für das neben Marti auch J. Quaglio in Paris verantwortlich war. Solche Bauweisen zeigen besser als viele Auseinandersetzungen, wieweit voraus zur wirklichen Maschine die Konstruktion $\mathrm{O}$ ttos geschritten war ${ }^{4.470}$ ).

Selbstverständlich begleiteten die Gaswerke die Entwicklung mit reger Anteilnahme. Bei den engen Netzen traten vielfach Schwierigkeiten wegen der stoß̧weisen Gasentnahme auf $\left.{ }^{4.577}\right)$. Durch den Patentstreit wurden wohl alle nur irgendwie zur Sache erreichbaren Wissenschaftler zur Mitarbeit herangezogen und dadurch die Thermodynamik sehr weit auch unter den älteren Ingenieuren bekannt gemacht $\left.{ }^{t .57 t}\right)$.

Die Deutsche Continental-Gas-Gesellschaft verbilligte, als Ottos neuer Motor auf den Markt kam, die Preise für Motorengas $\left.{ }^{4.57}\right)$. Um 1888 ging Remscheid zu einer ganz erheblichen Preisherabsetzung über. Statt des bisheringen Preises von $17 \mathrm{Pfg} . / \mathrm{m}^{n}$ mit Io bis $20 \%$ Rabatt je nach Abnahme wurden nur I2 $\mathrm{Pfg}$. erhoben. Das hatte in der Stadt des Kleingewerbes in kurzer Zeit eine Abnahmeerhöhung von 20000 auf $56000 \mathrm{~m}^{2}$ zur Folge. Gleiche Erfolge hatte Wermelskirchen, aber ähnliche auch Altona, Mönchengladbach und Kaiserslautern ${ }^{4.50}$ ). Die königliche Regierung zu Düsseldorf schaltete sich mit einem ungewöhnlichen Erlał an die Landräte ein. Sie beanstandete, dał die Normalpreise des Gases zwischen 32 und $I_{2} \mathrm{Pfg}$. in den verschiedenen Orten wechselten. Die Kraftgaspreise sollten auf $8 \mathrm{Pfg} . / \mathrm{m}^{3}$ wie in Köln und Duisburg festgesetzt werden. Motoren müften mietweise abgegeben werden $\left.{ }^{t .581}\right)$. Eine Zuschrift an das Journal betonte, dał die Gaswerke nicht dazu da seien, mit Verlusten Mittelstandspolitik zu treiben. Der Düsseldorfer Erlaf3 stiftete indessen auch in anderen Provinzen Unruhe. C. Wo lff, Quedlinburg, ein sehr genau rechnender Werksleiter, der mit Sommergasverbilligung stark voranging, wies statistisch nach, dafy bei ihm $90 \%$ des Motorengases von Groß̧betrieben abgenommen würden $\left.{ }^{4 * m g}\right)$. Umgekehrt sah sich das private Gaswerk Krefeld plötzlich einer Klage der Gemeinde gegenüber, weil es Gas für andere als Beleuchtungszwecke abgegeben und auf̧erdem das Stadtrohrnetz zur Abgabe an Nachbargemeinden benutzt habe.

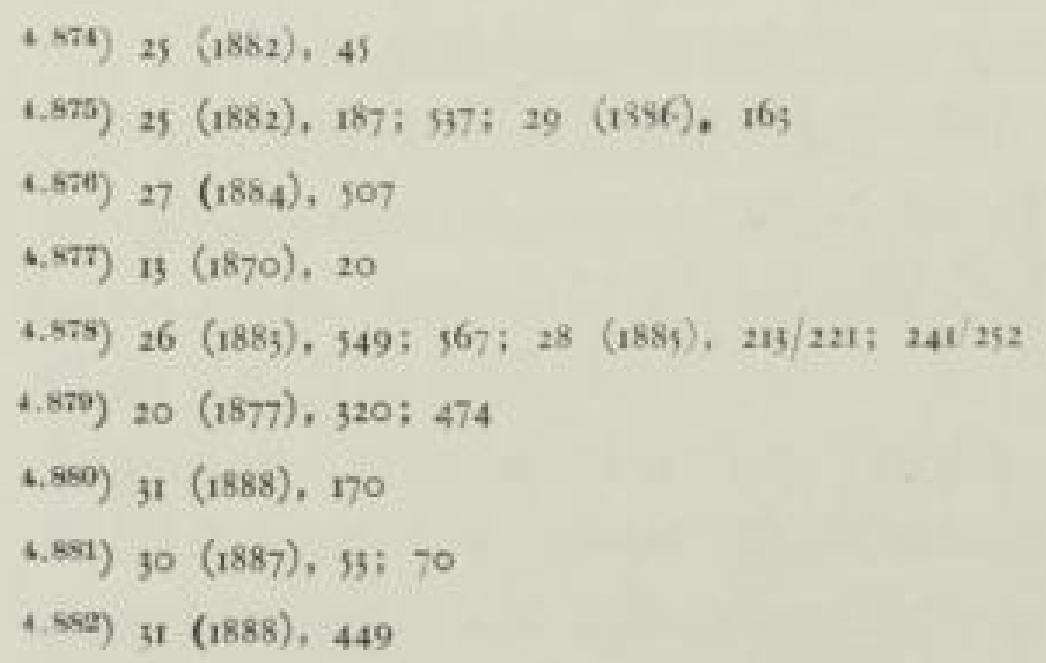


Das sei eine Verletzung der Beleuchtungsverträge. Von den Gerichten wurde diese Klage jedoch abgewiesen $\left.{ }^{4.960}\right)$. Ein Versuch in Oppeln, Gasmotoren an Handwerker zu vermieten, schlug fehl $\left.{ }^{4.85}\right)$. ${ }^{2} 894$ gab Fr. $S c b a ̈ f e r$, eine Übersicht über den Einsatz von Gasmotoren. Er stellte fest, daf̧ tatsächlich die Hälfte dem Kleingewerbe zugute kam. Die als Wettbewerb im Auslande entwickelten Druckwasser- und Druckluftzentralen kamen in Deutschland als zu teuer nicht in Betracht $\left.{ }^{\text {t.ss }}\right)$.

Grołye Hoffnungen setzte das Gasfach auf die Verwendung von Gasmotoren im Strafjenbahnbetrieb. Schon 1882 nahmen $\mathrm{Holl}$ und $\mathrm{Cr}$ ossley ein Patent auf eine Lokomotive mit Gasmotor. Beim Anlassen sollte Gas aus einem Druckbehälter entnommen werden, der bei der Kompression gefüllt wurde. Die Übertragung vom Motor auf die Achsen geschah durch Treibriemen. Die Achsenentfernung war verstellbar, so dał der Motor bei einem kurzen Stillstand der Lokomotive leer durchlaufen konnte. Von einem Erfolg wurde nichts bekannt ${ }^{4.565}$ ). 1888 wurden in Leipzig Straf3enbahnversuche angestellt ${ }^{4.587}$ ). Die Gasbahn Neuenburg-St. Blasien in der Schweiz"twe ) wurde mit einer „wüsten Reklame“ gerühmt. Auch die London-Greenwich Tramway betrieb die Bermondsey Line mit Gas ${ }^{4.859}$ ). Besonderes Aufsehen erregte die Probestrecke der Gasbahn nach System $L \ddot{u} b$ $r i g$ in Dresden $\left.{ }^{4.550}\right)$. Prof. Gostkowsky, Lemberg war nach anfänglicher Skepsis so begeistert $\left.{ }^{4.585}\right)$, dafy er sich zu der Meinung verstieg, elektrische Bahnen mit Oberleitung hätten eine Vergangenheit, Gasbahnen hingegen eine $\mathrm{Zu}$ kunft $\left.{ }^{t .500}\right)$. Den gröf̧ten Aufwand zur Entwicklung trieb die Deutsche ContinentalGas-Gesellschaft. Sie baute in Dessau eine Straß̧enbahnlinie von 4,4 km Länge. Die kleinen Wagen ( 12 Sitze und Is Stehplätze) wurden mit einem in Deutz entwickelten Motor mit einer zwischen zwei Zylindern liegenden Mittelwelle angetrieben. Man war stolz, statt der vorausberechneten Geschwindigkeit von $12 \mathrm{~km} / \mathrm{h}$ mit 13 gefahren zu $\left.\operatorname{sein}^{4.501}\right)$. Das Kapital der Gesellschaft belief sich auf 500000 M. Nach befriedigenden Ergebnissen wurde von der Gasgesellschaft eine Gasbahngesellschaft mit Waggonfabrik in Dessau mit 2 Mio Aktienkapital gegrün$\left.\operatorname{det}^{t .403}\right)$. Die Gesellschaft hat dann aber nur noch eine Bahnlinie in Hirschberg (Schlesien) von $13,3 \mathrm{~km}$ Länge betrieben. Die anderen zahlreichen Projekte blieben stecken (Nordhausen, Kolmar) oder kamen nur zu kurzem Probebetrieb (in Berlin: Westend-Bahnhof Zoo). Die „öffentliche“ Meinung gab allmählich ihre Stellung gegen die ,unschönen “ Drähte in den Straf̧en auf. Die langsamlaufenden Motoren mit Erschütterungen des ganzen Wagens und dem Riemenantrieb erwiesen sich als denkbar ungeeignet für den schwierigen Betrieb von Strał̧enbahnfahrzeugen auf den leichten, oft verschmutzten Schienen.

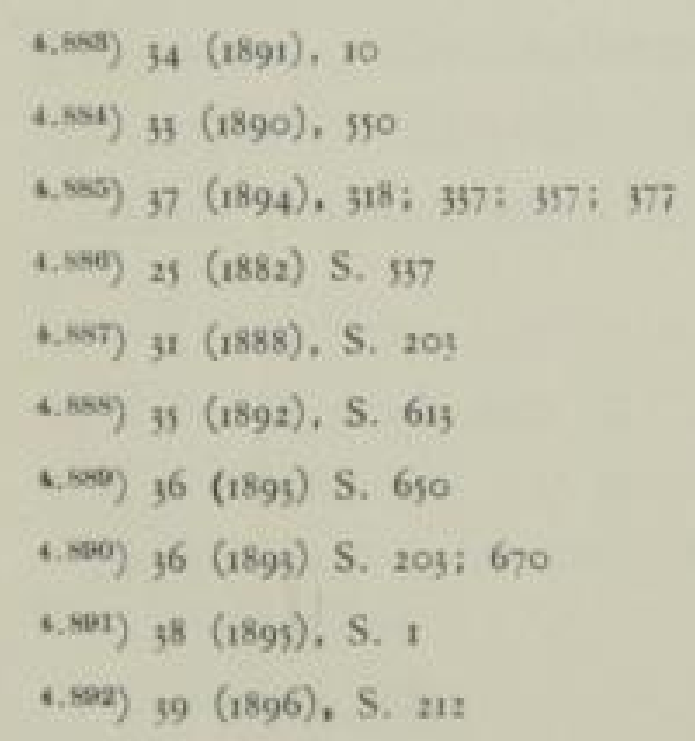


Eine andere Fehlentwicklung waren die Bemühungen, die elektrische Beleuchtung über den Gasmotor an das Gaswerk zu binden. Solange noch bei den hohen Preisen der Erstausführungen und bei den niedrigen Spannungen die Zentralen mitten in das dichtest besiedelte Gebiet mit kleinen Belieferungsbezirken eingebaut wurden, waren die Hoffnungen groł. Die ersten Versuche der städtischen Gaswerke Berlin im Werk Stralauer Platz waren allerdings unbefriedigend $\left.{ }^{4.909}\right)$. Aber schon 4 Jahre später gab S. S c biele auf der Hauptversammlung dringend den Rat, dał die Gaswerke die neue Beleuchtung in die Hand nehmen sollten. Die erste deutsche, probeweise ausgeführte Bogenlampenbeleuchtung mit DifferentialBogenlampen von Siemens (Potsdamer Platz und Leipziger Strafye) erhielt ihre Energie tatsächlich aus 4 Gasmotoren von je $12 \mathrm{PS}^{4 . \infty 4}$ ). Die erste endgültige Blockstation Berlin-Friedrichstraf̧e 8s der A. G. städtische Elektrizitätswerke, die die deutsche Edisongesellschaft einrichtete, wurde aber mit Dampf betrieben $\left.^{1.655}\right)$. Kohle und Dampfkessel mitten in der Stadt, der Kessel im Keller des Hauses waren aber nicht nach aller Leute Geschmack, so griff wieder die Deutsche Continental-Gas-Gesellschaft zu und errichtete die zweite deutsche Elektrizitätszentrale in Dessau zur Beleuchtung des Theaters, des eigenen Hauptverwaltungsgebäudes und anderer Abnehmer. Sie wurde am 13.9. 86 mit Gasmotoren in Betrieb genommen.

Durch diesen Bau wurde die Nachfrage nach stärkeren Motoren ausgelöst. 1886 war der gröfste erhältliche Motor 60 PS stark, 1892 I20 PS $\left.{ }^{4.500}\right)$. Der Gasverbrauch war bei kleinen Maschinen auf 800 1/PSh gefallen, bei grof̧en wurden gar 650 1/PSh gewährleistet. Der Generaldirektor der Gasgesellschaft, W. v. O e c b elbaeuser, nahm eigene Arbeiten zur Entwicklung einer Grofygasmaschine auf, zu deren Untersuchung und Weiterentwicklung er H. Junkers nach Dessau holte. Im Zusammenhang damit stand die Patentanmeldung auf Gaseinspritzung in komprimierte Luft ${ }^{4.60^{\circ}}$ ), ein Verfahren, das am grofen Volumen des Gases scheitern muf3te, wie es auch später R. Diesel noch einmal erfahren hat. Der Doppelkolben-Hochdruckmotor (D.R.P., 94 III vom 7. II. 96) war dagegen für besondere Anforderungen lebensfähig" $\left.{ }^{4.9 n o}\right)$. Die Steigerung der Leistung ging nunmehr schnell. 1898 wurde ein Einzylindermotor von 200 PS von Krupp-Grusonwerk gebaut $\left.{ }^{4.590}\right)$. 1900 hatte der Hörder Verein zwei Maschinen von je 1000 PS bei der Gasmotorenfabrik Deutz bestellt und eine 500 PS Oechelhaeusermaschine in Betrieb genommen ${ }^{4 \cdot w^{*}}$ ). Die Gasindustrie wurde aber nicht der Nutzniefjer dieser Entwicklung. Oechelhaeuser selbst stellte als Vorsitzender des Vereins fest, dał wegen steigender Kohlenpreise und Arbeitslöhne bei erschwertem $\mathrm{Ab}$ satz der Nebenerzeugnisse ein Preis von 4 bis , Pfg. $/ \mathrm{m}^{3}$ nicht erreichbar sei, sodaf Maschinen über roo PS nicht wirtschaftlich seien. Die grofen Maschinen gingen auf die Hüttenwerke zur Hochofen-Gichtgasverwertung.

4.58s) $21(1878), 581$

4.604) $25(1882), 639$

4.585) $27(1884) \cdot 738$

4.696) W. v. Oechelhacuscr: Aus deutscher Technik und Kultur, München 192t, R. Oldenbourg S. 100

4.597) 33 (1890), 308

4.815) 41 ( 1898$), 358$

4.500) Stahl und Eisen 1898

$4.900) 43$ (1900), 216

314 
Aber schon vorher war ein Teil der schönsten Hoffnungen zerflattert. Mit dem Dowsongas wurde 1886 das Generatorgas zum „Kraftgas ${ }^{\text {(4.6.601 }}$ ) und nachher zum Sauggas. M. Schröter stellte fest, daf̧ der Dowsongasbetrieb um $17 \%$ billiger als ein Dampfmaschinenbetrieb sein würde. Größ̧e de: Motore lag bei rd. 100 PS $\left.{ }^{1.002}\right)$. Damit wurde aber der Gasmotor wenigstens teilweise der Versorgung mit Stadtgas entzogen.

Immerhin konnte W. v. Oecbel baeuser 1890 bei einer Umfrage ermitteln: dafy 20 Gasmotorenfabriken bis dahin 18000 Maschinen mit insgesamt 60000 PS abgesetzt hatten. In den weiteren zwei Jahren hatte die Deutzer Fabrik weitere 1950 Motoren mit 8830 PS abgeliefert $\left.{ }^{4.000}\right)$. 1900 gab Fr. Schäfer als bei Gasversorgungen im Betriebe nachgewiesene Maschinen viel geringere Zahlen an; nämlich 26000 Motoren mit insgesamt 110000 PS. Die zuerst abgelieferten kleineren Maschinen waren also inzwischen offenbar schon wieder verschwunden.

Jedenfalls aber traf E. Me yer, Göttingen durchaus richtig die technische Lage, wenn er zur Jahrundertwende sagte: „Der Gasmotorenbau steht augenblicklich in einer Zeir gewaltigster Entwicklung".

\subsection{Andere Wärmeverbraucher}

Gegen die grof̧en Verbraucher: Haushalt und Motoren waren die übrigen Abnehmergruppen im ganzen Jahrhundert fast völlig unentwickelt. Dabei fand die Anwendung durchaus in Gasfachkreisen Beachtung. Das zeigt schon ein Blick in das Schrifttum. Em. Schreiber gab ein Buch über das Heizen und Kochen mit Gas, sowohl in industrieller als auch in hauswirtschaftlicher Beziehung heraus (Weimar 1858 bei B. F. Voigt). Wilhelm Siemens schrieb 1873 über die Benutzung des Kohlengases als Brennstoff. 1886 widmete J. G. Wo b be ein Buch der Verwendung des Gases zum Kochen, Heizen und in der Industrie (Troppau I886 bei Zenker).

In dem ständigen Musterlager des Gewerbeamtes, Stuttgart und i. d. Bad. Landesgewerbehalle, Karlsruhe wurden Lötkolben mit Gasfeuerung und Pref̧luft mit Fuf̧blasebalg gezeigt $\left.{ }^{4.00}\right)$. Auf der Pariser Ausstellung 1867 arbeiteten Juweliere mit einer Gebläselampe von $S u c b e t$. Eine Sengemaschine von $T u l p i n$, Rouen war vorhanden $\left.{ }^{4,0 \times c}\right)$. Aus Paris wurde über die Heizung mit Gas 1874 ein Bericht $\left.{ }^{1.000}\right)$ mit den Worten eingeleitet:

„Die Anwendung des Gases zu häuslichen und industriellen Zwecken bildet gegenwärtig für eine sehr grołe Zahl von Gasgesellschaften die Quelle ihres Wohlstandes und ihres künftigen Gedeihens". Im Ausstellungsraum des Gaswerkes in Paris fand man auch viele gewerbliche Heizvorrichtungen: Lötkolben, Bügeleisen, Lockencisen, Dampfbäder, die Thermosäule von Clamond für galvanische Betriebe, Gaszünder von Baumeister und Flürscbeim, Giroud Rheometer u. a. mehr.

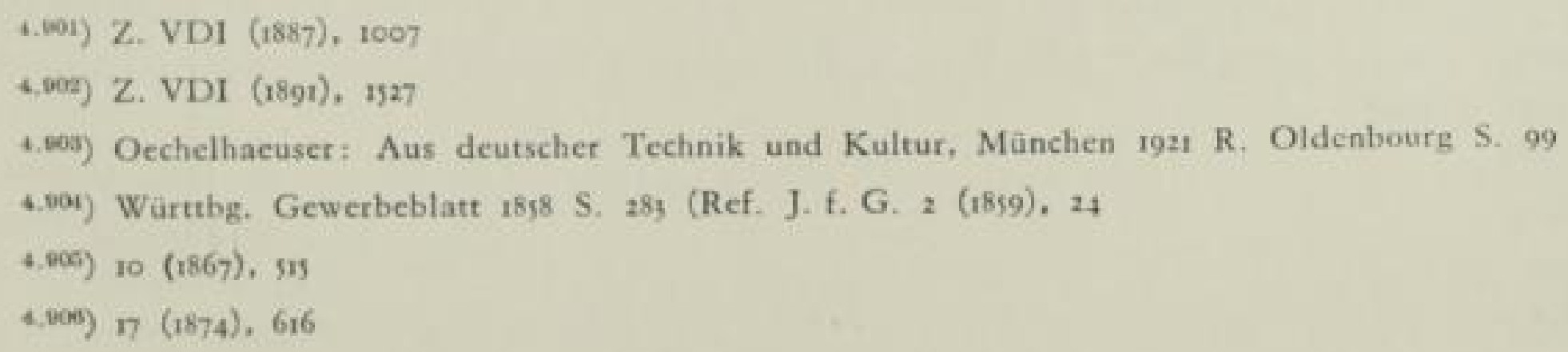


Nachdem in den letzten Jahrzehnten Nitrierhärtung, Oberflächenhärtung und Blankglühen in einer künstlichen Ofenatmosphäre ,ganz neu“ entwickelt worden sind, muf ein Leitartikel aus dem Jahre $1861^{4.007}$ ) der Vergessenheit entrissen werden. E. Fre my berichtete in der Akademie der Wissenschaften über Versuche Stahl zu nitrieren. Er leitete ein Gemisch von Ammoniak und Leuchtgas über rotglühendes Stabeisen, das Ammoniak zur Abgabe des Stickstoffes, das Gas zur Aufkohlung. Ohne Ammoniak verwandelte er Eisen in graues weiches Roheisen, das leicht-flüssig (also keine Stahleigenschaften) wurde. Dumas erkannte die Möglichkeiten, Oberflächen und Schneiden aus Schmiedeeisen zu härten. Die Tiefe der Stahlschichten lasse sich durch die Dauer des Gaszementierens mit einer Sicherheit regeln, wie es mit Einsatzpulvern nie gelinge. Gu ner, St. Etienne, warf ein, daßs zur Stahlbildung Stickstoff nicht nötig sei. Ma cintos b. Glasgow, habe bereits vor 25 Jahren mehrere Tonnen Zementstahl durch Leuchtgas in 18 bis 20 Stunden hergestellt. Daf3 die unterschiedlichen Ergebnisse mit dem Ausgangseisen und der Ofenatmosphäre zusammenhingen, wurde damais leider nicht untersucht. Dazu fehlten wohl noch die Kentnisse. (Die Lehre vom chemischen Gleichgewicht ist erst 1867 formuliert).

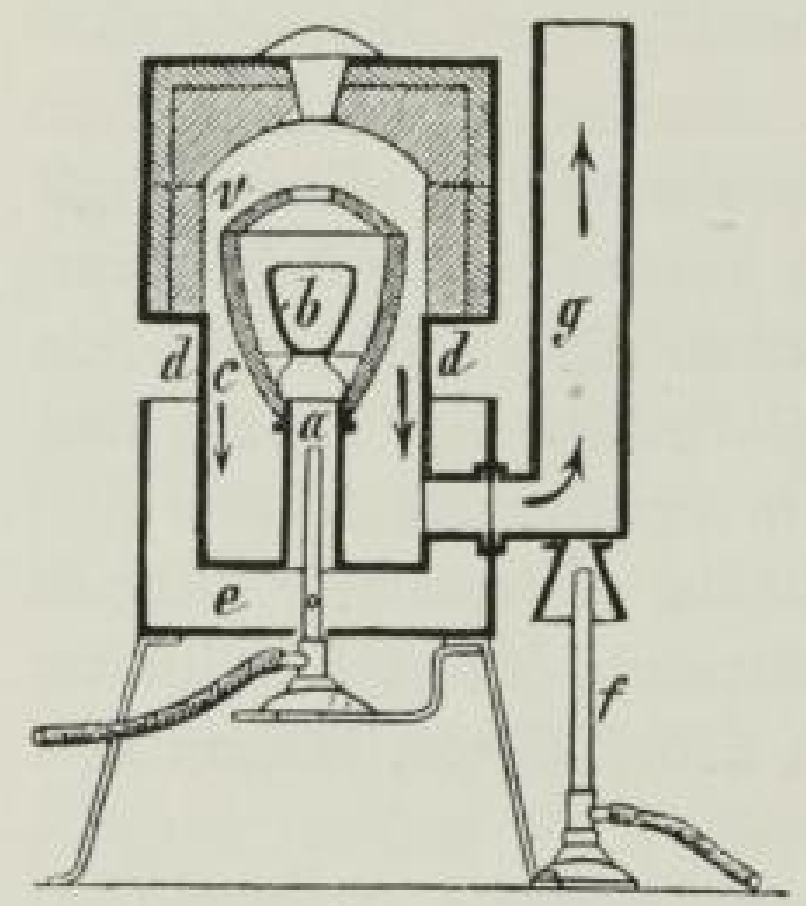

\author{
Bild 96 \\ Muffelofen von Rössler \\ (J.f. G. 28 [1885] S. 84 )
}

Der erste gewerbliche kleine Tiegelschmelzofen stammte von Per o $t$, Genf ${ }^{t .005}$ ). Pforzheim stellte 188 ; eine starke Zunahme des Industrieabsatzes zum Schmelzen fest. Bei einem Leuchtgaspreis von $20 \mathrm{Pfg} / \mathrm{m}^{3}$ war die Industrie mit is $\mathrm{Pfg} / \mathrm{m}^{3}$ für ihre Arbeiten zufrieden ${ }^{4.000}$ ).

Zwei Jahre später baute H. Rössler, Frankfurt, der Begründer der späteren Deutschen Gold- und Silberscheideanstalt (Degussa) den ersten Muffelofen für Temperaturen über $1100^{\circ} \mathrm{C}$ zum Schmelzen von Feingold auf. Er bediente sich einer gut ausgebildeten Bunsenflamme und isolierte den Ofen ${ }^{4.90}$ ) (Bild 96). Ein tüchtiger Erfinder glaubte, dał der Muffelofen mit Gebläsebrenner wegen der Rückschläge im Brenner sich nicht durchsetzte und empfahl seine Bauart, die diesen Übelstand behebe $\left.{ }^{4.911}\right)$. Ein Radbandagenofen mit Gasfeuerung der Metropolitan Railway (Untergrundbahn) in London dürfte der erste seiner Art gewesen $\left.\operatorname{sein}^{4.912}\right)$.

4.007) 4 (1861), 219

4.005) 10 (1867), 498; 11 (1868), 25

$4.800) 26(1883), 595$

$4.910)=28$ (1889), 84

4. v11) $41(1898), 320$

$4.912) 14(1871), 848$ 
Auf das Bäckerei-Gewerbe stürzte sich F. Reicbard in Karlsruhe mit der ihm eigenen Gründlichkeit und Energie. Er mufte sich aber, nachdem ihm zugegeben wurde, dał der Kohlenrauch in der Bäckerei sehr widerlich ist, mit Koksabsatz begnügen. Gas sei wohl anwendbar, verlange aber neuartige Öfen ${ }^{4.913}$ ). So sehen wir, dał auf diesem Gebiete nur einzelne klare Draufgänger die vorbereitenden Schritte taten. Die grołe Menge folgte noch nicht.

\subsection{Unfallverbütung}

Das Gasfach hat sich, wie auch andere Energieträger, in zweifacher Weise mit Unfällen zu befassen.

I. denen, die bei der Verteilung und Verwendung des Gases vorkommen,

2. denjenigen im Werk und bei Rohrnetzarbeiten.

Über die schweren Brandunfälle, insbesondere in Theatern ist bereits im Abschnitt über die allgemeine Entwicklung gesprochen worden, weil diese Katastrophen eine sehr weitgehende Wirkung hatten. Desgleichen wurden die Folgen der abzugslosen Gasbadeöfen bereits erwähnt. Den Gasfachleuten muß man auch rückblickend zugestehen, dał sie solche Ereignisse mit grołem Ernst bearbeiteten, was schon aus der freimütigen Besprechung im Fachblatt hervorgeht. Man zog Wissenschaftler und erfahrene Ingenieure heran, die sich irgendwie als Gutachter auf den verschiedenen Gebieten bewährten. Wegen der Feuersgefahr in Theatern im Vergleich zu der elektrischen Beleuchtung fand das Fach eine fruchtbare Unterstützung der angesehensten Feuerwehrleute.

Umso mehr war man erregt, als die Polizei in Preufyen die Gasbeleuchtung von Theatern ohne Anhören der Sachverständigen zu verbieten sich anschickte ${ }^{4.6914}$ ) und als auch in Straß̧burg i. Elsał die Polizei kurzerhand Gasbeleuchtung in Warenhäusern untersagte. Damals gab es aber schon eine Statistik der Feuerschutzverbände, die bewies, daß bei der damaligen Installations- und Sicherungstechnik Warenhausbrände häufiger auf Elektrizität als auf Gas zurückgeführt worden waren. Viel wichtiger wurden darum Bestimmungen allgemeiner Art erachtet: z. B. Schutz der Leuchten, einschließ̧lich elektrischer Glühlampen vor Berührung mit entzündlichen Stoffen, Offenhalten der Fensternischen und sonstigen Notausgänge ${ }^{4.015}$ ) und Beleuchten der Fluchtwege unter allen Umständen, besser mit Gas als irgend einem anderen Leuchtmittel ais Notbeleuchtung.

Hatte es doch sogar in der Synagoge von Ostrowo als Folge einer Panik, die durch das damals übliche Absperren des Gasmessers bei Wassermangel ausgelöst wurde, I4 Tote gegeben. Damals kamen die ersten Zweifel an der Zweckmäf̧igkeit solcher Absperrventile. Die Befürworter der trockenen Messer gewannen an Boden. Es stellte sich heraus, dał man in Deutschland für groß̧e Anlagen längst Ringleitungen mit zwei Speisepunkten verwendete $\left.{ }^{4.916}\right)$.

Der alte Gedanke einer Flammensicherung wurde auch gelegentlich wieder aufgegriffen. R. Muencke konstruierte solche für Laboratoriumseinrichtungen mit Hilfsflamme. Fin Doppelmetallstreifen, spiralig aufgewunden, betätigte eine

4.013) $14(1898), 697$

4.914) $33(1890), 16$

$4.915) 43(1900), 345$

4.170) is (1872), 606 


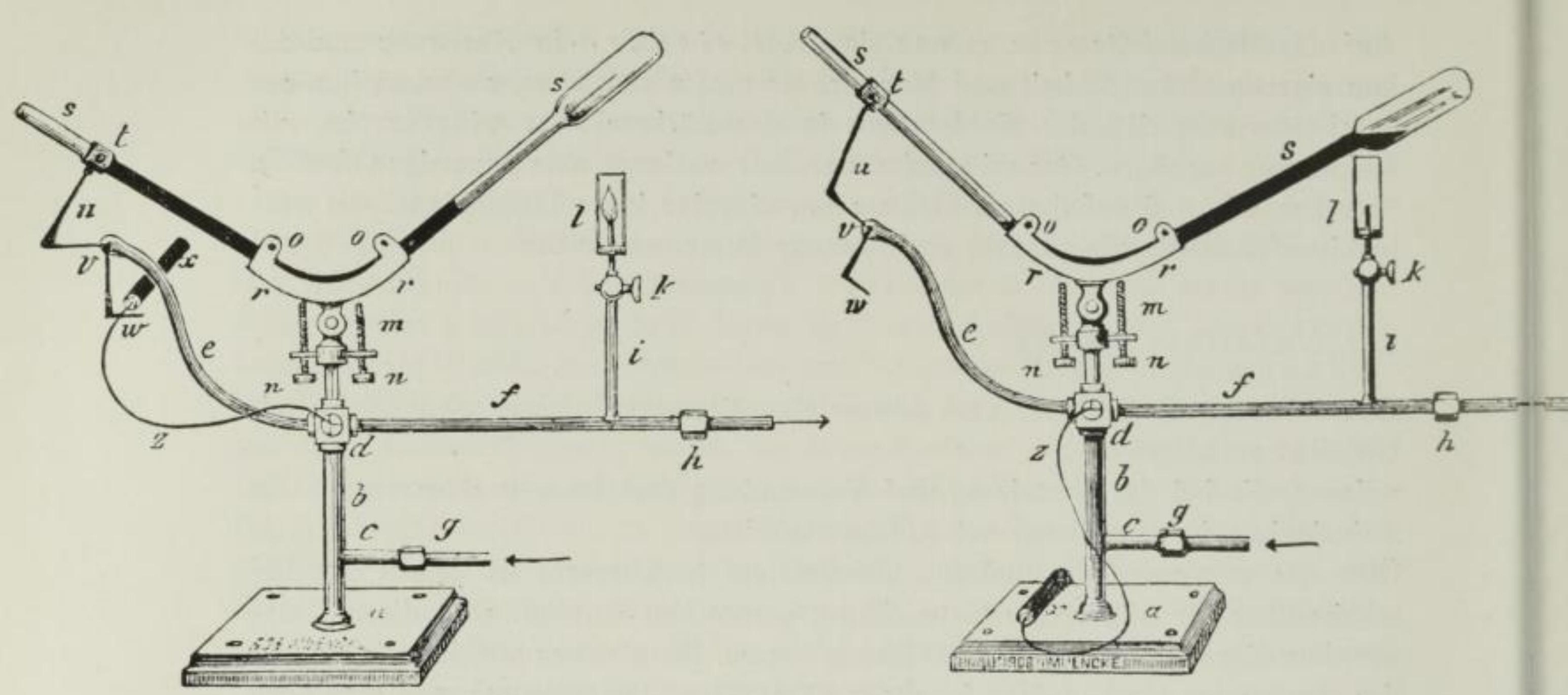

Bild 97 Flammensicherung von Muencke (J.f. G. 27 [1884] S. 744)

Quecksilberwippe mit Fallgewicht ${ }^{4.017}$ ). (Bild 97). C leggs Bauart von 1817 war entschieden unseren heutigen Ansichten nähergekommen. Der Sicherheitsreglet von F. $L u x$, arbeitete mit einer grof̧en Membran, die ein Ventil zum Schliefyen brachte, wenn die Verbrauchsstelle geschlossen wurde. Sie konnte dann nur wieder mit einem Stößzel von Hand geöffnet werden. Der Nebenstrom um die Membran konnte der Menge nach eingeregelt werden ${ }^{4.015}$ ).

Viel Aufmerksamkeit wurde den Meldungen über Gasvergiftungsfälle gewidmet. H. F. Ziegler, berichtete über die wahrscheinlich erste Anwendung der Sauerstoffeinatmung in Hanau. Der hinzugezogene praktische Arzt, Dr. Noll, lieł damals schon Sauerstoff einatmen, der von Heräus herbeigeschafft war ${ }^{\text {t.1010 }}$ ). Man glaubte, daf̧ die Kohlenwasserstoffe vergiftend gewirkt hätten, denn „nach der ersten Sauerstoffgabe hätte die ausgeatmete Luft nach Gas gerochen". Erst I2 Jahre später teilte M. Pet te nkofer mit, ein Dr. M. Gruber habe nachgewiesen, dał Kohlenmonoxyd die Vergiftung hervorrufe. Er sagte: „Es wäre von grołem hygienischem Werte, wenn es gelänge, im Großen anwendbare Mittel zu finden, um das Kohlenmonoxyd aus dem Leuchtgase zu entfernen, ähnlich wie man Mittel gefunden habe, Schwefelwasserstoff durch Eisenoxydul und Kohlendioxyd durch Kalkhydrat zu entfernen ${ }^{4.020}$ ). Pettenkofer hatte auch bereits die toxischen Grenzen der Kohlenmonoxydkonzentration festgestellt. Er unterschied zwischen lang dauernden Belästigungen bei geringer Konzentration und schnellen Schäden bei hoher. H. B un te stellte im folgenden Jahre fest, daf́, diese Entfernung des Kohlenmonoxydes mit chemischen Mitteln unmöglich sei. Seine Entstehung bei der Entgasung der Kohlen könne auch nicht verhindert

\footnotetext{
4. 117$) ~ 27(1884), 744$

4.016) 29 (1886), 355

4.P19) is (1872), 449/455

4. 020$) \quad 27(1884), 222$
}

318 
werden. Eine Waschung mit Palladiumchlorür würde dem Gase auch die Leuchtkraft nehmen $\left.{ }^{4021}\right)$. Sein Vorschlag, zur Untersuchung von Gasrohrleitungen Löcher in die Erde zu schlagen und Palladiumchlorürpapier einzulegen, wurde in Verbindung mit einer größeren Arbeit über die Art der Geruchsträger des Gases und ihre Ausfilterung im Erdboden gemacht $\left.{ }^{4,02}\right)$.

Der erste Gasprüfer nach dem Diffusionsprinzip mit elektrischer Alarmvorrichtung wurde von A. F a a s, Frankfurt/Main 1867 entwickelt $^{4.023}$ ). $188 \mathrm{t}$ wurden deren drei verschiedene Bauarten benannt $\left.{ }^{4.02 t}\right)$.

Eine Beschäftigung mit den Unfällen im Gaswerksbetrieb löste das Haftpflichtversicherungsgesetz von $187 \mathrm{r}$ aus. $S a c k u r$ schlug vor, wegen des Gesetzes eine gemeinsame Versicherung abzuschlief(3en $\left.{ }^{4.62}\right)$ und dazu einen gesonderten Verband zu gründen. Ihm schwebte also die „Berufsgenossenschaft" bereits damals vor. Er stief aber auf Widerstand: Die Haftpflichtversicherung, die die Leipziger Bank eingerichtet habe, schütze gegen alle Folgen des Haftpflichtgesetzes und stelle eine preiswerte Unfallversicherung dar, die allen offenstehe $\left.{ }^{\text {dinas }}\right)$.

Aber das Konzessionswesen führte im neu gegründeten Reiche zu ernstlichen Behinderungen beim Ausbau der Werke. Bei jedem Bauantrag gab es Einsprüche. Die Behörde zog dann Gutachten von Sachverständigen heran, die zum Teil unheilvoll einseitig, zum Teil zu vielseitig und oberflächlich verfuhren. Im Zweifel sei dann das Verbot die beste Rückendeckung der Behörde. So konnte Lübeck am Bau eines neuen Gaswerkes gehindert werden, an anderen Stellen wurde eine Ammoniakaufarbeitung unmöglich gemacht, was anderswo selbstverständlich war. Die Vorschläge, wie das gebessert werden könnte, sind nicht gerade klar $\left.{ }^{4.027}\right)$. Hier griff der preuf̧ische Handelsminister mit Richtlinien ein, indem er erklärte, daf̧ nur erhebliche, also über einen normalen Fabrikbetrieb hinausgehende $\mathrm{Be}$ lästigungen einen Grund zur Ablehnung geben könnten. Als solche wurden genannt: Rauchbelästigung durch die Retortenheizung, was bei der allgemein üblichen Koksfeuerung einige Verwunderung auslöste. Das Ausbrennen von Steigerohren sollte verboten werden, ohne daß eine andere Möglichkeit angedeutet war. Gebilligt wurde vom Fach sofort: Ein Verbot, Gaswasser in die Kanäle abzulassen und die Vorschrift, um die Gasbehälter eine freie Zone für Feuerwehrwagen zu schaffen ${ }^{4.025}$ ).

Der preufjische Innenminister ging mit der Polizei gegen Aufgrabungen der Straß̧en vor. Die Arbeiten sollten zusammengelegt mit Pausen von $1 / 2$ Jahr und nur nachts erledigt werden ${ }^{\text {tenge }}$. Die Gaswerke hatten einen schweren Kampf, auf die zwingenden Arbeiten bei Rohrbrüchen hinzuweisen. Das waren nur einige der Jugendsünden der im neuen Reich sich zurechtsetzenden Verwaltung, die dem Gasfach sehr viele Sorgen machten.

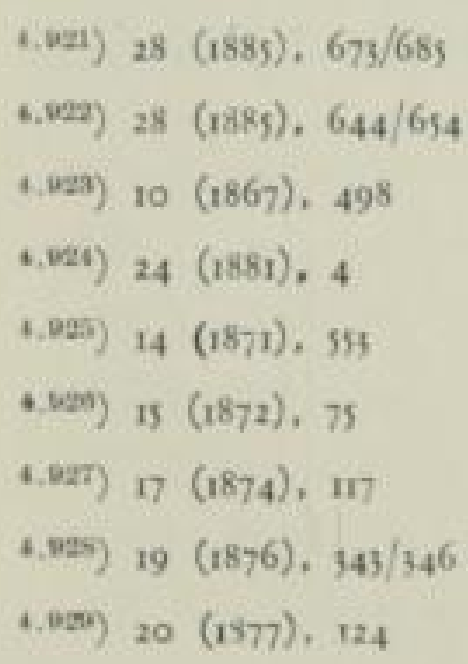


Darin lag wohl der Grund, warum später die befohlene Einrichtung einer Berufsgenossenschaft sehr sachliche Mitarbeit fand. Schon vor Erlał des Gesetzes am 6. 7. 1884 legte der Verein 1883 eine umfassende Unfallstatistik als Unterlage vor $\left.^{4.050}\right)$. Dic Gründungsversammlung fand am 9. 3. 1885 in Berlin statt $\left.{ }^{4.031}\right)$. Die ersten Unfallverhütungsvorschriften waren nach 5 -jähriger Arbeit im Entwurf fertig $\left.{ }^{4.939}\right)$. Nicht gleichgültig konnte es dem Gasfach sein, dafy das Reichsversicherungsamt jedes Installationsgeschäft, das Gas- und Wasserinstallationen ausführte, für einen Industriebetrieb erklärte, ihm die Eigenschaft als Handwerker absprach und der Berufsgenossenschaft verpflichten wollte $\left.{ }^{4.939}\right)$.

4.62 Arbeitsscutzgesetze und soziale Mafnabmen

Neue Schwierigkeiten gab es für die Betriebe, als sich die Behörden der Regelung der Arbeitszeit annahmen. Uberraschende scharfe Eingriffe, die die Betriebsbedingungen nicht erkannten, tat ein Industrieinspektor in Baden ${ }^{1.53}$ ). Das Arbeiterschutzgesetz regelte am I. 6. I891 die Arbeitsordnung. Wegen der Sonntagsruhe muf̧te schon der Entwurf des Gesetzes kritisch beleuchtet werden ${ }^{4.05}$ ). Dieserhalb folgte von 1892 bis 1895 jedes Jahr eine Eingabe.

Dabei waren die Gaswerke mit gutem Recht stolz darauf, mit Sozialma/znahmen an erster Sielle gelegen zu haben. Es würde aber zu weit führen, die Entwicklung der ersten Kranken-, Unfall-, Sterbe- und Invalidenkassen, der Beihilfen zur Ausbildung und Zusatzsparprämien im einzelnen darzustellen, zumal auch manche der Werke mit Mitteilungen darüber etwas zurückhaltend gewesen sind.

\subsection{Nacbwucbsförderung}

Von W. v. Oecbelbaeuser ging auch die Sorge um den Nachwuchs aus. Es mag vielleicht zunächst überraschen, dał diese Aufgabe verhältnismäfig spät (I896) erkannt wurde $\left.{ }^{4.906}\right)$. Die Geschichte belehrt uns aber, wie zu Anfang verhältnismäßjig wenige wissenschaftlich gebildete Mitarbeiter tätig waren. Die technische Ausführung und die Betriebsleitung lag in den Händen von angelernten oder selbstgebildeten Kräften. Das war auch um 1860 noch nicht grundsätzlich anders. Die technischen Ansprüche waren noch leicht zu erfüllen. Aber der Wandel zu langsam höher werdenden Anforderungen setzte nunmehr ein. Um dieser Entwicklung gerecht zu werden, gründeten die ,alten“ Fachleute ihren Verein. Noch genügte die universelle Ausbildung als Chemiker oder Ingenieur. Die Vertiefung in die Fachaufgaben verblieb den beruflichen Erfahrungen.

Die Forderung nach einer chemischen Betriebskontrolle stellte ein Leitartikel

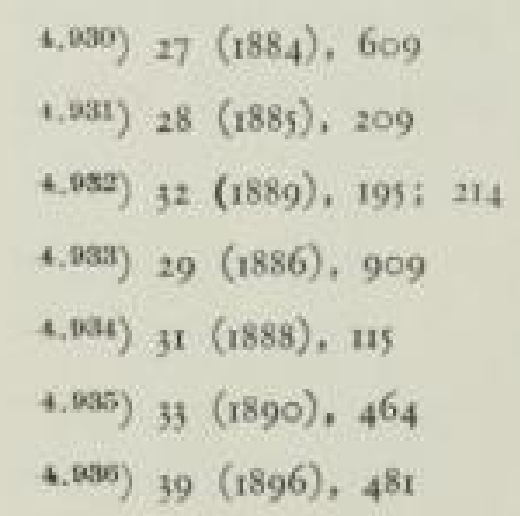


des Journals zum ersten Male $1884^{4.937}$ ) unter Hinweis auf die verbesserten Analysenverfahren. H. B unte wiederholte sie $\left.1888^{4.035}\right)$. Die erste Zusammenkunft der Gaswerkschemiker, die S. Scbiele bereits 1887 zur Vereinheitlichung der chemischen Methoden angeregt hatte $\left.{ }^{(4.250}\right)$, fand unter Buntes Leitung im Jahre darauf in Karlsruhe statt. (Schwerpunkt der Verhandlung war die Cyanbestimmung in Reinigungsmassen) $\left.{ }^{4.180}\right)$. Im Verein der Gasfachmänner Rheinlands und Westfalens erwog man 1890 , ob man für mehrere Werke einen Chemiker gemeinsam anstellen solle. Die Anregung an O. Knublaucb, Köln, diesen Posten im Nebenamte zu übernehmen, muf̧te dieser ablehnen $\left.{ }^{4.94}\right)$. Im folgenden Jahre gründete er aber ein eigenes Laboratorium und übernahm Verträge zur Betriebsprüfung kleiner Werke.

\section{LE B E N S B I L D}

Oskar Knublaucb wurde am 2. Mai 1849 in Korbach (Waldeck) geboren. Nach dem Besuch eines humanistischen Gymnasiums bezog er 1866 die technische Fachschule zu Braunschweig, um Chemie zu studieren. Durch Prof. Kn a $p p$ wurde er für das Gasfach gewonnen, studierte aber noch weiter in Göttingen bei Wöhler und Weber und promovierte $1870 / 71$ in Tübingen. Als Kriegsfreiwilliger unterbrach er seine Arbeiten. Von 1877 bis 1891 wirkte er als Assistent in Braunschweig. An das Gaswerk Köln gezogen, richtete er das neue Laboratorium dort ein. Seine Forschungen mit dem Ziele einer immer mehr verbesserten Betriebsaufsicht widmeten sich vor allem den chemischen Verfahren zur genauen Bestimmung des Benzols und Toluois, des Schwefels und Ammoniaks im Gas und im Teer. Seine Ergebnisse hat er freimütig veröffentlicht und zur Erörterung gestellt. I891 errichtete er sein eigenes Laboratorium, wobei er durch Verträge gebunden viele kleine Gaswerke betreut hat. Seine Vorträge im Rheinisch-Westfälischen Verein der Gas-Wasser- und Elektrizitätsfachleute und seine zahlreichen Veröffentlichungen sind voller Anregungen. Sein Verfahren zur Bestimmung des Schwefels in ausgebrauchten Gasreinigungsmassen wird heute noch als Konventionsmethode für die Festsetzung der Verkaufspreise angewandt.

Knublauch starb 1917 und wurde am 30. 10. 1917 unter groß̧er Beteiligung seiner Fachgenossen beigesetzt ${ }^{\text {t.titz }}$ ).

Die weitere Entwicklung, unter verschärften Wettbewerbsbedingungen immer vollkommener zu arbeiten und leichter und schneller richtig zum Ziele zu kommen, verlangte bereits in der Vorbildung eine Vertiefung des Wissens in den dem Fach besonders wichtigen Grundlagen. H. Bunte hat die ersten Studienpläne für Beleuchtungsingenieure in Karlsruhe aufgezeichnet $\left.{ }^{4.04}\right)$. Die breite allgemeine technische Ausbildung, die Vielzahl der Fächer, die damals noch in wenigen

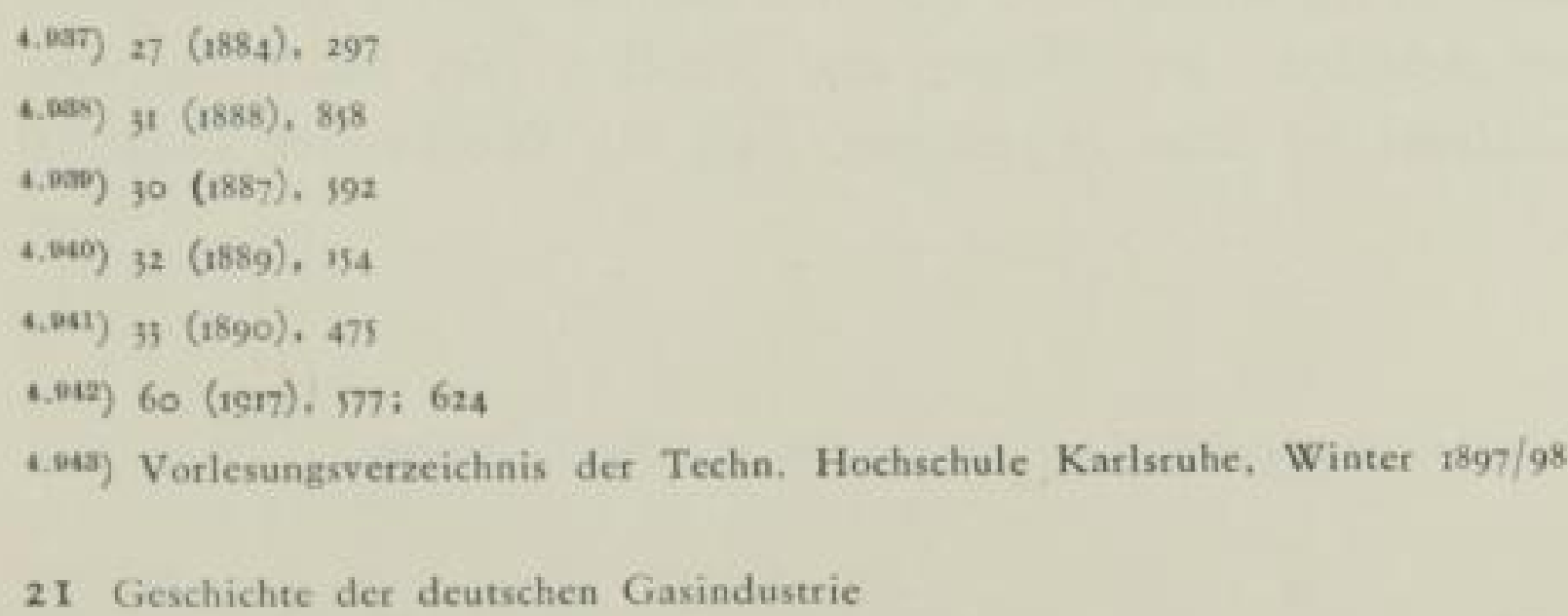


Jahren geboten werden konnte, ist heute, wo man um die Erhaltung der Allgemeinbildung äuß̧erst besorgt sein und kämpfen muf, ein Beweis für die richtige Grundauffassung. Als Beleuchtungsingenieure konnten Studenten der Chemie, des Maschinenbaus und der Elektrotechnik besonders ausgebildet werden, nebeneinander und miteinander.

W. v. Oechelbaeuser bezeichnete mehrfach die Ausbildung als mustergültig nach den Erfahrungen, die er in seinen Werken mit den jungen Ingenieuren gesammelt hatte. Er verlangte nur, daf auch an anderen Hochschulen gleiche Ausbildungsmöglichkeiten eingerichtet werden sollten.

Für die Werkmeister sorgte er zunächst selbst durch die Einrichtung der Gasmeisterschule in Dessau, in der im Gaswerk erfahrene Handwerker: Maurer, Schlosser und Schmiedegesellen, aber auch ,angelernte", die sich besonders bewährt hatten, aufgenommen wurden $\left.{ }^{4.94}\right)$.

Die ersten Fortbildungslehrgänge (Gaskurse) für Ingenieure, die in den Beruf des Gasfachmannes aus anderen technischen Berufen durch das Schicksal hineingewachsen waren, wurden 1898 durch H. B unte in Karlsruhe abgehalten ${ }^{4.45}$ ).

\subsection{Vereinsgründungen}

In diesem Rahmen mag mancher Leser eine ausführliche Geschichte vom Wirken des Deutschen Vereins von Gas- und Wasserfachmännern erwarten. Es muf aber davon abgesehen werden. Uber den vorliegenden Abschnitt hat der Verein zur Feier des 50-jährigen Bestehens berichtet, und eine ähnliche Arbeit ist zum Ioo-jährigen Bestehen erschienen. Vor allem war es aber bereits notwendig, die Arbeiten des Vereins unter den einzelnen Abschnitten nach sachlichen Erfordernissen aufzuführen, so daß̧ mit einer geschlossenen Darstellung Wiederholungen eintreten würden.

Die Entwicklung des Aufbaues der zentralen Gasfachsorganisation ist aber als kennzeichnend für die damalige Einstellung der Deutschen zur Umwelt von besonderer Bedeutung. Manche unserer besten Geschichtsschreiber sehen in der Aufnahme des Nationalismus, den die französische Revolution von 1789 geschaffen hatte, in das deutsche Denken eine der Hauptsünden des 19. Jahrhunderts. Der Verein der Gasfachmänner Deutschlands beschränkte aber gleich von Anfang an seine Mitgliedschaft nicht auf Deutsche. Daf3 Staatsangehörige der Österreich-Ungarischen Monarchie als Mitglieder selbstverständlich waren, ist in der Zeit vor dem Bismarckschen Reiche kein Wunder. Aber auch die Schweizer und Baltendeutschen traten damals ein ${ }^{4}$ ") ).

Wie stark aber selbst nach $187 \mathrm{I}$ bei den deutsch sprechenden Ingenieuren das Gefühl der Gemeinschaft war, zeigen am besten die Hauptversammlungen, die ohne Bedenken, meist aus Anlał besonderer technischer Ereignisse in ausländischen Städten abgehalten wurden: I871 Wien, 1873 Teplitz, 1885 Salzburg, I901 Wien, 1903 Zürich. Auffallend ist dem gegenüber, daf die Werke der Imperial

4.944) $40(1897), 404$

6.045) 41 (1898), 431

4.140) Eine Liste der Grūndungstage der einzelnen Bezirksvereine ist im Anhang 9 enthalten.

322 
Continental Gas Association dem Verein zunächst nicht beigetreten waren. Lange Zeit (seit 1868 ?) war von den Direktoren der Werke dieser Gesellschaft L. Körting das einzige persönliche Mitglied (im Vorstand zum ersten Mal I883/84 erwähnt). Damals aber trat die Gesellschaft mit s Einzelwerken, darunter Wien, bei. Die englischen Herren nahmen an den Verhandlungen des Vereins teil. Die Gesellschaft war danach lange Jahre unter den Spendern für wissenschaftliche Arbeiten vertreten.

Einige Daten aus dem Auslande mögen zur Ergänzung dienen: 186r The Waverley Association of Gas Managers. 1862 General Association of Gas Managers for Scotland. r863 British Association of Gas Managers; sie hat den Namen mehrfach geändert, heute Institution of Gas Engineers. I870 Société française de l'Industrie du Gaz. 1873 American Gas Association. 1877 Association des GaziersBelges.

Der erste Internationale Kongref̧ der Gasindustrie fand 1900 aus Anlaf̧ der Pariser Weltausstellung statt.

\section{SLUB}




\section{IM ZWANZIGSTEN JAHRHUNDERT BIS ZUM ERSTEN WELTKRIEG, I 90 I - I 9 I 4}

\subsection{ALLGEMEINE GESCHICH T E}

Mag man in der politischen Geschichte und auch in der Geschichte der Geisteswissenschaften eine ganz andere Meinung vertreten; dem Forscher auf dem Gebiete der Technik und der mit ihr verbundenen Wirtschaft drängt sich der Eindruck auf, dał die hier zu betrachtende Zeit menschlich ein Höhepunkt gewesen ist, wie er nachher, insbesondere aber als bedauernswerte Kriegsfolge noch vicht wieder erreicht worden ist.

Das bezieht sich nicht so sehr auf den Stand des technischen Wissens und Könnens, wo ja ein Stein auf dem andern liegt, als vielmehr auf die Geschwindigkeit, mit der immer höhere Stufen von Vollkommenheit erreicht werden und neue Arbeitsgebiete zum Bisheringen hinzukommen. Der Eindruck entsteht aber noch mehr, wenn man sieht, mit welchem Freimut ohne politische Behinderungen zwar im scharfen Wettbewerb, aber doch im lebhaftesten und freundschaftlichen Gedankenaustausch neben den persönlichen und nationalen ganz selbstverständlich auch die gemeinsamen alle Welt fördernden Ziele verfolgt wurden. Im Abendlande herrschte aufrichtiges Wohlwollen.

Auch das Gasfach hat diesen Zeitgeist gespürt. Die ersten grof̧en internationalen Normen wurden vereinbart, nachdem dazu die notwendigen Vereinigungen geschaffen waren. Gegenseitige Besuche der Fachgenossen, vor allem bei Gelegenheit grofer Tagungen und Ausstellungen begannen und wurden mit Freuden und liebenswürdig erwidert. Die Gasfachleute zog es natürlicherweise vor allem nach England, wo die Gastechnik sich zuerst und am umfassendisten entwickelt hatte. Die Reise einer englischen Delegation nach Deutschland war erfolgreich verlaufen. Ein Gegenbesuch in England und Schottland vom 3. bis 8. 10. 1910 ${ }^{5.1}$ ) brachte viele gegenseitige herzliche, ja fast überschwengliche Freundschaftsbeteuerungen hervor. Politisch schon verstimmenden Erörterungen über die deutsche Flotte wurde mit der liebenswürdigen Hoffnung der Engländer begegnet, dał wohl die Weltmeere ausreichend Platz für alle Schiffe bieten würden. An der Feier des so-jährigen Jubiläums der „Institution of Gas Engineers" nahmen die Deutschen herzlich Anteil. Der Verein liełs sich durch H. Bunte und E. Kör ting vertreten. Selbst bei Ausbruch des Krieges sagte noch das Journal of Gaslighting: ,Es ist nicht unsere Aufgabe als einem industriellen und technischen Blatt, auf das Recht und Unrecht der vielen Einzelheiten dieses grołen Umsturzes und der Entwurzelung des Weltlebens einzugehen ....... ${ }^{\text {.r.2. }}$ ). Leider

5.1) $54(1911), 1$

5.2) Gas Journal Centenary S. Iyo 
aber blieb dieser Standpunkt während des Krieges nicht erhalten, tief bedauert vom deutschen „Journal für Gasbeleuchtung (), das damals die Erörterungen abbrechen mufte.

\section{s.II Lebensgescbicbten fübrender Männer}

Wollen wir wiederum, um die menschlichen Beziehungen zu beleuchten, eine Reihe von Lebensbildern geben, so ergeben sich nicht geringe Schwierigkeiten. Ohne Zweifel treten nunmehr eine grofe Anzahl ausgezeichnet ausgebildeter Fachleute in Technik, Wissenschaft und Wirtschaft im Gasfach hervor. Trotzdem eignet sich die Mehrzahl der Lebensläufe nicht dazu, um in einem Sonderabschnitt als kennzeichnende Schicksale beschrieben zu werden. Ausbildung und Hineinwachsen in den Beruf ging glatt und ohne auf̧ergewöhnliche Taten vor sich, in einer Zeit, wo nach langem Frieden, wenn auch mit Konjunkturschwankungen eine dauernde Entwicklung nach höheren Stufen vorlag. Nur ganz wenigen Männern kann man einen richtunggebenden Einflu\} auf das ganze Fach zusprechen. Ein solches Bild gewähren in Wissenschaft und Vereinsführung der Geheime Rat Prof. Dr. Hans Bunte und in der Wirtschaft Wilhelm v. Oecbelbaeuser, wenn auch beide schon vor der Jahrhundertwende sich diese Stellung erarbeitet haben. Es erscheint uns richtig, ihr Bild an dieser Stelle zu geben.

\section{III LE B E N S B I L D}

Hans Bunte (Bild 98) wurde am 25. Dezember 1848 als Sohn des Rechtsanwaltes Karl Bunte in Wunsiedel (Oberfranken) geboren. Er besuchte in Erlangen das Gymnasium und studierte dann in Stuttgart, zunächst unentschieden, ob er Maschinenbauer oder Chemiker werden solle, Febling gewann ihn für Chemie, nach wenigen Semestern ging er aber nach Heidelberg, wo Bunsen, Helmboltz und Kircbbof lehrten. Er promovierte in Erlangen und gab danach einige Monate Unterricht an der Gewerbeschule in seiner Heimatstadt. 1872 ging er als Assistent zu Erlen me yer nach München, habilitierte sich I874 für analytische Chemie und hielt - wahrscheinlich als Erster - eine Vorlesung über Teerfarben. Damals wurde er mit N. H. Scbilling bekannt, der als Vorsitzender den Polytechnischen Verein reorganisierte, wobei die Arbeit des Vereins nach Fachrichtungen aufgegliedert werden sollte, deren eine sich der Chemie widmete. Schilling gewann Bunte zunächst probeweise zur Mitarbeit an der zweiten Auflage des Handbuches und am Journal für Gasbeleuchtung. Er gab Bunte die Möglichkeit durch einen Büroraum im Gaswerk, sich in die technischen Fragen des Faches einzuarbeiten. Io Jahre haben Schilling und Bunte gemeinsam die Schriftleitung gehabt, dann setzte sie Bunte allein fort.

5.8) 99 (1916), 237

326 


\section{Bild 98}

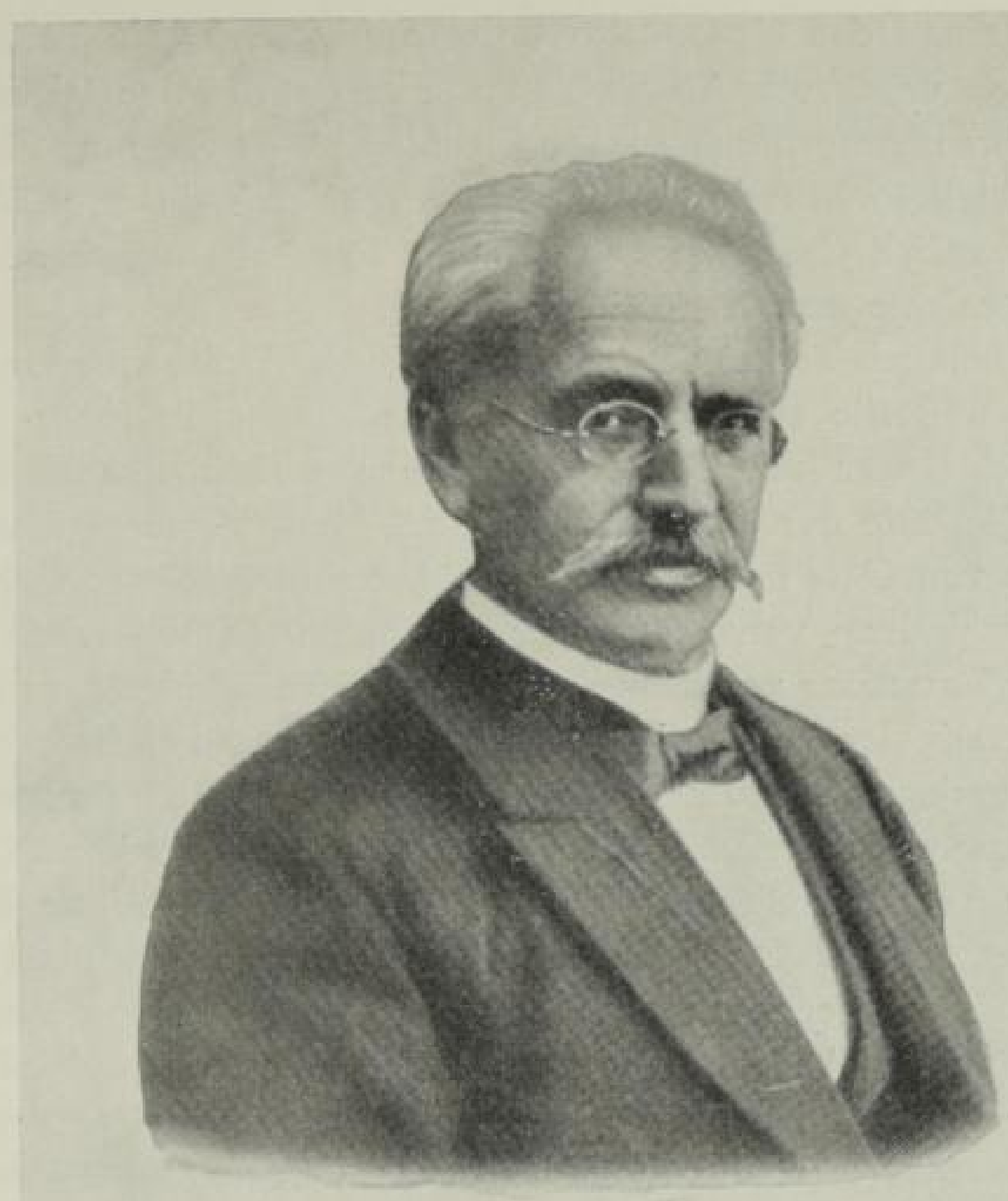

Hans Bunte

(so Jahre D.V.G.W.)

Die Arbeiten am Generator 1878 bis 1880 und in der Heizversuchsstation München zeigten, wie hervorragend Bunte befähigt war, die verwickelten Zusammenhänge der Feuerführung durch eine klare Darlegung der chemischen Grundlagen einfach begreiflich zu machen. Sein Schema der Verbrennungsrechnung in Tafelform ist noch heute für Ingenieure, die betriebliche Veränderungen verfolgen wollen, allen anderen Zusammenstellungen gegenüber als einfach und vollständig ausreichend vorzuziehen. Einzelheiten über seine Arbeiten können hier übergangen werden. Sie bilden einen Teil der Fachgeschichte und werden dort abgehandelt. Ergänzend mag aber erwähnt sein, dał die Arbeiten an der Versuchsstation der Ausgangspunkt waren für die „Normen für Leistungsversuche an Dampfkesseln“, ferner auch für die „Verbandsformel" über die Beziehung von chemischer Zusammensetzung und Heizwert von Kohlen. Ein Streit darüber mit dem hartnäckigen Ferd. Fiscber wurde nach einiger Zeit im Sinne Buntes durch die Berthelotsche Bombe entschieden.

Die Verwaltung der bayerischen Staatsbahnen wollte wie für die Kohlen auch für andere Rohstoffe insbesondere Schmieröle Lieferungsbedingungen haben, die Bunte bearbeitete. Das brachte ihn in Verbindung mit C. Engler in Karlsruhe, woraus dann 1887 seine Berufung nach Karlsruhe als o. Professor für Chemische Technologie entstand. Bunte bewältigte neben der Aufgabe, nunmehr die Vorlesungen mancher Gebiete der Chemischen Technik, die er noch nicht persönlich durchforscht hatte, zu bearbeiten, auch noch die Schriftleitung des

\section{SLUB}


Journals und das Generalsekretariat des Vereins erfolgreich. Das beweist nicht nur seine ungeheure Arbeitskraft sondern auch seine leichte Einfühlung in die besonderen Anforderungen der technischen Betriebe und nicht zum wenigsten die Fähigkeit, Mitarbeiter so einzusetzen, daf̧ sie selbständig aber doch ihm verantwortlich Grofes leisten konnten. Die Namen dieser Männer treten in der Fachgeschichte auf.

Dem Chemisch-Technischen Institut gliederte Bunte eine feuerungstechnische Abteilung und die staatliche Chemisch-technische Prüfungs- und Versuchsanstalt an. Nach langer gründlicher Vorbereitung auch in finanzieller Beziehung konnte er im Gelände des Gaswerkes die Lehr- und Versuchsgasanstalt des Deutschen Vereins von Gas- und Wasserfachmännern, das spätere Gasinstitut, gründen.

Die Verbindung von wissenschaftlich geführten Versuchen im Betriebsmałstab mit der Forschung und Lehre war an der Hochschule etwas ganz Neues, von ihm erprobt mit der Heizstation in München. Sie vollendete den Lehrplan für Beleuchtungsingenieure, der entwickelt war, um den Spezialisten im Gasgebiet eine allumfassende allgemeine technische Bildung zu vermitteln ${ }^{5.4}$ ).

Um die Anerkennung seiner Forschungsergebnisse, bei ihrer Erklärung durch neue Theorien und der Ubertragung in die Technik hat es natürlicherweise manchen harten Kampf gegeben. Bunte wufte sich zur Wehr zu setzen, ist aber niemals in persönliche Angriffe abgeglitten. Aber er war auch nicht halsstarrig. Die auffallende Erscheinung der ungewöhnlichen Strahlung des Auerglühstrumpfes wurde auf verschiedene Weise zu erklären versucht. Bunte glaubte lange Zeit nach verschiedenen Versuchen, daf in der Zone des Strumpfes eine beschleunigte Verbrennungsumsetzung stattfände. Er nahm auch eine Kontaktwirkung an. Schlieflich aber folgte er den Ansichten von Le Chatelier, Nernst und Bo se, daf es sich um eine selektive Strahlung handele, nachdem P. Eitner bei ihm überzeugende Versuche angestellt hatte ${ }^{5.5}$ ).

Die Ehrungen, die Hans Bunte vom Staate, von den Fachvereinen und Hochschulen erfuhr, sind zahlreich. $\left.{ }^{5.6}\right)$. Am 20. August 1925 wurde Hans Bunte feierlich dem Frieden der Erde auf dem Karlsruher Friedhof übergeben.

Unter all den Vielen, die die wissenschaftlichen Erkenntnisse in der Industrie verwerteten, ragt - man darf das wohl sagen, ohne die Verdienste der vielen Anderen zu schmälern - Wilhelm v. Oecbelbaeuser hervor. Um die Verbindung herzustellen, mag der Satz Oechelhaeusers, den dieser 1905 in seinen Betrachtungen über die fünfzigjährige Entwicklung der Deutschen ContinentalGas-Gesellschaft roos faß̧te, hier eingefügt $\operatorname{sein}^{5.77}$ ).

„Wir verdanken in erster Linie dem um die Gasindustrie überhaupt hochverdienten Professor an der Technischen Hochschule in Karlsruhe, Herrn Geheimen Hofrat Dr. Bunte, daf̧ wir die für die schnelle und eigenartige Entwicklung

\footnotetext{
5.4) Näheres darüber in J. Körting: Geschichte des Gasinstitutes, Selbstverlag. Karlsruhe S, $25 / 26$

5.5) $47(1904), 1012$. Durch neue einfache, aber überzeugende Versuche ist es Kurt Peters, Wien gelungen, nachzuweisen, dass neben der selektiven Strahlung auch eine katalytische Wirkung der Auermassen auftritt. (Vortrag in der Techn. Hochschule Karlsruhe am 13. Mai 1959) Bunte hat also doch, nicht ganz Unrecht gehabt.

5.6) Eine umfassende Darstellung enthält der Nachruf des D. V. G. W; J. f. G. 68 (1925), 603/606 und danach gestaltet: Festschrift zur 125 Jahrfeier der Technischen Hochschule Karlsruhe, 1950 S. $29 / 54$

5.7) W. v. Oechelhaeuser: Aus deutscher Technik und Kultur, 2. Aufl. München 1921, Verlag Oldenbourg S. 167.
} 
nötigen wissenschaftlich geschulten Kräfte in drei Assistenten von ihm übernehmen und auferdem eine Anzahl begabter Abiturienten aus Dessau nach dem von ihm an jener Hochschule eingeführten Studienplan für Beleuchtungstechniker auf unsere Kosten ausbilden lassen konnten."

\subsection{2

Wilhelm v. Oecbelbaeuser (Bild 99) ist ein vom Schicksal begünstigter Mensch gewesen insofern, als seine Lebensarbeit in die Zeit des stetigen Aufstieges der Europäischen Wirtschaft. in die lange Friedenszeit von $187 \mathrm{I}$ bis 1914 fiel. Als der Krieg mit der Niederlage endete, war er aus der Verantwortung entlassen, weltanschaulich so weit ausgereift, dał er mit der Weisheit des Alters die Grundlagen für einen Wiederaufbau lehren konnte.

Er wurde geboren am 4. Januar 1850 als Sohn des erfolgreichen Generaldirektors W. Oecbelbäuser der Deutschen Continental-Gas-Gesellschaft zu Dessau $\left.^{\mathrm{s} .5}\right)$. Sein Vater, in den Fragen des menschlichen Zusammenlebens ein Meister, lief $\mathrm{ihm}$ eine vorzügliche Erziehung angedeihen. Nach dem Studium an der Gewerbeakademie und der Technischen Hochschule zu Berlin trat der Sohn 1875 in die Familienfirma Ph. O. Oechelhäuser, Berlin, ein, die den Bau von Gaswerken betrieb, wurde aber bald darauf von seinem Vater zur Deutschen Continental-Gas-Gesellschaft geholt und von ihm persönlich geschult. Daınals I886 wurde ihm seine größzte technische Aufgabe gestellt: Die Entwicklung der Grofggasmaschine. Er hat die Richtung der Versuchsarbeit selbst entworfen und auch eigenhändig die ersten Versuche ausgeführt ${ }^{5.9}$ ). I 890 wurde er beim Rücktritt des Vaters als Generaldirektor an die Spitze der Gas-Gesellschaft berufen. Damit bekam er die schwere Aufgabe, das grołe Werk des Vaters zu neuen Höhen zu führen. Er ist dem voll gerecht geworden, denn sein Blick weitete sich über die technischen Einzelfragen hinaus, die keineswegs vernachlässigt wurden, auf die großjen gemeinsamen Aufgaben der Gasindustrie. 1891/92 schon baute die Gasgesellschaft 8000 Gasglühlampen ein und war damit Schrittmacher. 1893 besuchte Oechelhaeuser gemeinsam mit $\mathrm{H}$. Bunte die Weltausstellung in Chicago. Nach der Reise gab er auf die Frage der Wassergasverwendung in Deutschland nach amerikanischem Vorbilde eine klare Antwort, die bis heute ihre Richtigkeit erwiesen hat. Der Ausbildung des Nachwuchses widmete er viele seiner Sorgen. 1897 wurde die Gasmeisterschule in Dessau als erste derartige Lehranstalt eröffnet. Die Gründung der Lehr- und Versuchsgasanstalt 1904 1907 wurde von Oechelhaeuser in jeder möglichen Weise ideell und materiell gefördert, die der Zentrale für Gasverwertung r910 von ihm in die Wege geleitet. Den Vorsitz des deutschen Vereins von Gas- und Wasserfachmännern hatte er $1895 / 1896,1898$ und 1900 inne. Im Rahmen des Vereins Deutscher Ingenieure betrieb er die Gleichstellung der realen höheren Schulen mit den Gymnasien und

5.8) Die Erhebung in den exblichen Adelsstand hatte der Vater für sich abgelehnt, für seine Nachkommen aber angenommen. Woher die unterschiedliche Schreibweise des Namens v. Oechelhaeuser herstammte, ist nicht bekannt.

5.9) 59 (1916) S. 1; 27; 37; 57. W. v. Oechelhaeuser: Aus deutscher Technik und Kultur, 2. Aufl. München. 1921 R. Oldenbourg S. $20 \mathrm{rff}$. 


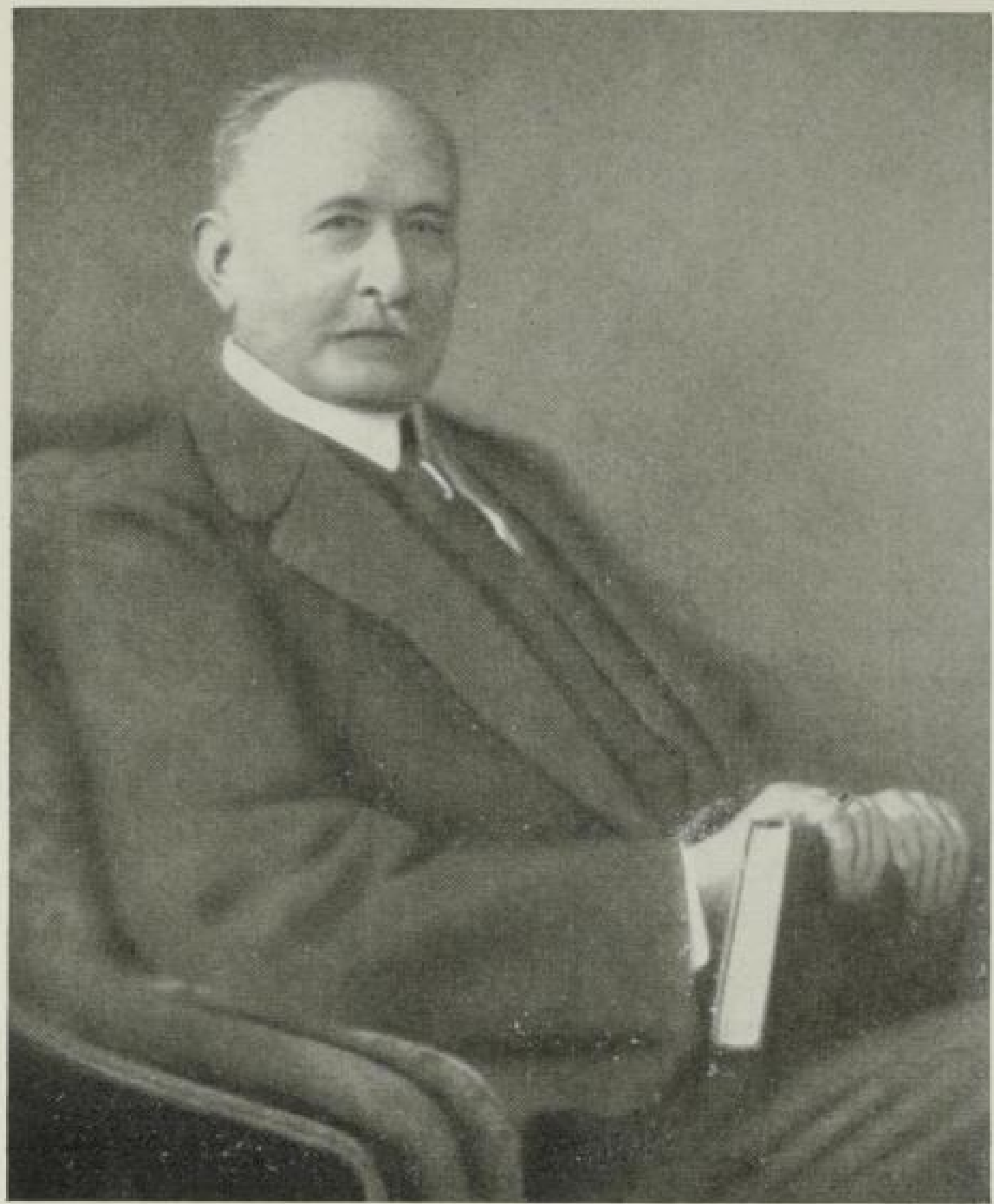

Bild 99

Wilhelm v.

Oechelhaeuser

(Aus deutscher Technik und Kultur)

der Technischen Hochschulen mit den Universitäten. Er war Vorsitzender des Vereins Deutscher Ingenieure in den Jahren 1902 und 1903 . Seinen Úberzeugungen gemäß̧ befruchtete er auch in diesem Verein die wirtschaftliche Ergänzungsarbeit der Ingenieure. Die später als Beilage zur Zeitschrift des Vereins Deutscher Ingenieure erschienerie Zeitschrift: „Technik und Wirtschaft" geht auf seine Anregung zurück. Seinen kulturellen Interessen folgte er als Präsident der Deutschen Shakespeare-Gesellschaft, in der Goethe-Gesellschaft und im Vorstandsrat des Deutschen Museums, bei dessen Eröffnung er 1903 die Wünsche des Vereins Deutscher Ingenieure überbrachte. Der Politik verpflichtete er sich als Reichstagsabgeordneter und im deutschen Kolonialverein.

Die Ehrungen, die Oechelhaeuser empfangen durfte, waren zahlreich. 1909 wurde er in der Jubiläumsversammlung des Deutschen Vereins zum Ehrenmitglied ernannt, I9I4 ihm die „Bunsen Pettenkofer Ehrentafel“ als höchste Vereinsehrung überreicht.

1912 trat W. v. Oechelhaeuser von der Leitung der Deutschen Continental-GasGesellschaft zurück und übernahm den Vorsitz im Aufsichtsrat. Er verstarb am 31. Mai 1923.

\section{SLUB}

Wir führen Wissen. 
Die abendländische Wirtschaft ging in das 20ste Jahrhundert im Zeichen einer bis dahin nicht erreichten lebhaften Geschäftstätigkeit. Auch das deutsche Gasfach war davon befruchtet. Die großen Gasgesellschaften berichteten von einer ansehnlichen Steigerung des Gasabsatzes ${ }^{5,10}$ ), ${ }^{5,11}$ ), ja die A. G. für Gas und Elektrizität in Köln sprach von dem bisher besten Geschäftsjahre ${ }^{5.12}$ ). Krisenzeichen waren allerdings bereits sichtbar, vor allem Kohlenmangel und -teuerung, da die Zechen der überstürzten Entwicklung der Industrie nicht zu folgen vermochten. Die Gaswerke waren dadurch natürlich besonders bedroht, wenn auch noch zunächst die höheren Kohlenpreise durch den Erlös für Koks ausgeglichen werden konnten $^{\text {5.12 }}$ ). Ein in Wirtschaftsfragen hochangesehener, dem Eisenhüttenwesen nahestehender Reichstagsabgeordneter Dr. Beumer, beruhigte die Öffentlichkeit, der Kohlenmangel sei wohl für mehrere Jahre hinzunehmen, es würden aber allmählich wieder gesunde Verhältnisse eintreten ${ }^{5.14}$ ). Im folgenden Jahre wurde dann auch festgestellt, daf der Zuwachs an Leuchtgas sich verlangsamt habe $\left.{ }^{3,15}\right)$. Die Thüringer Gesellschaft hatte ermittelt, dał dieser Rückgang auf Beleuchtung von Fabrikanlagen zurückzuführen war, für die in zunehmendem Maß̧e das elektrische Licht eingeführt wurde $\left.{ }^{\text {5.15 }}\right)$. Sehr schwer war die kleine Stadt Peine betroffen, als das Walzwerk die Gasbeleuchtung aufgab, und zudem Sauggasanlagen das Leuchtgas bei Motoren ablösten ${ }^{5.17}$ ). Im übrigen aber war der Gewinn im Koch- und Kraftgasabsatz lebhaft ${ }^{518}$ ). Die Thüringer Gasgesellschaft stellte als recht erfreuliche Beobachtung fest, daf der vermehrte Absatz von Kochgas an Haushalte die Abgabe vom Rhythmus der Wirtschaft unabhängiger werden lieł̧ insofern, als am Leuchtgas (für Fabriken), bei eingeschränkter Arbeit immer zucrst gespart wurde. Die Verhältniszahl von Winter-zu Sommerlast wurde dauernd günstiger: $1880 / 8 \mathrm{I}$ 4,I4; 1890/91 3.36; 1900/ 1901 2,34; 1910/19II 2,17. 1912 war der Jahreskonsum etwa das 237-fache der höchsten Tagesabgabe, früher rechnete man mit dem $200-\mathrm{fachen}^{5.19}$ ).

Das Bild der gesamten Wirtschaftslage ist etwas unklar. Der Koksabsatz sei, so sagte man, von der schlechten Geschäftslage behindert ${ }^{5.30}$ ). Insbesondere am Niederrhein verspürte man die Folgen eines Niederganges der Eisenindustrie ${ }^{5.21}$ ), während gleichzeitig Mitteldeutschland von einem lebhaften Koksabsatz als Folge eines kalten Winters berichtete $\left.\left.{ }^{5 . m}\right)^{5 . m}\right)$. Die Kokspreise waren gedrückt, Koks

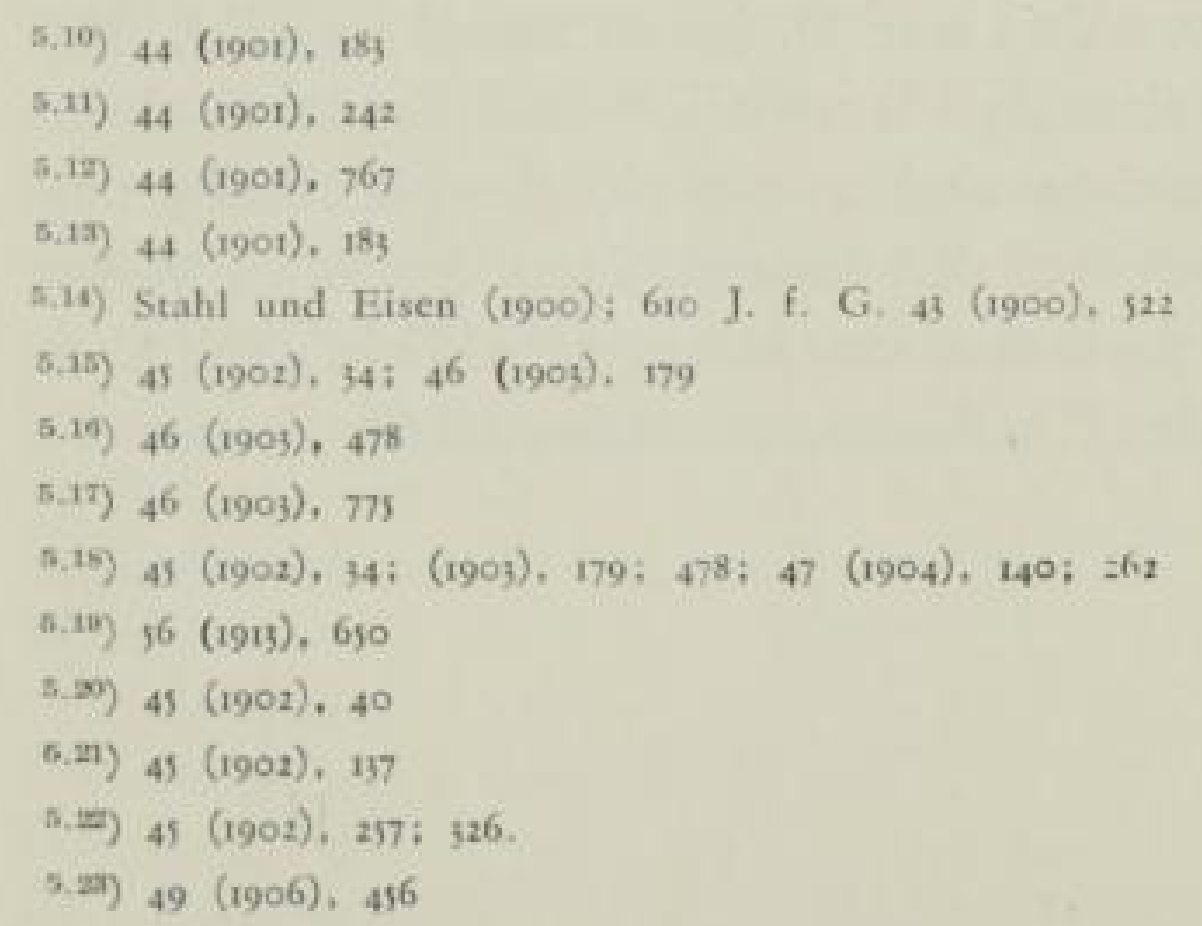


lag vielfach auf Halde (Preis $19 \circ 3$ 10 $\mathrm{M} / \mathrm{t}$ gegen früher $16,9 \circ \mathrm{M}$ ). Die Kohlenpreise aber wollten nicht nachgeben. In Gaswerkskreisen klagte man über Schwierigkeiten mit dem Kohlensyndikat. Dieses wurde durch englische Händler in Magdeburg unterboten. „Die Kohle blieb aber trotzdem so teuer, dał dort eine Wassergasanlage geschaffen werden konnte." Auch die Teerpreise waren nicht immer befriedigend. Der natürliche Markt wäre durch Einkaufsvereinigungen der Teerindustrie künstlich gestört, meinten die $\left(W_{e r k e}{ }^{5.24}\right)$. Zur gleichen Zeit gab es aber auch freundliche Beurteilungen des Marktes $\left.{ }^{5.25}\right)$. Entscheidend sei allerdings eine gute Abfuhrmöglichkeit mit gepflasterten Wegen zum Werke, Möglichkeit der Waggonabnahme durch Ansammelung in Zisternen, Entwässerung durch Schleudern. Dickteer für Briketts sei sehr gefragt. Die schon erwähnten Unterschiede in den Koksabsatzverhältnissen lassen allerdings vermuten, dał die Eisenbahnen mit ihren Beförderungsmöglichkeiten der um die Jahrhundertwende ausgeweiteten, industriellen Regsamkeit nicht schnell genug nachgekommen waren.

Die Erfahrungen mit dem Kohlensyndikat und den Teereinkaufsvereinigungen veranlaf3ten das Gasfach, auch seinerseits an einen festeren Zusammenschluf\} zu denken, um so den Markt günstiger ausnutzen zu können. Die schon seit I4 Jahren bestehende wirtschaftliche Vereinigung im Rheinlande sollte nunmehr ein festes Syndikat werden ${ }^{5.58}$ ). Im folgenden Jahre galt sie als neubefestigt, mit etwa 60 Werken, die die „weitaus größzere Hälfte“ des Gases erzeugten und entsprechend höhere Koksmengen nach auswärts verkauften ${ }^{5.25}$ ).

In diesen ganzen Jahren herrschte im Gaswerksbau ein besonderer Auftrieb. Mit dem Auerlicht wurden auch ganz kleine Ortschaften, die früher nicht hatten daran denken können, ein eigenes Werk zu bauen, vor die Frage gestellt, die Beleuchtung auf billige Weise zu verbessern, zumal auch das Verlangen nach Kochgas, dort wo man es nicht haben konnte, sehr deutlich wurde. E. Scbilling stellte schon 1903 fest, daf in 3 Jahren 237 kleine Orte mit im Mittel 3500 Einwohnern Kohlengaswerke erbaut hätten und kleinere Azetylenund Aerogen (Luftgas)- Anlagen aufführten. Die wirtschaftliche Grenze zwischen diesen Kleinanlagen und den Kohlengaswerken lag bei etwa 2500 Einwohnern. Die Gaswerke bauenden Firmen Karl Francke, Bremen und die Gasanstaltsbetriebsgesellschaft, die 1903 von den Firmen Bamag, Stettiner-Schamottefabrik, G. Kromscbröder, Deutscher Gasglühlichtgesellschaft und Cäsar $W$ oll beim zum Bau und Einfahren kleiner Werke gegründet war, fallen besonders durch rege Tätigkeit in dieser Zeit auf $\left.{ }^{5.28}\right)$. Johannes $B r$ and $t$, Bremen, übernahm mit der „Zentralverwaltung“ vornehmlich von Francke, einem Verwandten, erbaute Werke zur technischen und wirtschaftlichen Beratung und zur Betriebsführung. Offenbar lag gerade bei den ganz kleinen Werken das Bedürfnis nach fachmännischer Führung dort vor, wo es wirtschaftlich unmöglich war, einen eigenen Ingienieur einzustellen ${ }^{5.3}$ ). Sein später ganz allgemein an die

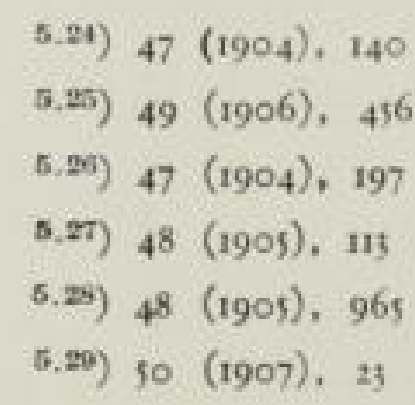


Gemeinden gerichtetes Angebot, eine solche technische Beratung vertraglich anzunehmen, wurde zwar von einem Bezirksverein des Vereins technischer Beamten des Gas- und Wasserfaches als ehrenrührig zerrupft ${ }^{5}{ }^{\text {.zo }}$ ). Wenn man aber weif, wie erfolgreich ein zentrales technisches Aufsichtssystem bei den grofen privaten Gasgesellschaften gewesen ist, so hat man das Gefühl, daf hier das Standesbewufztsein sich zu überschlagen drohte. Jedenfalls hat J. Brandt seine Zentralverwaltung bis fast zu seinem Tode mit vollem Erfolg betrieben und sicher den Werken redlich gedient.

Verhältnismäßjig plötzlich festigte sich die Wirtschaftslage wieder. Anlał zur Auslösung von schon verborgenen Spannungen scheint ein großer Bergarbeiterstreik gegeben zu haben. Lange Lieferfristen für Baustahl behinderten nunmehr die dringend notwendig gewordenen Erweiterungen der Gaswerke $\left.{ }^{5.31}\right)$. Anregungen, auch den Kohleneinkauf gemeinsam zu tätigen, kamen von kleinen Werken an die Wirtschaftliche Vereinigung. Indessen war die Auswahl der jeweils bestgeeigneten Sorte je nach Örtlichkeit und Einrichtung des Werkes gar nicht einfach und aufjerdem stellten sich vielfach die Stadtparlamente solchen Bestrebungen entgegen. Inzwischen aber war auch der Höhepunkt der Konjunktur überschritten und der Kohlenmangel behoben ${ }^{5 . x z}$ ). Vor allem konnte man nunmehr in Vertikalretorten und Kammern auch andere Sorten als ausgesuchte Gaskohlen gut verarbeiten.

Neue Sorgen bereitete eine fühlbare Geldverknappung ${ }^{5.39}$ ). Die Jahre 1908 und 1909 sind für Industrie und Handel eine Zeit betrüblicher Geschäftslosigkeit gewesen. Besonders auf dem Weltmarkt schlug sich die Schwerindustrie tiefe Wunden, die bis zu einer nie gekannten Mutlosigkeit das Geschäftsleben schwächten. Indessen erwies sich der Gaskoks im Gegensatz zum Zechenkoks als gut absetzbar. Der bessere Vertikalofenkoks konnte aber keine höheren Preise erzielen. Im Gegenteil machte die geringere Reaktionsfreudigkeit im Hausabsatz, der besonders in Süddeutschland die Grundlage für den schnelien Verkauf bildete, im Anfang Schwierigkeiten $\left.{ }^{5.34}\right)$. Der Ammoniakabsatz war zufriedenstellend, der neue Wettbewerber Kalkstickstoff beunruhigte die Lage noch nicht. Der Teerabsatz war befriedigend. Die englischen Händler kämpften um den im Jahre 1908 gewonnenen Kohlenabsatz.

Für die Lage sind die Zahlen des Berliner Kohlenabsatzes kennzeichnend (Tafel 2).

Der Anstieg belief sich für England auf $39 \%$, für Deutschland auf $20 \%$.

Schuld daran waren nicht nur die Preise der deutschen Syndikate, sondern auch die hohen Eisenbahnfrachten. Diese wirkten sich auch auf dem Gaskoksmarkt aus. Die deutschen Bahnen hatten wiederholt für Gaskoks die gleichen Sondertarife, zu denen der Zechenkoks befördert wurde, verweigert, „da kein Bedürfnis vorliege $\left.{ }^{45 . x}\right)$. Da die französichen Bahnen erheblich billiger waren, kam Pariser Koks nach Süddeutschland, Italien, Schweiz. Dem Gaskoks wurde jedes Ent-

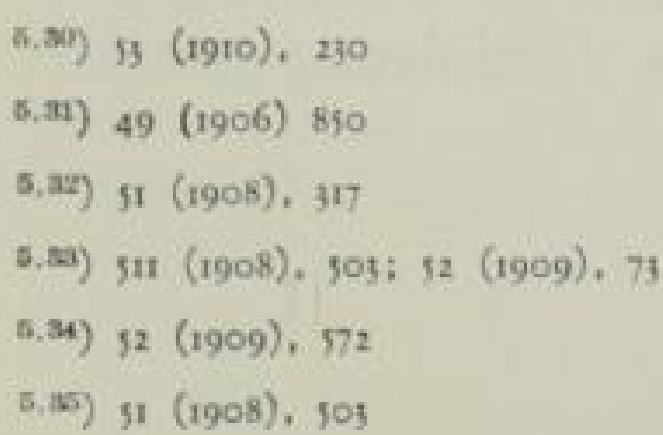


T afel 2: Berliner Kohlenbezug

\begin{tabular}{|c|c|c|c|}
\hline In den Jahren & 1897 & 1908 & 1909 \\
\hline $\begin{array}{l}\text { wurden in Tonnen angeliefert } \\
\text { aus England } \\
\text { aus Deutschland }\end{array}$ & $\begin{array}{r}371317 \\
1955214\end{array}$ & $\begin{array}{l}1295512 \\
2580423\end{array}$ & $\begin{array}{l}1489008 \\
2684604\end{array}$ \\
\hline \multicolumn{4}{|c|}{$\begin{array}{l}\text { Der Anstieg betrug für England } 301 \% \text {, für Deutschland } 37,3 \% \text {. } \\
\text { An Gaskohlen wurden aber geliefert in den gleichen Jahren: }\end{array}$} \\
\hline $\begin{array}{l}\text { aus England } \\
\text { von der Ruhr } \\
\text { von Niederschlesien } \\
\text { von Oberschlesien }\end{array}$ & $\begin{array}{r}183806 \\
69879 \\
130698 \\
292195\end{array}$ & $\begin{array}{r}557036 \\
40605 \\
42942 \\
469725\end{array}$ & $\begin{array}{r}901178 \\
53779 \\
26910 \\
513208\end{array}$ \\
\hline Deutsche Kohlen zusammen & 492762 & 553272 & 593897 \\
\hline
\end{tabular}

gegenkommen auf den Wegen nach Holland, Belgien, Frankreich und den Häfen versagt.

In den Jahren 1909 bis I9II wurde die Anschluß̧bewegung der Städte im und in der Nähe des Ruhrreviers und an der Saar an die Zechenkokerein lebhaft ${ }^{\text {(n) }}$ ). Das hatte auf den Absatz der Nebenerzeugnisse einen günstigen Einfluf. Es handelte sich ja nur zum Teil um eine Ausweitung der Kokereianlagen, zum anderen Teil wurde lediglich das erzeugte Gas besser ausgenützt. Allmählich trat überhaupt eine ausgeglichenere Geschäftstätigkeit ein. Der Ammoniakbedarf in Deutschland stieg an. Die Verkaufsvereinigung konnte die Preise gleichmäf̧iger - über die Jahreszeiten hin - halten, als es vergleichsweise in England der Fall war. Deutschland überflügelte die Erzeugung Englands ${ }^{5.37}$ ).

I9II konnte H. Bunte als Generalsekretär feststellen, daf die Zunahme der Zahl der Werke und des Gasverbrauches mit einer Verdoppelung im beendeten Jahrzehnt größ̧er war als im vorhergehenden $\left.{ }^{5.29}\right)$. Erst 1912 konnte, trotz Störungen durch Streiks an der Ruhr und in England, die Kohlengewinnung nicht mehr glatt abgesetzt werden. Auch ein kalter Winter 1913/14 brachte keine Belebung. Feierschichten im Bergbau wurden notwendig ${ }^{\text {sto }}$ ).

\section{I3 Straffere Organisation des Faches}

Während im Anfang des Jahrhunderts die Anteilnahme des Faches an der technischen Entwicklung überwog, kamen um die Mitte des ersten Jahrzehntes wirtschaftliche Erwägungen immer mehr zur Geltung. Der Grund ist nicht allein im verschärften Wettbewerb mit den Elektrizitätsunternehmen und der Braunkohle (Brikett) zu suchen, er lag vielmehr im Zuge der Zeit, die nach verbesserter Organisation strebte. Die Festigung der Wirtschaftlichen Vereinigung deutscher

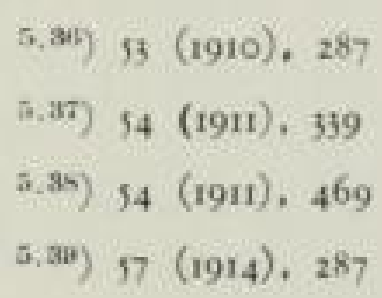


Gaswerke wurde bereits erwähnt $\left.{ }^{\text {s.t. }}\right)$. Anfänglich hatten sich fast ausschlieflich rheinisch-westfälische und süddeutsche Werke beteiligt, I907 wurde eine Wirtschaftliche Vereinigung in Bremen mit ${ }_{117}$ Mitgliedern gegründet, im Dezember I910 die Vereinigung von Sächsisch-thüringischen Gaswerken, die seit to Jahren bestand, als Genossenschaft m. b. H. von II Gaswerken in Krimmitschau eingetragen $^{\text {s.l }}$ ) und $\mathrm{I} 9 \mathrm{II}$ in Berlin als Zweigniederlassung der Kölner Vereinigung eine Gaskoksvertriebsgesellschaft gegründet.

1905 wurde die Vereinigung deutscher Gaskocher-Fabrikanten geschlossen ${ }^{5.42}$ ), 1907 der Verband der Armaturenfabriken ${ }^{5.12}$ ), 1912 folgten die Gasmesserfabrikanten, um sich gegen Unterbietung und unberechtigt lange Garantiezeiten zu wehren. Auch die Menschen strebten nach engerem Zusammenschluf. I910 wurde der Verband mittlerer technischer Beamten, Bezirksverein Bonn erwähnt $\left.\left.{ }^{5.4}\right)^{5.45}\right)^{5}$. Im Jahre darauf wurde der Verband der Gas- und Wasserfachbeamten, mit dem Sitz in Berlin, gegründet, der am I. Juli 1911 mit 2000 Mitgliedern unter dem Vorsitz des Inspektors W. Kölln er, Ruhrort, seine Tätigkeit begann ${ }^{5,46}$ ).

Außjerhalb der Wirtschaftlichen Vereinigung scheint der Verein Pfälzischer Gaswerke $^{\text {t.tiz }}$ ) und die Vereinigung Württembergischer Gaswerke mit 5I Werken gestanden zu haben. Neben dem Kohleneinkauf, dem Verkauf der Nebenerzeugnisse entwickelte er auch eine Betriebsrechnungsanleitung in Anlehnung an die kameralistische Buchhaltung ${ }^{r .45}$ ).

Ein folgenschwerer Schritt des Vereins wurde mit der ersten „Anleitung zur richtigen Konstruktion, Aufstellung und Handhabung von Gasapparaten“ getan. Veranlassung dazu waren Forderungen, die der im Heizungsfach hochangesehene Professor H. Rietscbel, Berlin, in der Versammlung der Heizungs- und Lüftungsfachmänner in Dresden 1903 gestellt hatte. Er verlangte ein Verbot, Gasheizöfen mit Bunsenbrennern und mit fallenden Zügen auszuführen. Abgasrohre sollten ein für alle Mal I, 5 m über Dachfirst geführt werden und die Benutzung von Aufzenwänden für Abgasrohre untersagt sein.

Eine solche Meinung konnte nicht unwidersprochen bleiben, zumal mit Recht befürchtet wurde, daf3 manche Polizei- oder Baupolizeibehörde sie sich in scharfen Vorschriften zu eigen machen würde. Rietschel nahm den Widerspruch technisch prüfend entgegen und danach wurden im Dezember 1905 mit der Heizkommission des Deutschen Vereins zunächst einmal zwei allgemein gehaltene Verpflichtungen festgelegt: $\mathrm{r}$.) Gasheizöfen sind allgemein an gute Schornsteine anzuschlief̧en 2.) Sie müssen so gebaut sein, daf̧ sie in sich selbst und unabhängig vom Schornstein gute Verbrennung ergeben ${ }^{5,10}$ ).

Diese beiden Sätze waren aber zu allgemein gehalten, um alle Fehler, die mancherorts begangen worden waren, für die Zukunft auszuschließ̧en. Darum wurde

\footnotetext{
5.40) 49 (1906), 197

5.41) 54 (1911), 45

5.42) 51 (1908), 106z

5.43) 10 (1907), 1042

3.45) 53 (1910), 398

6.65) $13(1910), 230$

5.46) $94(1911), 606$

5.47) $96(1913) \quad 1278$

3.45) $57(1914) \cdot 472$

5.49) $49(1906)$, 16 t
} 
vom Ausschuf als Ausführungsbestimmung die „Anleitung zur richtigen Konstruktion, Aufstellung und Handhabung von Gasheizapparaten " ausgearbeitet und damit der Weg in das Vorschriftenwesen beschritten, das sicher viel Unheil verhütet hat, aber auch Beschränkungen brachte, die eine freie Entwicklung hätten verhindern können, wenn nicht in dauernder Arbeit die Ergebnisse der Bestimmungen beobachtet und diese selbst den wechselnden Bedürfnissen und technischen Voraussetzungen entsprechend angepałst worden wären.

An sich waren die Vorschriften zunächst noch sehr unbestimmt gehalten. Zur genaueren Festlegung fehlten nicht nur der Wille, sondern auch die Prüfverfahren. Heute muf die Beurteilung der einwandfreien Verbrennung nach dem Aussehen der Flammen und dem Geruch Wunder nehmen, denn eine Kohlenmonoxydbestimmung wurde bereits, wenn auch noch nicht mit hoher Genauigkeit in Laboratorien vorgenommen. Eine beschränkte Höhe fallender Züge innerhalb der Geräte mit dem Verlangen voller Dichtheit in den Zonen des Uberdruckes war wohl ein Zugeständnis an H. Rietscbel. Für Badeöfen wurde ein Abzug vorgeschrieben, wobei Abführung der Gase in den Dachraum oder unmittelbar durch die Wand ins Freie überall dort als zulässig angesehen wurde, wo kein geeigneter Schornstein vorhanden war. Festgelegt wurde die Weite der Abzugsrohre. Auf die Notwendigkeit, kleine Baderäume auch zu belüften, wurde hingewiesen. Diese Vorschrift wandte sich in Einzelheiten auch an das Verständnis des Einrichters und des Benutzers.

Aber schon wurde der Wunsch rege, die Vorschriften so stark zu machen, dafy nicht nur die Benutzer, sondern auch die aufsichtführenden Werke in der Verantwortung entlastet wurden. G. Ker $n$, Strałburg, verlangte einheitliche Vorschriften für Installateure. Die Heizkommission vertrat damals den Standpunkt: „Dem übermäßigen Eifer der Behörden, der freien Entwickelung der Technik durch zu weitgehende Vorschriften Fesseln anzulegen, darf nicht auch noch durch den Verein Nahrung gegeben werden." Dem wurde auf der Hauptversammlung des Vereins beigepflichtet. ${ }^{5.50}$.

Dann aber kam ein Hinweis, dał der Sächsisch-Thüringische Verein schon 1902 Vorschriften zur Herstellung, Benützung und Unterhaltung von Privatgaseinrichtungen herausgegeben habe, die sich bewährt hätten. So kam es für die Neubearbeitung der Anleitung dazu, dał der Ausschuf̧ die Zustimmung zu grundsätzlichen, schwerwiegenden Richtlinien für die Bearbeitung nachsuchte:

,I.) Im Interesse der größtmöglichen Sicherheit von Gaseinrichtungen hält der D.V.G.W. neben der Ausbildung der Installateure in den vom Verein gegriindeten Fachschulen den Erlał von ortspolizeilichen Vorschriften über die Befugnisse der Installateure und über die Herstellung von Gaseinrichtungen für erforderlich. 2.) Die Vorschriften sind nach ihrem gesamten technischen Inhalt vom D. V. G. W. aufzustellen, der sich das Recht vorbehält, diese Vorschriften jederzeit nach dem Stande der Technik zu ändern.

3.) Die Einhaltung der Vorschriften und die Prüfung der Gaseinrichtungen ist von gastechnisch gebildeten Personen, welche mit polizeilichen Befugnissen aus. gestattet sind, nicht von Polizeiorganen zu überwachen ${ }^{\text {(5.5.51). }}$.

5.50) $50(1907), 587$

5.51) S1 (1908), 545 
Diese Gedanken stiefyen in der Hauptversammlung auf den lebhaftesten Widerstand rheinischer Werksleiter, die auch Elektrizitätswerke zu betreuen und dabei ihre Erfahrungen gesammelt hatten. Die weiteren Verhandlungen waren sehr langwierig und schwierig unter der Leitung von Dr. E. Scbilling. In Bayern bestanden schon vielfach ortspolizeiliche Vorschriften, gegenüber denen das Zugeständnis der Prüfung durch gastechnisch gebildete Personen schon ein Fortschritt zur Vernunft gewesen wäre $\left.{ }^{5.52}\right)$. Es kam so weit, dafs Schilling den Vorsitz im Ausschuł niederlegte, den er nach weiteren Aussprachen kurz vor der Hauptversammlung jedoch wieder übernahm. Erörterung und Kampf hatten sich aber gelohnt. Nachdem die Polizei nicht mehr erwahnt war, wurde die „Anleitung zur Aufstellung von Vorschriften und Regeln für den Gasbezug, die Einrichtung und den Gebrauch des Gases“, die den Gaswerken zur Ausgestaltung ihrer eigenen Vorschriften und Regeln an Hand gegeben wurde, ohne Erörterung angenommen. Auch mit dem Installateurverband kam wegen dieser Anleitung ein Einverständnis zustande. Dieser verlangte die Meisterprüfung als Befähigungsnachweis für Einrichtungen und war grundsätzlich mit Strafbestimmungen und Selbstkontrolle einverstanden.

S.I3r Besitzverhältnisse der Werke

Die Entwicklung der Eigentumsverhältnisse der Werke in diesem Abschnitt bildet eine Vorstufe zu den turbulenten Ereignissen nach dem Kriege.

Der Wunsch zur Kommunalisierung setzte sich fort. München, das von einer besonders rührigen Privatgesellschaft mit hervorragenden Fachkräften bedient worden war, nahm trotz allem angebotenen Entgegenkommen am I. November 1899 vom Werke Besitz ${ }^{5.57}$ ). Reichenhall nahm 1898 ein vollkommen abgewirtschaftetes kaum noch lebensfähiges Werk in seine Obhut und brachte es durch eine Umstellung von Holz auf Kohle sehr bald zu befriedigender Arbeit ${ }^{5.54}$ ). Die Privatgasgesellschaften, die kleinere Werke führten, gaben manches Werk an die Gemeinden ab. Auch die Deutsche Continental-Gas-Gesellschaft mufte 1903 die Gasversorgung von Mönchengladbach abtreten, ihr Werk dort benutzte sie weiter zur Versorgung von Rheydt, Odenkirchen und weiter entlegenen Orten. Erfurt wurde 19 II an die Stadt verkauft ${ }^{5.55}$ ).

Andererseits wurde die von den Gemeinden betriebene Aktiengesellschaft Rheintal in St. Margarethen von der Aktiengesellschaft für Gas-, Wasser- und Elektrizitätsanlagen Berlin, die bereits Bergedorf, Arnswalde und Diedenhofen betrieb, aufgekauft ${ }^{\mathrm{s}, 35}$ ).

Eine wichtige Umstellung vollzog die Aktiengesellschaft für Gas und Elektrizität, Köln, als sie 1908 ihre Werke in Ruhrrevier an das Rheinisch-Westfälische Elektrizitätswerk (RWE) Essen und an das Elektrizitätswerk Westfalen, Dortmund abgab und für den Erlös die Neue Gas-Aktiengesellschaft, Berlin, er-

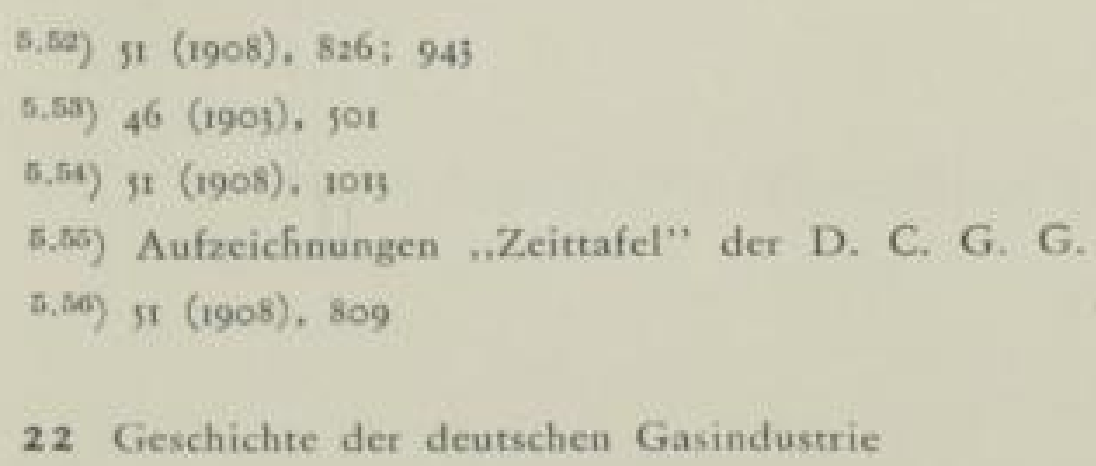


warb $^{5.57}$ ), die durch den Tod von Julius Nolte führerlos geworden war und sich als stark sanierungsbedürftig erwiesen hatte.

Wichtiger als diese Veränderungen in den Besitzverhältnissen waren die sich in der kommunalen Wirtschaft zeigenden Bestrebungen, die Werke innerhalb der Stadtverwaltungen selbständiger zu machen, damit sie den wechselnden An. forderungen der Wirtschaft leichter folgen könnten.

In Görlitz wurde, offenbar als erstem Fall und in der Presse besonders begrüfft, der Direktor der Gas-, Wasser- und Elektrizitätswerke zum besoldeten Stadtrat ernannt. Nunmehr konnte der Ingenieur die Belange des Werkes selber im Stadtparlament vertreten $\left.{ }^{5,55}\right)$. Die Stadtverwaltungen standen vielfach im Begriffe, die eigene Regie der Werke aufzugeben und sie der Form nach in Privatgesellschaften umzuwandeln unter Aufsicht und Beteiligung der Stadtverwaltungen ${ }^{5.50}$ ). Dabei spielten die guten Erfahrungen mit der Beteiligung an elektrischen Überlandzentralen, Straf̧enbahnen und anderen mit, für die der "Instanzenweg“ ein Hindernis war. Auch die Beteiligung an der Wirtschaftlichen Vereinigung de: Gaswerke war ja eine Bindung, die verwaltungsmäfjig nicht leicht zu behandeln war.

Die gemischt-wirtschaftlichen Unternehmen, teils privat, teils kommunaler Besitz, erfreuten sich der Billigung mancher Volkswirtschaftler ${ }^{\text {t.em }}$ ). Natürlich fand eine so krasse Äuf̧erung wie die von W. v. Oechel h a e u ser, ,daf städtische Verwaltungen für so schnelle technische Fortschritte und so scharfe Konkurrenzen ungeeignete Organisationen sind", auch lebhaften Widerspruch. F. Gö b rum prägte aber das für die Zeit bezeichnende Wort: „Die städtischen Betrieb€ müssen den Akzent mehr auf das Wort Betrieb als städtisch legen." Um die Jahreswende 1911/12 schlof Oechelhaeuser, als letzte Tat vor seinem Rücktritt von der Leitung der Deutschen Continental-Gas-Gesellschaft, das städtische Elektrizitätswerk Rheydt mit dem Gaswerk der Gesellschaft zur gemischt-wirtschaftlichen Gesellschaft: Niederrheinische Licht- und Kraftwerke A. G. zusammen. Beteiligt an den 8 Mio Aktienkapital waren Stadt und Gesellschaft je zur Hälfte $\left.e^{5.61}\right)$.

In Straf̧burg (Elsaß) wurde kurz vor dem Kriege mit einer französischen Gesellschaft ein gemischtwirtschaftliches Unternehmen mit einer Mehrheitsbeteiligung der Stadt ins Leben gerufen ${ }^{\text {s.ent)}}$.

\subsection{Wettbewerb}

Wenn auch bereits im Abschnitt 5.12 die Einflüsse von auß̧en als Grundlagen für die Wirtschaftslage angedeutet wurden, so dürfte doch eine zusammenfassende Darstellung des Kampfes im Wettbewerb mit anderen Wirtschaftsträgern notwendig sein. Bis zur Jahrhundertwende hatte das Gas seine überragende Stellung als Leuchtmittel verhältnismäßjig leicht, vorwiegend durch technische

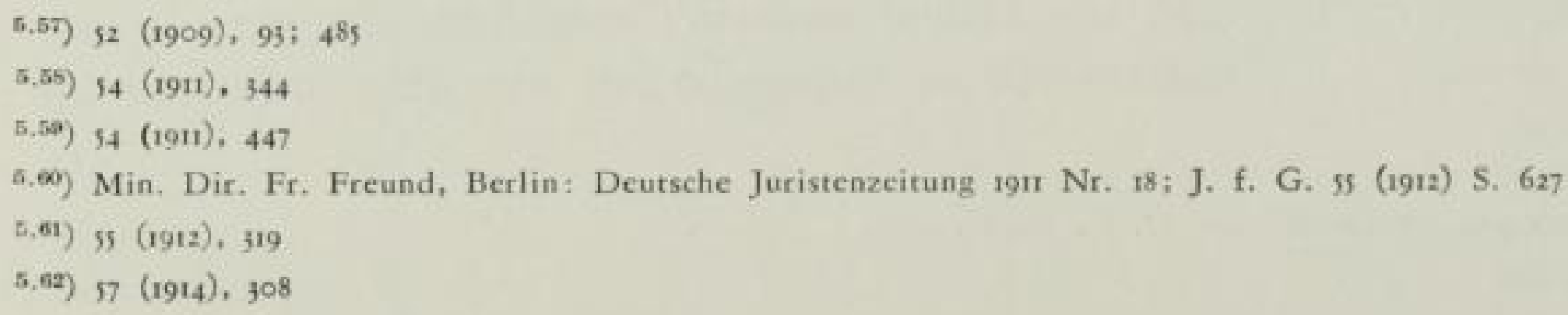


Entwicklungen bewahren können. Störungen waren jedesmal schnell verebbt. Nunmehr wurde das anders, ein dauernder Kampf hatte begonnen.

Der Hauptstörenfried war die Elektrizitätswirtschaft. Es kann hier unmöglich die ganze Entwicklung der Elektrotechnik zu immer besseren Installationen, Maschinen, Transformatoren und der Elektro-Wirtschaft zu immer kräftigeren Firmen beschrieben werden. Sie ging rasch vor sich, fesselte den Beschauer und gab den Jüngern der neuen Kunst einen berechtigten Schwung.

Hier muf es genügen, einige Epochen festzuhalten. 190r wurde es klar, dał Auers Osmiumlampe im Grofjen gefertigt werden würde $\left.{ }^{\text {s.es)}}\right)$. Die Nernstlampe mit Vorwärmung des Halbleiters wurde von der allgemeinen Elektrizitätsgesellschaft mit Nachdruck auf den Markt gebracht. Drei Lampen gab sie zur Einführung kostenfrei $a b$, bei Beschädigungen wurden sie für $30 \mathrm{Pfg}$ gegen neue ausgetauscht $\left.^{5.4}\right)$. Ein Jahr später wurde die Osmiumlampe tatsächlich angeboten ${ }^{5.65}$ ). Sie brauchte 1,5 W/HK und kostete 5.- M das Stück.

1905 war auch die Tantallampe da mit einem glastechnischen Wunderwerk zur Aufhängung der Fäden ${ }^{\text {t.out }}$ ). Gleichzeitig trat die Zirkonlampe auf (Patente 13370 I und ${ }_{137569)}$ und zeigte, daf3 noch viele Möglichkeiten, die Metallfadenlampe zu verbessern, vorlagen ${ }^{5.67}$ ). Die Wolframlampe der osterreichischen Auergesellschaft kam im Jahre $1906^{5.65}$ ) und 1914 die Halbwattlampe $e^{5.00}$ ).

Wenn auch der Vorzug des elektrischen Lichtes, die Schaltfähigkeit ohne Zündmittel, den Gasfachleuten bewufyt war, was die an anderer Stelle zu besprechenden vielen Bauarten von Zündeinrichtungen für Gaslampen beweisen, so werden in den Kampferörterungen fast ausschliefllich Kostenberechnungen aufgestellt. Selbst der Halbwattlampe konnte man nachrechnen, dał̧ die Hängelichtgaslampen bei den üblichen Preisen noch billiger im Betriebe waren ${ }^{5.79}$ ). Solche Rechnungen waren notwendig, weil von den Elektroingenieuren oft gänzlich falsche Zahlen aufgestellt wurden, wobei der Vergleich mit den fast ausgestorbenen Stehlichtbrennern eine grof̧e Rolle spielte $\left.{ }^{5.71}\right)$. Sehr übel waren Behauptungein der Elektrofachleute, dał̧ die Gasbeleuchtung schon damals rückläufig gewesen $\left.\operatorname{sei}^{-5.7 y}\right)$. Der Eindruck wurde erweckt, dadurch, dał Gasbeleuchtungen von Fabriken durch werkseigene Zentralen aus dem Felde geschlagen wurden und auch groß̧e Wohnungen vermögender Leute immer mehr die Elektizitüt bevorzugten. Die Statistik zeigte aber immer wieder, dał auch in der Beleuchtung das Gas Fortschritte machte, wenn auch langsamer als in der Gesamtaufnahme des Gases einschlief̧lich Kochen und Warmwasserversorgung. Gerade in dieser Zeit sahen sich kleine Gemeinden, die durch Uberlandzentralen für Elektrizität erschlossen waren, veranlaf̧t, nachdem in der Bevölkerung der Wunsch nach verbesserter Energieversorgung geweckt war, schleunigst auch ein kleines Gaswerk

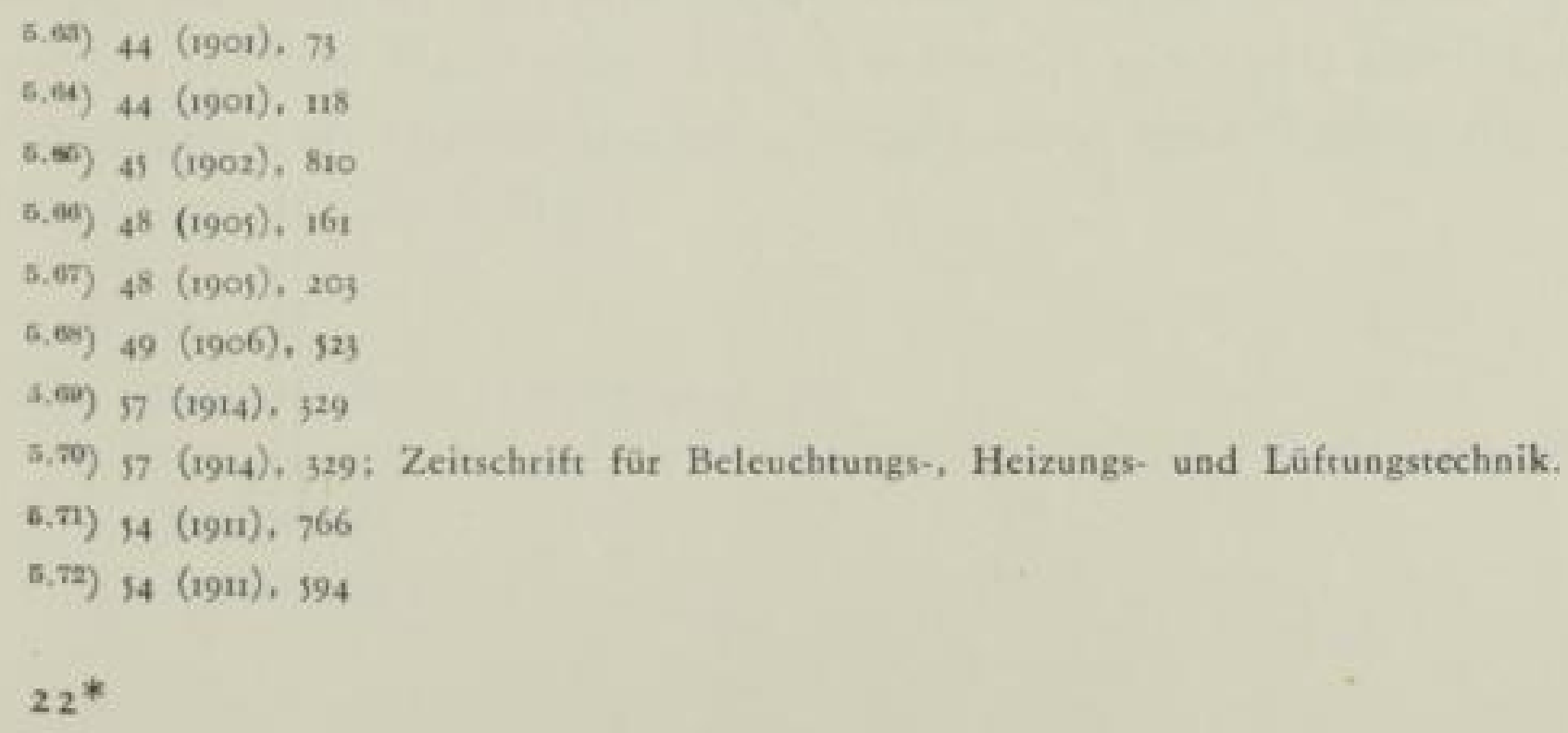


für den Kochdienst zu schaffen $\left.{ }^{5.73}\right)$. Darum wurde aber auch gerne, besonders von der ärmeren Bevölkerung, die Gasbeleuchtung statt der Petroieumlampe angeschafft. Die kleine Gemeinde Geisenheim (Rheingau) konnte in ihrem mit Elektrizität versorgten Gebiete $81 \%$ der Häuser und $72 \%$ der Wohnungen anschlief̧en, obwohl die Bedingung gestellt war, dał zum Gaskocher mindestens auch eine Gasleuchte installiert werden müsse $\left.{ }^{6.7 \pi}\right)$. Auch die meist aus Sparsamkeit reichlich dürftig ausgestattete Straf̧enbeleuchtung wurde mehrfach durch leistungsstärkere, aber nicht kostspieligere Gaslampen ersetzt $\left.{ }^{5,25}\right)$. Viel Staub wirbelte ein solcher Entschluf3 in Oranienburg auf ${ }^{70}$ ). Noch angreifbarer waren Vergleichsrechnungen, die damals schon beweisen sollten, daf3 wirtschaftlich das elektrische Kochen dem Gaskochen überlegen sei. Es gab da erbitterte Kämpfe: Ritter contra Scbäfer $\left.{ }^{5.77}\right)$, Dettmer contra Meurer mit Vergleichskochen und andere $\mathrm{mehr}^{5,76}$ ).

Viel unangenehmer waren Angriffe, in denen die Gefährlichkeit des Gases zum Mittel im Kampfe gemacht wurde. Fr. $S c b$ äfer hat zur Abwehr wiederholt die Statistik der Unfälle durchleuchtet, wobei zu beachten war, daf Gas etwa 8 mal soviele Anschlüsse belieferte als die Elektrizität ${ }^{5.73}$ ).

In Bergedorf waren längs einer neuverlegten Fernleitung 40 Bäume eingegangen. $B u b k$ nutzte diese Tatsache zu übertriebenen Angriffen gegen das Gas aus, indem er ohne Nachprüfung der wahren Ursachen den Fall in den Werbezeitungen der Elektrizität verallgemeinerte. A. Albrecbt wies an anderen Beispielen nach, dał das Indizium nicht stimme. Das führte zu einer wütenden Fehde, über deren Argumente man noch heute den Kopf schütteln muf $\}^{5.80}$ ).

Ein Bild, das von der Gasseite über Unfälle mit Elektrizität in die Tageszeitung gekommen war, war eine sehr peinliche Entgleisung. Es war allerdings auch ohne Wissen des ersten Zeichners verbreitet worden $^{5,51}$ ).

Die Wettbewerbsfehde wurde damals in einer Tonart geführt, die man heute kaum mehr versteht. Dafür werden noch einige Auseinandersetzungen von Erfindern und Firmen untereinander, die im Rahmen der Entwickelung der Technik gebracht werden müssen, Belege bilden.

A. Kraetzer, Bingen, der gegen die Schrift: „Kein Haus ohne Gas" die viel verbreitete Gegenschrift setzte: „Keine Gemeinde, kein Anwesen ohne Elektrizität " muf̧te sich wegen falscher Darstellungen sagen lassen, daf3 man in anständigen Werbeschriften nur seine Dinge positiv nenne, aber nicht den Gegner herabsetze ${ }^{\text {s.6z }}$ ).

Andererseits schauten aber auch die Gasfachleute manchmal etwas viel über den Zaun um das Arbeitsgebiet der Elektrotechniker. Verstehen kann man das,

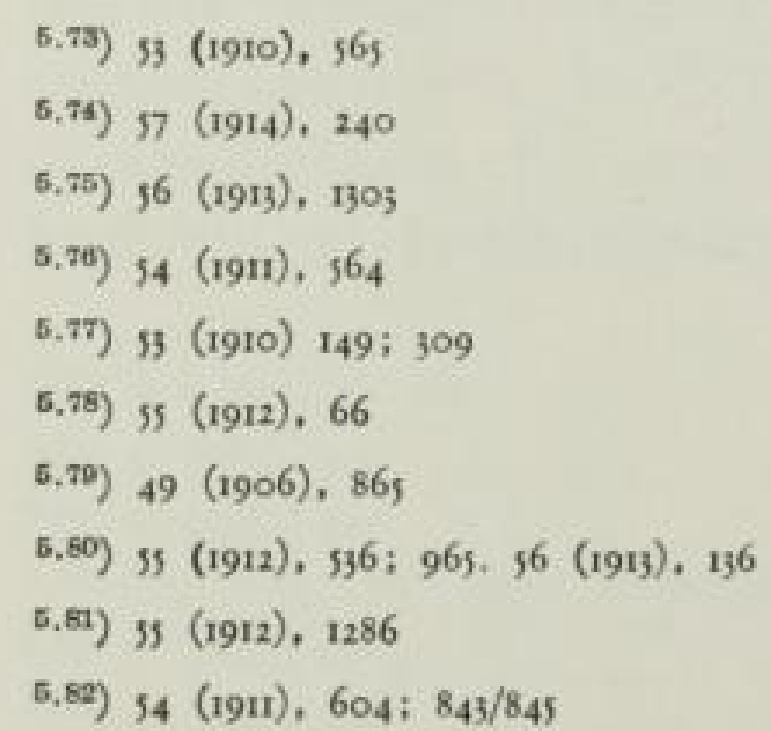


wo sie unmittelbar geschädigt wurden. In England wurden die neuen Elektrizitätswerke von den Kommunen errichtet, während die Gaswerke Privatunternehmen waren. Da kam es nun oft genug vor, dał die neuen Werke mit Verlusi arbeiteten, um das Gaswerk zu unterbieten, das auch noch die Steuern für diesen Unternehmungsgeist aufbringen mufte. Die South Metropolitan Gas Co. erreichte einen Spruch des Parlamentes, dałz vom Elektrizitätswerk Bermondsey die Strompreise die Rente sichern müften $\left.{ }^{5.85}\right)$. Wo Gas und Elektrizität beide in den Händen der Gemeinde waren, mufte das Gas das neue Werk oft mit durchziehen ${ }^{\mathrm{n} .84}$ ). Man hätte aber aus eigenen Erfahrungen auch daran denken müssen, dał in der Versorgungswirtschaft mit ihren langen Entwicklungszeiträumen auf Zuwachs gebaut werden muf. Hat man eine Konzession für 20 Jahre, so wird man am günstigsten fahren, wenn man gleich so baut, dał in den ersten Jahren ein geringer Verlust eintritt, der dann, nachdem der Rahmen besser ausgefüllt wird, einem umso gleichmäfrigeren Gewinne Raum gibt. Begreiflich ist aber der Einspruch, wenn diesem Baustil der Behörden auf Kosten der Steuerzahler noch mit aufwendiger und übertriebener Werbung Vorschub geleistet wird. So muf̧te die bayerische Landesgewerbeanstalt Angriffe entgegennehmen, weil in ihr lediglich Elektrizitätsfachleute tätig waren ${ }^{5,55}$ ).

Die Gegenwerbung wurde wirklich in mehrfacher Hinsicht gefährlich. Wegen der übetrieben gesehenen Gefahren kamen in den Behörden Gedanken an eine ganz scharfe Uberwachung der Gasanlagen, die aber sicherlich die Mehrzahl der Unfälle, so wie sie als entstanden nachgewiesen werden konnten, nicht zu beseitigen vermocht hätte ${ }^{\text {5.s6 }}$ ).

Den Wettkampf beim Absatz der Nebenerzeugnisse, einschlieflich des Kokses, kann man an dieser Stelle übergehen, da er sich ganz der im freien Markte üblichen Mittel - auf beiden Seiten - bediente.

Wohl aber muf des ersten geschlossenen Angriffes der Freien Vereinigung Deutscher Installateure am 5. 10. 1902 in Nürnberg auf die Installations- und Verkaufstätigkeit der Gaswerke gedacht werden. Örtlich waren Bemühungen, den Werken diese für die Ausbreitung des Gases notwendige Tätigkeit durch Eingriffe der Obrigkeit zu untersagen, schon oft geführt worden und dort teilweise mit Erfolg, wo es sich um kommunale Betriebe handelte. Jetzt wurde ein Antrag eingebracht, der die Mitglieder verpflichten sollte, ,ab Januar 1903 nicht mehr von Firmen zu kaufen, die an Stadtwerke..... Gasbeleuchtungsgegenstände jeder Art verkauften ${ }^{45.55}$ ). Gerade die besten Geräte wurden aber von den Gaswerken angekauft und vertrieben. Die rein wirtschaftlichen Streitfragen zum Mafsstab zu nehmen und nicht auf die Güte zu sehen, war das Bedrohliche für die Werke. Der Antrag scheint nicht wirksam geworden zu sein, der Kampf der Einrichter gegen die Werke ist aber nicht wieder aufgegeben worden. Umso erfreulicher war es für die Gaswerke, dał, wie bereits erwähnt, der Installateurverband die Anleitung zur Aufstellung von Vorschriften und Regeln für den Gasbezug sachlich würdigte und billigte.

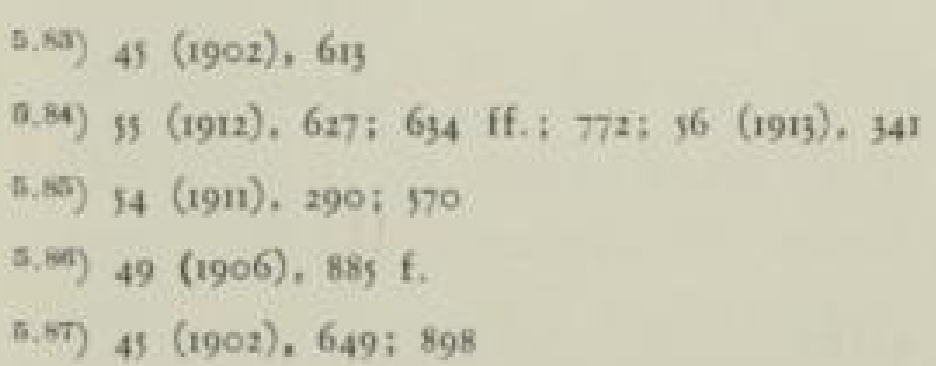




\subsection{G A S E R Z E U G U N G}

Um zu Anfang eine allgemeine Ubersicht zu geben, mag ein Reisebericht eines Engländers, der die kontinentale Technik mit der in seiner Heimat vorherrschenden vergleicht, in einem kurzen Auszuge wiedergegeben werden ${ }^{5.40}$ ). Vorweg bemerkte er, daf̧ die Ingenieure im allgemeinen in Deutschland besser ausgebildet seien. Dann kamm er auf technische Einzelheiten. Die De Brouwerrinne sei viel mehr benutzt; der Regeneratorofen* allgemeiner. Die Schrägretortenöfen seien dank der Patentlage auf dem Kontinente einheitlicher ausgeführt. Kurze Retorten würden wegen Befürchtungen mit dem Gasabgange bei Horizontalretorten bevorzugt. England wende $6 \mathrm{~m}$ lange Retorten an, der Kontinent im allgemeinen 3,5 m; Zürich 4,5 m Länge. Dagegen seien Lade- und Ziehmaschinen viel weniger zu finden. Die freimütige Benutzung der Elektrizität für Maschinenantrieb und Beleuchtung innerhalb der Gaswerke fiel ihm auf. Die Reinigeranlagen seien im allgemeinen kleiner, als Folge der leichteren Bestimmungen. Die geringe Gröłe der Behälter vermerkte er ohne Begründung, die darin zu suchen war, daf̧ im häufigen Nebel in England zeitweilig und plötzlich eine ganztägige Beleuchtung nötig wurde. Er rühmte die bessere Fürsorge für die Arbeiter durch Bäder und Werkswohnungen und die wegen der reichlichen Glühlichtbenützung bessere Straf̧enbeleuchtung.

Bei der Beurteilung eines solchen Vergleiches eines Reisenden mag man berücksichtigen, daf ihm natürlicher Weise bei Besuchen das Neueste und Beste gezeigt wurde. Immerhin aber gibt der Bericht eine erfreuliche grundsätzliche Anerkennung wieder.

\subsection{Ofenbau}

Im Ofenbau wurde in der Tat die Generatorgasfeuerung und die Luftvorwärmung in Rekuperatoren in Deutschland um die Jahrhundertwende als eine Selbstverständlichkeit bei neuen Öfen angesehen. Dic Schrägretortenöfen standen auf der Höhe der Beliebtheit. Besonders war es Edward Drory, der in Wien nicht nur den Betrieb der 1620 von der Stettiner Chamottefabrik A.-G. für das Gaswerk Simmering gelieferten Retorten gesehen, sondern auch selbst im Wiener Gaswerk der Imperial Continental Gas Association damit gearbeitet hatte. Beim Neubau des Gaswerkes Mariendorf für die gleiche Gesellschaft wählte er dasselbe System $\left.{ }^{5.59}\right)$. Auch von anderen Werken liegen freundliche Beurteilungen vor $\left.^{5.20}\right)$. In einem Reisebericht aus England wurden eine ganze Anzahl von Schrägretortenanlagen erwähnt ${ }^{5.91}$ ). Die Stettiner Chamottefabrik A.-G. erhielt den Auftrag für eine grołe Anlage in New York ${ }^{5,92}$ ). Bei diesen Anlagen wurde jetzt auch der mechanischen Forderung Aufmerksamkeit gewidmet.

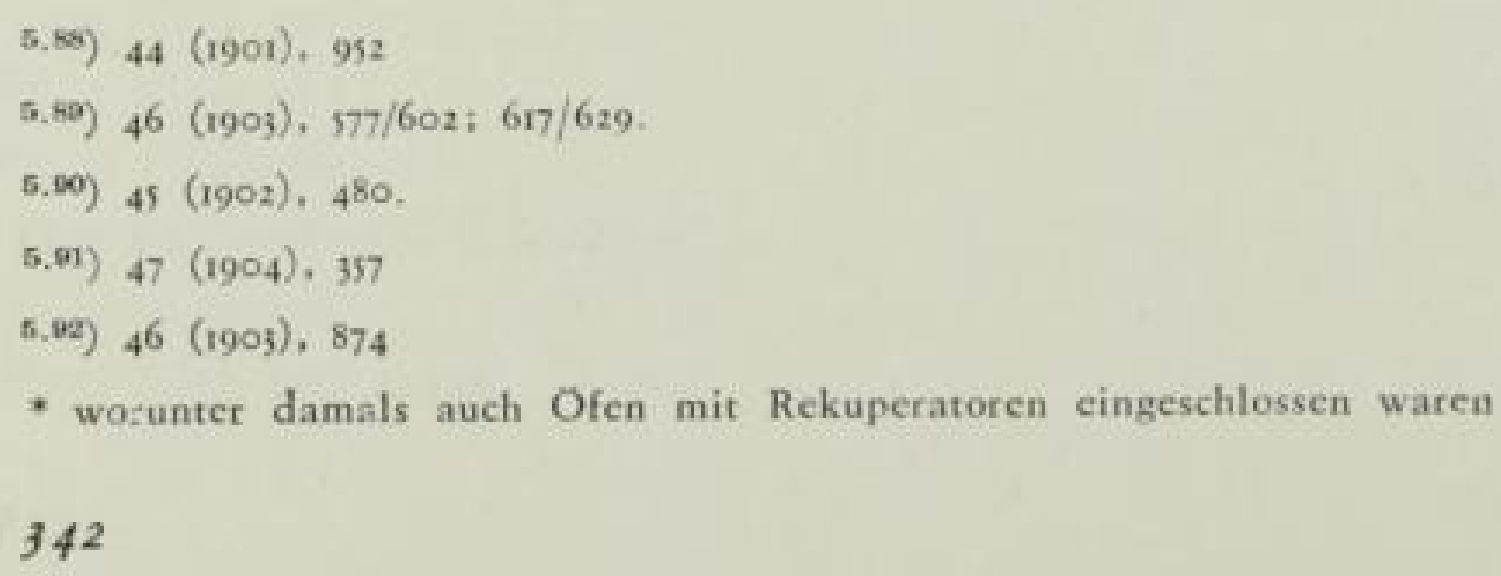




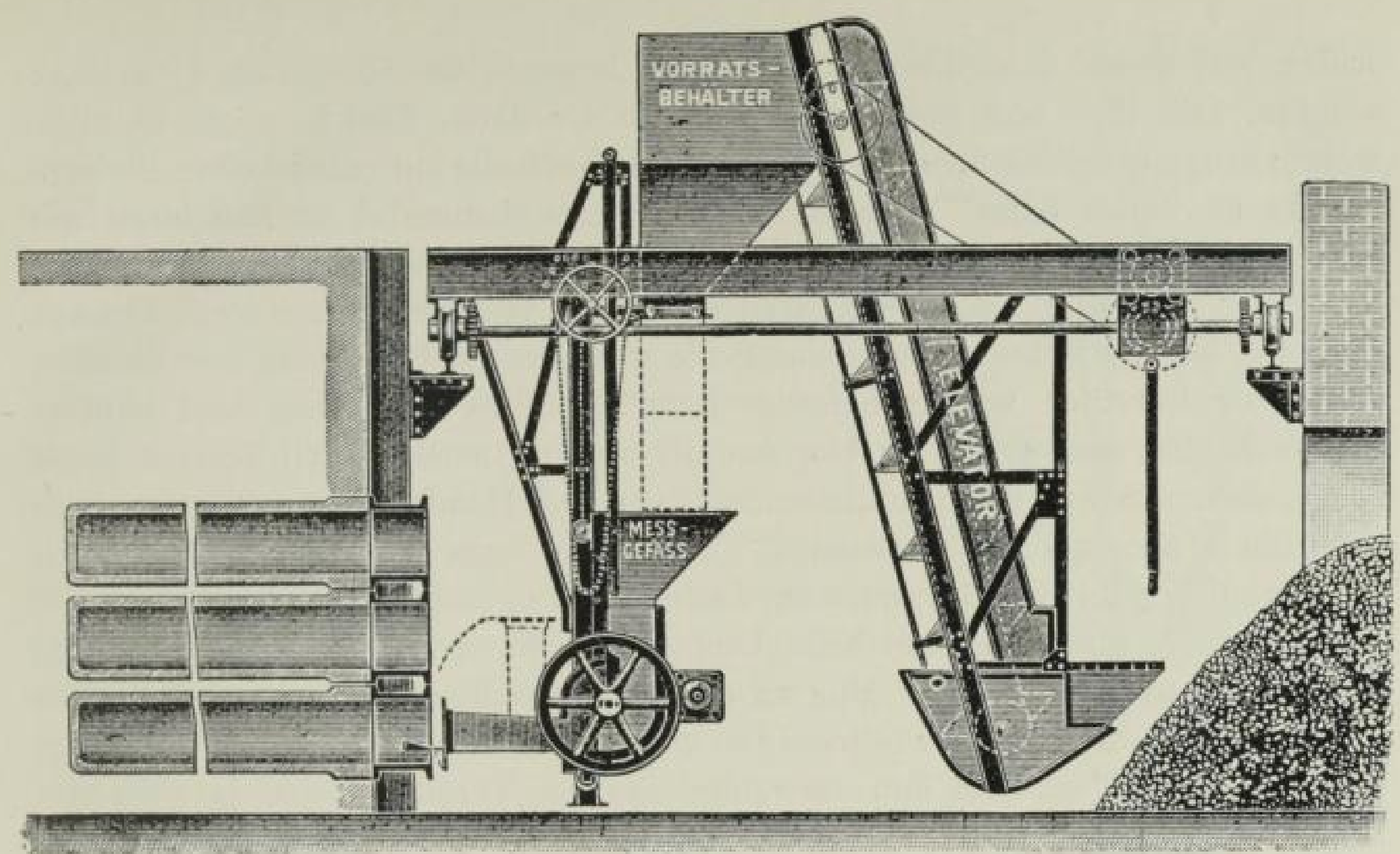

Bild too Lademaschine von Eitle (J. f. G. $47[1904]$ S. 884)

Noch aber gab es Ingenieure, die die Horizontalretorten vorzogen. Rot ber. Spandau, hielt sie bei Werken mit weniger als 3 Mio $\mathrm{m}^{3}$ Jahreserzeugung für am besten. Er wies auf den einfachen Betrieb hin, der bei ganz kleinen Werken auch noch die Rostfeucrung rechtfertige, wenn die Kokspreise schlecht wären. Allenfalls kämen Halbgasgeneratoren in Betracht, während Vollgasgeneratoren zuviel Verständnis für die Öfen und deren Betriebsführung erforderten. Bei einer Ausbeute von $280 \mathrm{~m}^{3} / \mathrm{t}$ und einer Leistung von $180-200 \mathrm{~m}^{3} /$ Retorte und Tag brauche ein Rostofen $35-40 \mathrm{~kg}$ Koks/100 kg Kohle, eine Halbgasfeuerung komme auf $310 \mathrm{~m}^{3} / \mathrm{t}$, d. s. $230 \mathrm{~m}^{3} /$ Retorte und Tag mit $28-30 \%$ Unterfeuerung. Die Retortenhaltbarkeit gab er mit 600 und 800 Feuertagen $\left.a^{3.04}\right)$. Lade- und Ziehmaschinen fanden nun mehr Beachtung als früher. L. Körting, hatte in Hannover bisher keine Wirtschaftlichkeit aus der Benutzung von Lademaschinen errechnen können. Die gestiegenen Ansprüche der Arbeiter, nicht nur in Hinsicht der Entlohnung brachten ihn aber dazu, Lademaschinen einzubauen ${ }^{\text {5.ph }}$ ). Statt 204 Mann bei Handbedienung waren nur noch 72 mit erleichterter Arbeit beschäftigt. Die Gasausbeute ging allerdings von 320 auf $310 \mathrm{~m}^{3} / \mathrm{t}$ zurück. Umgekehrt steigerte L. Lubszinsky, Krefeld, bei einem Rückgang der Lohnaufwendung auf die Hälfte seine Ausbeute von 286 auf $302 \mathrm{~m}^{3} / \mathrm{t}$, erreichte also, vermutlich mit anderen Kohlen, die Leistung Hannovers nicht. Die Maschinenfabriken entwickelten die Einrichtungen erfolgreich weiter. Die Maschinen von C. Eitle, Stuttgart, „Kobold“ mit Weiterentwicklung der Schleudertrommel (Bild roo) und seine Ziehmaschine mit einer Schneidschnecke ohne Mittelwelle, die den Koks in groß̧en Stücken herausholte, fanden besondere Beachtung ${ }^{5.05}$ ). Die Schleuderma-

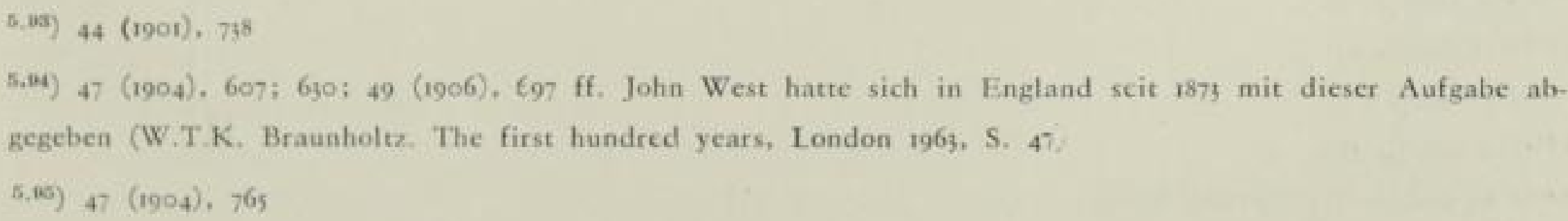


schine war gegen Staubbildung mit einem beweglichen Schutzkasten versehen worden. Die Ent- und Belademaschine von Oerlikon, Zürich, zeigte deutlich, welche neuen Möglichkeiten der Konstrukteur durch die gut entwickelten Elektromotore gewonnen hatte $\left.{ }^{5.06}\right)$. Auch andere Firmen bauten diese Maschinen mit jeweils eigenen Abwandlungen (Carl Francke, Bremen und Bamag, Berlin) ${ }^{5.07}$ ), die leider nicht alle beschrieben werden können. 1905 stellte J. Bueb, Dessau, fest, dafy die Horizontal-Retorte durch die mechanische Bedienung ihre Stellung gegenüber Cozeöfen wieder befestigt habe $\left.{ }^{5.95}\right)$. Nicht nur kleine und mittlere Werke bauten neue Öfen mit Horizontalretorten: Hameln durch Eduard Riepe \& Co. Braunschweig mit Handlademaschinen und Handentleerung $\left.{ }^{5.90}\right)$, Quedlinburg mit $18000 \mathrm{~m}^{3} /$ Tag Erzeugung ${ }^{\text {s.1nog }}$, sondern auch groß̧e. Den Haag mit $300000 \mathrm{~m}^{3} /$ Tag mit De Brouwerscher Lademaschine, Stof̧maschine und Kette für den $\left.\mathrm{Koks}^{5.101}\right)$. Stuttgart blieb beim Umbau des Werkes bei Horizontalretorten mit Lademaschinen ${ }^{5.105}$ ). Man ging zu den in Deutschland seltenen $6 \mathrm{~m}$ langen Retorten über, die sich als vollwertig erwiesen ${ }^{5.100}$ ). Im allgemeinen schwor jeder Betriebsleiter auf das bei ihm verwandte System. Vergleiche sind ja auch von Werk zu Werk auferordentlich schwierig, da nicht allein die Art der Retorte und ihre Bedienung, sondern der ganze Aufbau der Feuerungsanlage und die Preise von Kohle und Koks in die Betriebsrechnung als ganzes mit hineinkommen. Vor allem war aber noch bei mangelnden Wägeeinrichtungen die Schätzung vielfach leicht willkürlich eingeschaltet. Kra us e, Hamburg, der fast alle Arten der damals vorkommenden Ofen in den Werken zu betreuen hatte, fand gerade die $6 \mathrm{~m}$ langen Retorten nicht wirtschaftlich, da sie mit den dort benutzten Lademaschinen nicht ordnungsgemäf bedient werden konnten. Bei Handbetrieb betrug die Ausbeute $325 \mathrm{~m}^{3} / \mathrm{t}$, bei Maschinen nur $280 \mathrm{~m}^{3} / \mathrm{t}^{5,101}$ ). Bei $4 \mathrm{~m}$ langen Retorten wurden dagegen im Handbetrieb 300 bis $310 \mathrm{~m}^{3} / \mathrm{t}$ erreicht. Eine bemerkenswerte Lösung wurde in Lyon am Horizontalofen versucht, wo ein Kohlenkuchen in einem senkrechten Mantelkörper vorgestampft wurde und dieser Block beim Einschieben den Koks vor sich hinausdrückte ${ }^{\text {t.1075) }}$.

Gleich nach der Jahrhundertwende schickten sich die Ofenkonstrukteure an, die bis dahin theoretisch erörterte Möglichkeit auszunutzen, bei der Gaserzeugung die bisher geforderte Sorge, die lichtgebenden Kohlenwasserstoffe zu schonen, auf̧er Acht zu lassen. Die Entgasung in kleinen Einheiten aus flach liegenden Kohlenschichten war keine zwingende Voraussetzung mehr. So suchte man nach der besten Ausführung größerer Entgasungsräume auf zwei Wegen. r.) mit senkrecht gestellten Retorten, 2.) mit Grołraumöfen, die den Kokereiöfen im Grundaufbau nachgebildet waren.

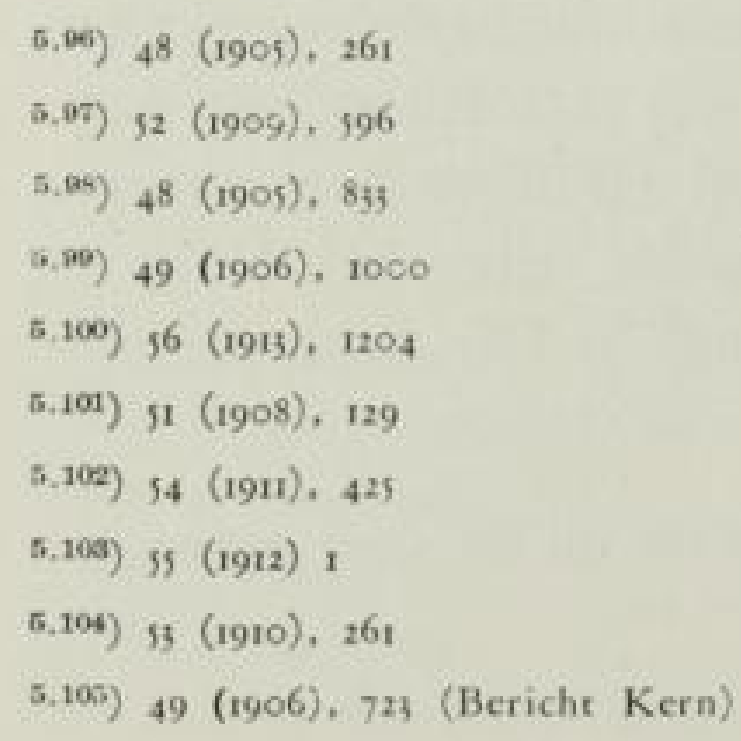




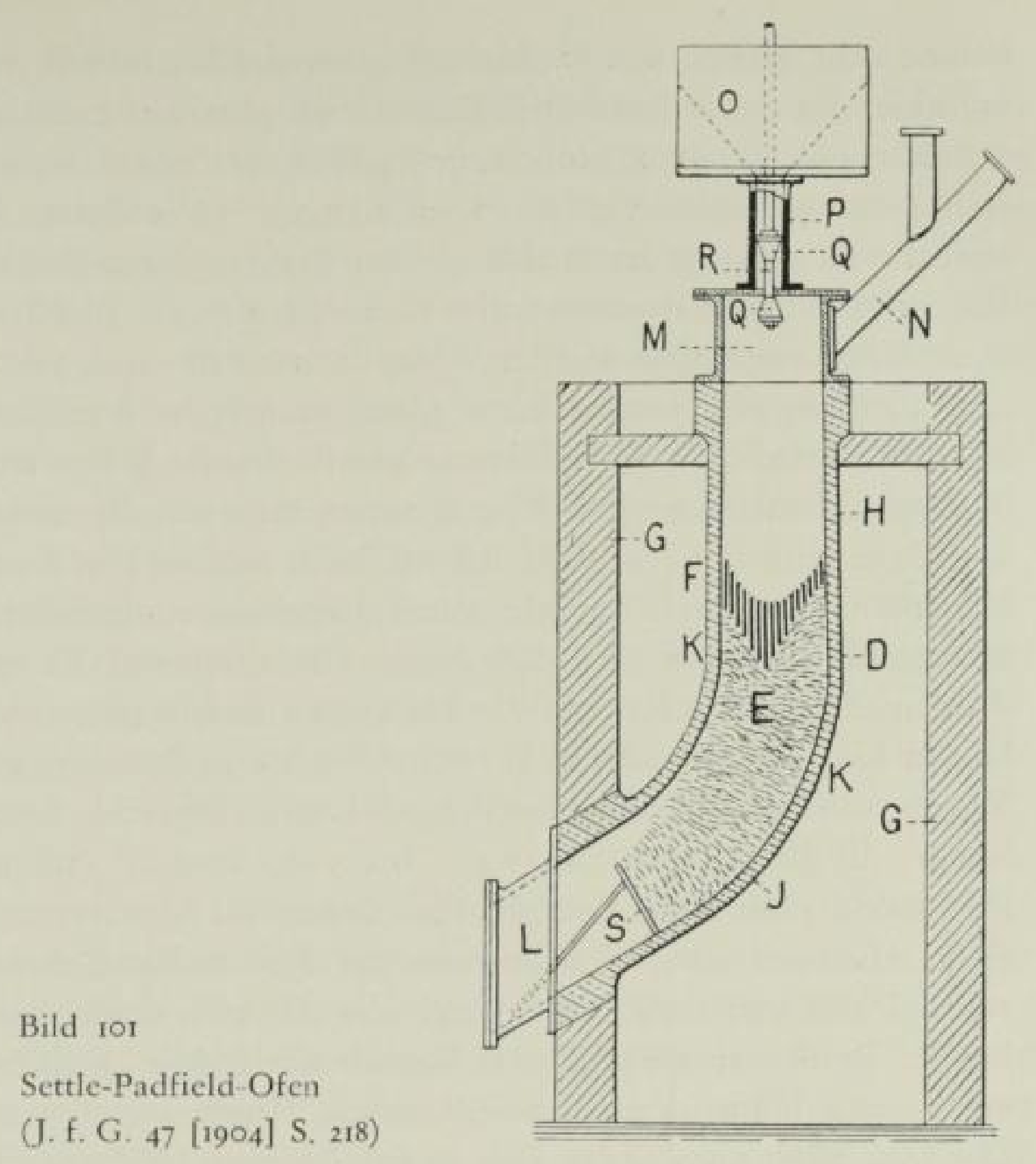

Ein Anfang war in England der Settle-Padfield-Ofen mit senkrechter unten aber schräg abgebogener Retorte mit kontinuierlichem Durchgang ${ }^{5.106}$ ) und Wassergaseinleitung, die die Teerbildung verhindern sollte (Bild Ior). Sie erregte grołes Aufsehen, lockte viele Besucher an, ihr geringer Unterfeuerungsbedarf wurde gelobt $\left.{ }^{5.100}\right)$. Ja, es gab sogar abfällige Vergleiche mit den deutschen stehenden Retorten, aber im Jahre 1906 kamen Nachrichten aus Cleethorp, die eine Fachzeitschrift als "nicht ermutigend" bezeichnete ${ }^{\text {s.105 }}$ ). Vor allem die kontinuierliche Speisung in kleinen Menge mußte aufgegeben werden. Dadurch aber war der Koks schwer herauszubringen. Probeöfen liefen in Rotterdam und Tegel bei den Berliner Städtischen Gaswerken.

Einen für mehrere Jahre sich auswirkenden überraschenden Erfolg erarbeitete J. B ue b für die Deutsche Continental-Gas-Gesellschaft mit der senkrechten Retorte. Das erste Patent wurde am 29. Juli 1903 (D.R.P.Nr. 167367) nach Vorversuchen genommen $\left.{ }^{5.100}\right)$. Nach den herrschenden Anschauungen aahm man an, daf̧ unten in den Retorten entwickelte Gas in Kanälchen zwischen der Ladung und den Wänden hochsteigen würde und sich dabei die Teerdämpfe zersetzen würden. Daher wurden auch zunächst seitliche Abzüge für das Gas nach unbeheizten Kanälen vorgesehen $\left.{ }^{5.110}\right)$. Damit hatte man aber Schwierigkeiten, dic Kohle gleichmäfjig vom Umfange her zu erhitzen, wodurch der Unterfeuerungs-

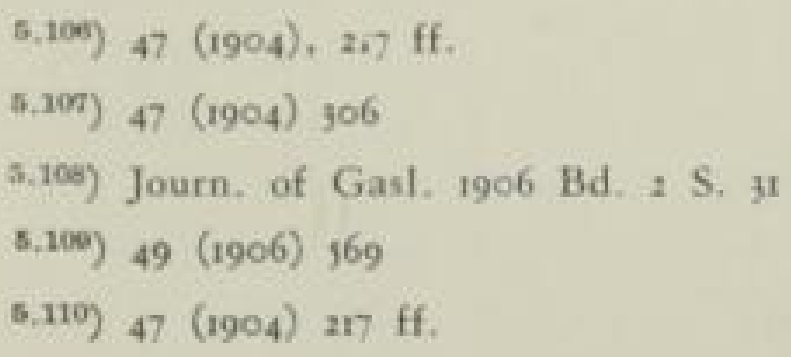


bedarf sehr erhöht wurde. Natürlich wurde der Bauart vorgehalten, dał es sich um eine alte Sache handele $\left.{ }^{5 .+11}\right)$. Bueb lief aber nicht viel verlauten, sodaf bereits Gerüchte über einen großen Fehlschlag verbreitet werden konnten; vielmehr stellte er das neue Verfahren erst nach vollendeter Entwicklung vor. Die seitliche Absaugung hatte sich als unnötig erwiesen. Bei höherer Temperatur am Fuf̧e der Retorte wanderte die Teernaht, die als plastische Masse für Gas undurchlässig angesehen wurde, V-förmig langsam nach oben. Die ersten an schwerem Kohlenwasserstoff reichen Gase gingen in der noch kühlen Mitte unzersetzt nach oben $\left.\left.{ }^{5.112}\right),{ }^{5.119}\right)$. Diese Theorie wurde später nach längeren Versuchen in Amsterdam bezweifelt. Man glaubte, dał nur die dichte Füllung der Retorte die Gase schnell nach oben steigen lasse und so die Zersetzung verhindere ${ }^{5.14}$ ). Wie dem aber auch sei, die guten Ergebnisse gegenüber den Horizontal- und Schrägretorten bereiteten allgemein Uberraschung. Es ergaben sich folgende Zahlen. Füllung je Retorte 500 bis $550 \mathrm{~kg}$ Kohle (gegen $\sim 160 \mathrm{~kg}$ bei der $3,5 \mathrm{~m}$ langen Horizontalretorte); Ausstehzeit 8 bis 10 Stunden, $400 \mathrm{~m}^{3} \mathrm{Gas} /$ Retorte und Tag; 310 bis $330 \mathrm{~m}^{3} / \mathrm{t}$ Kohle (bei trockenem Betrieb), Leuchtkraft. war höher als bisher; Verbrenungswärme 5400 bis $5100 \mathrm{kcal} / \mathrm{m}^{3}$ ( $\left.15^{\circ} 760\right)$, Koksausbeute bei Ruhrkohle $71 \%$; Koks war deutlich besser als bisher; $77,9 \%$ Grołkoks und 3,8\% Grus. Unterfeuerung $14 \%$ bezogen auf Kohle. Mehr Ammoniak, weniger Cyan, sehr leichter und mehr Teer, Naphtalin nur $50 \%$ des üblichen. 2 Mann Bedienung für ro Retorten; verringerter Raumbedarf. Alle Kohlensorten mit Ausnahme einer stark blähenden Oberschlesischen Kohle konnten gut verarbeitet werden. Das Gas blieb nur $1 / 5$ der Zeit in der Retorte. Heißzerer Ofengang als früher war üblich $^{5.115}$ ). In den laufenden Betrieb wurden in Dessau 2 Öfen am 31. Mai 1905 eingesetzt.

Die Entwicklungsarbeiten waren von der Deutschen Continental-Gas-Gesellschaft gemeinsam mit der Imperial Continental Gas Association, Berlin, durchgeführt, - nebenbei ein Beweis, wie gut die englischen und deutschen „Kapitalisten" der beiden grof̧en Gesellschaften, die als schärfste Wettbewerber aus nationalen Interessen begonnen hatten, sich zu vertragen inzwischen gelernt hatten. Aus dem Betriebe einer zweiten Anlage in Mariendorf konnte E. Kö rt ing alsbald die ersten Zahlen bekanntgeben $\left.{ }^{\text {s.110 }}\right)$. Die Öfen zeigten sich leichter regelbar als die Schrägretortenöfen, Teermenge 4,2 v. H. in guter Qualität. Ammoniakwasser $3,34 \mathrm{~kg} / \mathrm{t}$ gegen $2,24 \mathrm{~kg} / \mathrm{t}$ in den Schrägretortenöfen. Die Gasmengen und Heizwertzahlen lagen je nach der Kohlenart in den von $B u e b$ schon angegebenen Grenzen.

Die Herstellung von Wassergas durch Dampfen in der Retorte wurde anschlief̧end ausgeführt. Sie erwies sich je nach dem ermittelten Heizwert als auferordentlich anpassungsfähig. In einem gemeinsamen Bericht der beiden Gasgesellschaften wurde festgestellt, daß der Schwefelkohlenstoffgehalt im Gase bei stehenden Retorten wesentlich geringer wäre als bei den älteren Anordnungen ${ }^{5,117}$ ). Versuche

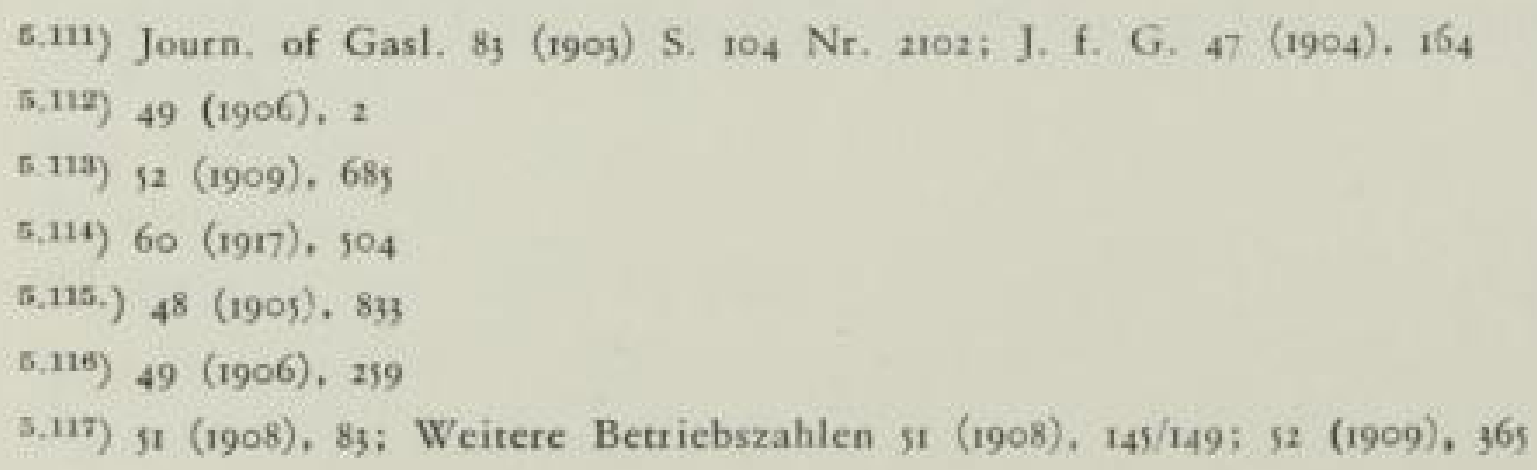


bei diesen Ofen, durch Verbindung zweier Retorten zu Kammern zu kommen, ergaben schlechtere Ausbeuten, man ging den umgekehrten Weg, statt 6 Retorten auf der gegebenen Grundfläche 9 Stück aufzubauen und erzielte noch bessere Ergebnisse $\left.{ }^{\mathrm{sin}}\right)$. Heute, nachdem die weitere Entwicklung zu übersehen ist, kann man annehmen, dał̧ hier wohl Umstände, die in der Benutzung der bereits vorhandenen Unterbauten lagen, einen falschen Weg gewiesen haben. Damals allerdings wurden mit $2 \times_{9}=18 \mathrm{er}$ Öfen und erhöhten Retorten tatsächlich bessere Ergebnisse erzielt. Die Unterfeuerung vor allem sank auf 12 v. H.

Die Verbreitung von Vertikalretortenöfen ging außzerordentlich rasch vor sich. Es seien aber nur wenige Werke herausgegriffen: Hamburg, Aschaffenburg ${ }^{5.117}$ ), Magdeburg ${ }^{5.120}$ ), Genua, Charlottenburg $\left.{ }^{5.12}\right)$, Zürich ${ }^{5.129}$ ).

Natürlich waren auch andere Ingenieure auf dem gleichen Gebiete tätig oder traten zum Kampfe an. J. H a s se, Berlin, liefz sich eine stehende Retorte mit Hohlzylinder zur inneren Absaugung patentieren (D.R.P. Nr. I63533 vom 4. Juni 1903), die aber keine Bedeutung gewann $\left.{ }^{5.12 \pi}\right)$. A. Klönnes Nichtigkeitsklage wurde beim Patentamt 1908 abgewiesen ${ }^{5.124}$ ) und ein Jahr später auch die Berufung beim Reichsgericht ${ }^{5.125}$ ).

C. Bolz, Budapest, setzte die Vertikalretorten hoch und die Generatoren darunter ${ }^{5,130}$ ), um sofort den heiß̧en Koks aufnehmen zu können. Auch der später mehrfach gebaute Pintsch-Bolz-Ofen ${ }^{\text {n.127 }}$ ) unterschied sich von den Öfen ,anderer Konstruktion" hauptsächlich durch die Lage der Einzelgeneratoren und die Anordnung von Einzelschornsteinen ${ }^{5.125}$ ). Ergebnisse waren im Naf3betrieb 382 $\mathrm{m}^{3} / \mathrm{t}$ mit $\mathrm{H}_{0}={ }_{1} 100 \mathrm{kcal} / \mathrm{Nm}^{3} ; \mathrm{s}=0,4 \mathrm{r}$. Unterfeuerung ${ }_{14} \mathrm{~kg} \mathrm{Koks} / 100 \mathrm{~kg}$ Kohle. Ein Patentprozeł der Dessauer Vertikalofengesellschaft gegen Pintsch endete mit ciner Feststellungsklage, dał die Pintschretorten oben $1 / 2 \mathrm{~m}$ umgefüllt und mit über $700^{\circ} \mathrm{C}$ betrieben werden müften ${ }^{5,129}$ ). Das behinderte aber ihren Verkauf nicht.

Ungefähr gleichzeitig mit J. Bue b beschäftigte sich $\mathrm{H}$. Wo o d a ll, Southampton, mit der senkrechten Retorte. Man hat über die Priorität von Bueb oder Woodall gestritten - wohlgemerkt nicht die beiden Konstrukteure miteinander -, aber dieser Streit ist sinnlos. Beide haben ihre ersten Patente im Jahre 1903 genommen, die Buebschen Darstellungen lassen allerdings vermuten, daf̧ eine längere Vorarbeit geleistet sein muß3te. Woodall begann 1902. Die Sache lag aber tatsächlich in der Luft. Auf den Einfluf̧ des Glühlichtes für die Beurteilung des Gases ist bereits mehrfach hingewiesen. Die senkrechte Kohlenbewegung war in den Generatoren und insbesondere den Wassergasgeneratoren schon gegeben.

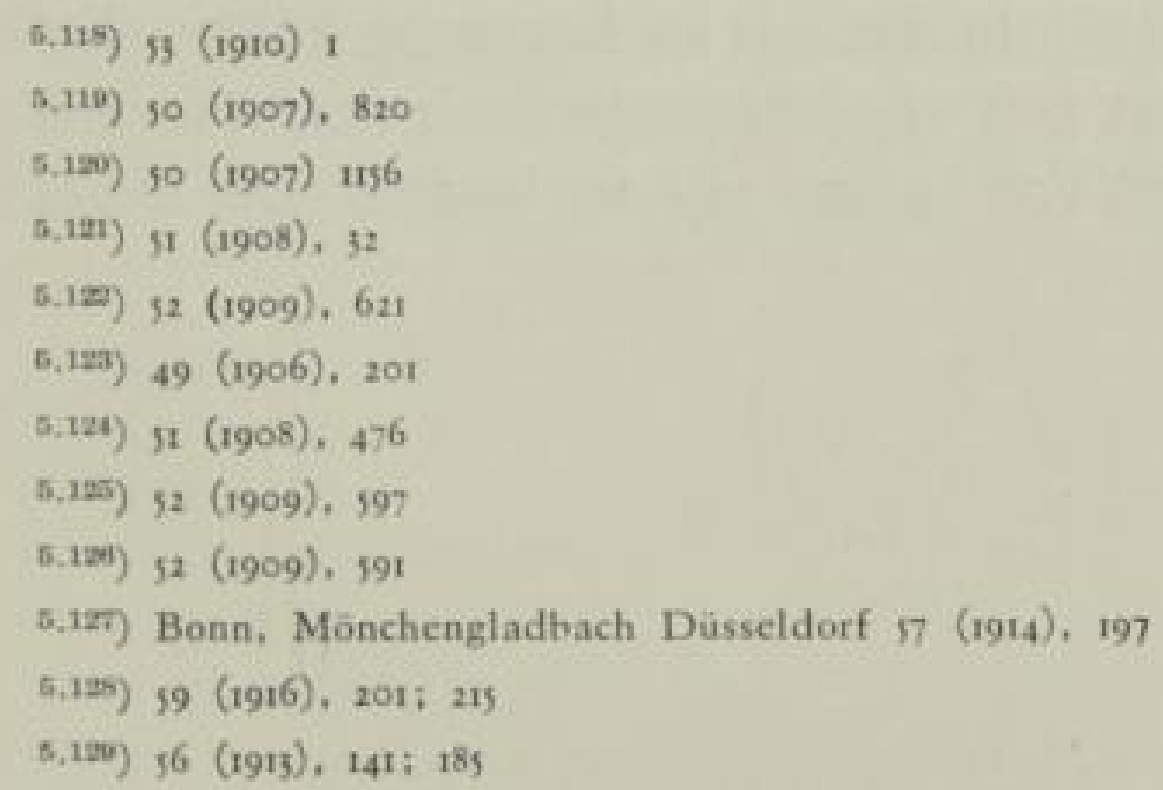


Dabei war die größere Sauberkeit gegenüber dem Betrieb der Retorten bereits angenehm aufgefallen. H. S $t$ racbe hatte nun schon 1894 auf die restlose Vergasung von Kohlen mit Hilfe von Wassergas aufmerksam gemacht ${ }^{6.130}$ ). An die Verbindung der Entgasung und der anschliefyenden Wassergaserzeugung in einem Gerät hatte er damals noch nicht gedacht. 1898 aber berichtete er auch davon, daf3 er dabei sei, Kohlen über Wassergas zu vergasen ${ }^{5.131}$ ), (Vgl. S. 217/18., Bild sI) und E. Besemfelder, Charlottenburg, theoretisierte I9or über die Verbesserung des Wirkungsgrades des kombinierten Wassergasverfahrens für Kohle. Die von ihm vorgeschlagene Schwelretorte mit Zwischenturm für 6 Generatoren wäre allerdings wohl nicht betriebsfähig gewesen $\left.{ }^{5.139}\right)$. Die verlockenden Aussichten: I. Arbeitsersparnis bei senkrechter Stellung einer Retorte, 2. Sauberkeit beim dauernden Nachfüllen waren also allgemeiner bekannt. Der Gedanke, nur die fühlbare Wärme des unten angekommenden Kokses zur Wassergaserzeugung auszunutzen, und die das Verfahren erschwerende Wiederaufheizung des Kokses zur restlosen Umsetzung in Wassergas (verbunden mit einer Verringerung des Heizwertes der gemischten Gase) fortzulassen, war naheliegend. Es bedurfte allerdings eines mutigen Konstrukteurs mit den Fähigkeiten und Kenntnissen eines alten Betriebsleiters und mit der für das Neue notwendigen Phantasie, um zu brauchbaren Lösungen zu kommen. Die gröfte konstruktive Schwierigkeit war offenbar der gasdichte untere Abschluf der Retorte, auf dem die ganze Last lag. $B u e b$ löste die Aufgabe in Anlehnung an den Mortonverschlufy. H. Woodall und A. Duckbam griffen zur dauernden Koksaustragung (Bild I02). Woodall berichtete später, dał seine Versuche im Jahre 1902 begannen, als die Bournemouth Gas and Water Co. die Poole Gas Co. angekauft hatte. 1903 wurde die erste Versuchsanlage errichtet, danach in mühevoller Arbeit die Koksabführung verbessert ${ }^{5,15}$ ). 1904 wurde er von deutschen Fachleuten besucht. Er zeigte freimütig das nach 8 -monatigem Versuchsbetrieb Erreichte: Koksaustragung ohne Staub und Dampf. Der Heizwert des Gases würde gegen trockene Entgasung sinken. Betriebszahlen konnten noch nicht gegeben werden $\left.{ }^{5.131}\right)$. 1907 war auch je eine Anlage auf dem Nine Elms Werk der Gas Light and Coke Co. und im Werk Linacre der Liverpool Gas Corporation im Betriebe ${ }^{5.155}$ ). H ult$m$ a $n n$, Stockholm, nannte für die erste zufriedenstellende Ausführung das Jahr $\left.1908^{5,135}\right)$ mit Retorten von $0,6 \times 0,25 \mathrm{~cm}$ oben, $0,75 \times^{\circ} 0,56$ unten und $7,60 \mathrm{~m}$ Höhe. Die Ergebnisse waren je nach der Betricbsweise verschieden, zum Teil selbst für englische Gaskohlen unwahrscheinlich hoch: Zuerst $529 \mathrm{~m}^{3} / \mathrm{t}$ mit I4 $_{4}$ HK Leuchtkraft. $1905514 \mathrm{~m}^{3} / \mathrm{t}, 13,7 \mathrm{HK} .1907368 \mathrm{~m}^{3} / \mathrm{t}, 16, \mathrm{I} \mathrm{HK}$. Nine Elms $347 \mathrm{~m}^{4} / \mathrm{t}$, $18, \mathrm{I} \mathrm{HK}$, $\mathrm{H}_{0}=5300,6 \%$ Stickstoff. Die Beheizung zu verbessern, war noch nicht gründlich bearbeitet. $\mathrm{Zu}$ verbreiteten Kritiken führte die I9II in Lausanne aufgestellte Anlage (Bild 103). Zunächst war man dort zufrieden besonders mit französischen Kohlen, die einen Unterfeuerungsaufwand von ${ }_{4} 4$ und ${ }_{12} \%$ verlangten. Der Koks

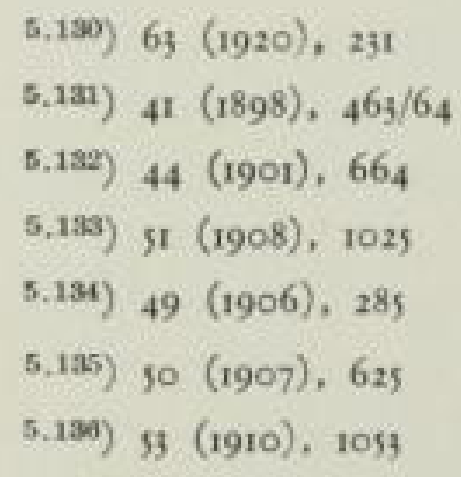


Bild 102

Erste kontinuierliche Retorte von Woodall und Duckham

(Gas-Journ Cent. [1949] S. 104)

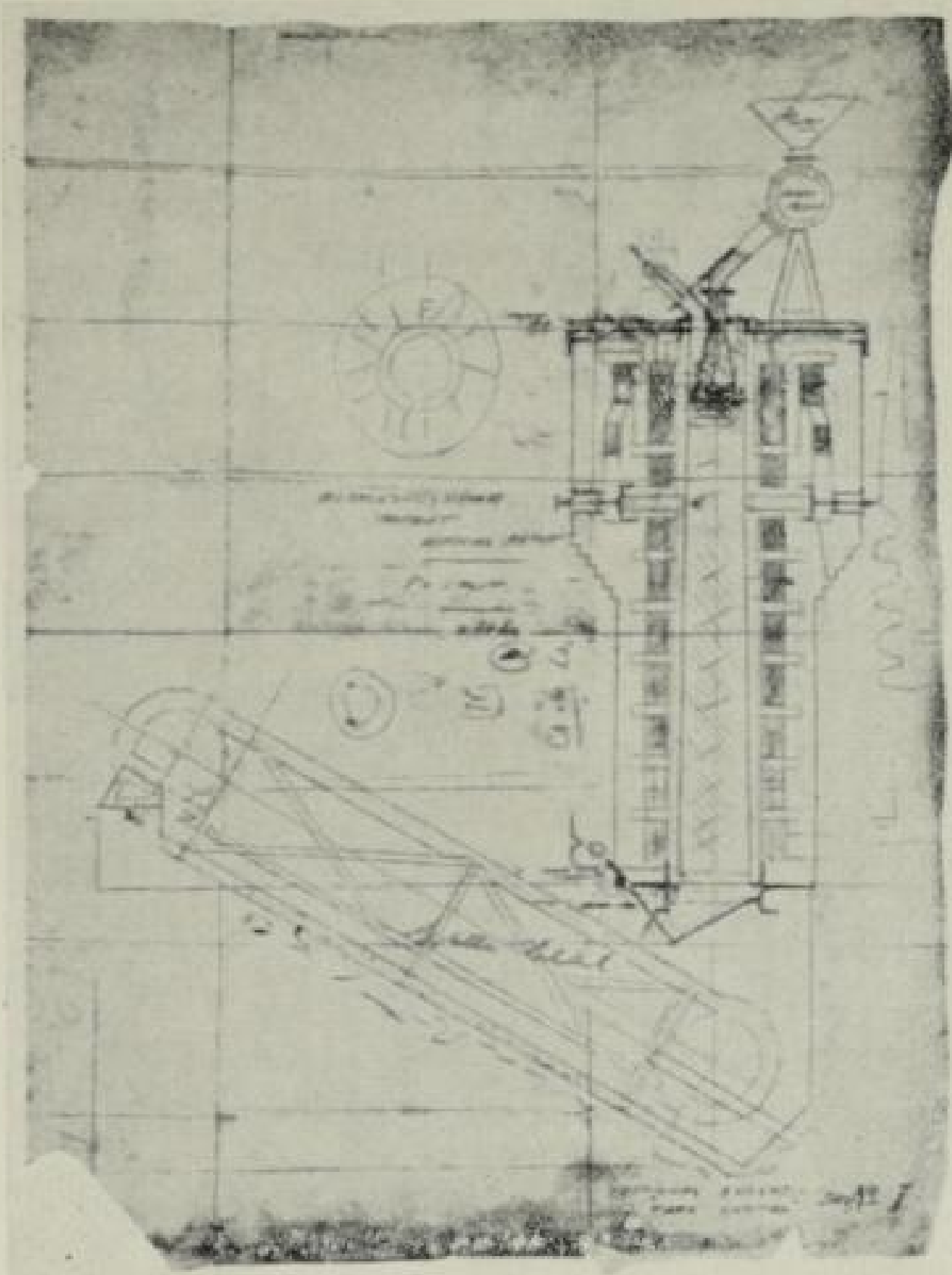

war gut, der Teer dünnflüssig und wurde bei Gebr. Sulzer, Winterthur, in Dieselmaschinen versucht $\left.{ }^{5.137}\right)$. Später wurde dieses gute Urteil zurückgenommen, die Betriebsschwierigkeiten seien auß3erordentlich groł gewesen ${ }^{5.125}$ ).

Eine aus Schweizer Zeitungen übernommene Äuß̧erung, die Firma sei mit dem Bau von Betriebsanlagen zu hastig vorgegangen, wurde von den Engländern

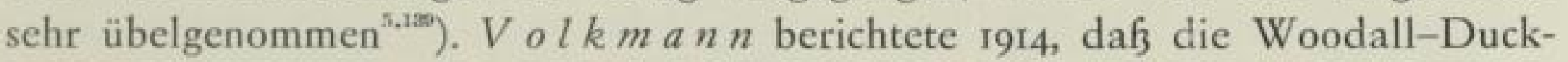
ham-Öfen sich in England viel weiter verbreitet hätten, als man in Deutschland geglaubt habe, und dał sie vor allem auch mit vergrößzerten Profilen einwandfrei arbeiteten ${ }^{\text {s.tal }}$ ). Busse, der Leiter der Kaolin- und Schamottewerke Adolfshütte, hatte Versuchsanlagen mit englischer Hilfe für Berlin und Dresden entwickelt und danach den bekannter gewordenen Kammerofen für Dresden mit $50000 \mathrm{~m}^{\mathrm{s}} /$ Tag Leistung gebaut $\left.{ }^{5.14}\right)$.

Die Arbeiten von W. M. Young und S. Glover wurden in Deutschland erst später beachtet. Als Vorbild hatten die Ofen zur Schwelung von Ölschiefer, wie sie die Paraffinindustrie in Schottland benutzte, gedient ${ }^{5.142}$ ). Nach englischen Berichten haben Glover und West mit einer unterbrochen arbeitenden Retorte die ersten Schritte getan ${ }^{5.143}$ ). Die dauernd durchgehenden Öfen von

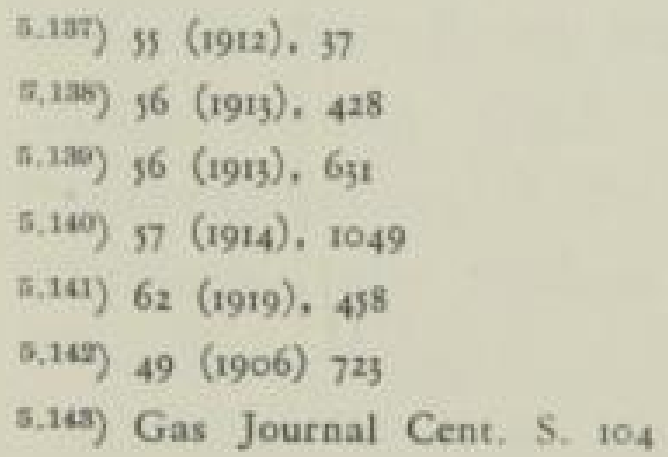

\section{SLUB}




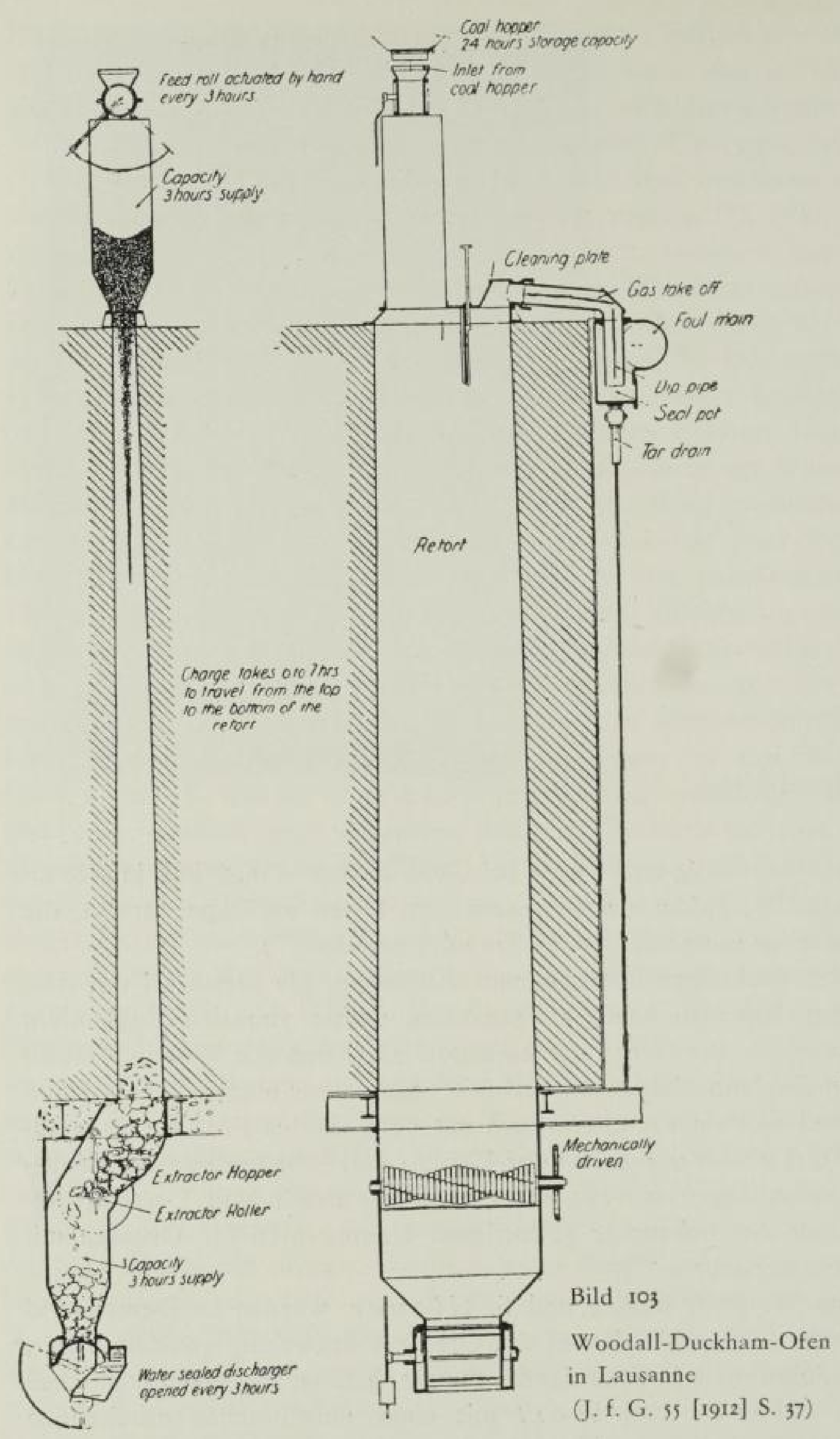

Th. Glover, Norwich wurden, wie es auch bei den Vertikalretorten Buebs der Fall war, unten heifsser betrieben als oben. Sie erhielten um die untergebaute Kokskammer einen Wassermantel zur Dampferzeugung. Auch minderwertige Kohle ergab einen guten Koks ${ }^{5.14}$ ). Den Bau der Öfen nach Glover-West übernahm 1913 die Dessauer Vertikalofengesellschaft. Eine Anlage zum Vergleich

\subsection{4) $49(1906), 810$}

\section{SLUB}


mit den unterbrochen arbeitenden Retorten wurde im Gaswerk Mariendorf erbaut $\left.{ }^{5.115}\right)$.

Im übrigen ist aber die „kontinuierliche“ Retorte in Deutschland wenig eingeführt worden, im Vergleich zu der überragenden Bedeutung in England. Die Ansprüche an den Koks, der in Deutschland für Füllöfen und Zentralheizungen brauchbar sein mufzte und stets in scharfem Wettbewerb mit dem Zechenkoks gestanden hat, mögen eine Rolle gespielt haben. Auch waren die Öfen für Kohlensorten empfindlich und diese wechselten in Deutschland je nach den Konjunkturen und Frachtverhältnissen oft genug. Es war nie ganz leicht, preisgünstig gerade eine passende Sorte dauernd zu erhalten.

Hauptsächlich aber wandten sich die deutschen Ofenbauer den Kammeröfen zu, die sich in den Kokereien der Zechen bestens bewährt hatten.

Der erste Gaswerkskammerofen, der von Baufirmen angeboten wurde, ist der Schrägkammerofen von Ed. Riepe \& Co., Braunschweig, mit Kammern von $3 \mathrm{I} / 3$ t Fassungsvermögen, $480 \mathrm{~mm}$ Breite, 12stündiger Entgasungszeit (den Vertikalretorten entsprechend) und 6 Kammern in einem Block ${ }^{5.145}$ ). Auffallend ist die unterschiedliche Höhenlage von je 2 Kammern, ,um beim Füllen der unteren Kammer den Gasausgang nicht zu verlegen, vor allem aber um den anfangs bei geringer Temperatur unten gebildeten Teer zu vergasen", eine Bemerkung, die man trotz eines Bildes nicht mehr zu verstehen vermag. Am oberen Ende der Kammer befand sich ein Verschluf zur leichteren Beaufsichtigung, zur Entfernung des Graphits und zur Wassergas- (nicht Wasserdampf-)einführung. Es handelte sich also offenbar um eine Autokarburation des Wassergases (siehe S. 358) und wahrscheinlich um die Zersetzung im freien Kammerraum über den Kohlekuchen zu mindern. Das Blasegas des getrennten Wassergasgenerators sollte zur Kammerheizung dienen. Dieser an sich mit viel Liebe erdachte, daher aber auch reichlich verwickelte Ofen scheint nicht ausgeführt zu sein.

Im Jahre I9or fügte H. Ries, München, in einen alten Retortenofen Schrägkammern als Versuch ein. An der unteren Tür wurde mit Zwischenraum eine Platte eingesetzt, um die Ladung von der unmittelbaren Berührung mit der Tür abzuhalten. Die Kammer erhielt 1,6 t Fassungsvermögen, wurde aber später nicht ganz gefüllt, wodurch der Unterfeuerungsaufwand erhöht wurde. Die Beheizung auf $1100-1300^{\circ} \mathrm{C}$ in den Zügen gelang befriedigend gleichmäf̧ig, wurde aber später verbessert. Die Leuchtkraft des erzeugten Gases war zunächst um 8-10\% geringer als bei den Retorten, der Heizwert um 6\%. Die Absicht, später gegen Ende der Entgasung Dampf zur Wassergasbildung einzuführen, wurde gleich ausgesprochen $^{\text {n.t. }}{ }^{\text {in }}$.

Aus dem Jahre 1904 stammte ein Patent von Gustav Horn. Braunschweig (I44 579), der der Kammer nur den schrägen Boden gab, die Decke aber waagerecht legte und das Gas aus dem sich so ergebenden hohen unbeheizten Raum absaugen wollte. Ausgeführt wurde ein solcher Ofen offenbar nicht ${ }^{5.145}$ ).

Zwischen den Anhängern der Vertikalretortenöfen und der Schrägkammeröfen

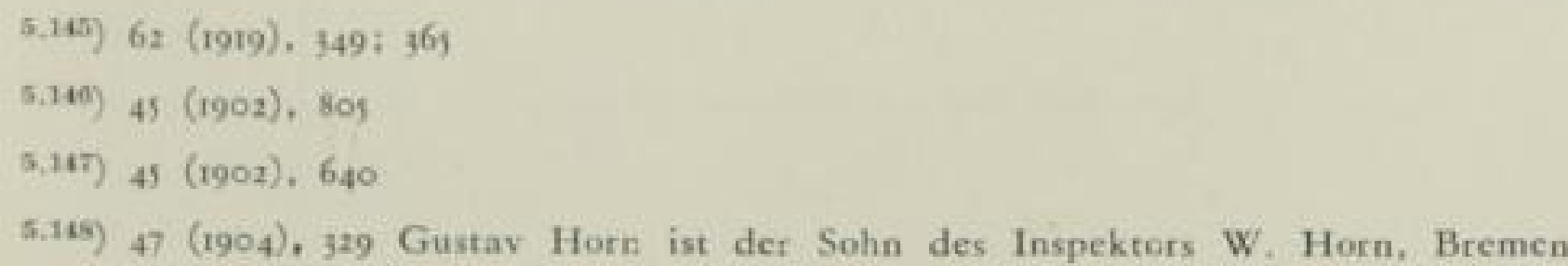


kam es zu lebhaften Auseinandersetzungen, vor allem auf der Hauptversammlung des Vereins 1908 in Berlin ${ }^{5.14}$ ). Beide Systeme hatten sich verbreitet, und jeder Gaswerksleiter trat lebhaft für „seinen“ Ofen ein.

Natürlich beteiligten sich daran auch die Ofenbaufirmen, die bereits Kokereiöfen ausgeführt hatten. H. Koppers. Essen, lieferte für Bochum einen Schrägkammerofen, bei dem nur die unteren $2 / 3$ der Wände beheizt wurden, nicht aber Boden und Decke $\left.{ }^{5.150}\right)$. W Wien-Simmering erbaute 1907 die erste Koppers-Schrägkammerofenanlage mit Zentralgeneratoren - nach System Duff mit festen Pultrosten. 1910 folgten Koppers Horizontalkammeröfen mit regenerativer Beheizung. In den Zentralgeneratoren wurden Kerpelyroste verwandt, nach Anregungen von K. Mariscbka wurden sie mit Dampfmantel und die letzte Serie für Leopoldau mit Hochdruck-Dampfkesseln (6 atü) mit Röhrenkörper im Gasabgange versehen. Damit sank die Unterfeuerung auf $\left.10 \%{ }^{5.515}\right)$.

Der Schrägkammerofen wurde nunmehr von mehreren Firmen nachgebaut. $\mathrm{K} n o c b$ \& Co., Lauban, entwickelten einen solchen in Zusammenarbeit mit der Thüringer Gasgesellschaft, Leipzig ${ }^{5.152}$ ). Für Rotterdam baute A. Klönne seinen ersten Gaswerkshorizontalkammerofen $\left.{ }^{5,150}\right)$. Als erstes Werk, das sich ganz auf den Horizantalkammerofen verlief, ist Innsbruck zu nennen, das von Koppers, Essen, beliefert wurde. Nach 3 Monaten wurden die folgenden Betriebszahlen ermittelt: $327 \mathrm{~m}^{3} / \mathrm{t}$ von $5287 \mathrm{kcal} / \mathrm{m}^{3}$, Unterfeuerung $16,4 \mathrm{I} \mathrm{kg}$ Koks $/ 100 \mathrm{~kg}$ eingesetzte Kohle.

Alle diese Ofenarten wurden vielfach ausgeführt. Eine Aufzählung im einzelnen würde zu weit führen. Der Streit der Meinungen war lebhaft. Die Vertreter der Kammeröfen betonten besonders die lange Ausstehzeit von 24 Stunden, die eine Arbeit in nur einer Schicht ermöglichte. Der Aufwand und die Leistungen wurden vielfach verglichen, wobei aber die betrieblichen Sonderbedingungen schwer abgewogen werden konnten. Oft genug waren aber für die endgültige Wahl des Systems Nebenumstände, wie etwa die Kohlenförderanlage oder die Kokslöschvorrichtung entscheidend. Eine Ansicht von A. Peters, Köln, lautete: „Der Horizontalkammerofen ist überall am Platze, wo man über genügenden Raum verfügt und die Mittel zum Bau beschränkt sind, der Schrägkammerofen da, wo man erhebliche Mittel aufwenden muf, um auf engem Raume eine bestimmte Leistung zu erzielen." Das war wohl die Ansicht der Firma $K l \ddot{\partial} n n e$, über deren Öfen Peters sprach ${ }^{5.154}$ ).

Sowohl Vertikalretorten wic auch Kammeröfen wurden vielfach nachbestellt, wo sie einmal Fuß gefaß̧t hatten. Unter den Verhältnissen vor dem großen Kriege muf also der Unterschied im Erzeugnis und in der Wirtschaftlichkeit sehr schwer feststellbar gewesen $\operatorname{sein}^{\text {n.155)}}$. Die Vertikalretorten wurden kaum mehr verändert, waren also im ersten Wurf gelungen, während die Kammeröfen Schritt für Schritt verbessert wurden.

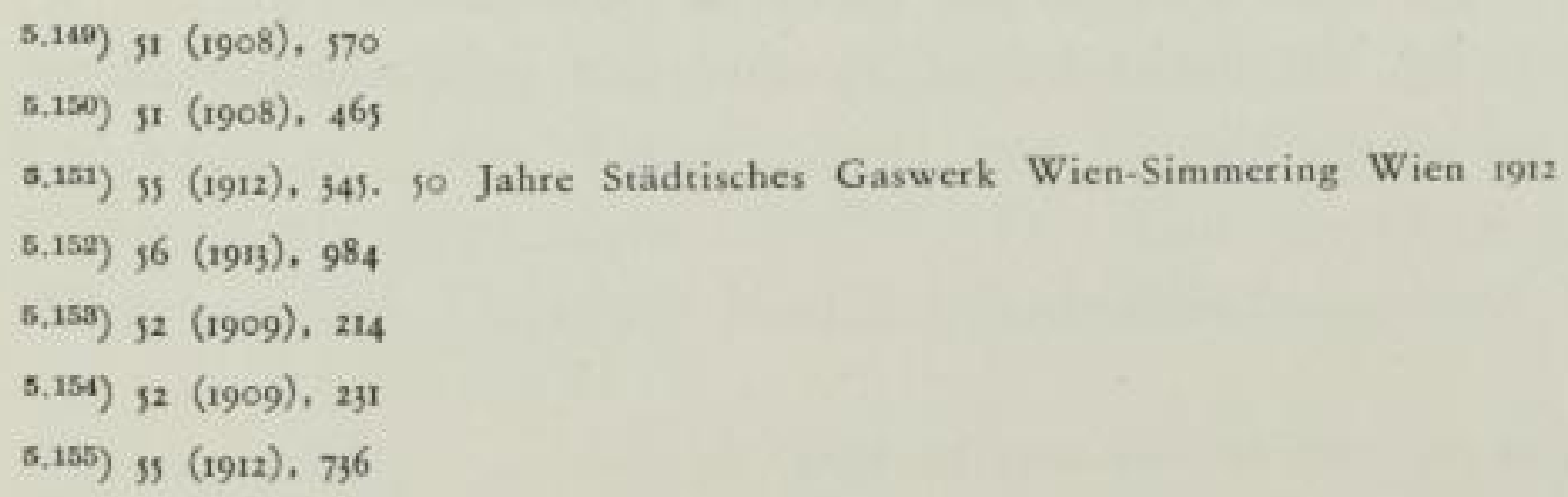


Mit den Vertikalretorten war zum ersten Male die Wassergaserzeugung im Entgasungsraum ausgeführt worden. Dieses Beginnen rief den Widerspruch einzelner Fachleute hervor, die unbedingt die getrennte Entgasung und Wassergaserzeugung vorzogen. Die Hartnäckigkeit und Schärfe der Auseinandersetzungen ist kaum verständlich $\left.{ }^{5.12 \pi}\right)$. Andererseits wurden auch die Kammeröfen vielfach mit Wasserdampfeinführung versehen. Die Hauptentwicklung trat aber erst nach dem groß̧en Kriege ein.

\subsection{Generatorgas}

Die Veränderung der Technik der Generatorgaserzeugung beschränkte sich auf Einzelheiten in der Ausführung der Generatoren. Mit den Kammeröfen wurden auch die Zentralgeneratoren im Zuge der Verminderung der Arbeitskräfte aufgenommen. Historisch sind vielleicht noch die Versuche von J. P intscb anregend, den im Kesselbau damals sich bewährenden Wanderrost auch am Generator einzusetzen ${ }^{5}{ }^{2}$ ). Der in Wien bei Gaswerken von Koppers zuerst eingesetzte Drehrostgenerator war von A. Kerpely, Hüttendirektor in Donawitz, nach einigen Vorbi!dern ${ }^{5.155}$ ) entwickeit. Den Rauchrohrkessel zur Abwärmeausnutzung ersetzte Carl Mariscbka durch den Damptkessel-Generator, der mit 6 atii betrieben wurde (Bild 104 ). Eine Übersicht über die Entwicklung an Hand der Patente von 1884 bis 1904 , dem Drehrost von Kerpely, brachte eine post mortem Veröffentlichung von H. R. Trenkler. dem gründlichen Kenner der Vergasung ${ }^{5,257}$ ).

\subsection{Förderanlagen in den Werken}

Die Förderanlagen für Kohlen und Koks erfreuten sich ganz besonderer Beachtung $\left.^{\text {s.teo }}\right)$. Die Bewegung war hervorgerufen durch die wachsende Größe der Werke, aber auch durch die Vereinfachung des Antriebes durch Elektromotoren. Offensichtlich verärgert wurden auch die wachsenden Ansprüche der Arbeiter und ihre Neigung zur Arbeitsniederlegung bei Auseinandersetzungen genannt. Deshalb sei die Ablösung der Schwerarbeiter erwünschtt, $\left.{ }^{5,101}\right)$. Sicherlich war aber der Anspruch, dał die schwere Förderleistung den neuen Maschinen aufgeladen werden müsse, zeitgemäß̧. Wie sehr ein gewisser Druck in dieser Hinsicht nötig war, möge an einem Beispiel aus etwas späterer Zeit deutlicher werden. Im Gas- und Wasserfach von 1926 beschrieb ein Aufsatz über die Koksverladung u. a. den Einsatz von Gurtförderern in kleinen Werken ${ }^{\text {s.162 }}$ ). Er rief eine Erwiderung hervor, wie mit Behelfsmitteln in Handarbeit weniger Arbeitsstunden

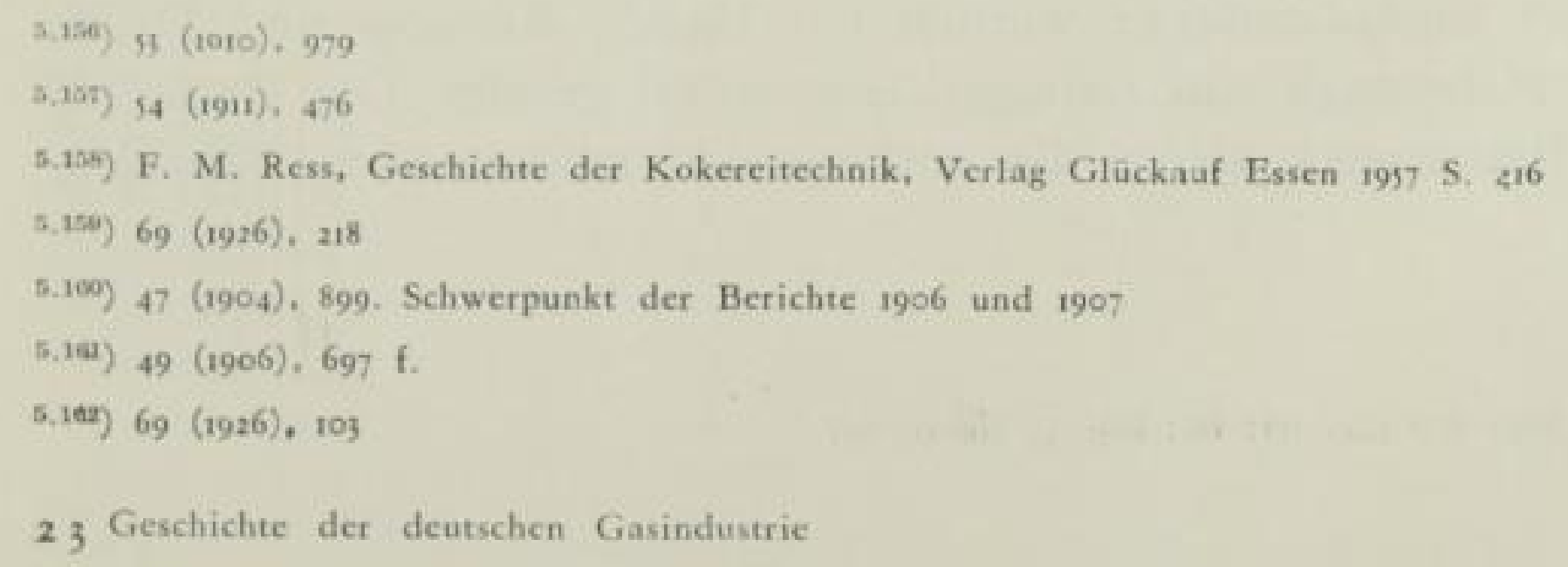




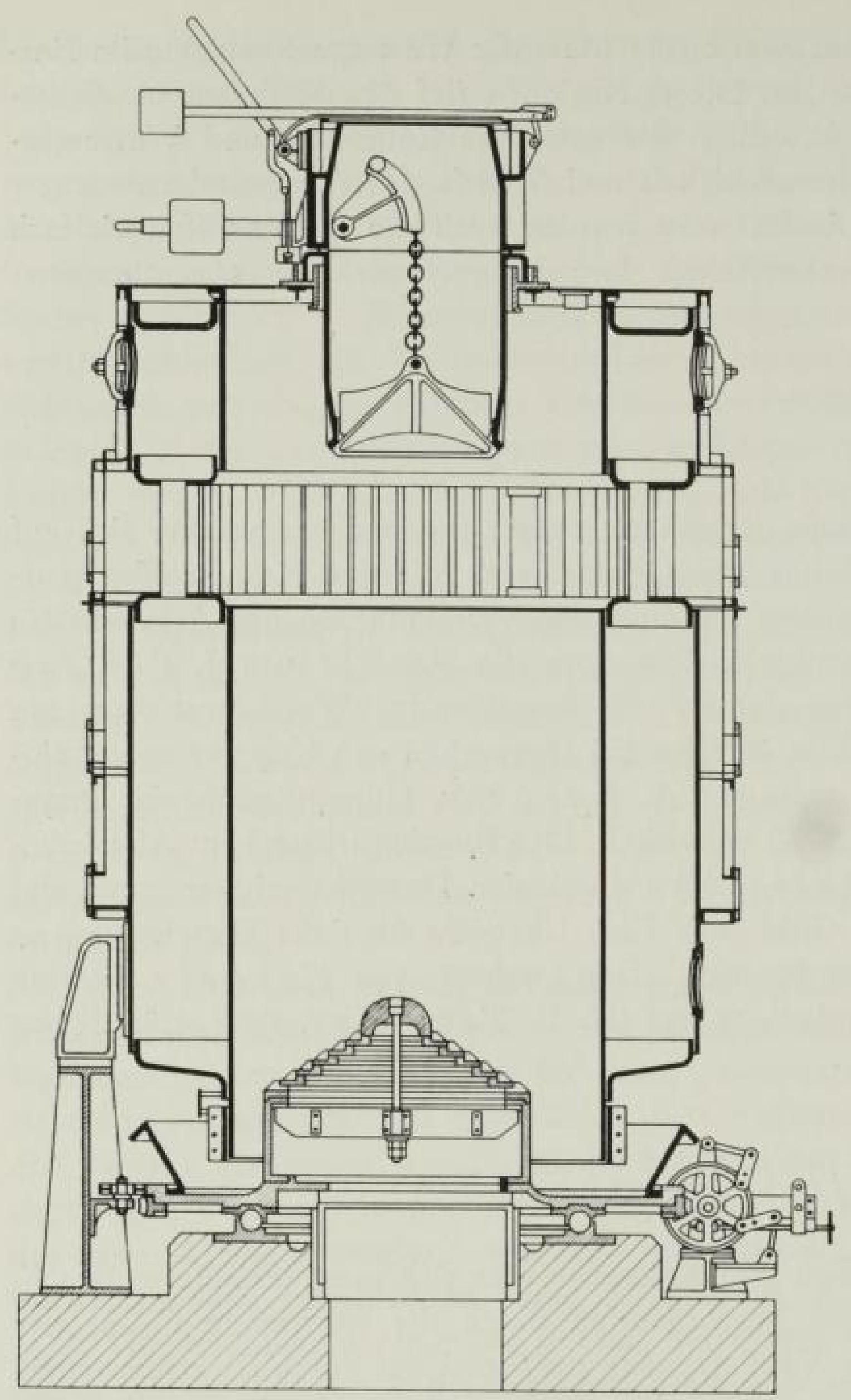

Bild 104

Dampfkesselgenerator von Marischka

E. G. Graf ,Technologie oder Brennstoffe", S. 507. 4. Aufl.)

benötigt würden ${ }^{511 e s}$ ). Übersehen war dabei, dał̧ schwere Kärrnerarbeit der einfachen Bedienung der mechanischen Einrichtungen gegenüberstand.

In Clichy wurden noch Handmulden und Handentladung für Retorten angetroffen, Maschincn waren zur Koksaufbereitung eingesetzt ${ }^{\text {, } 144}$ ). Sehr betont wurden die mechanischen Fördereinrichtungen eines neuen Gaswerkes in Charlottenburg von M. $B u b l e$. Als Fortschritt gegen früher, wo man sich auf waagerechte Förderungen und senkrechte Bewegung mit Aufzügen beschränkt hatte, wurden die schrägen Ebenen mit Bechern und Ketten hervorgehoben $\left.{ }^{5.165}\right)$. Hängebahnen, Lade- und Entladeanlagen wurden mit Hand-, Riemen- und Druckwasserantrieb für Hebezeuge und Reinigerkastendeckel gezeigt. Der Zugseilantrieb unter dem Becherwerk zeigte die vorliegenden mechanischen Schwierig-

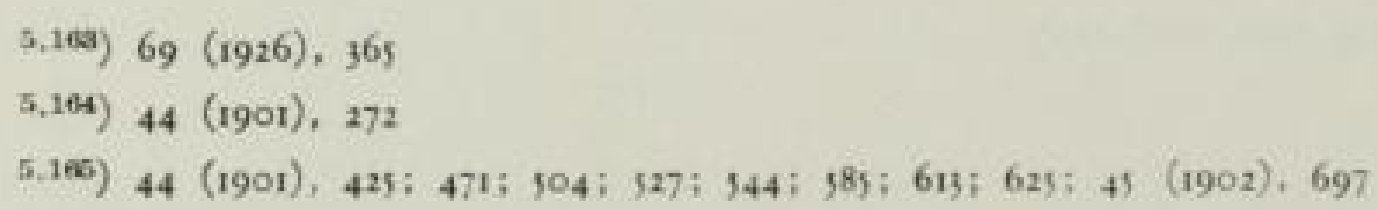

\section{SLUB}


keiten deutlich. Häufig genug wurde den Gaswerksingenieuren der Vorwurf gemacht, daf sie mit der Bevorzugung des rein mechanischen Antriebes, mit Antrieb durch eine Vielzahl kleiner, unwirtschaftlicher Auspuffdampfmaschinen, einen schädlichen Hang zum Aiten oder gar eine lächerliche Feindschaft gegen die Elektrizität, als dem Wettbewerber in der Beleuchtung entgegengebracht hätten. Man sollte dabei aber nicht vergessen, dał um die Jahrhundertwende Dreh- und Wechselstrommotoren noch nicht weit entwickelt waren und gerade für Fördereinrichtungen mit hohen Anfahrmomenten nur Gleichstrommotoren empfohlen wurden. Diese aber waren wieder mit ihren Kohlenbürsten im rauhen, staubreichen Betriebe eines Gaswerkes zu empfindlich und pflegebedürftig. Die Funken an den Kollektoren waren im Gaswerk gefährlich.

Die Gaswerke waren aber gar nicht grundsätzlich ablehnend. Schon 1893/1894 war in Lübeck der Elektrobetrieb für Kohlen- und Koksförderer angewandt. Man hatte sogar ein kleines eigenes Elektrizitätswerk, dessen Ausrüstung mit zwei 20 PS „Motoren“ (vermutlich Elektro-Generatoren) allerdings überraschend klein war. Die Gasförderung vom neuen zu den Behältern des alten Werkes geschah mit Elektroventilatoren, dagegen brauchte man zum Heben der Reinigerdeckel noch einen hydraulischen Antrieb. Für schwere Lasten mit geringem Hubweg bei ausreichender Zeit war eben der Elektromotor noch nicht reif, vielmehr wären Übersetzungen mit den damals noch ungenauen Zahnrädern recht geräuschvoll gelaufen. H. A $u m u n d$, damals noch bei Pohlig, Köln, zeigte die Entwicklung, die der Elektromotor hervorrief, an Greifern, „Huntschen Elevatoren" mit Kübeln, und Becherwerken. Beweis für die neu gewonnene konstruktive Beweglichkeit war eine Kokssieberei, die in der Stützsäule einer Verladcbrücke eingebaut war ${ }^{5.16 \%}$.

Das neue Gaswerk in Edinburg-Granton war ganz nach fördertechnischen Leitgedanken angelegt. Es besał zwei Bahnanschlüsse, die im Werk in einem Abstellbahnhof zusammengeführt waren. „,Die Einrichtungen für die Behandlung der Kohlen können vollautomatisch benannt werden." Sie waren ausgezeichnet durch einen großen Kohlenbunker mit einem darunter liegenden Förderband, in den 4 Wagenkipper die ankommenden Züge schnellstens entleeren konnten. Die Regenerierräume waren zur Erieichterung der Bewegung der Massen über den Reinigerkästen angeordnet worden ${ }^{5.177}$ ).

Aus den störungsanfalligen und schwerfälligen Hochbahnen mit Seilantrieb und Seilbahnen entwickelten sich die Elektrohängebahnen ${ }^{\text {5.1ng }}$ ). Mit Kübelförderung und Überbrausen des Kokses lösten sie zur Schonung des Kokses die Förderrinnen ab, besser als kleine Schiffchen, die durch einen Kanal gezogen wurden. ${ }^{5.100}$ ). 1916 und 1917 wurde immer wieder die Elektrohängebahn beschrieben ${ }^{5.170}$ ) und als das beste Fördermittel für Gaswerke gelobt $t^{\text {s.17z }}$ ). Das war auch die grołe Zeit der Führerstandslaufkatze $\left.{ }^{5.112}\right)$. „Großartige Transportanlagen“ wurden für

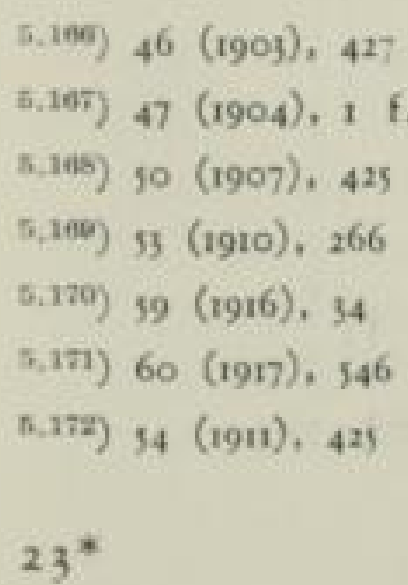




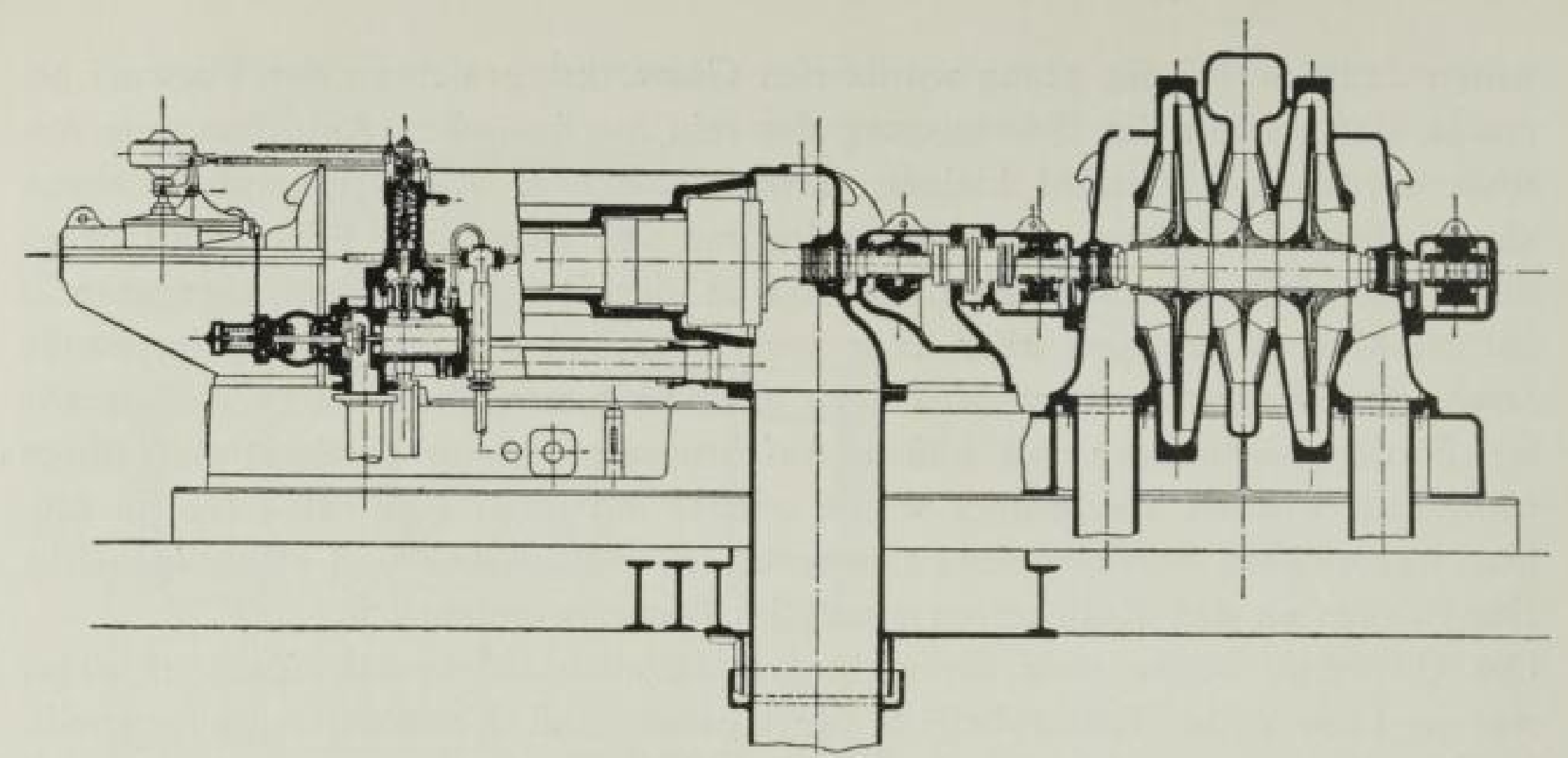

Bild 1os Rateau-Gcbläse für Gasfördcrung (J. f. G. 52 [1909] S. 651)

das neue Gaswerk in Budapest die Verladebrücke, Wagenkipper, Becherwerke und Förderbänder benannt $\left.{ }^{5.123}\right)$. E. $B u b e$, Duisburg, baute selbst einen Schrägaufzug mit 2 Wagen, die nach Art eines Bremsberges, aber übereinander herlaufend, gekuppelt waren ${ }^{5.174}$ ). Die Begeisterung für groß̧e Förderanlagen scheint sich sogar überschlagen zu haben. Bei der grołen Verladebrücke von $70 \mathrm{~m}$ Spannweite für das immerhin kleine Gaswerk Burg mit anschlief̧ender Elektrohängebahn dürfte eine wirtschaftliche Lösung wohl nicht gelungen sein $^{\text {s.t25 }}$ ).

Für Gebläse zur Gasförderung wurden jetzt Kreiselgeblase eingesetzt und mit den neuen Dampfturbinen angetrieben, da die neuen Öfen keinen Dickteer mehr erzeugten $\left.^{5.176}\right)$. Im Rootsgebläse mit Parsonsturbine rieben sich die Kolben bei den damals möglichen Fertigungsgenauigkeiten bei Leistungen von $12500 \mathrm{~m}^{3 /} / \mathrm{h}$ am Gehäuse und wurden heiß̧. Dagegen befriedigten Rateau-Gebläse mit 25000 $\mathrm{m}^{3} / \mathrm{h}$ Leistung selbst bei einem Durchmesser von $1200 \mathrm{~m} / \mathrm{m}$. (Bild 105). Nur die Regelfähigkeit war unvollkommen $\left.{ }^{5,1 \pi}\right)$. Auch als Sauger wurden Rateaugebläse für $5000 \mathrm{~m}^{3} / \mathrm{h}$ mit Lavalturbinen ( $\mathrm{s} 5 \mathrm{~kg}$ Dampf/PSh mit 25 PS Höchstleistung) eingesetzt $\left.^{5.185}\right)$.

\subsection{Wassergas}

Neben dem Steinkohlengas gewann das Wassergas für die Gasindustrie sehr schnell steigende Bedeutung. Zunächst war noch immer der Umstand, daf̧ man mit dem Ausbau der Werke zu lange gewartet hatte und schnell eine Erweiterung erstrebte, małggebend für die Entscheidung $\left.{ }^{5,177}\right)$. Allmählich aber gewann auch die Unterbringung des Kokses eine gewisse Anteilnahme und vor allem die gute Anpassungsfähigkeit an den schwankenden Bedarf und die Deckung

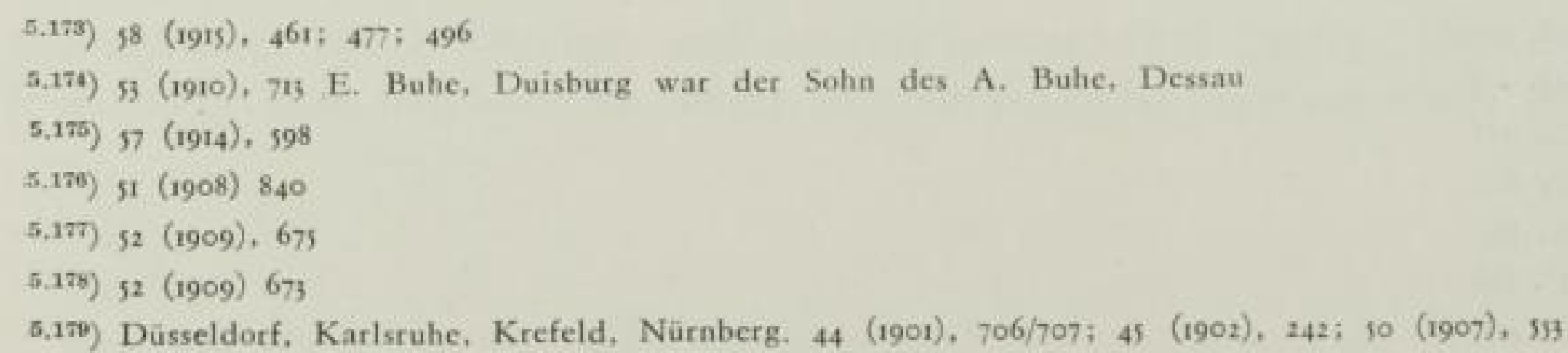

\section{SLUB}


der Bedarfsspitzen mit verhältnismäfig preiswerten Anlagen. Wenn man auch nunmehr wufte, dał eine beschränkte Herabsetzung des Heizwertes durch blaues Wassergas die Glühlichter und Kochgeräte in der Wirkungsweise nicht störten und die Leuchtkraft nicht gemindert wurde, so war man doch zunächst bestrebt, den üblichen Heizwert zu halten, soweit nicht bei privaten Gas-Gesellschaften die Versorgungsverträge mit der Gemeinde das sogar verlangten. In Magdeburg, das sich durch Vortrag bei der Stadtverordnetenversammlung als erste Stadt von den Bindungen freigemacht hatte, empfahl O. Pfe iffer roor noch neben der Heizwertkontrolle die der Leuchtkraft auf jeden Fall beizubehal$\operatorname{ten}^{5.119}$ ). Es zeigte sich, daf̧ man sich Beschränkung mit dem Zusatz von Wassergas auferlegen muf̧te, wenn nicht die Änderung der Brenneigenschaften stören sollte $\left.{ }^{5.151}\right)$.

Am schnellsten wäre man fertig gewesen, wenn man in Deutschland den von Amerika und England gewiesenen Weg der Herstellung von karburiertem Wassergas hätte gehen können. Dem stand aber der hohe Zoll auf Rohöi entgegen. Zwar bewies H. Gerdes, Berlin, an Hand der allerdings sehr unterschiedlichen Betriebsergebnisse, dał selbst bei den in Deutschland herrschenden Ölpreisen ein ölkarburiertes Wassergas billiger scin müsse, als reines blaues Wassergas mit Kohlengas zu mischen und dieses Gemisch mit Benzol kalt zu karburieren $\left.^{5.118}\right)$. Wie indessen der Preis der sehr beschränkten Mengen Gasöls aus den Thüringer Braunkohlenschwelereien sich entwickelt würde, wenn ein grołer Verbrauch einsetzte, war durchaus unklar. Auch spielten in die festgestellten Ergebnisse die Betriebszeiten hincin. Die ,universellere" Heißkarburieranlage war ja viel teurer. Noch aber wurde Wassergas oft nur stundenweise zugesetzt. Magdeburg stellte jedenfalls fest, daf unter den dort gegebenen Preisbedingungen das ölkarburierte Wassergas teurer wurde als das Retortengas. Auf̧erdem beobachtete man Schwierigkeiten im Netz durch Naphthalinauflösungen und Hängenbleiben von Gasmessern, ${ }^{5,187}$ ). Von Pforzheim kamen auch Nachrichten über Schwierigkeiten mit dem benzolkarburierten Wassergas beim Motorenbetrieb. In anderen Werken machte man die kalten Karburiermittel für Anfressungen und Abscheidungen in Gasmessern - ob mit Recht oder Unrecht ist niemals restlos geklärt - verantwortlich $\left.{ }^{5,184}\right)$.

Diese Umstände veranlaf̧ten den Verein, sich sehr lebhaft für die zollfreie Einfuhr von Ölen für Gaswerke einzusetzen ${ }^{5.155}$ ). Auch die einzelnen grof̧en Werke bearbeiteten die maßgebenden Dienststellen. Aber auf diese wirkten wohl noch andere wirtschaftliche Gruppen. Der Steinkohlenbergbau war das vermutlich weniger, umso mehr aber die Verbände der Braunkohlenindustrie, aber auch die grołagrarischen Spiritusbrenner ${ }^{5.186}$ ), worauf man nach den weiteren Erörterungen schlief̧en $m u f^{5,187}$ ). Man woilte auch wohl das Benzin treffen, ohne es der 
chemischen Industrie als Rohstoff zu entziehen. Jedenfalls war der Entwurf zum Zolltarif enttäuschend. Er lautete: „Der Bundesrat ist befugt, zollpflichtige Mineralöle, die für andere gewerbliche Zwecke als die Herstellung von Schmierölen, Leuchtöl oder Leuchtgas bestimmt sind, unter Überwachung der Verwendung vom Eingangszoll freizulassen “"ే.1ss").

Es ist gar nicht auszudenken, in welcher Richtung unsere Energiewirtschaft sich entwickelt hätte, wenn damals die Entscheidung anders gefallen wäre. Vergebens wies mit vielen anderen selbst ein reiner Wissenschaftler wie Prof. C. Engler in Karlsruhe darauf hin, wie man durch Besteuerung des Rohproduktes den Bau von Raffinerieen ausschlief̧en würde ${ }^{5,150}$ ).

Im Handelsvertrag mit Österreich sollte mit diesem Zoll Galizien gegenüber Rumänien, obwohl dort deutsche Besitzer beteiligt waren, begünstigt werden, indem der fast prohibitive Zoll von $10 \mathrm{M} / 100 \mathrm{~kg}$ auf $3 \mathrm{M} / \mathrm{r} 00 \mathrm{~kg}$ herabgesetzt wurde $\left.^{5,+100}\right)$. Erfolg war bei den kleinen Mengen nur der, dał die Verkäufer ihre Preise so hoch setzten, daß das Öl in Deutschland nicht billiger wurde.

Diese Beobachtungen führten noch einmal auf der Hauptversammlung des Deutschen Vereins zu einer angeregten allgemeinen Aussprache. Jedoch kann man sich nicht des Eindruckes erwehren, dafy unverstandene und verschiedene Grundauffassungen und Widersprüche bei der Entgegennahme der Wünsche durch den Vorstand mitgespielt haben. Der den Gaswerken willkommene Petroleumzoll war sicherlich auch gefährdet, wenn, wie angeregt wurde, das Gasöl freigestellt werden sollte $\left.{ }^{5.19}\right)$. So wurde keine klare Meinung herausgearbeitet und die Angelegenheit in einem Ausschuf begraben.

Unter diesen Umständen wandten sich die Fachleute dem Gedanken zu, das Wassergas mit Teerdämpfen anzureichern. Schon $190 \mathrm{O}$ bemängelte E. Be s e mfelder, den schlechten Wärmewirkungsgrad bei der üblichen getrennten Entgasung und anschliefyenden Wassergaserzeugung mit sehr guten theoretischen Zahlen. Die von ihm vorgeschlagene Schwelretorte mit einem Zwischenturm zur Verteilung des Kokses auf sechs Generatoren sieht baulich nicht gerade verlockend aus und ist auch niemals ausgeführt worden ${ }^{5,102}$ ). Vier Jahre darauf machte Besemfelder einen neuen Anlauf. Kohle sei wegen der Teerverunreinigungen ein unmöglicher Rohstoff für den Generator. Er wollte die Kohle in dünner Schicht durch den Entgaser flief̧en lassen, von auf̧en und innen mit den Heißblasegasen aus den Wassergasgeneratoren beheizen, bis sie glühend in die Vergaser falle. Damit war Besemfelder bei den Gedanken von G. Low e (s. S. 148) angelangt ${ }^{\text {s.109) }}$.

Die Bewegung der „Autokarburation" in den Retorten wurde von V. B. Lew es, London, eingeleitet. Er betonte, man brauche das Wassergas nur in richtiger Weise und heif̧ in die Retorten einzuführen, um eine Steigerung der Wertzahl aus Menge und Leuchtkraft zu erhalten. Dabei würden $6 \mathrm{~m}$ lange Retorten ohne schädliche Zersetzung der schweren Kohlenwasserstoffe benutzbar. Die

\footnotetext{
5.188) $44(1906), 736$

a.189) $45(1902), 241 \mathrm{ff}$.

$5,100)$ s० (1907), $387 / 388$

5.191) so $(1907), 825$

$5.192)_{44}(1901), 664 \mathrm{ff}$

$5,183) 4^{8}(1905), 182$
}

$3)^{8}$ 
höchste Wertzahl erhalte man bei Zusatz von 40 bis so Volumenprozenten Wassergas zum Steinkohlengas. Kohlendioxyd würde zu Monoxyd reduziert. Lewes stellte auch bereits fest, dafy gasreiche Kohlen bessere Ergebnisse als arme liefer$\left.\operatorname{ten}^{\mathrm{s.1P}}\right)$. Bis zu einem gewissen Grade war Lewes damit zu White und Leprince wieder zurückgekommen. (vgl. S. I49)

Der erste, der das Verfahren im Betriebe anwandte, war C. Borchardt, Remscheid. Er stellte fest, daf er, ohne K!agen zu erhalten, in die Retorten 40 bis $50 \%$ Wassergas einführen konnte und dabei an Benzol 45 bis $50 \mathrm{gr} / \mathrm{m}^{\prime \prime}$ Wassergas zugeben mußte, wenn das Gemisch 100 bis $150 \mathrm{kcal} / \mathrm{m}^{3}$ niedrigeren Heizwert als sein reines Steinkohlengas haben sollte. Bei to bis $15 \%$ Wassergaszusatz in der Retorte brauchte er für eine Leuchtkraft von ${ }_{3} 3$ bis ${ }_{4} 4 \mathrm{HK}$ im Schnittbrenner keinen Benzolzusatz. „Die weitestgehenden Hoffnungen auf einen Gewinn an Kohlenwasserstoffen aus Teer wurden übertroffen." Bei direkter Zumischung von Wassergas zum Steinkohlengas hatte man dagegen 70 bis $100 \mathrm{gr} / \mathrm{m}^{\mathrm{a}}$ Benzol gebraucht, um Heizwert und Leuchtkraft in der gewünschten Grenze zu halten $\left.^{5, t a 5}\right)$.

$\mathrm{K}$.W a bl, Güstrow, setzte mit „Autokarburierung“ des Wassergases in Retorten $50 \% \mathrm{zu}$, im Notfall sogar $100 \%$ bezogen auf die absolute Kohlengasmenge. Diese Angaben führten zu lebhaften Erörterungen $\left.{ }^{5.196}\right)$. Offenbar waren die Ansichten, was man den Abnehmern zumuten könne, nicht einheitlich. E. Kobbert, Königsberg, fand den Grenzwert bei $30 \%$, nicht bei $50 \%$, ,wie sonst behauptet wurde". Nach englischen Versuchen erwies sich die Autokarburation mit heif̧em Wassergas nur bei wenigen Kohlen als vorteilhaft ${ }^{5.127}$, während $A l b r e c b t$ und $B$ o yer bei Versuchen in Rohrschach keinen Vorteil fanden $\left.{ }^{5.196}\right)$. Die Versuche waren aber viel zu kurzzeitig gewesen, um ein sicheres Urteil zu fällen ${ }^{5.109}$ ). In Mariendorf glaubte man die Bewährung der Autokarburation nur mit Vorbehalten aussprechen zu können ${ }^{\text {s.200 }}$.

Hauptanwalt der Autokarburation ist der Leiter des Frankfurter Wassergassyndikates System $D e l l w i c k-F l e i s c b e r$ in Frankfurt/Main gewesen ${ }^{5.301}$ ). H. St $r a c b e$, Wien, und die Internationale Wassergas Aktien Gesellschaft, Patent Strache, griffen die Patente an unter Hinweis auf die alten Verfahren ${ }^{5.200}$ ), dem auch $\mathrm{H}$. Croissant, Ludwigshafen als Anhänger Straches lebhaft beitrat $\left.^{5.200}\right)$. Schliefylich wurde das Patent durch die Bamag vernichtet $\left.{ }^{5.200}\right)$.

Ein Schritt weiter war der Versuch von E. B l a b3, Essen, die gesamte Entgasung der Kohle mit Spülgasen herbeizuführen. Für Untersuchungszwecke baute er einen Ofen für Stadt- und Wassergas als Spülgas, der mit einem Zinkbad auf $700^{\circ} \mathrm{C}$ gehalten wurde, also mehr eine Schwelung erreichte $\left.{ }^{5.205}\right)$. Besenfelder be-

5.199) $45(1902)$, ins

5.195) $45(1902), 797$

5.120) $46(1903), 900$

5. 107) $49(1906), 265 / 269$

5.105) $47(1904), 493$

5.100) $47(1906), 598$

5. 2009$) 47(1904) 768$

55,201) 46 (1903) 1037

3.302) 46 (1903) 977

5. 2009$) \quad 46(1903) 1078$

5,201) 48 (1905) 1152

5. 305$) \quad 47(1904) 986$ 
merkte dazu, dał̧ bei heił̧em Einsatz des Kokses nur 50\% zu Spülgas vergast zu werden brauchten ${ }^{\text {s.50\% }}$.

Ähnliche Absichten verfolgte auch W. Young, Peebles. Auch er wollte zunächst die Kohle entgasen, Wassergas machen und dieses durch Entgasungsräume leiten. Auch den Teer wollte er vergasen, die Dämpfe fixieren und den Rest noch cinmal durch die Entgasung schicken. Eine Anmerkung, daf setzungsretorte laufend von Graphit gereinigt werden müsse, zeigt den schwachen Punkt auch dieses Verfahrens auf ${ }^{5.50}$ ).

Die von L. Mond (vergl. S. 215) und der Power Gas Corporation gegründete Deutsche Mondgasgesellschaft baute 1906/1907 auf Zeche Mt. Cenis, Sodingen, eine Anlage auf. $\left.{ }^{5.300}\right)$. Mit dieser wurden durch Prof. A. Frank. Charlottenburg, Dr. N. Caro und einen rheinischen Industriegruppe Versuche zur Verwertung der Torfmoore zur Erzeugung von Kraftgas und Ammoniak angestellt. Die Hannoversche Kolonisations- und Moorverwertungsgesellschaft, Osnabrück, gegründet von G. Kromschröder, Osnabrück, L. Löwe und E. B $l u m$, Berlin, am 2. Okt. I9II, erbaute im Schweeger Moor ein Elektrizitätswerk mit 3000 PS Leistung zur Belieferung von Osnabrück ${ }^{5.200}$ ). 1913 wurde von Mondgasanlagen in Komotau, bei der Zellstoffabrik Waldhof und der Badischen Anilin- und Sodafabrik in Oppau berichtet: „Es stcht zu hoffen, dafy der viele Stickstoff, der heute noch beim Generatorenbetrieb verlorengeht, in späteren Zeiten nutzbar gemacht wird" ${ }^{\mathrm{i}, 210}$ ".

Im gleichen Jahre gab H. Strache seine Erfolge mit Doppelgas in Bergedorf bekannt. Bild 106 zeigt den Wassergasgenerator mit Schweleinsatz der Kohle. Beim Heiß̧blasen, das nur kurze Zeiten dauert, wird der Schweleinsatz von aufzen durch das Blasegas erhitzt. Die Drosselklappe im oberen Gasstutzen mußz so eingestellt werden, dał sich kein Blasegas mit dem abgetriebenen Kohlengase mischt. Beim Gasmachen ist die Drossel ganz geöffnet, das Wassergas durchzieht den Schweleinsatz. Das Ergebnis ist ein Gemisch von Kohlengas und Wassergas von 3200 bis $3500 \mathrm{kcal} / \mathrm{m}^{3}$. Aus $100 \mathrm{~kg}$ Kohle wurden in der kleinen, und deshalb wärmetechnisch ungünstigen Anlage 120 bis $150 \mathrm{~m}^{\mathrm{a}}$ Gas gewonnen. Der Vergasungswirkungsgrad wurde zu 60 bis $70 \%$ ermittelt. Strache war sehr zuversichtlich. Er glaubte einmal wieder, das billige Universalgas aus Abfallkohlen gefunden zu haben. Er fand auf der Hauptversammlung teilweise freudige Zustimmung. Th. Grothe, Diedenhofen, sagte voraus, daf die restlose Vergasung über kurz oder lang zu einem zwingenden Bedürfnis werden würde. Dagegen betonte $K n o c b$, Lauban, dał für kleine Werke ein gutes Gas und auch ein guter Koks die Hauptsache seien.

Nun wies H. Stracbe darauf hin, daf̧ der Doppelgasgenerator auch so betrieben werden könnte, dał auch Koks anfiele. Dann steige der Heizwert des Gases auf $4000 \mathrm{kcal} / \mathrm{m}^{3}$. Bei der Einstellung Straches gegen die Wassergaserzeugung in vertikalen Retorten, die noch anschliełend zu erwähnen ist, war diese

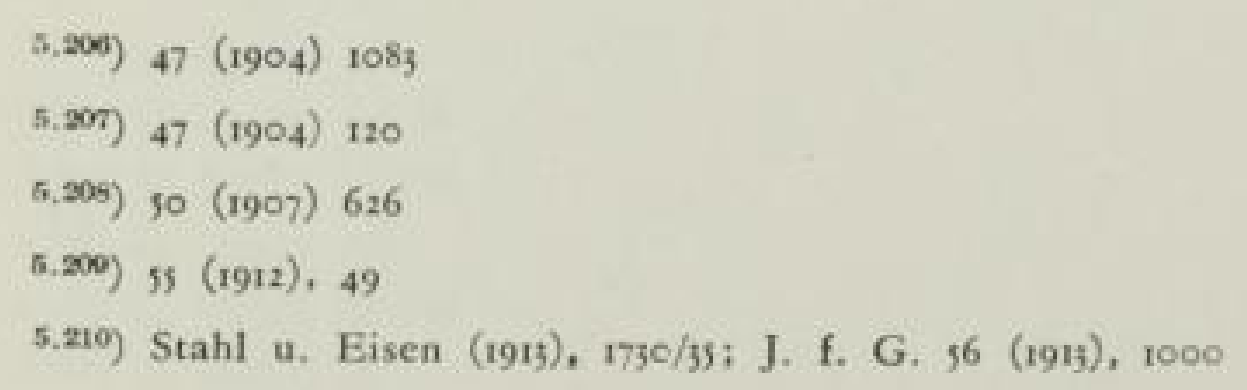




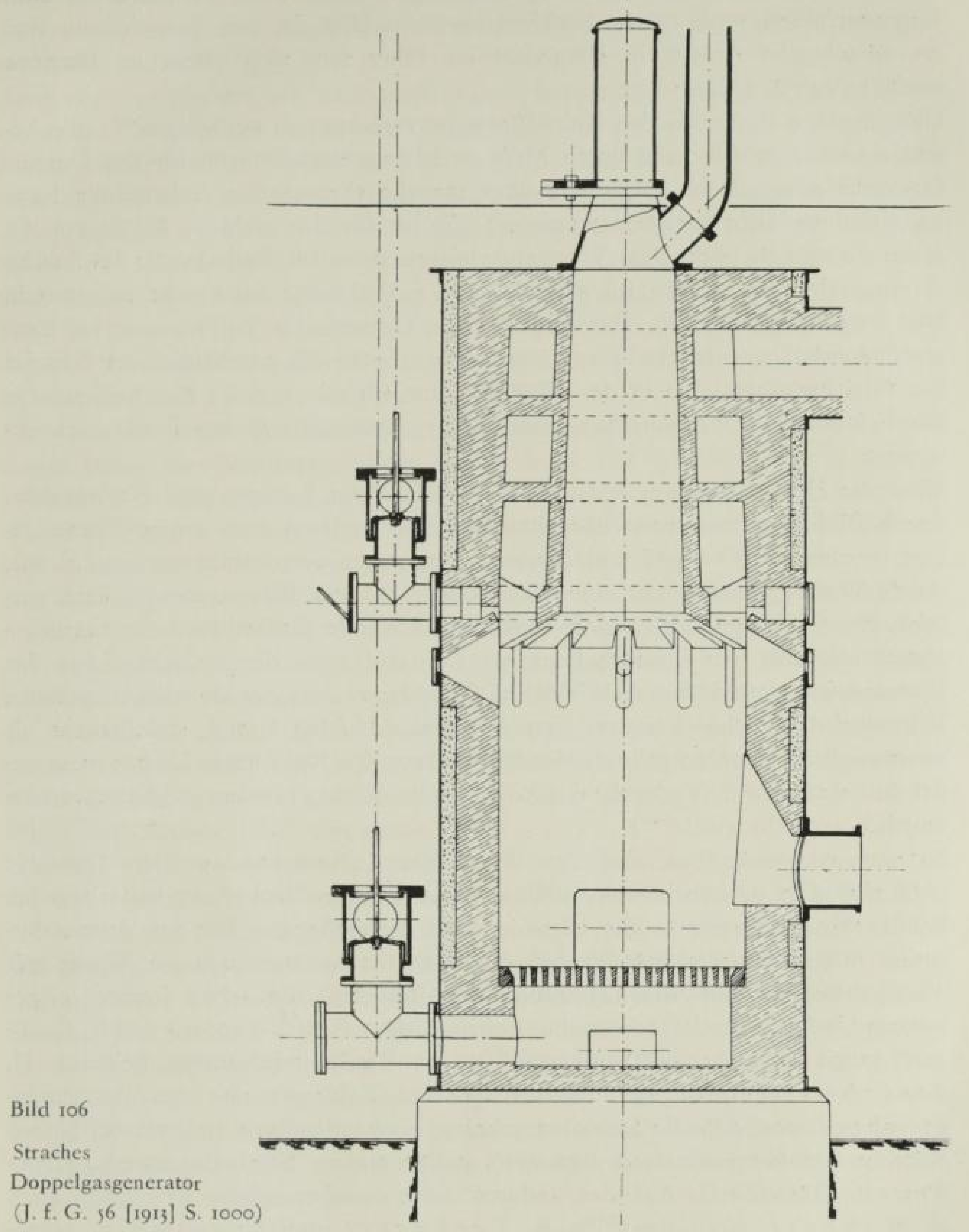

Äuf̧erung überraschend".mI). Besemfelder griff Strache heftig an, er selbst habe im D. R. Patent 115070 vom 4. 6. 1899 dasselbe gesagt. Mit Recht konnte Strache erwidern, daf er seinerseits schon 1895 von der restlosen Vergasung gesprochen habe, aber jetzt habe er das Verfahren zum ersten Male in die Technik eingeführt, und es sei einfach. An das alte Patent von Altvill und F a r mer, (vgl. S. 212/13) dachte wohl keiner von beiden.

\section{SLUB}


Über die weiteren Schicksale des Doppelgases und seine Abwandilung zum Trigasverfahren muf3 später berichtet werden. Hier sei nur festgehalten, daf die Strachesche Anlage in Bergedorf im Jahre 1919 nicht mehr im Betriebe war $\left.^{5,212}\right)$ (Vgl. S. 438).

Über manche Versuche, das Koks-Wassergasverfahren zu verbessern $\left.{ }^{5.217}\right)$, die besonders wiederum Strache durch Mef- und Steuereinrichtungen für das DampfGasverhältnis erstrebt hat, sowie über manche theoretische Abhandlung kann im einzelnen nicht berichtet werden. Lediglich für die wichtige Arbeit von O. Boudouard über das Wassergasgleichgewicht im Bulletin de la Société chimique de Paris 25 (I9OI) S. 484/489 (Vgl. S. 219) möge der Erscheinungstermin hier festgehalten $\left.\operatorname{sen}^{\text {s.2nt }}\right)$. Damit waren die Gesetze der Verbrennung im Bunsenbrennerkonus entdeckt. Das Gesetz dient heute als anschaulichstes Beispiel der Gleichgewichtslehre in der physikalischen Chemie und ist entscheidend für die Erfolge der Durchforschung der Schutzgasatmosphären aus Brenngasen geworden.

Über die Herstellung von Wassergas in senkrechten Retorten und Kammeröfen durch Einblasen von meist überhitztem Dampf müssen noch einige Worte gesagt werden. Woodall und $D u c k b a m$ waren von vornherein darauf aus, durch Wassergaserzeugung einen Teil der fühlbaren Wärme des Kokses auszunutzen. Gleich zu Beginn des Jahrhunderts war in Deutschland der Gaskoksabsatz schlecht. 190I bis 1903 konnte man dafür noch die schlechte Lage der Eisenindustrie verantwortlich machen $\left.{ }^{5.25}\right)$. Dann aber wurde die allgemeine Wirtschaftslage schnell besser. 1907 waren die Kohlen knapp, sodaf mehr als sonst englische Kohlen gekauft werden muften, die Kokspreise blieben aber gedrückt, wofür die Verkaufstaktik des Rhein. Westf. Kohlensyndikates verantwortlich gemacht wurde $\mathrm{e}^{5.26}$ ).

So war es verständlich, dał sich die Werke Luft machen wollten über das hinaus, was in den vorhandenen Wassergasanlagen an Koks verarbeitet werden konnte. Erinnerungen an die verschiedenen Feststellungen mit der Autokarburation mögen auch mitgespielt haben. Jedenfalls nahmen mehrere Werke mit Vertikal-Retortenöfen die Dampfung der Retorten, die schon immer in gewissem Umfange geschehen war, nunmehr kräftig auf. E. Körting und R. Geipert gaben in mehreren Vorträgen ${ }^{\text {n.a17 }}$ ) ihre Betriebserfahrungen bekannt. $H$. Stracbe kämpfte dagegen mit theoretischen Zahlen, muf3te sich aber entgegenhalten lassen, daß̧ die Betriebsergebnisse einwandfrei ermittelt wären. Neben Körting und Geipert traten auch noch einige andere Vertikalofenwerke ( $D e$ $b r u c k$, Düsseldorf). Auf der anderen Seite standen neben Strache ${ }^{5.215}$ ) auch E. Kobbert, Königsberg $\left.{ }^{5.20}\right)$, R. Terbaerst und Trautwein, Nürn-

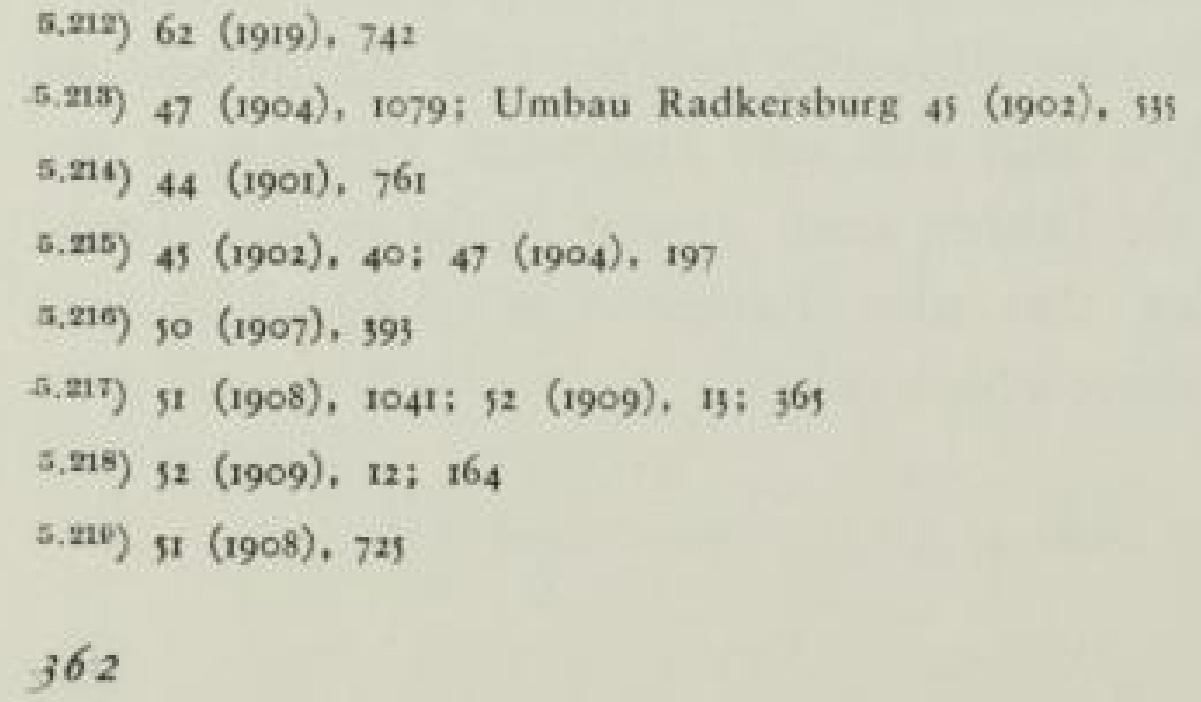


berg ${ }^{\text {t.mog}}$. Beide Parteien stellten geänderte Berechnungen auf und kamen zu ganz entgegengesetzten Ergebnissen. Daran änderte auch eine groß̧e Aussprache im Verein nichts $\left.{ }^{5.221}\right)$.

Auch die Vorteile der mit Sauerstoff angereicherten Luft wurden damals untersucht. R. P ictet, der mit seinem Gegenstromsauerstoffverfahren Linde den Rang ablaufen wollte $e^{5.2 n}$, stellte fest, daf mit einer Luft von $50 \%$ Sauerstoffgehalt der Wassergasprozess fortlaufend geführt werden könnte. Auch das Patent von J. G. L. Borma $n n$, Berlin (125 367) bewegte sich in der gleichen Richtung. Worin der wirtschaftliche Vorteil des Verfahrens liegen sollte, wird nicht recht klar. Es kam auch wohl gar nicht zur Versuchsausführung ${ }^{5.223}$ ).

Prof. V. Loos, Wien, versuchte, den städtischen Müll durch Vergasung zu verwerten. Er erhielt bei den niedrigen Betriebstemperaturen ein fast kohlenmonoxydfreies Gas von 2500 bis $\left.3000 \mathrm{kcal} / \mathrm{m}^{\alpha .25}\right)$.

Nicht nur die Frage der Beseitigung des Kohlenmonoxydes, vielmehr die ganze Entwicklung der Syntheseverfahren wurde durch die Arbeiten von P. $S a b a$ tier und J. B. Senderens an der Methanbildung durch Anlagerung von Wasserstoff an Kohlenoxyd in Gegenwart von frisch reduzicrtem Nickel bei $250^{\circ} \mathrm{C}$ angeregt. (3. März 1902 in der Academie des Sciences ${ }^{3.2 z}$ ).

Als Cedfordprozess wurde in England eine technische Lösung der Aufgabe, Methan aus Kohlenmonoxyd oder auch ein giftfreies Leuchtgas aus Wassergas herzustellen, entwickelt. Die Anregungen stammten von Prof. E. E r dma $n$, Halle/S. Um das nötige Kohlenstoff-Wasserstoff-Verhältnis zu erhalten, wurde mit Hilfe der Lindeschen Gasverflüssigung das Kohlenmonoxyd flüssig ausgeschieden. Dabei ging auch Schwefel aus dem Gase fort und der Nickelkatalysator wurde geschont. Damals wurde in England ein Preis von 2,6 $\mathrm{Pfg} / \mathrm{m}^{n}$ für ,"synthetisches" Gas genannt ${ }^{\mathrm{s}, \mathrm{zm} \text { " }}$.

In Brünn wurde mit Abhitze getrockneter Klärschlamm in Retorten entgast und ein Gas von $4500 \mathrm{kcal} / \mathrm{m}^{3}$ mit hoher Ammoniakausbeute erhalten ${ }^{5.27}$ ). Das Verfahren hat sich mehrere Jahre gehalten, besonders als durch den grofen Krieg und die Nachkriegsunordnungen selbst in Mähren Kohle knapp wurde ${ }^{5.25}$ ).

Dafy in dieser Zeit auch die Untertagevergasung ihren Anfang genommen hat, beweist, wie fruchtbar die Beschäftigung mit dem Vergasungsvorgang gewesen ist. Sir William Rams a y berichtete im Journal of Gaslighting II8 (1912) S. 95 mit Hinweis auf ein amerikanisches Patent vom Jahre 1909. Hier wurde aber in der Tat in der Grube ein Halbwassergas erzeugt und über Tage in Gasmotoren verbrannt. Damit wollte man die nicht abbauwürdigen Flöze verwerten. Zum Dauerbetrieb ist man nicht gekommen ${ }^{5.20 y}$.

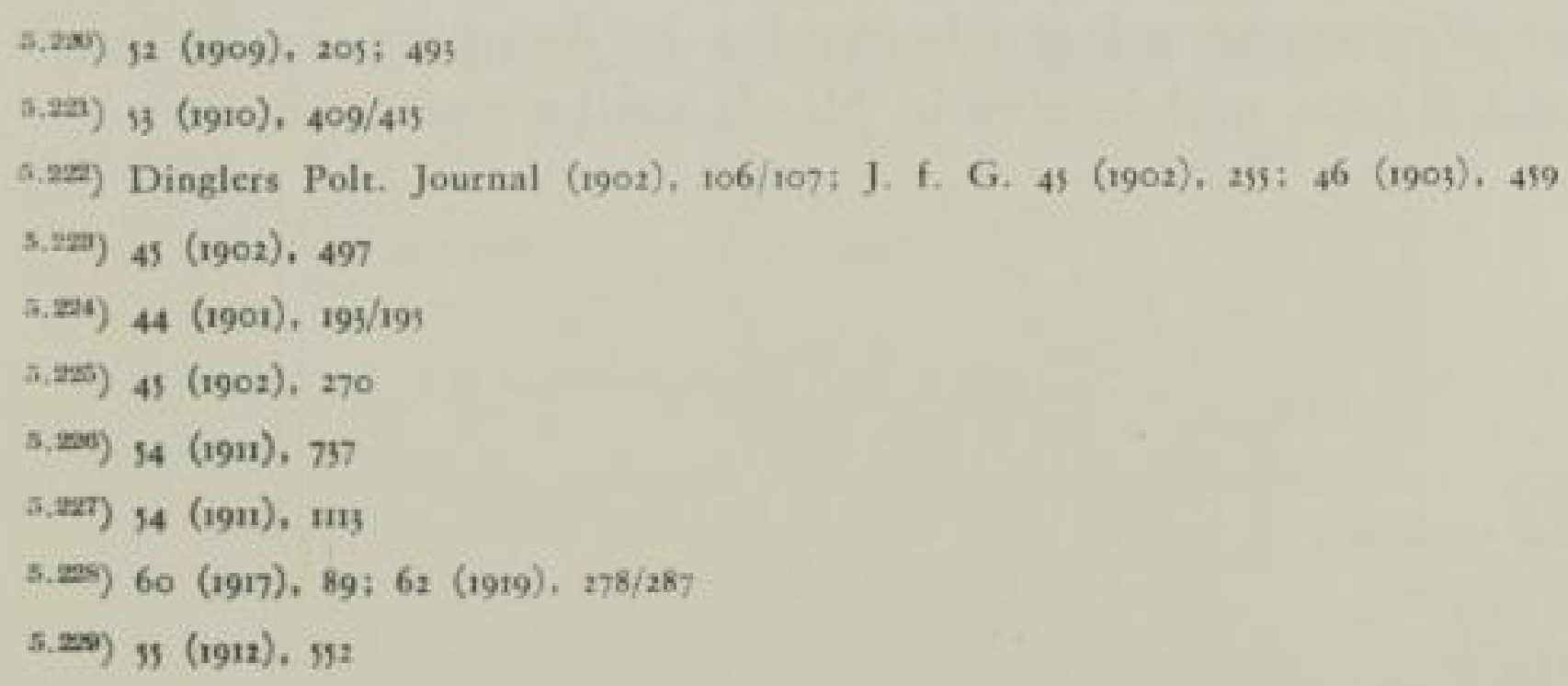


Die Erzeugung von Luftgas aus Luft mit leichtsiedenden Kohlenwasserstoffen, Solin, Pentan oder auch Handelsbenzin erlangte eine gewisse Bedeutung, nachdem die Anlagen so ausgebildet waren, dał sie unter Beachtung gewisser Vorsichtsmaf̧nahmen gefahrlos arbeiten konnten. Eine willkommene Lösung brachten sie den chemischen Laboratorien, die auf abgelegenen Werken an die Gasversorgungen nicht anschlief̧bar waren, die andererseits aber auch zu geringe Mengen benötigten, um eine Werksanlage für Kohlengas zu rechtfertigen. Auch der Absatz in überseeische Länder war nicht unbedeutend.

Die Aerogen Gas Gesellschaft in Hannover vergröß̧erte die Erzeugungseinheiten und nahm sogar für Ortsversorgungen den Wettbewerb mit Azetylengasanlagen auf $^{5.230}$ ). Mittelgroł̧e Anlagen wurden mit Heił̧luftmaschinen, größzere mit Gasmotoren zum Antrieb der Luftgebläse ausgerüstet $\left.{ }^{5.231}\right)$. Unter dem Namen Benoidgas bereiteten Thiem \& Töwe, Halle, ihr Gas aus Hexan und Pentan ${ }^{5.250}$ ). Die Erfolge waren sehr wechselvoll wegen der schwankenden Preise der Kohlenwasserstoffe, die bei geringem Lohnaufwand den Gaspreis stark beeinflufften ${ }^{5.23 a}$ ). Pentairgas von $B u s c b$, Bremen, war ein Benzinluftgas. Kleinanlagen wurden mit einer von Hand hochgewundenen Glocke in der Gröłe und Art eines Kubizierluftbehälters ausgeführt, größere mit Gasmotor.

Ungefährlich waren solche Anlagen niemals zu nennen. Das Einfüllen des Benzins aus den Lieferfässern in die Erzeuger in geschlossenen Räumen machte immer Sorge, und mancher war froh, die Anlagen durch Stadtgas oder Wassergas ablösen zu können ${ }^{5.231}$ ).

\subsection{Flüssiggas}

Unter diesen Umständen war auch die Möglichkeit, in Stahlflaschen verhältnismäßjig groł̧e Wärmemengen als Flüssigkeit zu beziehen, sehr verlockend. Den Anfang machte damit H. Bla $u$ in Augsburg. Er erzeugte ein hochwertiges Olgas bei $600-700^{\circ}$ das er zunächst tiefkühlte ${ }^{5.255}$ ) (Patent 175846 und 158 198), später unter einen Druck von roo atü setzte. Die sich dabei ausscheidenden flüssigen Kohlenwasserstoffe wurden noch benutzt, um möglichst viele der gasförmigen Kohlenwasserstoffe aufzunehmen. Die Restgase wurden zur Beheizung der Ölgasapparate oder für Motoren verwendet $\left.{ }^{5.200}\right)$. Immerhin war nicht nur das Gas an sich teuer, seine Verbreitung wurde auch durch die Fracht und Vertriebskosten erschwert. Erzeugungsanlagen bestanden in Augsburg, in Budapest von Riedinger und $B l a u$, und je eine in Nordamerika und Schweden.

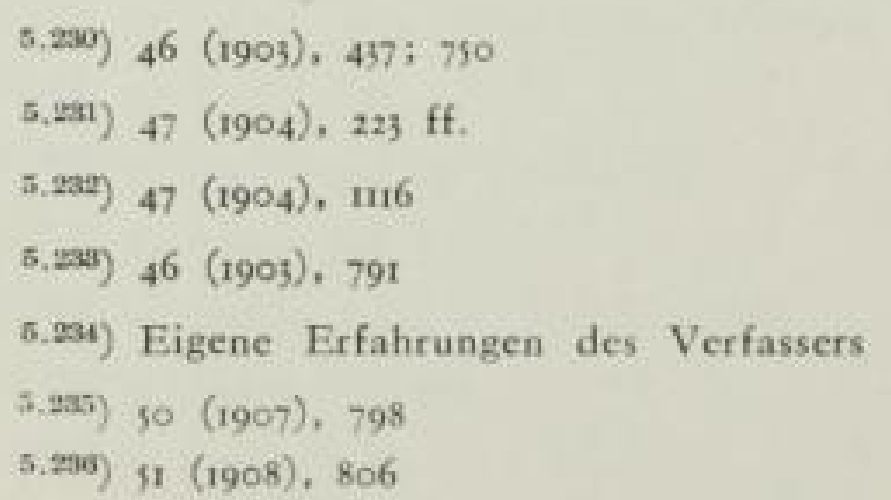


In Süddeutschland war Blaugas vor dem Kriege verbreitet ${ }^{5,47}$ ). I kg kostete ab Fabrik M 1.20. Die Flasche von $27 \mathrm{dm}^{5}$ Inhalt wog leer $47 \mathrm{~kg}$. Sie enthielt 9 bis 1o $\mathrm{kg}$ flüssiges Gas gleichwertig mit 7 bis $8 \mathrm{~m}^{3}$ Stadtgas. Die Schaustellung auf der grof̧en Ausstellung „Das Gas“ in München wurde als eindrucksvoll bezeichnet. Geliefert wurden 190720000 kg; $191058000 \mathrm{~kg}$; $191 \mathrm{II} 70000 \mathrm{~kg}$; 1913 $130000 \mathrm{~kg}$. Es wurde nunmehr vor allem auch zum Gasglühlichtbetrieb in abgelegenen Gebieten gern verwandt. Unfälle sind mit diesem Gas nicht bekannt geworden ${ }^{\text {5.2x }}$. Dem groß̧en Kriege fiel die ganze Mühe zum Opfer.

Die erste Nachricht über Propangewinnung aus Erdgas in Nordamerika erreichte uns $1913^{5.250}$. Das Verfahren stammte von Snelling und Peterson, Pittsburg, die bei 28 atü Druck ein Propan mit Äthananteilen erhielten. Das Flüssiggas sollte vor allem in Kraftwagen verwendet werden ${ }^{5.210}$ ). Nach einem Patent von M. Scbenk, Wirling, USA wurde das Gas, in bekannter Weise in Stahlzylindern komprimiert", was wohl eine etwas oberflächliche Darstellung war. Jedenfalls koste das Gas nur die Hälfte des Benzins. Pläne über ein groß̧es Tankstellennetz über ganz Nordamerika spukten in den Köpfen der Erfinder.

\subsection{Erdgas}

Vom Erdgas in Nordamerika wurde immer wieder berichtet, daf3 die Quellen in absehbarer Zeit versiegen würden $\left.{ }^{5.27}\right)$. Die Erforschung des Bodens war ja noch nicht wissenschaftlich unterbaut und man war auf Zufälle angewiesen. In Indianopolis muf̧te die Erdgasversorgung beendet werden. Das Leuchtgas wurde danach zum 4 -fachen Wärmepreis angeboten ${ }^{\text {*ntat }}$ ).

Grubengas wurde bereits 1909 auf Zeche Frankenholz, wo es unter Druck ausströmte, zur Kesselfeuerung benutzt. Zur Verringerung der Schlagwettergefahren sollten weitere Bohrungen vorgenommen werden ${ }^{5,213}$ ). Als dann bei Bohrungen für Wasserwerkbrunnen bei Neuengamme bei Hamburg ein heftiger Erdgasausbruch stattfand, nahm man dieses Ereignis zunächst als unangenehm und gleichgültig auf. Dann aber entzündete sich das Gas und gefährdete durch seine mächtige Flamme die Umgebung. Nach vielen Mühen gelang es, das Gas in Rohren zu fassen und einige hundert Meter fortzuleiten, wo man es zunächst abfackelte $\left.{ }^{5.244}\right)$.

Inzwischen kamen wieder sehr positive Nachrichten über das Erdgas in Nordamerika. Standard Oil hatte sich in den Besitz aller Felder Westvirginias gesetzt und kontrollierte die Pachtrechte fast aller Gesellschaften. Die Leitungen von dort mit $640 \mathrm{~km}$ Länge bis Buffalo und von Oklahoma, Texas und Louisiana von $710 \mathrm{~km}$ nach St. Louis liefzen auch nicht auf ein Nachlassen

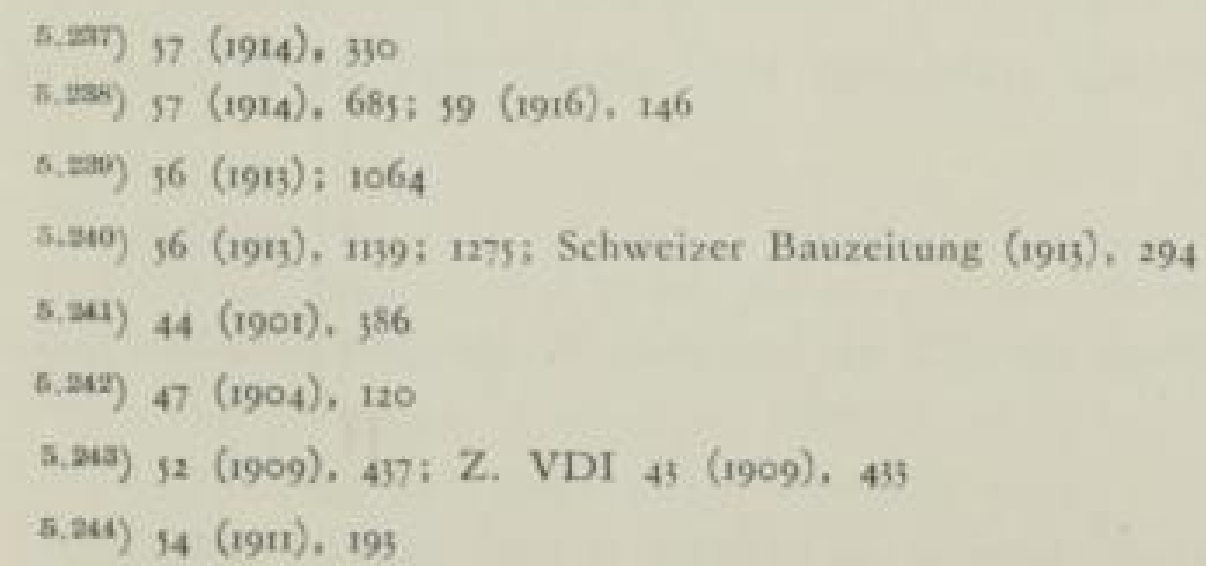


schlieben $^{5.245}$. 1910 wurden II Mia, nach einer anderen Auskunft 14.4 Mia m ${ }^{3}$ Erdgas gewonnen $\left.{ }^{5.246}\right)$; 1912 16; 1913 16,5; 1918 15; $19211^{16} \mathrm{Mia} \mathrm{m}^{35.247}$ ).

So entschlof sich die Stadt Hamburg im Jahre 1912, die Quelle von Neuengamme, die immerhin 500 bis $600000 \mathrm{~m}^{3} \mathrm{Gas} / \mathrm{Tag}$ bei 28 atü liefern konnte, auszunutzen $^{5.25}$ ). $25000 \mathrm{~m}^{3}$ sollten ( $15 \%$ der Kohlengasmenge) dem Stadtgas in Tiefstaak zugesetzt werden, $20000 \mathrm{~m}^{3}$ für das Pumpwerk in Rotenburgsort unter Dampfkesseln verfeuert und der Rest der Industrie zugeleitet werden $\left.{ }^{5.217}\right)$. Die Quelle wurde so im Kriege sehr wertvoll. Leider versiegte sie ziemlich plötzlich im Jahre 1918, als die höchste Brennstoffnot in Deutschland sich erst entwickeln sollte $e^{5.250}$ ).

In Oberialien in der Emilia wurde auch zufällig Erdgas erbohrt. Igro gewann man 8,8 Mio $\mathrm{m}^{3}$.wat $)$. Kleinere Vorkommen wurden bei Pisa gefunden und sofort ausgenutzt $\left.^{5,252}\right)$. In Siebenbürgen wurde man $1913 / 14$ fündig mit 2,4 $\left.\mathrm{Mio} \mathrm{m}^{3} / \mathrm{Tag}^{5,225 i}\right)$.

\subsection{Kokereigas}

Waren bisher nur Anregungen und Ratschläge über die Kokereigasverwendung als Leuchtgas bekannt geworden (vgl. S. 256/57), so begann um die Jahrhundertwende die ernste Arbeit an dieser Aufgabe.

Koksöfen für ein Gaswerk wurden im März 1897 von F. L. S lo cu m zu Halifax (Neu Schottland) errichtet. Es waren to Semet-Solvay Üfen ${ }^{5.25 t}$ ).

Bekannter ist die Kokerei Everett bei Boston (Mass.) geworden, die die Stadt mit Leuchtgas und Koks versorgen sollte $\left.{ }^{5,2 \pi}\right)$. Sie wurde von F. S $c b$ niewind mit der United Coke and Gas Company, New York, gebaut, die 400 Otto-Hoffmann Öfen errichtete, mit Kammern von 7 t Ladegewicht. Die Anlage war den jahreszeitlichen Bedarfsverschiedenheiten angepafyt. Normalerweise sollten die ersten $120 \mathrm{~m}^{3}$ Gas einer Kammer als Leuchtgas mit hohem Heizwert abgegeben werden und danach noch $140 \mathrm{~m}^{3}$ Heizgas. In Zeiten gröfter Abgabe wurde ein Mischgas mit Benzol aufgebessert. Zu dem Zwecke wurde dem Heizgas das Benzol im Sommer entzogen und für den Winter gespeichert. Die Freiheit in der Auswahl der Kohlen wurde besonders bewertet ${ }^{5.250}$ ). Schniewind hat auch noch mehrere andere Kokereien für Gaswerke gebaut. Unter Umständen wurde auch das Blasegas von Wassergasanlagen als Ergänzung der Armgase aus der Entgasung zur Ofenheizung herangezogen.

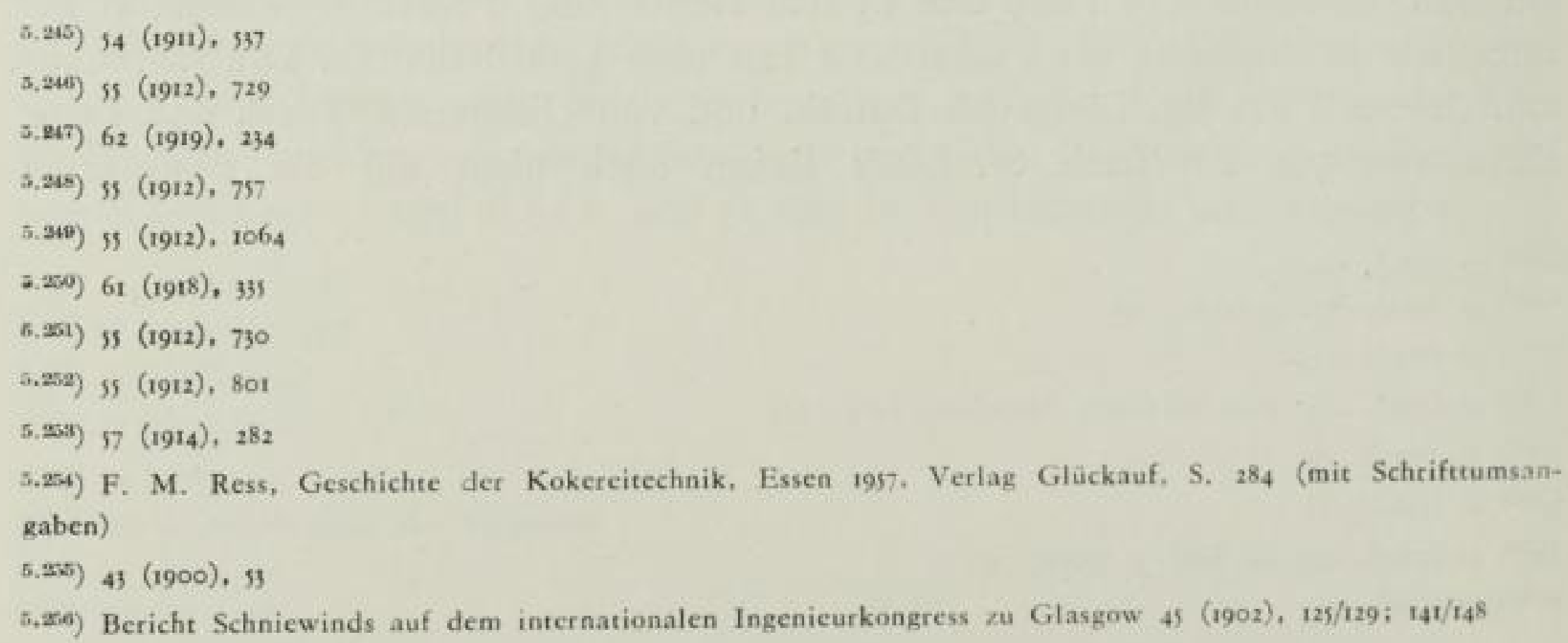


Die Anlage in Everett hat wirtschaftlich mit grof̧en Schwierigkeiten zu kämpfen gehabt. Das hat indessen mehr am Kapitalaufbau der Gesellschaft als am technischen Verfahren gelegen ${ }^{5,277}$ ).

Den fruchtbaren Gedanken, dał bei einer richtig ausgeführten Regenerationsanlage die Hälfte des erzeugten Gases zur Beheizung des Koksofens ausreichen müsse, faf̧te H. Koppers schon, als er als Mitarbeiter bei Dr. C. Otto \& Co., Dahlhausen, tätig war. Er rechnete und entwarf nach seinen Gedanken, stief\} aber auf Widerstand bei seinem Direktor G. Hilgen stock, der dazu führte, daf̧ sich Koppers von der Firma trennte und 19or selbständig begann. Seine Gedanken trug er H. Stinnes vor, der ihn die erste regenarative Kokereianlage auf Zeche Mathias Stinnes ausführen lief̧. Wenn auch dieser Ofen mit Beheizung mit ungereinigten Generatorgas noch nicht den Erwartungen entsprach, so dürfte doch durch Koppers in Stinnes die Erkenntnis hervorgerufen sein, daf3 das hochwertige Koksofengas für andere Zwecke abgegeben viel gröłgere wirtschaftliche Werte erschlief̧en konnte, als zur Unterfeuerung der schweren Kokereiöfen ${ }^{5.259}$ ). Schon 1902 griff H. Junkers den Gedanken auf, daf3 vom Standpunkte des Gasfachmannes die Erzeugung in Kokereien und die Fernversorgung günstig sein müsse. Eine günstigere Energieübertragung als die mit Gas in Rohrleitungen sei nicht denkbar. Allerdings glaubte er vor allem an eine Befruchtung der Raumheizung und übersah, dał gerade diese mit ihren jahreszeitlichen Spitzen zur Verzinsung des hohen Kapitalbedarfs erst nach einer mühevollen Entwickelung insbesondere der Speicherung größter Mengen am Verbrauchsort wirtschaftlich gelöst werden konnte ${ }^{\text {s.s.so }}$ ).

Die Kokereiöfen mit Nebenproduktengewinnung wurden durch die koksöfenbauenden Firmen im Wettbewerb immer besser ausgebildet, so dafy ein stetig gröłer werdender Gasüberschuf - über die Benutzung des erzeugten Gases zur Ofenbeheizung hinaus - eintrat. Zunächst geschah als nächstliegendes die Verwendung des Gases in den mit Kokereien verbundenen oder benachbarten Eisenwerken. 1907 wurden auf der Friedrich-Wilhelms-Hütte in Mülheim/Ruhr Siemens-Martinöfen mit Koksofengas beheizt, desgleichen in der Hubertushütte in Oberschlesien $^{5.200}$ ). O. Si mmersbacb berichtete I9II über allgemeine Gesichtspunkte und Erfolge der Benutzung des Gases aus dem "zweiten“ Entgasungsabschnitt mit $3500 \mathrm{kcal} / \mathrm{m}^{\mathrm{n}}$ in Siemens-Martin Öfen. Er sagte vor allem deutlich voraus, daf3 die Anwendung von Kokereigas metallurgisch Verbesserungen mit sich bringen würde ${ }^{5.251}$ ).

Sicherlich war es den Kokereibesitzern dabei klar geworden, dał der Groł̧verbrauch in solchen Öfen nicht die besten Erlöse bringen würde. Als dann durch weitere Verbesserungen der Kokereiofen (Verbundöfen für Reich- und Armgase) weitere Gasmengen verfügbar wurden, begannen $\mathrm{H}$. S t innes und A. T bys se $n$ damit, den Städten das Kokereigas anzubieten. Neben dem kleinen Orte Walsum und Hamborn roos machten Essen und Mülheim-Ruhr den Anfang ${ }^{\text {seme }}$ ).

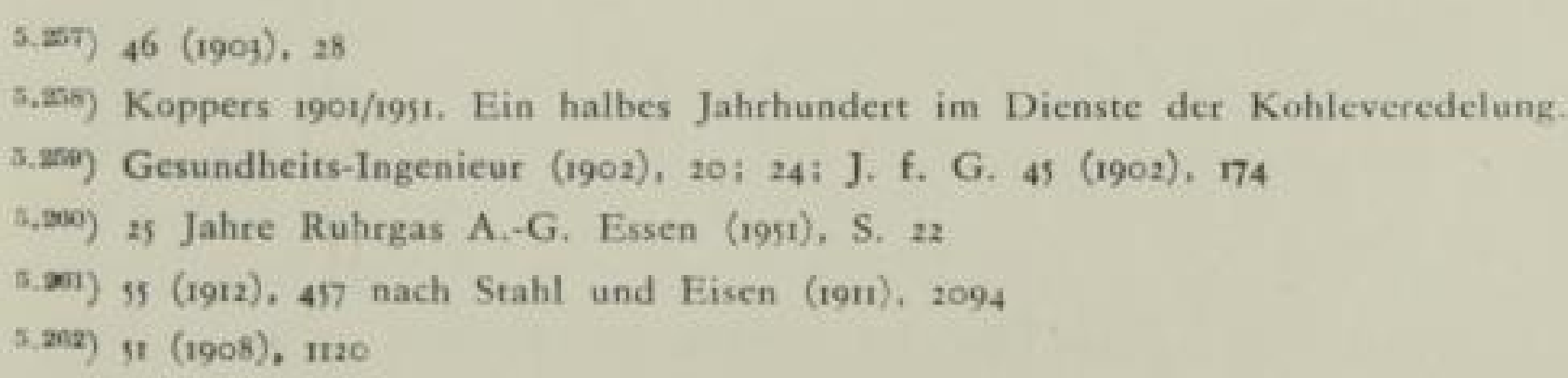


Essen bezog seit Ende 1905 bei in Mio $\mathrm{m}^{2}$ Gesamtbedarf 5,2 Mio $\mathrm{m}^{3}$ Koksofengas von den im Stadtgebiete liegenden Zechen Victoria, Mathias und Friedrich Ernestine. Die Schwefelwasserstoffreinigung geschah im Gaswerke. Mülheim bekam seit 1907 aus der Koksofengasleitung, die die Thyssenschen Werke verband, gereinigtes Gas der 2. bis Io. Destillationsstunde von $5000 \mathrm{kcal} / \mathrm{m}^{3}$ für 3,75 $\mathrm{Pfg} / \mathrm{m}^{3}$ als Spitzengas.

Die städtischen Behörden beschäftigten diese neuen Dinge genau so, wie sie von den Zechen vorangetrieben wurden. M. $H$ a s e, Lübeck, der vor der Frage stand, Gas aus der Kokerei Herrenwyk zu übernehmen, gab 1908 und 1909 zwei recht sachlich nüchterne Berichte. Technische Schwierigkeiten lief̧en sich sicherlich überwinden, bedenklich und schwierig sei immerhin der Entschluf3 eines Stadtstaates, sich von einem Privatunternehmen abhängig zu machen. Die Entscheidung sei aber rein kaufmännisch gefallen. Man habe der Stadt ungereinigtes Gas mit einer Abnahmepflicht aber keiner Lieferungsverpflichtung angeboten ${ }^{5}{ }^{203}$ ). Ein Jahr darauf setzte aber eine „Stimmungsmache in Rheinisch Westfälischen Tageszeitungen " für die Ferngaspläne des Rheinisch Westfälischen Elektrizitätswerkes und Stillsetzung der städtischen Werke ein. Ein "Spectator" erörterte dagegen die Wichtigkeit der Nebeneinnahmen, insbesondere die Deckung des Koksbedarfes in den städtischen Gebäuden. Das war aber anscheinend schon die Folge von Versuchen, den für Ferngas anlegbaren Preis abzutasten und von Stadtseite möglichst zu drücken ${ }^{5.25}$ ). Jedenfalls folgte einem Vortrage von Forster, Mülheim/Ruhr, dał grołe Gasmengen im Ruhrrevier auf Absatz warteten, eine lebhafte Aussprache im Verein der Gas-, Wasser- und Elektrizitätsfachmänner des Rheinlands und Westfalens. Man tröstete sich mit den hohen Rohrkosten, glaubte, daß ein Haibmesser von über $50 \mathrm{~km}$ nie überschritten würde und Berlin oder Magdeburg wohl niemals wirtschaftlich erreicht werden könnten. Daf der Tagungsbericht unter „Nachdruck verboten“ bekannt gegeben wurde, ist so ungewöhnlich, dał̧ damit die grof̧e Aufregung beleuchtet wird ${ }^{5.305}$ ). Jedenfalls war die Anschluß̧bewegung an Zechengas recht erheblich ${ }^{5.27}$ ). Und dennoch konnte auch gleich im Anfang eine angenehme Wirkung festgestellt werden. Da das Zechengas ja bei gleichbleibender Koksmenge durch die bessere Wärmewirtschaft der Ófen frei wurde, wurde der sehr schwach liegende Gaskoksmarkt spürbar entlastet ${ }^{5,507}$ ). I9II stief das Rheinisch-Westfälische Elektrizitätswerk von Essen aus ins Bergische Land vor. Die Kokereigasabgabe für Stadtversorgungen betrug 19072 bis 3 Mio; 1908 I2 Mio; 1909 25,2 Mio; 1910 43,1

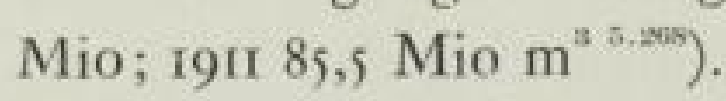

In Schlesien wurden 19n Waldenburg, Altwasser, Salzbrunn an Koksofengas angeschlossen ${ }^{5.200}$ ).

Wieder berichtete F. Kord $t$, Düsseldorf, im Jahre 1912, daf3 45 Gemeinden mit Kokereigas versorgt würden. Die Städte Elberfeld, Neuf̧ und Krefeld stünden

\footnotetext{
5. 225) $52(1909), 101$

5.254) 53 (1910), 199

$5.205) 53(1910), 287$

5. 206) 53 (1910), 287

5.207) 54 (1911), 23

$5.208)$ is (1912), 572

5.210) 54 (1911), 362
}

368 
in Verhandlungen. In Düsseldorf habe man sich zwar nicht einigen können, oft stünden einem Abschluf die nocht nicht getilgten Anlagekosten der Werke hindernd im Wege. „Es ist aber kein Zweifel, daß̧ die Koksofengasversorgung wei-

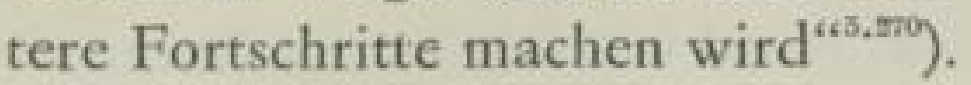

Die erste Zechengasversorgung in Frankreich im Departement Loire wurde 1913 erwähnt ${ }^{5.271}$.

Der Stand vor dem Kriege wurde von R. Wit ze ck, Köln, umrissen ${ }^{5.272}$ ). Das größzte Unternehmen der Ausdehnung nach waren die Thyssenschen Gas- und Wasserwerke in Hamborn mit den Leitungen nach Wesel und Barmen. I912 31 Mio $\mathrm{m}^{n}$ Abgabe. Das Netz des Rheinisch-Westfälischen Elektrizitätswerkes war größser ausgelegt, lieferte aber nur 25 Mio $\mathrm{m}^{3}$. Hinzu kamen noch mehrere kleinere Abgaben; Gewerkschaft Lothringen, Gerthe 1912 I3 Mio $\mathrm{m}^{3}$ an Herne, Witten, Langendreer; Zeche Hannover io Mio an Bochum; Rheineibe I4 Mio an Gelsenkirchen, Rotthausen, Wanne-Eickel, Wattenscheid. In Essen lieferten 5 Zechen 20 Mio $\mathrm{m}^{3}$. Im ganzen waren 50 Städte und Gemeinden 1913 mit 130 Mio $\mathrm{m}^{\mathrm{n}}$ versorgt. Die Fernversorgung an der Saar stand in der Entwicklung. Das Hochofenwerk Lübeck belieferte die Stadt mit $10,00 \mathrm{~m}^{3} / \mathrm{Tag}$ an Gas von $5400 \mathrm{kcal} / \mathrm{Nm}^{3}$ und zwar als gereinigtes Gas. Man hatte also den Weg zueinander gefunden. ${ }^{\text {s.m. }}$ ), Reserveanlagen, die man anfänglich beim Anschluß an Kokereien für erforderlich gehalten hatte, wurden nicht mehr benötigt. Die Zechen hatten es auch gelernt, die notwendige gleiche Güte des Gases einzuhalten.

Alles in allem betrug der Zechengasverbrauch 200 Mio $\mathrm{m}^{3}$ im Jahre. Das waren $8 \%$ der gesamten Gasmenge von 2,5 Mio $^{3}$, die die städtischen Werke vertrieben.

\subsection{AUFBEREITUNG DES GASES UND NEBENERZEUGNISSE}

In den Verfahren zur Aufbereitung der Gase wurden grundsätzliche Neuerungen nicht eingeführt. Erwähnt mag als Ausnahme der Zschocke-Wascher mit Kugelfüllung werden ${ }^{5.247}$ ) (Patent 109855 vom 24. 5. 98). Das neue Gaswerk in Hannover (1899) hatte noch parallelgeschaltete Luftkühler, danach einen Wasserkühler, in dem die Gasrohre senkrecht in einem alten Dampfkessel eingebaut waren und danach einen Hordenwascher, einen Dampfstrahlexhauster und zweiten Kühler. ${ }^{\text {s.rä }}$ ).

Die hohen Umdrehungszahlen, die mit Elektromotoren gegeben waren, lief̧en die Frage auftauchen, ob eine Trennung von Gasen nach dem spezifischen $\mathrm{Ge}-$ wicht erreichbar sei. So glaubte $M a z z a s$, die Luft auf diese Weise mit Sauerstoff anreichern zu können $\left.{ }^{5, n e}\right)$. Fr. $H a b e r$ und G. Bredig bewiesen durch

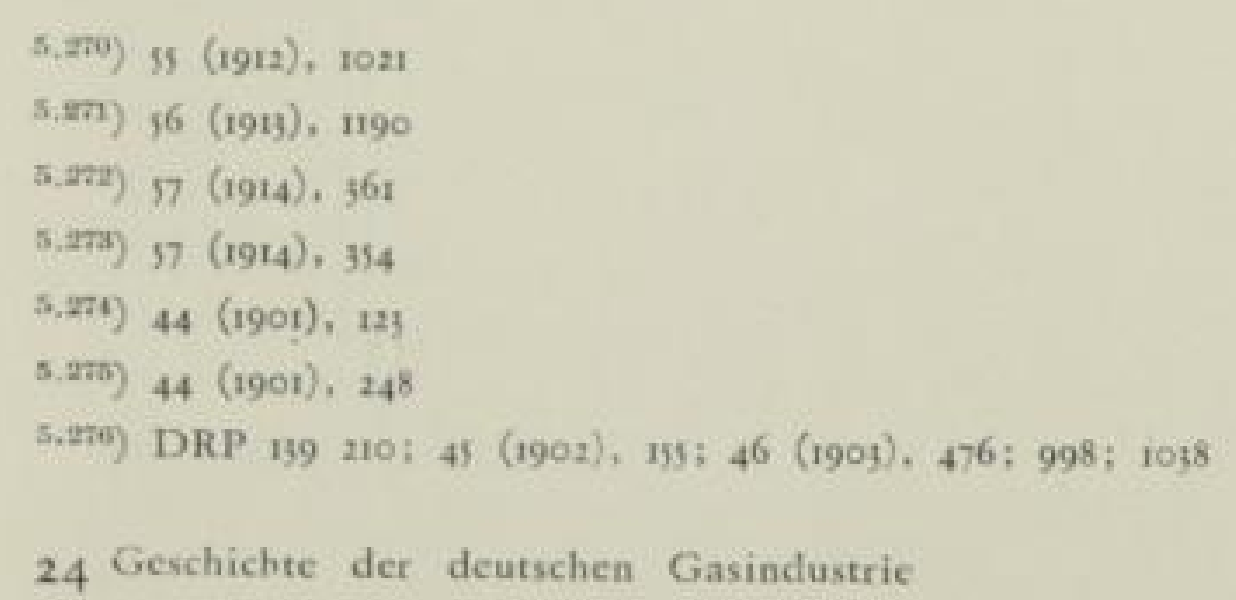


Nachrechnung der Fliehkräfte und Diffusionsvorgänge, daf̧ Abmessungen und Umdrehungszablen notwendig seien, die mit den zur Verfügung stehenden Baustoffen keineswegs zu meistern waren. Versuche von Bredig mit Wasserstoff und Jodwasserstoff mit grołem Dichteunterschied (1895) bestätigten die Rechnun$\left.\operatorname{gen}^{5.277}\right)$.

\subsection{Teergewinnung und-verwertung}

Die Zentrifuge wurde von H. Men zel, Berlin, zur Teerentwässerung empfohlen, um die grof̧en Absitzbecken und den Wärmeaufwand zu ersparen. Man könne so einen für Dachpappen geeigneten Rohteer erhalten $\left.{ }^{3.278}\right)$. Ein Zyklon wurde in England (Colman) als Teerscheider in den Gasstrom eingesetzt ${ }^{5,279}$ ). Die erste Nachricht über die elektrische Gasreinigung (Cottrellverfahren) aus Nordamerika berichtete über deren Einsatz in Koksofenanlagen und in einer Sauggasanlage bei Ford, Detroit, zur Abscheidung von Staub und Teer ${ }^{5.250}$ ). In Canada hatte G. Davidson das Verfahren auch für heif̧en Teer mit Erfolg angewandt. Er reinigte $28300 \mathrm{~m}^{3} \mathrm{Gas} / \mathrm{h}$ mit einer Leistung von 2 bis $3 \mathrm{PS}^{5.251}$ ). Das ist insofern auffällig, als sich das Verfahren bei uns zuerst zur Gewinnung von Metall und Metalloxydstauben eingeführt hat und zur Teerabscheidung mühselig entwickelt wurde ${ }^{5.22}$ ).

Viel lebhafter beschäftigte sich das deutsche Gasfach mit den Verwertungsmöglichkeiten des Teeres, besonders nach Gründung der Wirtschaftlichen Vereinigung deutscher Gaswerke im Jahre 1904. Denn der Absatz war noch sehr grofjen Schwankungen ausgesetzt, die teils durch Streikstörungen in der Welterzeugung, teils durch neue Verwendungsarten, teils aber auch durch Ankaufsvereinigungen der Verarbeiter ausgelöst wurden. Ein genaues Bild über alle Schwankungen zu geben, würde hier zu weit führen. Es sei nur das Wichtigste herausgegriffen.

Der steigende Kraftwagenverkehr lieł die Aufmerksamkeit auf die staubfreien Teerstraf̧en lenken. Die Technik war in England gut entwickelt worden, vor allem auch die Herstellung der Straf̧en mit vorgeteerten Baustoffen ${ }^{5.25}$ ). Einen besonderen Auftrieb erhielt der Straf̧enbau durch die Anteilnahme des Arztes E. Guglielminetti in Monte Carlo, wo sich einerseits die Reichen der Welt mit ihren neuen Wagen ein Stelldichein gaben, andrerseits aber doch die Luft klar und rein bleiben sollte $\left.{ }^{5,24}\right)$. Guglielminetti predigte gegen die Ansteckungsgefahren des Staubes, kümmerte sich selbst um die beste technische Ausführung von Teerstraf̧en und gründete eine Antistaubliga, die im November 1908 zu einem internationalen Straf̧enkongreł rief, wo die Verantwortlichen der grołen Städte sich tatsächlich auch äuf̧erten, warum jeweils eine gewisse Pflasterart bevorzugt werde $e^{5.255}$ ).

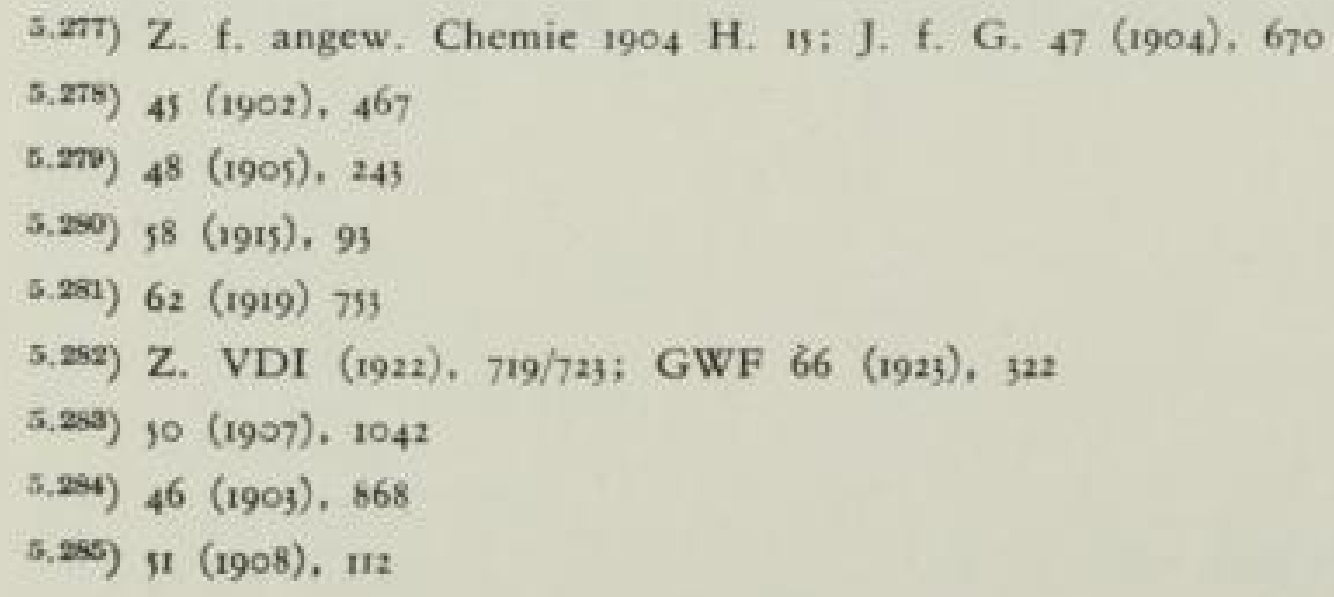


Die Wirtschaftliche Vereinigung berichtete ihrerseits von erfolgreichen Versuchen $^{\text {s.sog }}$. B Bindewald, Kaiserslautern, sprach von der Teerstrafe als der Strafje der Zukunft ${ }^{5.257}$ ). Der London County Council ersparte mit rund $20 \mathrm{~km}$ Teerstraf̧en $1000 \mathrm{Mk} / \mathrm{Jahr}$ an Unterhaltungskosten ${ }^{5.259}$ ).

Die Deutschen Gaswerke standen aber den Monopolabsichten der Aufkäufer gegenüber, die zwar von den Werken den Teer billig kauften, aber mit so hohen Aufschlägen weitergaben, dał selbst Versuche nicht reizvoll waren. Im Gaswerk Mariendorf wurde kurzerhand eine stark belastete Probestrafye und danach in ihrem Gebiete die Zufahrtsstraf̧e zur Grunewaldrennbahn als Teerstrafe gebaut ${ }^{5.285}$ ).

Der Dieselmotor wurde ein anderer Abnehmer für Teer. W. Alln er, Dessau, hatte den hellen Vertikalofenteer untersucht. Wegen seıner Naphthalinarmut war er zur Auswaschung für Naphthalin besonders günstig. Nach vorsichtiger Aufwärmung auf so bis $60^{\circ}$ zeigte er sich auch zur Verfeuerung als vorzüglich geeignet $^{5.20 y}$. Darauf regte die Deutsche Continental-Gas-Gesellschaft bei Gebr. Körting, Hannover, und bei der Maschinenfabrik Augsburg-Nürnberg Versuche mit Dieselmotoren an, die sehr bald zu befriedigenden Ergebnissen führten ${ }^{5.201}$ ). Die gleiche Anregung seitens Dr. C. O t to, Dahlhausen, in Nürnberg war einige Monate später erfolgt $\left.{ }^{5.922}\right)$. Der Verein Deutscher Chemiker bestätigte auf der Hauptversammlung in Freiburg, daf der reine Teerdiesel zu erwarten sei und die Benutzung von Teeröl bis zum Warmwerden des Motors unterbleiben kön$\left.n e^{5.25}\right)$. Die Entwicklung ging aber nicht ins Grołe, da Teeröl preiswert aus dem Auslande zu erhalten war. $\left.{ }^{5.94}\right)$. (Vgl. S. 413)

Die Teerverfeuerung mit Streudüsenbrennern war jetzt sicher und gut $\left.{ }^{5.295}\right)$. Besser aber als die Retortenheizung war die Beheizung von Dampfkesseln, wobei eine neunfache Verdampfung nachgewiesen werden konnte $\left.{ }^{\text {5.23no }}\right)$.

Pech wurde in steigendem Maf̧e für die Brikettierung von Staubkohlen benötigt. 1907 wurden 3,5 Mio t; 19II 6 Mio t Briketts hergestellt mit einem Pechzusatz von 240 und 420 Tausend $t$. Neu kam die Erzbrikettierung hinzu ${ }^{5.297}$ ).

Der Anteil des Gaswerksteers am Gesamtaufkommen ging dauernd zurück. Es erzeugten:

\begin{tabular}{l|r|r|r}
\hline & Kokereien & Gaswerke & \multicolumn{1}{c}{ Zusammen } \\
\hline 1908 & $682000 \mathrm{t}$ & $318000 \mathrm{t}$ & $950000 \mathrm{t}$ \\
1911 & $851000 \mathrm{t}$ & $370000 \mathrm{t}$ & $1201000 \mathrm{t}$
\end{tabular}

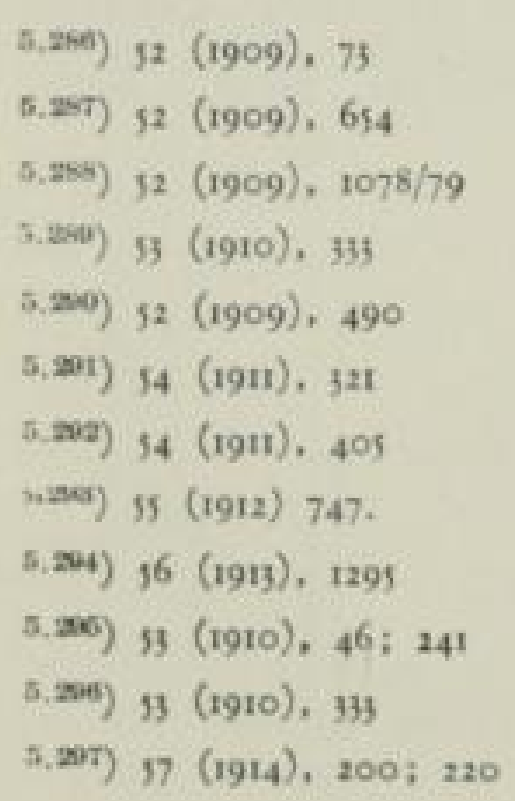


Dieser Umstand und der schon erwähnte Einfluß des Zwischenhandels zwang die Gaswerke, sich in der Wirtschaftlichen Vereinigung immer enger aneinanderzuschliefyen. Der Gedanke, in den Gaswerken eigene Destillationsanlagen zu errichten oder eine finanzielle Beteiligung an bestehenden Unternehmen zu suchen, tauchte innerhalb der Vereinigung im Jahre 1909 zuerst auf $^{\text {s.2ro }}$ ). Das fand natürlich den lebhaften Widerspruch G. Möllers, Essen, der von der Vereinigung zur Teerverarbeitungsindustrie gewechselt hatte $\left.{ }^{5.217}\right)$.

Immerhin war die Abnahme so fiott, daf die Vereinigung wiederholt mahnen mufte, die alte Stammkundschaft der Gaswerke, die Dachpappenindustrie, nicht zu vergessen.:20\%.

Zum Schluf mag noch der Oberflächenteerbrenner von I rinyl erwähnt werden, der zum Industrieofenbetrieb eine Zeitlang bevorzugt wurde ${ }^{5.2 n}$ ).

\subsection{Ammoniakwirtscbaft}

Der Absatz von Ammoniakwasser und schwefelsaurem Ammoniak war, dank der Ammoniakverkaufsvereinigung und der Wirtschaftlichen Vereinigung deutscher Gaswerke dauernd gesund ${ }^{5.300}$ ). Gewisse Schwankungen waren zwar zu verzeichnen, jedoch waren sie gering im Vergleich zu den Änderungen, die die allgemeine Konjunktur erlitt. Eine besondere Bereitschaft, Zyan zu kaufen, war vorhanden.

Die Nachrichten über die „wahrnehmbare Entwicklung ${ }^{\text {(6.5.00 }}$ ) der Gewinnung von Luftstickstoff über Kalkstickstoff und Kalksalpeter lösten eine gewisse Unruhe aus, obwohl Sicheres noch nicht bekannt war. ${ }^{\text {r.3ng }}$ ), ein Markteinfluß war aber nicht festzustellen ${ }^{5.000}$.

Um die Jahrhundertwende betrug die Jahreserzeugung von schwefelsaurem Ammoniak in: Deutschland $130000 \mathrm{t}$, England $220000 \mathrm{t}$, Frankreich $37000 \mathrm{t}$, Belgien, Holland 33000 t, Österreich, Ruß̧land und Spanien $35000 \mathrm{t}$, Vereinigte Staaten $60000 \mathrm{t}$. Die Ausfuhr Englands und Belgien nach Deutschland belief sich auf $\left.77000 t^{5.300}\right)$.

I9II hatte Deutschland in der Ammonsulfatherstellung England überflügelte ${ }^{5.300}$ ) mit $373000 \mathrm{t}$ gegen $369000 \mathrm{t}$ in England, während Frankreich nur $56000 \mathrm{t}$ und die Vereinigten Staaten 116000 t hervorbrachten $\left.{ }^{5.20}\right)$. Der Verbrauch im Lande war aber auch in 25 Jahren auf das siebenfache gestiegen. Dic Landwirte wufyten aber nunmehr auch, wo und wie die verschiedenen Düngemittel jeweils am besten eingesetzt wurden ${ }^{5,300}$ ).

Ein Histörchen über die Würdigung des Ammonsulfates durch den Grafen Tiele-Winkler in Schlesien soll hier nicht vergessen werden. Seine Reb-

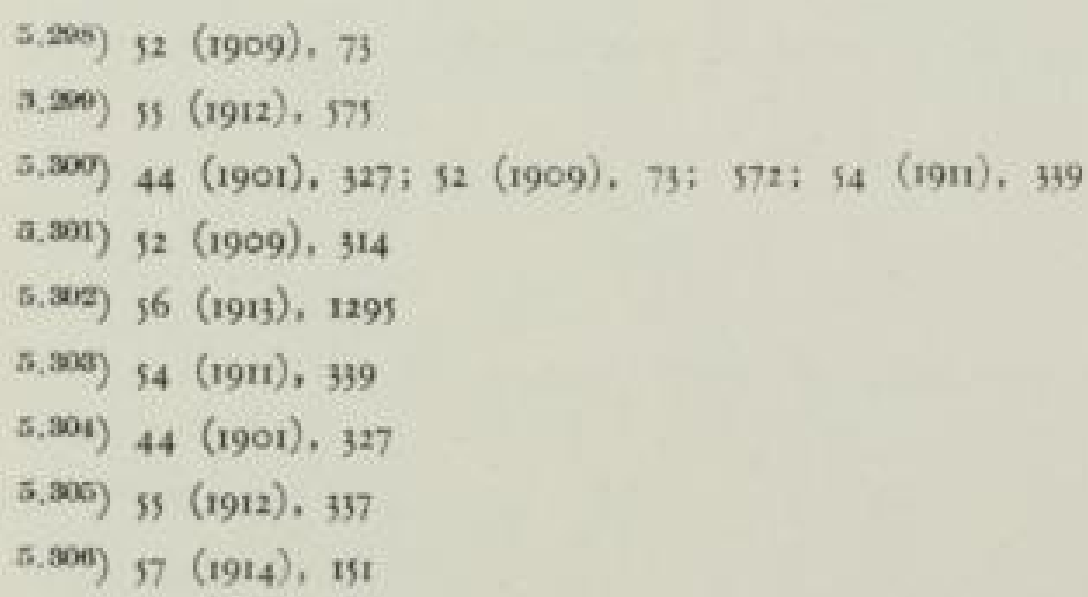


hühner litten bei trockenem Wetter unter Chilesalpeter, weshalb auf seinen Gütern für Halmfrüchte nur noch Ammonsulfat verwandt werden durfte $e^{5,307}$ ).

Kurz vor Ausbruch des Krieges sagte F. Bücbner zur Kennzeichnung der Lage: „Ungleich gefährdeter (als durch Kalkstickstoff) wird die Absatzmöglichkeit für Ammoniakwasser, da dic Badische Anilin- und Sodafabriken Ludwigshafen und Kunheim \& Co. Berlin, das Haberverfahren aus den Elementen Stickstoff und Wasserstoff praktisch zu verwerten angefangen haben. Es ist der beste Ersatz für Salmiak. Mit einem Sinken der Preise für Ammoniak mufz heute und in Zukunft gerechnet werden " ${ }^{5.304}$ ).

Kurz vor dem ersten Schuf im Kriege waren auch grołe Vorräte an Salpeter und Ammoniumsulfat vorhanden ${ }^{5,2000}$ ).

Aus dieser Lage entsprang die technische Weiterentwicklung. Das Buebsche Verfahren der Zyanwasserstoffauswaschung bürgerte sich immer mehr ein ${ }^{5.319}$ ). J. Bueb erhielt ausschließ̧lich unlösliches Ferrocyanammonium, über das A. $H$ and, Kunheim \& Co., Niederschönweide urteilte, dał es für die weitere Verarbeitung besser geeignet sei als das lösliche Ferrocyanammonium zusammen mit einer Menge gelösten Ammoniaksalzes ${ }^{\text {s.at1 }}$ ).

Dieses wurde beim trockenen Verfahren von W. F eld, Linz, erzeugt, der anstrebte, Zyan und Ammoniak gemeinsam zu gewinnen ${ }^{5.312}$ ) (DRP. is 820 J. f. G. 48 (1905) S. 20). Von W. Le ybold, wegen des höheren Zyanausbringens zunächst gut beurteilt ${ }^{5.315}$ ), wurde es in umfangreichen Versuchen in Hamburg ohne Ergebnis eingesetzt ${ }^{\mathrm{s} . a 12}$ ). Le $y b \circ l d$ und $S c b m i d t$ führten die Versuche mit von Ammoniak freigemachten Gasen mit Eisenvitriol und Kalk weiter und kamen zu einem sicheren Betrieb. Durch die vorherige Herausnahme des Zyans wurde die Reinigungsmasse wesentlich entlastet, so daß ein zur Schwefelsäureherstellung sehr gceigneter Rohstoff entstand.

J. Bueb wies schon frühzeitig darauf hin, daf̧ der Ertrag aus Zyan nur einen kleinen Teil des Reingewinnes der Werke darstelle. Entscheidend für die Werke sei die Reinigung des Gases und nicht die gewonnene Zyanmenge $\left.{ }^{5.31}\right)$. Die Preise fielen zudem, denn der Bedarf zur Goldextraktion belief sich auf $5500 \mathrm{t} / \mathrm{J}$ ahr, die Erzeugung betrug aber $12600 \mathrm{t}$. Davon stammten in Deutschland aus Synthese $1500 \mathrm{t}$; aus Schlempe $800 \mathrm{t}$; aus dem Gase $200 \mathrm{t}$; in Frankreich aus Gas $300 \mathrm{t}$; und in England aus Synthese $3500 \mathrm{t}$; aus Gas $300 \mathrm{t}^{5,313}$ ).

Die Schädlingsbekämpfung mit Blausäure, die in Nordamerika entwickelt worden ist, konnte an der Ungleichheit des Bedarfes und der Erzeugung auch nichts ändern $\left.{ }^{\text {s.xig }}\right)$.

Die Weiterentwicklung des Feldschen Verfahrens zur gleichzeitigen Schwefelwasserstoffreinigung wird im folgenden Abschnitt behandelt werden.

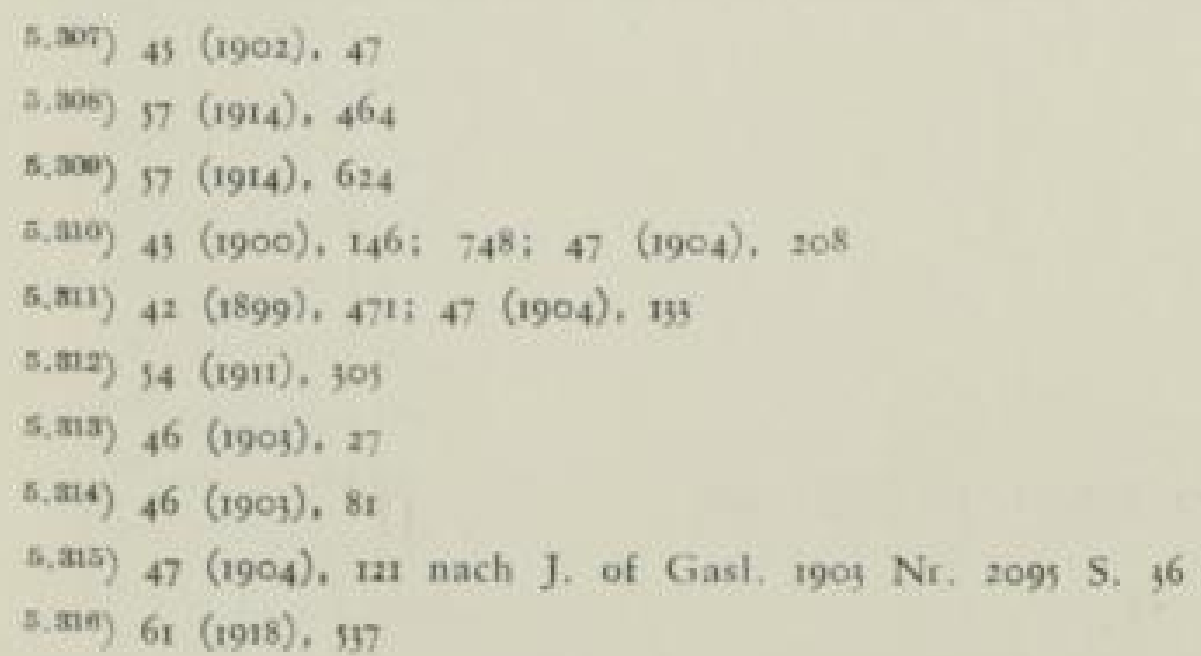


Auf das direkte Verfahren der Ammoniakgewinnung, das für die Bedürfnisse von Kokereien durch F. Brunck, S. Cooper, H. Koppers und C. Otto entwickelt wurde, kann hier nicht näher eingegangen werden ${ }^{5,317}$ ). Es blieb zwat in Gaswerkskreisen nicht unbeachtet. ${ }^{5.135}$ ), ist aber vor dem Kriege in den Werken nicht aufgenommen worden. Erst I9Is wurde von Budapest über eine Anlage berichtet, der Reinigerkästen nachgeschaltet blieben ${ }^{5.311}$ ).

$\mathrm{Zu}$ Anfang des Jahrhunderts war die Neigung der Gaswerke zu spüren, die Sulfaterzeugung zu Gunsten der Salmiakgewinnung aufzugeben ${ }^{5,300}$ ). Die Verwirklichung geschah aber nur in wenigen Werken. Wilhelm Ostwald griff ein Verfahren, das schon 1839 von Fr. $K \ddot{u} b l m$ a $n n$, Kolmar, angegeben war, auf, aus Ammoniak Salpetersäure herzustellen, das er mit Kontakten mit E. B r a u er im betrieblichen, allerdings beschränkten Maß̧e arbeitsfähig machte ${ }^{5.32}$ ). An der Ausnützung der Koksofengase zur Gewinnung von Salpetersäure arbeiteten Dr. C. Otto und Maschinenfabrik Augsburg-Nürnberg. Die Deutsche Stickstoff G. m. b. H. baute in Nürnberg eine Anlage, die Aktiengesellschaft für Stickstoffverwertung mit $\mathrm{I}$ Mio $\mathrm{M}$ eine solche in Heringen bei Hamm (Westf.) ${ }^{5.32}$ ). Das Mondgas-Verfahren, das wegen gesteigerter Ammoniakgewinnung entwickelt worden ist, wurde auf S. 215 und S. 360 erwähnt. Die Urbarmachung der Torfmoore, über die bereits berichtet wurde, sollte nach Frank-Caro über die Ammoniakgewinnung wirtschaftlich sein $\left.{ }^{5,393}\right)$. (vgl. S. 360).

Am 18. März roro hielt F. Haber, einen Vortrag über die Ammoniaksynthese im Laboratorium der chemisch-technischen Versuchsanstalt zu Karisruhe ${ }^{5, a n s}$ ). H. B unte machte darüber den Gasfachleuten im Märkischen Verein die ersten

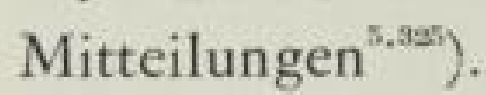

Lohnend erscheint es, gerade diese Entwicklung der Ammoniaktechnik vor dem grof̧en Kriege zusammenzufassen. Die zuerst mühevoll entwickelte Wertschätzung der Stickstoffdüngemittel hatte zahlreiche Wissenschaftler und Ingenieure dahin beeinflussen können, auf dem scheinbar unerschöpflichen Absatzgebiete mit neuen Verfahren zur besseren Ausbeutung des Stickstoffes der Kohle und zu seiner Gewinnung aus der Luft zu arbeiten. Die Grenze der Aufnahme und Umsatzeähigkeit des Bodens war keineswegs erreicht. Die sich stauenden erzeugten Mengen drohten zwar den Erzeugern verminderte Preise zu bescheren, man wufte aber auch, daf mit verminderten Preisen der Absatz sich sofort beleben würde. Die Vertriebsverbände für Ammoniak hatten sogar wahrscheinlich erreichbare Mengenzahlen errechnet.

Deutschland war im Begriff, der landwirtschaftlichen Erzeugung in ganz Mitteleuropa eine neue Möglichkeit zu erschließ̧en und damit die Lage der Landwirtschaft zu festigen. Gerade das aber war einigen Weltpolitikern unerwünscht und so kam es, dał die Stickstoffmengen statt zum landwirtschaftlichen Aufbau, um

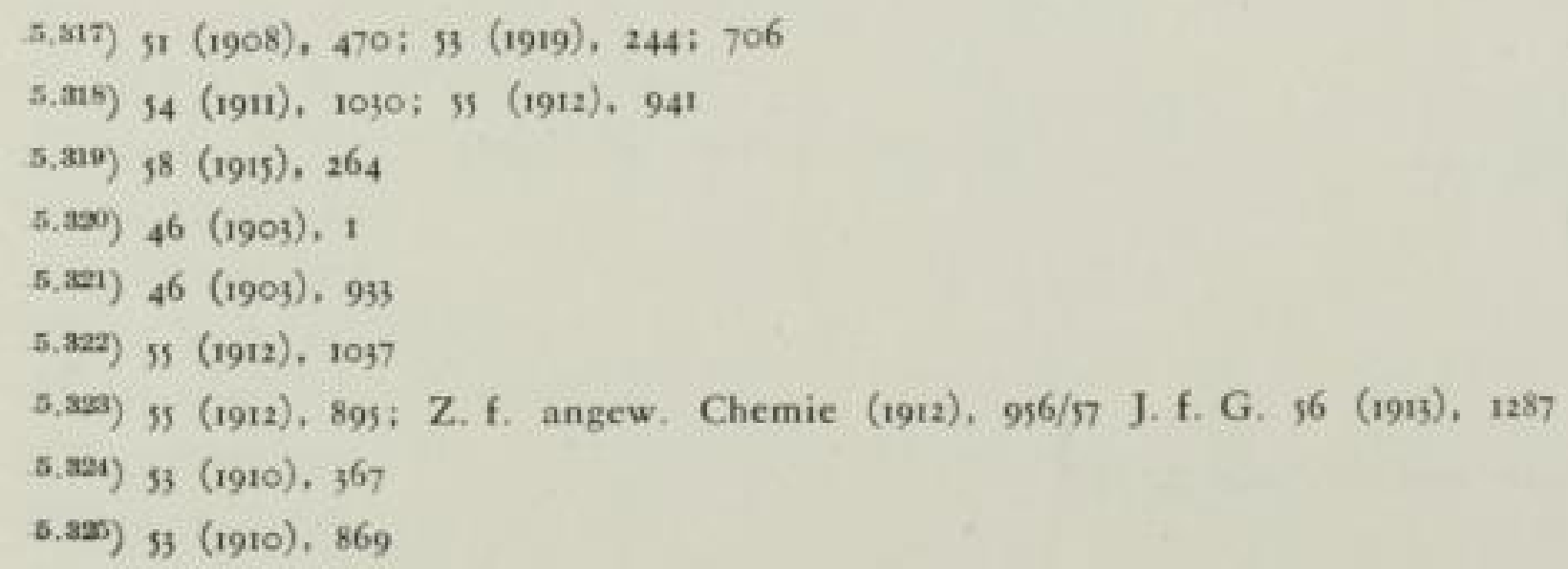


die Mitte Europas zu verteidigen, zur Herstellung von Zerstörungsmitteln benutzt werden muften. Für die Kriegstreiber wurde die Menge der erzeugbaren Salpetererzeugnisse eine nicht geringe und sehr unangenehme Überraschung.

\subsection{Scbwefelreinigung}

Die Reinigung des Gases von Schwefelwasserstoff wurde bei den Gaswerken fast ausschlieflich mit Eisenoxydhydrat (Reinigungsmasse) auf trockenem Wege fortgesetzt. Der Luftzusatz zum Gas zur laufenden Regenerierung der Masse im Kasten veranlaf̧te ein fortgesetzes gründliches wissenschaftliches Studium und Aufklärungen über die beste Art, Menge und Stelle des Zusa'zes ${ }^{5320}$ ). Nur gelegentlich wurde auch der Schwefelkohlenstoffentfernung Aufmerksamkeit gewidmet $^{5.327}$ ). Das Patent 250909 nach Knoevenagel, Reis, Kuckuk mit Natronzellulose konnte keine Bedeutung gewinnen, weil bei deutschen Kohlen die vorhandene Menge nicht störend empfunden wurde ${ }^{5.355}$ ).

Lebhafte Bemühungen knüpften sich an die Aufgabe, die Handarbeit beim Ausund Eintragen der Masse zu mindern. Edinburg-Granton bediente die auf Flurhöhe gebrachten Reiniger mit Baggermaschinen und setzte die Regenerierräume über die Kästen, damit die Füllung von oben durch das Schwergewicht erfolgen könne $\left.^{5.320}\right)$. Umgekehrt setzte Bremen die Kästen hoch und den Regenerierraum darunter $\left.{ }^{5.300}\right)$. E. Sch mied $t$, Aschaffenburg, schuf einen $5 \mathrm{~m}$ hohen senkrechten Kasten von I,5 m Durchmesser, durch den die Masse mit Leitblechen geführt abfallen sollte $\left.{ }^{5.321}\right)$. Auch J. Becker, Frankfurt, wandte Hochregeneratoren mit

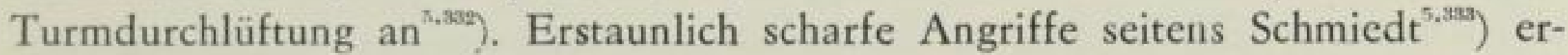
fuhr $F \ddot{o r} t s c h$ mit Erwägungen und einem Projekt, Reiniger im Freien aufzustellen $^{\text {s.364 }}$ ). F. Menzel, Wien, konnte dazu mitteilen, daf3 im Gaswerk Simmering bereits seit einigen Jahren die Reiniger im Freien standen.

Wichtiger aber und mit vielmals gröłeren Mühen und Kosten waren die Arbeiten von Feld und Burkbeiser verbunden.

W. Feld, Linz, a. Rhein, hatte die Absicht, den Schwefel, der sich im Gase als Schwefelwasserstoff befand, mit dem Ammoniak gleichzeitig zu entfernen (Polythionatverfahren) und dabei schwefelsaures Ammonium zu gewinnen. In East Hull wurden Versuche angestellt, die aber die theoretischen Erwartungen nicht erfüllt haben. Fast das ganze Ammoniak aber nur die Hälfte des Schwefelwasserstoffes wurden absorbiert $\left.{ }^{\text {tant }}\right)$. Auch in Königsberg wurde eine Anlage erbaut $\left.^{5.130}\right)$, die im Jahre 1912 von vielen Fachleuten günstig beurteilt wurde. Eine

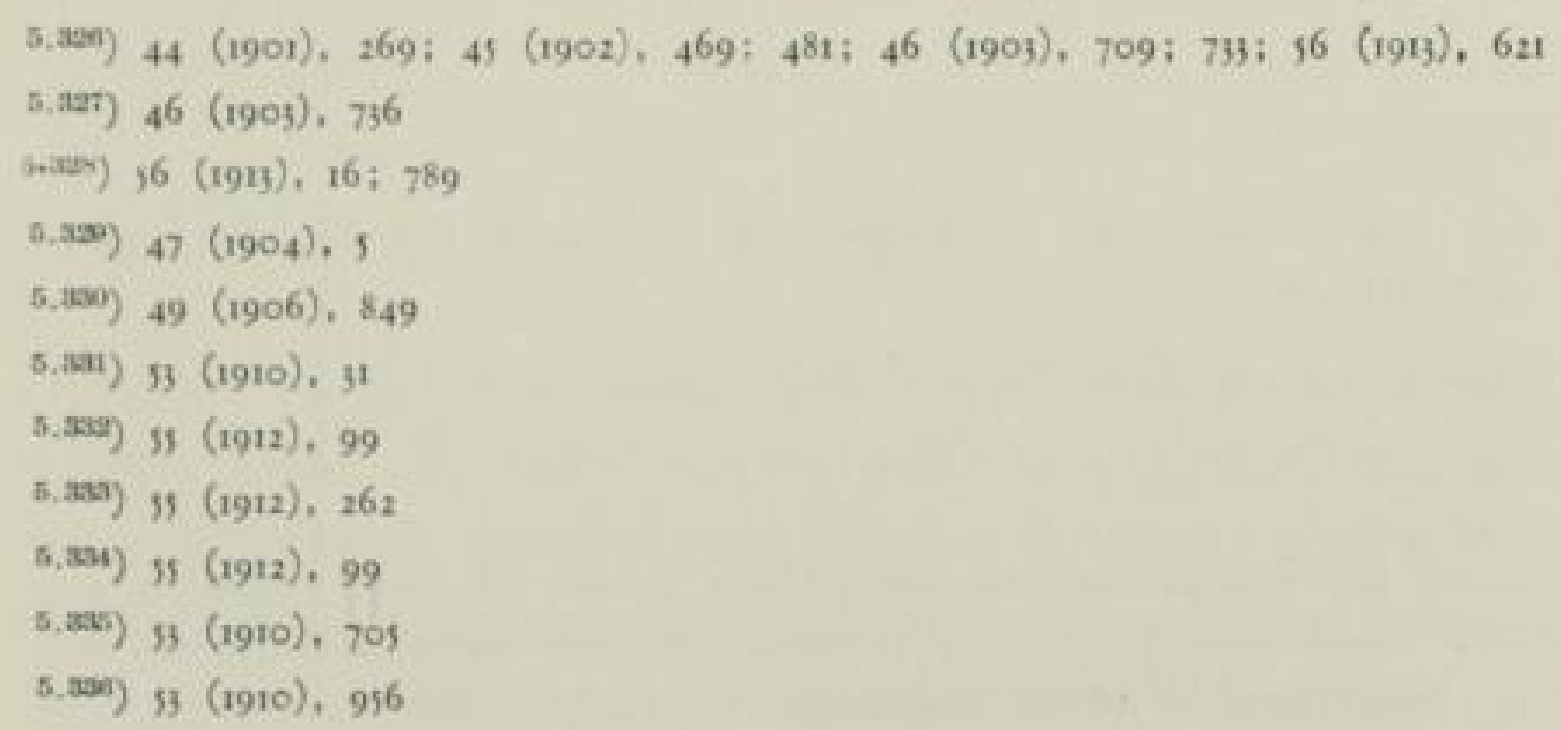


grołe Anlage lief bis 1915 in Königsberg. Feld hat sein Verfahren noch während dieser Zeit geändert, ohne die Umständlichkeit überwinden zu könnenen ${ }^{\text {t.san }}$ ). Schlief̧lich wurde noch auf der Gutehoffnungshütte in Sterkrade eine Anlage erbaut, bei der zur vollständigen Teerfreiheit noch eine von Feld entwickelte heiß̧e Teerwaschung mit anschlief̧endem Pelouzestoßabscheider vorgeschaltet wurde. Die Versuche liefen bis in die Kriegszeit hinein. Feld war mitten in der Arbeit am 15. 3. 1914 plötzlich erkrankt und gestorben. Man wurde der Schwierigkeiten, auch mit der Haltbarkeit der Apparaturen, nicht Herr und errichtete eine neue, kleinere Anlage auf Zeche Fröhliche Morgensonne. Die dort aufgenommenen Versuche hätten möglicherweise zu einem guten Ende geführt, wenn nicht die Kokerei der Zeche 1919 gänzlich stillgelegt worden wäre. So aber fand sich trotz grundsätzlicher Anteilnahme am Verfahren niemand, der weitere Versuche vornahm ${ }^{\text {s.ans }}$ ).

Den gleichen Zweck, den Schwefelgehalt des Gases zur Herstellung des Ammonsulfates zu benutzen, verfolgte K. Burkbeiser, Aachen. Burkheiser hat an Arbeiten von Young (DRP- 13940, 1880) angeknüpft, der schwefelwasserstoffhaltigen Ammoniakdampf mit Luft zu Sulfit und Sulfat verbrannte. Dabei muf̧te aber ein grof̧er Teil des Ammoniaks mit verbrennen. Burkheiser erhitzte körniges Raseneisenerz auf nahezu $600^{\circ}$ und erhielt ein wasserärmeres Hydrat, das ein grof̧es Aufnahmevermögen von Schwefelwasserstoff hatte. Günstig war auch die groł̧e Durchlässigkeit der körnigen Packung, die Schichthöhen von 2 bis $3 \mathrm{~m}$ und Gasgeschwindigkeiten von 150 bis $200 \mathrm{~mm} / \mathrm{s}$ gegenüber sonst s bis Io $\mathrm{mm} / \mathrm{s}$ gestattete. Im Apparat wurde die Masse völlig regeneriert und die Luft bei hoher Temperatur bir zur schwefligen Säurebildung zugeführt ${ }^{5,3 x}$ ) (Bild 107). Die schweflige Säure wurde mit Lauge ausgewaschen, die auch durch den Ammoniakwäscher umlief. Sie enthielt dann primäres Ammonsulfit, das sehr aufnahmefähig für Ammoniak war, wonach sich normales Ammonsulfit bildete, das als weifzes Salz ausfiel ${ }^{5 .+40}$ ). Das Verfahren ist mehrfach umgestaltet worden, wodurch eine genaue Beschreibung trotz der Veröffentlichungen nicht möglich wird. Burkheisers erstes Patent stammt aus dem Jahre 1907 (212209). Er arbeitete zunächst in aller Stille in Wattenscheid. Als dort die Gaserzeugung aufgegeben wurde, wurden die Versuche bei der Imperial Continental Gas Association erneut aufgenommen ${ }^{\text {a.sin }}$ ) und danach in Hamburg-Grasbrook eine Anlage für $6000 \mathrm{~m}^{3} / 24 \mathrm{~h}$ eingebaut $\left.{ }^{5.30}\right)$. Eine neuere Anlage wurde in Tegel errichtet, die H. Drebscbmidt betreut hat. Die belgische Société Anonyme d'OugréeMarinage erwarb die Rechte für 590000 frcs. Aber betriebsreif sind die Anlagen nicht geworden. Auch hier beendete der frühe Tod des Erfinders die Arbeiten. Die Patente sind rgis erloschen.1.2\%).

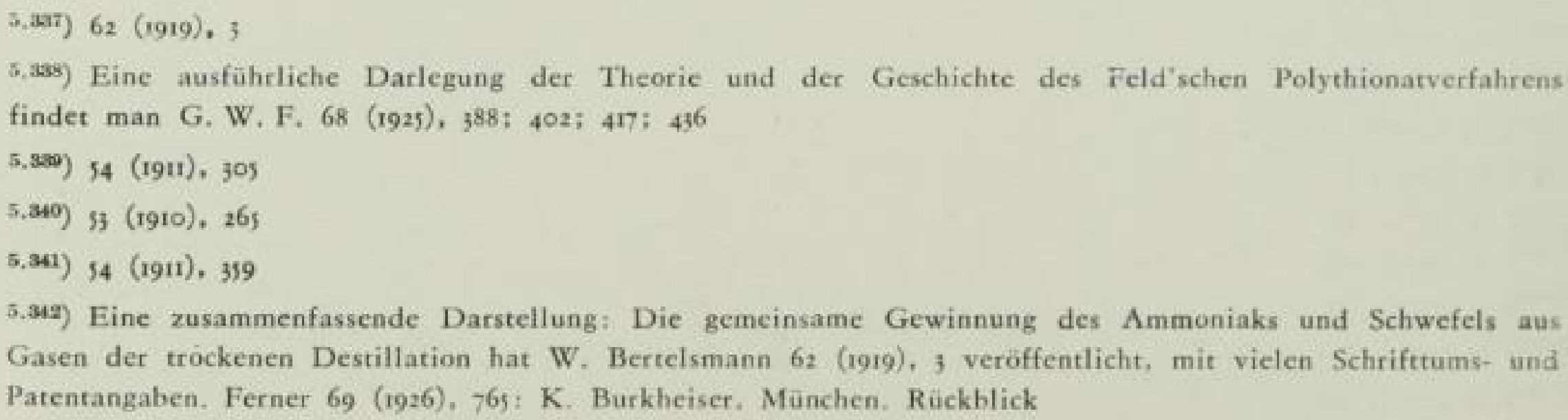



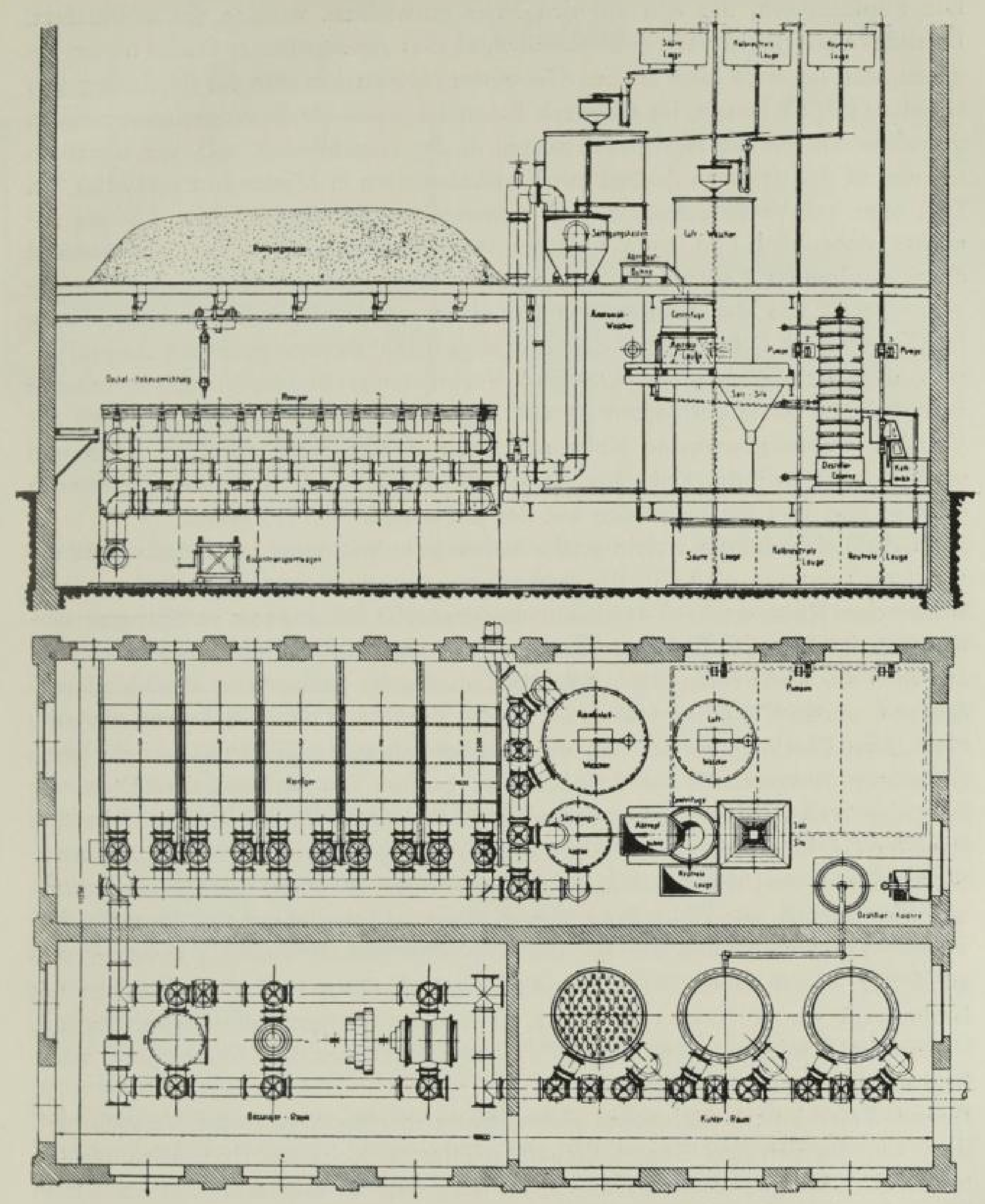

Bild 107 Schwefelreinigung nach Burkheiser (J. f. G. 54 [1911] S. 329)

\subsection{Koks}

Die Erkenntnis, daf dem Nebenerzeugnis Koks besondere Pflege zuteil werden müfte, wenn die Gascrzeugung höchste Erträgnisse liefern sollte, hatte sich nunmehr allgemein durchgesetzt. Diese Fürsorge erstreckte sich auf die Güte und auf die Marktpflege, durch Erschluł neuer Verwendungsgebiete aber auch durch Verarbeitung von reichlichen Mengen zu Wassergas. 
Die Förderkosten, die sich auf den Preis auswirkten, wurden genau beachtet. Betriebsvergleiche der Imperial Continental Gas Association in Berlin hatten ergeben, daf im alten aber kleinen Gaswerke Holzmarktstraf̧e die Förderung von Hand 2,34 Mk/t betrug, im Gaswerk Schöneberg mit De Brouwerrinnen 2,04, in der alten Anlage mit Horizontalretorten in der Gitschinerstr. 2,42, mit Cozeöfen $\mathrm{r}, \mathrm{I} 6$ und in der neuesten Anlage mit Vertikalretorten in Mariendorf $0,78 \mathrm{Mk} / \mathrm{t}^{5.343}$ ). Dał man bei Vertikalretorten und Kammeröfen mit festliegender Ladung zunächst stehenblieb und trotz mancher Vorzüge den Engländern mit dauernd durchwandernder Ladung in Retorten nicht folgte, lag neben der gröłgeren Unabhängigkeit von der Kohlensorte vor allem an der Rücksicht auf den Koks. In Deutschland fiel in diese Zeit die allgemeine Bevorzugung der Zentralheizung mit ihren grołen Speicher- und Verbrennungsräumen, die einen festeren und groberen Koks verlangten als die englischen offenen Feuerstellen. Der aus Vertikalretorten gewonnene Koks war dafür gerade recht, nicht so weich und ungleichmäßjig wie der Koks aus waagerechten und schrägen Retorten, aber auch nicht so hart und reaktionsträge wie der Zechenkoks für Hochöfen.

Dem Ablöschverfahren wurde groł̧e Aufmerksamkeit zuteil. Anfangs wurde die Meinung vertreten, daf3 die Brouwerrinne, wenn sie richtig gehandhabt würde, weder den Koks ertränke noch ihn zermalme $\left.{ }^{5.34}\right)$. C. Eitle in Stuttgart verbesserte die Brouwerrinne zur bandartigen Förderung mit gekuppelten Kästen, in denen der Koks ruhig liegen blieb und durch das flache Wasserbad hindurchgezogen wurde ${ }^{5.34 t}$ ). (Bild IOß) $G \ddot{o b} r u m$. Stuttgart, hob aber hervor, dał die vorsichtige Löschung in Körben, die nachher mit einer Elektrohängebahn ohne Umstürzen fortgeschafft werden konnten, bessere Ergebnisse habe. Dem trat auch der Anwalt der Brouwerrinne E. Körting, Berlin, nunmehr bei ${ }^{-5.34}$ ). Reubold, Bamag Berlin, empfahl die selbsttätigen Kokslöscheinrichtungen für Kammeröfen, weil der sich bildende Wasserdampf im geschlossenen Löschturme aufgehalten, mit zur Abkühlung des Kokses beitrüge. Das auf $60-70^{\circ}$ aufgewärmte Löschwasser schonte bei erneuter Verwendung den Koks wegen verminderter Abschreckung, ${ }^{5, a r}$ ). Eine fahrbare Koks-Sieb- und Verladeanlage mit Becherwerk von A. S to $t z$. Stuttgart, solite dazu beitragen, die Förderwege des Kokses im Werke zu vermindern ${ }^{\text {5.4.45 }}$ ). Solche Maschinen sind später noch mehrfach zusammengebaut worden.

Baurat $S t a c k$ vom städtischen Heizungsamt in Hannover stellte Versuche mit dem von der privaten Gasgesellschaft gelieferten Koks an. Er bezeichnete ihn schlechthin als gut, wenn auch der Aschengehalt zu ungleichmäfjig sei ${ }^{5.310}$ ). In Königsberg gab es eine Kommission zur Rauchbekämptung, die sich für Koksverwendung einsetzte $^{\text {s.son }}$ ). E. J. Const a m, Zürich, schlug vor, zur Erhöhung des Schmelzpunktes der Aschen dem Brennstoff Kaolin oder Quarzpulver zu-

\footnotetext{
5.343) yo (1907), 125

(5.) 34 (1911), 647

5.345) 48 (1905), 766

5. หอ) $\$ 4$ (1911), 1669

5.347) 55 (1912), 1079

5.,345) 56 (1913), 318

5.349) 47 (1904), 611

5. 000$) 54$ (1911), 69
}

378 


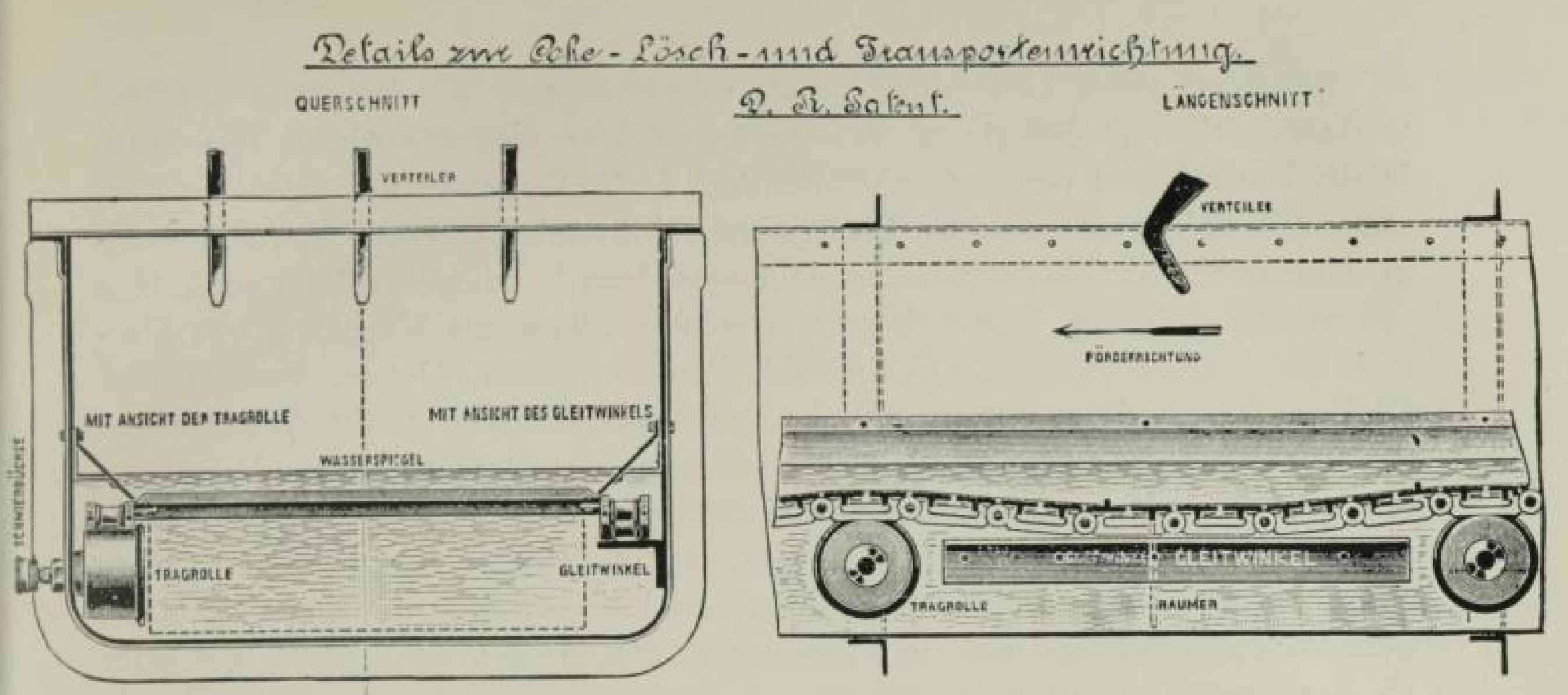

Bild ro8 Koksförderrinne nach Eitle (J. f. G. $4^{8}$ [1905] S. 768)

zusetzen. Besser sei allerdings die Wasserkühlung des Rostes oder Dampfeinführung oder eine Wasserpfütze unter dem Rost ${ }^{\mathrm{t}, \mathrm{si} 1}$ ).

Um den Absatz muf̧ten sich die Gaswerke mit viel Liebe kümmern. Koksfüllöfen bedurften immer noch einer werbenden Fürsorge. Kaiserslautern hatte erfahren, dał die mietweise Abgabe von soichen Ofen unmöglich war. Infolge Überbeanspruchung waren sie nach einem Jahre schon völlig zerstört. Dagegen bewährte sich der Verkauf auf Abzahiung in vier Raten durch Händler unter Finanzierung des Werkes $\left.{ }^{\mathrm{s}, 352}\right)$. W. Bucerius von der Landesgewerbehalle Karlsruhe empfahl den Bäckereien die Koksverwendung. Der Vorteil lag im Dauerbrand mit der Möglichkeit, nachmittags klein zu stellen, gegenüber der völligen Stillegung bei der Kohlenfeuerung mit dem Zwange, nachts viel früher den Ofen wieder aufheizen zu müssen. Die Meinung, daf̧ ein Bäckereiofen nur langflammige Brennstoffe verbrauchen könne, erwies sich als falsch. Die Gaswerke forderte er auf daran mitzuarbeiten, vor allem einen sauber klassierten Koks zu liefern ${ }^{5.753}$ ).

Beim Ortsverkauf muß̧te das Werk die Händler fest an die Hand nehmen. Es wurde beobachtet, dafy diese die Garantiesumme auf Wasserfreiheit beim Verkauf nach Gewicht nicht der Kundschaft weitergaben, wodurch dann Beschwerden wachgerufen wurden. Deshalb empfahl sich der Verkauf nach Volumen mit

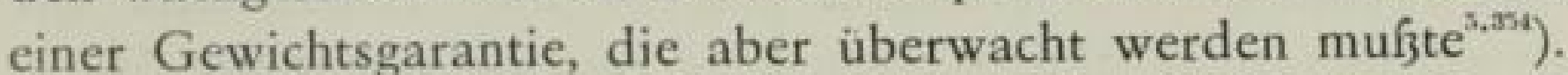

Besondere Sorge bereitete die Verwertung des Koksstaubes. Müller und Korte, Berlin, lieferten besondere Roste, mit denen 1903 bereits 200 Kessel ausgerüstet waren. Die Firma errechnete, natürlich unter Anrechnung des Marktpreises, mit 5o bis $60 \%$ Ersparnissen gegen Kohlenfeuerung (Gaswerk Mariendorf) ${ }^{5.555}$ ). Die Kridlo-Unterwindfeuerung für Koksgrus war eine Fortentwicklung des Kudlitzrostes von V. A. Kridlo, Prag. Durch eine Gruppierung der Düsen konnte

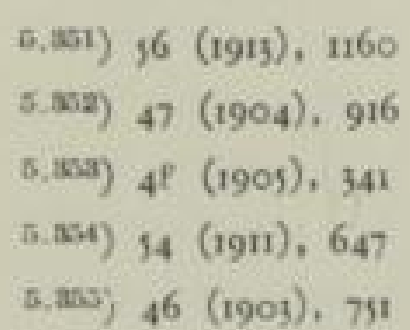


er trotz verringerter Düsendurchmesser mit geringerer Windpressung arbeiten, wodurch nicht nur Energie gespart wurde, sondern auch der Abflug von Staub in die Kesselräume vermindert wurde. Auf Zeche Dorstfeld war solch ein Rost sogar mit Erfolg unter einem Schrägwasserrohrkessel eingebaut ${ }^{5.350}$ ). Auch Sauggasgeneratoren hat man mit Koksgrus hergerichtet. In München lief eine Anlage mit 700 PS Leistung. Die Koksgrusverwertung führte zur Kupplung von Gasund Elektrizitätswerken in Greifswald, Rostock, Sorau, Guben, Bautzen und Diekirch $\left.^{5,35}\right)$. Andererseits wurde aber auch bei manchen städtischen Werken die Ausnutzung des Gruses zur Energiedeckung der Gaswerke behindert, wenn diese verpflichtet waren, wegen der Grundlast die Elektrizität aus dem Ortsnetz zu entnehmen ${ }^{5.35}$ ). Me y er, Pintsch, Berlin, berichtete von umfangreichen Versuchen der Vergasung von Kokslösche und Koksgrus in Sauggas-, Kerpely-, Drehrost-, Wasserrost- und Treppenrostgeneratoren, die alle ,gleich gut oder gleich schlecht" ausgefallen seien.

Rosenkranz. Riga, führte wohl zuerst erfolgreich die Koksgrusbrikettierung durch. Er erhöhte den Reingewinn aus Grus von 3289 Mk auf I8 000 Mk im Jahre. Klempt und Bonnet, Duisburg, nahmen statt der bisher versuchten Sulfitablauge als Bindemittel Dickteer des Gaswerkes Mönchengladbach. Solche Briketts wurden zur Unterfeuerung der Öfen in den glühenden Koks des Generators eingebracht. Langsames Aufheizen lieł sie dagegen zerflieł̧en. Beliefert wurden mit Brikettiereinrichtungen mehrere Zechen und die Gaswerke in Tegel, Como und Kolberg ${ }^{\text {s.350 }}$ ).

Die Wirtschaftliche Vereinigung beteiligte sich an der Aufklärung und sorgte vor allem durch die angemessene Verteilung des Kokses im In- und Auslande für geringere Preisschwankungen. Durch alle diese Anstrengungen gelang es, die Preise, die in der Krise von 1903 bei $10 \mathrm{Mk} / \mathrm{t}$ gelegen hatten, allmählich stetig in die Höhe zu bringen. Zwar wurde der Koksmarkt 1913 wieder durch eine schwache Geschäftslage in der Eisenindustrie bedroht ${ }^{5.500}$ ). Indessen konnte F. $B \ddot{u} c h n e r$ noch 1914 sagen, dał die Preise den Abnehmern das Gruseln beibrächten. Diese Abnehmer für Gaskoks waren r. Zentralheizungen, 2. Zementwerke und Kalkwerke für Schachtöfen, 3. Zuckerfabriken zum Darren, 4. Eisengief̧ereien zur Trocknung der Formen, 5. Neubauten mit Kokskörben, 6. Filter für Wasserwerke, 7. Lokomotiven dort, wo kein Rauch aufkommen durfte: Dampfstraf̧enbahnen, die älteste deutsche Eisenbahn, die Ludwigsbahn von Nürnberg nach Fürth, Zahnradbahnen. - Nuß̧koks ging in die Tonindustrie für Schmauchöfen und wurde für Bügelöfen benutzt. - Perlkoks brauchten Haushalt und Industrie, und der Koksgrus fand Verwendung in den erwähnten Sonderfeuerungen $\left.{ }^{5.301}\right)$.

Immerhin machte sich kurz vor dem Kriege eine lebhafte W'erbung für Braunkohlenbriketts störend bemerkbar. Zur Abwehr wurde eine „Technische Zentrale für Koksverwertung" (schon der Name lehnt sich an die Zentrale für Gas-

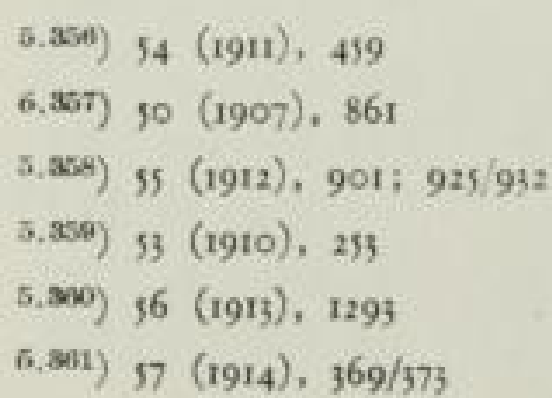


verwertung an und verrät den Anreger zur Vereinigung) durch das RheinischWestfälische Kohlensyndikat, das Oberschlesische Kohlensyndikat und die Wirtschaftliche Vereinigung deutscher Gaswerke gegründet ${ }^{5}$ ). Sie brauchte dann aber leider nicht mehr tätig zu werden.

\subsection{B E TRIE B S K O N T R L LE}

Eine besondere Schwierigkeit ergibt sich, wenn man der dauernden Kleinarbeit der Chemiker in den Gaswerken gerecht werden möchte, andererseits sich aber in Einzelheiten nicht verlieren darf. Was die Chemiker Grofes erreicht haben, ist in den technischen Abschnitten bereits abgehandelt. Namen wie $B u e b$, Geipert, Feld, Burkbeiser u. a. sind dabei hervorgetreten. Was aber täglich erarbeitet wurde, verblaf̧t bedauerlicherweise vor den Enderfolgen dieser Männer. Dabei wurde sich das Fach der Wichtigkeit der Aufsicht gerade in dieser Zeitspanne sichtbar bewuf̧. Man erkennt das aber mehr am Ruf nach Ausbildung des Nachwuchses als an den wirklichen chemischen Fortschritten in der Betriebsführung. Die Sorge um den Nachwuchs wird zum Schluf zu besprechen sein.

Das Verlangen nach Laboratorien und Versuchsanstalten mag aber hier als Zeichen der Anerkennung der wissenschaftlichen Arbeit in den Betrieben verzeichnet werden.

Die Hilfe der Chemiker war aber durchaus nicht allgemein vorhanden. Ein Schlaglicht liefert die Begründung über die Notwendigkeit, einen Gaswerkschemiker einzustellen, in Breslau, einem Werke, das 190428 Mio m" Jahr absetzte. Es heifft da: nunmehr sei ein Chemiker im Werke notwendig, weil eine Wassergasanlage eingerichtet würde. Dann folgen die Aufgaben, die dieser wohl sonst noch für das Werk und auch für andere städtische Betriebe (Wasserwerk) leisten könne. Die Beurteilung der Kohlen auf ihren Wert für die Gaserzeugung stand im Vordergrunde der Anteilnahme. Dał die damals üblichen Laboratoriumsuntersuchungen keine ausreichende Gewił̧heit über die Bewährung bei der Entgasung boten, wurde allgemein anerkannt $\left.{ }^{3.35}\right)$. H. B unte mufzte sogar hervorheben, daf̧ zum mindestens ein erster Anhalt aus den Analysen gefunden würde, allerdings allein nicht genüge $\left.{ }^{5.165}\right)$.

Deshalb wurde nach dem Muster S c bill in $g$ s in Hamburg 1897 und im Gaswerk Charlottenburg 1902 eine Versuchsgasanstalt eingerichtet $\left.{ }^{\text {t.s.6. }}\right)$, der noch mehrere folgten. Zürich und Breslau $\left.1908^{5.306}\right)$, Wien $\left.1909 / 10^{5.307}\right)$. Geipert sagte: Die Untersuchung der Kohlen gehört zu den wichtigsten Aufgaben der Gasindustrie $\mathrm{i}^{5,306}$ ).

G. Wunder, Leipzig, hatte sich bemüht, für die sächsischen Werke einen gemeinsamen Einkauf von Kohlen in die Wege zu leiten. Dabei fand er, dał die

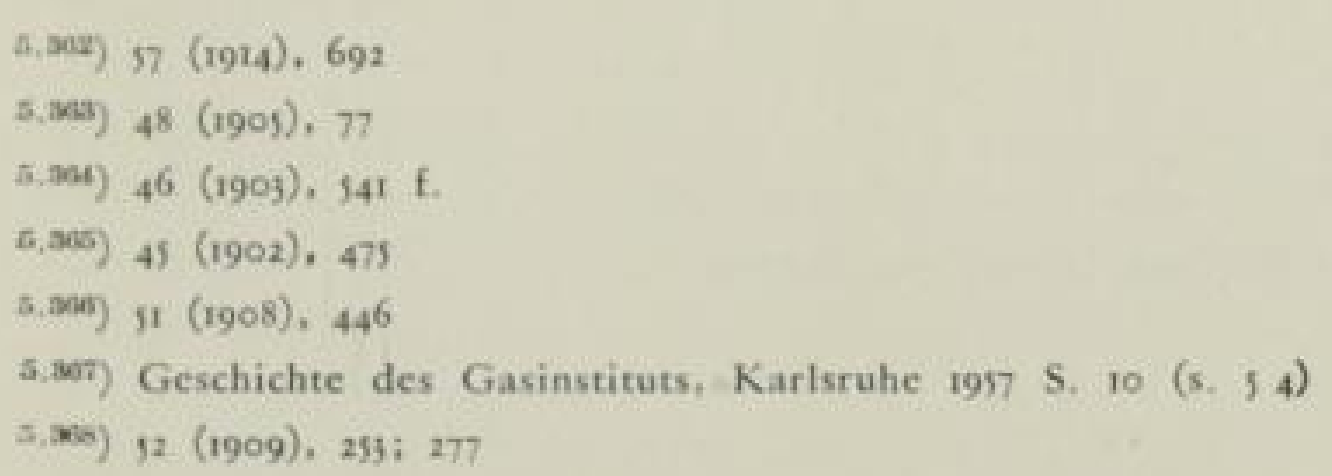


Werke wohl jeweils die von ihnen benutzte Kohle recht gut kannten, aber vollkommen im Ungewissen schwebten, wie sich eine andere Kohle, die wumöglich in einem anderen Werke sich bewähtt hatte, bei ihnen ausnützen lief̧e. Nach einem Gedankenaustausch mit H. Bunte kam er zu einem Antrag: Vorstand und Ausschuf möge Mittel zur Lösung der Frage nach dem wirtschaftlichen Wert der Kohle bereitstelien ${ }^{\text {t.mo }}$ ). Bunte gab dazu das erwähnte Urteil über den Wert der chemischen Analyse. Es sei, so sagte er, nur noch eine Frage der Zeit, daß̧ Kohlen zur Feuerung nach dem Heizwert, zur Gaserzeugung nach dem Gaswert gekauft würden.

Das war der Angelpunkt, an den sich die Einrichtung einer Lehr- und Versuchsgasanstalt, des späteren Gasinstitutes, knüpte $\left.{ }^{5, a 7^{\circ}}\right)$. Der Antrag auf ihre Einrichtung wurde auf der Hauptversammlung in Hannover mit 58 gegen 49 Stimmen angenommen $\left.^{\text {s.3.1. }}\right)$. Die Einweihung erfolgte drei Jahre später ${ }^{\text {t.j7g }}$ ). Damit begannen die systematischen Entgasungsversuche an Kohlen, die sich durch viele Jahre hinzogen. Das Beispiel erweckte Nacheiferung in der Schweiz durch Ausbau von Versuchsretorten in Zürich ${ }^{5.372}$ ), in Wien durch eine selbständige Versuchsanstalt $\left.^{5.3 \pi t}\right)$. Das Karlsruher Institut wurde später erweitert $\left.{ }^{5.3 \pi}\right)$. Die Einrichtung wurde durch den Krieg unterbrochen. I9I2 wurde in Mülheim/Ruhr auf Anregung von Emil Fischer, des Ordinarius für Elektrochemie in Berlin das Kaiser-Wilhelm-Institut für Heizstoffe und Krafterzeugung gegründet $\left.{ }^{5.370}\right)$. Zum Leiter wurde Prof. Franz Fis $c$ ber, $r^{5, a r 7}$ berufen. Die auch das Gasfach befruchtenden Arbeiten können nicht abgehandelt werden, der Name der FischerTropschsynthese mag für viele andere Arbeiten einstehen (s. S. 586).

Für betriebliche Untersuchungsgeräte wurden besonders die Kalorimeter weiterentwickelt. Ferdinand $F$ is $c$ ber hatte bereits $1897^{5.375}$ ) Angriffe gegen das Junkersche Kalorimeter gerichtet, die er in mehreren feuerungstechnischen Büchern hartnäckig aufrechterhielt ${ }^{3.37^{9}}$ ), obwohl schon r9or O. Pfeiffer, Magdeburg, eine eingehende Nachprüfung vorgenommen hatte ${ }^{5.350}$ ) und auch die Physikalischtechnische Reichsanstalt und H. Bunte schlichtweg das Urteil „gut" gefällt hatten. Ferd. Fischer hielt wie W. He mpel die Bombe für geeigneter als das Durchfluf̧kalorimeter, weshalb er auch seine eigene Bauart empfahl. Auch Stracbe erklärte sein Verpuffungskalorimeter für das beste $\left.{ }^{5.581}\right)$.

Die schreibende Gaswaage von Fr. $L u x$, Ludwigshafen, war ein anderes Gerät, das dem aufkommenden Wunsch nach laufender Betriebskontrolle entgegen$\left.\operatorname{kam}^{5.3 .32}\right)$.

5.3007) $46(1903), 541$

5.370) Einzelheiten darüber: Körting, Geschichte des Gasinstitutes, (s. 9.4) auch 47 (1904), 96

5.371) $47(1904), 582 ; 613$

5.372) 50 $(1907), 537$

5.373) $49(1906), 35$ u. 36:51 (1908), 589:52 (1909), 770

5.374) $51(1908), 730$

3.375) 57 (1914) 697; 662

5.978) $55(1912), 805$

5.377) $55(1912), 1228$

5.374) Z. f. angew, Chemic (1897), 698

5.97v) Taschenbuch für Feuerungstechniker 1908; Kraftgas Leipzig ron Spamer

$3,350) 44(1901), 68_{4} / 688$

5.\$21) $\$ 3$ (1910), 217

5.352) 57 (1914), 416

$3^{82}$ 
Für den Ofenbetrieb war es äuf̧erst wertvoll, dał nunmehr über die Strahlungserscheinungen die optischen Pyrometer entwickelt wurden. Sie fanden entspre-

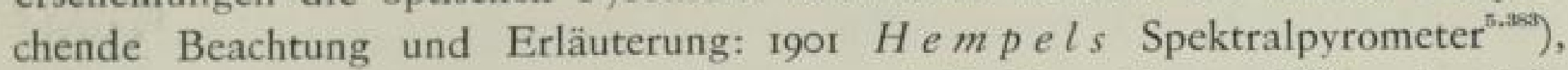
Glühfadenpyrometer von L. Holborn und F. Kurlbaum$m^{3.34}$ ), ein Jahr später H. W a n ner, gebaut von Dr. R. H as $\left.e^{5.355}\right)$, Hannover, 1903-1908 die in Deutschland allerdings nicht verwandten Konstruktionen von $F \dot{e} r y^{5.35 \%}$ ).

\subsection{Gasbebälter}

In der technischen Entwicklung der Gasbehälter wurden umwälzende Neuerungen nicht erarbeitet, vielmehr vertiefte man die theoretischen und praktischen Erkenntnisse an den gegebenen Bauarten. Versuche, mit Seilführungen Verbilligungen zu erzielen, waren noch nicht aufgegeben $\left.{ }^{\text {s.357 }}\right)$. Es zeigte sich aber, dał was an Gerüsten erspart wurde, an der Glockenstärke reichlich mehr aufgewendet werden mußzte $\left.{ }^{n, 355}\right)$. Auch der alte Streit: hie Radial - hie Tangentialführung lebte noch einmal auf $\left.{ }^{5.50}\right)$. Der spiral geführte Behälter in Altona blieb zunächst der einzige in Deutschland. Bei dieser Bauart werden die Windkräfte auf die Behältertasse übertragen, dafür waren aber die als Blechtassen ausgeführten in Deutschland beliebten Bauweisen ungeeignet.

Der bisher gröłte Gasbehälter der Welt in East Greenwich wurde durch einen solchen von $415000 \mathrm{~m}^{\prime \prime}$ Inhalt in New York übertrumpft. Es zeigte sich dabei, dał trotz der heftigen Schneestürme Nordamerikas in Deutschland höhere Winddrucke der Berechnung zu Grunde gelegt wurden als dort ${ }^{\text {s.mog }}$ ). Ein schwerer Zusammenbruch eines soeben aufgeführten Behälterbaues offenbarte bei der gerichtlichen Untersuchung, dał der Behälter sicherlich zu schwach bemessen war. Alle Gutachten bestätigten aber, daß̧ die Berechnung dem üblichen Stand der Technik entsprochen hatte, diese aber anscheinend noch unvollkommen war.

Obwohl durch die gleichmäfjigere Abgabe (vgl. S. 258/59) der für notwendig erachtete Behälterraum mit $60 \%$ der Tagesabgabe viel geringer, also relativ zur Gaserzeugung billiger geworden war, zeigte ein statistischer Vergleich ausgeführter grof̧er Behälter, dał offenbar unter dem Einflufy des weithin geübten Ausschreibungsverfahrens an den Herstellungskosten der Behälter sehr gespart worden war. Der richtigere Weg lag darin, daß sich ein Gaswerk bei einem grofyen Bauvorhaben die Konstruktionsangebote im einzelnen erläutern und durch Sachverständige nachprüfen lieł̧. Das bewährte sich bei einem Streit um einen groß̧en Gasbehälter in Berlin-Schöneberg. Die Klausel für alle Bauten in Schöneberg lautete: „Eine erteilte Genehmigung erlischt, wenn der Inhaber nach Empfang

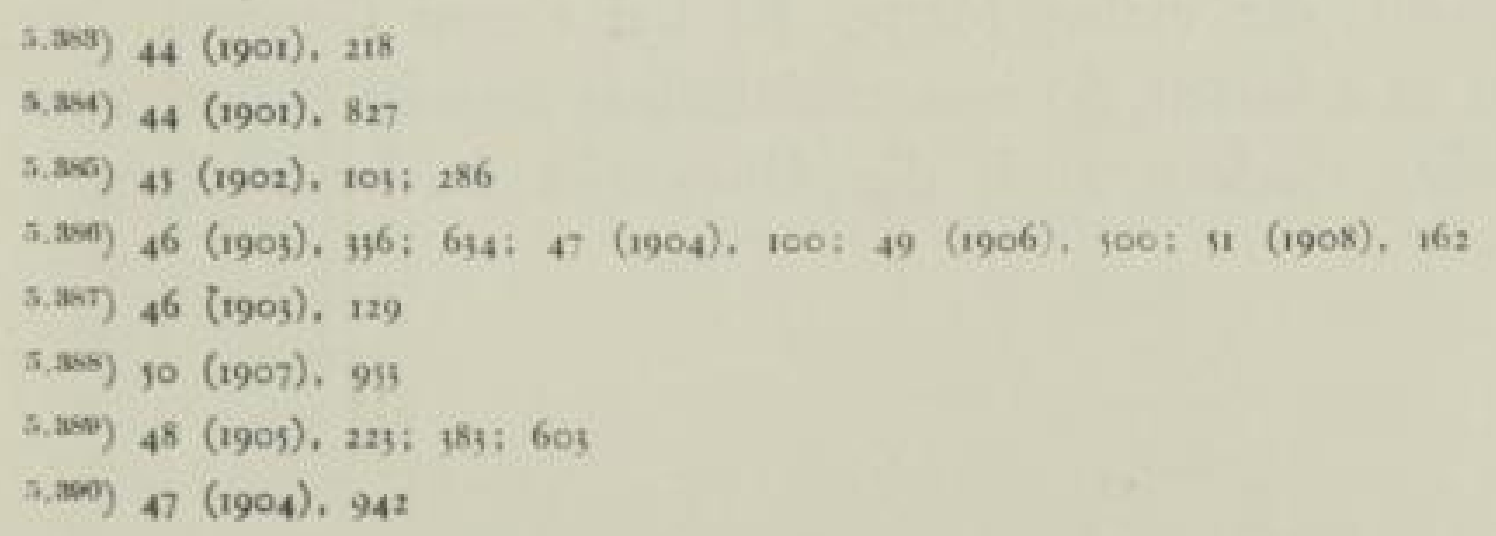


derselben ein ganzes Jahr verstreichen läf̧t, ohne davon Gebrauch zu machen." Wegen eines schweren Unfalls, Umsturz des Montagekrans auf die Schienen der Eisenbahn, den der Bauunternehmer zu verantworten hatte, wurde der Behälterbau innerhalb des angesetzten Jahres nicht fertig. Zweifelhaft war die Auslegung, ob unter „Gebrauchmachen von der Genehmigung der ernste Beginn der Arbeiten oder die Inbetriebnahme des Bauwerkes verstanden sein sollte." Der Gaswerksleiter entschloł sich für die erste Auffassung, zumal nur wenige Wochen zur Vollendung fehlten und durch das inzwischen bekannt gewordene Unglück in Hamburg ein neues Genehmigungsverfahren für das teuere Objekt sehr beschwerlich geworden wäre.

Die Stadtverwaltung vertrat aber die andere Auffassung, zumal sich die „öffentliche Meinung", das heiß̧t vor allem die Stadtverordneten inzwischen gegen den Behälter eingestellt hatten. Es war das wohl der erste Fall, in dem, wie heute leider sehr häufig, mit allen sachlichen und unsachlichen Mitteln gegen Gasbehälter Sturm gelaufen wurde. Das Gericht entschied zu Gunsten der Stadt. Der Werksdirektor wurde mit 3 Mk. oder I Tag Haft bestraft. Die Milde des Urteils war auffallend, aber eine Vorstrafe für den Werksdirektor Tatsache geworden. Bevor der fertige Behälter betreibbar war, der ja nicht aus Liebhaberei, sondern einem dringenden Bedürfnis zur verbesserten Versorgung des ganzen Stadtteiles dienen sollte, muß̧te nunmehr ein neues Verfahren eingeleitet werden. Es half nichts, daß in diesem Falle die Gutachten über die richtige statische $\mathrm{Be}$ rechnung vorgelegt werden konnten, die vor dem Bau von den ersten Fachleuten eingeholt waren. Neue Gutachten muf̧ten herangezogen werden, darunter auch von namhaften Städtebauern. Diese bemühten sich auch mit ästhetischen Fragen über den im Stadtviertel umfangreicher Eisenbahnanlagen mit vielen Buden und Werkstätten stehenden Behälter und mit seiner Wirkung auf das Stadtbild. Alle Gutachter kamen zu günstigen Urteilen. Drei Jahre durfte der Behälter seinen „Dienst am Volke“ nicht erfüllen, bis die neue Genehmigung erteilt war. Der Rekurs der Stadt wurde vom Minister abgelehnt $\left.{ }^{5.507}\right)$.

\subsection{Robreund Robrleitungen}

Die betrachteten I4 Jahre brachten eine Fülle von Kleinarbeit an den für die Gasverteilung so wichtigen Rohren. Die Forderungen gingen nach vereinfachtem Einbau, verläßlicher Dichtigkeit auch bei erhöhten Drücken und nach verlängerter Haltbarkeit. Die Arbeit erstreckte sich nicht allein auf die Hauptversorgungsleitungen, sondern auch auf die schon lange genormten einfachen Gasrohre.

Besonders in Frankreich war im Laufe der Zeit das Gewinde verwildert. Der Grund lag in der Schwierigkeit, die vielen Maf̧e, die bei einem Gewinde beachtet werden müssen, genau zu erfassen. So hatten nicht nur manche Rohrfirmen allmählich ihr Sondergewinde, sondern auch die Gaswerke forderten jeweils ,ihr" Gewinde ${ }^{\text {s.x." }}$ ).

\footnotetext{
5.391) $56(1913), 650$

3.502) 44 (1901), 557
} 
In Deutschland war es bei Gasmessergewinden nicht anders, eine erneute Normung wurde schnell durchgesetzt. Im Thüringer Bezirksverein deutscher Ingenieure befaß̧te sich ein $\Lambda$ usschufy für Gewindenormen mit den Rohren. Er stellte zunächst einmal fest, daf die im Rheinlande und in Oberschlesien verschiedenen Rohrwanddicken keine gleichen Gewinde zuliełen. Empfohlen wurden einheitlich die Rohrgewindenormen von Reinecker, Chemnitz, einer Firma, die damals im Feinmef̧wesen eine besonders geachtete Stellung errungen hatte $\left.{ }^{5,3 a n}\right)$. Der Niedersächsische Verein von Gas- und Wasserfachmännern trat nach eigenen Untersuchungen von F. Rodeck, Hamburg, den Anregungen aus Thüringen bei.s.my $)$. Ein Jahr später wurde ein Normalgasgewinde nach Vorschlägen des Vereins deutscher Ingenieure angenommen. ${ }^{5.305}$ ).

Erhöhte Drücke in den Rohren ließ̧en immer wieder die Frage auftauchen, ob die übliche Muffendichtung mit Teerstricken und Bleiausguf weiterhin brauchbar sei. Vielfache Aussprachen bejahten das grundsätzlich. Nur hin und wieder wurde von besonderen Małnahmen an hochbeanspruchten Stellen berichtet. Ein Hochdruckdüker von $600 \mathrm{~m}$ Länge unter dem Mississipi und von $150 \mathrm{~mm}$ Durchmesser wurde mit Schraubengewinden mit besonders scharfen Gewindegängen ausgeführt $\left.{ }^{5 ., n o}\right)$. Die ersten Versuche mit Bleiwolle, die von der Firma A. B $\ddot{u} b n e$ \& Co., Freiburg, hergestellt wurden, um die lästige Arbeit mit flüssigem Blei zu vermeiden, die das Gaswerk in Freiburg anstellte, stief̧en zunächst auf Miftrauen $^{5, \infty 27}$ ). Sechs Jahre darauf aber hatte sich die neue Bauweise als gut bewährt und vielfach durchgesetzt ${ }^{\text {s.soge }}$ ).

F. Burgemeister, Celle, trat plotzlich wieder als Anwalt der Gummidichtungen auf. „Noch nie habe ich in 30 Jahren, wo ich mit Gummidichtungen arbeite, eine undichte Muffe gefunden, wohl aber haben wir nach der Herstellung der Kanalisation viele Rohrbrüche und undichte Bleimuffen gefunden."

Über die Frage, ob Guf̧eisen oder Schmiedeeisen - meist wohl schon SiemensMartinstahl fälschlich noch als Schmiedeeisen angesprochen - für Gasrohre vorzuziehen sei, kam es im Märkischen Verein zu einer lebhaften Aussprache. Die Städtischen Werke Berlin hatten sich ganz auf Schmiedeeisen umgestellt, mit einer Masse aus Teer, Goudron, Pech, Sand, Lehm und Kalkmörtel umkleidet. Veranlassung war die Beobachtung sich steigernder Brüche bei Guf̧eisenrohren, mit denen seit 1892 keine neuen Leitungen mehr ausgeführt waren. Deren Bruchzahl hatte sich aber innerhaib von to Jahren verdoppelt. Nunmehr sollten die Gufrohre entfernt werden $\left.{ }^{5,3 \times n}\right)$. Ein neuer Vorzug der Mannesmannrohre - die leichtere Schweif̧ung der Verbindungen wurde zuerst für eine Wasserstoff-Leitung von $1000 \mathrm{~mm}$ Druck von Griesheim zum Zeppelin-Flughafen in Frankfurt/Main mit $4,5 \mathrm{~km}$ I.änge ausgeführt. G. Aicher, Pasing, benutzte sie im Rohrnetz. Er hatte sich um Sorgfalt bei der Verlegung und Prüfung Schweif̧ung auf̧erhalb des Grabens - persönlich gekümmert. Auch die Haus-

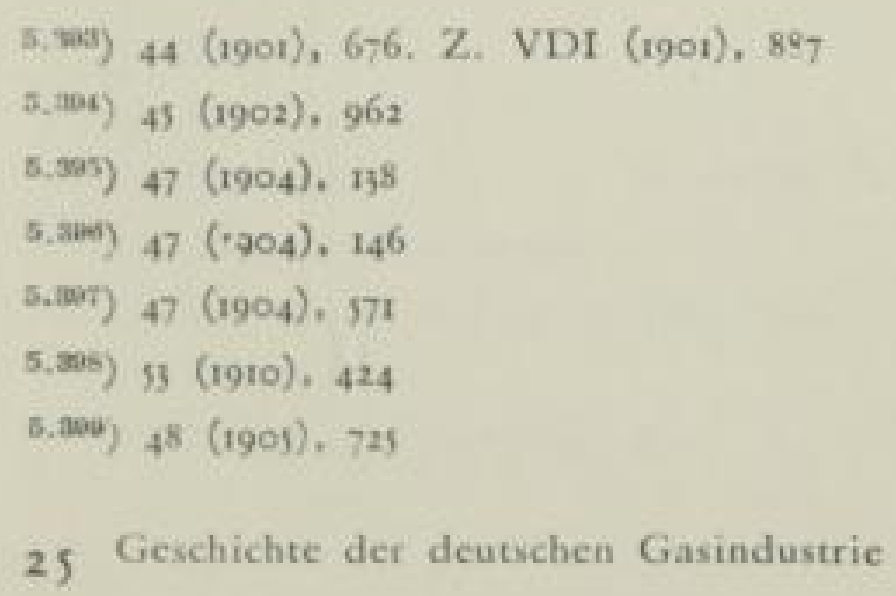


anschlüsse lief̧ er einschweił̧en $\left.{ }^{\text {s.to }}\right)$. Seine Mitteilung wurde ergänzt durch Nachrichten aus Nordamerika über die Schweif̧ung an einer to $\mathrm{km}$ langen Rohrieitung von $100 \mathrm{~mm}$ Durchmesser für Hochdruckbetrieb. Hierbei wurde auch von maschinellem Grabenaushub und Stampfen erzählt ${ }^{5.401}$ ). Eine Bewährungsprobe legten die Stahlmuffenrohre im Elsaf̧ bei einer Brückensprengung ab, bei der sich die Rohre verbogen hatten, die Bleidichtungen gelockert, aber nach einfachem Nachstemmen wieder dicht geworden waren ${ }^{\text {s.tog }}$ ). Aber auch eine vom Hochwasser unterspülte Gußrohrleitung mit Bleimuffendichtungen blieb trotz des freien Durchhanges auf $20 \mathrm{~m}$ Länge in Elsterwerda dicht ${ }^{5+503}$ ).

Die Fortschritte in der Technik des Rohrleitungsbaus und die gröf̧ere Unabhängigkeit vom niedrigen Leistungsdruck nutzten die Gaswerke zu „Fern“-Versorgungen aus, womit zunächst einfache Vorort- und Gruppengasversorgungen bezeichnet worden sind.

Noch vor der Jahrhundertwende waren einige Verbindungsleitungen von den erzeugenden Werken nach Behälterstationen mit Drücken von etwa $300 \mathrm{~mm}$ Wassersäule gebaut worden ${ }^{5+44}$ ). In Nordamerika wurde die mit Erdgas entwickelte Leitungstechnik auch auf Erzeugerwerke übertragen. Mehrere Anlagen mit Erfahrungen sind schon roor beschrieben worden $\left.{ }^{5.005}\right)$. H. Zollikofer, St. Gallen, nahm für sich in Anspruch, mit dem Projekt einer Speiseleitung in Metz von $1200 \mathrm{~m}$ Länge Schrittmacher in Deutschland gewesen zu sein. Da deutsche Firmen ablehnten, baute er Sturtevant-Ventilatoren mit $390 \mathrm{~mm} \mathrm{Be}$ triebsdruck ein. Als 1899 St. Gallen ein neues Werk erbauen muf3te, verlegte es Zollikofer an den Bodensee und ließ das Gas 9,9 km weit nach St. Gallen fördern $^{5.600}$ ). Das erste Gruppengaswerk dürfte das von St. Margarethen (Schweiz) im Rheintal oberhalb des Bodensees gewesen sein. Dort wurden ${ }_{4}$ Orte mit 40000 Einwohnern erschlossen. Neben dem Hauptbehälter von $3000 \mathrm{~m}^{3}$ Inhalt in St. Margarethen waren im Netz noch drei weitere Behälter aufgestellt. Damit war eine gleichmäßige Abgabe im Hauptrohr unter dem Behälterdruck von $280 \mathrm{~mm}$ W. S. ermöglicht. Für Spitzenanforderungen stand ein Rootsgebläse, das mit $6000 \mathrm{~mm}$ W. S. Druck arbeiten konnte, zur Verfügung ${ }^{\text {s.nm7 }}$ ). Das Gruppengaswerk wurde 1908 von der A. G. für Gas-, Wasser- und Elektrizitätsanlagen, Berlin (Agwea) erworben. Etwa gleichzeitig baute Eisele, Heidelberg, eine Gasversorgung von Vorortgemeinden aus und gab damit vielen Kollegen einen Anstoł̧. Von seinen Plänen sprach er bereits 1902 und stellte den Möglichkeiten, bei einem Behälterdruck von $100-150 \mathrm{~mm}$ im Netz von $8 \mathrm{~km}$ Länge am Ende 70 bis $120 \mathrm{~mm}$ Betriebsdruck zu halten, auch die amerikanische Technik mit Drücken bis zu 7 atü gegenüber. Verlä̧liche Regler müften bei uns für diesen Zweck noch entwickelt werden $\left.{ }^{\text {s.tan }}\right)$. Die Tatsache, dał er die Neckarbrücke nur mit je einem Rohre von Iso und $200 \mathrm{~mm}$ Durchmesser benutzen konnte, brachten

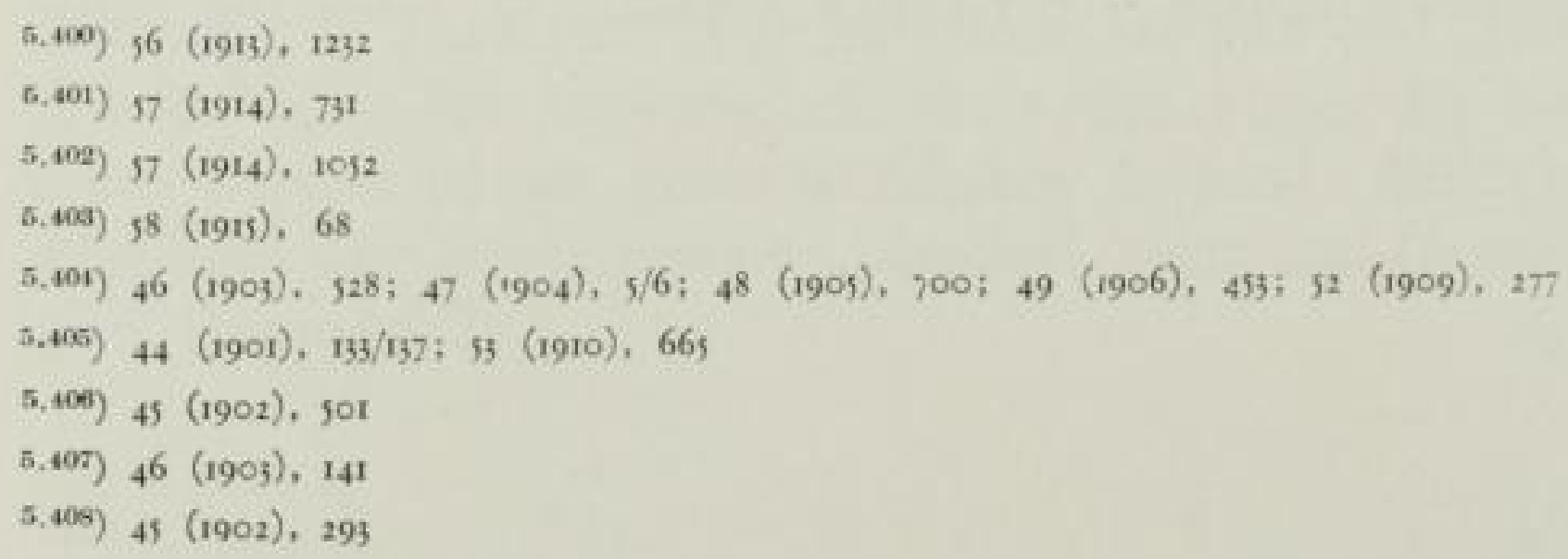


Eisele dazu, für die Hauptabnahmezeiten (etwa 2 Stunden täglich) Gebläse vorzusehen und die Abnehmer ohne Zwischenbehälter, wie sie in St. Margarethen benutzt waren, unmittelbar mit Reglern an die Hauptrohre anzuschliełzen. ${ }^{5.400}$ ).

Die Leitung von Lübeck nach Travemünde von $19,5 \mathrm{~km}$ Länge aus 6 bis $9 \mathrm{~m}$ langen juteumwickelten Mannesmannmuffenrohren lieł M. H a se, der Sicherheit wegen in einen Ausgleichsbehälter in Travemünde speisen. Sie hatte nur $80 \mathrm{~mm}$ Durchmesser und wurde mit einem 3 PS Kapselradgebläse mit Stufenscheibenantrieb auf höchstens $6000 \mathrm{~mm}$ am Werk Lübeck gebracht. Die Anzapfung unterwegs mit Einzelregeln wurde erwogen, zunächst aber nicht ausgeführt ${ }^{\text {s.110 }}$ ).

Die erste überlagerte Mitteldruckleitung mit Einspeisung durch Bezirksregler in Niederdrucknetze dürfte in Deutschland mit der Leitung von Mariendorf nach Lankwitz, Lichterfelde, Steglitz und Schmargendorf von E. Körting geschaffen sein. Die Länge betrug $9 \mathrm{~km}$, Durchmesser am Werk roso $\mathrm{mm}$, im weiteren Verlauf auf $450 \mathrm{~mm}$ verkleinert, Ausgangsdruck $1000 \mathrm{~mm}$ W. S. durch Rootsgebläse erzeugt. Die Regler wurden teils aus England, Parkinson und Cowan, und teils von der Bamag bezogen ${ }^{\text {5.tut }}$ ).

Als Gruppengasversorgungen folgten 1908 die Versorgung der Uferorte am Zürichsee mit iro km Rohrnetzlänge ${ }^{5.12}$ ) und Anlagen der Deutschen ContinentalGas-Gesellschaft im Elbgau und in Schlesien ${ }^{\text {s.tiz }}$ ). 1909 stellte F. Kuckuk. Heidelberg, fest, daf damals etwa 32 Ferndruckanlagen bestanden, die etwa roo Orte mit I,5 Mio Einwohnern versorgten. Mit Einschluf̧ der Behälterdruckanlagen erreichten insgesamt 102 Anlagen zur Versorgung von 344 Orten 19 Mio $\mathrm{m}^{\text {" }}$ Jahr Gasabgabe $\left.{ }^{5.14}\right)$. Die größte Leitungslänge war die von Lübeck nach Travemünde mit rund $20 \mathrm{~km}^{5.45}$ ). Inzwischen wurden die ersten Koksofengasfernversorgungen ausgeführt (Abschn. 5.28). 19I2 wurde von der Deutschen Continental-Gas-Gesellschaft die Leitung von Barr nach Molsheim und Mutzig gebaut. Der Rohrdurchmesser betrug $80 \mathrm{~mm}$, der Betriebsdruck 2,5 atü $\left.{ }^{5,42}\right)$. Mehrere Berichte $^{5.417}$ ) beschäftigten sich mit der wirtschaftlichen Bedeutung der Gas-Überlandzentralen. Dabei stellte man fest, dał die Behörden reichlich einseitig elektrische Überlandzentralen begünstigten, die Gasindustrie aber sich selbst überlief̧en. Am umfassendsten ist der letzte Bericht von L. S a u t ter, Duisburg.tus), der alle mit der Ausführung und Berechnung verbundenen Fragen behandelte. Sein Schrifttumsnachweis beweist, wie viel Arbeit bereits international an die Aufgabe aufgewandt war. Seit 1907 setzte die Kritik an den bisher benutzten Formeln von Pole ${ }^{5.419}$ ) und Pole-Monnier ${ }^{5.450}$ ) ein, die bei hohen Drücken zu grofe Werte ergaben.

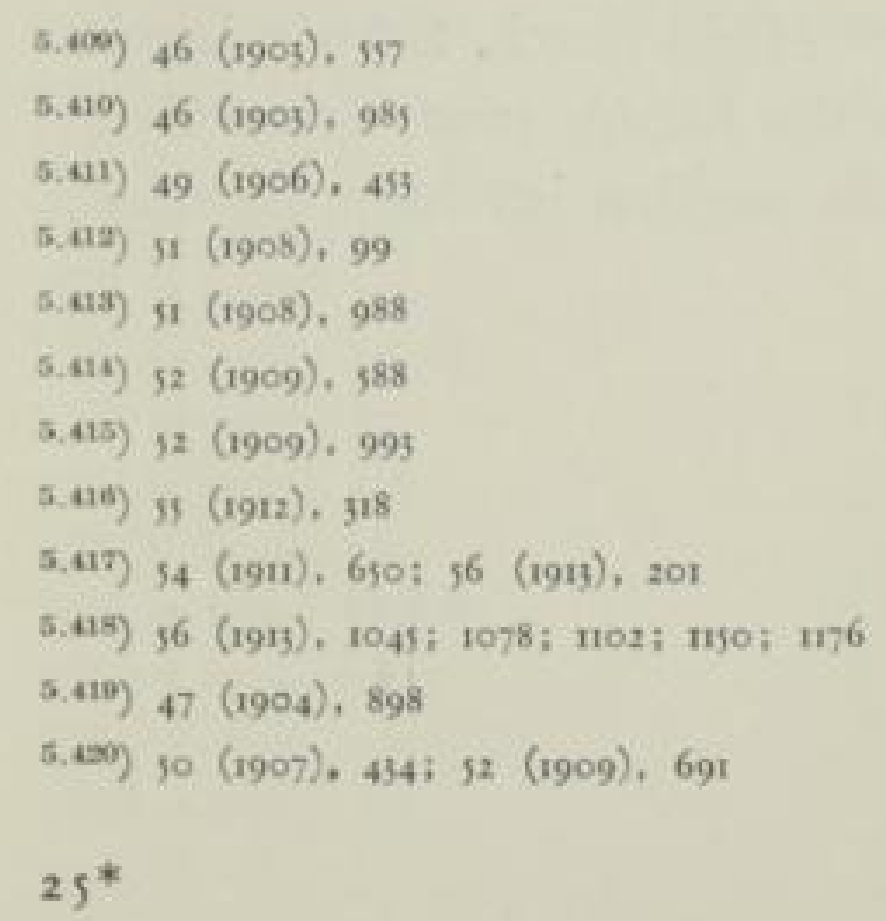


Der Daléndruckregler mit Verstärker bei starker Abnahme durch Venturirohr als selbständigem Regler wurde 1909 durch Bamag angeboten ${ }^{5.42}$ ).

Die Erforschung der Streuströme und die Entwicklung der elektrischen Messungen wurde in der ganzen Periode lebhaft weitergetrieben ${ }^{5.42 z}$ ). Die erstrebte Einigung mit den Elektrizitätswerken wurde anfangs nicht: erreicht: Die Kommission des Vereins arbeitete daher zunächst allein weiter unter Hilfe eines unabhängigen Elektrofachmannes $\left.{ }^{5 .+23}\right)$. Ein umfangreicher Fragebogen über Schäden durch Streuströme ${ }^{5,42}$ ) durch Prof. J. Te ic bmüller, Karlsruhe, ergab verhältnismäfig wenige nachgewiesene Schäden. Grund dafür war, dał die Werke im allgemeinen nicht beobachteten und auch die elektrischen Bahnen erst kurze Zeit betrieben wurden, so dał die Schäden sich noch nicht voll ausgebildet hat$\operatorname{ten}^{\text {s.t25 }}$ ). Am 8. Dez. $1906 \mathrm{kam}$ dann eine gemeinsame Sitzung des Vereinsausschusses mit Vertretern des Verbandes deutscher Elektrotechniker (VDE) und des Vereins Deutscher Straf̧en- und Kleinbahnverwaltungen zustande. Eine gemeinsame Erdstromkommission unter dem Vorsitze des Wasserfachmannes W. H. Lindle y, wurde im März 1907 zusammengeschlossen $\left.{ }^{5.137}\right)$. Die gute Verbindung des Gasrohrnetzes mit der elektrischen Maschine wurde als schlechte Lösung erkannt. Die schädlichen Stromdurchgänge wurden dadurch erhöht ${ }^{5.427}$ ). Dagegen wurde mit Erfolg die erste deutsche Schutzstromanlage, um die sich F. $\mathrm{Haber}$ verdient gemacht hat, in Karlsruhe von Geppert und Liese ausgeführt.

Eine Zusammenfassung dieses Abschnittes ist wohl berechtigt, weil die lebhafte Arbeit an Rohren und Rohrnetzen nach fast hundertjähriger Entwicklung der Einzelgaswerke und ihrer Erzeugungsverfahren den Weg gebahnt hat zu einer viel weiter ausgreifenden Technik. Sie ermöglichte erst, die Fortschritte der Erzeugungstechnik mit der fühlbaren Verbilligung in groß̧en Werken ganz einzusetzen. War noch zu Beginn der betrachteten Zeit die große Welle, auch in den kleinen Gemeinden Ortsgaswerke zu bauen, festzustellen, so begann man doch bereits 1903 damit, kleine Orte mit den Leitungen von Gruppengaswerken zu erschlief̧en. Die Gasindustrie selbst leistete die technische Vorarbeit auch für die ersten Fernleitungen für Zechengas. Die Entwicklung wäre wohl stetig fortgeschritten, wenn nicht der Krieg 1914 eine Unterbrechung gebracht hätte, so daf3 später ein sehr grołer Schritt, der manchen alten Fachmann erschreckt hat, getan werden mufte.

\subsection{Gasmessung}

Die trockenen Gaszähler setzten sich in steigendem Maß̧e durch. Schwierigkeiten entstanden zeitweilig durch Angriffe des Gases auf die Membranen, deren Grund lange Zeit von Fabrikanten und Gaswerken gesucht worden ist. Man vermutete,

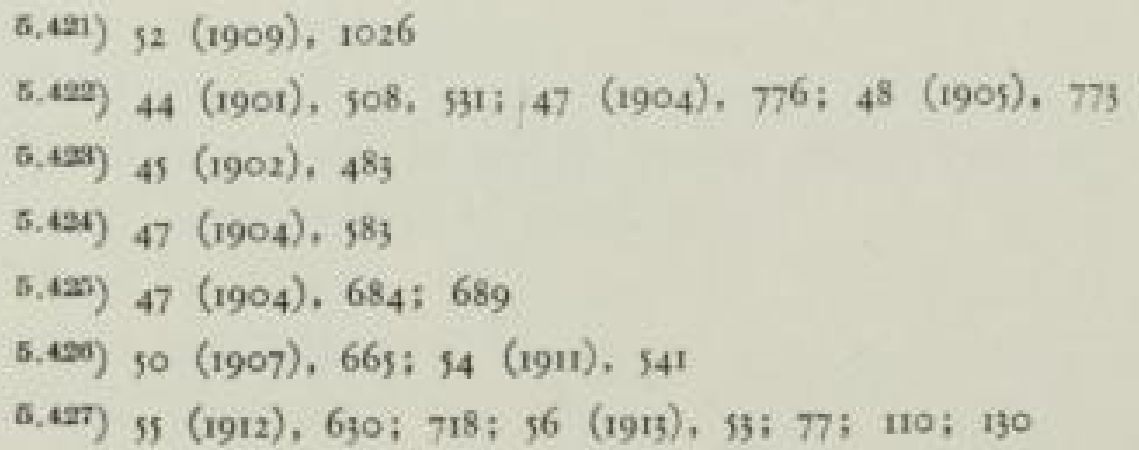


daf die Karburiermittel schuld seien. Vor allem wurden die von den Ol-Azethylen-Gasen der Eisenbahn bei der Verdichtung ausscheidenden Kondensate verdächtigt, die oft zur Karburierung verwandt wurden $^{5.425}$ ). Dann aber beschuldigte man die Imprägnierung und verlangte vorsichtige Oxydierung des Leinöles bis zu einer bestimmten Menge Linoxyd $\left.{ }^{5.49}\right)$. Versuche, die Balgenleder durch Textilien zu erzetzen, liefen viele Jahre ${ }^{\text {5.4.450}}$ ). Man glaubte $1914, \mathrm{zu}$ einer befriedigenden Stoffart gekommen zu sein.

Die Stadt Berlin entschloß 3 sich 1912, auf trockene Zähler überzugehen. In Bayern war das Verhältnis $28 \%$ nasse, $72 \%$ trockene Zähler $\left.{ }^{5.51}\right)$. Ein neuartiger, kleiner und schnellaufender Ol-Gaszähler „Vesta" gewann Freunde. Königsberg schaffte neue Zähler nur nach diesem System an ${ }^{5.42 z}$ ).

Ein Flügelradzähler wurde in England entwickelt ${ }^{5 . t 3 a}$ ). Er war klein, aber nicht eichfähig. In Königsberg wurde er wegen der Platzersparnis als Stationsgaszähler eingebaut $\left.^{5 . \Delta 4}\right)$. Bei kleinen Durchgängen ergaben sich Fehler bis zu $300 \%$.

Für Hochdruckgas von mehreren Atmosphären Uberdruck wurde von Westing bouse, Amerika, als Stationszähler ein Teilstromzähler entwickelt. Zur Sicherheit wurden bei unmittelbaren Anschlüssen in Nordamerika auch bei heruntergeregeltem Druck Zähler mit festem Gehäuse aufgestellt ${ }^{5+45}$ ).

Messer mit Sprungzählwerk waren 1900 in Paris ausgestellt gewesen $\left.{ }^{5.430}\right)$ M. B es s in machte auf Ausführungen aus schwer oxydierbaren Weißmetall aufmerksam, womit das bisher $a b$ und an auftretende Festsitzen vermieden sein sollte ${ }^{5.437}$ ).

Die Vor- und Nachteile der Münzgaszähler waren so gut geklärt, dał weitere Erörterungen nicht mehr zu finden sind. Nach langen Kämpfen konnten Absichten, die Nacheichungspflicht für Gasmesser einzuführen, abgewehrt werden ${ }^{\text {natab }}$ ). Die neue Eich- und Gewichtsordnung gab grỏłere Freiheiten bezüglich der Schwimmerventile an nassen Gasmessern. Diese durften aber nicht völlig abschlief̧en $\left.^{\text {sas }}\right)$. Die ersten Schritte zur Normung der Verschraubungen wurden getan. Die Lehr- und Versuchsgasanstalt gab das von ihr entwickelte Eichverfahren für Stationsgasmesser bekannt ${ }^{5.400}$ ).

Auf die Strömungsmesser nach dem Differenzdruckverfahren machte H. S trache die Gasfachleute aufmerksam. Er benutzte mit Vorteil zur Betriebsaufsicht von Wassergasanlagen Krellsche Stauscheiben (erfunden 1897$)^{5.41}$ ) mit Mikromanometer und hatte auch ein Gerät entwickelt, um die bei Analysen absorbierten Mengen festzustellen ${ }^{5.4 u}$ ). Der Rotamesser, System K. Kü p p e r s, der Rotawerke

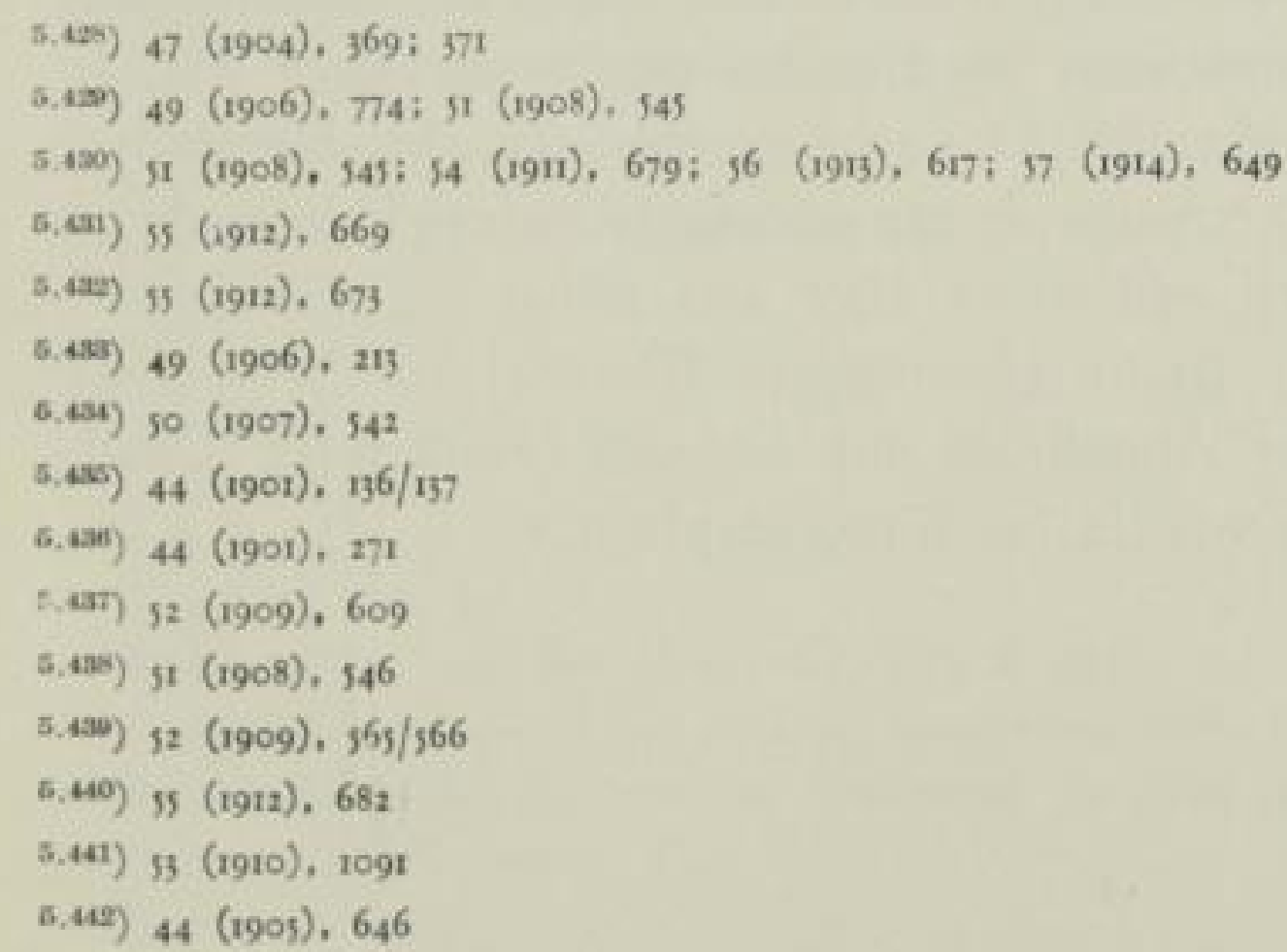


Aachen tauchte 1910 auf $\left.{ }^{5.4 t}\right)$. Ihm wurde bei kleinen Mengen eine ungenaue Eichkurve vorgeworfen. Deshalb bevorzugten L. $\mathrm{Ub} b e \mathrm{lo} b d e$ und M. $\mathrm{Hof}$ säss, Karlsruhe, im Laboratorium den Capomesser. Dieser bestand aus 5 parallelgeschalteten Kapillaren verschiedenen Durchmessers, die jede einzeln durch einen Hahn absperrbar waren. Bei den kleinen Durchmessern ergab sich als Eichkurve eine Gerade, bei den zwei größ̧eren eine schlanke Parabel. Ein Zähigkeitsmesser war als Hilfsgerät für die Umrechnung auf verschiedene Gassorten beigegeben ${ }^{5 \cdot 44}$ ).

\subsection{G A S V ER W EN D U N G}

\subsection{Brenneigenscbaften}

Bei der Verwendung des Gases insbesondere im Glühlicht zeigten sich alsbald Mängel, die durch verschiedenartig erzeugte Gase und deren Gemische auftraten. War man beglückt gewesen, mit dem Zwange, eine hohe Leuchtkraft des Gases zu halten, die enge Bindung an die Entgasung in der liegenden Retorte loszuwerden, so war im Ringen um das wirtschaftlichste Verfahren, beeinflufyt auch noch durch den Wechsel im Preisverhältnis von Kohle und Koks, die Industrie zu einem grołen Versuchsfeld geworden. Das spiegelt auch der Abschnitt 5.2, insbesondere der Unterabschnitt 5.24 wider. Deutlich wurden als Grenze der Beimischung von Wassergas mit und ohne Autokarburation die Klagen der Abnehmer besprochen $\left.{ }^{5.45}\right)$. Obwohl schon vor langer Zeit H. B unte auf den wesentlichen Einfluf des Wasserstoffgehaltes eines Gases auf die Brenngeschwindigkeit hingewiesen hatte, hatte man allgemein aber noch keine klaren Vorstellungen und überschätzte den Einfluf des Heizwertes. H. Sainte Claire-Deville sagte 1904: „Wenn derselbe Strumpf mit verschiedenen Gasen geheizt und auf höchste Leuchtkraft eingestellt wird, so wird stets die gleiche Intensität für die gleiche Wärmemenge erhalten." Der Heizwert eines Gases sei ein genaues Kritérium seines Wertes für seine Verwendung für Glühlichtbeleuchtung ${ }^{5}$ ). O. Pfeiffer, der in Magdeburg für sein Gaswerk die Befreiung von den Fesseln der Leuchtkraft zuerst durchgesetzt hatte, war vorsichtiger. Er sprach sich zwar gegen die Bewertung nach der Leuchtkraft allein aus, aber der Heizwert sei auch nicht allein mafygeblich wegen des Temperatureinflusses. Er empfahl beide Bestimmungen zur Beurteilung eines Gases ${ }^{5.477}$ ). Die starken Unterschiede der Gasgemische von Ort zu Ort machten den Herstellern von Gasgeräten, insbesondere von Leuchten, bereits grołe Schwierigkeiten, denen mancher nicht gewachsen war. Noch schlimmer aber war selbst für die einstellbaren Hängelichtbrenner der allzu leicht genommene Wechsel im Wassergaszusatz. Die trüben Erfahrungen der Abnehmer mit schlecht brennenden Leuchten wirkten sich allmählich sehr nachteilig im Wettkampfe aus.

$5.443) \$ 3(1910), 351$

6.44) 55 (1912), 557

$5.445) 45(1902), 797 ; 46(1903), 900 ; 977,981,1068 \mathrm{ff}$

$5.46)^{4} 47(1904), 91 / 93$

5.447) 44 (1901), 409 
H. Bunte ging deshalb im Chemisch-technischen Institut der Techn. Hochsch. Karlsruhe diesen Fragen grundsätzlich nach. M. Ma yer und H. Scbmiedt wiesen von $\mathrm{H}$. Bunte angeleitet nach, daf der Satz von St. Claire-Deville nut eine in engen Grenzen brauchbare Regel darstelle ${ }^{5.48}$ ). Karl B un te schlug 1909 einen einheitlichen Heizwert von $\mathrm{H}_{0}=5200 \mathrm{kcal} / \mathrm{Nm}^{n}$ vor. Dieser solle möglichst geringe Schwankungen aufweisen und $5000 \mathrm{kcal} / \mathrm{Nm}^{3}$ auf keinen Fall unterschreiten. Unter Wahrung der Gleichmäfigkeit könne man reines Steinkohlengas, Wassergas, Koksofengas oder Mischungen der Gase zulassen ${ }^{\text {s.14s }}$ ). Stracbe bemängelte Buntes Versuche, weil bei ihnen wegen der Mengenmessung die Luft zugeführt und nicht wie im Betriebe angesaugt wurde. Er sprach sich, seine Doppelgaserzeugung im Kopfe, gegen eine die Entwicklung hemmende Festlegung des Heizwertes aus, da ein Gas von geringem Heizwert die Luft leichter ansauge ${ }^{5,43}$ ). Über den Einfluß̧ der Dichte auf Ausflufmenge und Luftansaugung sprach aber nock keiner von beiden Forschern. Das betonte erst 1913 H. Menzel bei einer Rechtfertigung der Druckwellenzundung, als Ordnung schaffendes Hilfsmittel im Rohrnetze $\left.{ }^{\text {s.t.5it}}\right)$.

Nach dreijähriger Pause gab K. B unte Erfahrungen der Lehr- und Versuchsgasanstalt bekannt. Er äuf̧erte den Wunsch, die Gaswerke möchten sich auf wenige Gastypen einigen, dann aber örtlich auch die Zusammensetzung gleichmäßjig halten $\left.{ }^{5, u a}\right)$. F. Gö $b r u m$ stellte fest, dał der Heizwert von Ort zu Ort zwischen 4400 und $5200 \mathrm{kcal} / \mathrm{Nm}^{3}$ schwanke. Man solle wieder nach Buntes Vorschlag $5000 \mathrm{kcal} / \mathrm{Nm}^{\|}$anstreben. Dann begannen die Arbeiten unter H. Bunte im chemisch-technischen Institut über die Zündgeschwindigkeiten nach der Methode von $G$ ou $y^{5.455}$ ), die mit vielfach verschiedenen Gassorten, systematischer Veränderung der einfluß̧reichen Zusätze und veränderter Vorwärmung über lange Jahre selbst im Kriege fortgeführt wurden und allmählich die erste Klarheit geschaffen haben ${ }^{\text {n.t.54 }}$ ).

\subsection{Beleuchtung}

Die Verbesserung der Glühlichtbeleuchtung wurde mit allen Mitteln betrieben. Der Antrieb kam keineswegs durch den Wettlauf mit der elektrischen Beleuchtung allein, sondern auch durch den Wettbewerb der verschiedenen Systeme, die eine Erhöhung der Leuchtkraft und der Ausnutzung des Gases erstrebten. Der Kampf war durchaus kein Rückzugsgefecht, vielmehr schwankten die Erfolge, so dafy auch die schon eingeführte elektrische Strafjenbeleuchtung an manchen Stellen wieder aufgegeben wurde $\left.\left.{ }^{5.455}\right),{ }^{5.450}\right)$. Noch 1914 wurden in Wien sämtliche Schulzimmer mit Gasglühlicht eingerichtet ${ }^{5.457}$ ), wofür der Preis entscheidend war.

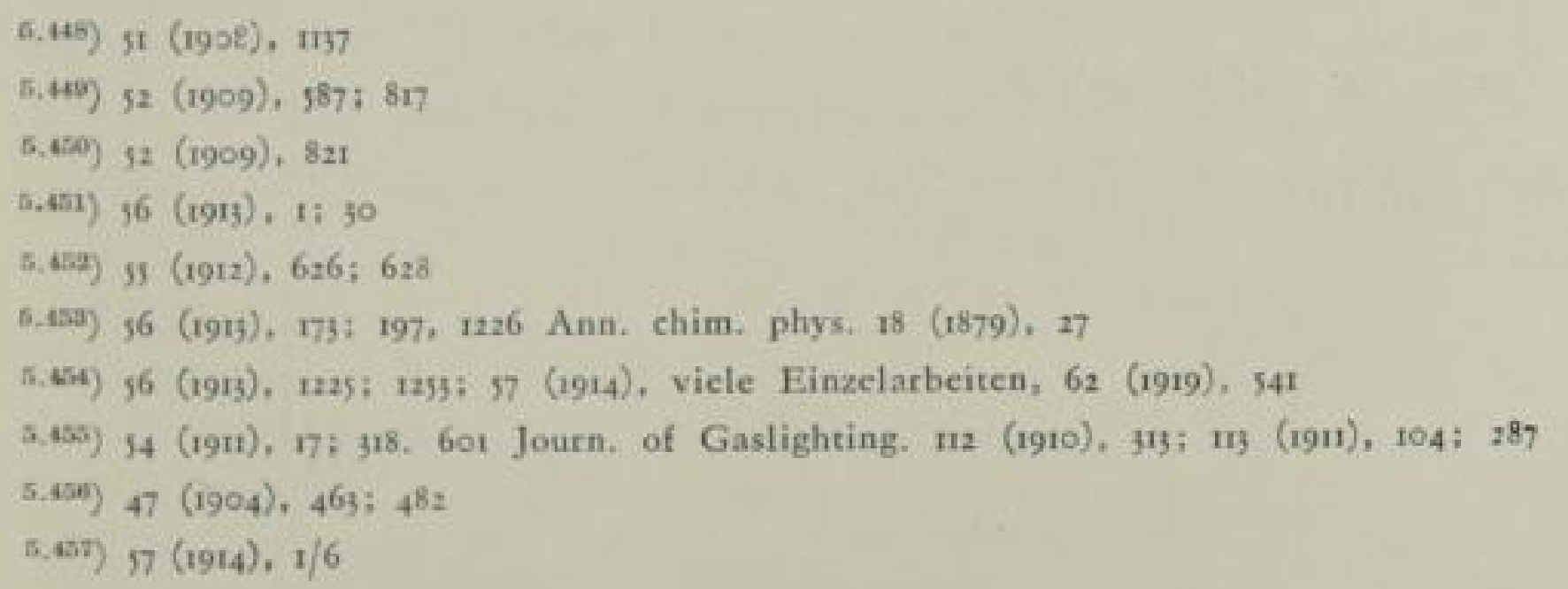


Die Verbesserung der im Abschnitt 4.515, S. 286 erwähnten Starklichtlampen wurde weiter getrieben. Allerdings wurde mehrfach festgestellt, dał der Verbrauch höher war, als von den Herstellern angegeben wurde ${ }^{5+4 a}$ ). Die hohen Drücke zerstörten auch die Glühkörper schneller als das Niederdruckgas. Th. Grotbe, Altenburg, forderte eine sorgfältigere Herstellung, weil Ungenauigkeiten die Leuchtkraft stark beeinträchtigten. Grundsätzlich verlangte er einen Diffusor nach der Mischdüse, was auch sicher zur Schonung des Gewebes wertvoll gewesen wäre ${ }^{\text {tan }}$ ). G. W $o b b e$ schlug zur Regelung des Gasdurchganges bei voller Aufrechterhaltung der Wucht des Strahles eine Zentralspindel vor, die er aber mit einfachen Gewinden einsetzen wollte. Damit gefährdete er aber gerade die wichtige genaue Führung des treibenden Strahles ${ }^{500}$ ).

Am erfolgreichsten hat sich wohl das Milleniumlicht mit Prefggas durchgesetzt, das in Berlin einen guten Absatz fand, aber auch auswärts aufgenommen wurde $\left.^{5.461}\right)$. Die Leuchtstärke einer Lampe war bis auf 1800 HK getrieben worden, später wurden aber kleinere Brenner bevorzugt $\left.{ }^{5.455}\right)$. O. K l a t te e, Hamburg, bildete 1902 Prefggas- und insbesondere Pref̧luftlampen aus ${ }^{5.43}$ ). Die von ihm gegründete Firma Pharos-Licht, Klatte \& Co. wurde 1908 von der Deutschen Auerlicht-Gesellschaft, Berlin, übernommen. io Jahre lang hat O. Klatte als Leiter der Abteilung Pharoslicht für diese Gesellschaft gearbeitet. Höchstleistung war eine Leuchte von $\left.4000 \mathrm{HK}^{5.184}\right)$. Einen Mittelweg ging Selas mit dem Patent Nr. 117284 vom 9.4.99 (Zusatz zu dem Patent 105645 vom 22.4.85 auf Steuerung der Mischung von Gas und Luft durch ein veränderliches Reibrädergetriebe mit 2 Blasebälgen). Damals wurde nur soviel Luft zum Gas gegeben, dał die obere Zündgrenze des Gemisches nicht erreicht war (Bild 109). Es muf̧te also noch Zweitluft in der Leuchte zugeführt werden, wozu aber die größzere Masse des Gemisches gegenüber Prefggas günstig war. Im Auerlicht wurden 0.667 1/HKh erreicht $^{5.45}$ ). Die A. G. für Selasbeleuchtung wurde rgor mit I Mio M Kapital gegründet $\left.^{5.606}\right)$. Welche Opfer durch die Unternehmen zur Entwicklung aufgebracht wurden, beweist eine Nachricht, daf3 1907 von dieser Gesellschaft die erste Dividende ausgeschüttet werden konnte ${ }^{5.467}$ ).

Um die kostspieligen und lästigen Verdichter zu vermeiden, setzte $L u c a s$ einen Schornstein für die Abgase auf ${ }^{5.165}$ ). Er erreichte r.02 1/HKh. Sein Patent scheint schwach gewesen zu sein. Es gab bald mehrere Ausführungen von Lucaslampen. Grundlage war ein weites Mischrohr mit kleinen Widerständen, so daf der Unterdruck an der Einsaugestelle der Luft in das Gas fast in voller Höhe des Auftriebes wirksam werden konnte $\left.{ }^{5.400}\right)$. Der Erfinder glaubte, einen

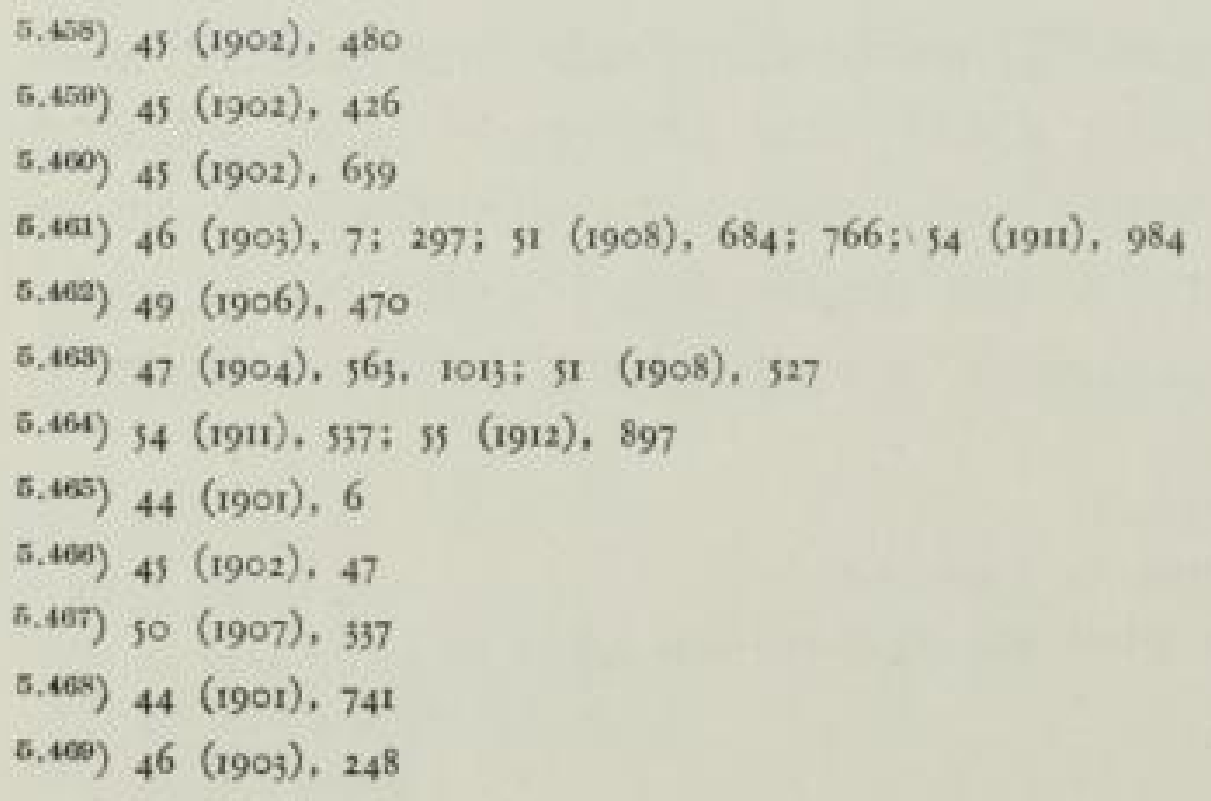




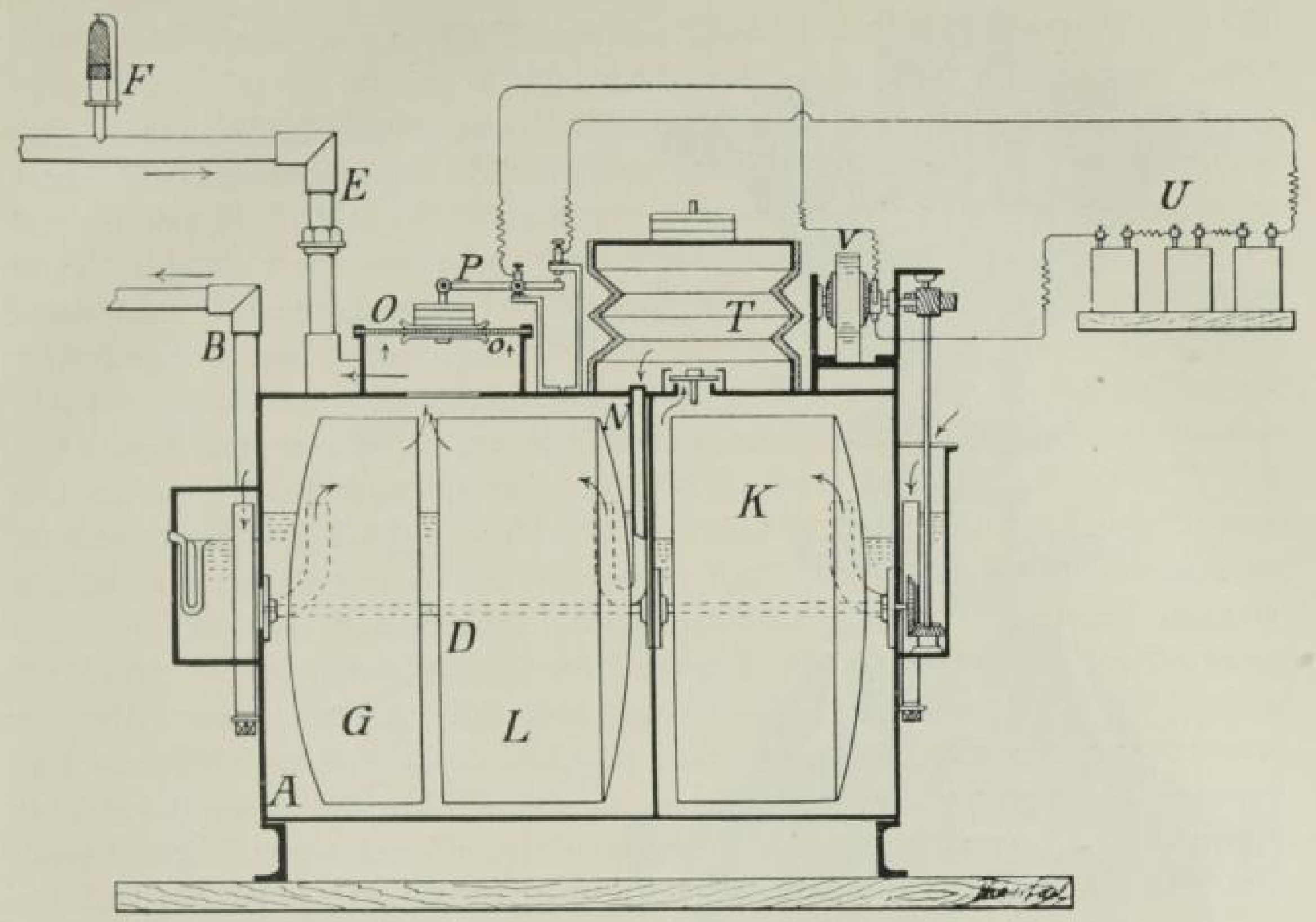

Bild rog Selasbrenner (J. f. G. 44 [1901] S. 7)

beträchtlichen Luftüberschuf zu erreichen, hatte aber ohne den aufgesetzten Strumpf gemessen. Tatsächlich lag das Gemisch bei $10 \%$ weniger Luft, als dem theoretischen Verhältnis entsprach. Damit arbeitete er, wie erst später ganz unabhängig von ihm festgestellt worden ist, im Bereich der höchsten Zündgeschwindigkeit $^{\text {s.tion }}$.

Das Patent wurde 1906 vernichtet $\left.^{5.471}\right)$. Lucas versuchte es dann mit einer neuen Lampe, bei der eine Thermobatterie den Antriebsstrom für ein Luftgebläse geben sollte. Das war also ein Rückfall zur ersten Bauart von De na yrouze, die keine Verbreitung gefunden hat ${ }^{\text {s.tizg }}$.

Von ganz anderer Bedeutung sollte das Hängelicht werden. Ein Vorläufer wurde auf der Weltausstellung von der langnamigen „Compagnie pour l'éclairage des villes et la fabrication des compteurs et appareilles divers" als L'Héliogène mit horizontal eingespannten mit Auerflüssigkeit getränkten Fäden gezeigt $\left.{ }^{\text {s.taz }}\right)$. Vom ersten Hängelicht (Bild nо) nach System Henry der Firma La Lumic̀re moderne, Paris, rühmte der Berichterstatter den Vorteil, daf nach unten keine Beschattungen aufträten, er glaube aber nicht, daf̧ die Konstruktion den gedachten Zweck erfüllen werde $\left.{ }^{5.47 \pi}\right)$. Man hatte zunächst auch die für diesen Zweck zu lang gezogenen Körper des Stehlichts unverändert verwandt. Mehrere Bauarten, die nach diesen Anregungen in England auf den Markt kamen, hatten zwar gekürzte,

$5.470) 47(1904) \cdot 771$

5.471) 49 (1906), 411

5.472) 49 (1906), 387, 682

5.473) 44 (1901), 187

5.474) 44 (1901), 188 


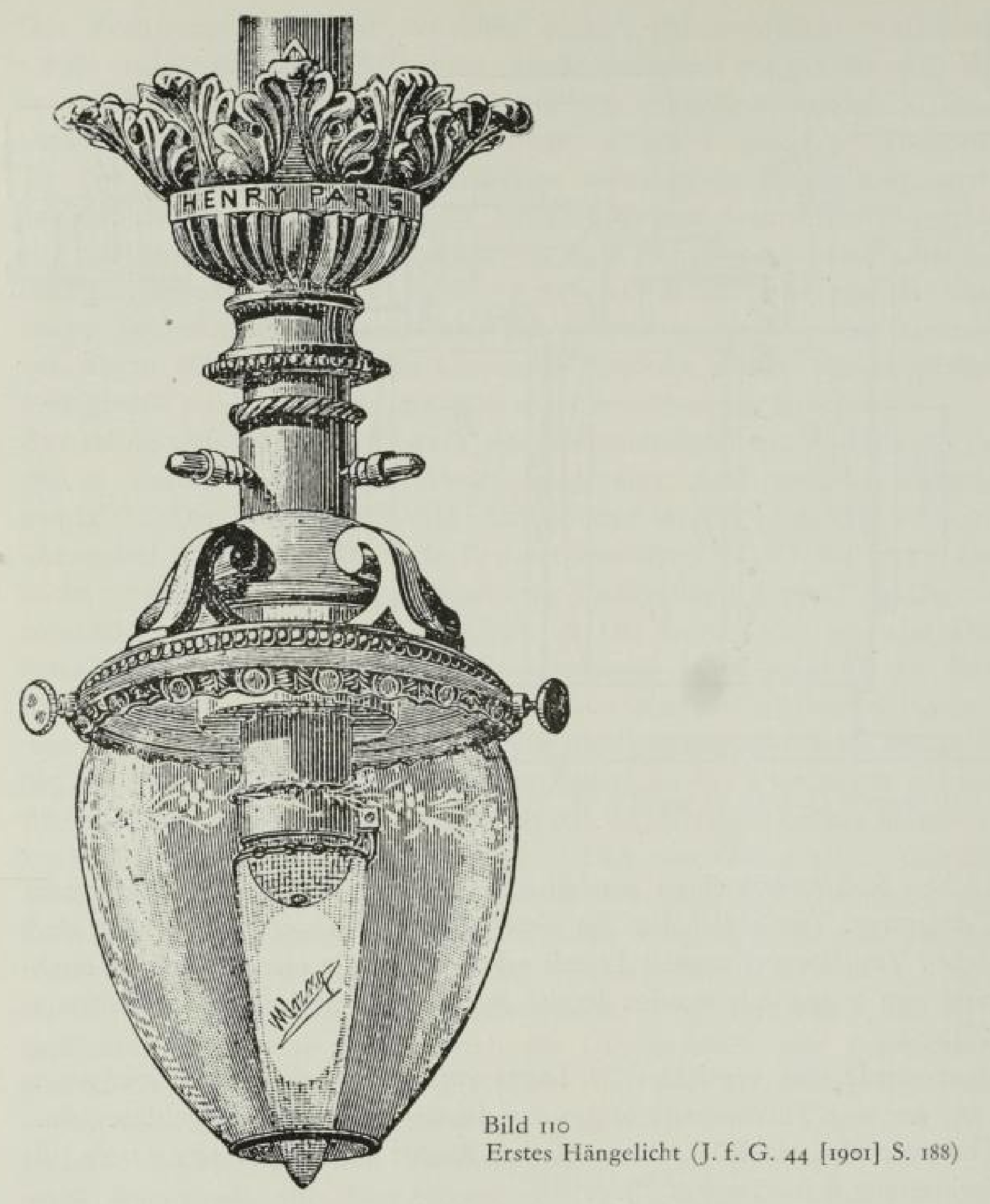

aber immer noch zu lange Glühkörper ${ }^{5 \pi t z}$ ). Die Hauptschwierigkeit bereitete aber die Ansaugung der Erstluft ohne Störung durch Abgase. Um diese an der Zweitluftzuführung auszuschalten, fügte $M$ annesmann innerhalb der Glocke einen kurzen Hilfsglaszylinder $\operatorname{ein}^{5.476}$ ), und lieł die Zweitluft durch Löcher in der Glocke unten eintreten ${ }^{5.47}$ ). Das wurde zwar als Notlösung bezeichnet, hat sich aber lange Zeit als vorteilhafte Führung der Luft- und Abgasumwälzung bewährt. Das zeitweilig vom Patentamt für nichtig angesehene Mannesmannpatent wurde vom Reichsgericht wieder in Kraft gesetzt. Lizenznehmer waren die Deutsche Gasglühlicht Gesellschaft und Ehrich und Graetz, Berlin ${ }^{5,45}$ ). Ähn-

\footnotetext{
5.475) $45(1902), 226$

$5.470)$ so $(1907), 155$

5.477) 50 (1907), 159

5.475) 53 (1910), 96
}

\section{SLUB}


liche Wege gingen gleichzeitig Bernt und Cervenka, Prag, während die Venuslampe von Wolff \& Co., Berlin, mit einem aufrechten Glühstrumpf innerhalb einer anhängbaren Kuppel deutlich werden läf3t, daf̧ nicht der lichttechnische Vorteil, sondern die Nachahmung der frei hängenden elektrischen Glühlampen der Antrieb war $\left.{ }^{5 .+2 \pi}\right)$. Immerhin kamen über eine Vielzahl von Bau$\left.\operatorname{arten}^{5 .+48}\right)$, unter denen auch schon Gruppenbrenner als Starklichtlampen waren ${ }^{5.451}$ ). brauchbare Lösungen heraus $\left.{ }^{5+45}\right)$. (Dr. Paul Wolff, Berlin, C. Killing, Düsseldorf, Ehrich und Graetz, Berlin u. a.). Prof. H. Drebscbmidt, Berlin, stellte fest, dał für die mittlere Leuchtstärke der unteren Hemisphäre das Hängelicht mit ז,08 1/HKh nur die Hälfte des Stehbrenners verbrauche. Eine ausführliche Geschichte des Hängelichtes bis 1907 hat F. A brens, Berlin, geschrieben $\left.{ }^{5.485}\right)$. Als Straß̧enbeleuchtung fand das Hängelicht 1906 in Berlin Anwendung ${ }^{5.154}$ ). 1908 konnte man bereits von einem Höhcpunkt der öffentlichen Prefjgasbeleuchtung sprechen, der von den Niederdruckstarklichthängelampen erfolgreich angegriffen wurde $\left.{ }^{5.45}\right)$. Nachdem zuerst 1910 Leuchten mit 1000 HK mit Vorwärmung geschaffen waren, folgten Einheiten von 600 HK mit 0,69 1/HKh für Straf̧en und schlieflich solche von $350 \mathrm{HK}$ mit $0,6 \mathrm{r} 1 / \mathrm{HKh}$ bis $0,641 / \mathrm{HKh}$, deren zwei als Doppelbrenner mit $700 \mathrm{HK}$ sich gut einführten. Damit war auch die Leistung guter Pref̧gaslampen von o,5 1/HKh soweit erreicht, dał wegen des Aufwandes an Energie und Anlagekosten die Niederdrucklampe wirtschaftlicher sein konnte $\left.{ }^{5,460}\right)$.

Zur Eisenbahnwagenbeleuchtung entwickelten die Franzosen die ersten Hängeleuchten $^{\text {s.ts7 }}$ ), die die Ostbahn einführte ${ }^{5, \Delta+5}$ ). In Deutschland führte Julius $P$ ints $c b$ mehrere Bauarten aus ${ }^{3,459}$ ). Die Verteilung der Wagen mit Hängelicht war: England 303, Vereinigte Staaten 250, Frankreich 2716, Österreich 124, Deutschland 119 , Rußlland 5, Schweden $2^{5.490}$ ). Ein Jahr darauf waren bei der Preufisch-Hessischen Staatsbahn von 196000 Flammen insgesamt bereits 143000 auf Glühlicht umgebaut ${ }^{\text {s,al }}$ ). Für die Eisenbahnen brachte die Umstellung das Gute, dał man auf den Zusatz von Azetylen zum Olgas verzichten konnte. Ein Glühkörper hielt gewöhnlich 200 Brennstunden, in einzelnen Fällen wurden aber auch rooo Brennstunden erreicht.

Das Gasglühlicht zu verbessern, bemühten sich nicht nur die Konstrukteure der Leuchten, man beschäftigte sich auch dauernd mit den Glühkörpern. Allerdings

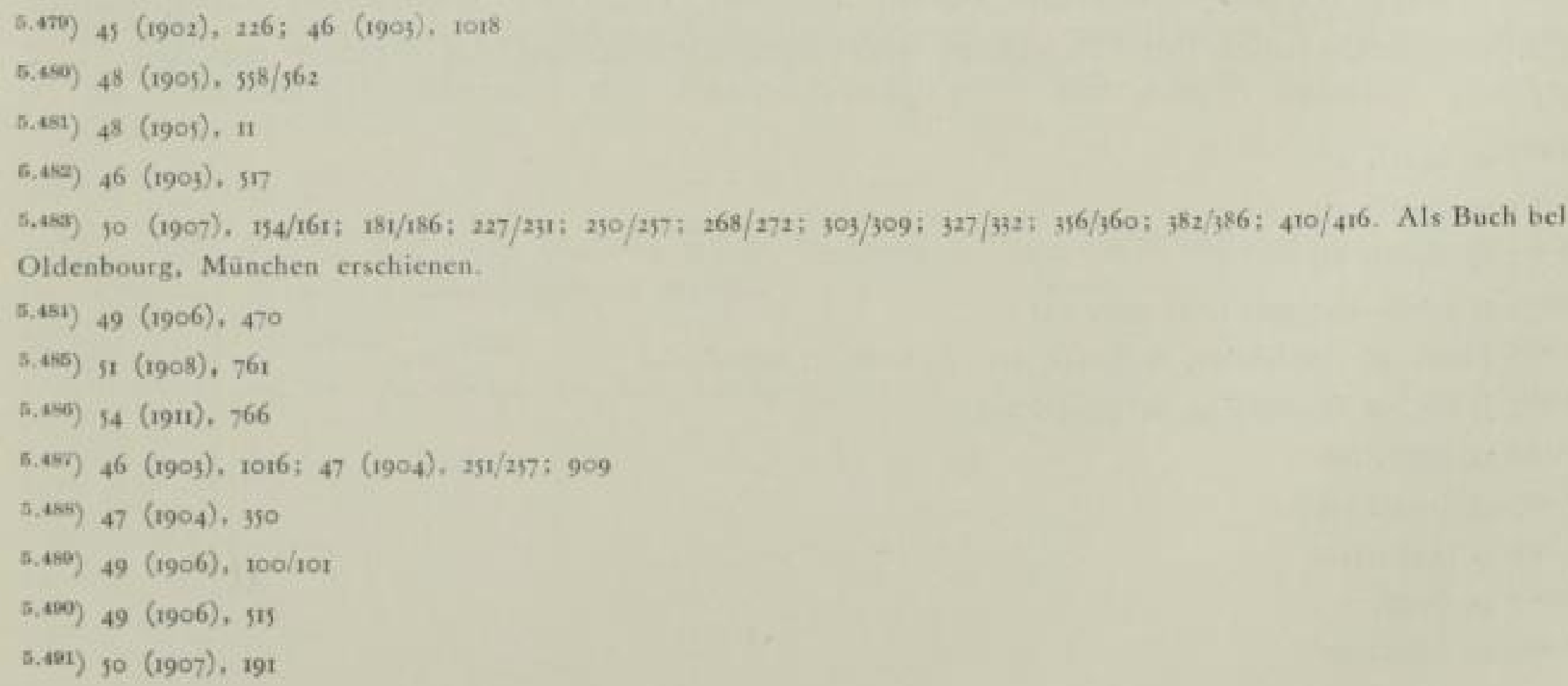


führte der Wettbewerb zeitweilig auch zu Klagen über geminderte Haltbarkeit der Glühkörper, ohne dał Fortschritte im Leuchteffekt erzielt würden ${ }^{5.102}$ ). Magdeburg fertigte sogar, um sich vor schlechten Lieferungen zu schützen, seine Glühkörper im Gaswerkslaboratorium selbst $a^{5,409}$ ) E. Schilling stellte demgegenüber aber Fortschritte in der Haltbarkeit fest, und rühmte den Degea (Deutsche Gasglühlicht Aktiengesellschaft) - Körper als besonders beständig. Lange Jahre hatte man Baumwollgarn (gestrickte Körper von Pintscb) als den besten Träger angesehen. I89 8 wurde die Ramiefaser (Steingrass) durch $B u b l m a n n$ eingeführt, deren rauhe Oberfläche günstig zu sein schien. $C b a r$ donnet nahm Kollodium-Kunstseide (Lösung von Kollodium und Schief\}baumwolle; Zellstoffseide). Lieferant solcher Fäden wurden die Vereinigten Glanzstoffabriken Elberfeld. Neben dem Patent spielte noch die geheim gehaltene Behandlung bei der Tränkung ${ }^{5.44}$ ) eine Rolle. Es wurden also nicht nur die Grundstoffe der Fäden, sondern auch die gewählten Thoriumsalze und das Bearbeitungsverfahren dauernd verbessert. ${ }^{5.405}$ ).

Eine grofe Gefahr für die gesamte Gasindustrie wandte G. Live se y ab; als er Monopolbestrebungen zum Zwischenhandel mit Monazitsand aus Brasilien, der einzigen Fundstelle in der W'elt, durch Sendboten durchkreuzte $\left.{ }^{5.400}\right)$. Verbrauchte doch die Deutsche Gasglühkörper-Industrie zur Herstellung von 100 Mio Glühkörpern im Jahr (einschliefjlich grofer Exporte) allein roo t Leuchtsalze aus 25000 t Monazitsand $\left.{ }^{5.45}\right)$. Weniger wichtig, aber immerhin unangenehm genug erwies sich ein groß̧angelegter Verkäuferschwindel mit Bestäubungsmitteln, ,um Glühkörper haltbarer zu machen “5.465).

Versuche mit Sauerstoff-Glühlichtbrennern wurden immer wieder vergebens angestellt $\left.^{5,400}\right)$. Unter Hinweis auf die verbilligte Sauerstoffherstellung nach $L$ in de wurde sie zuletzt von Prof. $F r a n k$, Berlin, angeregt. Dieser arbeitete mit $C$ a ro am Kalkstickstoffverfahren, bei dem viel Sauerstoff unverwendbar anfiel ${ }^{5.500}$ ). Regeldüsen am Hängelicht wurden allgemein notwendig, für Stehlichtbrenner wurden sie vergeblich gefordert $\left.{ }^{5,5 n 1}\right)$. Druckregler waren nicht überall günstig wegen des Druckverlustes bei an sich zu niedrigen Gasdrücken. Insbesondere versagten die damals schon versuchten Hausdruckregler, die aus Weiß̧blech gefertigt allzu leicht beschädigt wurden. Dazu kam noch die Unsicherheit der Membran als Abschluf gegen die Auf̧enluft ${ }^{5.507}$ ). Mit einem "Aerostat", der, abhängig von der Temperatur des vorgewärmten Luftstromes, die zuzuführende Luftmenge richtig einstellen sollte, wurden von der Deutschen Gasglühlicht Aktiengesellschaft bei Prefgas- und Prefluftleuchten 0,5 1/HKh erreicht. Die

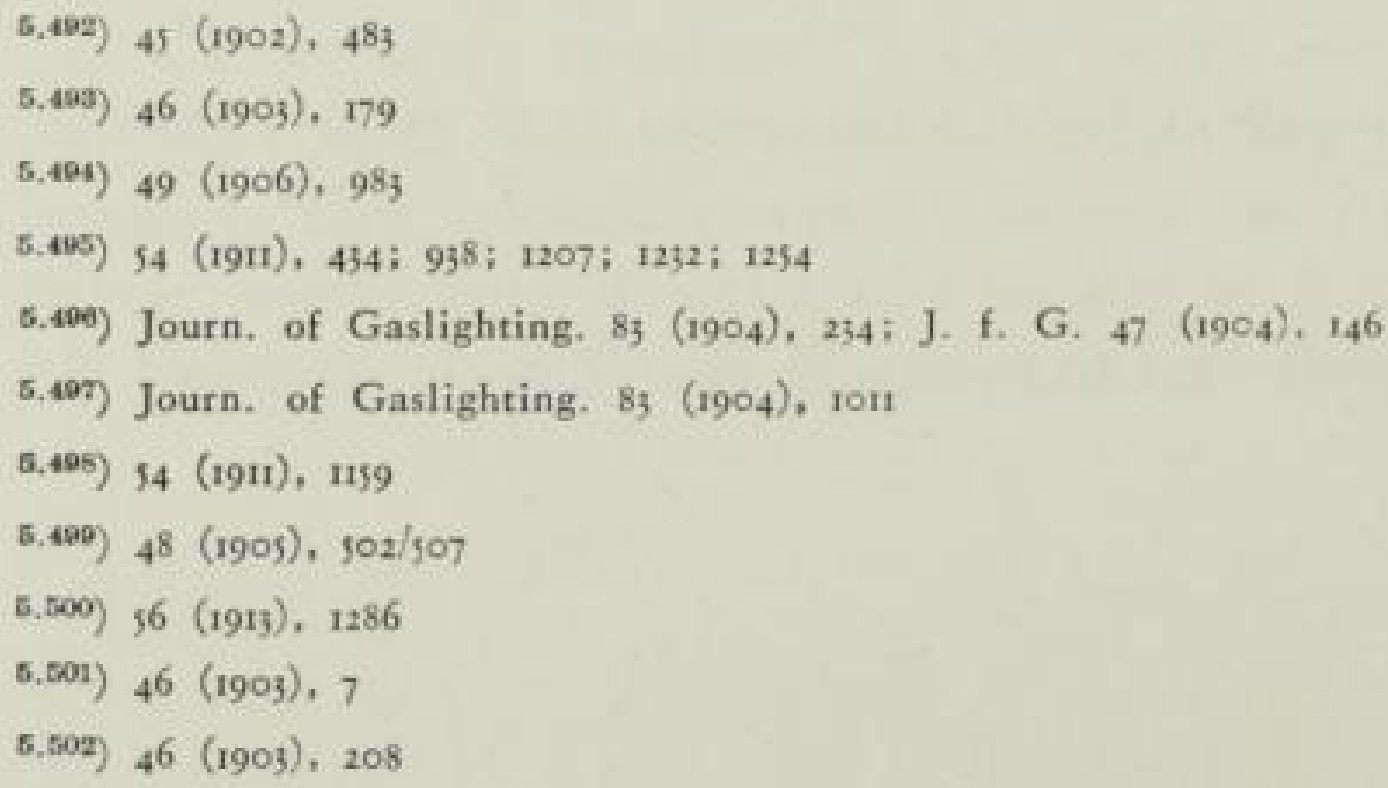


Temperatur der Luft stieg nämlich nur langsam an, und so bekamen ohne Regler die Geleuchte in der Zeit nach dem Anzünden bis zu einer Stunde mehr Luft, als gut war ${ }^{\text {s.t.ne }}$ ).

Die Förderung der Gasbeleuchtung durch formschöne Leuchten wurde auch wohl als Folge der Freizügigkeit, die die Elektrizität bei der Herstellung der Lampen gewährte, gefordert und erstrebt. Was allerdings dabei an „künstlerischen" Beleuchtungskörpern herauskam, ist anregender als Dokument des Zeitgeschmacks, denn als technische Stufe $\left.{ }^{5.501}\right)$. Geradezu grotesk ist die preisgekrönte Nachahmung der elektrischen kleinsten Glühlampe als Krönung eines Glaskerzensticls durch einen fast geschlossenen und fast ebenso kleinen Glaszylinder in dessen Innerem eine Gasflamme „,verborgen“ brennt. Der Jugendstil war überwunden bei den Entwürfen von R. und F. Wille, Berlin, die die englische Gasgesellschaft dort anregte $\left.{ }^{5.505}\right)$. Für einen allgemeinen Erfolg waren die Modelle aber zu aufwendig. Wirklich ansprechend waren die Lampen, die W. J. Stockvis in Arnheim in ro-jähriger Entwicklungsarbeit nach alten Gemälden als Vorbild herstellen lief $\left.{ }^{5,500}\right)$. W Wieder aber erwiesen sich solche hochwertigen Modelle als zu kostspielig, um allgemein aufgegriffen zu werden.

Wertvolle Arbeit wurde an den Aufhängemasten für Strafjenbeleuchtung geleistet. Insbesondere $\mathrm{Himmel}$, Tübingen, schuf schon 1900 für die Pariser Weltausstellung Straf̧enüberspannungen und führte sie auch für Prefggasbetrieb dicht aus. Bei 400 Lampen der Württemberger Staatsbahn waren in 12 Jahren nur so Stopfbüchsenerneuerungen notwendig geworden ${ }^{5,30 \pi}$ ).

Unendlich viel konstruktiver Scharfsinn und schwere Meinungskämpfe wurden der Fernzündung gewidmet. Die Entwicklung ging in zwei Richtungen, der verbilligten Straf̧enlaternenzündung und der vereinfachten Zündung in der Wohnung „,wie bei der Elektrizität" von der Wand aus. Die Druckwellen, auf die man für die öffentliche Beleuchtung schon früher verfallen war, wurden von vielen Fachleuten als störend bekämpft, von anderen als unzuverlässig angesehen. So versuchten Friedrich Siemens, Dresden ${ }^{5,500}$ ) und $\mathrm{Ph}$. Lenze, Düren, besondere Luftdrucksteuerleitungen zu verlegen, die auch einigen Anklang fanden, aber zu teuer wurden, besonders, wenn die Anlagen für ein vorhandenes Netz nachträglich eingebaut werden sollten $\left.{ }^{5.500}\right)$. Unzählig waren die Bauweisen, bei denen Elektrizität die Zündbewegung auslösen sollte. Eine besondere Schwierigkeit, die nur hin und wieder gemeistert wurde, bestand darin, die Hähne, die leicht beweglich sein muß̧ten, dicht zu bekommen ${ }^{5.517}$ ). In Berlin wurden „,nur" s Systeme elektrischer Fernzünder für Schaufensterbeleuchtungen zugelassen ${ }^{3.511}$ ). Der „Multiplex" Fernzünder arbeitete mit Batteriestrom oder mit einem Schalter mit in

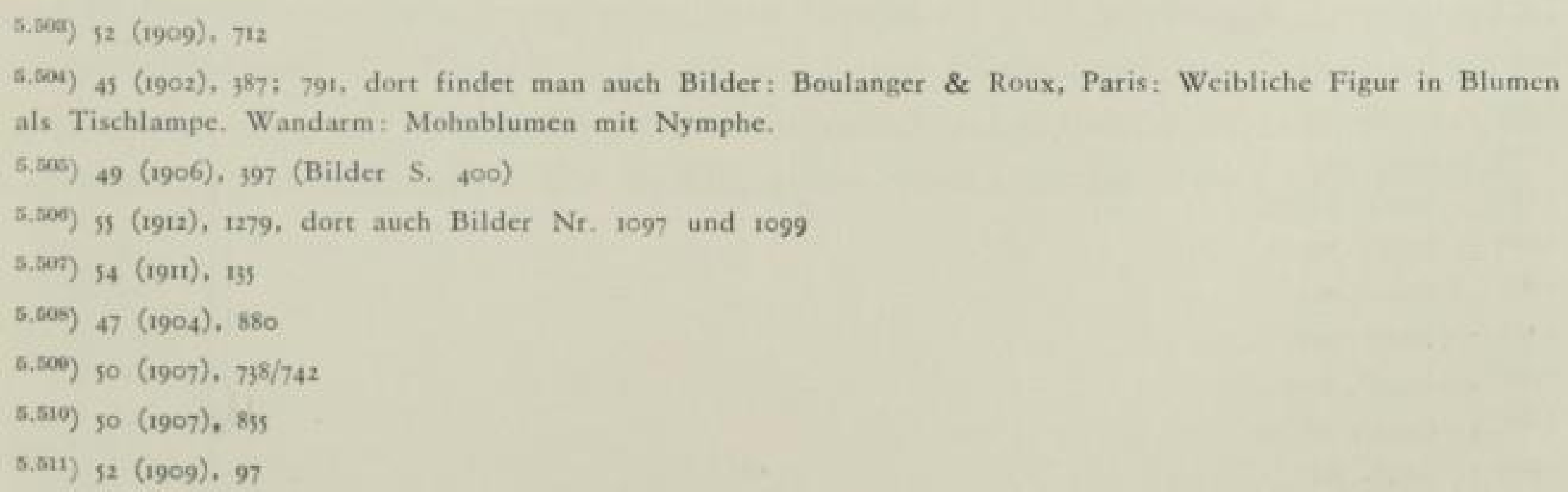


Spitzen gelagertem, leicht beweglichem Hahn und Induktor $\left.{ }^{5.512}\right)$. Günstiger waren bei weit ausgreifenden Netzen Uhrwerkszünder, wie sie Rotben $b a c b$, Bern, schon 1897 entwickelt hatte (Aktiengesellschaft für automatische Zünd- und Löschapparate, Zürich), Deutsche Gaszünderfabrik, Elberfeld ${ }^{5.5 i n}$ ) und E. Kilcbma $n$, Wohlen. Die Elberfelder Firma hatte in kurzer Zeit 6000 Uhren zum Preise von $35 \mathrm{M}$ abgesetzt.

Auch für Zünder, die von Druckwellen im Gasstrom betätigt werden sollten, gab es viele Ausführungen: Tauchglocken mit Quecksilber und Glyzerin mit einfachen und, zum verstärkten Ansprechen auf geringe Druckunterschiede, mehrfachen, sinnvollen d. h. verwickeiten Bauarten (Dr. Rostin), beschwerten Lederbälgen und gespanriten Membranen, von denen sich sehr bald die Ausführung von Bamag für $25 \mathrm{M}$ das Stïck am meisten durchgesetzt hat ${ }^{5.514}$ ). Meinungen, daß̧ die Wellen die Konsumenten stören würden, wurde lebhaft als unberechtigt entgegengetreten ${ }^{5.555}$ ). Die Auffassung, dał sich Druckwellen vor allem bei kleinen Werken eigneten, in stark belasteten Netzen nicht zuverlässig, aber für Auß̧enbezirke immer angebracht seien ${ }^{5.5 i n}$ ), wurde bald überwunden. Im Gegenteil käme man bei Versagern schlechten Netzverhältnissen und Verstopfungen auf die Spur ${ }^{3.517}$ ), „Durch Fernzündung sind eigentlich erst geordnete Verhältnisse in vielen Rohrnetzen geschaffen worden."15.515) I9II konnte man sagen, dafy die Druckwellenzündung sich überall durchgesetzt hatte ${ }^{\text {jistg }}$ ).

Der reine Kostenvergieich zwischen Zimmerbeleuchtung mit Gas oder Elektrizität erwies sich als nicht ausrcichend. Die Abnehmer schätzten die einfache Schalterbewegung der elektrischen Anlagen $\left.\operatorname{sehr}^{5,3 a n}\right)$. Sie auch für Gas zu schaffen, setzten die Bemühungen zahlreicher Konstrukteure ein. Die Forderung eines Pariser Preisausschreibens, auch eine dauernd brennende Zündflamme zu vermeiden, konnte aber nicht erfüllt werden ${ }^{5,52}$ ). Der Zimmerfernzünder „Fix “ benutzte einen Gummibeutel als Druckwellengeber, wobei die Zuleitung vom Messer her mit einem Rückschlagventil gesperrt wurde $\left.{ }^{5.52 z 2}\right)$. Er war aber wohl zu unzuverlässig. Der „Multiplex“-Fernzünder mit Batteriestrom wurde vielfach benutzt ${ }^{\text {5.52z }}$ ), besonders auch als Treppenhausbeleuchtung mit selbständiger Ausschaltung. Er erwies sich aber als nicht einfach in der Einstellung und Wartung und verlangte einen Kundendienst, der dann allerdings auch für andere Fehler in den Anlagen aufkommen konnte. Deshalb brauchten die Werke auch eine Installationsabteilung $\left.{ }^{3.54}\right)$. Später wurde die Multiplex-Treppenhausbeleuchtung als vollkommen und billig bezeichnet ${ }^{5,525}$ ). Auch die Treppenhausbeleuchtung von

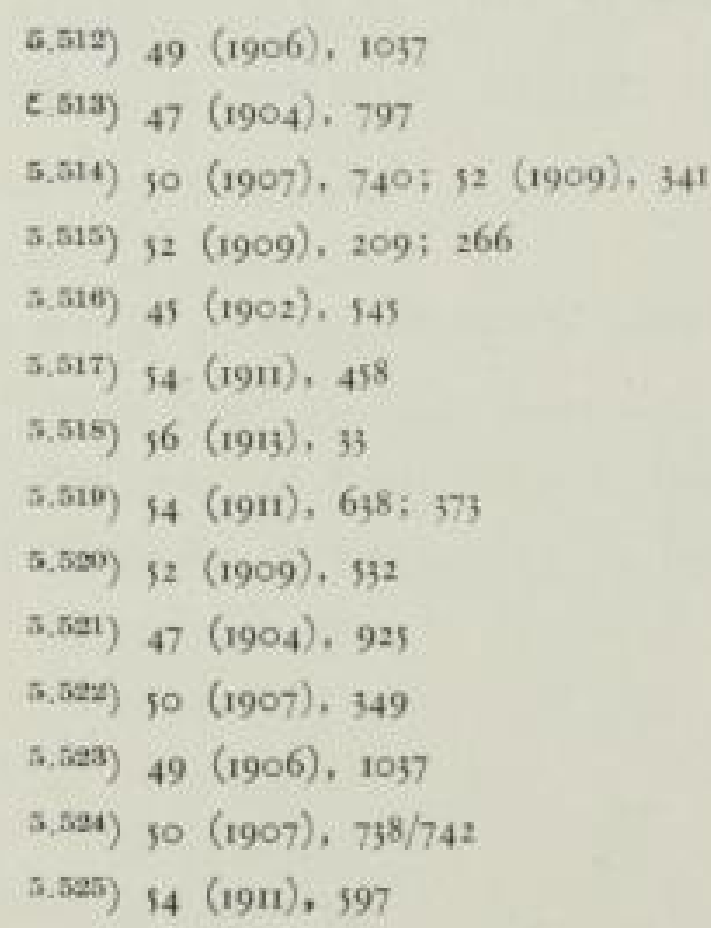


Him mel, Aktiengesellschaft für Gasbeleuchtung, Tübingen, „,funktionierte in ähnlicher Weise wie die bekannten elektrischen Anlagen “5.5ast). Eine dieser Einrichtungen benutzte eine Öldurchflufyuhr als Zeitrelais ${ }^{3}$ ). Schlieflich wurde die Askania-Fernzündung mit einem dünnrohrigen Druckluftsystem entwickelt, die aber auch viel Pflege besonders am Kolben und seiner Stopfbüchse beanspruchte $\left.{ }^{5.258}\right)$. So einfach, wie der elektrische Schalter, erwies sich auf die Dauer keine der Einrichtungen. Nach dem Kriege waren sie fast verschwunden.

Grofje Sorgen bereitete es, die ersten „Gassparer“ zu bekämpfen, die meist durch Auflegen einer Platte auf den Zylinder einer Stehlampe, die Füllung des Strumpfes „verbesserten“. Prachtvolle Namen wurden für die Vertriebsfirmen gefunden: "Süddeutsche oder Norddeutsche Gaslichtzentrale" oder auch „Deutsche Gaszentrale". 30-40\% Gasersparnis wurden freimütig versprochen. Scharfe Kämpfe gab es in Karlsruhe. In Hamburg verurteilte ein Schöffengericht einen Reisenden zu 4 Monaten Gefängnis ${ }^{\text {tajog }}$. Trotzdem gab es weitere Schwierigkeiten, den Vertrieb zu verhindern ${ }^{\text {r.ang }}$ ).

Abschlief̧end kann man feststellen, dafy die Beleuchtung in einem schweren Abwehrkampfe gestanden hat, aber wegen der Preiswürdigkeit durch den Einsatz von Münzgasmessern bei wirtschaftlich schwächeren Bevölkerungsschichten das ausgleichen konnte, was sie bei anspruchsvollen Kunden verloren hat. In der Straf̧enbeleuchtung wechselten Verluste mit Gewinnen ab. Im groß̧en und ganzen konnte die Lage gehalten werden.

\subsection{Preise und Werbung}

Bevor die anderen Gasverwendungsgebiete technisch abgehandelt werden, wird es sich lohnen, die allgemeine Wirtschaftsrichtung zu verfolgen. Denn es ist auffallend, wie allmählich um die Jahrhundertwende nach den fetten Jahren der Hochkonjunktur die nötige Absatzwerbung gegen das betrieblich-technische Ergebnis und den Handelsgewinn der grołen Nebenerzeugnisse zurücktrat.

Die Tatsache wird aber verständlich, wenn man beachter, wie der erste Werbestoł für Kochgas so viel Erfolg hatte, daf̧ die Werke mit der Anschlufarbeit bei der plötzlich ansteigenden Konjunktur nicht mehr nachkommen konnten, und daf andererseits die in den 8oer Jahren befürchtete Gefahr für die Beleuchtung durch C. A uer von Welsbach abgewendet wurde und dadurch die Leuchtgaspreise gehalten werden konnten. Nunmehr holte die Elektrizität zunächst installationstechnisch viel auf. Die beschriebene Nachahmung elektrischer Leuchten ist bezeichnend. Man mufte nunmehr mit den Leuchtgaspreisen entgegenzukommen suchen. So erklärt sich das plötzliche Abrücken vom getrennten Leucht- und Kochgaspreis und die Einführung eines mittleren Einheitspreises. Dabei ist auch zu beachten, daf die vorgeschlagenen erhöhten Kochgaspreise an sich durch die Verteuerung des Rohstoffes, der Kohle, allein gerechtfertigt waren. Sie bedeute-

\footnotetext{
$5.5909) 54(19 n), 370$

5.527) 48 (1905), 728

$5,525), 57(1914), 389$

5. 5020) 53 (1910), 298

$5.510)$ 54 (1911), 872; 900
} 
ten, gemessen am Kaufwert der Kohle - für Kochen und Wärme im Haushalt nicht einmal die Wiederherstellung des alten Wertverhältnisses.

Dał die zusätzliche Werbearbeit für das Kochen aufhörte - die einzige allgemein in Anspruch genommene Vortragsdame, Frl. Hobtmann, gab ihren Dienst auf, ohne daf eine Nachfolgerin gewonnen wurde - mag zurückblickend als kurzsichtig erscheinen. Die inzwischen eingerichteten örtlichen Verkaufs- und Ausstellungstäume blieben aber bestehen.

So ging als erstes Werk Wiesbaden vom Zweimessersystem zum Einmessersystem über mit Sommerpreisen von I2 $\mathrm{Pf} . / \mathrm{m}^{3}$ und Winterpreisen von $16 \mathrm{Pf} . / \mathrm{m}^{3}$, um die Ersparnisse an Zählerwartungskosten einzuheimsen $\left.{ }^{5,537}\right)$. Berlin setzte den Einheitspreis auf 12,35 Pf./m $/ \mathrm{m}^{3}$ fest. August $\mathrm{Be}$ e el hielt einen Preis von $10 \mathrm{Pf} . / \mathrm{m}^{3}$ für angemessen, hatte dafür aber wohl nur politische Gründe anzuführen ${ }^{5.5 a 9}$, Die ausgiebige Erörterung über die rechte Tarifform zeitigte eine bemerkenswerte statistische Feststellung von E. M erz, Kassel $\left.{ }^{5,558}\right)$. Von 64 befragten Werken wurde nachgewiesen, dał die Verhäitniszahl von Winterspitze zu Sommerlast betrug: 18842,36 bis 6,95; $1896 \mathrm{I}, 47$ bis 3,95; $1898 \mathrm{I}, 4$ bis 3,6. In diesem Jahre hatten 2 Werke als Verhältniszahl weniger als 2, 2I Werke weniger als 2,5, 26 Werke weniger als 3 und is Werke mehr als 3 . So empfahl Merz die Bevorzugung des sommerlichen Gasverbrauches, mit je einem Einheitsprcis im Sommer und im Winter.

W. v. Oechelbaeuser äußerte sich scharf gegen Einheitspreise. Er wollte lieber höhere Preisunterschiede als verbilligtes Leuchtgas haben ${ }^{5054}$ ). Seine $\mathrm{Ge}-$ sellschaft und auch Hannover berichteten von großen Erfolgen mit dem Doppeltarif. Das konnte aber auch Wiesbaden nachweisen $\left.{ }^{5,535}\right)$. Mit einem allgemeinen Einheitspreis folgten alsbald Charlottenburg, Landau, Quedlinburg, St. Johann/Saar und Stockholm. ${ }^{\text {s.seg }}$ ). Hamburg beantragte bei der Bürgerschaft statt der bisherigen Preise von 18 und $12 \mathrm{Pf} . / \mathrm{m}^{n}$ einen Einheitspreis von ${ }_{15} \mathrm{Pf} . / \mathrm{m}^{35.537}$ ), ging aber nach to Jahren des Doppeltarifs auf $\mathrm{I}_{4} \mathrm{Pf} . / \mathrm{m}^{3}$ hinunter $\left.{ }^{5,509}\right)$.

Natürlich verlief die Umstellung nicht reibungslos. In Berlin wehrten sich die Besitzer von Gasmotoren, 400 an der Zahl, die dann auch bald dem Gase als Abnehmer verloren gingen ${ }^{5,537}$ ). In St. Gallen kam es bei der Úmstellung von ${ }_{14,4} \mathrm{Pf} . / \mathrm{m}^{3}$ im Sommer und $20 \mathrm{Pf} . / \mathrm{m}^{3}$ im Winter auf durchlaufend $17,6 \mathrm{Pf} . / \mathrm{m}^{3} \mathrm{zu}$ einer allgemeinen Erregung der Abnehmerschaft, die sich $16,8 \mathrm{Pf} . / \mathrm{m}^{3}$ als angemessen ausgerechnet hatte.

Inzwischen hatte aber auch v. Oecbelbaeuser anerkannt, dafy unter den gegebenen Verhältnissen (Kampf um die Beleuchtung) der Einheitspreis grundsätzlich richtig sei. Dafür aber solle man mit gewerblichen Gasabnehmern hohe Rabatte von Fall zu Fall aushandel $\left.{ }^{5.340}\right)$. Am weitesten ging in dieser Hinsicht

\footnotetext{
5.531) 44 (1901), 129

5.58ir) $44(1901), 181$

5.523) 44 (1901), 205/210

5.521) 44 (1901), 565

$5.595) 45(1902), 348$

$5.530) 44(1901), 845$

5.597) $48(1905), 510$

6.539) 49 (1906), 998

5.5\$2) 44 (1901), 785

5.540) 33 (1910), 364
} 
Darmstadt, um die chemische Fabrik von Merck mit $500^{\circ} 000 \mathrm{~m}^{3}$ Jahresabnahme zu gewinnen. Es gewährte einen Preis von $7 \mathrm{Pf} . / \mathrm{m}^{3}$ und erhielt später $9 \mathrm{Pf} . / \mathrm{m}^{3}$ mit einem angemessenen Gewinn.

I912 kamen erneut Bedenken, ob man mit dem Einheitspreis das Richtige getroffen habe. Vorschläge eines Mehrverbrauchstarifes mit $10 \mathrm{Pf} . / \mathrm{m}^{3}$ Grundpreis erläuterte F. Greineder $\left.{ }^{5.5 i 1}\right)$. Eine ausführliche Statistik vom folgenden Jahre zeigte auferordentlich verschiedene Tarifsysteme ${ }^{5,442}$ ). Einheitspreise waren in Kaiserslautern, Duisburg und Düsseldorf 12 Pf. $/ \mathrm{m}^{3}$, in Straf̧burg 12,9 Pf., in Berlin ${ }_{13} \mathrm{Pf}$., in Karlsruhe ${ }_{14} \mathrm{Pf} . / \mathrm{m}^{3}$. Motorengas wurde zu 9, 10 und $20 \mathrm{Pf}$. abgegeben. Einen Mehrverbrauchstarif auf Grund der Zimmerzahl schlug F. Gö $b r u m$, vor, was zu einer außjerordentlich regen Auseinandersetzung führte ${ }^{5.568}$ ).

In Nordamerika war 19os die National Commercial Gas Association als Werbeorganisation gegründet. Dieses wurde aber in Deutschland erst 1914 bekannt $^{3.54}$ ). Das Empfinden, dał man inzwischen die Werbung zu sehr vernachlässigt hatte, trat 1909 sehr plötzlich und stark an die Öffentlichkeit. F. S c bäfers Buch: "Kein Haus ohne Gas" hatte 7 Auflagen erlebt $\left.{ }^{5.345}\right)$. Die englische Gesellschaft in Berlin schuf eine Abnehmerzeitschrift: „Steinkohlengas und seine Verwendung", die vietteljährlich erschien. Diese vom guten Willen des Kunden als Leser abhängigen Schriften wurden als ungenügend empfunden. Die Deutsche Continental-Gas-Gesellschaft hatte mit dem später sehr bekannt gewordenen Frl. J. Wirtb eine äufzerst befähigte Vortragsdame in Dienst gestellt. E. S $c b i l$ li $\mathrm{g}$, verlangte als Leiter des Heizausschusses eine Zentralstelle für Gasheizung mit den Zielen: 1 . wissenschaftliche und praktische Untersuchung und Prüfung von Gasapparaten und Gaseinrichtungen zum Heizen und Kochen, 2. Einrichtung von Ausstellungen und Musterräumen, 3. Belehrung des Publikums über die zweckmäßigste Anwendung durch Schriften, Vorträge und praktische Beihilfe, 4. Ausbildung von Kochlehrerinnen und 5. Agitation bei Architekten, Künstlern, Behörden und Kochschulen ${ }^{\text {5.5.5n }}$ ). Auch die Zeitschrift: "Gas für Haushalte", die in Nürnberg ins Leben trat, und sich der Mitarbeit einer Reihe führender Fachleute samt der erwähnten J. W irt $b$ erfreute, stief den Ruf nach mehr Werbung aus. (Vgl. Abschnitt über Wettbewerb 5.14 mit dem Höhepunkte des Kampfes durch Unfallstatistiken S. 340.) Sie verlangte mehr Vorträge in Volksbildungsvereinen, kaufmännischen, gewerblichen, Handwerker- und Bürgervereinen, in denen regelmäßjig von Seiten der Elektrizität gesprochen wurde. Dazu forderte sie die Gewinnung namhafter Redner und die Bereitstellung von Lichtbildern und Vorführgeräten ${ }^{5.517}$ ).

Die Übertreibung der Gefahren des Gases hatte Erfinder von Schutzeinrichtungen auf den Plan gerufen, die nun ihrerseits diese Übertreibung noch wilder betrieben ${ }^{\text {5.n.th }}$ ).

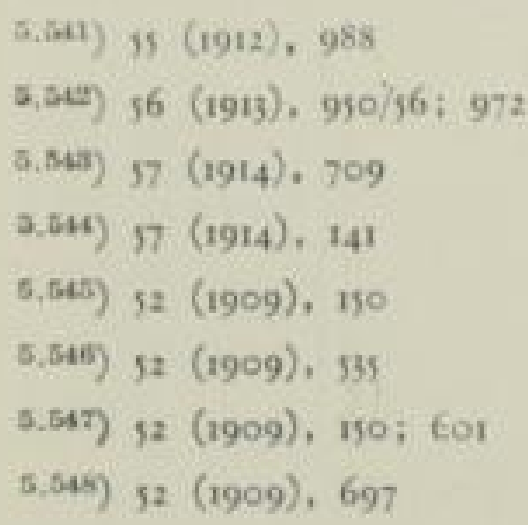


William Anderson, Hannover, legte dar, wie sein persönlicher Einsatz als Werksdirektor an Brennpunkten Werbeerfolge gebracht hatte ${ }^{5.5 i n}$ ).

Diese vielfachen Anregungen griff W. v. Oecbelbaeuser mit H. Prenger, Köln, E. Körting, Berlin, G. Möllers, W. V. und E. Blum, Bamag, Berlin auf. Die "Zentrale für Gasverwertung" wurde mit der Aufgabe gegründet, in Fühlung mit dem Deutschen Vercin und der Wirtschaftlichen Vereinigung Druckschriften herzustellen und Damen und Herren für Vorträge auszubilden und zu gewinnen. Technische Aufgaben sollten nicht bearbeitet werden. „Fest steht, dał keine besondere Zeitschrift geschaffen wird." Vorstand, geschäftsführender Ausschuf und Verwaltungsrat brachten die breite Grundlage im Fache. Zum Direktor wurde K. Lcmpelius, Barmen, bestellt ${ }^{5, s 50}$ ).

Dank der Rührigkeit kamen sofort greifbare Erfolge bei Ausstellungen in Bochum und Hagen mit überfüllten Kochvorträgen von J. W ir $t h$, die auch zu Verkaufserfolgen führten $\left.{ }^{5.55}\right)$. Auf der Hauptversammlung wies Körner, Dresden, darauf hin, daf̧ für die Werbung im Gewerbe werkseigene Beamte notwendig seien, deren Ausbildung die Zentrale anfassen müsse $\left.{ }^{5,53}\right)$. In seinem Vortrag vor dem Verein zur Beförderung des Gewerbefleif̧es, Berlin, „,Die Flamme als Werkzeug" faljte Fr. Schäfer den Begriff sehr weit und beschrieb alle Wärmeverfahren samt Öfen und Einbau in Arbeitsmaschinen. Er traf die heute noch wichtigen Hauptpunkte: I. die Zunahme der Vielgestalt der Erzeugnisse, 2. Beschleunigung, Verfeinerung und Verbesserung der Werkzeuge, 3. Automatisierung und Unabhängigkeit vom Geschick des Arbeiters ${ }^{653 \pi}$ ). I9II lief der erste Ausbildungskursus für Werbedamen in der Lehrküche von J. W irt $b$ in Dessau für die Zentrale, bei der F. $S c b a ̈ f e r$ und W. Allner die technischen Erläuterungen in die Hand nahmen.

Nunmehr übcrstürzten sich die Mitteilungen über erfolgreiche Vorträge (mit Konzert $\left.)^{5.5 .54}\right)$, Einstellung von Lehrdamen $\left.{ }^{5,55}\right)$, Ingenieurbesuche bei Gewerbetreibenden $^{\text {n.s5e }}$ ), das Gasmuseum in Chariottenburg ${ }^{5.577}$ ) usw. Der Plan für eine grołe Gasausstellung in München 1914 wurde im Jahre vorher gefaf̧t und für das Unternehmen lebhaft geworben.

Ein Verkaufsraum 1913 bei den städtischen Gaswerken in Berlin sollte die hochwertigen Lampen unterzubringen helfen und für die Warmwasserbereitung werben $\left.^{\text {3.555 }}\right)$. Die erste Gasgemeinschaft mit den Installateuren des Ortes wurde in Duisburg mit einem gemeinsamen Verkaufsraum geschaffen ${ }^{5,55}$ ).

Alles in allem waren die s Jahre auferordentlich fruchtbar gewesen, bei den Werken den Sinn für gute und doch sachliche Werbung zu wecken.

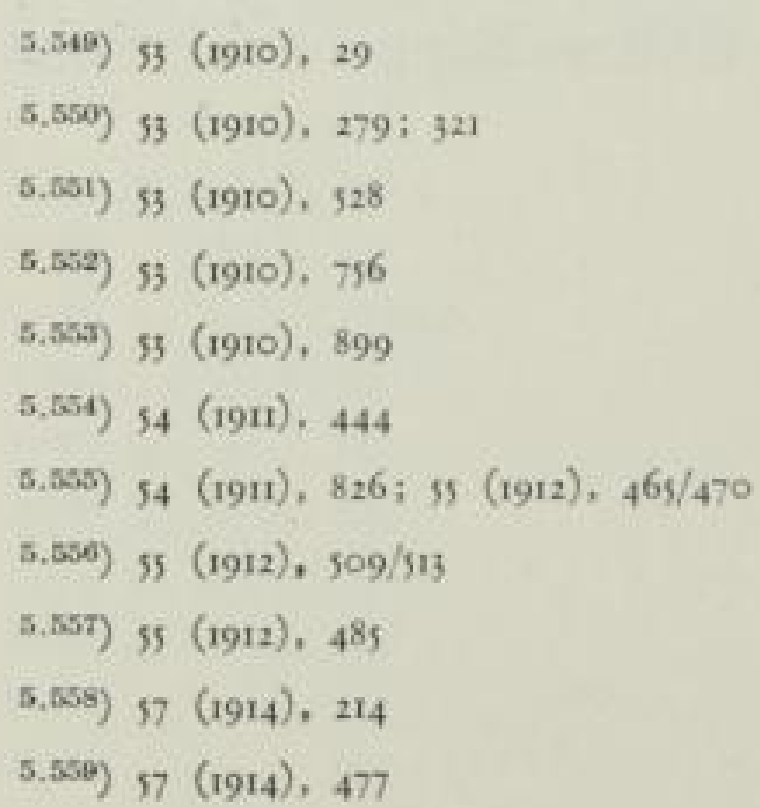


In England wurde eine British Commercial Gas Association am 12. Okt. I9II gegründet. Der Name war von Nordamerika übernommen, aber auch die Tätigkeit der Zentrale für Gasverwertung hat als Vorbild gedient ${ }^{5.500}$ ).

Die rege Tätigkeit des Faches mag auch noch durch die Vielzahl technischer Bücher, die gegen $19: 4$ erschienen, belegt werden. Verfasser waren Fr. $S c b \ddot{a}-$ fer-Dessau, A. Scbäfer-Ingolstadt, R. Witzek-Berlin, W. Bertelsmann-Berlin und H. Stracbe-Wien.

\subsection{Kocben}

Die Entwicklung von Kochern und Herden schritt in ruhigen Bahnen, aber stetig zum Besseren fort. Die äußzeren Formen aus emaillierten Blechen mit dem Aufbau des Bratofens unter der Kochplatte wurden so, wie sie noch heute vorwiegend gebaut werden, entwickelt. Vernickelte Leisten an den Bratofenöffnungen und besonders für Westdeutschland auch vernickelte Beine trugen dem $\mathrm{Ge}$ schmack der Kundschaft Rechnung.

Viele Brennerformen wurden als Neuheit gebracht. Sie waren sich im Gesamtaufbau aber sehr ähnlich. Der Doppel(spar)brenner war besonders geschätzt und wurde in irgendeiner Weise abgewandelt von jedem Gasherdhersteller angeboten. Bei den grołen Schwankungen in der Gaszusammensetzung hatte er auch eine besondere Bedeutung, um bei stark wassergashaltigen Mischungen den Rückschlag bei Kleinstellung zu vermeiden. Der Wirkungsgrad lag um $70 \%$. Eine Darstellung der verschiedenen Firmenerzeugnisse lohnt sich nicht. Es wäre auch fast unmöglich festzustellen, wer irgend eine neue Form nun als erster gebracht hat. Die Hersteller täuschen sich gerade in diesem Punkte heute vieifach.

Damals schon gab es Brenner mit Luftzufuhr im senkrechten Rohrteile, die auch wohl gegen größjerer Unempfindlichkeit gegen verschiedene Gasmischungen als Fortschritt gewertet wurden $\left.{ }^{\text {}, \overline{\sigma 61}}\right)$. Einstellvorrichtungen, um die Brenneraustrittsschlitze den Gasarten anpassen zu können, ergaben sehr verwickelte Brennerkopfbauarten.

Die geschlossene Kochplatte mit offener Nebenkochstelle ${ }^{\text {t.se }}$ ) wurde von mehreren Firmen hergestellt und sehr gepriesen. Aus einem Stück gepresste Blechkocher waren billig und leicht. Für Münzzählermietanlagen gab es auseinandernehmbare schwere Gufjkocher, ${ }^{5.503}$ ). Auch der Kocher mit einer sehr kleinen Dauerzündflamme von 5,5 bis $6 \mathrm{l} / \mathrm{h}$ Gasverbrauch wurde von Meurer schon 1910 angeboten $\left.{ }^{3.565}\right)$. Eine Fehlkonstruktion war der Lilienthal-Kocher, eine Kochkiste mit Wärmestein und Haube, die damals aber als brauchbar angesehen wurde $e^{5,645}$.

Sorgen bereiteten die Einbaubrenner für Kachelherde, die in Ostdeutschland unentbehrlich waren, wo die „Kochmaschine“ als Kohlenherd vom Hauswirt ein-

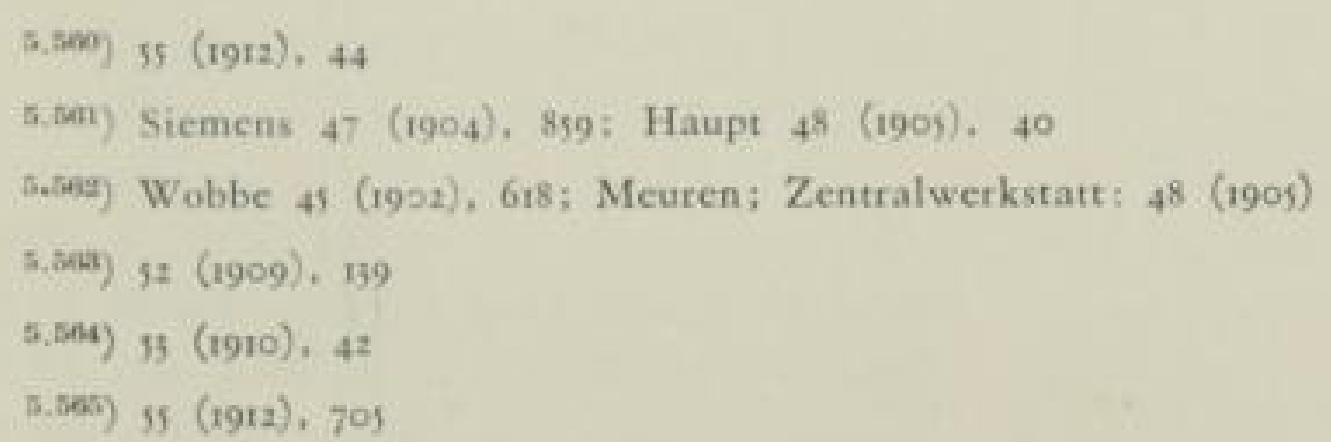


gebaut wurde. Die Töpfer setzten die Brenner oft unrichtig ein. F. $K u c k u k$, verlangte dringend von den Herstellern Einbauanweisungen ${ }^{5.5 n 9}$ ).

Die Unfälle mit Gasschläuchen riefen 1908 eine ernste Aussprache hervor. Angeboten wurde eine Schlauchmuffe mit Befestigungsspange. Die feste Verbindung der Kocher wurde als wünschenswert bezeichnet ${ }^{3.000}$ ). Ein Streit, ob man die Schliefzung des Haupthahnes über Nacht empfehlen solle oder das Gegenteil besser sei, war heftig, verlicf aber unentschieden. Einen Gasstecker mit Hahn so, daf̧ dieser nur bei festsitzendem Schlauch geöffnet werden konnte, erschien mit dem Namen „System Behr“" die Deutsche Continental-Gas-Gesellschaft empfahlen solche Hähne nach eingehenden Versuchen ${ }^{5.5 n t}$ ).

Einen guten Eindruck über die ganze Lage gibt der Bericht über die grofe Ausstellung „Das Gas" in München ${ }^{\text {s.5no }}$ ). Unendlich viele Lösungen des Doppelsparbrenners waren zu finden. Besonderheiten waren ein Kohlenherd von W. Hom a n $n$, Vohwinkel, mit im Sommer einsetzbaren Brennern und einer Vorrichtung, die den Austritt von Kohlengasen verhindern sollte, wenn der Gasteil arbeitsbereit ist. Noch mehr staunt man über die Wärmespeicher unter den Kocherbrennern und über oder unter den Bratöfen zur „kostenlosen" Warmwasserbereitung $\left.^{5,571}\right)$.

Groł̧küchenherde und ergänzende Bratöfen wurden als Einzelausführungen von verschiedenen Firmen geliefert.

Eine allgemeine Aussprache über die Kocherprüfung zog sich über einige Jahre $\left.\operatorname{hin}^{5.572}\right)$.

\subsection{Warmwaserbereiter}

Auch die Verbesserung der Warmwasserbereiter schritt ruhig fort. Nachdem die zweckmäßjige Grundform des Wärmeaustauschers mit großem Verbrennungsraum und Lamellenkörper gefunden war (Bild III), richtete sich die Aufmerksamkeit auf Einfachheit der Bedienung und Sicherheit. J. Vaillants Patent von 1899 auf eine Wassermangelsicherung wurde 190 or bekannt ${ }^{5,573}$ ). Der gewichtsbelastete Gasdruckregler der Zentralwerkstatt kam 1909 (Patent von 1907 Nr. $199 \overline{7}^{25} 7^{\text {s.tit }}$ ). Obwohl W. Le ybold, der sich sehr um den unfallfreien Betrieb der Badeöfen bekümmerte, den Zugunterbrecher verwarf, dafür aber einen direkten Austritt der Abgase durch die Wand ins Freie für gut hielt, kam Houben mit der ersten eingebauten Rückstromsicherung heraus ${ }^{5,070}$ ), die sich auch in einfachster Weise am Junkers-Ofen mit Sturzzug durch einfache Öffnungen unter diesem

\footnotetext{
5.500) $47(1904), 859$ f

5.507) 51 (1908), 685

5.506) $55(1912), 314$

$5.500)$ s5 (1913), 969

$5.570), 88$ (1915), 353

$5,571)$ \$8 (1915), 370

5.572) G. H. Wobbe, Pisa: 55 (1912), 1106

$5,573) 44$ (1901), 403

5.674) $\$ 2$ (1909), 317

5.575) $\$ 2(1909), 1128$ 


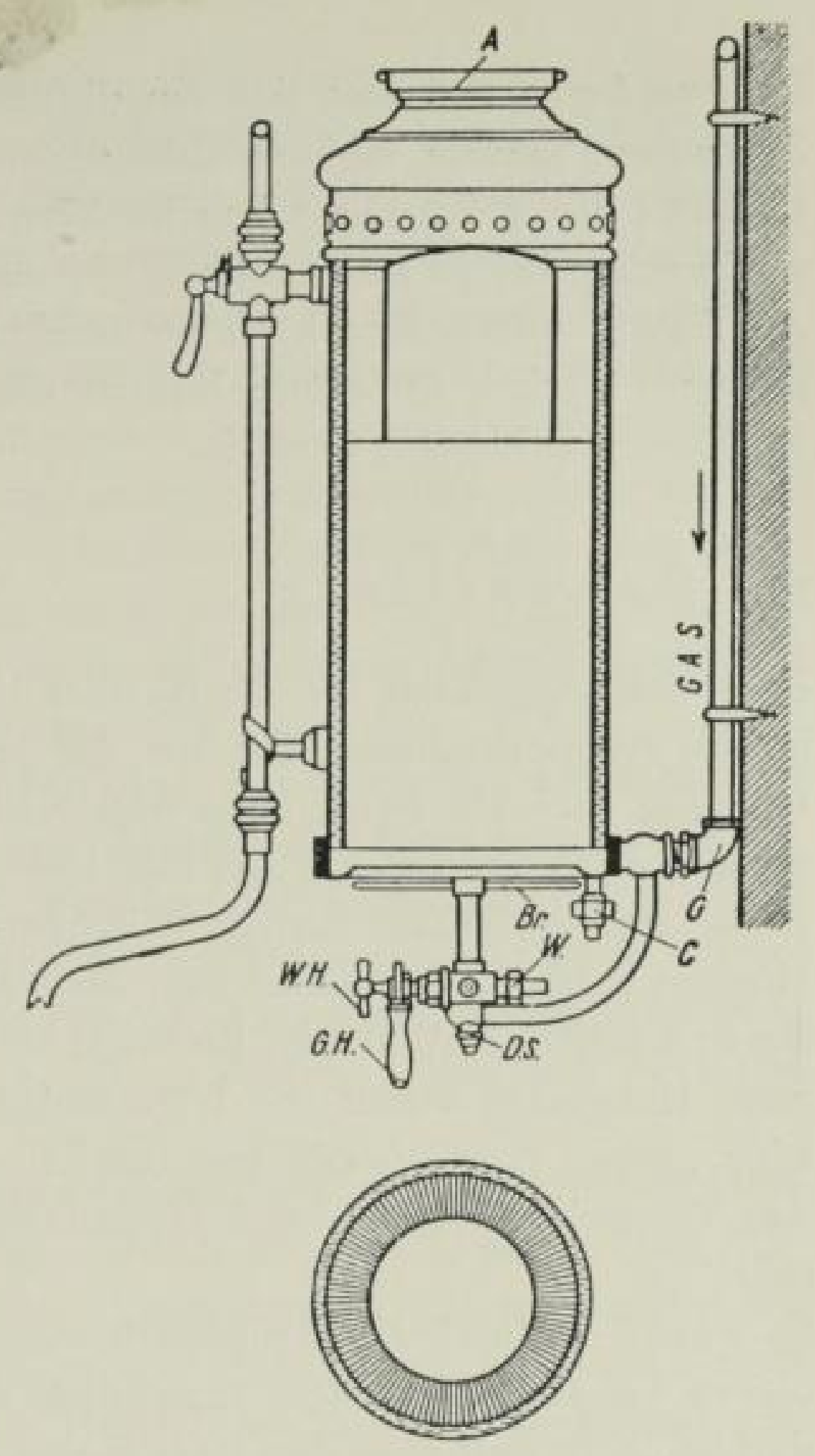

Badeofen mit Lammellenkörper

(Handbuch der Gastechnik [1916] S. 34)

entwickeln lief $\left.3^{\text {s.mog }}\right)$. Vorherrschend war wohl noch der grofe runde Standbadeofen, vielfach mit Reflektorheizofen als Untersatz ${ }^{5,377}$ ). Aber auch der Wandofen wurde angeboten, bei $V$ a ill a $n t$ der runde Ofen auf eine Konsole gestellt, von der Zentralwerkstatt wie ein schwerer Briefkasten an die Wand geheftet, bei Junkers als flacher Ofen mit Lamellenblock am Gasrohr aufgehängt ${ }^{5.575}$ ). Im Journal für Gasbeleuchtung kündete die Godesberger Badeapparatefabrik G. m. b. H. einen Druckautomat als etwas Neues an ${ }^{5 r y}$ ). Nach Fr. S c bäfer: "Muf der Badeofen im Badezimmer stehen?" war der Automat aber bereits eine geläufige Einrichtung ${ }^{3.50}$ ). Junkers baute - unter Betonung des Vorzuges einer geringen im Ofen stehenden Wassermenge - die Verbrennungskammer mit auf̧en umwickelter Rohrschlange, die zur schwitzwasserfreien Bauart geführt hat. Die Zentralwerkstatt hatte die Schlange zunächst im Innern des Mantels, änderte aber nach Patentstreitigkeiten mit Junkers als Lizenznehmer die Bauweise auf Aufzenschlangen um. $\left.{ }^{3,581}\right)^{5.558}$. Der Durchmesser des Abzuges sollte nach W. Le y b o ld das 6-fache des Gasrohrdurchmessers haben ${ }^{5.389}$ ).

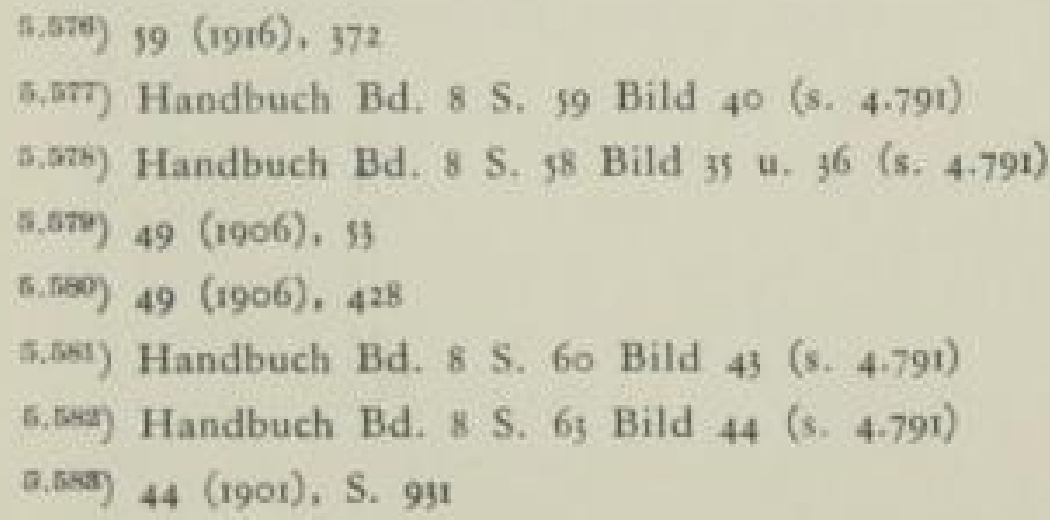

\section{SLUB}


H. Junkers bemühte sich um die preiswerte Badeanlage für jedermann. Die Sparwanne kostete mitsamt dem Ofen 143 M, ein Bad von I20 Ltr. bei I2 Pf. Gaspreis nur $8 \mathrm{Pf}$. Die schon im Wettbewerb stehenden Elektroboiler kosteten allein schon bei $50 \mathrm{Ltr}$. Inhalt $230 \mathrm{M}$ und ein Bad bei to Pf./KW/h $40 \mathrm{Pf}$.

Als äuß̧ere Ausstattung herrschte lackiertes Kupfer vor, für kleine Speichergeräte poliertes Nickel. Führende Firmen waren Houben, Junkers, Vaillant, Zentralwerkstatt, Eschebach, Godesia.

\subsection{Raumbeizung}

Sehr viel anregender als die Entwicklung der Kocher und Warmwasserbereiter ist die Aufmerksamkeit, die vor der Jahrhundertwende die Raumheizung fand. Hier lag noch ein wenig bekanntes Neuland vor. Als gute Leistung wurde vielmehr bezeichnet, daf3 in Paris 1899 bereits (!) 2053 Heizöfen aufgestellt wären ${ }^{5.551}$ ). Eine Umfrage ergab, daf̧ an Kirchenheizungen ausgeführt wurden von: J. G. Houben Sohn Carl, Aachen 100; Zentralwerkstatt Dessau II; R. Kutscher, Leipzig 6; Schäffer \& Walcker, Berlin 5; F. Siemens, Dresden 5 grołe Anlagen. Von allen Heizungen wurde die Wirtschaftlichkeit bestätigt, ${ }^{5,565}$ ).

Eine ,grołe Zahl“ (3000) von Schulöfen System Medinger-Reichatd waren von den Warsteiner Gruben- und Hüttenwerken geliefert, davon fast 500 nach Karlsruhe ${ }^{5.550}$ ).

So wurde es durch Erfahrungen bestätigt, dał die vorübergehende Heizung der Gasverwendung besonders zugänglich war, Zweifel und Streit aber entstanden darüber, wie weit man den Begriff vorübergehend fassen konnte. E. Kobbert ging damit in Königsberg sehr weit, wenn die Gewerbe- und Industrieabgabe als Ergänzung die Spitzen abschwäche. Er trat für den Zweck für eine verstärkte Herabsetzung des Heizwertes ein. K. Bunte meinte dazu, Kobbert habe den festen Boden, auf dem sich die Industrie bewegen müsse, verloren, ein Heizwert unter $5000 \mathrm{kcal}$ sei nicht zu empfehlen ${ }^{5 \times 55}$ ). Die spätere Entwicklung hat aber Kobbert recht gegeben. Auch E. Körting glaubte damals, bei 5000 kcal bereits so viel Koks aus dem Markte genommen zu haben, daf̧ Raum für eine

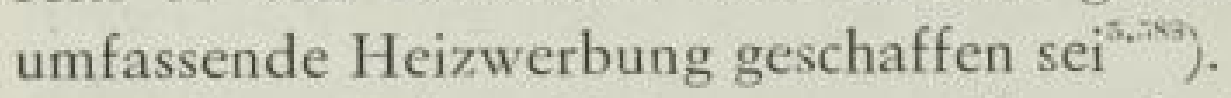

Den theoretischen Erörterungen über die Gründe, warum mit kurzen Anheizzeiten die Gasheizung wirtschaftlicher sei, besprach P. Spaleck, Dessau, an Rechenbeispiclen der Kirchenbeheizung mit Anheizzeiten von 1 bis I I/2 Stunden $^{\text {s.ses }}$ ). F. Meurer, Cossebaude, trat ihm bei. Damals schon wurde mit den „Kirchenformeln“ von Spaleck und den Tafelwerken klargestellt, dał die übliche Wärmedurchgangsberechnung der Zentralheizungsindustrie nach dem Schema von H. Rietscbel für diese Gasheizungen eine unrichtige Grundlage war. Allerdings wurde der Einfluß̧ der zunächst kalt bleibenden Wände auf die Abstrahlung der Wärme vom Körper, die nach etwas überhöhter Raum-

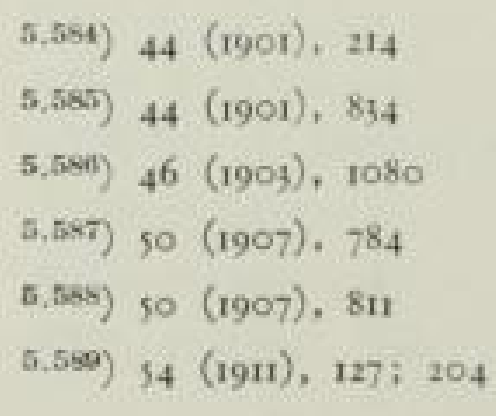


lufttemperatur verlangte, nicht richtig bewertet. Mif̧erfolge mit Gasluftheizungen in Kirchen mit ausgesprochen starkem Mauerwerk waren die Folge ${ }^{5.507}$ ). Der Wert der Strahlung als Klimafeid wurde überhaupt keineswegs richtig erkannt. So kann man vielleicht erklären, dał sich Gaswerksleiter, nicht etwa die Hersteller bestimmter Ofenarten allein, mit dem Kampfruf: hie Konvektionsofen, hie Strahlungsofen erheblich befehdeten. Man stand zwar vor der Tatsache, dał in England die hell strahlenden Glühkörperöfen eine Entwicklung der Gasheizung brachten, die den deutschen Erfolgen weit vorauseilte. Man warf in Deutschland dunkle Strahlung mit ihren unangenehmen Wirkungen und Hellrotstrahlung in einen Topf, und so kam es von seiten der Firma des Strahlungspioniers Siemens und von seiten man die Öfen nur der Beschreibung nach kannte. ${ }^{x .501}$ ).

P. Fischer, Stuttgart, bejahte die Strahlwirkung. Einen eigenen Ofen belegte er leider mit dem Namen Sparofen und rief dadurch die Gegner ins Feld ${ }^{505}$ ). Ganz eigentümliche Ansichten über die Wirkung der Strahlung, die mit Erfahrungen keineswegs im Einklang standen, äuf̧erten P. S p a le $c k$ und F. Me u$\left.r e r^{5.5 a 9}\right)$. Nach den ersten Untersuchungen trat M. Frank, Dresden, nun aber bedingt für die Strahlöfen ein $\left.{ }^{5.59}\right)$, und E. Ott, Zürich, schlof sich dem Urteil an.

Inzwischen wurden in London in 9 Monaten 110000 der neuen Ófen abgesetzt. Als Abnehmer wurden vor allem 2500 Ärzte durch die Gas Light \& Coke Co. gewonnen, die sich als begcisterte Werber betätigten ${ }^{\text {swo5}}$ ). Dazu wurde die schwierige Strahlungsmessung eifrigst studiert und dabei drei, wenn auch noch nicht vollkommene, so doch vergleichbare Ergebnisse liefernde Verfahren entwickelt $\left.{ }^{5.5 n g}\right)$. Abgasaustritte wurden durch den Shadowgraph aus zwei durchleuchteten parallelen Glasplatten, durch die Kühlwasser lief, bestimmt. Das war ein Vorläufer der einfachen Tauplattenmethode $\left.{ }^{5,5 a n}\right)$. In Deutschland hielt man aber den Konvektionsofen für unübertrefflich. Der Gufzeisen-Elementofen von C. Meurer aus dem Jahre 1906 war sicherlich auch ein Ofen von erfreulicher Einfachheit. Der Hinweis, dał H. Meidingers Grundsätze beachtet seien, war nicht ganz unberechtigt, wenn auch die Staustöpsel oben seiner Forderung zuwiderliefen, die Rohre so eng zu machen, daf3 der Auftrieb und die Wandreibung beim richtigen Luftüberschuß ins Gleichgewicht kämen. Werbetechnisch war wertvoll, dał er äuß̧erlich den „vornehmen“ Zentralheizungskörpern ähnlich war. Er hat ohne Frage die Gasheizung am meisten von alien Modellen in den Jahren bis zum zweiten Weltkriege gefördert ${ }^{\text {t.3ng }}$ ). Viele Nachahmer hat es gegeben, die aber gleiche Erfolge nicht hatten. Ein Rückfall war der geschlossene Ofen des sonst so rührigen Gaswerksdirektors O. Peiscber, Inns-

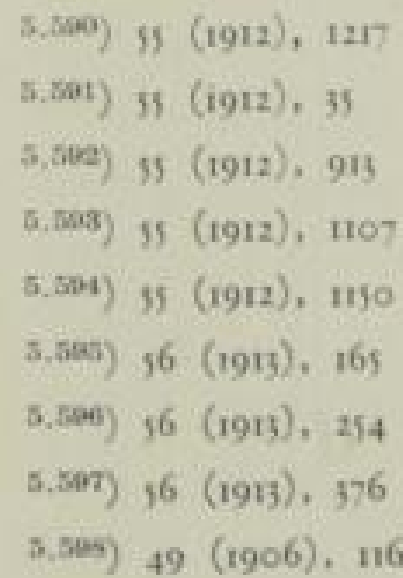


bruck, der glaubte, den übermäßigen Luftüberschuł der üblichen Reflektoröfen beseitigen zu können. Peischer bekämpfte auch die Abgasberechnung über den Kohlendioxydgehalt, wandte sie dann aber zur Kennzeichnung seines Ofens selbst an. Er täuschte sich über die Höhe der tatsächlich mit dem Luftüberschuf̧ abgeführten Wärmemenge $\left.{ }^{5,550}\right)$. Pfleiderer, Nürnberg, stellte umfangreiche Versuche an verschiedenen Heizöfen an, ging aber von vornherein von Annahmen aus, die eine Voreingenommenheit gegen die Strahlung bewiesen ${ }^{5,000}$ ).

Darum nahm K. Bunte in einem langen Vortrag auf der Hauptversammlung des Vereins in München zu allen Streitfragen Stellung. Er erläuterte erneut Anweisungen zur richtigen Untersuchung von Heizöfen und kam zu dem Schluf̧, daf̧ die Strahlungsheizer auch in Deutschland ein grołes Arbeitsgebiet finden könnten, vor allem bei kurzzeitiger Aufheizung, in der Übergangszeit und als Ergänzung von Zentralheizungen und Kachelöfen ${ }^{\text {T.001 }}$ ). Zum gleichen Ergebnis kam E. $O t t$, nachdem er verschiedene Gasheizöfen mit einem kalorimetrischen Strahlungsmesser untersucht hatte. Er gab einen sehr genauen Bericht über alle Möglichkeiten, wo man die Strahlheizer günstig einsetzen könnte, im Jahre $\left.1915^{5,007}\right)$. Die Gasluftheizung der Königsberger Festhalie von $40000 \mathrm{~m}^{3} \mathrm{zu}$ beheizendem Rauminhalt, die E. Kobbert durchsetzte, bewirkte berechtigtes Aufsehen $\left.{ }^{5.605}\right)$. Die Höchstleistung von nur $185 \mathrm{~m}^{3} / \mathrm{h}$ Gas war sicherlich auch erstaunlich gering; zumal damals der Ort, wie man aus den Auf̧̧erungen Kobberts schliefzen kann, keinen besonders hohen Heizwert einhielt.

Unter dem Eindruck der Vorteile, die das Prefggas im industriellen Ofen zu ermöglichen versprach, kam A. W. O n slow, Woolwich, zu dem Vorschlag, auch Prełgasluftgemische in geschlossenen Kammern zur Raumheizung unter Druck zu verbrennen und die Abgase durch die Heizrohre unmittelbar nach aufzen zu blasen. Eine solche Anlage laufe bereits 6 Monate lang befriedigend. Da grundsätzlich gleiche Gedanken von führenden Gerätebauern mehrfach als vorteilhaft für die höchste Steuerfähigkeit und Unabhängigkeit von den Schornsteinen auch später ausgesprochen worden sind, ist es vielleicht gut zu wissen, wie alt solche Erwägungen schon $\left.\operatorname{sind}^{5,804}\right)$.

Über das Eingreifen durch H. Rietscbel, Berlin, ist bereits wegen der Folgen, die er für das Vorschriftenwerk des Gasfaches hervorrief, auf S. 335 berichtet worden $\left.{ }^{5.600}\right)$. Die dabei angeschnittene und später im Heizausschuf\} lebhaft erörterte Frage der guten Abgasführung veranlaf̧te $1908 \mathrm{H}$. Junkers Versuche in einer Broschüre: „Die Abführung der Abgase von Heizöfen“ zu veröffentlichen, deren Zeichnungen noch heute zum Teil für die Lehre benutzt werden. Junkers griff auch auf $M$ eidingers erste Versuche zurück $\left.{ }^{5.000}\right)$. Eine Kirchenheizung mit Gas mit Abgasabsaugung durch Gebläse wurde bereits 1905 ausgeführt. Sie erforderte damals noch beim Anheizen eine sorgfältige Einstel-

\footnotetext{
5.519) $56(1913), 1212$

$5.000) 57$ (1914), 597

5.601) 57 (1914), 69.4

$5.002)$, 8 (1915), 669/676

5.003) $53(1910), 22$

5,.004) 53 (1910), 806

5. .605$) 49(1906), 161$

$5.600)$ \$1 (1908), 169
} 
lung verschiedener Drosselstellen, die das Gaswerk mit seinen Monteuren jedes Mal vornahm ${ }^{\text {s.007 }}$ ).

Normen für Gasheizöfen brachte der Heizungsausschuß im Laufe des Jahres 1910 heraus ${ }^{5.005}$ ).

Die ersten Zentralheizungskessel, zunächst kleinere Typen für Stockwerks- und Zusatzheizungen, erschienen im Jahre 1908. Der amerikanischen Bauweise von Ruud, Hamburg ${ }^{\text {nog }}$, folgten die Askaniakessel für Dampf und Wasser der Zentralwerkstatt Dessau ${ }^{5 . a 19}$ ). Daf3 im gleichen Jahre K. H a r t m a $n n$ vom Gewerbeaufsichtsamt Berlin auf der Hauptversammlung des Vereins über Gas als Abwehrmittel gegen die Rauchplage in Grofstädten sprach, dabei allerdings eine wesentliche Verbilligung des Gases für die zentrale Wärmeversorgung forderte, mag als Beleg dienen, dał weite Kreise sich bereits mit diesen Fragen beschäftigten $^{\text {s.an }}$ ).

\subsection{Gewerblicbe und industrielle \\ Gasverwendung}

Einer der seltenen Fälle in der Technik, dał ein umfassendes, allgemein aufgenommenes Arbeitsgebiet der Willensäuf̧erung eines Mannes oder höchstens ganz weniger Köpfe entstammt, ist die Pflege der gewerblichen und industriellen Gasverwendung. Gewif̧ gab es auch vor 1910 gelegentlich Berichte über eine gewerbliche Anwendung. Die technischen Mittel waren auch durchaus einsatzfähig, wenn auch noch wegen unzureichender Erfahrungen in mancher Hinsicht unvollkommen. Offensichtlich hat es aber daran gefehlt, dafy die Bedeutung allgemein erkannt war. Industrie und auch zum Teil Gewerbe verlangten nach so billigen Preisen, daf̧ ohne nähere Begründung die Werke zur Ablehnung neigten. Mit der Verfeinerung der Unkostenrechnung lernte man aber die Bedeutung der gleichmäf̧igen Benutzung über lange Zeiträume zu würdigen. Auch erkannte man, daß̧ die richtige Ausbildung der Beheizung den für das Gaswerk notwendigen Mindestpreis auch für den technischen Zweck brauchbar machen konnte. Um 1908 begann W. $v$. Oecbelbauser damit, Beamte ausschlieflich für Industriewerbung ausbilden zu lassen ${ }^{5.31}$ ). Er lief̧ auch alle Fälle von gewerblicher Anwendung ermitteln und war selbst überrascht, wie vielseitig der Einsatz des Gases bereits war $\left.{ }^{\text {s,anz }}\right)$. In der Tat konnten Fr. Scbäfer und E. Scbilling schon fast alle Gewerbe, die auch heute noch als besonders gute Kunden geschätzt werden, als in Einzelfällen versorgt aufzählen ${ }^{5,5 i 4}$ ). Schilling brachte eine überraschend umfangreiche Tafel von Herstellern $\left.{ }^{5.515}\right)$. Es fehlte also zunächst nur daran, daf̧ einmal errungene Gebiete allen Fachgenossen mit

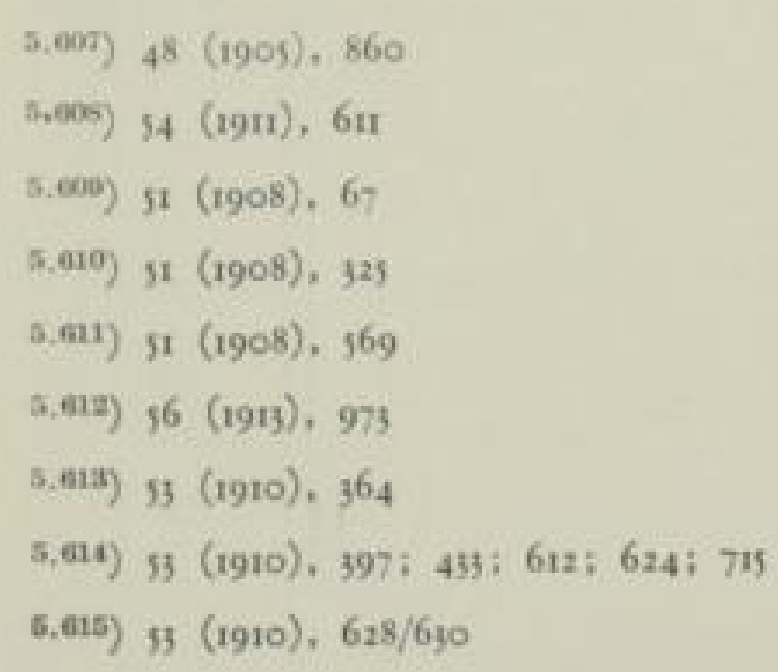


allen Unterlagen bekannt wurden. Daraus war der Gedanke an die Zentrale für Gasverwertung herangereift.

$\mathrm{Zu}$ einer gewissen Überschätzung kam man mit der Bewertung des Prefggases. Als man die für die Beleuchtung geschaffenen Anlagen auch für gewerbliche Wünsche einsetzte, beobachtete man natürlicherweise überraschende Ersparnisse, deren Grund in der richtigen Einstellung und Einschaltung der Luftzahl lag. Prof. W. A. Bon e, Leeds, lief̧ 1910 seine Oberflächenbrenner patentieren, die trotz der hohen Widerstände im Glühkörper mit voller Luftvormischung arbeiteten $\left.^{\text {s.610 }}\right)$. Er benutzte sie zunächst zum Eindampfen chemisch aggressiver Flüssigkeiten, für Schmelzöfen und Muffelöfen bis zu $2000^{\circ} \mathrm{C}$ und zur besseren Ausnutzung von Starkgasen in Röhren-Dampfkesseln ${ }^{5, a 17}$ ). Die gleichen Gedanken hatte R. Scbnabel unabhängig in die Tat umgesetzt. ${ }^{\text {s.6. }}$ ). Gewif fand man im Schrifttum auch Angaben, daf ähnliche Absichten schon früher von anderen Erfindern geäuf̧ert wurden ${ }^{5.6 i 9}$ ), ${ }^{5.6 i 9}$ ). Auch die Annahmen über eine katalytische Wirkung der keramischen Massen war keineswegs erwiesen. Indessen wurde ein Weg gewiesen, um große Kesseleinheiten mit der Vielzahl der Brenner in einem Grade zu regeln, den damals und auch spater keine andere Bauweise erreicht hat. Ungleich der Mehrzahl solcher gleichzeitiger Erfinder erkannten Bone und Schnabe! ihre Selbständigkeit gegenseitig an. Die Auswertungsgesellschaften Radiant Heating Co. Ltd. Leeds und die im Juli mit 5 Mio M gegründete Bonecourt Surface Combustion Lrd. auf der einen Seite und die Thermotechnische Gesellschaft m. b. H. Berlin schlossen einen Interessengemeinschaftsvertrag ab, mit Erfahrungs- und Patentaustausch, wobei das Arbeitsgebiet der deutschen Gesellschaft auf Deutschland, Österreich, Ungarn, Schweiz und Luxemburg beschränkt wurde. Die Kesselbauart mit einzelgefeuerten Rauchrohren wurde von Bamag übernommen und isi zu einer sehr leistungsfähigen und sicheren Einrichtung durchgebildet worden ${ }^{\text {s.asong }}$.

Eine Dampfüberhitzungsanlage von $N$ e ef $f$, Rapallo, als Einzeleinrichtung für Überhitzung von $400 \mathrm{~kg} / \mathrm{h}$ Dampf von $175^{\circ}$ auf $350^{\circ}$, darf man aber wohl gerade wegen der völlig überflüssigen Pref̧luftanwendung, noch dazu mit tangential in das Niederdruckgas eingeführter Luft als Fehlbauart ansprechen $\left.{ }^{\text {siel }}\right)$.

Einige besondere Zeitangaben mögen noch ausgewählt sein: Die erste gewerbliche Gaswaschmaschine lieferte I9I0 die Firma J. A. John A.-G. Ilversgehoven $^{5.02 z}$ ). Einen Waschautomat ohne Reiben, Zerren oder Walken (Wäschesprudler) empfahl die Imperial Continental Gas Association, Berlin, angelegentlichst $\left.\mathrm{I} \mathrm{II}^{5.62}\right)$, gleichzeitig auch eine Geschirrspülmaschine für Gasbetrieb. Trockenverzinkungsanlagen (Sherardisieren) fertigte E. Bernheim, Düsseldorf, zunächst mit Einpacken des auf 350 bis $270^{\circ}$ vorgewärmten Stückes in Zinkstaub ${ }^{5.52}$ ).

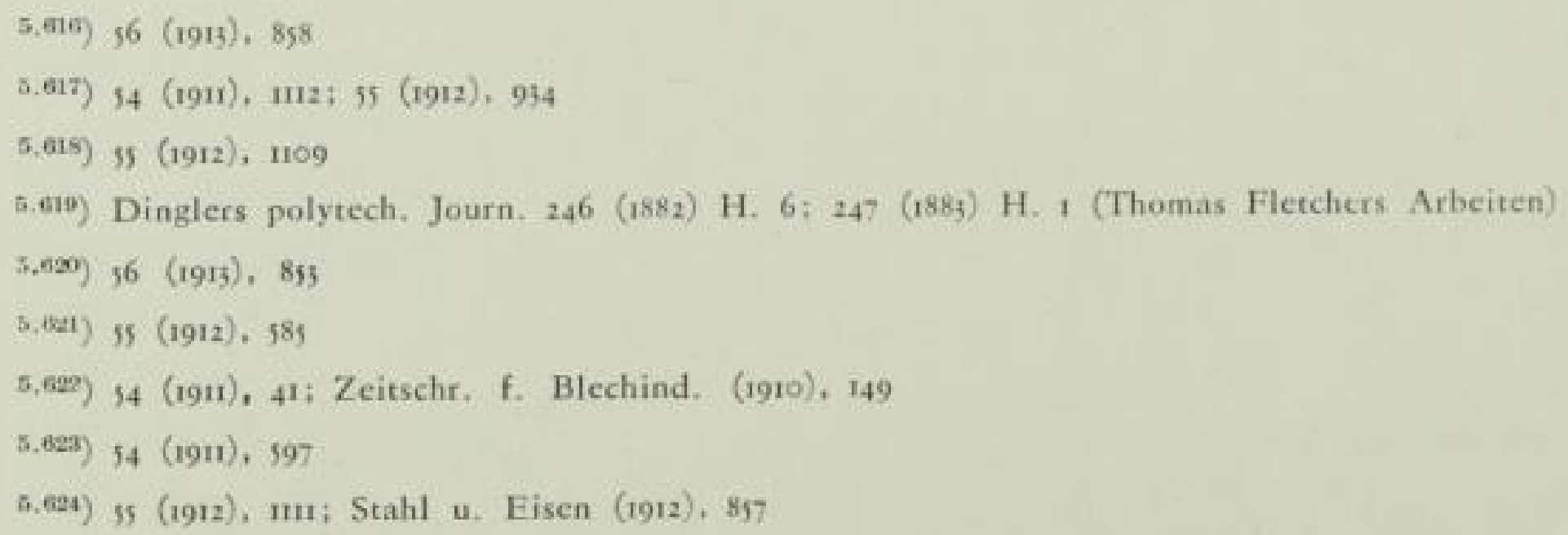


Die Theorie wurde als abenteuerlich bezeichnet, was aber der Bewährung keinen Abbruch getan hat. Einen Kupolofenanzünder erwähnte Stahl und Eisen $\left.1910^{5.455}\right)$. O. W ind el, Wilhelmsburg, beschrieb als neu den Bau von Lack- und Ölschmelzkesseln mit Luftvorwärmeröhren, die gleichzeitig zur gewendelten Führung der Abgase um den Kessel dienen sollten, und mit Pharospref̧gasbrennern. Bei 8 Pf. $/ \mathrm{m}^{3}$ für das Gas wurde die Koksfeuerung geschlagen ${ }^{5.050}$ ), auch die hochentwickelten Bornkesselbrenner zur Glasbearbeitung mit Pref̧luft und Prefggas waren schon vor $19: 4$ in ihren ersten Ausführungen $\mathrm{da}^{5,007}$ ). A. Albrecbt, Berlin, erwähnte im Rahmen einer grołen Übersicht über die Gasverwendung im Gewerbe ein Kohlengasungsbad der American Furnace Co. zur Aufkohlung mit Kohlenmonoxyd. Nähere Angaben über die Gaszusammensetzung konnte Albrecht nicht erhalten. Jedenfalls war hier aber der Anfang gemacht, mit künstlichen Ofenatmosphären zu arbeitei $\left.{ }^{5,092}\right)$. Albrecht erwähnte auch LeuchtgasSauerstoffschweif̧en dünner Bleche auch aus Messing, Bronze und Rotguß mit einem Wasserabsperrtopf als Sicherheitsvorlage in der Gaslcitung. Das Schneiden war der Firma Griesheim patentiert, die Wasserstoff verkaufen wollte und für Stadtgas eine besondere Vergütung verlangte ${ }^{\text {5.,ege }}$ ).

Auch die Jubiläumstagung (5o-jähriges Bestehen) der englischen Institution of Gas Engineers hörte einen Vortrag über industrielle Gasheizung an ${ }^{5.630}$ ).

Besondere Beachtung verdient die Werbearbeit der Pariser Gaswerke in den Bäckereien, die 191230 Bäcker mit 40 Öfen als Kunden gewann. Neben wenigen Sonderbacköfen für Gas wurden Einbaubrenner und Einsteckbrenner in den alten schweren Sturzöfen verwandt, darunter der Mékerbrenner mit Siebkopf, der von hier aus seinen Weg antrat $\left.{ }^{\text {,.eiz }}\right)$. Die Erfolge waren möglich, weil bislang Holzfeuerung vorgeherrscht hatte $\left.{ }^{5,023}\right)$. Das Vorgehen löste überall besondere Anstrengungen um die Bäckereien aus. Der Bericht über die Musterbäckerei auf der Ausstellung „Das Gas“ in München zeigt aber, dał die Technik noch nicht ausgereift war. Es gab als Dauerheizung Einschubbrenner von Méker, die P. F. Dujardin Co, in Düsseldorf lieferte, und Gasdampfbacköen mit offenbar mangelhafter Abgasausnützung ${ }^{\text {(axin }}$ ). Auch der in den Berliner städtischen Werken äuf̧erst rührige Inspektor Messing er hatte keineswegs erfafyt, wie leicht man bei Gasfeuerung die Backöfen bauen muf̧te (Bild п12). Er hielt Bleche unter Schamottemuffeln für einen Vorzug ${ }^{5, n u}$ ). So ist sein Urteil, daf̧ die Gaspreise für die Bäckerei zu hoch seien, verständlich. Leichter, aber doch noch bewuf3t schwer mit viel Guß̧eisen war der Askaniabäckereiofen für Brötchenbäckerei mit Schwadengeber gebaut. Viel leichter dagegen der Mehretagenbackofen von Se n king, Hildesheim, der aber dem Grofküchenbedarf angepaf̧t war und besser

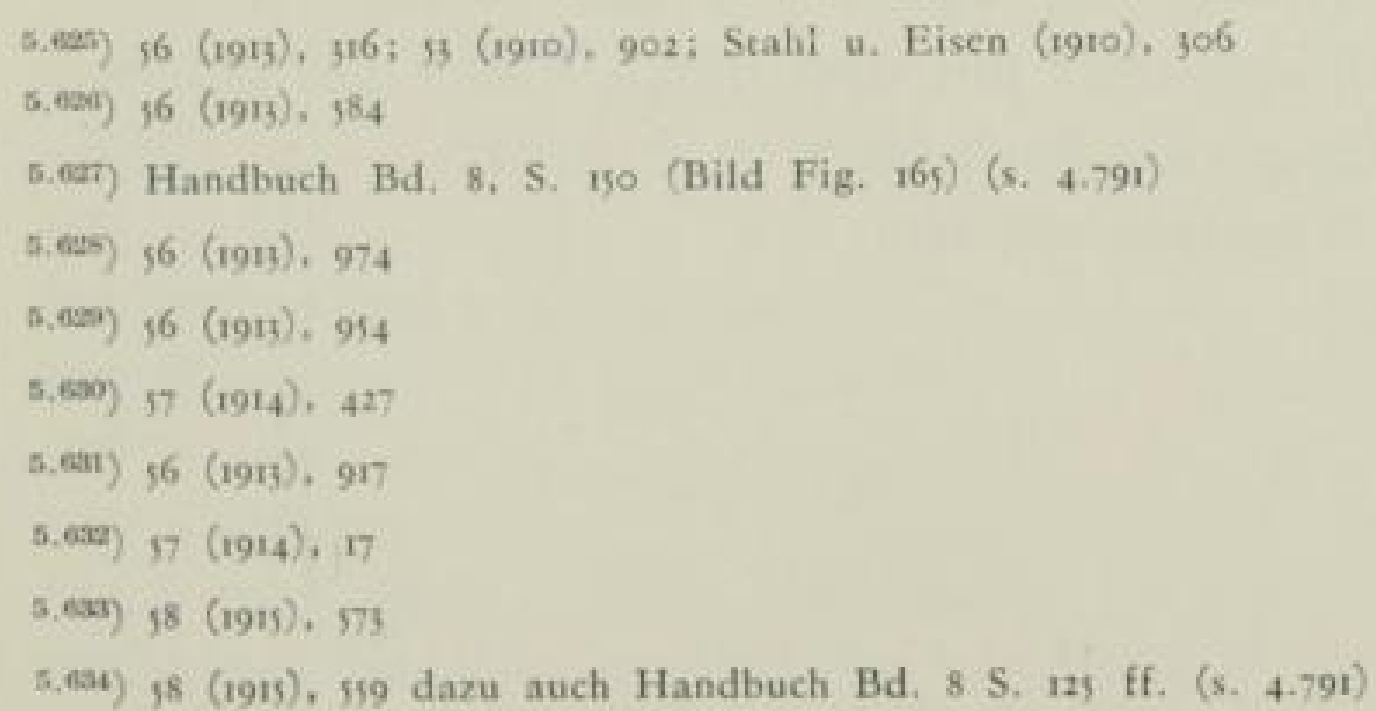




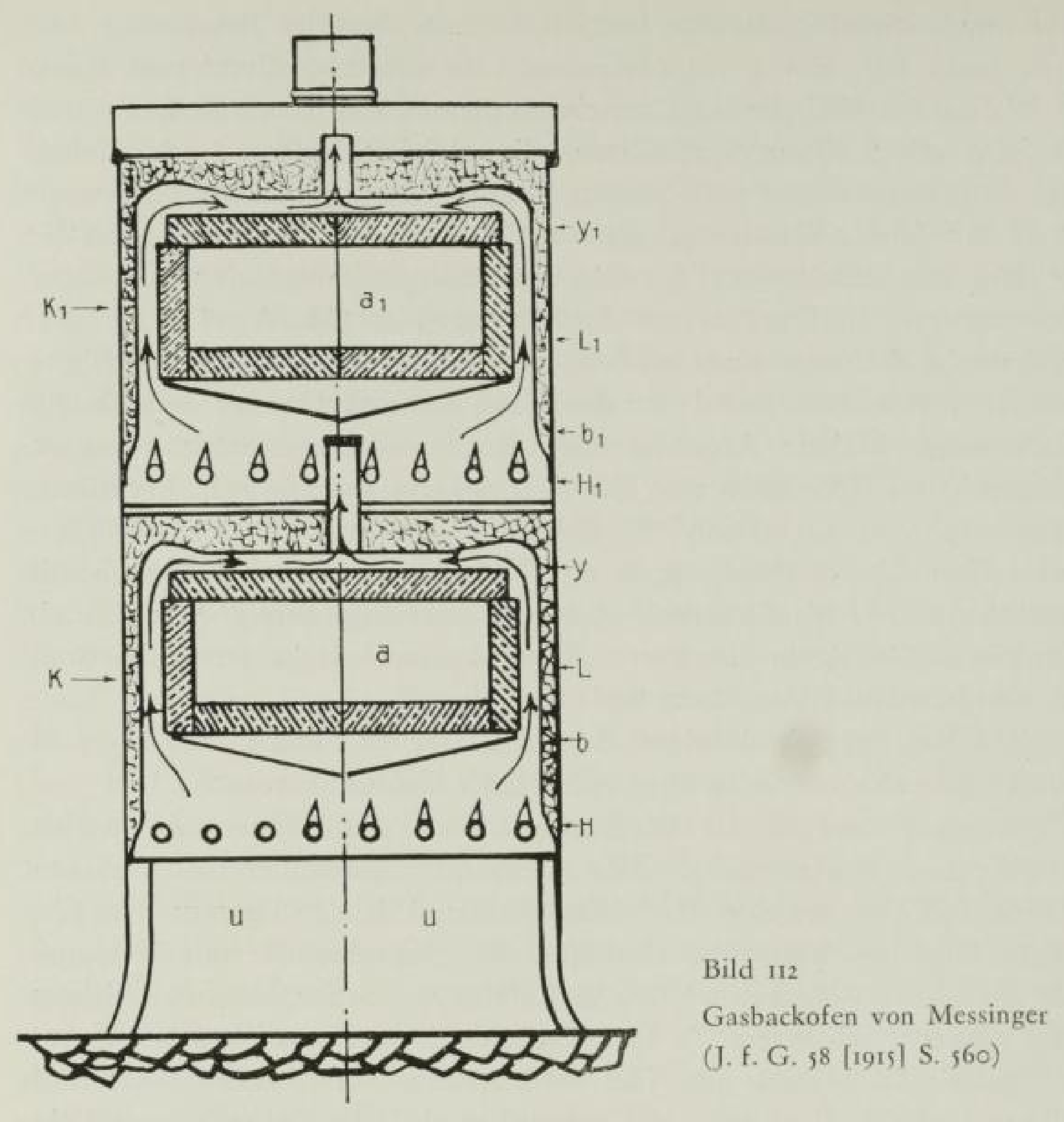

für Konditoreien geeignet war. Noch glaubte man an den Vorteil des Wärmeausgleichs durch die Steine und rüstete die Backöfen mit möglichst viel Steinen aus $\left.^{5,635}\right)$.

Der sorgfältigen Regelung des Gases als Wärmequelle insbesondere für Setzmaschinen widmete sich Dr. $F$ in k, Berlin. Sein Auté-Wärmeregler mit einem Dehnungskörper mit Hebelübertragung war sicher nicht billig und die gewährleistete Genauigkeit von 5\% auch für Schmelzkessel noch unzureichend. Der Thermoregulator von Warmbrunn, Quilitz \& Co., Berlin, benutzte ein Thermoelement. Seine Bauart bleibt aber unklar. Ein amerikanisches Modell mit Thermoelement nahm Prefluft als Hilfsenergie, benötigte auł̧erdem Wasserkühlung und Ölbad, war also reichlich verwickelt und teuer (500 M das Stück) ${ }^{5,650}$ ).

Dr. Fin $k$ bot auch einen Gasgemischregler mit drei durch Räder gekuppelten Ventilen an. Das alles waren Anfänge, die noch nicht zu durchgreifenden Erfolgen geführt haben und im Kriege vergessen wurden.

\footnotetext{
5.a5) Handbuch Bd. 8 S. 130 (s. 4.791)

5.6a5) $56(1913), 325$

$4 I 2$
} 
Die Gasmotoren gingen für den Jeuchtgasbetrieb sehr bald verloren. v. Oecbelbaeuser drückte sich in einem Rückblick auf seine Arbeiten ${ }^{5.037}$ ) so aus:

„Eine ganz wesentliche Herabsetzung der Preise war die unerläßliche Voraussetzung für den Betrieb von Grołgasmaschinen mit Steinkohlengas gewesen. Jetzt aber, nachdem das Steinkohlengas im Auerbrenner einen so vielfach höheren Lichteffekt abgab, stieg es aufzerordentlich im Werte, und es dachte niemand mehr daran, die Gaspreise für Kraftbetrieb, die ohnehin schon als Extrapreise auf Io bis $12 \mathrm{Pf} . / \mathrm{m}^{2}$ ermäßjigt waren, noch weiter herabzusetzen. Man hätte auf etwa s Pf. kommen müssen, um wirklich große Gasmaschinen rationell betreiben zu können."

Die Grołgasmaschinen blieben auf Gichtgase und zum Teil auf Kokereigasbetrieb beschränkt. Ihre Weiterentwicklung kann daher hier auf̧er Betracht bleiben. Es blieb also zunächst bei den Kleinmotoren für das Gewerbe, die E. Neuberg. Berlin, 1903 im Kampf mit Sauggas und Elektrizität in Größzen von 3 bis 8 PS bei 3000 Betriebsstunden im Jahre, bis ro PS nur bis $1500 \mathrm{~h} / \mathrm{J}$ ahr für wirtschaftlich hielt ${ }^{\text {s.ais }}$ ). Sie wurden aber bald durch den Elektromotor völlig verdrängt.

Der allgemeineren Einführung von Sauggas-Motoren bis etwa 150 PS $^{5,635}$ ) auf Kosten der Dampfmaschinenanlagen wurde Halt geboten durch die gleichzeitige schnelle Entwicklung der mit überhitztem Dampf arbeitenden Lokomobile ${ }^{5.509}$ ). Ihnen wurde auch der Dieselmotor ein ertolgreicher Wettbewerber. Diese Maschine verlangte indessen die Anteilnahme des Fachs, weil sie nach einigen Versuchen ein Teerverbraucher zu werden versprach, der gute Preise vertrug. Als sich bei den Vertikalretortenöfen ein besonders leichter Teer ergab, wies W. Allner. Dessau, schon 1909 auf den Dieselmotor hin $\left.{ }^{\text {5.6il }}\right)$. Versuche der Deutschen Continental-Gas-Gesellschaft bei Gebr. Körting, Hannover, ergaben ohne weiteres die Verwendbarkeit, nur muf̧te man mit der Vorwärmung, wie schon bei Verfeuerung von Vertikalretortenteer unter Dampfkesseln sich gezeigt hatte, recht vorsichtig zwischen 50 und $60^{\circ} \mathrm{C}$, am besten bei 57 bis $58^{\circ} \mathrm{C}$ verbleiben $^{5.065}$ ). (s. S. 371) Von Insterburg konnte 1920 berichtet werden, dafy dort im Wasserwerk ein Dieselmotor to Jahre lang mit Vertikalofenteer gelaufen war ${ }^{5.613}$ ). Zunächst hielt man nicht alle Teere für geeignet. F. G $\ddot{o} \mathrm{brum}$ bezeichnete nach seinen Erfahrungen auch den Betrieb mit normalen Teeren bei Maschinen bis 80 und 90 PS als durchaus betriebssicher. Er regte an, schon in den Gaswerken im Teer Treiböl und Pech zu trennen $\left.{ }^{5.3 u}\right)$. G. Tremus berichtete vom Wasser-

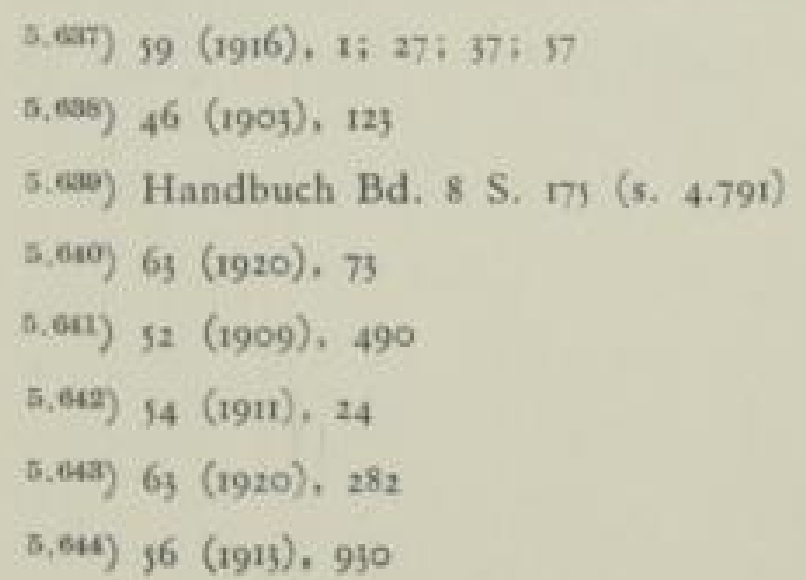


werk Lichtenberg, wie man einen Dieselmotor von 200 PS mit Gasöl warm werden lasse und dann mit Rohteer weiter betreibe.

Neue Hoffnungen schöpfte die Gasindustrie, als die den Automotoren nachgebauten schnellaufenden Kleinmotoren auf dem Markte erschienen ${ }^{5.65}$ ). Die Fafnierwerke in Aachen waren die ersten, die 1908 derartige Maschinen bauten, einzylindrige Maschinen von 0,5 bis I PS bis zu 5 bis 8 PS, - die kleinsten mit 600 bis 950 Umdrehungen, die grofen mit 450 bis $750^{5,640}$ ). Diese wie auch der Gnommotor dier Motorenfabrik Oberursel waren stehende Maschinen mit oben liegenden Zylinder. Körting und Deutz bauten liegende Motoren bis 6 PS mit etwa 300 Umdrehungen.

Aufsehen und Kopfschütteln erregte die vom Gasmotorenbauer A. Humphre y s entwickelte kolbenlose Explosionsgaspumpe, zumal sie mit Überexpansion (wie die atmosphärische Maschine Ottos ${ }^{8667}$ ) arbeitend im 'Zweitakt lief ${ }^{.407}$ ). Sie arbeitete aber durchaus wirtschaftlich und wurde von den Siemens Schuckert Werken in Lizenz gebaut.

Die Gasturbine wurde erörtert. 19II erfolgte die erste grołe Veröffentlichung durch H. Holzwartb bei Oldenbourg, ,als eine der sensationellsten Erscheinungen der technischen Literatur". Sie kam aber für Stadtgasbetrieb noch weniger in Betracht als die Motoren.

5.672 Luftschiffahrt

Im Laufe dieses Abschnittes kam das älteste Anwendungsgebiet des Kohlengases, das schon vor der französischen Revolution Minckelers und Lapostolle (vgl. I.3 S. 29 ff) zur Beschäftigung mit der Gaserzeugung gebracht hatte, zu einer unerwarteten neuen Blüte.

Ausgelöst war die Bewegung durch die Arbeiten des Grafen Z eppelin, gefördert aber durch militärische Stellen mit Versuchen von Lenkluftschiffen, Fesselballonen und Begünstigung der Freiballonfahrt. Zunächst benutzte das Militär Flaschenwasserstoff, dann aber ging es zum preiswerteren Stadtgas über. Die erste grof̧e Flugplatzanlage wurde auf dem Neubaugelände des Gaswerkes Tegel errichtet, wo die erste internationale Wettfahrt allein $25000 \mathrm{~m}^{3}$ Gas benötigte ${ }^{5.615}$ ). E. Winkert, Metz, regte ein das ganze Land überdeckendes Tanknetz für lenkbare Luftschiffe an ${ }^{5, r i p}$ ). Dr. Frank wollte technisch reinen Wasserstoff aus Wassergas mit Hilfe des Lindeschen Verflüssigungsverfahrens gewinnen. „In jeder Tageszeitung wurde über Versuche mit Luftschiffen berichtet. „Die Versuche der Aviatiker mit Aeroplanen dürften schon wegen des Kraftaufwandes nur mühsame und kurze Flüge eines einzelnen ermöglichen ${ }^{45.55}$ ). Man war also für einen grof̧en Absatz sehr optimisch gestimmt. Im Journal de l'éclairage au gaz 1908 S. 161 wurden folgende Absatzziffern für Luftfahrten festgehalten in

5.645) $52(1909), 87 \pi$

5.640) Handbuch Bd. 8 S. $186(5,+791)$

5.647) 53 (1910), 668/669; 54 (1911), $89 ; 349 ; 378$

5.448) so (1907), 31

5.

$5,650)$ ) $11 \quad(1908), 4^{8}$ 
$1000 \mathrm{~m}^{3}$ : Deutschland 496, Frankreich 49I, England 289, Belgien 207, Spanien 108, Italien 89, Vereinigte Staaten 70, Schweiz 33, Österreich-Ungarn 19, Schweden $\left.9^{5.651}\right)$. Das Gordon Bennet Wettfliegen mit Zeppelinbesuch in Zürich erforderte 1909 allein $79000 \mathrm{~m}^{3}$ Gas. Die Rohre wurden von der Industrie geliehen, die Einrichtung allein verschlang $35000 \mathrm{Mk}^{5,050}$ ). In Utrecht wurde in der Ölgasanlage von Rincker \& Wolter ein besonders wasserstoffreiches Gas mit einer Dichte von $s=0,33$ mit erhöhter Temperatur in einem der mit Schamotte gefütterten Generatoren durch Spaltung erzeugt $\left.{ }^{5,5 i 5}\right)$. Oecbelbaeuser lief in Dessau, Flugplatz beim Gaswerk, das in einer Retorte erzeugte Gas in einer zweiten mit Koks gefüllten Retorte spalten und erreichte mit 80,7 bis $\$ 4,1 \%$ Wasserstoffgehalt eine Dichte von 0,225 bis 0.3 . Er war im Begriff, eine eigene Anlage aufzubauen und die Gasbehälter zur Ortsbezeichnung für die Luftschiffe zu verwen$\operatorname{den}^{3,55}$ ). Eine Schwierigkeit war die Undichtheit der Retorten, da sich kein Graphit ausschied. Der Aufpreis des gespaltenen Gases betrug nur 2 bis 3 Pf./m? Alsbald aber waren für sportliche Zwecke die fast reinen Wasserstoff enthaltenden Abfallgase der Ätznatron- und Ätzkaliherstellung in Bitterfeld, Griesheim, Bernburg und Rheinfeiden beliebter $\left.{ }^{5, n 5}\right)$. Für Kriegszwecke wurden fahrbare Ölgasanlagen in Anlehnung an Rincker und Wolter entwickelt und von der Bamag gebaut ${ }^{\mathrm{s}, \text { ato }}$ ).

Sehr eingehend ist die ganze Technik im Handbuch der Gastechnik, R. Oldenbourg 1916 Bd. 8 S. $217 \mathrm{ff}$. (s. 4,79I) behandelt worden.

Das war also für das Gasfach eine schöne, aber schnell vertrocknende Blüte gewesen, an der man indessen die W'endigkeit des Faches bei neuen Aufgaben bewundern kann.

Der Gesamterfolg der fleif̧igen Arbeit der Gaswerke, Industrie- und Gewerbegas abzugeben, war vor 1914 keineswegs überwältigend. Auch das zeigt zusammenfassend das Handbuch der Gastechnik Bd. 8, das zwar 1916 erschien, aber ohne Frage den Stand von I9I4 richtig wiedergab.

Die geleistete Arbeit war aber keineswegs vergebens gewesen. Sie stellte eine gute, klärende Vorarbeit dar, auf der man ro Jahre später, als der Krieg langsam überwunden war, wieder aufbauen konnte.

Die Gaserzeugung belief sich 1914 insgesamt auf 2,3 Mia $\mathrm{m}^{3}$ pro $\left.\mathrm{Jahr}^{5 ., 557}\right)$. Die Thüringer Gasgesellschaft gab olgende Verteilung $a^{5,505}$ ) (Tafel 3).

Die Ausbeute betrug 1913 bei 87 Werken im Durchschnitt $324 \mathrm{~m}^{3} / \mathrm{t}$ gegen $295 \mathrm{~m}^{3} / \mathrm{t}$ 20 Jahre vorher ${ }^{5,650}$ ).

Die Gasabnehmerzahl von 80 Werken betrug 1913 16 \% der Einwohnerzahl. Der Kopfverbrauch war $189355 \mathrm{~m}^{3} / \mathrm{a}, 190376 \mathrm{~m} / \mathrm{a}$, 1913 105 mª, der Höchstwert eines Werkes $184 \mathrm{~m}^{3} / \mathrm{a}^{\mathrm{s} \text {.ecog. }}$.

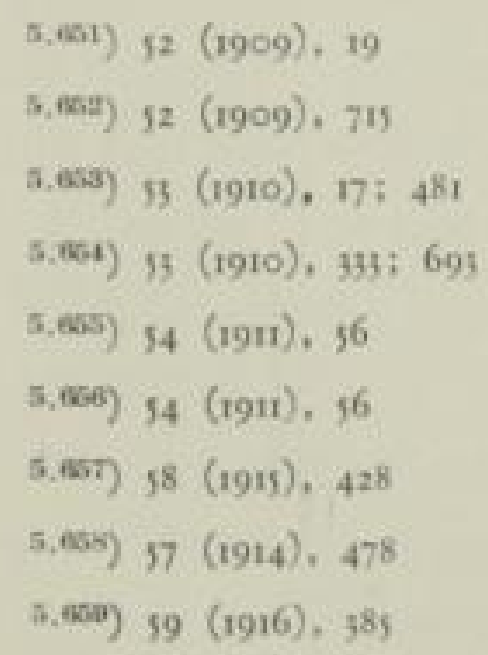


Tafel 3: Gasverteilung auf Verbrauchsgruppen in der Thüringer Gasgesellschaft.

Beleuchtung zu Spitzenpreisen

Motoren- und Kochgas

Münzgasmesser

mittlere Einheitspreise

Strafenbeleuchtung

Seibstverbrauch

Verluste

$$
\begin{array}{r}
27,75 \% \\
33,38 \% \\
8,82 \% \\
\text { II, } 26 \% \\
8,67 \% \\
1,96 \% \\
8,16 \% \\
\hline 100,00 \%
\end{array}
$$

Ausgestattet waren 100 erfaf̧te Werke mit

$$
\begin{aligned}
& \text { II } 042 \text { Horizontalen Retorten } \\
& 7710 \text { Schrägretorten } \\
& 5605 \text { Vertikalretorten } \\
& 728 \text { Kammern. }
\end{aligned}
$$

Eine mit freundlichem Humor gewürzte Rückschau auf die alten Zeiten mit persönlichen Erlebnissen brachte die Eröffnungsrede des Vorsitzenden E. Kör $r$ ting in der Jubiläumsversammlung des Deutschen Vereines r909. Sie ist auszugsweise als Anhang to beigefügt. Die Schaubilder dazu sind ohne Erläuterungen verständlich.

\section{SLUB}




\section{DIE ZEIT VOM KRIEGSAUSBRUCH I 9 I 4 BIS ZUM JAHRE I 926}

Den letzten Abschnitt der ersten Hundert Jahre Geschichte des deutschen Gasfachs zusammenzufassen, hat seinen guten Grund. Zwar war das, was man neuerdings als heiß̧en Krieg bezeichnet, mit dem Waffenstillstand 1918 und dem nachfolgenden Friedensschluł beendet, ein kalter Krieg dauerte aber noch viele Jahre an. Er ging gegen die deutsche Wirtschaft, und das hat das Gasfach härter getroffen als der heiłe Krieg. Erst als die Weltwirtschaft sich einer Übersättigung näherte, kam, wenn auch langsam und auch nie allgemein eine Einsicht, dał̧ eine verkrüppelte Wirtschaft inmitten Europas Absatzmöglichkeiten vernichtete, die man eigentlich, um den Weltfrieden zu sichern, pfleglich hätte behandeln müssen. Das Gasfach hat durch seinen tapferen Kampt um sein Dasein und danach um Fortschritte zu neuen ganz grof̧en Zielen als einer der Träger der lebensnotwendigen Energiewirtschaft einen ganz bedeutenden Beitrag geleistet, um eine ausgeglichene Weltwirtschaft wieder zu ermöglichen.

Mit groß̧en, ganz neuartigen und später für andere europäischen Ländern äuß̧erst anregenden Plänen und Arbeiten schloł es sein Jahrhundert im Jahre 1926 ab.

\section{I A LLGEMEINE GESCHICHTE}

Der Ausbruch des Krieges hatte zunächst eine lähmende Wirkung. Ursache war nicht das Gefühl für die Gefahren, obwohl einige Grenzbezirke im Elsał und vor allem in Ostpreufen den Einfall des Feindes erlebten. Das Vertrauen in die Kraft zur Verteidigung des Landes war vollkommen. Vielmehr gab es einen seelischen Schock, daf ein Krieg unter den so freimütig, freundschaftlich und im lebhaftesten Austausch lebenden Völkern überhaupt möglich war; man ahnte in Deutschland unbewuf3t, dał ein solcher Krieg allen Beteiligten Verluste bringen muf̧te. So gab es nur wenige Geschäftsleute, die daran dachten, dał die Erwerbsarbeit möglichst sofort weitergetrieben werden müfte, um denen, die zu Hause blieben, Arbeit und Brot zu geben und hernach die Quellen des Nachschubs an das kämpfende Heer zu erschließ̧en.

Wirtschaftlich organisatorisch war der Krieg von deutscher Seite keineswegs vorbereitet.

Die Gaswerke muf̧ten zwar ihren Betricb aufrechterhalten. Das ging auch trotz des Verlustes der zum Heere einrückenden Reservisten und Landsturmmänner, und obwohl die Eisenbahn während des Aufmarsches keinerlei Güter befördern 
konnte, recht gut. Rohstoffe, insbesondere Kohlen, waren infolge der vorher schlechten Konjunktur reichlich vorhanden. Auch der Vorrat an Rohstoffen für Glühkörper erwies sich als reichlich.

Die Kohlenförderung an der Ruhr ging auf 60 bis $65 \%$ des bisherigen zurück $\left.{ }^{6.1}\right)$. Dafür fielen aber die Miehrzahl an Exportverpflichtungen fort. Der Gasabsatz sank im ersten Kriegsjahr um $20 \%$. Die Verringerung der Arbeitskräfte und der Ausfall der exportierenden Firmen, allgemeines Sparen einschlief̧lich der öffentlichen Beleuchtung, Fortfall des Bedarfs von Gaststätten und Vergnügungsbetrieben brachten die Einbußje. Einen kleinen Ausgleich gab dagegen der Bedarf der Lazarette, neuer Truppenunterkünfte und Verpflegungsstellen.

Noch im Oktober 1914 glaubte W. v. Oecbelb a e u ser, in zwei bedeutsamen Ansprachen eine Mahnung aussprechen zu müssen, uns selbst so schnell wie möglich wirtschaftlich zu mobilisieren, namentiich in der Richtung einer Neuorientierung, da wo sie sich als notwendig ergäbe ${ }^{n .2}$ ).

Dabei zeigte es sich, dał der Ausbau der grołen Gaswerke mit Förderanlagen und Wassergasanlagen den Betrieb mit neueingestellten Hiltskräften leichter möglich machte, als bei den kleineren Werken. Von Gaspreiserhöhungen wurde trotz vermehrter Belegschaftsziffern zunächst abgesehen. Die ersten Kriegsmałnahmen waren: die Beseitigung veralteter Tarife, meist mit einer Verbilligung verbunden, die Aufstellung von Münzgaszählern dort, wo der kleine Abnehmer das Petroleumlicht ersetzen muf̧te, und ein Rückgriff auf das Handwerk, um die dabei üblichen Freiinstallationen ${ }^{0.3}$ ) auszuführen.

Erstaunlich sind fortwährende Absatzschwierigkeiten für den Koks ${ }^{a, 4}$ ). Im Bericht über das Jahr I9Is stellte der Deutsche Verein fest, daf3 die Gaswerke gut durchgekommen $\operatorname{seien}^{n .3}$ ). Die notwendigen Kohlenmengen waren geliefert worden, obwohl der Fortfall englischer Kohlen die Gasausbeute je Tonne in vielen Werken sinken lief und die Ersatzkohlen einen schlechteren Kok's ergaben. Die Preise der Kohlen waren zum Teil durch die längeren Frachtwege um 30 bis $60 \%$, vereinzelt um $100 \%$ gestiegen $\left.{ }^{6.6}\right)$. Ab Grube wurden sie 1917 in 2 Stufen um s $\mathrm{M}$ erhöht und noch mit $20 \%$ Steuer belegt $\left.{ }^{6.7}\right)$. Diese Steuer sollte nach dem Wunsche der Gesetzgeber auf die Abnehmer abgewälzt werden. Doch bereitete die Ausführung den Werken viel Verdruf, da die Nebenerzeugnisse teils preisgebunden waren, teils durch den freien Markt keine Erhöhung vertrugen (Koks). Nach langen Beratungen kam man dahin überein, allein das Gas zu belasten, schon um den unlohnenden Rechenaufwand der Verteilung auf die vielfachen Erzeugnisse zu vermeiden.

Viel unangenehmer war aber der im Winter 1916/1917 sich bemerkbar machende Kohlenmangel. Mit wenig Erfolg wurde verlangt, daf die Kokereien sich einschränken möchten. Diese behaupteten, dał sie gerade im Sommer die wertvollen

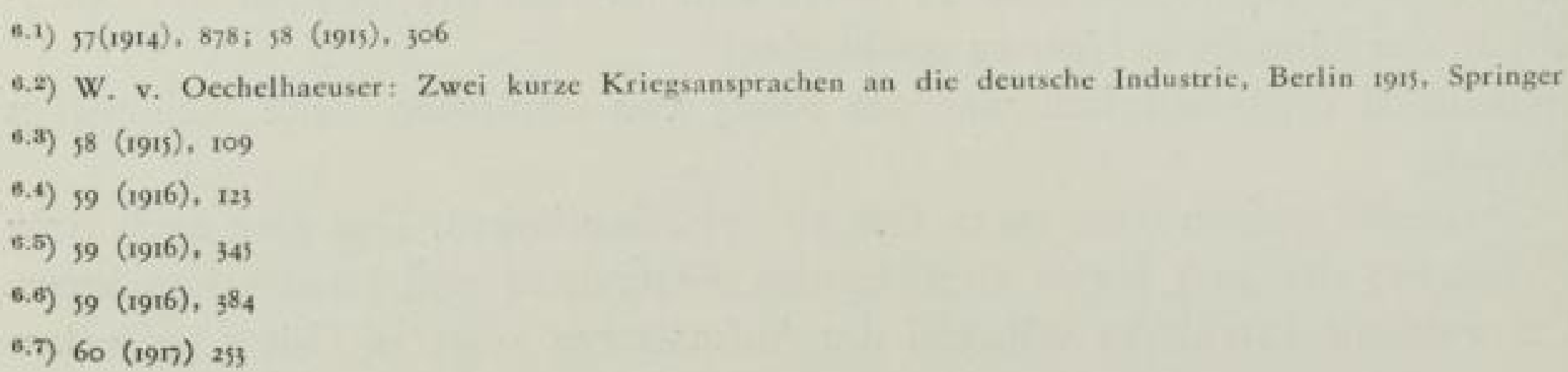


Nebenerzeugnisse gleichmäfjig hervorbrächten; die Gaswerke entgegneten, sie holten aber mehr aus dem Gase heraus ${ }^{4,5}$ ).

Angesichts der oft wechselnden Kohlensorten bewährten sich überraschender Weise die Schrägretorten noch am besten ${ }^{\text {s." }}$ ). Immerhin sank die Gaserzeugung je Retorte von Jan. $1914=360 \mathrm{~m}^{3}$ über Jan. $1915=337 \mathrm{~m}^{3}$ auf Jan. $1916=313 \mathrm{~m}^{3}$, so dafy die Werke versuchen muß̧ten, gute Gaskohlen trotz der Lagerverluste dieser Kohlenarten für Spitzenanforderungen in Bereitschaft zu halten. Wegen der Schwierigkeiten mit der Verarbeitung der Kohlen stieg die Ofenmannschaft eines grof̧en Werkes von 150 Arbeitern je $320000 \mathrm{~m}^{3}$ Tageserzeugung auf 223 Arbeiter je $330000 \mathrm{~m}^{3}$. Die Aufsicht über die neuen Arbeiter verlangte eine umfassende Organisation. Die Anleitung immer neuer Ersatzkräfte belastete die Werke. Wegen Stromunterbrechungen muften Dampfmaschinenreserven eingebaut werden.

Seit Juni 1915 stieg der Gasabsatz wegen des Ersatzes der Petroleumbeleuchtung stetig, in den ersten Monaten 1916 stärker und in denen des Jahres 1917 kam es zu einer Lieferungskatastrophe ${ }^{6,19}$ ) wegen der groł̧en Kälte bei Kohlenmangel. Man muf̧te sich über die notwendigen Mał̧nahmen bei Betriebsuntersuchungen verständigen und suchte mit Druckminderungen auszukommen ${ }^{\text {n.11)}}$ ). R. Ge i per t erprobte die Herstellung von Wassergas in Vertikal-Retorten aus Koks mit Dampf $\left.f^{(12}\right)$. Im Winter $1917 / 1918$ folgte dann die Kontingentierung des Gasabnehmers auf $80 \%$ des Vorjahres, wovon nur die kriegswichtigen Industrieabnehmer befreit wurden ${ }^{8,12}$ ).

Mochte auch England darüber triumphieren, weil dort in allen größeren Städten der Absatz bedeutend stieg ${ }^{\mathrm{a} .1}$ ), die verringerte Gasausbeute aus einer Tonne Kohlen konnte man auch dort nicht verhindern ${ }^{6.15}$ ) und Mitte 1918 gab es auch in England eine scharfe Rationierung von Heizung und Beleuchtung $\left.{ }^{4.10}\right)$. Viel schlimmer sah es in Frankreich und in Italien, das sich den Gegnern angeschlossen hatte, aus. Dort waren vor allem die Kohlenpreise mehr als verdoppelt ${ }^{6.17}$ ).

Der Heizwert des Gases war schon rors gesunken, die Gaspreise bei einzelnen kommunalen Werken heraufgesetzt, um den üblichen Gewinn zu erzielen, im allgemeinen aber suchte man, die alten Preise zu halten, bis die Kohlensteuer zur Erhöhung zwang. Nicht aber konnte man die ungieichmäfige Beschaffenheit des Gases vermeiden. Trotzdem war die Anschluf̧bewegung lebhaft. Der durchschnittliche Gasverbrauch je Abnehmer ging aber zurück, bei grofen Werken von 632 auf $505 \mathrm{~m}^{3}$ und bei kleinen von 579 auf $498 \mathrm{~m}^{3}$ noch vor der Kontingentierung. Es waren eben die „kleinen“, früheren Petroleumverbraucher hinzugekommen. Schon I9Is wurden mehr neue Gasmesser geliefert als im Frieden. Der Einheits-

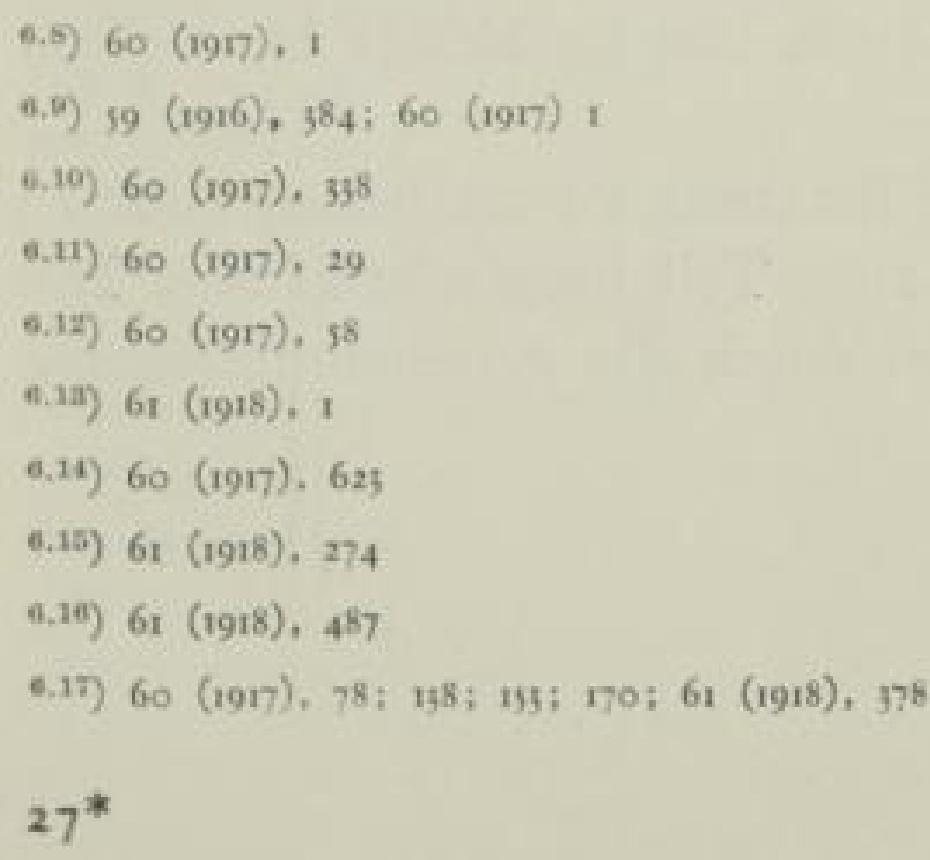


preis setzte sich schnell durch, berechtigt vom Gaswerksstandpunkt aus, nachdem der Kochgasabsatz den Leuchtgasverbrauch hinter sich lieł. Dabei wurden in sehr erwünschtem Maß̧e Gasmesser für neue Anschlüsse frei.

In den Werken wurden Anlagen für Konzentrieren von Ammoniakwasser, Teerdestillationen und Benzolgewinnung gebaut. Nürnberg widmete sich auch der Abwärmeausnutzung für Gemüsetrocknung und Futtermittel, während das Parlament in Breslau einen solchen Antrag ablehnte, weil Obst nicht genügend vorhanden $\left.\operatorname{sei}^{6,+15}\right)$.

Die aufkommenden Nöte sollten durch die behördliche Planwirtschaft gemindert werden. Für das Gasfach war der Reichskommissar für die Kohlenverteilung zuständig, der sich ais stellvertretenden Reichskommissar für Gas, K. Le mpel $u s$, verpflichtete. Trotz bevorzugter Einstufung, gleich nach der kriegswichtigen, vor allen anderen Industrien war die Belieferung der Gaswerke schwierig. Immerhin gelang es im Laufe des Jahres, wenn auch nur geringe Vorräte anzulegen unter Einhaltung des Kontingentes, das auch für die Elektrizität später eingeführt wurde. Besonders M. Hase, als Vorsitzender des Vereins und E. Körting verhandelten wiederholt beim Minister persönlich und muften den guten Willen der Behörden anerkennen.

Als dann das Kriegsende mit den erschütternden Waffenstilistandsbedingungen kam, regten sich die führenden Fachleute gleich im Sinne des Wiederaufbaus. Es gälte nun, neue Gaswerksinstallateure anzulernen, die verwahrlosten Kochgeräte wieder herzurichten und den Arbeitsmarkt gleich zu beleben. Mit Aufträgen zum Etsatz verschlissener Werkseinrichtungen an die freie Industrie solle man nicht zurückhalten. Auch die Reichsstelle Gas rügte, dał die städtischen Verwaltungen mehr als andere Bestellungen unterlief̧en ${ }^{6.11}$ ).

Aber das war ein ungerechtfertigter Optimismus. So einfach sollte der Wiederanfang des Friedens nicht werden. Die erste Bilanz auf den das Gasfach berührenden Gebieten war erschreckend. Die Kohlengrundlage war durch Verlust von Saar und Oberschlesien um 35\% vermindert. An die Sieger sollten to Mio t Kohlen im Jahre 1919 mehr abgeliefert werden, als im Jahre 1913 ausgeführt waren. Deutliche Zeichen lagen vor, dał England als Sieger wieder grof̧e Kohlenlieferungen gegen Bezahlung haben wollte".20). Fortgenommen wurden aus dem Bestand der verschlissenen Lokomotiven und Wagen sooo der brauchbaren Lokomotiven und 24000 der besten Wagen. So fehlten gleich täglich 6000 Wagen in der Gestellung. Täglich muß̧ten 1300 Wagen Kohlen-Lieferungen an die Entente fahren, die noch dazu besonders hergerichtet verlangt wurden. Daraus allein fehlten weitere 5200 Wagen. Von einer im Ruhrrevier angefordeten Wagenzahl von If bis 20000 täglich, konnten kaum 9 bis 1 \% 000 rechtzeitig gestellt werden. So wurde die Kohlennot organisiert, die die Not im Kriege bei weitem übertreffen sollte.

Wichtig war es auch, eine klare innenpolitische Richtung zu erarbeiten oder zu erstreiten. Der Vorstellungen waren gar viele, zum Teil utopische Ideale. Die Energiewirtschaft wurde jedenfalls recht wirksam durch die Auseinandersetzung

\footnotetext{
(6.35) $61(1918), 592$

7.19) 61 (1918), 592

(b.20) $62(1919), 325$ 
über die Sozialisierung des Kohlenhandels gestört $\left.{ }^{\mathrm{a}, 21}\right)$. Selbstverständlich sollten nach vieler Leute Meinung zunächst schnell die privaten Gaswerke sozialisiert werden $^{6 *}$ ). Streiks in den Kohlenrevieren und bei den Eisenbahnen brachten cine trostlose Kohlenlage hervor, so daf̧ schon im Sommer rorg Störungen in der Versorgung eintraten. Sperrstunden wurden in is Städten notwendig; Einstellung des Betriebes in 9 Städten, besondere Maf̧nahmen in 6 Städten $^{6.27}$ ).

So wurde dann zunächst einmal das Kohlenwirtschaftsgesctz aus dem Boden gestampft. Am 23. März 1919 wurde der Zusammenschluf der Kohlenerzeuger vom Reichswirtschaftsministerium bis zum 30. Juni befohlen ${ }^{6.24}$ ), mit Zwangssyndikaten der Erzeuger, Händler und Verbraucher, wozu das Gasfach seine Wirtschaftliche Vereinigung als brauchbare Grundlage zur Verfügung stellen konnte ${ }^{6,25}$ ). Im Reichskohlenrat und Sachverständigenrat hatte man aber die Gaswerke als Grołabnehmer und Kokslieferer zunächst vergessen ${ }^{1.25}$ ). Aber auch mit Räten ohne eingeordnete Machtbefugnisse war die Lösung noch nicht gefunden. Der Kohlenmangel war eben schlimmer als selbst im Kriege. Vergebens verlangten die Gaswerke eine Einschränkung bei den Zechen, wo der Koks sich häufte ${ }^{0.27}$ ).

Aber die Kohlen, die städtische Elektrizitätswerke erhielten, waren oft genug bessere Gaskohlen, als sie den Gaswerken geliefert wurden. „Daf es sich nicht um Zufälligkeiten handelt, beweist, dał̧ die Ursprungsangaben der Kohlen systematisch verwischt wurden ${ }^{(40.25)}$. So spricht aus den Äufzerungen der Gaswerke eine Erbitterung, die verständlich, aber der Sache nicht förderlich war.

Die Zukunft zu Beginn des Jahres war düster. Der Leitartikel des Journals für Gasbeleuchtung verwies auf den Kohlenmangel nach dem Kriege 1870. Er sagte dann weiter: „1875 aber schon war das Kohlenangebot größer als die Nachfrage. Eine derartige $W$ andlung dürfen wir nach diesem Kriege nicht erwarten, wenn wir nicht mit Wundern rechnen wollen ${ }^{(4, n)}$ ). Und doch war, wenigstens auf dem Weltmarkt dieses Wunder nach wenigen Monaten bereits eingetreten. Obwohl bei dem Preisverhältnis von Kohle zu Koks, wie es seit 1917 bestand, die Wassergasherstellung unwirtschaftlich war, muften die vorhandenen 120 Wassergasanlagen mit 2 Mio $\mathrm{m}^{2}$ Leistungsfähigkeit voll eingesetzt werden. Die Benzolauswaschung wurde eingestellt. Trotzdem kamen auch groß̧e Werke wie Altona und Halle/Saale zum Erliegen ${ }^{n .39}$ ). Bemühungen um Mehrförderung der Bergarbeiter, 51000 Mann Neueinstellungen, Aufnahme des Baues von Bergarbeiterwohnungen trafen auf die Gegenforderung nach der 6 Stunden-Schicht $\left.{ }^{\text {n.th }}\right)$. Die Frankfurter Gas Gesellschaft versuchte nach Art einer Genossenschaft, wie in Konsumvereinen, die Arbeiter über das Kapital am Gewinn zu beteiligen und die sozia- 
len Wünsche zu befriedigen. Der Betriebsrat nahm auch an. Aber die Belegschaftsversammlung lehnte unter dem Druck der Gewerkschaften ,aus Prinzip, eine Einzelsozialisierung $\left.{ }^{\prime \prime}, a^{6,07 z}\right)$.

Zu den Transportschwierigkeiten auf der Reichsbahn kam noch hinzu, daf selbst der Vater Rhein unzuverlässig wurde. Auch die Rheinflotte war ja durch „Entnahmen" geschwächt, entscheidend waren aber die ungewöhnlichen W/asserstände, erst zu niedrig, dann zu hoch, in der Zwischenzeit restlose Inanspruchnahme für die rückständigen Lieferungen nach Frankreich und zum Schluł Eisenbahnerstreik an der Ruhr. So lagen 1920 in Süddeutschland mittlere und kleine Werke lange Zeit still ${ }^{0,50}$ ).

Die Schieferentgasung in Württemberg ${ }^{0.34}$ ), Hoiz- und Torfentgasung in Celle ${ }^{0.55}$ ) waren nur örtliche Notbehelfe. Um die Mitte des Jahres war selbst ein fast berüchtigter Optimist über die Möglichkeiten der Gasverwendung wie Fr. $S c b \ddot{a}$ fer völlig mutlos. Er begründete das nicht nur mit der Kohlenlage, sondern auch mit dem vorschnellen Verschleif der Einrichtungen, den Unfallhäufungen und dem Verlust der häuslichen Beleuchtung als Folge der Sperrstunden. Münzgasmesser wurden bei sich stetig ändernden Preisen unbenutzbar, ja Ärgernis erregend. Aber auch die Zeit des Kraftgases sei vorüber. Ja, selbst die Straf̧enbeleuchtung sei gefährdet, da die Stromarbeitspreise weniger gestiegen wären

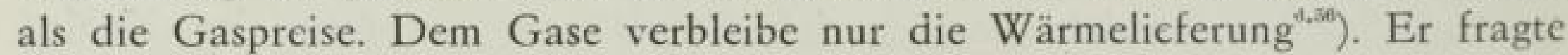
nach all dem enttäuscht: „Ob das etwa soziale Errungenschaften“ seien?

Im Herbst 1920 machten sich die ersten Anzeichen bemerkbar, daf3 die Weltkohlenförderung den Ansprüchen nachkam. Im Dezember war der Kohlenmarkt auf̧erhalb Deutschlands übersättigt ${ }^{6.37}$ ). Nordamerika unterbot England frei europäischem Hafen, nachdem die Frachten von 35 auf 8,5 Dollar/t gesunken waren $\left.^{6.35}\right)$. Frankreich verzichtete auf die englischen Lieferungen aus dem kurz vorher dringlich gewünschten Abkommen, womit auch in England die Läger sich füllten. Die deutschen Gaswerke hofften, dał nunmehr auch die deutsche Lage erleichtert würde. Aber trotz aller Vorstellungen erhöhte die Reparationskommission die monatlichen Anforderungen von 2 auf 2,2 Mio $t^{\text {tas }}$ ). Frankreichs Läger waren überfüllt. Die eigene Förderung wurde gefährdet. In der von ihm bewirtschafteten Saar muften Feierschichten, 2 Tage im Monat, eingelegt werden. Trotzdem durfte die Saar aber nicht nach Süddeutschland liefern.

In Deutschland muf̧te die Umstellung auf Braunkohle, wo immer sie angängig war, fortgesetzt werden, zumal deren Förderung erhöht werden konnte. Der Gaskoksmarkt stockte zeitweilig trotz der geringen erzeugten Mengen. In England muf̧te die Gas Light and Coke Co. die Gaspreise von 4 Sh. 8 d auf 5 Sh. 6 d (1000 cu. ft.) erhöhen, weıl der Kontinent keine ausreichenden Kokspreise mehr zahlte $\left.{ }^{\text {e.40 }}\right)$.

\footnotetext{
ब.32) 63 (1920), 50

6.33) 63 (1920), 99

6.34) 63 (1920), 133

6.35) 63 (1920), 817

6.36) 63 (1920), 509

6.37) 63 (1920) 814

6.35) 64 (1921), 124

อ.งอ) 64 (1921), 44

6.40) 64 (1921), 160
}

422 
Frankreich verkaufte Reparationskohlen unter Weltmarktpreis nach Holland und Belgien, wo nun für eigene Kohlen ein Preisabschlag von $10 \%$ und eine Lohnsenkung um $5 \%$ nötig wurde $\left.{ }^{6 . t 1}\right)$. Trotzdem mufzte Belgien zur 4 -Tage-Woche im Bergbau übergehen.

In Oberschlesien kam es aus politischen Gründen zu Bergarbeiterunruhen. Die Förderung versagte. Aber auch dort erhöhte die Entente ihre Forderungen. Deutsche Abnehmer konnten selbst im Rahmen der Kontingente nicht mehr voll beliefert werden.

Der Kohlenumschlag wurde nach militärischer Besetzung der Rheinhäfen wegen steigender Qualitätsforderungen und Zurückweisungen erschwert, wobei ein „Spazierenfahren“ der knappen Eisenbahnwagen erreicht wurde ${ }^{6.49}$ ).

Der Vorstandsbericht des Vereins fafte das Geschehen dahin zusammen: „Es geht nicht mehr um die Kohle, sondern um das Kohlenrevier ${ }^{\text {(6i.t3 }}$ ). Im Winter wurde die Kohlenlage wieder ganz hoffnungslos. Die Gaswerke hatten auch mehrere Streiks auszustehen ${ }^{\text {s.t }}$ ), deten letzter grofer in Berlin aber zu einem Tarifmantelvertrag zu „vernünftıgen Bedingungen“ (insbesondere hinsichtlich Schichtzeit, Arbeitsdauer, Ferien u. s. w.) führte. Die Belegschaften setzten sich von den Gewerkschaftsforderungen $\left.a b^{a, 45}\right)$. Es begann ein erfreuliches gegenseitiges Verständnis von Werksleitung und Belegschaft für das gemeinsame Ziel und eine Hand-in-Hand-Arbeit. Die Belegschaftsziffern eines grofen Werkes waren bei etwas verminderter Gaserzeugung von 1100 Arbeitern 1914 auf 2000 1921 gestiegen. Der Lohnanteil am Kubikmeter Gas betrug $191317,4 \%$, $192126 \%$, dabei war schon der Zuwachs der Arbeiterzahl nach dem erwähnten Streik um $50 \%$ vermindert worden $\left.{ }^{n, 4}\right)$. Neue Störungen in der Kohlengewinnung brachte die Abwerbung von Berg- und Hüttenarbeitern nach Lothringen in das Frankenwährungsgebiet ${ }^{0.47}$ ) und vor allem in Oberschlesien die neue Grenzziehung, durch die der Wagenumlauf der Eisenbahn stockte $\left.{ }^{0,45}\right)$. Kohle war so knapp, daf oft der gesamte Koks zu Wassergas verarbeitet werden mufte $\left.{ }^{\text {a.tit }}\right)$. Das ergab natürlich wirklich schlechtes Gas mit verheerenden Verlusten in der Gasbeleuchtung, die niemals wieder eingebracht werden konnten. Englische Kohlen wurden eingeführt, bis die Devisenlage ein Ende machte - im Juni 1922 I,3 Mio t gegen vor dem Kriege $700000 \mathrm{t}$ im Höchstfalle ${ }^{0.30}$ ). In einer langen Sitzung des Reichskohlenrates wurde geäuß̧ert, dał die Bergarbeiter bereit wären, mit Überschichten zu arbeiten, wenn das nicht zwecklos wäre, da ein Mehrertrag nur gesteigerte Forderungen der Entente bringen würde $\left.{ }^{6.51}\right)$. Die Gaswerke sollten nur noch $60 \%$ des bereits auf $2 / 3$ des Bedarfs eingeschränkten Kontingents erhalten. So faßte

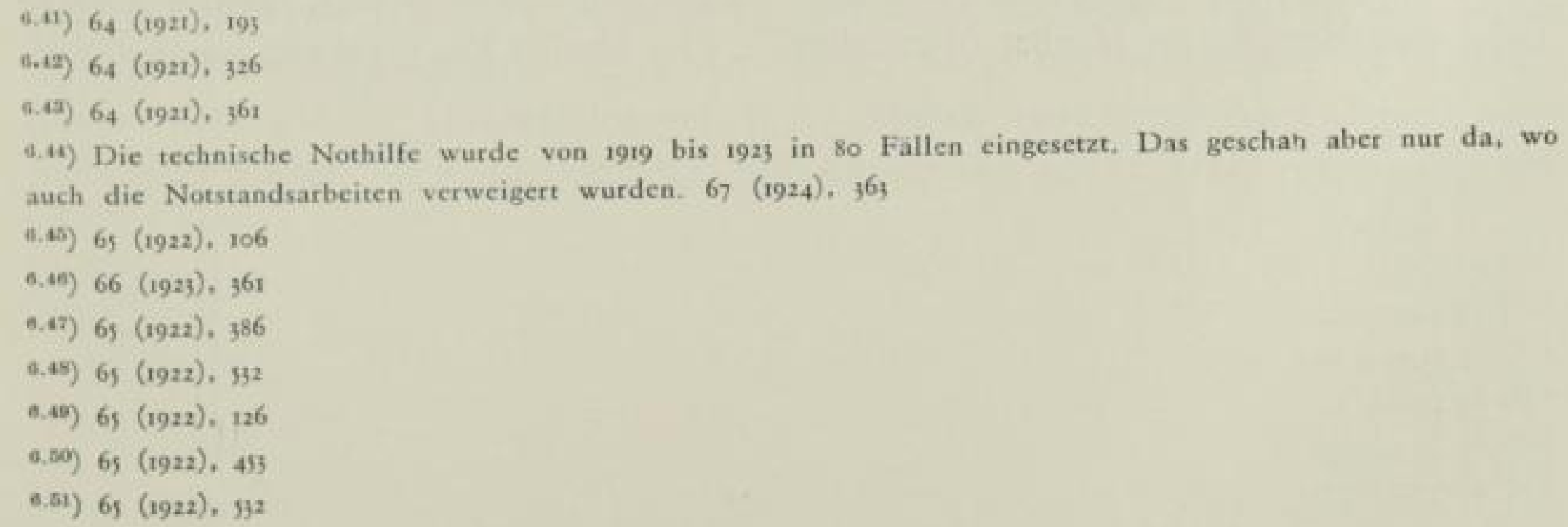


Reichskohlenrat und Ruhrkohlenverband einen Entschluf: „Der R.K.R. und R.K. Verb. halten das von der Reparationskommission für die Monate August bis Oktober 1922 neu festgestellte Lieferungsprogramm an Reparationskohle für unvereinbar mit der Kohlenlage...... Aus allen diesen Gründen erachten der R.K.R. und R.K.V. das neue Programm für unerfüllbar und erwarten seine Ablehnung durch die Reichsregierung $\left.{ }^{6.32}\right)$. Diese aber suchte immer noch, den Anforderungen nachzukommen. Zum Ende des Jahres wurde eine Fehlmenge von etwa $10 \%$ festgestellt und am II. Januar 1923 erfolgte der kriegerische Einmarsch in das Ruhrrevier ${ }^{0.53}$ ).

Der Erfolg war zunächst anders, als sich die Urheber gedacht hatten. Kohlen flossen, da die Reparationslieferungen fortfielen, reichlich ins unbesetzte Deutschland $\left.^{(4,5 i}\right)$. Der Koksmarkt war schwach $\left.{ }^{a,{ }^{*}}\right)$. Die Förderung ging im Januar/ Februar auf $3 / 4$ des Durchschnitts im Vorjahre, im Mai auf $1 / 4$ zurück. In Frankreich kam es zu Kohlen- und Koksmangel mit Stillegung von Hochöfen, da an der Saar und in Lothringen gestreikt wurde. Im ganzen Jahre 1923 erhielt Frankreich mit seinen Zwangsmałnahmen 3,7 Mio $t$ Kohle gegen I92I von 8,5 Mio $t$ und dem Soll von 1922 von etwa 25 Mio t. Frankreich führte aus England 1923 18,5 Mio t ein gegen 6,r Mio t 192I. Auch die Frankenwährung sank bedeutend. Nach Deutschland wurden dann Kohlen aus Nordamerika und England reichlich eingeführt, bis die Währung ins Uferlose absank.

Der Verlauf der Inflation mit den folgenden Preisangleichungen, der Versuch mit Goldmark zu rechnen und über Papiermark zu zahlen, kann unmöglich im einzelnen geschildert werden. Dał̧ die Gaswerke überhaupt im Zahlungsverkehr durchkamen, verdankten sie dem Eingreifen der Wirtschaftlichen Vereinigung, die sich der üblich gewordenen Kreditschöpfungsmethoden bei der Reichsbank bedienen konnte.

Auf der aus dem Sommer verschobenen Hauptversammlung des Deutschen Vereins im September 1923 stand man vor dem Trümmerhaufen nach Abbruch des Widerstandes an der Ruhr. Es war der Höhepunkt der Schwierigkeiten, viel schlimmerer Art als während des Krieges $\left.{ }^{6.50}\right)$.

Das Wiederanlaufen an der Ruhr war sehr schwer, obwohl der Arbeitswille überall gut war. Während sich in England eine deutliche Belebung des Geschäftsverkehrs zeigte, herrschte in Deutschland Arbeitslosigkeit: I,5 Mio Arbeitslose $=27 \%$ der Kräfte und 2,8 Mio Kurzarbeiter $={ }_{42} \% 0^{6,577}$ ). Der Rahmenvertrag der Micum (Mission interallié de controle des usines et de mines) mit führenden Ruhrindustriellen war ein verzweifelter Versuch zum wirtschaftlichen Wiederanlauf ${ }^{6,55}$ ). Die noch im Besitze der rheinischen Bahnen befindliche "Regie" kam mit der Wagengestellung nicht zurecht ${ }^{t . s i}$ ). Das wurde erst besser, als die Reichsbahn den Betrieb im Herbst übernahm ${ }^{n}$ ). Die Preise für Gaskoks, nach Gold-

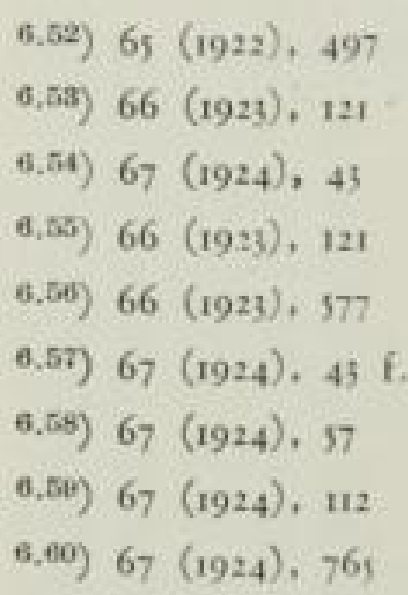


währung umgerechnet, erwiesen sich - wie übrigens bei vielen anderen Waren als höher als die Auslandspreise, so dał der Koks nur schlecht abgesetzt, keinesfalls exportiert werden konnte $\left.{ }^{\text {e. at }}\right)$. Auch der Kohlenabsatz an der Ruhr stockte. Eine gewisse Belebung der Industrie brachten im Anfang 1925 ausländische Kredite. Um die Mitte des Jahres versteifte sich die Lage, schon kamen auch wieder Streikstörungen vor. Im zweiten Halbjahr wurde die Handelsbilanz passiv, was bei dem schwachen Währungsfundament natürlich erneute Sorgen brachte. Konkurse wurden als Reinigung von unsoliden Inflationsgründungen betrachtet ${ }^{6.02}$ ). In die Jahre 1924 und 1925 fallen aber viele Anregungen und Ausbauten für Gruppengaswerke, als größtes Projekt wohl die Großggeserei Magdeburg mit mitteldeutschem Ferngasnetz. Die Gaswerks-Ofenbauarten unterlagen strenger Kritik bei der Vorbereitung von Neubauten. Mit lebhafter Klein- und Feinarbeit wurde die Technik der Gasheizung verbessert. Die Werbung kam wieder in Gang.

Auf der Hauptversammlung des deutschen Vereins in Danzig sprach zur Nedden als Vertrer des Reichskohlenkommissars über „die Gaswirtschaft als Teii der Energiewirtschaft". Er fafte zusammen, was damals das Fach bewegte: Die elastische Koks- und Ol-(Benzol-)erzeugung, die Verbreiterung der Kohlengrundlage und Verbesserung des Kokses durch Mahlen und Mischen; restlose Vergasung und Verwertung der kleinstückigen Koksteile; Verbund der Gaswerke mit Elektrizitätswerken und Hydrierwerken; zusammengefałte Erzeugung und Fernversorgung. B. $L u d$ wig. München, trug nach einer Reise nach Nordamerika Pläne für eine straffere Organisation des Faches im Deutschen Verein vor. Diese hatten zunächst die Wirkung, dał anwesende Hersteller den festen Zusammenschluł der Firmen für die Bearbeitung technischer Aufgaben - unter Ausschluf der üblichen Verbandsaufgaben: Preis-, Rabatt- und Gewährleistungsabreden zu gründen beschlossen ".*at).

Der zukunftsfreudigen Stimmung kam ein besonderer Umstand zugute, der die Hoffnungen leicht in Erfüllung gehen lieł. In England war es nach langem Hin und Her zu einem Streik um die Grundlagen des Kohlenbergbaus gekommen. Dieser dauerte vom I. Mai bis in den November ${ }^{0.04}$ ). Langsam konnten die Läger an Kohlen dann auch an Koks an der Ruhr geräumt werden; Gaskoks folgte. Die Förderung stieg gewaltig $\left.{ }^{4,3}\right)$. Als man im Herbst von einer Wagenknappheit sprach, hatte die Ruhr 33000 Wagen angefordert und 32000 erhalten, Zahlen, wie sie bis dahin noch nicht annähernd erreicht worden waren. Für Oberschlesien, das immer noch an der Zerstückelung litt, mufte ein Ausfuhrverbot erlassen werden, das sich an der Ruhr aber vermeiden lief.

Erfreulicherweise trat eine Beruhigung schon im September ein, als die Hoffnungen auf Beilegung des englischen Streiks stiegen. Übertriebene Angstkäufe hörten auf. Die im Höchstfalle auf 35277 Wagen gestiegene Anforderung ging auf 33000 zurück $\left.^{6,00}\right)$. Natürlich hatte der Abstof der Läger gegen gutes Geld zur

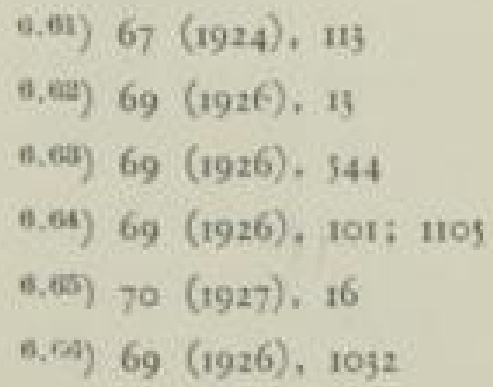


Abdeckung von drückenden Verbindlichkeiten geführt. Die allgemeine Geschäftslage besserte sich durch die neue Durchblutung. Das Gasfach wurde mitgerissen. I925 waren schon 3,2 Mia ${ }^{3}$ Gas in den Werken abgesetzt gegen 2,8 Mia (einschlieflich Ferngas) im Frieden ${ }^{0.67}$ ).

Die Gaswerke rangen nach 1924 anfangs vergeblich um die Güte der Kohlen, wie sie vor dem Kriege geliefert wurden. Nach einigen Erwägungen im Verein machte K. Bunte einen Vorstof in der Deutschen Bergwerkszeitung, indem er auf die Nachteile eines zu grof̧en Aschengehaltes für die Frachten, besonders aber für die Entgasung hinwies $\left.{ }^{0.09}\right)$. Mehrere Berichte zeigten, dał die englischen Gaswerke gleiche Sorgen hatten. Im Jahresbericht für 1925 muf̧te der Vorstand des Vereins berichten, daf̧ ein Versuch, eine Gütegewähr im Handel zu erreichen, vom Syndikat abgelehnt worden sei. Dieses verlangte vielmehr einen willkürlichen Austausch von ihm für gleich erachteter Kohlensorten ${ }^{6.09}$ ). Ein langer Streit zwischen R. Kat $t w i n k e l$ und $B a ̈ b r$ wegen Untersuchung und Bewertung von Kohlen entbrannte ${ }^{6.50}$. Aus Dänemark kam eine Zuschrift, dał der Dänische Verein eine Kohlenkontrolle durchgeführt habe und von England eine Gewährleistung für Asche, Wasser und Flüchtiges erhalte. Die Deutschen möchten auch bei ihrem Syndikat das gleiche durchsetzen $\left.{ }^{6.71}\right)$. Als dann E. Kö r t in $g$ durch eine Zuschrift an eine Kohlenzeitung in England auf seine Lieferanten einen Druck ausüben wollte unter Hinweis auf die Ferngasabsichten der Kohlenverwertungsgesellschaft, wurde er in der Deutschen Bergwerkszeitung als wirtschaftlicher Landesverräter angeprangert ${ }^{6.7 z}$ ). Dabei handelte es sich lediglich um einen Bruchteil der in Berlin verbrauchten Kohlenmenge, und es war wesentlich, überhaupt erst einmal von einem Lieferanten grundsätzlich das Zugeständnis der Abnahmekontrolle zu erhalten. Die Auseinandersetzung mit den deutschen Zechen schien also aussichtslos zu sein.

Allerdings traten neuartige grofe Sorgen an die Gasfachingenieure heran. Die eigene Freude, mit den Rohrnetzen in die Vorstädte und in das Land zu gehen und Gruppenversorgungen zu errichten, führte zu grołjen Plänen zusammengefafter Gasversorgungen. In Sachsen kam eine Druckschrift der „Landesstelle für Gemeinwirtschaft" an die Regierung heraus, die vorschlug, vom Staat aus das ganze Land planmäßjig und gleichmäßjig zu versorgen ${ }^{n, 7 z}$ ), die also nichts weniger als die Verstaatlichung der Gasindustrie als Endziel hatte.

Noch mehr Aufregung bereitete den für die örtliche Gaserzeugung Verantwortlichen die Gründung der Aktiengesellschaft für Kohlenverwertung ${ }^{6.74}$ ). (vgl. Abschnitt 6.31 S. 654 f). Die Tagespresse war nicht gerade glücklich mit der Darstellung der Endziele. Erst nach vielen Kämpfen wurde es klar, daß̧ eine Entwicklung begonnen hatte, die gar nicht aufhaltbar war und schlieflich auch den örtlichen Gaswerken zugute kam.

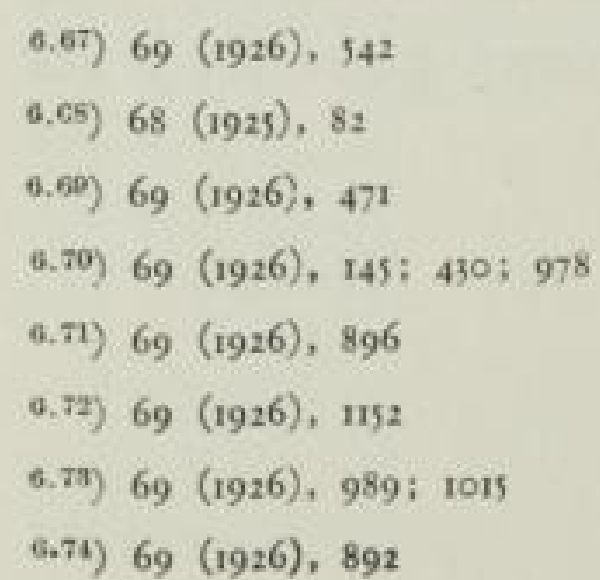


Die Ferngasversorgung in Deutschland, insbesondere die Ruhrgasgesellschaft wurde anderen Ländern zum Vorbild. Zum 100. Geburtstag der Gasindustrie in Deutschland hatte eine neue, ganz ins Grof̧e gehende Entwicklung ihren Anfang genommen.

6.II Organisationdes Facbes

Die im vorigen Abschnitt in groß̧en Zügen besprochenen starken Wandlungen in den Voraussetzungen zur wirtschaftlichen Arbeit verlangten eine Wendigkeit in der Organisation, die rückschauend gerade bei den vielen kommunalen Betrieben Staunen erregen muł.

Die Zentrale für Gasverwertung konnte sich während des Krieges ihren Werbeaufgaben nur in beschränktem Maß̧e widmen. Sie war aber gemäß dem $\int 2 \mathrm{e}$ ihrer Satzungen und durch die Persönlichkeit ihres Direktors K. Le mpelius zum Mittler ziwischen den lenkenden Behörden und dem Fach geworden $\left.{ }^{6.25}\right)$. Das wurde noch wichtiger in den dem Kriege folgenden Jahren. Deshalb nahm sie auch in ihren geschäftsführenden Ausschuf Vertreter des Ferngasbezuges ( $B$ olsto $r f$, Essen) und der Zechen (A. Pott, Essen) auf.

Erst nach der Stabilisierung der Währung kam die Werbetätigkeit wieder richtig in Gang. Da aber als eingetragener Verein die Zentrale geschäftlich behindert war, so wurde getrennt der „Gasverbrauch, G.m.b.H.“ zur Fertigung und zum Vertrieb von Werbedrucksachen gegrundet ${ }^{6070}$ ).

Die Fülle von Schwierigkeiten, die durch den Krieg und die Zerstörung der Geldwerte entstanden, muß̧te die Wirtschaftliche Vereinigung deutscher Gaswerke auffangen, die kaufmännisch aufgezogen, heute kaum verständliche Lösungen für finanzielle Notlagen gefunden hat. 1916 trat sie der Ammoniakverkaufsvereinigung bei, deren 70 Mitglieder deutsche Zechen waren ${ }^{6.77}$ ) und die seit I895 arbeitete. Die kriegswirtschaftliche Verteilung des wichtigen Ammoniaks wurde dadurch erleichtert $\left.{ }^{0.76}\right)$.

Schon 1918 regte Lempelius an, die Wirtschaftliche Vereinigung freiwillig zu einem Reichs-Gaskokssyndikat gemäf3 dem Reichskohlengesetz umzubilden ${ }^{6.70}$ ). Das Syndikat wurde aber am 27. Sept. 1919 getrennt von der Wirtschaftlichen Vereinigung gegründet $\left.{ }^{6.50}\right)$. 860 Werke hätten wegen ihrer Größe beitreten müssen, aber nur 643 mit allerdings $91 \%$ des Kohlenverbrauchs taten das freiwil$\left.\operatorname{lig}^{n}{ }^{87}\right)$. $192 \mathrm{I}$ wurde dann das Gaskokssyndikat zum Zwangskartell erklärt ${ }^{0.68}$ ).

Als eine Fehlgründung kann man wohl rückschauend die Dux A.-G., Metallwarenfabrik deutscher Gaswerke Frankfurt/Main bezeichnen, die in den alten Werkstätten der Imperial Continental Gas Association in Frankfurt für alle

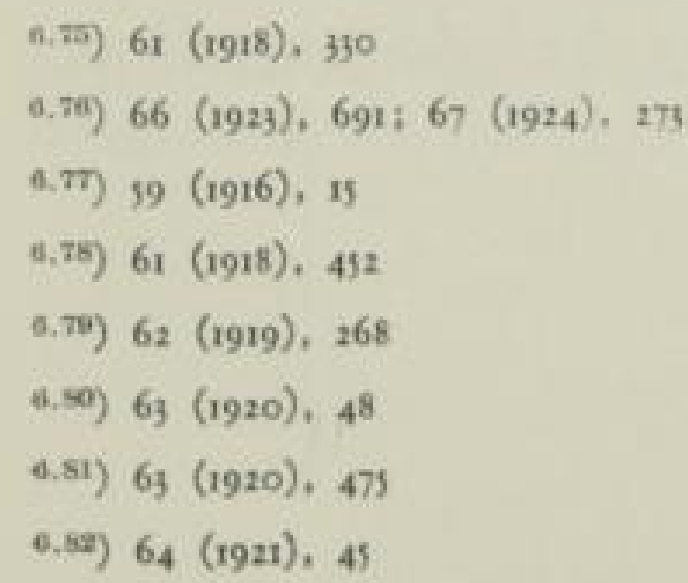


Gaswerke Gasmesser instandsetzen und bauen sollte $\left.{ }^{6 . \infty}\right)$. Man wollte damit den „Verteuerungen“ der Industriewerke entgegentreten. Die Ursachen für die Preisaufschläge waren sicherlich verkannt, Vertriebserfahrungen fehlten, die Kunst Absatz zu finden wurde unterschätzt, ein dringender Bedarf nach einer neuen Fabrik lag auch nicht vor. So blieben die Aufträge spärlich. Das Gesellschaftskapital wurde 1921 auf 5 Mio $M$ erhöht $\left.{ }^{e .84}\right)$. Im folgenden Jahr wurden von der Wirtschaftlichen Vereinigung 4 Mio M neue Aktien übernommen. Eine Beteiligung der in Dessau neu gegründeten Askaniawerke A. G. (aus Zentralwerkstatt, Dessau und Carl Bamberg, Friedenau) belastete diese später mit verlustreichen $\mathrm{Ab}$ wicklungsaufgaben. Alles muß̧te auf eine nach der Währungsreform noch angemessene Größe zurückgeschnitten werden. Ein Stołseufzer aus dem Jahre 1924 „Wirtschaftliche Vereinigung und Dux werden oft nur zum Drücken der Preise bemüht", ist bezeichnend für die Lage $\left.{ }^{6.5}\right)$.

Besser begründet war wohl die Nebenproduktenverwertungsgesellschaft deutscher Gaswerke, Frankfurt/Main, die auf gemeinsame Arbeit mit den teerverarbeitenden Betrieben unter Benutzung der vorhandenen Anlagen abzielte. „Die Gaswerke werden jetzt ihren Teer in einträchtigem Zusammenwirken mit führenden Firmen der Teerindustrie selbst auf eigene Rechnung verarbeiten in Fabriken, deren Leitung paritätisch so geordnet ist, daf̧ die bisherigen Besitzer und die Gasanstalten gemeinsam bestimmen werden, wobei jede von beiden Parteien das gleiche Gewicht besitzt." Man kann aus den Bekanntmachungen nicht ermitteln, welche Verlegenheiten oder Gewinnaussichten die alten Firmen veranlaf̧ten, ihren Besitz mit der Vereinigung zu teilen, vermutlich aber lag es an den Finanzverhältnissen durch die Inflation. Durch die Fiktıon Mark bleibt Mark, die Hilfe des Wuchergesetzes und die Wertzuwachssteuer wurden die Firmen um die Substanz gebracht und muften, was immer schwierig war, die Kapitalien erhöhen. Banken gaben die neuen Gelder zu schweren Bedingungen, und so erschien wohl der Weg zur Vereinigung sicherer. Für die Leitung der W'irtschaftlichen Vercinigung war es eine gute Leistung, die nötigen Gelder zu beschaffen. Im Jahre 1922 besaf sie bereits ${ }^{4} / 5$ der Anteile ${ }^{6 / 0}$ ). Dem Aufsichtsrat und ihrem Vorsitzenden F. Till metz mitsamt der Frankfurter Gasgesellschaft wurde denn auch ein besonderes Lob zuteil.

Die Wirtschaftliche Vereinigung sprang aber auch noch den Vereinsorganen mit finanzieller Hilfe bei und ermöglichte die Fortarbeit, wo die Mitglieder wegen der Entwertung nicht in der Lage waren, angemessen „erhöhte“ Beiträge zu leisten. Dem Gasinstitut allein wurden 1928400000 M zur Verfügung gestellt, eine Summe, die nach anderen Zahlenangaben etwa eine Kaufkraft von 40000 Goldmark hatte.

Die Organisationen zur Verwertung der Nebenerzeugnisse, mit denen das Gasfach zu arbeiten hatte, waren - eine typische Erschennung der Zeitperiode - verwirrend nach Zahl und Zwecken. I.) Die Ammoniakverkaufsvereinigung, 2.) der Benzolverband, 3.) die deutsche Teerverkaufsvereinigung (Verkaufsvereinigung

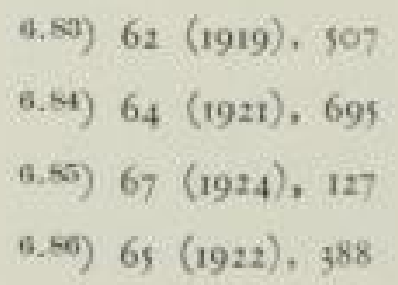


für Teererzeugnisse, Essen), 4.) das Gaskokssyndikat und Wirtschaftliche Vereinigung deutscher Gaswerke, 5.) die Nebenproduktenverwertungsgcsellschaft deutscher Gaswerke, 6.) das Stickstoffsyndikat, dessen Mitglied die Wirtschaftliche Vereinigung war. 7.) Gasreinigungsmassenverkauf durch die Wirtschaftliche Vereinigung, 8.) ein freiwilliger Lieferverband benzolerzeugender Gaswerke, der mit dem Benzolverband zusammenarbeitete ${ }^{6.57}$ ).

Hinzu kam nun noch durch die Wirtschaftliche Vereinigung gegründet eine neue .Industrie- und Handelsvereinigung" mit dem Zweck, die Finanzierung in der Inflation zu verbessern. Auch über den tieferen Sinn der vielen Vereinigungen schweigen die Dokumente. Man darf aber wohl aus Erfahrungen in dieser Zeit vermuten, dał sich bei so viel als kreditfähig angesehenen, juristischen Personen die zur Reichsbank zu gebenden Wechsel leicht beibringen lieł̧en, die zur Finanzierung damals eine ungeheuere Rolle gespielt haben.

Das Bild u3 des W. V.-Konzerns wurde 1923 veröffentlicht ${ }^{0.55}$ ).

Mit der Festigung der Währung wurde es nötig, diese Organisation wieder zu vereinfachen. Angefangen wurde 1925 mit der Zusammenlegung des Gaskokssyndikats mit der Wirtschaftlichen Vereinigung ${ }^{0.50}$ ).

Die Erwägungen über den Besitz der Stadtgaswerke, die angesichts der erweiterten Aufgaben in der Versorgung über den Stadtbezirk hinaus zu neuen Formen, vor allem der gemischtwirtschaftlichen Gesellschaft geführt hatten, ruhten natürlicherweise während des Krieges.

Nur als im Rahmen der kriegerischen Auseinandersetzungen, nachdem der deutsche Besitz im Ausland zerschlagen worden war, auch die englische Gasgesellschaft liquidiert wurde, ergab sich für das große Berliner Unternehmen die Notwendigkeit, nach einem besonders sorgfältigen Aufbau zu suchen.

Zur Aufnahme des grołen Kapitals wurde die „Deutsche Gasgesellschaft" mit 83 Mio M genuischtwirtschaftlich gegründet. Aktionäre waren: Die Kreise Teltow und Niederbarnim und die Deutsche Continental-Gas-Gesellschaft, während den Städten Wilmersdorf, Schöneberg und Berlin Optionsrechte eingeräumt wurden. Um aber die traditionelle, von den Engländern begünstigte ${ }^{6,000}$ ) sehr unabhängige aber erfolgrciche Geschäftsführung fortsetzen zu können, wurde die Gasbetriebsgesellschaft mit , Mio M gesondert gegründet. ${ }^{2} / 3$ dieses Kapitals übernahm die Deutsche Continental-Gas-Gesellschaft. Mit der Deutschen Gasgesellschaft wurde auf so Jahre ein Betriebsvertrag geschlossen ${ }^{6.91}$ ).

Selbstverständlich wurde eine so scharfe Aufgabenteilung nicht überall gut geheiffen. Eines aber wurde von allen Werksleitern gerade nach dem Kriege sehr deutlich empfunden, der Vorzug, als Direktor eines Gaswerks ebenso unabhängig zu sein, wie es in der privaten Wirtschaft selbstverständlich war. Das hatten die Eingriffe neu an die Entscheidungen herankommender Politiker hervorgebracht, die unter Verabscheuung irgendwelcher wirtschaftlicher Gesichtspunkte rein nach Ideologien entscheiden und eingreifen zu können glaubten. Auß̧erdem

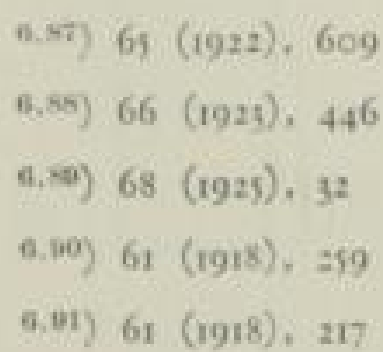




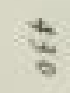

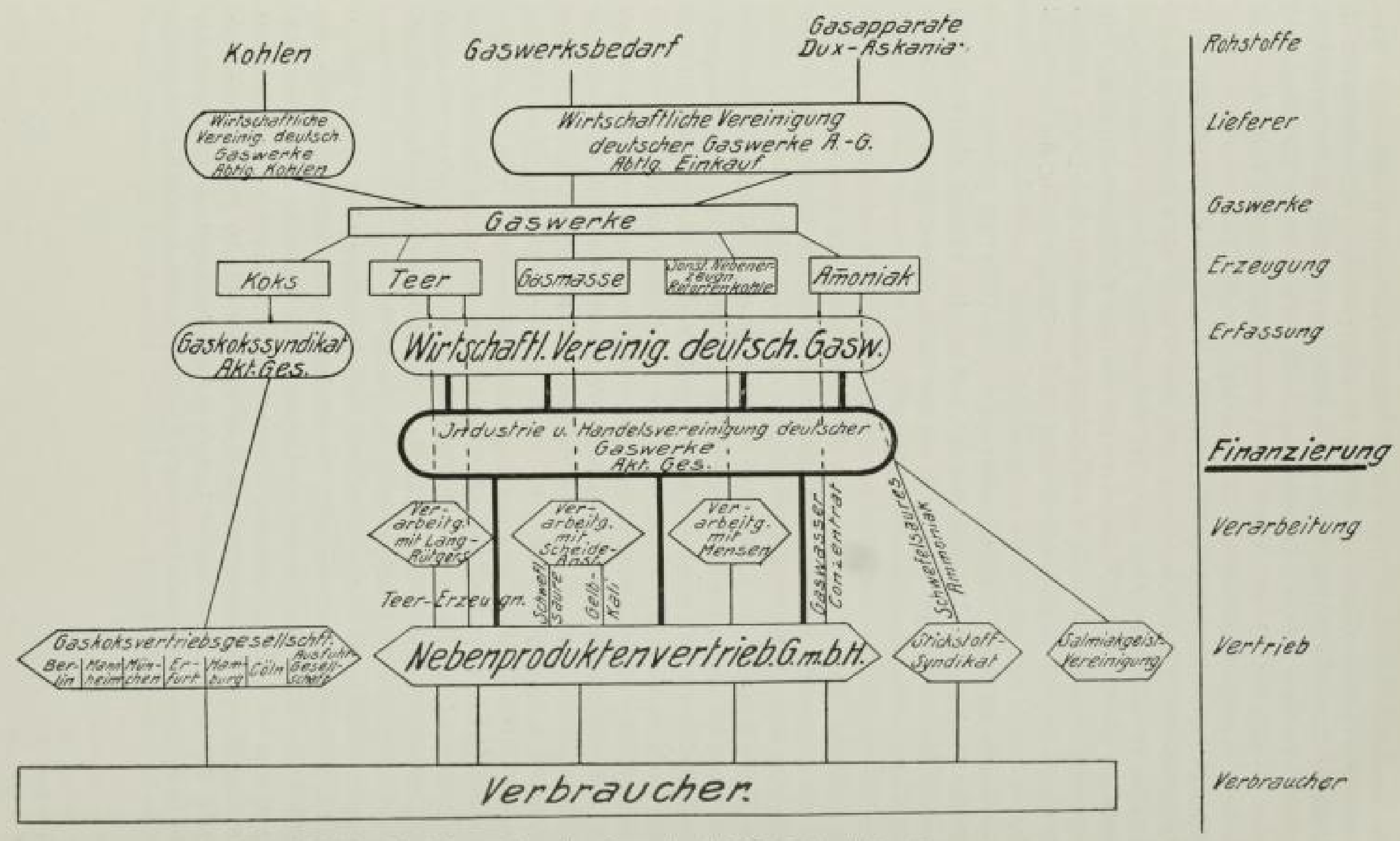

Bild in Konzern der Wirtschaftlictien Vereinigung deutschet Gaswerke (J. f. G. 66 [1921] S. 446

\section{SLUB}

Wir fuhren Wissen. 
aber waren die Werke auch durch die Verwaltungsbedingungen nicht frei genug, um den sich überschlagenden Ereignissen in der Wirtschaft schnell genug zu folgen. So gab es zwei Ziele, Entpolitisierung und Entbürokratisierung. Über die Art, wie das zu erreichen sei, gingen die Meinungen auseinander.

H. Koop, Leipzig, schrieb als Kaufmann überraschend offen über die Mängel der kommunalen Verwaltung und erstrebte eine Verselbständigung im bisherigen Eigentumsverhältnis nur durch entsprechende Beauftragungen ${ }^{e .2 n}$ ).

Etwas ungleich im Mafsstab war die Entgegenhaltung F. Herzberg s, dał der Gemeindeverband Leisnig den Ferngasverband selbständig führen lasse und keine Organisation nach dem Berliner Muster brauche $\left.{ }^{6.27}\right)$. Der Entwurf der preufisischen Städteordnung sah nur die Verselbständigung städtischer Betriebe nach kaufmännischen Gesichtspunkten vor zum Zwecke der Entpolitisierung ${ }^{6.90}$ ). Die Hauptversammlung des Vereins trat einer Resolution des Vereins Deutscher Ingenieure auf dessen Hauptversammlung bei, die lautete: Die in Dortmund tagende 62. Hauptversammlung des Vereins deutscher Ingenieure tritt mit aller Schärfe dafür ein, dał̧ in den Reichs- und Landesgesetzen wie in Städte- und Gemeindeordnungen eine eindeutige und zwingende Grundlage geschaffen wird, damit anstelle der jetzigen formalen Verwaltung öffentlichrechtlicher gewerblicher Betriebe die zur Erzielung der Höchstmaßes ihrer Leistungen unbedingt gebotene rein kaufmännisch, wirtschaftlich-technische Betriebsführung und Verwaltung zum Besten der Allgemeinheit unbedingt sichergestellt wird ${ }^{4.95}$ ).

Der bayrische Städtebund verwarf die gemischt-wirtschaftliche Form, solange die Städte noch Kapital bekämen. Die rein kommunale Form mit entsprechenden Freiheiten wurde für die allein richtige erklärt ${ }^{0.00}$ ).

So entstanden drei Formen nebeneinander. I.) Der reine Kommunalbetrieb mit erweiterten Rechten der Betriebsdeputation, wobei Bedenken bestanden, weil die preuß̧ische Städteordnung das nicht zulief̧. 2.) Nach Königsberger Muster eine Aktiengesellschaft oder G.m.b.H. ohne Fremdkapital (13 Werke). 3.) Der gemischtwirtschaftliche Betrieb (Is Werke). Unangenehm fiel auf, dał der Städtetag dazu sagte: „Welche Form gewählt wird, ist nach allgemein politischen Erwägungen zu entscheiden $\left.{ }^{0.07}\right)$. Gerade die Zügellosigkeit politischer Forderungen hatte ja sehr viele schädliche Störungen verursacht. Sie fand hier wieder eine offene Tür. Der Städtetag bezeichnete die gemischtwirtschaftlichen Unternehmungen als verhängnisvollen Schritt zurück $^{0.05}$ ).

So gestärkt meldeten sich auch die politischen Richtungen wieder zum Wort. In den Satzungen der städtischen Werke Aktiengesellschaft, Stettin, wurde ausdrücklich das Recht des Aufsichtsrats, dem Vorstand bindende Weisungen zu erteilen, verankert ${ }^{\mathrm{es}}$ ). Die Forderung der Tariffestsetzungen durch die Stadtverordnetenversammlung öffnete der Politisierung wieder das Tor $\left.{ }^{5,45}\right)$. Die Wirt-

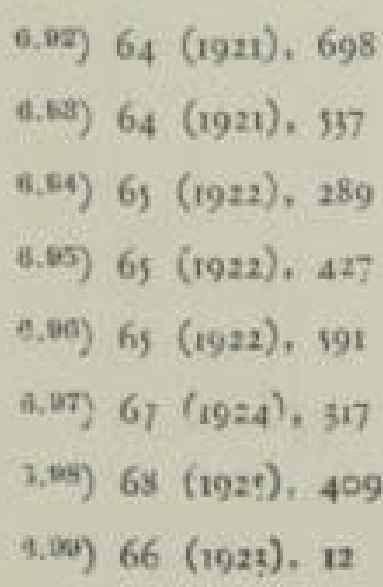


schaftspartei sprach sich gegen den Geräteverkauf und die Installationstätigkeir aus. $D$ ö $r$, Berlin, verlangte die kostenlose Abgabe von Strom, Gas und Wasser an Arbeitslose und die Einstellung jeder Lieferung an bestreikte Betriebe. Dic Gewerkschaften hatten sich dagegen positiv zur Umorganisation der Werke, ja zur wissenschaftlichen Betriebsführung (Taylorsystem) geäufzert ${ }^{0.100}$ ).

Überraschend war eine Stimme auch Schweden (Blo mquist, Höganäs, früher Stockholm) im Anschluf an einen Bericht über die Werbung in den Vereinigten Staaten: „Weitsicht und guter Wille sind nötig, um das Geld für Konstruktion und Untersuchung der industriegeräte zu wagen. In der Regel haben die kommunalen Werke keine Bewegungsfreiheit. Eine freie Aktiengesellschaft ist nötig $\left.^{8.101}\right)$.

So war gegen Schlu\} dieses Zeitabschnittes keine einheitliche Auffassung gewonnen.

\section{I2 Wettbewerb}

Der Wettbewerb nahm im Kriege ruhigere Formen an. Was geschah, wurde durch die Małnahmen der Staatslenkung hervorgerufen und war durch Streitschriften nicht zu beeinflussen. Solange das Gas reichlich vorhanden war, kamen neue Kunden schneller, als die Installationen geschaffen werden konnten. Stadt Berlin verzeichnete 1916 63331 neue Gaskunden, die Elektrizitätswerke 4500.

Umso unangenehmer wurde ein Angriff in der Elektrotechnischen Zeitschrift empfunden, der lautete: „Zahlen zeigen zwingend, daß̧ die Abgabe von Gas für Beleuchtungszwecke ganz eingestellt werden sollte und nur für Kochen und Heizen zu benutzen ist ${ }^{(4,100)}$ ).

Die Gesamtzahl der zugewachsenen Beleuchtungsanschlüsse wurde von $L e m$ pelius auf 2 Mio geschätzt, gleich $40 \%$ der 1914 vorhandenen Zahl. Aber nach dem Kriege kam es mit Sperrstunden und zwangsläufig ungeeigneten Ersatzgasen zu einer Katastrophe. „Wegen des schlechten Gases gehen jetzt die Abnehmer an das Elektrizitatswerk verloren." (G. Tremus im Märk. Verein) ${ }^{6.109}$ ). „Die starke Beschränkung der verfügbaren Gasmenge zwingt die Werke vielerorts, freiwillig die Lichtverbraucher der Elektrizität zuzuschieben." (K. Bunte in der Hauptversammlung) ${ }^{n, 10 t}$ ).

Die Elektrizitätswerke erklärten den Verteilungsstellen, für Sperrstunden nicht eingerichtet zu sein. Sie konnte sich auch auf die von den Feinden nicht begehrte Braunkohle, deren Förderung stieg, stützen. Die Notlage der Gaswerke ausnutzend warben sie sogar für die elektrische Küche $\left.{ }^{6.100}\right)$. Die alten fehlerhaften Umrechnungen, um die elektrische Beleuchtung auch als die preiswertere erscheinen zu lassen, griff Dr. Blocb auf. Er setzte die Leuchtkraft eines Gasglühlichtes trotz der Arbeiten von E. Terres und H. Stra ube einfach proportional dem Heizwert herunter $\left.{ }^{0.100}\right)$. Erfreulich war es immerhin, daf angesehene

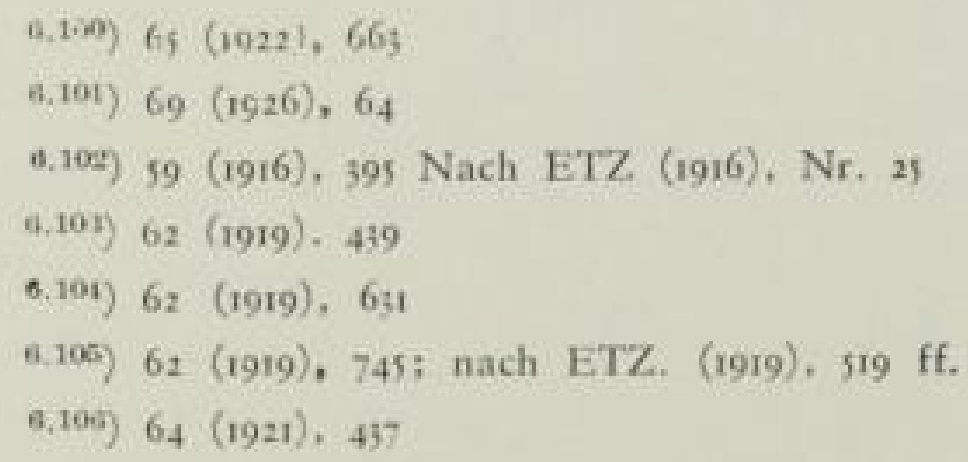


Elektrizitäts-Fachleute wie H. P a ss a v a nt zugaben, dał in der Küche das Gas noch lange nicht entbehrt werden könnte und die Elektrizität zur Raumheizung gar nicht erörtert zu werden brauche $\left.{ }^{0.107}\right)$. Noch erstaunlicher allerdings war unter den gegebenen Verhältnissen ${ }^{6.100}$ ) eine Empfehlung von Ölfeuerungen für Zentralheizungen.

\subsection{GASERZEUGUNG}

\subsection{Ofenbau}

Während des Krieges ruhte auch der Ofenbau in den Gaswerken fast vollständig. Angefangene Bauten konnten fertiggestellt werden (Pintsch-Bolzöfen in Düsseldorf $\left.^{6.100}\right)$. Die vorhandenen Ofen waren aber durch die vielfach wechselnden Kohlensorten einer harten Erprobung unterworfen. Die Erörterung der Vor- und Nachteile wurde lebhaft fortgesetzt. $S c b a d e c k$ empfahl Verbund-Kammeröfen auch für Gaswerke ${ }^{6.119}$ ). W. Ka rle, Worms, konnte aber leicht nachrechnen, dał die Starkgasbeheizung bei Gaswerken wegen der Frachtaufschläge auf die Kohle und bei größzeren Lieferungen auf den Koks sehr leicht die Grenze der Wirtschaftlichkeit überschreiten muf $\left.\hat{\wp}^{\mathrm{e} .111}\right)$.

Uberraschend sind die Feststellungen E. Körting s, der Retortenöfen jeglicher Art in den verschiedenen Werken hatte, dał die Cozeöfen bei plötzlichen Wandlungen der Kohlensorten die geringsten Schwierigkeiten verursacht hatten ${ }^{n .112}$ ). Aber auch G. Aicber, Pasing, und Wandsbek waren mit dem Schrägkammerofen, der ja ebenfalls vom Schüttwinkel der Kohlen beeinfluf̧t wurde, im Kriege zufrieden gewesen $\left.\left.{ }^{0.119}\right),{ }^{6.114}\right)$. Horizontal-Retorten mit Maschinenbedienung hatten bei gestiegenen Löhnen (und festgehaltenen Kapitalwerten) in Berlin am schlechtesten abgeschnitten $\left.{ }^{\text {n.un }}\right)$. Krefeld, das anfangs so warm für seine Öfen eingetreten war, hatte schon vor 1914 unter dem Verschleif der Bedienungsmaschinen sehr gelitten, im Kriege aber noch mehr und ging deshalb 1922 zu Klönne-Vertikalkammeröfen über ${ }^{0.110}$ ).

Anders urteilte E. Goffin, Heddernheim, der unter Einschaltung des zur Verfügung stehenden Raumes im Ofenhause die Retorten von $3 \mathrm{~m}$ auf $4,5 \mathrm{~m}$ verlängerte, durch volle Füllung der zu beiden Enden offenen Retorte und Durchstołverfahren, Ausbeute und Durchsatzmenge um die Hälfte steigerte (Goffins erste Versuche wurden 1918 erwähnt), sein Verfahren zur Wassergaserzeugung ausbaute, die Fördereinrichtungen und mit einem Rauchrohrkessel an jedem Ofen die Wärmewirtschaft verbesserte. Nachdem er auch noch das Kokstauchund Erstickungsverfahren in Kübeln eingeführt hatte, war das Werk wirtschaft-

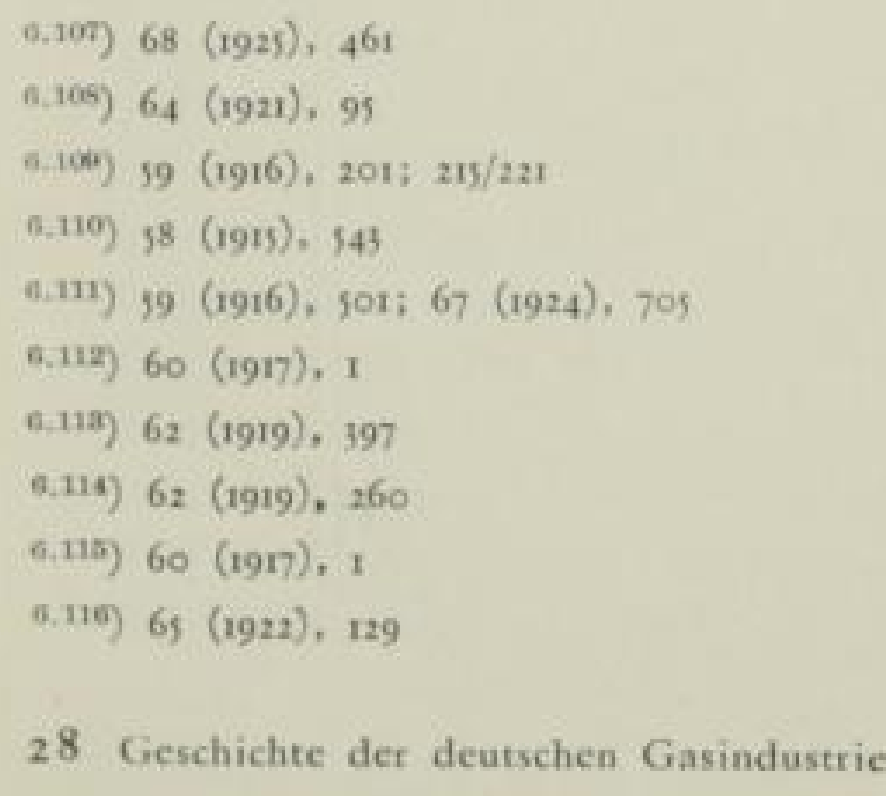


lich geworden. Aus $100 \mathrm{~kg}$ Saarkohle wurden $52,8 \mathrm{~m}^{3}$ Mischgas von $\mathrm{H}_{0}={ }_{4} 600$ $\mathrm{kcal} / \mathrm{m}^{3}$ gewonnen $\left.{ }^{8.117}\right)$. In zwei Schichten wurden $6 \mathrm{Mio}^{3}$ Mischgas mit 2 bis 3 Mann erzeugt. Das Goffin-Wassergasverfahren wurde vieifach eingeführt (Freudenstadt ${ }^{6.118}$ ), Solothurn.111 $)$. F. $S c b$ äfer berichtete mit sichtlicher Freude, dał in England in grołen Werken neue Horizontal-Retortenöfen gebaut wurden, wegen mancher Kohlensorten, die sich schlecht anders entgasen lief̧en. Dabei dürften aber die starken Heizgasspitzen mit ausschlaggebend gewesen sein $\left.^{6.120}\right)$. Ebenso wurden in Liverpool noch zwei Jahre später Horizontal-Retorten gebaut $\left.^{8.121}\right)$.

„Überraschend schnell hat sich in Deutschland der Vertikal-Kammerofen eingeführt." Die Thüringer Gasgesellschaft bevorzugte ihn auch für kleine Werke ${ }^{n+122}$ ). Auch die Münchener Kammerofengesellschaft und die Dessauer Vertikalofengesellschaft verliefzen ihre alten Baumodelle, obwohl Vertikal-Retorten im Kriege in Mariendorf am billigsten gearbeitet hatten und Haltbarkeiten von beinahe $4000 \mathrm{~h}$ aufwiesen $\left.{ }^{6.122}\right)$. Die Gesellschaft baute in Freiburg i. Br. zur Steigerung der Leistungen die Vertikal-Retortenöfen auf Kammeröfen um. Klönne baute solche Öfen in Gera $\left.{ }^{6.124}\right)$. Pintsch zur Entgasung von Böhmischer Braunkohle in Aussig $\left.^{6.125}\right)$. Bamag stattete selbst ein kleines Werk wie Parchim damit aus ${ }^{6.120}$ ). Es folgten Delmenhorst mit Dessauer Vertikal-Kammeröfen ${ }^{6.127}$ ), Krefeld ${ }^{0.125}$ ), Bückeburg $^{6.127}$ ), Hannover ${ }^{6.209}$ ), Potsdam ${ }^{6.131}$ ). In Glatz baute H. Ko p pers seinen ersten kontinuierlich arbeitenden Vertikalkammerofen für Mischgas mit Zentralgeneratoren-Anlage für ein kleines Werk ${ }^{8,13 z}$. Breda; Mannheim; Krakau; Minden folgten ${ }^{6.133}$ ). Selbst in Schöneberg im Bereich der Gasbetriebsgesellschaft standen nunmehr Vertikalkammeröfen, allerdings mit Einzelgeneratoren ${ }^{6.14}$ ). Der kontinuierliche Kammerofen System Dresden der Adolfshütte, Kaolin \& Chamottewerke Crosta, wurde von Bayer, Leverkusen, übernommen $\left.{ }^{8.155}\right)$. Alle Anlagen können auch in dieser Aufstellung, die en Bild vermitteln soll, wie vielseitig der Ofentyp in kleinen, mittleren und großsen W/erken eingesetzt wurde, nicht aufgenommen werden. Die Hauptbauperiodie fiel in das Jahr 1921/22, als die Inflation noch verhältnismał̧ig langsam voranschritt.

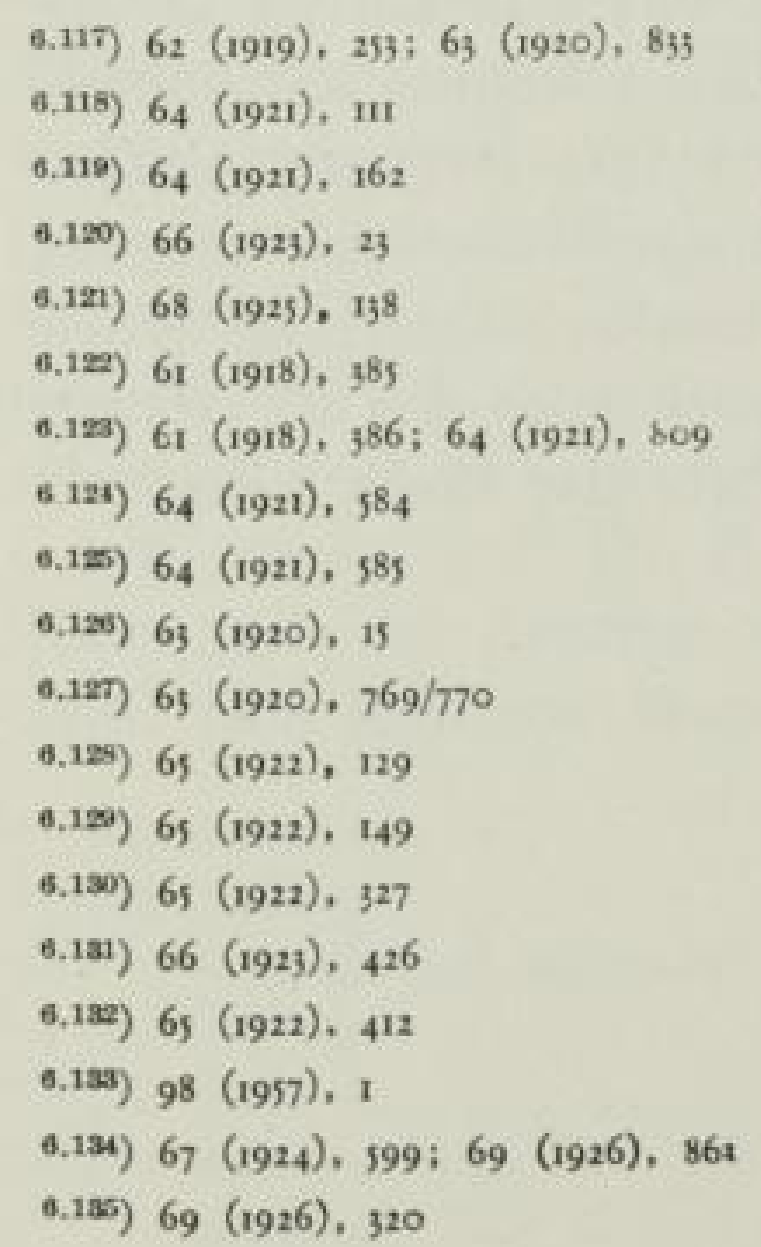


Vom Schrägkammerofen wird in dieser Zeit nur von Siegburg berichtet $\left.{ }^{6.130}\right)$. Horizontalkammeröfen von Dr. C. O $t$ to wurden 1916 in Kiel-Wik errichtet ${ }^{6.137}$ ). Etwas Besonderes war in Ulm der Umbau der Horizontalretortenöfen zu Horizontal-Kleinkammeröfen, um auf dem zur Verfügung stehenden beengten Raume die Leistung zu steigern ( $500 \mathrm{~kg}$ Kohle/Kammer) ${ }^{0.125 s}$ ).

Bedenken wurden laut, dał̧ man mit dem Ubergang zu Groł̧raumöfen bei kleineren Werken zu weit ginge $\left.{ }^{a .19}\right)$, daßz die modernen Anlagen überzüchtet wären und im Winter gegen Frost empfindlich seien ${ }^{0.149}$ ). Brubn, Rathenow, schlug für kleine Werke 12 Stunden Ausstehzeit statt der üblichen 24 Stunden vor, um ein gleichmäf̧igeres $\mathrm{Gas}$ und ausgeglichene Kühlerbelastungen zu erhalten ${ }^{6.14}$ ). Geipert hatte wieder neue Feinheiten im Betrieb entwickelt, um Schwankungen im Gasbedarf auszugleichen: Bei geringen Verschiedenheiten komme man mit gleicher Ofenzahl durch, wenn man im Sommer auf höchste Ausstehzeit und Wassergaserzeugung ginge. Bei gröłeren Unterschieden solle man das ganze Jahr 18 Stunden Ausstehzeit einhalten und nur in der Spitze auf 12 Stunden mit Wassergas gehen, wobei $50 \%$ mehr Gas erhalten würde. Notfalls könne noch karburiertes Wassergas eingesetzt werden ${ }^{6.142}$ ).

Über die Frage der Regeneration oder Rekuperation löste Koppers heftige Kämpfe aus $\left.{ }^{6.34}\right)$. Insbesondere widersprachen G. A l l i a t $a$, Locarno $\left.{ }^{0.144}\right)$, und Go ebel, Bochum, für Dr. C. Otto. Eine genaue Untersuchung in Kiel-Wik bewies, dafy Zentralgeneratoren auch mit Rekuperatoren verbunden gute Ergebnisse lieferten $\left.{ }^{6.145}\right)$. K. B unte trat mehrfach für Zentralgeneratoren ein wegen der sicheren Feuerführung, aber auch wegen der Möglichkeit, die damals sehr begehrten Schwelteere im Generator wirtschaftlich zu erzeugen ${ }^{6.14}{ }^{\prime \prime}$ ). In Frankfurt/Main-Gaswerk West wurde ein Braunkohlengenerator (Francke-Werke) eingebaut. Die Durchsatzleistungen waren gering ${ }^{0.147}$ ). In Christiania (Oslo) hatte man sogar die elektrische Beheizung von Retorten ausgeführt ${ }^{1.49}$ ).

In Chemnitz konnte man die Kosten der Gaserzeugung in Doppelgasgeneratoren (nach Strache) mit der Entgasung im Vertikalofen vergleichen. Als Gutachter herangezogen bewies C. Westpbal, Leipzig, die Überlegenheit des Ofenbetriebes, der Werksdirektor $S c h i p k e$ das Gegenteil. Der Unterschied kam durch die eingesetzten Preise für Koks, Benzol und die Dampfbewertung ${ }^{\text {g.ap }}$ ). Für solche Vergleiche war jedenfalls das unruhige Jahr 1922 auch ungeeignet. Beide Rechner waren sich einig, daf3 nach Fortfall der Kohlennot die Doppelgasanlage nicht weiterbetrieben werden könne.

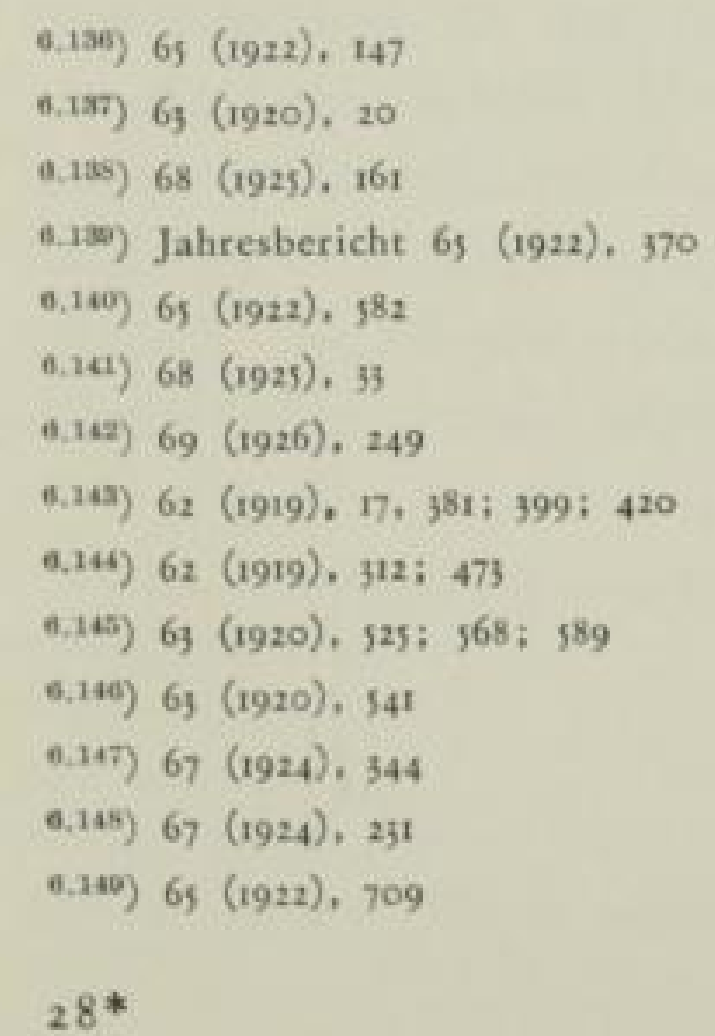


Das Bedürfnis, bei solchen Verschiedenheiten in den Urteilen erster Fachleute zu Garantiebedingungen für Gaserzeugungsöfen und Normen für Abnahmeversuche zu kommen, war offenbar. K. B unte beriet sich mit den Ofenbaufirmen ${ }^{6.150}$ ). Während des Krieges brachte die Not die Schweizer Werke zu einer gründlichen Durcharbeitung der Wärmewirtschaft. Besonders hervorgehoben wurden: Hochdruckabhitzekessel und Verbreitung der trockenen Kokskühlung ${ }^{6.151}$ ).

Entgegen den Beobachtungen und Erklärungen, die in Deutschland bekannt waren, kam man in Amsterdam zur Feststellung, dał die ausgetriebenen Gase in Vertikalöfen zwischen Kohlen und Wänden aufstiegen. Nur im Anfang ginge ein geringer Teil durch den Kern nach oben. Darum wurde ein geringer Dampfzusatz viel früher, als bisher üblich war, verlangt. Auch die oben ermäßjigte Temperatur sei günstig zur Verhütung der Zersetzung $\left.{ }^{6.150}\right)$. Eine später angesetzte englische Arbeit endete mit der Erkenntnis, wie schwierig es sei, hierüber klare Einsicht zu erhalten ${ }^{6.158}$ ).

Ein bedeutender Fortschritt wurde init der Einführung von Silikasteinen in den Gaswerksofenbau getan. H. Ko p pers hatte wegen der Rohstofflage in Nordamerika den gewagten Schritt vom erprobten Schamottestein zum Silikastein 1908 mit viel Umsicht getan $\left.{ }^{6.154}\right)$. Berichte über den Erfolg blieben nicht aus ${ }^{6.155}$ ). Bedenken, dał bei dem höheren Feuchtigkeitsgehalt deutscher Kohlen die empfindlicheren Steine bald unbrauchbar sein würden, ging Koppers schon 19п् und 1913 auch in Deutschland mit mutigen Erstausführungen zu Leibe. 192I bezeichriete Strassmann, Krefeld, Silika bereits als alleinigen Baustoff, auch für horizontale Retorten $\left.{ }^{6.156}\right)$. 1924 wurden die Erfahrungen mit den von Koppers in Wien aus Silika gebauten Kammeröfen bekannt gegeben $\left.{ }^{6.157}\right)$. Es waren das: Die hohe Druckfeuerbeständigkeit und die gute Wärmeleitfahigkeit durch die Wände die ein Mehr an Gas ausbrachte. Vorsicht muf̧te beim Aufheizen und Auskühlen des Mauerwerks walten. Stillsetzung von Öfen sei schädlich und solle möglichst vermieden werden. Immerhin wurden bis 3000 Feuertage nachgewiesen.

Einzelverbesserungen waren die empfindlichen Kammerabsaugeregler, deren Einbaubedingungen zunächst zum Gedankenaustausch anregten ${ }^{0.155}$ ). Ferner der Gläserrost für Einzelgeneratoren mit beweglichen Einzelstäben, dem ein Pforzheimer Ofenmeister den Namen gegeben hatte: Er erzielte damit is bis $20 \%$ Ersparnis an Unterfeuerung und konnte die Stocharbeit beschleunigen ${ }^{6.15 i}$ ). Auch in Stuttgart hatte sich der Rost bewährt ${ }^{6,100}$ )

\footnotetext{
6.150) $65(1922), 370 ; 67(1924), 101 ; 119 ; 122$

6.151) $59(1916), 576$

6.152) $60(1917), 504$

6.15s) 66 (1923), 69

6.154) Koppers: Ein halbes Jahrhundert im Dienste der Kohleveredelung S. $44 \mathrm{f}$.

6.155) $60(1917), 130$

6.156) $64(1921), 817$

6.157) 67 (1924), 358

6.158) 69 (1926). 168

6.150) 69 (1926), 215

6.100) 69 (1926), 916

$+36$
} 
In der betrachteten Zeitspanne ist die Entgasung von Steinkohlen bei niedriger Temperatur in einem Umfange aufgenommen und untersucht worden, wie niemals vorher. Gewif̧ hat es schon früher hie und da Versuche gegeben, die bei Braunkohlen seit langem und vielfach geübte Technik auf Steinkohlen zu übertragen. Der Anstoł kam kurz vor dem Weltkriege aus England. Dort reizte vor allem die Herstellung eines etwas gashaltigen Kokses. Denn in den vorherrschenden offenen Feuerstellen brannte Hochtemperaturkoks schlecht und nicht mit den beliebten züngelnden Flammen. Führte man die Entgasung bei 450 bis $690^{\circ} \mathrm{C}$ durch, erhielt man aber nur die Hälfte der Gasmengen. Der Teer wurde als reich an Benzol bezeichnet $\left.{ }^{\text {ater }}\right)$. Der Koks wurde aber so teuer, dał er nur zu einem beträchtlich höheren Preis abgegeben werden konnte.

In Deutschland reizte dagegen mehr der Tieftemperaturteer oder Urteer, wic ihn F. Fiscber, Mülheim, nach Vorschlag von Hoffmann, Berndorf, nannte. ${ }^{\text {e.tee }}$ ), weil er reich an Teerölen war und die Leichtölfraktion als Motorentreibstoff verwendet werden konnte. Leider wurden die Berichte der deutschen Forschungsstellen während des Krieges durch die Zensur von der Veröffentlichung ausgeschlossen. So findet man nur eine Angabe des Kaiser-Wilhelm-Instituts, Mülheim, über die wissenschaftlichen Ergebnisse ausländischer Versuche bei Vakuum, insbesondere von R. Pictet und W beeler $r^{8,164}$ ) und eine Mitteilung über eine Versuchsanstalt in London für Tieftemperaturteer und ihre Absichten. Das Gelände wurde von der South Metropolitan Gas Company in East Greenwich zur Verfügung gestellt, die sich auch bereit erklärte, alle Transporthilfon zu leisten und die bei den Großversuchen ankommenden Erzeugnisse aufzukaufen. Baugelder stellte der Staat in Aussicht $\left.{ }^{\text {s.tec }}\right)$. Versuchsziele waren: I.) Herstellung cines flammenden Kokses, 2.) Gewinnung von Marine-Heizöl aus dem Teer. 3.) Verbilligung des ganzen Verfahrens. 4.) Verbilligte elektrische Energie ausden Entgasungserzeugnissen. 5.) Verwertung von Torfmooren. 6.) Gasverwendung in der Metall-, Keramischen und Chemischen Industrie. Das waren Gedanken, die auch die in Deutschland arbeitenden Konstrukteure erhofften.

Nach dem Kriege wurden in den Mitteilungen des Kaiser Wilhelm-Institutes für Kohleforschung die wichtigen Ergebnisse bekanntgegeben ${ }^{6.165}$ ). Über die englischen Ergebnisse bei der Coalite-Herstellung berichtete G. Anders o $\left.n^{0.106}\right)$. Ein Volumen Schwel-Gas stellte sich zwar in der reinen Betriebsrechnung ohne Anlagekosten billiger als mit der Hochtemperaturentgasung, infolge der umfangreicheren Anlagen, sobald Zinsen und Abschreibungen berücksichtigt wurden, jedoch teurer. In Vertikalretorten wurde mit Trägergasen durch den verminderten Partialdruck eine Verbesserung des Teers erreicht. W. Allner behandelte hauptsächlich die Generatorenvergasung mit Urteergewinnung. Die mitteldeutsche Schwelkohle würde wirtschaftlicher sein als Steinkohle. Der Staat unterstützte

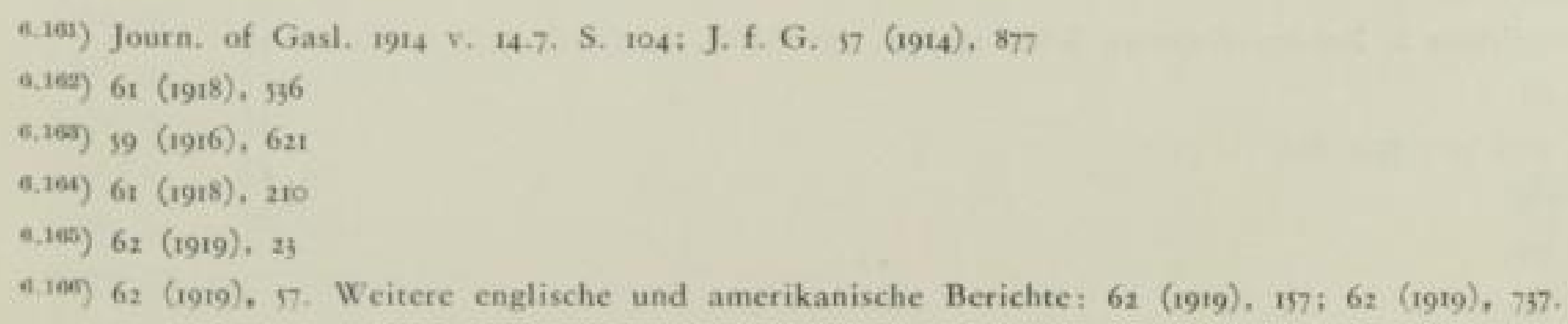


die Arbeiten durch Steuervorteile wegen der Schmierölgewinnung. A. Frank sprach in der Brennkrafttechnischen Gesellschaft $\left.{ }^{6.107}\right)$. Nach Anregungen von Fr. Fischer bauten Roser, Thyssen, Mülheim/Ruhr, und Fellner \& Ziegler, Frankfurt, liegende Drehrohröfen für Halbkokserzeugung ${ }^{\text {0.156 }}$ ). Selbst so kleine Einheiten, wie sie Halbgasfeuerungen darstellten, wurden für Urteergewinnung hergerichtet $\left.^{0.100}\right)$. In Wien äuf̧erte sich W. Gl a se $r$, Institut für Kohlenvergasung, über die Gewinnung von Cumaronharzen aus Teerölen und insbesondere von Kunstharzen aus Urtecren ${ }^{8,17}$ ).

Wie wichtig die Entscheidung vom Gasfach genommen wurde, beweist die Aufnahme in den Jahresbericht des deutschen Vereins. „Zeigt sich durch die Tieftemperaturentgasung ein neuer wirtschaftlich gangbarer Weg zu Gewinnung gasförmiger Brennstoffe...., ist die Elektrizitätserzeugung mit Gewinnung von Nebenprodukten, also die organische Verbindung von Gas- und Elektrizitätswerken das Gebot der Stunde $\left.{ }^{(6,171)}\right)$ ? Für die Hauptversammlung wurden allein drei Vorträge vorgesehen $\left.{ }^{8.17 z}\right)$. Angesehene Fachleute wie A. O. Pot t, Essen: H. R. Trenkler, Berlin, und $S c$ ballen berg, Frankfurt/Main, warnten vor zu vielem Optimismus. Die Schwierigkeit läge in der Verwertung des anfallenden Halbkokses.

Drehrohröfen hatte das Gaswerk Lichtenberg aufgestellt $\left.{ }^{\text {s.173 }}\right)$. Auch auf einer rheinischen Zeche war später ein Drehrohrofen in günstigem Betrieb $\left.{ }^{4,174}\right)$.

Sonst lagen dem Gasfach wohl die Kohlengeneratoren mit Schweleinsa`z näher. Besonders lebhaft betätigte sich H. S $\mathrm{r} a c b e$ mit der Entwicklung der Doppelgasanlage. (Vgl. Seite 360/6r.) Er arbeitete beim Heißblasen auf Generatorgas und benutzte dieses zur Beheizung des der Kohlenentgasung dienenden Teiles. Beim Wassergasmachen wurde dieses als Spülgas zur Entgasung durch den oberen Teil geschickt ${ }^{6.135}$ ), wobei Urteer im Gas erhalten wurde.

\section{E B E N S B I L D}

Hugo Strache wurde am 10. April I86s in Wien geboren. Er studierte in Aachen und Zürich. $188 \delta$ vorübergehend an der Universität Wien tätig, begann er 1899 eine Assistententätigkeit an der Technischen Hochschule. I89r habilitierte er sich als Privatdozent für organische Chemie und nahm 1897 die Tätigkeit im Beleuchtungswesen und für industrielle Feuerungsanlagen auf. 1909 schuf er und leitete danach die Versuchsanstalt für Brennstoffe, Feuerungsanlagen und Gasbeleuchtung. 1913 a. o. Professor, erhielt er 1919 den entsprechenden Lehrs'uhl als ordentlicher Professor für das gleiche Arbeitsgebiet. Seine vielfachen Arbeiten auf dem Gebiete der Wassergaserzeugung seit 1895 wurden schon mehrfach

0.167) 62 (1919), 777

6.165) $63(1920), 567 ; 64(1921), 11$

6.108) 64 (1921), 125

6.170) Mitt, d. Institutes f. Kohlenvergasung Wien 1920 S. 65; GWF. 64 (1921), 123; 63 (1920), 159

e.171) $64(1921), 361$

6.172) $64(1921), 426 ; 333 ; 574 ; 681$

6.175) $63(1920), 168$

6.174) $67(1924), 135$

a.175) $63(1920), 25$

$43^{8}$ 
berührt. 1910 trat er der restlosen Vergasung der Kohle näher und entwickelte den Doppelgasgenerator. Strache blieb aber nicht nur im Kohlengasgebiet. Holzverkohlung und Mitarbeit an einer Mineralölverordnung von Österreich entsprangen den Kriegsbedürfnissen. Seine vielseitige und gründliche Arbeit belegen drei Hauptwerke: Gasbeleuchtung und Gasindustrie, Kohlenchemie und Technologie der Brennstoffe.

I924 richtete er noch ein neues Institut auf modernster Basis am Getreidemarkt in einer Zeit ein, in der die Bauschwierigkeiten im allgemeinen als unüberwindbar auch in Osterreich galten. Er verstarb am 28. 10. $\left.1927^{0.175}\right)$.

Das Trigasverfahren von A. Pott und Dolensky (Dellwick-Fischer) Frankfurt/Main kann man als Fortbildung des Doppelgasverfahrens von Strache ansehen $^{6,177}$ ). Hier war noch ein Richtungswechsel beim Heifblasen und der Wassergaserzeugung eingeschaltet. Auf den Stinneszechen und bei der Frankfurter Gasgesellschaft wurden Trigasgeneratoren aufgestellt. Diese 1920 untersucht, erreichten nur einen Vergasungswirkungsgrad von $\left.46 \%^{0.175}\right)$. Strachesche Doppelgasgeneratoren wurden schon 1918 in Brünn mit Erfolg betrieben. Anlagen in Bergedorf und Elberfeld waren dagegen 1919 nicht mehr in Benutzung ${ }^{3.175}$ ). In Graz 1920, in Zwickau und Chemnitz Ende 1921 wurden Schwelgasgeneratoren errichtet $^{0.100}$ ).

Auch Julius Pintsch A.-G. Berlin entwickelte einen Schwelgenerator mit Urteergewinnung bei gewöhnlichem Generatorgas ${ }^{6,151}$ ). (Bild II4). K. Bunte sah in dieser Verbindung einen zusätzlichen Vorteil für Zentralgeneratoren für Gaswerksöfen ${ }^{\text {n.10z }}$.

Mit einer senkrechten, stehenden Doppeltrommel, in deren Ringraum die Kohle durch eine $W^{\prime}$ endel geführt werden sollte, wollte $M e g u \imath n$ die noch immer bestehenden Schwierigkeiten der Drehöfen überwinden ${ }^{0.193}$ ). (Bild IIs a und b). Ein ähnlicher Schwelofen der Kohlenveredelungs G. m. b. H. Berlin wurde in Edderitz bei Köthen für eine besonders gut geeignete Braunkohle aufgestellt. Der Schwelkoks wurde im Elektrizitätswerk verbrannt. Man hat dort den 4,3 -fachen Erlös gegenüber der unveredelten Verbrennung festgestellt. Das war aber ein besonderer Fall ${ }^{0.154}$ ).

A. $T$ b $a u$, der sich wohl mit am fleifjigsten um die Kunst, Kohlen zu schwelen, bemüht hat, stellte fest, dał der Steinkohlenhalbkoks aus Drehöfen nicht absetzbar sei. Man müsse einen unterbrochenen Betrieb mit ruhender Beschickung und stückfestem Koks anwenden. Damit war man aber grundsätzlich wieder zu den Ausgangspunkten im Generator zurückgelangt ${ }^{4.150}$ ).

Die ernsten Arbeiten an dieser Aufgabe dauerten 1926 noch an. Erfolge wurden vorwiegend mit Braunkohlen erzielt.

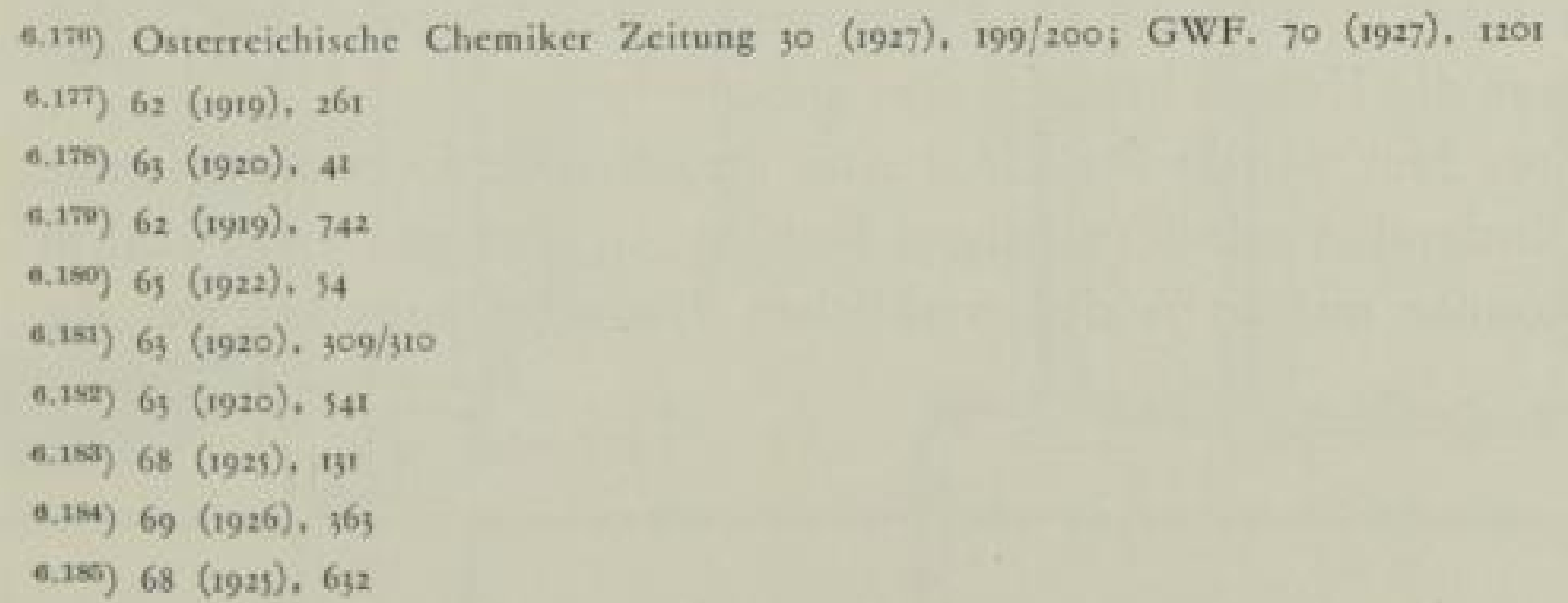




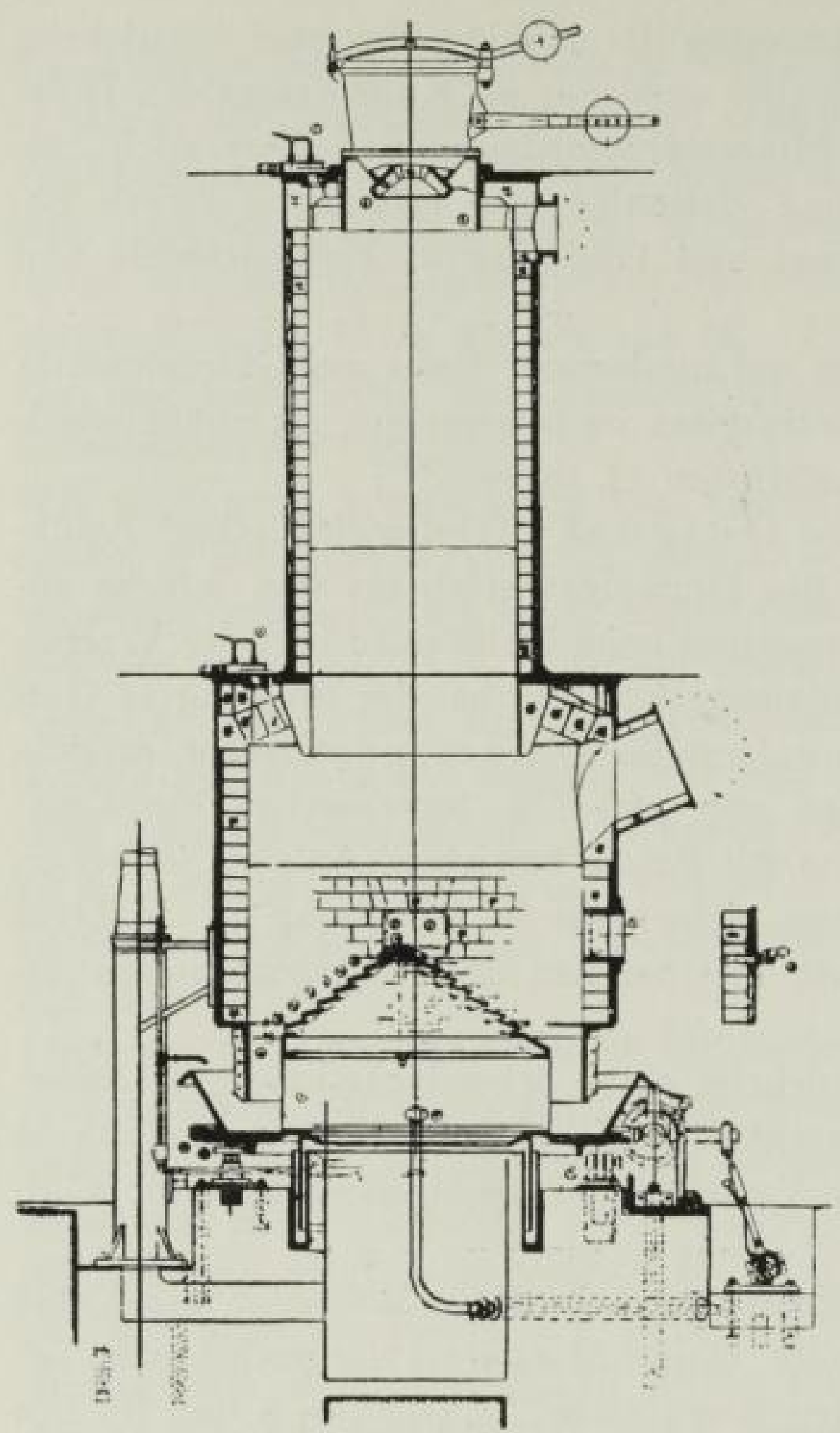

Bild 114

Schwelgenerator von Pintsch (J. f. G. 63 [1920] S. 544)

\subsection{Vergasung}

Indessen fesselte die Gaswerke an den Doppelgasanlagen nicht allein die Möglichkeit, Urteer zu gewinnen. Vielmehr hatte die Knappheit von Gaskohlen alle Möglichkeiten, überhaupt ein brauchbares Gas aus irgendwelchen Kohlen zu gewinnen, in den Vordergrund gebracht. E. R. Besemfelder und A. Nau$\left.m a n n^{8.108}\right)$ griffen schon 1916 ihre alten Gedanken an die restlose Vergasung und die Verteilung von Kraftgas wieder auf. F. $S c b$ afer erwiderte, indem er erneut darauf hinwies, dał in den vergleichenden Betriebsrechnungen die Kosten für Verzinsung und Verteilungsenergie, ferner Verwaltung und Gewinn vergessen waren $^{6.187}$ ). H. Stracbe griff Schäfer heftig an, weil er gegen Wassergas als Kraftgas aufgetreten war ${ }^{\text {..155 }}$ ), obwohl die Erfahrungen der Gasmotorenfabriken Schäfers Ansichten, was die Kosten betraf, recht gaben.

Ein Retter in äufzerster Not wurde für Graz eine Strachesche Doppelgasanlage, die mit den dort zu findenden minderwertigen Kohlen ein Gas von $3200 \mathrm{kcal} / \mathrm{m}^{3}$ lieferte. Allerdings konnte mit $20 \%$ des wirklichen Bedarfes zunächst nur das

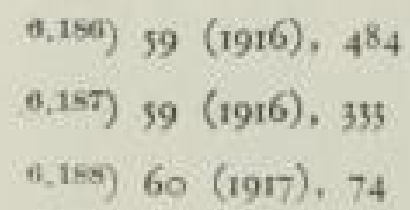




\section{Bild IIs}

Drehofen mit Doppeltrommel von Meguin (J. f. G. $68[1925]$ S. 132/33)
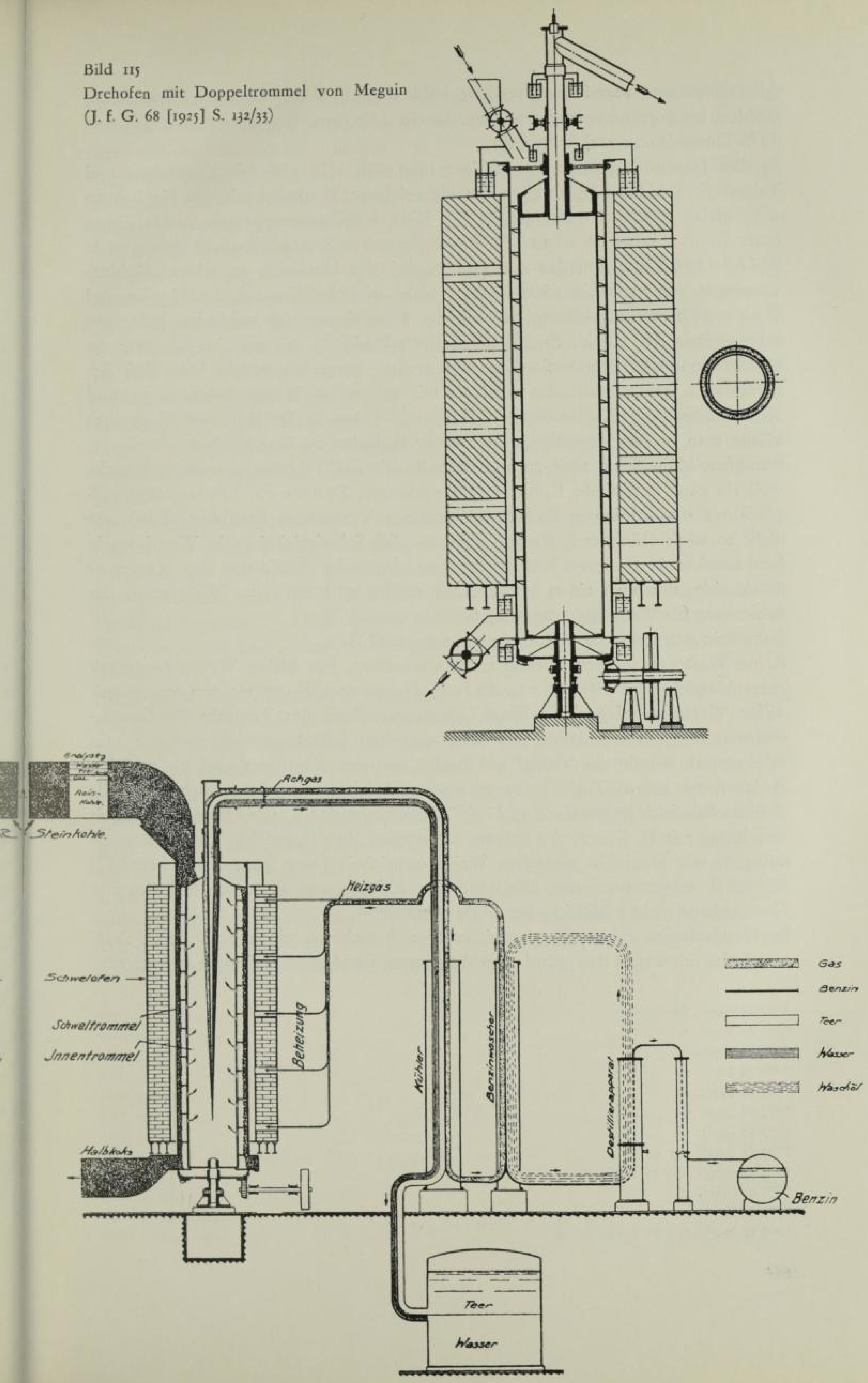
Allerschlimmste vermieden werden; baid darauf aber, nachdem brauchbare Kohlen herangekommen waren, wurde ein Mischgas mit dem Kohlengas (bei $60 \%$ Doppelgaszusatz) hergestelit.

In den folgenden Jahren beschäftigte man sich sehr viel mit Doppelgas und Trigas. F. Till melz verglich die übertriebene Werbung mit der für Schwelung gleich nach dem Kriegsende $\left.{ }^{6.159}\right)$. Eine Kohlenwassergasanlage für Zittau hatte Julius $P$ int $s c b$ erbaut ${ }^{9,100}$. Im Gegensatz zu Straches Ansicht kam aber A. Wilb el m, Zittau, zu der Auffassung, dał der Übergang zu reinem Kohlenwassergas mit 3300 bis $3600 \mathrm{kcal} / \mathrm{m}^{3}$ nicht wirtschaftlich sei. Scbipke und $V$ a te $r$, Chemnitz, erklärten sich mit der Doppelgasanlage zufrieden, jedenfalls solange jede Art Kohle, einschlief̧lich Braunkohle ${ }^{6.101}$ ), die man im Gaswerk ergattern konnte $\left.{ }^{0.102}\right)$ verarbeitet werden mufte. Immerhin wurde klar, dał der Koksmarkt weniger entlastet wird als mit getrennter Wassergaserzeugung und Koh'enentgasung. (Tullyanlage in Halifax) ${ }^{6.1083}$ ) und in St. Germain ${ }^{6.184}$ ). Jedoch könne man in der Doppelgasanlage mehr Kalorien zu Gas machen.

Frankfurt/Main hatte abcr gerade deshalb mit der Trigasanlage wenig Freude, weil sie ganz bestimmte Kohlensorten verlangte. $S c b$ euer, Landau, (Doppelgasanlage der Aktiengesellschaft für restlose Vergasung, Frankfurt/Main) war nicht so stark ablehnend. Er gab aber zu, dał Schwierigkeiten in Westdeutschland bestünden, geeignete Kohlensorten zu bekommen. Nötig war eben e ne reine Stückkohle, die auch einen festen Koks ergibt, weil sonst der Widerstand der Schichtung für Wassergaserzeugung zu hoch wurde ${ }^{6,155}$ ).

Immerhin wurden noch weitere Anlagen gebaut $\left.{ }^{0,1 t^{150}}\right)$.

Reine Wassergasanlagen blieben nicht unbeachtet. Für kleine Werke baute mit einer Magdeburger Firma Friedricb. Zerbst, nach einem eigenen System mit Eifer Wassergasanlagen ${ }^{6.107}$ ). Eine Zusammenstellung der Zentrale für Gasverwertung führte Iзо Anlagen mit einer gesamten Leistungsfähigkeit von 2 Mio $\mathrm{m}^{3} /$ Tag auf, wovon ein Viertel auf Berlin entfielen. Darunter sind viele kleine Anlagen mit $\left.200 \mathrm{~m}^{3} / \mathrm{Tag}^{\text {ni,1109}}\right)$. Einen in seiner Schärfe kaum begreiflichen Angriff richtete Friedrich gegen E. Go ff $\left.i n^{6,190}\right)$. Ebenso muß3te R. Ge ipert einen kleinen Krieg mit H. Stracbe führen, als er über Betriebsaufsicht von Wassergasanlagen, wie er sie in einfacher Weise entwickelt hatte, gesprochen hatte ${ }^{0.300}$ ) Sicherlich waren trotz des überstandenen Krieges und der höchsten Not die Gasfachleute nicht schläfrig oder müde geworden.

In Nordamerika setzte die American Gas Association einen besonderen Ausschuf ein, um wegen des geänderten Angebotes die Heił̧karburierung mit Schwer-

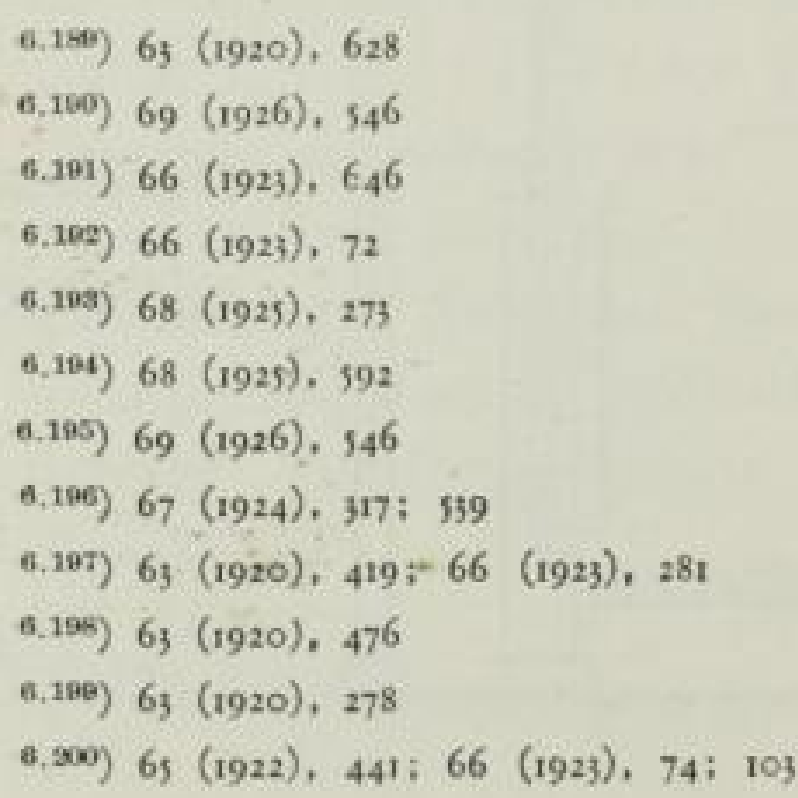


ölen statt wie bisher, mit den leichtesten Fraktionen zu untersuchen. Die Möglichkeit, auch schwere Öle zu verwenden, wurde erwiesen. Allerdings verminderte sich die Leistung der Anlagen ${ }^{6.001}$ ).

Englische Versuche über den thermischen Wirkungsgrad von Wassergasanlagen bestätigten die groß̧en Unterschiede von Einzeluntersuchungswerten und Bétriebszahlen. Jene ergaben unter Einschluf des gewonnenen Dampfes $70 \%$, ohne diesen $56 \%$, diese dagegen nur 56 und $46 \%$, c.00\%).

Ein altes Pferd zog End e rle, Ettlingen, aus dem Stall. Teer mit Wasserdampf vernebelt über glühenden Koks zur Bildung von Wassergasstarkgas zu benutzen. Ein entsprechender Generator wurde tatsächlich nach Untersuchungen von K. Bunte auch in Betrieb genommen ${ }^{3,200}$ ). Man kam bis auf $4200 \mathrm{kcal} / \mathrm{m}^{3}$, aber mit sehr hohem Dichteverhältnis, so daf̧ der Leitungsdruck füglich von 60 auf $80 \mathrm{~m} / \mathrm{m}$ erhöht werden muß̧te $\left.{ }^{0,994}\right)$.

Auffallend ist eine Mitteilung in der Zeitscbrift des Vereins Deutscher Ingenieure $^{6.200}$ ), daf̧ industriell Wassergas nicht nur für Schmiedefeucr, Muffelöfen, Weichmetallschmelzen im Tiegel, sondern sogar in Siemens-Martinöfen benutzt wurde ${ }^{0.200}$ ).

Eine Notmaf̧nahme war auch wohl der Torfkokssauggasbetrieb, den Julius Pintsch „mit gutem Erfolg" für einen Berliner Omnibus eingerichtet hatte ".2n).

Vorläufer für eine später gut entwickelte Technik waren die Kohlenstaubvergasungsversuche von R. T. Harlem und H. Harries im Massachussetts Technical Institute $\left.{ }^{\text {namy }}\right)$. Hauptschwicrigkeit war die Aufrechterhaitung der hohen Temperatur und eine innige Mischung von Staub und Luft. Die Luftvorwärmung betrug $1000^{\circ} \mathrm{C}$.

Noch mehr den Charakter vorbereitender Taten hatte die Sauerstoffvergasung von J. W. Cobb und H. J. Hodsman, die die Schriftleitung mit der Warnung vor Explosionsgefahren mit Sauerstoff glaubte anbringen zu müssen ${ }^{4.200}$ ). Sechs Jahre später sprach R. D r a we auf der Hauptversammlung des deutschen Vereins über die Fragen, ob mit Sauersto ff in kontinuierlichem Betriebe ein hochwertiges Gas erzeugt werden könne. Er führte damit die Öffentlichkeit in seine Arbeiten ein, die im Lurgidruckgasverfahren ihre Lösung finden sollten ${ }^{\text {6.20 }}$ ). Die ersten Versuche mit Untertagevergasung in Italien, mit dem damals schon erdachten Ziel, ein Schwachgas zur Elektrizitätserzeugung billig zu gewinnen, endeten mit einem Fehlschlag $\left.{ }^{6.21}\right)$. Auch als Gedankenbau blieb die Vergasung mit elektrischer Beheizung von Helfenstein, um die Energie des Überschufystromes im Koks zu speichern, stecken ${ }^{0.212}$ ).

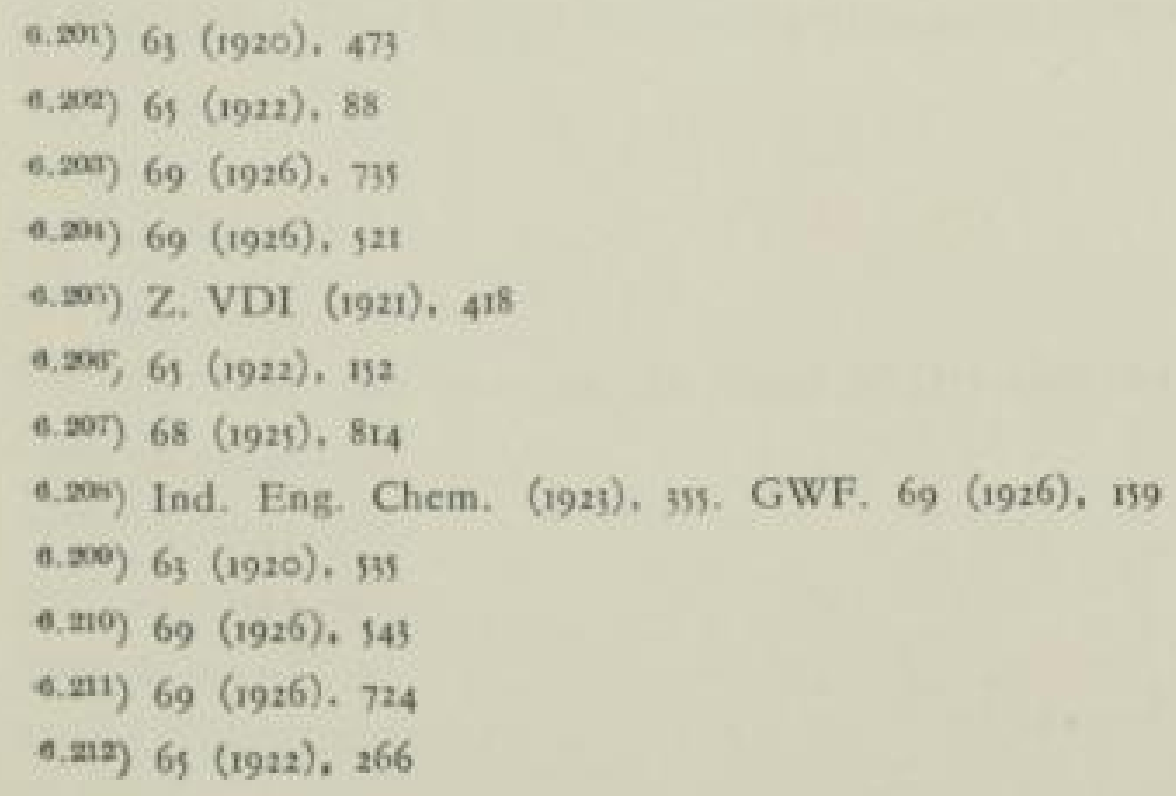


Pionierarbeit, wenn auch anderer Art, war das Dreiecksdiagramm der Vergasung von Wa. Ostwald $\left.d^{a .213}\right)$. Die Garantiebedingungen von F. Plenz, Gasinstitut, wurden mit Erläuterungen der Rechnungen, den Versuchsbedingungen und der Mef̧fehlerwahrscheinlichkeit 1926 bekannt $^{t .21}$ ). Post mortem wurde noch H. R. Trenklers Übersicht über die Patententwicklung bis zum Kerpely-Drehrost veröffentlicht ${ }^{4.915}$ ). Der DIN-Entwurf ${ }_{1356}$ über die Benennung technischer Gase kam damals heraus ${ }^{6.219}$ ).

\subsection{Andere Gaseund Robstoffe}

Not macht erfinderisch, läß̧t aber auch Verzweiflungsakte geschehen. So mag man die Versuche, Fichtenwaldböden zu vergasen, betrachten ${ }^{6,217}$ ). Holz hatte dagegen schon immer unter besonderen wirtschaftlichen Vorbedingungen als Rohstoff gedient. Im Kriege beschäftigte sich E. O $t t$, Zürich, mit Holz- und Torfentgasung $\left.{ }^{n .218}\right)$. Stockholm ging mit vieleriei Besonderheiten bei starker Abgasung zu Werke. Schrägretorten wurden zur Hälfte mit Holzkohle zum Zwecke der Gasspaltung und Anreicherung gefüllt, Holzscheite oben aufgelegt, und dann wurde ein wenig Steinkohle daraufgetan, deren Ammoniakdämpfe den Holzessig neutralisieren sollten $\left.{ }^{6.210}\right)$. Eine Übersicht von 1919 faß̧te die Arbeiten zusammen $\left.^{n, 20 x}\right)$. Die Klärschlammentgasung in Brünn wurde seit I9II mit Liebe und Erfolg betrieben ${ }^{n . m p}$ ).

Erdgas wurde in Pisa ausgenützt mit täglich ,vielen tausend Kubikmetern ${ }^{40,07}$ ). In Nordamerika wurden in Mio $\mathrm{m}^{3}$ benutzt: $1912 \mathrm{16}$; $1913 \mathrm{I6,5}$; 1915 18; 1916 21; 1925 33. Während des Krieges stieg der Anteil der Industrie um $26 \%$, der Hausbedarf sank anteilig um 10\%. Er machte 1925 noch $23 \%$ aus. Die erste genauere Nachricht über Propan- und Butangewinnung aus Erdgas mit Erläuterung der Zustandseigenschaften, des Heizwertes und über die Verwendungsarten erreichte Deutschland $1920^{6.223}$ )

F. Bergi us berichtete über seine 1913 begonnenen Arbeiten über die Hydrierung bei 120 bis 130 at und $430^{\circ} \mathrm{C}$ im Jahre $\left.1925^{6.25 n}\right)$.

Die Azetylenbeleuchtung belebte sich anfangs des Krieges wegen des Petroleummangels. Vor dem Kriege war die Zahl der Beleuchtungsanlagen von 40000 im Jahre 1906 auf die Hälfte zurückgegangen ${ }^{6.20}$ ).

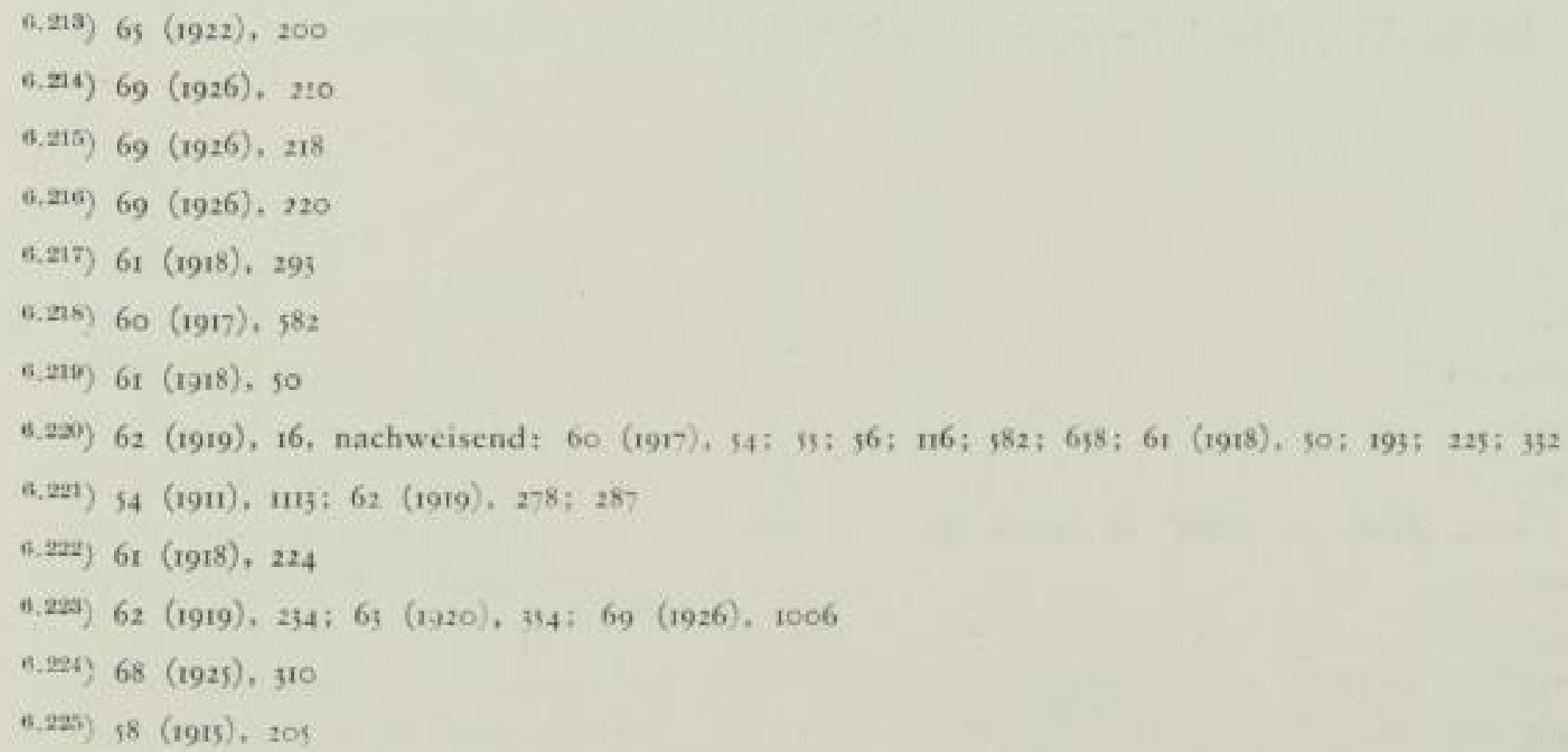


In der Entwicklung neuer Aufbereitungsverfahren brachte der Krieg eine ruhige Zeit.

Für die Ammoniakverwertung trat ein großjer Umschwung $\operatorname{ein}^{5.25}$ ). $\mathrm{Zu}$ Beginn des Krieges war ein Úberfluf an Stickstoff vorhanden. Das Ammoniak aus Kohlen konnte nur $1 / 3$ des laufenden Bedarfes decken. Die Kalkstickstoffwerke liefen, als schon erprobt, zuerst an. Die Vollendung bis zur Gleichheit mit der Kohlenammoniakgewinnung wurde nicht erreicht. Sie wurde abgebrochen, weil das Haber-Bosch-Verfahren die höchste Stickstoffausbeute bei geringstem Kohlenaufwand ergab und seit 1917 an der Versorgung teilnahm. Der Munitionsbedarf war gesichert, die Landwirtschaft erhielt nur die Hälfte des Friedensbedarfs. Nach dem Kriege war der Anteil der Gaswerke nur noch 5\% der Erzeugung.

Auf der Hauptversammlung von 1925 ging A. T b a u, Halle, alle Ammoniakverwertungsmöglichkeiten durch und beschrieb die Verfahren, Apparate und Sättiger mit dem Ergebnis, dał das Ammonsulfat für Gaswerke immer noch am günstigsten in der Herstellung sein würde $\left.{ }^{6.927}\right)$.

Die erste elektrische Gas-Reinigungsanlage für Hochofengase errichteten die Rheinischen Stahlwerke in Duisburg-Meiderich $\left.1924^{0.225}\right)$. Die Heißwäsche von Teeren mit Elektrofiltern war schwieriger wegen der isolierenden Durchführung der Hochspannungsdrähte. Die erste Cottrell-Möllersche Teerscheidung lief 1926 in einer westfälischen Zeche ${ }^{5,202}$ ).

Teer war auch nach dem Kriege noch ein begehrter Stoff. Er blieb wegen des Benzols und der leichten Teeröle bewirtschaftet. Verheizung war durch das Reichswirtschaftsministerium untersagt ${ }^{6.20}$ ). Die Anteilnahme an der Teerforschung war stark. Eine Zentrale für Asphalt- und Teerforschung wurde in Charlottenburg erstrebt $\left.{ }^{0.2 n}\right)$. nachdem Anregungen von $M o b r$, Altenburg, im Kriege nicht verfolgt werden konnten. Die Gewinnung der ersten Kunstharze (Cumarone aus Teerölen und Formaldehyd-Kondensationsprodukte aus Tieftemperaturteeren) wurden bereits auf Seite 438 erwähnt.

K. Goldscbmidt beschrieb die Anlagerung von Wasserstoff an Teerprodukte nach dem Berginverfahren zur Gewinnung von Benzin, Leucht- und Treibölen $\left.{ }^{0.2 y}\right)$. Mehr aber setzte sich das Gasfach für den Teerstraf̧enbau ein, als bekannt wurde, daf̧ in England im Jahre $1924500000 \mathrm{t}$ Teer für Straf̧en $(1 / 3$ der Erzeugung), in Deutschland nur $3000 \mathrm{t}$ gebraucht würden. Die Gaswerke wurden von $L \ddot{u}$ er, Essen, aufgefordert, sich örtlich um die sachgemäßze Ausführung der Arbeiten (Trockenheit, Temperaturen) zu kümmern ${ }^{0.223}$ ).

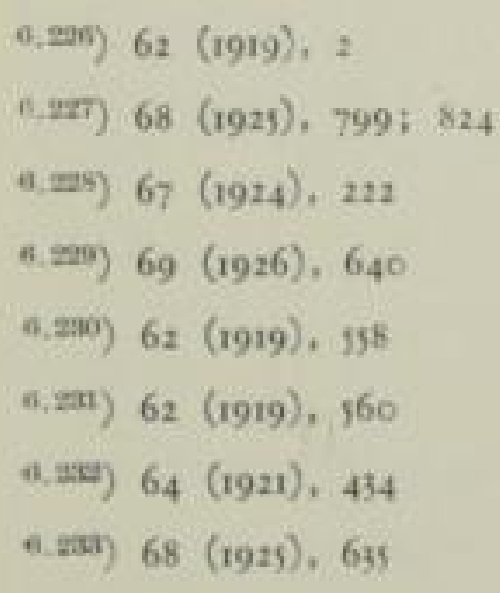


Besonders rege war man im Hannoverschen, wo man auf dem alten natürlichen Asphaltvorkommen aufbauen konnte. Eine gute Übersicht gab E. Müller, Celle ${ }^{6.24}$ ). Re in bard, Hildesheim, veranstaltete eine grofe Werbeveranstaltung unter Führung seines Werkes, auf der Vorträge über Erfahrungen in Celle, Braunschweig und Hildesheim gehalten wurden ${ }^{0.25}$ ).

Die Teerverarbeiter, Zechen und die Wirtschaftliche Vereinigung gründeten eine Auskunfts- und Beratungsstelle für Teetstraf̧enbau e. V. in Essen ${ }^{0.2 x}$ ).

Eine der wichtigsten kriegswirtschaftlichen Leistungen der Gaswerke wurde die Benzolauswaschung aus dem Gase; die in den grofen Werken, so schnell nur die Anlagen geschaffen werden konnten, nach dem Muster der Zechen eingerichtet wurden. Die Zensur hat die Veröffentlichung von Einzelheiten verhindert. Das ist aber wohl auch nicht als Lücke zu betrachten, da die Gaswerke im Kriege Ausführende von Befehlen waren.

Entschlüsse und Sorgen kamen erst nach dem Kriege, wo immer noch die Treibmittelknappheit herrschte, andererseits aber die Kohlen so knapp waren, dał das Benzol im Gase belassen werden mufte, um mit einem hohen Anteil von Wassergas noch einen einigermałen befriedigenden Heizwert zu erreichen. Ja, wo die Wassergaserzeugung nicht möglich war, kam man auf die schreckliche, starke Saugung als Aushilfsmittel ${ }^{6,237}$ ). Angesichts des Ringens um erträgliche Friedensbedingungen, bei dem Benzolablieferungsanforderungen in ungewisser Höhe erörtert wurden, muf̧te K. Bunte den mittleren und kleineren Gaswerken dringend abraten, sich der Benzolgewinnung zuzuwenden ${ }^{6.2 y}$ ). Im folgenden Jahre war die Lage wieder ganz anders. Die Entente hatte ihre Auflage mit 35000 t Benzol festgesetzt. Nun war es zwar erwünscht aus volkswirtschaftlichen Gründen, wo irgend möglich Benzol zu gewinnen ${ }^{6.2 x^{\circ}}$ ), aber dann brauchte man für den Hauptdienst am Kunden ausreichend Kohle. Aufjerdem gab es auch Schwierigkeiten infolge der Auswaschung des Benzols, wie etwa Wanderungen von Naphthalin im Rohrnetz und Gasmesserlederschrumpfungen ${ }^{6.810}$ ). Sehr bald wurde bei schon sinkenden Preisen die Frage eine Sache des Rechenstiftes. F. Sentke, Karlsruhe, verdiente noch gut, weil er statt Teerwaschöl Paraffin und Mineralöl verwendete $\left.^{n+2 t 1}\right)$. In Berlin stellte R. Geipert sehr bald fest, daf3 mit $20 \mathrm{Pfg}$. für das Vorprodukt die wirtschaftliche Grenze erreicht war ${ }^{6.24}$ ). Bald darauf wurde dort die Benzolanlage stillgelegt ${ }^{0.23}$ ).

Bei Bayer, Leverkusen, gebrauchte F. $R$ unk $e l$ zuerst aktive Holzkohle zur Benzolgewinnung $\left.{ }^{6.24}\right)$. Die Hauptkosten machte die Bereitstellung des Dampfes aus.

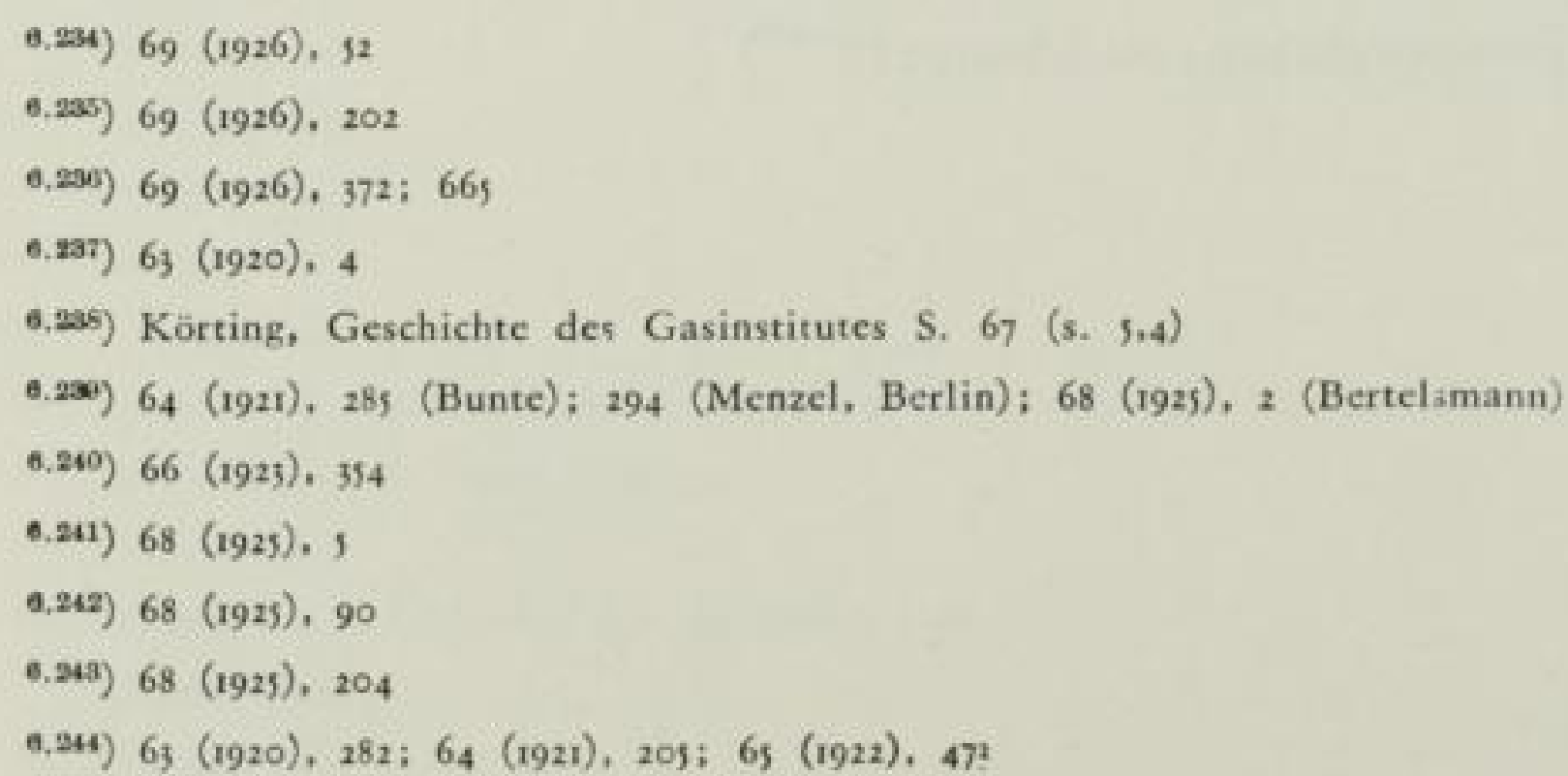




\section{$6.26 \mathrm{Koks}$}

Die Absatzmöglichkeiten von Koks waren zunächst nach Ausbruch des Krieges beschränkt, aber doch nicht so behindert, dał eine schwierige wirtschaftliche Lage entstand.

Anders war es mit dem Koksgrus. Deshalb machte $B$ e $b r$, Kolberg, seine Erfolge mit Koksgrusbrikettierung nach Rigaer Muster bekannt. Im Kleinzylinderformat fand er einen so guten Absatz zum Hausbrand, dał er Grus von anderen Werken zukaufen mufte. Er fertigte seine Briketts mit Hartpech als Bindemittel, das auf 300 bis $400^{\circ}$ erwärmt war. Die Briketts eigneten sich auch gut zur Unterfeuerung der Gaswerksöfen ${ }^{0.25}$ ). Der Deutsch-Luxemburgische Bergwerksverein stellte Formlinge mit Zement und Pech her (Patent 275 5II v. 31. 6. 23) ${ }^{\text {6.216 }}$ ). Ka $y$ ser, Vorstand der Zentrale für Koksverwertung besprach die verschiedenen Brikettierungsverfahren, die darauf hinausliefen, die notwendige Pechmenge zu vermindern. Er hat auch Versuche mit ihrer Vergasung und Verbrennung selbst auf Wanderrosten angestellt ${ }^{\text {b.227}}$ ). Eine Koksbrikettanlage von Humboldt, KölnKalk, arbeitete in Nürnberg. Leistung war 60 bis $70 \mathrm{t} / \mathrm{Tag}$, Teerbedarf 6 bis $8 \%$. Die Briketts waren für Dampfkessel, Hausbrand und Zusatz zum Unterfeuerungsgenerator geeignet, nicht aber zur Wassergaserzeugung.

Mit der Ausnützung der fühlbaren Wärme des Kokses bei der Löschung beschäftigte man sich schon vor dem Kriege. E. Schmiedt. Aschaffenburg, schrieb I9Is noch sehr skeptisch: Die rationelle Ausnützung der Kokswärme beim Kühlen sei unmöglich. Soviel bekannt sei, würde Ersticken des Kokses ans'att Löschen versucht, doch sei Näheres nicht zu erfahren ${ }^{6.260}$ ). Das Bonner Gaswerk $^{n, 209}$ ) hielt wohl noch mit Veröffentlichungen zurück. H. Wunderlich, Karlsbad, ist wohl der Mann, der das Verfahren technisch reifen lief. Er hat im Kleinen Versuche angestellt ${ }^{\text {a.2.50 }}$ ) und das Vorbild für das Schweizer Verfahren von Gebr. Sulzer, Winterthur, gegeben $\left.{ }^{0.551}\right)$. 1922 berichtete F. $K u c k u k$ über die trockene Kokskühlung nach Sulzer in Zütich ${ }^{\text {6.2ng }}$ ) und P. Eit ne r sprach über die physikalischen und chemischen Grundlagen ${ }^{0.255}$ ). Besonders trat er Befürchtungen, es möge wegen des Kohlenmonoxydgehaltes der Spülgase zu Verpuffungen kommen, entgegen. Die Kokslöschung mit Dampf und Wassergasgewinnung nach Heller-Bamag wurde 1925 beschrieben $\left.{ }^{0.24}\right)$. An den neuen Koksöfen in KielWik wurde eine trockene Kokskühlung eingebaut, um den Dampfbedarf für das mit dem Gaswerk gekuppelte Elektrizitätswerk zu decken. Die Anlagekosten würden in einem Jahr abgedeckt werden ${ }^{0.25}$ ).

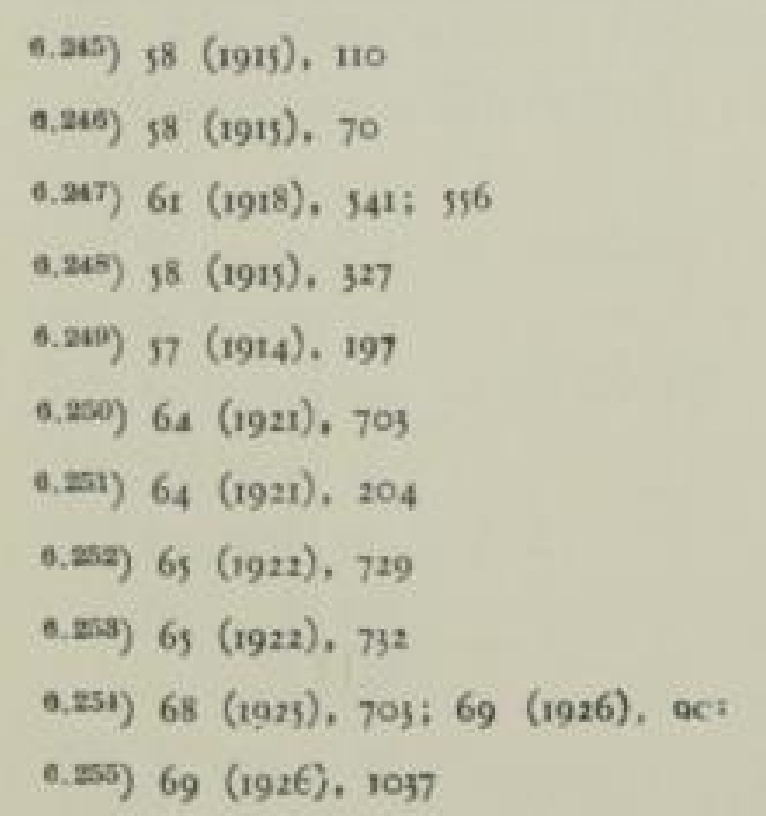


Damit war wohl der wunde Punkt kenntlich gemacht, weshalb die Gaswerke zurückhaltend waren. Der erzeugte Dampf stand im Wettbewerb mit dem aus Koksgrusfeuerungen entwickelten und wurde zu gering bewertet. Wollte man mit dem Dampf Elektrizität erzeugen und den Strom verkaufen, so bcten die Stromversorgungsunternehmen im allgemeinen unzureichende Preise. In Rotterdam-Keilehaven wurde 1922 eine Sulzeranlage eingebaut, die sich als sehr vorteilhaft erwies $\left.{ }^{6.250}\right)$.

Deshalb versuchten die Gaswerke auf verschiedene Weise, den Koks bei der Wasserlöschung möglichst zu schonen. Geringe Wassermengen waren in Frankfurt-Heddernheim nötig, wo zweistufig der Koks zunächst in Kübeln mit Brausen berieselt wurde, danach der Kübel abgedeckt und der sich entwickelnde Dampf zum Ersticken benutzt wurde ${ }^{0.277}$ ). Auch in Augsburg wurde der Koks mit Kübelwagen glühend zu dem am Ende der Batterie stehenden Berieselungsturm gefahren ${ }^{6,25}$ ).

Als Absatzgebiet wurde die Verfeuerung von Koks in Dampfkesseln umworben. Viele Versuche mit dem Wanderrost wurden unternommen, als Steinmüller mit dem Pendelstauer den starken Verlust bei ungleichem Ausbrand mindern konnte $\left.^{(6,250}\right)$. Auf der Hauptversammlung des Vereins deutscher Ingenieure trat $B r a b b e ́ e$, ein anerkannter Heizungswissenschaftler, für die Entgasung aller nur irgend geeigneten Kohlen vor der Verfeuerung $\operatorname{ein}^{6.306}$ ). G. Klingenberg, der Fachmann für grołe Elektrizitätswerke, konnte allerdings den Optimismus einer Verbilligung nicht teilen. In Delmenhorst aber hatte G. Franke günstige Ergebnisse, als er seit 1923 etwa $50 \%$ der erzeugten Koksmengen an das Elektrizitätswerk abgab $\left.{ }^{6.20]}\right)$. Bei einem groß̧en Gaswerk zeigte ein sorgfältiger Vergleich zwischen Grus, Koksbrikett und Kesselkohlen, dał die Grusverfeuerung den billigsten Dampf ergab. Eine Bedingung, geringe Rostbelastung, muf3te allerdings beachtet werden $\left.{ }^{0.203}\right)$. Natürlich war das Ergebnis nicht zu verallgemeinern, weil sehr starke Verschiedenheiten in den Preisen von Ort zu Ort vorhanden waren.

Von bleibendem Wert aber sollten die Bemühungen der heiztechnischen Landeskommission für das Hafnergewerbe in München sein, den Dauerbrandofen für Koks geeigneter zu machen $\left.{ }^{6,23 a}\right)$. Der Ofen wurde vom bayerischen Wärmewirtschaftsverband, C. Eberle, Darmstadt, und dem Gasinstitut geprüft und für gut befunden, danach als Dauerbrandofen Oranier von den Franck'schen Eisenwerken Niederscheld hergestellt und vertrieben.

Um die Güte des Kokses zu verbessern, breiteten sich Mahl- und Mischanlagen aus $\left.^{(., 0 u}\right)$. Über die Kohlenbeurteilung und besonders die Reaktionsfähigkeit arbei-

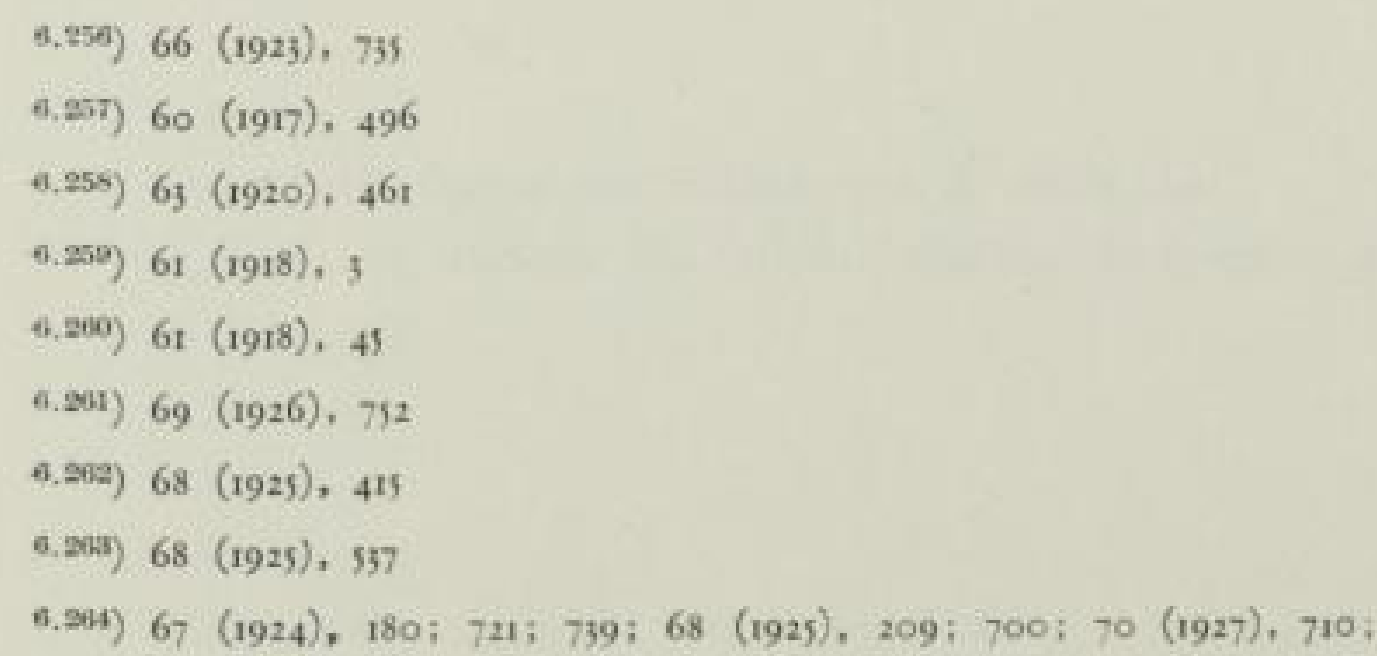


teten mehrere Forscher ${ }^{0.25}$ ). Nach eingehenden Versuchen schrieb die Oberpostdirektion Düsseldorf vor, für alle Dienstgebäude Gaskoks zu verwenden ${ }^{6.200}$ ).

Eine Zeitkrankheit waren die verschiedenen Schlackenscheider durch Trommel und Walze im Wasser, Magnettrommel, Flotation, auch mit spezifisch schwererer Flüssigkeit ${ }^{0.0 \pi 5}$, und die darauf aufgebaute Schlackensteinfertigung der Gaswerke $\left.{ }^{0.025}\right)$.

\subsection{Heizwert und Brenneigenscbaften}

Heizwert und Brenneigenschaften sind so entscheidend für die Verwertbarkeit des Gases, dafy man im allgemeinen diese Dinge in Verbindung mit der Gasverwendung am klarsten bespricht. In der betrachteten Kriegs- und Nachkriegszeit ist ihre Wahl - oder sollte man besser sagen? - ihr zufälliges Herauskommen so stark durch die Behinderungen der Gasherstellung hervorgerufen, dał es richtig erscheint, die Besprechung nach vorn zu ziehen.

Schon in der Zeit vor dem Kriege hatte sich, wie geschildert, die Freiheit in der Wahl der Erzeugungsverfahren dahin ausgewirkt, daf̧ die führenden Fachleute mahnten, eine einheitliche Verbrennungswärme von 5200 bis $5000 \mathrm{kcal} / \mathrm{m}^{3}$ einzuhalten. Im Kriege aber und vor ailem nacher sank der Wert noch mehr und in ganz verschiedenem Maß̧e. Allein die Benzolauswaschung brachte eine Senkung von $10 \%$ und mehr mit sich, die angesichts des festen Kontingents nicht durch verminderten Wassergaszusatz ausgeglichen werden konnte. Man stellte mit Befriedigung fest, dał Störungen dabei nicht gemeldet worden waren. Das gleiche war auch im Kohlenlande England geschehen. Dort lag der obere Heizwert zwischen 4700 und $\left.4000 \mathrm{kcal} / \mathrm{m}^{36.200}\right)$. In Deutschland war man sich einig, dał nach dem Kriege eine Norm vorgesehen werden müsse, wenn nicht weitere Schäden, besonders bei der Beleuchtung, eintreten sollten. Über die Höhe des wirtschaftlich besten Wertes sah man aber durchaus nicht klar. K. Bunte schlug $4700 \mathrm{kcal} / \mathrm{m}^{2}$ vor und kam damit in den Bereich, der sich bei Zechen natürlich ergab $\left.{ }^{6,209}\right)$. E. Körting stellte dagegen fest, daf̧ die üblichen Geräte auch noch bei 4200 bis $4100 \mathrm{kcal} / \mathrm{Nm}^{3}$ einwandfrei gearbeitet hätten ${ }^{6.211}$ ). Gegen beide Vorschläge wandtc sich aber mit grof̧er Schärfe und jahrelang mit Hartnäckigkeit R. Terbaerst, Nürnberg, der $5000 \mathrm{kcal} / \mathrm{Nm}^{3}$ wiedersehen wollte. Er behauptete, durch seine Versuche festgestellt zu haben, daf3 der Wirkungsgrad der Geräte stärker absänke, als die zugefügten Kalorien des Wassergases ausmachten $^{\text {n.2rz }}$ ).

Alle diese Vorschläge waren aber noch während des Krieges ausgesprochen worden, als man keine Vorstellungen davon hatte, welche Schwierigkeiten nachher der deutschen Wirtschaft bereitet werden würden.

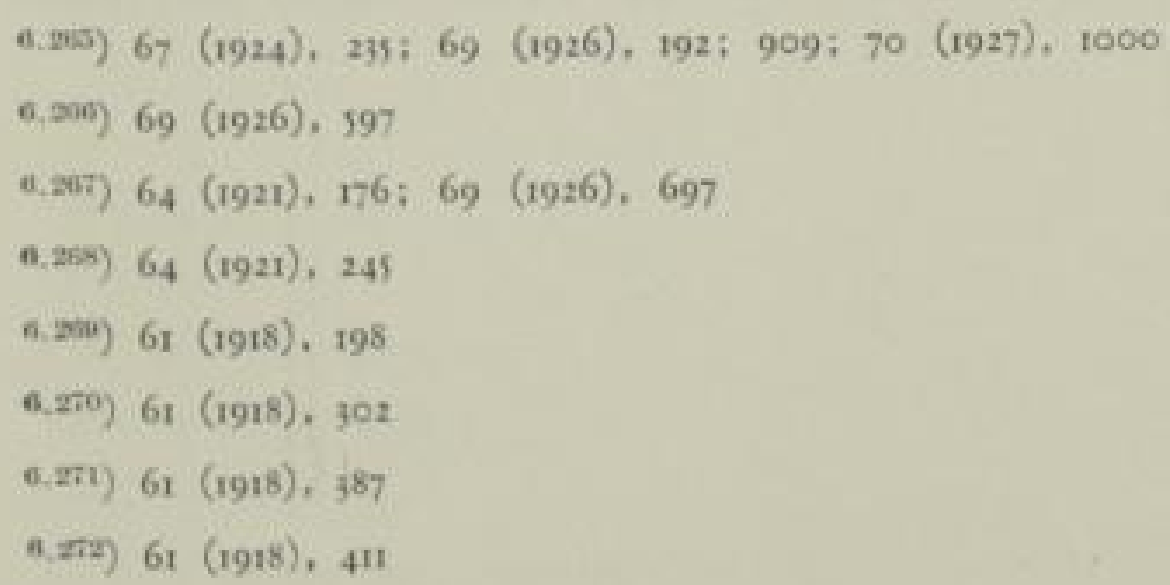


Das Beispiel des früher so konservativen England war nicht gerade ermutigend für die Forderungen nach Einheitlichkeit. Dort hatte der Fuel Research Board schon seit 1917 ein Gutachten über den bestgeeigneten Heizwert gefordert. Dieses Verlangen war übrigens, wie sich einmal K. Bunte ausgedrückt hat, bei der Menge der zu berücksichtigenden, aber kaum genau zu errechnenden Einflüsse der Pilatusfrage nach der Wahrheit ebenbürtig. Die Antwort, der Bericht von 1919, war dann auch in England ein Versuch, den Gaswerken eine nie vorher gehabte Freiheit zu gewähren, damit sich das rechte Mał von selbst durch freie Wirtschaftskräfte einstelle. Es war der Vorschlag, das Gas nach Wärmeeinheiten zu verkaufen und den Gaswerken vier Heizwerte zur Auswahl zu überlassen, und zwar: $3550,3850,4150$ oder $4450 \mathrm{kcal} / \mathrm{m}^{3}$. Ferner wurde verlangt: Freiheit von Schwefelwasserstoff, aber keine Aussage über organische Schwefelverbindungen, dagegen Beschränkung der inerten Gasbestandteile auf $\left.{ }_{12} \%{ }^{4,275}\right)$. Die dem Bericht von deutscher Seite angefügte Frage, wie bei so weiten Grenzen die Gerätehersteller zurechtkommen könnten, war nur zu berechtigt. Durch die umfangreichen Versuche über den Wirkungsgrad von Kochern und Leuchten waren sie jedenfalls keinesfalls gelöst ${ }^{0.07 t}$ ).

Die Beratungen wurden in Deutschland nach zwei Richtungen gelenkt, von Gaswerksseite muß̧te die Wirtschaftlichkeit abgeschätzt werden, was bei den stark schwankenden Preisverhältnissen kaum gelang. Terhaerst machte sich die Sache etwas leicht, wenn er den hohen Heizwert verlangte und dazu die Forderung aussprach, daß darum die Kohlenversorgung gebessert werden müsse ${ }^{0.275}$ ). Die Erörterungen der Gaswerke muften auch die Wertverhältnisse der Erzeugungsarten umfassen, wollte doch $S t r a c b e$ wegen der Doppelgasversorgung einen oberen Heizwert von 3200 bis $3500 \mathrm{kcal} / \mathrm{m}^{3}$ festgesetzt haben ${ }^{6.20}$ ).

Auf der anderen Seite war K. Bunte emsig tätig, die bereits vom chemischtechnischen Institut erarbeiteten Erkenntnisse über die Brenneigenschaften, die im Kriege recht gut fortgesetzt waren (E. Terres und Mitarbeiter und M.

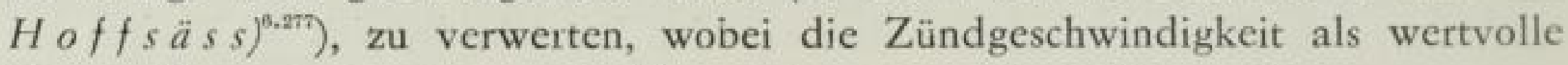
Kenngröße unter immer neuen Voraussetzungen untersucht wurde.

Die restlos durcheinander geratene Kohlenlage war aber dann wohl der Grund, warum in der Hauptversammlung zu Krummhübel nach dem Vortrag des Vorsitzenden F. Tillmet $z$ die Richtlinien mit der niedrigst möglichen Verbrennungswärme von 4000 bis $4300 \mathrm{kcal} / \mathrm{Nm}^{3}$ angenommen wurden ${ }^{0,275}$ ). Wichtige $\mathrm{Be}$ stimmungen waren noch ein Dichteverhältnis unter 0,5 , Inerte unter $15 \%$, Reinheit von Schwefelwasserstoff, Ammoniak und Teer und vor allem Gleichmäßjigkeit über die Zeit hin. Das waren unter den gegebenen Verhältnissen hohe Anforderungen. Deshalb sah man auch von einer Norm ab und gab nur Richtlinien. Sobald die Geräte mit ihren Brennern ihnen angepaf3t waren, konnte man ohne Schwierigkeit, ja bei vielen Geräten besser als mit reinem Kohlengas, mit dem Gase arbeiten.

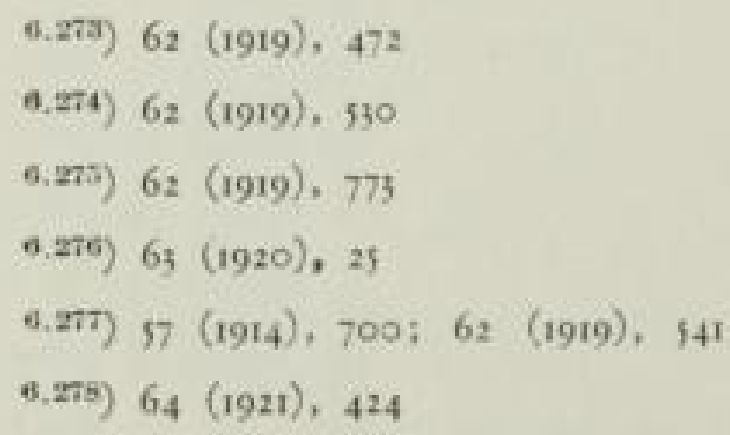


Im Anschluf̧ an die Beratungen wurde von sechs angesehenen Fachleuten die Verteilung des Gases mit höherem Druck gefordert. Es waren das: P. Spaleck; E. Körting; K. Bunte; H. Stracbe; L. Scbomburg, Gelsenkirchen; W. Ferbers, Waldenburg $\left.{ }^{6,2 \pi 7}\right)$. Letzterer hatte einen Teil seines Netzes mit Drücken bis $200 \mathrm{~mm}$ ohne erhöhte Verluste und ohne Nachteile tür die Abnehmer betrieben. Leider wurde dieser Mahnung nicht die Beachtung zuteil, die sie verdient hätte.

Aber es bedurfte schon umfassender Anstrengungen, um überhaupt diesen Richtlinien Anerkennung zu verschaffen. Die Gasfachleute der Vereinigten Staaten hatten zwar 1920 ebenfalls überlegt, von 5200 auf 4000 ja $3500 \mathrm{kcal} / \mathrm{Nm}^{3}$ zurückzugehen $^{6.50}$ ). Das war aber noch im letzten Augenblick der für dauernd gehaltenen Weltkohlenknappheit. Nach dem Umschwung dort gegen Ende des Jahres hatte man von Änderungen abgesehen.

In dem dem Beschluf folgenden Jahre mufzte K. Bunte noch einmal über die Gesichtspunkte für die Gasbeschaffenheit eine umfassende Erläuterung geben ${ }^{8.201}$ ). „Die deutsche Gasindustrie muł also zunächst sich selbst, dann aber endlich auch die breite Masse zur Überzeugung bringen, daß3 der Wassergaszusatz nicht ein letzter Rest von Kriegsersatz ist, den man sobald wie möglich beseitigt, sondern eine klare, sachlich durchaus berechtigte, technisch und wirtschaftlich richtige Maßnahme."

In der Erörterung mufte einem als tüchtigem Ingenieur bekanntem Fachmann noch die Aufklärung gegeben werden, dał̇ im geschlossenen Glühofen keineswegs Heizwert und Temperatur voneinander abhängig $\left.\operatorname{seien}^{6.23 \pi}\right)$. E. $S c b u$ $m a c b e r$. Frankfurt, bestätigte, daf̧ erst durch den Wassergaszusatz austauschbare Mischgase erzielt waren, die in zwei Werken mit verschiedenartigen Öfen hergestellt wurden.

Noch 1924 war W. Bertelsmann, Berlin, auf der Hauptversammlung des Vereins für die Aufhebung der Schranke für die Inerten eingetreten ${ }^{6.2 x}$ ). Er fand aber sehr lebhaften W/iderspruch, auch von Schweizer Seite $\left.{ }^{0,234}\right)$.

\subsection{Betriebsaufsicbt}

Den vielfachen Arbeiten an den Betriebsmefggeräten kann man auch in diesem Abschnitt nicht gerecht werden, wenn man nicht zu weitschweifig werden will. Es müssen einige wenige Angaben genügen.

Als Kalorimeter herrschten die Junkersschen Modelle in ihren verschiedenen Ausführungen als Hand-, Reise- und schreibendes Betriebskalorimeter in den Werken vor.

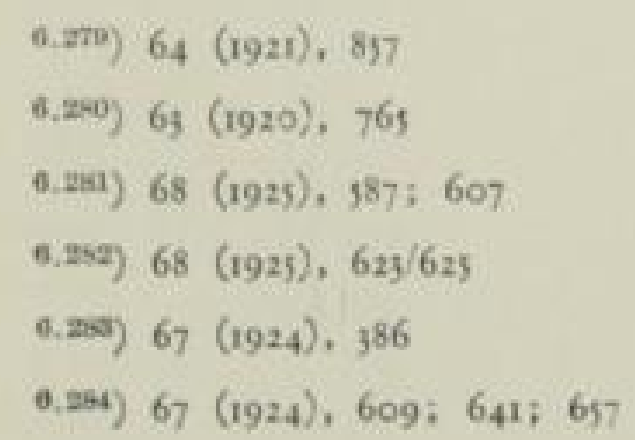


Das Kalorimeter von O. Dom mer, Karlsruhe, wurde als Verbesserung des Stracheschen Modeils angesprochen. Es teilte mit ihm den Vorzug, mit kleinen Gasmengen auszukommen $\left.{ }^{p \cdot s k}\right)$. Aus England kam eine Warnung, sich nicht auf die schreibenden Kalorimeter zu verlassen. Sie seien mit Handkalorimetern nachzuprüfen, sonst könne man grofe Verluste erleiden $\left.{ }^{0.250}\right)$. Das entsprach aber der deutschen Handhabung.

Do m me $r$ lief̧ den Union Gasdichteschreiber und den Heizwertschreiber folgen, die vom Gasinstitut untersucht und für gut befunden wurden ${ }^{0.25}$ ).

Vielfältig war die Beschäftigung mit Reglern aller Art. Ja, man kann sagen, dał der moderne Reglerbau nach dem ersten Kriege seinen Anfang nahm und vom Gasfach stark beeinflufyt wurde.

Der Gasselbstschlief̧er von Junkers kann als Vorläufer der Zündflammensicherungen angesprochen werden. Er benützte noch Stäbe verschiedenen Ausdehnungsmafes über den Brennerflammen, die mit Kniehebeln und einer $\mathrm{Ab}$ reiß̧kante arbeiteten. Der Hahn wurde dann durch einen schweren Griff geschlossen ${ }^{\text {4..255) }}$ ).

Der Regler der Gesellschaft für selbständige Temperaturregelung mit Hilfsenergie (Wasser), von A. Albrecbt angegeben, wurde für Gasbacköfen eingesetzt $\left.^{0.250}\right)$. 1925 wurde bereits eine außjerordentlich große Zahl von Temperaturreglern beschrieben, wobei auch ein Bild des Regulo von Kromschröder. Osnabrück, mit Hilfsgasstrom gezeigt war $\left.{ }^{60200}\right)$. Genau beschrieben ist dieser Regler so, wie er auch heute noch grundsätzlich ausgeführt wird und bekannt ist. von Dietz im folgenden Jahre $\left.{ }^{6.201}\right)$. Mit ihm war ein entscheidender Schritt zur Vollkommenheit der Temperaturregelung getan.

Die Firma Josef Heinz Reinecke - Physikalisches Laboratorium und Apparatebau in Bochum -, die zunächst vorwiegend auf dem Gebiete der drahtlosen Telephonie gearbeitet hatte, baute zur Bestimmung des Benzolauswaschungsgrades ein Gerät, das die Leuchtkraft des ungewaschenen mit der des entbenzolierten Gases verglich. Dazu war eine feinfühlige Druckregelung nötig. Das führte zur Herstellung des indirekt arbeitenden Zweimotorenreglers, der berechtigtes Aufsehen erregte. Ihm folgte, vom Aufstellungsplatz unabhängiger, der hydraulische Kraftbügelregler ${ }^{8,222}$ ).

Vom Druckmesser mit sorgfältig ausgewogener Metallmembran ${ }^{0.25}$ ) kam die Firma Carl Bamberg, Friedenau (später Askaniawerke A. G.), zum Kammerofendruckregler (Absaugungsregler) mit Strahlrohr, der sich über die ganze Welt verbreitet hat $\left.{ }^{\text {n:sar }}\right)$. Ein einfacher Regler mit Staurändern und Wasserspiegeln von Liese, Hamburg (Ausführung Bamag), arbeitete ebenfalls gut ${ }^{0,255}$ ).

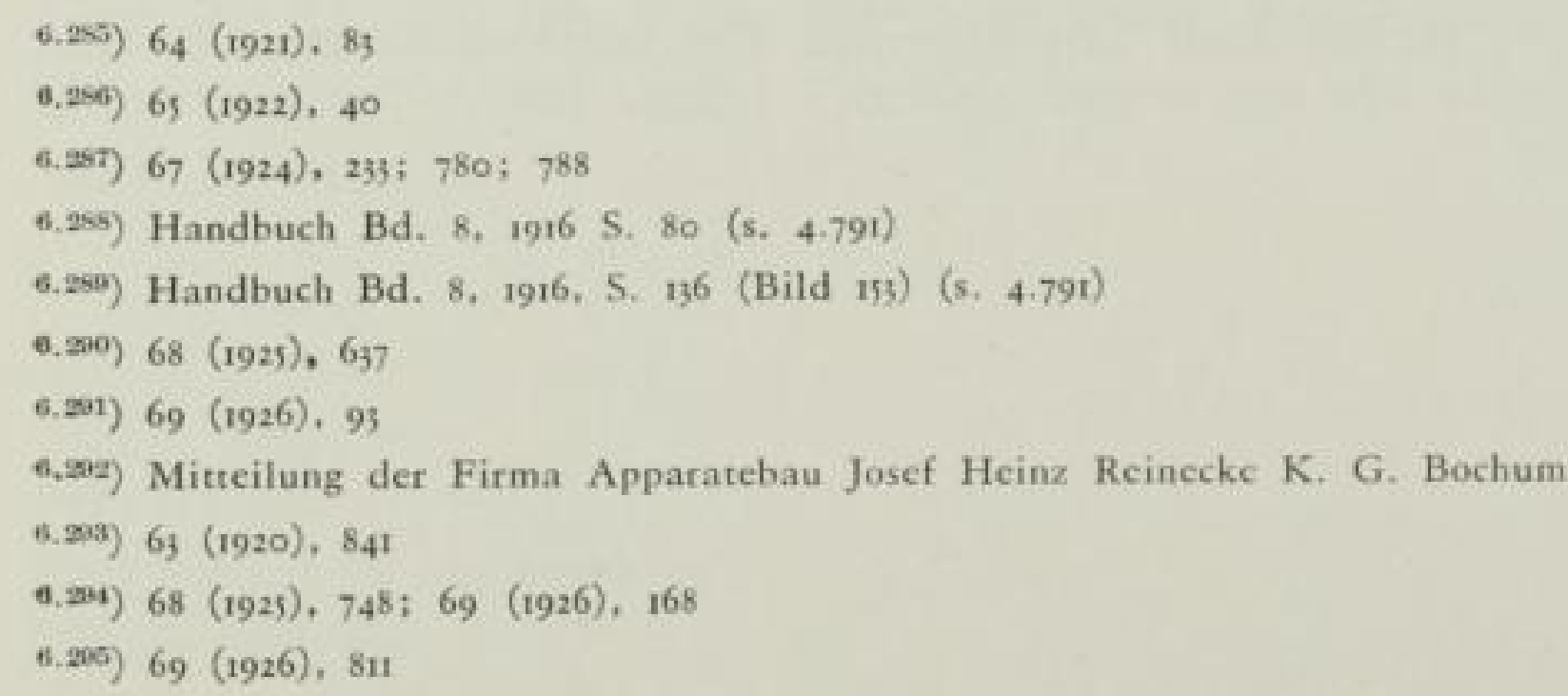




\subsection{Robre und Robrleitungen}

Die Arbeiten an neuen Rohrnormen wurden durch den Krieg gestört. Es gab so viele Augenblickssorgen, dafy keine Aussprachen über weiter in die Zukunft weisende grundsätzliche Fragen möglich waren. So konnte auch keine Einigung mit dem Guf̧rohrverband über neu gewünschte Längen erzielt werden ${ }^{4.20}$ ).

Viel mehr Sorgen machte die Beschaffung der Rohre und Hilfsstoffe. Nur wegen des Mangels an Dichtungsstoffen ging Zürich dazu über, Mannesmannrohre zu verschweifen, und zwar, wie auch schon in Pasing vor dem Kriege, mit gutem Erfolge $^{0.027}$ ).

Schlimmer waren Vorschläge, als Ersatz geleimte Papierrohre auch für Gas zu verwenden, wenn man auch nur an kleine Durchmesser gedacht hat $\left.{ }^{(.25)}\right)$. Auch Betonrohre, wie sie J. G. W iebeng a in Holland auch für Gas mit hohem Druck verwenden wollte, waren keineswegs gasdicht ${ }^{\text {(.2000 }}$ ).

Eine grundsätzliche Umstellung brachte der Krieg wegen des Anschlusses der Blitzableiter an Gas- und Wasserrohrnetze. Ursache war die gewandelte Ansicht über wirkungsvolle Blitzschutzanlagen. Die hohen Auffangstangen Franklins wurden als weniger wirksam erkannt als eine Schutzanlage, bei der möglichst alle Metallteile, die an einem Hause vorhanden waren, leitend verbunden und so Teile der Schutzanlagen wurden ${ }^{6.300}$ ). Waren diese Installationen auch zunächst nur für die Kriegsdauer gedacht, so wurden sie doch in den neuen Richtlinien von $192 \mathrm{I}$ entgültig verankert. Gaszähler muß̧ten durch eine Leitung überbrückt werden ${ }^{6.301}$ ). Wieder wurde über Gummidichtungen gestritten. Oberhausen hatte mit dem im Bergbaugebiet ungewöhnlichen Druck von $75 \mathrm{~m} / \mathrm{m} \mathrm{W}$. S. seit 22 Jahren gute Erfahrungen gesammelt $\left.{ }^{0.005}\right)$. Auch Gelsenkirchen, Rheinisch-Westfälisches Elektrizitätswerk und Hamburg waren zufrieden. Mit aufrichtiger Freude wurde vermerkt, als über diese Gummidichtungen eine sachlich technische Anfrage aus England als erstes wahres Friedenszeichen einlief ${ }^{\text {f.3ng }}$ ).

Auch ein später noch mehrmals versuchter Einsatz der im Kriege zur Suche nach Verwundeten so bewährten Spürhunde im Rohrnetz wurde ernsthaft durch Universität Greifswald untersucht mit dem Ergebnis, daf die Hunde als Gassucher völlig versagt hatten $\left.{ }^{0.500}\right)$.

Die Wünsche einiger Fachleute, bei dem geminderten Heizwert einen Ausgleich durch Druckerhöhung im Netz bis zum äuß̧ersten Abnehmer zu gewähren, wurde bereits auf Seite 451 berührt. Selbstverständlich hat diese Frage das Fach nicht nur einmal, sondern mehrere Jahre beschäftigt, ja sie ist heute noch nicht endgültig erledigt.

\footnotetext{
6.1200) 58 (1915), 386

6. \$7) 99 (1916), 577

a.216) $60(1917), 221$

6. 2007) 64 (1920), 11

a.2009) 61 (

6.501) $64(192 v), 428$

0.302) 65 (1922), 282

s.303) 66 (1923), 693

0.304) 68 (1925), 188
} 
Im Jahre 1917 meinte der Röhrenausschuf, eine Druckerhöhung im Niederdrucknetz auf 100 bis $150 \mathrm{~m} / \mathrm{m}$ würde den Abnehmern keine Vorteile, ja wegen der Umstellung der Geräte sogar nur Nachteile bringen ${ }^{n, 305}$ ). Das war wohl unter Berücksichtigung der Arbeitslage im Kriege recht gesehen und so ist verständlich, daf̧ nach dem Waffenstillstand der Ausschuf ausdrücklich beauftragt wurde, die Vor- und Nachteile der Gasverteilung unter erhöhtem Druck gründlich zu beraten $\left.^{0.320}\right)$. Eis ele schlug im Dezember 1919 sehr dringend vor, fortan einen höheren Verteilungsdruck anzuwenden; dazu berichtete $M e n z e l$, dał er in Königshütte mit Erfolg $200 \mathrm{~m} / \mathrm{m}$ WS. gehalten habe, wobei der Behälter mit Gewichten beschwert war $\left.{ }^{0.30}\right)$. Diese Technik griff F. $S c b a ̈ f e r$ scharf an ${ }^{0.000}$ ), er mufte aber eine humorvolle Antwort Eiseles hinnehmen ${ }^{\text {6.smen }}$ ). Inzwischen kam die schon erwähnte Aussprache in Krummhübel. Besonders weit ausholende Versuche hatte P. $S_{p}$ a le $c k$, unternommen, deren Ergebnis leider nicht vollständig im Schrifttum festgehalten ist. Er hat für alle Haushaltsgeräte Vorteile in der Verbrennung, ganz abgesehen von der genau möglichen Druckregelung festgestellt $\left.^{6.310}\right)$. Jedenfalls erklärte der Röhrenausschuß̧, dał̧ man ohne Gefahren auf $200 \mathrm{~m} / \mathrm{m}$ Druck im Netz gehen könne. Der Rheinisch-Westfälische Verein trat dieser Erklärung bei $\left.{ }^{6.311}\right)$. Leider aber kam man nicht dazu, so hohe Vordrücke vor den Geräten wirklich allgemein einzuführen.

Der ohne Frage größjte Entschlu\} wurde bereits auf den Seiten $426 / 27$ angedeutet. Er muf̧ hier noch ausführlicher beschrieben werden.

Überall regten sich die Gasfachleute nach der Währungsreform und Überwindung der ersten Geldknappheit, die ausgereifte Rohrleitungstechnik zur Erweiterung ihre Absatzgebietes auszunützen.

Die schon bestehende Gasversorgung Rheingau schloł Niederwalluf und Eltville an. Besonders rege wat die Thüringer Gasgesellschaft mit den Nordharzer Kraftwerken G. m. b. H. Goslar und den Westharzer Kraftwagen A. G. in Osterode mit Leitungen nach Bad Grund, Clausthal-Zellerfeld, Hahnenklee, Bad Lauterberg $\left.{ }^{6,319}\right)$. Ferner wurden erbaut die Strecken zu den grofen Ostseebädern von Swinemünde bis Zinnowitz $\left.{ }^{6.313}\right)$, Rostock-Warnemünde, Villingen-Schwenningen $\left.^{0.314}\right)$. Frankenstein-Silberberg in Schlesien, Reichenbach in Schlesien mit Anschluf der Landgemeinden, Augsburg desgleichen ${ }^{\text {e.s15 }}$ ). We i g el, Niederbarnim, belegte die wirtschaftliche Berechtigung solcher Leitungen, die viel billiger käme als der Neubau kleinster Werke $\left.{ }^{6.310}\right)$. Der Jahresbericht des Vereins beschäftigte sich mit diesen vielen Ferngasplänen ${ }^{n .317}$ ). Neu gegründet wurde das Fcrngaswerk

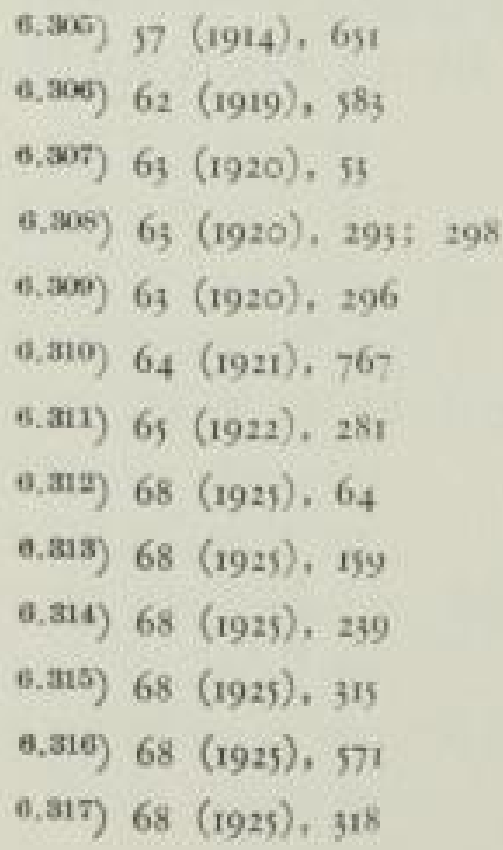


Erfurt A.-G. $\left.{ }^{6.351}\right)$. Die Gasversorgung Westsachsen A-G. stützte sich auf das Zwickauer Gaswerk und auf das Überschufggas des Erzgebirgischen SteinkohlenAktienvereines. Neu war auch der Fernversorgungsverband Hohenstein-Ernstthal und die Leitung von Köln nach Gummersbach, mit der Berohrung des gewerblich lebhaften Aggertals ${ }^{\text {a.min }}$ ). Mannheim schlof3 Vororte, Ladenburg, Edingen, Friedrichsfeld und schlief̧lich Weinheim an $\left.{ }^{6.5 m}\right)$. Lübeck unterdükerte die Trave zum Anschlu\} an seine Leitung nach Travemünde ${ }^{0.2 x}$ ). Mühlhausen (Thüringen) hatte Pläne im Eichsfeld bis Langensalza, ${ }^{6,207}$ ).

Nunmehr kam es zu viel weiter ausgereifenden Plänen. E. Kobbert gab eine Anregung für Gruppengaswerke in ganz Ostpreufyen ${ }^{6.22 \pi}$ ). Die Deutsche Continental-Gas-Gesellschaft plante mit Magdeburg die Großgaserei Magdeburg und begann sofort mit dem Rohrleitungsbau von dort nach Süden ${ }^{6,2 e n}$ ). Ungewisse Nachrichten gab es über Pläne einer Fernleitung von Köln über Bonn, Koblenz nach Wiesbaden ${ }^{0.325}$ ).

Eine sehr lebhafte Aussprache im Sächsisch-Thüringischen Verein entstand um eine Denkschrift an die sächsische Regierung, die von der „Landesstelle für Ge-

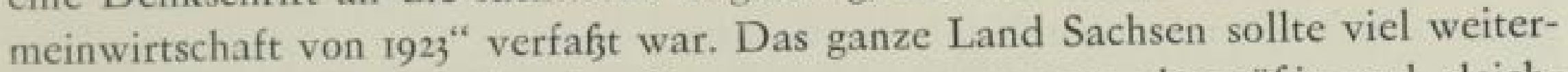
gehend als mit den bestehenden Gruppengasversorgungen planmäßjig und gleichmäß̧ig erschlossen werden. Durchzuführen sei das durch die Landesregierung, deren Beteiligung auszuweiten sei. Zwang könne auf Gemeinden bei Absichten, Staatsstraf̧en zu benutzen, ausgeübt werden. Das Ganze war offensichtlich ein politisch beeinflufytes Machtstreben. (s. a. S. 426)

Der Verein setzte sich sachlich mit den Plänen auseinander. Die dicht besiedelten Gebiete, so führte HermannMüller aus, seien bereits erschlossen. Man würde also wirtschaftlich schr ungeeignete Gebiete berohren müssen. Schon ohne diese Pläne würden mit Staatsgeldern Werke ausgebaut, um andere gemeindliche stillzulegen $^{(0.250}$ ). Die Aussprache ergab teilweise eine günstigere Beurteilung, als sie vorgetragen war, indessen wurden recht störende Angriffe mit Hilfe von staatlichen Mitteln mehrfach erwähnt ${ }^{6, \text { aas }}$ ).

Noch mehr Sorgen und Aufregungen brachten Pläne für ein allgemeines Ferngasnetz im Deutschen Reich, die von den Kohlenzechen an der Ruhr ihren Ausgang nahmen.

Aus der allgemeinen Geschichte (Abschnitt 6.I) geht zur Genüge hervor, wie stark gerade der Kohlenbergbau durch die Eingriffe der Entente, durch innenpolitische Auseinandersetzungen und durch den ausländischen Wettbewerb belastet worden war. Immer wieder gab es Rückschläge, wenn sich ein Ansatz zur Beruhigung und Besserung der Lage zeigte. Die verantwortlichen Zechenbesitzer wollten nun ihre Wirtschaft von Grund auf verbessern, indem sie von der Koh-

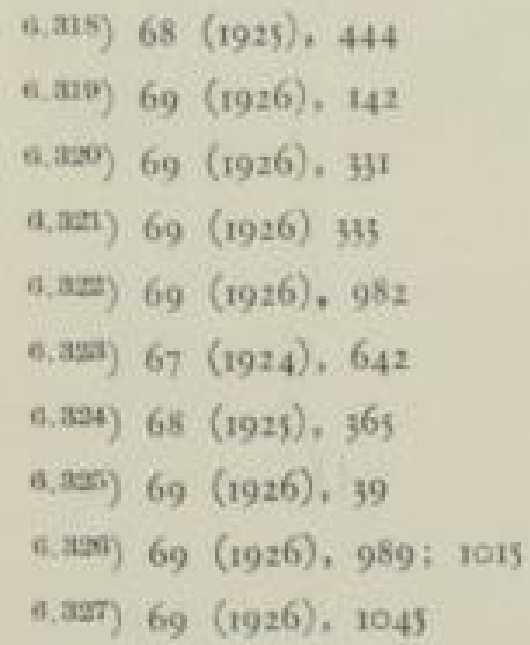


len- und Kokslieferung mit Gas- und Wertstoffabgabe als Abfallerzeugnis zur wirtschaftlichen Hebung durch Veredelung der Kohle vorschritten.

A. P o t $t$ stellte fest, dafy 1925 im Ruhrgebiet $9 \mathrm{Mia}^{3}$ Starkgas erzeugt worden waren, gegen $3 \mathrm{Mia}$ in den deutschen Gaswerken, dał aber nur $300 \mathrm{Mio} \mathrm{m}^{\text {" des }}$ Zechengases als Ferngas verteilt wurden $\left.{ }^{6,354}\right)$.

R. F. S tarke hatte errechnet, dał der günstigste Heizwert für eine Ferngasversorgung von den Zechen aus bei $4640 \mathrm{kcal} / \mathrm{Nm}^{3}$ läge, und dafy damit die wirtschaftliche Reichweite sich etwa bis zu $500 \mathrm{~km}$ stellte $\left.{ }^{0.32}\right)$. Am 30. Sept. 1926 wurde die Aktiengeseilschaft für Kohleverwertung in Essen mit 60000 M Kapital gegründet. Ihr Programm war: Die Aktiengesellschaft übernimmt fast die ganze Gaserzeugung und verteilt sie. Sobald das Überschufgas untergebracht ist, wird Generatorgas zur Unterfeuerung benutzt. Danach ist die Schwelerei mit Halbkoksverwertung im Generator durchzuarbeiten. Die Kohleverwertung A. G. sei im Besitz eines Kontaktverfahrens, um Phenole in gesättigte Kohlenwasserstoffe umzuwandeln. Die Synthese zu Ölen sei noch nicht erforderlich. Wegen der Anwendung der Verfahren bestünde keine Sorge, da mit der Interessengemeinschaft Chemie eine Kapitalverflechtung bestehe. Die Gasindustrie habe nichts zu fürchten, vielmehr erstehe ihr ein Bundesgenosse bei der Mühe, den Gasverbrauch zu steigern ${ }^{6.300}$ ).

Die Pläne ließ̧en an Grołzzugigkeit im Interesse der Zechen nichts zu wünschen übrig. Die Tagespresse griff sie gierig auf. Dabei kam es zu einem Totalitätsanspruch, daf̧ alle Gaswerke stillgelegt werden müften. Die Vertreter der Gaswerke waren über solche Absichten natürlicherweise ungehalten. Eine besondere Schärfe kam dadurch zustande, daf̧ in der Presse die Preise s Pf. $/ \mathrm{m}^{3}$, wie sie frei Gaswerk genannt waren, einfach mit dem Verkaufspreis der Gaswerke Is Pf./ $\mathrm{m}^{3}$ als auf gleicher Grundlage stehend betrachtet wurden: „Ist es im Volksinteresse nicht unverantwortlich, die Stadt- und Landgemeinden wie bisher in dieser Weise wirtschaften zu lassen $\left.{ }^{\left({ }^{(4.33}\right)}\right)$ ? Dementiert wurden später Pressenachrichten, von einem Reichsgesetz über Bedingungen, unter denen die Reichsstraf̧en freizugeben seien, sowie eine Behauptung, die Wirtschaftliche Vereinigung der Gaswerke habe sich angeboten, sich an der Aktiengesellschaft für Kohleverwertung zu beteiligen.

Gegen Ende des Jahres meideten sich viele Gaswerksleiter zum Wort, um ihren Standpunkt zu diesen weitausgreifenden Plänen zu erläutern ${ }^{0.320}$ ). Man kann im Rahmen dieser Geschichte unmöglich alle Aussagen für und wider abhandeln. Bedauerlich ist es, daf, wie fast immer bei solchen Streitereien, persönliche Verunglimpfungen und Vorwürfe einer kleinlichen Auffassung der Gegner, die gerade in ihrem Lebenswerk Grofzügigkeit bewiesen hatten (vgl. Seite 426), nicht ausblieben. Leider spuken sie zum Teil auch heute noch, offenbar trotz ihrer nachweisbar keinesfalls vorhandenen Berechtigung, in manchen Köpfen weiter. Hier mag nur festgehalten werden, daf immer wieder von Gaswerks-

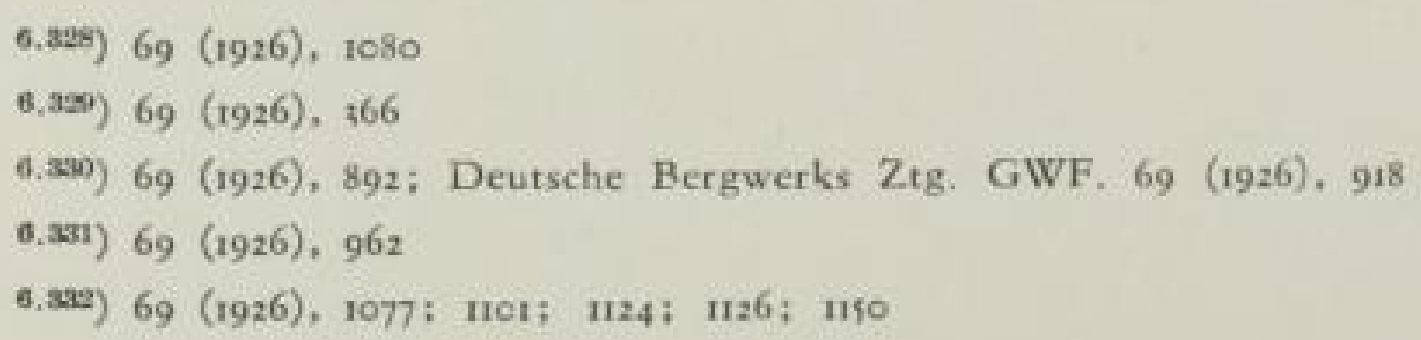


seite betont worden ist, daf̧ angesichts der groß̧en wirtschaftlichen Umwälzung das Für und Wider gewissenhaft zu prüfen sei $\left.{ }^{i+3 i z}\right)$.

Unter dem Vorsitz des Vereinsvorsitzenden des Deutschen Vereins H. Preng e r, Köln, fand eine Aussprache zwischen A. Vögler, A. Pott und Gasfachleuten in Berlin statt, über die zunächst ein ganz kurzer Bericht erschien: „Einstimmigkeit, die Fernversorgungspläne weiter zu verfolgen “6.34).

Am 24. Nov. 1926 wurde das Kapital der A. G. für Kohleverwertung auf 25 Mio M erhöht. Damit war der Rahmen der "Studiengesellschaft" üherschritten. Der erste grołe Sturm war überwunden. Die weitere Aussprache sollte allmählich sachlicher werden. Die Mittel zum Bau waren zusammengefaftst. Mit dem ersten Jahre ihres neuen Jahrhundert trat die deutsche Gasindustrie in die Entwicklung ein, die heute in der Form der ausgedehnten Ferngasanlagen neben grołen Gaskokereien als Stützpunktwerken ein ausgewogenes Bild gewährt.

\subsection{Gasbebälter}

Gleich im Anfang dieses Abschnitts steht eine grofe technischen Tat, die in aller Welt dem Gasfach nutzte, die Konstruktion des wasserlosen Gasbehälters durch die Maschinenfabrik Augsburg-Nürnberg A. G. (MAN). Die immer größ̧er werdenden Werke und Kokereien muf̧,en natürlich auch größzere Mengen Gases speichern. Der trockene Behälter wurde zu einem wichtigen Glied in der Kette der Anlagen, die der Vergröł̧erung der Industrie dienten, denn gerade bei groß̧en Behältern wurden die Ersparnisse gegenüber den nassen Bauweisen sehr bald deutlich. Natürlich begann die Firma zuerst mit kleinen Behältern, um die neue technische Schöpfung zu erproben. Schon $1913 / 14$ wurde ein trockener Behälter zum Versuch im Werke Gustavsburg der M.A.N. erbaut, ein Modell wurde I9I4 auf der Ausstellung „Das Gas“ in München gezeigt ${ }^{\text {e.s5s }}$ ). Der erste Auftrag eines Gaswerkes war ein Behälter von $1600 \mathrm{~m}^{3}$ für Augsburg. Schon bald kam es zu einer Lieferung in das Ausland, nach Holland, wo wohl die geringeren Fundamentkosten entscheidend waren $\left.{ }^{0.30 x}\right)$. 1920 konnten schon 13 städtische Gasbehälter nachgewiesen werden, darunter der gröfte in Posen von $50000 \mathrm{~m}^{3}$ Jnhalt $\left.{ }^{6,377}\right)$. 1925 wurde bereits ein Riesenbehälter von $300000 \mathrm{~m}^{3}$ Inhalt, 67,26 m Durchmesser und 107,5 m Höhe von Thyssengas in der Nähe der August Thyssenhütte in Hamborn errichtet, der dazu diente, das Koksofengas zu speichern, das an Sonntagen anfiel, wenn die Unterfeuerung der Öfen bei stilliegenden Verarbeitungswerken durch Gichtgas erfolgte ${ }^{0.325}$ ).

Alles war bestens im zügigen Vorwärtsstreben, als die Nachricht kam, daf der Posener Behälter zerknallt war. Die Betriebsleitung hatte Unregelmäßjigkeiten im Durchlauf des Dichtungsteeres beobachtet, den Gaszutritt abgestellt, aber weiter Gas entnommen. Die Scheibe hakte und rutschte plötzlich ab. So war

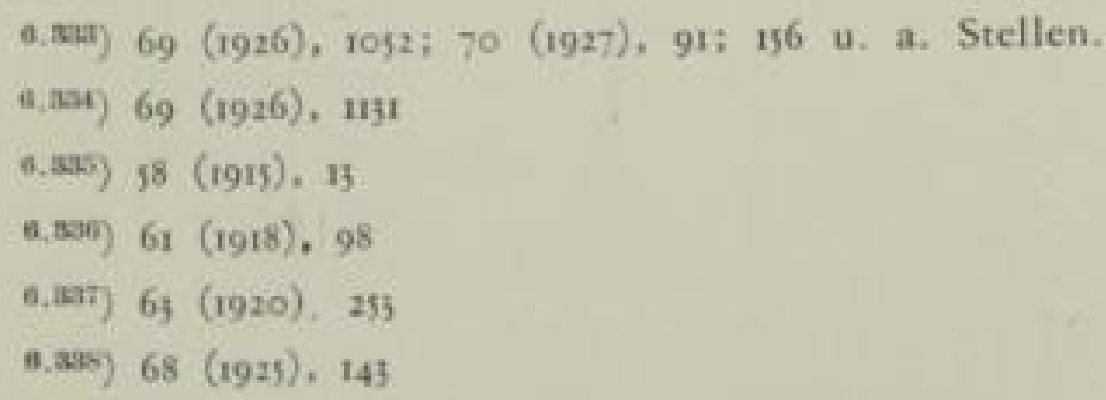


die erste Meldung $\left.{ }^{6.35}\right)$. Bei einer näheren Untersuchung, die im Kreise aller zur Aussprache geladenen Besitzer trockener Gasbehälter stattfand, gab die Maschinenfabrik Augsburg-Nürnberg zu, dał die Führung der Scheibe an den ersten Behältern verbessert werden mufze. Sie behauptete aber, dafy es an Aufsicht gefehlt hätte. Der Wassergehalt im Teer wäre durch eindringenden Regen allmählich auf $50 \%$ angestiegen. Dieses Wasser wäre im Winter als Eisschicht an den Wänden angefroren. Als die Scheibe dadurch hakte und sich schräg stellte, suchte der Meister durch einseitige Verlagerung der Belastungsgewichte, die Schräglage auszugleichen. Ein hinzugerufener Monteur der MAN gab sofort den Rat, die Gewichte wieder gleichmäßjig zu verteilen und vor allem auch die ÖImenge oberhalb der Scheibe zu verringern. Beides geschah nicht, ein Ingenieur der MAN erhielt nicht die nachgesuchte Einreisegenehmigung nach Polen. So kam es erneut zum Hängenbleiben, wobei noch das Ölgewicht zusätzlich zu den Steinen einseitig die Scheibe umschlagen lief. Ein Gasluftgemisch hätte sich dann oberhalb der Scheibe entzündet ${ }^{0.519}$ ). Die sich widersprechenden Erklärungen der Betriebsleitung und der Herstellerfirma wurden nie völlig in Einklang miteinander gebracht $\left.{ }^{\text {(-3it }}\right)$. Alle Anwesenden bekundeten ihr Vertrauen in die Bauart. Eine Revision sämtlicher bestehenden Behälter befriedigte alle Werke ${ }^{\text {0.32 }}$ ).

Während des Krieges wurden Versuche zum Ersatz des nicht mehr möglichen Farbanstrichs nasser Behälter mit einer Ölschicht auf dem Sperrwasser angestellt, die sich zunächst bei umbauten, dann aber auch bei freistehenden Behältern bewährte ${ }^{6.343}$ ). Inertol als Schutzöl wurde von Paul Lechler, Stuttgart, I923 entwickelt. Dieses griff auch Beton nicht $\left.a^{6.34}\right)$. Für Dampfbeheizung bewährte sich der Askania-Dampfautomat ${ }^{0.355}$ ). Die erste Flickschweif̧ung an einem in Betriebe befindlichen Behälter war befriedigend gelungen $\left.{ }^{0.30^{\circ}}\right)$.

\subsection{Gasmessung}

Auf dem Gebiete der Gasmessung gab es einige Anregungen für neue Wege. Zunächst fanden Strömungsmesser, Rotamesser, Prandtlsches Staurohr und Mef̧blende Beachtung ${ }^{\text {a.sin }}$ ). Neu war der Thomasmesser von Pintsch nach dem Prinzip der Abkühlung eines elektrisch geheizten Drahtes entsprechend der durchflief̧enden Masse, also unabhängig vom Druck $\left.{ }^{\text {a.as }}\right)$. Grołe Bedeutung erreichte der Messer nicht.

Bemühungen um eine Normung der Anschlufmałe von Haushaltsgaszählern scheiterten wegen der hohen Umstellungskosten ${ }^{6.3 i g}$.

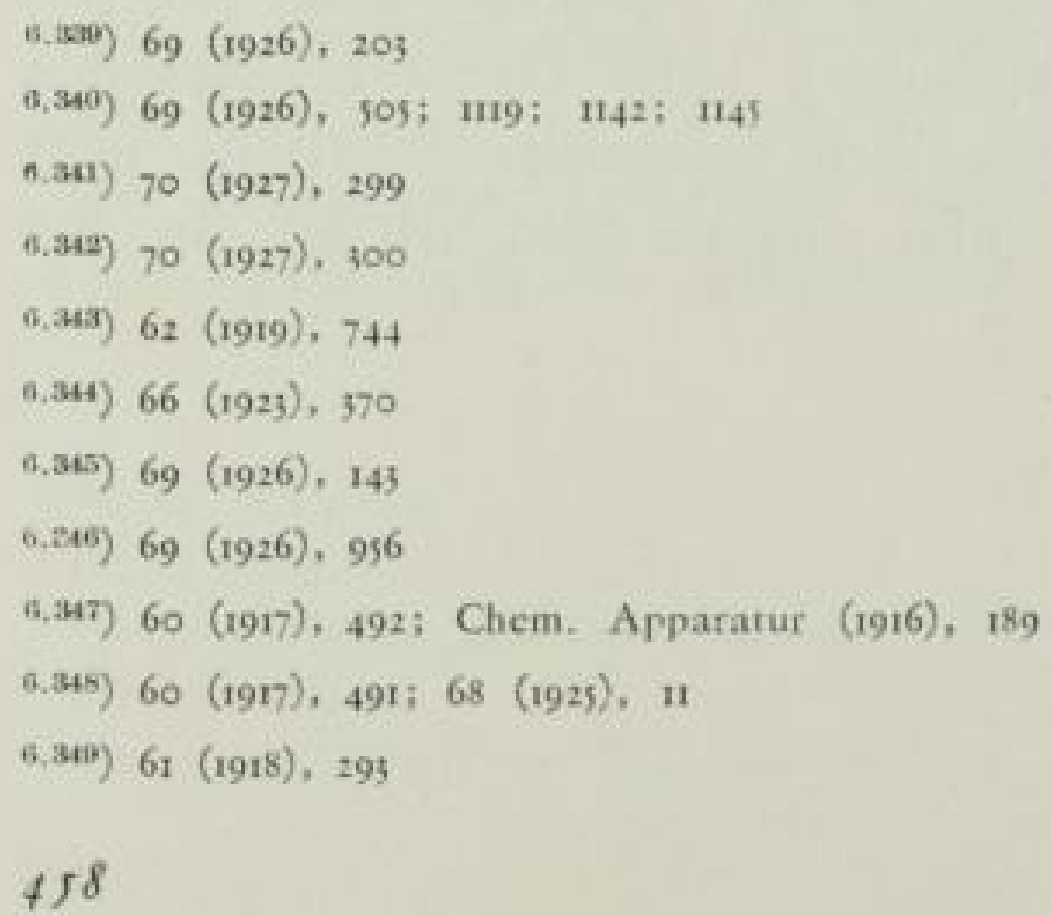


Durch die fortschreitende Geldentwertung wurden die Münzgasmesser schwer behindert, die Zentrale für Gasverwertung meinte sogar: unmöglich. Man brauche sie auch zur Werbung nicht $m^{-h^{0.350}}$ ). Die Gaswerke waren jedoch anderer Meinung. Mit besonderen Blechmarken, die dem jeweiligen Geldwert entsprechend verkauft wurden, suchte man sich anzupassen. Der Vertrieb mit Hilfe der Lebensmittelgeschäfte war aber nicht einfach. Wollte man die Hamsterung ,als wertbeständige Anlage" verhüten, so mufzten nebenher Markenheftchen ausgegeben werden $\left.{ }^{\text {o.asi }}\right)$. Der Reichsfinanzminister war mit der Ausgabe von Blechmünzen aus Sorge um die Währung nicht einverstanden ${ }^{0 . x 2}$ ), obwohl die Marken in der Größze des ro Pf.-Stückes nur für rund I $\mathrm{M}$ ausgegeben wurden ${ }^{6.753}$ ). Eingeführt haben sich Blechscheiben mit Schlitzen und Kerben, so daf3 die Münzgasmesser gegen entwertete Münzen geschützt werden konnten. Wie wichtig die Erhaltung des Münzgasmessers in der Zeit nach der Währungsfestigung mit knappem Geld geworden war, beweist eine Feststellung der Gasbetriebsgesellschaft Berlin, dał die Gasabgabe durch Münzgasmesser die durch gewöhnliche

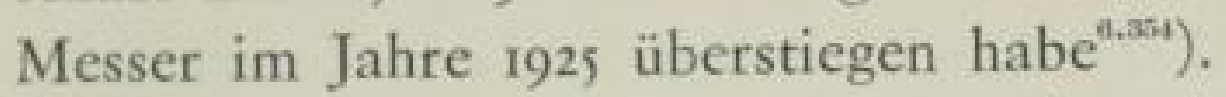

Durch die Heizwertminderung wurden leistungsfähigere Zähler für gleichen Wärmebedarf notwendig $\left.{ }^{\text {G.us }}\right)$. Hieraus entstand der trockene Hochleistungsmesser, zuerst von G. Kromschrö der, Osnabrück, entwickelt ${ }^{0.35}$ ). Der Tauchglockenmesser von Tollens (Max Bessin \& Co. Berlin) sollte für nasse Gasmesser den hohen Durchgang ermöglichen, ohne dał die Bewegung der Füllflüssigkeit störte $\left.^{0.35 i}\right)$. Er hat sich indessen nicht eingeführt.

\subsection{G A S VER WEND UN G}

\subsection{Werbung und Preise}

Für Werbung mit groß̧en Veranstaltungen und Druckschriften war im Kriege nicht die rechte Zeit. Die Zentrale für Gasverwertung benutzte die Muf̧e, um Unterlagen über technische Gasfeuerstätten zu sammeln ${ }^{6.355}$ ). Später wurde sie durch die Belastung ihres Direktors K Lempelius mit der Vertretung bei den Planungsstellen sehr stark nach dieser Richtung beschäftigt.

Erst nach der Beendigung der Feindseligkeiten regte man sich wieder. Zunächst waren es Ingenieure, C. R $\ddot{o} b m$, Potsdam und P. Fis c ber, Stuttgart, die betonten, dał wegen der Schwierigkeiten mit den wechselnden Gasgemischen Ingenieure der Werke sich beratend und versuchend um die Abnehmer kümmern müf̧ten $\left.^{\text {caxis }}\right)$. Die erste Firmenausstellung von dreitägiger Dauer aus Anlał der

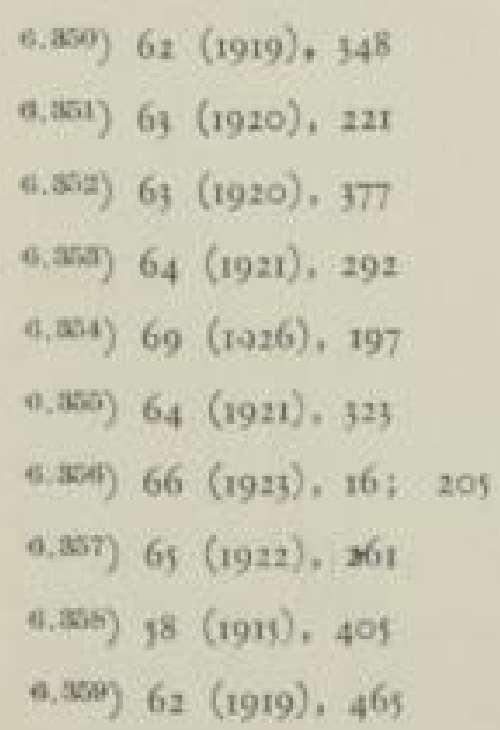


Harzburger Hauptversammlung des Vereins wurde reich beschickt $\left.{ }^{0,000}\right)$. Die Beteiligung an der wieder in Gang gebrachten Leipziger Frühjahrsmesse wurde lebhaft erörtert $\left.{ }^{\text {a.kxin }}\right)$. Man erwartete sicherlich, gemessen an den Schwierigkeiten, überhaupt zu arbeiten, von den Herstellerfirmen reichlich viel Aufwand für die allgemeine Werbung, war sich allerdings auch bewufyt, dafy die Gaswerke sich ihrerseits auch wieder betätigen müf(ten $\left.{ }^{6.382}\right)$. Das Gasmuseum in Charlottenburg wurde trotz der Geldentwertung pfleglich behandelt. Der Museumsverein zählte s5 Mitglieder. Schatzmeister in dieser schwierigen Zeit war J. Elster, Berlin, Vorsitzender Direktor i. R. A. Müller, Charlottenburg. Die physikalischtechnische Reichsanstalt beteiligte sich $\left.^{0.320}\right)$. Trotzdem muf3te das Museum in dic Räume des staatlichen Verkehrsmuseums im alten Hamburger Bahnhof abwandern $\left.{ }^{\text {t.354 }}\right)$.

F. Escher, Zürich, gab einen eindrucksvollen Reisebericht über die großen Ausstellungsräume in den Vereinigten Staaten, die oft in Verbindung mit den von den Kunden besuchten Abrechnungsstellen eingerichtet worden waren ${ }^{0.34}$ ). Der erste Ausbildungslehrgang für Werbedamen wurde von der Zentrale für Gasverwertung noch während der Inflation abgehalten ${ }^{0.300}$ ).

Erst als die Geldwerte wieder fest geworden waren, konnte man lebhafter vorgehen. Um die Drucksachen auf geschäftlicher Grundlage vertreiben zu können, was der Zentrale als eingetragenem Verein nicht möglich war, wurde daneben der „Gasverbrauch, G.m.b.H.“" gegründet $\left.{ }^{0.377}\right)$. Die Werbemarke ,Gasvogel“, den ausflammenden Brenner versinnbildlichend, wurde geschaffen ${ }^{\text {a.men }}$ ). E. Eb erle, Liegnitz, behandelte in einer langen Aufsatzreihe alle Fragen der Werbung ${ }^{\text {a.san }}$ ). England wurde in der Werbung vorbildlich. Man sprach dort von Scientific promotion of Gas = wissenschaftlicher Gaswerbung ${ }^{0.350}$ ). Das alte Journal of Gaslighting gab getrennt den "Gas Salesman" als Fachblatt der Werber heraus.

Es zeigte sich aber auch, dał solche zentrale Werbearbeit ihre Gefahren in sich trägt, wenn die Zentralstelle des Fachs von Schlagworten der Hersteller beeindruckt wird. Der Ruhm des Clasenbrenners (vgl. Seite 465) war sicherlich unberechtigt, da die schr scharf entleuchtete Flamme in Kochvorgang nicht ganz einwandfrei war $\left.^{0.371}\right)$. So wurden einzelne Hersteller von Kochgeräten veranlaf̧t, ähnliche Brenner zu entwickeln, die dann mitsamt den Clasenbrennern wieder verlassen werden muften. Auch die unterteilte Lamelle, die mit ihren technischen Argumenten eine gute Firmenwerbung war, hätte nicht die Unterstützung der Zentrale finden dürfen. Für das Gasfach kam es auf den Gesamtaufwand im Verhältnis zur Leistung des Warmwasserbereiters an und nicht darauf, ob

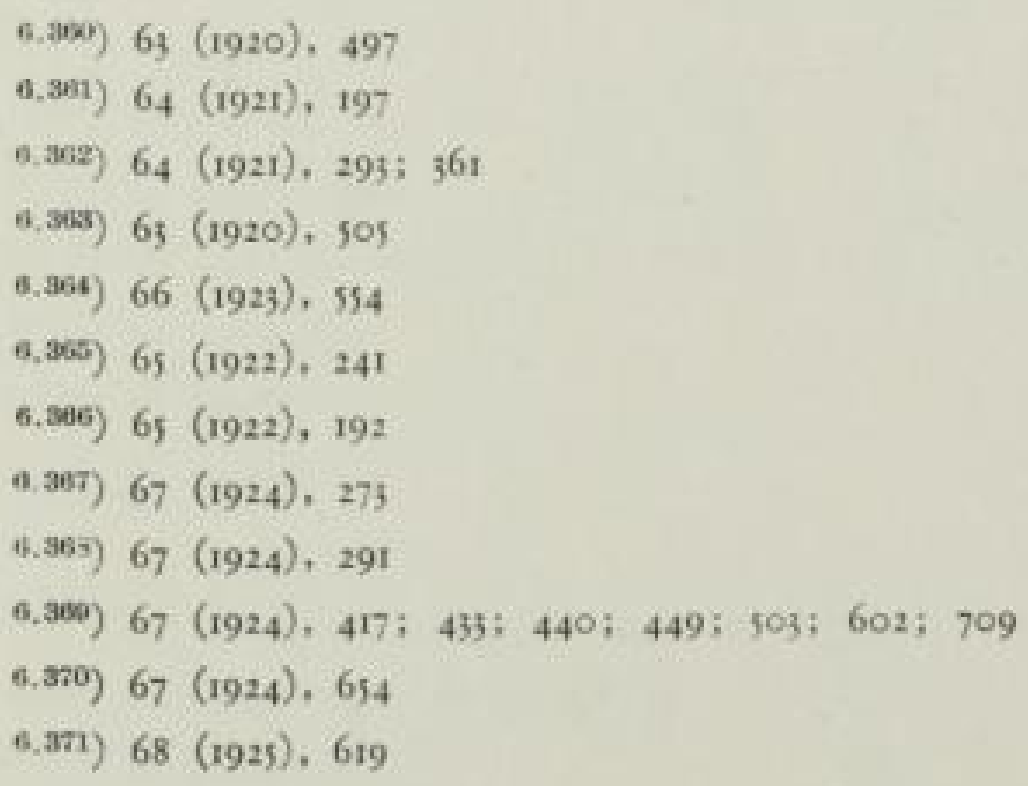


innerhalb des Gerätes ein gleichmäßjiger oder ungleichmäf̧iger Wärmeübergang stattfand ${ }^{\text {6.anz }}$.

Solches Nachgeben an technische Schlagwörter war damals, als der Vertrieb mit allen Mitteln von den Herstellerfirmen gesteigert wurde, auch eine Gefahr für Ausstellungsräume und Beratungsstellen in den Gaswerken. Man mufte als Hersteller seine neuen Geräte mit irgendeiner technischen Besonderheit ausrüsten, die oft genug nur in den Augen des Konstrukteurs selbst als Vorteil erschien oder als ein solcher gerühmt werden konnte, um in die Werbegespräche autgenommen zu werden.

Abzahlungsfinanzierung für Geräte und auch für ganze Anlagen kamen in Gang $^{\text {a.ang }}$ ).

Die Fieberkurven der Gaspreise in der betrachteten Zeit zu verfolgen, ist unmöglich. Je nach den Sprüngen der Währung lagen die Preise im Verhältnis zum Kurs der Mark einmal höher, einmal tiefer. Man sprach aber von Verteuerungen. ohne sich Rechenschaft über den wirklichen Preis im Verhältnis zum Markkurs zu geben.

Im Anfang versuchte man, die Gaspreise aus politischen Grïnden festzuhalten. Kommunale Gaswerke, die „nur“, um den Gewinn nicht absinken zu lassen, Gaspreise erhöhten, wurden gerügt. Der Einheitspreis, der sich sehr schnell überall durchsetzte, um Gasmesser für Neuanschlüsse freizumachen, war oft sogar eine Verbilligung $\left.{ }^{\text {a.3at }}\right)$. Erst die staatliche Kohlensteuer, die auf das Gas abgewälzt werden muf̧te, brachte die Lawine zum Anrollen. Die Öffentlichkeit setzte sich zur Wehr gegen „Wucher“. In Bromberg predigte man mit Engelszungen das Verständnis für Gaspreiserhöhungen, insbesondere für das Aufgeld für Mehrverbrauch, das die Kontingentierung nötig gemacht hatte $\left.{ }^{6.375}\right)$. In Berlin muf3te den Abnehmern die Kohlenklausel im Gaspreis begreiflich gemacht werden ${ }^{0.376}$ ). Es kam aber an vielen Crten zu Wucherprozessen wegen der hohen Preise ${ }^{0.177}$ ). So klagte ein mittlerer Justizbeamter gegen den Gaswerksdirektor wegen Wucherpreisen für Koks. Der Gutachter konnte nachwiesen, dał üblicherweise das dreifache vom Geforderten bezahlt werden müsse. Die beanstandeten Preise seien Schleuderpreise ${ }^{\text {tan }}$ ). In Leipzig lehnte ein Staatsanwalt das geforderte Vorgehen wegen Preiswuchers der Gaswerke ab. Die städtischen Werke seien ohnehin zur volkswirtschaftlichen Einstellung verpflichtet, und nachweislich seien auch insgesamt vom Werke keine überhöhten Gewinne erzielt worden ${ }^{\text {n.azp }}$ ).

Diese Dinge zeigen aber deutlich, in welch einer schwierigen Lage die Werke nach der Währungsumstellung waren. Selbstverständlich versuchte man, um den Absatz zu beleben, irgendwie entgegenzukommen. Ein Versuch in Frankfurt Main, ,soziale“ Preise, d. h. nach dem Einkommen gestaffelt, den besten Abnehmer besonders teuer zu beliefern, scheiterte erfreulicherweise an dem un-

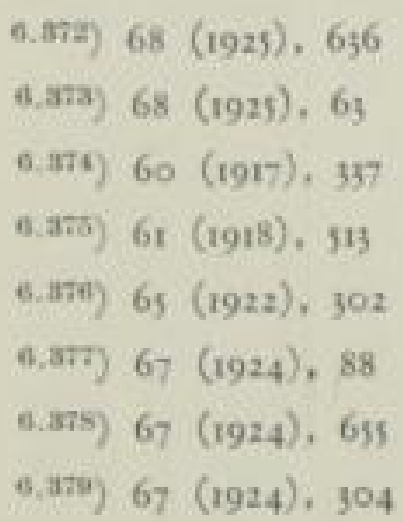


überwindlichen Durcheinander bei der Einziehung ${ }^{6.390}$ ). Selbstkostenermittlung und Rabattsysteme muften durchberaten werden, um das genaue Rechnen erst einmal wieder zu lernen $\left.{ }^{0.331}\right)$. U $\mathrm{m}$ einen sehr niedrigen Gaspreis gewähren zu können, versuchte Zwickau, allgemein eine Mindestabnahme von $12 \mathrm{~m}^{3}$ aufzuerlegen. Das Werk muf̧te den Tarif zurückziehen $\left.{ }^{0.352}\right)$. Höchst bot eine Mindestabnahmebedingung bei ermäßjigten Preisen mit fünf-jähriger Vertragsbindung wahlweise an und hatte Erfolg $\left.{ }^{\text {s.asin }}\right)$.

\subsection{Beleucbtung}

Mit der Hausbeleuchtung erlebte die Gasindustrie eine grołe Katastrophe, die deshalb auch bereits in der allgemeinen Geschichte (Seite 422 u. 423 ) erwähnt werden mufte.

Kurz nach Ausbruch des Krieges kam eine Flut von Anschlufgesuchen aus den Kreisen, die sich bis dahin des billigsten Lichtes, des Petroleums, bedient hatten. Gas war noch verhältnismäfig preiswerter als elektrisches Licht, zumal wenn die Werke mit den Installationskosten entgegenkamen. Man rechnete noch mit dem Pfennig. Bis zum Ende des Krieges konnte auch die Abnehmerschaft hinlänglich befriedigend bedient werden. Dann aber kam der Zusammenbruch der Kohlenversorgung und als Folge ein minderwertiges Gas und Sperrstunden in der Abgabe. Die Elektrizitätswerke konnten sich gegen solche Sperrzeiten besser wehren. Wenn einzelne grofie Energieverbraucher durch Vereinbarung zeitweilig stillsetzten, so brachte das mehr Einsparungen an Strom, als die Menge der Lichtverbraucher. So kam Gas in der Zuverlässigkeit zum ersten Male und zeitweilig nach der Elektrizität. Hinzu kam noch das Erlebnis, wie alle Schulden und Ersparnisse einfach in nichts zerrinnen konnten. Das lief̧ eine gänzlich neue Einstellung zum Aufwand für Bequemlichkeil gegenüber der bedingungslosen Sparsamkeit Platz greifen. Man findet in den Berichten dieser Periode auch zum ersten Mal Klagen über die Ausgabenfreudigkeit der öffentlichen Verwaltung. Die Schaltmöglichkeit des elektrischen Lichtes wurde entscheidend, die Einrichtungen zur Fernschaltung des Gases waren viel zu verwickelt und pflegebedürftig. So ging die Hausbeleuchtung in wenigen Jahren verloren.

Ja! Eine gewisse Mutlosigkeit lieł die Gasfachleute die Sorge um die Hausbeleuchtung vernachlässigen $\left.{ }^{0.354}\right)$. Es gab zwar noch einige Ausnahmen, die auch noch später Widerstand leisteten, aber schon die Entwicklung neuer Brenner beschränkte sich fast ganz auf die öffentliche Beleuchtung. Sehr übel spielten dem Gasfach auch noch die Sparbrenner mit. Richtig war, was W. Bertels$m a n n$ sagte: „Die Miłsstände der Geräte haben einzig und allein ihre Ursache darin, dał̧ unsere Gasapparate sämtlich auf reiches Gas zugeschnitten sind und daher für armes Gas nicht ohne weiteres passen “6,38s $)$. Da sollten die Gassparer die Luftansaugung vermindern. Sie waren mehr oder weniger behelfsmäßfig ge-

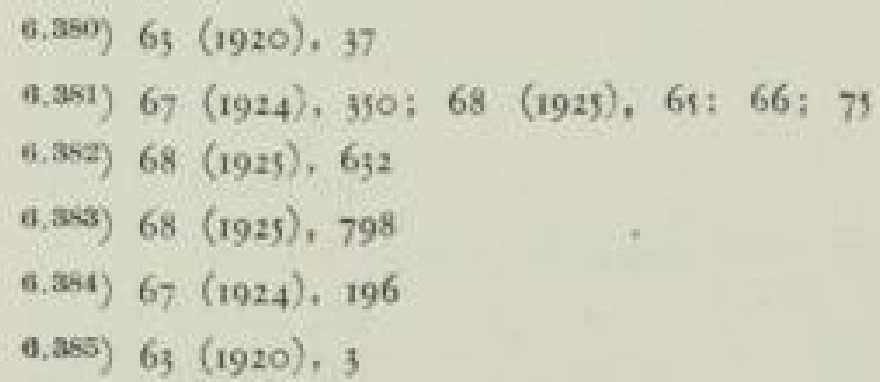


fertigt. Beim Regeln verbrannte man sich die Finger. Die Brenner knallten beim Anzünden und zerstörten die Glühkörper. Am schlimmsten aber waren einfache Deckel, die auf die Zylinder der Stehlichtbrenner gelegt wurden. Sie zogen zwar die Flamme in die Länge, sodał der Körper auch noch in Sperrzeiten zum Leuchten kam, aber sie brachten starke Kohlenmonoxydentwicklung mit sich $\left.^{0.35}\right)$. Am schlimmsten war aber die Anreiferwerbung. Eine Firma von gutem Ruf pries $100 \%$ Gasersparnis für die „Gasglühlicht-Heif̧luftsparkochertrommellaterne Home Star" an. Hundert Prozent einfach deswegen, weil man mit Aufsetzen eines Topfes auf den Stehlichtbrenner kochen könne $\left.{ }^{0,357}\right)$. So etwas konnte die Offentlichkeit nicht mehr ernst nehmen. Der Kampf gegen diese Werbung war aber sehr erschwert, wie noch im nächsten Abschnitt zu zeigen sein wird. Gewił waren die Hängelichtbrenner weniger empfindlich gegen Wassergaszusatz $\left.^{\text {a.ass }}\right)$. C. K ill i ing, Düsseldorf, hatte auch mit einem stark verkürzten Glühkörper eine größ̧ere "Intensität", insbesondere in der unteren Halbkugel erreicht $\left.^{6.35}\right)$. Sein Bis-Zylinder mit trichterförmiger Öffnung um den Hängelichtkörper steigerte den Erfolg im Winkelbereiche von $0^{\circ}$ (gegen die Senkrechte nach unten gemessen) und $\left.30^{\circ 6.00 y}\right)$. Einen weiteren Fortschritt brachten die „ClusterLampen“. Das waren Mehrfachbrenner mit 2 und 3 Glühkörpern an einem Pilzaufsatz zur Änderung der stehenden Straf̧enlaternen in Hängelicht ${ }^{\text {a.sol }}$ ). Pref̧gas hatte seine Vorzüge stark eingebüfft, weil auch bei Niederdruckgas die notwendige Luftmenge bei dem heizwertarmen Gas mit erhöhter Dichte leichter angesaugt wurde. In geschlossenen Räumen waren die leise brennenden Mehrfachbrenner mit hoher Vorwärmung des Gasluftgemisches durch die Abgase siegreich (Ehrich und Gractz) ${ }^{6 \cdot m}$ ). Aber auch für die Straß̧enbeleuchtung befriedigten Starklichtlampen bis zu is kleinen Glühkörpern. Prefggas mit $2000 \mathrm{HK}$ in der Einheit war noch preiswerter gegenüber diesen Niederdrucklampen, wo in einem geschlossenen Bezirk mehr als 20 Lampen nötig wurden. Berlin hatte von $1917 \mathrm{~km}$ Straf̧enbeleuchtung 105 km elektrisch, 105 km mit Prefgas und $1707 \mathrm{~km}$ mit Niederdrucklampen betrieben. Insgesamt gab es dort 71000 Gasleuchten, davon rund $10 \%$ mit Prefggas und an Starklichtlampen mit Niederdruck: 183 von $600 \mathrm{HK}$, 6233 von 1000 HK; mit Prefggas 255 von I 000 HK; 1027 von I500 HK, 5200 von 2000 HK und 160 von 4000 HK. In Paris war das Verhältnis nicht anders: Von ${ }^{1300} \mathrm{~km}$ beleuchteten Strafen hatten nо $\mathrm{km}$ elektrische Beleuchtung, ${ }^{2} 5 \mathrm{~km}$ Hochdruckgas. Der Rest waren Niederdruckleuchten, darunter noch viele Stehlichter.

Ein Versuch, an Boden zu gewinnen, waren Richtschildlampen in Hameln ${ }^{6.303}$ ).

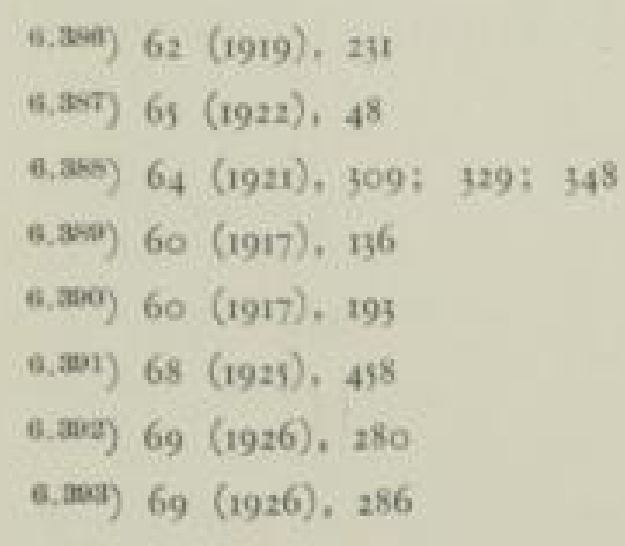




\subsection{Kochen}

Im Gegensatz zu den Gaswerken, die die Preise zunächst unverändert lassen konnten, muften die Hersteller von Geräten bei steigenden Belastungen alsbald die Verkaufspreise erhöhen. I916 wurde der Teuerungszuschlag von 25 auf $30 \%$

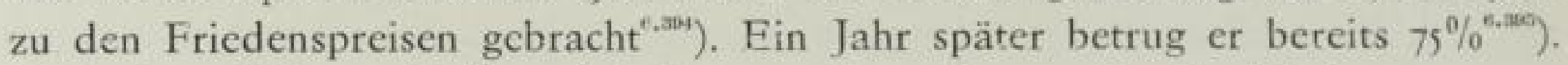
Nach dem Kriege schlof̧ er sich der unruhigen Kurve aller Preisänderungen an. Nunmehr setzte sich das Bestreben durch, leicht aber doch schöner als bisher zu bauen. Bei steigendem Anteil des Vollherdes gegenüber dem Kocherabsatz wurde die technisch ausgeklügelte Bauart mit einem waagerechten Querschnitt von $480 \times 480 \mathrm{~m} / \mathrm{m}$ mit io $\mathrm{m} / \mathrm{m}$ für Abkantungen allgemein, die ein Mindestmał von Verschnittverlusten aus der normalen Blechtafel von $1000 \times 2000 \mathrm{~m} / \mathrm{m}$ gestattete. Diese Entwicklung fand ihren Höhepunkt, als mit dem hochgesetzten Bratofen ohne Wärmeraum auch die Seitenwand mit $480 \mathrm{~m} / \mathrm{m}$ ausgeführt werden konnte. Das war eine bisher nicht erreichte gute Ausnutzung der Bleche, die vor allem bei grof,en Lieferungen an Siedlungsgesellschaften entscheidend wurde. Gewił war die Ausstattung schlicht, der Herd aber weifjemailliert doch ansprechend, dem Zuge zur Sparsamkeit entsprechend.

Mitten im Kriege wurde die Forderung nach Abführung der Abgase von Herden von den Baubehörden wieder aufgegriffen $\left.{ }^{6.306}\right)$. Dabei wurde auch die gleichzeitige Belegung der Schornsteine mit Gas- und Kohlenfeuerstätten in Frage gestellt. Sie war in wenigen Städten verboten, in anderen nicht. Die Behauptung, daß̧ Schornsteinexplosionen möglich seien, konnte durch wirklich eingetretene Unfälle nicht belegt werden $\left.{ }^{\text {e.397 }}\right)$. In Osterreich muf3te von den Gaswerken zugestanden werden, nur noch dreiflammige Herde ohne Abzug aufzustellen $\left.{ }^{6,355}\right)$. Die gewichtigeren Sorgen, die Krieg und Nachkriegszeiten brachten, lie\}en aber diesen Sturm von selbst wieder abflauen.

Grołe Mühen bereiteten nach dem Kriege die überall auftretenden Gassparer, die in meistens wenig zweckmäf̧iger Weise die Lufteinsaugung im Bunsenbrenner beschränken sollten. K. Bunte konnte eine ganze Reihe geradezu schauerlicher Sparer abbilden $\left.{ }^{6.300}\right)$. Mit gröfster Frechheit wurden diese Dinge zu hohen Preisen durch Hausierer an den Mann gebracht. In Eisenach erreichte die VestaGassparerindustriewaren G.m.b.H., Frankfurt, sogar eine einstweilige Verfügung gegen das Gaswerk, obwohl sie sich um Einbauforderungen des Gasinstituts, das die Brenner untersucht hatte, nicht kümmerte $\left.{ }^{0.400}\right)$. In Berlin und Hamburg endeten die Schwindeleien beim Verkauf mit Gefängnisstrafen für die Ver$\left.\operatorname{treter}^{6.401}\right)$.

Harmloser war ein Kocherbrenner mit Luftvorwärmung, die allerdings nicht feststellbar war, weil wenigstens unvollkommene Verbrennung nicht eintrat ${ }^{0.40 z}$ ).

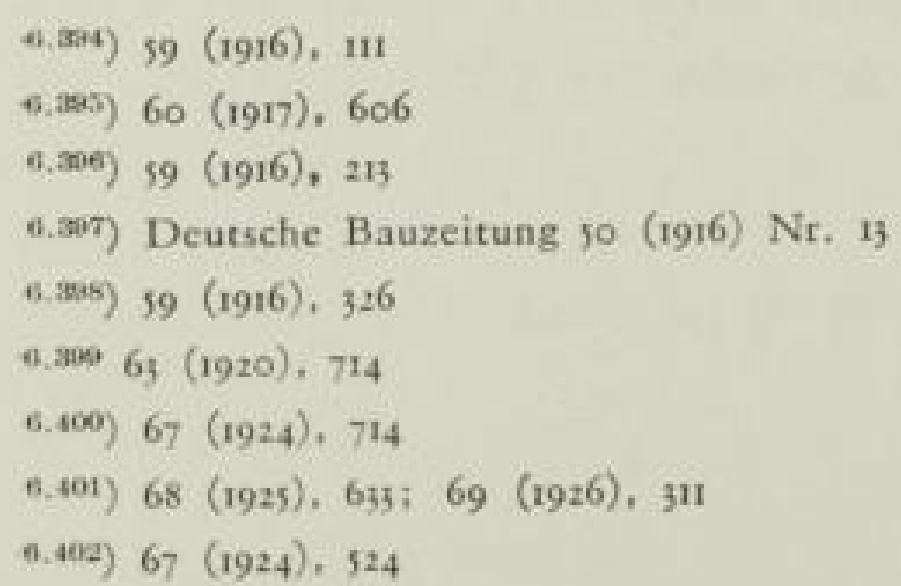


Der schwedische Wärmeschrank, unbrauchbar für unsere Kochgewohnheiten, zum ersten Male - wie später noch oft - entdeckt, wurde als Spareinrichtung auch gelobt $\left.{ }^{6.009}\right)$.

Der von der Firma Richard Kahn A.-G. Berlin vertriebene Einfachbrenner mit kurzer senkrechter Luftansaugung des Stadtbaumeisters $C$ l a s e $n$, Berlin, wurde vom Gasinstitut als beachtenswerte Neuerung begrüßft. 1,5\% CO Gehalt im Abgas muf̧ten erst durch Vergröß̧erung des Topfabstandes beseitigt werden $\left.{ }^{6.104}\right)$. Von der Zentrale für Gasverwertung wurde er wegen Rückschlagfreiheit überschwänglich gelobt ${ }^{0.00}$ ), wie auch einzelne Gaswerksleiter die Neuerung als Groftat bezeichnet haben wollten ${ }^{0.400}$ ), während andere die Brenner anderer Firmen gleichwertig fanden $\left.{ }^{0.407}\right)$. Die Bemühungen der alten Firmen, seine kochtechnischen Schwächen (Anbrenngefahr und Topfzerstörung) rechtzeitig klar zu machen, beantwortete die Firma Kahn: „Die Konkurrenz setzt alle Hebel in Bewegung, um unsere vom Gasinstitut als gut anerkannten Brenner in Mif̧kredit zu bringen." Nach wenigen Jahren war der Brenner vom Markt verschwunden.

Wertvoll war dagegen der Schritt der Firma Wilhelm $H$ o mann, Vohwinkel, mit einer Aluminiumlegierung einen preiswerten glattwandigen Brenner üblicher Form, aber mit einer engen Düse, angepaf̧t an das wassergasreiche Mischgas und herausnehmbar, zu schaffen $\left.{ }^{6.405}\right)$. Auch ihm begegnete man wegen des niedrigen Schmelzpunktes der Legierung mit Miffrauen, er ist aber Schrittmacher auf dem Gebiete des Brennerbaues geworden. Der Bakhuizenbrenner zur Vermeidung des Rückschlages, ganz ohne Erstluft arbeitend, beschritt einen Weg, der noch oft nacherfunden worden ist. Wäre der Rohrnetzdruck, den Wünschen der Fabrikantenvereinigung gemäf, kräftig erhöht worden, so hätte das Brennersystem eine viel weitere Ausdehnung finden können.

Von Nordamerika brachte F. Escher, Zürich, die Backofenprüfung mit Papierbräunung mit, die, als sie später von München übernommen und empfohlen wurde, den Konstrukteuren viel Kopfschmerzen bereiten muß̧te. Papierbräunung ist eine Folge der Strahlungsverteilung, Kuchenbräunung unter Wasserverdampfung abhängig von der konvektiv herangeführten Wärme. Jene ist also kein Mafsstab für diese. Wer das als Hersteller betonte, galt aber als Reaktionär.

Holland ahmte das amerikanische Prüfzeichen nach, begrüßst von vielen Gasfachleuten. Daraus setzte ein Kampf um das Selbstaufsichtsrecht der Hersteller ein. Es begann eine Zeit sehr schwieriger Weiterentwicklung, weil den alten erfahrenen Ingenieuren nicht mehr ein richtiges Urteil geglaubt wurde.

Die Groß̧küchen, die bisher eigentlich nur mit vergrößerten und verstärkten Haushaltsherden beliefert wurden, wurden nunmehr stärker beachtet. Auffallend ist, daf̧ das Handbuch Bd. 8 (1916) nur Kochkessel und Bratöfen, aber keine Herde beschrieben hat. Dabei wurden gerade in dieser Zeit die ersten Sondergeräte, Grillapparate, Pfannen, Kippkessel entwickelt. Die Werbung der Fischindustrie hatte die Konstruktion besonderer mit Thermometer überwachter

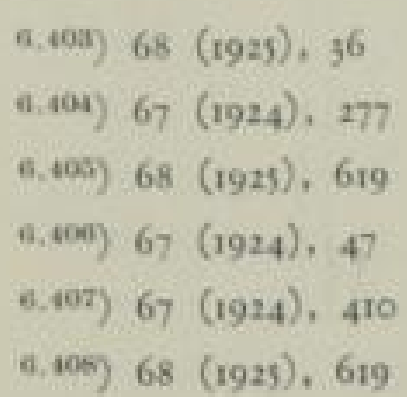


Fischküchenherde zur Folge, die sich auch in der Grof̧küche selbst zum Backen im schwimmenden Fett eigneten.

F. Küppersbusch, Gelsenkirchen, gab als erste Firma dem Drängen der Küchenchefs nach einer geschlossenen Herdplatte für den ,à la carte-Betrieb“ Raum ${ }^{\text {e.tog }}$. Die Frankfurter Gas Gesellschaft bemühte sich sehr darum, den damit höheren Gasverbrauch durch Prefggasbrenner wieder herabzudrücken ${ }^{0.410}$ ).

Geschirrspülmaschinen aus einer Gemeinschaftsarbeit des Alexanderwerks A. von der Nahmer A.-G., Remscheid, und den Houbenwerken in Aachen tauchten auf ${ }^{\text {s.t11)}}$.

\subsection{Warmwasserbereitung}

Die Warmwasserbereiter wurden in dieser Zeit kaum verändert. Das heif̧t aber nicht, dafy nicht unter dem Druck der gestiegenen Lohnkosten sehr eifrig an der verbesserten Herstellung gearbeitet worden wäre. Im Gegenteil, mit ihren groß̧en Bauserien waren gerade die Gasgerätefirmen mit der Fliefffertigung eifrig beschäftigt und führend. Junkers \& Co., Dessau, konnten wohl als geschickteste Fertigungswerkstätte um 1925 bezeichnet werden.

An Neuheiten mag der Gasmengenregler von Junkers (Patent in Norwegen I914) mit pendelnder Klappe erwähnt werden ${ }^{\text {B.t12 }}$ ). Leider setzte sich das Prinzip erst sehr viel später durch. Die Drücke in den Leitungen waren oft nicht hoch genug, um regeln zu können. Das Gasfach nahm aber auch technische Verbesserungen nicht an, wenn sie mit Mehrkosten verbunden waren. Schlimmes richteten Bemühungen an, auch hier mit abzugslosen Badeöfen zu sparen. 6 Namen werden genannt. Dazu noch 3 "Tauchbadeöfen", die ebenso gefährlich waren ${ }^{6.113}$ ).

\subsection{Raumbeizung}

Umso mehr beschäftigte sich das Fach mit der Raumheizung. Schon in der Abhandlung der Gaserzeugungsverfahren wurde berührt, daf̧ einige begeisterte Anhänger der restlosen Vergasung die Zeit für gekommen erachteten, die Raumheizung ganz dem Gase zuzuführen. Kurze Zeit trat 1923 eine eigenartige Lage ein. Die Einfamilienhausbewohner konnten das Geld für den einmaligen Koksankauf nicht zusammenbekommen und suchten, mit Gaseinzelöfen eine Notheizung einzurichten $\left.{ }^{\text {a.t4 }}\right)$. Eine Anfrage nach Erfahrungen mit Einbaubrennern in die Zentralheizungen zeigte, dał diese Arbeit lebhaft im Fluf3 war ${ }^{\text {set }}{ }^{5}$ ). Auch auf dem Kongreł für Heizung und Lüftung 1924 wurde die Gaszentralheizung erörtert ${ }^{0.14}$ ). Ein allgemeiner Vortrag F. $S c b a ̈ f e r s$ über den Wettbewerb von Elektrizität

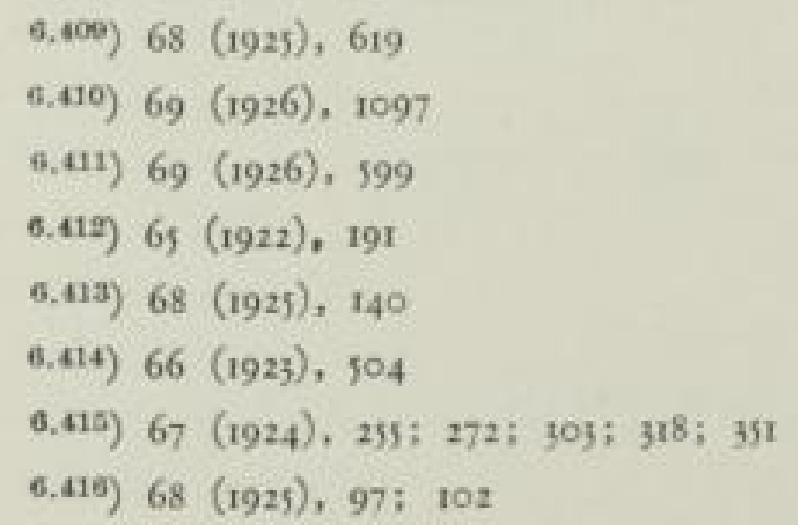


und Gas löste eine Aussprache über die Gasraumheizung aus $\left.{ }^{6.417}\right)$. K. Blume, Bayreuth, berührte den Spitzenbedarf an kalten Wintertagen. Schon wenn $10 \%$ der Heizung mit Gas betrieben wurde, schätze er die Winterspitze auf das vierfache der Sommerlast. Trotzdem seien die Gaswerke für diese Ansprüche herzurichten $^{\text {o.tis }}$ ). Betriebsinspektor W. Neuffer, Wattenscheid, ein Mann, der sich um die richtige Ausführung der Gaszentralheizung in geeigneten Fällen sehr verdient gemacht hat, benutzte zuerst einen Gasdampfautomaten zur selbsttätigen Beheizung eines alleinstehenden Behälters ${ }^{6.119}$ ).

Einen Vergleichsversuch zwischen Gaszentralheizung, allerdings an einer einfach umgebauten Anlage ohne Ausnutzung der Sparmöglichkeiten, mit einem gleichartigen Hause mit Einzelöfen nahm P. Spaleck vor und kam zu einem sehr viel größzeren Gasverbrauch bei der Zentralheizung $\left.{ }^{0.20}\right)$. F. Ka i se $r$, Meurer, Cossebaude bekräftigte diese Ansichten und kam mit M. $N u$ B , Darmstadt, der den Darmstädter Radiator entwickelt hatte $e^{6.42}$ ), zu einer tiefgreifenden Meinungsverschiedenheit $^{\text {0.422 }}$ ).

E. Kobbert behandelte erneut die Einflüsse des Windes auf den Gasabzug. Er stützte sich mit Beispielen stark auf die alte Arbeit von Junkers, ergänzte sie aber mit seinen Erfahrungen. Eine von ihm entwickelte Abzugshaube sollte dic Schwierigkeiten erleichtern ${ }^{0,25}$ ). Von Königsberg aus wurden auch Holz-Gasabzüge empfohlen. Bedenken gegen langsame Verkohlung wurden verworfen, haben sich aber später als berechtigt erwiesen ${ }^{6.421}$ ).

F. Hurdelbrink und R. Polenske, Königsberg, untersuchten den Anteil der strahlend abgegebenen Wärme an der Wärmewirkung von Gasheizöfen. Sie waren ohne Frage von den Vorzügen der in Königsberg ausschlief̧lich vertriebenen Elementöfen eingenommen und muß̧ten sich sagen lassen, daf̧ die von ihnen beim Glühkörperofen gewählte Überbelastung von $50 \%$ der Nennlast eine ungewöhnliche Vergleichsgrundlage sei $\left.{ }^{-6,45}\right)$. Strahlungstechnische Untersuchungen eines Glühkörperofens durch die Münchner Forscher H. Reiber und O. Knoblaucb ergaben mit den damals als bestgeergnet angesehenen Methoden einen abgegebenen Strahlungsanteil von 36 und $28 \%$ und einen Ofenwirkungsgrad von 84,25 und $\left.8 \mathrm{r}, 5^{\%} \%^{0.425}\right)$.

Um bei Gasöfen, die mit Halblast betrieben wurden, einen besseren Wirkungsgrad zu erzielen, versahen schon 1916 zwei Firmen die Öfen mit einer Drosselklappe im Abgasstutzen, die abhängig vom Gashahn gesteuert wurde ${ }^{\text {f.utrit}}$ ). Spätere Untersuchungen haben gezeigt, dał die Schwenkwinkel von Hahn und Klappe durch geeignete kinematische Abhängigkeiten bei der Drosselklappe in Anfang schneller durchlaufen werden müssen, wenn das Ergebnis befriedigen soll.

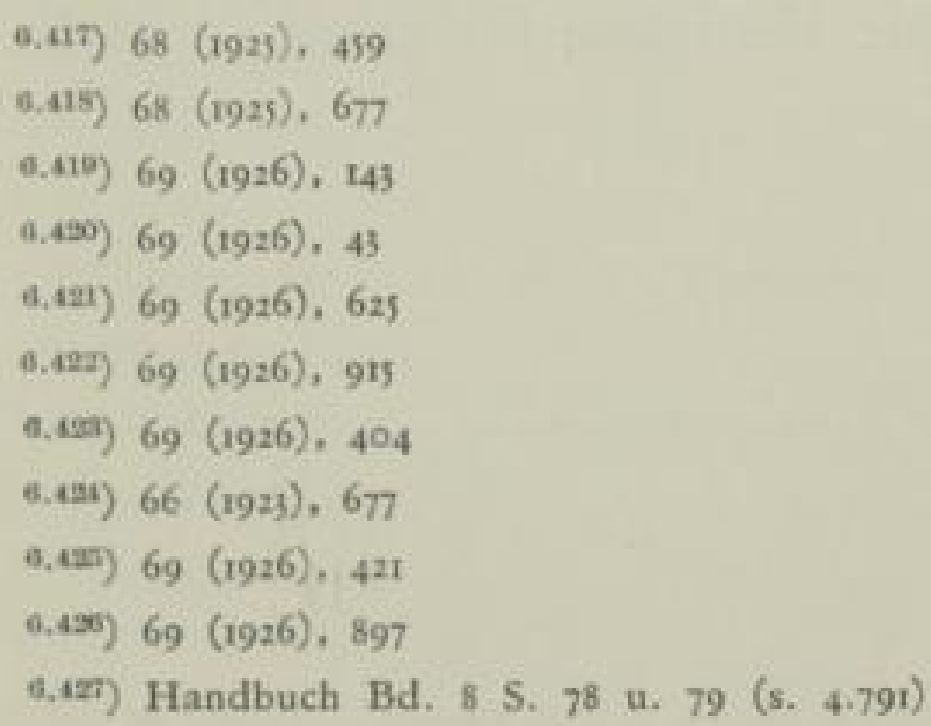


Damit wurde aber die Einrichtung so teuer, daf̧ der Einbau kaum lohnend war.

Sehr willkommen waren Raumtemperaturregler, von denen der von P. Fiscber, Stuttgart ${ }^{(.42)}$ ), mit Flüssigkeitsblase vorzüglich für Einzelöfen, der von G. Kro m$s c h r o ̈ d e r$, Osnabrück, je nach der Ausführung für Öfen und Zentralheizungen geeignet war $\left.{ }^{0.025}\right)$.

\subsection{Gewerbiicbes Gas}

Die Arbeit an der richtigen Anwendung des Gases in Gewerbe und Industrie kam während des Krieges lebhaft in Gang. Wegen der Kriegswichtigkeit war allerdings die öffentliche Erörterung nicht gestattet. Aber tatsächlich geschah der entscheidende Durchbruch zu einem besonderen Pflegegebiet vornehmlich dort, wo bereits Zechengas durch die Werke abgegeben wurde.

Als einen Markstein kann man vielleicht den Bericht von F. Hugersboff, Leipzig, über die Verwendung von Leichtsteinen zunächst aus Silika nach G. Frerichs und Normann, Bonn, für kleine 'Tiegelbeheizung ${ }^{6.40}$ ) ansehen, weil Leichtsteine später für den Wettbewerb der Gasfeuerung eine entscheidende Hilfe wurden. Daß̧ die Zentrale für Gasverwertung Unterlagen während des Krieges gesammelt hat, wurde schon auf Seite 459 erwähnt; ebenso die Forderung nach Ingenieurarbeit in den Gaswerken auf diesem Gebiete, Was $A l b r e c b t$ 1923 in einem Vortrag: „Ausgewählte Kapitel auf dem Gebiete der gewerblichen Gasfeuer" erzählt hat, dürfte der Niederschlag der Sammeltätigkeit sein ${ }^{\text {c.asi }}$ ).

Ortlieb, Berlin, machte auf den grof̧en Gasbedarf der Zuckerwaren- und Textilindustrie aufmerksam ${ }^{6 .+203}$ ).

Wichtig war auch die Beobachtung von Kindler, Offenbach, daf3 vielfach sehr schlechte Brenner an technologisch hochentwickelten Maschinen angebracht wurden. Er nannte dafür Druckerei-, Wäscherei-, Kaffeemaschinen und Frägepressen und schlug zur Besserung nach dem Muster des Karlsruher Staatstechnikums Lehrkurse an allen Staatslehranstalten vor $^{6.439}$ ).

Über das sich ausbreitende Gebiet der Grof3küchen ist im Abschnitt 6.43 berichtet. Fortschritte wurden auf dem Gebiete der Bäckerei erzielt, als sich die führenden Firmen von der beim festen Brennstoff notwendigen Wärmespeicherung durch grofye Steinmassen freimachten. Der neue Doppelauszugsofen von Werner \& Pfleiderer, Stuttgart-Cannstatt, ging diesen Weg. Hier wurde zunächst Prefgas verwendet. Erstmalig war wohl die Benutzung des Boschzünders an diesen Öfen. Die Kettenbacköfen von Danger, Hamburg, und Werner und Pfleiderer, Stuttgart, von Selas, Berlin, und der Drehbackofen von Tantesch, Düsseldorf, eine schwedische Bauweise, brachten die fließ̧ende Fertigung für grołe Gebäckmengen, die weitaus am besten mit Gas gelang. ${ }^{6}{ }^{434}$ ).

\footnotetext{
6.425) $67(1924), 377$

6.420) 68 (1925), 637; 69 (1926), 93

6.430) $60(1917), 524$

6.431) $66(1923), 346$

6.432) $69(1925), 715$

6.433) $69(1926), 404$

6.434) 68 (1925), 620
} 
Kummer bereitete die Oberflächenverbrennung für Ofen. Unter den gegebenen Verhältnissen mit erhöhten Drücken hielt O. Essich, Breslau, die Schüttung des Baustoffes für unwesentlich, die Kontaktwirkung der Steine für unwahrscheinlich. Unangenehm war die Rückleitung der Wärme von der glühenden Oberfläche dem Gasstrom entgegen. Auch ein Versuch mit konischen Düsen im feuerfesten Stein mit einem Gemischdruck von nur $50 \mathrm{~m} / \mathrm{m}$ WS. auszukommen, scheiterte an der Wärmeleitung $\left.{ }^{6 . t a 5}\right)$. Der Kruppsche Steinstrahlofen war eine Weiterbildung des Gedankens, mit Kanälen in den Steinen zu arbeiten. Er wurde für größjere industrielle Öfen benutzt ${ }^{6.430}$ ).

Neu war die Bevorzugung des Gases zum Sherardisieren ${ }^{6 .+37}$ ).

Die Bauweise der Fischbackherde in Deutschland bei den Askaniawerken 1924/1925 $\left.5^{6.125}\right)$, hatte ihr Gegenstück in fahrbaren Fischküchen in Paris, die in einfachster Weise an Laternen angeschlossen wurden ${ }^{\text {n.4.39 }}$ ).

Der Antrieb von Kraftwagen mit Gas als Kriegsnotmaf̧nahme wurde in Deutschland nicht aufgenommen. In England, Manchester, griff man das schon I9I5 auf ${ }^{\circ}$.40). 1918 erreichten uns die ersten Bilder der englischen Omnibusse mit einem Ballon als Behälter auf dem Dache ${ }^{\text {e.tu }}$ ) und solcher mit Flaschengas, deren Totgewicht aber bedeutender war. $\left.{ }^{\text {c.uag }}\right)$. Man war dabei, eine grofe Organisation von Tanklagern mit Münzgasmessern zu schaffen. In Manchester bestanden 6 Verdichterstationen, die mit 200 at betrieben wurden. In England liefen am Ende des Krieges 4000 Wagen $^{0.43}$ ), in Kopenhagen 200 Lastkraftwagen mit Hochdruckgas.

Über Gasmotoren für das Gewerbe in Deutschland ist es völlig still gewesen. Aufsätze während des Krieges und nachher beschäftigten sich nur mit den Grofgasmaschinen $\left.^{6.44}\right)$.

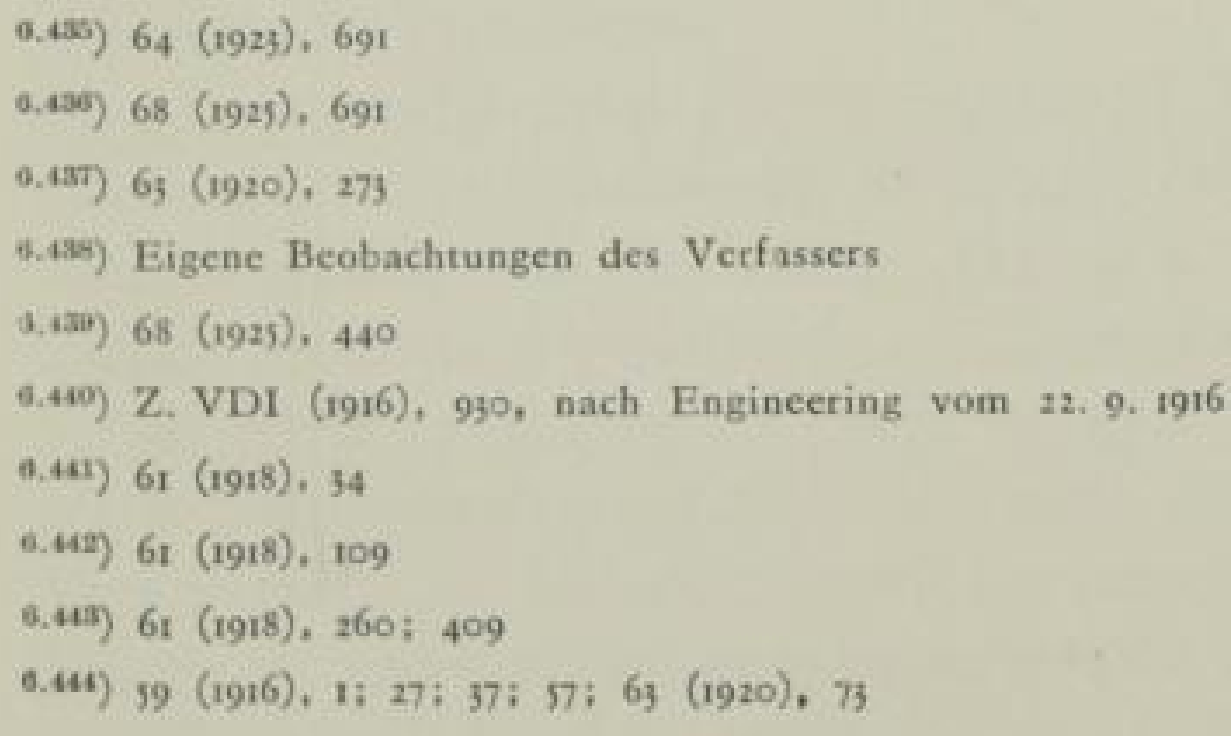




\section{$7 \underset{\text { wirtabrenv }}{\operatorname{SLUB}}$} Wir führen Wissen. 


\section{DIE ZEIT VON 1926 BIS 1939}

Der Darstellung dieses Abschnittes mag als einziges Lebensbild das des ausschlief̧lich für das Gasfach tatigen Wissenschaftlers Professor Dr. K. B u n te vorangestellt werden, weil er in dieser Zeit den Höghepunkt seines Schaffens erreicht hat.

Es erwies sich nämlich im Laufe der Bearbeitung als unmöglich den vielen tüchtigen Männern, die in inniger Verbindung miteinander am Werke waren, gerecht zu werden. Eine grołe Zahl der mafggebenden Männer ist zudem noch am Leben. Aber auch die allgemeinen Lebensläufe sind mit meist geordneter Schulbildung, Hineinwachen in die Lebensaufgabe und dann den bedeutenden Leistungen sehr ähnlich, gleichgültig, ob es sich um Beamte, in der Privatwirtschaft Angestellte oder in wenigen Fällen freie Unternchmer handelt.

Darum wurde trotz sorgfältiger Vorbereitungen die Erzählung weiterer Lebensläufe unterlassen.

\section{LEB ENSBIL D}

Professor Dipl.-Ing. Dr. phil. Karl B unte (Bild n6) wurde geboren am is. Juni I 878 als Sohn des Betriebschemikers am Gaswerk und Privatdozenten an der Technischen Hochschule zu München, des späteren Geheimen Rates Prof. Dr. Hans Bunte. Nach dem Besuch des Gymnasiums zu Karslruhe studierte er in Leipzig, Karlsruhe und Berlin. Unter seinen Lehrern waren: Wislicenus, Be ckmann, Engler, Wöbler, H. Bunte. Die Diplomarbeit (19or) über die Sauerstoffaufnahme des Wassers bei der Enteisenung führte zur ersten selbständigen Veröffentlichung im Journal für Gasbeleuchtung 1903. Bei E. F is cher promovierte K. Bunte im Jahre roos magna cum laude auf Grund einer Arbeit über die Geschichte der Konstitution der Harnsäure und Synthese aromatisch substituierter Harnsâuren.

In den folgenden zwei Jahren wirkte K. Bunte in den Diensten der Deutschen Continental-Gas-Gesellschaft zu Dessau bei der Bauleitung, Inbetriebsetzung und Betriebsleitung der Gaswerke Hamborn-Neumühl und Frankfurt a.d.O. und zuletzt als chemisch-technischer Betriebsprüfer.

Seine grofie Lebensaufgabe fand er aber 1907 in der neueröffneten Lehr- und Versuchsgasanstalt zu Karlsruhe, deren Betriebsleitung er 1908 übernahm. Seiner Veranlagung im Erkennen und Bearbeiten betrieblicher und wissenschaftlicher Fragen ist es zu verdanken, wenn alsbald die Versuchsgasanstalt über den ersten

\section{SLUB}


Auftrag, der Wertbestimmung der in Deutschland verwandten Gaskohlen und der Durchforschung des Entgasungsvorganges hinauswuchs. Die Fühlung mit den Gaswerken brachte Aufträge auf Untersuchung von Haupt- und Nebenerzeugnissen, für die geeignete Methoden in der Mehrzahl der Fälle neu entwickelt werden muf̧ten, sowie auf Beratung in Betriebsschwierigkeiten, so dafy die Anstalt zum Zentrallaboratorium der Gaswerke wurde.

Mit den vorbildlichen photometrischen Einrichtungen und ihrer Ausnutzung wurde die Beleuchtungstechnik nach Karlsruhe als vornehmlicher Pflegestätte gezogen. Folgerichtig ist dann auch der weitere Schritt zur Prüfung anderer Gasgeräte, von Gasherden, Heizöfen und Wasserheizern, nach chemischen und physikalischen Gesichtspunkten getan worden. Viele der heute international gebrauchten Untersuchungsverfahren sind dem Kopfe K. Buntes entsprungen.

Nach einer Unterbrechung der Tätigkeit der Lehr- und Versuchsgasanstalt in den Kriegsjahren 1914-I9I8 nahm die Entwicklung der Anstalt einen stetigen Fortgang. Ihr Name wurde entsprechend der Bedeutung in Gasinstitut umgewandelt und dieses im Jahre 1939 als staatliches Institut in die Hochschule eingegliedert.

Eine Habilitationsschrift über Abnahme- und Leistungsversuche an Gaserzeugungsöfen wurde von $\mathrm{K}$. Bunte im Felde fertiggestellt und 1918 angenommen. Im Jahre 192I wurde der Lehrstuhl für Gastechnik und Brennstoffverwertung an der Hochschule geschaffen, den K. Bunte bis zu seinem Tode innehatte.

Gleichzeitig mit dem Eintritt in die Versuchsgasanstalt wurde er Mitarbeiter im Journal für Gasbeleuchtung und Wasserversorgung. In den Jahren 1909 bis I914 und im Jahre 1919 war er Schriftleiter unter seinem Vater, ab 1920 bis 1925 selbständig. Wegen der zeitweiligen Verlagerung des Schwergewichts zum Wirtschaftlichen wurde die Schriftleitung der neu betitelten Zeitschrift „Gas- und Wasserfach" nach Berlin verlegt. K. Bunte blieb als Mitherausgeber der Zeitschrift verbunden.

Durch diese Bindung kam die überaus umfangreiche literarische Tätigkeit in erster Linie der genannten Zeitschrift zugute. Erst in späteren Jahren kamen in sich steigerndem Mał̧e Aufsätze in anderen in- und ausländischen technischen Zeitschriften hinzu. Kennzeichend für die Arbeiten ist es, daf̧ fast ohne Ausnahme eigene oder von ihm bei den Mitarbeitern angeregte und geführte Forschungsarbeiten behandelt sind.

Wegen der Vielseitigkeit ist es kaum möglich, im Rahmen des zur Verfügung stehenden Raumes eine erschöpfende, geordnete Ubersicht über die das Schaffen des Mannes widerspiegelnden Arbeitsgebiete zu geben. Sie befassen sich mit allen Einzelheiten der Gaserzeugung von der Lagerung und Behandlung der Kohle bis zu den Verfahren der Reinigung des Gases und der Gewinnung der Nebenerzeugnisse, sie zeigen die Entstehung der vielen Vorschriften und Richtlinien zur Begutachtung dieser Erzeugnisse, von Gaswerksöfen, von Gasgeräten and Mef̧einrichtungen. Besondere Bedeutung beanspruchen die klärenden Aufsätze über Brenneigenschaften der Gase und über die Gasbeschaffenheit.

Es ist verständlich, daf̧ so vielseitiges und immer kurz und klar dargebotenes Wissen den Wunsch, diesen Forscher als Mitarbeiter in Ausschüssen des Gasfachvereins und anderer technischer Arbeitsgemeinschaften zu haben, erweckt hat. $\mathrm{K}$. Bunte hat sich solchen Wünschen niemals verschlossen und ohne Vorbehalt seine Kenntnisse und viel Arbeitszeit in den Dienst des Ganzen gestellt. Eine 
Bild 116

Karl Bunte

(Gaskursus 1946)

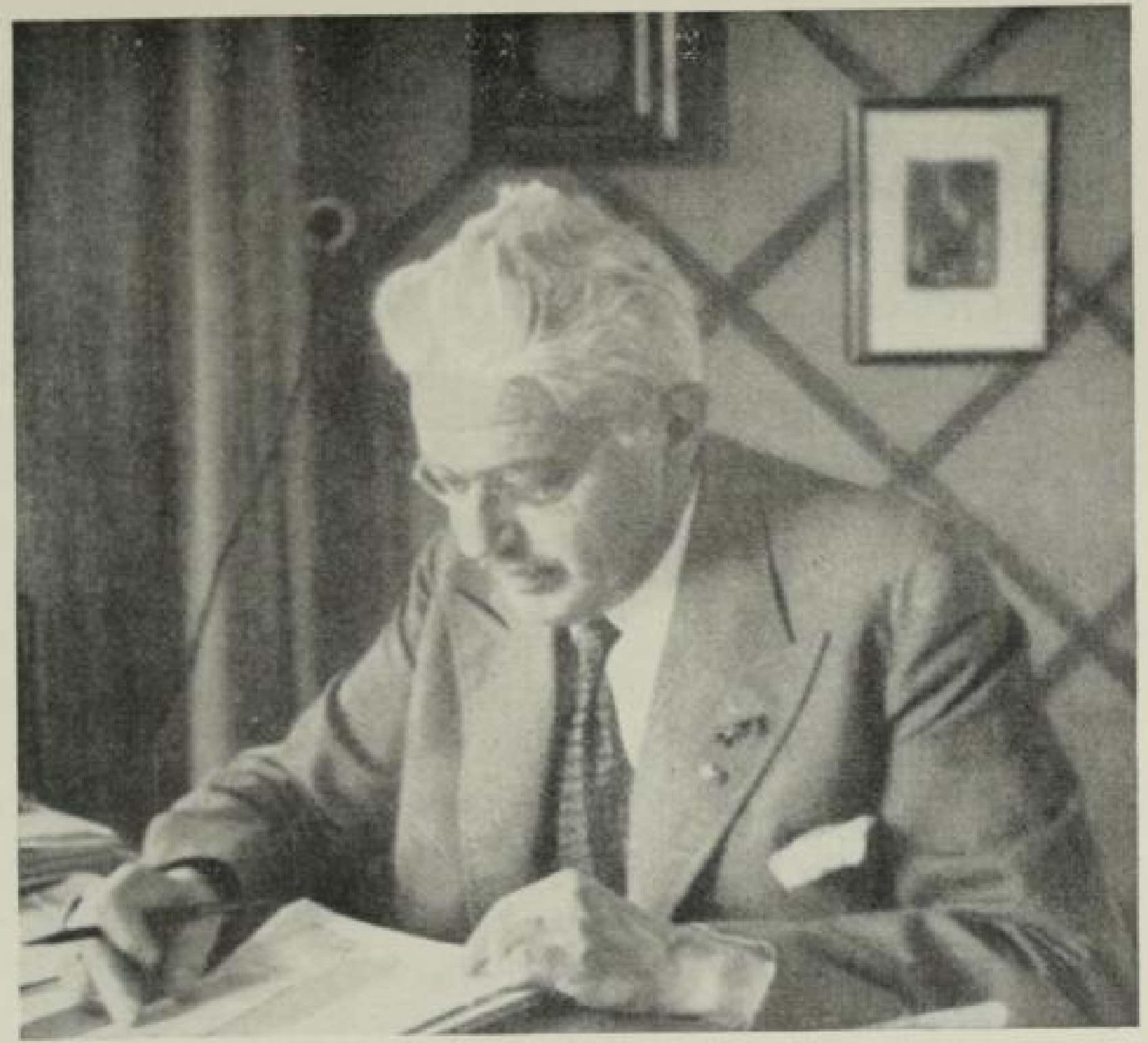

grołe Zahl der Ausschüsse wurde von ihm nicht nur organisatorisch, sondern auch sachlich geführt. Anerkennung fand sein Können und Wirken nicht nur innerhalb Deutschlands, sondern auch unter den europäischen und nordamerikanischen Fachleuten der Gas- und Brennstofftechnik, durch ihn ehrende Inanspruchnahmen und Entsendung von jungen Leuten zur Ausbildung.

Damit wird das letzte grofe Interessengebiet, die Erzichung des Nachwuchses, angeschnitten. Dieses hat er in Hinsicht der organisatorischen Notwendigkeiten nie aus den Augen verloren. Am meisten aber zeigte sich die Liebe zur Jugend in der Art der täglichen Arbeit als Lehrer und Forscher. Oft genug wurden die wertvollsten Anregungen an die Mitarbeiter in sprudelnder Lebhaftigkeit einer scheinbar leichten Unterhaltung dargeboten, oft wurden Nächte geopfert, wenn es galt, eine Aufgabe, auch für den Mitarbeiter, zu lösen. Es zeigte sich hier der Mensch als Helfer und Freund, dem ganz gerecht zu werden einen besonderen Schriftsatz erfordern würde.

Die Worte, die Prof. Dr. E. Terres aus Anlaf̧ des 25 -jährigen Jubiläums des Gasinstituts geprägt hat, mögen als wertvolle Zusammenfassung nachgefügt sein: „Seine besondere Aufgabe in den Anfangsjahren war, Fühlung und Zusammenarbeit mit den Gaswerken zu suchen und die Organisation der Versuchsanstalt durchzuführen. Seit 1920, nach Ubernahme des Lehrstuhls für Gastechnik und Brennstoffverwertung ist immer mehr die Leitung des Instituts in Lehre und Forschung zu seinem Arbeitsfeld geworden. Nach schwerem Anfang, überschattet durch den grofzen Vater, hat er in ehrlicher Gemeinschaftsarbeit unter Einsatz seiner ganzen Persönlichkeit mit unermüdlichem Fleif̧ und zäher Schaffenskraft die Gründung seines Vaters zu einem umfassenden Institut aus- und umgestaltet. Er hat dieses Vermächtnis in treuen Händen gepflegt und ist an der ihm zugefallenen Aufgabe selbst gewachsen. Er ist der einzige von uns, der die Lebens- 
arbeit des Vaters Bunte in gerader Linie weiterentwickelt und mit neuem Geist und neuer Zukunft erfüllt hat. Diese Aufgabe war nicht immer leicht; der grof̧e Name des Vaters hat ihm den eigenen Aufstieg eher erschwert als erleichtert. Vielleicht nahm er auch manchmal die Verantwortung zu schwer und die unvermeidlichen Kämpfe zu ernst. Aber Kampf ist Leben, und wo sich lebendige Kräfte regen, werden Gegenkräfte ausgelöst. Das ist ein gutes Zeichen für ihn und das Institut. Heute ist der Aufbau im wesentlichen vollendet und die Entwicklung - auch seiner Lebensarbeit - in ruhigere und stetigere Bahnen gelenkt. Das zweite Vierteljahrhundert ist die Zeit der Ernte, sie wird reiche Früchte bringen, ihm und dem Institut zur Ehre und dem Gasfach zu immer wachsendem Nutzen."

Leider trat diese Beruhigung, die E. Terres sah, nicht ein. K. Bunte hatte weiter schwer zu ringen und nebenher die altgewohnte Fülle an Arbeit.

Eine schwere Herzerkrankung im Frühjahr 193? zwang ihn zur Ruhe für ein halbes Jahr. Weitere Schonung wäre notwendig gewesen, aber das lag K. Bunte nicht. So verschlimmerte sich das Leiden. Am 24./25. April 1944 wurde das Gasinstitutsgebäude zerstört, am 27. September 1944 brannte auch das Wohnhaus K. Buntes aus. Am 3. November 1944 verstarb K. Bunte in Baden-Baden ${ }^{\hat{2} .1}$ ).

Die Umsatzkurve jeder technischen Entwicklung verläuft bekanntlich, wenn die Neuheit an sich gesund und zeitgemäßz ist, ganz ähnlich wie das Bild der Gauss'schen Fehlerkurve, zunächst steil ansteigend, um dann einem Wendepunkt zuzustreben und später zum mindesten im Verhältnis zum allgemeinen Fortschritt zurückzubleiben ${ }^{7.2}$ ). Im Umkehrpunkt ist dabei durchaus kein absoluter Stillstand im technischen Fortschritt notwendig. Es treten aber gegenüber der technisch umwälzenden Neuerung durch den schaffenden Ingenieur andere Hilfsund Pflegemittel stärker hervor, als da sind: verfeinerte Ausführung vorhandener Verfahren durch Messen und Regeln, wirtschaftlich kaufmännische Durchleuchtung und Verbesserung des betrieblichen Ablaufes (Rationalisierung).

An diesen Punkt war die Steinkohlengaserzeugungstechnik nach der Ausbildung der Kammeröfen gekommen. Die Schwelung erwies sich nach dem Kriege keineswegs als die neue umstürzend belebende Technik, die dem Fach einen neuen Umsatzstoł zu geben vermochte, so viele gute Dinge auch als Verbesserung noch erarbeitet und befruchtend für einzelne Zweige der Technik wurden. Nach den Theorien von $D$ a eves hätte die Gasindustrie dringend eines neuen umstürzlerischen Impulses bedurft, und dieser kam 1926 mit dem Vorstoł des Kohlenbergbaus in die Ferngasversorgung, der in den ersten Phasen noch in die vorhergehende Zeitspanne (Äbschnitt 6) fällt. Er wirkte für das Fach in der Tat aufregend und erschreckend, aber belebend und zwar nicht nur rein technisch-wirtschaftlich als Umstellung, sondern tief das grüblerische Denken, vorausschauende Sorgen und ernste Schaffen der ganzen Industrie einschlief̧lich der groß̧en und kleinen Gaswerke anregend.

Daf3 das vor einem politischen Hintergrunde geschah, der selbst noch wild seine

7.1) Joh. Körting, Geschichte des Gasinstitutes Karlsruhe, 1957 (5. 5.4)

7,2) Karl Daeves: Vorausbestimmungen im Wirtschaftsleben. Praktische Energiekunde Heft 2 (1992-53), 127 , Karlsruhe, Energiewirtschaftlicher Verlag, H. L. Meyer und Helmut Steiner: Energieprognosen in Theorie und Praxis, Vortrag auf der Jahrestagung der Vereiniigung Deutscher Elektrizitätswerke, Berlin am 12, 5. 1959 
Zeichnungen veränderte, weil die demokratische Ordnung, durch Feinddiktat erzwungen, noch innerlich und äuferlich ausreifen muf̧te, macht die Vorgänge sicher dermaleinst für einen Historiker noch besonders stark anziehend. Im Augenblick ist aber die Darstellung durch diese Umstände nech in reichlichem Mafe erschwert. Es bedürfte neben dem technischen Studium auch noch der kritischen Durchsicht aller sonstigen allgemeinen Darstellungen über das politische Geschehen. Das aber würde weit über den Rahmen der Arbeit hinausgreifen. So möge denn dieser Abschnitt, in dem gewisse politisch anschauliche Vermutungen unentbehrlich sind, um die Industriegeschichte zu verstehen, als Beitrag zu dem noch immer schwer übersehbaren Schrifttum aufgefaf̧t werden.

\section{ALLGEMEINE GESCHICHTE DES FACHES}

Wir haben gesehen, (Seite $425 / 26$ ) wie der grofe Kohlenstreik in England im Jahre 1926 die lähmenden Kräfte, die Deutschland seit der Niederlage 1918 immer erneut zurückgeworfen hatten, unwirksam gemacht hatte. Man schöpfte neuen Mut und hatte den Sinn für weitgehende Pläne, um ins Freie durchstoß̧en zu können, entwickelt. Freilich konnte, nachdem England wieder Kohlen förderte, Deutschland nicht im gleichen Ausmałe wie zu Ende des Jahres 1926 arbeiten $\left.^{7.4}\right)$. Die Überschichten im Bergbau wären aber ohnehin auf die Dauer nicht möglich gewesen. Immerhin war zu Anfang des Jahres 1927 die erzielbare Förderung bis zum Mai ausverkauft $\left.{ }^{7.4}\right)$. Aber das aus dem Verkaul der Vorräte erlöste Geld und eine neue Kreditwürdigkeit hatten zur Folge, dał die gesamte Industrie „erfreulich“ beschäftigt war. ${ }^{7,3}$ ). Dagegen deutete die auf s Mia RM angestiegene Auslandsschuld und die vermehrte Lieferung aut Wechsel sofort darauf hin, dał die Schwierigkeiten keineswegs endgültig überwunden wären. Einzelne Feierschichten im April, obwohl der Inlandskohlenmarkt noch gut war, unterstrichen diese $\operatorname{Lage}^{{ }^{7.3}}$ ), die dann auch mehrfach mit „befriedigend" eine vorsichtigere Beurteilung erfuhr ${ }^{5.7}$ ).

Um die Jahreswende $1927 / 28$ stellte J. T i emessen, Wirtschaftliche Vereinigung deutscher Gaswerke, fest, daf der Ortsabsatz an Gaskoks befriedigend gewesen sei. Er führte das auf die Güte des nunmehr erzeugten Kokses zurück, die endlich auch aus nunmehr ausgewählten Kohlen erzielt werden konnte. Auch der Markt der Nebenerzeugnisse mit Ausnahme des Ammoniaks hatte sich gebessert. Zwei kalte Winter $1927 / 28$ und 1928/29 lief̧en den Gaskoks zeitweilig äuf̧erst knapp werden ${ }^{7.7}$ ). „Wären (im März) noch ausgesprochene Frostperioden eingetreten, so hätte der Mangel zu einer Katastrophe getührt ${ }^{\text {"*." }}$ ). Neue Störungen brachte bei ciner Verschuldung Deutschlands von nunmehr 8 Mia RM ein Streik in der Rheinschiffahrts- und der Eisenindustrie ${ }^{7.9}$ ), und die Tatsache, daf3 die Preise für Koks und auch wohl andere Erzeugnisse bereits über dem Welt-

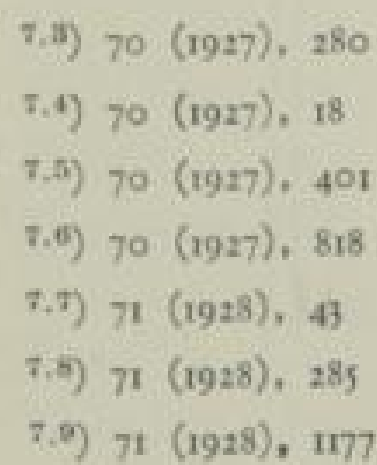


marktpreise lagen. Beides tat aber der lebhaften Nachfrage nach Koks und Kohlen keinen Abbruch ${ }^{\text {7.10 }}$.

Die Steinkohlenförderung war in den ersten , Monaten des Jahres 1929 stark gestiegen, noch mehr die Kokserzeugung der Zechen ${ }^{7.11}$ ).

Die Erzeugung der Gaswerke belief sich im Jahre 1927 auf 3,46 Mia, I928 auf 3,66 Mia; 1929 auf 3,83 Mia m" Gas' ${ }^{5,2}$ ).

Dann aber wurden neue Krisenzeichen sichtbar. Bei gleichbleibender Einfuhr war die Ausfuhr geringer geworden. In den Vereinigten Staaten kam es zu einer Stockung im Kohlenbergbau wegen der schlechten Beschäftigung der Stahlindustrie. Am „schwarzen Freitag“ im Oktober 1929 brach die Hochkonjunktur dort jäh zusammen. Der internationale Bergarbeiterverband forderte noch in diesem Augenblick die allgemeine Durchführung des siebenstündigen Arbeitstages bei gleichen Gesamtlöhnen.

Nun zeigte es sich, wohin eine freigebige W'irtschafts- und Sozialpolitik des Reiches und der Gemeinden geführt hatte. In einem grofen Gaswerk hatte die Steigerung der Personalausgaben vier Jahre lang jährlich $0,5 \mathrm{Pf} . / \mathrm{m}^{3}$ ausgemacht. Die Pensionslasten waren durch die Verdoppelung der Zahl der Arbeiter und Angestellten nach dem Kriegsende und nachfolgendem Wiederabbau stark gestiegen. Stadt Berlin zahlte an Ruhe- und Abkehrgeldern rund I Pf. $/ \mathrm{m}^{3}$ Gas $=$ s $\mathrm{RM} /$ Gasabnehmer und $\mathrm{Jahr}^{7.13}$ ).

Die Regierung suchte nun, den Sturz aufzuhalten. Die Lohnerhöhungen im Bergbau sollten aus Erträgen der Lex $B r \ddot{u} n i n g$ gedeckt werden $\left.{ }^{7.4}\right)$, um einen weiteren Anstieg der Kohlenpreise zu vermeiden ${ }^{7.15}$ ). Die Einflüsse der weltweiten Krise konnten aber so keineswegs abgewandt werden. Der Kapitalmarkt war äuß̧erst schlecht geworden. Betriebseinschränkungen und die daraus folgende Notlage der Bevölkerung behinderten auch den Gaskoksabsatz. Auf den Zechen wuchsen trotz Feierschichten die Halden an.

Die Regierung wurde ermächtigt, mit Verordnungen zu regieren, um eine Preissenkung und einen Abbau der Löhne und Gehälter gleichmäßjig durchzudrücken, und ohne Währungsabwertung den Anschluf an die Weltmarktpreise zu erreichen. (Brüning-Verordnungen). Die Hoffnung aber auf billigere Preise lieł̧ den Absatz noch geringer werden. Für das Gasfach wurden Preisermäßjigungen für Badeöfen, Eisen, Flanschen, Rohre und Privatanschlufgebühren belangreich ${ }^{7,16}$ ). Die Hersteller aber kamen in immer größere Schwierigkeiten und suchten Moratorien und Vergleiche mit den Gläubigern, einer den andern als Zulieferer in Verlegenheit setzend. Manche traten in Liquidation. Eine Auffanggesellschaft setzte dann den Betrieb mit verminderter Belegschaft fort ${ }^{7 \cdot 1 \pi}$ ). In der Öffentlichkeit wurde jede Stützung dieser Art mit Rücksicht auf die Arbeitslosigkeit begrüft. Für die im Wettbewerb stehenden Firmen, die ihre Lasten nicht auf ähn-

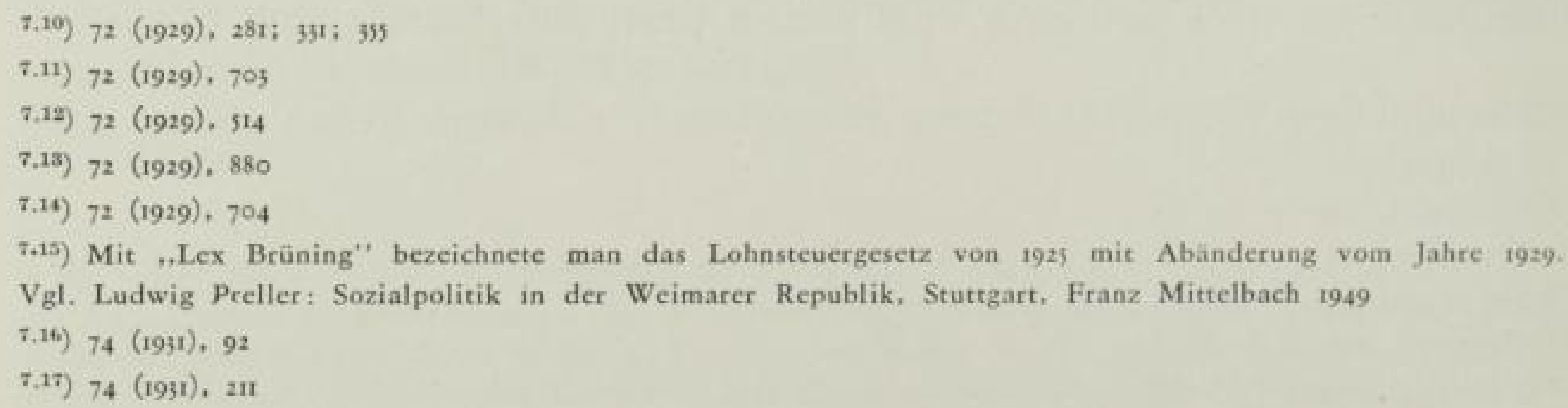


liche Weise abstołjen konnten, wurde damit die Lage aber noch mehr erschwert. Entwicklungs- und Verbesserungskosten konnten kaum mehr aufgebracht werden. Selbst die Stadt Berlin muß̧te versuchen, irgendwie die Schuldenlast zu erleichtern. Für den Ankauf der Gaswerke fanden sich keine Liebhaber. Über die städtischen Elektrizitätswerke wurde mit einem Konsortium aus fast allen deutschen Groß̧banken, der Preuf̧ischen Elektrizitäts-Aktiengesellschaft (Preag) und ausländischen Banken verhandelt $\left.{ }^{7.15}\right)$. Kennzeichnend für die Notlage ist, dafy um einen Zwischenkredit von 75 Mio RM verhandelt werden mufte, um 40 Mio RM fällige Verbindlichkeiten abdecken zu können, der erst am Tage vor der Fälligkeit gewährt wurde. Der Verkauf des Elektrizitätswerkes kam erst später zustande $e^{7.19}$ ).

Der grołen Zahl kleinerer Gemeinden wurde durch eine Umschuldungsbewegung geholfen. Die kurzfristigen Schulden der Gemeinden über 25000 Einwohner beliefen sich auf ${ }_{1.45}$ Mia RM. Ein Gewerkschaftssekretär stellte fest. ${ }^{{ }^{7.50}}$ ), sie wären durch die steigenden Wohlfahrtslasten in diese Lage gekommen. Die Umschuldungsstelle verlangte, daß die Gemeinden alle Maßnnahmen ergriffen, um aus den Gas-, Wasser- und Elektrizitätswerken ohne Erhöhung der Tarife größzere Erträge zu erzielen.

Dabei häuften sich schen vorher die Klagen, dał von den Werken immer gröf̧ere Summen zur Deckung der Fehlbeträge abverlangt würden ${ }^{7.21}$ ), 15 bis $20 \%$ der Deckungsmittel stammten aus den Betrieben ${ }^{5.22}$ ). Ohne Rücksicht auf die Erzeugungskosten wurden die Preise erhöht.

Die Gasabsatzbewegung war nicht einheitlich. Am stärksten sank der Absatz an Industriegas, während das Haushaltsgas in der Provinz kaum eine Einbuf̧e erlitt $^{\text {r.25)}}$ ). In Berlin indessen mit den vollausgebauten Netzen und auch wohl einer gewissen Abwanderung von Menschen aus der Grofstadt setzte ein Rückgang in Jahre 1930 ein $^{7.21}$ ). Dieser hielt bis 1934 an. Der Gaskoks wurde im grofyen und ganzen gut untergebracht, wenn auch von gewissen Schwankungen über Zeit und Ort berichtet wurde.

K. Blume forderte von den Gaswerken angesichts der Krise: I. keine Erweiterungen, 2. keine Vorratswirtschaft, aber 3. Rationalisierungen, 4. Kalkulationen unter Berücksichtigung der gesunkenen Wertansätze, 5. Abschreibungen, was'wohl, wie auch andere ähnliche Äuß̧erungen, darauf hindeutet, dał selbst diese selbstverständlichen Bilanzansätze von den hilflosen Kämmerern beseitigt wurden ${ }^{\text {t.5.5 }}$ ). Preissenkungen, durchschnittlich etwa von $10 \%$, wurden nunmehr im Sinne der vierten Notverordnung der Regierung an manchen Orten vorgenommen $\left.{ }^{7.20}\right)$.

Allmählich aber kam die Erkenntnis, dał mit der erzwungenen Deflation die Arbeitslosenfrage niemals gelöst, vielmehr verschärft würde. Als leuchtendes Beispiel wurde von Generaldirektor Fr. Lenze, Thyssensche Werke, berich-

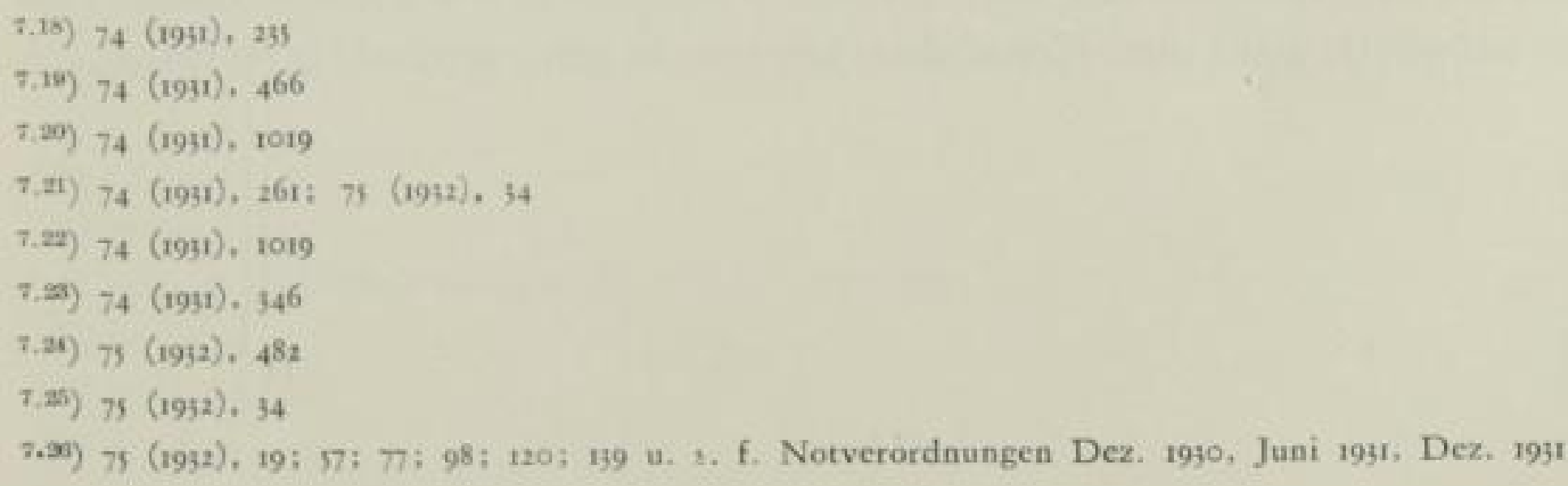


tet, daf3 er seine Belegschaft durch die Krise voll durchgehalten habe, ja daf3 sogar von ihm als einzigem Unternehmer im Ruhrrevier ein neuer Schacht abgeteuft würde. Er handelte damit übrigens ganz nach einer Lehre August T b y s sens, der gesagt hat, Hochkonjunkturen solle man nicht durch Erweiterungen und Umbauten stören, vielmehr die erworbenen Gelder zurücklegen, um zu Zeiten schlechter Konjunktur grołe Bauten billig ausführen zu können.

Am 2. 9. 1932 warf die Regierung v. $P$ a $p e n$ das Steuer wieder herum, indem sie Reichszuschüsse zur Arbeitsbeschaffung gewährte. Die Ausführungsbestimmungen vom 17. 9. 32 waren für das Gasfach wichtig, da Instandsetzungen und Umbauten der Werke begünstigt waren, und die Aufteilung großer Wohnungen neue Gasgeräte benötigte, ferner Sichlichtstraß̧enbeleuchtungen mit Hängelichtansätzen ausgerüstet werden konnten (Sitzung der Fabrikantenvereinigung im Gas- und Wasserfach vom 10. 12. 32). Gegenüber oberflächlichen Angaben, die die Arbeitsbeschaffungsmaf̧nahmen erst nach Januar 1933 anzusetzen pflegen, muf3 man wohl hervorheben, dał bereits gegen Ende 1932 eine spürbare Belebung eingetreten ist $\left.{ }^{* 2 *}\right)$. Die Deutsche Continental-Gas-Geselischaft steigerte 1932 den Gasabsatz und gab als Grund eine Erholung der Industrie an ${ }^{7.55}$ ).

Mit den Mitteln der Diktatur beschleunigte die Regierung im Jahre 1933 den Kampf gegen die Arbeitslosigkeit. In der ,gelenkten Wirtschaft" wurden weniger Geldhilfen als auch Auflagen gegeben. Vor allem wurde der Ausbau der Fernversorgungsanlagen zur Grof̧verbundwirtschaft weitergetrieben. Die Bemühungen, die Treibstoffversorgung Deutschlands vom Auslande möglichst unabhängig zu machen, führten zum Ausbau eines Tankstellennetzes für Hochdruckstadtgas, zur Wiederaufnahme der Schwelversuche für Steinkohle und der Inbetriebnahme der Ölsyntheseanlagen mit einem gesteigerten Anfall von Propan und Butan und Auflagen, diese Gase in Verkehrsbetrieben zu benutzen.

Der Gasverbrauch nahm bei den Ferngasbetrieben und Gruppengaswerken stetig zu, nur die Grofstädte wie Berlin und Hamburg zeigten bis 1935 Rückgänge im Gasabsatz ${ }^{7.25}$ ). 1936 wurden in Gaswerken 3.5 Mia m ${ }^{3}$ erzeugt, mit Ferngas insgesamt $6 \mathrm{Mia} \mathrm{m}^{3}$, von der Ruhrgas Aktiengesellschaft allein $2 \mathrm{Mia} \mathrm{m}^{3}$ abgegeben. Der Koksabsatz war so gut, daf̧ das Ausland nicht umworben werden konnte ${ }^{\text {T.2.0 }}$ ). Im Jahre 1937 liefen die Ruhrzechen mit volier Belastung, die Höchstförderung von 1929 wurde überschritten $\left.{ }^{\text {r.at }}\right)$. Durch eine Ermächtigung des Reichskommissars für die Preisbildung zur freiwilligen Vereinbarung höherer Kohlenpreise und die gesetzliche Bildung der Kohlenwirtschaftsgruppe bekamen die Zechen ,ihre alten Rechte" wieder. Nunmehr konnte nicht mehr von unverantwortlicher Seite hineinkommandiert werden $\left.{ }^{7,2}\right)$. In den Sortenanforderungen war allmählich eine vollständige Wandlung eingetreten. Während der Überfluß̧ an Feinkohlen 1926 die Gedanken zur Ferngasversorgung wachrief, wurde 1937 diese Kohle äufjerst knapp. Bei festgehaltenen Preisen und gutem Koksabsatz waren die Gaswerke, wo immer es möglich war, zur Koksfahrt übergegangen, und sie verbrauchten

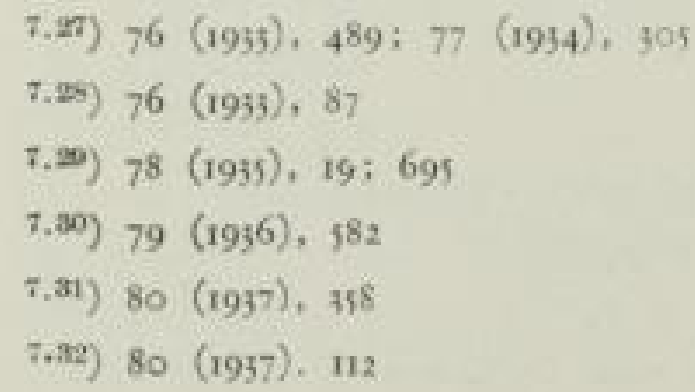


mehr Kohle. Die Zementindustrie verfeucrte mit Staubfeuerungen ebenfalls Feinkohle. Die Anforderungen der Hydrierwerke waren neu hinzugekommen.

So wurden, für die Gaswerke ein böser wirtschaftlicher Schlag, die Preise für kleine Nüsse und Feinkohle laufend verteuert, der Koks verbilligt $\left.{ }^{7.31}\right)$. Die Übernahme von Stadtgas aus der Druckvergasungsanlage mit Braunkohlen nach Drawe-Lurgi in Böhlen war eine Folge dieser Preisverhältnisse ${ }^{7.34}$ ).

1938 erzeugten die Gaswerke 3,4 Mia $\mathrm{m}^{\mathrm{x}}$ Gas und kauften o,94 Mia $\mathrm{m}^{3}$ Kokereigas dazu. Die Ruhrgas A. G. allein vertrieb 1938 2,679 Mia m³, 1939 fast 4 Mia m ${ }^{3}$ Gas. 1939 erzeugten die Gaswerke 3,8 Mia m³ verbrauch $19,7 \mathrm{Mia} \mathrm{m}^{3}$. Insgesamt wurden also 23,5 Mia $\mathrm{m}^{3}$ erzeugt ${ }^{7,45}$ ).

7.II Organisation des Facbes

Im Einklang mit der wirtschaftlich und innenpolitisch bewegten Zeit war auch die Organisation des Faches grofen Veränderungen unterworfen. Die Kommunalisierung privater Werke setzte sich fort, teilweise unter Gründung gemischtwirtschaftlicher Betriebe. Für 1937 wird im Vergleich zu 1933 folgende Gegenüberstellung gegeben ${ }^{5.37}$ ):

\section{T afe 1 4: Aufteilung der Gaswerke}

\begin{tabular}{lrr} 
& I933 & I937 \\
\hline Im Gemeindebesitz & 981 & 953 \\
$\begin{array}{lr}\text { Gemischtwirtschaftlich } \\
\text { Privat }\end{array}$ & IO6 & I54 \\
\hline $\begin{array}{l}\text { Zusammen } \\
\begin{array}{l}\text { ohne die in dem Zeitraum } \\
\text { hinzugekommenen Saarwerke }\end{array}\end{array}$ & I2OI & II82 \\
\hline
\end{tabular}

Im allgemeinen erlangten, wenigstens formeli, die Gaswerke aber eine größ̧ere Selbständigkeit. Der Jahresbericht des Deutschen Vereins von 1930 führte aus ${ }^{\text {T.2. }}$ ): „Die Zahl der bisher in Form selbständiger Rechtskörper betriebenen Werke wuchs unter dem Zwange, die Kreditfähigkeit solcher selbständigen Rechtskörper auszunutzen, deren fast alle Städte, zum Teil in dringlicher Weise bedürfen." Verwaltungstechnisch war aber manchmal nicht so viel gewonnen, wie sich die Werksleiter im Kampfe mit den schnell wechselnden wirtschaftlichen Umweltsbedingungen wünschen mochten.

Ein Bericht aus Lübeck lautete auszugsweise wie folgt $\left.{ }^{-.35}\right)$ : Die kameralistische Buchführung wurde 1903 aufgegeben. Am 14. April 1923 wurde eine Körperschaft des öffentlichen Rechts gegründet. So entstand ein Unternehmen, zu dessen Preisbildung nicht mehr die soziale Notwendigkeit seiner Leistungen, sondern das Streben nach einem möglichst hohen Gewinn mafggebend ist. Ein Teil des Reingewinnes muß̧ an die Stadt abgeführt werden. Die Höhe der Abgabe wird

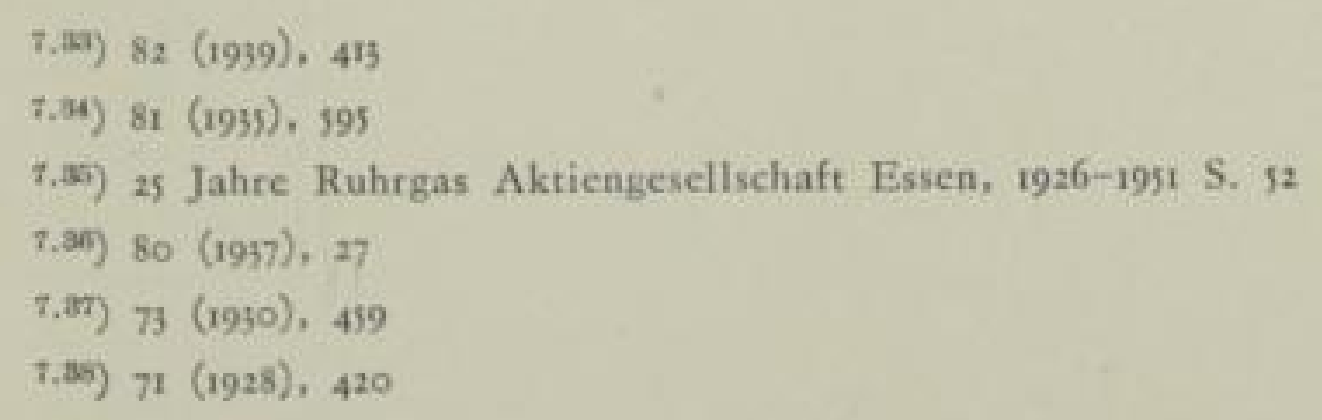


alljährlich durch den Verwaltungsrat aus zwei Senatoren und fünf Mitgliedern der Bürgerschaft festgesetzt, die wegen der politischen Parteien nicht immer in der Lage ist, die Delegierten nach der Befähigung und Tauglichkeit zur Leitung industrieller Betriebe auszusuchen, die insbesondere Schwierigkeiten haben, die Abweichungen im Ergebnis des kommenden Jahres vorauszusehen.

1929 plante man, die Frankfurter Gas-Geselischaft einen reinen Erzeugungsbetrieb werden zu lassen, um sie in den Fragen der Ferngasversorgung unabhängiger zu machen. Die Gaswerke Heddernheim und Griesheim sollten stillgelegt werden. Der Gasvertrieb sollte ganz in die Hände der Stadt kommen ${ }^{7,39}$ ).

Die Form einer Aktiengesellschaft wurde beispielsweise in Wiesbaden ${ }^{7.40}$ ) und Halle $^{7.41}$ ) gewählt.

Am auffallendsten war die Umwandlung der Dresdner städtischen Gas-, Wasser- und Elektrizitätswerke und städtischen Straf̧enbahn in eine Aktiengesellschaft im Jahre $\left.1932^{7.42}\right)$, da dort mit deutlicher Betonung, daf3 die Lösung besser sei, ein autonomer Regiebetrieb viele Jahre bestanden hatte. Der Grund war die Möglichkeit, eine Amerikaanleihe für die Aktiengesellschaft zu erhalten ${ }^{\text {i.ts }}$ ). Dał aber bei den städtischen Aktiengesellschaften die Freiheit nicht errungen war, belegt eine Äuß̧erung des kaufmännischen Direktors der Berliner städtischen Gaswerke. Er forderte die völlige Offenlegung der Geschäftsberichte solcher Aktiengesellschaften $\left.{ }^{7.4}\right)$. In der Zeit der größten Arbeitsnot und der ersten Maßnahmen dagegen ergänzte er seine Gedanken: „Die kaufmännisch aufgezogenen Werke folgen strengen Anordnungen der Gemeinden und geben an die Gaswerke bauende Industrie keine Aufträge. Rechtzeitige Reparaturen bringen aber Ersparnisse gegenüber der Verzögerung notwendiger Arbeiten." Die Vorschriften für die Auftragsvergebung führten auch zu einer Úberbeanspruchung der Industrie mit Projekten. A. $S c b m i d t$ nannte einen Fall, wo von fünf Firmen Angebote auf drei verschiedene Ausführungsformen verlangt wurden. Die Ausarbeitung kostete auf diese Weise insgesamt 14000 .- RM bei einem möglichen Bruttogewinn am Objekte von 5000 bis $6000 \mathrm{RM}^{7.45}$ ).

Es gab also der Form nach finanziell selbständige Werke, aber alle Direktionsgewalt einschliç̧lich der Tariffestsetzung, Betriebsänderungen u. s. w. lag bei einem vielköpfigen (in einem Falle 15) Werkausschuf3 ${ }^{7+16}$ ).

Es kam aber auch hin und wieder zur gegenteiligen Bewegung. Die Kösliner technischen Werke G.m.b.H. wurden liquidiert, da die städtischen Körperschaften wieder mehr Einfluł, insbesondere auf die Tarife, haben wollten ${ }^{7.47}$ ).

Die allgemeine Stimmung war den kommunalen Betriebsformen durchaus günstig. Unwidersprochen konnte der Staatssekretär Dr. Po pit $z$ auf der Jahresversammlung des Bundes der Elektrizitätsversorgungsunternehmen und der privatwirtschaftlichen Gas- und Wasserwerke eine Lanze für die Versorgungsbe-

$7.30) 72(1929), 284$

$7.40) 73(1930), 239$

7.41) $73(1930), 45$

$7.42) 73(1930), 118 ; 931$

7.43) $76(1933)+256$

7.44) $74\left(195^{\circ}\right), 25$

7.45) $75(1932), 157$

7.46) 76 (1933), 506

7.47) 71 (1928), 431 
triebe (der Name stammte aus dem Körperschaftssteuergesetz von 1925) brechen. Sie seien in der liberalen Wirtschaft (als Gegensatz zu der Wirtschaft Mitte 1932) wegen des monopolartigen Charakters der Versorgungen auch nicht abgelehnt worden. Anregungen, den Radius der Gemeinwirtschaft gegenüber der Privatwirtschaft über Gas und Elektrizität auf Kohle, Stahl und Eisen auszudehnen, wurden dagegen als gewagt abgelehnt $\left.{ }^{7.45}\right)$. Nach dem 30 . Januar 1933 wurden Gedanken an eine allgemeine Uberführung der Werke in die öffentliche Hand lebhaft erörtert, aber alsbald dagegen gesagt, daß̧ die Regicrung genügend Mitte! habe, die Wirtschaft zu lenken, und daher die Frage des Besitzes ohne Bedeutung sei. Die Mittel gab das Gesetz zur Förderung der Energiewirtschaft (Energiewirtschaftsgesetz vom 15. Dez. 1935) in die Hand. Dieses Gesetz stellte die Elektrizitäts- und Gasversorgung unter staatliche Aufsicht. Die private und öffentliche Unternehmertätigkeit blieb in der Form erhalten.

Die Rückführung gemeindeeigener Unternehmen in Eigenbetriebe wurde für die dem allgemeinen Gesundheitsdienst dienenden Krankenanstalten, Müllabfuhr, Strałenreinigung, Schlacht- und Viehhöfe gefordert $\left.{ }^{3 . t 3}\right)$. Für die Versorgungsbetriebe wurde die Musterbetriebssatzung des deutschen Gemeindetages aufgestellt. Sie stellte klar, daß̧ die Verwaltung in den Händen des Gemeindeleiters, die Werkleitung aber beim Betriebsführer liege. Der Gemeindeleiter konnte Einzelheiten seiner Entscheidung vorbehalten. Der Beirat sollte einmal im Vierteljahr zusammentreten ${ }^{7.50}$ ).

Oberbürgermeister Strölin, Stuttgart, behauptete, daß ,die im Interesse der örtlichen Gemeinschaft liegende" Einflußnnahme der Gemeinden auf die Versorgungswirtschaft durch die finanzielle Notlage der Gemeinden vielfach verloren gegangen sei. Noch in jüngster Zeit seien Werke an Gesellschaften verkauft und langfristige Versorgungsverträge zu überaus ungünstigen Bedingungen abgeschlossen $^{\text {i.51). }}$.

Darum habe der Reichs- und Preufzische Minister des Innern mit einem Runderlał am is. 8. 1935 eingegrifien, nach dem Gaswerke keine neuen Verträge mit Privatgesellschaften abschließzen oder in gemischtwirtschaftliche Unternehmen eintreten durften, weil die Energie in den Händen der Kommunalgewalt bleiben müsse. Es folgten noch Vorschriften für Pacht-, Konzessions- und Energiebezugsverträge ${ }^{7 . \mathrm{nz}}$ ).

Berlin bildete bald die Gasag wieder in einen Eigenbetrieb um ${ }^{7.55}$, Doch stellte H. Bebrens auf der Hauptversammlung des deutschen Vereins fest, daf der Charakter der gemeindeeignen Werke die Möglichkeit der freien Entfaltung der in ihnen tätigen schöpferischen Kräfte im allgemeinen nicht zulasse $\left.{ }^{7.54}\right)$. Das hatte sich bei der völligen Umwandlung des Arbeitsmarktes gezeigt. Es galt nunmehr, Arbeitskräfte für andere Aufgaben freizumachen. Das gelang nur bei nach privatwirtschaftlichen Grundsätzen geführten Unternehmungen ${ }^{7.55}$ ).

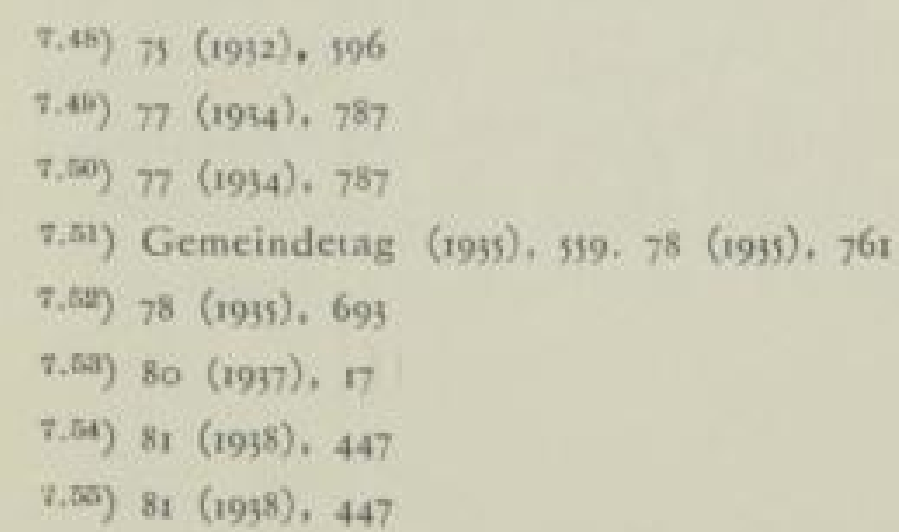


1938 wurde dann eine Eigenbetriebsordnung erlassen. Sie verankerte die Selbständigkeit der Oberbürgermeister bei der Festsetzung der Tarife, der Rechtsformen, der Beteiligungen, der Schuldenaufnahme, bezüglich des Jahresabschlusses und der Verteilung der Gewinne. Das Sondervermögen war auszuweisen, eine Verzinsung mufte erarbeitet werden. Der Wirtschafts-, Erfolgs- und Finanzplan wurde vorgeschrieben, die kaufmännische Buchführung verlangt ${ }^{\hat{7} .56}$ ).

Die Arbeiten der Vereinigungen im Gasfach wurde durch die wirtschaftliche und politische Unruhe stark beeinflufyt. Selten sind wohl Zusammenschlüsse so oft umgestaltet worden, wie gerade in dieser Periode.

Im Anfang steht als Folge der wieder möglichen Verbindung mit dem Ausland ein umfangreicher Bericht B. $L u d$ wigs über Organisation und Tätigkeit der amerikanischen Fachvereinigungen $\left.{ }^{7.57}\right)$. Allgemein war der Wunsch, möglichst viel davon nachzuahmen. Es ist nun aber wohl immer gefährlich, Eindrücke einer kurzen Besuchsreise, bei der unmöglich die tiefen technischen und wirtschaftlichen Voraussetzungen und Folgen im Einzelnen erforscht werden können, zur Grundlage umwälzender Änderungen zu machen.

Fabrikanten haben dagegen durch mehr oder weniger erfolgreiche Versuche, im Auslande Fuß zu fassen, und durch Berichte von Geschäftsfreunden oder gar Tochterunternehmen mit dem Alltag zu ringen. So war es verständlich, dał der draufgängerische Vortrag Sorgen hervorrief, stand doch den amerikanischen Kollegen ein viel größ̧erer Markt der jahrelang ungestörten Hochkonjunktur zur Verfügung und hatten sie auch daher viel größzere Mittel, um die vielen vorgehaltenen Aufgaben zu erfüllen.

Gewił konnten die Hersteller den frischen Geist, der nun plötzlich auf Gaswerksseite mit Begeisterung aufgerufen wurde, nicht ängstlich ablehnen. Aber die Mittel, mit dem alten festgeschlossenen Partner auf Gaswerksseite gleichgewichtig verhandeln und Hand in Hand arbeiten zu können, mufjen sofort geschaffen werden. Die bestehenden Verbände der lndustrie der Geräte, Messer, Rohre und des Ofenbaues waren dazu ungeeignet, weil sie durch Preisabreden und Garantie- und Abnahmevereinbarungen dauernd in den eigenen Reihen vermitteln und schlichten mufyten.

So schlug unmittelbar nach dem Vortrage Ludwigs J. Körting, Dessau, einigen führenden Geräteherstellern vor, eine allgemeine Vereinigung zu schaffen, die sich ausschlieflich mit technischen Anliegen befassen, wirtschaftlich aber nur die grołge Linie, die allen Firmen gemeinsam war, verfolgen solle. Der Vorschlag wurde günstig aufgenommen und durch P. Spaleck, G. Heise, M. Bessin und J. Körting noch verfeinert, auf das gesamte Gas- und Wasserfach ausgedehnt. Nach der gründlichen Aussprache aller zu Beteiligenden kam es Anfang Januar 1927 zur Gründung der Fabrikantenvereinigung im Gasund Wasserfach ${ }^{7.55}$ ), für die G. He is e den Abkürzungsnamen Fagawa geprägt hat. Den Vorsitz übernahm P. Spaleck, der ein leuchtendes Beispiel gab, wie unter Zurücksetzung augenblicklicher eigensüchtiger Vorteile die Gesamtheit gefördert werden muf und kann, wobei letzten Endes auch die eigene Firma ganz von selbst den vom Direktor verlangten erhöhten Nutzen erntet.

$\begin{array}{ll}7.36) & 81(1938), 866 \\ 7.57) & 69(1926), 544 \\ 7.55) & (1927), 500\end{array}$

482 
Um das neue Verpflichtungsgefühl zu belegen, griff die Fagawa die Fragen um die Druckerhöhung des Gases im Rohrnetz bis vor das Gerät, die schon vieie Mitglieder beschäftigten, erneut auf und veranstaltete, als sich im Rahmen der Vorträge der Hauptversammlung 1927 die Erörterungen nicht unterbringen lief̧en, gleichzeitig mit dieser eine eigene Vortragstagung. Diese war gut besucht und konnte insofern als Erfolg betrachtet werden, als nun weithin klar geworden war, wie die Arbeit der neuen Vereinigung aussehen sollte.

Der Deutsche Verein begann in der gleichen Hauptversammlung mit der Neueinteilung seiner Fachgruppen und Arbeitsausschüsse. Einzelheiten darüber können nicht dargestellt werden. Selbst die Festschrift: Hundert Jahre Deutscher Verein von Gas- und Wasserfachmännern 1859-1959 kann nur die wichtigsten Dinge herausgreifend ein allgemeines Bild geben. Zunächst wurden 24 Ausschüsse gebil$\left.\operatorname{det}^{\text {t.tsp }}\right)$. Was alles sofort bearbeitet werden sollte, war so viel, daf man wohl von einem überstürzten Tempo sprechen darf. Allein der Geräteausschuf̧ bearbeitete gleichzeitig I4 neue Normen und Vorschriften. Das Gasinstitut bekam dabei allein 9 Entwicklungsaufgaben in Auftrag. Darunter so verwickelte Aufgaben wie etwa „der Einfluß\} der Gestaltung der Düse auf die Verbrennung". Diese ist ja auch heute trotz der fleißjigen jahrelangen Arbeit mit hervorragenden Beiträgen groß̧er Institute für Strömungsforschung keineswegs wissenschaftlich befriedigend gelöst. Die zahlenmäßjig sehr umfangreichen amerikanischen Versuche, die wohl zu dieser Aufgabe angeregt hatten, waren als rein empirische Feststellungen jedenfalls keine geeignete Unterlage.

Die Fülle von neuen Vorschriften und Richtlinien ist von der Mchrheit der Gaswerke begrüf̧t worden, nur wenige, die hartnäckig an der Einrichtertätigkeit der werbenden und technisch aufklärenden Arbeit der Gaswerke festhielten, fürchteten Fesseln bei der jeweiligen Anpassung an die örtlichen Gegebenheiten, die sie von Fall zu Fall dem Urteil des Ingenieurs vorbehalten wissen wollten. Eine eindeutige allgemeine Stellungnahme ist aber heute noch immer sehr schwierig. Ohne Frage ist es richtig, daf vor allem den kleineren, selbständigen Werken, die keine Spezialingenieure halten konnten, eine grołe Hilfe gewährt wurde. Die Gaswerke waren auch durchaus nicht frei in ihren Entschlüssen. Wie bereits auf S. $335 / 36$ beim Entstehen der „Anleitung zur richtigen Konstruktion, Aufstellung und Handhabung von Gasapparaten“ geschildert werden konnte, kamen Einmischungen in die Gastechnik vielfach von auf̧en. Der ,übermäf̧ige Eifer der Behörden, der freien Entwicklung der Technik durch zu weitgehende Vorschriften Fesseln anzulegen“, war keineswegs erlahmt. Im Gegenteil, sie wurden noch belebt durch politische und ideologische, meistens vermeintlich soziale Anschauungen. Gerade in der betrachteten Zeitspanne herrschte vielfach unbewuf3t die Meinung, dał, wenn ein Ingenieur in einer amtlichen Dienststelle eine Ansicht vertrat, diese ohne Frage sachlich richtiger sein müsse als die der Ingenicure in auf Gewinn ausgerichteten Unternehmen. Es war also eine Notwendigkeit, was an Erfahrungen und Untersuchungen an Tatbeständen errungen war, durch gegenseitigen kritischen Austausch zu klären und zusammenzustellen.

Man sollte aber nicht übersehen, dał durch die vorgelegte Geschwindigkeit und die weit ausgreifende Vielheit der Aufgabenstellung gerade die Firmen, die 
sich ganz und gar mit ihrem Arbeitskreis dem Gas- und Wasserfach widmeten, ganz ungeheuerlich mit Forschungen, Nachprüfungen, Beratungen und Ausspracheterminen belastet wurden. Das war noch erträglich bis 1929 in der lebhaften Weltkonjunktur, wurde aber sehr gefährlich in der Zeit der stark rückläufigen Wirtschaft, wo es geldlich einfach unmöglich wurde, eine beliebig große Zahl von Mitarbeitern an solche Aufgaben zu setzen. Ohne Frage ist manch guter und aussichtsreicher konstruktiver Gedanke vernachlässigt worden, der von der technischen Arbeit her einen neuen Impuls hätte bringen können, weil dem antreibenden Deutschen Verein mit seinen Neuerungsgedanken der Vorrang im Konstruktionsbüro gewährt werden muf̧te.

Andererseits ist aber auch wieder nicht bestreitbar, daf die aufeinander platzenden Meinungen Überlegungen und Versuche auslösten, die als scharfe Selbstschulung den Stand des Wissens, auch durch den Erfahrungsaustausch der Firmen miteinander innerhalb der Fagawa, ungemein anhoben. Das mag hier als Eindruck aus dieser Zeit lebhaftester Tätigkeit festgehalten werden, weil immer wieder als menschliche Schwäche des Europäers besonders in Mitteleuropa der Vorwurf auftritt, es ginge irgend etwas nicht schnell genug voran.

Eine der bedenklichsten Seiten des engen Rahmens der Normen und Vorschriften ist aber die dadurch entstehende Beurteilung von Unglücksfällen. Nur wer als Sachverständiger häufig bei der Klärung solcher Fälle mitgewirkt hat, hat auch erfahren, mit welchem Leichtsinn der Buchstabe einer Richtlinie herangezogen wird. Es wird dem Beurteiler gar nicht mehr klar, wo und in welchem Maf̧e bei technischen Dingen ganz natürlich - in den Vorschriften und Richtlinien Unvollkommenheiten geblieben sind, die von den Bearbeitern trotz besten Willens nicht beseitigt werden konnten. Immer wieder ist es verwunderlich, wie verbissen mancher Ingenieur, der eine Entwicklungsaufgabe offenbar niemals selbst übernommen hat, sich mit seinem Urteil festlegt, während man bei dem Juristen als technischen Laien meist viel leichter das Verständnis für gegebene Unzulänglichkeiten erreichen kann.

Solche Unterwerfung unter den Buchstaben war in der Zeit nach 1933 oftmals ganz auffallend. Die Normung war wirklich eine Gefahr geworden, fortschrittshemmend zu werden. Ganz und gar bedenklich war es aber, dał man eben aufgenommene technische Verfahren sofort durch Normen fördern wollte. Es ist ein in der Betriebswirtschaft allgemein anerkannter Zahlenwert, dafy eine Neuerung selbst in einem eingearbeiteten Betriebe etwa 4 Jahre vom ersten Gedanken bis zur Fabrikationsreife mit eingeschalteten Erprobungszeiten braucht. Dagegen wurde, nachdem ein Jahr vorher die erste Tankstelle in Hannover errichtet war, bereits 1936 der deutsche Normenausschuf beauftragt, in Hannover mit der Wirtschaftsgruppe Gas und Wasserversorgung die Treibgasverwendung zu fördern. Wenn auch die Ergebnisse ,vorläufige Richtlinien“ genannt wurden ${ }^{\text {7.0 }}$ ) und damit die Unvollkommenheit angedeutet war, so gab es gerade damals genügend Dienststellen, die ihren Stolz darin sahen, eine Richtlinie die von oben kam, nach unten als Vorschrift weiterzugeben. Aber man glaubte auch an den ersten Stellen des Faches, nicht nur Wirtschaft und Geschäftsgebahren sondern auch die Wissenschaft durch Befehle lenken zu können. Die unter Abschnitt 7,323 S. 510, erwähnte Arbeit der Physikalisch-technischen Reichsanstalt mufte, verglichen mit

$7.00) 79(1936), 223$

$4^{84}$ 
den Grundgedanken, die Werner von Siemens als Anreger dieser Anstalt geprägt hatte $\left.{ }^{\text {7.a1 }}\right)$, Wunder nehmen. Daf̧ auch beim Gasinstitut des Deutschen Vereins an der Technischen Hochschule Karlsruhe gegen Ende dieses Abschnittes solche Lenkungseingriffe vorkamen, hat der Verfasser in der Geschichte des Gasinstitutes kurz angedeutet.

Damit ist diese Darstellung, um die Geschlossenheit zu wahren, der zeitlichen Entwicklung enteilt.

Ende des Jahres 1929 wurden beim Tode des 1925 als Geschäftsführer der Zentrale für Gasverwertung und „Der Gasverbrauch, G.m.b.H.“ berufenen H. Elvers diese Organisationen samt dem Sckretariat der deutschen Gaswerke von 1928 einem gemeinsamen Ausschu\} und einer Geschäftsfürung unterstellt, die W. Bertelsmann für die Abteilung Technik und W. A. Franke für die Werbung übernahmen ${ }^{\text {7.0z }}$ ). Die Wirtschaftsberatung deutscher Städte, Versorgungsund Verkehrsunternehmen A. G. mit einem Kapital von 150 ooo RM brachte organisatorisch die gemeindliche Selbstverwaltung zum Abschluf ${ }^{7.65}$ ). Die Einrichtung einer Abteilung Gas/Wirtschaftsfragen, die die grołe allgemeine Linie bearbeiten sollte, spiegelt die Wichtigkeit wider, die in dieser Notzeit der Wirtschaftsführung zukam ${ }^{7.65}$ ).

Die Internationale Gas Union erbrachte eine erfreuliche Vertiefung der freundschaftlichen Beziehungen der in der Gastechnik führenden Länder. Hatte England nur gelegentliche Tagungen nach dem jeweiligen Bedürfnis im Auge, so forderte Frankreich einen festen Verein mit dem Sitz in Paris. Deutschland konnte erfolgreich vermitteln, so daf̧ seitdem alle drei Jahre eine Tagung von Land zu Land wechselte, wobei auch der Sitz der Union wanderte. Den Vorsitz übernahm 1930 zuerst F. Escber, Zürich, die Geschäftsstelle wurde nach Paris verlegt $\left.{ }^{7.65}\right) .1937$ wurde in Paris H. M üller, Dessau, zum Vorsitzenden gewählt.

$\mathrm{Ab} 1933$ kamen dauernd neue Organisationsänderungen in Deutschland. Dr. H. Chr. Gerdes, der seit 1932 als Direktionsassistent bei der Zentrale für Gasverwertung tätig war, wurde zum Kommissar bei sämtlichen Organisationen des Gasfaches ernannt. Der Vorstand des Deutschen Vereins kooptierte ihn. Bei der Wirtschaftlichen Vereinigung trat er in den Aufsichtsrat und er wurde Vorsitzender der Zentrale für Gasverwertung ${ }^{7.00}$ ). Er hat das Verdienst, manchen örtlichen Eingriff übereifriger Parteistellen, die den Fortgang der Arbeiten hätten schädigen können, abgewehrt oder wenigstens bis zum Erträglichen abgewandelt zu haben.

Alsbald wurde die Gesamtorganisation des Gasfaches im Reichsverband des Deutschen Gas- und Wasserfaches e. V.zusammengefafyt. Alleiniger Vorstand dieses Verbandes wurde J. Tie messen, der einen Beirat bestellte ${ }^{7.67}$ ). Dieser Verband wurde im Rahmen der Neuorganisation der deutschen Wirtschaft in die Wirtschaftsgruppe Gas und Wasserversorgung als Teil der Hauptgruppe Ener-

7.9i) Werner v. Siemens, Lebenserinnerungen 16. Aufl. 1956 München Prestel S. 268

7.a2) 73 (1930), 382; 74 (1931), 616

7.es) 74 (19931), 23

7.64) 74 (1931), 346

$7.65) 74(1931), 489 ; 803$

$7,06) 76(1939), 275$

7.57) $76(1933) \cdot 572$ 
gieversorgung umgewandelt $\left.{ }^{7.09}\right)$. Als Geschäftsführer des Vereins schied mit 70 Jahren K. Lempelius aus, für ihn trat F. zur Nedden ein ${ }^{\text {7.en }}$. Gedanken, die Zentrale für Gasverwertung und „Der Gasverbrauch“ aufzulösen, wurden nicht ausgeführt. Deren Geschäftsführung wurde ebenfalls F. zur Nedden anvertraut, der gleichzeitig noch Herausgeber der Zeitschrift: Das Gas und Wasserfach und stellvertretender Vorsitzender der Wirtschaftsgruppe wurde. So sollte die Einheitlichkeit im ganzen Fache erzielt werden $\left.{ }^{n .73}\right)$. Alsbald aber wurde Th. Lingens stellvertretender Geschäftsführer des Vereins und Geschäftsführer der wirtschaftlichen Vereinigung, später auch der Wirtschaftsgruppe ${ }^{7 \pi \pi 1}$ ). Der Verein unterlag einer völligen Umorganisation. Die bisher selhständigen Bezirksverbände wurden aufgelöst und angepał̧ an die Wirtschaftsgebiete der Treuhänder der Arbeit 14 Vereinsbezirke mit 36 Arbeitsgruppen als Glieder des einheitlichen Reichsvereins abgeteilt $\left.{ }^{772}\right)$. H. Bebrens wurde vom Vorsitzer des Vereins zum stellvertretenden Vorsitzer ernannt. $\left.{ }^{7.73}\right)$. Er wurde auch 1937 nach dem Rücktritt Tiemessens vom Minister zum Leiter der Wirtschaftsgruppe bestellt $\left.{ }^{7, \bar{A}}\right)$, ein Jahr später von F. $T o d t$ vor der Hauptversammlung des Vereins zum Vorstand bestimmt ${ }^{7,75}$ ), und wieder ein Jahr später zum Vorsitzenden des Aufsichtsrates der Wirtschaftlichen Vereinigung gewählt ${ }^{7 . * 0}$ ).

Wohin der Weg ging, wurde bei der Hauptversammlung 1936 in München deutlich. Technische Vorträge wurden nicht abgehalten. Ein Tagungsheft sollte sie ersetzen, die Erörterung wurde schriftlich und damit umsonst erbeten. Dafür gab es „technopolitische“ Keden. Man kann leicht nachlesen, daf3 in den Versammlungen des Deutschen Vereins, der Wirtschattsgruppe und der Wirschaftlichen Veteinigung die gleichen Themen abgehandelt wurden, wobei man höchstens gewisse Widersprüche feststellen $k^{2} n^{7 \pi}$ ). Ein Jahr später heif̧t es: „Die Neuregelung arbeitet den Charakter des Deutschen Vereines von Gas- und Wasserfachmännern als technisch-wissenschaftlichen Verein wieder in völliger Klarheit heraus.“ Das Wort „,wieder" war zum mindesten ein Irrtum. Wie jeder gute Ingenieur sich über die wirtschaftlichen Auswirkungen seiner technischen Arbeit unterrichten muf, wie gerade eine wirtschaftliche Weitsıcht die technischen Entwicklungsrichtungen auswählerisch bestimmen kann, so hat sich, wie diese $\mathrm{Ge}$ schichte gezeigt hat, der Verein trotz seiner technischen Grundarbeit stets auch den wirtschaftlichen Fragen zugewandt. War doch die erste grołe Vereinsarbeit der Kampf um den „Einpfennigtarif“" gewesen. Ihr Erfolg war schlief̧lich entscheidend für den Übergang von Holz und Kohle auf Rohstoff in Süddeutschland. Nunmehr bekam der Verein die Aufgaben gestellt, sich forschend, prüfend, normend zu betätigen, sich um den Nachwuchs zu kümmern und technische Gutachten abzugeben. Die ihm 1933 angegliederte technische Abteilung ging mitsamt

\footnotetext{
7.65) 78 (1935), 236

7.69) 78 (1935), 237

7.70) 78 (1955), 502

7.71) $79(1936), 112$

7.72) 79 (1936), 310

7.73) 79 (1936), 31

7.74) 80 (1937), 611

7.75) 81 (1938), 448

7.7v) 82 (1939), 173

7.77) $79(1936), 433 \mathrm{ff}$
} 
den Arbeiten des Deutschen Vereins auf diesem Gebiete wieder an die Zentrale für Gasverwertung zurück, deren Direktor R. Hartmann geworden war. Es blieb fürwahr ein beengtes Arbeitsgebiet, dessen Grenzen zu durchstoßen das Anliegen eines Ingenieurs immer sein wird.

Eine wesentliche Verbreiterung der wissenschaftlichen Arbeit sollte dem Verein durch die Gründung des Gaswärmeinstitutes zuwachsen. Die ersten Pläne gingen darauf hinaus, ein solches Institut in engster Verbindung mit dem eisenhüttenmännischen Institut in Aachen ins Leben zu rufen $\left.{ }^{7.75}\right)$. Danach sollte nach Wunsch des Unterrichtsministeriums ein ordentlicher Lehrstuhl geschaffen werden. W. Heiligenstaedt nahm sogar bereits die Forschung auf $\left.{ }^{-n}\right)$. Dann aber setzte W. Dillgard, der Oberbürgermeister der Stadt Essen, in der auf Initiative von Dr. Reisner 1926 das „Haus der Technik“ für ganz neuartige Zwecke gegründet worden war, die Angliederung der 1932 ins Leben gerufenen „Vereinigten Institute für Wärmetechnik“, deren eines das Gaswärmeinstitut war, an dieses Haus der Technik durch. Als Leiter des Gaswärmeinstituts wurde Prof, Dr. Ing. G. W a gener berufen. Gründer der Vereinigten Institute waren: Das Amt für Technik, das Amt für deutsche Roh- und W/erkstoffe, die Energiewirtschaftsorganisationen, die Ruhrgas Aktiengesellschaft, das Rheinischwestfälische Elektrizitätswerk $\left.{ }^{7.89}\right)$. Ohne nähere Begründung bezeichnete der Vorsitzende W. Hoffman, Berlin, auf der Jahrestagung das Gaswärmeinstitut als Vereinsinstitut. Das Institut sollte Sammelstelle und Mittelpunkt für die Erforschung der Vorgänge werden, die den gasbeheizten Arbeitsofen in Industrie, Gewerbe, Handwerk und Haushalt „weitestmöglich" zu vervollkommenen geeignet $\left.\operatorname{sind}^{7 . k 1}\right)$. Im nächsten Jahre umrił der Geschäftsführer F. zur Nedden noch einmal den Arbeitsplan. Das Schwergewicht des neuen Instituts solle auf dem Begriff Wärme liegen. Das Gasinscitut sei im Gegensatz dazu von jeher Prüfstelle und sollte das Schwergewicht beim Haushaltsgas behalten. Das Gaswärmeinstitut solle auch umgekehrt wie das Gasinstitut zentral bestellte Forschungsaufgaben dezentralisierter Bearbeitung zuführen ${ }^{7,82}$ ).

Das waren klare Ziele, die sich aber so nicht durchführen lief̧en. Das Gasinstitut erhielt im gleichen Jahre als zweites Ordinariat einen Lehrstuhl für technische Gasverwendung und Industrieofenbau, wurde also zum mindesten in der Lehrtätigkeit auf die dem Gaswärmeinstitut zugedachten Arbeiten gelenkt. Auf̧erdem war es die Ansicht der Vereinsführung, dał die Forschungsarbeiten auch dem Professor befohlen werden könnten und müßten. Die „Arbeitsgemeinschaft Forschungszwecke Gas“ ging dagegen an den Instituten vorüber. Die unerfreulichen Störungen, die dadurch der Forschung erwuchsen, sind in der schon erwähnten Geschichte des Gasinstituts kurz angedeutet. Hand in Hand-Arbeit hat in den Jahren von 1933 sehr unter persönlichem Ehrgeiz mancher Fachleute gelitten. Sie waren auch verantwortlich für den schnellen Wechsel in Geschäftsführerstellen. Es lohnt aber nicht, alle diese Dinge zu belegen und damit als geschichtlich bedeutsame Ereignisse zu werten.

\footnotetext{
7.75) 77 (1934), 399

7. พี*) 79 (1946), 320

$7.80) 80(.937), 4^{61}$

7.81) 80 (1937), 735

$7.62) 81(1938), 275$
} 


\subsection{A USBAU DER FER NGASVERSORGUNG}

Der Gedanke, die bei der Zechenkoksgewinnung anfallenden Gasmengen einer besseren Verwendung zuzuführen, als sie bis dahin, von einzelnen Ausnahmen abgesehen, geübt wurde, hat den Aufbau der deutschen Gasindustrie von Grund auf umgestellt. Jeden Wärmetechniker mufte es quälen, daf die hochwertigen Gase, die durch Verbesserung der Öfen immer größzere Mengen erreichten, auf den Zechen selbst oder in ihrer Nähe nur unvollkommen ausgenutzt werden konnten. Die guten physikalischen Eigenschaften des Gases geben die Möglichkeit, es in groß̧en und kleinen Feuerungen mit gleich gutem Wirkungsgrad zu verbrennen, es durch Verteilungsleitungen an den Platz des Wärmebedarfes in Rohren zu leiten und es dabei den Erfordernissen entsprechend zu regeln, es abzustellen und mit voller oder geminderter Flamme zu verbrennen. So ergibt sich eine umso wirtschaftlichere Verwertung, je anspruchsvoller das technische Verfahren ist. Überall, wo nur mengenmäf̧ig Wärme verlangt wird, wo etwa das Ofengut ohne große Nachteile zeitliche Schwankungen ausgleichend aufnehmen kann, ist Gas gegenüber festen und flüssigen Brennstoffen minder leistungsfähig. Das ist der Fall bei groß̧en Verdampfern oder Schmelzen. Gerade dort aber mufyten bisher die Zechen ihren Überschuf abzusetzen suchen, wenn er nicht gar einfach abgefackelt werden sollte, mit dem Erfolg, dał, verglichen mit dem Gase im Haushalt und im Kleingewerbe der Städtischen Werke nur niedrige Preise erzielt werden konnten.

So war der Gedanke naheliegend, das Gas über grołe Gebiete zu verteilen und damit den Stellen zuzuführen, wo die günstigen Bedingungen für bessere Preise gegeben waren, als es galt, die Zechenwirtschaft aus den immer wieder erneuten Krisen im ersten Viertel des Jahrhunderts herauszureif̧en. Gleichzeitig setzte eine grofzügige Rationalisierung der Kokereien im Ruhrgebiet ein ${ }^{7.88}$ ). 1926 betrieben 140 Kokereien 16200 Öfen zur Erzeugung von 28 Mio t Koks. 1928 wurden auf 32 Anlagen 2770 neue Öfen erbaut, wovon 1060 Öfen zur Vergröłerung und Vervollständigung von 14 bereits bestehenden Anlagen dienten, während 1710 Öfen in I8 neuen Kokereien standen. So gab es am Ende des Jahres 1936 Großkkokereien mit 7000 Ofen, die allein 25 Mio t Koks erzeugten.

Um 1925 hatte Albert $V \ddot{o} g$ ler mit der Gründung der Vereinigten Stahlwerke, deren Direktorium er vorstand, den Weg zur Gesundung der Stahlindustrie an der Ruhr gefunden. Ihm war es möglich auch der Grofraumverbundwirtschaft der Elektrizität über das Rheinisch-Westfälische Elektrizitätswerk (RWE) neuc wirtschaftsfördernde Wege zu eröffnen. Die Vereinigten Stahlwerke waren der gröfte Abnehmer des RWE, das andererseits gelegentlich von den Werken nicht benötigten Strom abnahm. (G. v. Klass: Albert Vögler, Tübingen 1957 Wunderlich.) Es war verständlich, dał gerade er auch der Gaswirtschaft der Zechen einen freien Weg bahnen wollte. Als Partner fand er den Generaldirektor Dr. Alfred Pott, Essen, auf Zeche Viktoria Mathias. Beide kamen im Sommer 1926 dahin überein, ihre Gedanken dem Koksabsatzausschuf des Syndikats zu unterbreiten $\left.^{7.165}\right)$.

Der weitausgreifende Plan, mit einem Rohrnetz gleich das ganze deutsche Wirtschaftsgebiet für das Zechengas zu erschlieł̧en, den die Aktiengesellschaft für

7.83) W. Gollmer: Kokereiausschuss GWF 72 (1929), 163

488 
Kohleverwertung 1926 in wenigen Strichen der Öffentlichkeit unterbreitete, mufzte die bisherigen Betreuer der Gasverwendung beunruhigen. Schon auf den Seiten $456 / 57$ wurde erwähnt, wie gerade die besten Gaswerksleiter, die ihrerseits auch ähnliche Vorteile in der den Einzelbedingungen angepaf̧ten örtlichen Gaserzeugung kannten, sich auflehnten.

Begeisterung verführte auch wohl die Anwälte der neuen Aufgabe, die Berechtigung der Sorgen ihrer Gegner von grundsätzlich ingenieurmäfiger Art, nicht genügend durchzudenken. Mit echt deutschem Draufgängertum wurden die verallgemeinerten Gesichtspunkte zu stark hervorgehoben. Über Einzelheiten hinweggehend kam es zu den in solchen Fällen oft schon beobachteten persönlichen Angriffen. Es kam noch hinzu, dał die Vorwärtsdrängenden selbst gar nicht genau genug wissen konnten, welche Vielheit von Trümpfen sie in der Hand hatten. Erst als die Versorgung allgemeiner wurde, konnten die Technologen der neuerschlossenen Industrien feststellen und berichten, welche Verbesserungen in den Verfahren, verbunden mit einer grundsätzlichen Umgestaltung der Öfen und ihrer Arbeitsweise, durch Verminderung des Ausschusses und Verbesserung der Erzeugnisse das Gas eigentlich anbot. So konnte es nur angedeutet werden, daf3 mit der Fernversorgung ein neuer technischer Zweig mit vielen anregenden neuen Ingenieurarbeiten entstehen würde. Wäre eine ins einzelne gehende Aussprache von Ingenieur zu Ingenieur möglich gewesen, so hätte der technisch sicher anregende Gedankenaustausch Streitigkeiten unter den Ingenieuren wohl vermeiden können.

Der Widerstand kam aber noch viel heftiger ab 1927 von ganz anderer Seite. Oberflächlich gesehen handelte es sich um einen Kampf um den Besitz der Gasversorgung, der von kommunaler Gaswerksseite auch mit politischem Akzent als Monopolbestrebung der Privatwirtschaft auf dem Gasmarkt, ja noch mehr auf dem Koksmarkt angesehen wurde ${ }^{\text {7.4.4}}$ ).

Viel später, als die Ruhrgas-Aktiengesellschaft bereits im Verein für Kommunalwirtschaft und Kommunalpolitik in Hamburg zu Worte kam, sah ihr Vertreter die ersten Schwierigkeiten darin, daf die erste Welle in eine Zeit gefallen sei, in der sich die Finanzwirtschaft der Kommunen ernsten Angriffen der Privatwirtschaft ausgesetzt gesehen hätte. Das war aber wohl mit Rücksicht auf den Hörerkreis so ausgesprochen. Tatsächlich waren ja die kommunalen Vertreter im Angriff gewesen. Die Privatwirtschaft in den Gasversorgungsbetrieben war unter dem im Unterbewuf̧stsein gebilligten Programm der Sozialisierung oder Gemeinwirtschaft mehr als früher im Rückgang, obwohl gerade die private Wirtschaft die Initiative zur Rationalisierung gezeigt hatte $\left.{ }^{7.87}\right)$. Der Übergang zu gemischtwirtschaftlichen Unternehmungen war bereits ein Zugeständnis der Privatgesellschaften, das, als es Anerkennung und Erfolg brachte, vom Städtetag mit scharfen Worten abgelehnt war $\left.{ }^{7.86}\right)$. Erstaunlich ist es, mit welchem Grad von Selbstbewuftsein die kommunalen Verwaltungsstellen für sich in Anspruch nahmen, dał̧ sie sich immer nur von dem Gedanken leiten liefzen, die Interessen der Verbraucher vor die der Erzeugung gestellt zu haben, d. h. höchste Sicherheit

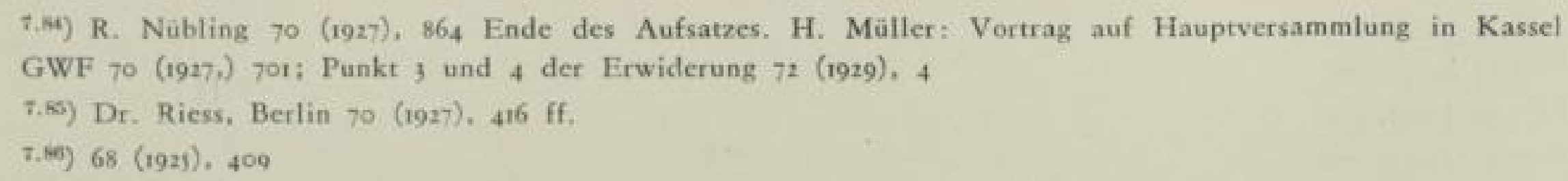


und gleichmäßjige und beste Beschaffenheit des Gases zu erzielen $\left.{ }^{\gamma .57}\right)$. Die gemeinnützige Gasversorgungsgesellschaft m.b.H. im Saargebiet, der Städte Homburg, St. Ingbert, Saarbrücken und des Landkreises Saarbrücken identifizierte den Begriff gemeinnützig mit Besitz der offentlichen Hand ${ }^{7.85}$ ).

Die Ruhrgas verkenne, so sagte $M o b r m a n n$, Bremerhaven, die Aufgabe der Kommunen, die kein billiges Industriegas zu verkaufen haben, sondern im Interesse der Allgemeinheit abgeben. „Als Folge der Finanznot der Städte bildeten zwar sehr hohe Abführungen der Werke an die Stadtkasse eine schwere Gefahr, die aber nur vorübergehend sei $\left.^{7.50}\right)$. Gerade in diesem entscheidenden Punkte täuschte sich aber der Bürgermeister. Noch im Jahre $193^{8}$ waren die Runderlasse der Ministerien einer autoritären Regierung in dieser Hinsicht „,in geringem Umfange erfolgreich ${ }^{\text {(7..00 }}$ ).

Was nützte es, wenn schon 1925 der Städtetag formuliert hatte: „Die der Versorgung der Bevölkerung mit Wasser, Gas und Elektrizität dienenden Betriebe gehören ...... in die öffentliche Hand, und zwar in erster Linie in die Hand der Gemeinden. Die Verwaltung und Betriebsführung ist nach technischen und wirtschaftlichen Gesichtspunkten zu regeln. Eine Besteuerung dieser Betriebe ist ohne Rücksicht auf die Verwaltungsform aus sozialen, politischen und wirtschaftlichen Gründen abzulehnen ${ }^{47.01}$ ), wenn die Kämmerer selbst die den Abschreibungen entsprechenden Beträge einbehieiten $\left.{ }^{72}\right)$. A. $S c b m i d t$, Berlin, rügte gleich eine Reihe von Tatsachen, wo die gemeindeeigenen Werke gemeinwirtschaftliche Gesichtspunkte aus den Augen verloren ${ }^{7.08}$ ).

Viel schlimmer aber war, dał auch die verschiedenen öffentlichen Körperschafter bereits untereinander in einem Kampf um die Gasversorgung standen. Die Kämpfe der groł̧en sächsischen Städte gegen die Pläne des Staates, die ganze Gasversorgung in die Hand zu nehmen ${ }^{7.94}$ ), sind bereits erwähnt (S. 426 und S. 455 ), Sie verhinderten aber nicht die Gründung der Landesgasversorgung A. G. Leipzig mit Bestrebungen auf Zusammenfassung der Gasversorgung im Freistaate Sachsen ${ }^{7.05}$ ), bei der nunmehr aber neben der Energie A. G. Oetsch-Markkleeberg auch die Elektra A.-G. Dresden, und zwar je zur Hälfte, beteiligt waren. Diese war nun wieder in der Hand der Gemeinden und der Energie A.-G., an der auch die Thüringer Gasgesellschaft beteiligt war $\left.{ }^{\tau .00}\right)$. Sie verfolgte im grof̧en und ganzen die gleichen Gedanken wie die Denkschrift von $\left.1926^{7.07}\right)$. Allerdings zunächst nur mit Gruppenversorgungen, wobei die Stützpunktwerke bestehen bleiben sollten. Bis 1933 waren nur 7 Werke stillgelegt worden.

Ein Schlaglicht liefern die Kämpfe um die Versorgung der Nachbargemeinden Breslaus $^{\text {,.eng }}$ ). Schon $192 \mathrm{r}$ versuchten die städtischen Werke, als Gruppengaswerk

7.87) $72(1929), 7$

$7.88) 71(1928), 360$

7.89) 73 (1930), 186 Erwiderung Mohrmann

7.00) 81 1938), 28x; 82 (1939), 412

7.01) $68(1925), 409$

7.02) 73 (1930), 1079

7.98) $75(1932), 157$

7.94) 69 (1926), 989; 1015

$7,95) 75(1932), 367$

7.96) $71(1928), 456$

7.07) 76 (1933), 368

7.88) $70(1927), 258$ 
auf das Land zu gehen, um den stadtnahen Einwohnern die Segnungen einer Gasversorgung zu geben. Der Landkreis aber lehnte die Freigabe der Kreisstrałen ab in der Sorge, dał damit der Eingemeindung Vorschub geleistet werden solle. Er bemühte sich vielmehr, eine eigene Versorgung zu errichten, obwohl die Stadt Breslau mit einzelnen Gemeinden bereits Verträge abgeschlossen hatte. Schlieflich wurde von Breslau ein Vorschlag gemacht, eine gemeinsame Versorgungsgesellschaft zu betreiben, aber ohne eine ,überflüssige " Privatbeteiligung, die wohl bei den Plänen des Kreises eine Rolle gespielt hatte. Die Stadt beantragte und erlangte nach längeren Verhandlungen von der Regierung das Enteignungsrecht, um ihre eingegangenen Verpflichtungen erfüllen zu können. Nunmehr wurden alle angefangenen Anlagen des Kreises der Stadt übereignet.

Nach dem ersten Sturm kam im Juni 1927 die Aktiengesellschaft für Kohleverwertung mit einer Denkschrift über die Deutsche Grołgasversorgung heraus, die deutlich von dem Gedanken abrückte, die bestehende Gasversorgung in den deutschen Gemeinden und Gemeindeverbänden von heute auf morgen in umstürzlerischer Weise durch eine ausschließ̧liche Gaslieferung von den Zechen des Ruhrgebietes aus zu ersetzen. Sie setzte sich für eine zeitgemäße Ausgestaltung und Sicherstellung der Gasversorgung ein. ,.Die Fernversorgung mit Gas soli, in der für jeden Einzelfall zweckmäf̧igen Form, allmählich von der Kohlenrevieren aus in die vorhandene deutsche Gasversorgung hineinwachsen $\left.{ }^{7.00}\right)$. Die Einwände der Gaswerke in einer Gegenauslassung zu Einzelheiten der Denkschrift mögen übergangen werden, ${ }^{7,100}$ ). Beide Denkschriften hatten aber den Erfolg, dafy es zu einer ruhigeren Zusammenarbeit kam ${ }^{\text {7.101 }}$ ).

Indessen war die Bewegung aller Betroffenen nicht mehr aufzuhalten. Überall traten neue Verbundversorgungen ins Leben. Eine vollständige Übersicht zu geben, kann nicht Aufgabe dieser Geschichte sein. Beispiele müssen genügen: Die Fernversorgung von Stuttgart aus erschlof das kleinindustrielle Gebiet um die Landeshauptstadt ${ }^{7.100}$ ). Der Anschluf von Offenbach an Frankfurt/Main, die Umkreisung des Harzes durch mehrere Unternehmen, wobei sich die Thüringer Gasgesellschaft, die Deutsche Continental-Gas-Gesellschaft von Nordhausen aus und die Agwea, später Gesfürel-Ludwig Loewe beteiligten, sind weitere Beispiele.

Vor allem suchten sich auch die Provinzialverwaltungen zu beteiligen. Als $\mathrm{Zu}-$ sammenfassung der gemeinsamen kommunalen Interessen wurde eine Ferngasversorgung Rheinprovinz unter Vorsitz des Landeshauptmanns gegründet, an der Großsstädte, Kreise, Landkreise und Landgemeinden teilhaben sollten ${ }^{7.105}$ ). Fernleitungen sind durch diese Gesellschaft nicht gebaut worden.

Für die Fernversorgung Niederschlesien wurde der Provinziallandtag ermächtigt, sich bis zu s Mio RM zu beteiligen ${ }^{\text {ina }}$ ). Ein im Auftrage der Provinz erstattetes Gutachten von R. F. S t arke zeigte aber, dał diese weitgreifenden Pläne nicht wirtschaftlich durchführbar waren $\left.{ }^{7.105}\right)$. Im Riesengebirge kam es zu einem

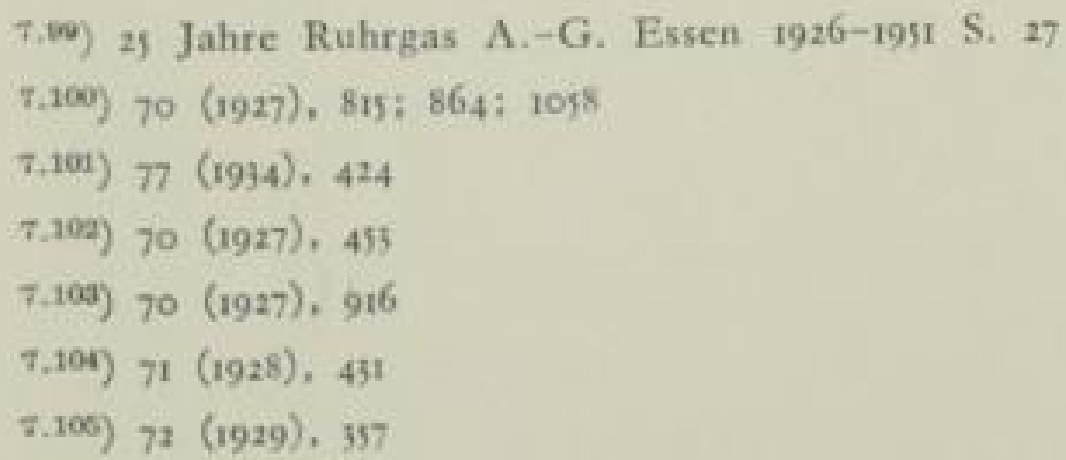


kleineren Verbund durch die Ferngas Niederschlesien A.-G., einer unter dem Provinzialausschu\} gegründeten rein kommunalen Aktiengesellschaft, deren Abnehmer die Aktiengesellschaft für Gas und Elektrizität, Köln, und deren Lieferer die Niederschlesische Gaswerks A.-G. war. Die bestehende Absicht, in Warmbrunn ein Gaswerk zu bauen, wurde aufgegeben ${ }^{7,100}$ ). Erst sehr viel später wurde die Ferngas Schlesien gegründet ${ }^{7.107}$ ), die die Majorität der A.-G. für Gas und Elektrizität, Kölner Gas, Berlin erworben hatte ${ }^{7.105}$ ). Ihr Aufsichtsratsvorsitzender wurde der Oberpräsident der Provinz Schlesien.

Die Landesgasversorgung Süd-Niedersachsen wurde als gemischtwirtschaftlicher Betrieb im Regierungsbezirk Hannover gegründet. Beteiligt war die Provinz Hannover mit $67 \%$ (davon wurden $5 \%$ für den Staat Braunschweig reserviert gehalten) und die Thüringer Gasgesellschaft mit $33 \% \%^{7+100}$. Gas lieferte die Ilseder Hütte. Die Stadt Hildesheim hatte schon vorher mit der Ilseder Hütte einen Lieferungsvertrag abgeschlossen, nachdem das Gaswerk völlig heruntergewirtschaftet war und kaum mehr erweiterungsf̈̈hig erschien, um den Wünschen der ansässigen Industrie nach Belieferung gerecht zu werden ${ }^{\text {7.119 }}$ ). Stadt Braunschweig hatte dagegen den Bezug von der Ilseder Hütte abgelehnt. Die Stillegung des Gaswerkes in der Zeit der höchsten Arbeitslosigkeit sei unerwünscht.

An der Gasfernversorgung Saale, Halle/Saale, beteiligten sich der Provinzialverband mit $23 \%$, die Gemeinden und Kreise mit $23 \%$, die Stadt Halle mit $16 \%$, die Deutsche Continental-Gas-Gesellschaft mit $16 \%$, Stadt Leipzig mit $8 \%$, Merseburg mit $3 \%$, die Landelektrizität Halle mit $3 \%$ und die Gesellschaft zur Förderung der Braunkohlengaserzeugung mit $3 \%$. Man erkennt aus der Anzahl das Drängen der öffentlichen Stellen nach den Geschäften.

Zur Gasversorgung Magdeburg-Arhalt, deren Entstehung mit der Errichtung einer Grołggaserei bei Magdeburg, über die später noch einiges zu sagen ist, zusammenhing, traten zusammen: Die Stadt Magdeburg $(\$ 1 \%)$, Provinz Sachsen $(9 \%)$, Freistaat Anhalt $(3 \%)$ und die Deutschen Continental-Gas Gesellschaft $\left.\left(37^{\%}\right)^{7.111}\right)$.

Im gleichen Raum wurde von der Thüringer Gasgesellschaft und dem Kreis Calbe mit je $50 \%$ Beteiligung die Gas- und Stromversorgung Mittelsachsen gegründet, zur Versorgung von 40 Gemeinden aus den vorhandenen Werken der Thüringer Gasgesellschaft Schönebeck und Hecklingen ${ }^{\text {7.113 }}$ ). Der erläuternde Satz: „Den weitsichtigen Plänen der Provinzialverwaltung ist damit wertvolle Vorarbeit geleistet" klingt nicht recht glaubwürdig. Man'steht vielmehr unter dem Eindruck, dał der Wettbewerb der grołen Gasgeselischaften trotz der Anteilnahme der Provinz im Begriff stand, etwas Unorganisches zu schaffen.

Noch viel verworrener waren aber die Verhältnisse in Hessen. Fast gleichzeitig wurden dort die Südwestdeutsche Gas-Aktien-Gesellschaft (Süwega) auf kommunaler Grundlage, die sich zunächst auf das Gaswerk Michelstadt stützte, und

\footnotetext{
$7.106) 72(1929), 963$

7.107) 81 (1938), 213

$7,105) 82$ (1939), 63

$7,1009) 73(1930), 762$

$7.110) 73(1950), 740$

7.111) 71 (1928), 120

$7.112) 72(1929), 709$
} 
die Hessische kommunale Gasfernversorgung (Hekoga) in Darmstadt gegründet. Mainz, Darmstadt, Worms und Gieben und die drei hessischen Provinzen hatten sich zur Hekoga als Körperschaft des öffentlichen Rechtes zusammengeschlossen ${ }^{\text {z.tiz }}$ ).

Im Rhein-Main-Gebiet betrieb auf̧erdem die der Thüringer Gas-Gesellschaft nahestehende Hessen-Nassauische Gas A.-G. Höchst, eine Gruppenversorgung und mehrere kleine Werke $\left.{ }^{7 \cdot n}\right)$. Auf̧erdem hatte die Frankfurter Gas-Gesellschaft Neigungen sich auszudehnen. Sie erwarb zur Sicherung der Kohlengrundlage gemeinsam mit der Stadt Köln am Niederrhein unaufgeschlossene Kohlenfelder $^{\text {7.115 }}$ ) und versuchte, auch in der Braunkohlenveredelung Fuf zu fassen. Die Steinkohlenfelder wurden erst 1937 unangegriffen abgestołen ${ }^{\text {7.11 }}$ ).

Der Süwega traten die Städte Ludwigshafen, Pforzheim, Heidelberg, Frankfurt/Main, Mannheim und Karlsruhe bei ${ }^{7.17}$ ).

Aus dieser Lage entwickelte sich ein Kampf in der Fach- und Tagespresse, den man unmöglich genau darzustellen vermag ${ }^{7.45}$ ). Ruhrgas und Saarferngas wurden als mögliche Lieferanten mit hineingezogen. Zeitweilig wurden Pläne erwogen, das Gaswerk Mainz an die Ruhrgas zu verpachten. Der Gaswerksleiter in Darmstadt gab ein Gutachten gegen Fremdbezug ab, dem sein Bürgermeister mit einem Gegengutachten des Geschäftsführers der Hekoga entgegentrat. Er konnte aber damit nicht erreichen, dał der Stadtrat seinen Vorschlägen folgte. Auswärtige Fachleute mischten sich ein, Krisen innerhalb der Hekoga wurden sichtbar.

Eine Teillösung brachte plötzlich ein Vertrag der Städte Mainz und Wiesbaden $^{7.111}$ ) für eine gemeinsame Gasversorgung unter Benutzung des Mainzer Gaswerks.

Die Südwestdeutsche Gas-A.-G. Frankfurt/Main wurde 1937 aufgelöst, nachdem die Verhältnisse geklärt und die „Angriffe der Ruhrgas auf kommunale Selbständigkeit" abgeschlagen wären. In Wirklichkeit war ein Zulieferungsvertrag für die Industrie des Rhein-Main-Gebietes zustande gekommen ${ }^{7 \times 2}$ ) und der Rohrleitungsbau von Siegen nach Frankfurt hatte bereits begonnen ${ }^{\text {T.12: }}$ ).

In Westfalen hatten dic Vereinigten Elektrizitätswerke Westfaien (VEW) in Dortmund schon nach der Jahrhundertwende einige Gaswerke erworben (Vgl. Seite 337), eine Gasabteilung gebildet und, wo Gelegenheit war, Zechengas verwendet. Sie begannen selbst den Bau von Ferngasleitungsnetzteilen ${ }^{\tau .12}$ ). Die rein kommunale Westfälische Ferngas A.-G., Dortmund, wurde am 24. Juli 1928 mit 4 Mio RM gegründet $\left.{ }^{7.125}\right)$. Da als drittes Unternehmen auch die Ruhr-

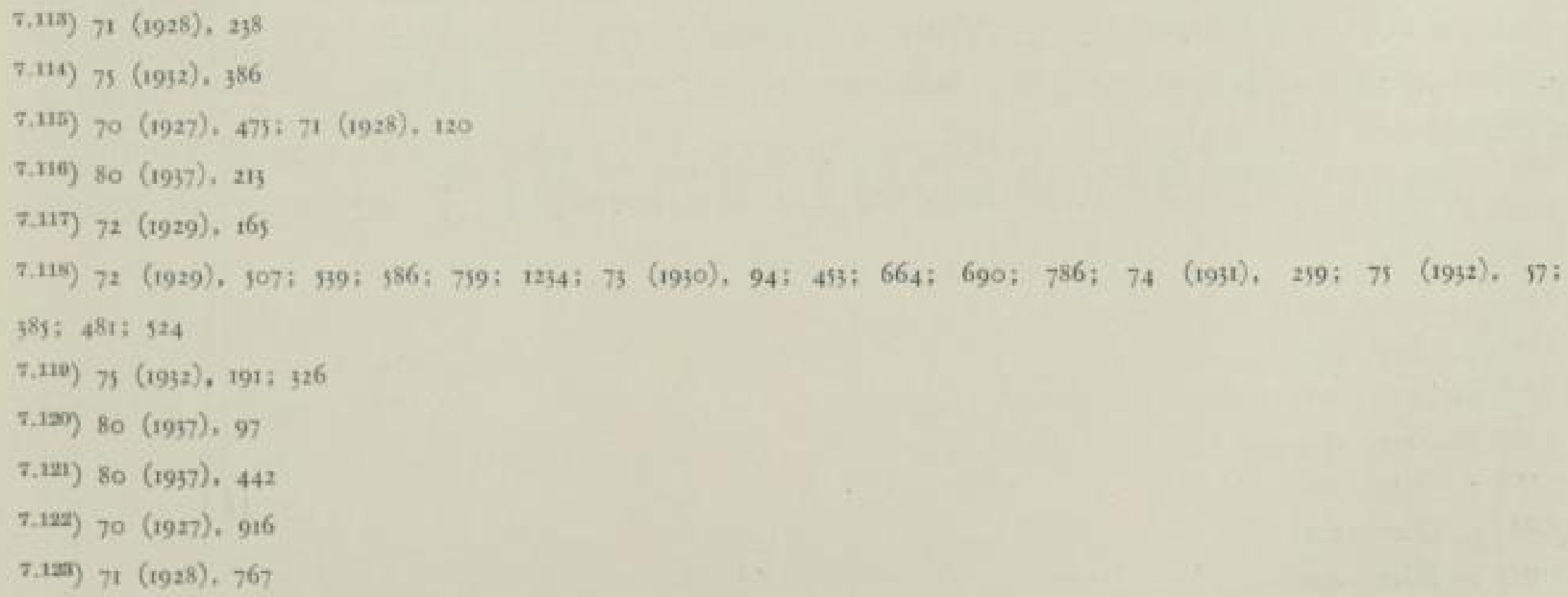


gas A.-G. mit Leitungen in dieses Gebiet eintrat, schaffte man Ordnung durch Gebietsabgrenzungs- und Hilfsverträge $\left.{ }^{7.121}\right)$. Nach einigen zwischenzeitlichen Umgründungen ${ }^{T .125}$ ) nahmen die VEW ihr Ferngasnetz wieder als Abteilung in ihre Stammfirma auf. Hier war man also schnell zur Zusammenarbeit gekommen.

Dagegen war in Mitteldeutschland eine Widerstandsbewegung gegen die „Pläne der Ruhr" im Gange. Obwohl die Deutsche Continental-Gas-Gesellschaft sicherlich mit zu den groß̧ten Abnehmern des Ruhrkohlensyndikates gehörte, war das Verhältnis nicht ungetrübt gewesen, und obwohl im Jahre 1926 ihr Gaswerk Hagen-Eckesey an die Vereinigten Elektrizitätswerke Westfalen angeschlossen wurde, machten doch die weitausgreifenden Pläne der Aktiengesellschaft für Kohleverwertung, so wie sie zuerst bekannt wurden, erhebliche Sorgen, zumal die Gasgesellschaft schon länger erwog, in Mitteldeutschland das unter ihrer starken Beteiligung entwickelte Elektrizitätsversorgungsnetz durch ein Gasnetz zu ergänzen ${ }^{7.125}$ ).

Die Sorge wurde noch vermehrt, als berichtet wurde, daf die Aktiengesellschaft für Kohleverwertung ihren Aktionären d. h. den Zechen einen Verpflichtungsschein vorgelegt hätte, an Gaswerke keine Feinkohlen zu liefern ${ }^{7.12}$ ), sofern sie Gas an Dritte verkauften ${ }^{\text {r.129 }) . ~}$

Von der Bergwerksgesellschaft Georg von Giesches Erben koante die Gasgesellschaft die Zeche Westfalen bei Ahlen kaufen und damit die Kohlenbasis für eine bei Magdeburg zu errichtende GroGgaserei Mitteldeutschland gewinnen. Der Plan einer Ferngasleitung von Ahlen zum Gaswerk Hannover-Linden, das der Gesellschaft gehörte, muß̧te aufgegeben werden ${ }^{7,129}$ ). Auch ein Angebot, die Stadt Hannover von I.inden aus zu versorgen, das im Rahmen der Verhandlungen dieser Stadt mit der Ruhrgasgeselischaft wegen Ferngasbezuges gemacht wurde, wurde nicht angenommen ${ }^{\text {T.120 }}$ ). Am I5. 12. 28 wurde dagegen der Mantelvertrag mit der Stadt Magdeburg unterzeichnet, der am Ir. I. 29 zur Gründung der Grofgaserei und der Gasversorgung Magdeburg-Anhalt (Gamanag) führte ${ }^{7.12}$ ). Mit dem Ruhrkohlensyndikat kam es zu Streitigkeiten wegen der Selbstverbraucherrechte $^{\text {7.122 }}$ ). Dazu wurde festgestellt, daf mit der Ruhrgas A.-G. keine schwerwiegenden Differenzpunkte bestünden. Jedenfalls könnten beide Gesellschaften friedlich nebeneinander arbeiten, da jede ein groß̧es Arbeitsgebiet zu beackern habe ${ }^{\text {7.123 }}$ ).

Noch ein anderer Wirtschaftszweig suchte sich in die Ferngasversorgungspläne einzuschalten ${ }^{7.13}$ ), der Mitteldeutsche Braunkohlenbergbau, der eine „Gesellschaft zur Wahrnehmung der Interessen an der Fernversorgung “ gründete ${ }^{\text {z. } 125}$ ).

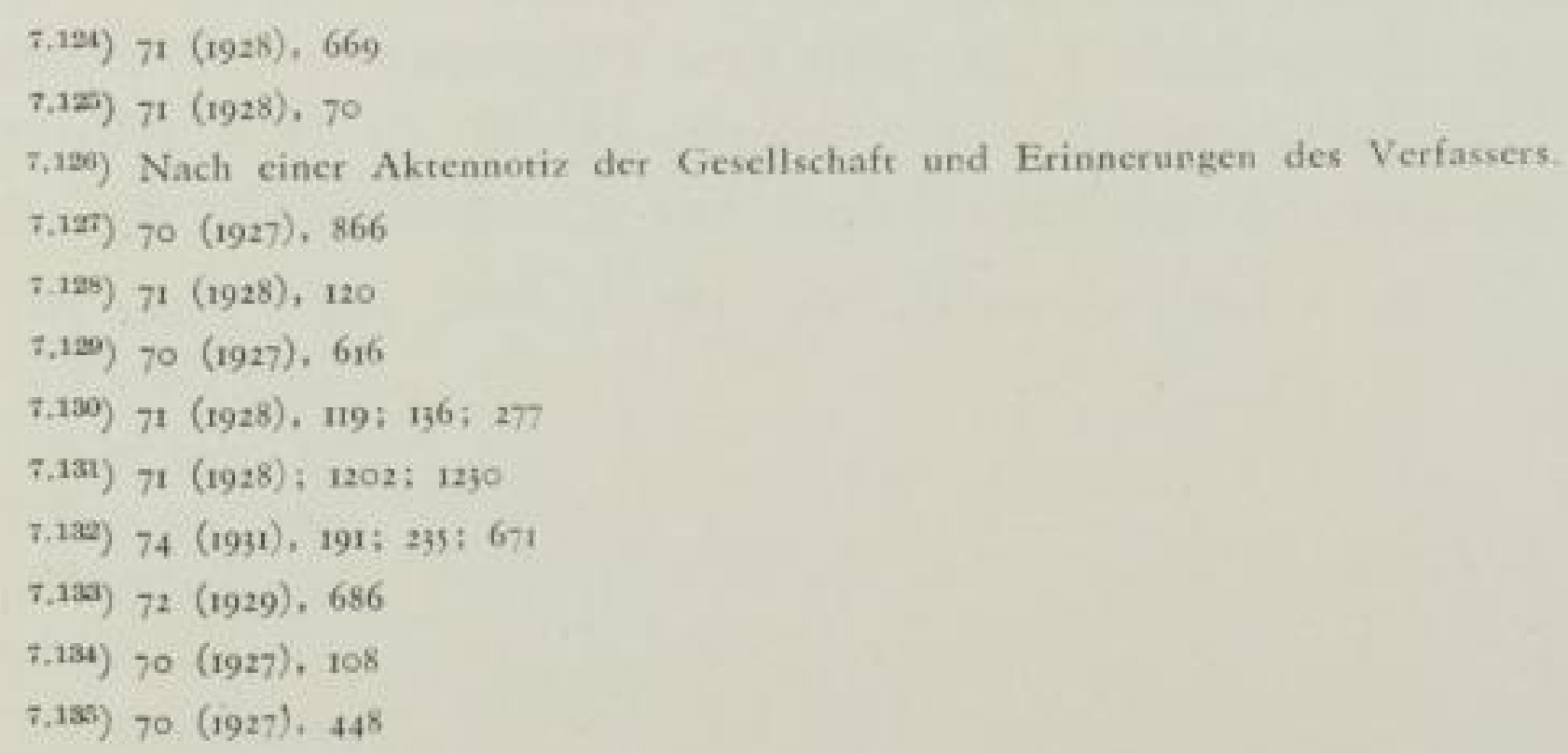


Die Braunkohlenwerke lieferten ein Schwelgas, das aber nicht ohne weiteres als Ferngas geeignet war $\left.{ }^{7.100}\right)$. Erst nach langen und nach vielen Richtungen gehenden Versuchen gelang der große Wurf mit der Sauerstoffhochdruckvergasung nach R. Drawe, Berlin, und Lurgi Gesellschaft für Wärmetechnik, Frankfurt/Main $\left.{ }^{712 \pi}\right)$. (Vgl. S. 511/12)

Dem gröften deutschen Ferngasunternehmen, der Aktiengesellschaft für Kohleverwertung vom II. Okt. 1926 und der am 30 . Mai 1928 durch Umbenennung entstandenen Ruhrgas Aktiengesellschaft wurde durch diese Verhältnisse der Anfang nicht leicht gemacht. Der heute als Segen für die deutsche Energiewirtschaft offenkundige Gedanke war aber gesund und setzte sich dank der Ausdauer derjenigen, die die Aufgabe auf sich genommen hatten, durch. Vielleicht war es ein Glück, dał die Pflanze nicht allzu schnell aufschof, weil die Wirtschaft sich keineswegs so gut und störungsfrei entwickelte, wie man es 1926 erhoffte. Man ging Schritt für Schritt voran, zuerst die nächstliegenden Städte erfassend, wobei die Westfälischen Ferngasunternehmen eifrig halfen, und stieß danach weiter vor.

Wie ernst und technisch durchdacht das Vorgehen war, wird vielleicht am besten beleuchtet durch die Beteiligung der Ruhrgas- $A$ ktiengesellschaft an der Ofenbaugesellschaft: Indugas in Krefeld-Linn ${ }^{\text {7.138 }}$ ). Es war klar geworden, daf3 bei grof̧en Industrieöfen nicht einfach die vorhandenen Bauarten auf Gas umgestellt werden konnten, sondern daf sie oft völlig anders aufgebaut, ja dał oft genug die Arbeitsverfahiren geändert werden muf̧ten. Wenn auch die groß̧en Industrie-Werke mit ihren Ingenieurabteilungen und vor allem die Wärmestelle des Vereins deutschen Eisenhüttenleute viel Entwicklungsarbeit leisteten, so muß̧ten doch die Erfahrungen und Erkenntnisse ausgenützt und weiterverbreitet werden. Dazu war die konstruktive Arbeit einer dem Zwecke völlig verschriebenen Ofenbaufirma die beste Lösung. Auch eine eigene Baugesellschaft für Leitungen mit einem Kapital von 20000 RM wurde als G. m. b. H. geschaf $\mathrm{fen}^{\text {7.1280 }}$ ).

Als Kapital standen der Ruhrgas Aktiengesellschaft 25 Mio RM, wovon zunächst nur ein Viertel einbezahlt war, und eine Auslandsanleihe von I2 Mio RM zur Verfügung ${ }^{7.40}$ ). Diese Auslandsanleihe wurde mit Recht als Vertrauensbeweis angesehen, denn die grołe Flut der spekulativ leicht nach Deutschland gegebenen Anleihen war 1928 bereits verebbt, nachdem die Gesamtverschuldung der deutschen Wirtschaft auf 8 Mia RM gestiegen war.

Der erste grołe Ausbruch aus dem Kohlenrevier wurde im gleichen Jahre 1928 durch einen Fernlieferungsvertrag nach Hannover eingeleitet $\left.{ }^{7.14}\right)$. Das deutsche Gasfach brauste auf in Erregung, kritisierte den Vertrag und die Stadt, weil sie Absprachen des Städtetages nicht eingehalten habe, ohne daf3 der Vertragstext genau bekannt war $\left.^{7.142}\right)$. Indessen war ein entscheidender Erfolg errungen.

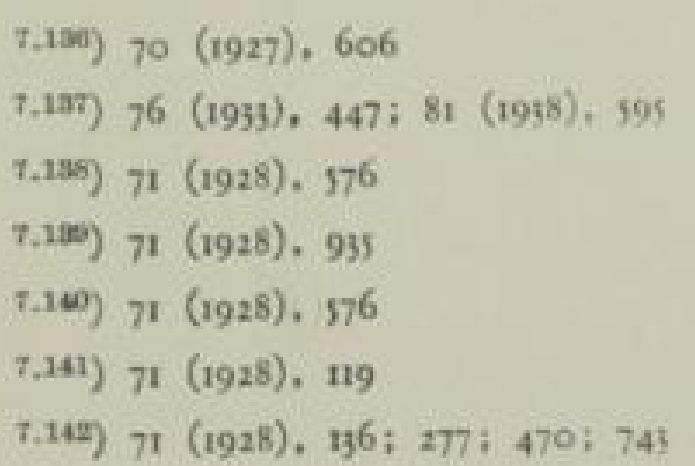


Das Ziel, im Auge, eine einheitliche Versorgung zu verwirklichen, kam es auch zu einem Vorschlag der Ruhrgas A.-G., in Riesa (Sachsen) nach dem Muster der Grołgaserei in Magdeburg in Anlehnung an die Mitteldeutschen Stahlwerke Riesa ein Stützpunktwerk zu errichten ${ }^{7.143}$ ). Dieser wurde aber nicht verwirklicht. Als zweite grołe Stadt außjerhalb des Reviers entschloł sich Köln zum Bezug von Ferngas. Dort hatte man schon jahrelange Überlegungen über eine Neuordnung der Gasversorgung angesteilt ${ }^{t^{.114}}$ ). In einer Denkschrift hatte die Stadt der Öffentlichkeit alle Möglichkeiten, die sich boten, dargelegt ${ }^{7.145}$ ). Zunächst wurde eine Teilversorgung mit Ferngas vorgesehen. Leitungen wurden aus dem Ruhrrevier und Aachener Revier herangeführt. Gaswerk Ehrenfeld sollte zunächst im Betrieb bleiben, und durch eine gemeinsam mit Ruhrgas-Thyssen und Stadt Köln gebildete „Kölner Gas G. m. b. H. zur Errichtung von Gaserzeugungsanlagen, Leitungen, Apparaturen und Maschinen" eine Kokerei im Hafen gebaut werden ${ }^{7.140}$ ). 1935 wurde das Gaswerk Ehrenfeld stillgelegt. Die Kokerei im Hafen ist niemals gebaut worden ${ }^{7.15}$ ). Am 12. Mai r930 wählte die Generalversammlung der Ruhrgas A.-G. neun hervorragende Kommunalvertreter und jeweils den Landeshauptmann der Provinzen Rheinland, Westfalen und Hannover in den Aufsichtsrat. Der privatwirtschaftliche Charakter der Gesellschaft wurde dadurch nicht geändert. Der Beitritt dieser führenden Männer der öffentlichen Verwaltung war aber ein Bekenntnis zum Ferngasgedanken an sich $^{7.14}$ ).

Düsseldorf, das ein leistungsfähiges Gaswerk besał, verhandelte mit der Ruhrgas Aktiengesellschaft wegen Durchleitung und späterer Belieferung der Konzernwerke der Ruhrgas Aktiengesellschaft. ${ }^{\text {i.14 }}$ ). Ein Lieferungsvertrag auf to Jahre auf Zusatzgas, ohne Mindestabnahmeverpflichtung proportional mit der Eigenerzeugung ansteigend wurde am II. $\Lambda$ pril 1930 abgeschlossen ${ }^{7,40}$ ). Solche Durchleitungsverträge und die auflagenfreie Belieferung der ausserhalb des Reviers liegenden Verarbeitungsbetriebe der Gesellschafter waren aber für alle Abnehmer, insbesondere die angeschlossenen Kommunen, wie besonders die spätere Entwicklung der Absatzverhältnisse gezeigt hat, von gröfter Bedeutung. Erst mit den groł̧en Gasmengen, die die Verträge über den Transport für diese Zwecke erwarten lieł̧en, war es möglich die Fernleitungen genügend groł zu bemessen. Das war die Grundlage für eine allgemeine günstige Preisstellung ${ }^{7.14}$ ). Nimmt man dazu noch die erwähnten Verhandlungen bei der Hekoga, die zeitweilig auf eine Pachtung des Mainzer Gaswerkes durch die Ruhrgas zielten, so kann man die grołzügige Wendigkeit bei der Verfolgung des Hauptziels nicht leugnen. Wie eigentlich immer beim Aufbau eines für die zukünftige Entwicklung bemessenen Energieversorgungsnetzes schlossen die ersten Geschäftsjahre mit Unterbilanzen ab. Im Jahre 1931 war der erste Bauabschnitt mit $933 \mathrm{~km}$ vollendet (Bild S. 578$)^{7.150}$ ). Die Abgabe betrug $800 \mathrm{Mio}^{2}$ bei einer Abgabemöglich-

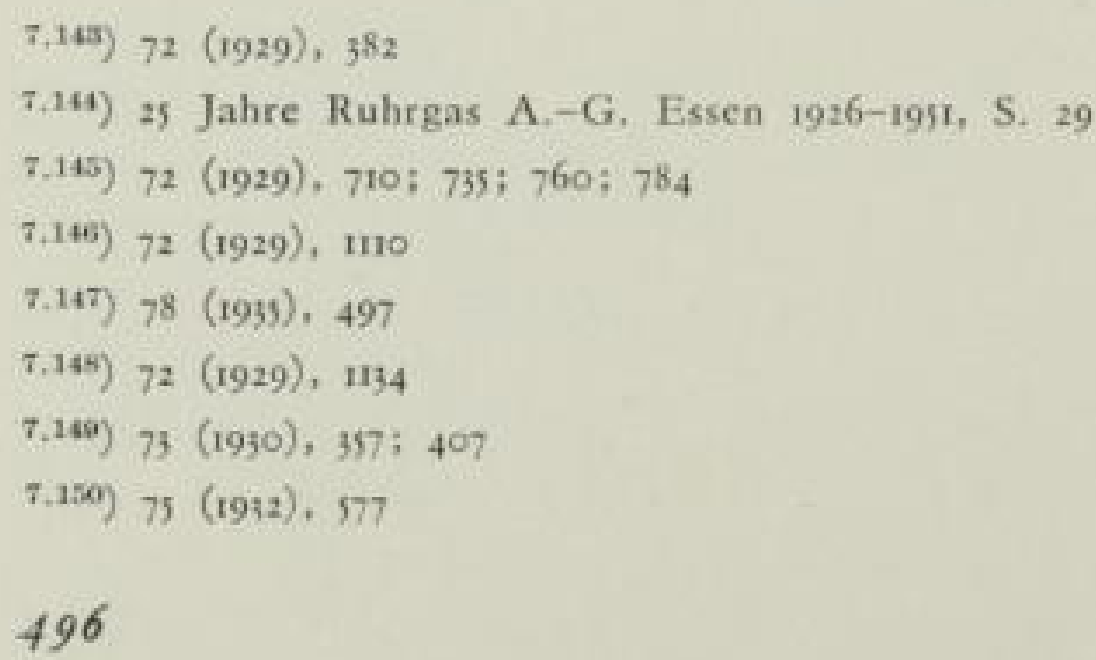


keit der angeschlossenen Zechen von 2 Mia m". Die Abgabe war als Folge der äuf̧erst schlechten Wirtschaftslage um $100 \mathrm{Mio} \mathrm{m}^{3}$ gegen den Voranschlag zurückgeblieben. Das Jahr 1932 wurde zum inneren Ausbau verwendet. Zwei neue Zechen wurden noch angeschlossen, der Bau eines groß̧en Gasbehälters geplant und die Leitung nach Hannover, die sich zunächst nur auf die östlichen Zechen des Reviers gestützt hatte, wurde mit dem Hauptnetz verbunden $\left.{ }^{7.151}\right)$. Die vorbildliche Pionierarbeit, die die Gesellschaft in der Entwicklung des Industrieabsatzes geleistet hatte, wurde vom gesamten Gasfach öffentlich anerkannt ${ }^{7.155}$ ). Der Gasbedarf an der Ruhr stieg sprunghaft ${ }^{\text {i.jin }}$ ). Nach ernsten Verhandlungen mit der Stadt Berlin über einen Anschluf̧ wurden diese Erwägungen zurückgestellt $\left.^{\mathrm{r}, 15 \mathrm{t}}\right)$. Die Schwerindustrie hatte die Vorteile der Gasfeuerung erkannt und war äuß̧erst günstig gestimmt. Der Ferngasabsatz an die Industrie belief sich bereits auf das 3,5-fache des Absatzes an Gemeinden ${ }^{7.155}$ ). 1933 wurden I Mia m Abgabe überschritten, was ohne die schiechte Lage der Industrie bereits $1930 \mathrm{zu}$ erwarten gewesen war.

Man zog daraus die Folgerungen, zur Abdeckung der angesammelten Verlustbeträge das Kapital in erleichterter Form von 27 auf 20,25 Mio RM zusammenzulegen $^{\text {T.15g }}$ ). Dieses Opfer der Aktionäre erinöglichte aber, in der Zukunft Gewinne zu erarbeiten, und nachdem der Reingewinn des Jahres 1934 aus I,4 Mia m Gasabgabe im Betrage von 816000 RM zu Rücklagen benützt worden war ${ }^{7.157}$ ), konnte für 1935 bei einem Absatz von 1,7 Mia $\mathrm{m}^{n}$ erstmals eine Dividende von $5 \%$ ausgezahlt werden ${ }^{\% 15}$ ).

Úberraschend ist eine Kritik aus Gasfachkreisen, die daran Anstoł nahm, daf3 nicht allein Überschufgas abgegeben, sonderi in steigendem Małe Schwachgas aus Koks eingesetzt wurde, um Starkgase freizumachen ${ }^{7.150}$ ). Gerade die Verschwendung, die in der Verfeuerung des hochwertigen Gases für Zwecke, die mit minderwertigen Brennstoffen oder Gasen aus solchen ebenso wirtschaftlich erfolgen konnten, war doch ein technisch-volkswirtschaftlich vordringliches Anliegen. Die Äuf̧erung führte aber zu einer willkommenen Aufklärung: Von den Kokereien erzeugt wurden ${ }_{13} \mathrm{Mia} \mathrm{m}^{\mathrm{a}}$, davon waren bereits frei 6,6 Mia m" und konnten kurzfristig freigemacht werden: aus der Dampfkesselbeheizung I Mia $\mathrm{m}^{\mathrm{n}}$, aus der Unterfeuerung I, $\mathrm{Mia}^{\mathrm{a}}$ bei bestehenden Schwachgasverbundöfen. Insgesamt konnten ro Mia $\mathrm{m}^{3}$ freigemacht werden, nur bei ${ }_{3,4} \mathrm{Mia} \mathrm{m}^{3}$ war keine kurzfristige Freimachung möglich ${ }^{\text {T.tan }}$ ).

1936 war die Leitung nach Köln und Bonn voliendet und die von Siegen nach Frankfurt geplant, nachdem die grołen Industriewerke des Rhein-Main-Bezirks ausreichende Abnahmenmengen in Aussicht gestellt hatten $\left.{ }^{7.161}\right)$. In der neu-gegrün-

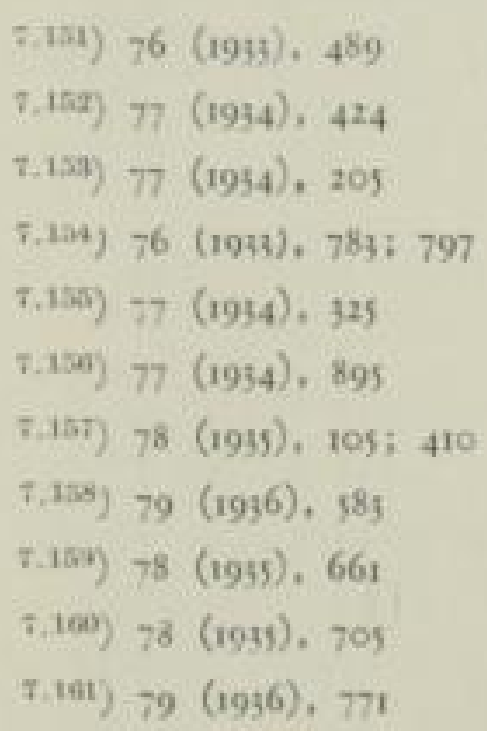


deten Reichsgruppe Energiewirtschaft wurde die Groß̧verbundwirtschaft aus Fernleitungen mit Stützpunktwerken stark propagiert ${ }^{7.16 e}$ ), besonders als im Aufbau der Reichswerke Hermann Göring neue Kokereien in Baden, Bayern und am Harz in Auss cht genommen wurden. Fur 1938 wurde der Absatz der Ruhrgasgesellschaft mit 2,7 Mia m², der der Thyssenschen Gas- und Wasserwerke mit I,I Mia m angegeben $\left.{ }^{\text {Thes }}\right)$. Die Gaswerke erzeugten darnals 3,4 $\mathrm{Mia} \mathrm{m}^{3}$ und hatten auf3erdem $0,9 \mathrm{Mia} \mathrm{m}^{3}$ Kokereigas weiterverkauft $\left.{ }^{7.154}\right)$. Indessen sind verschiedene Angaben aus dieser Zeit nicht ganz übereinstimmend. Der Grund mag darin zu suchen sein, daf̧ bei der Meldung der Erzeuger und der Grof- und Kleinverteiler manche Gasmengen mehrfach gezählt wurden. Für 1939 gibt die Ruhrgas A.-G. eine Gaserzeugung der Gaswerke von 3,8 $\mathrm{Mia} \mathrm{m}^{3}$ und der Kokereien von 19,7 $\mathrm{Mia} \mathrm{m}^{3}$ an. Verbraucht wurden in der Industrie und im Gewerbe $12 \mathrm{Mia}^{3}$; in den Haushaltungen 2,6 Mia $\mathrm{m}^{8}$ und für sonstiges, einschließ̧lich Straß̧enbeleuchtung $\left.0,3 \mathrm{Mia} \mathrm{m}^{37.25}\right)$. Die Ferngasgesellschaften waren aus dem Absatzbedürfnis für die zunehmend anfallende Kokereigasmenge entstanden. Zwölf Jahre nach der Gründung tauchte erstmals das Problem auf, das uns heute geläufig ist, damals aber allgemein überraschte: Die Gaserzeugung konnte dem Bedarf nicht mehr folgen.

In den letzten Jahren vor Kriegsausbruch erhöhten die bereits angeschlossenen Verbraucher ihren Bezug in einem bisher nicht bekannten Ausmaß̧e (Geschäf:sbericht der Ruhrgas A.-G. 1938). Ruhrgas muß̧te sich entschliefzen größzte Zurückhaltung bei Neuanschlüssen zu üben. Das war wohl die beste Rech+fertigung für das, was einst die Pioniere der Zechengasverteilung im Auge gehabt hatten ${ }^{\text {T.15 }}$ ). Einen schönen Abschluf̧ vor dem zweiten grof̧en Kriege bildete die Herausgabe des ersten Forschungsheftes der Ruhrgas Aktiengesellschaft als Reichenschaftsbericht über die wachgerufenen und bewältigten wissenschaftlichen Arbeiten in der Verteilung, Messung und Untersuchung der Gase.

Die groß̧en Bauten des Jahres 1937, die zum ersten Male seit 1931 die Summe der Abschreibungsbeträge überstiegen, wurden durch eigene Mittel (bei verstärkter Abschreibung der Auslandsanleihe) und einen Bankkredit von 5,5 Mio RM bezahltt $\left.{ }^{7.100}\right)$. 1939 wurde eine Anleihe von 20 Mio RM aufgenommen und das Aktienkapital um 750000 RM auf 21 Mio RM erhöht ${ }^{\text {t.167 }}$ ).

Die Ferngasversorgung an der Saar nahm ihren Anfang mit der Gründung der Ferngasgesellschaft Saar m. b. H. mit einem Kapital von 200000 ffrcs. Beteiligt waren die Stadt Saarbrücken mit $58 \%$, und Hütten und Gasanstaltsbetriebsgesellschaft mit je 2r \%. Die Gaserzeugung der bestehenden Werke sollte aufrechterhalten bleiben und nur zusätzlich Zechengas Verwendung finden ${ }^{7 \cdot 105}$ ). Unabhängig davon wurde die Pfälzische Gas A.-G. Ludwigshafen gebildet, von den Städten der Pfalz, Ludwigshafen, Homburg, St. Ingbert. Für mittelbadische

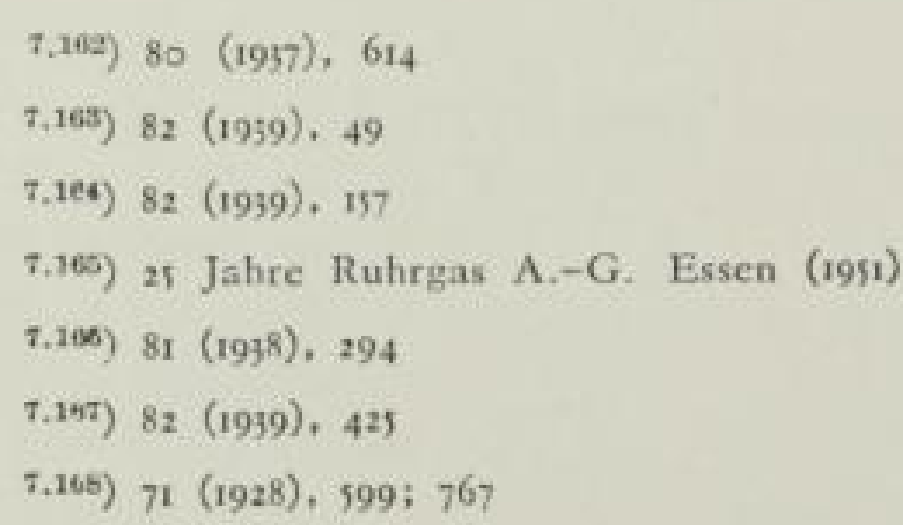


Werke waren Aktien vorgesehen ${ }^{\text {7.aen }}$ ). Im Rahmen der wirren Verhandlungen um die Lieferung nach Hessen kam es zu einem Gebietsabkommen zwischen der Ruhrgas und Saarferngasgesellschaft $\left.{ }^{7,170}\right)$. Die Ausbaupläne kamen aber erst nach der Rückkehr des Saarlandes in das Reich in Gang. Das Hauptrohr in der Pfalz wurde 1935 verlegt $^{7.171}$ ). Immerhin waren 193780 Mio $\mathrm{m}^{3}$ Gas abgesetzt (gegen 37 Mio im Jahre vorher) ${ }^{7.17}$ ). Pfälzische Gas A.-G. und Saarferngasgesellschaft wurden am 21. 12. 37 vereinigt. Es besaßzen: Gruben $21 \%$, Hütten $21 \%$, Stadt Saarbrücken $19 \%$, Landkreise der Saar $18 \%$, Gemeinden und Kreise der Pfalz 21\%. Die Leitungen nach Bad Dürkheim und Grünstadt und Speyer-Germersheim als Abzweige des bestehenden Hauptstanges waren im Bau $\left.{ }^{7.175}\right)$. Eine Kapitalerhöhung von 1,5 Mio auf 4 Mio RM und eine Anleihe von to Mio RM stellten das Ausbaukapital zur Verfügung $\left.{ }^{\text {tit }}\right)$. Mit der Regierung des Landes Württemberg wurde wegen einer Hauptieitung von Heilbronn über Stuttgart, Göppingen nach Aalen mit Abzweigen nach Ulm und Reutlingen verhandelt, die als Teil der grofen deutschen Ringleitung ausgelegt werden sollte $\left.{ }^{7.1 \pi}\right)$. Anfang 1939 verwies das Reichswirtschaftsministerium als Gasbezugsquelle für Württemberg auf eine in Neudingen bei Donaueschingen zu bauende Kokerei. Die Pläne wurden im Kriege weitergesponnen, kamen aber nicht mehr zur Ausführung ${ }^{7.170}$ ).

\subsection{G ASERZEUGUNG}

Rund 30 Jahre war nach der Entthronung der liegenden Retorten als allgemein gebräulicher Einrichtung lebhát an der Entwicklung der Kammeröfen für Gaswerke gearbeitet worden. Nunmehr konnte die Arbeit als abgeschlossen betrachtet werden, wenn auch noch manche Verfeinerungen in Einzelheiten die Industrie beschäftigten.

Neue Wege wurden mit der restlosen Vergasung ohne Koksbildung in vielerlei Richtung gesucht. Die Verwertung der Braunkohle zur Stadtgaserzeugung wurde ebenfalls auf viele verschiedene Arten erstrebt. In der zweiten Hälfte dieser Zeitspanne fand mit der Suche, die deutsche Wirtschaft in den Motortreibstoffen für den Verkehr autark zu machen, die Schwelung wieder regste Anteilnahme.

Über den Stand der Kohlenveredlung trug R. Beiscblag, Berlin, im Verein zur Beförderung des Gewerbefle f̧es am 7. Febr. 1927 eine Übersicht vor ${ }^{7.127}$ ). Im Bere'ch der geeigneten Steinkohlensorten wäre die Verkokung mit Nebenproduktengewinnung durchaus das wirtschaftlichste Verfahren. Die Verschwelung der Steinkohle habe sich nicht durchsetzen können. Die Schwier gkeiten lägen

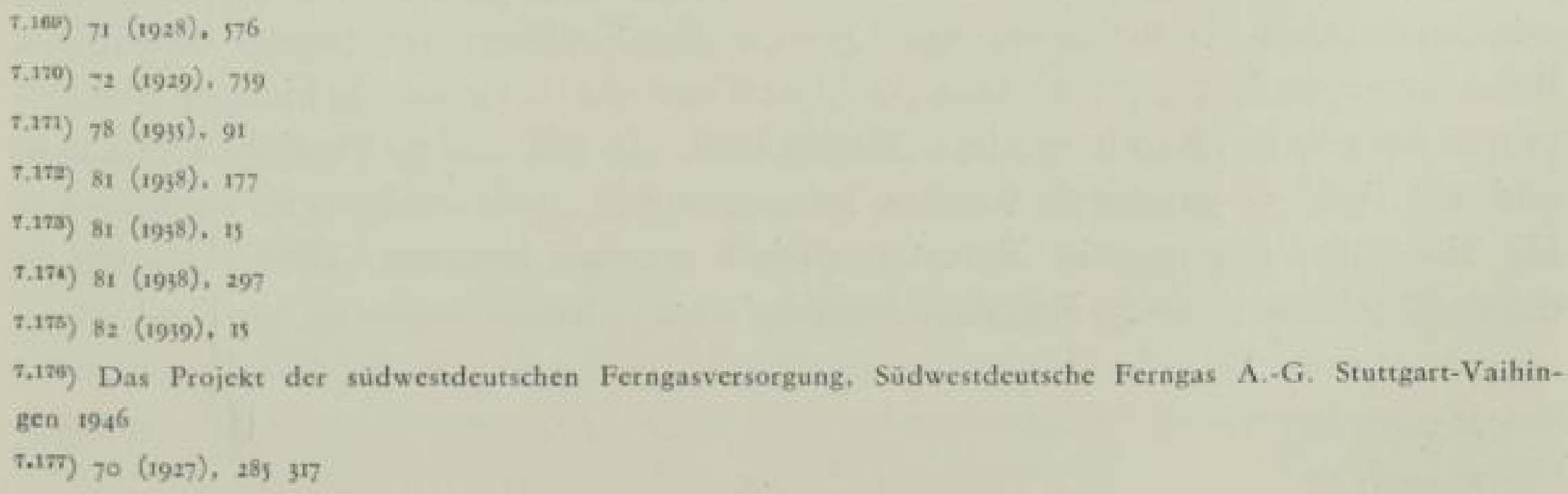


in der Art des Urteeres und in der geringen Festigkeit des Schwelkokses. Möglichkeiten, ihn zu verwenden, sähe man in der Vergasung im Generator besonders auch in der kontinuierlichen Wassergaserzeugung mit an Sauerstoff angereicherter Luft. Das 3chwelverfahren 'der Kohlenscheidungsgesellschaft auf Zeche Matthias Stinnes benutzte zwei ineinanderlaufende Drehrohre, das der ChemischTechnischen Gesellschaft in Duisburg auf Zeche Prosper bei Essen einen Zellenofen. Nachgerechnet wurde, dał der Ersatz der eingeführten Treib- und Schmieröle eine wesentliche Entlastung des Kohlenmarktes nicht bringen köane. Die bisher betriebenen Ölsyntheseanlagen hingen von der Marktentwicklung des Erdöls ab, auf dem eine baldige Verknappung des Rohstoffes als möglich erachtet wurde. Der Steinkohlenbergbau würde sich aber nicht auf sie stützen können. So bleibe vor allem der Koksabsatz, abhängig von der Beschäftigung der Eisenindustrie und der Absatz als Ferngas als Lösungen für die Krisen im Bergbau.

In der Braunkohlenindustrie würden zwei Drittel der Rohkohlenförderung zu Briketts verarbeitet, was aber keine echte Veredelung darstelle. Für die chemische Aufarbeitung waren bitumenreiche Pyropissite Anlał zur Montanwachsherstellung. Bei der Schwelung, die seit I855 im Zeitz-Weif̧enfelser Revier ausgeübt wurde, hatte der gemauerte Rolle-Ofen geführt, mit dem aber nur wegen der Zersetzung an den Wänden so bis $60 \%$ des Bitumengehaltes der Teererzeugung zu gute kamen. Bei den 1927 nur noch vorhandenen Kohlen geringeren Bitumengehaltes war der Rolleofen unwirtschaftlich geworden. Die drehenden Schwelöfen von Thyssen und von Fellner und Ziegler hätten eine stark störende Staubentwicklung. So kam man auf die verschiedenen Spülgasverfahren von Lurgi, Seidenschnur, Arnemann, Limberg und anderen. Der Ofen der Kohlenveredelungsaktiengesellschaft, einer Tochter der Allgemeinen Elektrizitätsgesellschaft, wie er in Edderitz errichtet worden war, war in der Grundform des hohen Rolleschachtofens gehalten, hatte aber eine verbesserte Innenfeuerung. Er wurde zur Vereinigung der Schwelanlage mit Kraftwerken entworfen, deren Abdampf die Vortrocknung der Braunkohle besorgen sollte. Mit vier liegenden gut ummauerten Trommeln arbeitete der Sauerbergofen. Der Braunkohlenkoks sei vor allem zur Staubfeuerung unter Dampfkesseln geeignet, könne aber auch ein günstiger Ausgangsstoff der Wassergasherstellung für die Ölsynthese werden. Die Abgabe von Ferngas sei nur durch Ablösung durch Generatorgas zu ermöglichen. Dem widersprach in gewisser Hinsicht F. Frank, Berlin, der an die Verkrackung des entstehenden Teeres dachte ${ }^{\text {T.1in }}$ ).

Eine Gesellschaft zur Förderung der Braunkohlengaserzeugung wurde 1927 mit dem Sitz in Halle gegründet ${ }^{7.173}$ ).

Prof. F. Seidenscbnur von Braunkohlenforschungsinstitut in Freiberg (Sa) erläuterte seine Arbeit unter dem Druck der Steinkohlenwerbung, obwohl er lieber gewartet hätte, bis er ganz fertig gewesen wäre. Er drückte in der Brikettpresse Formlinge ohne besondere Bindemittel, die mit grofer Vorsicht getrocknet und mit Spülgas geschwelt werden sollten, sodał noch genügende Teermengen für ein gutes Stadtgas in Retorten erzielt werden konnten. Der Teer könne durch Krackverfahren zu Benzinen verarbeitet werden.

5.174) $70(1927), 338$

$7.170) 70(1927), 721$ 
Besonders wurde auch uncer Einsatz der Physikalisch-chemischen Erkenntnisse die Umwandlung der Gase versucht und lehrreiche Forschungsarbeit parallel mit den Arbeiten der Erdölindustrie im Gasfach geleistet. Sicherer und klarer als je zuvor konnte die gewollte Umwandlung festgelegt und das Ergebnis vorausgesagt werden. Lehren und Lernen wurde mit einem Eifer betrieben, der die Grundlage für strukturelle Umwandlungen der Gasbehandlung bildete, die allerdings erst in neuester Zeit sich ergeben haben. Als eine Krönung der vielfachen unermüdlichen Arbeit in allen drei Hauptgebieten darf man die Druckvergasung der Braunkohle mit Sauerstoff unter Gewinnung eines wertvollen Teeres und eines Gases von Stadtgaseigenschaften ansehen. Die erwähnten, ersten großzen technischen Anlagen, die aus dem Geiste R. Drawes in Zusammenarbeit mit der Lurgi-Gesellschaft für Wärmetechnik geschaffen wurden, haben kurz vor dem zweiten Weltkriege bewiesen, daf3 sie dauerad, sicher und wirtschaftlich betreibbar sind. Sie bilden heute nach der Übertragung in die Steinkohlenverwertung die Grundlage grofzer Hoffnungen der Gasfachleute, nicht nur in Deutschland sondern auch in Australien, Schottland und England. So ist also auch diese Arbeit nicht vergebens gewesen, weil sie neben der offensichtlich vollendeten Entgasungstechnik eine ganz neue Technik der Gaserzeugung sich entwickeln lief.

\subsection{Gaswerksofenbau und-betrieb}

Zu einem vollständigen Bilde würde die Beschreibung der Kokereiöfen gehören, nachdem das Zechengas sich anschickte mengenmäfzig ein größzeres Gewicht in der Gesamtgasversorgung zu erlangen als das Stadtgas. Die Ófen sind so, wie sie im betrachteten Zeitabschnitt gebaut wurden, auch oft genug in der Gasfachliteratur beschrieben, insbesondere aber im Handbuch der Gasindustrie, herausgegeben von Dr.-Ing. H. Brü $\mathrm{u} k n$ er, Karlsruhe, Bd. I., München und Berlin $1938 \mathrm{R}$. Oldenbourg. Die Technische Entwicklung ist ein Hauptanliegen des grofen Werkes von Dr.-Ing. F. Ress im Auftrage des Steinkohlenbergbauvereins: Geschichte der Kokereitechnik, Essen 1957, Glückauf G. m. b. H., so dafy hier lediglich auf diese Werke verwiesen werden darf.

Für Gaswerke wurden die Öfen zwar in wesentlichen Teilen abgewandelt. Der Horizontalkammerofen, meistens jedoch kleiner als der Zechenofen, war nur bei wenigen grołen Gaskokereien zu finden, der Vertikalkammercfen - mit ruhender oder dauernd bewegter Ladung - hatte zahlenmäfig für die Gaswerke mehr Bedeutung. Im Grundsätzlichen waren die Öfen von den Kokereiöfen nicht mehr so verschieden, dał eine eingehende Darsteilung in den Rahmen dieser Arbeit passen würde. Es wäre zudem eine Beschreibung der Gegenwart, nicht der Vergangenheit.

Wie die Lage zu Beginn der betrachteten Zeitspanne war, entnimmt man am besten einem Bericht von K. Lempelius zur Weltkraftkonferenz aus dem Jahre $1930^{7.180}$ ). Die neueren Systeme der Kammeröfen hätten wahrscheinlich das Ende der Entwicklung erreicht. Die selbsttätige Absaugeregelung werde allgemein als notwendig anerkannt. Die Zentralgeneratoren für das Unterfeuerungsgas verdrängten die Einzelgeneratoren. Neue Ziele seien noch: die Beseitigung der Starr- 
heit des Betriebes, die eine Folge der Emptindlichkeit der Ofensysteme sei, die Anpassung an Betriebsschwankungen und die Gaserzeugung aus billigeren Kohlen. So erhielt auch das neue Gaswerk Stettin Verrika'kammeröfen mit Zentra'generatoren. Besonders erwähnt wurden die vielen Mengen- und Druckmef̧einrichtungen mit einer Instrumentenzentrale für das ganze Werk $\left.{ }^{7+181}\right)$. Den Absaugereglern von Arca, Reinecke und Askania widmete A. We yricb im Gasinstitut eine lange Arbeit mit der Feststellung, da\} der Einzelregler für jede Kammer das beste $\left.\operatorname{sei}^{-7.102}\right)$. 1925 wurden in Düsseldorf Kuppersverbundöfen fur to t Ladegewicht erbaut $^{7.185}$ ). Wichtig war dem Werke die Erzeugung eines dem Zechenerzeugnis gleichwertigen Kokses. Durch Mahlen und Mischen der gut ausgesuchten Kohlensorten war der Grusanfall von $90000 \mathrm{t}$ im Jahre 1922 auf ro oos $\mathrm{t}$ im Jahre 1926 gesunken. Die Arbeiten führten schlief̧lich zu Richtlinien für KohlenMahl- und Mischanlagen, zu denen der Obmann des Ausschusses E. $S c b u$ macber. Frankufrt, Erläuterungen mit zahreichen Ausführungsbeispielen gegeben hat $\left.{ }^{7,25}\right)$.

Die Ausbeuten betrugen in $\mathrm{m}^{3} / \mathrm{t}$ im Jahre 1913 345; 1922 382; 1923 425; 1924 468; 1927504 und für 1928 wurde eine weitere Steigerung erwartet, weil das Benzol im Gase verbleiben sollte. Auch in Frankfurt wurde im folgenden Jahre (1926) e'n Koppersverbundofen aufgeführt.

Die Starkgasbeheizung, bislang bei Gaswerken skeptisch beurteilt, wurde also im Verbund jetzt wenigstens eingeplant, wozu der trotz aller Krisen im groß̧en und ganzen flotte Koksabsatz natürlich seinen Teil beitrug. Sie hatte auch ihre Bedeutung bei den Bestrebungen, die Gaserzeugung dem wechselnden Bedarf besser anzupassen. Mit dieser Aufgabe befałte sich R. Me z ger, S'uttgart, alsbald sehr ausführlich".155). Hierzu schrieb auch J Dollinger. Wien ${ }^{7.180}$ ), wo ein besonders groß̧er Heizgasabsatz bewältigt werden muß̧te. Die größ̈tc, aus der Wochenabgabe gemittelte Abgabe eines Tages belief sich dort auf I,2 Mio m", die kleinste auf $526000 \mathrm{~m}^{3}$. Das war also ein Verhältnis von 2,33: 1. Vom März bis in den Oktober erwies sich die wahrscheinliche Gasabgabe als abschä zbar, im Winter aber nicht. Trołzdem gelang es, im Winter und Sommer die Anzahl der im Betriebe gehaltenen Öfen gleich zu halten. Mit den Zusa zanlagen für Wassergas von $364000 \mathrm{~m}^{\prime \prime}$, von denen $160000 \mathrm{~m}^{3}$ karburiert abgegeben werden konnten, und $72000 \mathrm{~m}^{3}$ Doppelgas gelang die Anpassung so gut, daf Starkgasunterfeuerung vermieden werden konnte. Diese war deshalb unerwünscht, weil man in den Zeiten des schlechtesten Koksabsazes zusätzliche Koksmengen erhalten hätte. Bei der grof̧en Sorge, die gerade Wien der Doppelgaseızeugung zugewandt hatte, ist die $\Lambda$ ufserung wertvoll, daf sich die Wassergaserzeugung preiswerter stellte.

Der Vortrag löste eine lcbhafte Aussprache aus, die mehr als die Einzelaufsätze beweist, welche Aufmerksamkeit damals den wechselnden Mengen in der Gaserzeugung zuteil wurde.

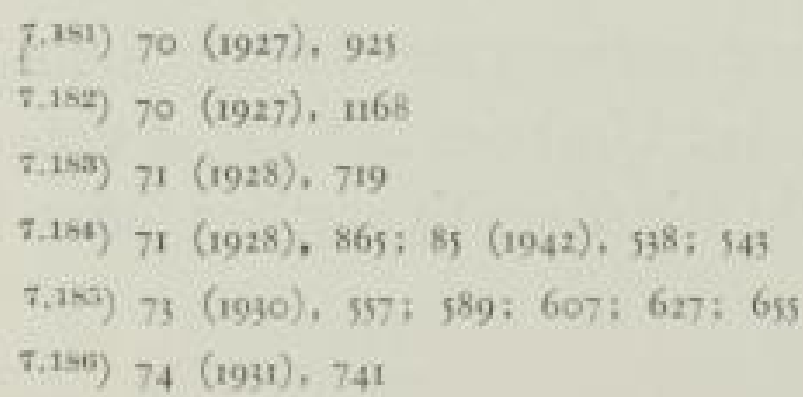


E. $D u b o$ is hatte schon vorher nachgerechnet, dafy selbst bei schlechten Kokspreisen Starkgasheizung wirtschaftlich sein könnte, wenn damit die Belastung der Öfen günstiger wurde ${ }^{7.187}$ ).

In Hamburg bemühte man sich auch bei Schrägkammeröfen mit Einzelgeneratoren, die an sich für Starkgasbeheizung nicht eingerichtet waren, dem Schwachgas bis zu $50 \%$ der Wärmemenge als Starkgas zuzusetzen. Die ersten Berichte wurden 1930 veröffentlicht, wobei auch die Abhängigkeit vom Kokspre's und dem Anfall der Nebenprodukte festgestellt wurde ${ }^{7+16 n}$ ). Vier Jahre später konnte berichtet werden, daß̧ in Grasbrook mit diesem Zusatz, den H. M üller schon 20 Jahre vorher vergeblich in München erstrebt hatte, unter seiner Leitung ein voller Erfolg für eine gleichmäfige Beheızung erzielt war $\left.{ }^{\text {.10 }}\right)$. Man mag daraus ersehen, wie hartnäckig ein Ziel oft verfolgt werden muf̧, das, nachdem es erre cht ist, in einem Bericht als ganz einfache Mafnnahme erscheint.

Die Öfen der Großggaserei Mitteldeutschiand, die von der Hnsclmann Koksofenbaugesellschaft m. b. H., Essen, entwickelt waren, wurden vornehmlich für Starkgasbeheizung ausgelegt. Für die Schwachgasvorwärmung wurden kleine Regeneratoren einzeln für jede Kammer eingebaut ${ }^{7.150}$ ).

In diese Zeit fiel auch eine allgemeine Beschäftigung mit der Verbesserung der Nałzentgasung in Grofraumöfen jeder Bauart. Schon 1930 berichtete F. W e br ma n $n$, daf̧ hochüberhitzter Dampf für Vertikalkammern besondere Vorteile habe $\left.{ }^{* .191}\right)$. Die Mehrzahl der dabei vorgeschlagenen und zuerst angewandten Verfahren wird auch noch heute je nach den Umständen in der einen oder anderen Form angewandt $\left.{ }^{\tau}{ }^{* 1 *}\right)$. Eine keitische Studic über die technischen Grundlagen und wirtschaftlichen Grenzen hat K. B a u m. Berlin, gegeben ${ }^{\text {t.tug' }}$ ).

Mit allen Mitteln wurde das alte Problem angeg iffen, Teer zur Gasgewinnung zu verwerten, da leichte Gasöle zur Karburicrung intolge der Entwicklung der Treibstoffölindustrie nicht mehr zu bezahlen waren. Die amer kan schen Verfahren, Schwer- und Heizöle zu verwenden, führten zu Kohlensºffabscheidungen und zwangen dazu, zur Reinigung des Gitterwerkes einen Rückwär'sgasegang (backrun) einzulegen. E. Scbumacber, Frankfurt, faf̧te den Gedanken, den Wassergasgenerator ähnlich wie beim Doppelgas aus zwei Teilen aufzubauen*) um in der heif̧esten Zone einen Ringraum zu schaffen, in den gemäß̧ einer Anregung von K. Bunte Teer und Dampf eingeblasen wurden $\left.{ }^{7.184}\right)$. Der dabei ausgeschiedene Kohlenstoff wandert dabei mit dem Koks zur restlosen Ümsetzung nach unten. Der im oberen Teil befindliche Koks diente zur Rekuperation der fühlbaren (Wärme ${ }^{7 x}$ ). Ein Generator dieser Art wurde auch in Sutga t betrieben. Es zeigte sich, dafs der gewonnene echte Hochtemperaturteer sehr viel

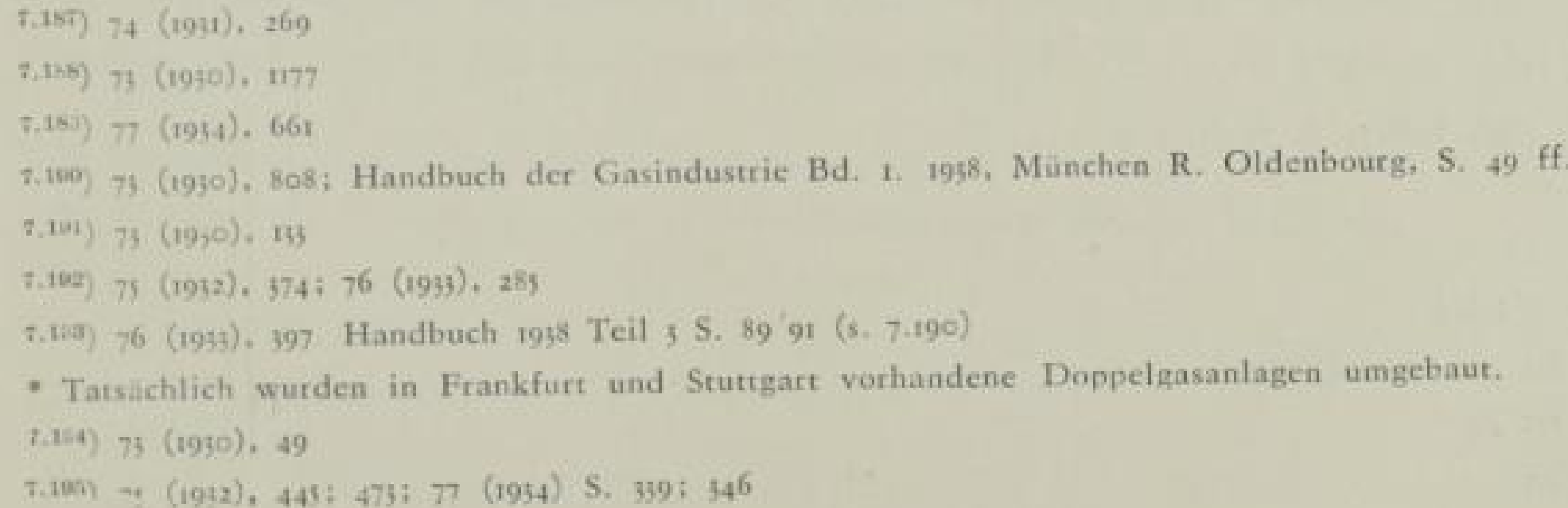


weniger gut zu gebrauchen war als Vertikalofenteer. Dr. C. Otto \& Co., Bochum, baute hierauf weitere Arbeiten auf, indem er Teer und Dampf in den freien Kammerraum oder durch den oberen Teil hindurch in Vertikalkammeröfen, Schrägkammerófen und Horizontalkleinkammeröfen einblasen lief $\left.{ }^{7,1196}\right)$. Immerhin kommt die Teerkrackung einer Vernichtung eines hochwertigen Stoffes gleich ${ }^{5.107}$ ). Man suchte, den entstehenden Teer mit allen Mitteln vor der Krackung zu bewahren. Unabhängig voneinander kamen J. $G \ddot{u} l i c b$, Jena ${ }^{7.1109}$ ) und W. Bueb und A. T $b a u$ dazu, vom Entgasungsraum des Vertikalikammerofens getrennt einen Schacht zur Wassergaserzeugung unmirtelbar daneben anzuordnen, auf̧erdem aber auf die zu entgasende Kohle noch $60 \mathrm{~cm}$ bzw. $2 \mathrm{~m}$ Koks aufzubringen. Dieser sollte die grof̧en Teermengen im Anfang der Entgasung aufsaugen. Sic sollten später beim Dampfen wierler ausgespült werden. Ferner wurde das im Nebenteil erzeugte Wassergas unmittelbar im oberen Teile der Kammer mit dem Entgasungsmischgas zusammengebracht. An dem sicherlich für die Beladung etwas umständlichen Verfahren nahm weder Gülich noch M. Permien, Rostock, Anstofy. Es wurde festgestellt, dał $10 \%$ mehr Ausbringen an Gas durch die Koksauflage erzielt wurde $\left.{ }^{7.199}\right)$. Die Anordnung der Kammern ist auf der Suche nach einem immer besseren Ergebnis vielfach verändert worden. Das mag aber übergangen werden $\left.{ }^{\gamma, m v}\right)$. Ganz kurz kann auch nur erwähnt werden, daf in diesen Öfen in Jena auch Braunkohlenbrikett-Ent- und -Vergasung versucht wurde $^{7.201}$ ), wobei statt des einfachen Mischraumes ein besonderer „Kracker" eingebaut wurde.

Ein wertvolles Schlaglicht, wie ernsthaft selbst in kleinen Werken nun Wege für rationelle Kohlenentgasung in mittleren und kleinen Gaswerken gesucht und beschritten wurden, vermag ein Erfahrungsaustausch in Pommern zu geben. Selbst in kleinen Werken bewährten sich Horizontalkleinkammeröfen, System Didier, mit Lade- und Stof3maschine mit Staubabsaugung und trockener Kokskühlung zur Erzeugung eines grofstückigen Kokses ${ }^{7.000}$ ).

Nur eine Stimme trat bei dieser Aussprache für das Goffinverfahren mit Retortenöfen ein. E. Go ffin selbst hat sich noch später gegen Zentralgeneratoren ausgesprochen und für den engen Zusammenbau von Kleinkammer, Einzelgenerator, Abhitzekessel und den Betrieb mit Wassergaserzeugung im überstehenden Koksrest gleich zu Beginn der Entgasung eingesetzt. Seine Voraussetzung eines gut überwachten Betriebes, wofür er Richtlinien gab, war indessen wohl nur erfüllt bei einem Ingenieur, der wie Goffin, mit seinen Öfen lebte und liebte $\left.{ }^{\text {T.209 }}\right)$.

Es ist aber nicht so, daf nunmehr der Verbesserung der Arbeit mit horizontalen Retorten keinerlei Aufmerksamkeit mehr geschenkt wurde. Man suchte vielmehr, durch sehr volle Ladung die Ergebnisse der Kammeröfen zu erreichen. Dazu

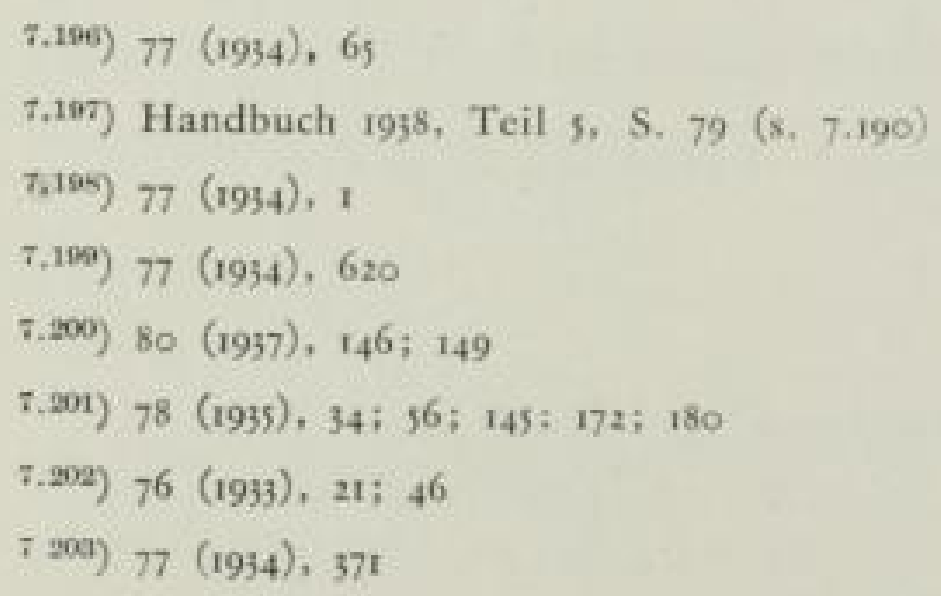


diente vor allem die stetige Verbesserung der Lademaschinen. Sehr dichte Ladungen erreichte $\mathrm{K} l a$ \& $\mathrm{m}$ a $n \mathrm{n}$ mit einer Förderschnecke $\left.{ }^{\tau, 201}\right)$.

Dem Bestreben, den entstehenden Teer vor der Zusetzung bsi hohen Temperaturen zu bewahren, dienten auch die Einrichtungen zur Innenabsaugung durch besondere Rohre (C. Still, Recklingshausen) durch die Türwände (H. Nig gemann, Bottrop) oder durch einen auf die Ofendecke gelegten besonderen Kanal (F. Goldscbmidt). Ein Miehrausbringen von dünnflüssigen Schwelölen wurde mehrfach festgestellt ${ }^{7.305}$ ).

Einige Zahlen über die technische Entwicklung wurden auf der Ausstellung "Gas" 1929 in Berlin von Wien mitgeteilt $\left.{ }^{7.300}\right)$.

Tafel 5: Für 100 t Kohle/Tag benötigte man in Wien 1907 bis 1920

\begin{tabular}{|l|l|c|c|c|}
\hline Jahr & \multicolumn{1}{|c|}{ Ofenart } & $\begin{array}{c}\text { Ladung } \\
\text { in t }\end{array}$ & $\begin{array}{c}\text { Entladung } \\
\text { je Tag }\end{array}$ & $\begin{array}{c}\text { Unterfeuerung } \\
\text { ic 100 } \mathrm{m}^{3} \text { Gas } \\
\text { in kg Reinkohle }\end{array}$ \\
\hline 1909 & Schrägofen 3 Kammern je Ofen & 8 & 1 & 40 \\
1907 & Horizontalkammern $500 \mathrm{~mm}$ breit & 11 & 1 & 30,3 \\
1913 & Horizontalkammern $350 \mathrm{~mm}$ breit & 10,5 & 2 & 27 \\
1919 & Vertikalkammern periodisch & 2,4 & 2 & 31 \\
\hline 1920 & Vertikalkammern stetig arbeitend $11000 \mathrm{~kg} / \mathrm{Tag}$ & & \\
\hline
\end{tabular}

\subsection{Scbwelung}

Die Steinkohlenschwelung hatte, nachdem die außzergewöhnliche Knappheit an Treibölen verschwunden war, keine grołe Bedeutung mehr. R. Heinze und A. $T b a u$ erwähnen nur noch zwei Schwelöfen, die aber nicht von Gaswerken sondern Zechen betrieben wurden ${ }^{\top .25}$ ). Die Halbkoksverwertung war ungelöst.

Das Deutsche Fach verfolgte die weiteren Versuche in England, wo zwar mit dem Coalite-Verfahren eine technische Lösung gefunden war, indessen durch die umständlichen Anlagen der ersehnte Halbkoks zu teuer wurde. Dort war nach den Untersuchungen des Brennstoff-Forschungsrates (Fuel Research Board) eine eigene Betriebsgesellschaft unter Leitung der Gas Light and Coke Company gegründet worden für eine Anlage mit roo $t /$ Tag Durchsatz, die die Gasgesellschaft nach drei Jahren zu erwerben das Recht erhielt $\left.{ }^{7.305}\right)$. Die Wandlungen, die die Verfahren erfuhren, können nicht alle verfolgt werden. Einmal verwarf man nach zahlreichen Versuchen die eisernen Retorten und benutzte die üblichen kontinuierlich arbeitenden Öfen ,mit besserem Erfolge als je $\left.{ }^{4 \pi .500}\right)$. Man war also zum Ausgangspunkt zurückgekehrt. Dann verlief̧ man wieder den wandernden Einsatz und kehrte zur Guf̧eisenretorte zurück ${ }^{7.20}{ }^{2}$ ). 1933 wurden 317000 t Kohle

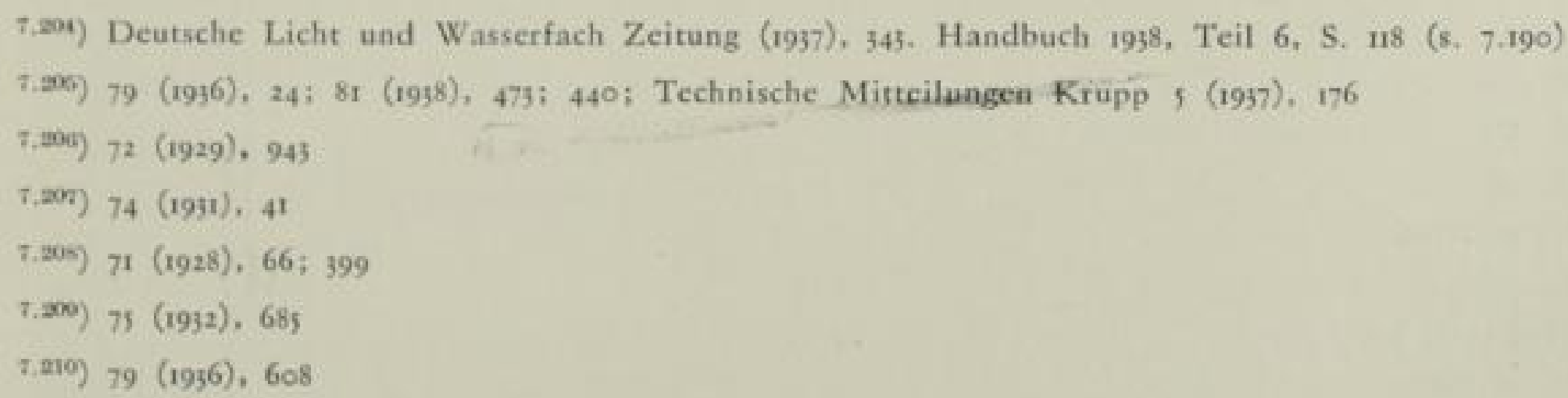


durchgesetzt und $222000 \mathrm{t}$ Schwelkoks erzeugt. Dazu wurden gewonnen: 56 Mio $\mathrm{m}^{3}$ Schwelgas, $20000 \mathrm{~m}^{3}$ Teer, $2100 \mathrm{~m}^{3}$ Benzin. Die Low Temperature Carbonisation Ltd. betrieb allein 3 Anlagen. Sie war e ne von vier Firmen, die sich mit Steinkohlenschwelung befaß̧ten. Neu versucht wurde die Schwelung von Kohle-Öl-Gemischen ${ }^{7.21}$ ). Auf der Weltbrennstoffkonferenz in London wurde festgestellt, daf in England bereits 1928400 verschiedene Verfahren patentiert waren, wovon 16 bis zum Groß̧versuch gekommen waren. Besonders erwähnt wurde das Schwelkraftwerk Dunston ${ }^{7.212}$ ). Der Halbkoks wurde im Kraftwerk verfeuert, die Retorten mit Dampf aus der Trockenkokskühlung und in der zweiten Stufe mit Koksofengas beheizt. Die Anlage wurde damals bereits drei Jahre lang betrieben $\left.{ }^{7.213}\right)$. Man war also auch in England jetzt auf den Schwelteer mit seinem Gehalt an Treibstoffen als Haupterzeugnis aus. Es wurden viele neue Anlagen auf Zechen errichtet ${ }^{7.24}$ ).

\subsection{Braunkohieneinsatzin Gaswerken}

In manchen mitteldeutschen Gaswerken lag es nahe, Braunkohlengenera orgas aus Zentralgeneratoren zur Unterfeuerung in den Entgasungsöfen zu verwenden. Eine besondere Stellung nahmen die Anlagen der Allgemeinen Vergasungsgesellschaft, Berlin ein, deren eine, die im Gaswerk Berlin-Lichtenberg errichtet war, durch C. Arneman $n$ beschrieben und von F. Plen $z^{7.215}$ ) untersucht worden ist. Die Braunkohlenbriketts wurden durch einen aufgesetzten Schwe'schacht dem im unteren Teile mit einem Wassermantel umhüllten Generator zugeführt. Für den Betrieb m t Schwelgas war der Gasabgang ganz oben am Schwelschacht angebracht. Ein zweiter Gasabgang oben am Generatorteil ermöglich+e den Betrieb auch mit Koks. Der erhaltene Teer entsprach in der Ausbeute von $92 \%$ der Thüringischen Schwelanalyse. Das Leichtöl bestand zu $80 \%$ aus Fraktionen um $200^{\circ} \mathrm{C}$. Der Vergasungswirkungsgrad belief sich bezogen auf $\mathrm{H}_{0}$ für das Generato gas auf $69,4 \%$ und unter Zurechnung des Teer- und Leichrölwertes auf $91 \%$. (Utber die Teerverwertung s. Seite 413 )

Sehr w chtig war in Deutschland die Braunkohlenindustrie, die über das Schwelgas versuchte, sich in die Ferngasversorgung einzuschalten. Hierüber hat besonders A. T b a u in vielen Aufsätzen berichtet, der damals Be riebsdirektor der Schwelereien der A. Ricbeckschen Montanwerke A.-G., Halle, war ${ }^{7.2}$ "). Er erwähnte auch die erfolgreiche Anwendung von Spülgasen (Wasserdampf, brennbare und inerte Gase ${ }^{\text {t.t7 }}$ ). Die Ubernahme des Schwelgases nach dem Verfahren der Kohlenveredelungs A.-G. Berlin aus Edderitz nach Dessau ergab zunächst große Schw erigkeiten ${ }^{\text {T.215 }}$ ).

Bei diesen Arbeiten halfen auch die Gaswerke lebhaft mit. Die Frankfurter GasGesellschaft beteiligte sich mit dem Staate Hessen an der Errich ung des Braun-

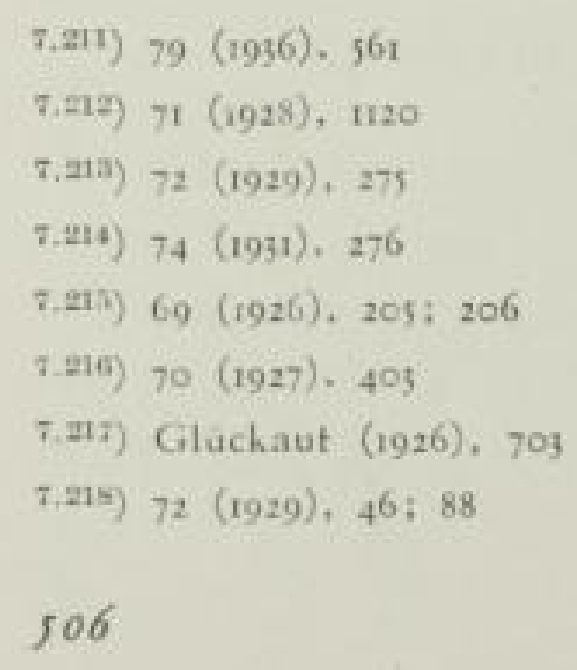


kohlenschwelkraftwerks A.-G., Hessen (Hefrag). Der Schwelkoks sollte in einer Staubkohlenfeuerung unter Kesseln von 35 atü zur Stromerzeugung und Lieferung nach Frank'urt/Main verwertet werden, das Gas als Ferngas durch die Gasgesellschaft verteilt werden. Das Werk konnte aber nur Teer und Elektriz tät absetzen $^{7.219}$ ). Durch grołe Wassereinbrüche in der Grube entstanden bedeutende Vermögensverluste. Die Beteiligung wurde spater abgestof̧en.

Im Gaswerk Halle liefen Versuche, Leuchtgas aus Braunkohlen herzustellen, über die Karl Schmidt $t^{7.250}$ ) und andere mehrfach berichtet haben $\left.{ }^{7.21}\right)$. Technisch gelang es „sogar“, einen festen Koks aus Braunkohle zu erzielen ${ }^{7.2 .2}$ ). Die für das Gas erforderliche $\mathrm{CO}_{2}$-Wäsche war wohl der Hauptgrund für einen zu teueren Gaspreis.

Vom Braunkohlenforschungsinstitut, Prof. F. Seidenscbnur, sind offenbar Versuche in Dresden angeregt worden ${ }^{\text {7.zza }}$ ). Dort ging man indessen mit wirtschaftlichem Erfoig auf Spülgasentgasung bei hohen Temperaturen über ${ }^{7.24}$ ). Man benutzte offenbar die vorhandenen Vertikalöten mit wandernder Ladung.

Auf den Dresdner Arbeiten bauten neue Versuche der Gesellschact zur Förderung der Braunkohlengaserzeugung gemeinschaftlich mit der Braunkohlen- und Br'kett-Industrie A.-G. (Bubiag) und der Stettiner Chamottefabrik, Berlin, auf. Die Arbeiten begannen 1928/29 Die ersten Berichte über ein Versuchsgaswerk für I Mio $\mathrm{m}^{3}$ Gas/Jahr, das auf 3 bis ${ }_{4}$ Mio $\mathrm{n}^{3}$ erweitert werden soilte, erschienen 1931.3.). Man sprach von Entgasung der Kohle, wonach aber die Gase nach unten durch den glühenden Koks gezogen wurden, der katalytisch wirke. Der erhaltene Teer war ein Hochtemperaturerzengnis. Nach sechsjähriger Versuchszeit wurde ab Oktober 1934 das ,erste deutsche reine Braunkohlengaswerk in Kassel in stetigem Betriebe" gemeldet ${ }^{7.20}$ ).

Im Gaswerk Merseburg versuchte Abrens mit Wassergas als Spülgas zu arbeiten, das von oben in die Rohbraunkohle eingeleitet und in der Mitte des Schachtes herausgesaugt wurde $\left.{ }^{7,22}\right)$. Das stieł auf abfällige Kritiken, indessen konnte 1936 festgestellt werden, daß̧ nach Vortrocknung der Briketts deren Entgasung und anschlief̧ende Vergasung des Kokses zu Wassergas als Spülgas ein Endgas von $4200 \mathrm{kcal} / \mathrm{m}^{3}$, ein Spülgas von $3200 \mathrm{kcal} / \mathrm{m}^{3}$ und ein fester Brikettkoks gewonnen wurden ${ }^{7,2 m}$ ).

\subsection{Erneute Arbeiten an der Steinkohlenschwelung}

Nach 1933 wurde der bis dahin vernachlässigten Steinkohlenschwelung erneut viel Aufmerksamkeit zugewendet, weil man mit alien Mitteln bestrebt war, sich von der Öl- und Benzineinfuhr freizumachen. Eine technisch geschichtliche Darstel-

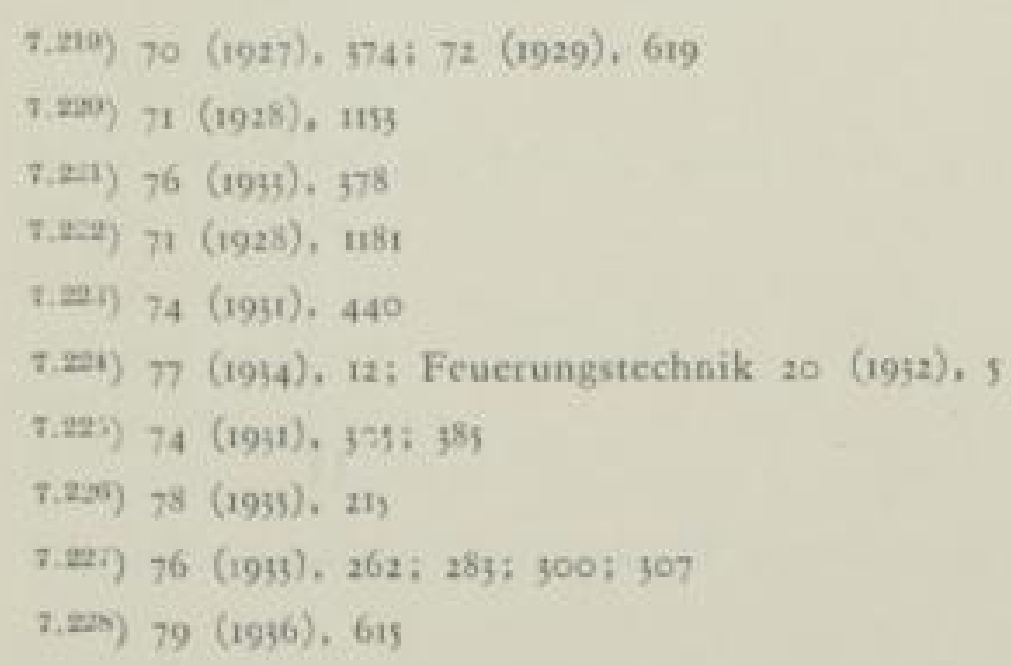


lung ist sehr erschwert, nicht nur weil sich unter dem Drängen der Regierung die Vorschläge überstürzten, sondern auch weil die verschiedenen Wirtschaftsgruppen, Ministerien, Preiskommissar und der Generalinspektor für Wasser und Energie sich gegenseitig beeinfluf̧ten. Wollte man das alles, was so an Eingriffen kam, ausführlich darstellen, so würde die Industriegeschichte sich völlig verlaufen. Immerhin kann das Hin und Her nicht völlig übergangen werden. Der Aufbau der Syntheseanlagen muf aber als das Gasfach nicht unmittelbar betreffend unberücksichtigt bleiben, obwohl die groł̧en gaswerkbauenden Firmen sich lebhaft an der Entwicklung der benötigten Gaserzeuger bereiligt haben und manche Anregung für die Gasindustrie nutzbar gemacht werden konnte.

In der Zeitschrift: Das Gas und Wasserfach trat zuerst ein Vortrag von H. Kop per $s$ vor der Biennkrafttechnischen Gesellschaft über die Hersteliung der Koppers Kohle, Carbolux, auf $\left.{ }^{7.229}\right)$. Koppers verwandte, wie die neuesten Steinkohlenschwelverfahren solche Kohlen, die reichlich Teer gaben und noch genügende Backeigenschaften aufwiesen, um einen festen Koks zu ergeben ${ }^{\text {7.2n }}$ ). Er betrieb einen Kammerofen von 250 bis $350 \mathrm{~mm}$ Breite mit $800^{\circ}$ seit 1930 in Bruay in Frankreich, erhicit einen wertvollen Teer und die "Kopperskohle", die in Zentralheizungen, Hochöfen und Generatoren auch für Fahrzeuge benutzt werden konnte. Über die Wirtschaftlichkeit des Verfahrens wurden Bedenken laut. Immerhin wurde eine Anlage in Carmaux auf die dreifache Leistung ausgebaut $\left.^{7.231}\right)$. Aufträge für England und die Türkei lagen vor.

Am 26. 2. 36 fand eine Aussprache der Wirtschaftsgruppe Gas und Wasserversorgung mit den Herstcllern von Schwelanlagen und von Fahrzeuggeneratoren statt, in der Stimmung für die Steinkohlenschwelung gemacht wurde. Hauptziel war natürlich der Schwelteer, von dem $2 / 3$ im Dieselmotor verwendet werden könnten. Das Schwelgas sollte als Treibgas abgegeben werden, der in grof̧en Mengen anfallende Schwelkoks als Hausbrand und Brennstoff für Fahrzeuggeneratoren untergebracht werden ${ }^{72 a z}$ ). In einem zweiten Bericht über die Steinkohlenschwelung wurden die Verfahren beschrieben. I) Mitteltemperaturverfahren von H. Koppers, G. m. b. H., Dr. C. Otto \& Co. G. m. b. H. und Carl Still 2) Tieftemperaturverfahren der Brennstoff Technik G. m. b. H., Essen, mit beweglichen Stahlkammern, Krupp-Lurgi diesem ähnlich mit festen Stahlkammern $^{7.233}$ ). Mehrere grofe Gaswerke hatten sich bereit gefunden, Probeanlagen zu bauen $\left.{ }^{7.24}\right)$. C. Krecke, der Führer der Reichsgruppe Energiewirtschaft, benannte Berlin, Frankfurt/Main, Königsberg, Breslau ${ }^{725}$ ). Bald danach hatte auch Nürnberg einen Auftrag erteilt $\left.{ }^{\text {T.2a }}\right)$. Daf3 dabei noch Bedenken wegen der Wirtschaftlichkeit, die vom erzielbaren Kokspreis abhängig war, geäufert wurden, paß̧te nicht in die Linie. Wohin das ging, erfuhr A. T bau, der in einer technisch-wirtschaftlich sachlichen Studie eine Bemerkung fallen lieł̧, dał die

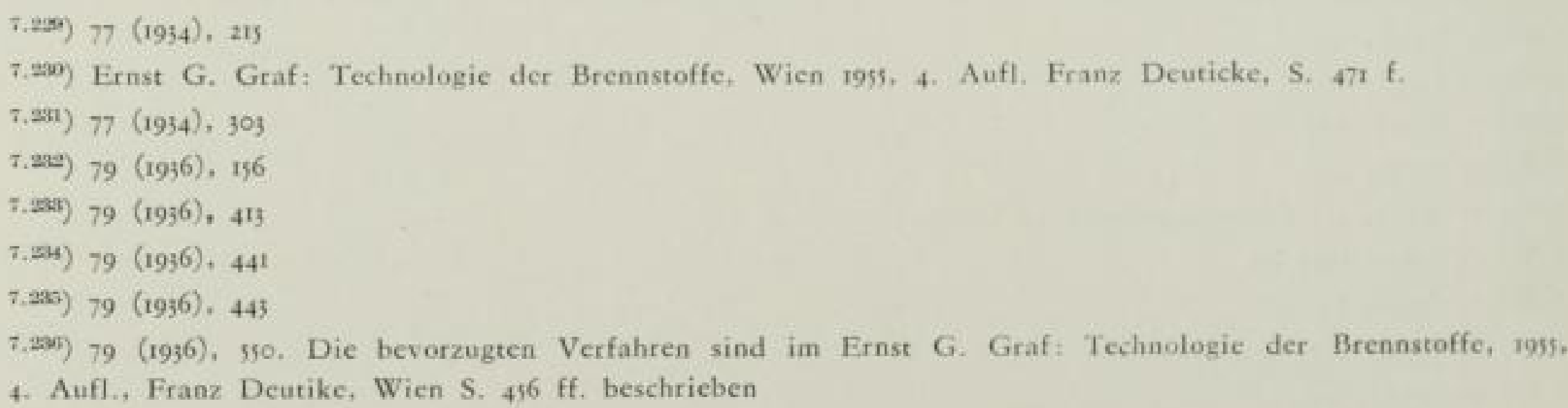


Möglichkeit der Ölerzeugung bei der Steinkohlenschwelung überschätzt würde ${ }^{\text {T.2n7 }}$ ). In einem zweiten Absatz muf̧te er sich dagegen verwahren, daf3 er beabsichtige, die Einführung der Schwelung entgegen den nationalen Bestrebungen zu hemmen $\left.{ }^{72 n}\right)$. Die deutsche Olwirtschaft erwarte von den Gaswerken, daf3 sie einen fühlbaren Beitrag lieferten in dem Bestreben, das Reich von der Öleinfuhr unabhängig zu machen. Die Gaswerke seien in der Lage, den Schwelkoksmarkt (für Haushaltabsatz) zu schaffen, und könnten das Gas dem Stadtgase beimischen. Es sei gelungen, sich von der Kohlenbeschaffenheit weitgebend unabhängig zu machen. Die Verfahren, deren er 6 verschiedene beschrieb, seien im Versuchsbetrieb erprobt.

Der Gau Franken veranstaltete einen Tag der Technik mit Festkundgebung mit dem Thema: Steinkohlenschwelung und Treibstoffwirtschaft ${ }^{\text {T.2. }}$ ).

Ruhrzechen hatten sich zu einer Vereinigung zum Studium der Steinkohlenschwelung zusammengeschlossen. Das veranlafyte wohi W. S a ug eon, Erlangen, zu einer Bemerkung: „Einflußreiche Kreise versuchen, die Veredelung der Steinkohle nicht von den Zechen zu trennen. Die Kosten werden durch die Syndikatspreise abgewälzt. Es entsteht eine unerwünschte Anhäufung im Kohlenrevier. Den Gaswerken würden für die Schwelung wichtige Kohlensorten oft vorenthalten. Machtpolitik und Geldinteressen führten dazu, die Steinkohlenschwelung nicht genügend zu würdigen ${ }^{(47.800}$ ).

Auf der Tagung der Fabrikantenvereinigung im Gas und Wasserfach forderte H. Rosentba $i$, daf die Elektrizitätswerke ihre Kohlen grundsätzlich vor der Verfeuerung zu schwelen hätten $\left.{ }^{\text {T.2st }}\right)$. Zahlreiche Mitteilungen über Versuchsergebnisse beweisen, dał an der geforderten Lösung eifrig gearbeitet worden ist. Auch sehr zukunftsfrohe Äußzerungen finden sich darunter. Über eine KruppLurgi-Anlage auf Zeche Amalie heiłt es: Der Schwelkoks findet reiß̧enden Absatz als Ersatz für Holzkohlen ${ }^{\text {Taly }}$ ). Ferner: Schwclkoks ist berufen, ein wichtiger Vergasungsstoff zu werden, nachdem verschiedene Gaserzeuger für Treibgas untersucht worden waren ${ }^{7,45}$ ). Trotzdem wurde die Förderung der Steinkohlengasschwelung der Wirtschaftsgruppe Kraftstoffindustrie übertragen ${ }^{1.24}$ ).

Eine erste Übersicht vor dem Kriege brachte H. We it te $n$ bille ${ }^{7.25}$ ). Darin werden neben den schon bekannten Verfahren mit Heizflächen zur Schwelung von Feinkohle und geformtem Koks, die Spülgasverfahren - Kollergas und Lurgi erwähnt. Ruhrkohlen seien nicht geeignet, es sei da noch vieles zu beobachten. Die Lösung sei aber in greifbare Nähe gerückt. Der Spülgasteer sei nicht ohne weiteres brauchbar; es müsse gelingen, einen als Heizöl verwendbaren Teer zu bekommen.

Tatsächlich wurde auch noch während des Krieges an dieser Aufgabe lebhaft weitergearbeitet.

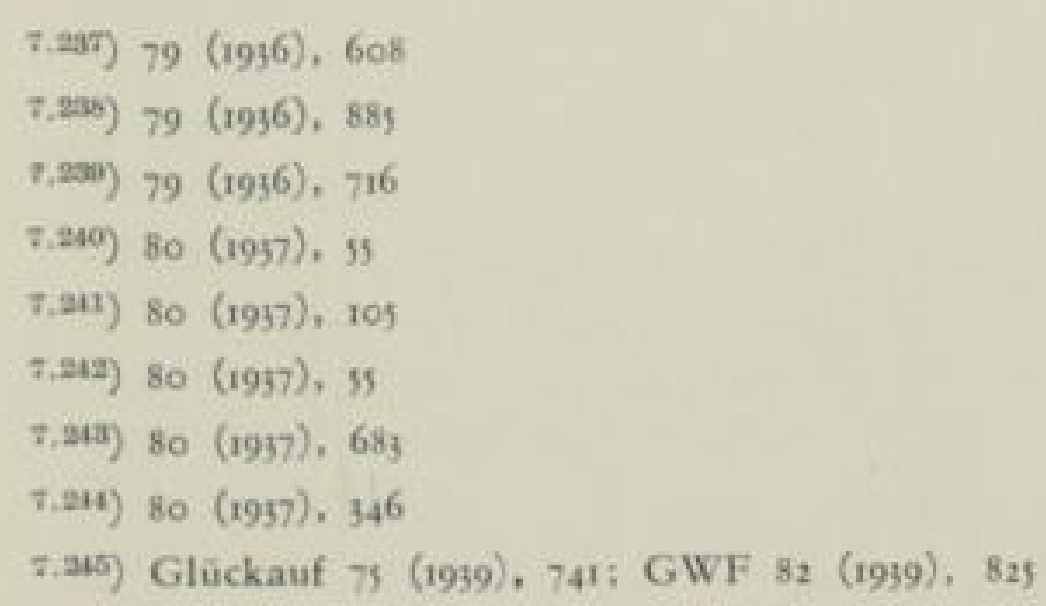


Nach Berichten über die verschiedenen Verfahren der Schwelung estnischer Olschiefer wurde auch die Verwertung in Deutschland vorgenommen. In Heide, Holstein, wurde die Uberlegenheit des Spülgasschachtofens gegenüber dem Drehofen für die Behandlung von Olkreide festgestellt ${ }^{7,210}$ ). Die ersten Versuche mit Torfschwelung wurden überraschend für den Fachmann durch die Physikalischtechnische Reichsanstalt angestellt. Die Weiterentwicklung zu O'sen erschien möglich $\left.{ }^{\tau, 217}\right)$. Sie ist ja auch für gewisse Torfsorten erfolgreich betrieben worden.

\subsection{Vergasung}

Wie schon aus den ersten Abschnitten dieses Teiles 7,3 hervorgeht, ist die Entgasung und Vergasung, sowie die Wassergaserzeugung in dieser Entwicklungszeit nicht mehr streng zu trennen. Der Zusammenbau eıner Entgasungskammer mit einer Wassergaskammer wurde schon auf S. 504 erwähnt. Verfahren im Generatorschacht entwickelt, wurden in ähnlicher Weise in der Kammer versucht. Das ist besonders der Fall, wo auch Schwelteer zu erhalten erstrebt worden ist. Die Trennung nach den Abschnitten hat also etwas Künstliches an sich, das aber kaum vermeidbar ist, wenn man die Entwicklung aufzeigen will.

Eine Auf̧erung, die K. Lempelius für die Weltkraftkonferenz tat, möge zur allgemeinen Kennzeichnung der Lage vorangestellt werden: Die Wassergasanlagen würden dauernd verbessert und mechanisiert. Die restlose Vergasung, ebenso wie die Tieftemperaturverkokung scheine nicht recht voranzukommen ${ }^{7,215}$ ).

Doppelgasanlagen nach $S t r a c b e$ der Aktiengesellschaft für restlose Vergasung wurden vielfach aufgestellt ${ }^{7.29}$ ), für kleine Werke mit Selbstkarburation. Als Abart mag man das Kreisevertahren von Breisig, Wien, ansehen, bei dem ein Teil des erzeugten Wassergases durch den Uberhitzer hindurch dem Generator wieder zugeführt wurde. Bamag-Meguin hat eine Anlage in Posen aufgestellt, bei der ein Heizwert von $3500 \mathrm{kcal} / \mathrm{m}^{n}$ und mit zusätzlicher Teerkarburierung von 3700 bis $3800 \mathrm{kcal} / \mathrm{m}^{3}$ erz elt wurde ${ }^{\tau .250}$ ). In Marburg (kroatischer Teil der Steiermark wurde eine Doppelgasanlage zur Verarbeitung des Köflacher Lignits mit s bis 7 Stunden täglicher Arbeitszeit betrieben ${ }^{\top .31}$ ). R. Mezger und Th. P a y er, Stuttgart, hielten 1930 die Doppelgasanlagen noch immer für bedeutungsvoli. Leider seien nur ganz wenige Kohlensorten geeignet. Sie arbeiteten fleif̧ig im Laboratorium, um die Ursachen für Eignung zu ergründen $^{\text {7.x2 }}$ ). Über Erfahrungen, Untersuchungen und Versuche an grołen Doppelgasanlagen äufzerte sich W. $S c b$ rot $b$, Dresden, in einem Sonderheft zur Weltkraftkonferenz ${ }^{7,253}$ ). Eine Verkürzung des Schweleinsatzes auf wenige Zentimeter

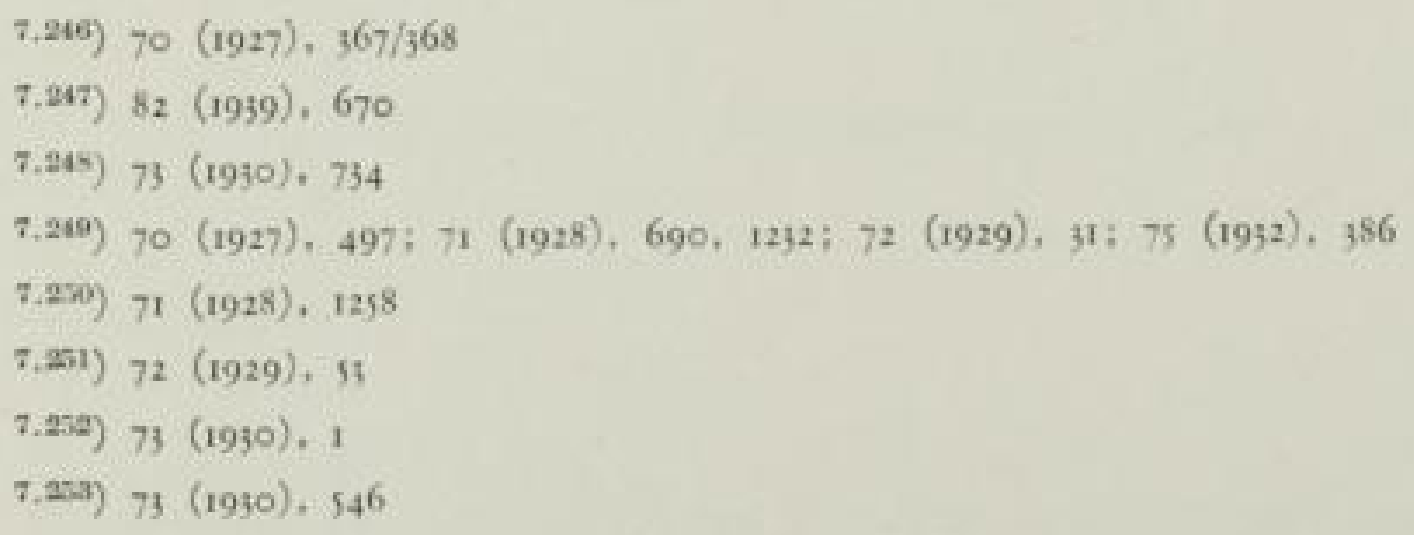


erbrachte die erwünschte größere Unabhängigkeit von den Kohlensorten. Es wurden sogar Staubkohlen mit hohem Aschengehalt verwertet ${ }^{\text {T.:PT }}$ ).

Eine Doppelgasanlage von Pintsch mit Schwelteerkrackung wurde 1930 in Plauen errichtet. $^{7,25}$. Es ergab sich ein Gas mit einer Verbrennungswärme von 3486 $\mathrm{kcal} / \mathrm{m}^{\mathrm{n}}$ und einem Dichteverhältnis von 0,56 .

In Berlin wurde eine Spülgasanlage nach Pintsch-Hillebrand für $75000 \mathrm{~m}^{3} /$ Tag gebaut $^{\text {..unt }}$. Die Hamburger Gaswerke G. m. b. H. widmeten sich e ner kontinuicrlich arbeitenden Wassergasanlage nach diesem System für Braunkohlenbriketts mit umfangreichen Werksversuchen. Da 1932 noch 8 bis $10 \%$ Unverbranntes im Abgas gefunden wurden und 9 bis II \% Verlust als Flugs'aub festgestellt wurden, konnte die Anlage noch nicht als vollendet angesehen werden. Der Vergasungswirkungsgrad betrug nur $50 \%$. Man hoffte, $70 \%$ noch zu erreichen $\left.{ }^{-2 m 7}\right)$. Im Grofyen wurde das Verfahren im Hydrierwerk Wesseling mit II Genera+oren eingesetzt. ${ }^{\text {i. }}$ ). Hier handelte es sich um die Herstellung e nes für die Benzinsynthese geeigneten Ausgangsgases mit einem $\mathrm{CO} / \mathrm{H}_{2}$-Verhältnis von $I: 2$, das durch entsprechenden Wasserdampfüberschuf erzielt wurde.

Die Wasserstoffherstellung nahm überhaupt jetzt einen breiten Raum e $n$. E. F. Armstrong träumte beim Aufbau des englischen Stromverteilungsne'zes von der billigen elektrolytischen Herstellung des Wasserstoffes ${ }^{T, 2 \pi}$ ). Aber selbst in Norwegen wurde die Anwendung dieses Verfahrens durch den Platzbedarf behindert $\left.{ }^{7 . w 0}\right) .52 \%$ allen Wasserstoftbedarfs wurde aus Wassergas mit katalytischer Oxydation des Kohlenmonoxydes und der Druckauswaschung des Kohlendioxydes in den Fabriken für Ammoniaksynthese hergestellt; $30 \%$ aus Koksofengas durch Tiefkuhlung ${ }^{7.201}$ ), 16,5\% durch Elektrolyse, 1,5\% als Abfall.

Einen epochemachenden Erfolg errang R. Drawe mit seinen langiährigen Arbeiten um die Vergasung mit Sauerstoff oder angereicherter Luft. Als er 1927 über die Arbeiten von T. Cerasoll, Rom, über die Vergasung mit Sauerstoff und Wasserdampf berichtete, ahnte man noch nicht, was aus diesen Gedanken herauskommen sollte.

Cerasoli reizte die Nutzbarmachung des als Abfall bei der Luftammoniaksynthese anfallenden Sauerstoffes ${ }^{7,902}$ ). In seiner Rektoratsrede 1929 sprach Drawe über die Vergasung zu Kohlenmonoxyd und Wasserstoff in einem gewünschten und zweckmäßjigen Verhältnis, einem Industriegas mit höchster Verbrennungstemperatur. „Die Methansynthese läßt sich heute bei atmosphärischem Druck und $200^{\circ} \mathrm{C}$ fast quantitativ durchführen. Heizwert und Wichte können in beliebigen Grenzen verändert werden ${ }^{\tau .205}$ ).

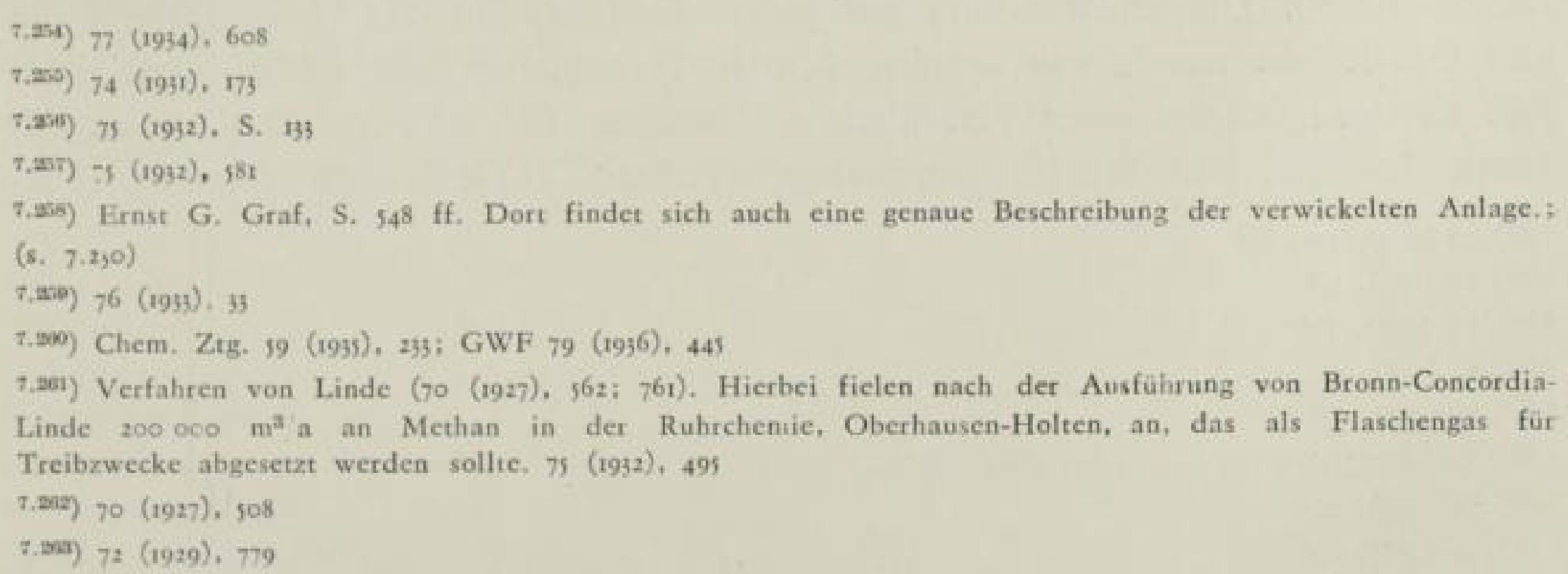


In der Hauptversammlung des Deutschen Vereins in Berlin am 26./27. Mai 1933 konnte er über die inzwischen erarbeitete Druckvergasung zur Stadtgasherstellung berichten. Das Verfahren sei mit der Lurgi Gesellschaft für Wärmetechnik, Frankfurt/Main, in Verbindung mit den sächsischen Werken entwikkelt worden. Die Kompressionskosten wären gering und könnten bei anschließ̧ender Ferngasverteilung nutzbar gemacht werden. Die Kühlanlage und Teerabscheider seien klein. Teeröle und Benzin würden durch Kühlung gewonnen, das Kohlendioxyd unter Druck auf einfachste Weise ausgewaschen, wobei auch der Schwefelwasserstoff zum größten Teile gewonnen würde $\left.{ }^{-2 u}\right)$. In der Aussprache wies G. V ater, Chemnitz, auf das grołe Gasausbringen von $1070 \mathrm{~m}^{3} / \mathrm{t}$ hin. Das ergäbe einen neuen Auftrieb für die Vergasung, die ansonsten aussichtlos sei. Drawe hielt das mit Braunkohle betriebene Verfahren auch mit anderen Kohlen für möglich ${ }^{\top .25}$ ). Vier Jahre später konnten die Betriebserfahrungen in Hirschfelde-Zittau in einer Anlage für 3,5 Mio m/Jahr bekannt gemacht werden. Zur Verfügung standen Braunkohlentrockenknorpel und der Sauerstoff aus der elektrochemischen Fabrik für Kalkstickstofferzeugung. Es sei jede Gasart herstellbar - auch Synthesegas. - Auf die Teerkrackung könne bei hohen Ausbeutezahlen an Teer verzichtet werden $\left.{ }^{7, * x)}\right)$. Im Jahre darauf konnte $\mathrm{H} . M \vec{u} l l e r$, Dessau, über den Abschlufy der Deutschen Continental-Gas-Gesellschaft mit der Aktiengesellschaft Sächsische Werke auf so Mio $\mathrm{m}^{3} / \mathrm{Jahr}$ aus einer Großanlage in Böhlen bcrichten. Hierbei würden Leichtöle und Schwelteere gewonnen nicht die geringste Ólmenge gehe verloren ${ }^{\top * 50^{\circ}}$ ). Die Wirtschaftlichkeit war durch die Anlehnung an eine grołe Brikettfabrik gut. Für die Gasgesellschaft war es von besonderem Werte, zum ersten Male mit einer so großen Gasmenge vom Ruhrsyndikat unabhängig zu werden.

In England begann die South Metropolitan Gas Company Versuche mit der Hochdruckvergasung mit Wasserstoffzusatz gleichlaufend mit Arbeiten der Universität Leeds, wo sich bekanntlich der älteste englische Lehrstuhl für Gastechnik befand ${ }^{\tau, 205}$ ).

Zum Schluf3 dieses Abschnittes mag noch die Entwicklung der Fahrzeuggeneratoren erwähnt werden, die dem Streben nach Unabhängigkeit von Importölen entsprang. Politisch nicht gleichgültig mag es sein, daf3 der erste Bericht über Fahrzeuggeneratoren aus Frankreich kam. 1931 hatte das dortige Kriegsministerium deren Einbau fur Industriekraftwagen angeregt ${ }^{\text {T.2030 }}$. In Deutschland hatte eine kleine Firma: Niebaum und Gutenberg A.-G., Herford, in aller Stille schon immer Fahrzeuggeneratoren für Anthrazit, trotz des Vordringens des Dieselöls hergestellt ${ }^{\text {T.2.270 }}$ ). Die Entwicklung geeigneter Generatoren für Fiolzkohle, Holz und Grudekoks wurde von arbeitsuchenden Firmen nunmehr lebhaft betrieben. 1936 konnten bereits sechs verschiedene Bauarten für schwere Personenwagen, Lastkraftwagen und Schiffe besprochen werden $\left.{ }^{\text {T.2at }}\right)$. Der erste Generatorgas-

$7.464) 76(1933), 447 ; 541$

$7,205) 76(1933), 545$

7.266) $80(1937), 808$

$7.2077) 81(1938), 595$

7.205) 81 (1938), 821

7.2509) Cézanne Usine (1931), S. 31/33; GWF 76 (1933), 210

$7.270) 79(1936), 267$

7.271) $79(1936), 678$ 
schlepper, der Brechkoks verarbeitete, erschien auf dem Rhein $1935^{7.927}$ ). Für die Kanalschiffahrt nach Mitteldeutschland benutzten die Schlepper Grudekoks ${ }^{\text {7.273 }}$ ). Von Untertagevergasung in Ruf3land wurde 1935 berichtet. Man sprach von der Erzeugung von Leuchtgas und Wassergas. $\left.{ }^{7.2 \pi}\right)$. Neue grof̧e Anlagen waren für das kommende Jahr geplant.

\subsection{Andere Treibgase}

Das künstlich als Flüssiggas aus Ölgas abgeschiedene Blaugas fand erneut Beachtung bei seinem Einsatz für Zeppelin-Luftschiffe. Der Vorteil war gegenüber Benzin, dał̧ es in gasförmigem Zustande in die Bailonblasen eingebracht mit dem Dichteverhältnis von nahezu I den Auftrieb des Ballons beim Verbrauch unverändert lief̧. Für die Rückfahrt von Nordamerika bot sich ein aus Erdgas gewonnenes Acthan mit Propan und Butanbeimischungen als sehr hochwertiges Treibmittel an $\left.{ }^{\Upsilon 2.27}\right)$.

Nunmehr machte das Flüssiggas aus Propan und Butan immer mehr von sich reden. Die erste Nachricht in Deutschland knüpfte an die Erzeugung der Skelly Oil Co. in den Vereinigten Staaten an ${ }^{\text {T.27\% }}$ ). Verschärfte Anforderungen an das Benzin zwang die nordamerikanischen Raffinerien zur Gewinnung des Propans und Butans, für das aber erst ein ausreichender Absatz auf allen Gebieten, für die es auch heute noch benutzt wird, erschlossen werden muffte $\left.{ }^{7.477}\right)$. Deutsche Erzeuger wurden zunächst die Leuna Werke bei Merseburg und die „Deurag“ Hannover, die sich darum bemühten, die Verbraucherschaft über die Eigentümlichkeiten dieses Flaschengases aufzuklären ${ }^{7.27}$ ) und auch Zweiflaschenschränke für Hausversorgungen entwickelten. Die ersten Kocher und W'armwasserbereiter wurden 1933 bei den Askania-Werken, und zwar für Lcunabutan gebaut. Man nahm ohne besondere Dankbarkeit auf, dał sich deren Brenner auch für Propan eigneten, während bekanntiich, wo man den umgekehrten Weg gegangen war, bei der Umstellung von Propan auf Butan Schwierigkeiten auftraten ${ }^{-2.25}$ ). 1937 wurden in den Vereinigten Staaten $350000 \mathrm{t}$ Flüssiggas verbraucht. Das war gegen das Vorjahr ein Anstieg von $35 \%$. Sie verteilten sich mit $100000 \mathrm{t}$ auf die Haushalte, mit $173000 \mathrm{t}$ auf Industrie, einschlief̧lich chemischer Veränderung und als Lösungsmittel; mit $42000 \mathrm{t}$ auf Motoren und den Rest für verschiedene Zwecke $^{7.250}$ ).

In Deutschland liefen 193822000 Flüssiggaskraftfahrzeuge. Ab I. Okt. 1939 durften Omnibusse im Linienverkehr mit 16 Steh- und Sitzplätzen nur noch mit Flüssiggas betrieben werden ${ }^{\text {T.231}}$ ).

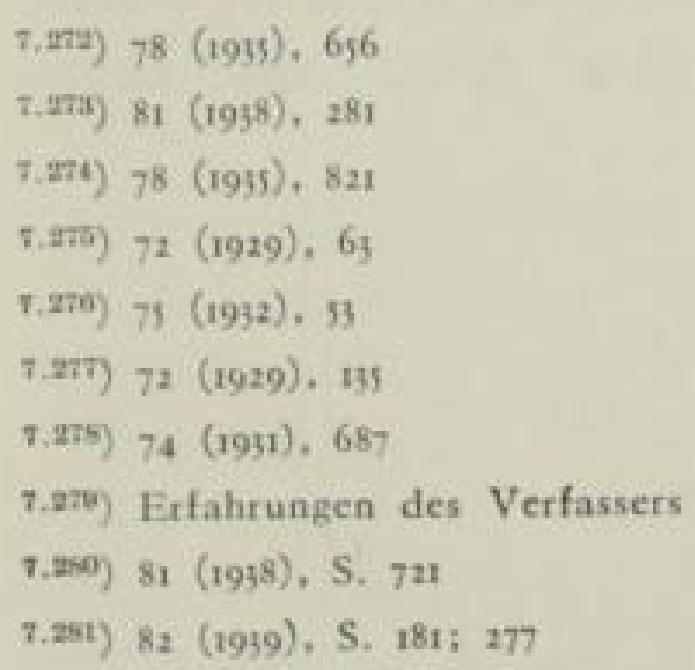

\section{SLUB}


Den Einsatz von Stadtgas, Kiärgas und Methan als Treibgas könnte man natürlich auch unter das Stichwort Gasverteilung oder Gasverwendung einordnen. Es erscheint aber eine geschlossene Übersicht über die Bemühungen, den Benzinverbrauch einzuschränken, an dieser Stelle wichtiger.

Die ersten Nachrichten, daß die im ersten Weltkriege in größerem Małstabe in England, Frankreich und Dänemark ausgeführten Versuche, Stadtgas für Kraftfahrzeuge zu verwenden, fortgesetzt waren, kamen aus Frankreich. L. $C b a p-$ puis und Pignot, Paris, erstatteten für die zweite Weltkraftkonferenz einen allgemeinen Bericht. In den Vereinigten Staaten hätte man Erdgas in Flaschen mit 150 bis 200 atü gefullt. Die Gesellschaft Pyrofax versorgte is ooo Abnehmer. Damals schon wurden wertvolle Erfahrungen über Schmierung, Energieaufwand, Leichtflaschen aus Chromnickelstahl und mechanische Flaschenprüfungen gesammelt. Zur Anlieferung dienten Lastwagen, die in Flaschen $1200 \mathrm{~m}^{3}$ Gas speichern konnten. Die Société du Gaz de Paris hatte einige ihrer Lastwagen und solche der städtischen Müllabfuhr auf Gas umgebaut und Vorteile erzielt ${ }^{7.25}$ ). Stuttgart belieferte 193350 Abnehmer mit Gas unter 120 atü für verschiedene Verbrauchszwecke zum Preise von $40 \mathrm{Pf} . \mathrm{m}^{3}$. Man machte darauf aufmerksam, dafy in Dänemark eine allgemeine Versorgung von Laaland und Falster von Nyköbing aus an 1000 Abnehmer in einem Umkreis von $70 \mathrm{~km}$ betrieben wurde $\left.{ }^{7,25}\right)$. In Frankreich wurde die Versorgung einiger kleiner Orte mit Zechenflaschengas von Bethune aus vorgenommen. Auch die Deutsche Continental-Gas-Gesellschaft erwog im Jahre 1930 ernstlich, das Gas für die Gasversorgung Lehrte G. m. b. H. (gegründet 2. 12. 29) vom Gaswerk Hannover-Linden aus mit der Eisenbahn heranzuführen, als sich unerwartete Schwierigkeiten wegen der Verlegung der Verbindungsleitung von Linden nach Lehrte ergaben. Die Verlegenheit wurde durch den Anschluf\} der Gasversorgung an die Rohrleitung von der Ilseder Hütte nach Hildesheim gelöst.

Mit der Ausrüstung von Kraftwagen mit Hochdruckgasflaschen begann 1926 die Zeche Concordia unter Einsatz von Methan, das bei der Kokereigaszerlegung anfiel $\left.^{7.29}\right)$. Ein Jahr darauf kam „Ruhrgasol“ als flüssige Abscheidung zum Versand.

Im Jahresbericht des Deutschen Vereins für 1933 wurde der Kraftwagenantrieb nach Besprechungen mit dem Reichsverkehrsministerium ais aussichtsreich bezeichnet $\left.^{\tau, 25}\right)$. Auf einer Tagung der Automobil- und Flugtechnischen Gesellschaft am 29. Okt. 1934 stellte das Ministerium die Forderung auf: „Wo immer es möglich ist, die flüssigen Brennstoffe durch feste und gasförmige zu ersetzen, da muf es geschehen. "In der Tat wurde nunmehr ,von oben herab" die Umstellung mit größtem Aufwand vorangetrieben. Neue Berichte aus England zeigten, dał̧ auch dort die Bewegung im Gange war. $\left.{ }^{7,250}\right)$. In Berlin wurde zunächst ein 1,5 t Lastwagen betrieben ${ }^{-\ldots \pi}$ ). Der erste Omnibus wurde umgebaut. Drei Jahre später

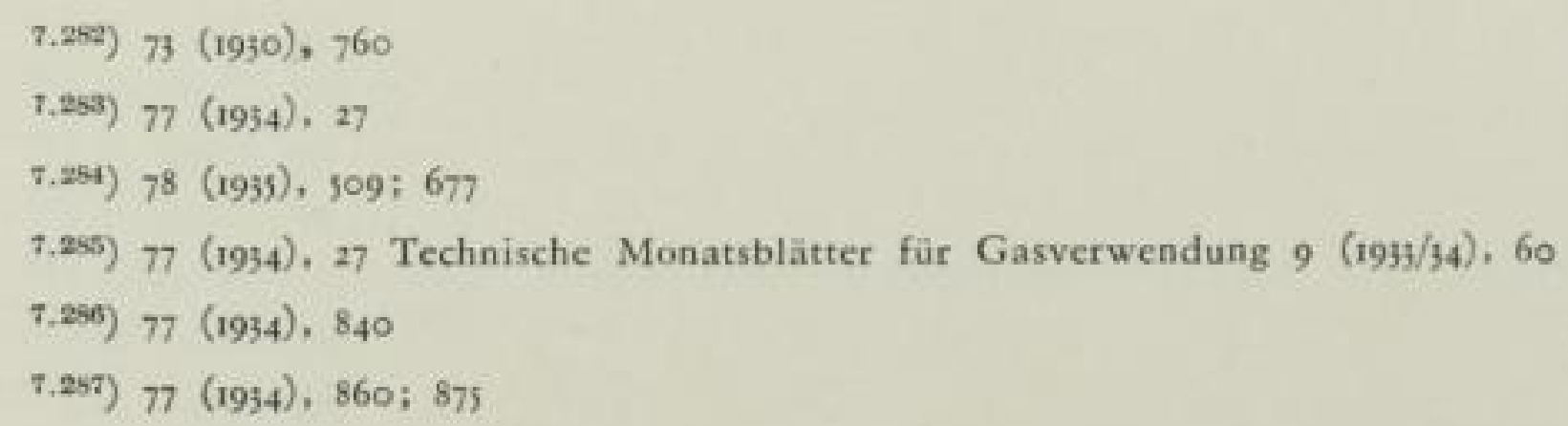


konnte eine Autobus-Linie von $15 \mathrm{~km}$ Länge mit 23 Wagen betrieben werden ${ }^{7.25}$ ). Zur feierlichen Eröffnung der Linie war der Aufsichtsratvorsitzende der Berliner Verkehrsgesellschaft persönlich anwesend, um die historische Bedeutung des Tages herauszustreichen ${ }^{\text {T.ms }}$ ). Ein Unfall mit einer „fahrbaren Tankstelle“, einem Lastwagen mit Hochdrucksgasflaschen, konnte auf einen Bedienungsfehler zurückgeführt werden. Die Flaschen brannten lediglich lecr. Nach einjährigem Betrieb gab es eine Denkschrift. Man hatte 23 mal $57000 \mathrm{~km}$ gefahren, 1,37 Mio m ${ }^{2}$

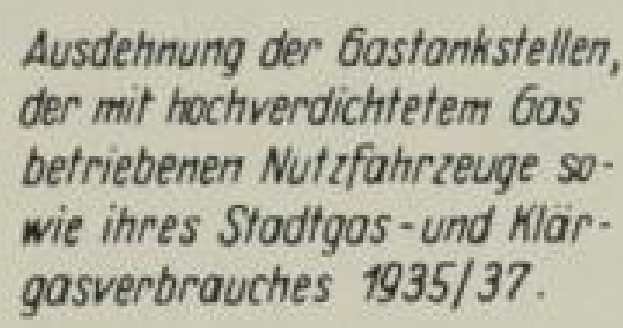

Ausdehnung der Gastankstellen, der mit hochverdichtetem Gas betriebenen Nutzfahrzeuge sowie ihres Stadtgas - und Klar. gasverbrauches 1935/37

Bild 17

Stadtgas als Treibstoff $1935-1937$ (J. f. G. 81 [1938] S. 252)

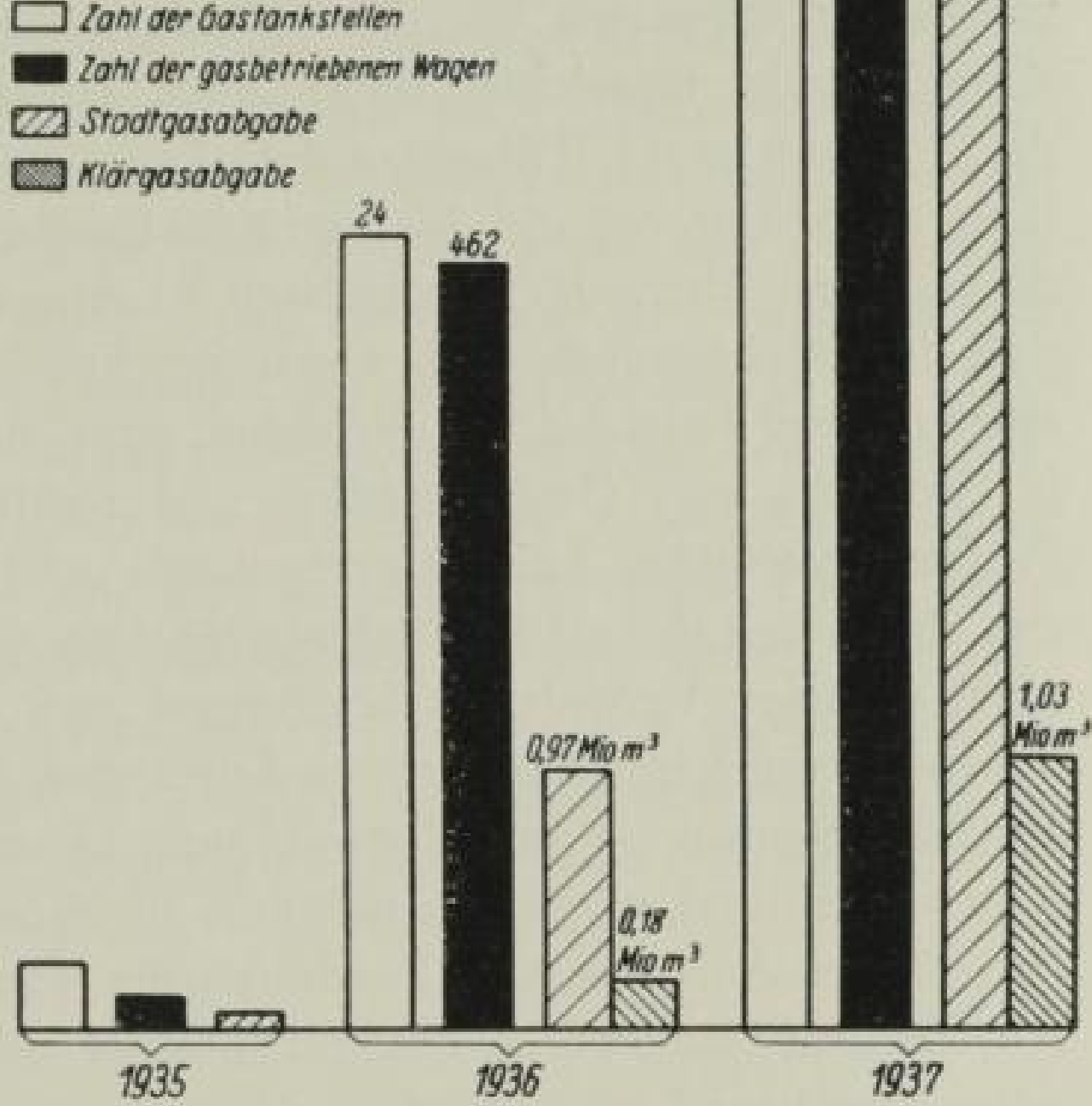

Gas verbraucht, also $1,04 \mathrm{~m}^{3} / \mathrm{km}$ und dabei 680000 Ltr. Benzin und 1950 Ltr. Schmieröl eingespart ${ }^{\tau .1 .00}$ ). (Bild ${ }_{117}$ ). In Berlin sollten weitere Omnibuslinien auf Stadtgas umgestellt werden ${ }^{\gamma}$. $)$.

Die erste deutsche offentliche Tankstelle wurde in Hannover erbaut $\left.{ }^{7.200}\right)$. Es liefen dort 37 Gaskraftwagen $\left.^{\text {7.250}}\right)$. Andere Tankstellen folgten schnell $\left.{ }^{7.20}\right)$. Es wurde Mode, solche Eröffnungen mit einer Feierlichkeit zu verbinden. In Rati-

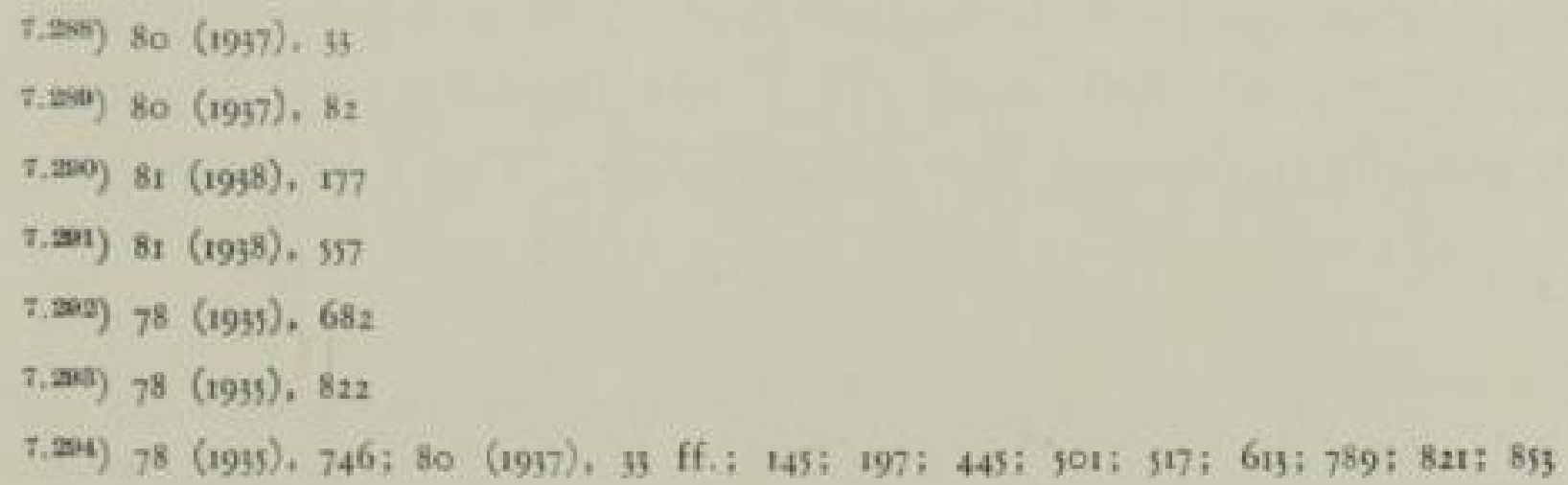


bor war es der Oberbürgermeister persönlich, der die Feierrede hielt $\left.{ }^{7.05}\right)$. Inzwischen plagten sich die Ingenieure, diese neue Technik wirtschaftlich ergiebig zu machen. Die aus hochlegierten Stählen hergestellten Leichtflaschen wurden 1935 vom Ministerium für Wirtschaft und Arbeit zugelassen ${ }^{7.30}$ ). Trotz der noch ganz unausgereiften Technik wurden entsprechend dem Zuge der Zeit, alles schön in Paragraphen gefaf̧t zu haben, zwar nicht Vorschriften, so doch vorläufige Richtlinien für den Umbau von Kraftfahrzeugen herausgebracht ${ }^{7.3 \times 7}$ ). Im privatwirtschaftlich verantwortlich geführten Gaswerk Frankfurt/Oder erwies A. Körting, da\} ein Bruttogewinn aus dem im Wettbewerb mit Benzin möglichen Gaspreis nur errechnet werden konnte, wenn der Bau so schlicht wie nur möglich im Gaswerk selbst, wo der Tankwächter ein sonst nicht voll beschäftigter Aufsichtsführender war, aufgeführt wurde. Rohrleitungskostenanteile muf̧ten selbstverständlich ausgeschieden werden, aber auch die Tatsache, dał man die Speicher auf̧erhalb der Hauptabnehmerzeiten füllen konnte, muf̧te gewertet werden. Ein echter Gewinn war aber kaum erzielbar. ${ }^{7.95}$ ). Stuttgart widmete sich den Versuchen, vor allen Dingen das heizstärkere Klärgas für Treibzwecke zu verwerten $\left.{ }^{\gamma \cdot m n}\right)$. Die französischen Flaschen aus Leichtmetall, die mit Klarvierdraht umwickelt dem Druck entsprechend hergerichtet waren ${ }^{7.800}$ ), auf die Brunklaus, Tilburg, aufmerksam machte, erwiesen sich bei der Nachprüfung als teurer als die Mannesmannflaschen ${ }^{\text {t.30 }}$ ). Inzwischen wurde dem Fach durch einen Oberst im Generalstab im Amt für Roh- und Werkstoffe bescheinigt, dał der Speichergasbetrieb einen beachtlich hohen Stand technischer Vollkommenheit und betrieblicher Sicherheit erreicht habe $\left.{ }^{7.302}\right)$. Ein Erfahrungsaustausch im Betriebe von Gastankstellen und Kraftwagen für Stadt- und Klärgas ${ }^{7.200}$, Prüfstandversuche, Leistungsmessungen und konstruktive Einzelheiten bestätigten, daf3 keine technischen Schwierigkeiten vorlagen ${ }^{\text {.304 }}$ ). In Frankreich kam es zu einer scharfen Verordnung im August 1937, daf3 bis zum I. Juli 1939 alle öffentlichen Betriebe mit mehr als ro Lastwagen $10 \%$ der Wagen auf Gas-Generatorgas oder Stadtgas - umstellen müften. Omnibusse, die stillgelegte Nebenbahnen ersetzten, sollten, wo immer möglich, mit Stadtgas betrieben werden ${ }^{\text {Tata0 }}$ ). Alles war im größten Aufschwunge. Pendelfahrten waren zwischen Hannover und Bremen mit Zwischentankstellen schon frühzeitig möglich $\left.{ }^{7.300}\right)$. Man träumte von einem ausreichenden Tankstellennetz über ganz Deutschland, da geschah das Unerwartete, daf̧ in Berlin mehrere Hochdruckflaschen zerknallten. Mit kaum zu erwartender Wendung wurde von höchster Stelle die Benutzung von Hochdruck-

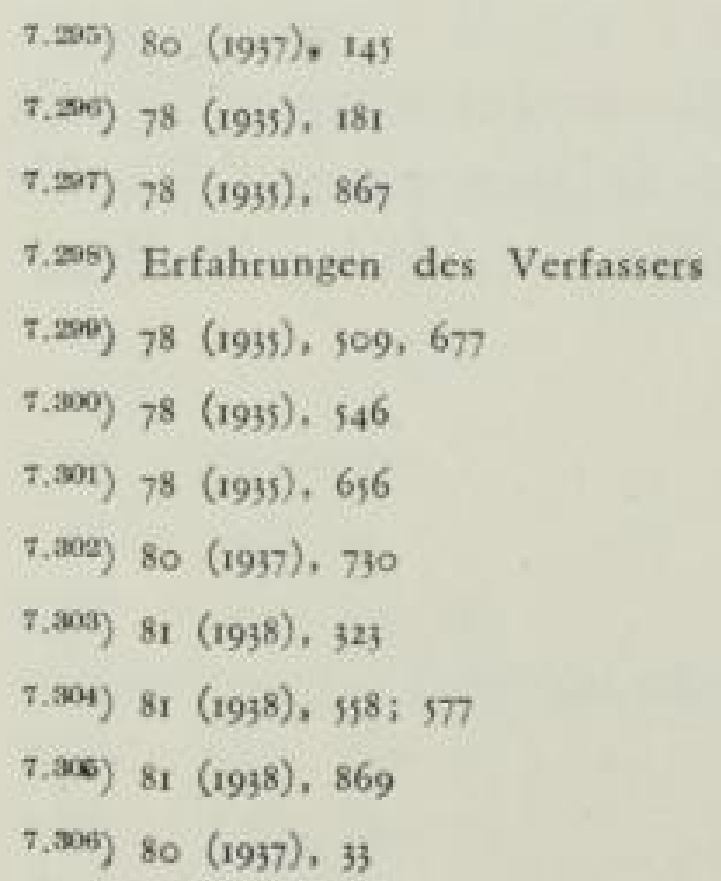


flaschen für Stadtgas untersagt, ohne dafy das Ergebnis der Suche nach den Ursachen abgewartet wurde. Die Mannesmannwerke stellten sich mit ihren ausgezeichneten Laboratorien der Baustoffuntersuchung zur Verfügung. Sie arbeiteten mit dem Gasinstitut Hand in Hand. Da zeigte sich, daf3 vielfach, um an Verdichtungskosten zu sparen, ein Teil des Gases auf roo atü, ein weiterer auf 200 atü gebracht war. Mit diesem Gas wurden die Flaschen stufenweise gefüllt. Nun scheiden sich aber bei der Endverdichtung des Stadtgases auf Drücke von 350 atü (in den Hauptspeichern der Tankanlagen) Kohlenwasserstoffe aus, die die angriffslustigen Bestandteile des Gases in Lösung nehmen. Diese Flüssigkeiten vergleiche das ursprüngliche Blaugasverfahren - müssen aber vor der Einfüllung in die Betriebsflaschen entfernt werden. Sie schlugen sich aber in diesen Flaschen bei der stufenweisen Verdichtung aus dem Gase der ersten Stufen nieder, sobald sie auf vollen Druck gebracht wurden. K. Bunte gab als Lösung an, daf̧ das gesamte Gas zunächst auf 350 atü verdichtet werden und entölt werden müsse. Kompressionskosten konnten dennoch erspart werden, wenn man die Entspannung beim Füllen der Flaschen stufenweise vornahm ${ }^{\text {r.mon }}$ ).

Bunte kam aber mit diesem Ausweg zu spät. Nach dem Verbot waren die Tankstellen grofzenteils sofort abgebrochen und vielfach nach Frankreich verkauft worden. Sie halfen während der Besetzung von Paris dort den Omnibusverkehr aufrecht zu erhalten. Dieser schnelle Entschluf der Gaswerke, die Tankstellen loszuwerden, beweist mehr als alles andere, dał es sich um ein Verlustgeschäft gehandelt hatte. Hinzu kam, daf die Feinkohle für Gaswerke knapp und teuer geworden war, dał auch die Gaserzeugung nicht mehr den allgemeinen Anforderungen nachkam. In der gelenkten Wirtschaft hatte man ja mit Baugenehmigungen die groß̧en Stützpunktwerke im Verbundnetz begünstigt. Die kleinen Gaswerke hatten mit Erweiterungen Schwierigkeiten erlitten, wobei eine drohende Stillegung nicht die geringste Sorge war. So platzte das ganze groł angelegte Unternehmen „Tankstellennetz" gleichzeitig mit den Stahlflaschen ${ }^{\text {7.100 }}$ ). Im Schrifttum ist hierüber aus leicht verständlichen Gründen nichts zu finden. Die „hohen Stellen“ zogen sich völlig zurück.

\subsection{G A S A UFB ER E I T U N}

Über den Stand der Gasaufbereitung berichtete K. Le'mpelius 1930 auf der Weltkraftkonferenz: In der Verarbeitung und Reinigung des Gases sei eine lebhafte Bewegung zu beobachten. Die Kühlung gelinge mit einem Mindestaufwand an Wasser. Die althergebrachte trockene Schwefelwasserstoffreinigung sei vorherrschend. Die nasse Reinigung sei vor allem in den Vereinigten Staaten eingeführt. Von Deutschen Anlagen im Versuchsstadium erwähnte er das CAS-(Cyanwasserstoff-Ammoniak-Schwefelwasserstoff)-Verfahren von Koppers, das Gelbkalilaugeverfahren von $F$ is $c$ ber und die Entfernung bei hoher Temperatur von Rosti $n^{\text {q.amm }}$ ), (Waschung mit ammoniakalischer Kupferoxydlösung).

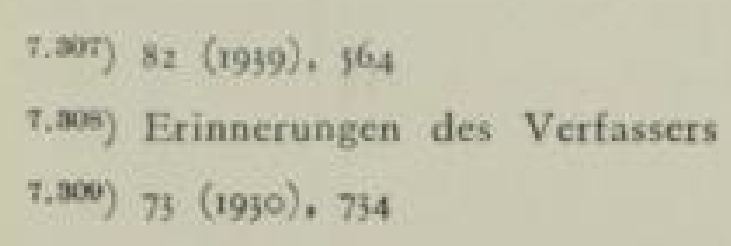




\subsection{Scbwefelwasserstoffreinigung}

Über die nassen Reinigungsverfahren kann hier in der Tat nicht ausführlich berichtet werden. Sie wurden hauptsächlich gepflegt, um die grof̧en Gasmengen bei Kokereien und Syntheseanlagen zu bewältigen. Erst in neuester Zeit nach dem zweiten Kriege werden auch nasse Verfahren in Gaswerken hin und wieder eingesetzt. Es sei auch hier auf die Arbeit von F. M. Ress verwiesen ${ }^{\text {z.sio }}$ ). Auf̧erdem mag auf Einzelaufsätze der Zeitschrift „Das Gas- und Wasserfach" aufmerksam gemacht werden $\left.{ }^{7.811}\right)$. Erwähnt möge indessen werden, dał die Gaswerke sich für Probeanlagen zur Entwicklung der Verfahren zur Verfügung stellten. Das Schwefelsäure-Naß̧katalyse-Verfahren der Metallgesellschaft wurde im Gaswerk Ost der Frankfurter Gasgesellschaft als Betriebsanlage zuerst erbaut ${ }^{\text {7.s.2 }}$ ).

Man unterhielt sich noch über die Vorteile der getrennten Zyanwäsche, obwohl die erlösten Preise keine Wirtschaftlichkeit mehr erbrachten ${ }^{\text {T.sag }}$ ). Beachtung fand die Oxydierung von Schwefelkohlenstoff in vier Londoner Werken mit Nickelkontakten $^{\text {T.sut }}$ ), K. Bunte u. F. Lorenz nahmen versuchsweise Uran und Molybdänoxyd mit Erfolg $\left.{ }^{\gamma \cdot \mathrm{sta}}\right)$.

Beim trockenen Verfahren erregte der Turmreiniger der Thyssen-Gas- und Wasserwerke G. m. b. H. in Hamborn von F. Len ze und A. Borcbardt berechtiges Aufsehen $\left.{ }^{7.319}\right)$. Um die Mühen und Kosten der Aufbereitung der Reinigungsmassen zu erniedrigen, benützte man Maschinen zunächst nach dem Vorbilde der damals entwickelten Formsandaufbereitungsmaschinen, dann mit Brechern, um die harten Knollen zu zertrümmern, und schlief̧lich Maschinen, bei denen gleichzeitig für eine besonders lebhafte Durchlüftung während der Zerkleinerung gesorgt wurde ${ }^{7.817}$ ).

Besondere Aufmerksamkeit erforderte die Schaltung der Reinigerkästen, als mit der Gastrocknung die Harzbildung aus Stickoxyden lebhafter und störend auftrat. K. Bunte, H. Brückner und G. R. Ha as zeigten die Möglichkeit, die Stickoxyde in der Reinigungsanlagen zu entfernen. Die Luft zur dauernden Regenerierung soll erst im zweiten Kasten zugeführt werden. Dann bilden sich mit dem in genügender Menge angereicherten Eisensulfid des ersten Kastens Roussinsche Salze $\left.{ }^{7.218}\right)$. Das Verfahren wurde zuerst in Würzburg mit Erfolg angewandt $\left.{ }^{\text {7.ng }}\right)$. G. Biscboff kehrte zum gleichen Zweck zur periodischen Regenerierung in Turmreinigern zurück (vergl. Seite 248). In einer zweiten Bauart schaltete Bischoff die Reinigung nach den Verdichtern ein. Die Masse wurde in liegende Stahlzylinder eingebracht, die zur Regelung der Feuchtigkeit mit Dampf

\footnotetext{
7.a0) F. M. Ress: Geschichte der Kokereitechnik. Essen 1957 Glückauf

7.a11) 69 (1926), 125; 71 (1928), $169 ; 717 ; 1075 ; 1133 ; 72$ (1929), 442 ff; 75 (1950), $827 ; 77$ (1934), 35; 109; 390; so (1937), 356; $517 ; 81$ (1938), 764; 82 (1939), 333

7.312) $77(1934), 33$

7.313) 70 (1927), $165 ; 71$ (1928), 77

7.314) 73 (1930), $776 ; 78$ (1935), 462

7.916) $75(1932), 765: 787$

$7,316) 74(1931), 445$

7..877) $75(1932), 776$

7.8.89) 78 (1935), 754

7.a19) $81(1938), 261$
} 
und Streudüsen für Wasser ausgerüstet waren. Regenerierung geschah wiederum periodisch ${ }^{7.3 \infty}$ ). Im Jahre 1934 wurde in Homburg (Saar) die erste Hochdruckschwefelreinigung von Gottfried Bischoff erbaut für eine Leistung von 360000 $\mathrm{m}^{3} / \mathrm{d}$. Sie wurde später auf das Doppelte erweitert.

\subsection{Gastrocknung}

Vermutlich angeregt durch Beobachtungen, dał das hochverdichtete Ferngas nach der Ausdehnung völlig trocken wurde, und dann die Wandungen der Rohre nicht mehr angriff, tauchten die Gedanken an eine Gastrocknung um 1930 auf. Gestützt auf vorwiegend englisch-amerikanisches Schrifttum gingen R. Me z ger und F. Pistor die Vor- und Nachteile der verschiedenen anwendbar erscheinenden Verfahren durch. r.) Die Entwässerung durch Druck unter Kühlung und nachfolgender Entspannung 2.) Die Kühlung allein mit tiefen Temperaturen 3.) Die Adsorption mit Silikagel 4.) Die Verwendung hygroskopischer Flüssigkeiten: Schwefelsäure, Glyzerin und viele andere $\left.{ }^{7.3 z 1}\right)$.

Chlorcalciumlösung wurde im Haag von einer englischen Baufirma eingeführt $^{\text {z,nz }}$ ). G. W. A nderso n, London, bestätigte die Erfolge dieses Verfahrens in England.

Die Tiefkühlung wurde in Deutschland durch F. Lenze (D.R.P. $)^{\text {7.asas }}$ ) entwickelt. Eine Tiefkühlanlage in Berlin brachte die ersten Schwierigkeiten mit Stickoxydverharzungen. Das führte K. Bunte zur Untersuchung der Kondensate, um die Ursachen zu finden ${ }^{7.2 n}$ ). Wie dann das Stickoxyd aus dem Gas entfernt wurde, ist im vorhergehenden Abschnitt 7.4I berichtet. In Mainz entstand die Schwierigkeit, dafy das getrocknete Gas in der Schwefelwasserstoffreinigung sich wieder bei $20^{\circ}$ Betriebstemperatur mit Wasserdampf sättigte, so daf insbesondere im Winter nach diesen Reinigern noch einmal tiefgekühlt werden mußzte. Die Anlage lieferte die notwendige Leistung, weil im Winter die Erstkühlung geringere Wärmeabfuhr verlangte. Die Tiefkühlung vor dem Reiniger machte diesen aber um $20 \%$ leistungsfähiger ${ }^{7.2 \pi}$ ). Die Wasseroberfläche der nassen Behälter wurde mit Immunol abgedeckt. In Würzburg ging man mit einer Temperatur von $-4^{\circ} \mathrm{C}$ ins Rohrnetz $\left.{ }^{\gamma .200}\right)$. Der Austrocknung der Dichtungsstricke in den Muffen muf̧te durch Immunoleinspritzungen entgegengewirkt werden.

\subsection{Koblenmonoxydentfernung}

Um eine geschlossene Übersicht zu zeigen, darf wohl auf die Arbeiten von P. Sabatier und J. B. Senderens zurückgegriffen werden, obwohl sie bereits auf S. 363 erwähnt sind. Es handelte sich um die Methansynthese durch

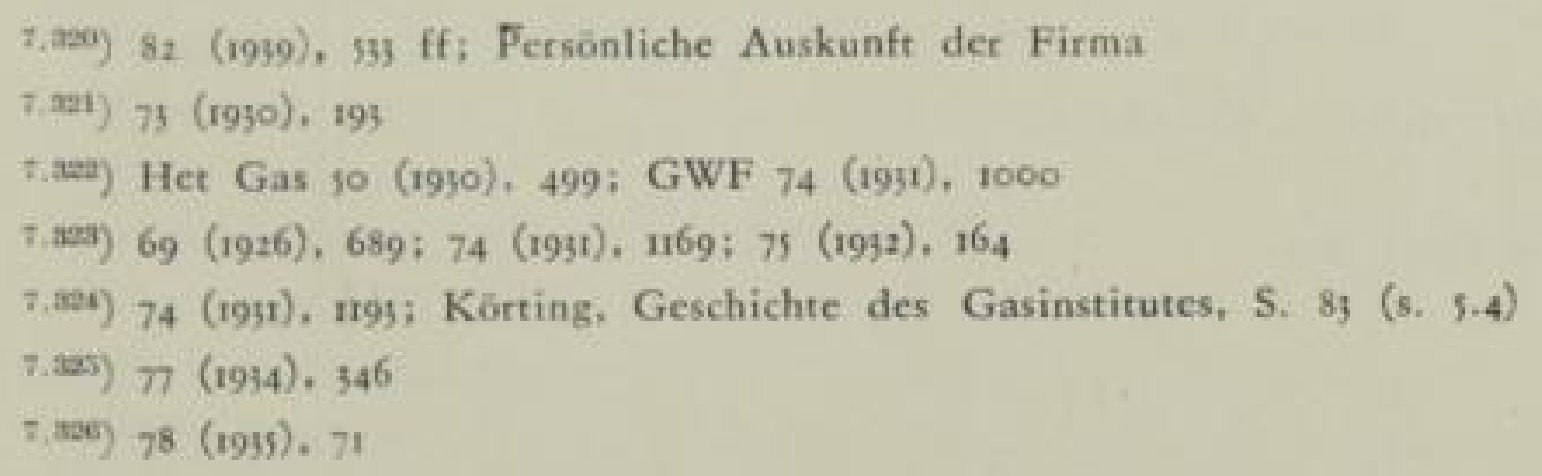


Anlagerung von Wasserstoff an Kohlenmonoxyd und -dioxyd ${ }^{\text {i.as }}$ ). Seine technische Verwirklichung wurde im Cedford-Prozeł 1909 in England erstrebt, um ein giftfreies Leuchtung aus Wassergas herzustellen. Anregungen gingen von E. Erdma $n n$, Halle/S. aus, der, um das erwünschte Kohlenstoff-Wasserstoff-Verhältnis zu erhalten, einen Teil des Kohlenmonoxydes flüssig nach dem Lindeverfahren ausschied. Dabei ging auch der Schwefel mit fort und der Nickelkatalysator wurde geschont $\left.{ }^{\text {t.eer }}\right)$. Der Heizwert des Gases stieg dabei an.

Im Laboratorium beschäftigte sich 1914 P. $J o c b u m$ im Chemisch-technischen Institut, Karlsruhe, mit Versuchen, durch Kühlung mit Kohlensäureschnee $\left(-80^{\circ} \mathrm{C}\right)$ störende Dämpfe und Schwefel vor der Methansynthese zu entfernen, als „Beiträge zur Frage der Anreicherung des Methans in technischen Gasarten und über kohlenoxydfreies Leuchtgas $\left.{ }^{47.30}\right) .1916 \mathrm{nahm} W$ il $d$, Ludwigshafen, ein Patent auf die Wasserdampfkatalyse im Kohlengas.

1928 wurde in Oppau nach Wild eine Anlage durch Bamag-Meguin A.-G. errichtet. Tun kam das Gespräch in Gang. H. Ke $m m e r$, Berlin, machte die breitere Offentlichkeit mit den drei Möglichkeiten bekannt I.) Absorptionsverfahren 2.) Katalytisches oder Kontaktverfahren 3.) Tiefkühlung ${ }^{\text {7. }}$. $)$. Schon in diesen Anfängen konnte A. T $b a u$ darauf hinweisen, dał man in England an die Frage der Folgen des Kohlenmonoxydes im Stadtgas viel sachlicher heranginge. Man sei in der technischen Entwicklung nicht weiter als in Deutschland, habe sich aber sehr viel genauer mit der Unfallstatistik beschäftigt, die man mit Erfolg den Behörden und Gesetzgebern bekannt gemacht habe. Er empfahl auch in Deutschland die Fortsetzung einer genauen Statistik ${ }^{\gamma+3 x}$ ).

Auch in Holland stellte G. A. Brender à Brandis fest, dafy die Kohlenmonoxydentfernung kein technisches, sondern ein wirtschaftliches Problem sei ${ }^{\text {7.sarg }}$ ). W. J. Müller und E. Graf, Wien, entwickelten ein eigenes Verfahren (Patent $\mathrm{II}_{3} 333$ vom 16. 4. 1927) mit katalytischer Oxydation und nachheriger Kohlendioxydauswaschung ${ }^{\text {7.asas }}$ ).

H. Chr. Gerdes führte das Verfahren der Gesellschaft für Gasentgiftung, Berlin, in Hameln ein. Auch hier wurde katalytisch mit Wasserdampfzusatz gearbeitet, das Kohlendioxyd aber im Gase belassen. „Hameln wird als erstes und einziges Werk der Erde ein katalytisch entgiftetes Gas ( $1 \%$ CO-Rest) liefern und dabei Naphthalin zu Tetralin hydrieren ${ }^{\text {T.3an }}$ ), und dabei wird das entgiftete Gas kaum teurer werden als das bisherige ${ }^{\text {it7.355)}}$.

R. Mezger, Stuttgart, rechnete eine Verteuerung heraus und sagte richtig, dał der wirtschaftliche Erfolg mit der Koksverwertungsmöglichkeit zusammenhänge. Leider kam nicht klar heraus, dał einmal um diese Zeit das Preisverhältnis von Kohle zu Koks allgemein günstig war, insbesondere aber kleine und mittlere Werke durch gediegene Kokswerbung im Einzelabsatz besonders gute

7.327) Chem, Ztg. 22.3.02 S. 263: Journ. f. Gasbel. 45 (1902), 270; 338; 689

7.325) $\$ 4$ (1911), $73^{7}$

$7.200) 57(1914), 73 ; 103 ; 124 ; 149$

7.320) 72 (1929), $744: 1178 ; 73(1930), 927 ; 75(1932), 150: 269: 507$

7.at11) $73(1930), 348$

7.an2) Het Gas 92 (1932), 417; GWF 76 (1933), 829

7.3233) 77 (1934), 122

7.34) 77 (1954), 122

7.35) 78 (1935), 86 
Kokspreise erzielen konnten. Der Verfasser hat in diesen Jahren über Ratschläge, den Kleinabsatz des Kokses zu pflegen, viele Gaskessel für Zentralheizungen in kleinen Werken abgesetzt. Hamburger Arbeiten ab 1930, unmittelbar an Wild anknüpfend, bestätigten die Abhängigkeit vom Koksabsatz $\left.{ }^{7.350}\right)$. Sehr unerfreuliche Auseinandersetzungen entwickelten sich über die Schädlichkeit des durch Umwandlung des Monoxydes erhöhten Kohlendioxydgehaltes des Gases als Korrosionsursache im Rohrnetz und über die Brenneigenschaften, die in der Mehrzahl der Fälle rein empirisch an den Geräten, wie sie sich zufällig im Netz vorfanden, beurteilt wurden $\left.{ }^{\text {fun }}\right)$. Mehr als sonst wurde die sittliche Forderung nach Entgiftung in das Gespräch gezogen. Es kam zu einem Gutachten des Vereins für den Gemeindetag, unterzeichnet von der Abteilung Wissenschaft und Unterricht, vertreten durch Gerdes und Stief und von der Abteilung Gaserzeugung, vertreten durch $P$ le $n z$, das wahrhaft salomonisch erscheint: Die wirtschafliche Auswirkung könne nur örtlich beurteilt werden. Im allgemeinen betrüge der Mehraufwand $0,22 \mathrm{Pfg} . \mathrm{m}^{3}$. Als sittliche Forderung sei sie unbedingt wünschenswert. Die Herstellung von Anlagen dürfte nicht als Verwaltungsmaf̧nahme allgemein untersagt werden $\left.{ }^{7.3 a 5}\right)$. $193^{8}$ wurde von der Deutschen Continental-Gas-Gesellschaft in Nordhausen die Entgiftung eingeführt nach einem katalytischen Verfahren, das H. Müller mit H. Brandt mit Kohlendioxydauswaschung und gleichzeitiger Veredelung des Benzols in Zusammenarbeit mit Rost in entwickelt hatten. In Nordhausen war die Voraussetzung eines kaum mehr zu befriedigenden Koksmarktes gegeben. Ein Vortrag Müllers darüber ${ }^{\text {z.ass }}$ ) löste erneute scharfe Auseinandersetzungen mit Gerdes aus ${ }^{7.30}$ ). Inzwischen waren neue Anlagen der Gesellschaft für Gasentgiftung in Chemnitz und Potsdam gebaut worden $\left.{ }^{7.31}\right)$. Ein weiterer Gedankenaustausch von Gerdes mit E. Gral und C. Mariscbka, Wien, wurde schließlich von letzterem damit abgebrochen, daf̧ er im Kriege zuviel andere Dinge zu tun habe, um ihn fortführen zu kön-

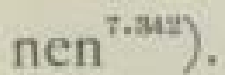

\subsection{Benzolgewinnung}

Wir haben gesehen, daf die Beurteilung der Benzolgewinnung um 1926 sehr verschieden war. Am positivsten waren wohl die städtischen Gaswerke in Berlin eingestellt. Zwar verdiente man an dem Benzol nur $0,2 \mathrm{Pf} . \mathrm{m}^{3}$ Gas, aber die Entlastung der Reinigungsanlage war wertvoll $\left.{ }^{7.343}\right)$. H. Ke m mer und G. B a u er, Berlin, gaben eine Ubersicht. Die Benzolpreise betrugen $191420,65 \mathrm{RM} / \mathrm{t}$, $191983,45 \mathrm{RM} / \mathrm{t}$; 1924 4I,43 RM/t; 1926 49,20 RM/t; 1928 43,90 RM/t. Die gewonnenen Mengen betrugen in $1000 \mathrm{t} / \mathrm{Jahr}$ : In Deutschland 320; England 150; Frankreich 70; Saargebiet 35; Belgien 30; Holland 25. 1929 wurden in Deutschland

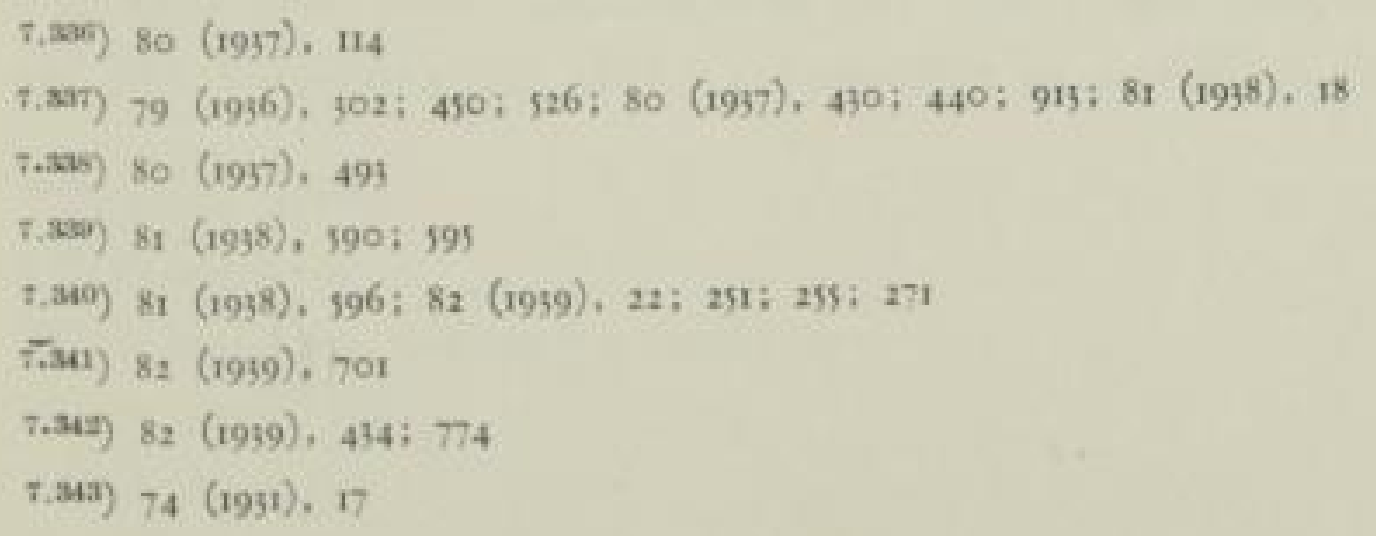


$390000 \mathrm{t}$ erzeugt und $160000 \mathrm{t}$ eingeführt. Die Gaswerke lieferten nur 20 bis $30000 \mathrm{t} / \mathrm{Jahr}$. Nach der Gaserzeugung hätten aber in den grof̧en Werken 50000 $\mathrm{t} / \mathrm{Jahr}$ gewonnen werden können ${ }^{\text {T.Mu }}$ ).

Im Jahre 1935 kündigte J. T i e mes sen auf der Hauptversammlung des Deutschen Vereins an, dafy die Gaswerke mit einer Erzeugung von über 3 Mio m Gas/Jahr verpflichtet wären, Benzol auszuwaschen ${ }^{\text {7atit }}$ ). Im Jahresbericht für 1936 der Wirtschaftlichen Vereinigung wurde festgestellt, dał nur sehr wenige Werke mit über 2,5 Mio $\mathrm{m}^{3}$ Jahreserzeugung ohne Benzolanlage seien und $39000 \mathrm{t}$ abgeliefert hätten ${ }^{7.34}$ ). (Bild II8.) $193^{8}$ wurden von den Zechen $540000 \mathrm{t}$, von Gaswerken 55000 t Benzol erzeugt ${ }^{7.37}$ ).

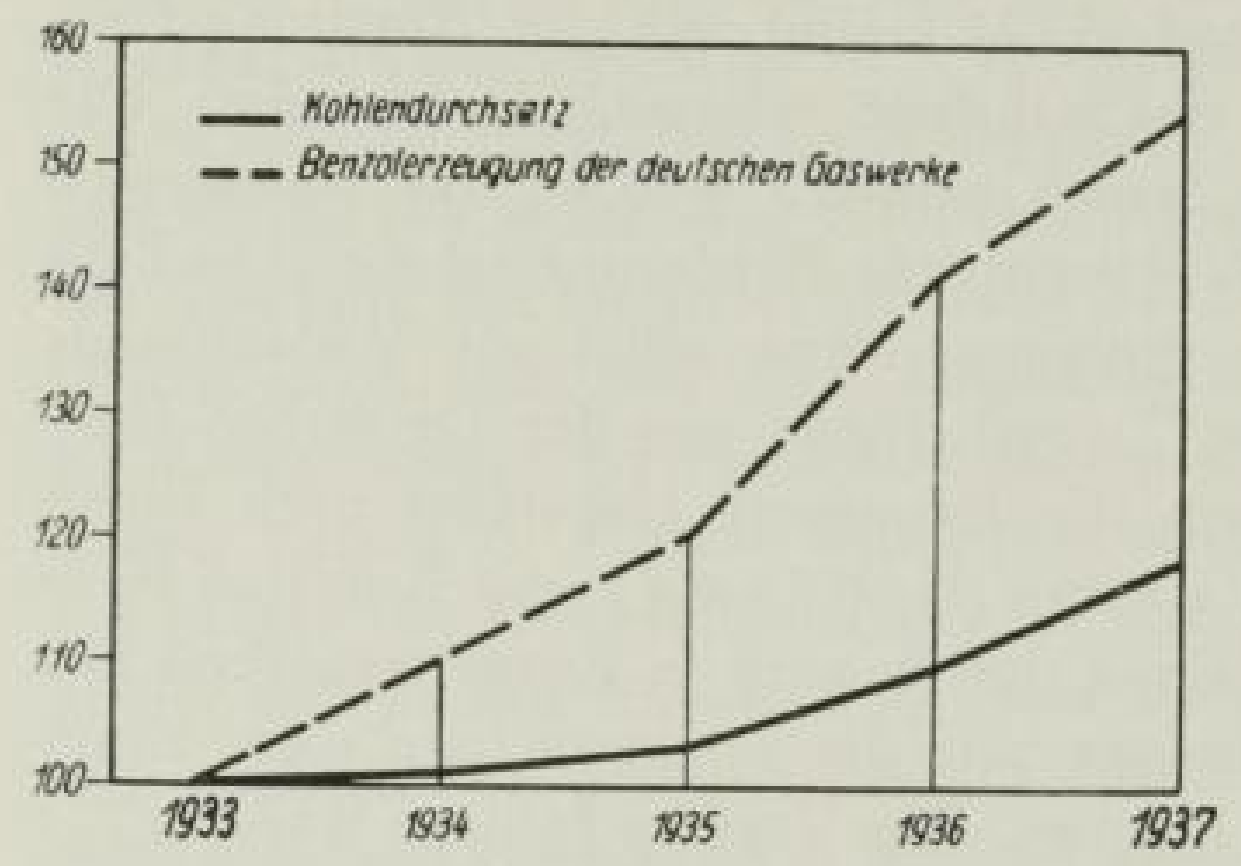

Bild 118

Benzolerzeugung 1933-1937

(GWF. 81 [1938] S. 252)

Die erste Benzolgewinnungsanlage mit aktiver Kohle der Lurgigesellschaft. Frankfurt/Main, wurde im Werk Beckton bei London errichtet. Uber die Anfangsschwierigkeiten, die dort dem Betriebsleiter aus der Wasserart entstanden, wurde allerdings nicht berichtet ${ }^{7.35}$ ). Fast gleichzeitig kamen Anlagen in Paris

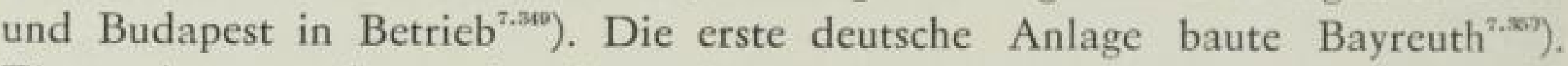
Eine weitere wurde von Lurgi gemeinsam mit Bamag-Meguin im Gaswerk Charlottenburg errichtet ${ }^{7.551}$ ).

J. Wucberer, Wiesbaden, beschrieb gleich mehrere Verfahren wie bei hohem Drucke Benzol mit dem Tiefkühlverfahren gewonnen werden könne ${ }^{7 . .55}$ ).

Julius $P$ intscb führte in Ratibor ein verbessertes Waschölverfahren ein, wobei das Waschöl zur Vorwärmung vor der Abtreibung nicht mehr unmittelbar mit dem Dampf zusammengeführt wurde und so geschont werden konnte ${ }^{t . \pm 0}$ ). Krautwurst bestätigte, dał das Verfahren sehr gut und wirtschaftlich arbeite.

\footnotetext{
7.344) 73 (1930), 509: 519

7.345) 78 (1935), 506

7.346) $80(1937), 36 \mathrm{r}$

(..นว) 82 (1939), 49

7.tus) 76 (1933), 478

7.349) 76 (1933), 554

ร.300) 77 (1934), 401

7.351) 79 (1936), 357

7..559) 78 (1935), 118

7.353) 79 (1936), 898
} 
G. Lorenzen, Bochum, vertrat die Ansicht, daf die Toluolabscheidung sich bei Gaswerken nicht lohne. Es würden auch nur 2000 bis $2500 \mathrm{t} / \mathrm{Jahr}$ benötigt, die durch Verbesserungen in den Kokereien leicht gedeckt werden könnten ${ }^{7.35 t}$ ). Eigentümlich wirkt in den sonst zur Schau getragenen günstigen Hoffnungen ein etwas undurchsichtiger Aufsatz von L. Piatti, Berlin, über naphthalinfreies Gas. Es sei nicht möglich, sich auf die Wirkung des Benzolwaschöles zu verlassen; Tiefkühlung sei zu teuer. Auch Aktivkohle lasse Verunreinigungen durchgehen, die das ohne Benzol im Gase schutzlose Rohr angriffen. So sei Tetralineinspritzung zur Bindung des Rostes nötig ${ }^{q, 255}$ ).

W. De mann nannte als Verbesserungen in der Benzolgewinnung in den letzten 1o Jahren: Die Vervollkommnung: der Wäscher als Drei-Stufen-Glockenwäscher, der Berieselung, der Wärmeaustauscher, Regeneratoren, Überhitzer, der Ölbeschaffenheit und der wissenschaftlichen Erkentnisse über die Ursachen der Olverdickung. Erniedrigung des Kraftverbrauches bei erhöhter Auswaschung ${ }^{7.3 \times a n}$ ).

\subsection{B ETRIEBSA UFS I C H T}

Es muł in dieser Darstellung auffallen, dał in diesem Abschnitt die technische Betriebsaufsicht kaum behandelt werden kann und nur ein Teilgebiet, die Beurteilung der Brenneigenschaften der Gase, in wertvoller Weise gefördert zu sein scheint. Das liegt aber wiederum daran, dał Verfahren und Geräte der technischen Aufsicht in ihren Grundlagen fertig entwickelt waren, dabei aber durchaus verfeinert und erweitert wurden, ohne daf man aber ein geschichtlich beachtenswertes Ereignis feststellen könnte.

Ganz anders lag es mit der kaufmännisch-statistischen Betriebsaufsicht. Was früher Anregungen und Ansätze gewesen waren, die je nach Einstellung und Verständnis verschieden von den Werken auch mehr oder weniger vollkommen durchgesetzt wurden, das wurde nun in der Zeit einer ganz ungewöhnlichen Not allgemeiner, vor allem mit dem Ziele, vergleichbare Zahlen zu erhalten. Ohne dem, was vorher schon mit allmählich steigender Würdigung der Rechnungslegung geschehen war, in der Wertung Abbruch zu tun, kann man sagen, dał mit der Neuordnung des Vereins 1927 die Würdigung Allgemeingut wurde. Eine besondere Vereinsabteilung Gas, Wirtschaft und Betriebsführung wurde eingerichtet. Dieser wurde - noch deutlicher auf die Erfolgsstatistik ausgerichtet - die Abteilung: Gas, Wirtschaftsfragen etwa 1932 zur Seite gestellt. 1929 waren bereits: „Richtlinien für die Aufstellung der kaufmännischen Rechnungslegung bzw. Betriebsrechnung in deutschen Gaswerken herausgebracht $\left.{ }^{47.357}\right)$. Vielleicht muf man darauf hinweisen, dał die immer schärfere Erfassung der Einzelertrags- und Lastzahlen in der Privatwirtschaft sehr stark durch die sich schnell steigernde und vor allem verfeinernde Steuererfassung beeinflufyt wurde, während bei den Gaswerken die Körperschaftssteuer nach einigen Vorkämp̣fen um die Besteuerung der Gasabgabe in ortsfremde Gebiete ${ }^{7,259}$ ) und des Einkom-

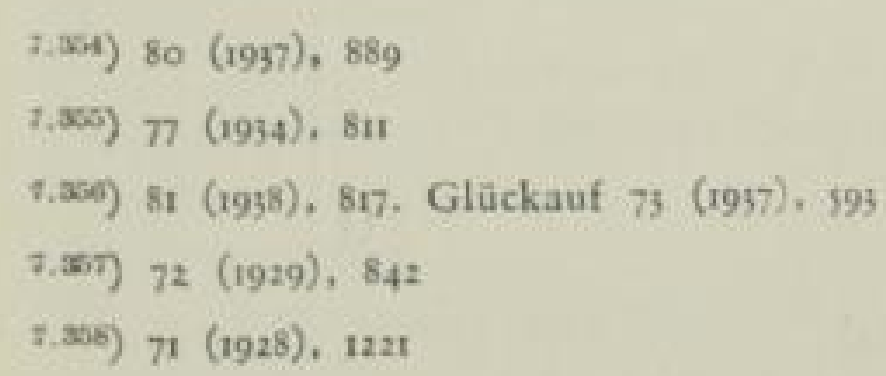


mens aus dem Absatz der Nebenerzeugnisse, erst ab 1935 erhoben wurde $\left.{ }^{\text {r.3959}}\right)$. Bei den Werken war also allein die gewissenhafte Erfolgsaufsicht der leitende Gedanke.

Die Arbeiten führten zum GWF-System, in dem alle Formblätter der Arbeitsverteilung, Bewertung und Verarbeitung bis ins Einzelne als Muster ausgearbeitet waren $^{\text {7.200\% }}$.

Der Gedanke, den gleichen Ertrag nach der Anweisung: Kleiner Nutzen Großjer Umsatz zu erzielen, wurde damals als Mittel gegen den Geschäftsverfall in der Fertigungsindustrie so stark in den Vordergrund gestellt, dał er fast zum Schlagwort wurde und damit die Gefahr leichtfertiger Preisbildung heraufbeschwor. Auch im Gasfach wurde er aufgenommen ${ }^{\text {?.men }}$ ), aber sehr bald wiesen doch die Fachleute darauf hin, daf̧ die Beschränkung auf das gegebene Versorgungsgebiet zur Vorsicht mahne. Die Lage ist ja auch mit einem Unternehmen, das einen großen kaum ausfüllbaren und fast ohne Grenzen erweiterungsfähigen Marktbereich um seine Erzeugungsstätte besitzt, kaum zu vergleichen, zumal wenn die Ware auch im Ausland grundsätzlich Absatz findet. Über Tarife und Preise wird aber noch im Zusammenhang mit Werbung und Wettbewerb berichtet werden.

$\mathrm{Ab} \quad 1933$ wird es stiller um die kaufmännischen Erträge und die Organisation. Das mag daran liegen, dafy bereits im Herbst 1932 infolge der Arbeitsbeschaffungsgelder sich die wirtschaftliche Lage der Gaswerke entspannte. Auf̧erdem aber mahnten gewisse Wirtschaftsgrundsätze zur Vorsicht bei öffentlichen Erörterungen. Mit dem bis zum Überdruł verwendeten, eigentlich für einen guten Kaufmann ganz selbstverständlichen Schlagwort: „Gemeinnutz geht vor Eigennutz erschien bei manchen lauten Rednern ein Gewinn fast als unmoralisch.

Von den Mitteln der technischen Betriebsprüfung mag zunächst aus dem Jahre 1927 die Geipertapparatur zur Bestimmung der Heizwertzahl ${ }^{7.55}$ ) und die im Chemisch-technischen Institut zu Karlsruhe von J. T a usz und K. Jungmann erarbeitete Jodpentoxydmethode zur genauen Bestimmung geringer Kohlenmonoxydgehalte ${ }^{\gamma \cdot .20}$ ) erwähnt werden. Diese wurde alsbald für die Untersuchung der Abgase für Gasgeräte nutzbar gemacht.

\subsection{Beurteilung der Brenneigenscbaftender Gase}

Einen Markstein für die Beurteilung der Gasbrenneigenschaften bildete die Arbeit des Goffredo Wobbe, Gaswerksleiter in Bologna, Sohn des Johann Gottfried Wobbe, der mit dem Wobbebrenner die Entwicklung der Kocherbrenner sehr nachhaltig beeinfluf3t hatte. Die Arbeit erschien in der Zeitschrift Industria del Gas e degli Acquedotti 1926. Sie ist heute noch lesenswert $\left.^{7.304}\right)$. Wobbezahl und Wobbezahlmesser sollten nach dem Willen dieses In-

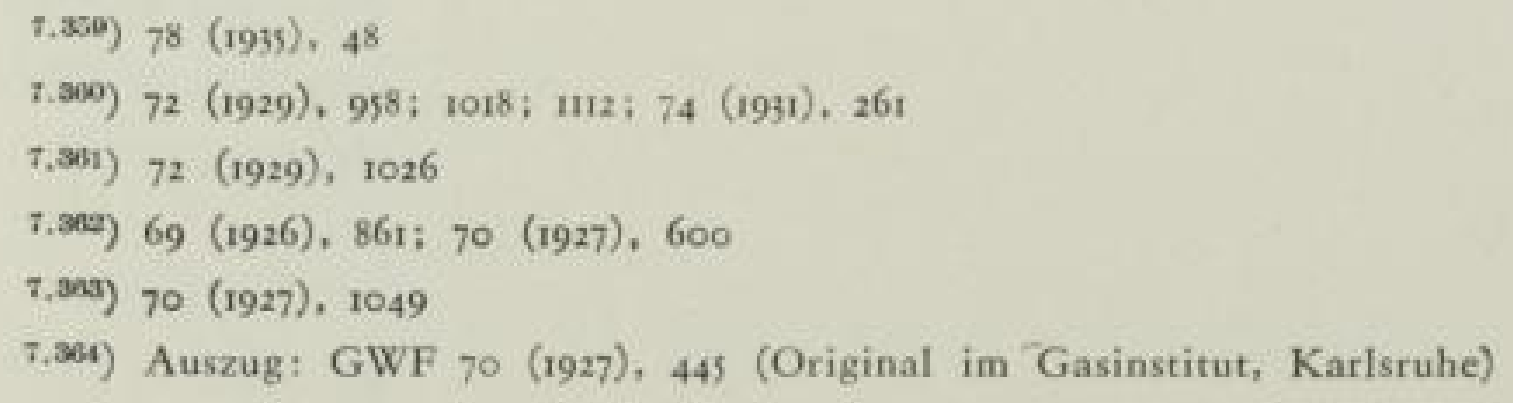


genieurs nicht Kalorimeter und Dichteschreiber ersetzen. Sie sollten vor allem nicht zum Vergleich verschiedener Gassorten gänzlich verschiedenen Ursprungs dienen. Vielmehr sollte der Wobbezahlmesser neben den Grundgeräten zur laufenden Betriebsaufsicht in der örtlichen Gaserzeugung herlaufen. Wie sehr diese von Wobbe an Beispielen gezeigten Beschränkungen nach einiger Zeit vergessen waren, zeigte eine sehr umfassende Arbeit von D. Witt über die Brenneigenschaften des Stadtgases. Nach Betrachtung der Zündgeschwindigkeitskurven, des Heizwertes, der Wärmeleistung nach Wobbe und Alliata sagt er: Es liege auf der Hand, dał Gase, die die gleiche Wobbezahl haben, nicht die gleichen Brenneigenschaften hätten. Deshalb stützte er sich auf den Ottbrenner in der Meinung, daf̧ durch eine Normung dieser Brenner der Unterschied in den Ausführungen behoben werden könne. Die Schwierigkeiten, gerade an Umschlagpunkten, wie dem Eintreten des Flackerns oder dem Rückschlag eine Einstellung zu messen, bedachte er nicht. Er glaubte, durch Messung der Wärmeleistung des Ottbrenners und der Ottzahl seien die Brenneigenschaften eines Gases eindeutig festgelegt. Es erübrige sich, Dichteverhältnis und Zündgeschwindigkeit zu bestimmen. Die Arbeit enthält im übrigen eine Fülle wertvoller Mef̧werte ${ }^{7.305}$ ).

Auf die Bedeutung der Ottzahl hatten E. $C z a k o ́$ und F. $S c b a a c k$ bereits drei Jahre vorher mit weitausgreifender Behandlung aller Erscheinungen hingewiesen $\left.{ }^{7.500}\right)$. Sie hatten auch die Anregung gegeben, die Richtlinien über die Normalgase um die Ottzahl zu erweitern. Der viel sicherer zu handhabende PolluxGasprüfer von Czakó und Schaack, der mit Einstellung der Kernlänge arbeitete, wurde schon vorher entwickelt $\left.{ }^{7.3 n}\right)$. Der ganze Fragenbereich wurde in neuartiger Weise in der Dissertation E. Schaack von 1937 abgehandelt $^{7.365}$ ). Leider fand der Pollux-Prüfbrenner, vor allem als nicht gerade billiges Betriebsgerät in der Gaserzeugung angesehen, nicht die Aufnahme wie der ihm nachgebaute englische Prüfbrenner. Die Hauptstärke des Gerätes liegt darin, dał mit einem Normalgas als Grundlage auch das Verhalten verschieden ausgeführter Geräte auf eine sichere Bezugsgröł̧e gebracht werden kann, die die Voraussetzung der Beurteilung verschiedener Gase in irgend welchen Gasgeräten darstellen sollte. Statt dessen ist in diesem Punkte mit Hereinnahme von zufällig vorhandenen Bauarten in die Versuche eine völlig unbestimmbare Empirie hineingekommen.

Das darf man wohl schon vom umfassenden Versuchsprogramm der American Gas Association in Cleveland über den Einfluf̧ der Mischungen von fünf dort zur Verfügung stehenden Gasarten auf Gasgeräte behaupten ${ }^{\text {r.se⿰ }}$ ), und an diesem Punkte liegt heute noch die Schwäche fast aller Arbeiten.

$\mathrm{K}$. Bunte dagegen setzte systematisch viele Mitarbeiter an die Beobachtungen über die Flammenentwicklung unter immer wechselnden äuferen Einwirkungen $^{\text {T.aro }}$ ) und berichtete wiederholt zusammenfassend über alle Arbeiten auch des

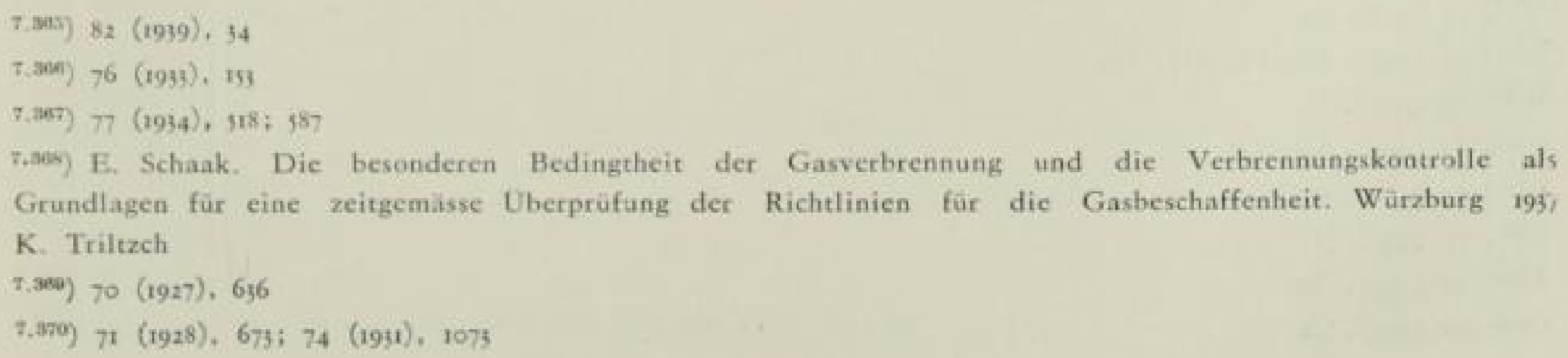


Auslandes $^{\text {7. }{ }^{* 11}}$ ). Dabei wies er die entscheidende Rolle, die der Wasserstoffgehalt auf die Zündgeschwindigkeit ausübt, erneut deutlich nach. $\left.{ }^{7.572}\right)$. Für die Durchbildung der Haushaltsgeräte gab er damit mehr Anregungen, als öffentlich allgemein bekannt geworden ist, vor allen Dingen, wo die Ausnutzung der Gasstrahlung erstrebt wurde ${ }^{7.373}$ ). Der von $\mathrm{H}$. Brü ckner geprägte Begriff der Flammenleistung brachte volle Klarheit über die Spitzenleistung der Azetylensauerstofflamme $\left.{ }^{\text {T.3in }}\right)$. In den neuen Richtlinien für die Gasbeschaffenheit, die die Begrenzung des Gehaltes an inerten Gasen fallen lief̧en, wurde die Zündgeschwindigkeit nach Ottprüfer oder Pollux Prüfbrenner mit Richtzahlen eingebaut, ohne daf gerade $\mathrm{K}$. Bunte damit voll befriedigt war. ${ }^{7.35}$ ). Immerhin war man nach etwa 30-jähriger Arbeit zu einer gröłeren Klarheit gekommen und hatte den Weg gewiesen, auf dem man die Austauschbarkeit von Gasgemischen hätte erfassen können, wenn nıcht der Krieg die noch laufenden Arbeiten jäh unterbrochen hätte.

\subsection{Heizwert}

Der in den Krummhübeler Richtlinien festgesetzte Heizwert wurde im allgemeinen von den Gaswerken eingehalten. Einzelne kleinere Werke, besonders im Gebiete der Thüringer Glasindustrie, glaubten einen höheren Heizwert einhalten zu müssen. Man darf heute wohl sagen, dał die Meinung durch ungenügende Kenntnis der Anpassungsmöglichkeit der verwendeten Brenner auf die gleiche Flammenleistung genährt wurde.

Die Ruhrgas Aktiengesellschaft lieferte einheitlich ein Gas mit einer Verbrennungswärme von $4500 \mathrm{kcal} / \mathrm{m}^{37.370}$ ).

Gegen den Heizwert liefen Einzelgänger, L. W inkler, Frankfurt/Main ${ }^{\gamma .3 \pi}$ ) und H. $\left.S c b a ̈ l e r^{7.375}\right)$, Berlin, an mit Berechnungen, daf̧ aus dem Koksverkauf ein besserer Erlös möglich sei als aus dem W'assergas. Die Änderung des Preisverhältnisses zwischen Feinkohlen und Koks dürfte die Grundlagen dieser Rechnungen umgestofjen haben ${ }^{\text {7..77 }}$ ).

\subsection{G A S VERTEILUNG}

\subsection{Bebälter}

Der Fortschritt im Behälterba:ı kam in erfreulicher Unabhängigkeit von den wirtschaftlichen Stürmen mit auffallender Stetigkeit voran. Es ist das ein selten schönes Beispiel, wie beruhigend ein technisch begründeter Fortschritt wirken kann. Gibt es doch kein bessereres Mittel, ein Ingenieurunternehmen durch

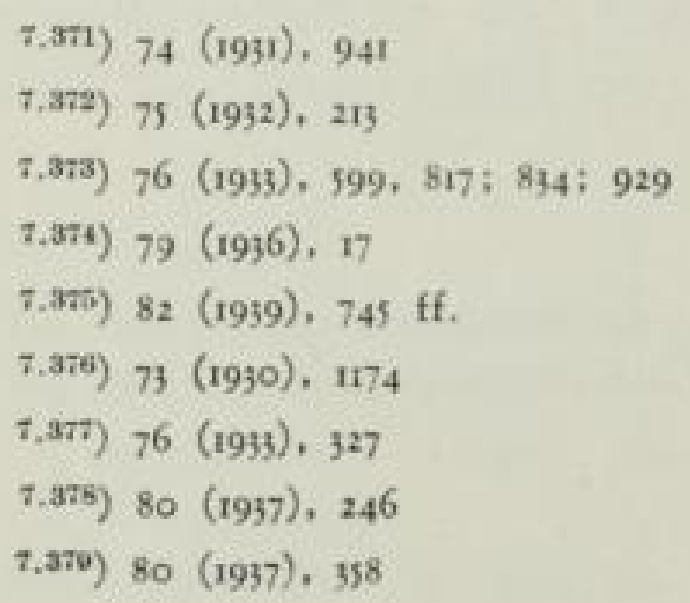


Krisenzeiten hindurch zu retten, als die rechtzeitig vorbereitete Aufnahme von wirklich guten technischen Neuheiten. Man soll aber den guten Ingenieur rufen, bevor man rein kaufmännisch am Ende ist, und den Kaufmann einsetzen, wenn der Ingenieur seine Neuheit gut herausgebracht hat.

Im Behälterbau schaffte die durch die Fernversorgung ausgelöste Forderung nach Speicherung immer gröf̧erer Gasmengen neues Leben: die Weiterentwicklung der trockenen Gasbehälter, die Aufnahme der Hochdruckspeicherung, die Schweił̧ung und den wissenschaftlich ergründeten Korrosionsschutz.

Nach der Klärung des Posener Unglücks war das Vertrauen zum trockenen Behälter der Maschinenfabrik Augsburg-Nürnberg wiederhergestellt. Nur in England wurde der erste von Prentice in Ipswich aufgestellte Behälter mit Mif̧trauen aufgenommen. Dort war man ganz auf den spiralgeführten nassen Behälter eingeschworen. In Ipswich war aber an der Küste der Untergrund so schlecht, daß̧ für Prentice die Gewichtsverminderung entscheidend war ${ }^{7.350}$ ).

Nach dreijährigem Kampf erhielt A. Klönne im Januar 1929 ein Patent auf das von ihm entwickelte System $\left.{ }^{\tau, s+1}\right)$. Fortgesetzte Patentstreitigkeiten mit der Maschinenfabrik Augsburg-Nürnberg führten zu einem für das Fach segensreichen Vergleich, indem sich Klönne zur Zahlung einer Lizenz bereit erklärte $\left.{ }^{7,450}\right)$. Ein großer trockener Gasbehälter mit $300000 \mathrm{~m}^{3}$ Inhalt wurde in Stuttgart erbaut ${ }^{7.353}$ ). Beachtenswert ist der anschauliche Bericht, wie sich die Öffentlichkeit nach anfänglichem Toben mit dem Gasturm, als Wahrzeichen des technischen Fortschritts schnell ausgesöhnt hat und stolz auf das Bauwerk wurde $\left.{ }^{7.3 x}\right)$. In Chikago baute man einen Behälter von $565000 \mathrm{~m}^{3}$ Inhalt, dem später als dem größ̧ten jemals erbauten Behälter über Tage der $600000 \mathrm{~m}^{3}$ fassende auf Zeche Nordstern folgte $\left.{ }^{7.35}\right)$. Bamag suchte sich in den Bau trockener Behälter einzuschalten mit einem versteiften flachen Kolben, eine Art Glocke, die durch zwei mit Öl gefüllten Lederwiilsten in Halbschlauchform abgedichtet wurde. Der Behälter von $2000 \mathrm{~m}^{3}$ Inhalt in Bernau scheint aber der einzige seiner Art geblieben zu $\left.\operatorname{sein}^{2.350}\right)$.

Berechtigtes Aufsehen crregte eine schwere Explosion eines trockenen Behälters in Neunkirchen/Saar $\left.{ }^{7.8 \infty 7}\right)$. Wie die langen Untersuchungen ergaben, hatte man an einer Umgehungsleitung in der Nähe des Behälters mit Schweiß̧ungen gearbeitet. Das Rohrstück war gegen den Behälter mit einer Blindscheibe abgedichtet, nach dem Rohrnetz aber nur der Schieber geschlossen, der offenbar nicht dicht gewesen war. So bildete sich in dem Rohrstück ein Gasluftgemisch. Eine Vorexplosion zerstörte das Rohr und den Blindflansch zum Behälter, und alsbald brannte außzen an der Behälterwand eine grołe Stichflamme. Die Bleche erglühten und verzogen sich. Danach trat Gas um die Behälterscheibe, und das sich bildende Gasluftgemisch wurde entzündet. So kam es zu dem verheerendsten Zerknall, der jemals mit Leuchtgas beobachtet worden ist. Obwohl der

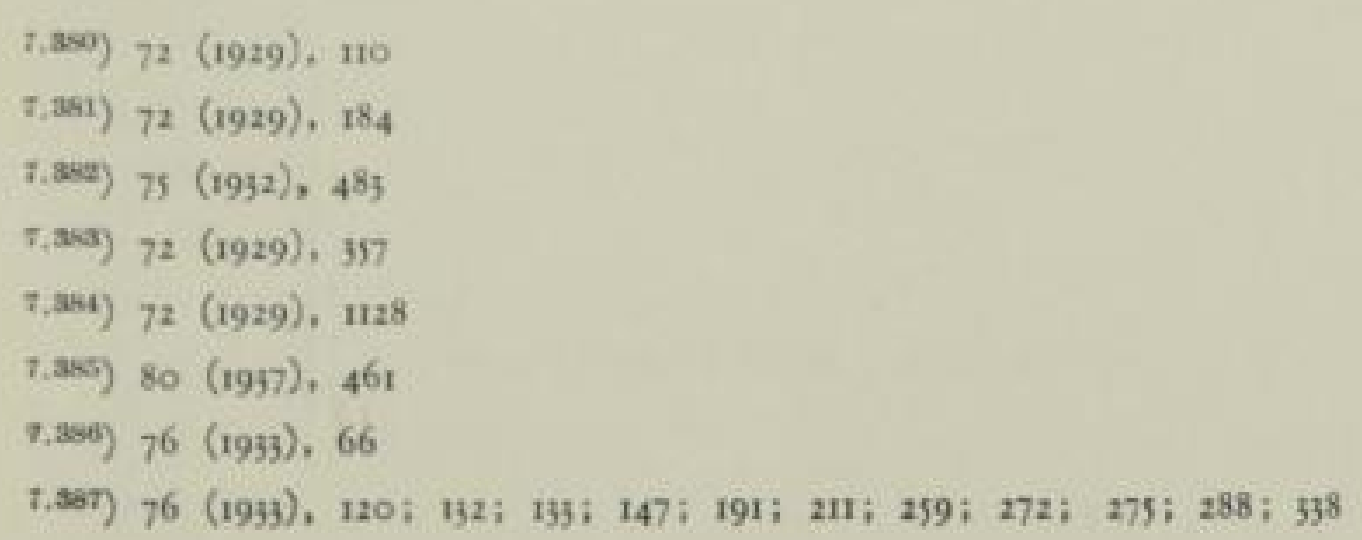


Behälter nicht im Bereich einer Gasversorgung stand, wurden die Fachleute des Behälterausschusses in die von allen Seiten mit größter Sachlichkeit unterstützten Ermittlungen einbezogen. Der Staatsanwalt stellte nach einiger Zeit das Strafverfahren ein, da den Arbeitern die grofe Gefahr nicht klar sein konnte. Die notwendige strenge Aufsicht hatte gefehlt, weil die Gefahr nicht erkannt war. Die Lehre blieb, dał man, was dem Gasfach selbstverständlich erschienen war, sich auf die Dichtheit eines Schiebers nicht verlassen kann. Das fehlte aber in Form einer Vorschrift $\left.{ }^{7,35 s}\right)$. Die Richtlinien für Errichtung und Betrieb von Niederdruckbehältern wurden zwei Jahre darauf fertig ${ }^{7.350}$ ).

Uber ein Patent auf einen Hochdruckbehälter zunächst von 4 bis $5 \mathrm{~m}$ Wassersäule, dann mit einer Atmosphäre Überdruck sprach A. $S c b u l z$, Spandau $\left.1927^{7.300}\right)$. Eine selbsttätige Gasbehälter-Schaltvorrichtung, die den Hochdruckbehälter besonders wertvoll machen sollte, wurde im gleichen Jahre erwähnt ${ }^{\text {T.299 }}$ ). Alte Hochdruckdampfkessel waren in den Vereinigten Staaten offenbar schon mehrfach als Gasbehälter benützt, als Horton, Chicago Bridge and Iron Works, den ersten Kugelbehälter von 17,5 m Durchmesser für 4,22 atü Betriebsdruck mit einem Speichervermögen von II $550 \mathrm{~m}^{7}$ Gas in Long Island bei New York ausführte $\left.{ }^{\tau, \text { ano }}\right)$. Seine Ubernahme in Deutschland war nicht leicht zu erreichen, weil die Abnahmevorschriften für Druckfässer der Dampfkesselvereine im Wege standen. Diese verlangten eine Wasserdruckprobe. Das ergab aber Gewichte, für die man weder Wandungen noch Fundamente zur Aufnahme der nur einmal auftretenden Last verantworten konnte. Während also der Bau von Kugelbehältern in Nordamerika sich schnell ausdehnte, mufte man sich in Deutschland zunächst mit kleinen Walzenkesseln begnügen. Deren erste wurden in Menden (Westf.), zwei für 4 atü mit zusammen $800 \mathrm{~m}^{3}$ Speichermöglichkeit eingebaut $^{\text {t.asa }}$ ), zwei andere in Waren (Westf.) von je $40 \mathrm{~m}^{3}$ geometrischem Inhalt für 5 atü, also zusammen $\left.400 \mathrm{~m}^{3} \mathrm{Gas}^{7 . m 4}\right)$. Der nächste Kessel in Stein am Rhein wurde von Arnold am Ende seiner Fernleitung in das Schweizer Gebiet um Konstanz hereingenommen. Arnold hat sich über alle Vor- und Nachteile sehr genau Rechenschaft gegeben, sie öffentlich zur Aussprache gestellt und damit nicht wenig dazu beigetragen, dał in der Schweiz solche Behälter sehr bald mehrfach genommen wurden. Der Behälter in Stein hatte auch eine selbsttätige Einschaltung und Fernüberwachung von Konstanz aus. Er ermöglichte es, in dem zu knapp gewordenen Fernnetz die Spitzenabgabe zu decken ${ }^{7.065}$ ). Zwar gab es auch abfällige Urteile. E. Dubois rechnete sehr bald die Vorteile bei einem lange unter Druck stehenden Reservespeicher und bei kurzfristiger, selten verlangter Spitzendeckung nach $\left.{ }^{7.350}\right)$. Ubertrieben möchte bei den damals geringen Speichermengen der Gedanke von J. H. Brunklaus, Tilburg, erscheinen, durch Ausnützung des Druckes beim Entladen mit einer Expansionsmaschine bis

$7.365) 76(1933), 532 ; 536$

7.350) 78 (1935), 947

7.300) $70(1927), 4^{81}$

7.391) $70(1927), 974$

$7.32) 71(1928), 642 ; 1270 ; 72$ (1929), 136

7.303) $73(1930), 1024$

7.354) $76(1933), 46$

7.315) 74 (1931), 213

$7.306) 74(1931), 910$ 
zu 50 v. H. der Verdichtungsarbeit zurückzugewinnen, dabei mit Nachtstrom aufzuladen und bei der Entladung wertvollen Spitzenstrom zu gewinnen ${ }^{7.509}$ ). $\mathrm{Zu}$ nächst wurden ja auch die Hochdruckbehälter gern an das äuf̧ere Ende des Netzes gebracht und der Druck zur Fortleitung zum Teil wieder ausgenutzt. Ob indessen nicht bei regelmäß̧ig betriebenen grof̧en Erdspeichern, wie deren einer in England zur Wochenendgasaufnahme neuerdings erprobt ist, der Gedanke von Brunklaus fruchtbar sein kann, sollte nicht aus den Augen verloren werden.

In Calw, das sehr beengt in einem Tale liegt, wäre ein Kugelbehälter die beste Lösung gewesen. Man mußte sich mit einem liegenden Kessel begnügen, da die ohne sachliche Erfahrungen gemachten Sicherheitsauflagen unerfüllbar waren ${ }^{\text {t.ms }}$ ). Wenn man über Vorzüge und Nachteile von Vorschriften und Normen streitet, sollte man die damalige Lage eingehend studieren. Dem Verein blieb, um den Weg freizumachen, gar nichts anderes übrig, als trotz der Jugend der Technik schleunigst einen Entwurf von Normalbedingungen für die Herstellung und den Betrieb von Hochdruckbehältern auszuarbeiten, um Ordnung in die vielfachen Bauvorschriften zu bringen und vor allem die Luftdruckabnahme der Kugelbehälter durchzusetzen $\left.{ }^{\tau .300}\right)$.

Der erste deutsche Kugelbehälter von 15,7 m Durchmesser, also mit $2000 \mathrm{~m}^{3}$ geometrischem Inhalt für einen Druck von 5 atü wurde in Siegen errichtet $\left.{ }^{\tau, 400}\right)$. Mit dem Angebot eines Kugelbehälters konnte die Firma F:A. Neuman, Eschweiler, in Ostende die Landeskonkurrenz schlagen $\left.{ }^{7.410}\right)$. Ein Kugelbehälter von $5000 \mathrm{~m}^{3}$ geometrischem Inhalt für 5 atü, also $25000 \mathrm{~m}^{\text {n }}$ Speichergas wurde 1937 in Stettin gebaut.

Von einer Behälterinstandsetzung durch Schweif̧ung wurde 1926 berichtet $^{\hat{i} \cdot 102}$ ). Die elektrische Schweif̧ung der Tasse eines gefüllten Behälters von $15000 \mathrm{~m}^{\mathrm{a}}$ wurde zuerst bei der Instandsetzung angewandt ${ }^{7 ., 03}$ ). Die Erörterung zeigte das Mifztrauen der Fachwelt dem Verfahren gegenüber ${ }^{7.104}$ ).

Ein neuer nasser Gasbehälter von $8400 \mathrm{~m}^{3}, 22,6 \mathrm{~m}$ Durchmesser und 34,6 m hoch in ganz geschweif̧ter Ausführung einschlieflich der Führungsstützen wurde in Albion (Michigan) in Nordamerika errichtet. Verschweif3t wurden $6435 \mathrm{~m}$ laufende Nähte mit $3600 \mathrm{~kg}$ Schweifstäben $\left.{ }^{7.45}\right)$. Klönne erbaute 1937 einen trockenen Gasbehälter von $55000 \mathrm{~m}^{3}$ für die Ford Motor Co. in Dagenham in geschweiß̧ter Ausführung ${ }^{7+400}$ ). Auch der schon erwähnte große Gasbehälter von $600000 \mathrm{~m}^{3}$ erhielt einen geschweiß̧ten Mantel $\left.{ }^{7.400}\right)$.

Über einen wirkungsvollen Schutz der Gasbehälter gegen Anfressungen durch Farbanstriche besonders an den Eintauchstellen der Bleche in das Wasser hatte man sich bereits oft ausgesprochen, als die systematischen Arbeiten im Gasinsti-

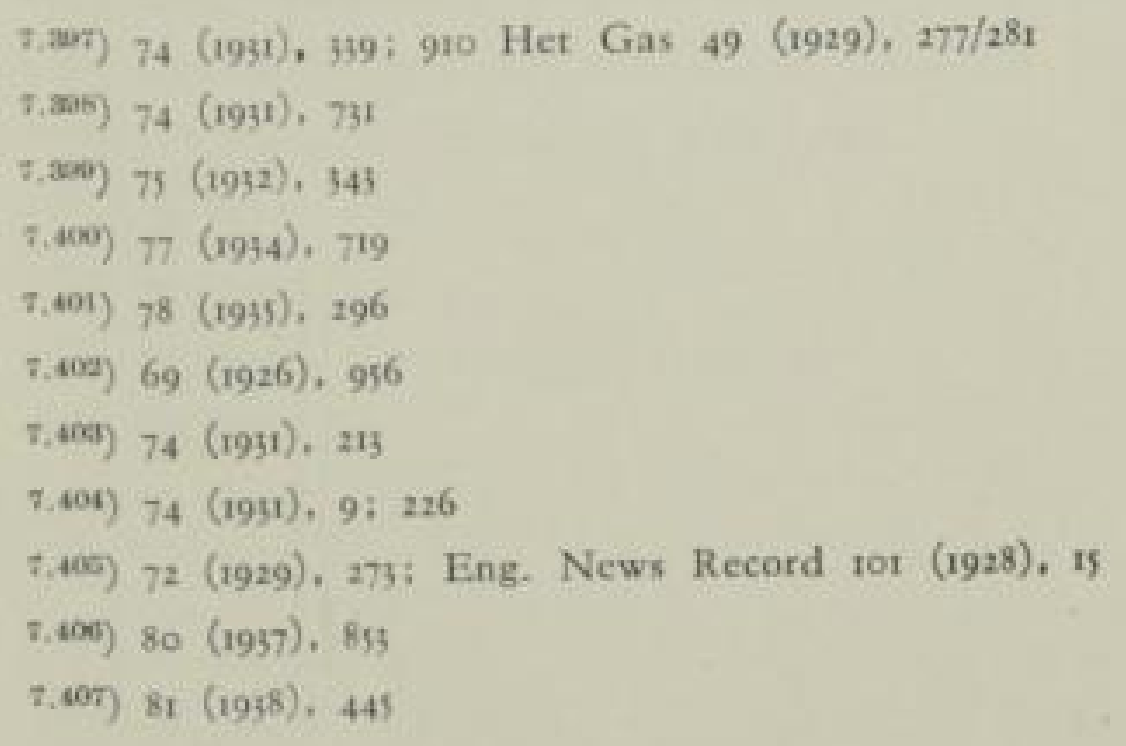

34 Geschichte der deutschen Gasindustric 
tut durch P. Struck 1934 aufgenommen wurden. Sie sind bis heute fortgesetzt und erstrecken sich auf alle angebotenen Farbarten, auf die Ausarbeitung der Prüfmethoden und das beste Auftragsverfahren ${ }^{\tau+40 \%}$.

\subsection{Robre und Robrnetze}

Daf3 durch den Ausbau der Fernversorgungsunternehmen die Rohrleitungstechnik eine ungeheure Belebung erfuhr, ist natürlich. Hatte man anfänglich (1908) geglaubt, bei Drücken von 0,5 bis I atü mit Stemmuffen auskommen zu können, so wurde nunmehr klar, daf bei den hohen Drücken, wie sie tatsächlich angewandt werden muften, um einen Mindestwert aus der Verzinsung der Baukosten und den Verdichtungskosten zu erzielen, das geschweiß̧te Stahlrohr mit verhältnismäfjig wenigen aber sehr sorgfältig durchgebildeten Ausdehnungsmuffen die allein geeignete Bauart sein würde. Daran konnten auch die neuen festen und leichten Schleudergufzrohre der Vereinigten Stahlwerke Abt. Schalker Verein ${ }^{7.409}$ ), Gelsenkirchen, nichts ändern. Diese fanden ihren eigenen Markt in Ortsnetzen. Sie wurden später auch von den Buderusschen Eisenwerken in Wetzlar und von der Halberger Hütte hergesteiltt ${ }^{\tau, 00}$ ).

Über die schönen baulichen Aufgaben machte schon 1928 Peterson, Essen, im Namen der Aktiengesellschaft für Kohleverwertung genaue Mitteilungen ${ }^{*} \cdot{ }^{* 11}$ ). Der ungewöhnlich kalte Winter brachte, wie bei vielen Gaswerken, auch in den neuen Gasfernleitungen in Duisburg und Mülheim Rohrbrüche ${ }^{7.12}$ ). Das veranlaß̧te das Fach, nachdem schon 1927 sehr ausführlich über die Technik der Rohrschweif̧ung berichtet worden war $^{7.113}$ ), vorläufige Richtlinien über Schweifverbindungen aufzustellen $\left.{ }^{\tau, 14}\right)$. Sehr notwendig war die 1937 von W. W unscb und H. Geilenkeuser gegebene. Aufklärung über den Einfluf̧ der Temperatur im Erdboden auf die Beanspruchung geschweifter Rohrleitungen, die auf vielfachen Messungen und theoretischen Betrachtungen beruhte, und über die Dehnung und Schrumpfung der Rohre auch Klarheit über den Einfluf der Temperatur zur Zeit der Verlegung brachte ${ }^{\text {z.15 }}$ ).

Mit den in den langen Jahren gewonnenen Erfahrungen bildete ein Vortrag von W. Wunsch, Essen, 1939 eine überraschend vielseitige Übersicht über alle Betriebsfragen von Fernleitungen: Die Belastungskurve, den Einfluł der Außzentemperatur auf die Absatzmenge, den Druckabfall im Verhältnis zur Liefermenge, die Auswirkung der Zwischenverdichtung, die Speichermöglichkeit in Fernleitungen, die Fernmessung, die Streckenüberwachung durch Fernsprechdienst, Streckenwärter, Bereitschaftskolonnen, Hilfsmittel für erste Instandsetzungen, Erdstromfragen, kurzum alles, was an diesen Dingen benötigt wird ${ }^{7.416}$ ).

\footnotetext{
$7.605) 77(1934), 765$

$7.400) 71(1928), 391$

7.410) 76 (1933), 97

7.411) 71 (1928), 847

7.412) $72(1929), 94$

7.413) 70 (1927), 501

7.414) 72 (1929), 734

$7.415) 80(1937), 691$

7.416) 82 (1939), 673
} 
Durch die Erfahrungen mit Fernleitungen veranlafyt, wurden die Formeln zur Berechnung von Rohrleitungen erneut durchgearbeitet $\left.{ }^{\tau .117}\right)$. Eine gute historische Ubersicht über die Rohrhydraulik in 200 Jahren erarbeitete H. Richter, Freiberg/Sa $\left.{ }^{\text {r.t.t }}\right)$.

Die Naphthalinbekämpfung im Rohrnetz machte mit der Anwendung von Tetrahydronaphthalin (Tetralin) einen grofen Fortschritt. Die Lösungsverhältnisse erläuterte G. Weif́enberger r.t") mit Zahlenwerten. Gedanklich zuerst in Stuttgart geprüft, wurde sie durch die Patente der Fa. Martini und Hünecke G. m. b. H., Berlin, in die Technik eingeführt ${ }^{7.45}$ ). In der Kälteperiode $1928 / 1929$ wurde auch Anthrazenöl oder Solvinin der Chemischen Werke Rhenania, NiederIngelheim, eingesetzt.

Rohrnetzprüfer nach dem Diffusionsprinzip wurden verbessert. Zuerst kam der Cajo-Gasprüfer von W. H. Joëns, Düsseldorf, heraus ${ }^{7.42}$ ). L. Rodde, Stettin, konnte 1929 bereits 7 verschiedene Prüfgeräte nach dem Diffusionsverfahren oder mit Wärmeleitung durch elektrische Geräte beschreiben, darunter Vulkan, Nellison, Severin ${ }^{7+2 z}$ ).

Die Arbeiten an Korrosionsschäden von Rohrleitungen und Erdstromschäden gingen nur zögernd voran. Die hohen Kosten sachverständiger Untersuchungen wurden vielfach gescheut ${ }^{\text {7, }}{ }^{23}$ ). Die internationale Forschungsarbeit der „Commission mixte international pour les expériences relatives à la protection des lignes de télécommunication et des canalisations souterraines" erlebte auch keinen starken Widerhall bei Gaswerken $\left.{ }^{7+13 t}\right)$. Eine grołe Umfrage über Korrosionen an Gasleitungen durch K. Bunte und P. Struck brachte keine neuen umwälzenden Erkenntnisse ein ${ }^{7,4 x^{2}}$ ).

Die Mannesmannwerke arbeiteten lebhaft an der Verbesserung des Rohrschutzes. Sie empfahlen zunächst Sonderlacke zum Streichen der Schweifstellen und eine Rohrschutzmasse zur Tränkung von Jutebinden, die bei im Freien lagernden Rohren nicht rissig wurde ${ }^{7.45}$ ). Bei der Schadebinde wurden Produkte der Paraffinreihe in bandartige Gewebe eingewalzt. Statt Jute- und Leinenstreifen wurde auch eine elastische Pappe als Unterlage herangezogen ${ }^{\tau .12 \pi}$ ). Über den kathodischen Schutz einer blanken Stahlrohrleitung von $600 \mathrm{~m} / \mathrm{m}$ Durchmesser wurde im Gas Age 83 (1939) Nr. 8 S. i3/18 ausführlich berichtet ${ }^{7.43}$ ).

Im Rahmen der Bemühungen „Sparmetalle“ zu ersetzen, wurde Aluminiumwolle für Muffenverstemmungen angewandt. Mit Rücksicht auf die Korrosionsgefahr bei der Berührung von Aluminium mit Eisen empfahl F. We brman n, Duis-

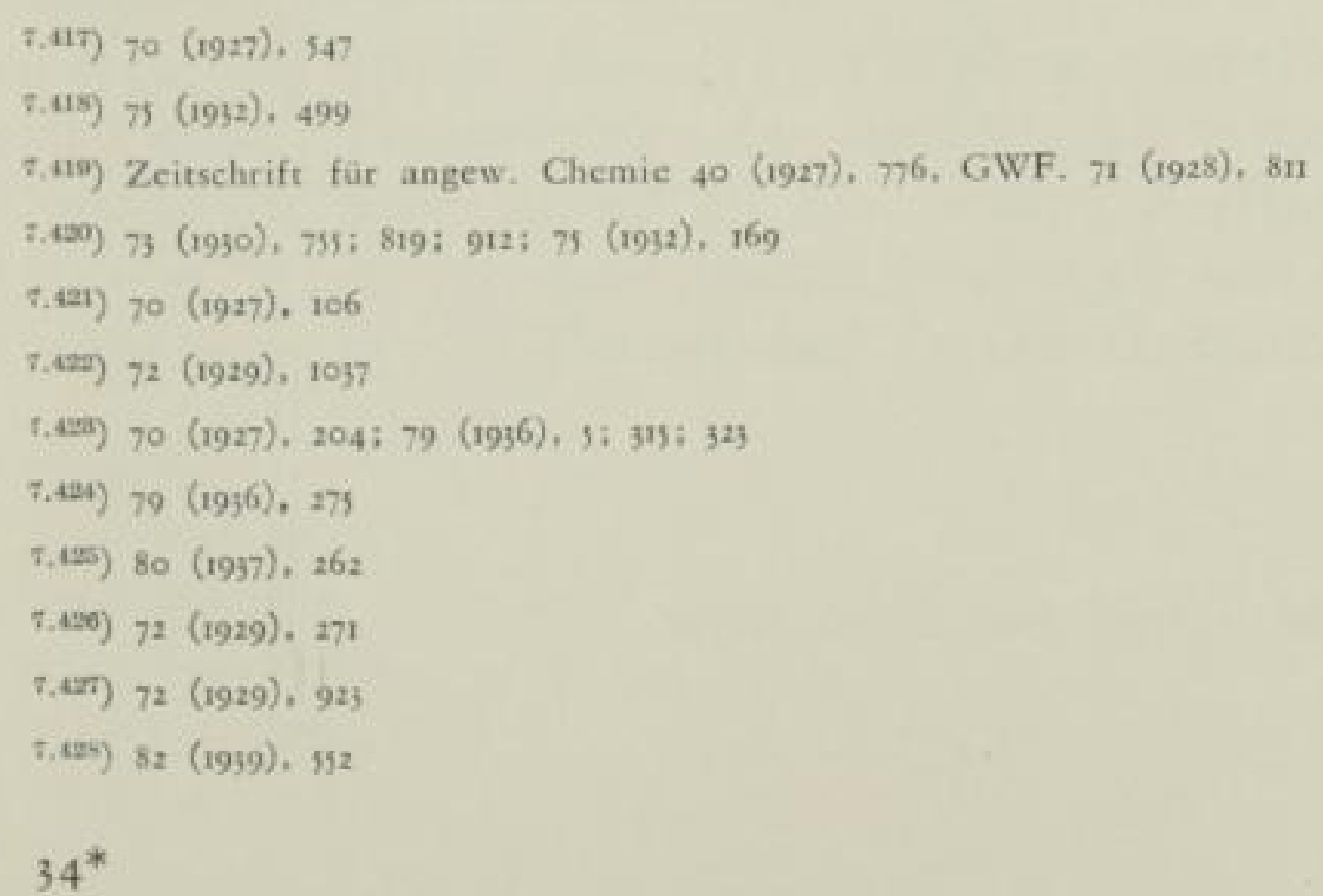


burg, einen Schutz durch Bitumen einzubringen $\left.{ }^{7.49}\right)$. Versucht wurden auch als Ersatz Jutekordel, Jute mit Papiereinlage, getränktes Papier, Holzwolle getränkt mit Paraffinen und Bitumina.

G. Goos, Hamburg, stellte mit dem Endziel, die Netze gleichmäfiger zu belasten und damit besser auszunutzen, Geschwindigkeitsmessungen im Rohrnetz mit Staurohren und Hitzdrahtanemometern an. Er entwickelte ein Verfahren zur Feststellung der Strömungsrichtung $\left.{ }^{7.430}\right)$. Die elektrische Schweif̧ung von Rohrverbindungen wurde unter seiner Leitung erfolgreich ausgeführt ${ }^{\text {t.tin }}$ ).

Für die Hausinstallation wurde versuchsweise Kuprema-Rohr, ein schwaches mit Kunststoff umhülltes Kupferrohr, das gegenüber einer reinen Kupferleitung 80\% an Metall einsparte, eingebaut. Dabei wurde die Ermetoverschraubung beschrieben $^{\text {T.423a }}$ ).

Ein bisher nicht berücksichtigter Wunsch der Gerätehersteller war der nach einer wesentlichen Druckerhöhung in den Stadtnetzen, um auf fester Grundlage bautechnisch dem sich deutlich abzeichnenden Verlangen nach einem gleichmäfigen Gasverbrauch durch Regler, nach Sicherheitsventilen in den Gasleitungen, Stellgliedern für Raumtemperaturregler u. a. m. gerecht werden zu können. Die Tagung der neugegründeten Fagawa anläßlich der Kasseler Hauptversammlung ist bereits auf Seite 483 erwähnt worden ${ }^{\text {7.43 }}$ ). Sie brachte das Gespräch in $\left.\mathrm{Gang}^{\text {7.tuit}}\right)$. Verschiedentlich wurden $300 \mathrm{~mm}$ Wassersäule als wüns henswert bezeichnet, daf3 man aber als Gerätebauer den hohen Druck unmittelbar am Gerät mit Sicherheit zur Verfügung haben muf̧te, wenn grof̧e Fortschritte im Aufbau erreicht werden sollten, wurde allgemein nicht erkannt. Sicherlich nicht aus Erfahrungen heraus wurde von Gaswerksseite sehr unbedingt erklärt, daf̧ Einzelgeräteregelung zu teuer würde. Die Londoner Gas Light and Coke Co. nahm diese deutschen Erörterungen zum Anlał, in ihrem grołen Bezirk Regler vor jedem Gerät, selbst in den Zündflammenleitungen der Kessel, die der Sicherheit wegen vor dem Hauptregler abgezweigt werden müssen, vorzuschreiben. Sie begünstigte sogar die Einfuhr und Fertigung geregelter Geräte nach deutschem Muster. ${ }^{\text {s.t. }}$ ).

In Berlin (Städtische Werke) und Hameln wurde zwar der Netzdruck auf 300 und $350 \mathrm{~mm}$ WS. erhöht, aber vor dem Hause mit einem Druckregler heruntergesetzt. Die gründliche Verbesserung der Geräte wurde unmöglich gemacht.

Drei Jahre später wurde noch einmal in einem Vortrag von W. W alt e r, Leipzig, auf die Möglichkeit der Eisenersparnis aufmerksam gemacht, wenn der Rohrnetzdruck auf $500 \mathrm{~mm}$ Wassersäule gesteigert würde. Die Anregung blieb ohne Widerhall ${ }^{7.430}$ ).

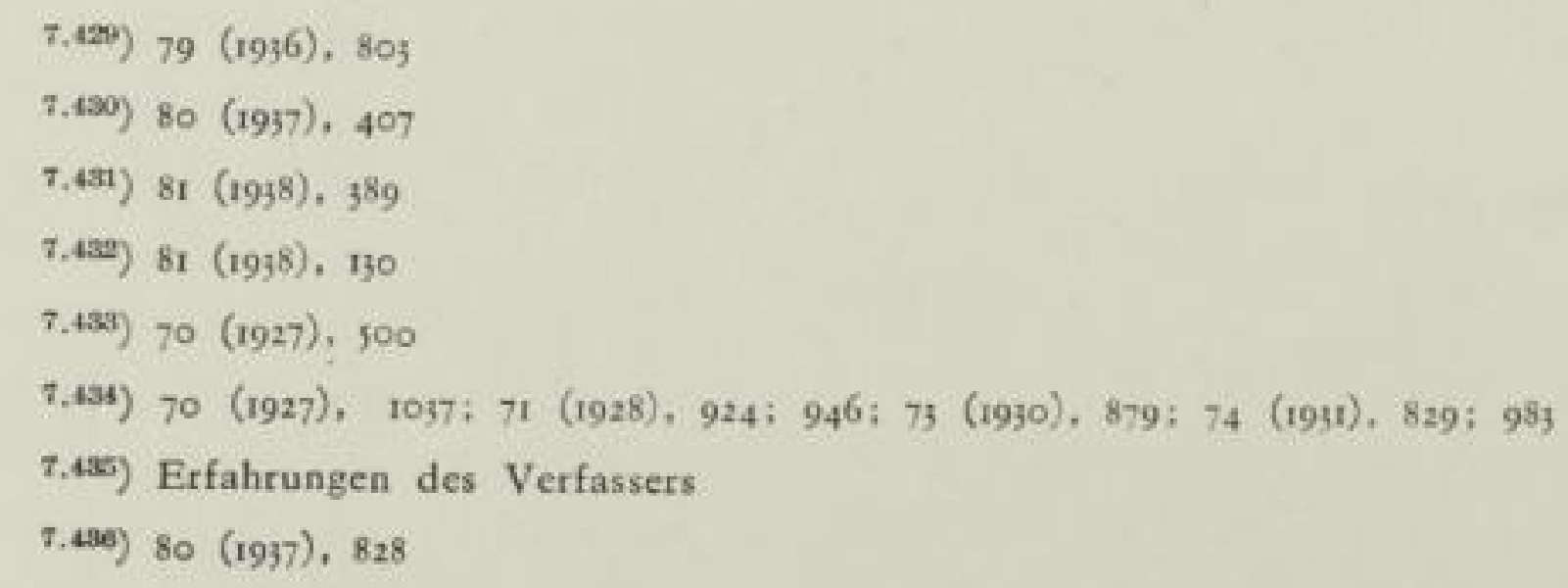




\subsection{Gasmessung}

Die Hauptaufgabe, die in diesem Zeitraum zu lösen war, war die genaue Messung der grof̧en Mengen, die bei Ferngasversorgungen abgegeben wurden. Hierbei mufte auch der Zustand des Gases, also Temperatur und Druck (bei mehreren Atmosphären Überdruck) berücksichtigt werden. Für die Verrechnung innerhalb eines Betriebes hatten sich Staurand und Venturimesser bewährt. Sie haben aber eine untere Mef̧grenze, unter der keine Genauigkeit gewährleistet werden kann, und müssen bei Verstaubungs- und Verschmutzungsgefahr gepflegt werden. Vor allem waren sie nicht eichfähig, was für den Gasverkauf aber eine gesetzliche Bedingung war. Die untere Mefgrenze war für den Ferngasbetrieb verhältnismäßjig leicht vermeidbar. Am meisten aber störte, dał̧ sie lediglich die Leistung anzeigten und nicht die Arbeit. Für Betriebsmessungen konnte der Nachteil durch Schreibgeräte mit Streifen überwunden werden, diese muften aber planimetriert werden und rechnerisch der Zustand berücksichtigt werden. Das mufte im Verkauf zu Streitigkeiten führen.

Deshalb wurden die Teilstromzähler von Askaniawerken und Bamag entwickelt. Der Teilstrom konnte auf Atmosphärendruck und Raumtemperatur entspannt werden und mit einem genau gearbeiteten, meist nassen Experimentiermesser gezählt werden ${ }^{\text {2.tiz }}$ ). Mit der Physikalisch-technischen Reichsanstalt kam es zu Verhandlungen, um mit Hilfe eines vom Charlottenburger Gaswerk zur Verfügung gestellten Gasbehälters eine Eichstation für grofje Menge herzurichten ${ }^{\text {t.tas }}$ ). Inzwischen kamen Nachrichten, dał in Nordamerika Connersville Roots-Gebläse als Zähler eingesetzt wurden. Auch diese hatten den Nachteil, dał sie bei geringer Belastung wegen des Durchlasses einer gleichbleibenden Mindestmenge an den nie ganz dichten Kolben ungenau wurden. Das konnte aber durch selbsttätige Umschaltung auf einen kleinen Nebenmesser überwunden werden ${ }^{7,435}$ ). Um die Verbesserung der Drehkolbenzähler hat sich die Aerzener Maschinenfabrik G. m. b. H. in Aerzen bei Hameln große Verdienste erworben. Die Askaniawerke lieferten zuerst einen zusätzlich benutzbaren selbsttätigen Mengenumwerter zur Berücksichtigung des Zustandes. 1933 wurde der Drehkolbenmesser durch W. $W u n s \mathrm{cb}$ für geeignet erklärt $\left.{ }^{7.40}\right)$. Trotzdem wollte man auch den Strömungsmesser amtlich anerkannt haben, was aber nicht erreicht wurde. Die Drehkolbenmesser führten sich schnell, insbesondere auch als Stationsgasmesser in Gaswerken, ein, weil sie sehr viel weniger Raum beanspruchten als die alten nassen Zähler.

A. Brandl und K. Mariscbka, Wien, entwickelten für große Gasmengen einen nassen Taumelmesser, der immerhin bei $12000 \mathrm{~m}^{3} / \mathrm{h}$ Leistung etwa $8 \mathrm{~m}$ Durchmesser haben muftete $\left.{ }^{7.41}\right)$. Eine spätere Ausführung hatte bei to 500 bis $16000 \mathrm{~m}^{3} / \mathrm{h}$ Leistung einen Haubendurchmesser von $6,5 \mathrm{~m}$ bei einem Anschlufstutzen von $900 \mathrm{~m} / \mathrm{m}$ Durchmesser $\left.{ }^{7.44}\right)$. Der Drehkolbenmesser blieb Sieger.

\footnotetext{
$7.437) 71$ (1928), 1107

7. 436) 76 (1935), 343

$7.439) 71(1928), 1168$

$7.440) 76$ (1933), 637/642

7.411) 73 (1990), 721

$7.42) 73(1930), 1205$
} 
Die Haushaltsmesser trockener Bauart wurden sehr eifrig weiterentwickelt, ein$\mathrm{mal}$ in der Richtung, daf3 sie bei kleinen Abmessungen den Verbrauch des immer mehr eingeführten Gasbadeofens mit erfassen konnten, das andere Mal, daf̧ sie auch den geringen Bedarf der Zündflammen und Kühlschränke sicher und genau anzeigten. Die Hersteller entwickelten besonders gut arbeitende Steuerschieber mit verkleinerten Schieberflächen und nicht metallischen Baustoffen. Eine Reihe von Herstellern baute Einbalgventilmesser mit Kippspannwerk, die den beiden gestellten Bedingungen voll gerecht wurden. Leider aber zeigten die Gaswerke nicht die Geduld, ihre Bewährung im langjährigen Betriebe abzuwarten. Untersuchungen mit verkürzten Schnellprüfungen sind, das muf̧ leider als Zeichen dieser Zeit ausgesprochen werden, nicht immer loyal ausgeführt worden. Wurde doch bei als unbrauchbar zurückgegebenen Messern nach solchen Versuchen eines großjen Gaswerkes mehrmals Sand im Getriebe festgestellt.

Normen für Anschluf̧verschraubungen ${ }^{7.43}$ ) und Anschlufmaf( $\mathrm{e}^{\text {7.4. }}$ ) wurden 1927 verabschiedet, diejenigen für Mef̧inhalte $1937^{7.45}$ ).

B. $L u d w i g$ stellte, gestïtzt auf einige Zählerausführungen, die die Bedingungen erfüllten, die Forderung, dał die Messer nach langer Benutzungszeit über die gesetzlich festgelegte Verkehrsfehlergrenze hinaus noch innerhalb der Eichfehlergrenzen anzeigen sollten. Es kam zu Vorschriften für die Systemprüfung von trockenen Gas-Messern und Münzgas-Messern, die diese verschärften Bedingungen enthielten ${ }^{\text {T.49 }}$ ). Von den Gasmesserfabriken wurden sie ohne Widerspruch argenommen, also auch erfüllt.

Unter Tetralineinspritzungen zur Bekämpfung des Naphthalins litten die Gasmesserleder. Das führte zu einer eingehenden Beschäftigung mit den Imprägnierölen, die in Benzol und Tetralin unlöslich sein sollten ${ }^{\text {7.t." }}$ ). Die Veränderung des Benzoldampfdruckes durch Auswaschung des Benzoles oder gar durch Gastrocknung lieł̧ jahrelang bewährte Lederbalgen plotzlich spröde werden. K. Bunte und Wittig haben damals den Messerfabriken eine sehr klare Darstellung über die Vorgänge gegeben ${ }^{\text {T.145}}$ ). Es zeigte sich, dał ein Messer, der niemals mit einem benzolreichen Gase in Berührung kam, verhältnismäß̧ig leicht so behandelt werden konnte, dał er nicht austrocknete.

Die Münzgasmesser bekamen in der Zeit der höchsten Not von 1930 bis 1932 wieder eine groł̧e Bedeutung. Sie wurden nicht nur zur laufenden Abgabe eingesetzt, sondern auch noch benutzt, um durch einen Aufschlag (Veränderung des Zählwerkes) rückständige Zahlungen allmählich abzutragen ${ }^{\text {7.t.49 }}$ ). Damit konnten grof̧e Sorgen, wie man sich schlechten Zahlern gegenüber mit Mahngebühren und Beitreibungen verhalten sollte ${ }^{4.45}$ ), gebannt werden. 1932 betrug der Anteil an Münzgasmessern bei 636 befragten Werken $17,16 \%$. Nur 81 Werke hatten keine

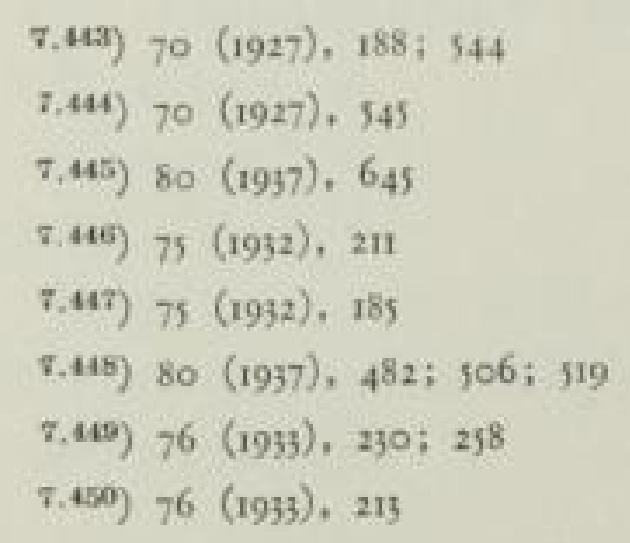


Münzgasmesser aufgestellt ${ }^{7 \cdot{ }^{\text {sin }}}$ ). Ende 1934 waren von 7,8 Mio Messern 1,6 Mio Münzgasmesser, also $20,5 \%{ }^{7.43 z}$ ).

Mit dem Eichgesetz vom 13. 12. 35 wurde der lange Jahre geführte Kampf der Gaswerke gegen die Nacheichungspflicht verloren. Nachträglich wurde die Durchführung der Maf̧nahme auf Antrag wegen der entstehenden Belastung ausgesetzt. $\left.{ }^{7 \cdot 45}\right)$.

\subsection{G A S VER WENDUNG}

\subsection{Wettbewerb}

Unter dem Bemühen, den neuen Wirtschaftsimpuls des Jahres 1926 auszunutzen und bisher Versäumtes aufzuholen und zur Vermehrung der Anwendungsmöglichkeiten ihrer Energie zu verwenden, war der Wettbewerb vor allem zwischen Gasund Elektrizitätswirtschaft sehr lebhaft.

Diese wollte sich nicht mehr auf die Geräte mit gelegentlicher und geringer Wärmeleistung, wie Tauchsieder, einzeine Kochtöpfe, Aushilfsheizung u. ä. beschränken, sondern erhob Ansprüche auf eine allgemeine Wärmeversorgung ${ }^{\text {T.45 }}$ ). Im Haushalt wurden Kocher, Bratöfen und Warmwasserspeicher angeboten, im Gewerbe Backöfen für Konditoreien, kleine Schmelzöfen, Salzbad-Härteöfen und Schweiłapparate. In den Druckereien gingen die Letternmetallschmelzkessel vielfach dem Gas verloren ${ }^{\gamma, 450}$ ).

Im Kampfe kam es zu theoretischen Vergleichen, zu Vergleichskochen mit mehr oder weniger gut getroffenen Arbeitsplänen ${ }^{\text {7.456)}}$. Dabei zeigte sich, daf̧ es sehr schwierig war, allgemein gültige „Äquivalenz"-zahlen zu finden, so dał wenig erfreuliche, für die groł̧e Entwicklung nicht gerade wichtige Streitigkeiten über Einzelheiten entstanden ${ }^{7.457}$ ).

Sehr ernst war ein Vorstof in der Römerstadt in Frankfurt/Main, wo laut Entschluł der bauführenden Siedlungsgesellschaft kein Gas für, 60o Wohnungen installiert wurde. Das Gasfach hatte zwar die Genugtuung, dał es zu Protestversammlungen der Mieter kam, die eine wesentliche Senkung der Strompreise oder Gasanschluf\} forderten ${ }^{7.55}$ ). Klare Vergleichszahlen zu gewinnen, war aber gar nicht möglich, da ja oft gar nicht mit Elektrizität, sondern mit festen Brennstoffen gekocht wurde $\left.{ }^{\tau, 4 \pi}\right)$. Unter den 1930 beginnenden wirtschaftlichen Einschränkungen wurde der wilde Kampf für beide Seiten unerträglich. Es kam zu einer Vereinbarung, die man den Frieden von Halle nannte: ,Deutscher Verein von Gasund Wasserfachmännern und Vereinigung der Elektrizitätswerke verständigen sich, dał sie selbst sich in ihrer Propaganda gegenseitiger Angriffe mittelbarer und unmittelbarer Art enthalten und ihren Einfluf auf die ihnen nahestehenden

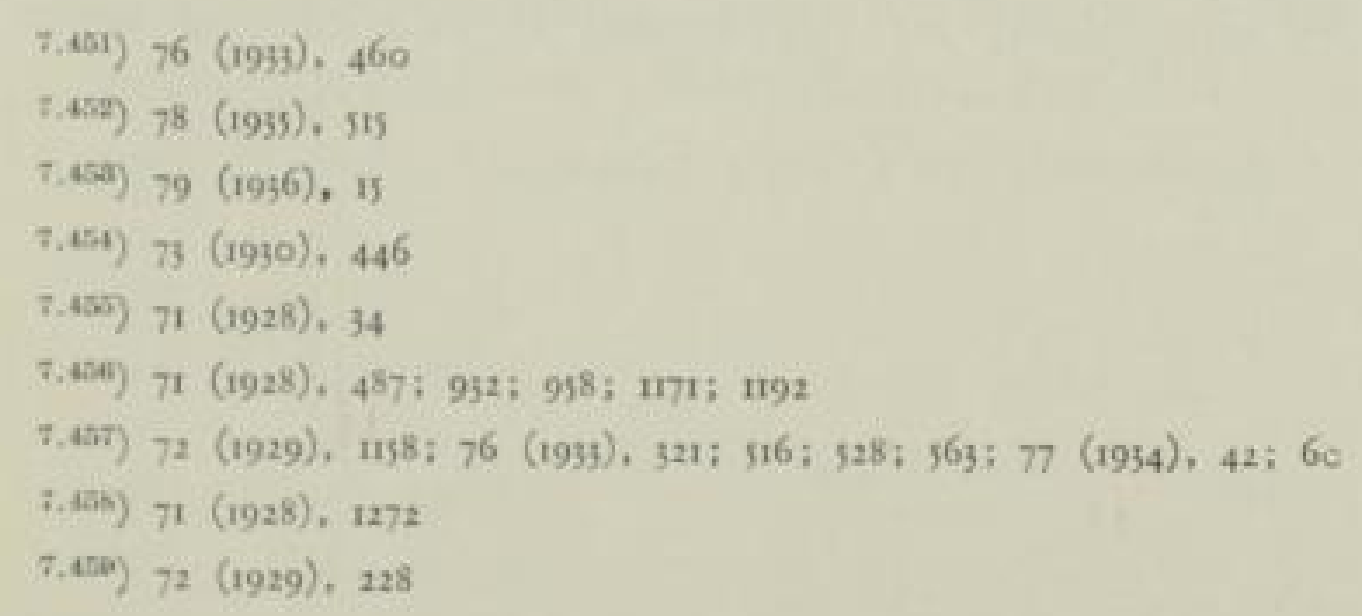


Organisationen in gleichem Sinne ausüben werden. Das gleiche gilt für Ausstellungen ${ }^{(\pi+4.40 \%}$ ).

Wenn sich zwei Hunde verbissen haben, ist es unmöglich, sic durch einen mündlichen Befehl auseinanderzubringen. So kamen auch hier die Streiter im Auß̧endienst nicht gleich zur Ruhe. Vor allem wurde der Unsinn von der milderen oder schärferen Kochwärme im Wasserbade noch ernsthaft breitgetreten, so dał die Friedensverkündigung der Organisationen schon angeprangert wurde, als Mittel, heimlich noch ungehinderter in den Garten des Nachbarn einzufallen. Das war aber sicher Unrecht, der Anfang zur vernünftigen gegenseitigen Anerkennung war trotz aller Schwierigkeiten gemacht.

Nach 1933 kam zwar noch einmal eine Welle von Auseinandersetzungen, durch die die staatliche Lenkung für die eine oder die andere Energieart gewonnen werden sollte. Auch die Kupplung von Gas- und Elektrizitätswerken wurde in verschiedenster Weise empfohlen, mit Zahlenbeweisen, wie gut sich Gas- und Elektrizitätserzeugung ergänzen könnten $\left.{ }^{7+41}\right)$.

R. Nübling forderte als Vorstand des Deutschen Vereins einen Generalwirtschaftsplan für Elektrizität und Gas. Er leitete in Stuttgart sowohl das Gaswerk als auch das Elektrizitätswerk und war sich über die Grenzen der wirtschaftlichen Anwendung klar $\left.{ }^{\text {7.ten }}\right)$. Man müsse nicht mehr nach energetischen, sondern bevölkerungs-, wirtschafts-, wehr-, devisen- und arbeitspolitischen Gesichtspunkten eine beste Lösung finden ${ }^{\text {7.tes }}$ ). Die Äuf̧erung des Reichsamtsleiters der Technik, G. Seebauer, sieht wie eine Ablehnung solcher Planungen aus: „Würde man etwa das Gas durch Gesetz vor Konkurrenz schützen wollen, so würde damit gewify den Gaswerken ein schlechter Dienst erwiesen, abgesehen davon, dał̧ es einem Eingeständnis der Schwäche gleich käme. - - - Das Verbot der Elektrowärme in Haushaltungen würde die Meinung herausbilden ..... Energieleistungen zu höheren Preisen abnehmen zu müssen ${ }^{\text {(77.345)}}$ ).

In Graz kam es zu einer gemeinsamen Tagung der österreichischen Gas- und Elektrizitätsvereinigungen, die von deutscher Seite durch den Elektrizitätswirt-

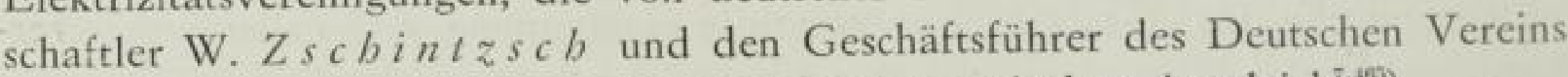
$z u r N e d d e n$ beschickt war. Sie diente erfolgreich dem Ausgleich $\left.{ }^{7.45}\right)$.

Als Leiter der Reichsgruppe Energiewirtschaft schnitt C. Krecke die Aufgabe noch einmal an: „Die Frage, ob der Haushalt im engeren Sinne Möglichkeiten zu einer schnellen und wesentlichen Absatzsteigerung bieten kann, ist umstritten $\left.^{(\pi, 4.000}\right)$. Se eb a uer, nunmehr im Reichswirtschaftsministerium, Leiter des Reichskuratoriums für Wirtschaftlichkeit und stellvertretender Leiter der Reichsgruppe Energiewirtschaft, stellte sich aus Eisenersparnisgründen nicht gegen eine einseitige Energieversorgung. Er griff den Ausdruck: „Vollversorgung“ als Herabsetzung der einschienigen Versorgung an. Stellte aber Leitsätze auf: In Stadtnähe seien die Häuser mit beiden Energieen zu versorgen, in Stadtferne ohne

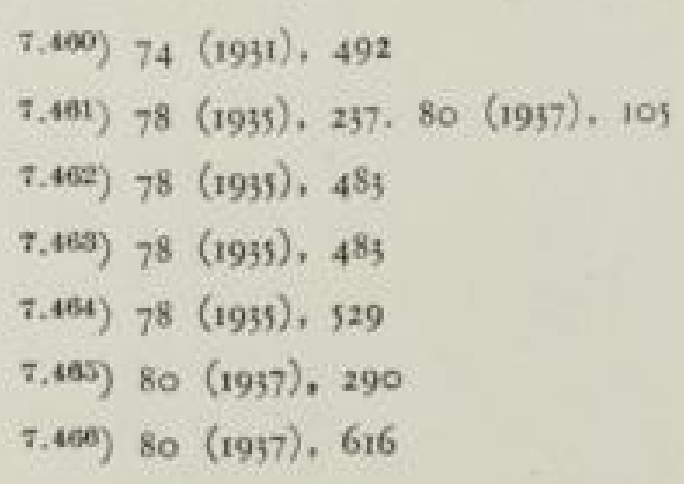


Industrie nur mit einer. Sobald in Stadtferne auch Industrie vorhanden sei, sei deren Verbrauchsbedürfnis für die Auswahl übergeordnet ${ }^{\text {tate }}$ ).

Damit waren wohl diese Kampfpunkte auf eine gesunde Grundlage bezogen worden. Im übrigen hatten beide Energieträger alsbald so grołe Schwierigkeiten, dem sich schnell steigernden Bedarf zu genügen, daf der neidische Wettbewerb von selbst verschwand.

7.72 Werbung

Die Veränderungen in der Hauptwerbeorganisation des Gasfaches, Zentrale für Gasverwertung und „Der Gasverbrauch“ sind im Abschnitt 7.II in grofjen Zügen im Rahmen der allgemeinen Organisation des Faches dargestellt worden.

Wichtig wurde in dieser Zeit der beträchlichen Schwankung auf dem Geldmarkte die Eltgas G. m. b. H. zur Finanzierung der Teilzahlungsgeschäfte zunächst der sächsisch-thüringischen Gas- und Elektrizitätswerke. Geldgeber waren die Allgemeine deutsche Creditanstalt (Adca), Leipzig, und die Sächsische Staatsbank $\left.^{7}{ }^{405}\right)$. In ihren Geschäftsberichten klingt eine gewisse Enttäuschung durch, dał die Eltgas nicht lebhafter in Anspruch genommen wurde. 1930 zählte man 23 Gaswerke und 48 Elektrizitätswerke ${ }^{t .460}$ ) als Kunden, 193770 Gaswerke und Iо Elektrizitätswerke $\left.{ }^{\tau \cdot t m}\right)$. Dieses Unternehmen hatte gewiß̧ das Verdienst, die mit den Finanzierungsgebräuchen manchmal weniger vertrauten Werksleiter mit den Möglichkeiten der Absatzfinanzierung und der Sicherheit des Einganges der Ratenzahlungen vertraut zu machen. Diese war bei den Dauerabnehmern der Werke besonders erfreulich. Es war aber doch wohl falsch, aus den Beobachtungen der Gesellschaft ein Urteil über die Einstellung der beiden Energieträger zur Kreditfinanzierung zu ziehen. Wenn nämlich über die sicherlich auch bei der Eltgas von den Banken in Anspruch genommenen Zinsen eine Dividende von $5 \%$ herausgewirtschaftet werden konnte, so zeigte das wohl, daf kreditfähige Betriebe, vor allem privatwirtschaftliche Gaswerke und auch Gerätehersteller zur Finanzierung der Abzahlung mit unmittelbar von Banken aufgenommenen Krediten billiger zurecht kamen. Die Hersteller nahmen sich der Werbung zur Belebung des Abzahlungsgeschäftes durch Vorträge in Zusammenarbeit mit Gaswerken sehr lebhaft an und konnten selbst in den mageren Jahren eine fabrikatorisch besonders wertvolle Grundbelastung mit Sicherheit für ihr eigenes Erzeugnis erreichen.

Besondere Aufmerksamkeit widmete das Fach grof̧en Ausstellungen, die sich leider gerade in der schwierigen Zeit als Ausfluß der Betriebsamkeit mancher Stadtverwaltungen häuften. Darunter war die grołe Ausstellung für Gesundheitspflege, soziale Fürsorge und Leibesübungen (Gesolei) in Düsseldorf 1927 und die Ausstellung Gas und Wasser in Berlin $\left.1929^{i, 4 i 1}\right)$. Beide waren rein ausstellungsmäßjig ein grofjer Erfolg für das Fach. Die Hersteller aber muf̧ten feststellen, dafy Aufwand und Verkaufserfolg viel geringer war als die tatkräftige

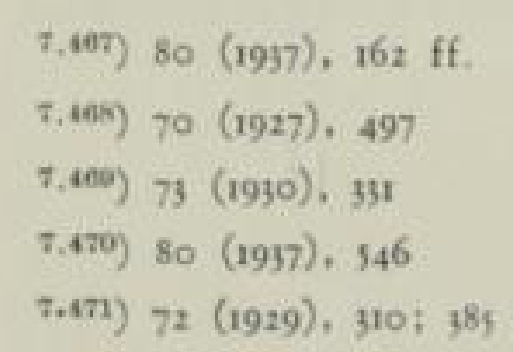


Betätigung an örtlich günstigen Schwerpunkten zur Anregung der Teilzahlungsverkảufe. Hinzu kam noch, dał immer mehr Werke dazu übergingen, für die Schaustellung in Ausstellungsräumen zur Beratung der Abnehmer Leihgaben der Hersteller zu verlangen, wobei natürlich keine Gewähr gegeben war, ob die betreuenden Angestellten nicht nach eigenem Ermessen irgendwelche Marken bevorzugt empfahlen. In dieser Hinsicht wurde von den meist nicht gerade fürstlich besoldeten Mitarbeitern wohl etwas zuviel an unparteiischer Kritik erwartet $^{\text {;.uzz }}$ ). Ja, ein grołes Gaswerk ging sogar dazu über, für die Aufstellung der Leihgeräte Platzmiete zu verlangen, ein anderes verlangte Prüfung im Gaswerkslaboratorium vor der grundsätzlichen Zulassung zur Verwendung im Versorgungsbezirk des Werkes ${ }^{\text {T.tza }}$ ). Das war aber ein mit Rücksicht auf die Gewerbefreiheit bedenkliches Vorgehen, wenn der Hersteller beweisen konnte, dał die Geräte in einer Vielzahl von Gaswerken dauernd bezogen wurden und befriedigten. Nur wo Abzahlungen von Gaswerken aus finanziert werden sollten, konnte man eine besondere Prüfung als berechtigt anerkennen.

Dadurch stiegen die Vertriebskosten durch Schaustellungen im Verhältnis zum unmittelbaren Absatz mit Einschaltung von geeigneten Händlern und Geräte verkaufenden Gaswerken, dał schlieflich in der Zeit der Krise die Hersteller beschlossen, die zweimal im Jahre stattfindende Leipziger Messe nicht mehr zu beschicken. Dort war es üblich geworden, eine besondere Messehalle für das Fach zu belegen.

Die Geräteindustrie bekam böse Vorwürfe des Vorstandes der Zentrale für Gasverwertung zu hören, worunter mangelnde Weitsicht und geringe Unternehmungslust genannt wurden $\left.{ }^{7,47}\right)$. Er lobte dagegen den Stand, auf dem der eben neu entwickelte Zapfhahnerhitzer eingefüht werden sollte. Die Fabrikantenvereinigung drückte ihr Befremden über diesen Aufsatz sehr milde in den Worten aus: Man sei nicht über die Gesichtspunkte der Fabrikanten unterrichtet ${ }^{7.45}$ ). Denn tatsächlich war, wie auch manche Zahlungsunfähigkeiten bewiesen, die Lage der Hersteller sehr gefährlich geworden. Infolge der für den entstandenen Geschäftsumfang übersetzten Vertriebsorganisation über Groß̧händler und Einzelhändler als Partner der Gaswerke in Gasgemeinschaften erhielt der Hersteller etwa nur die Hälfte des Bruttoverkaufspreises. Dafür muf̧te er nicht allein die Ware liefern, sondern auch alle die eigenen Vertriebsunkosten einschlieflich der beim Rückgang des Umsatzes verhältnismäfjig zu grof̧ gewordenen Unkosten für das Ausstellungswesen in jeder Form tragen.

Unsinnig waren manche Vorhaltungen von Gaswerksseite, wie die Hersteller billiger arbeiten könnten, um für die allgemeine Werbung gröłsere Mittel zur Verfügung zu stellen. Ohne zu bedenken, dał groß̧e Zusammenschlüsse von Erzeugern im allgemeinen dazu dienen, die Verkaufspreise zu erhöhen, verlangte H. A. Herzfeldd, Dresden, einen Zusammenschluf der Geräteindustrie mit dem Ziele einer Arbeitsteilung: Spezialfabriken jeweils mit ausschlieflicher Fertigung von Kochern und Herden, Warmwasserbereitern, Heizöfen oder Grofküchen. Er bedachte dabei keineswegs, dał der jahreszeitliche und konjunkturelle

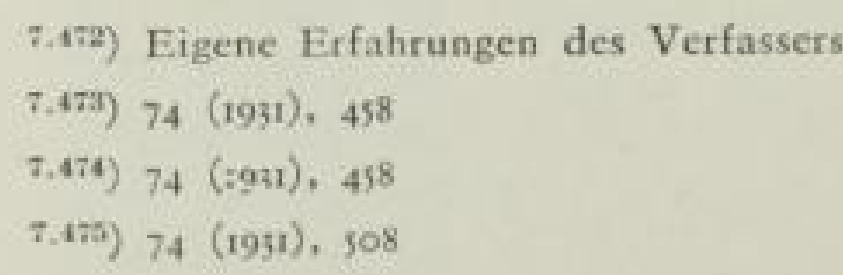


Ausgleich die vielseitigen Arbeitsprogramme hatte natürlich wachsen lassen. Solche Gedanken fanden dann noch als ,vorzügliche Grundgedanken“ Anerken-

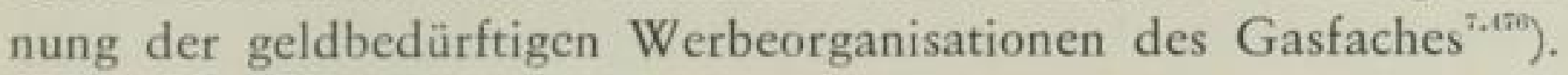

In der Zeit, in der die ganze Ingenieurwelt aus der Massenfertigung möglichst mit Bandarbeit das Heil sah, fehlte es nicht an dauernden Hinweisen in dieser Richtung. Auf der Ausstellung 1929 Gas und Wasser in Berlin wurde ein Band für Gasmesser gezeigt, 1931 auf der Hauptversammlung des Vereins im Bilde ein ähnliches für Herde ${ }^{7 \cdot 4 \pi}$ ). Sie fanden den Beifall des Faches. Beide aber waren etwas unbedacht aus den üblichen Lieferungen für schwere Maschinenteile entnommen und für die leichten Blechwaren zu schwer, also auch zu teuer und zu kraftbedürfend. Damals betrug bei einem Herd der Montagelohn I RM. Wurden etwa roo Herde am Tag gefertigt, was wohl dem mittleren Ausstoł entsprach, und man konnte durch das Band $10 \%$ an Löhnen einsparen, so standen also Io RM zur Amortisation und zum Energieaufwand zur Verfügung. Dafür konnten aber nur ganz leichte, billige Einrichtungen, die ja auch den Gewichten der Messer und Herde entsprachen, wirtschaftlich betrieben werden. So ist denn auch die Entwicklung in dieser Richtung gegangen. Die Askaniawerke nahmen für Gasmesser und deren Teile einen ganz leichten Balatariemen, der mitten über den mit blankem Blech versehenen Tisch schurrte, und für Herde wohl als erste, kleine Wägelchen, die in leichten Winkeleisen geführt wurden. Damit war man zum Beginn durchaus nicht auf Massen angewiesen.

Der Zapfhahnerhitzer verdient aber ebenfalls eine besondere Beachtung. Die von B. $L$ ud wig, München, ausgegangene Anregung war an sich gesund. Das kann man heute an der Tatsache ermessen, dafy sich die Bauart von Deutschland aus über die ganze Welt als eines der besten Werbeobjekte für Gaswarmwasserbereitung in hunderten von Abänderungen verbreitet hat. Nicht richtig aber war die Ungeduld, mit der das Gasfach die Entwicklung und Lieferung erwartete. Das Gerät muß̧te, wenn es die Hoffnungen erfüllen sollte, sehr billig werden. Das verlangte eine sehr grändliche konstruktive, materialmäß̧ige und fertigungstechnische Durcharbeitung. Gewifł war eine Aufjerung gut gemeint, die Werke sollten, wenn sie schon eine Marktanalyse für ein neuartiges Gerät angestellt hätten, den Herstellern die zur flotten Serienfertigung notwendigen Mengen gewährleisten $\left.^{7 .+17}\right)$. Ein erfahrener Fabrikant wird aber bei einer unerprobten Neuheit zunächst etwas zurückhalten, vielleicht den Anfangspreis bewuf3t etwas höher stellen, um an den ersten Lieferungen Betriebs- und Fertigungserfahrungen zu sammeln, kurzum er wird das Wagnis zu beschränken suchen. Eine auf diesem Gebiete nicht erfahrene Firma ging schnell in die gewünschten groß̧en Scrien hinein. Sie wählte für den Wärmeaustauscher statt des üblichen Kupfers Aluminium. Jedem aufmerksamen Beobachter muf̧te es auffallen, daf3 Prof. Junkers wohl mit Aluminiumverarbeitung und Bewährung die gröf̧ten Erfahrungen gesammelt hatte und beim Kupfer verblieb. Eine Nachfrage bei der Aluminiumberatungsstelle, deren Anliegen es war, den Absatz zu mehren, bestätigte Bedenken, die zwar vorsichtig ausgedrückt wurden. Aluminium würde zwar den

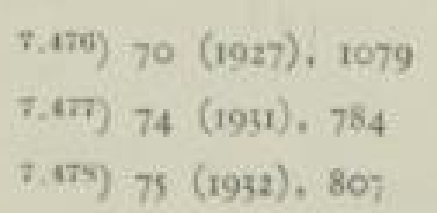


Abgasen standhalten, nicht aber dem sich erwärmenden durchlaufenden Wasser. So kam es dann auch. Die Geräte wurden schnell unbrauchbar. Die Firma erlitt grof̧e Veriuste und muf̧te alsbald ihre Pforten schlief̧en. Für das Fach wurde ein allgemeiner Rückschlag vermieden, weil inzwischen kupferne Geräte auf den Markt kamen.

Die Beteiligung der Industrie an der allgemeinen Werbung konnte über die Fabrikantenvereinigung geregelt werden ${ }^{\text {T.ting }}$. Es blieben nur die Vorwürfe, daf3 angesichts der Krise die Unterstützung nicht ausreichend wäre. Dabei wurde auch mit Bedauern festgestellt, dał von den Gemeinden die Werbungskosten eingeschränkt würden, obwohi doch den Werken im Gegensatz zu den Herstellern die Stammkundschaft, die einmal errungen war, ohne neue Anstrengungen erhalten blieb $\left.{ }^{\gamma, 400}\right)$. Anscheinend war aber selbst diese Feststellung nicht allgemein richtig, denn der Werbemittelumsatz des "Gasverbrauchs" war gestiegen, eine steigende Zahl von Veranstaltungen, neuartige Werbewochen, wurde trotz der Krise festgestellt. ${ }^{7.41}$ ).

Eine wichtige Hilfe zur Erweiterung der Abnehmerzahl war seit jeher der Verkauf der notwendigen Geräte durch die Gaswerke gewesen. Mit der Übernahme der Werke durch die Kommunen gelang es Händlern und Installateuren an immer mehr Orten, über die politischen Parteien diesen Verkauf ohne Ansehen der Werbewirkung zu verhindern

Deshalb verhandeite die Zentrale für Gasverwertung mit den Installateurverbänden über Richtlinien für die Zusammenarbeit dieser Verbände mit den Gaswerken. Der Grundsatz, dał die Gaswerke verkaufen dürften, wurde als rechtlicher Standpunkt gewahrt. Indessen wurde er abgeschwächt durch eine Empfehlung, die Herrichtung von Privatanlagen dem Gewerbe zu überlassen, eine Zulassung der geeigneten Einrichter auszusprechen und Gasgemeinschaften für den Verkauf zu gründen. Auf den Bau sanitärer Anlagen verzichtete die Zentrale im Namen der Werke ${ }^{7.452}$ ). Nicht mit groß̧em Erfolg wandte sich F. $K u c k u k$ gegen die Beschneidung der Freiheit wegen der örtlichen Belange ${ }^{7.487}$ ). Der Wert der Gasgemeinschaften als Verkaufshilfe der Werke war sehr unterschiedlich. Er beschäftigte das Fach sehr, kann aber in ihren verschiedenen Arten und Formen nicht dargestellt werden. Im Jahre 1933 stellte W. W' o lff noch fest, dafy bei den kommunalen Werken sich zum großzen Teile der Zwang der wirtschaftlichen und technischen Notwendigkeiten so weit durchgesetzt habe, daf auch sie (neben den Privatgaswerken) Geräte verkauften und installierten ${ }^{\text {T.ts }}$ ).

Dabei setzte mit Hilfe mancher örtlicher Instanzen ein erneuter Angriff des privaten Gewerbes gegen die Tätigkeit der Werke, selbst bei privaten Gaswerken, ein. Ungern wurden statistische Feststellungen von dem Gewerbe entgegengenommen, daf, wo ein Werk in den Verkauf eingeschaltet blieb, auch beim Gewerbe im Vergleich mit ähnlichen Werken größere Ümsätze erzielt wurden ${ }^{\text {T.4.55 }}$ ).

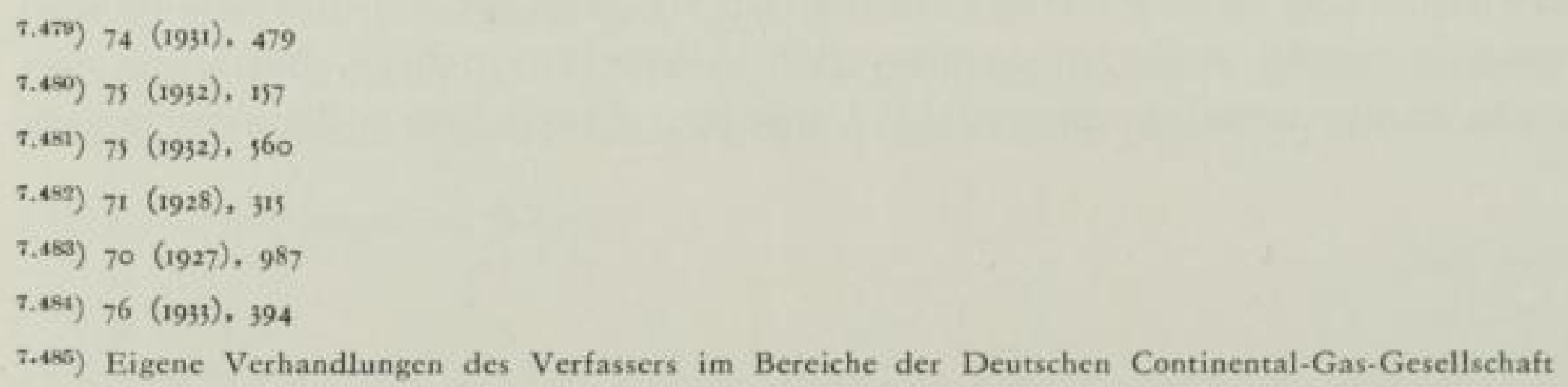


Schön und fruchtbar wurden die Werbertreffen in einzelnen Bezirken, 8 für 1935 und II für 1936, die dem Erfahrungsaustausch dienten ${ }^{7.489}$ ).

Eine besondere Leistung der Zentrale für Gas- und Wasserverwendung (früher Zentrale für Gasverwertung) war die als Ringhefter in festem Umschlage herausgegebene Mappe: Gas in Gewerbe und Industrie, kurz das Ringbuch genannt. Sie gestattete es, die einzelnen Gewerbe in großen Umrissen technologisch zu erläutern und daran die Gasverwendung zu schildern. Die Loseblattheftung gab die Möglichkeit, durch die oft sehr schnelle Wandlung überholte Darstellungen durch neue zu ersetzen und auf diese W/eise das Buch vor dem Veralten zu bewahren $^{\text {7.457 }}$ ). Damit wurde eine schwere Klippe der zeitgebundenen technischen Handbücher glücklich umschifft.

\subsection{Gaspreise}

Man darf wohl ohne Úbertreibung sagen, daf̧ die wissenschaftlich errechnete Tarifgebarung unter dem Druck der Notzeit und des starken Wettbewerbes in der betrachteten Zeitspanne vom deutschen Gasfach erarbeitet worden ist.

Die ersten Vorschläge von Gieseking, Leipzig, waren noch reichlich willkürlich gewählt. Es wurden danach im Sommer 5 im Winter 3 Abnehmergruppen gebildet, in denen Preise von 20 bis hinab zu 10 Pfg. nach dem Verbrauchszweck gestaffelt wurden $\left.{ }^{7.45}\right)$. G $\ddot{u} m b e l$, Bruchsal, erläuterte die Rangordnung der Selbstkostenarten als absolut feste, bedingt feste und bewegliche Kosten $\left.{ }^{7+45}\right)$. Er unterschied den Einheits-, Grundgebühren-, Staffel- und Zonentarif und die Grundgebührenarten nach Einheitsgebühr und Stufengebühr nach Zimmerzahl, nach Verbrauch oder nach Anschlufwert.

F a lck, Detmold, sprach über die Werbekraft des Grundgebührentarifs: „Da aber bei den städtischen Werken im allgemeinen nicht Fachleute, sondern Laien die Tarife festsetzen, wobei mehr oder weniger politische oder vermeintlich soziale Erwägungen die wirtschaftlichen übertönen, so kann ..... nicht oft genug auf die Erfolge (des Grundgebührentarifs) hingewiesen werden ..... 1926 und 1927 finden wir auffallend hohe Zunahmen der Gasabgabe gegenüber den Vorjahren bei zugleich hohen Gasabgaben je Einwohner fast nur bei Werken mit gleitenden (Grundgebühren- oder Staffel-) Tarifen ${ }^{7.400}$ ).“

Man kann die vielfachen Erörterungen nicht alle anführen. Sie führten auch zu Verhandlungen in den Hauptversammlungen. Immer wieder wurden Klagen über die Hemmungen durch Finanzaufschläge laut: „Die heutige Steuer- und Finanzpolitik muf3 vielfach geradezu ais Raubbau bezeichnet werden “7.t91). „Man bestraft Leute, die Arbeit beschaffen.“ „Den Versorgungsbetrieben darf das Blut nicht abgezapft werden ${ }^{\left(*,+w^{*}\right.}$ ). Geringe prozentuale Abschläge, die unter dem Druck der Regierung zustande kamen, wurden zum Teil im Grundbührentarif-

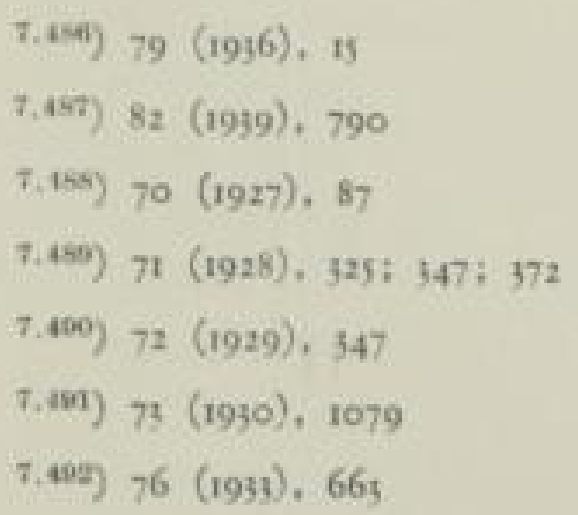


aufbau verwirklicht $\left.{ }^{i-4}\right)$. L. Winkier, Frankfurt, griff den Block-Regelverbrauchstarif nach Zimmergröł̧e wieder auf und erläuterte auf der Hauptversammlung des Vereins sorgfältig die Vor- und Nachteile ${ }^{\text {stin }}$ ). In cier lebhaften Aussprache $^{\tau, 405}$ ) schlug F. Burgbacber, Köln, zum ersten Male vor, nach dem englischen Vorbilde nach der 1000 kcal-Einheit das Gas zu verkaufen, was damals mit Kilowärme bezeichnet wurde $\left.{ }^{\tau+400}\right)$. Etwas überschwänglich sagte H. Bebrens dazu: „Wir fanden einen klaren und zutreffenden Wert in der neuen Gasmef̧einheit: Kilowärme. Technisch und organisatorisch ausgereift, haben wir jetzt unsere Vorschläge für den Ubergang zum Gasverkauf nach Kilowärme statt nach Kubikmetern der Wirtschaftsgruppe Gas- und Wasserversorgung übergeben ${ }^{\text {“7.407 }}$ ). Kurz vorher war eine Tarifordnung für Haushaltsgas geschaffen, die als Richtlinie durch die Reichsgruppe Energiewirtschaft herausgegeben werden sollte $\left.{ }^{7 \cdot 465}\right)$. Der Regelverbrauchstarif im Verhältnis der Preise von $9: 6: 4$ für Kochen, Warmwasser, Heizung wurde empfohlen $\left.{ }^{7, u m}\right)$. Eine jährliche sehr unterteilte Statistik führte Melcbinger durch $\left.{ }^{7.500}\right)$. Erneut kam es zum Sturm gegen die Finanzzuschläge ${ }^{\text {T.sal }}$ ), die bis zu $25 \%$ des Zuschufbedarfs decken mufjten. Sogar die Tagespresse beteiligte sich daran ${ }^{i .002}$ ). 1938 versprach der Reichsinnenminister einen neuen Finanz- und Lastenausgleich, der auch den gewünschten Abbau der Zuschläge ermöglichen würde ${ }^{7.500}$ ). Der Finanzminister muf̧te indessen mahnen, die Ersparnisse an Arbeitslosenunterstützung, die ja als Hauptgrund für die Finanzzuschläge genannt worden war, nicht zur Schuldentilgung sondern zum Abbau der Zuschläge zu verwenden ${ }^{\text {t.sa }}$ ). Ein Erlaf̧ des Vorjahres sei wenig erfolgreich gewesen ${ }^{7.500}$ ).

Nach all diesen Bemühungen konnte aber H. Bebrens nur feststellen, dafs $31 \%$ des Gases nach dem Regelverbrauchstarif abgegeben würden $\left.{ }^{7 \cdot \pi x}\right)$. Die Fortschritte seien nicht ganz befriedigend gewesen $\left.{ }^{7.507}\right)$. Offenbar war die Selbstverwaltung der Städte im Geldwesen doch noch sehr ungestört. „Gemeinnutz geht vor Eigennutz" galt nur, soweit der Gemeindeverwaltungsnutzen mit Gemeinnutz gleichgesetzt werden konnte.

Kurz vor dem Kriege folgte dann vom Reichskommissar für die Preisbildung eine Tarifverordnung über die Bildung allgemeiner Tarifpreise für die Versorgung mit Gas vom 15. 5. $39^{\text {7.50n }}$ ), mit der die Lenkung aber auch nicht mehr zum Zuge kam.

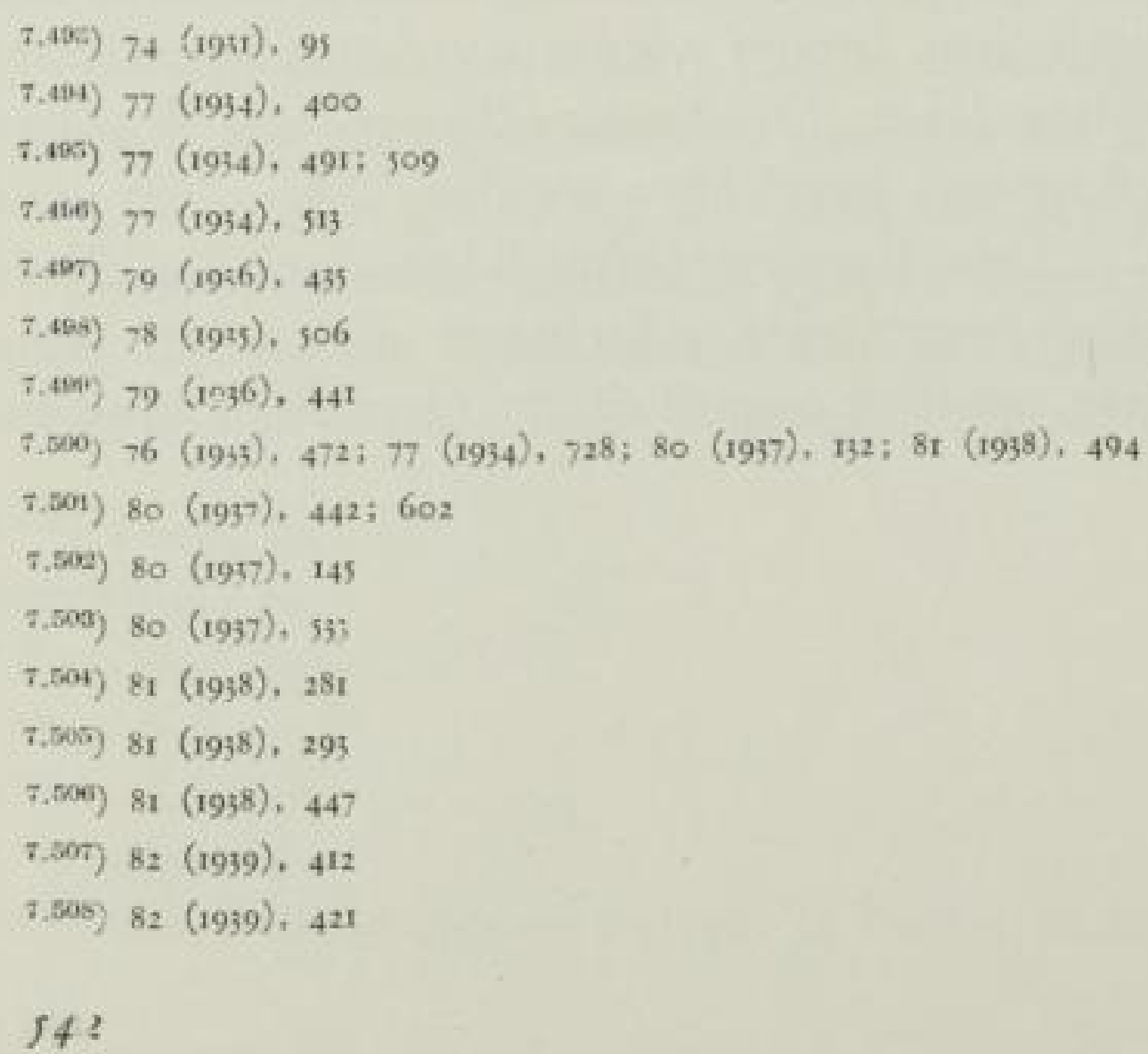


In der Haushaltsversorgung war die Abwanderung zur elektrischen Beleuchtung nicht mehr aufzuhalten ${ }^{7.500}$ ). Die Bemühungen der Fachleute richteten sich auf die Strafjenbeleuchtung. Der statistische Nachweis ergab noch erfreuliche Zahlen über den Anteil des Gases an dieser. 1929 wurden $303 \mathrm{Mio} \mathrm{m}^{\mathrm{a}}$ Gas gegen $70 \mathrm{Mio}$ KWh Strom abgesetzt; die Steigerung gegen 1928 lag bei II bzw. $17 \%$. Der Anteil lag bei $80 \%$ für Gas und $20 \%$ für Elektrizität. 1938 waren in 56 Städten mit über $100000 \mathrm{~m}^{3}$ Gaserzeugung 515000 Gasleuchten vorhanden. Die beleuchtete Straß̧enlänge betrug $26000 \mathrm{~km}$ für Gas und $18000 \mathrm{~km}$ für Elektrizität, das waren so zu $4 \mathrm{r} \%$, in den Gemeinden von to 000 Einwohnern aufwärts. Von den Gemeinden unter 10000 Einwohnern hatten nur $3 \%$ Gasbeleuchtung, in denen darüber $72 \% .44,2 \%$ aller Strał̧enbeleuchtungskörper waren mit Gas betrieben, von den Gemeinden über to ooo Einwohner $64,7 \%^{7.310}$ ).

Als Neuheiten wurden die Zeifreflektorlampen, die Blohmglocken ${ }^{\text {T.5n }}$ ) und das Gasflutlicht erwähnt ${ }^{\text {7.dig }}$ ). Einbaubrenner zur Umwandlung von Stehlicht in Hängelicht waren noch nicht allgemein. Thre Einrichtung wurde als Mittel zur Arbeitsbeschaffung empfohlen $\left.{ }^{7.513}\right)$. Würzburg veröffentlichte viele Bilder über formschöne neue Gasbeleuchtungsmaste $\left.{ }^{7.5 i t}\right)$. Die Beleuchtung der Gas-Ausstellung "Schaffendes Volk" in Düsseldorf wurde als besonderer Erfolg gewertet ${ }^{\text {t.,.515 }}$ ). Eine Vereinheitlichung der Gasleuchten brachte DIN-DVGW-Vornorm 3245 ${ }^{\text {T.310 }}$ ). Eine grofye Prefygasanlage der South Metropolitan Gas Co. in London erstreckte sich auf $200 \mathrm{~km}$ Straf̧enlänge, sie verbrauchte $3840 \mathrm{~m}^{3}$ Gas in der Stunde mit einem Aufwand von 230 PS zur Verdichtung auf $2000 \mathrm{~mm}$ Wassersäule ${ }^{7.517}$ ). Ein Ersatz des Thoriumoxydes für Glühkörper kam nicht in Betracht, weil damit die einzige Quelle für Mesothorium, das als Ersatz für Radium für medizinische Zwecke benötigt wurde, verstopft worden wäre ${ }^{7.39}$ ).

\subsection{Kocben}

Der lebhafte Kampf um die Kocharbeit in der Haushaltsküche löste viele Vergleichskochversuche aus, die bereits auf Seite 535 erwähnt worden sind. Als Neuerung wurde von A. Albrecbt der Gaskochschrank als Mittel gegen den Elektroökonom begrüßzt ${ }^{7.51}$ ), obwohl von Schweden, woher der Schrank stammte, berichtet war, daf beide Arten grołe Vitaminvernichter seien $\left.{ }^{-. .20}\right)$. Die ersten Temperaturregler von Gasbratöfen wurden angeboten ${ }^{7.57}$ ).

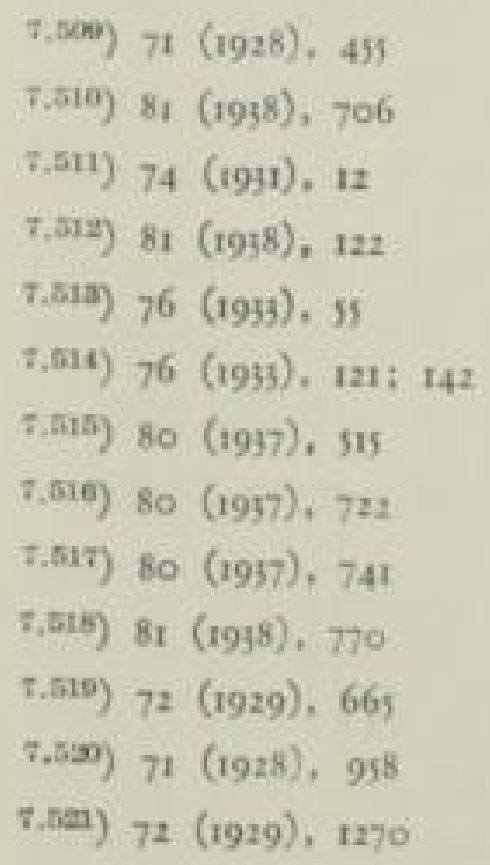


Die Normung der Kochgeräte wurde mit DIN-DVGW-Vornorm E. 3233 mit Vorschriften für die Prüfung und Beurteilung von Gas-Brat- und -Backöfen für den Haushalt abgeschlossen ${ }^{7.5 z}$ ). Viel Mühe machte es, die Unzulänglichkeit der von München aufgegriffenen Papierbräunmethode (Seite 465) zur Beurteilung der Wärmeverteilung im Bratofen zu beweisen ${ }^{7.529}$ ). Wie ein Stofseufzer klingt die Mahnung, daf̧ nunmehr auch die Normenherde durchgedrückt werden, insbesondere die Gaswerke über die gar nicht gern angenommene Rippenplatte Aufklärungsarbeit leisten müßten ${ }^{7.2 n}$ ). Immerhin wurde 1936 die bis dahin noch nicht erreichte Menge von 600000 Gaskochgeräten und zwar überwiegend von Herden abgesetzt. 1932 waren es nur 132000 gewesen ${ }^{7,525}$ ).

Der Kampf gegen ",Gassparer“ ging weiter. Der Geräteausschuf nahm dazu Stellung $\left.{ }^{7.50}\right)$. Trotzdem tauchte 1931 die Gehi-Spardüse erneut auf, gestützt auf ein gefälschtes Gutachten des Gaswerkes Liegnitz ${ }^{\text {T.627 }}$ ).

Im Groß̧küchenwesen verlief der Aufbau stetig, aber ohne Aufregungen. Die geschlossene Herdplatte, nunmehr als Hauptarbeitsfläche in die Mitte verlegt und seitlich mit offenen Kochstellen für schnelle Arbeiten versehen, hatte sich durchgesetzt ${ }^{\text {Tabog }}$ ). E. Scbumacber. München, stellte die ersten sehr aufschlufreichen Untersuchungen über die Wärmeverteilung bei geschlossenen Kochplatten $\left.a^{7.529}\right)$. Die erste Heeresküche mit Gasfeuerung konnte entgegen den Hausbauvorschriften der Heeresverwaltung in Allenstein ausgerüstet werden, eine zweite folgte alsbald in Neuruppin $\left.{ }^{7.55}\right)$. Der Herd in der Kaserne war eine unerhörte Neuigkeit. Bis dahin gab es nur Kochkessel mit Vitaminabtötung, meist mit Dampf betrieben.

Die Gaswerke wandten ihre Aufmerksamkeit auch in erhöhtem Małze dem Kochen der Wäsche zu. Nicht nur A. Scbäfer, Ingolstadt, vertrieb Sprudelwäscher und Trommelwäscher mit Handantrieb für den Haushalt mit Erfolg ${ }^{\text {T.an }}$ ).

\subsection{Warmwasserbereitung}

Die Entwicklung des Zapfbahnschnellwasserheizers ist wegen der werblichen Bedeutung dieses Gerätes auf Seite 539 abgehandelt. Wenn auch wegen der überstürzten Ausbreitung groß̧e Anfangsschwierigkeiten zu überwinden waren, so ist sie dennoch ein erfreuliches Beispiel von einer Zusammenarbeit der Gaswerke als Entdecker eines groß̧en Bedürfnisses und der Hersteller als Erfüller der Wünsche. Die erste Schaustellung erfolgte auf der Kölner Messe des Jahres 1931, also mitten in der Krise der Wirtschaft ${ }^{7.35}$ ). Die weitere Durchbildung zum Kochendwassergerät war 1935 vollendet $\left.{ }^{7.539}\right)$. Es folgte der mit einem Speicher

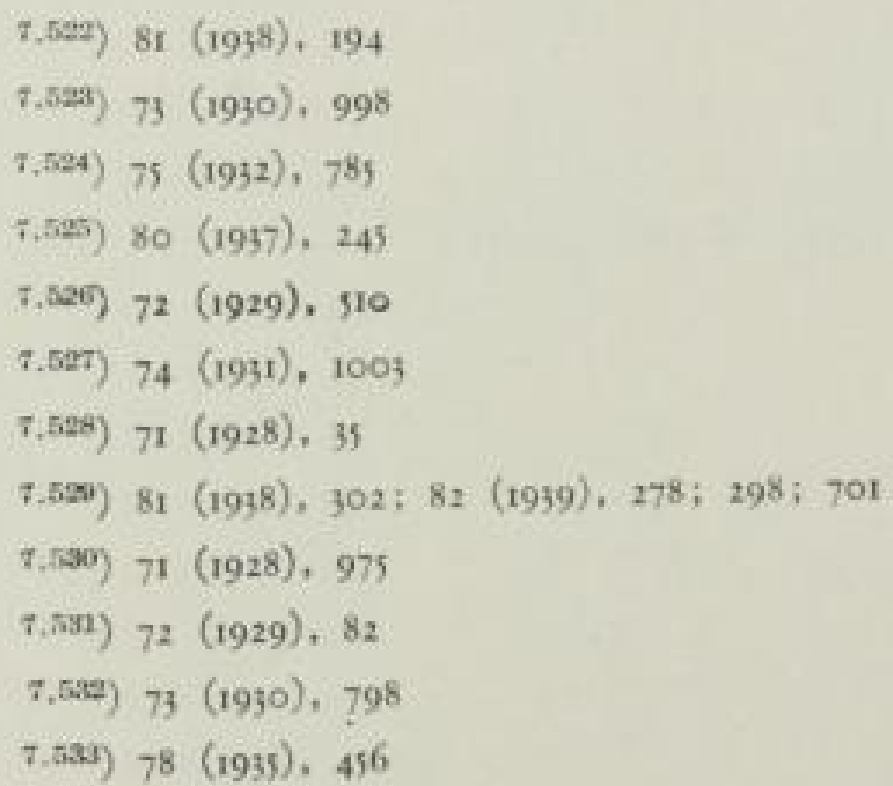


verbundene Durchlauferhitzer von Butzke, Berlin $\left.{ }^{7.54}\right)$. In dem im Bedarfsfalle eingeschalteten offenen Speichergefäßz kann Wasser schnell zum Kochen gebracht werden.

Eine wertvolle, den Absatz erleichternde Äufjerlichkeit brachte der emaillierte Mantel der Warmwasserbereiter mit sich. Er hat eine eigenartige Geschichte. Die Askaniawerke hatten 1930 nach englischen Vorbildern einen 90 Ltr. Wasser haltenden Speicher mit untergesetztem Erhitzer mit Schwerkraftumlauf, die Speichertherme, aufgebaut. Der Mantel war weiß lackiert. Dieses an sich unförmig grołe Gerät, das eigentlich nur für besondere Bedürfnisse gedacht war, fand eine überraschend freundliche Aufnahme bei der Architektenschaft. Insbesondere in der Siedlungsausstellung Weißgenhof, Stuttgart, wo sich die bekanntesten Architekten des In- und Auslands mit eigenwilligen Entwürfen maf̧en. wurde die Speichertherme lebhaft aufgenommen. Eine Nachforschung ergab, dał die weife Farbe ausschlaggebend war.

Da nun bei den inzwischen üblich gewordenen druckfesten Durchlauferhitzern der Mantel nicht mehr wie früher ein Teil des wasserführenden Körpers war, war es konstruktiv ohne weiteres möglich, ihn durch ein emailiiertes Blech zu ersetzen. Es mufyte lediglich die Herrichtung im Ofen unter besonderen Vorsichtsmafnnahmen geschehen. So brachten sehr bald die Askaniawerke den ersten weif̧emaillierten Badeofen heraus. Junkers \& Co. u. Joh. Vaillant folgten alsbald $^{\text {T.was }}$ ) und entwarfen dafür die Schalenform des Mante's, die zieh- und emailletechnisch besondere Vorteile bot und sehr schnell zur allgemein nachgeahmten Form wurde.

Gleichzeitig damit wurde auch die von München aus und durch Versuche E. $S c b u m a c b e r s$ als betriebssicher erwiesene, fest eingebaute Rückstromsicherung eingeführt.

Zeitweilig brachte eine Auflage des Wasserfachs ernste Unannehmlichkeiten. Durch die Verwendung der beweglichen Schlauchbrause war die Gefahr entstanden, daf3 diese in das Badewasser eintauchte und bei heftigen Zapfungen in darunterliegenden Stockwerken das seifige Wasser in die Trinkwasserleitung gesaugt wurde. Das erste Mittel dagegen war die Vorschrift, eine Rückschlagklappe in die Wasserzuleitung einzubauen. Damit aber zerstörte das bei der Erwärmung sich ausdehnende Wasser die Körper von Druckautomaten. Das Gegenmittel, den Ventilsitz durch einen Feilstrich mit Sicherheit undicht zu machen, war technisch nicht einwandfrei, wurde aber auch unabhängig vom geschilderten Vorgehen bei Druckautomaten ${ }^{7.5 \times 2}$ ) auch bei den Speicherthermen notwendig. Dieser unbef́riedigende Zustand hat veranlaf̧t, daf̧ die Therme später nicht mehr gebaut wurde.

$S c b w a r z, F r e i$ und Deckert setzten ihre Untersuchungen über zulässige Baderaumgrößzen fort $\left.{ }^{7.37}\right)$. Für die sichere Auslegung der Gröłe von Warmwasserbereitern waren die Verfahren von W. Geck zur Berücksichtigung der Gasstrahlung und die Messungen von W. Brümmerboff bei den Askaniawerken entscheidend $\left.{ }^{7 \text { sat }}\right)$. Dort wurde auch 1934 zuerst ein Wärmewähler bekannt-

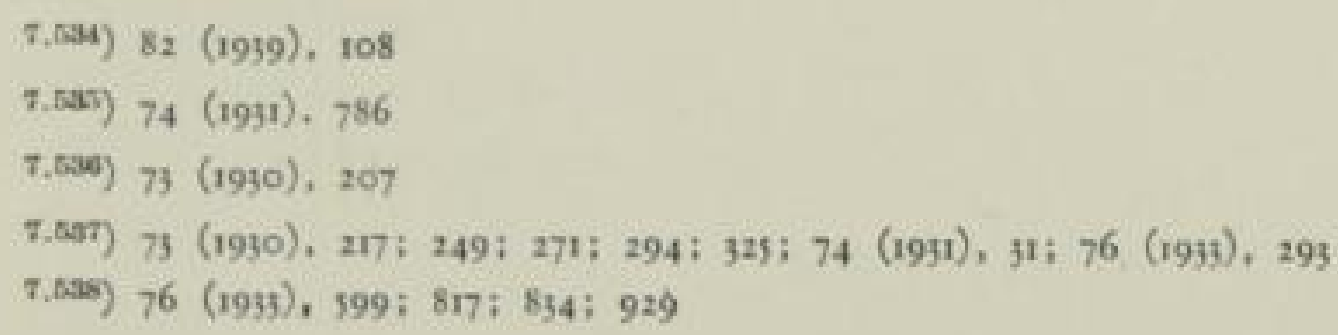


gegeben. Durch Veränderungen im Venturiteil der Druckautomaten und Badeöfen konnte der Gebraucher an einem einfachen Handrad die gewünschte Temperaturhöhe einstellen $\left.{ }^{7.539}\right)$. Eine Weiterbildung mit geregelter Wasser- und Gasmenge, jene durch einen Wärmefühler am Einlauf verändert und veränderlich einstellbar war der Nachwärmer $\left.{ }^{7,{ }^{3} 40}\right)$. Dieser sollte vor allem dazu dienen, daf3 aus Speichern im Anschluf3 an Zentralheizungen in den Ubergangszeiten ungenügend warmes Wasser auf die gewünschten Temperaturen unter voller Ausnutzung des Erhitzers im Durchlauf zu bringen. Bedenken wurden geäuß̧ert, daf solche Einstelleinrichtungen zu verwickelt und anfällig wären. Dem Verfasser sind aber Fälle bekannt, wo die Geräte noch nach mehr als 30 Jahren einwandfrei im Betriebe sind.

Nach all diesen sichtbaren Verbesserungen, die mit einer vorbildlichen Werbung bekannt gemacht wurden, konnten im Jahre 1936 I50 000 Warmwasserheizer, davon 80000 grofe und 70000 Schnellwasserheizer untergebracht werden. Das war für die damalige Lieferfähigkeit der Herstellerwerke eine Spitzenleistung $\left.^{\text {7.s11 }}\right)$.

Die 1939 geforderte Zinneinsparung wurde durch Hartlötung der kupfernen wasserführenden Teile erfüllt. Die Forderung aber, Kupfer ganz zu ersparen und durch Edelstähle zu ersetzen, war leichter gestellt als ausgeführt, da die unterschiedliche Wärmeleitfähigkeit von Kupfer und Stahl das Verhältnis vom Gewicht zur Leistung ganz ungewöhnlich beeinflufte $\left.{ }^{7.512}\right)$.

\subsection{Heizung}

Der Markt der Einzelraumheizung wurde überwiegend durch die Firma C. Meurer A.-G., Cossebaude, mit Elementöfen und zum geringeren Teile durch andere Firmen mit Nachahmungen beliefert. Erst gegen Ende des Abschnittes konnte man feststellen, daß̧ sich der Geschmack zu ändern begann und Öfen mit geschlossenem Auß̧enmantel gewürdigt wurden.

Die größte Sorge bereitete die Unklarheit über die Möglichkeiten der Abgasführung in Schornsteinen. Die Baubehörden litten unter Vorstellungen von Explosionen durch eingeströmtes Gas in Schornsteinen, die allerdings nicht durch irgendwelche Unglücksfälle bewiesen werden konnten. Sie verboten aber vielfach „,vorsichtshalber“ die Einführung von Abzügen der Gasheizöfen in Schornsteine, an denen bereits Kohlenöfen angeschlossen waren, also gemischt belegte Schornsteine $\left.{ }^{\tau . . .13}\right)$.

Ohne Trübung durch Sachkenntnis stellte der Preufische Minister für Volkswohlfahrt in einem Erlał vom 26. Januar 1929 fest: „Die Einführung der Abgase von Gasöfen in Schornsteine der Kohlenfeuerung kann leicht zu Gasexplosionen führen." Er verlangte also getrennte Schornsteine $\left.{ }^{7.54}\right)$. Ausnahmegenehmigungen

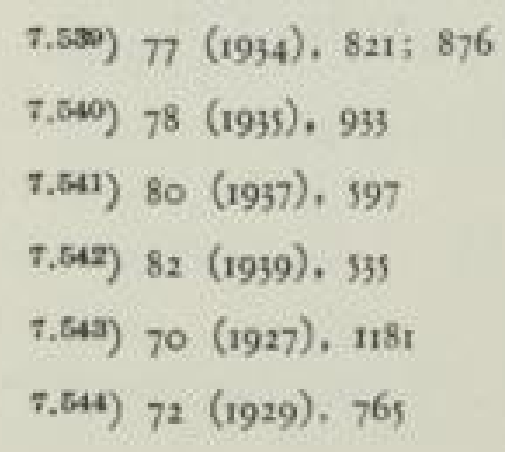


schob er den Bezirksschornsteinfegermeistern zu, die aber manchmal reichlich voreingenommen gegen Gasheizung waren, da deren Abzüge scheinbar keiner Aufsicht durch den Schornsteinfeger bedurften. Erst als durch Aussprachen mit den Innungsverbänden die Aufsicht über Gasabzüge - Schornsteinpflege - vom Gasfach ausdrücklich verlangt wurde, änderte sich allmählich die Einstellung der Meister $\left.{ }^{7.65}\right)$. Vor dem erwähnten Erlał̧ des Wohlfahrtsministers war in Preuß̧en eine Bresche in die Polizeibestimmungen gelegt worden.

E. Me yer, Dresden, hatte durch umfangreiche Arbeiten zur ermitteln versucht, unter welchen Bedingungen Explosionen in Schornsteinen zustande kommen konnten. Das Ergebnis war für die Gaswerke erfreulich, denn nach sorgfältiger Herstellung eines hoch explosiblen Gasgemisches puffte das Abgas harmlos oben zum Schornstein aus. Es fehlte die für Zerstörungen notwendige Verdämmung ${ }^{7.36}$ ). Auch Versuche der Gasbetriebsgesellschaft, Berlin, den bestgeeigneten Schornstein herauszufinden, gaben das gleiche Ergebnis. Die Vorschriften der Baubehörden hatten zudem eine Lücke, da nach dem bestehenden Verfahren der Bauherr nicht gezwungen werden konnte, im Bauplan vorgesehene Schornsteine wirklich auszuführen ${ }^{7.37}$ ).

Die Abgasabsaugung unter Flur durch Gebläse wurde durch C. Meurer A.-G., Cossebaude, sehr sorgfältig entwickelt. Sie hatie besondere Bedeutung für Kirchen, wo Abzüge nach oben unschön wirkten, ist aber auch für grołe Hallen (Leipziger Messe) mit Erfolg gebaut worden ${ }^{\text {tits }}$ ).

Unruhe brachte die Forderung E. $S c b u m a c b e r s$, München, wie es erfolgreich beim Badeofen geschehen war, in Gasheizöfen eine Rückstromsicherung einzubauen. Nach ihren Erfahrungen lehnte sich C. Meurer A.-G. dagegen auf, zumal der Ofenbetrieb nur in kaltem Wetter mit längeren Heizzeiten viel günstiger lag, als bei Badeöfen. Man hatte auch erkannt, dał̧ Abzugstörungen völlig vermieden wurden, wenn man den Wirkungsgrad bei Heizöfen nicht zu hoch züchtete $\left.^{7.540}\right)$. Bei den Elementöfen war auch eine Rückstromsicherung nicht leicht unterzubringen. Nun lieferten die Askaniawerke A.-G. schon ihren Glühkörperofen seit 1930 so, dał rückströmendes Abgas unten am Ofen, ohne die Brenner zu stören, austreten konnte. Dort wurde dann auch von C. Meurer eine ähnlich gebaute Sicherung angebracht ${ }^{7.450}$ ).

Die Beschäftigung mit Windeinflüssen auf den Schornstein wurde fortgesetzt. L. Rodde, Stettin, übertrug wohl als erster die in der Flugtechnik ausgebildeten Verfahren an einem mit Bärlappsamen bestreuten Wasserstrom die Stromlinien zu erkennen, auf die Schornsteinmündungen $\left.{ }^{7.051}\right)$. A. Albrecbt stellte eine Fülle von ausgezeichneten, lehrreichen Bildern zusammen.

Die Gasverwendung bei Zentralheizungen suchte J. Körting, Dessau, mit allen Mitteln unter Ausnützung der gegebenen Preise, nicht mit der Forderung nach

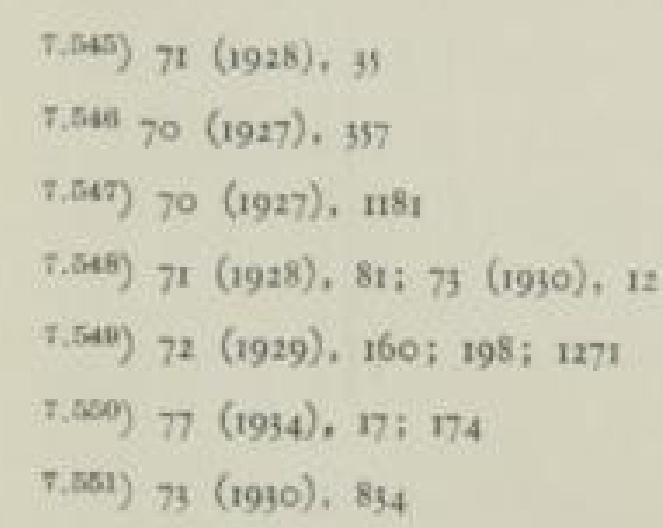


billigerer Gaslieferung einzuführen. Er behandelte wiederholt den Einfluf der Feuerung auf die Gestaltung der Heizungsanlage, um zu klären, dał, warum und wie die Anlagen aufgeteilt werden müften, um bei ausreichenden Preisen, erfolgreich arbeiten zu können ${ }^{7.552}$ ). Richtig verstanden wurde Körting nur von den belgischen Gasfachleuten, die zeitweilig mit einem ungeheuren Draufgängertum arbeiteten $\left.{ }^{7.533}\right)$. Meistens wurde der Fehler begangen, zu grołe Kesseleinheiten zu wählen, ja überhaupt statt der Vielzahl kleiner Anlagen grołe Bürohäuser, Hotels u. ä, mit Gas zu beheizen, und danach ungünstige Äquivalenzzahlen zu verbreiten $\left.{ }^{7.554}\right)$. Daß die Abgasabführung der Kesselanlagen im Gegensatz zur Einzelofenheizung viel leichter zu lösen war, selbst bei hohen Kesselwirkungsgraden wurde zu wenig bewertet.

Gebläseluftheizer mit Gasfeuerung wurden vor allem für grołe Arbeitshallen gern eingebaut. Viele verschiedene Firmen hatten ihre eigenen Bauarten, teils ausgezeichnet ausgewogen hinsichtlich Wärmeübergang, teils aber auch unzuverlässig mit Schwitzwasserbildung. Die von J. Körting in der Giełerei der Askaniawerke eingerichtete Gebläseluftheizung mit Gasdampfkesseln, die sich sehr zum Erstaunen der Gas- und Gieß̧ereifachleute durchaus wirtschaftlich und staubfrei führen lieł, dürfte wohl die einzige preiswerte Heizungsanlage für diesen Zweck geblieben sein. An sich waren mit lautlos arbeitenden Motoren und Gebläsen alle Mittel da, um die Stockwerksheizung mit Gas in vollendeter Form, in Anlehnung an die Klimatechnik zu schaffen $\left.{ }^{7.555}\right)$. Es fehlten aber in der seit ${ }_{1938}$ herrschenden Hochkonjunktur die Männer, die diese Aufgabe zu übernehmen bereit waren. Ja, es wurden sogar die Richtsätze, nach denen - natürlich ohne Berücksichtigung bisher unausgeschöpfter technischer Möglichkeiten - die Wohnungen nach dem Willen der Regierung hergestellt werden sollten, als Abweisungsgrund entgegengehalten.

Gründlich täuschte man sich auch im Gasfach über die Möglichkeiten, mit Ferngas die Heizung mit Gas allgemeiner werden zu lassen $\left.{ }^{7.550}\right)$. Selbstverständlich waren in der Nähe der Zechen sehr viele Heizanlagen entstanden, aber je länger der Weg wurde, umso unangenehmer war die Heizungsbelastung mit ihren grołen und vom Wetter abhängigen, unregelmäfigen Spitzen, so dał gerade die Ferngasgesellschaften auf diesem Gebiete sehr vorsichtig sein muften.

Zum Schluß̧ mag noch erwähnt sein, daß Strahlungsheizer für groß̧e Hallen im benachbarten Auslande in vielen verschiedenen Ausführungsarten Eingang fan$\operatorname{den}^{7.50 \pi 7}$ ). Der Nachteil, dał hierzu ein erhöhter Gemischdruck erforderlich zu sein schien, wurde erkannt und von mehreren Seiten angegriffen $\left.{ }^{7.35}\right)$. Auch G. $S c h w$ ank arbeitete zuerst im französischen Elsał an einer erfolgreichen Lösung. Die Arbeiten der Askaniawerke, im gleichen Sinne, kamen schon früher zum Erliegen, als die Führung des Dessauer Werkes in andere Hände überging.

\footnotetext{
$7, \operatorname{5ra}) 70(1927), 376 ; 889$

7..559) $82(1959), 766$

$7.054) 81(1938), 75: 82(1939), 91$

7.655) 81 (1938), 314

7.566) 82 (1939), 91 ff.

7.557) 79 (1936), 445

7.655) $81(1938), 172$
} 


\subsection{Gewerbliches Gas}

Eine umfassende Darstellung mit allen Einzelheiten über die Arbcit zu geben, die an vielen Stellen gleichzeitig, sich geradezu überstürzend geleistet wurde, ist leider im Rahmen dieser allgemeinen Geschichte unmöglich. Die Gaswerke wandten sich dem gewerblichen und kleinindustriellen Absatz $\left.\mathrm{zu}^{7.550}\right)$. Sie gaben durch Erfahrungsaustausch vor allem auch über die Zentrale für Gasverwertung viele Anregungen zu Verbesserungen. Die Ferngasversorgungsunternehmen wid meten sich den Großverbrauchern in vorzüglicher Weise. Daneben arbeiteten aber gerade in der Grofindustrie die Abnehmer selbst daran mit, aus dem Gaseinsatz nun auch das Beste an Wärme aber auch in der Verbesserung der Erzeugnisse herauszuholen und dabei an Löhnen zu sparen. Ihnen zur Seite standen, vielfach die Grundlagen erforschend, die Wärmestellen. Allen voran darf man wohl die des Vereins deutscher Eisenhüttenleute nennen, die dank der Fähigkeiten ihres Leiters, Prof. K. $R u m m e l$, bald die Wissenschaft um die Gasverwendung im Eisenhüttenwesen völlig geschlossen aufbaute, unterstützt durch die lebhafte Arbeit der Ausschüsse des Vereins. Namen wie A. $S c b a c k$, W. Heiligenstaedt, W. Eilender mag man herausgreifen, ohne den vielen anderen, die mitarbeiteten, Unrecht zu tun. Aber auch andere Industrien griffen zu. Auch da mag herausgegriffen sein: die Hüttentechnische Vereinigung der deutschen Glasindustrie mit H. Mauracb. Frankfurt a. M. Natülich wurden auch die Ofenbaufirmen, grołe und kleine, zu regster Tätigkeit angeregt. Für den Ruhrbezirk mag der Name von $\mathrm{O}$. Wo olff, Essen, für viele stehen.

Will man die Leistung der deutschen Gasındustrie an der Steigerung der Gasverwendung für industrielle Zwecke aus dem Schrifttum ermitteln, so fällt vor allem auf, daß ihr eine umfangreiche und vielseitige Aufklärung aller derer, die mit Öfen zu tun hatten, oblag. Wenn ein Ofen sich bei den üblichen Brennstoffen bewährt hatte, war er noch bei weitem nicht für Gasverwendung geeignet. Deshalb begann man von Gasfachseite mit den grundlegenden Fragen des Ofenwirkungsgrades und dessen Gütegrades. Immer wieder wurden einfache Ofenbilanzen mit dem Vergleich von festen und gasförmigen Brennstoffen veröffentlicht. Um die Mitte der dreifiger Jahre wurden die Einflüsse der Feuerführung dargelegt. Ein Brennstoff, der bequem an den Ofen herangeführt wird, wird auch leicht verschwendet, denn beim festen Brennstoff mahnt schon die Schürarbeit, der Antransport des Brennstoffes und die Beseitigung der Asche aus dem Betriebe zur Einschränkung. Die zunächst zur Einführung gewährten dem Wärmewert entsprechenden Gaspreise des „Abfallgases“ der Koksöfen waren unter solchen Umständen dann noch enttäuschend. Danach wandte sich die Erziehung der Gasindustrie dem richtigen Aufbau der Öfen zu. Vor allem muf3ten die neuentwickelten wärmedämmenden Leichtsteine, die auch weniger Wärme speicherten, bekannt gemacht werden. Diese Eigenschaft war bei täglich unterbrochenem Betriebe von groß̧em Einfluf. Auch die Rekuperation, d. h. die Rückführung des für den Schornstein unnötigen Wärmeinhaltes der Abgase zur Vorwärmung der Luft, muftte erklärt werden. Bei dem sauberen Abgas war sie leichter zu erreichen, als beim Ruf und Staub tragenden Abgas der bisherigen Brennstoffe.

7.3019) $76(1933), 273 ; 77(1934) \cdot 349 ; 79(1936), 398$ 
Vor allem muf̧te die Regelbarkeit erst voll erfaf̧t werden. Regler für Industrieöfen sind in der Anschaffung nicht billig. Sie lohnen sich aber, weil nicht nur unnötige Temperaturen, unvollkommene Verbrennung oder zu hohe Luftbeigaben vermieden werden. Sie sind es, die der Verschwendung infolge von Bequemlichkeit des zugeführten Brennstoffes entgegentreten können. Zuletzt muf̧te aber auch noch auf die Vorteile der vollen Auslastung der Öfen aufmerksam gemacht werden. Der Gasberater der Versorgungsunternehmen mußzte ganze Fertigungsprogramme entwerfen. Am allerschwersten aber wurde die Aufgabe zu beweisen, daf̧ der neue Brennstoff oítmals eine Änderung dei üblichen Technologie erforderlich machte. Der beratende Ingenieur mufte sich in die Anforderungen des Verfahrens einarbeiten und den Abnehmer überzeugen, wie es besser zu machen sei. Aus all diesen Gründen überwog die persönliche Beratung in jedem einzelnen Falle, die der allgemeinen Gesichtspunkte. Die Gasindustrie hat auf diese Weise in den Jahren zwischen den beiden grołen Kriegen eine ungeheure Arbeit mit steigendem Erfolg geleistet. W. Trinks kennzeichnet im Vorwort der deutschen Ubersetzung seines Buches: Der Industrieofenbau, Berlin 1928 VDI-Verlag die Lage: „Amerikanische Urteile hielten das Buch im allgemeinen für zu theoretisch, während verschiedene deutsche Kritiker erklärten, dał es zu einseitig auf die Bedürfnisse der Praxis eingestellt sei... Vom Standpunkte der heutigen wissenschaftlichen Erkenntnisse aus entbehrt das letztere Urteil nicht einer gewissen Berechtigung, weil in den letzten Jahren auf dem Gebiete des Wärmeflusses und der Festigkeit von Baustoffen bei hohen Temperaturen grofe Fortschritte gemacht worden sind. Trotz dieses gelegentlichen Nacheilens ist das vorliegende Buch grundlegend für das Berechnen und Entwerfen von Industrieöfen. Es hat viel dazu beigetragen, mit der Geheimniskrämerei im Ofenbau aufzuräumen und wird hoffentlich in dieser Hinsicht noch weiterhin von Nutzen $\left.\operatorname{sein}^{7.500}\right)$." Nun, ein voller Erfolg ist in dieser Hinsicht damals noch nicht erreicht worden. Das lag aber nicht allein an dem Bestreben möglichst viel geheim zu halten, sondern auch an der erwähnten Tatsache, daf̧ gerade in der Industrie jeder einzelne Anwendungsfall für sich behandelt werden muf3. Die Notwendigkeit aber, einen gasgefeuerten Ofen nicht allein nach allgemeinen Erfahrungen zu entwerfen, sondern die grundlegenden der Berechnung zugänglichen Ermittlungen auch tatsächlich rechnerisch im voraus zu bestimmen, wurde mehr und mehr zur Übung. Die Gasindustrie darf mit Recht für sich einen entscheidenden Anteil an dieser Aufgabe in Anspruch niehmen.

Das Gas war nach langem Ringen als vorzüglicher, sauberer, regelfähiger und zuverlässiger Helfer bei vielen schwierigen Aufgaben der Fertigung erkannt und anerkannt.

Neben den Großkküchen, deren Technik gründlich durchforscht werde ${ }^{7.51}$ ), wandten sich die Gaswerke der Bäckerei zu, auch wieder Klein- und Großbetriebe erfassend. Eine Bäckereifachausstellung in Essen zeigte noch alte schwere Öfen, auch Perkinsrohre mit Pref̧gasfeuerung, aber auch die neuen leichten Öfen, die mit besonderer Sorgfalt isoliert wurden $\left.{ }^{7.35}\right)$. Der bis dahin vielfach noch geübte Einbau von Gasbrennern in alte schwere Backöfen wurde endgültig als unwirt-

7.500) Gaswärme n $(1962), 56$

7.5ai) 70 (1927), 429. Vosswerke Sarstedt: Die Technik der GroBktiche, 1929 und 1936 Selbstverlag

$7.502) 70(1927), 1023,72(1929), 641 ; 669: 695$

550 
schaftlich verlassen. Den Zyklothermofen von Werner und Pflesderer, Stuttgart, darf man wohl als Markstein bezeichnen. In ihm war durch Umwälzung der Gase mit einem Gebläse die Lösung für den Wärmeübergang, der bei den industriell betrachtet - niedrigen Temperaturen konvektiv geschchen muf, gefun$\left.\operatorname{den}^{7.5 a 3}\right)$. Das Verfahren ist danach in vielen Wärmöfen, die unter ähnlichen Bedingungen arbeiten müssen, mit grofem wirtschaftlichem Erfolg angewandt worden. Der Ofen hatte nicht nur besonders entwickelte Brenner sondern auch Sicherheitseinrichtungen in einem damals noch nicht gekannten Ausmafe ${ }^{7.504}$ ). 1937 wurden bei einer Erhebung der Wirtschaftsgruppe Gas- und Wasserversorgung 862 Gasbacköfen mit 17,6 Mio $\mathrm{m}^{3}$ Gasverbrauch gezählt. Wegen der vielen Nebenarbeiten verbrauchten aber die deutschen Bäcker und Konditoren 58 Mio m im Jahre $\left.{ }^{7.5 m^{\prime}}\right)$.

In Fleischereien wurden Brühbottiche, Wurstkessel und Räucheröfen wegen der Sauberkeit gern mit Gas beheizt. Ein Kleinautoklav zur Fettgewinnung aus Knochen fand zeitweilig Beachtung $\left.{ }^{7.506}\right)$. Eine unermüdliche Kleinarbeit war notwendig. 1938 zählte man immerhin 20000 Fleischereibetriebe, die Gas verbrauchten, und zwar mit insgesamt 30 Mio $\mathrm{m}^{3}$ im Jahre ${ }^{7.367}$ ).

In der Groł̧wäscherei kam man nicht so durchschlagend zum Erfolg. Die grołen Wassermengen stellten einen guten Ausgleich bei den unvermeidlichen Schwankungen der Feuerung mit festen Brennstoffen. Die Sauberkeit wurde durch die Zwischenschaltung des Dampfes als Wärmeträger hinreichend wirtschaftlich erreicht. Groß̧bügelanlagen mit Pref̧gasfeuerung waren die ersten Angriffspunk$\left.\mathrm{te}^{7, \mathrm{san}}\right)$. Gasbefeuerte Bügelmaschinen wurden entwickelt, dann aber auch allmählich mit dem Brennereinbau verbessernd eingreifend, konnten die Gaswerke die Waschmaschinen als Abnehmer gewinnen ${ }^{7.50 m}$ ).

Von der großen Industrie lag die Eisen- und Stahlindustrie deutlich in der Führung. Zunächst muf̧ten auch dort, ganz ähnlich wie im Bäckergewerbe, die vorhandenen Ofen einfach mit neuen Brennern auf Gas umgestellt werden ${ }^{7.35 \%}$ ). Prefggasbrenner, bei denen man den Druck des angelieferten Ferngases zur Luftansaugung ausnutzen wollte, wurden zunachst gern genommen. Damit war abet wàrmetechnisch und für die Gleichmäßjigkeit des Betriebes nicht viel gewonnen. Schon bald gab es Verbesserungen. Vor allem beschäftigte man sich mit den Wärmeverlusten durch die Ofenwände und begann mit den wärmedämmenden Ausführungen ${ }^{7.077}$ ). Der Preßggasbrenner erhielt einen Wettbewerber im Pref̧luftbrenner, bei dem eine vielmals genauere Einstellung des besten Gasluftverhältnisses möglich und dauernd zu halten war $\left.{ }^{7.372}\right)$. Diese Brenner ergaben auch die Möglichkeit, die Verbrennungsluft durch die Abgase in Rekuperatoren vorzu-

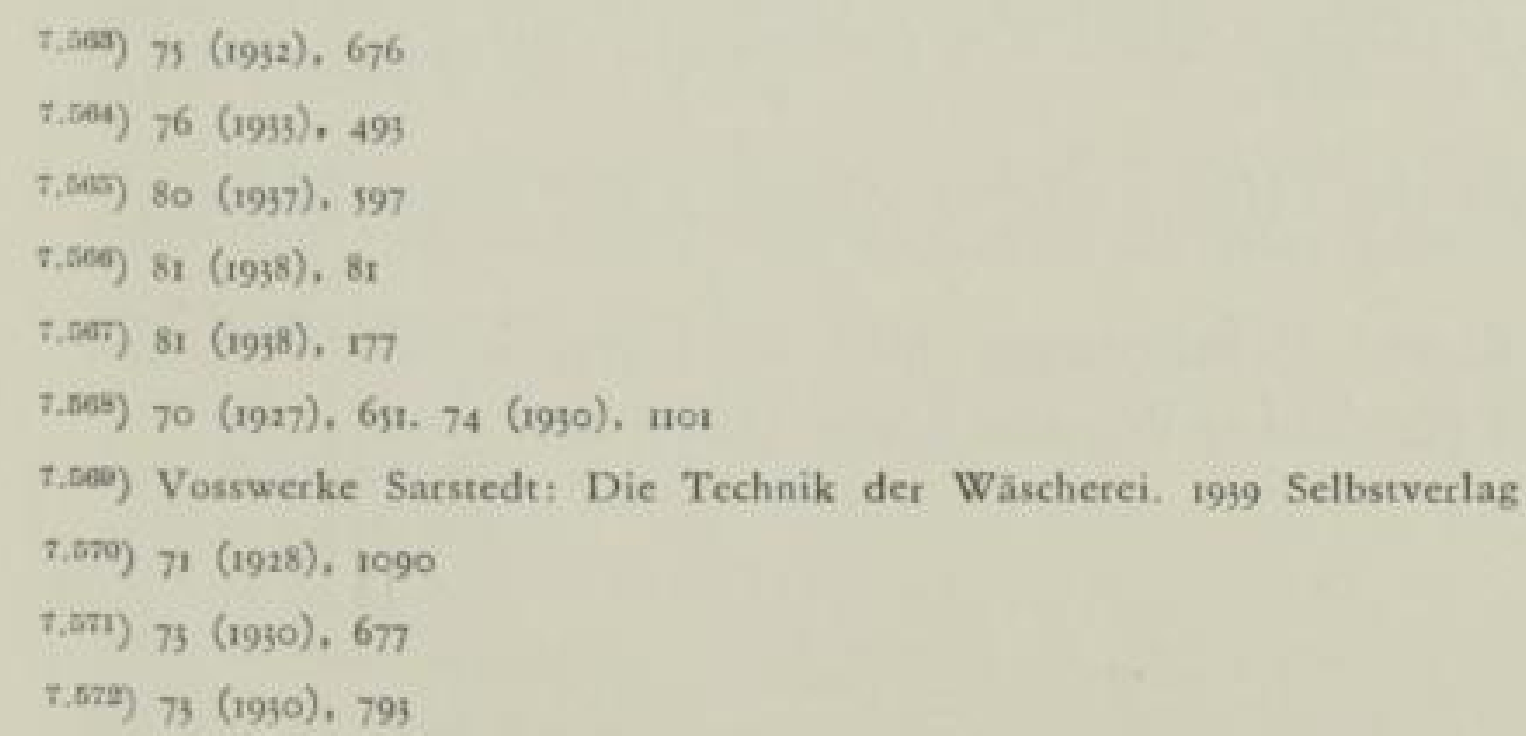


wärmen. Diese muf̧ten allerdings, um wirtschaftlich zu sein, Lufttemperaturen von $400^{\circ} \mathrm{C}$ zum mindesten erreichen ${ }^{7.573}$ ).

Die Aufgabe war nicht leicht zu lösen, insbesondere bei nur schichtweise betriebenen Ofen. Um überhaupt zuerst bei den vorhandenen Öfen wirtschaftlich anzukommen, muften ja die Gaspreise sehr niedrig gehalten werden. Dann aber lohnte sich die Ersparnis wegen der zusätzlichen Bau- und Betriebskosten der Rekuperatoren wieder nicht. Der Verfasser hatte damals mit einem der besten Ofenbauer geradezu einen Ringkampf um die Lieferung von Rekuperatoren für kleine Glühöfen. Erst als er erklärte, dał das grołe Gaswerk die Baukosten für den Zusatz übernehmen würde, um mit einem ortsüblichen höheren Preise an die Gasverwendung zu kommen, wurde die Lieferung zugesagt.

Inzwischen beschäftigten sich mehrere fähige Ingenieure mit der Verbesserung des Wärmeüberganges vom Gas auf das Wärmgut. In Siemens-Martinöfen war eine Karburierung des Kokereigases notwendig, in langen Blockwärmeöfen erwies sie sich als unnütz. Billiger war die Verwendung einer Mischung aus Generatorgas und Kokereigas in Siemens-Martinöfen.

1935 bewicsen Vorträge der Energietagung Gas in Essen, daf3 man bereits recht weit gekommen war mit den Verbesserungen und vor allem mit den Kenntnissen, in welcher Richtung man weiterarbeiten muf3te $\left.{ }^{7.574}\right)$. W. Robland, Krefeld, faß̧te in einem Vortrage auf der Hauptversammlung des Deutschen Vereins in Leipzig nach seinen Erfahrungen in der Edelstahlindustrie die acht wärmetechnischen, technologischen und arbeitsmäfrigen Vorzüge in einer Art zusammen, daf̧ sie heute noch als vollgültig betrachtet werden können ${ }^{\text {T.5.5. }}$ ). Sie sind inzwischen Allgemeingut der Industriegaswerber geworden:

I. Äuß̧erste Regelfähigkeit der Öfen, zum Teil vollelektrisch bei gleichzeitig gröłter Gleichmäßjigkeit der Temperaturen. Hierdurch Verminderung des Ausschusses, Steigerung der Qualität und gröłere Produktionssicherheit.

2. Verwendungsmöglichkeit von vollmechanischen und auch von transportablen Öfen (Luftumwälzöfen).

3. Geringerer Raumbedarf und höhere Leistungsfähigkeit der Ofeneinheit.

4. Ersparnis an Baumaterialien durch Fortfall der groß̧en Verbrennungsräume, der Abuzgskanäle und der Schorristeine; dazu größ̧ere Lebensdauer der Öfen.

5. Einfache Transportfähigkeit und Verteilungsmöglichkeit unter Wegfall jedes Kohle- und Aschetransportes und aller Bunkeranlagen. Einfache Ofenbedienung.

6. Sauberkeit und Übersichtlichkeit der Betriebe sowie bessere Lüftung, verbunden mit höherer Leistung der Gefolgschaft.

7. Dauernde Kontroll- und Mełzmöglichkeit des Brennstoffverbrauches eines jeden Ofens.

8. Gröłte Anpassungsfähigkeit der Öfen an Schwankungen der Beschäftigung.

Ein besonders klares Bild dieser Erfahrungen gibt Bild ${ }_{1} 9$, in der die Entwicklung der Verhältnisse des Krefelder Werkes festgehalten ist.

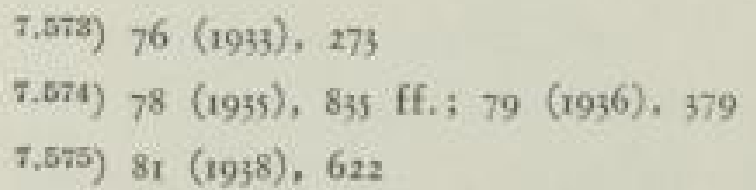


Bild ng

Entwicklung des

Krefclder Stahlwerkes

(GWF 81 [1938] S. 625)

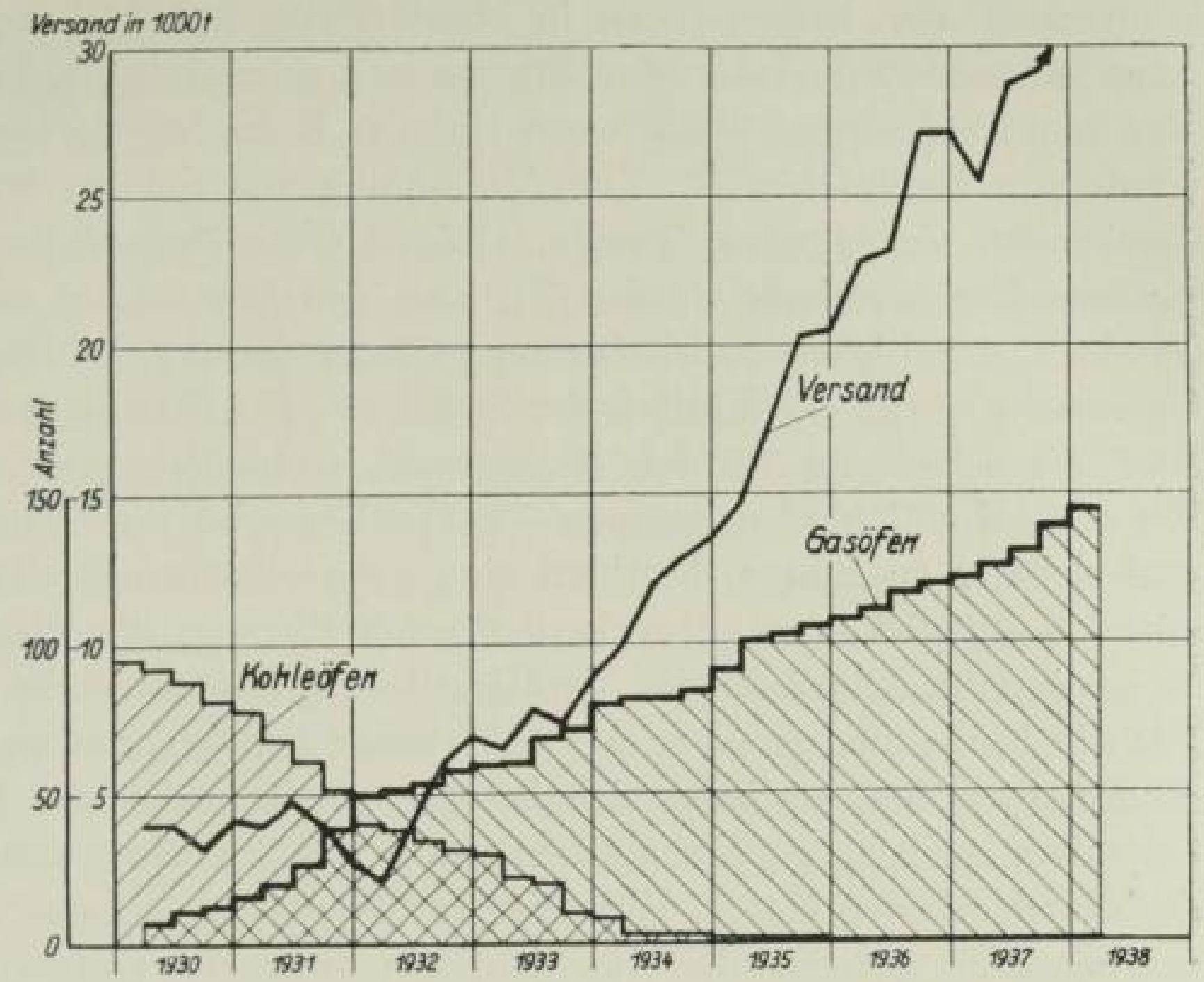

1930 besafy es fast roo kohle- und generatorgasfeuerte Öfen, die einen Versand von $4000 \mathrm{t}$ zu bewältigen hatten,

I93I stieg bei stärkstem Rückgang des Versandes die Zahl der gasgefeuerten Öfen am schnellsten.

1935 erzielte man mit 100 gasgefeuerten Öfen einen Versand von is $000 \mathrm{t}$, also fast das Vierfache von 1930.

1938 wurde bei nicht ganz I5O gasgefeuerten Öfen einen Versand von mehr als 30000 t erreicht.

"Ich glaube“, so sagte Rohland, „es erübrigt sich, diesen Zahlen noch etwas hinzuzufügen. Berücksichtigen Sie hierbei nur noch, daf̧ wir in Krefeld heute rd. ro Mio $\mathrm{m}^{3}$ Gas im Monat gebrauchen. Der Transport dieser Energiemenge in Form von Kohle würde für unser Werk heute ein Problem sein; für den Gastransport benötigen wir lediglich eine Leitung von $300 \mathrm{~mm}$ lichter Weite“.

Dic erste Nachricht vom Strahlrohrofen nach Lee-Wilson findet man im Iron Age ${ }_{13} 6$ (1935) S. $26^{7.350}$ ). Er war mit abnehmbarer Haube ausgeführt ${ }^{7,577}$ ). Ein anderer Strahlrohrofen war zum Emaillieren bestimmt ${ }^{7.577}$ ).

Die Oberflächenhärtung mit einer Flamme durch Azetylen-Sauerstoff und nachfolgendem Abschrecken wurde 1934 von der Griesheimer Autogen Verkaufs G. m. b. H. Frankfurt/Main vorgeführt ${ }^{\text {T.mag }}$ ). Ihre Umstellung auf Stadtgas-Sauerstoff gelang Ferd. Pedding $b$ a us, Gevelsberg. Er wurde unterstützt durch H. W. Grönegress, der in der Bezirksstelle Essen der Zentrale für Gasverwertung tätig $\left.\mathrm{var}^{7.350}\right)$. Sie erlangte als Maschinenhärtung sehr rasch eine allgemeine Bedeutung.

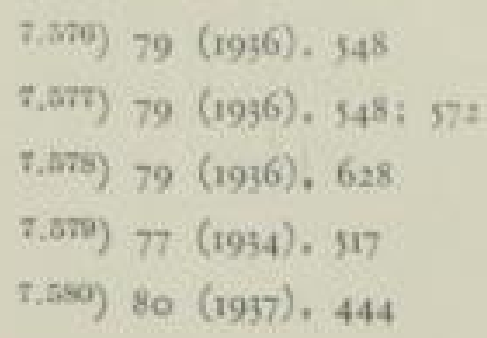

\section{SLUB}


Schutzgasanlagen kamen zuerst in Nordamerika auf. Nebeneinander wurde die Ammoniakzersetzung oder Methanzersetzung entwickelt $\left.{ }^{7.581}\right)$. Ein Durchgangsglühofen zum zunderfreien Gluhen von Hahn \& Kolb, Stuttgart, nach System Harter wurde 1931 beschrieben...5sz). Zur Aufkohlung von Stählen benutzte die Surface Combustion Corporation, Toledo, Ohio, Verbrennungsabgase, die mit Kohlenwasserstoffen vermischt wurden $\left.{ }^{7,858}\right)$. Die Verfahren regten auch in Deutschland zu einer gründlichen Beschäftigung mit der Randentkohlung von Stählen an. Untersucht wurde der Einfluß der Stahlsorte, der Flammenart und der Zeit. Als mögliche Schutzgase wurden Wasserstoff, Kohlenmonoxyd und Gemische aus Wasserstoff und Methan genannt $\left.{ }^{7.585}\right)$. Die Versuche, die Verfahren zu verbessern und sicherer zu führen, brachten eine ganz allgemein wertvolle Beschäftigung mit den Möglichkeiten der physikalischen Chemie, die Wirkungen im Voraus zu bestimmen. Die Zahl der Veröffentlichungen wurde sehr grof $\left.{ }^{7.585}\right)$.

Für die Einhaltung genauer atmosphärischer Bedingungen und Temperaturen im Innern des Ofens erwiesen sich langgebaute Tunnel- oder Durchgangsöfen als besonders geeignet, ganz abgesehen von den Wärmeeinsparungen im Gegenstrom des Gutes mit den Gasen. Ein Ofen zur Wärmebehandlung von Kraftwagenachsen mit drei nacheinander durchlaufenen temperaturgesteuerten Zonen fiel als erster auf $\left.{ }^{7.560}\right)$. Durchlaufemaillieröfen mit Niederdruckgasbrennern kamen auch von Nordamerika ${ }^{7.57}$ ). Der erste Ofen dieser Art in Europa wurde in Falkirk (England) aufgestellt. Er hatte $43 \mathrm{~m}$ Baulänge ${ }^{7,585}$ ).

In der keramischen Industrie war die wirtschaftliche Möglichkeit, mit Starkgas zu fahren, fast ausschlief̧lich an den Tunnelofen gebunden $\left.{ }^{7.580}\right)$. Die Umstellung alter Rundöfen auf Gas in Waldenburg war trotz der sichereren Führung und des Fortfalls der Kapseln nur durch sehr niedrige Freise möglich ${ }^{7.500}$ ).

Die ersten Versuche, Farben und Lacke durch Strahlung schnell zu trocknen, wurden mit offenen Gasflammen vorgenommen. Es konnte sich also nur um ungefährliche Zusätze zur Farbe handeln ${ }^{7.501}$ ).

\subsection{Regler und Sicberbeitseinricbtungen}

Einen Abschnitt für sich könnte die Entwicklung der Regelanlagen bilden, wenn nicht auch diese Technik zu weit vom allgemeinen Thema abläge. Äuß̧erst vielseitig wurde die Ausbildung der elektrischen Temperaturregler für Gasöfen, die als Fühler Widerstandsthermometer oder Strahlungspyrometer benutzten und

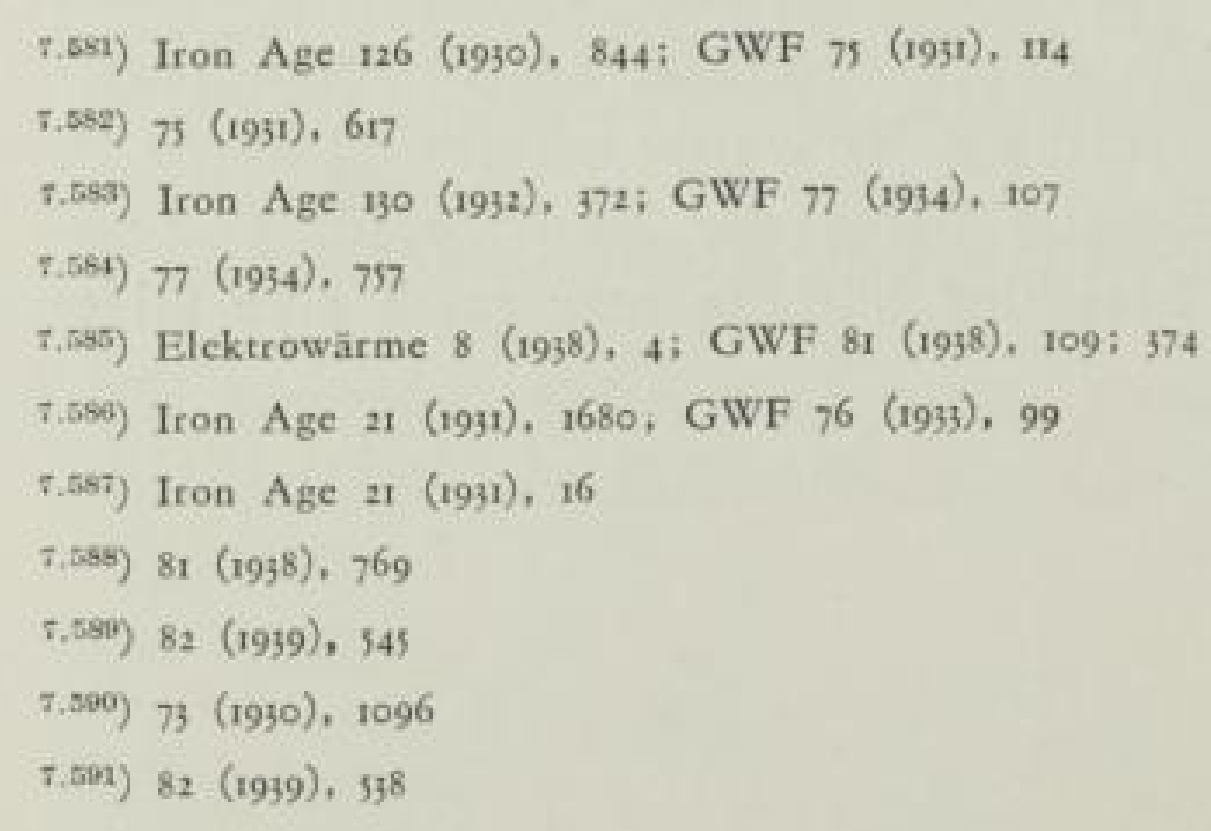


meistens als Fallbügelgeräte sich an die Galvanometeranzeiger anschlossen. Damit konnten auch Programmregelungen vorgenommen werden $\left.{ }^{\text {7.5ng }}\right)$. Druck- und Gemischregler wurden mit Vorteil verwendet, um gleichmäßjige Arbeit zu erreichen.

Zur Sicherung stützte man sich auf die für Hausgeräte entwickelten Zündsicherungen. Bimetallstreifen, auch die Bimetallklixonscheibe und Ausdehnungsstäbe wurden 1928 erwähnt $\left.^{\text {T.sons }}\right)$. Der Sicherheitsgasschalter von Bosch, Stuttgart, erschien 1934 in der Offentlichkeit, gut beurteilt vom Chemiker E. Fre i, Hamburg $\left.{ }^{7.58}\right)$. Gleichzeitig wurde die erste deutsche Magnetsicherung, verbunden mit einem Thermoelement, von den Askaniawerken bekanntgegeben $\left.{ }^{7.505}\right)$. Da sie die Zündflamme nicht mit absicherte, stief̧ sie auf Kritik des deutschen Gasfaches, setzte sich aber trotzdem auch bei Ofen durch, insbesondere in Nordamerika. Der „Regulo” von G. Kromschröder, Osnabrück, ließ̧ sich schnell mit einer Zündflammensicherung versehen ${ }^{7,390}$ ).

Vorschriften für die Prüfung von trockenen Gasdruckreglern für Häuser und Wohnungen erschienen $\left.193^{7.5 n}\right)$.

\subsection{B EHOORDLICHE EINGRIFFE UND VOR SCHR IF TEN}

Angesichts der sich allmählich vermehrenden und verschärfenden behördlichen Eingriffe in die Technik wäre es naheliegend, auch darüber eine geschlossene Darstellung zu geben. Es wäre aber notwendig, dabei auch von Begründungen und Kritiken zu berichten, die sich leichter in den einzelnen Abschnitten aus der allgemeinen Besprechung ergaben. Die Angaben sind also auf die einzelnen Abschnitte verstreut, können aber mit Hilfe des Registers gefunden werden.

Falsch wäre der Eindruck, als ob diese Eingriffe erst mit dem Regierungssystem der gelenkten Wirtschaft nach 1933 entstanden wären, oder in freiheitlichen Staatsverfassungen nicht vorgekommen wären. Alle Länder sahen sich gezwungen, in der einen oder anderen Weise mehr oder weniger streng einzugreifen. Die Geschichtsdarstellung mufte bereits erwähnen, wie streng und einschneidend für die Technik die Staatsaufsicht gerade das Gasfach im liberalen England traf. Auch wie die Fülle der Richtlinien, Vorschriften und Normen des Faches aus der Abwehr oder Mäßjigung und technischen Berichtigung irgendwelcher Eingriffe der Aufsichts- insbesondere der Baubehörden in Deutschland entstanden ist, wurde von Fall zu Fall gezeigt. Man mag den Weg, der gegangen wurde, für unvermeidlich ansehen. Daf die technischen Fortschritte in manchen Fällen gefördert, in anderen auch gehemmt wurden, unterliegt aber keinem Zweifel.

Auf der Weltkraftkonferenz setzte man sich, angeregt durch die deutsche Delegation, überwiegend mit den in der Energiewirtschaft in den verschiedenen Ländern getroffenen Maßznahmen auseinander. (Staatliche Eingriffe Roosevelts mit

\footnotetext{
$7.502) 75(1931), 801$

$7.503) 71(1928), 697$

7.504) $77(1934), 19: 25$

$7 . \operatorname{sic}) 77(1934), 112$

$7.6007) 78$ (1935), 196; 633

(7.)
} 
der Tennessee Valley Corporation, Englisches Elektrizitätsgesetz, französische Bestimmungen $\left.{ }^{-35}\right)$. Die geschichtlichen Betrachtungen zum Energiewirtschaftsgesetz, lagen in der Richtung eines Rechtfertigungsversuches. Schon 1908 habe der Reichsbankpräsident eine Reichsaufsicht über die Elektrizitätsversorgung verlangt, die starken Reichsbeteiligungen im Kriege und Forderungen nach Sozialisierung wurden hervorgeholt $\left.{ }^{7.550}\right)$. 1927 sei Oskar von Miller mit einer Planung beauftragt worden. Das Gas interessierte erst nach Veröffentlichung der Ruhrgaspläne. Das Energiewirtschaftsgesetz greife aber den Besitz nicht an. Besitz mit vielen Arbeitsbeschränkungen war aber entwertet worden. Das wurde verschwiegen.

Andrerseits wurden die Behörden und Parteistellen aber auch von irgendwelchen Gruppen gedrängt einzugreifen. Ein klares Beispiel aus dem Gasfach möge eingeschaltet sein :

Nach 1933 häuften sich Erfindungen über Anzeigegeräte für gefährliche Gasausströmungen. Fast alle diese Einrichtungen benutzten als Auslöser Platinmohr, dessen Wirksamkeit in jedem Falle durch Küchendünste (Fettdämpfe) vernichtet wurde. Der Reichsarbeitsminister, inwiefern gerade er auf diesem Gebiete zuständig war, ist schwer einzusehen, kam dann am 13. 12. 38 mit einem Erlał heraus: Die Chemisch-technische Reichsanstalt habe sich bereit erklärt, Untersuchungen anzustellen. Einzelne Geräte für Leuchtgas und eine Reihe Giftgase seien bereits untersucht und zum Teil als geeignet befunden worden. (Das Gasinstitut hatte trotz zahlreicher Versuche in vielen Jahren ein solches Glück nicht gehabt). Mit dieser Möglichikeit der Prüfung in einer staatlichen Versuchsanstalt seien die Voraussetzungen zur Herstellung und zum Gebrauch ennwandfreier Geräte zunächst in ausreichenden Maß̧e geschaffen. In Haushaltungen sei die zwangsweise Einführung zum mindesten verfrüht.

Man erkennt eine grundsätzlich veränderte Einstellung gegenüber der Zeit vor 1933, in der die technische Entwicklung und sachverständige Prüfung vom Gasfach in Selbstbeaufsichtigung ihren Schwerpunkt hatte. Dabei war aber in einigen Sondergebieten mit den staatlichen Anstalten zusammengearbeitet worden (Eichwesen, Lichtmessung). Die Erwartung, daß3 staatliche Anstalten ex officio ein besseres Urteil haben müften, ist umso verwunderlicher, als die Vielseitigkeit der an sie herantretenden Aufgaben sicher schnell größger ist als bei einem Fachinstitut.

Nach einem weiteren Jahre urteilte dann auch das Reichsarbeitsministerium, sicherlich vom Gasfach unter der Hand unterrichtet, viel klaret und neue Wege weisend. Es verwahrte sich gegen Zumutungen, Alarmgeräte für verbindlich zu erklären, denn es gäbe auch andere Mittel zur Sicherung, nämlich Aufklärung, Entgiftung des Gases, Ersatz alter Geräte, Verbesserung der Installation und Zünd- und Druckmangelsicherungen ${ }^{\text {T..mo }}$.

Mit der Aufstellung der Normen war das Gasfach den Erfahrungen des Deutschen Normenausschusses gefolgt, der die Verantwortung für die Beachtung der Normen dem Benutzer des als Marke geschützten DIN-Zeichens aufbürdete.

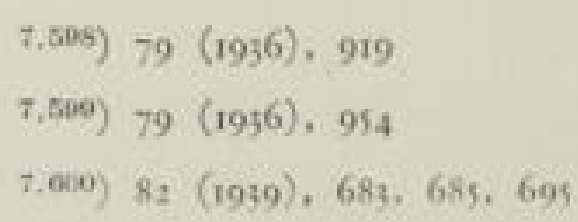


Das wurde auch bei der Einführung der Prüf- und Qualitätsmarke mit dem geschützten Zeichen DIN-DVGW eingehalten und durch Abkommen des Vereins mit der Fabrikantenvereinigung sorg eältig unterbaut $^{7.001}$ ). Deutschland war damit einerseits freiheitlicher als die anderen Gasländer, wo die Prüfmarke erzwungen wurde, andrerseits strenger, da die Prüfmanke keine Gewährleistung der prüfenden Stelle aussprach. Dies hat in anderen Ländern zur Daueraufsicht geführt. Leider sind diese Grundsätze neuerdings sichtlich verwässert worden.

Dał aber allein mit der überreichlichen Aufstellung von Normen der Verwaltung ein Anreiz zum Hineinbefehlen gegeben wurde, zeigte die Ermächtigung des Reichswirtschaftsministers in der Person des Generals Göring (ab 8. 9. 1939) die Verbindlichkeit von Normen, Geschäfts- und Lieferbedingungen, Güte- und Bezeichnungsvorschriften für die gewerbliche Wirtschaft oder einzelne Wirtschaftszweige anzuordnen. Die Befugnis konnte anderen Stellen übertragen und die Befolgung mit Strafen erzwungen werden ${ }^{7.007}$ ).

\footnotetext{
7.601) 77 (1934). 391
}

7.002) 82 (1919), 672

\section{SLUB}




\section{VON 1939 BIS 1960}

Wenn man Geschicht schreibt, mufy man sich hüten, mit seinem Urteil den Anschauungen des Augenblicks zu erliegen. Sie können durch plötzliche Umschwünge, sei es in der Politik, sei es bei der angewandten Technik durch den Wirtschaftsverlauf, völlig geändert werden. Schon im Abschnitt 7 haben Rücksichtnahmen auf die gegenwärtige Lage, Arbeitsziele einzelner noch lebender Menschen oder Firmen die Darsteilung in zunehmendem Małe erschwert.

Es ist gute Übung, geschichtliche Werke nicht zu nahe an die Gegenwart heranzuführen. In diesem Sinne bestand auch die Absicht, diese Geschichte mit dem Beginn des zweiten Weltkrieges abzubrechen.

Einige sicherlich urteilsfähige Leser des Manuskriptes haben aber darauf hingewiesen, daf gerade im Gasfach, die letzten ro und ganz besonders 3 Jahre einen tiefgreifenden Umschwung in den Grundlagen der Facharbeit gebracht haben. Es wurde daraus gefolgert, daß̧ ein kurzgefałter Ausblick, die Verbindung der Historie mit der gegenwärtigen Entwicklung herstellen möge. Die Schwierigkeiten sind groß̧, die Konjunkturschwankungen durch äułere Einflüsse sind in Deutschland heftiger denn je gewesen. Aus all diesen Gründen können technische Einzelheiten nur soweit erläutert werden, dafł die grof̧e Linie sichtbar wird. Beispiele wird man allerdings nicht ganz unterdrücken können, weil es um technische Fragen geht. In der Auswahl ist aber kein Werturteil über die vielen nicht gebrachten Arbeiten enthalten. Eine Systematik lief sich bei dem zur Verfügung stehenden Raum nicht erreichen. Das Geschichtsbuch kann nicht zum Schluf ein Handbuch des Faches oder gar ein vollständiger Nachweis der Fachliteratur werden.

So mag denn versucht werden, mit dem folgenden dem geäufzerten Wunsche nachzukommen.

\section{I DIE ZEIT DES ZWEITEN WELTKRIEGES}

Während im ersten Weltkriege als Folge der unzureichenden wirtschaftlichen Vorbereitungen manches neue in den Gaswerken aufgebaut wurde, (Benzolgewinnung, erweiterter Wassergaszusatz u. a.) sind im zweiten die schon angelaufenen Arbeiten fortgeführt worden. Es entsprach auch dem Wesen der Machthaber, daf die natürliche Beunruhigung möglichst unterdrückt wurde. Am leichtesten waren die theoretischen Erwägungen über die Gasherstellung einschlief- 
lich der Untersuchungsmethoden weiter vorzutreiben $\left.{ }^{8.1}\right)$. Wir finden auch verschiedene Erörterungen über die rechnerische Bewertung der Gaskohlen ${ }^{8.2}$ ). $\mathrm{Zu}-$ sammenfassende Berichte über die Wasser- und Synthesegaserzeugung aus Braunkohlen, Steinkohlen und Torf ${ }^{8.5}$ ), insbesondere aber über Schwelgasanlagen ${ }^{5.4}$ ) und Hochdrucksauerstoffvergasung ${ }^{\text {s.F }}$ ) sind die Hauptthemen mehrerer Tagungen. Von bleibendem Werte waren aber sicherlich die verschiedenen Arbeiten über die Umwandlung der neuen Gase - Syntheserestgase u. a. - in Stadtgase ${ }^{\mathrm{vec}}$ ) weil sie die Gasfachleute mit den Möglichkeiten der Verfolgung der Vorgänge auf physikalisch-chemischen Berechnungswegen vertraut machten. Diese Dinge waren dem Durchschnitt der alten Ingenieure noch ungeläufig, sind aber eine Vorstufe gewesen, um sich in die Olspalttechnik einzuarbeiten, die heute für das Gasfach wichtig geworden ist. Über die Krackung von Ölen in Retorten, die mit feuerfesten Steinen ausgesetzt sind, konnte 194I aus Frankreich berichtet werden ${ }^{8.7}$ ). Allmählich machten sich aber doch die Kriegseinflüsse, Mangel an Kohlen und Baustoffen und die Beschäftigung mit Ersatzstoffen und Lagerung der Kohlen bemerkbar. Hierbei wurde auch die Wichtigkeit des richtigen Mahlens- und Mischens für die Kokseigenschaften erneut betont $\left.{ }^{5.5}\right)$. Um den notwendig gewordenen Veränderungen in der Zusammensetzung der Gase mit den Vorschriften nachzukommen, lebte die Beschäftigung mit den Brenneigenschaften auf $\left.{ }^{\circ}\right)$. Sie fand in neuen Richtlinien für die Gasbeschaffenheit mit der Ott- und Prüfbrennerzahl unter Fortlassung der Begrenzung des Gehaltes an Inerten ihren Niederschlag ${ }^{8.10}$ ). Das allgemeine Streben nach besserer Ausnützung der Kohlen und nach Verbreiterung der Kohlengrundlage wurde deutlich.

Bcrichte über den Fortschritt in den Werken findet man vereinzelt in der Nachkriegsliteratur. Sie durften offenbar während des Krieges wegen der Geheimhaltung von innerdeutschen Zuständen nicht veröffentlicht werden. H. S i e b el schrieb über die Schwierigkeiten und glückliche Durchführung der Wassergaserzeugung in den groł̧en Horizontal-Kammeröfen Kiels ${ }^{8.11}$ ).

Am 12. Nov. 1939 wurde Ferngas Sudetenland A.-G. mit dem Sitz in TeplitzSchönau gegründet ${ }^{8.12}$ ). Das Aktienkapital von zunächst s Mio RM lag zu $70 \%$ in den Händen der Gauselbstverwaltung und zu $30 \%$ bei der Thüringer Gasgesellschaft. Ihr Zweck war der Bau einer leistungsfähigen Ferngasleitung zwischen Schlesien und Bayern zur Versorgung des industriereichen Nordböhmens (Glas, Keramik, eisenverarbeitende Industrie u. s. w.) und zur Belieferung von etwa $2 \mathrm{c}$ kommunalen Gaswerken in diesem Raume. Das Gas sollte bezogen werden vom Hydrierwerk Brüx aus einer Sauerstoff-Hochdruckvergasungsanlage

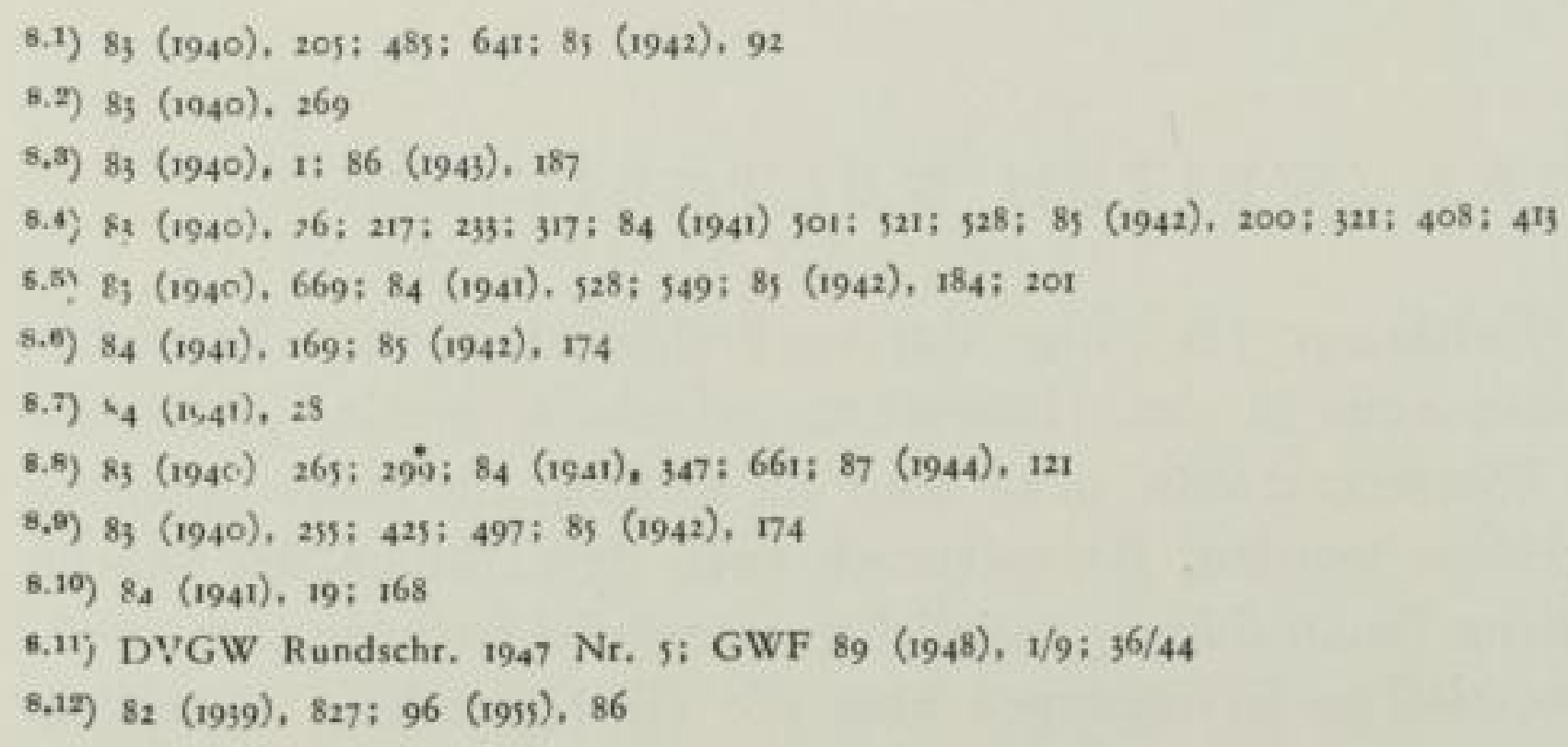


nach Lurgi auf der Grundlage der hochwertigen böhmischen Braunkohle. Die erste Ausbaustufe war auf 250 Mio mª festgelegt, nach Bedarf der weitere Ausbau vorgesehen. Das Hochdruckverteilungsnetz bei 20 at bestand aus einem Rohrstrang von $500 \mathrm{~mm} \mathrm{NW} \mathrm{ab} \mathrm{Brüx} \mathrm{und} \mathrm{einer} \mathrm{Ost-Westleitung} \mathrm{von} 300 \mathrm{~mm}$ NW. Mit der Rohrverlegung wurde im Mai 1940 begonnen. Bis Anfang 1945 waren $300 \mathrm{~km}$ Leitung ostwärts bis Reichenberg, westwärts bis in den Raum von Karlsbad verlegt. I4 Gaswerke und eine grof̧e Zahl von Industricbetrieben wurden versorgt.

Die Anlagen wurden 1945 von einer tschechischen Staatsgesellschaft übernommen und inzwischen in Übereinstimmung mit den ursprünglichen Planen weiter ausgebaut (Bau einer Hochdruckleitung Brüx-Kladno-Prag, Projekt enner zweiten Gaserzeugungsgrundlage im Falkenauer Braunkohlenrevier u. s. w. $)^{\text {s.is }}$ ).

Die ersten Erdgasfunde in den Pyrenäen wurden in der Besatzungszeit erbohrt. F. Totzek war durch das Streben nach verbilligten Verfahren zur Herstellung von wasserstoffreichen Gasen 1938 auf Versuche mit Kohlenstaub gekommen. Es genügte aber nicht die Wärme mit dem Dampf zuzuführen. 1940 ging er von Braunkohlen zu Steinkohlen über und löste die Aufgabe durch ein vor dem heif̧en Reaktionsraum hergestelltes Steinkohlenstaub-Sauerstoffgemisch. Der Ausgang des Krieges setzte 1943 den im Ruhrgebiet laufenden Arbeiten ein Ende. Totzek muf̧te die Arbeit in Nordamerika fortsetzen ${ }^{8.14}$ ).

In der Gasverwendung gab es lebhafte Überlegungen, die mit dem Ersatz von Ol oder Benzin durch Gas in Feuerungen ${ }^{8.15}$ ) und Fahrzeugen ${ }^{9.19}$ ) insbesondere Omnibussen in Berlin ${ }^{8.17}$ ), Lübeck ${ }^{8,18}$ ) und Paris ${ }^{8.19}$ ) zusammenhingen.

Auch hier beherrscht der Gedanke an Sparsamkeit im Verbrauch das Feld ${ }^{5.20}$ ). Auffallend ist die Zeit, die mit vielen Sitzungen dem sozialen Wohnungsbau gewidmet wurde $\left.{ }^{8.22}\right)$. Veranlassung war ein Erlaf3 vom is. Nov. 1940 zur Vorbereitung des Wohnungsbaues nach dem Siege $\left.{ }^{8.2}\right)$. Der Reichskommissar für den Wohnungsbau ordnete die Erstellung von Erprobungstypen an ${ }^{5.27}$ ), aber nach $194^{2}$ wurde es still um diese voreilig festgesetzte Aufgabe.

Die Richtlinien für Gasanzünder für Kokszentralheizungen, die nach einigen Versuchen im Gasinstitut aufgestellt wurden, entsprangen dagegen einem augenblicklichen Bedürfnis. Das bisher übliche Holz zum Feueranlegen feblte und etliche Fehlkonstruktionen, die schnell geschaffen wurden, brachten Gefahren mit sich ${ }^{8.21}$ ). Die mit dem Luftschutz zusammenhängenden Erörterungen mögen, obwohl sie in der Literatur einen breiten Raum einnehmen, übergangen werden. Was damals erarbeitet wurde, dürfte heute veraltet sein. Über Zerstörung und Wiederherstellung von Werken während des Krieges wurde in der Öffentlichkeit nichts

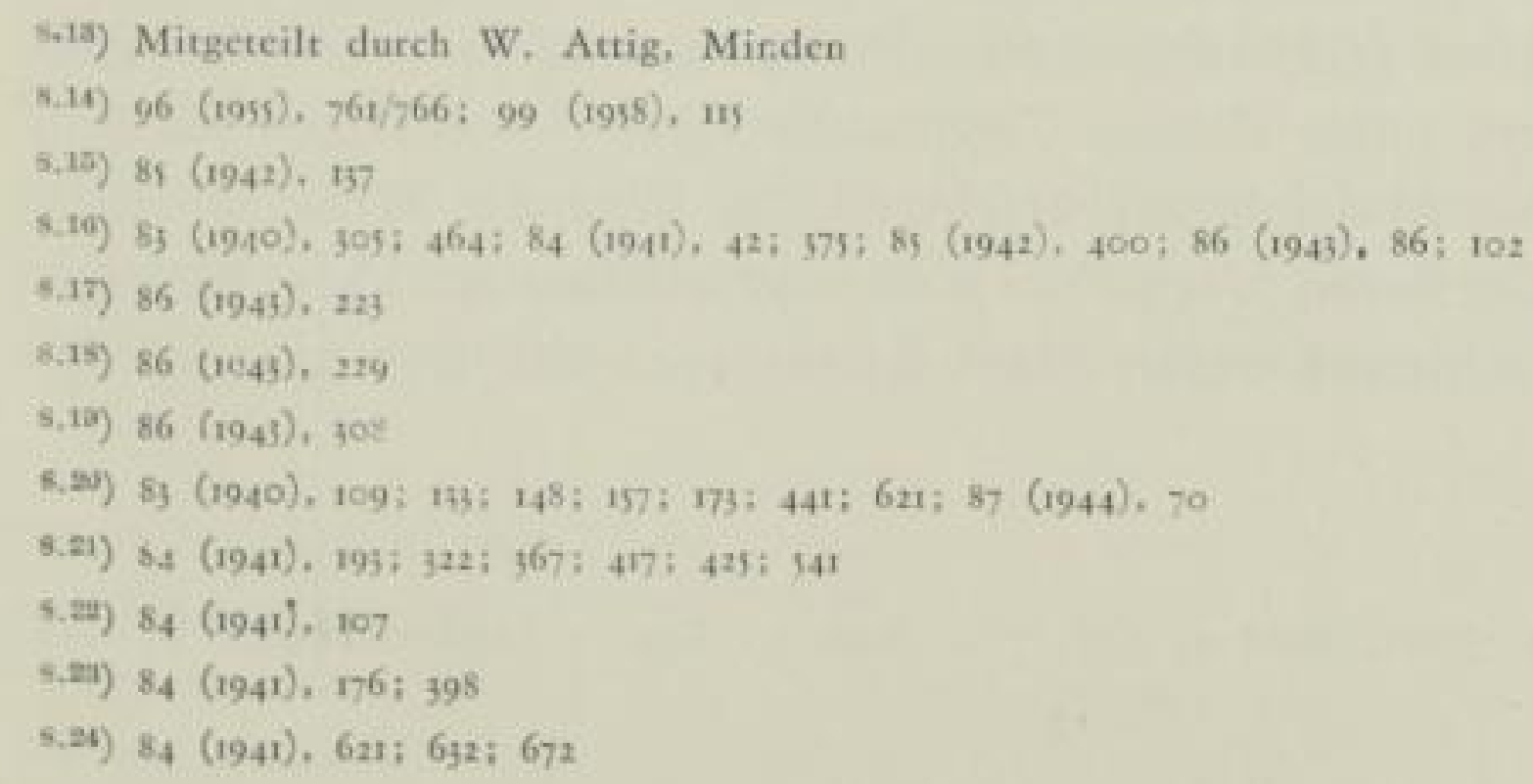


berichtet. Man findet darüber vicle anschauliche Schilderungen in den späteren Jahren, vor allen in den Druckschriften der Werke, die ihr hundertjähriges Bestehen um 1950 herum feiern konnten. Zum Schluf̧ des Krieges brach die Gasversorgung fast überall zusammen.

Von den 51 im Jahre 1943 an die Ruhrgas A.-G. liefernden Kokereien waren zu Anfang des Jahres 1945 zeitweilig nur noch 3 als Gaslicferanten tätig. Das Rohrnetz der Gesellschaft war durch 371 groß̧e Schadensstellen gegen Kriegsende weitgehend aufer Betrieb gesetzt ${ }^{\text {7.1ex }}$ ).

\subsection{WJEDERAUFBAU NACH DEM KRIEGE}

Die groß̧en Städte und in ihnen der Stadtkern waren vom Bombenkrieg am meisten betroffen. Damit war der Schwerpunkt der kommunalen Gasversorgungen ausgeschaltet. Zahlen, wie sie wegen der Entschädigungen errechnet werden muften, geben ein schlechtes Bild. Von Berlin wurde beispielsweise berichtet ${ }^{5.25}$ ): „Nach Beendigung der Kampfhandlungen waren sämtliche Gaswerke auß̧er Betrieb, die Werksanlagen zu so bis $60 \%$ zerstört, das Rohrnetz war völlig lahmgelegt, zu $0,9 \%$ betriebsfähig “. Was noch dastand, hatte eben auch gelitten. Eine Ofenanlage, die durch in der Nähe niedergehende Bomben mehreren Erdbeben ausgesetzt gewesen war, konnte wohl zur Not noch geflickt etwas Gas abgeben, aber Risse und Klüfte muften schon in den Kammern zu Verbrennungen und Gasverlusten führen. Wo in verzweigten Rohrnetzen an einigen Stellen Zertrümmerungen vorgekommen waren und wohl noch gar durch das Wasser der ebenfalls zerschlagenen Wasserleitung ersoffen waren, konnten diese nicht mit Gas beschickt werden. Wenn dann nach Einbau von Wassertöpfen und Abtrennung hoffnungslos zerstörter Gebietsteile, es gewagt wurde einen kleinen Bezirk wieder mit Gas zu beschicken, so muf3te man mit Gasverlusten bis zu $50 \%$ noch zu-

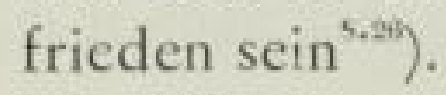

Der Wiederaufbau war gehemmt nicht nur durch den Mangel an Baustoffen, die Grundindustrien waren ja auch nicht mehr an der Arbeit, oder durch den Mangel an Facharbeitern, es war zunächst auch die sehr unvollkommene Organisation der Besatzungsmächte, die sich stolz Militär-Regierung nannte, bei der Arbeit hinderlich. Deutschland war keine Einheit mehr. Der schon vor 200 Jahren herumgeisternde Gedanke, Deutschland zu vierteilen ${ }^{8.27}$ ), war Tatsache geworden. Schon die Errichtung von vier getrennten „Zentralen Landesbanken“, die sich nicht verständigen konnten oder durften zur Betreuung ein und derselben Währung, muf̧̧te trotz der gewaltigen Steuererhöhung zum endgültigen Verfall der Reichsmark führen. Aber selbst der „offizielle Kompensationsverkehr" zwischen den einzelnen Zonen, unter diesen Voraussetzungen der einzige Ausweg, wurde durch bürokratische Mafgnahmen erschwert $\left.{ }^{8,25}\right)$. Was an Willkürlichkeit einer manchmal bewuf̧t zügellosen Verwaltung alles geschehen ist, kann hier nur angedeutet werden. Sehr schlimm waren die Verhaftungen der sich mit der In-

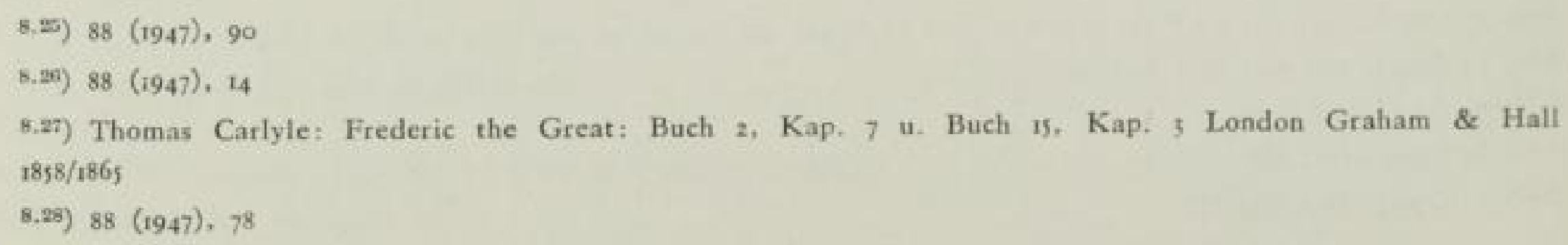


standsetzung abmühenden Fachkräfte, oft genug lediglich auf böswillige Denunziationen hin, deren Unhaltbarkeit sich erst nach ein oder zwei Jahren beim ersten Verhör herausstellte. Die Leute, die einsprangen, waren oft dem Fach völlig fremd $^{\text {s.zo }}$ ). Ein Gaswerksleiter z. B. fragte persönlich ,zu seiner In£์ormation“ beim Gasinstitut an, wie man Stadtgas verflüssigen könne, um es in Flaschen zu verkaufen.

Daf̧ die Kohlenzuteilungen nicht in Ordnung waren, lag vor allem an den Transportschwierigkeiten mit zerstörten Bahnen und Brücken. So erhielten Gaswerke schönen Anthrazit zur Entgasung.

Allerdings sahen die Besatzungsdienststellen sehr bald, daf3 auch für sie selbst Gas und Wasser notwendig waren, zumal bald nach den Soldaten auch deren Familien nach Deutschland einströmten. Die Gassachverständigen aus den fremden Ländern, die als Mittler zwischen den Verwaltungen eingesetzt wurden haben wirksam geholfen. Statt der vielen Namen, die hier unmöglich alle aufgezählt werden können, möge zum Zeichen der Dankbarkeit der des in der britischen Zone und nachher in der Zweizonenverwaltung tätigen H. D. Greenwood genannt sein. Manche Werke kamen überraschend schnell in Gang. Karlsruhe brauchte einen Teil seiner Öfen überhaupt nicht kalt werden zu lassen. In Berlin waren zwei Monate nach dem Ende der Kämpfe alle Erzeugungsstätten wieder im Betrieb ${ }^{\text {aso }}$.

Bei der Ruhrgas A.-G. erhöhte sich bis Ende 1945 die Zahl der Lieferkokereien auf 26, bis Ende 1946 auf 45 . Das Rohrnetz war bis zum Ende 1945 zu $88 \%$ wieder betriebsbereit ${ }^{\text {This }}$ ).

Die Festlegung der Verbrennungswärme auf höchstens $3600 \mathrm{kcal} / \mathrm{m}^{3}$, die der Kontrollrat für die Begrenzung der Kohlenmengen festgesetzt hatte, war ein Fehlgriff $\left.{ }^{\text {(at) }}\right)$. Zwar hatten die Deutschen während des Krieges in Paris die gleiche Małnnahme ergriffen, aber dort war auch eine ausreichende Wassergasanlage vorhanden, die bei vielen deutschen Werken fehlte. Die Herabsetzung der Verbrennungswärme durch kräftiges Saugen bei den ach so undichten Kammern, ließ3 nicht allein Rauchgas, sondern auch Luft ein, die Kohlen und das eben entstandene Gas zu Rauchgas verbrannte. Mit einem solchen Gase waren aber bei allen geschlossenen Ofen des Haushaltes und der Industrie die vorgesehenen Temperaturen nur mit einem Meiraufwand an Kalorien zu erreichen. Die verwickelten Zusammenhänge sind von W. Z ankl klar herausgearbeitet worden $^{\text {s.az }}$ ). Eine gründliche Besserung trat im Jahre 1947 ein, als das Zwe zonenverwaltungsamt gegründet werden durfte. Damit nahmen im Westen die allgemeinen Zertrümmerungstendenzen ein Ende. Nur einige Sinnlosigkeiten wic die Konzernzerschlagung und die Demontagen erhielten sich noch einige Zeit. Damals wurde auch der Erfahrungsaustausch der verschiedenen inzwischen gegründeten Vereinigungen des Faches mit einem interzonalen Treffen wieder aufgenommen. Am frühesten war wohl in der britischen Zone mit dem Auftrag den Deutschen Verein von Gas- und Wasserfachmännern wieder zu gründen im Herbst

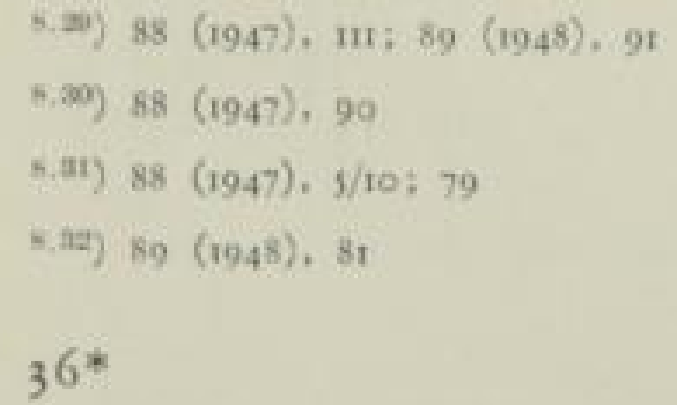


1945 Ordnung geschaffen worden $\left.{ }^{6.05}\right)$. In der amerikanischen Zone durften anfangs nur Verbände der Gas- und Wasserwerke der einzelnen Länder gebildet werden $^{8 \cdot 34}$ ).

Die nunmehr einsetzende technische Arbeit war eine hohe Schule der Gastechnik. Die Notwendigkeit mit den verschiedensten, schnell wechselnden Steinkohlensorten, ja zeitweilig auch Braunkohle, Holz und Torf fertig zu werden, forderte von den Ingenieuren viel mehr als der ruhige Betrieb mit erprobten sich gleich bleibenden Sorten. Man darf wohl sagen, daf3 die Fachleute selbst auf den kleinen Werken ihrer Aufgabe gerecht geworden sind. Leider läßt sich die Fülle der aus den Erfahrungen entstandenen Veröffentlichungen aus Platzmangel nicht wiedergeben. Einige der wichtigsten Aufsätze mögen wenigstens mit den Titeln genannt werden, wie die Absage von A. T $b a u$ an die Steinkohlenschwelung, seine Auseinandersetzung über Dickteerbildung ${ }^{4.45}$ ) die Kritik von $G u m z$ über die Aussichten der Vergasungstechnik und die Aussprachen beim ersten Erfahrungsaustausch der Gaswerkschemiker nach dem Kriege ${ }^{5.00}$ ). Das Schwcrgewicht liegt ganz deutlich bei der Durchleuchtung der ,klassischen" Entgasungsverfahren, die auf möglichst guter Koks- und Gaskohle aufbauen. Nur am Rande wird schon die amerikanische Ölverarbeitungstechnik erwähnt ${ }^{5.37}$ ).

Die Gasverwendung und -verteilung beschäftigte sich mit dem Wiederaufbau der Strałjenbeleuchtung, mit dem Mangel an brauchbaren Gaszählern, wo man mehrere Haushalte an einen gemeinsamen Messer anschlief̧en mufte. Berichtsweise wurde die Aufmerksamkeit auf die neue Technik der Strahlungstrocknung mit Gas gelenktt ${ }^{2.35}$ ).

Nach 20 Monaten waren $94 \%$ der Gasversorgung wiederaufgebaut. Die monatlichen Gasabgabezahlen in Südbaden waren beispielsweise gegen ${ }_{13}$ Mio $\mathrm{m}^{3}$ im Jahre 1937 im August 1945 auf 2,3 Mio, im Januar 1946 auf 4,7 Mio und im Dezember des gleichen Jahres auf 10,4 Mio, also immerhin auf $80 \%$ gegen 1937 gestiegen. Im Laufe des Jahres 1946 konnte mit dem 87. Jahrgang auch die Zeitschrift: Das Gas- und Wasserfach (GWF) wiedererscheinen, nachdem H. Ka $u n$, Stuttgart, sich bereit erklärt hatte, die Hauptschriftleitung zu übernehmen. Es war vieles nachzuholen, nicht nur um die breite Masse der Fachgenossen über die Erfahrungen einzelner zu unterrichten, sondern auch, um die seit 1939 fast abgerissenen Verbindungen mit dem Auslande wiederaufzunehmen. Vieles war durch Kurzberichte den Lesern zu unterbreiten. Bei beschränkter Papicrzuteilung war der Umfang im Anfang gering, weitete sich aber bald aus.

Im europäischen Auslande waren zwei schwerwiegende Veränderungen eingetreten. 1946 wurden die Gaswerke Frankreichs, 1949 die Englands verstaatlicht. Die Art des Aufbaues war aber ganz verschieden. Frankreich schuf mit der Gaz de France eine in Paris völlig zentralisierte Verwaltung. Die Entwicklung aber brachte es mit sich, dał die grołen Gasquellen in privater Hand blieben. Zechengas wurde von Lothringen und der Saar nach Paris geleitet und die Erdgasquellen in den Pyrenäen blieben ebenfalls im Besitz von Gesellschaften. In

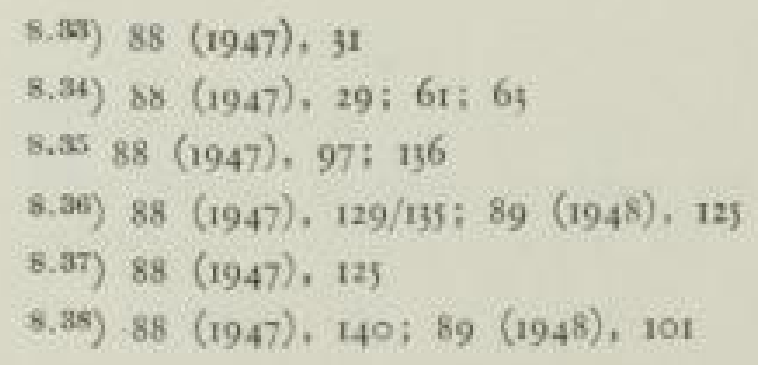


England trug man den starken Unterschieden in den Ansprüchen und der Verteilung der über das ganze Land verbreiteten Kohlenzechen mit ihren verschiedenen Sorten durch 12 Gasprovinzen (Gas Boards) Rechnung. In diesen Bezirken aber wurden durch Gruppengaswerke groß̧e Einheiten gebildet. Die Stillegung einer groł̧en Zahl kleiner Werke ist in beiden Ländern schnell erfolgt, aber aus zwei verschiedenen Gründen, in Frankreich durch den Überfluł an Erdgas, in England durch moderne Grołgasereien.

\subsection{VON DER W ÄHRUNGSUMSTELLUNG I 948 BIS Z UR KOHLENFÜLLE I 958}

Die zehn Jahre dieses Abschnittes sind durch die internationale Verflechtung der deutschen Wirtschaft äußerst bewegt gewesen. Von einer Stabilisierung der Wirtschaft, die von der Währungsneuordnung erwartet wurde, kann keine Rede sein. Zunächst vertiefte sich an der Geldfrage die Teilung Deutschlands. Es war eine Unmöglichkeit, die im Westen aufgerichtete Bundesbank mit dem Staatskapitalismus Mitteldeutschlands zu kuppeln. Die Blockade Berlins und die Spaltung der Stadt werfen ein scharfes Licht. Im Gasfachblatt lauten die schwerwiegenden Worte von H. B a uscb: „Die Verwaltung der Berliner Gaswerke ist nicht freiwillig in den Westen übergesiedelt ${ }^{(\mathbf{8 . 3 0})}$.

Der Geldmangel war für die nächsten vier Jahre die Hauptsorge der westdeutschen Gaswerksleiter. Man suchte ihr durch langfristige Planungen beizukommen. Der Marshall-Plan sah nur eine geringe Steigerung der Gasdarbietung, verglichen mit dem Anwachsen der Industrie im allgemeinen vor $^{8.40}$ ). Dagegen war der schnelle Ausbau der europäischen Raffinerieen von 12 auf ro8 Mio t Ölverarbeitung auf I Mia DM an Marshallplangeldern zurückzuführen $\left.{ }^{8.41}\right)$. Mit dem Ausbruch des Koreakrieges wurde die Zahlung von ERP-Geldern (Europeen Relief Payments) eingestellt. Deutschland war auf Selbsthilfe angewiesen. Dic Gaswerke litten aber unter politischen Einflüssen. Verglichen mit 1936 waren die Preise 195r angestiegen: für Kohle um $317 \%$, Eisen $260 \%$, Kapital 200 bis $250 \%$, Löhne $170 \%$, Ecklohn in den Tarifen $220 \%$, Haushaltsgas 130 bis $150 \%$ und Industriegas 140 bis $250 \%$. Mit diesem Zurückbleiben war den Gaswerken die Finanzierung aus Gewiniten, wie sie die Industrie zu Neubauten verwandte, unmöglich gemacht. Auch die Kreditfähigkeit war untergraben ${ }^{8.22}$ ). Hier sollte die Investitionshilfe der deutschen Industrie durch Darlehen einspringen. Zugesagt wurden zunächst (1949/5I) für die deutsche Gaswirtschaft 126 Mio DM für die Elektrizitätswirtschaft wurde ungefähr die doppelte Summe vorgesehen ${ }^{\text {s.43 }}$ ). Später konnte festgestellt werden, dał mit dieser Hilfe der Gaswirtschaft ro6 Mio DM für $4^{9}$ Einzelvorhaben zugeflossen waren. Verbaut waren 215 Mio DM, wovon 94 Mio DM aus eigenen Mitteln stammten ${ }^{8.4}$ ). Die Kohle wurde auf lange Jahre hin als alleinige Grundlage angesehen ${ }^{8,45}$ ). Sie mufte aber auch ein Engpaf3.

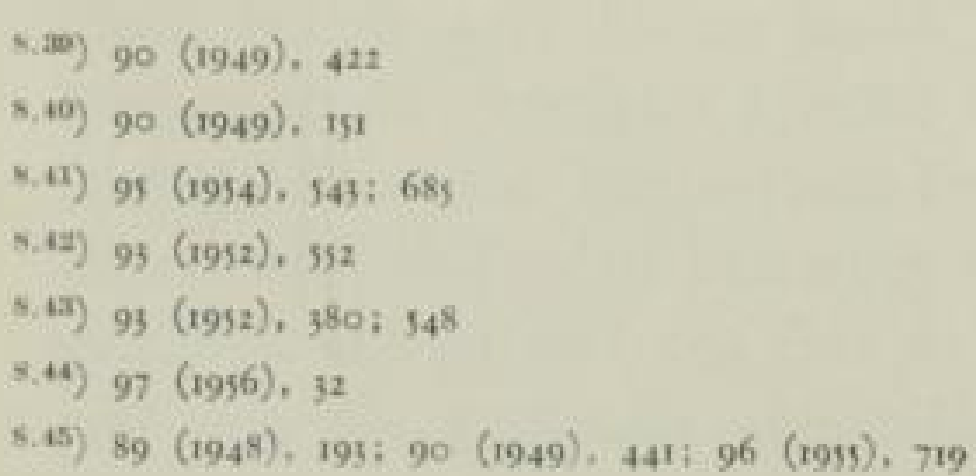


bleiben $\left.^{8.46}\right)$. Auch in anderen Ländern konnte man sich keine Umstellung auf einen anderen Rohstoff vorstellen ${ }^{5.47}$ ). Die technische Losung wurde in einer Verbreiterung der brauchbaren Kohlensorten durch Entgasung nichtbackender Kohlen, durch Vergasung (Vgl. Abschnitt 8,3I) und durch Zusammenschlüsse zu Gruppengaswerken gesehen.

Darum wurde auch der Bau von Grołkokereien keineswegs vernachlässigt. Es muß̧ten ja auch die durch den Krieg zerstörten oder bis zur Unwirtschaftlichkeit beschädigten Ofen ersetzt werden, solange der Koksmarkt noch Anforderungen stellte. Bild $120 \mathrm{~g}$ bt eine Übersicht über Neubauten und Instandsetzungen von Gaswerksöfen von 1945 bis 1953. Herausgegriffen seien: Grołkkokerei Hamburg-

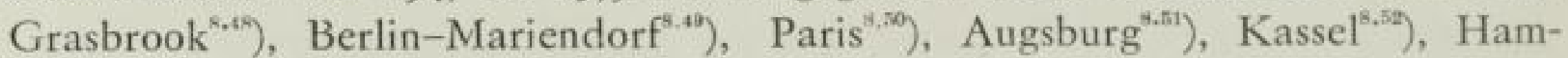
burg-Kattwyk ${ }^{8.23}$ ), Karlsruhe ${ }^{5.54}$ ), Düsseldorf ${ }^{8.55}$ ).

Selbstverständlich wurden aber auch die neuen Rohstoffe, Erdöl, seine Nebenprodukte bei der Raffinierung und Erdgas aufmerksam verfolgt. Zuerst kamen die Berichte aus dem Auslande. Dann begannen die deutschen Fachleute zu sinnen, wie sie in den vorhandenen Anlagen Öl einzusetzen vermöchten und schlief̧lich zunächst zur Deckung der Spitzen Olspaltanlagen bauen sollten (Abschnitt 8,32). Schon im Jahre 1950 sagte W. Spittank: „Besonders starke Impulse werden vom Erdgas und Kokereigas ausgehen. Grundsätzliche Strukturwandlungen sind dagegen wenig wahrscheinlich $\left.{ }^{8.56}\right)$. 9 Jahre darauf wurde H. A. Lebmann noch deutlicher mit der Frage: „Los von der Kohle"? Er sagte: „Es kriselt nicht nur bei den Preisen für Eisen und Stahl, sondern die Anzeichen mehren sich, dał der Markt die jetzigen Kohlenpreise ebenfalls nicht auf die Dauer zu tragen vermag... Das Heizöl drängt nun gleich aus zwei Quellen auf den Markt, aus der unerwartet gestiegenen Eigenförderung an Erdöl, die ros2 I,8 Mio t erre chte, 1953 aber bereits im ersten Halbjahre I, O Mio t, und zum anderen aus eingeführten Rohölen, die sich im Jahre 1952 auf 3,4 Mio t beliefen. Der volkswirtschaftlich erfreuliche Umstand, dał es heute für den Weltmarkt interessant ist, in Deutschland Erdöle zu verarbeiten und dafür erhebliche Raffineriekapazitäten zu errichten, läł̧t zusammen mit der Eigenförderung verschiedene Nebenprodukte anfallen, die für Gaswerke verwertbar sind. (Vgl. Abschnitt 8,33) ... Bei der restlosen Vergasung der Kohle bleiben Gaswerke auf billigste Kohle angewiesen, da die Nebenprodukte fortfallen. (Aber auch die wird wegen der Frachten für die meisten Werke zu teuer). Ganz anders liegt es bei der Krackung von Mineralölrückständen. Sie sind gegenüber der Kohle interessant $\left.{ }^{5.57}\right) . "$

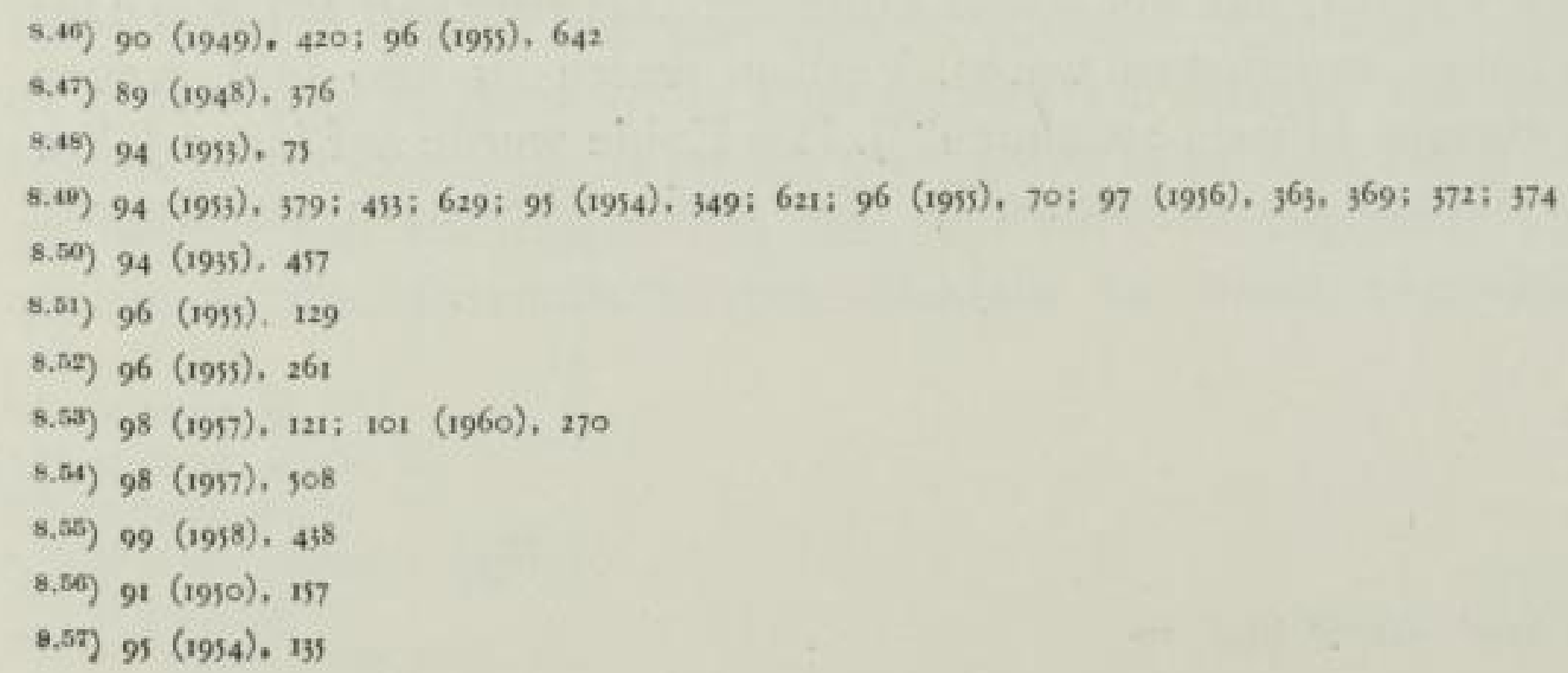


Bild 120

Neubauten und Instandsetzungen von

Werken 1945 bis 1953

(GWF 95 [1954] S. $74^{8}$ )

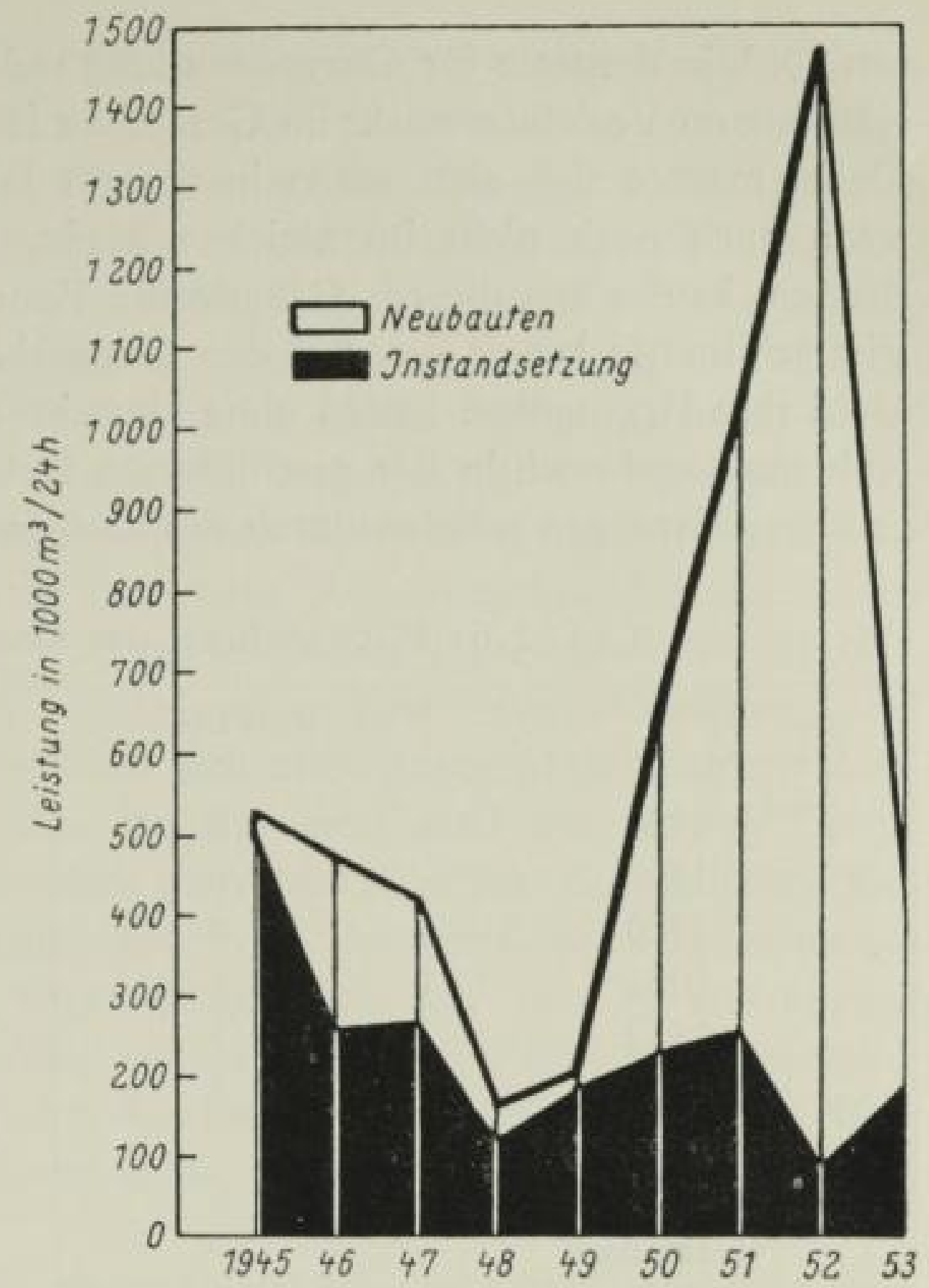

Nachdem der grof̧e Kapitalmangel einigermaf̧en überwunden war, wurde der Kohlenmangel um so mehr empfunden. Die Währungsumstellung mit den Verlusten der verfügbaren Bankmittel hatte bei der breiten Masse des Volkes Zurückhaltung mit Käufen erzwungen. So konnten sich in den Lägern und Läden die Güter, insbesondere die Verbrauchsgüter, die in den Vormonaten als Festwerte in Erwartung der Abwertung sich angehäuft hatten, re chlich zeigen. Dafür war auch im Gasfach ein typischer Fall. Das noch in der Reichsmarkzeit (1946) in ungewöhnlich groß̧er Auflage erschienene Buch: „Zum Gaskursus“ war in wenigen Monaten vergriffen. Als dann nach 1948 ein Nachdruck vollzogen war und entsprechend den neuen Herstellungskosten vertrieben wurde, kamen auch die gehamisterten Exemplare heraus, wobei der neue Preis unterboten wurde. Die die Gaswerke beliefernden Firmen hatten allerdings in dieser Weise keine Bestände angesammelt. D e Rohrlieferanten kündigten vielmehr gleich nach der Währungsumstellung eine Vergrößzerung ihrer Anlagen an ${ }^{\text {s.t }}$ ). Auch de Gasgerätefirmen hatten in ihrer Verbundenheit mit dem Fach regelmäß̧ig geliefert. Ihnen konnte auch bis zu einem gewissen Grade durch Rücklieferung verschrottungsreifer beschädigter Geräte die Materialbeschaffung erleichtert werden. Sie muf̧ten aber den Neuaufbau ihrer Werke und ihre Erweiterung während des angestrengt laufenden Betriebes ausführen. Junkers \& Co., früher in Dessau, der zunächst in Stuttgart den Bau von Wasserheizern wieder begonnen hatte, konnte erst 1954 ein grofzügig entworfenes neues Werk in Wernau am Neckar eröff- 
nen $\left.^{5.55}\right)$. Die Zentrale für Gasverwendung stellte bereits 1953 den Umschwung vom Käufer zum Verkäufermarkt im Gerätebau fest ${ }^{\text {s.5ng }}$.

Dabei machte sich aber schon in diesem Jahre Facharbeitermangel bemerkbar, wenn auch noch nicht im gleichen Maßje, wie ab 1960. Carl Neff G.m.b.H., Bretten, kaufte aus diesem Grunde die Erste Bruchsaler Herdfabrik an ${ }^{50 \%}$.

Viel schlimmer lag es aber bei den Gaswerken selbst, die ja natürlich nur gegen Geld ihre Erzeugnisse hatten ohne Unterbrechung absetzen müssen und nun bei Kohlenmangel noch in der geschilderten Geldnot steckten $\left.{ }^{5.01}\right)$. Die trotzdem steigenden Leistungen werden durch die nachstehende Tafel klar $\left.{ }^{5.45}\right)$ :

Tafel 6: Entwicklung der Gaserzeugung in Mia $\mathrm{m}^{3} / \mathrm{a}$

\begin{tabular}{|c|c|c|c|}
\hline & Ortswerke & Kokercien & Zusammen \\
\hline 1948 & 1,3 & 9,2 & 10,5 \\
1949 & 1,6 & 10,3 & 11,9 \\
1950 & 1,8 & 11,5 & 13,3 \\
1951 & 2,1 & 14 & 16,1 \\
1952 & 2,3 & 15,6 & 17,9 \\
1953 & 2,3 & 16,2 & 18,5 \\
Kohlenmangel & & & 18,1 \\
1954 & 2,6 & 15,5 & \\
Gasmangel & 2,8 & & 20,9 \\
1955 & 3,1 & 18,1 & 22,5 \\
1956 & 3 & 20,95 & 27,7 \\
1957 & 6,7 & 20,97 & \\
1958 & & & \\
\hline
\end{tabular}

Im Jahre 1949 behinderte der Kohlenmangel in der Zweizonenverwaltung die Befriedigung des Gashungers, $\left.{ }^{8,65}\right)$. M. Rascbig trat sogar für einen niedrigeren Gasheizwert ein und verlangte die Umstellung der Geräte trotz der schlechten Erfahrungen nach dem Zusammenbruch ( $\mathrm{vgl}$. Seite $\left.5_{63}\right)^{\mathrm{s.a4}}$ ) und das alles, obwohl die deutsche Förderung sich günstiger entwickelt hatte, als es erwartet worden $\left.w a r^{8,25}\right)$. Indessen entspannte sich die Lage auf dem internationalen Kohlenmarkte. Importe aus Nordamerika wurden erwartet. ${ }^{8,6)}$ ) und auch der Koksmangel sollte aufhören. Ja, in der Schweiz begann man an neue Unterfeuerungen zu denken, und zwar mit Koks und sauerstoff-angereicherter Luft ${ }^{5.67}$ ). Im Jahre 1950 ging der Koksabsatz der Schweiz durch eine Krise. Es wurde aber ausdrücklich erklärt, daf̧ die anlaufende Umstellung von Zentralheizungen auf

\footnotetext{
8.58) $95(1954), 29$

8.50) $94(1955), 267$

8.60) 94 (1953), 503

8.61) 89 (1948), 317; 90 (1949), 46

8.62) 99 (1958), 1305; 101 (1960), 834

$8.63) 90(1949), 313$

8.64) 90 (1949), 96

$8.25)$ 90 (1949), 150

$8,66), 90(1949), 318$

$8,87) 90(1949), 586$
} 
Ol dabei noch keinen Ausschlag gab $\left.{ }^{8,65}\right)$. So trat eine verwirrte Lage ein. Im Bereich der Ferngaswirtschaft muf̧ten im Laufe des Winters 1951/52 fühlbare Einschränkungen stattfinden ${ }^{8.0 \%}$ ). Det Winterbedarf der Ruhrgas A-G. lag $25 \%$ über dem niedrigsten Sommerbedarf, die Gesellschaft entschlof sich, ihre Beschränkung auf die Verteilung allein aufzugeben und in die Gaserzeugung mit den neuentwickelten Verfahren ohne Koksanfall zur Erfüllung der Spitzenanforderungen einzutreten $\left.{ }^{8.20}\right)$. Die Ortsgaswerke waren völlig ausgelastet. Soweit noch Kapazitäten frei waren, wurde die Lohnkokerei für amerikanische Rechnung betrieben. Die Einfuhr amerikanischer Kohle stieg auch bei den Gaswerken an. Aus dem Jahre 1952 liegen die ersten Erfahrungsberichte mit diesen Kohlen in Kiel ${ }^{8.21}$ ) und Hamburg ${ }^{5.27}$ ) vor. Im folgenden Jahre nahm dic Einfuhr aus Nordamerika wieder etwas ab, obwohl sofort eine Frachtermäßjigung entgegengeworfen wurde. In Belgien bildeten sich zum ersten Male Kohlenhalden von 2,5 Mio t. Frankreich senkte den Beschäftigungsgrad der Zechen $\left.{ }^{8,23}\right)$. Es kriselte in der Eisenindustrie gerade nach dem Abschluf der Europäischen Gemeinschaft für Eisen und Stahl (Montanunion). Im Bundeswirtschaftsministerium wurde ein Beirat berufen mit der Begründung: „Die mit der Kokserzeugung zwangsläufig gekuppelte Gasdarbietung reichte wegen des inzwischen rückläufigen Koksbedarfes, besonders während der kalten Tage des vergangenen Winters $(1953 / 54)$ nicht aus $\left.{ }^{46.74}\right)$. Der Beirat sollte beraten, wie die Kokereigasdarbietung gesteigert werden könne.

Die Gaswerke muf̧ten indessen sehr teure amerikanische Kohle einführen, hatten aber wegen der Preisvorschriften Schwierigkeiten den daraus anfallenden Koks mit angemessenen Preisen abzusetzen. Das für die $W^{\prime}$ irtschaftlichkeit der Werke ausschlaggebende Kohlenkokspreisverhältnis änderte sich nach der nachstehenden Tafel 7.

T a fel 7: Kohlen-Kokspreis-Verhältnis unter den amtlichen Preisen

\begin{tabular}{|ll|ll|l|}
\hline 1930 & $1: 1,78$ & 1953 & $1: 1,30$ & $1958 \quad 1: 1,17$ bis 1,10 \\
1948 & $1: 1,47$ & 1954 & $1: 1,19$ \\
1950 & $1: 1,45$ & 1956 & $1: 1,20$ & \\
\hline
\end{tabular}

Zwar hob sich im Laufe des Jahres 1954 der Koksabsatz mit einer Erholung der Eisenindustrie. Die Kokshalden sanken bei den Zechen von 3,8 auf 2,8 Mio t und bei den Gaswerken auf $\left.109000 \mathrm{t}^{\mathrm{s}, 75}\right)$. Im Juni 1956 beliefen sich die Haldenbestäride der Montanunion auf 6,54 Mio t Kohle, wobei die $5 / 6$ ausmachenden Vorräte in Frankreich zu $80 \%$ aus minderwertigen aschenreichen Kohlen bestanden. An Koks waren $\left.430000 \mathrm{t} \mathrm{da}^{8,76}\right)$. England verfügte 1956 einschneidende

\footnotetext{
8.65) 91 (1950), 203

9.65) $93(1952), 549$

8.79) $95(1954), 362$

8.71) $93(1952), 15$

8.72) $93(1952), 118$

s.7a) 94 (1953), 54

8.74) $95(1954), 220 ; 362$

9.75) 95 (1954), 755

s.76) 97 (1956), 742
} 
Kürzungen der Kohlenausfuhr und trieb die Preise bis an die der USA hinauf ${ }^{6 \pi}$ ). Aber die Unruhe und die Anzeichen der Sättigung des Koksmarktes bei ungedecktem Gasbedarf veranlaf̧te die Werke sich eifrig mit der Technik der Gaserzeugung auf Öl-Benzin- und Flüssiggasgrundlage zu beschäftigen (s. Seite 578). Von da ab gingen die Vethandlungen einerseits um Schutzzölle für das heimische $\left.\mathrm{Ol}^{5.79}\right)$, andererseits um die Befreiung des für die Gaserzeugung verwendeten Oles von Zöllen und Steuern ${ }^{8.70}$ ). W'egen der Ölpreise konnte zunächst nur an die Spitzengasdeckung gedacht werden. Die stückweise Freigabe, zunächst nur für Verfahren, die am I. März 1953 noch nicht grof̧technisch betrieben wurden, führte zu Verzerrungen. Zeitweilig war die kalte Karburierung mit Flüssiggas gegenüber der mit heimischen Benzol bevorzugt, das noch der Steuer unterlag. Die weitere Klausel, daf̧ nur solche Verfahren begünstigt werden dürften, bei denen ein als Stadtgas oder Ferngas geeignetes Gas erzeugt würde, führte dazu, dał unwirtschaftliche Umwege begangen werden muf̧ten, wo im Spaltgas in der ersten Stufe Metban oder gar schwere Kohlenwasserstoffe enthaiten waren.

Eine neue Belastung erfuhr die Gaswirtschaft durch den sich 1957 durchsetzenden betriebsfreien Sonnabend, sei es durch höhere Speichermöglichkeiten ${ }^{5.0}$ ), sei es durch eine neue Betriebszeiteinteilung ${ }^{8.51}$ ).

Der Kohlenmangel hielt aber in Deutschland an und beschäftigte das Gasfach und alle Behörden $\left.{ }^{8,82}\right)$. Vorausschätzungen des Energiebedarfes fur die nächsten zehn Jahre kamen mit der Extrapolation der Umsatzsteigerung zu unheimlich hohen Zahlen. Die hohe Behörde (Montanunion) schätzte für 1956 gegen 1955 einen Mehrbedarf von ${ }_{4}$ Mio $\mathrm{t}$ Kohle, von denen der heimische Bergbau nur ${ }_{4}$ Mio mehr beitragen könne. Auch die ECE (Economic Commission for Europe) Genf nahm die Knappheit der Energiegrundstoffe zur Grundlage ${ }^{8,89}$ ). Was Wunder daf auch die Bohrtätigkeit der Olgesellschaften einen spekulativen Charakter annahm und die vielen neuen Gesellschaften die Preise des Kartells unterboten. Die Kartellfirmen wurden dadurch gezwungen, ihrerseits die Anlagen bis zum äuß̧ersten auszunutzen, um bei gesenkten Preisen die übliche Rente und die erhöhten Abgaben an die besitzenden Länder herauszuwirtschaften. Zahlreiche Abnehmerstaaten setzten durch Einfuhrbeschränkungen dem Ölzuflu\} einen Damm entgegen. In Deutschland aber war der Markt frei und so sank der Ölpreis hier unter den Weltmarktpreis. (Bild 121. und 122) Während der Suezkanalsperre waren die großgen Vorräte in Deutschland natürlich willkommen. Die Preise zogen beträchtlich an, um dann aber nach dem Ende des Streites wieder zu fallen.

Trotz dieser Erscheinungen wurden noch, um die Steigerung der Kohlenpreise abzufangen, langfristige Verträge empfohlen zunächst auf $1^{1} / 2$, dann auf 4 Jahre laufend $\left.{ }^{\mathrm{s} s}\right)$. Viele Gedanken wurden erneut auf etwas abseits liegende Roh-

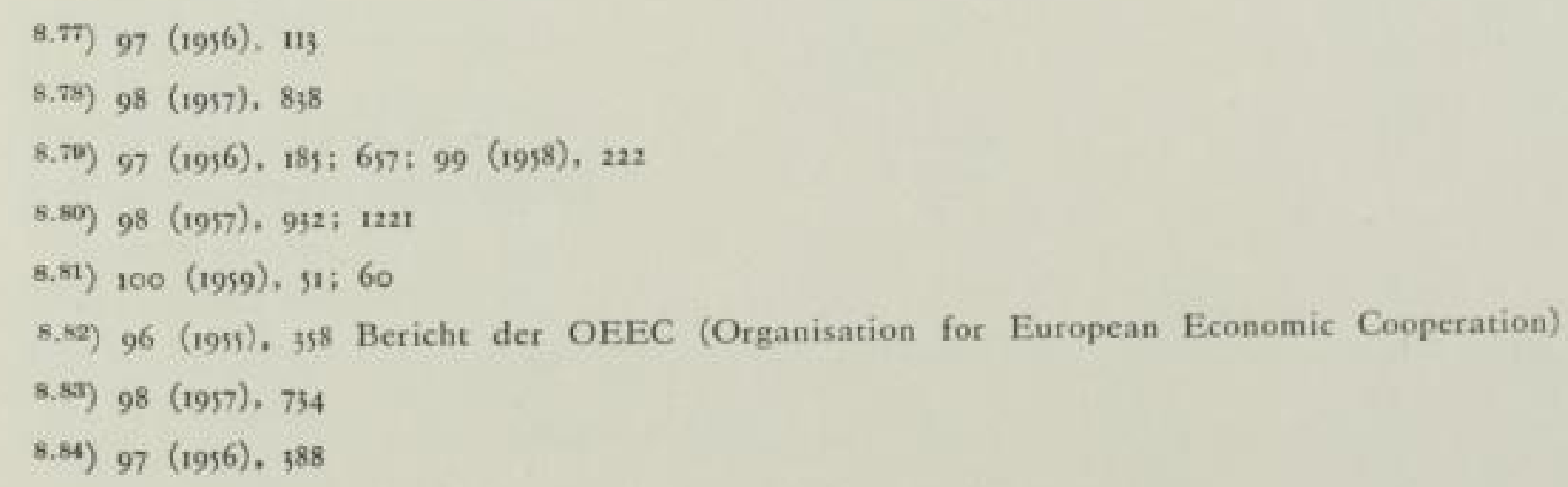


Bild 121

Einige internationale Preise für leichtes

Heizöl in DM/t 1956 bis 1959 (nach Morgenthaler (GWF ror [1960] S. 840)

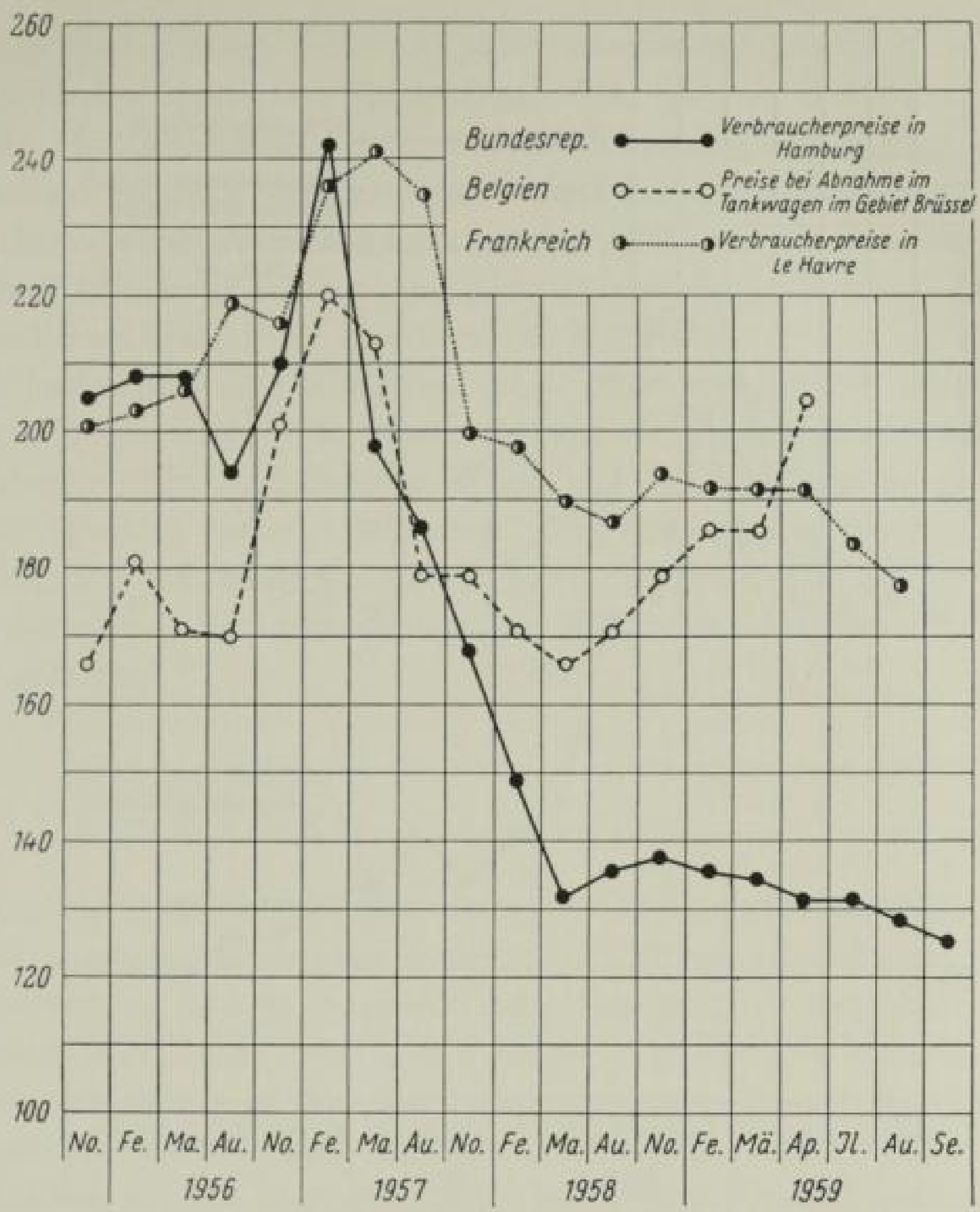

stoffe gerichtet, darunter auf landwirtschaftliche Abfälle, die in Faulanlagen in Bio- oder Bihugas, eincr Art Klärgas verwandelt werden sollten ${ }^{5.55}$ ). Auch an die Atomenergie zur Entlastung der Unterfeuerungen bei der Entgasung wurde gedacht $\left.{ }^{4,0}\right)$. Nachdem noch F. Etzel zu Beginn des Jahres 1957 auf eine weitere Steigerung der Kohleneinfuhr setzte $\left.{ }^{8.87}\right)$, stellte gegen Ende des Jahres das Rheinisch-Westfälische Institut für Wirtschaftsforschung den Stillstand im Kohlenverbrauch fest: ,wegen stärkeren Verbrauches anderer Energiearten und wegen der niedrigen Kohlenfrachten von Nordamerika."

Dann trat zu Beginn des Jahres 1958 der unerwartete Umschwung ein. Man hatte offenbar aus den Geschehnissen von 1872,1903 und 1929 nichts gelernt. So war es zu verstehen, daf die Lage zunächst verkannt wurde $\left.{ }^{8.55}\right)$. Der Bericht der OEEC steckte noch ganz in den Anschauungen vom Kampf gegen die kommende Energielücke $\left.{ }^{8.89}\right)$. Er war wohl zu sorgfältig und langsam erarbeitet und kam deshalb zu spät. Jedenfalls war der Bedarf der Eisenindustrie auch durch den Einsatz der neuen verbesserten Anlagen deutlich rücklaufend, im Durchschnitt um $10 \%$

8.85) 96 (1955), 134; 366; 650; Noack, W.: Biogas in der Landwirtschaft. Darmstadt 1955; Pfeiffer, E. G.: Anleitung zur Kompostfabrikation aus städt. u. Indust. Abfällen Stuttgart 1917

8.08) $97(1956), 473 ; 99(1958), 112$

$8.87) 98(1957), 318$

6.88) $99(1958), 165$

6.88) 99 (1958), 108 


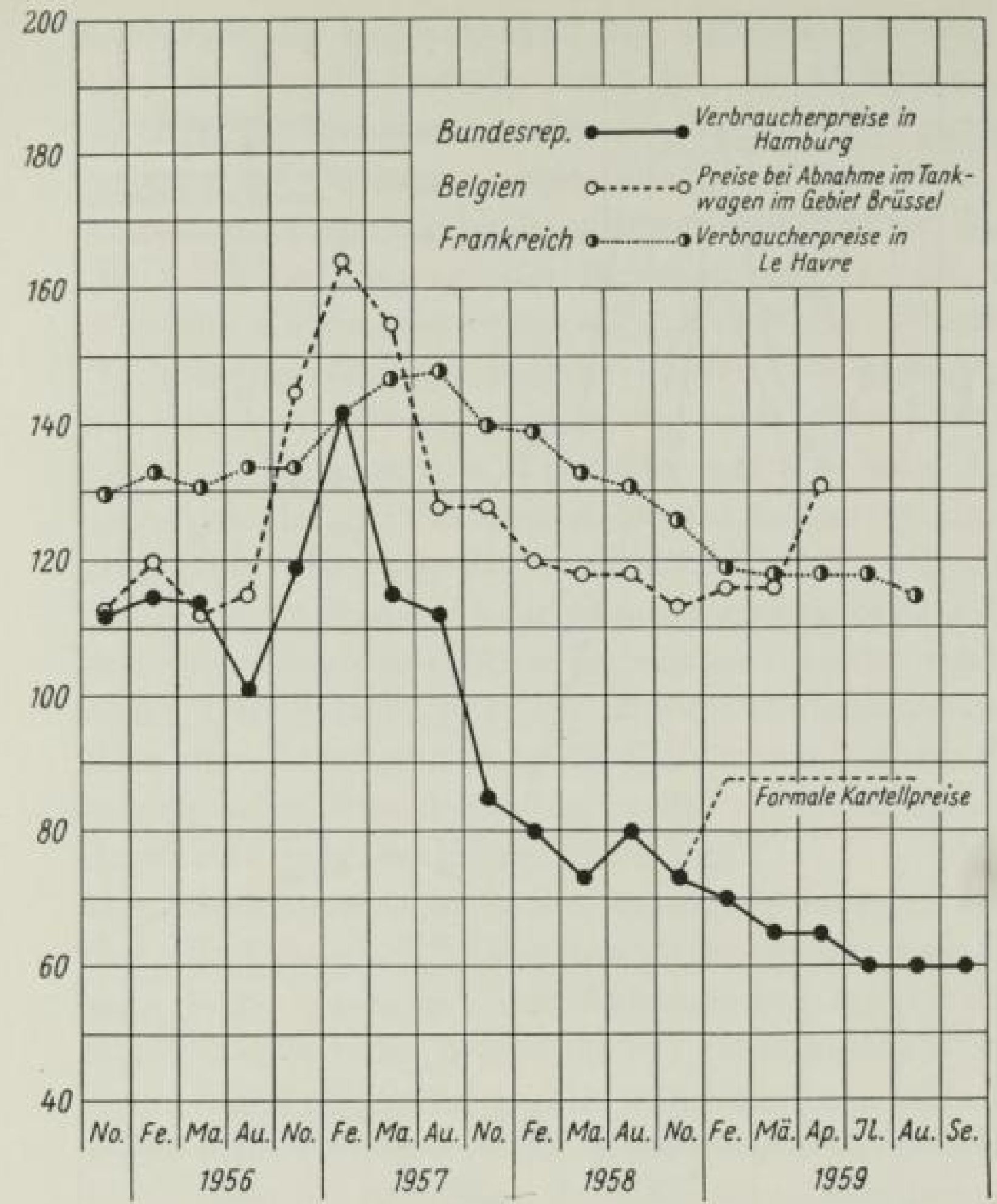

Bild 122

Einige internationale Preise für schweres Heizöl in $\mathrm{DM} / \mathrm{t} 1956$ bis I559 (nach Morgenthaler) (GWF 101 [1960] S. 840)

für die Tonne Stahl $\left.{ }^{8,40}\right)$. Die hohe Behörde änderte ihre Meinung über den notwendigen Ausbau der Zechen innerhalb sechs Monaten $\left.{ }^{8.91}\right)$.

Eine Welle von Empörung ging vom Kohlenbergbau aus mit einer Ablehnung der Eingriffe von Staaten und Stellen, die diesen gleichzusetzen wären $\left.{ }^{8.02}\right)$. Unlogisch ist demgegenüber das Verlangen eines Leiters der Schwerindustrie nach einer Steuerung der Kohlen- und Heizöleinfuhr im gleichen Augenblick $\left.{ }^{5.23}\right)$. An der Ruhr lagen Ende 1957 auf Lager: 800000 t Koks und 1,2 Mio t Kohle ${ }^{8.41}$ ), zu Ende des Winters, der sehr mild gewesen war, 3 Mio $\left.t^{5.05}\right)$. Die Gaswerke konnten sich über die Wirtschaftliche Vereinigung mit dem Streckenversand bei gedrückten Preisen noch helfen ${ }^{5.90}$ ).

Nunmehr wurden die Kohleneinfuhren, die 1957 auf 15,4 Mio $t$ gestiegen waren, mit allen Mitteln und erheblichen Opfern des Bergbaus für die Ablösung der langfristigen Verträge gedrosselt. England griff zu einer drastischen Schlief̧ung von 36 Zechen mit 12000 Arbeitern, hatte aber auch 38 Mio t Kohlen auf Lager.

\footnotetext{
8.90) 99 (1958), 112

8.101) 99 (1958), 312

$8,02) 99$ (1958), 30

$8.03) 99$ (1958), 774

8.24) 99 (1958), 250

$8.95), 99(1958), 410$

8.06) 99 (1958), 474
}

\section{SLUB}


Als besondere Beigabe zu den eigenen wirtschaftlichen Sorgen erfuhr die Bundesrepublik noch eine bösartige Kritik der Rotterdamer Schiffer im Niewe Rotterdamsche Courant. Die Montanunion solle angerufen werden, da die Mafznahmen im Widerspruch zu den Genfer Verträgen stünden: „Man hat es mit einem kleineren Fall von Protektions- und Autarkiebestrebungen zu tun. Die nationalen Kräfte der Bundesrepublik haben die Gelegenheit benutzt, der europäischen $\mathrm{Ge}$ meinschaft einen empfindlichen Schlag zu versetzen (Kohlenzoll).

Aber die Hohe Behörde hatte selbst den Kopf voll. Zum Ende 1959 muf3ten ohne Feierschichten 3I,6 Mio t Kohle auf Halde erwartet werden ${ }^{5.97}$ ) Damit schlief3t die lange Zeit der Kohlennot. Ein erfrischendes Wort fand F. Burg $b a c b e r$ bei der Jahrestagung des Vereins r959: „Ohne eine völlig irrtimliche Kohlenimportpolitik hätte es das, was wir heute als Kohlenkrise empfinden, überhaupt nicht gegeben... Ausgesprochene Fehldispositionen... Ein Schnupfen wird für eine Lungenentzündung gehalten $\left.{ }^{65.05}\right)$.

\subsection{Gaserzeugung aus Koblen}

Sicherlich muf̧te in Deutschland die Kohle das Rückgrat der Energieversorgung bleiben. Bei der Kohlenknappheit war es aber notwendig, jede nur irgend geeignete Kohle auf ihre Verarbeitung zu Gas zu prüfen und entsprechende Verfahren zu finden. Ein Teilproblem war durch den Anfall an zwar gasreichen Flammkohlen gegeben, die für sich allein in die Kammern eingesetzt keinen festen großstückigen Koks ergaben. Von der Bindung an die Herstellung eines guten Kokses und die Beschränkung auf die knappen hierfür geeigneten Kohlen, wollte man freikommen. Mit ungeheurem Schwung und immer neuen Mahnungen suchte F. Stief, Hamburg, die Entgasung nicht backender Kohlen durchzusetzen ${ }^{8.09}$ ). Den anfallenden staubförmigen Koks verbrannte Stief erfolgreich in Staubfeuerungen, die Schwierigkeiten in der Mühle nicht achtend. Er nahm alte Gedanken aus der Frühzeit der Gastechnik wieder auf (Winsor Seite 6r), mit der Forderung alle Kohlen vor der Verbrennung zu entgasen. „Man mufj Gas und Strom in Zukunft aus dem gleichen billigen Brennstoff erzeugen ${ }^{5.100}$ " . .., Es bleibt kein anderer Weg ${ }^{\text {s.10 }}$ )." Das Verfahren war nach der Änderung der Kohlenlage nicht mehr von entscheidender Bedeutung, es dürfte aber u. U. bei neuen Umwälzungen doch beachtlich sein. Auch die Ruhrgas A.-G. sprach in ihrem Geschäftsbericht vom Jahre 1957 von einem Grołversuch der Vorentgasung von Kraftwerkskohle

Währenddem richtete sich die allgemeine Aufmerksamkeit auf die verschiedenen zum Teil erprobten, zum Teil noch entwickelungsfähigen Vergasungsverfahren. Darüber wurde schon einführend 1949 auf der 9osten Jahresversammlung des Vereins durch F. Plenz referiert ${ }^{\mathrm{s}, 107}$ ). Der Altmeister der Druckvergasung

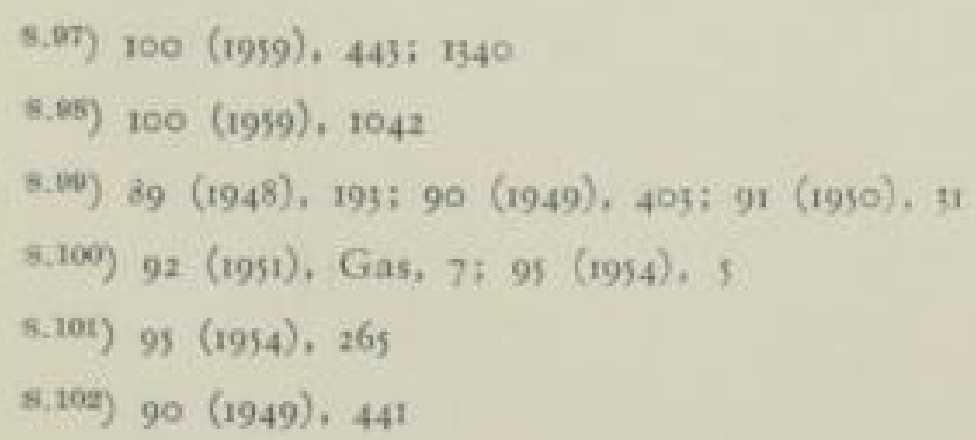


R. Drawe forderte die Kupplung des Verfahrens mit der Synthese ${ }^{5.100}$ ), was in England in Dr. Dent einen lebhaften Anwalt fand $\left.{ }^{5.101}\right)$.

Doppelgas fand erneut Beachtung (Vgl. Seiten 439/40). Der in den letzten Kriegsjahren von der Vergasungsindustrie A.-G. (Viag) Wien geplante Umbau im Gaswerk Ulm, in dem der Platz äuf̧erst beschränkt war, wurde $194^{8}$ bis $5 \mathrm{I}$ ausgeführt. Die für den Ofen benötigte schwachbackende Kohle konnte kaum beschafft werden. Ausserdem war der Schwelschacht wegen Baustoffschwierigkeiten nicht in der vorgeschriebenen Weise konisch, sondern zylindrisch ausgeführt worden, womit die Kohle zum Hängenbleiben neigte. F. E $c k$ konnte aber den Ofen mit einem Gemisch von Flammkohle und Koks im Verhältnis I : 3 bi I: 5 gut betreiben. Dann erfolgte der Limbau des Aufsatzes durch Il Gas Integrale, Mailand bzw. durch Industriebedarfsgesellschaft, Innsbruck (Ibeg), wonach kein Kokszusatz mehr erforderlich war ${ }^{5.05}$. Im Jahre 1955 muf3te auch Freiburg erweitern. Man wählte eine Kohlenwassergasanlage von Dr. C. O tto \& Co. Bochum, nach Lizenzen der eben erwähnten Ibeg. Zwei Generatoren von je $40000 \mathrm{~m}^{3 /} / \mathrm{d}$ lieferten ein $\mathrm{Gas}$ von $\mathrm{H}_{0}=3200 \mathrm{kcal} / \mathrm{Nm}^{\prime \prime}$. Dieses wurde mit Leichtöl auf 4200 kcal gebracht ${ }^{8.000}$ ).

Anregend war auch der Gedanke durch Wälzgase die restlose Vergasung kontinuierlich zu fahren. Er stammte nach F. $D$ o m a $n n$ zuerst von M. Mannesmann. der schon 1891 mit D.R.P. 66326 die stetige Vergasung von Koks und Steinkohle geplant hat. Mannesmann scheiterte an den nicht nach der Eignung ausgesuchten Kohlen. Für Braunkohlenbriketts wurde nach Pintsch-Hillebrand D.R.P. 422999 in Hamburg-Tiefstaak die erste Anlage mit erhöhtem Druck betrieben $\left.^{8.107}\right)$. F. Stief, den wir schon als Anwalt der Entgasung jedes Brennstoffes vor der Verbrennung kennengelernt haben, beanspruchte auch diesen kontinuierlichen Wassergasprozef̧ mit aus der Taufe gehoben zu haben ${ }^{\text {s.105 }}$ ). Jüngere Anlagen der gleichen Art liefen in Wesseling und der Lausitz.

L. Winkler forderte 1949 die Mitverwendung junger Kohlen in der restlosen Vergasung zu Schwachgas und dieses dann zu methanisieren ${ }^{\mathrm{v}, 100}$ ). Der Vorschlag begegnete Zweifeln, insbesondere aber die Absicht für das Methangas eine besondere Fernleitung im Ruhrrevier zu verlegen $\left.{ }^{8.110}\right)$. Im Jahre 1951 waren aber bereits $17 \mathrm{~km}$ vorhanden und man war dabei sie auf $67 \mathrm{~km}$ zu verlängern ${ }^{8.111}$ ).

Auch die Arbeitstagung Gaswirtschaft in Wildungen nahm einen Bericht seitens F. $S c b$ üssl, über die restlose Vergasung im Generator entgegen. Er erwähnte die kontinuierlichen Kohlenwassergas-Generatoren mit einem Gase von $3200 \mathrm{kcal} / \mathrm{Nm}^{3}$. Die Schwelgeneratoren in Vierzon, eine Versuchsanlage für eine Erzeugung von $30000 \mathrm{~m}^{3} / \mathrm{d}$, hatten Aufsehen erregt $\left.{ }^{\mathrm{s} .112}\right)$. In Italien und Frank-

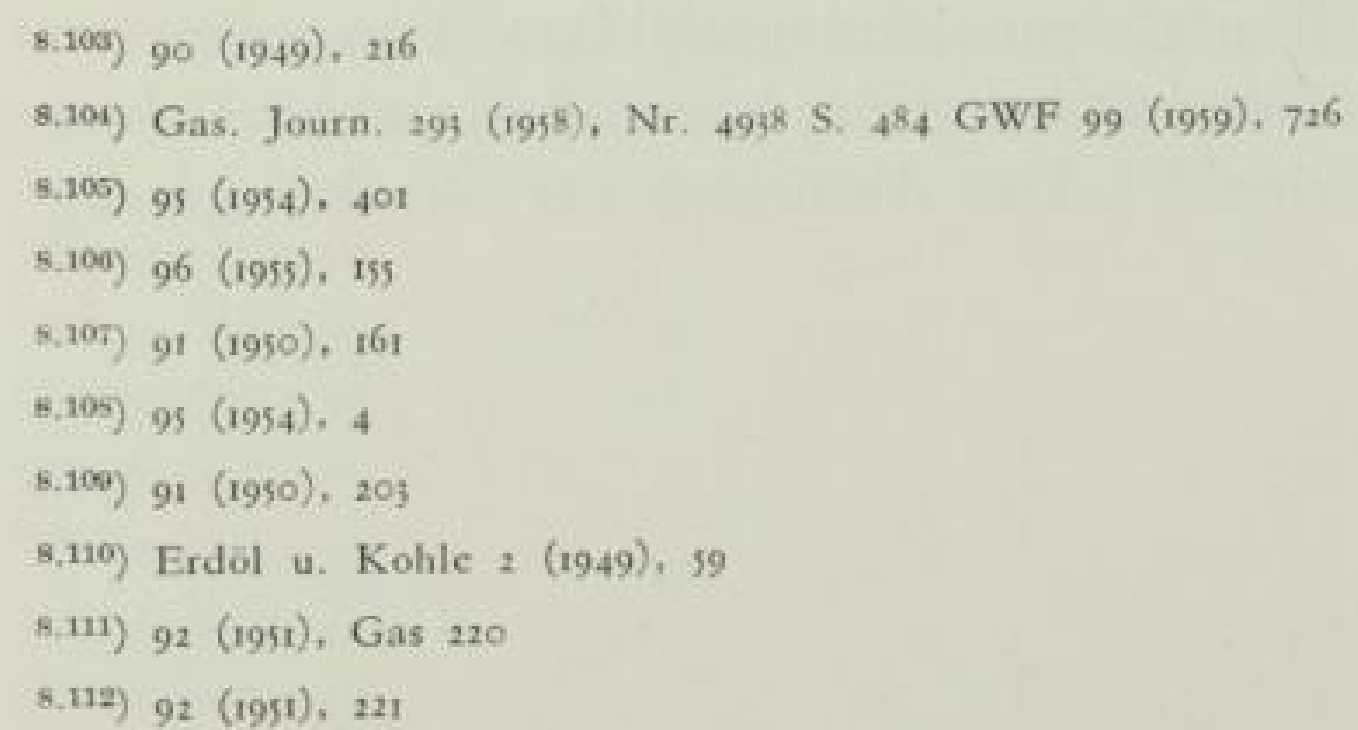


reich hatten sich dic Schwelgase stark eingeführt ${ }^{5.119}$ ). Die Vergasung in der Schwebe nach F. WV inkler, Ludwigshafen, hat wegen der Schnelligkeit der Reaktion zu den verschiedenartigsten Versuchen geführt, auch bei anderen chemischen Aufgaben diesen Weg zu gehen z. B. in der Schwefelwasserstoffreinigung. Die Fortbildung von Flesc $b^{\text {s.114 }}$ ) war für die Ammoniakherstellung und Grofsynthese wegen des hohen Wasserstoffgehaltes bestens geeignet, auch für Kohlen mit hohem Aschengehalt.

Ein anderer Weg, um des Aschenreichtums Herr zu werden und gleichzeitig die Leistung zu erhöhen, wurde durch Temperaturerhöhung bis zur Verflüssigung der Schlacke begangen. Schon 1950 versprach sich W. $G u m z$ in einem Bericht aus den Vereinigten Staaten eine grofe Zukunft, besonders als Zweikammerverfahren für Heiz-, Kraft-, Wasser- und Synthesegasherstellung $\left.{ }^{\mathrm{s} \cdot 125}\right)$. R. $\left.R u \mathrm{~m} \mathrm{mel}^{10}\right)$ entwickelte den Schlackenbadgenerator in Zusammenarbeit mit Dr. C. Otto \& Co. weiter, indem er den Impuls des einströmenden KohlenstaubSauerstoffgemisches zum Kreisen der Schlacke ausnützte. In Wesseling wurde zuerst ein solcher Generator mit Braunkohle betrieben. Versuche mit Steinkohle erregten die Aufmerksamkeit des englischen Gas Council, der eine Versuchsanlage für Blauwassergas mit einer Leistung von $60000 \mathrm{~m}^{3} / \mathrm{d}$ aufstellen lief ${ }^{5.117}$ ). Die Versuche sind noch nicht beendet, werden aber als aussichtsreich betrachtet. Eine andere Möglichkeit in Generatoren einen flüssigen Abstich zu erzielen, ergab sich aus dem Einsatz stark eisenhaltigen Kokses. H. B arking und C. E $y$ mann erhielten solchen Eisenkoks bei dem Bemühen, die hochbituminösen Kohlen durch Zusatz von Erzstaub verkaufsfähig zu machen. Der Generator lieferte ein Gas von $125 \mathrm{kcal} / \mathrm{Nm}^{3}$ und Roheisen ${ }^{\text {s.115 }}$ ). Auch dicser Weg wird zur Zeit nicht mehr begangen. Das sagt aber ebensowenig, wie bei dem Weg zur Kraftwerkskohle, daf nicht bei einem Umschwung der Kohlenlage auch dieses Verfahren wieder herbeigezogen werden kann.

Umfangreiche Versuche hat die Ruhrgas A.-G. schon seit 1936 angestellt, um neue Verfahren für Steinkohlen zu entwickeln, die 1948 wieder aufgenommen wurden. K. Traenckner berichtete darüber $\left.1952^{8.110}\right)$. Im Vordergrunde standen drei verschiedene Wege: I. Vergasung staubförmiger Kohle mit Luft in der Schwebe. I. Vergasung in einer Wirbelkammer. 2. Vergasung im Schwingrohr (bei dem die stołartigen Bewegungen durch die Impulse der Verbrennung geliefert wurden). II. Vergasung im ruhenden Bett mit Sauerstoff und Wasserdampf (Lurgidruckverfahren). III. Kontinuierliche Vergasung feinkörniger Brennstoffe mit festen Wärmeträgern ohne Sauerstoff (Lurgi-Ruhrgasverfahren). Das älteste deutsche Patent auf diese Gedanken stammt schon aus dem Jahre 1905. Schutzansprüche von Koppers von 1921. Der Gedanke ähnelt einem amerikanischen Verfahren zur thermischen Ölspaltung (Pebbles Heater-Steinchenerhitzer).

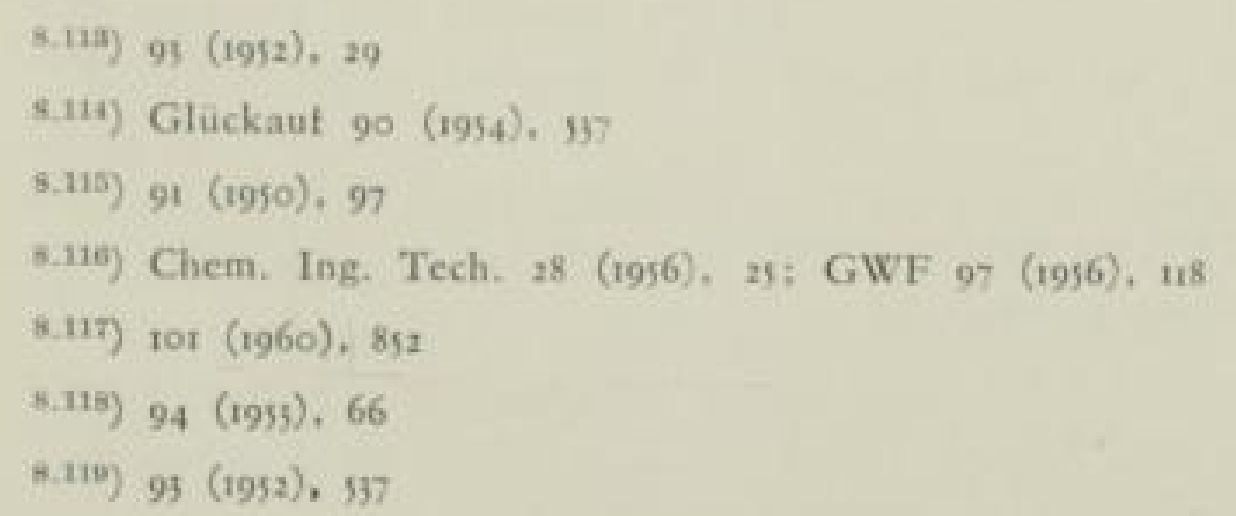


Am erfolgreichsten war von diesen Versuchen seit 1950 das Druckverfahren. 1956 wurde eine Grofanlage in Dorsten feierlich eingeweiht $\left.{ }^{8.100}\right)$. 1959 konnte $\mathrm{H}$. Weittenbilier auf der Hauptversammlung des Vereins von überraschenden Fortschritten sprechen $\left.{ }^{8.121}\right)$. Das Verfahren fand in Groß̧britannien starken Anklang $\left.^{8.122}\right)$. Die erste Anlage in Schottland ist im Betrieb, eine zweite in Mittelengland im Bau. Im Augenblick sehen die Fachleute in diesen Anlagen mit nachheriger Aufwertung des Gases durch importiertes Erdgas geradezu die Lösung der Krise um Kohle und Gas.

Über das Koppers Totzek-Verfahren ist bereits im vorigen Abschnitt geschrieben worden. Anlagen wurden als ,amerikanisches Koppers-Verfahren“ in Finnland, Spanien und Belgien errichtet $\left.{ }^{8.123}\right)$. Festgehalten sei eine Anmerkung von $\mathrm{O}$. Grosskink $y^{8,121}$ ), dał der Mangel an schwachbackenden Kohlen zu Versuchen geführt habe, durch Oxydation grober Kohlen das Verkokungsvermögen herabzusetzen.

Alles in allem ist wohl durch diese Darstellung der Eifer um die preiswerte Herstellung von Gasen mit Stadtgaseigenschaften aus heimischer Kohle deutlich geworden. Die internationale Anteilnahme an den deutschen Arbeiten war grof3. In England beschäftigte sich seit 1950 fast jede Versammlung der Institution mit diesen Fragen ${ }^{\text {s.125 }}$ ). E. Gral schrieb 1952 über Versuche in den Vereinigten Staaten $\left.^{8.120}\right)$. In Lüttich trafen sich 600 Besucher aus allen Ländern, um die Fortschritte zu hören $\left.{ }^{\text {s.127 }}\right)$. Im gleichen Jahrc behandelte das englische Forschungstreffen die Fragen genau ${ }^{\varepsilon .155}$ ) und auch die 5. Weltkraftkonferenz in Wien beschäftigte sich damit $\left.{ }^{8.128}\right)$.

F. We $\operatorname{rom} a n n$ hatte schon 1949 die Kosten der neuen Verfahren und der Entgasung einander gegenübergestellt (Tafel 8).

\section{Tafel 8: Größenordnung der Verfahrenspreise}

\begin{tabular}{|l|c|c|}
\hline & Heizwert & $\mathrm{rfg} / 1000 \mathrm{kcal}$ \\
\hline Stadtgas Kokereien und Werke & $4200 \ldots 4500$ & $0,8 \ldots, 0,6$ \\
Stiefverfahren & 4200 & 0,7 \\
Lurgi Druckverf. Braunkohle & $4300(30 \mathrm{at})$ & $1,1 \ldots 1,2$ \\
Ahrensver. Braunkohle & 4500 & $1,0 \ldots 1,2$ \\
Didier-Bubiag Gleichstromverf. & 4200 & $1,3 \ldots 1,5$ \\
Wassergas aus Koks & - & $1,5 \ldots 1,8$ \\
Winkler Schwelverf. Braunkohle & 2300 & $1,2 \ldots 1,5$ \\
Thyssen-Galoszy Steinkohle & 3000 & $0,9 \ldots 1,1$ \\
Koppers-Totzek & 2300 & unbekannt \\
Kontinuierlich Wassergas methanisiert & 4200 & 2,0 \\
Generatorgas & $1150 \ldots 1250$ & 0,63 \\
\hline
\end{tabular}

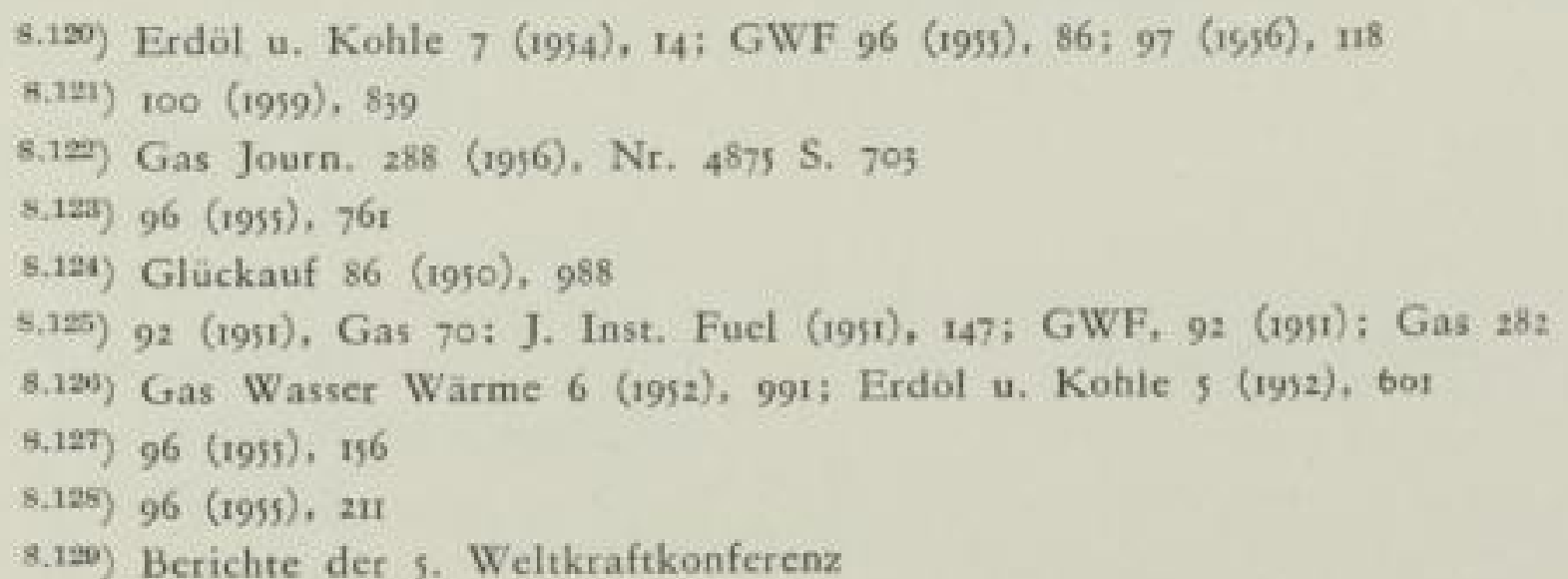


Nebenher lief die Anteilnahme an der Untergrundvergasung, von der sich andere Länder viel versprachen, weil die Bergmannsarbeit eingespart werden könnte. Führend waren die Russen ${ }^{8.139}$ ), ${ }^{5.131}$ ), ${ }^{8.129}$ ), Marokko ${ }^{8.123}$ ), Nordamerika ${ }^{8.13}$ ), $\left.{ }^{8125}\right)$, Belgien $\left.{ }^{8.129}\right)$ und England $\left.{ }^{4.137}\right)$. Hier wurden nach grofen Hoffnungen die Arbeiten eingestellt, als die Kohlennot behoben war. Deutschland hat sich an den Versuchen nicht beteiligt.

\subsection{Gaserzeugung aus Mineralölen und deren Produkten}

Die ersten Berichte kamen aus den Vereinigten Staaten und Frankreich. Der Hall-Prozeł cuürfte aus den üblichen Wassergasverfahren mit Karburierung entwickelt $\left.\operatorname{sein}^{8.125}\right)$. Zunächst stand aber die einfachere Spaltung von Propan, Rohnaphtha und Gasöl auf ein Gas von $4600 \mathrm{kcal} / \mathrm{Nm}^{3}$, mit einer Dichte von 0,7 im Vordergrund ${ }^{\text {s.19o }}$ ), um dort der stark störenden Winterspitze bei der allgemeinen Aufnahme der Raumheizung mit Erdgas begegnen zu können. Bei der Spaltung mögen Vorbilder der Ölindustrie mitgewirkt haben, jedoch sagt eine Meldung aus Long Island über die Umwandlung von Flüssiggas, die Schutzgasanlagen für Industrieöfen hätten das Beispiel gegeben ${ }^{810}$ ). Darauf deuten wohl auch die Nachrichten auf dem 5. Internationalen Kongress in Brüssel über die Teilverbrennung von Propan ${ }^{8.14}$ ) hin.

Teilverbrennung von Ol wurde auch bei der Gas Light \& Coke Co versucht ${ }^{\text {s.14ag }}$ ). Das Ergebnis war ein $\mathrm{Gas}$ von $4000 \mathrm{kcal} / \mathrm{Nm}^{3}$ ohne und von $5000 \mathrm{kcal} / \mathrm{Nm}^{3} \mathrm{mit}$ Vorwärmung. Der Wirkungsgrad belief sich auf $60 \%$. Das Dichteverhältnis war $\mathrm{I}, \mathrm{O}$, so daf3 das Erzeugnis nur zur Spitzendeckung in beschränktem Umfange dem Steinkohlengas zugesetzt werden konnte.

In Deutschland war man wegen des Baustoff- und Kapitalmangels gezwungen zu versuchen, durch Ölzusatz zur Kohle und Einspritzung in leere Kammern die Leistung vorhandener Anlagen zu erhöhen. Darüber sprach man schon beim Erfahrungsaustausch der Gaschemiker in Detmold 1949. F. W $u r z$ widmete sich in Baden-Baden, wo das Hauptquartier der Franzosen einen ungeheueren Anstieg der Anforderungen an Gas gebracht hatte, dem Zusatz von Ol zur Kohle mit besonderem Fleif3.143). Gegenüber dem alten Verfahren von Rieb eck

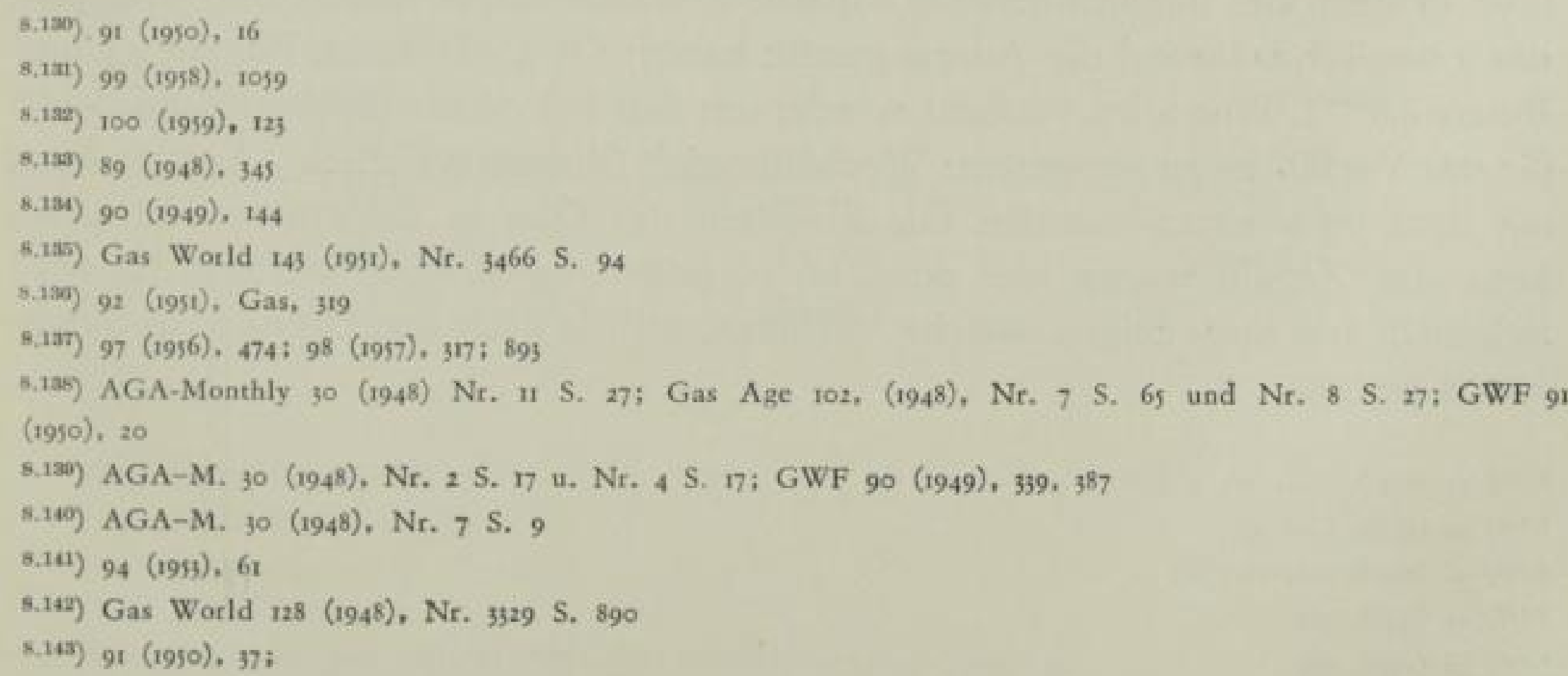


(Vgl. Seite 205) hatte er zwei Vorteile, einmal waren die Öle nicht so leicht flüchtig, wie die Destillate der Braunkohle, und dann erleichterte die vorhandene Kohlen-Mahl- und Mischanlage den Zusatz. Wurz verwandte auch Altöle. Bei Zusatz bis zu $3 \%$ wurden bis $10 \%$ Kohlen im Vertikalkammerofen eingespart. Das Gasinstitut konnte im Laboratorium und durch Versuche an den Ofenanlagen die Ergebnisse bestätigen. 70 bis $75 \%$ des Öleinsatzes wurden im Gas wieder festgestellt ${ }^{5,144}$ ). Gleichartige Versuche, aber auch mit Einspritzung des Öles in die beladenen Kammern führte P. $S c b e n k$ in Stuttgart aus. Er verarbeitete die verschiedenartigsten Kohlen, auch amerikanische, die Kohlensorte spielte aber keine Rolle ${ }^{8,15}$ ).

F. W $u r z$ ging dann weiter und füllte die Kammern lediglich mit Koks, kam also zu einer reinen Ölvergasung ${ }^{8,14}$ ). Der Koks konnte nur $25 \%$ des Gewichtes an Öl aufnehmen. Eine Erhöhung der Gasleistung wurde erreicht, die abzusetzende Koksmenge verringert. W. $Z$ a n $k l$ konnte in weiteren Versuchen von besseren thermischen Ergebnissen berichten. Die Koksfeuchtigkeit spielte insofern eine Rolle, als Wasser und Öl zusammen mit $30 \%$ eine feste Grenze sind. Vortrockung und Trennung des Kondensates aus Kohlen und Ölkammern muften empfohlen werden.

Die Internationale Gas-Union beschäftigte sich 1952 eingehend mit dem OIeinsatz. Ihm waren allein s Vorträge gewidmet. Präsident M. Brabant kennzeichnete die Lage folgendermał̧en ${ }^{\text {s.1.7. }}$ ): „Die Gaswerke verlangen in größzerem Umfange nach eingeführten Ölen. Zu den klassischen Verfahren mit karburiertem Wassergas treten neue, deren Ausgang natürliche und künstliche Mineralölerzeugnisse sind. ı. Die Benetzung der Kohle mit Erdöl. 2. Das Kracken von Gas- und Heizöl in Retorten und Kokskammern. Diese weichen jetzt den mehr wissenschaftlichen Verfahren, bei denen aus besonderen Vorrichtungen teils ein mit dem Stadtgas austauschbares Gas, teils ein Streckgas entsteht, das nur in beschränktem Umfange zugesetzt werden kann."

In der Tat setzte nunmehr eine umfangreiche Arbeit, ein gewisser Wettlauf der Ofenbaufirmen ein. Man gab sich auch in den Werken, die zur Mitarbeit berufen waren, Rechenschaft über die physikalisch-chemischen Vorgänge. Die in Amerika vorwiegend entwickelten Verfahren, die einen hohen Heizwert dem Erdgas entsprechend erstrebten, waren nicht ohne weiteres in Europa übernehmbar, da hier ein wasserstoffreiches Gas von $4300 \mathrm{kcal} / \mathrm{Nm}^{\text {s }}$ verlangt wurde. Die Schwierigkeit liegt in dem viel ungünstigeren Kohlenstoff/Wasserstoffverhältnis der Stadtgase, das 2 beträgt, während die Ausgangstoffe haben: $\mathrm{Ol} 7$, Methan 3, Propan 4,5, und Butan $\left.4,8^{8,115}\right)$. Was alles versucht wurde, um den sich abscheidenden Kohlenstoff für das Verfahren zu verwerten: Wechselbetrieb (diskontinuierlich), Auswaschung mit dem noch einzusetzenden Öl, Eindüsen des Öles in Generatoren u. s. w., kann der Anzahl wegen hier nicht im einzelnen beschrieben werden. Es wird sich auch erst noch zeigen, welche Verfahren sich je nach den Umständen durchsetzen werden.

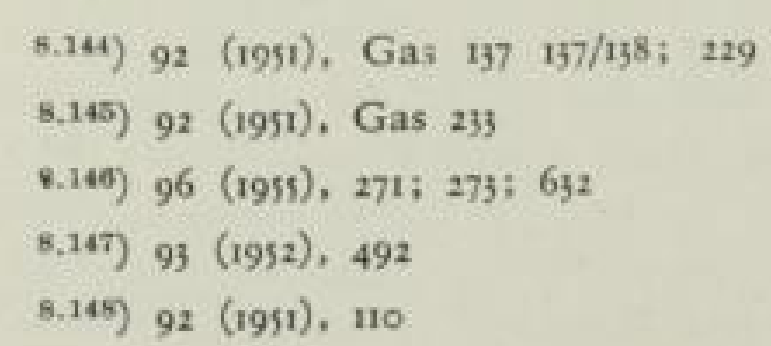


Die ersten als Spitzengaserzeuger in deutschen Gaswerken eingesetzten Spaltanlagen waren in Berlin-Mariendorf $\left.{ }^{2.149}\right)$ von Demag-Onia-Gegi (Onia = Office National Industrie de l'Azote, Gegi $=\mathrm{Gaz}$ à l'Eau et Gaz Industrielle) und Stuttgart ${ }^{2.150}$ (Anlage der Ibeg, Innsbruck, die $60000 \mathrm{~m}^{3} / \mathrm{d}$ Gas mit $6800 \mathrm{kcal} / \mathrm{m}^{3}$ liefert). Hameln rang sich als erstes Werk dazu durch, sich ganz auf Öl umzustellen. Die Spaltanlage baute Didier nach Segas (Segas = South Eastern Gas Board $\left.)^{8.151}\right)$. Statt der Einzeldarstellung der sehr stürmischen Entwicklung möge die Formulierung eines Vortrages von T. Heike (1960) folgen ${ }^{5.152}$ ): „Die Spaltung flüssiger Kohlenwasserstoffe ist wegen der ungünstigen $\mathrm{C} / \mathrm{H}$-Verhältnisse an den diskontinuierlichen Verfahrensablauf gebunden; bei der Umwandlung gasförmiger, wird die kontinuierliche bevorzugt, jedoch arbeitet auch hier eine Reihe von Anlagen diskontinuierlich. Leichtbenzin stellt bezüglich seiner Vergasbarkeit einen Grenzfall zwischen den genannten Kohlenwasserstoffen dar." (Es wird in England immer mehr auch in den alten Wassergasanlagen zur Karburierung verwandt.) „Die Anlagen haben im allgemeinen eine der klassischen Gaserzeugung vergleichbare Betriebsreife erreicht. Das Gleiche gilt auch für den Einsatz von Flüssiggas oder Öl in Verbindung mit der Gaserzeugung aus Kohle oder Koks. Für die Spaltung von Flüssiggas in den Entgasungsräumen von Vertikalkammeröfen bzw. Generatoren wurden Zusätze entwickelt, die einen im Verhältnis geringen Aufwand an Kapital und fast keinen zusätzlichen Bedienungsaufwand erfordern".

Die für jede Ölsorte geeigneten mit Katalyten arbeitenden Anlagen laufen heute vornehmlich in großen Werken, zumal sie wegen der schwefelhaltigen Rohstoffe auch noch Reinigungsanlagen benötigen, während die thermische oder auch katalytische Spaltung von Flüssiggas oder Leichtbenzin von den kleinen Werken bevorzugt wird. In Schweden hat z. B. Stockholm eine Zusatz-Ölspaltanlage, Norrköpping und Eskilstuna Leichtbenzinspaltung gewählt.

Tafel 9: Öl- und Flüssiggaseinsatz bei Gaswerken und Kokereien in 1000 t/a nach Fußnote 8,153

\begin{tabular}{|c|c|c|}
\hline a) Gaswcrke & Ol & Flussiggas \\
\hline 1954 & & 0,75 \\
1955 & 4,8 & 2,0 \\
1956 & 11,0 & 5,7 \\
1957 & 15,2 & 7,7 \\
1958 & 12,7 & 16,0 \\
1959 & 29,0 & 22,9 \\
1959 & 28,9 & nicht erfaßt \\
b) Kokereien 1958 & 33,5 & 16,3 \\
\hline
\end{tabular}

\footnotetext{
6.149) 97 (1956), 201; 99 (1958), 552

8.150) $97(1956), 287$

s.157) $98(1957), 508$

8.152) $101(1960), 477$

8.153) 97 (1956), 476; 741; 1007; 98 (1957), 269; 99 (1958), 220; 101 (1960), 325 
Diese Tafel wird durch das Bild 123 ergänzt. Wegen der Schwankungen ist der Einfluf des Wetters auf die Spitzengaserzeugung zu bedenken.

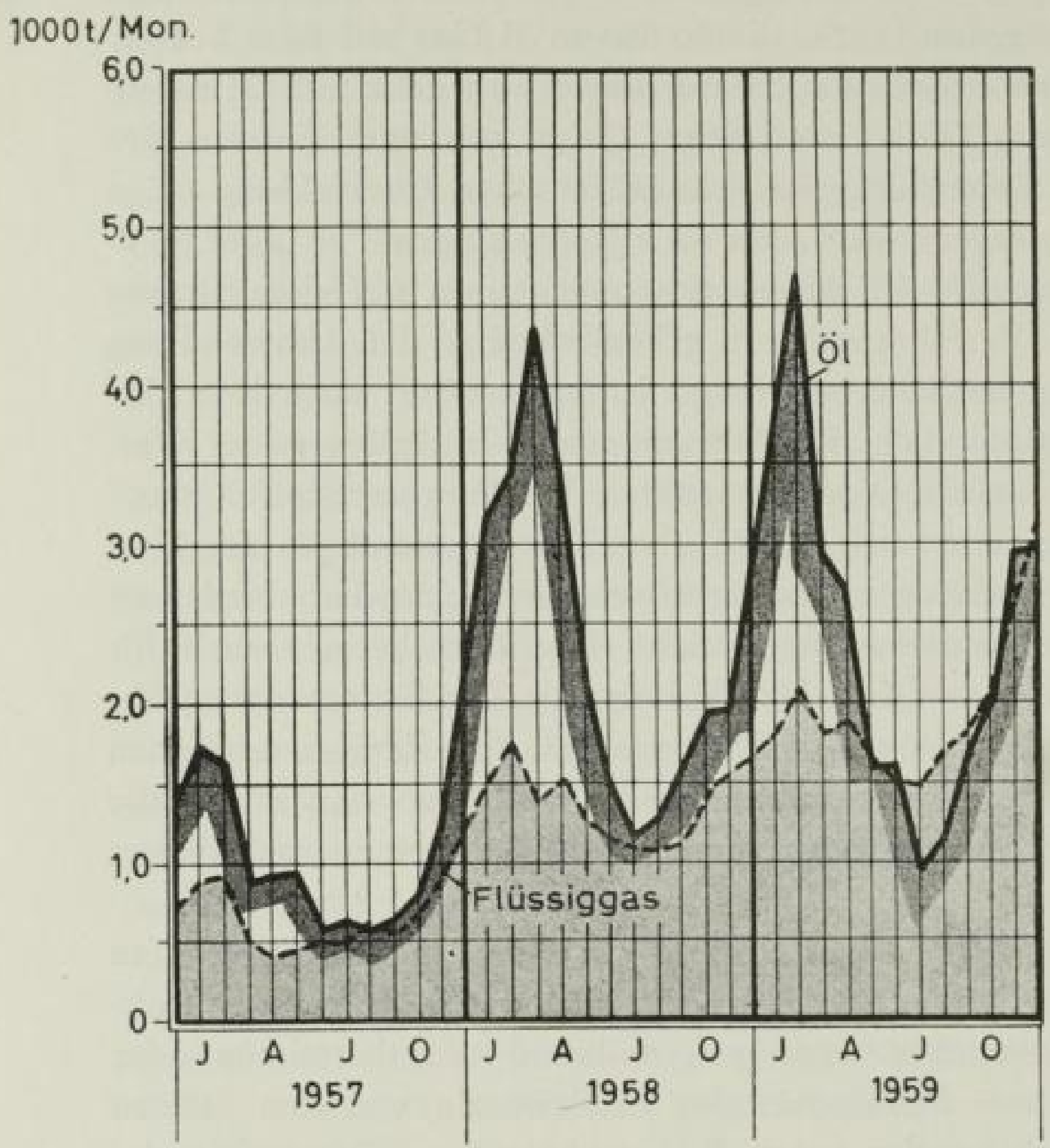

Bild 123

Einsatz von OOl und Flüssiggas für die Gaserzeugung der Gaswerke 1957 bis 1959 (nach H. Laurien u. L. Segelken (GWF I0I [1960] S. 828)

8.33 Umwandlung von Raffinerierestgas (Raffgas) in $S$ tadtgas

Ein guter Rohstoff für die Gasindustrie hat sich in den Raffgasen neuerdings angeboten. Es ist in der Tat ein Rohstoff, als je nach der Marktlage des Öles verschiedene Verfahren oder Krackungen angewandt werden müssen, und die Restgase mit anderen Eigenschaften und Heizwerten anfallen $\left.{ }^{8.154}\right)$. Es können zudem auch Verunreinigungen insbesondere verschiedene Schwefelverbindungen in den Raffgasen enthalten sein. Die Raffinerieen hatten solche Gase zunächst, soweit sie nicht allzu bösartig waren, zur Beheizung ihrer Apparate und Öfen benutzt und den Rest abgefackelt, um sich ohne Beschwerden ganz ihren in der Entwicklung befindlichen Verfahren zu widmen. Sie sind nun aber den gleichen Weg wie die Kokereien 50 Jahre vorher gegangen und nutzen die Gase und ihre Beimengungen als immer wertvoller aus. Dabei kommen immer größ̧ere Mengen frei. Für die werdende Karlsruher Raffinerie spricht man von 400 Mio $\mathrm{m}^{3}$ Raffgas mit Ferngasqualität im Jahre, die nur von grołen Abnehmern aufgenommen werden können. 
Die erste Nachricht von einer Kupplung von Raffinerie und Gaswerk kam nach Deutschland im Jahre $194^{8.155}$ ). Die Manchester Gas Corporation wollte Raffgas von $7900 \mathrm{kcal} / \mathrm{Nm}^{3}$ übernehmen und mit Wassergas auf $4000 \mathrm{kcal} / \mathrm{Nm}^{3}$ absenken. Auch die Australian Gas Light Co. von Victoria kaufte Raffgas auf und setzte bis $40 \%$ des gesamten Absatzes dem erzeugten Gase $\left.z^{8.435}\right)$. Mit diesem Vorgehen ist aber die abnehmbare Menge von der Leistung der vorhandenen Generator- oder besser Wassergasanlagen abhangig ${ }^{5.17}$ ). Das war unbefriedigend. F. St ief ging deshalb darauf aus, das Raffgas zu spalten. Er hoffte aus 50000 $\mathrm{t} / \mathrm{a}$ Raffgas $120 \mathrm{Mio}^{3}$ Stadtgas zu erhalten ${ }^{8,15}$ ). Im Jahre darauf schlossen die Hamburger Gaswerke mit der Esso einen Vertrag ab, ab Herbst 195680 Mio m Raffgas $=120$ Mio Stadtgas abzunehmen. Der Gesamt-Gasabsatz in Hamburg betrug damals 375 Mio $\mathrm{m}^{3} / \mathrm{a}$, die Werkskapazität lag bei $490 \mathrm{Mio} \mathrm{m}^{3} / \mathrm{a}^{5,150}$ ). Die Gaswerke bauten eine Spaltanlage in Tiefstaak, die ein Gas von $1900 \mathrm{kcal} / \mathrm{m}^{3}$ lieferte, das mit Raffgas auf $4200 \mathrm{kcal} / \mathrm{m}^{3}$ gebracht wurde. Durch diese Kupplung belief sich der Wirkungsgrad insgesamt auf $96 \%{ }^{5,100}$ ). Eine Entschwefelungsanlage dazu hatte $12000 \mathrm{~m}^{3} / \mathrm{h}$ Leistung.

Fast gleichzeitig ging in England auch der South Eastern Gas Board an die Aufgabe heran. Die Raffinerie sollte eine Segas-Spaltanlage errichten und zwar in der ersten Baustufe für $50000 \mathrm{t} / \mathrm{a}$. In späteren Anlagen anderer Gasbezirke wurden die Spaltanlagen bei den Gaswerken, nicht mehr in den Raffinerieen betrieben.

Romford wurde als erstes Werk ganz auf Raffgas umgestellt mit einer OniaGegi-Anlage (s. Seite 579$)^{\text {s.161 }}$ ), hatte aber Ferngasverbindung als Sicherheit. Bei diesen Aufstellungen im Werk wirkt sich für die Verbindungsleitung zwischen Raffinerie und Gaswerk der hohe Heizwert des Gases günstig aus. Die Schwefelentfernung muf allerdings in der Raffinerie ausgeführt werden.

Dem Gaswerk Bremen bot schon 1955 die Mobil Oil A.-G. Raffgas an. Aber erst 1957 entstand beim Werk der entsprechende Bedarf. Die Anlage wurde von Heinrich Koppers erbaut und nach einigen Anlaufschwierigkeiten, die mit dem Wechsel des Schwefelgehaltes zusammenhingen, läuft sie seit 1959 befriedigend. Falls Raffgas fehlt, kann auch Leichtbenzin eingesetzt werden ${ }^{\text {s.tez }}$ ).

Im Haag wurde zunächst Raffgas von oben in koksgefüllte Kammern eingeleitet und Heif̧ampf mit Luft gemischt zugegeben. Der Koks nahm an der Reaktion nicht teil. Auch im Woodall-Duckham-Ofen gelang die Spaltung im Koks bei einer Leistungssteigerung um $\left.50 \%^{8.12 e y}\right)$. Später wurde eine Ibing-Anlage eingesetzt $\left.^{\mathrm{s} .107}\right)$.

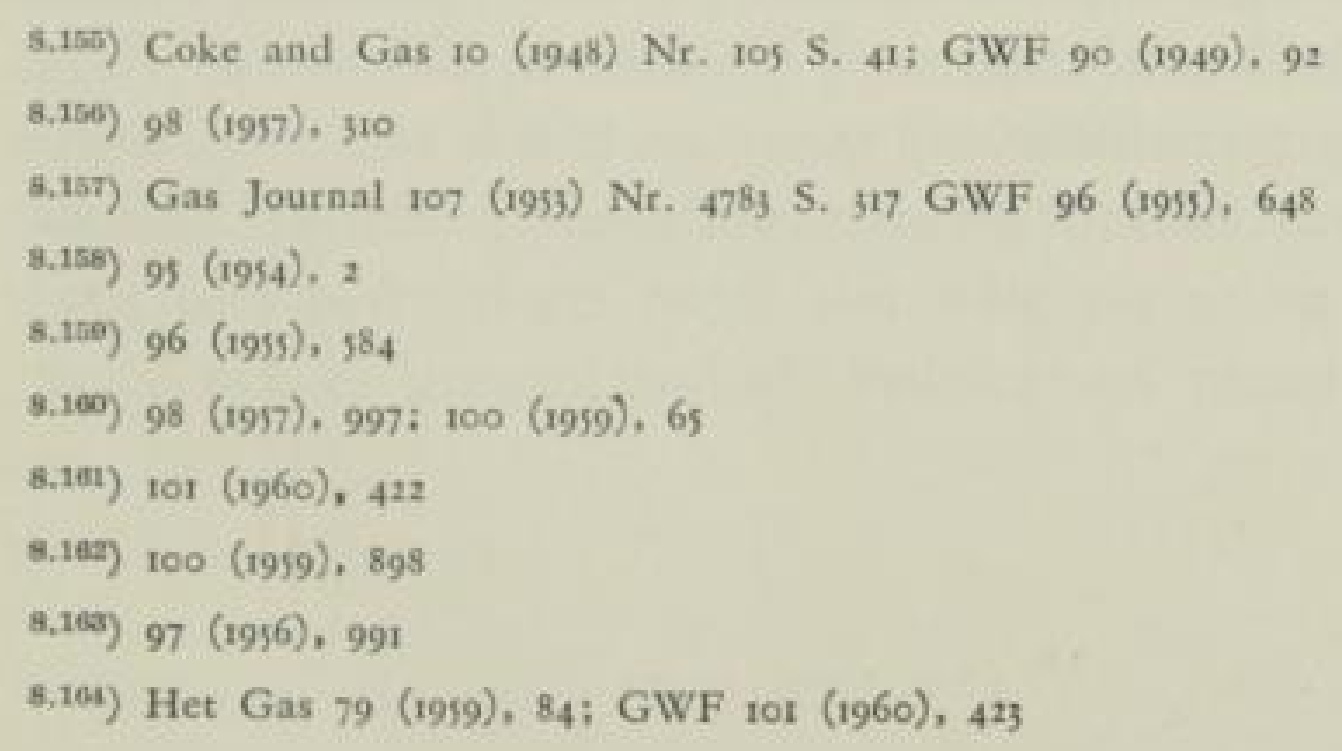


In Norwegen bot die Esso-Raffinerie am Oslo-Fjord an, die Gaswerke Oslo, Bergen und Stavanger ganz auf Raffgas umzustellen. Das Gas sollte verflüssigt (Vgl. Seite 585 ) in Tankschiffen nach den einzelnen Werken gebracht wer$\left.\operatorname{den}^{6.105}\right)$.

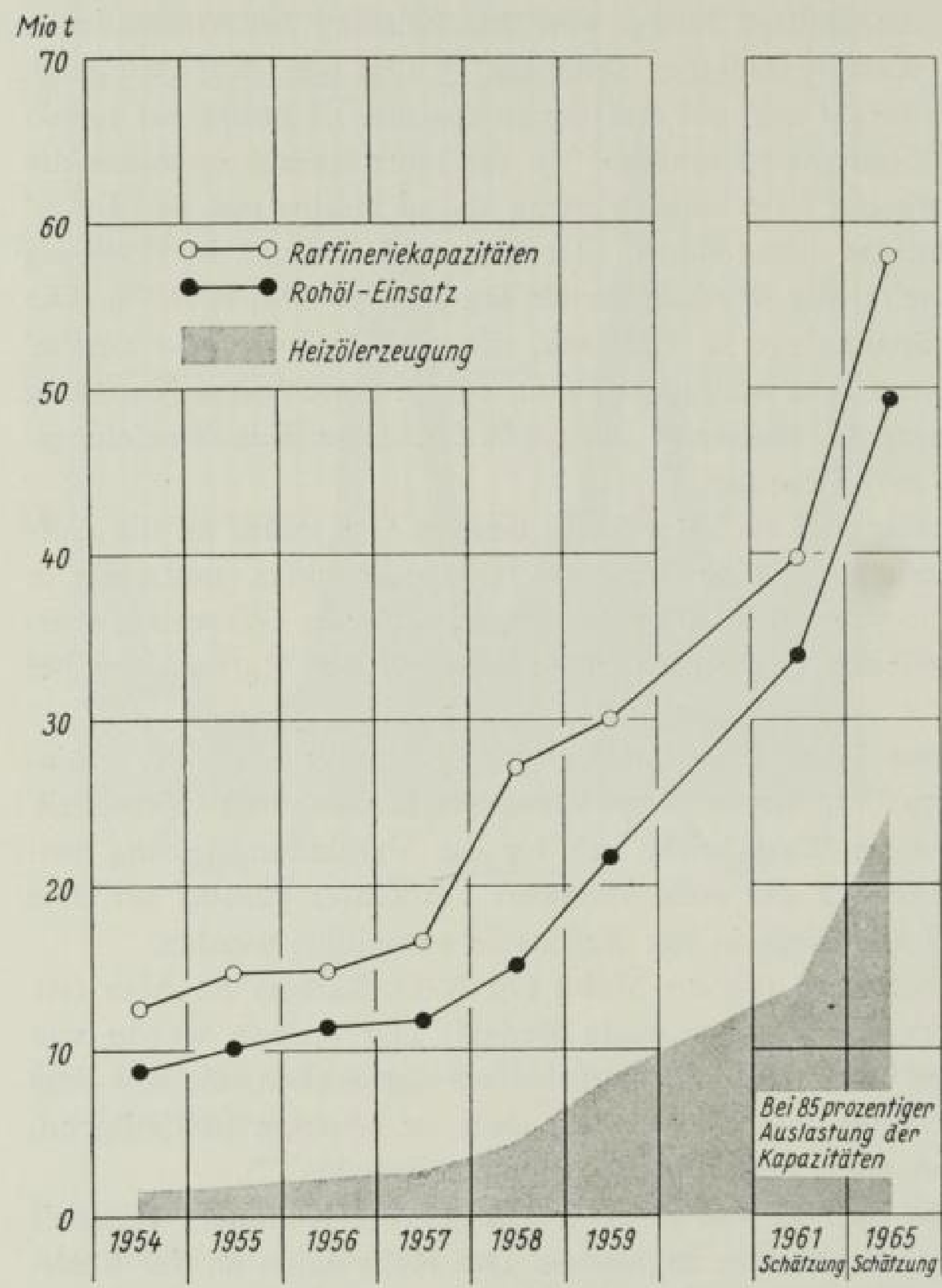

Bild 124

Raffineriekapazitäten und Heizölerzeugung in der Bundesrepublik (ohne Saar) (nach Morgenthaler (GWFio [1960] S. 841)

Die Anfänge sind in Deutschland vielversprechend. Der Aufbau von Raffinerieen ist zügig im Gange. Bild 124. War im Jahre 1955 der Ausstoł an Ölen erstmalig über to Mio $t$ gestiegen $^{8.105}$ ), so betrug er 1957 schon 17 Mio $t$ und soll 1965 auf 60 bis 70 Mio t steigen. Der Gasindustrie können also preiswerte gasförmige Rohstoffe in ungewöhnlich groß̧en Mengen zuflief̧en, wenn sie bereit ist, die Umsetzungsschwierigkeiten, die mit den wechselnden Gasen verbunden sind, auf sich zu nehmen und zu bändigen. Dazu sollte sie aber mit ihren chemischen und gasphysikalischen Erfahrungen wie kaum ein zweiter Industriezweig in der Lage sein.

5.125) $101(1960), 271$

8.106) 97 (1956), 198

582

\section{SLUB}


Wie aus den ersten Abschnitten dieser Geschichte hervorgeht, ist Erdgas früher als Steinkohlengas beobachtet worden. Es handelte sich aber immer um zufällige Entdeckungen vor allem bei der Ölsuche (Vgl. Abschnitt 5,27 u. 6,24). Die systematische Suche nach Gas konnte erst nach reichen geologischen Beobachtungen aus solchen Zufällen und mit den geophysikalischen Methoden, die zwischen den Kriegen entwickelt wurden, aufgenommen werden.

In der Weltausstellung Chicago $1933 / 34$ stand in der repräsentativen Amerikahalle, die man zuerst betreten muf̧te, im Mittelpunkt die Erdwaage der American Askania Corporation, einer Tochter der deutschen Askaniawerke. Sie sollte offenbar die Bedeutung der neuen grofen Funde und die Hoffnung auf eine großartige Weiterentwicklung der amerikanischen Energiewirtschaft verdeutlichen. In Nordamerika wurden, umgerechnet auf Stadtgas, im Jahre 1959 $748 \mathrm{Mia} \mathrm{m}^{3} / \mathrm{a}$ Erdgas gewonnen und davon konnten nach Abzug des Selbstverbrauches $640 \mathrm{Mia} \mathrm{m}^{3} / \mathrm{a}$ abgegeben werden. ${ }^{8,177}$ ).

In Europa ging man erst während des zweiten Weltkrieges und noch mehr nach dessen Ende auf die systematische Suche mit allen wissenschaftlichen und technischen Mitteln. In Deutschland hatte man allerdings 1938 begonnen, war aber nicht weit gekommen. Man hatte vorher angenommen, daß̧ nennenswerte Mengen nicht zu finden wären.

In Italien kam man von $7,6 \mathrm{Mia} \mathrm{m}^{3} / \mathrm{a}$ (umgerechnet auf Stadtgas) im Jahre 1958 auf 12,6 Mia 1959, in Frankreich von 0,3 Mia 1955 auf 2,5 Mia 1959, in den Niederlanden von 0,106 Mia 1957 auf 0,181 Mia 1959 und in der Bundesrepublik von 0,575 Mia 1955 auf 0,909 Mia 1959 verfügbares Erdgas ${ }^{8,106}$ ). Für Mitteldeutschland werden umgerechnet $32 \mathrm{Mio} \mathrm{m}^{\circ} / \mathrm{a}$ als Gewinnung angegeben. Für die Sowjetunion werden $8 \mathrm{r}$ Mia $\mathrm{m}^{3}$ für 1959 bei stark steigender Förderung genannt ${ }^{\text {s.1177 }}$ ).

Wenn auch das Aufkommen an Erdgas in der Bundesrepublik nur $5,4 \%$ der gesamten Gaserzeugung ausmacht, so muß es doch als wirtschaftlich ganz besonders wertvoll angesehen werden, in einem Augenblick, in dem der Koksmarkt sehr schwach ist. (Bild I25). Die Gasindustrie steht vor der schwierig zu entscheidenden Frage, ob sic angesichts der immerhin beschränkten Mengen und der wahrscheinlichen Erschöpfung einer Quelle nach etwa einem Jahrzehnt, das Gas auf Stadtgas umwandeln, oder den Umbau der Geräte bei Verwendung des unveränderten Erdgases in Kauf nehmen soll. Jene Lösung bringt uns einen dauernden Verlust für die Unwandlung, diese einen groł̧en Aufwand an Arbeit und Kosten und einc dauernde Abweichung der Geräte vom normalen in den Erdgasbezirken, die bei Umzügen von Stadt zu Stadt störend sein kann. München $^{\text {s.tai }}$ ) und Wien hatten ${ }^{5.179}$ ) zunächst das Erdgas ihren sonst erzeugten Gasen zugemischt. Als die Mengen größer wurden, ging man zur Spaltung über. Oldenburg ${ }^{\text {g.tag }}$ ) entschlof sich dagegen zum Umbau der Geräte. In Landshut in Bayern,

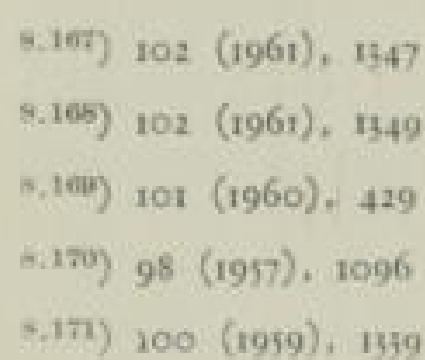




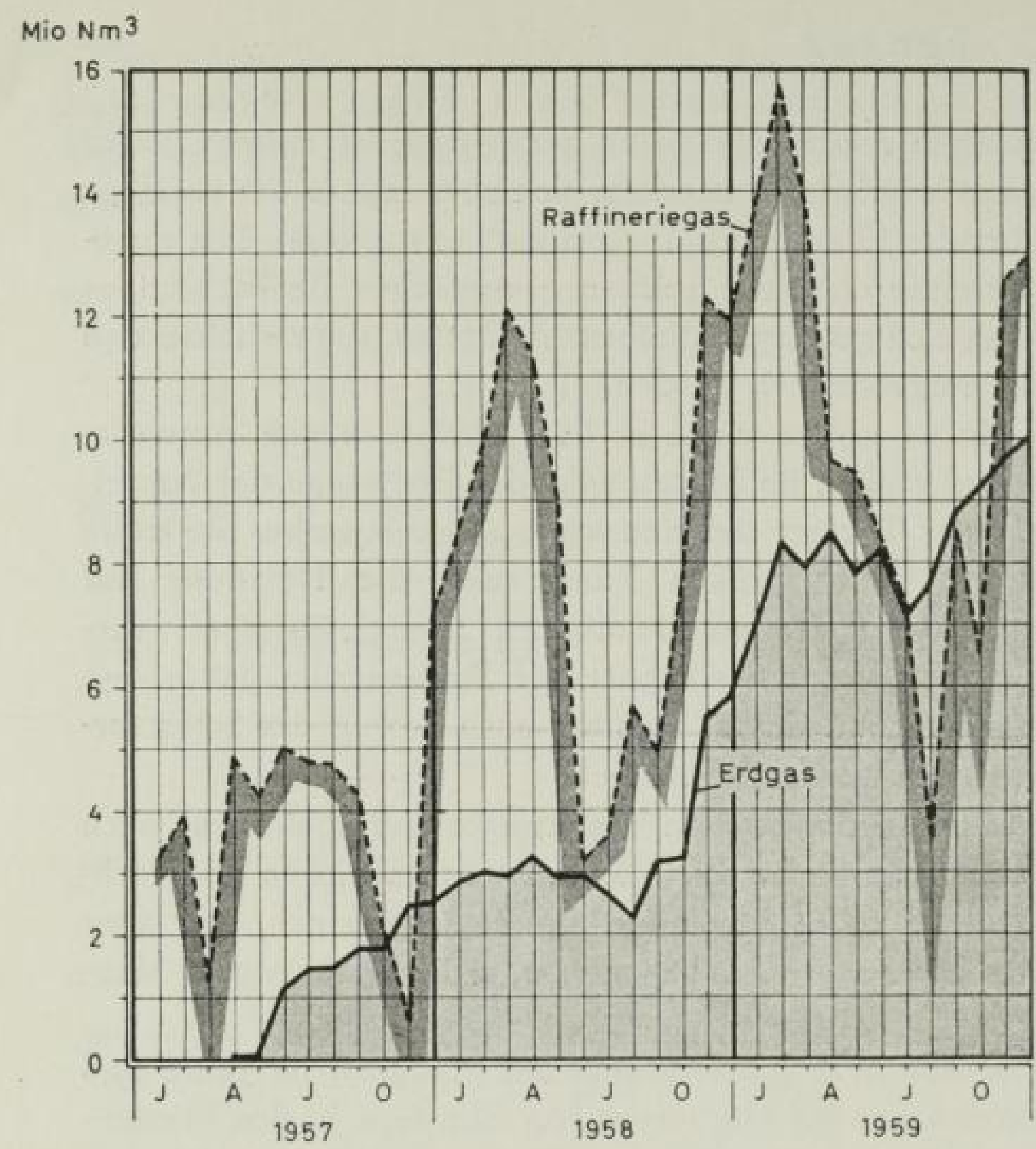

Bild 125

Einsatz von Raffinerie- und Erdgas für die Gaserzeugung der Gaswerke 1957 bis 1959 (nach H. Laurien u. G. Segelken (GWF ror [1960] S. 829)

wo auch ein Chemiewerk beliefert wird, steht eine Spaltanlage nach Dr. C. $O$ tto, die im Wechselbetrieb arbeitet. Der Wirkungsgrad ist unter Berücksichtigung des unverändert zugesetzten Aufwertungsgases $96 \%$, bei Erdgas und $95 \%$ bei Flüssiggas ${ }^{5.172}$ ).

Immerhin wird das deutsche Gasfach insbesondere, wenn grofye Mengen Raffgas zu den in einer Menge von $2 \mathrm{Mia} \mathrm{m} / \mathrm{a}$ erwarteten Erdgas hinzukommen, im Auge behalten müssen, ob man nicht hesser den Heizwert der Ferngase erhöht: Die Spaltung wäre leichter und wirtschaftlicher und die Fortleitung auch verbilligt, andererseits wäre die Abhängigkeit von dem vielleicht schnell verbrauchten Erdgas größer. Die Holländer, die einem verhältnismäßjig noch stärkerem Andrange der beiden Gasarten gegenüberstehen, zeigen deutliche Anzeichen für eine Steuerung zu erhöhten Heizwerten.

Wieder ganz andere wirtschaftliche Umstände können eintreten, wenn es gelingt, das Erdgas der Sahara preiswert nach Europa zu bringen. Die technischen Aufgaben scheinen lösbar zu sein. Die $W^{\prime}$ irtschaft ist aber noch mit vielen Ungewifheiten belastet. Nicht nur die Kosten einer Leitung oder des Schiffstransportes sind im Augenblick nicht genau vorherzusagen, es ist auch gar nicht unmöglich, daf̧ die Eigentümer der Gewinnungslandstriche und die Durchleitungsländer an hohe mühelose Gewinne mit Auflagen denken, die dann zum Schluf̧ den Hauptwert des Erdgases z. B. in Amerika, den billigen Preis an den Abnehmer

$8.172) \mathrm{ICI}(1960), 747$

584 
zunichte machen. Auch aus diesem Grunde wäre es wertvoll, mit dem gebotenen deutschen Erdgas und Raffgas den möglichen Preis und seine wirtschaftliche Auswirkung jetzt schon zu erproben.

Wegen des Saharagases dachte man zuerst an Leitungen durch das Mittelmeer. Italien glaubte mit dem Weg über Sizilien die kürzeste Meeresstrecke anbieten zu können. Es wurde ${ }^{\text {s.17 }}$ ) bereits eine Rohrleitungsgesellschaft gegründet. Inzwischen ist man aber auch in Süditalien fündig geworden. Die Sahara-EuropaLeitung ohne Unterwegsabgabe würde sich sehr schwierig bewirtschaften lassen. Die Franzosen wollten mit ihrer Leitung über Cartagena gehen. Man möchte daran erinnern, dał die erste Telegraphen - Kabellegung zwischen Afrika und Europa an der Steilküste dort gescheitert ist $\left.{ }^{5.174}\right)$. Allerdings wird bereits eine Unterseeleitung von $45 \mathrm{~km}$ Länge von Canada nach Vancouver in Tiefseekabeltechnik in England aufgebaut. Ein überraschender Erfolg ist daher nicht ausgeschlossen. Der englische Gas Council hat das besondere Verdienst, den Seetransport von tiefgekühltem flüssigem Erdgas in Tankschiffen technisch gelöst zu haben. Vorstadien waren die Verflüssigung in Nordamerika zur Heliumgewinnung und $194 \mathrm{I}$ in Cleveland zur raumsparenden Speicherung ${ }^{\text {s.15 }}$ ).

1959 wurde probeweise auf dem Mississippi flüssiges Erdgas verfrachtet ${ }^{5.176}$ ), in Rufbland seit 1959 nach Moskau gefahren. Als dorthin eine Leitung gebaut war, wurde das $G$ as als Motortreibstoff benutzt $\left.{ }^{8.17}\right)$. In Europa überlegte man, auch das bei der Ölgewinnung im nahen Osten verlorengehende Gas veflüssigt mit Tankern heranzubringen. Eine Rohrleitung schien an den politischen Verhältnissen zu scheitern ${ }^{\text {s.178 }}$ ).

Nach einem vorbereitenden Vortrage von J. Burns und L. J. Clark mit technischen Erläuterungen über die besonderen Bedingungen für Hochseetankschiffe und deren Wirtschaftlichkeit ${ }^{{ }^{* 1.17}}$ ), ging man an die Arbeit ${ }^{8.150}$ ). Gas Council und die amerikanische Constock arbeiteten zusammen. Oktober 1958 fuhr das auf Erdgas umgebaute Tankschiff Methan Pioneer zur Probe im Golf von Mexico $\left.^{8.125}\right)$. Am 28. Jan. 1959 konnte das Schiff mit der ersten Ladung in England feierlich begrüfłt werden. Es kreuzte insgesamt siebenmal den Ozean. 196r wurden die Verträge mit den Franzosen geschiossen. Diese übernahmen zu je $50 \%$ den Aufbau der Verflüssigungsanlagen in Afrika. Der Gas Council gründete ebenfalls mit Constock zu je so \% die British Methan Ltd, die die auf englischen Werften zu erbauenden Tanker chartern wird und die Speicheranlagen bauen soll. Von dort soll eine Methanleitung nach Mittelengland mit einem Abzweig nach Reading, wo man Hoffnung auf einen Untergrundspeicher hat, gebaut werden. Der Minister für Energie stimmte den Plänen zu, so daf̧ nunmehr der Ausführung nichts mehr im Wege steht ${ }^{8.181}$ ).

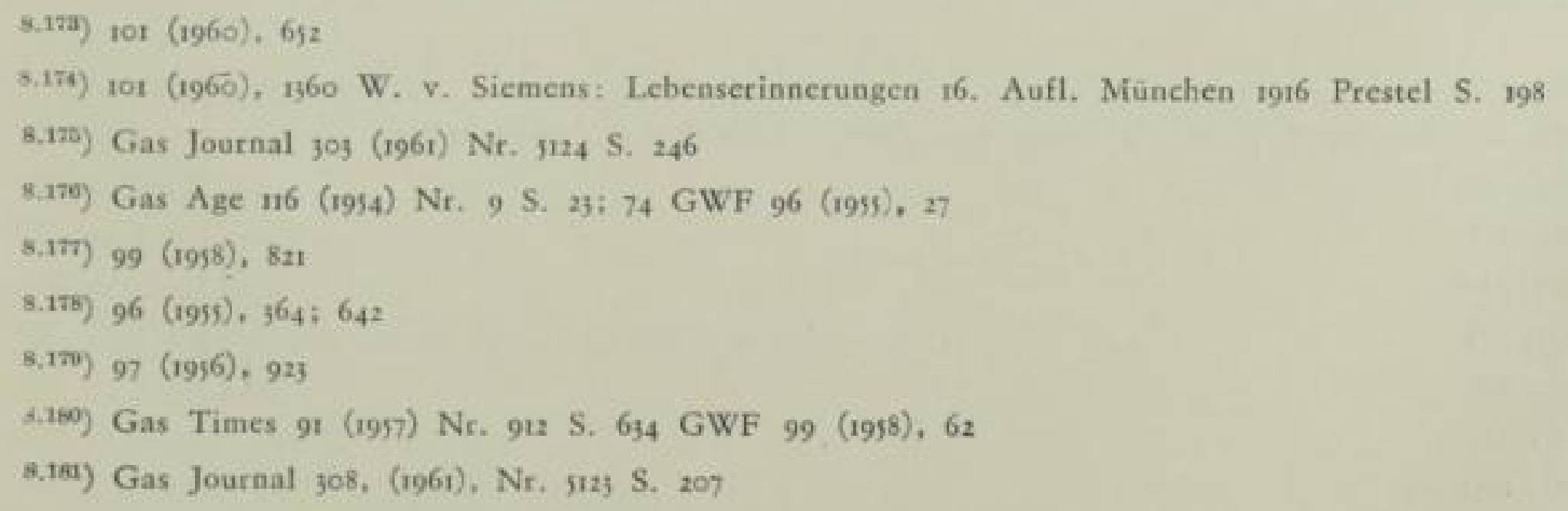


In Italien wurde ein kleines Motorboot von 1386 BRT für flüssiges Erdgas in Dienst gestellt ${ }^{8.152}$ ).

Als Käufer für Erdgas sind nicht allein die Gasversorgungen zu betrachten, sondern auch die chemische Industrie. Die erste Leitung von Bentheim nach den Chemischen Werken Hüls dient der Petrochemie. In Hüls stehen 17 Lichtbogenöfen zur Herstellung von Azetylen. Schon Bertbelot hatte sich mit der Spaltung von Methan zu Azetylen beschäftigt. Umfassende Arbeiten leistete das Kaiser-Wilhelm-Institut für Kohlenforschung. Hierüber hat H. Pichler in der Vortragstagung des Institutes vom Is. Dez. 1930 berichtet. Ausgehend von allgemeinen Erklärungen der Teilverbrennung belegte er durch Versuche die Bedingungen, unter denen so bis $60 \%$ des eingeführten Methanes als Azetylen gewonnen werden können. Der Rest des Methankohlenstoffs und ein Teil des Wasserstotts wird verbrannt und liefert die für die Azetylenbildung notwendige Reaktionswärme $\left.{ }^{8.187}\right)$.

Von der Leitung Bentheim-Hüls wurde zunächst ein Abzweig zur Bedienung der Lurgidruckanlage in Dorsten verlegt, dann eine zweite Leitung vom Erdgasfeld Adorf nach Dorsten gebaut. Die Badische Anilin- und Sodafabrik in Ludwigshafen bezieht $100000 \mathrm{~m}^{3} / \mathrm{d}$ Erdgas von Frankenthal ${ }^{5.151}$ ) und aus den Quellen bei Darmstadt, von wo auch die Farbwerke Höchst versorgt werden ${ }^{8.155}$ ). Stahlwerke bei Osnabrück haben sich auf Erdgas umgestellt. Auch ein Elektrizitätswerk benutzt Erdgas. In Österreich sind Fernleitungen aus dem Wiener Becken nach Linz und der Steiermark im Bau ${ }^{\text {s.15n }}$ ).

Das Erdgasnetz in den Vereinigten Staaten hatte 1956 schon eine Gesamtlänge von $215000 \mathrm{~km}$ Fernleitung. Rußjland baut zur Zeit über $3000 \mathrm{~km}$ Leitung im Jahr.

Im allgemeinen ist Erdgas trocken. Es kann aber auch mit Wasserdampf, Kohlendioxyd und Schwefelwasserstoff beladen sein. Dazu reichen meistens die in der Gastechnik bewährten Aufbereitungsanlagen aus. Besondere Schwierigkeiten aber ergaben sich im Lacq, wo das Rohgas mit 450 bis 500 at, $15 \%$ Schwefelwasserstoff, 9,5\% Kohlendioxyd bei hohen Temperaturen sehr aggressiv austritt (s. S. $587 / 88)$.

Als vorwiegend aus Methan bestehend kann man das Grubengas als verwandt betrachten. Die erste Grubengasabsaugung fand auf Grube Mansfeld (Ruhr) 1943 statt $\left.^{8.155}\right)$. 1948 folgte die Saar, 1949 Belgien und 1950 England. 1952 wurde in Belgien durch die Distrigaz, Brüssel, die erste Umformungsanlage zu Ferngas fur $30000 \mathrm{~m}^{\circ} / \mathrm{d}$ Grubengas errichtet $\left.{ }^{8.185}\right)$. Auf Zeche Viktoria, Lünen, werden $6,2 \mathrm{~m}^{3}$ Grubengas je geförderte Tonne Kohlen gewonnen. Die Saar erhielt 1950 $12000 \mathrm{Nm}^{3} /$ d. $1953220000 \mathrm{Nm}^{3} /$ d, Das Gas wird teilweise zu Ferngas umgewandelt, teilweise in Motoren, teilweise indirekt über freigemachte Unterfeuerung verwertet $\left.{ }^{t .100}\right)$.

S.182) $100(1959), 801$

5.153) 98 (1957), 211; Brennstoff Chemic II (1930), 501: Erdöl und Kohle it (1958), 515/521

8.151) $10 \mathrm{t}(1960)$, 158

$8.185) 97(1956), 277$

$8.1800) 100(1959), 1181$

8.187) $97 \quad(1958), 475$

$8,185) 96(1955), 213$

$8.189) 94$ (1953), 27

8.100) 96 (1955), 195; 213

586 
In der Steinkohlenentgasung wurden die alten erprobten Verfahren mit Sorgfalt im Betriebe und Laboratorium weiter beobachtet und nach vielen Einzelfeststellungen etnwickelt. Das kann aber nicht einmal durch Anziehen der Veröffentlichungen dargestellt werden.

Eine neue Technik verlangten die Trocknungsanlagen bei der Erdgasgewinnung $\left.^{\text {s.121 }}\right)$. Der hohe Druck des Gases und die damit ermöglichte hohe Geschwindigkeit beim Ausströmen kann bestens in Fliehkraftabscheidern ausgenutzt werden, wobei auch noch staubige Verunreinigungen abgehen. Bei staubfreien Gaser kann der preiswertere Mattenabscheider in mehreren Stufen genügen. Je nach der Länge der nachgeschalteten Rohrleitung wird dann noch der Taupunkt abgesenkt entweder durch Erwärmung bei einer kurzen Leitung bis nach einer Sammelaufbereitung, oder durch Kühlung mit einer Kälteanlage oder durch Absorption. Hierbei ist neben Kieselgel und Aluminiumoxyd auch das flüssige Trioder Diäthylenglykol (Pintsch-Bamag) gebräuchlich geworden.

Die nasse Schweifelentfernung fand vor allem als Vorstufe und Entlastung der trockenen Reinigung in Gaswerken erneut Beachtung ${ }^{8.102}$ ). Mainz-Wiesbaden griffen zum Verfahren von Koppers-Sombathy $\left.{ }^{\text {s.123 }}\right)$. E. Terres widmete sich der Fortbildung des W. Feld-Verfahrens. Er zeigte die Wege, die man bei den Untersuchungen stufenweise gehen müsse, da noch viel Arbeit nötig sei, $\left.{ }^{8,184}\right)$. Zur vollkommenen Entschwefelung von Synthesegasen hatte schon F. Winkler sein beim Generator bewährtes Schwebeverfahren angewandt, wobei hochwertiger Schwefel gewonnen wurde $\left.{ }^{5,105}\right)$. In England versuchte man selbständig diese Reinigungsmethode. Sie erwies sich technisch als möglich, war aber baulich und betrieblich doppelt so teuer, wie die Kastenreinigung $\left.{ }^{8.100}\right)$. Die trockene Reinigung unter Druck bis zum Kriege nur in Homburg (Saar) nach Gottfried Bischoff $K G$, Essen, ausgeführt, wurde nunmehr allgemeiner aufgegriffen ${ }^{8.187}$ ). Im Gaswerk Leer (Ostfriesland) wurde von Firma Gastechnik 1953 mit Erfolg ein Trockenreiniger nach Raffloer aufgestellt $\left.{ }^{8,100}\right)$. Dieser hatte aus Reinigungsmassen porige und dennoch druckfeste Kugeln hergestellt, die in hoher Schichtung in einen stehenden Zylinder ohne Einbauten eingefüllt werden können.

Eine besondere Aufgabe stellte das Erdgas im Lacq, das wie bereits gesagt mit hohen Temperaturen, 450 bis 500 at, hohem Schwefel- und Kohlendioxydgehalt aus der Sonde tritt. Das Gas ist unter diesen Umständen äuf̧erst aggressiv. Die Ruhrleitungen nach einer Sammelstelle sind aus einer neuentwickelten widerstandsfähigen Stahllegierung gebaut und nach je, $5 \mathrm{~km}$ mit cinem Schieber versehen. Sie werden mit Sorgfalt überwacht $\left.{ }^{8,100}\right)$. An der Sammelstelle wird das

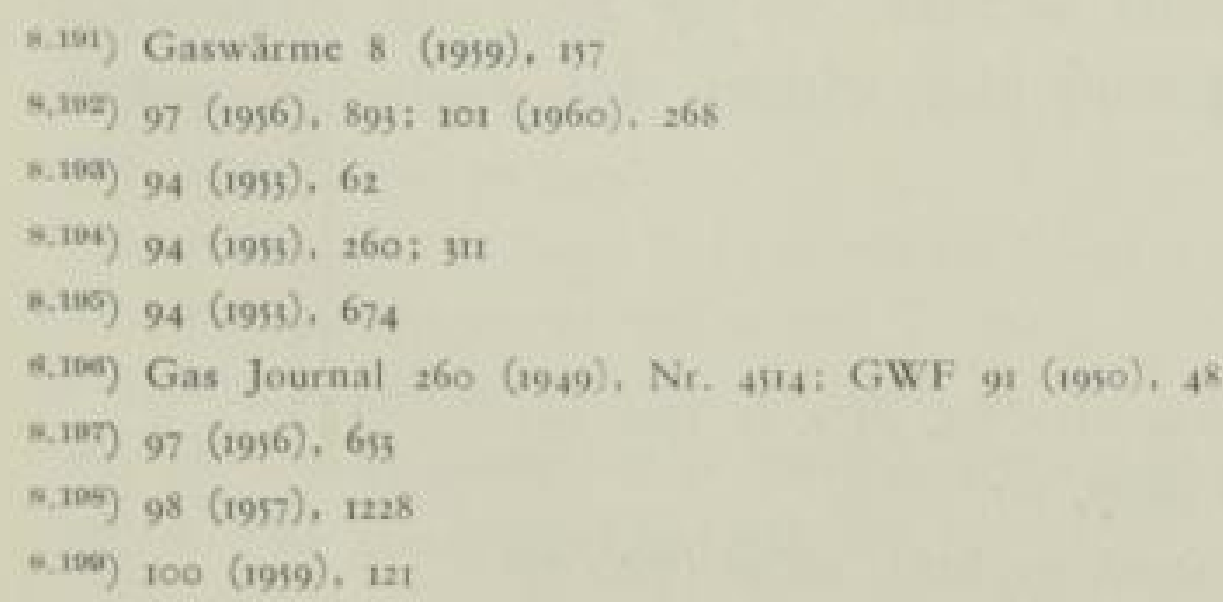


Gas in zwei Stufen auf 70 at entspannt und entwässert (Vgl. den vorhergehenden Absatz). Eine Druckwasserwäsche reinigt es dann auf $2 \%$ Schwefelwasserstoff und $8 \%$ Kohlendioxyd. Das abfließzende Waschwasser gibt bei der Entlastung den Schwefelwasserstoff wieder ab, der danach in der üblichen Weise verbrannt und zu reinem Schwefel verarbeitet wird. Im Erdgas, das vom Wascher abziehend im Gegenstrom mit Äthanolaminlösung gewaschen wird, werden die Reste von Schwefelwasserstoff und Kohlendioxyd chemisch gebunden. Die Lösung wird durch Erhitzung regeneriert und der Schwefelwasserstoff der Schwefelgewinnungsanlage zugeführt ${ }^{5.300}$ ).

An die Gasentgiftung durch Kohlenmonoxydentfernung konnte zunächst in Deutschland nicht mehr gedacht werden. Die früher vorhandenen Anlagen wurden nicht wieder aufgebaut. Dagegen fand sie in der Schweiz jetzt Beachtung. Dort hatte in der Kriegsnot hergestelltes sehr giftiges Gas die Unfallquote deutlich erhöht. 1945 griff der große Rat des Kantons Basel-Stadt die Frage auf. Nach eingehender Prüfung durch F. Jordi wurde der Bau einer Konvertierungsanlage für Kohlenmonoxyd beschlossen. Der Rat leistete 2,5 Mio sfr an Baukosten. Eine Volksabstimmung gab Gelegenheit auf die Verteuerung des Gases um I, $\mathrm{Rp} / \mathrm{m}^{3}$ hinzuweisen. 1958 wurde der Betrieb aufgenommen ${ }^{5.201}$ ). Auswaschung mit Kupfersalzen sah Deringer in Winterthur vor. Bei diesem Verfahren gewinnt man reines Kohlenmonoxyd, das in günstigen Fällen von der chemischen Industric verwertet werden kann ${ }^{8.502}$ ). Ein drittes Verfahren, das Kohlenmonoxyd in Verbindung mit der Fischer-Tropsch-Synthese zu hydrieren, scheidet zur Zeit wegen des sehr erhöhten Kohlenverbrauchs und der niedrigen Preise für die Erzeugnisse Benzin und Dieselöl aus ${ }^{5.3 x}$ ).

In der Schweiz liegen die Verhältnisse im Gasabsatz aber auch umgekehrt wie in Deutschland. Dort gehen $80 \%$ des Gases in den am meisten gefährdeten Haushalt und nur $20 \%$ in die Industrie, wo die Anlagen sachverständig überwacht zu werden pflegen. Der Haushalt mag wenigstens für Koch- und Warmwassergas die Preiserhöhung um rund einen bis zwei Pfennig verkraften können, die Industrie aber nicht.

Man hat die Frage auf dem internationalen Gaskongref in Rom eingehend beraten. Deutschland vertrat den Standpunkt: I. Soweit sich in den Herstellungsverfahren ohne Mehrkosten ein kohlenmonoxydarmes Gas bereiten läßzt, soll das gefordert werden. Flüssiggase unmittelbar verwandt, oder luftverdünnt, sind giftfrei. Bei Spaltanlagen läßzt sich im gleichgearteten Nebenbetrieb eine Konvertierung leicht einschalten und jedenfalls ohne mehr Personal betreiben. Die Mischung solcher Gase mit dem üblichen Stadtgas setzt dessen Kohlenmonoxydgehalt herunter. 2. Wichtiger ist, dafs mit allen Mitteln durch Sicherungen und feste Installationen u. U. durch bewegliche Metallschläuche unbeabsichtigte Austritte von unverbranntem Gas vermieden werden, womit auch die Explosionsgefahr gebannt wird. Die Aufklärung muß hier wirken, dał auch alte ungesicherte Geräte ersetzt werden.

5.300) 99 (1958), 1217; 100 (1959), 1179

8.201) F. Jordi : Forschung und Technik, Nationalzeitung Basel Nr, 585 v. 18. Dez. 1958

8.902) Schweizer Monatsbull, 27 (1947), 189; GWF 89 (1948), 20 r

8.203) Schweizer Monarsbull. 32 (1952), 295; GWF 93 (1952), 374 (1953), 28; 96 (1955), 786

588 
In England teilt man diese Ansichten. Dort ist, nachdem die Unfallhäufigkeit in den verschiedenen Altersstufen festgestellt wurde, eine besondere Werbung bei alten Leuten für die gesicherten Geräte angelaufen.

Die Untersuchungsmethoden des Gases mögen kurz als Anhang der Aufbereitung erwähnt werden, da sie der Beaufsichtigung des chemischen und physikalischen Betriebsablaufes dienen. 1952 konnten die gegen 1940 gründlich überarbeiteten Untersuchungsmethoden durch P. Struck im Auttrage des Gasinstitutes neu herausgegeben werden $\left.{ }^{n, 204}\right)$. Seitdem sind in den verschiedenen Laboratorien wieder neue verbesserte Verfahren vorgeschlagen.

Eine Umwälzung brachten die physikalischen Untersuchungsgeräte, die während des Krieges für die hohen Ansprüche der Synthese erbaut waren. Das waren in der Hauptsache dauernd messende und schreibende Sauerstoffprüfer auf der Grundlage des Paramagnetismus des Sauerstoffes ${ }^{9.005}$ ), der Ultrarotschreiber (Uras) $^{8.2007}$ ), das Massenspektrometer ${ }^{8.207}$ ) und der Gaschromatograph, der in der Gaserzeugung zuerst im Saarbergbau eingesetzt wurde $\left.{ }^{r, 005}\right)$. Sie haben sich schnell auf Werke und Forschungsstelien ausgebreitet.

Besonders viel gearbeitet wurde an der Bestimmung der Brenneigenschaften det Gase und an der Klärung, welche Einzelgase den Hauptanteil an diesen hätten. Dadurch sind viele Veröffentlichungen auch als Streitgespräche in dieser Zeit zu finden $\left.^{8.250}\right)$. Empirische Geräte zur Feststellung der Haupteigenschaften, Zündgeschwindigkeit, Abhebegrenze und Rückschlag bei Bunsenbrennern begrïndet mit halbtheoretischen Formeln kamen von Amerika, Schweden, Frankreich und England.

Die Wichtigkeit der Wobbezahl und zwar weit über die Absichten von Goffredo Wo b be hinaus, (Vgl. Seite 525) wurde von Holland betont, weil dort zuerst stark von einander abweichende Gasarten mit etwa gleicher Bedeutung aufeinanderprallten ${ }^{8.21}$ ). Als Folge bekamen die betrieblichen einfachen Heizwertmesser und mehrere Geräte zur Bestimmung der Wobbezahl Freunde.si1).

\subsection{Gasverteilung-und messung}

Die bisher üblichen Formeln zur Rohrleitungsberechnung wurden einer Kritik unterzogen und neu aufgebaut ${ }^{5.21}$ ), wobei besonders die genaue Ermittlung der Reibungszahlen hervortritt ${ }^{\text {s.213 }}$ ). Mit dem Höchstdruck für Fernleitungen auch unter Berücksichtigung von arbeitsleistenden Entspannungsmaschinen beschäftig-

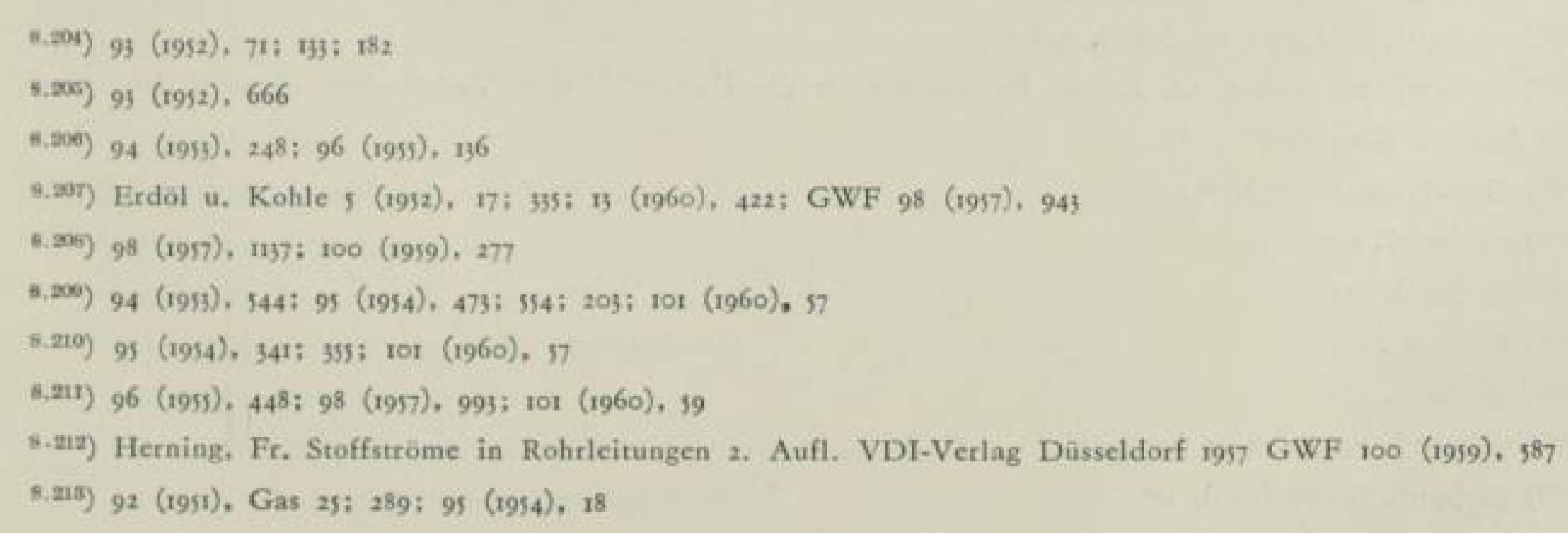


ten sich mehrere Arbeiten $\left.{ }^{5.214}\right)$. Die Erleichterung der Netzberechnung durch Analogieverfahren und durch Einsatz von Lochkartenmaschinen wurde erklärt $\left.^{\text {s.225 }}\right)$. Flugstaubbekämpfung war lebhaft erörtert, als sich in den Fernleitungen die nach dem ersten Aufbau noch fehlende Schwefelwasserstoffreinigung auswirkte $\left.{ }^{\text {s.9. }}\right)$. Kohlenwasserstoffhydrate wurden störend in Erdgasleitungen bei ungenügender Trocknung beobachtet ${ }^{8.27}$ ). Wie stark die allgemeine Sorge um das Rohrnetz wurde, zeigt die Herausgabe eines Sonderheftes des GWF 91 (1950) H. 23. Der deutsche Verein schuf frühzeitig eine Beratungsstelle für Rohrschutz ${ }^{6.26}$ ). Diese wurde aber, wie auch eine später auf Wunsch des Vereins beim Gasinstitut ausgebildete Mannschaft zur Untersuchung von Korrosionen wenig gerufen. Grołe Werke hatten ihre eigenen Ingenieure und kleine haben wohl wenig unter Schäden gelitten. Der kathodische Schutz wurde in steigendem Mafje als wertvoll gewürdigt ${ }^{\text {s.trg }}$ ). Aufsuchen von Rohrleitungen und Isolationsschäden mit elektrischen Induktoren gewann an Boden ${ }^{\text {s.mo }}$ ).

Das Ferngasnetz breitete sich stetig aus $\left.{ }^{8,297}\right)$. Die Ruhrgas A.-G. überschritt $19522000 \mathrm{~km}$ Leitungslänge. In Österreich wurde O. Rieger ein Verfechter der Ferngasversorgung auf Grund der heimischen Braunkohlenvorkommen ${ }^{n, 22}$ ). Er spann seine Gedanken zu einem europäischen Netz aus ${ }^{8,29}$ ).

Im Bau der Fernleitungen mögen die ersten Hàngebrücken und die freitragenden Bogenbrücken der Ruhrgas nicht vergessen $\left.\operatorname{sein}^{\text {s.2ut }}\right)$. Eine schöne Leistung waren Druckregler und Mef̧anlagen für einen in den Grenzen von I bis I29 at schwankenden Vordruck und für die besonders hohen Drücke von Nordhorn von 60 bis 204 at $^{6.25}$ ).

Die Verbilligung der Kleinverteilung in den Häusern wurde durch lebhafte Empfehlung der als Einheit gebauten Installationswand ${ }^{5.20}$ ) und durch genaue Ermittlung der Gleichzeitigkeitszahl in grołen Wohnhäusern erstrebt ${ }^{\text {s.2m }}$ ).

Neuerungen im Gaszählerbau waren die Schraubenradzähler von Elster ${ }^{8,225}$ ), der Einrohranschluf̧ von Hausgaszählern von Kromschröder und die verschiedenen Belastungsschreiber für Hauszähler ${ }^{8,207}$ ).

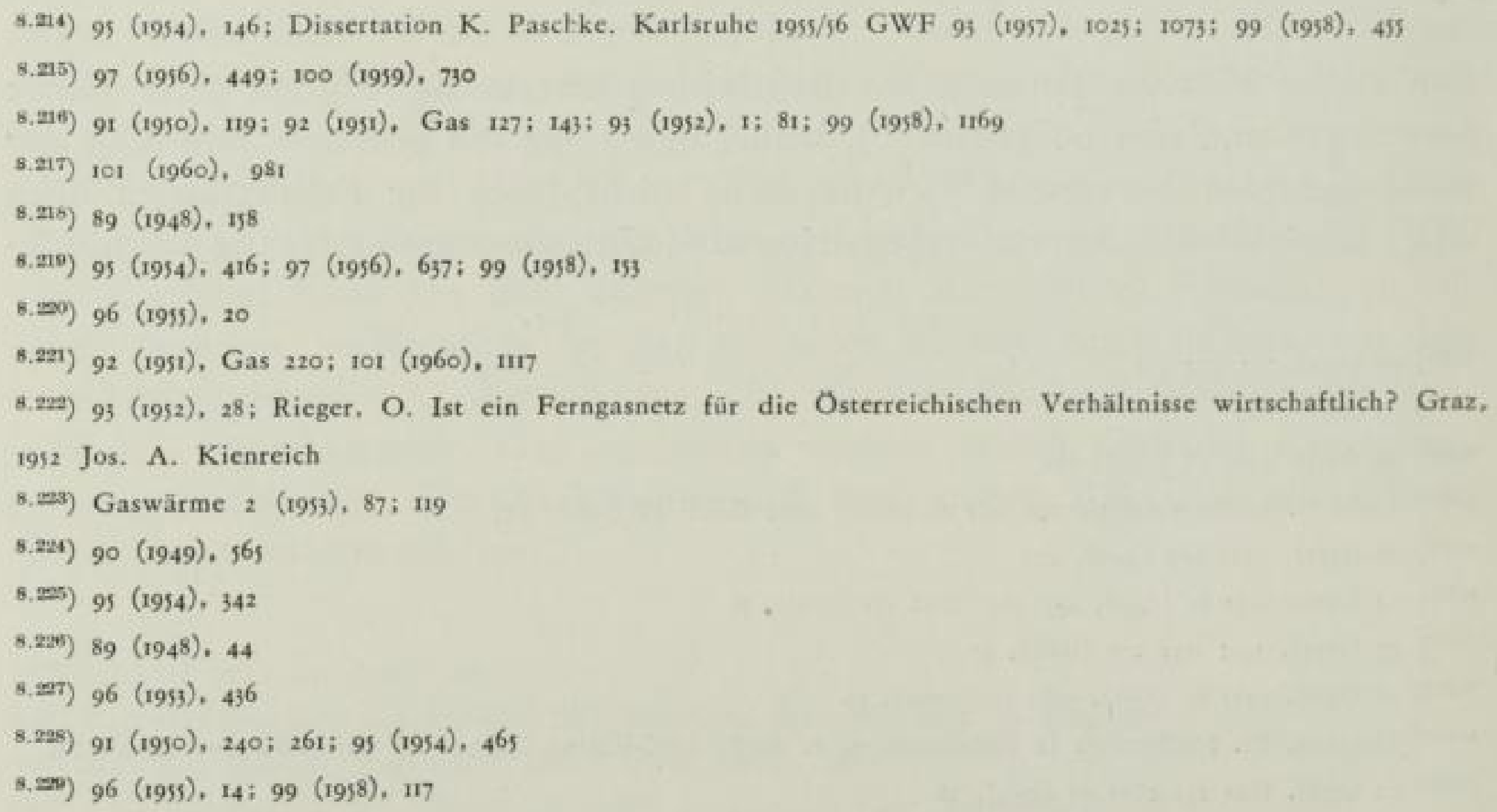


Beim Abbruch eines Behälters in Hannover kam es zu einem bedauerlichen Zerknall in dem Augenblick, als der Behälter mit Kohlensäure ungefährlich gemacht werden sollte. Er regte zu umfassenden Untersuchungen an, einmal über die Gasaufnahme und Freigabe bei den Abdeckmitteln des Wassers, die sich als ungefährlich erwiesen $^{\text {n.rog }}$, dann aber über die elektrostatische Aufladung von Flaschen und Düsen bei lebhaften Gasausströmungen ${ }^{5.231}$ ), von der offenbar der Verderben bringende Funke ausgelöst war. Mit dieser Feststellung war auch die Abhilfe, sorgfältige Erdung, gefunden.

Hochdruckgasbehälter wurden weiter entwickelt. Der Gröłze nach kamen Behälter an die erste Stelle, die $112000 \mathrm{~km}^{3}$ speichern konnten ${ }^{5.229}$ ). In Frankreich führte man einen Kugelbehälter mit Betonmantel und einen Hochdruckbehälter für 1,5 at mit gewelltem Boden aus ${ }^{5.235}$ ). Ein ganz geschweifter Behälter wurde erst möglich, nachdem die geeignete Stahllegierung gefunden war $\left.{ }^{5.23 t}\right)$. Der zweite deutsche Schraubenbehälter ( $30000 \mathrm{~m}^{3}$ Inhalt) wurde in Bamberg durch F. A. Neuman aufgestellt. Die Befürchtungen, daf̧ diese Bauart bei Kälte versagen würde, erwies sich im Winter $1955 / 56$ als unbegründet ${ }^{8.25}$ ). Heute gibt es in Deutschland 6 bis 7 Schraubenbehälter.

Ganz neue Aussichten, nämlich die Speicherung des Gases zum Jahresausgleich eröffnete die Untergrundspeicherung. Gelang diese zu tragbaren Kosten, so wurde allgemein die Gasheizung möglich. Die grof̧en Fernleitungen, die dann voll belastet werden können, wenn im Hauptabnahmegebiet ein Speicher eingebaut wird, können damit mit einer bisher unerreichten Wirtschaftlichkeit betrieben werden. Die ersten Berichte kamen aus den Vereinigten Staaten, wo man zunächst erschöpfte Erdgasquellen heranzog, dann aber auch geeignete Formationen herrichtete. Das waren vornehmlich mit gasundurchlässigen Tonschichten abgedeckte gewölbte wasserführende Sandschichten (Dome), aus denen man mit dem Gas das Wasser fortdrückte. Der gröfte Speicher faf̧te dort 560 Mio $\mathrm{Nm}^{3.250}$ ).

In Europa hat als erstes Unternehmen die Ruhrgas die grołe Bedeutung dieser Speicher erkannt. Die ersten Arbeiten gleich nach dem Kriegsende mufzte sie ohne Kenntnis der amerikanischen Erfahrungen beginnen, wobei insbesondere die Nachricht fehlte, daf bei Pittsburg seit 1930 Kokereigas in alten Gasquellen aufgehoben wurde. Sie fand die Unterstützung der Geologen zu Vorversuchen. Diese wiesen auch auf das ihnen bekannte geeignete Feld in Engelbostel bei Hannover hin $^{8.237}$ ). Im August 1954 konnte diese Anlage in Betrieb genommen werden, mit io Mio $\mathrm{Nm}^{3}$ Kokereigas als Beginn. 1959 waren 150 Mio m³ dort eingespeichert, die Jahrcsabgabe betrug $700000 \mathrm{~m}^{3}$ mit einer Höchstleistung von

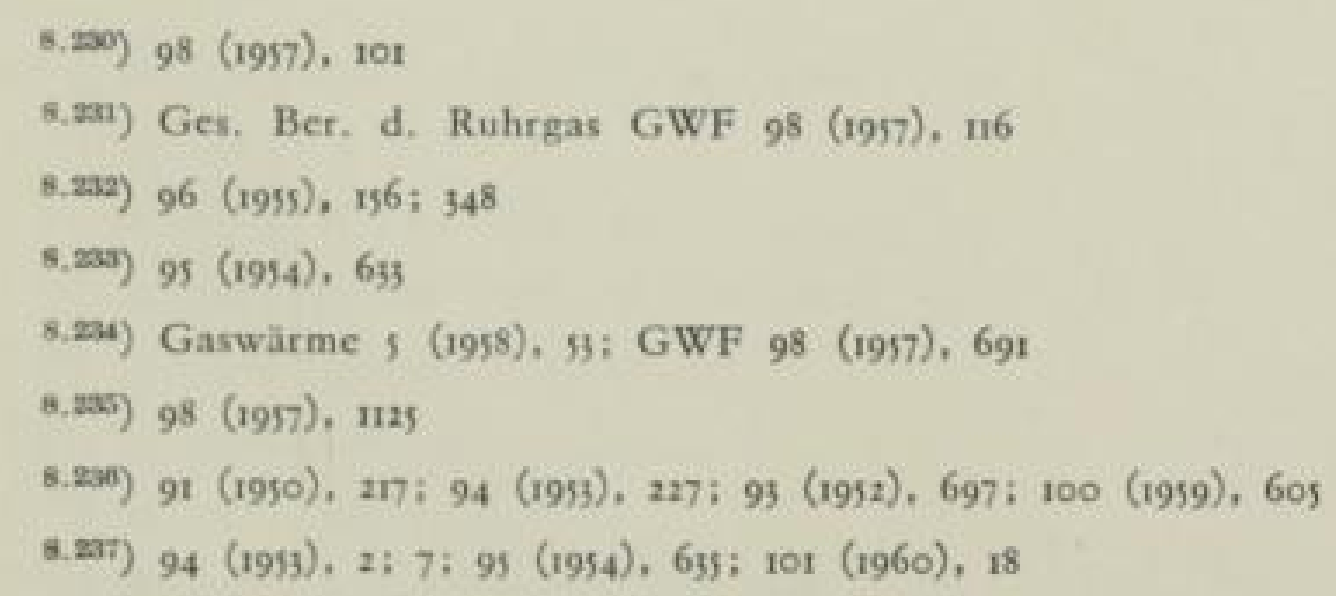


$70000 \mathrm{~m}^{3} / \mathrm{h}$. Schon gleich nach dem erfolgreichen Anlaufen dieses ersten Untergrundspeichers wurden die Arbeiten an einem zweiten bei Darmstadt aufgenommen ${ }^{8.20}$ ), mit dem eine Entlastung der Leitungen von Essen zum Rhein-Maingebiet erreicht wurde, der aber auch für die in Süddeutschland anfallenden Raffineriegasmengen bedeutsam werden kann.

Ein Untergrundspeicher in Hamburg-Reitbrook wurde in Verbindung mit der Raffgasumwandlung geschaften ${ }^{\text {8.23a }}$ ). Durch die deutschen Erfolge wurden auch die Gaz de France angeregt nacheinander zwei Speicher zum Ausgleich des Pariser Bedarfes anzulegen ${ }^{\text {s.20 }}$ ). Der Untergrundspeicher für Erdgas bei Lussagnet mit $\mathrm{I}, 5$ Mio $\mathrm{m}^{5}$ Speichervolumen, wovon o, 5 Mio $\mathrm{m}^{3}$ als „Kissengas“ dienen, erfüllt die eigentliche Aufgabe der Behälter in den Werken. Er sorgt nämlich dafür, daß̧ die aufwendigen Entspannungs-, Kühlungs- und Reinigungsanlagen trotz schwankender Abnahme gleichmäß̧ig betrieben werden können. In England wurde als erster Versuch ein Speicherraum aus Steinsalz ausgewaschen. Er dient mit $475000 \mathrm{~m}^{2}$ bei 50 at als Wochenendspeicher ${ }^{8.24}$ ). In Verbindung mit den Plänen, Erdgas über See einzuführen, sucht man nach einer Speichermöglichkeit.

Bergmännisch gewonnene Höhlen im Sandstein mit Abdichtung durch Kunststoffüberzüge werden in den Vereinigten Staaten zur Aufbewahrung von Flüssiggas versucht ${ }^{\mathrm{s} .22}$ ).

Anregend sind Raumvergleiche zur Speicherung von I Mio kcal (I Gcal) bei Heizöl 1,3 $\mathrm{m}^{3}$, Kohle 7,5 , Gas mit 50 at 74 , bei I at 2950, Wasser mit $100 \mathrm{~m} \mathrm{Ge}$ fälle $\left.51000^{8.23}\right)$. In Frankreich wurde errechnet, daß̧ Behälterspeicherung in 700 Behältern von je $200000 \mathrm{~m}^{3}$ Inhalt das Zweihundertfache des Untergrundspeichers kosten würde $\left.{ }^{8,24}\right)$.

\subsection{Gasverwendung}

8.38r Straf̧enbeleuchtung

Nach den großen Zerstörungen wurde auch die Straßenbeleuchtung wieder hergerichtet. Fortschritte in der Lichttechnik wurden erreicht. Die Blohmglocke (Vgl. Seite 543) wurde durch eine unten offene Schale zur klaren Trennung von Luft und Abgas in überraschender Weise verbessert ${ }^{8.45}$ ). Noch wirkungsvoller war die bei den Beriiner Gaswerken vorgeschlagene Reihenleuchte, die die gegenseitige Anstrahlung der Körper im Runảbrenner ausschaltete. Weiter wurden die Glühkörper in neuer Weise vergütet. Dabei war zwar die Lichtstärke um s\%

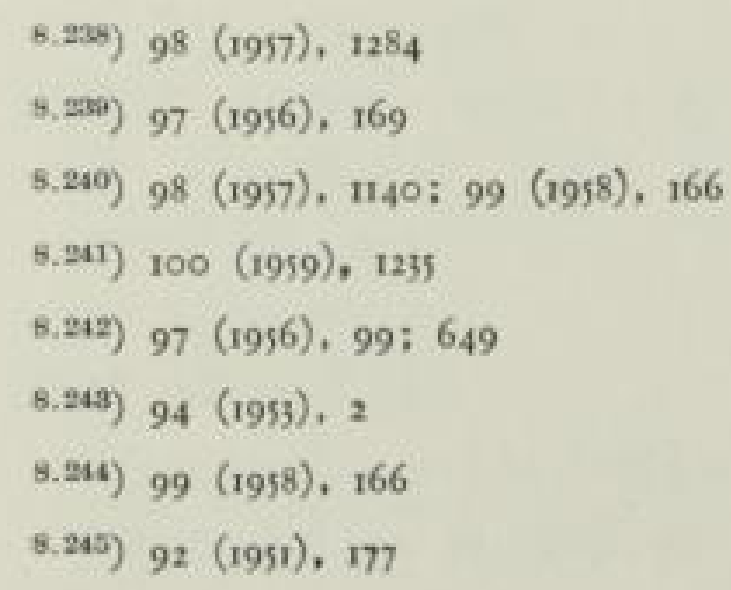


verringert, aber die Haltbarkeit „wahrhaft erstaunlich" gestiegen. Der Jahresverbrauch lag jetzt bei 0,38 Glühkorpern je Flamme $\left.{ }^{8,210}\right)$. Der Beleuchtungsausschufł stellte die allgemein erhöhte Lichtausbeute um ss bis $65 \%$ fest. Bei gleicher Lichtstärke hoffte man den Gasverbrauch von 55 bis 65 auf $40 \mathrm{dm}^{3} / \mathrm{h}$ senken zu können. Die Unterhaltungskosten lagen nun unter der vergleichbaren elektrischen Leuchte $\left.{ }^{8.947}\right)$. Formschöne Leuchten und Maste unterstützten die Zuneigung zur zuverlässigen Beleuchtungsart ${ }^{\text {s.ats }}$ ).

\section{$8.382 \mathrm{G}$ askochen}

Die Geräteindustrie folgte den Überlegungen der Werke und schuf verläßliche Sicherungen für Herde, entwickelte zentrale Zündeinrichtungen mit Sicherung für alle Kochstellen und den Bratofen ${ }^{\text {s.2no }}$ ). Temperaturregelung am Bratofen wurde zu einer Selbstverständlichkeit ${ }^{8.250}$.

Der Einbruch von Gasen sehr verschiedener Art in die Normbereiche gab Anregungen wenigstens beim Kocherbrenner eine Bauart zu finden, die alle Gassorten einwandfrei verbrennen kann, - den Allgasbrenner. Die Lösung gelang unter der Bedingung, dał bei weit auseinanderliegenden Eigenschaften, etwa Stadtgas und Flüssiggas, eine Düse ausgewechselt wird. In Holland ist man noch weiter gegangen, wobei bei sehr geringer Brenngeschwindigkeit kleine Hilfsflammen der Hauptflamme nahe gebracht sind. Ein abschlief̧endes Urteil kann über die Weiterentwicklung technisch-betrieblich wie auch wirtschaftlich noch nicht gefällt werden $\left.{ }^{\text {s.Min }}\right)$.

Hatten bisher die Gaswerke auf den festen Rohranschluf ohne irgendeinen Schlauch hinausgewollt, so wurde wegen der neuen Einbauküchen, bei denen Herd und Kühlschrank in der Flucht der Arbeitstische stehen müssen, eine bewegliche Verbindung nötig. Die Metallschläuche haben sich bewährt. Die schon alte Gassteckdose mit Sicherung, so dał der Hahn beim Lösen geschlossen sein muf, ist nun auch anerkannt worden ${ }^{5,229}$ )

\section{${ }_{8.383} \mathrm{~W}$ arm wasserbereiter}

Eine geschichtlich auch schon seit 30 Jahren bekannte geregelte Gas- und Wasserzufuhr, die Einstellmöglichkeit der Temperatur des auslaufenden Wassers, wurde nunmehr allgemein und mit reichlich viel Gerede über die Neuheit aufgenommen $\left.^{\text {s.ra }}\right)$. Neu sind Geräte, deren Abgase nach dem Vorbilde der Heizöfen (s. Seite 594) durch die Hauswand unmittelbar ins Freie abziehen kön-

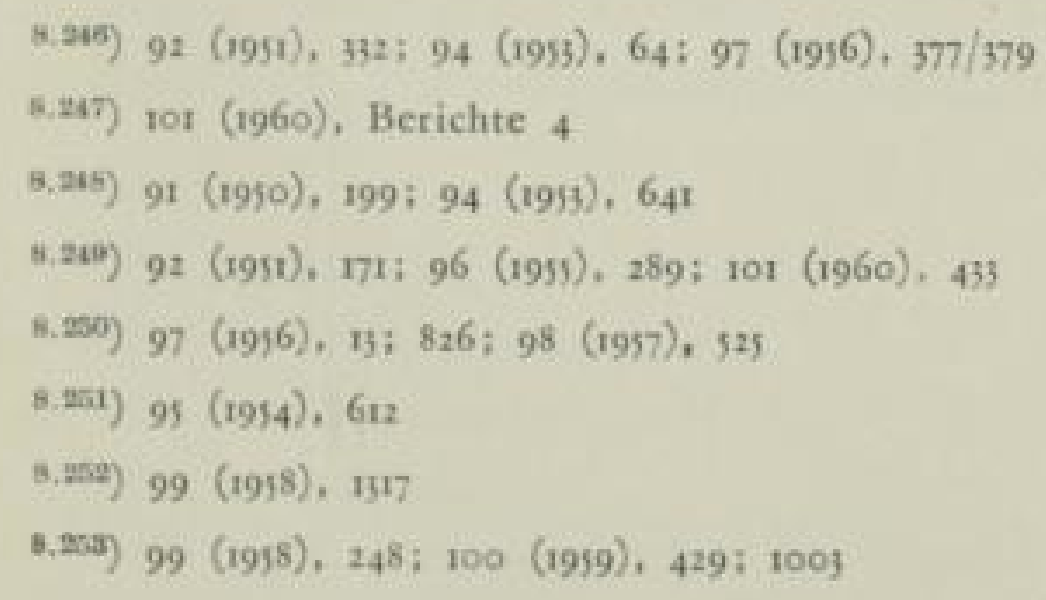


nen, deren Heizzüge also gegen den Aufstellungsraum dicht abgeschlossen sind. Sie werden geliefert als Speicher und als Durchlauferhitzer ${ }^{5.24}$ ).

Der Einsatz von Heißwasserheizern für kleine Zentralheizungen wird im folgenden Abschnitte besprochen werden.

\subsection{Gas raum heizung}

Um die Raumheizung hat unter den Fachgenossen ein harter Kampf stattgefunden. An vielen Anzeichen wurde es deutlich, daf3 sie auch die Kochgasverwendung zu stützen vermöge. Sorge aber bereitete der vom Wetter abhängige hohe Spitzenbedarf, der mit I : 7 zwischen Sommerlast und höchstem Winterbedarf bei voller Heizung in einem Bezirk befürchtet wurde ${ }^{b .250}$ ). So etwas war besonders bei Ferngasleitungen schwerwiegend und löste die Bemühungen um eine preiswerte Spitzengaserzeugung und Untergrundspeicherung aus (Abschnitt 8.37).

Die Geräteindustrie stellte einige wertvolle Neuerungen zur Verfügung. Am bedeutendsten ist der Niederdruckoberflächenheizer von G. $S c b$ w ank. Dieser Ingenieur hatte sich schon vor 1939 mit der Aufgabe beschäftigt und war zum betriebsfähigen Gerät gekommen (Vgl. Seite 548 ). Er nahm glücklich aus dem Kriege zurückgekehrt unter grołen Schwierigkeiten die Arbeit wieder auf ${ }^{5,200}$ ) und hatte einen weltweiten Erfolg. Bei Einzelöfen verlief; man endlich die schweren, unschönen Elementöfen und brachte dem Zeitgeschmack entsprechende Formen heraus. Die Einführung des in Holland entwickelten Gasojar mit unmittelbarem Abzug durch die Hauswand wurde durch die entgegenstehende Vorschrift der TVR (Technische Vorschriften und Richtlinien füt Niederdruckgasanlagen DVGW-TVR Gas, herausgegeben vom Deutschen Verein von Gas- und Wasserfachmännern e. V. Frankfurt), über die sich die Gasversorgungen zum Teil unter eigener Verantwortung hinwegsetzten, kaum aufgehalten. Jedoch zeigte sich, dał eben Vorschriften hinderlich sein können, wenn

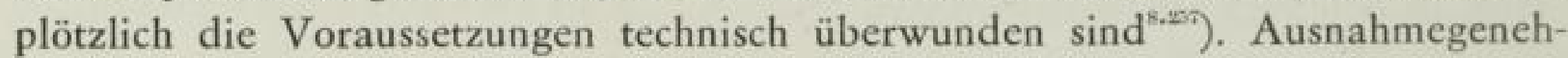
migungen mußten nachher die einzelnen Firmen einholen. Immerhin wurden bereits 1953 vier deutsche Typen von verschiedenen Firmen angeboten ${ }^{\text {s.2.5 }}$ ). Diese Ofenart ist wohl inzwischen am beliebtesten geworden.

Die Gebläseluftheizung für Wohnungen, wie sie in England mit Erfolg geschaffen wurden, ist leider in Deutschland noch nicht aufgenommen, obwohl vom Gasinstitut auf Grund weit rückwärts liegender Gedanken verbesserte konstruktive Vorschläge gelegentlich geeigneten Firmen unterbreitet wurden ${ }^{\text {s.s5o }}$ ). Fernzünder und Regler mit thermoelektrischer Zündsicherung wurden in vielerlei Art angeboten $^{\text {s.200 }}$ ).

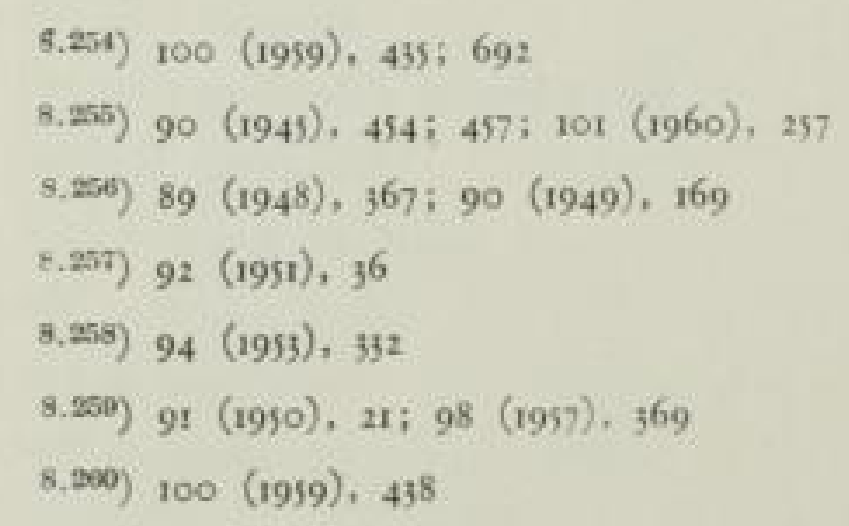


Die Weiterentwicklung des Durchlaufhitzers zum Einbau in eine kleine Zentralheizung kam von England. Sie werden mit Pumpe und Raumwärmefühler ausgerüstet. Sie waren zuerst dort mit Nachdruck durch die Kohlen- und Ölindustrie vertrieben worden. Auf der Brüsseler Weltausstellung 1958 waren zwei Systeme von Frankreich zu sehen $\left.{ }^{8.501}\right)$. Deutsche Ausführungen kamen im Jahre 1960 heraus, und zwar stattete sie Joh. Vaillant KG, Remscheid, mit doppelten Rohrschlangen aus ${ }^{\text {s.2no }}$ ). In zwei Jahren wurden die ersten 2000 Anlagen erbaut und für $196 \mathrm{r}$ mit 3 bis 4000 gerechnet $^{8,200}$ ).

Die Wichtigkeit eines Kundendienstes zur planmäßjigen Überprüfung von häuslichen Anlagen wurde von E. Hecker mit Erfolgszahlen belegt ${ }^{8.2 n}$ ).

8.385 Gewerbe- und Industrieabsatz

Die Gesichtspunkte, wie sie von W. Robland (Vgl. Seite 552) herausgestellt worden sind, wurden jetzt so wirksam, dał sich daraus allein der erwähnte Gashunger in dieser Zeitspanne erklären läft. Die ständige Fühlungnahme der Gaswerbeingenieure mit den Abnehmern und den Ofenbaufirmen brachte eine sehr schnelle Entwicklung zustande, gekennzeichnet durch eine immer bessere Ausnützung der chemischen und physikalischen Eigenschaften des Gases. In dem Buche: Die Gasversorgung ${ }^{\text {s.an }}$ ) wurden einige allgemeine Richtlinien zusammengestellt, die etwas ergänzt, lauten: I. Die leicht lenkbare Strömung des Gases in Rohrleitungen ermöglicht es, den Brenner und damit die Wärmeentwicklung dort anzusetzen, wo sie für das Verfahren örtlich gebraucht wird. Nur selten werden Wärmezwischenträger, wie Dampf und warmes Wasser zur Schonung des Erzeugnisses oder zur Verteilung der Wärme, die immer mit Verlusten verbunden ist, notwendig oder gar wirtschaftlich.

2. Die Unterteilung auf mehrere Brenner wird dadurch begünstigt, dał sich gleich vollkommene Verbrennung in kleinen und grof̧en Brennern erreichen läßzt. An die Zündflammen dürfen die gleichen Anforderungen hinsichtlich des Ausbrandes gestellt werden, wie an grofe Industriebrenner. Damit ist immer ein guter Wirkungsgrad möglich, der nur durch die Abgastemperatur, die sich aus der Aufgabe ergibt, begrenzt wird. Das Verfahren aber kann von Forderungen, die andere Brennstoffe verlangen, unabhängig werden. Die Fertigung kann mit Rücksicht auf einen wirtschaftlichen Arbeitsfluf̧ laufen.

3. Die Geschwindigkeit des Verbrennungsablaufes ist durch bauliche Maßnnahmen am Brenner und am Ofen beeinfluß̧bar. Lange mild heizende Flammen, kurze Stichflammen bis zu fast flammenlosen Oberflächenheizungen bestimmen das Übergewicht des konvektiven oder strahlenden Wärmeüberganges, Teilerwärmung oder gute Durchheizung. Es ist bis zu einem Wettlauf der Systeme gekommen. Den wirksamen Strahlern wurden Höchstdruckbrenner mit geschlosse-

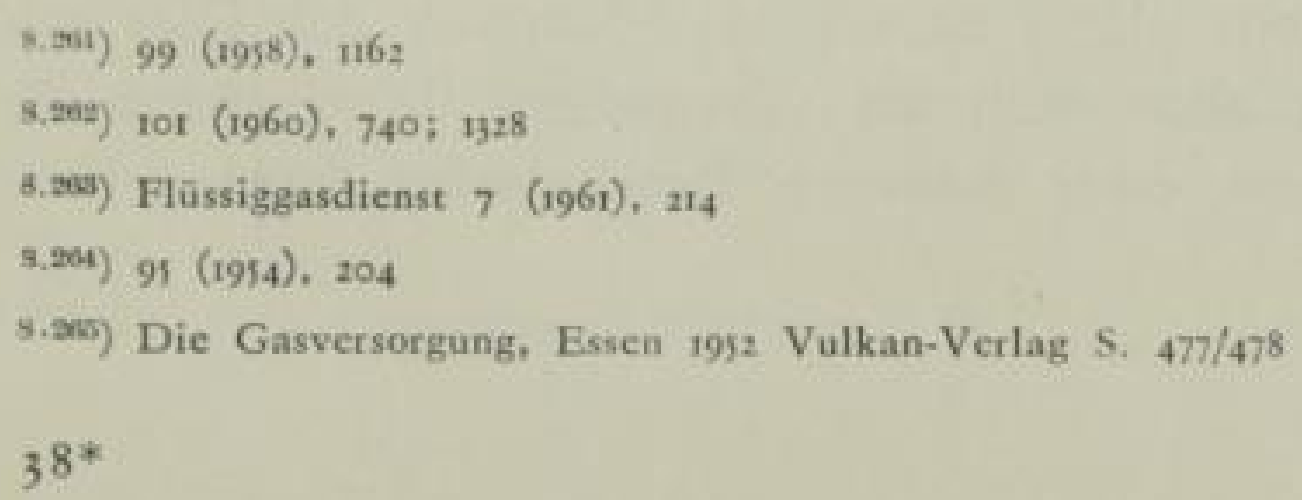


nen Kammern, aus denen das Abgas mit hohen Geschwindigkeiten ausströmt, um örtlich beschleunigte Aufheizungen zu erreichen, entgegengestellt. Sie haben sich in Deutschland bisher nicht stark eingeführt. Ein ohrenbetäubendes Geräusch läß̧t sich bisher nicht vermeiden. Neuerdings wurde in England in Versuchen bestätigt, dał bei eng ausgeführten Ofenräumen z. B. Stangenwärmöfen die üblichen Pref̧luftbrenner mit mäßjigen Drücken gleich gute Arbeit leisten $\left.{ }^{8,200}\right)$. Das besagt aber nichts über die Bewährung bei örtlichem Wärmedarf, wo wegen des Arbeitsgutes grołe Räume notwendig sind.

4. Die Regelung der Gasmenge durch Veränderung des Brennerquerschnittes oder des Druckes in der Zuleitung bringt die Beherrschung der freiwerdenden Wärmemenge mit sich. Voraussetzung ist ausreichender Druck vor dem Regler, gleichbleibender Heizwert, Dichteverhältnis (Wobbezahl) und Zündgeschwindigkeit des Gases. Um diesen Vorzug recht wirksam zu machen, ist auf richtige Auslegung der Heizflächen größter Wert zu legen. Berechnung mit den Hilfsmitteln der Wissenschaft vom Wärmeübergange ist ebenso unerläßlich, wie die Nachprüfung der gewählten Formen durch Versuche. Überlastbar sind gasgefeuerte Öfen oder Geräte nicht, wenn sie richtig entworfen sind.

5. Die Wucht des austretenden Gases kann zur Energiequelle für die Bewegung der Abgase im Ofen werden. Mit Erfolg sind durch Ausbildung von strahlpumpenartigen Mischkörpern Abgasumwälzungsöfen gebaut worden. (s. a. vorstehend 3.)

6. Die Abgase gut gereinigten Gases sind in der Mehrzahl der Fälle unschädlich für das Ofengut, insbesondere wenn der Taupunkt nicht unterschritten wird. Lebensmittel nehmen keinen schlechten Geschmack an. Bei besonders empfindlichen Stoffen können sie zu Schutzgasen umgewandelt werden. Bei grofen Abgasmengen müssen sie durch Leitungen abgeführt werden. Was groł und klein ist, hängt von den örtlichen Verhältnissen ab. In grołen offenen Hallen bedarf es oft bei Ofen mit so $\mathrm{Nm}^{3} / \mathrm{h}$ Gasverbrauch keines Abzuges, in geschlossenen Werkstätten kann aber eine gute Absaugungsanlage notwendig werden.

7. Ganz allgemein muf alles getan werden, um die Wärme zusammenzuhalten. Türen und Abgasschieber müssen dicht und leicht verstellbar sein. Die Wände sind auf gute Wärmedämmung hin zu bauen. Bei unterbrochenem Betriebe ist auf geringe Speicherfähigkeit der Baustoffe zu achten. Bei hohen Arbeitstemperaturen soll die Abhitze möglichst gut ausgenützt werden.

An den theoretischen Arbeiten wurde sofort nach dem Zusammenbruch weitergearbeitet. Um die notwendige Aufklärung erneut zu stärken, wurden an verschiedenen Stellen Brennkanäle zum Teil lang zur Verfolgung des Ausbrandes und des Temperaturverlaufes, zum Teil den Ofenformen sich nähernd in den Instituten des Gasfachs und bei vielen Firmen mit und ohne Kühlung ausgeführt.

Der Erforschung der Flammenstrahlung kamen allerorten im In- und Auslande die verfeinerten Methoden der Strahlungsmessung zugute, die schnelle Fortschritte machten. Es kam dabei vor allem darauf an, Flammen des Öles mit denen des Gases zu vergleichen, aber auch bei Gemischen die Grenzen für wirksame Einwirkungen des einen oder anderen Brennstoffes festzustellen.

8. 200$) 91(1950), 76 ; 98(1957), 1048$ 
Diese Arbeiten sind bisher trotz allem Eifers nur bis zu ganz allgemeinen Richtwerten gekommen. Sie werden noch sehr viele Forschungsarbeiten erfordern, ehe bestimmte Aussagen für Konstruktionsunterlagen erreicht sind. Immer neue Absaugungspyrometer wurden erdacht, um die Ofengastemperaturen genauer zu erfassen $^{\text {s.ent }}$.

Über die Ofenatmosphäre ist sehr viel aus dem Auslande berichtet und mit deutscher Forschungsarbeit ergänzt worden. Es galt zu klären, aus welchen Gasen sie preiswert, aber den verschiedenen Zwecken entsprechend hergestellt werden können. Dabei war nicht nur das durch die physikalisch-chemischen Gleichgewichtsbedingungen gegebene Mengenverhältnis der Gase in den Gemischen, bei den verschiedenen Temperaturen zu errechnen und zu erproben, sondern es mufte auch der Einfluf\} des Ofengutes etwa als Katalyt auf die Gase bekannt werden. Eine ganze Reihe von Firmen des Ofenbaues fand mit diesen Aufgaben ein neues Schwergewicht ihrer Arbeit $\left.{ }^{8.25}\right)$. Die alten Begriffe: reduzierende Atmosphäre bei Verbrennung mit Luftmangel, oxydierende bei der mit Luftüberschuf haben sich zwar noch im Sprachgebrauch erhalten, sie sind indessen den neuen Anschauungen gegenüber sinnlos geworden z. B. wird das Molybdän im Stahl sehr leicht vom Kohlenmonoxyd oxydiert.

Ein neuer Gedanke war es, das Gas in zwei Stufen zu verbrennen, um in der ersten den Abbrand mit starkem Luftmangel wirksam zu vermindern, und die Temperaturerhöhung in der zweiten Verbrennungsstufe durch Einstrahlen oder Rekuperation dem Ofen zugute kommen zu lassen. Dał hierfür sehr sorgfältige Luftmengenregelung und Mischung durch die Brennerwirkung Voraussetzung ist, leuchtet ohne weiteres ein $\left.{ }^{\text {s.mio }}\right)$. Diesen Arbeiten der Forschung und der Aufklärung einerseits, aber anderseits auch dem großzügigen Aufbau der Ferngasversorgung zur erhöhten Gasdarbietung, ja deren Übergang zur Erzeugung und zur Entwicklung der Untergrundspeicheranlagen ist die schnelle Steigerung des Industriegasabsatzes, die durch Tafel to wiedergegeben ist, zu verdanken. Andere statistische Erfassungen kommen dazu, daf in Deutschland $80 \%$ des Gases an die Industrie gehen, die in anderen Ländern mit überwiegender Gasfabrikation auch nicht annähernd erreicht werden. In der Schweiz ist das Verhältnis gerade umgekehrt (Vgl. Seite 588). In England betrug im Jahre 1960 der Haushaltsabsatz $50 \%$, der Industrie- und Gewerbesatz $44 \%$, des gesamten Gasverhrauches. Der Rest verteilt sich auf Eigenverbrauch und Straß̧enbeleuchtung ${ }^{\text {s.rno }}$ ). Die Hauptverbrauchsgruppen der Industrie sind im folgenden betrachtet.

\subsection{5r Eisen-und Stahlindustrie}

Sie ist der Hauptverbraucher von Industriegas geworden. An sich ist die Gasverwendung in Stahlwerken schon sehr alt. Schon Fr. Si e mens entwickelte seinen Generator, weil er die für eine wirksame Regeneration erforderliche Gleichmäßjigkeit mit der Rostfeuerung nicht erreichen konnte. Der Starkgasein-

\footnotetext{
8.307) 93 (1952), 386; 441; 98 (1957), 112; 92 (1951), Gas 201; 2C3; 207

8.205) 91 (1950), $79 ; 92$ (1951), Gas 197; 93 (1952), 665

8.2nin) 100 (1959), 1059

8.xoy Gas Journal Directory London, 1962 S, D is
} 
satz wurde vor allem im Anfang versucht, ehe durch die Fernleitungen Kokereigas, das an den wärmetechnisch verbesserten Kokerei-Ofen eingespart wurde, zu wertvollerer Verwendung fortgeleitet werden konnte. Es zeigte sich, daf3 die wasserstoffreichen Gase nicht gut leuchteten und die Wärmeabstrahlung gering war. Man begnügte sich mit dem Zusatz von Starkgas zum Generatorgas oder Gichtgas, womit in der Einschmelzzeit bei festem Einsatz die Leistung erhöht werden konnte. Neuerdings aber tut das ungewöhnlich billige Öl dem Gase, auch dem Generatorgas Abbruch. Nur Erdgas erweist sich in der Nähe der Fundorte als wettbewerbsfähiger Brennstoff. Es verbrennt aber durch die üblichen Brenner hineingeführt mit der rötlichen Methanflamme, die langgezogen für die Abstrahlung ungünstig ist. Schon im Kriege wurden aber unter deutscher Führung in Polen erfolgversprechende Versuche ausgeführt, das Methan im Brennerkopf durch die Wärmeeinstrahlung aus dem Ofenraum zu spalten und den sich dabei ausscheidenden Kohlenstoff mit der Flamme in den Ofen zu blasen. Dabei ergab sich eine helle weifglühende, starkstrahlende Flamme.

Günstiger für Starkgas sind die Tieföfen zum Ausgleich frisch gegossener oder auch zum Wiederaufwärmen erkalteter Blöcke. Umfangreiche Modellversuche über die günstigste Anordnung der Brenner, die Form der Flamme und die Führung der Gase um die Blöcke, führten zu groß̧en Ersparnissen. Hierbei spielt Volumen und Querschnitt der Flamme eine Rolle, die vom Gas erfüllt werden kann. Stahlgufpfannen mit feuerfester Auskleidung werden durch Strahlbrenner mit Gas getrocknet und vorgewärmt. Um das Brennerrohr ist ein kragenartiger Deckel zu legen, der nur die Abgase an seinem äusseren Umfang aus dem so gebildeten „Ofenraum“, nicht aber die Wärmestrahlen austreten läßt. Versuche haben gezeigt, daß kleinere und mittelgrołe Pfannen vorteilhaft liegend, also mit der Pfannenöffnung in senkrechter Lage, getrocknet werden. Ein Vorzug gegen Öl ist es, dafy die Brenner leicht und mit beweglichen Metallschlauchverbindungen an die an der Füllstelle bereitgelegten Pfannen gebracht werden können, während bei den mit Gebläsen fest aufgebauten Ölbrennern, die schweren Pfannen mit Kränen zum Trocken- und Arbeitsplatz geschafft werden müssen.

Am wichtigsten wurde aber die Gasfeuerung für die Ausgleichs- Glüh- und Wärmeöfen für die Weiterverarbeitung. Hierbei ist die Vorwärmung des Ofengutes vorteilhaft dazu dienen Nebenkammern, wo das Einzelstück also nicht zu schwer ist, oder auch Durchgangsöfen im Gegenstrom, wo eine gute Anpassung an die Feuerungsleistung möglich ist. In langgestreckten Stoßöfen kann man nicht nur den Gegenstrom der gesamten Gasmenge vom Anfang her anwenden, sondern kann auch durch seitliche Brenner Zonen erhöhter Temperatur oder durch Absaugung eines Teiles des Gases vor dem Ende schwächer beheizte Zonen schaffen. Der Arbeitsgeschwindigkeit, die durch die Pressen oder Walzen gegeben ist, kann man sich mit der Brennereinstellung anpassen. Das hat bei der Aufwärmung hochlegierter Stähle auf̧erordentliche Vorteile gebracht, denn diese müssen bis zu einer Temperatur bis etwa $600^{\circ} \mathrm{C}$ sehr vorsichtig, dann aber möglichst schnell erhitzt werden ${ }^{\text {s.271 }}$ ).

Die Zahl und Art der Ofen im Schmiedebetrieb ist fast unübersehbar als Folge der verschiedenen Anforderungen nach Art und Menge der Werkstücke und der

8.271) Die Gasversorgung Essen 1952 Vulkan- Verlag s. $486 / 487$

598 
Tafel 10: Gasabgabex) an Industrie und Gewerbe im Bundesgebiet bzw. ehem. Reichsgebiet (Mia $\mathrm{Nm}^{3}, 4300 \mathrm{kcal} / \mathrm{Nm}^{3}$ )

\begin{tabular}{|c|c|c|c|c|}
\hline \multirow{2}{*}{ Jahr } & \multicolumn{4}{|c|}{ an Industric und Gewerbe } \\
\hline & Reichsgebiet & & Bundesgebiet & \\
\hline 1913 & 0,6 & - & & \\
\hline 1928 & 2,2 & - & & \\
\hline 1936 & 8,4 & 5,3 & & \\
\hline 1939 & 12,0 & - & & \\
\hline 1949 & & 5,5 & & \\
\hline 1950 & & 6,7 & & \\
\hline 1951 & & 8,0 & & \\
\hline 1952 & & 9,1 & & \\
\hline 1953 & & 9,3 & davon an Gewerbe & 0,8 \\
\hline 1954 & & 10,0 & & 0,8 \\
\hline 1955 & & 11.5 & & 0,8 \\
\hline 1956 & & 12,0 & & 0,9 \\
\hline 1957 & & 12,0 & . & 0,8 \\
\hline 1958 & & 11,5 & & 0,9 \\
\hline 1959 & & 11,3 & & 0,9 \\
\hline $1960 *$ & & 13,0 & & 0,9 \\
\hline
\end{tabular}

*) einschliesslich Saarland

X) Gasverbrauch aus Lieferungen der Zechen- und Hüttenkokereien sowie der Ferngasgesellschaften und Gaswerke (ohne Erdgas- und Raffgas-Direktlieferungen an Industrien). Bei der Chemie sind RestgasRücklieferungen abgesetzt.

Verfahren. Die Ofenbauindustrie hat cine Fülle von neuen Konstruktionen geschaffen. Mit den inzwischen gesammelten Erfahrungen und ihren Versuchswerkstätten und Laboratorien ist sie in der Lage neue Aufgaben zu bewältigen.

Wichtiger als wohl bei allen anderen Ofenarten ist bei den hohen Arbeitstemperaturen der wärmedämmende Aufbau der Ofenwände und der Türen. Bei unterbrochener Arbeitsweise muf3 auch die Speicherwärme der Wände gering sein. Das hat zur besonderen Ausbildung vieler Arten poröser Leichtsteine geführt, die aus hochfeuerfesten Grundstoffen durch die Lufteinschlüsse wenig Masse haben. Diese sollen die Innenauskleidung bilden. Eigentliche Isoliermassen z. B. Kieselgur dämmen die Wärme zwar noch wirksamer, sind aber den Temperaturen im Inneren nicht gewachsen und können also nur an die Aussenwände gebracht werden. Sie sind besonders lohnend für Dauerbetrieb. So ergeben sich viele Möglichkeiten, die je nach dem Zweck des Ofens verschieden ausgeführt werden.

Die Gasbrenner müssen den Arbeitsanforderungen entsprechend ausgewählt werden. Die Baurichtlinien, um je nach Bedarf lange milde oder kurze heife Flammen zu erzielen, wurden immer besser geklärt. Hatte man bei Schwachgasen und festen Brennstoffen vorzugsweise gemauerte Brenner, war also auf die sach-

\section{SLUB}


verständige Ausführung durch den Maurer angewiesen, so sind fortschreitend immer mehr in sich geschlossene Bauarten aus Metall als Parallelstrom-, Schrägstrom- bis zum Wirbelbrenner entwickelt worden. Der Prefygasbrenner, bei dem man den hohen Druck des Ferngases zur Luftansaugung auszunutzen trachtete, wurde durch Gebläseluftbrenner mehr und mehr verdrängt. Diese haben den Vorteil, dał man Gas und Luft besser regeln und messen, ausserdem die Luft in Rekuperatoren vorwärmen kann. Denn immer bringt eine Regelung nicht nur der Temperatur, sondern auch des Gas-Luftverhältnisses, möglichst selbsttätig, wirtschaftliche Vorteile. Der Schmied kann seine ganze Aufmerksamkeit seiner Arbeit am Hammer widmen. In kleinen Betrieben wird der Meister oder ein Vorarbeiter die Regelung, den Ofendruck, die Wirkung (Verstaubung) des Rekuperators und die Temperatur im Ofen nach den eingebauten Mefjeinrichtungen beobachten, in grofen sich ein Ingenieur des Betriebes annehmen. Durch diese Hilfen, die allmählich immer feiner ausgebildet wurden, konnte in den Bezirken, in denen die Gesenkschmieden als selbständige Unternehmen vorwiegend angesiedelt sind, diese durch die Ferngasversorgung aus einer ernsten allgemeinen Krise gerettet werden und sich als leistungsfähige Unterlieferanten der größzten und bestorganisierten Fabrikationsstätten z. B. in der Kraftivagenindustrie halten.

Ein typisches Beispiel bieten dafür die Stahlfedern für Motorenventile und Wagen, weil bei dem Masseneinsatz das Erzeugnis ganz engen Toleranzen der Charakteristik von Belastung und Formänderung entsprechen muf. Hier kommt es nicht allein auf zuverlässig gleichartigen und gleichförmigen Rohstoff, sondern ebensosehr auf das genau gleich gehaltene Glüh- und Härteverfahren an, zu dem Gas eine Voraussetzung bildet.

Die für den Schmiedebetrieb entwickelten Muffel- und Plattenöfen, als Kammeroder Förderbandöfen gebaut, werden auch in den Maschinenbauanstalten in Schlossereien und an Montagebändern gebraucht. Hierbei ist ihr rauch- und staubfreier Betrieb wertvoll. Die Eisenummantelung, ursprünglich rein konstruktiv als Kasten, dann als gasdichter Abschluf der Wände eingeführt, wird glatt verschweif̧t mit abgerundeten Kanten zum Zierstück in der Werkstatt, das sich den glatten vollen Formen der Werkzeuge und Werkzeugmaschinen im Stil anpafyt.

In Gieß̧ereien bedient man sich der Gasfackeln, die im Kriege entwickelt wurden, zum Anzünden der Kupolöfen, zum Trocknen der Formen und Kerne, worüber weiter unten noch zusammenfassend berichtet wird. Bei Kernen findet mit der Trocknung auch eine chemische Umsetzung statt, die langsam ablaufend die Arbeitsgeschwindigkeit bestimmt. Die erforderliche Wärmemenge, um schnell aber doch nicht mit Riß̧bildung zu arbeiten, kann mit Gas leicht eingehalten werden. Formen werden in Öfen eingesetzt oder an Ort und Stelle mit tragbaren Heiß̧luftgebläsen getrocknet. Auch hier ist die Regelbarkeit bei oft verhältnismäfig niedrigen Temperaturen entscheidend für ein befriedigendes Ergebnis ohne Ausschuf̧. Guf̧eisen mit besonderen Zusätzen z. B. Silizium kann in kleinen Trommelöfen mit Gasfeuerung erschmolzen werden.

Neuerdings vornehmlich da, wo Erdgas billig zu haben ist, hat man die unmittelbare Reduktion körniger Erze in Hochöfen versucht zum mindesten, um an Koks zu sparen. Dabei wurde für feine Erze auch das Wirbelschichtverfahren 
angewandt ${ }^{5.272}$ ). Die Arbeiten begannen in Frankreich ${ }^{8.273}$ ) und Mexico ${ }^{\text {(2074 }}$ ). In Deutschland wird sich bei den bisher üblichen Gaspreisen das Verfahren nicht gegen den Koksbetrieb im Hochofen durchsetzen können ${ }^{8.275}$ ).

8.3852 Glasindustrie

Auch in der Glasindustrie ist Gas schon lange ein Helfer. Bei den Schmelzöfen hat Fr. Siemens wegen der Regeneration das Generatorgas eingeführt, ja über die Gasfeuerung nach Art des Siemens-Martinofens wurde er der Erfinder des Wannenofens. Heute liegen die Verhältnisse bei diesen großen Einheiten ganz ähnlich wie bei den Stahlöfen mit der Auswahl zwischen Öl, Erdgas und Ferngas. Günstiger ist die Aufbereitung des Gemenges mit Trockentrommeln. Bei Kühlöfen fördert der Wunsch nach Einhaltung einer genauen Temperatur manchmal bei stark wechselndem Einsatz der Stücke nach Größe und Masse, die Verwendung des selbstregelnden Gasbrenners. In der Weiterverarbeitung insbesondere zu Thermometern, Ampullen, Röntgen- und Radioröhren und Kunstarbeit vor der "Lampe" ist Gas schon seit der Jahrhundertwende vorzüglich benutzt worden. Auf den grofjen Ausstellungen München 1914, Berlin 1929 und Weltausstellung Paris 1937 war der Stand des Glasbläsers ein Hauptanziehungspunkt. Die Entwicklung der Metallfadenlampe insbesondere mit den ersten aus Glasstäben bestehenden Gerüsten wäre ohne die Gasflamme als Werkzeug nicht möglich gewesen. Bei den automatischen Maschinen werden an die Form und Leistung der Flamme die höchsten Anforderungen nach Gleichförmigkeit gestellt. Sie ermöglichten erst den Verkauf der Glühbirne zu so billigem Preis, daf3 die Gasbeleuchtung bis auf die Straf3enbeleuchtung aufgegeben wurde. Hat sich das Gasfach damit sein Grab selbst geschaufelt? Mancher hat das so gesehen, aber in Wirklichkeit war es einsichtig genug, daf, die große Umstellung vom Beleuchtungsbetrieb zum Wärmelieferanten im Zuge der Zeit mit allen Mitteln gefördert werden mufzte. Übrigens brachte die Umstellung der Thüringer Kleinbetriebe vom reinen Steinkohlengas mit einem Heizwert von $4900 \mathrm{kcal} / \mathrm{Nm}^{3}$ auf Stadt- und Ferngas zunächst Einsprüche und Klagen bis durch Untersuchungen und Aufklärung des Beratungsdienstes der Werke und Gasinstitute, die vorhandenen Brenner auf das neue Gas eingerichtet waren.

8.3853 Keramische Industric

Schon auf Seite 554 wurde darauf hingewiesen, dał die keramische Industrie erst über den Tunnelofen als Abnehmer für Gas gewonnen werden konnte, weil hier das sich abkühlende Ofengut zur Vorwärmung der Luft verwendet werden konnte und die abziehenden Gase das Ofengut vorwärmen. Eine einschneidende Entdeckung wurde bei den Ümstellungen in Wales gemacht. Bei Gasfeuerung

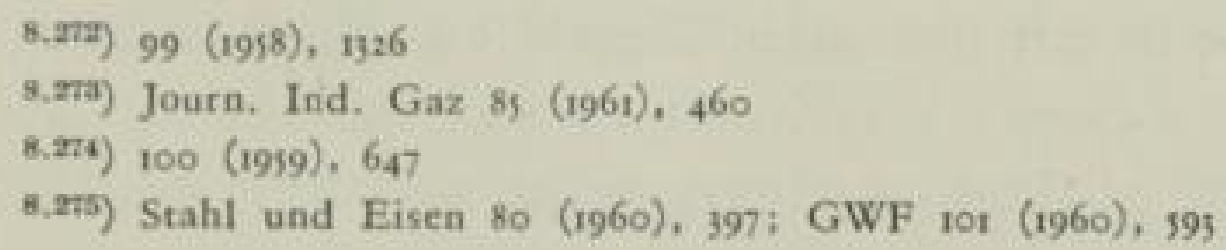


sind die bisher üblichen Qucrschnitte der Tunnel reichlich weit gehalten. Um das auf den groß̧en Wagen gestapelte Gut gleichmäßjig durchzuwärmen, bedarf es Zeit. Die Öfen bauen sich sehr lang, bis zu $75 \mathrm{~m}$. Die Beladung der großen Wagen ist eine Kunst und braucht auch Zeit. Stofweiser Vorschub ist die Folge. Auf gleicher Höhe und Breite der alten Öfen lassen sich aber vier Kanäle, zwei nebeneinander, zwei ein Stockwerk höher unterbringen. In diesen kleinen Kanälen kann man die Heizbelastung steigern und trotzdem die notwendigen ausgeglichenen Temperaturen erzielen. Die Öfen können so kurz gebaut werden $(\mathrm{r} 3 \mathrm{~m})$, dał sie auf dem von den alten Kammeröfen einschlief̧lich Feuerung gegebenen Platze untergebracht werden können. Das erwies sich beim Umbau der alten Werke von ausschlaggebender Bedeutung ${ }^{8.270}$ ).

8.3854 Metallindustrie

Für die Nichteisenmetalle kennt man in der Verarbeitung eine noch vielfach größzere Anzahl von Verfahren als in der Eisenindustrie.

In den grof̧en Hüttenwerken wird in Schacht- und Flammöfen, aber auch Destillier- und Röstöfen die erste Stufe der Erzverarbeitung vorgenommen, bei deren Massen die Vorzüge eines veredelten Brennstoffes wenig zur Geltung kommen können. Aber selbst in diesen Hütten sind die Erze in Deutschland selten einheitlich und auch kaum ausschlief̧licher Rohstoff, vielmehr werden auch verunreinigte Fabrikationsabfälle, deren Metallwert noch hoch genug ist, wieder aufgearbeitet. Sie verlangen dann sehr genau geführte Öfen, je nach der oft wechselnd anfallenden Menge in groß̧en und kleinen Abmessungen. Es bilden sich aber bei der Aufarbeitung auch wieder Oxydschichten, Krätzen, Schlacken und metall(-oxyd)haltige Abgase, aus denen die hochwertigeren Metalle wieder gewonnen werden müssen. Darum gibt es dort eine Vielzahl kleiner Öfen als offene Herdöfen z. B. zur Ausseigerung des Zinns aus einer Zinnbleilegierung, als Muffelöfen zur Zinkoxydreduktion oder Sintermetallherstellung, für die genaue Temperaturen aber oft auch sehr genau zusammengesetzte Ofenatmosphären bis zum Schutzgas verlangt werden. Dafür ist Gas ein willkommener Brennstoff. Auch Säure- und Laugebäder mit genau zu haltenden Temperaturen kann man mit Gas (Tauchrohrbrenner aus widerstandsfähigen Stoffen) sehr vorteilhaft beheizen.

In der Weiterverarbeitung kommt es oft auf Temperatur und Ofenatmosphäre sehr an. z. B. beim Tiefziehen von Messing zum Ausgleichsgühlen zwischen den einzelnen Stufen. Am bekanntesten ist das Blankglühen von Messingblechen und Drähten unter Schutzgasen geworden. Auch hier ist wieder das fast schwefelfreie Gas als Ausgangsstoff am wohlfeilsten.

Wie überall bei den angedeuteten Fällen kommt es in der Metallgief̧erei darauf an, bei den hohen Preisen des Rohstoffes die Verflüchtigung durch überhöhte Temperaturen zu vermeiden. Bleioxyddämpfe aus dem Letternmetallkessel aufsteigend sind giftig, Zinkoxyddämpfe aus Messingbädern nicht minder unangenehm. Auß̧erdem verändert sich die Legierung. Die Wasserstoffaufnahme von Kupfer ergibt die Kupferkrankheit, die in gut gebauten Tiegelöfen mit erprobter 
Umführung der Abgase um den Tiegel vermieden werden kann. Jedenfalls muß3 die Verbrennung vorsichtig geführt werden, auch wenn metallurgische Hilfsmittel, wie die Abdeckung mit Entoxydationsmitteln oder dichten Deckeln vorgesehen sind.

Bei Leichtmetall ist die Wärme an die Tiegel durch eine Vielzahl kleiner Brenner gleichmäß̧ig zu übertragen. Auß̧erdem muß man Brenner auswählen, die eine langsame und doch vollständige Mischung von Gas und Luft im Brennraum ergeben. Sie müssen, ohne dał die luftsatte Verbrennung gestört wird, nach lebhafter Aufheizung kleingestellt werden können, wo durch längeres Stehenlassen das flüssige Metall entgasen soll. Für großje Metallmengen werden auch Trommelöfen verwendet, in deren Achse ein runder Parallelstrombrenner eingesetzt wird. Strahlrohrbeheizte Schmelzöfen mit Schutzgasatmosphäre haben sich seit etwa 1950 eingeführt. Abhitzeausnützung ist bei den geringen Temperaturen selten wirtschaftlich, zumal bei kalten Gasen die Mengenregelung erleichtert ist. Schwermetall ist wegen der hohen Wärmeleitzahl des Einsatzes etwas leichter zu beheizen, Rekuperation wird früher wirtschaftlich. Wegen des Abbrandes und der Wasserstoffaufnahme muß man aber ebenso vorsichtig sein.

\subsection{Trocknung}

Die Trocknungstechnik ist ein verästelter Zweig der Verfahrenstechnik geworden. Schon auf Seite 600 mufte darauf hingewiesen werden, daf mit der Trocknung auch oft chemische Veränderungen verbunden sind. Dann muf aber durch den Versuch die richtige Geschwindigkeit erprobt werden. Sie muf auch bei veränderten Abmessungen der Werkstücke erneut ermittelt werden. Das verlangt eine Einrichtung, die in hohem Maf̧e regelbar ist, also Gasfeuerung. Früher bediente man sich fast ausschlief̧lich eines warmen Luftstromes. Manchmal ist aber der Wasserdampfgehalt der Abgase bei empfindlichen Gütern durchaus vorteilhaft, so dafy das Gas unmittelbar in den Luftstrom hinein verbrannt wird. Unmittelbare Wärmeeinstrahlung hat für manche Trocknungsvorgänge auß̧ergewöhnliche Zeitersparnisse gebracht. Das hatte der Elektrizität wegen der ersten erfolgreichen Trockungsanlagen bei den Fordwerken in Detroit zunächst einen grołen Aufschwung verschafft. Sehr bald aber zeigte es sich, daf̧ Gas sich noch vielseitiger den Erfordernissen anpassen lief. Neben die offenen Glühstrahler, für die schon in Amerika während des Krieges Höchstdruckbrenner entwickelt worden waren, konnten auch dunkle Strahler mit geschlossenen gasbeheizten Räumen gestellt werden. Die mit der Temperatur sich ändernde Wellenlänge war nicht ohne Einflufy auf den Vorgang, insbesondere die Eindringungstiefe bei einige Millimeter starken Teilen. Je nach den zu trocknenden Stoffen erwies sich das eine oder das andere Verfahren als angebrachter. Die ersten Nachrichten erreichten Deutschland nach dem Kriege bei der Wiederanknüpfung der privaten Beziehungen über England. In Deutschland wurde die Aufgabe gründlich untersucht. Die Einführung von Zonen im Durchlaufofen mit verschiedenen Temperaturen, ja auch die Umwälzung mit ähnlichen Zonen förderte nunmehr auch die konvektive Trocknung. Die Verbindung beider Verfahren, die sich bei offenen Gasbrennern von selbst ergab, wobei die Strahler an gewünschten Hochpunkten 
eingesetzt wurden, zeigte neue Möglichkeiten auf. Auch auf diesem Gebiete ist die Weiterentwicklung noch in vollem Gange ${ }^{8.277}$ ).

Gasturbinen mit Erdgasbetrieb, Wärmepumpen mit Gasmotor und Klimaanlagen auf gleicher Grundlage sind bisher nur mit den niedrigen Preisen in Nordamerika wirtschaftlich gewesen. Ein Versuch in England in einer Ausstellungshalle schlug fehl, allerdings infolge des zu groł geratenen Maschinensatzes $\left.{ }^{8,228}\right)$.

Die vorstehende Darstellung, die nur einen kurzen Einblick über die Abhängigkeit von technologischen Bedingungen und Änderungsmöglichkeiten in den ausgeübten Verfahren auf die Wirtschaftlichkeit der Gasverwendung geben konnte, zeigte deutlich, wie schwer die Aufgabe eines Gasingenieurs ist, der in der Industrie seinen Rat erteilen soll. Darauf wurde auch schon im Abschnitt 7.78 hingewiesen.

In vorzüglicher Weise wurde die Aufgabe den Gasingenieur an die Technologie heranzuführen durch die Zentrale für Gasverwendung in der zweiten Auflage des Ringbuches „Gas in Gewerbe und Industrie“ gelöst. In völlig neuer Darstellung durch sorgfältig ausgewählte Einzelsachbearbeiter wurde Gebict für Gebiet abgehandelt. Die immer wieder herausgearbeitete Abhängigkeit der Brenner oder der Ofenart, die die Technologie nun einmal ergibt, die aber auch nicht, in bezeichnenden Fällen eine Kritik der üblichen Verfahren scheut, dürfte wohl einzigartig in der Gasfachliteratur der Welt sein.

\subsection{Vereine, Zeitscbriften und Organisation des Facbes}

Am 6. 4. 48 wurden die bestehenden Landesverbände von Gas- und Wasserwerken in Wiesbaden zu einer Arbeitsgemeinschaft zusammengefaßjt. Diese AG wurde am 23. Okt. 1950 mit dem Deutschen Verein zu gemeinsamer Arbeit durch Austausch der Vorstandsmitglieder koordiniert. Damit verlor der Verein seine im Anfang ausgeübte Tätigkeit auch in wirtschaftlichen Fragen erneut. Auf dem Gebiete der Normung, Vorschriften und Richtlinien entfalteten die Ausschüsse des Vereins eine sich immer mehr steigernde Tätigkeit. Einzelheiten über den Fortschritt müssen hier ausgelassen werden. Nach der Gründung der Arbeitsgruppen des Vereins in Bayern am 23. Sept. 1948, der hessischen Landesgruppe am I8. Jan. 1949, der Landesgruppe Württemberg-Baden am 29. März 1949, der Landesgruppen Rheinland-Pfalz und Westberlin am 9. Jan. I950 hatte der Verein das ganze Bundesgebiet mit Westberlin wieder aufgeschlossen.

Die AG wurde 1951 als Verband der Deutschen Gas- und Wasserwerke (VGW) gestrafft und entwickelte eine rührige Tätigkeit, insbesondere wegen der Kohlenund Kreditlage $\left.{ }^{y, 27 y}\right)$. Seinen vielfachen Bemühungen gelang es, daf3 r959 die Staats-

\footnotetext{
8.257) Zentrale für Gasverwendung: Gas in Gewerbe und Industrie Frankfurt a. Main 1955 Bd. I TI. $3 \mathrm{~g}, 3 \mathrm{~h}$ : Die Gasversorgung. Essen 1952 Vulkan-Verlag S. 456; 487; J. H. Brunklaus: Industricofenbau. Essen 1957 Vulkan-Verlag S. 188/197; Gaswãrme 2 (1953), 134; 6 (1957), 198; 386; GWF 91 (1950), 196; 248; 92 (1951), 114 ; $94(1953), 692$

5.278) 96 (1955), 26; 646; Gas Age 144 (1954) Nr. 11 S. 320; in (1953). Nr. 12 S. 32; GWF 98 (1957), 16

8.anv) 92 (1951), Berichte 6

604
} 
aufsicht über die Gaspreise aufgehoben wurde. Eine gleichzeitig erlassene Tarifordnung vom I. Okt. 1959 war lediglich ein Rahmen. Jedoch meinte der VGW dazu, daß es zu spät sei, um den Werken wirksam zu helfen ${ }^{\text {r.soo }}$ ).

Die Wirtschaftliche Vereinigung deutscher Gaswerke (WV) wurde zunächst mit dem Sitz in Düsseldorf erneut. Sie schuf Einkaufsstellen in Frankfurt a. M. und Düsseldorf. Es konnten aber nicht sofort alle Formalien erledigt werden ${ }^{5.251}$ ). 1948 siedelte sie nach Frankfurt a. M. um ${ }^{\text {s.xan }}$ ). Sie widmete sich der Einkaufsvermittlung auch für Kohlen aus den Vereinigten Staaten und der Absatzfinanzierung von Geräten, wobei die Kreditschwierigkeiten hemmten ${ }^{8,259}$ ), neben ihren alten Aufgaben. Später schaltete sie sich auch in die Beschaffung von Flaschen für Flüssiggas ein. Die Geschäftsberichte geben ein getreues Bild über die Lage am Kohlen- und Koksmarkt in ihrem Wechsel.

Der Berufsverein für das Energie- und Wasserfach in Tradition des Deliwavereins hatte zunächst in der britischen Zone als Deliwagruppe innerhalb des Deutschen Vereins gearbeitet und wurde im Oktober 1948 neu gegründet. Mit aller Kraft setzte sich der Vater dieses Vereins, der schon als Ehrenvorsitzender gewirkt hatte, W. Köllner, erneut ein. Im Jahre darauf konnte die Vereinszeitschrift als Neue Deliwa Zeitschrift wiedererscheinen ${ }^{8,284}$ ).

Die Werbeorganisation feierte ihre Auferstehung mit der Zentrale für Gasverwendung (ZfG) am 10. Sept. $1949^{8.350}$ ). Ein Jahr darauf erschien als Zeitschrift: Der Gasverkauf ${ }^{5000}$ ). Man freute sich über die Absicht, über die in Berlin noch bestehende ZfGW auch mit den Werken in Mitteldeutschland in Verbindung zu bleiben, wobei Werbeblätter in ganz Deutschland zu gleichen Preisen geliefert werden sollten ${ }^{\text {s.ms }}$ ). Als eigener Verlag wurde 1952 der ZfGW-Verlag gegründet. Das Ringbuch wurde bereits erwähnt $\left.{ }^{8.259}\right)$. 1958 war ein Bezirksstellennetz in der Bundesrepublik ausgebaut. Für den Erfolg bei der Gewinnung gewerblicher und industrieller Abnehmer war die Anwesenheit von Ingenieuren in den einzelnen Ländern eine Hilfe für die einzelnen Werke $\left.{ }^{8.250}\right)$. Uber den Geräteverkauf durch die Gaswerke, der für den Absatz eine wertvolle Hilfe darstellt, ergab eine Umfrage der Internationalen Gasunion das folgende Bild: England $100 \%$, Italien, Schweden, Osterreich 90 bis $95 \%$, Frankreich $75 \%$, Holland $62 \%$, Deutschland 12 bis $15 \%$, Dänemark 10 \% der Werke $\left.{ }^{8.200}\right)$.

Die Technische Vereinigung der Firmen im Gas- und Wasserfach (Figawa) stellte mit dem neuen Namen die Arbeitsziele der früheren Fagawa (Fabrikantenvereinigung im Gas- und Wasserfach) deutlicher als bisher heraus. Sie arbeitet eng

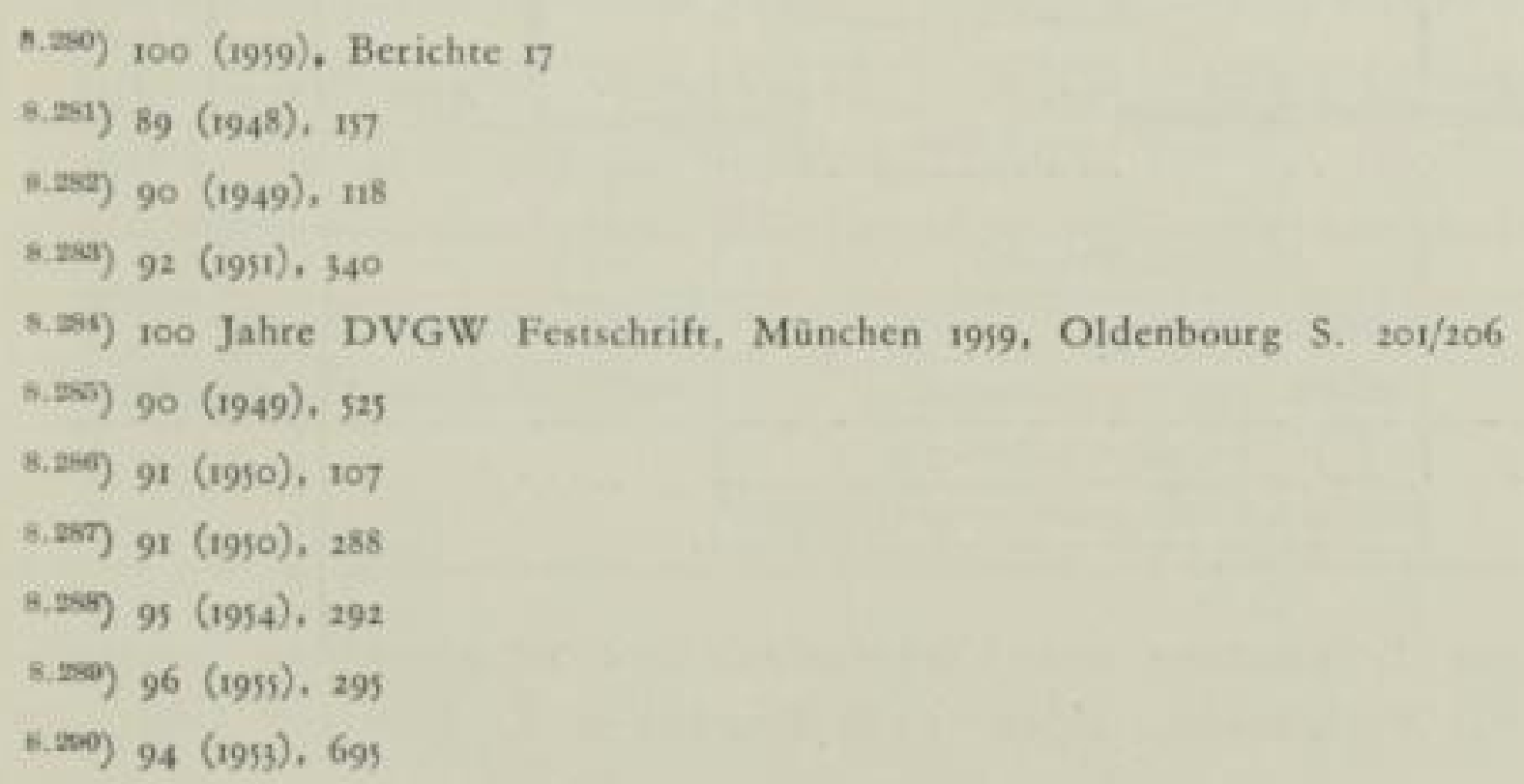




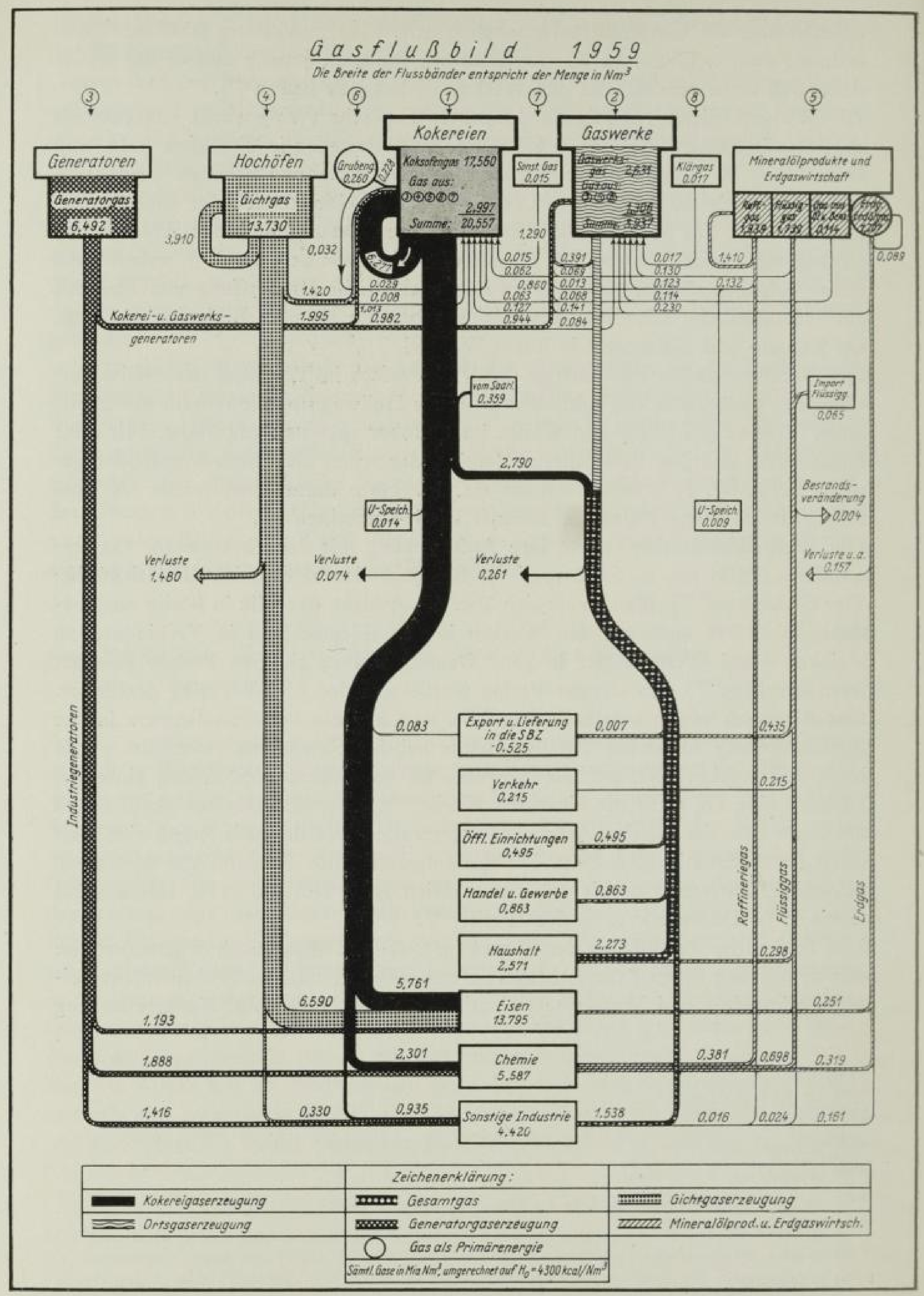

Bild 126 Gasfluf̧bild 1959 zur Erläuterung der Verknüpfung der verschiedenen Gaserzeugungsstellen mit den Verbrauchsgruppen (nach Laurien u. L. Segelken (GWF ror [1960] S. 826) 


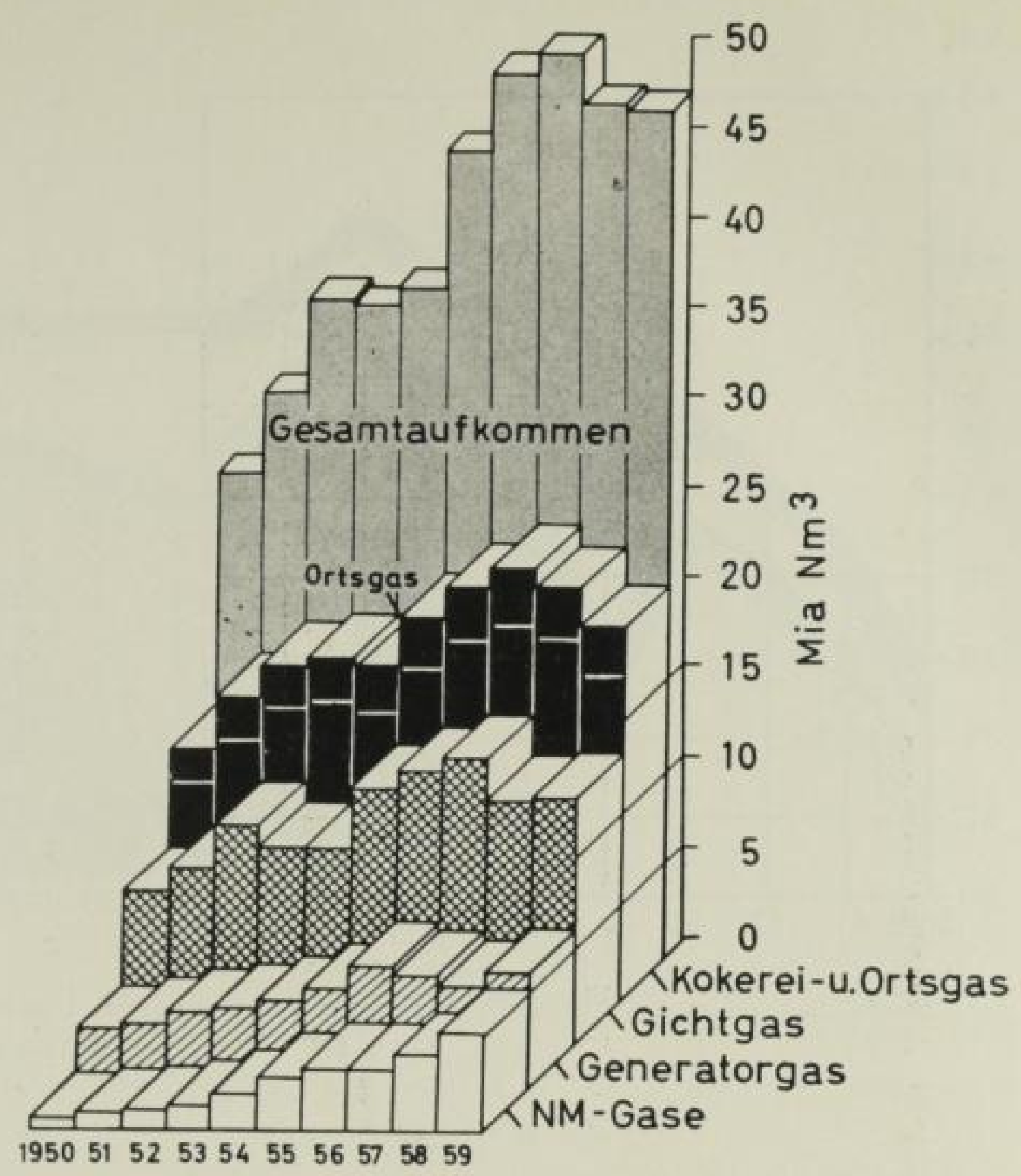

Bild 127 Gasaufkommen in der Bundesrepublik (Entwicklung der einzelnen Gasarten 1950 bis 1959 nach H. Laurien u. L. Segelken (GWF ror [1960] S. 825)

mit den Ausschüssen des Vereins zusammen $\left.{ }^{5.201}\right)$. An weiteren für das Fach wichtigen Veröffentlichungen seien erwähnt: Die Zeitschrift: Gaswärme, das Organ des Gaswärme-Instituts, Essen (Vulkan-Verlag, Essen) ${ }^{8.222}$ ) und statt des alten Gaskalenders das Gastaschenbuch des DVGW, Wissenschaftliche und technische Unterlagen von Dr. H. Laurien, Verlag Oldenbourg, München $\left.{ }^{8.203}\right)$.

Zum Schluf\} mögen noch einige Bilder 126 bis 133 die Entwicklung anschaulicher machen. Sie sind dem Bericht von 1960 der alljährlichen Aufstellungen von H. Laurien und L. Segelken entnommen und bedürfen auf̧er den Unterschriften keiner weiteren Erläuterung $\left.{ }^{8,29}\right)$.

\footnotetext{
8.201) 88 (1947), 160

3.202) 94 (1953), 79

$8,2003) 98$ (1957), 740

8.924) $101(1960), 824 / 8=8$
}

\section{SLUB}




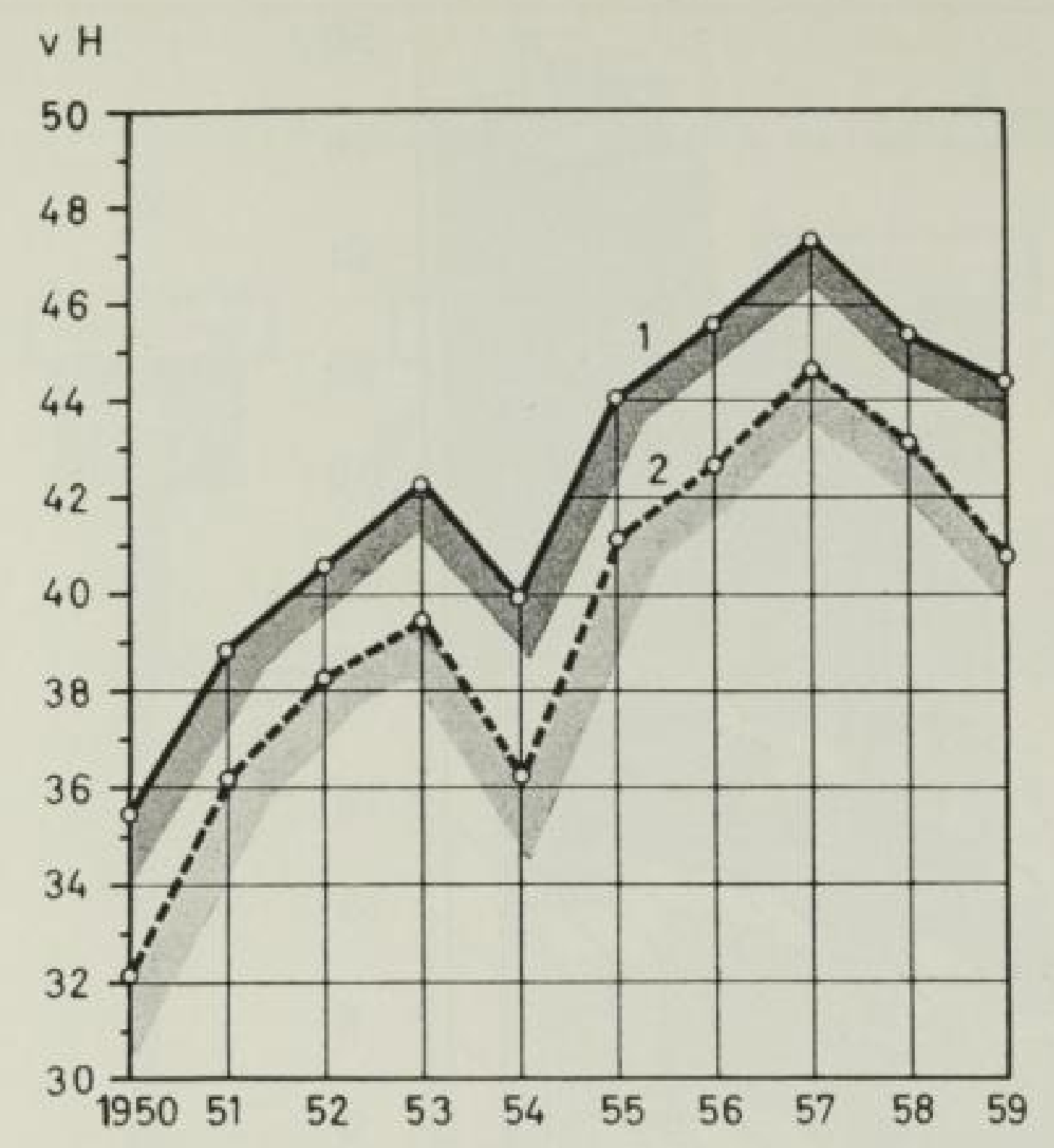

Bild 128

Kohlenverbrauch der Kokereien und Gaswerke in \% der gesamten Kohlenförderung 1950 bis 1959 (nach H. Laurien u. L. Segelken (GWF ror [1960] S. 827)

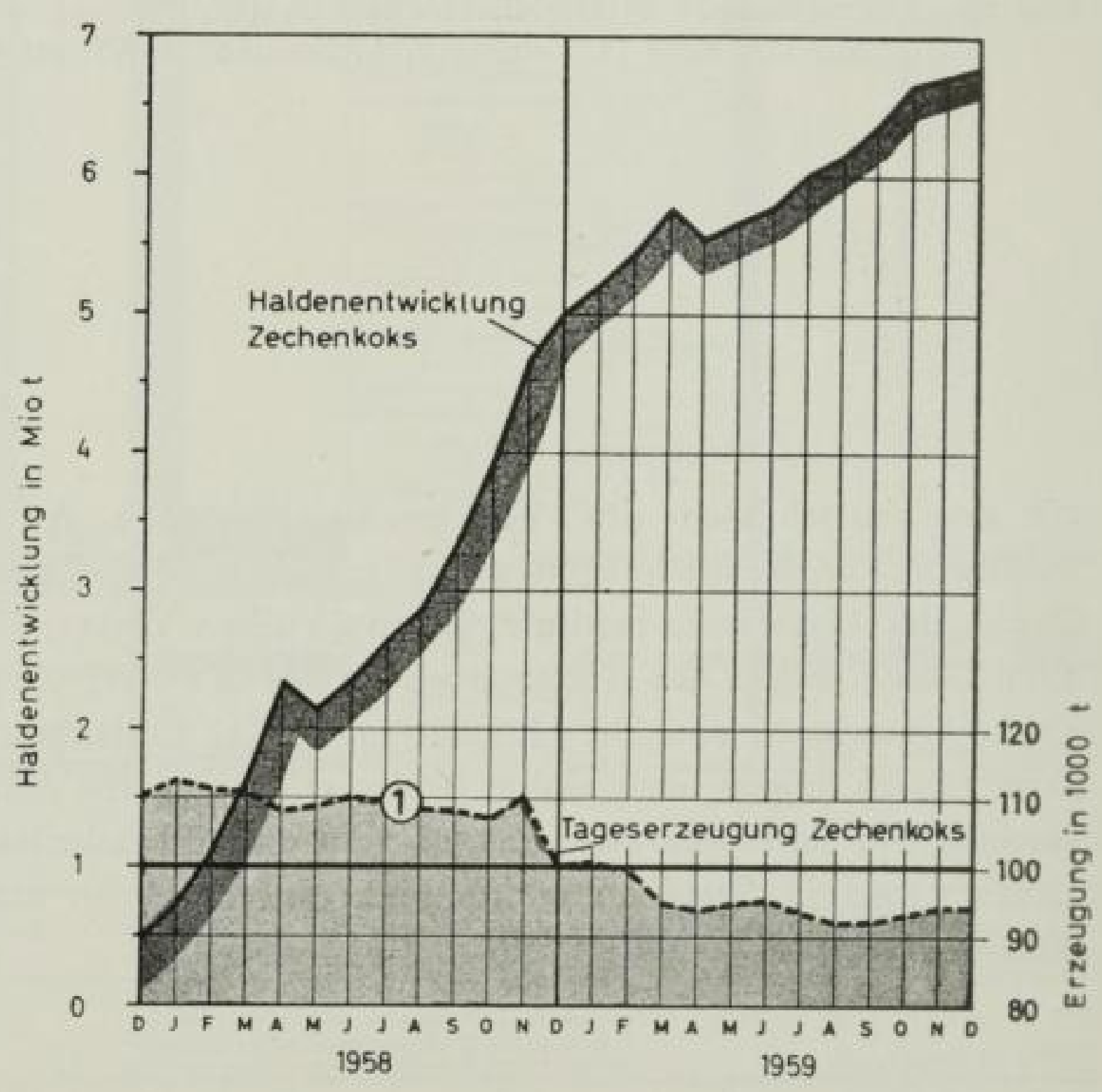

Bild 129 Kokshalden und Tageserzeugung an Zechenkoks 1958/59 (nach H. Laurien u. L. Segelken (GWF ror [1960] S. 828) 


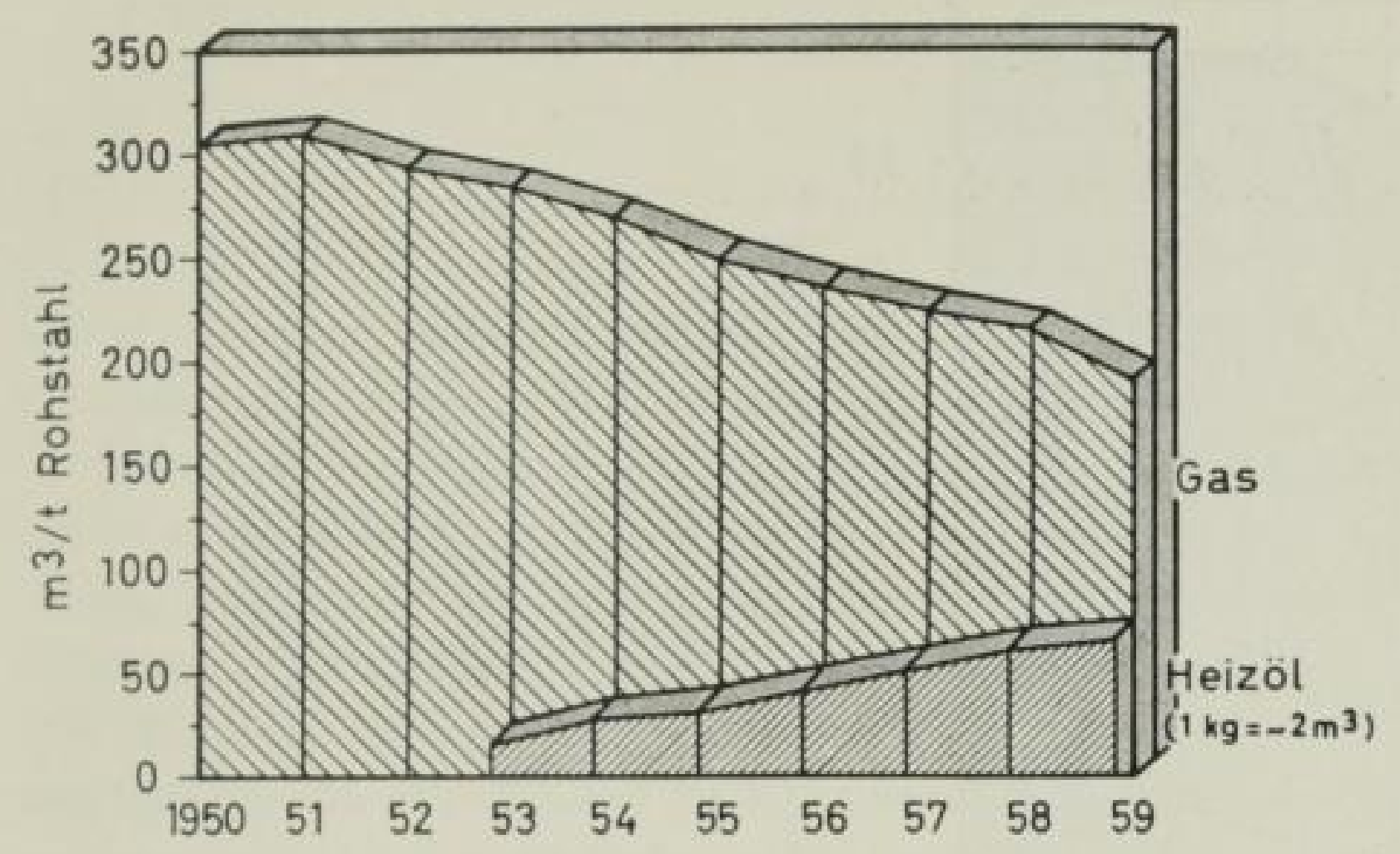

Bild 130 Gas und Olverbrauch der Eisenindustrie je t Rohstahl (nach H. Laurien u. L. Segelken (GWF ror [1960] S. 828)

\section{Bild 131}

Anteil der Kohlenwasserstoffgase für die Gaserzeugung der Gaswerke 1952 bis 1959 (nach H. Laurien u. L. Segelken (GWF I0I [1960] S. 828)

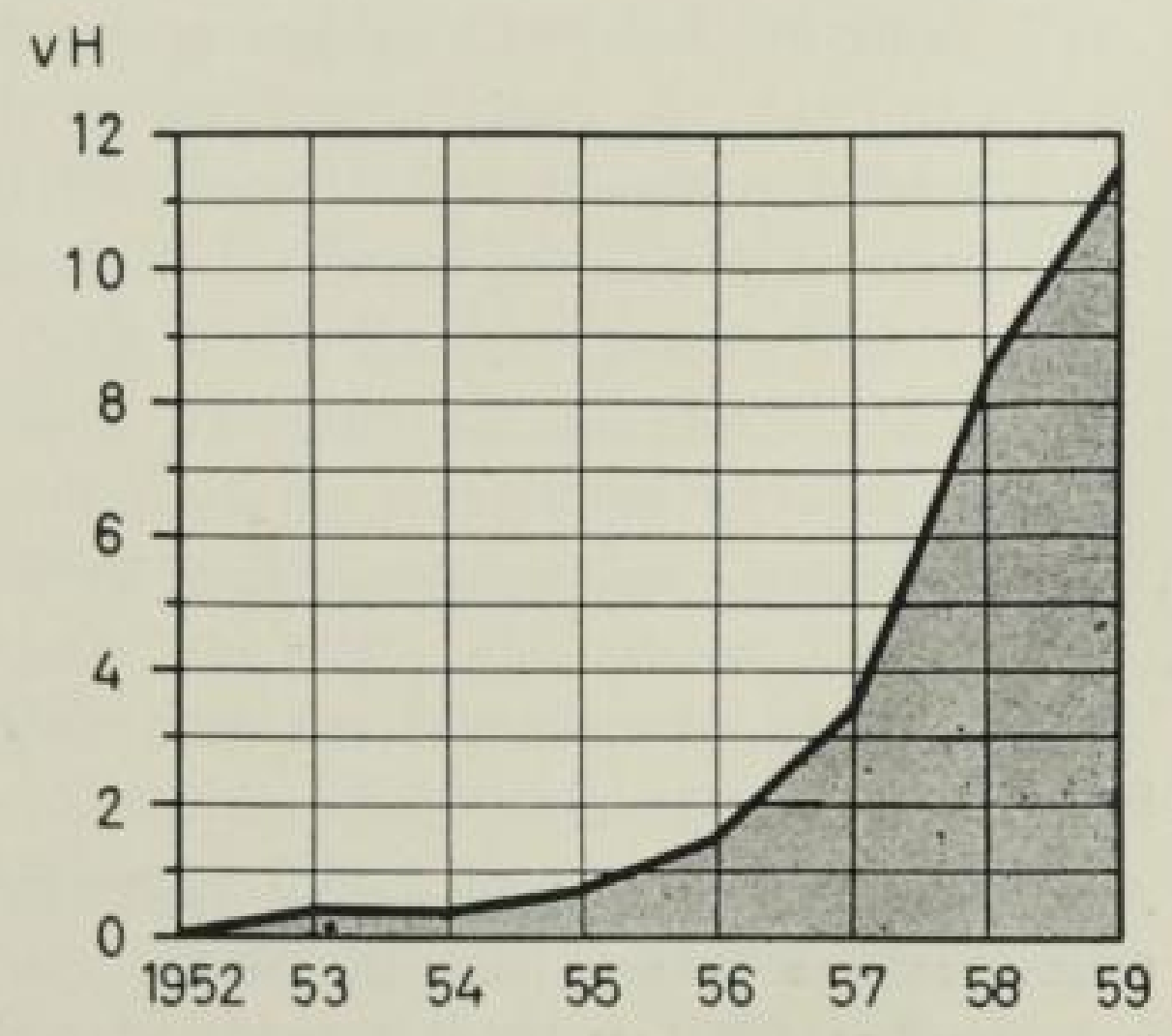

609

\section{SLUB}

Wir führen Wissen. 


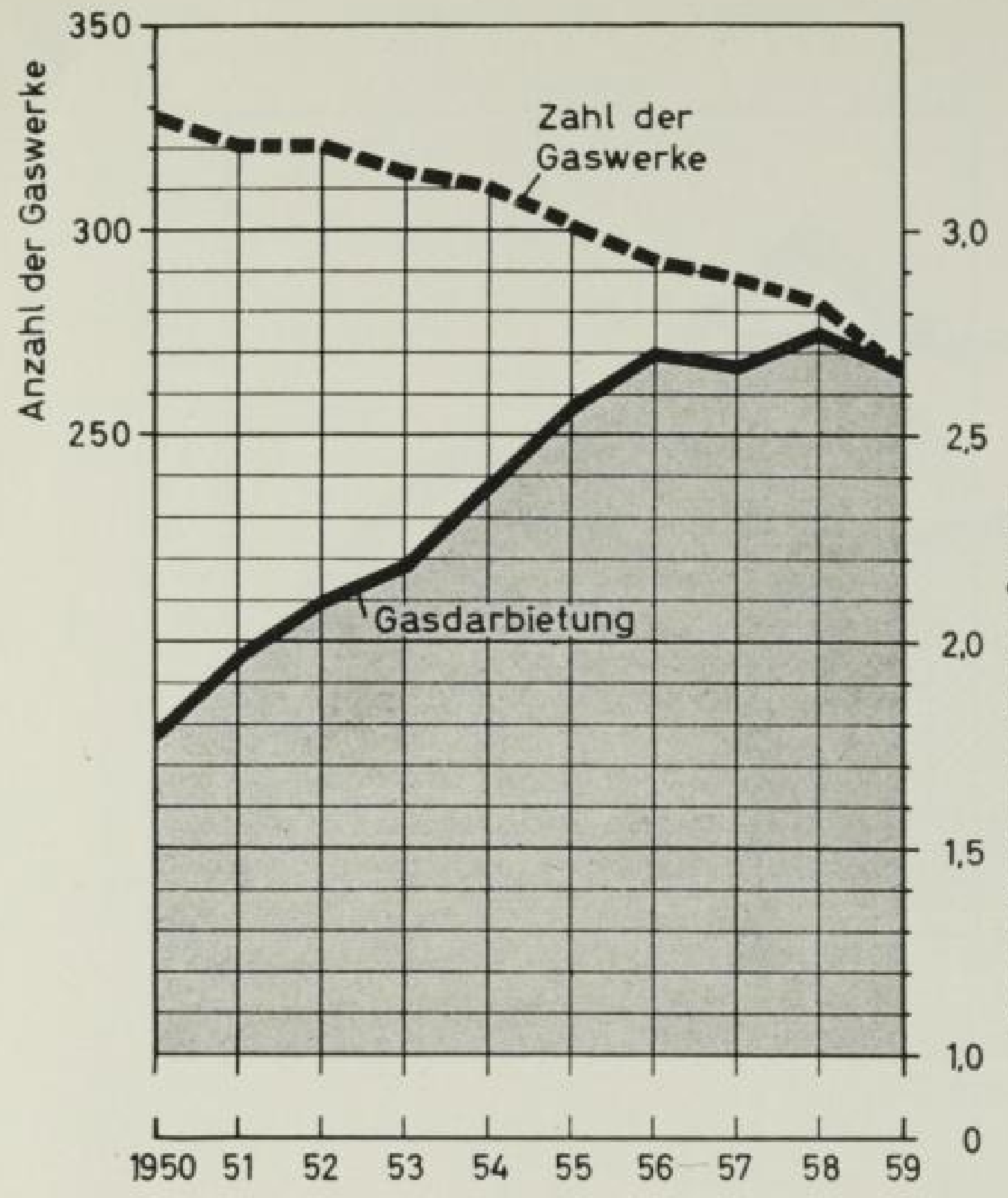

Bild 132

Steigender Einflufy der Gaswerksgröfe 1950 bis 1959 (nach H. Laurien u. L. Segelken

(GWF 101 [1960] S. 829)

\section{Bild 133}

Auswirkung der Rationalisierung bei den Gaswerken 1950 bis 1959 (nach H. Laurien u. L. Segelken (GWF Iог [1960] S. 829)

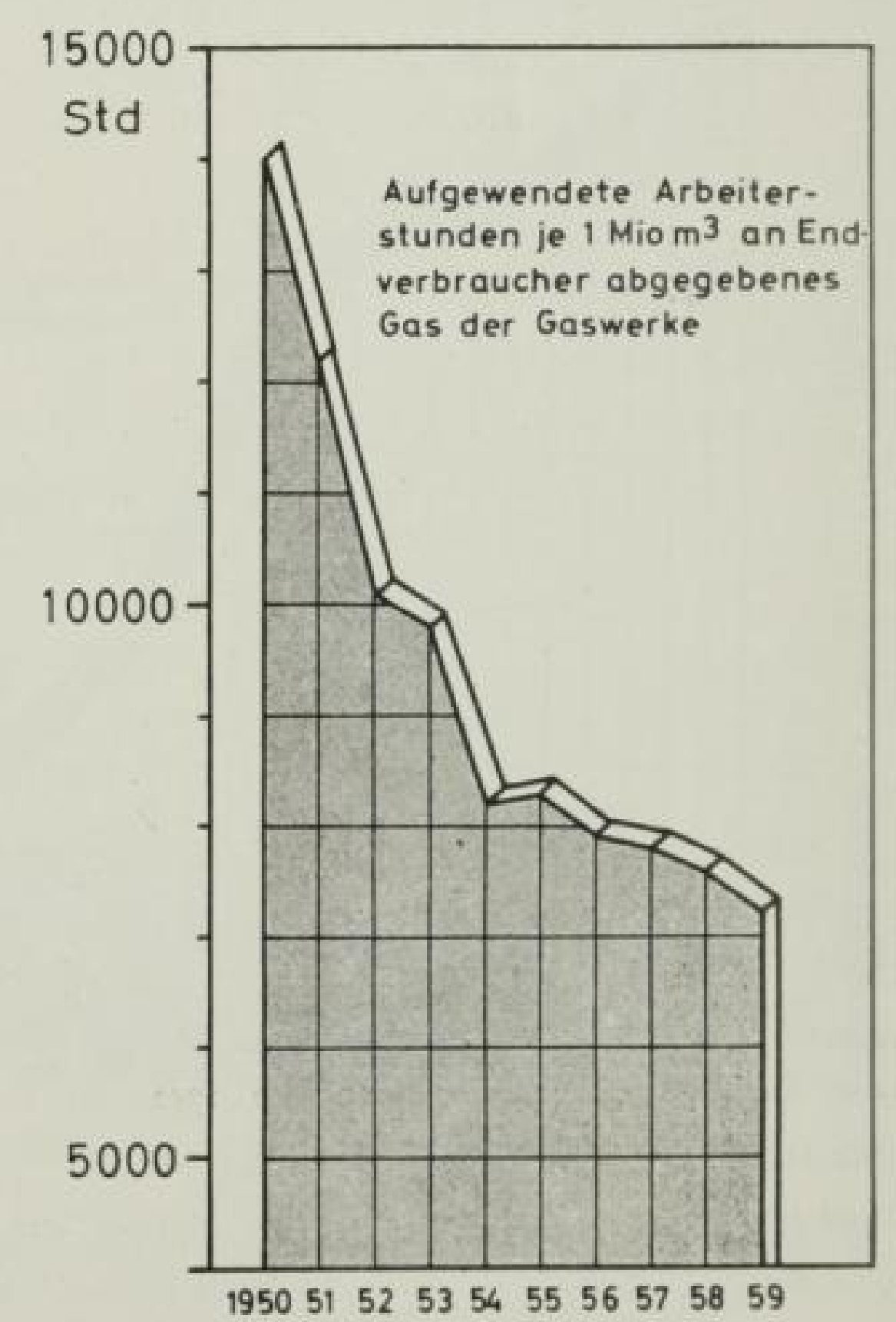

\section{SLUB}




\section{ZUSAMMENFASSUNG UND AUSBLICK}

Die Geschichte des Gasfachs in Deutschland weist zwei grofe Umstellungen von epochaler Bedeutung auf. Das sind die Aufnahme der wissenschaftlichen Arbeit ab 1860 und der Verzicht auf Leuchtgas durch die Erfindung des Glühstrumpfes durch Auer v. Welsbach. Alle anderen Neuerungen sind die Folgen dieser beiden Taten, mag man auch, wie es 1908 ausgesprochen wurde (s. Anhang 10), die Erklärung H. Buntes des Generatorbetriebes von 1879 als die erlösende Tat feiern. Die Vorarbeiten sind indessen älter. Der Ubergang vom Leucht- zum Stadtgas ermöglichte die Entgasung in Kammern. Koksofengas wurde gleichwertig. Zusammen mit dem inzwischen vollendeten Rohrbau wurde die Ferngasversorgung möglich, mit der Deutschland eine groß̧e Achse, weit eher als alle europäischen Länder erhielt.

In dieser ganzen Zeit bis 1958 war Kohle die einzige Grundlage der Gaserzeugung. Die ersten und alle späteren Versuche mit Öl blieben in bescheidenen Grenzen für Sonderzwecke.

Heute stehen wir mit dem in Deutschland sehr billigen Öl und mit Erd- und Raffineriegas als möglichen Rohstoffen vor einem neuen Umschwung, dessen Ausmał noch nicht zu ermessen ist. Wahrscheinlich wird sich die Achse zu einem Netz über die ganze Bundesrepublik, hoffentlich über ganz Deutschland, ja Europa auswachsen. Es wäre zu wünschen, dafy bei den groß̧en Kapitalfestlegungen alle möglichen Träger des gesamten Unternehmens rechtzeitig mit $\mathrm{Zu}$ sammenschlüssen und Verträgen ein wirtschaftlich gesundes Gewicht gemäß̧ der: Interessen und dem Besitz fänden.

Die Auswirkungen werden gewaltig sein. Sie beginnen schon bei der Ausbildung der Gas- und Brennstoffingenieure. Mehr als je werden Chemiker, Physiker, Verfahrens-, Maschinen- und Elektroingenieure benötigt werden, die das ganze Gebiet der Veredlung und Umwandlung der Brennstoffe übersehen können. The enges Fachwissen kann lediglich Schwerpunkt für ihren jeweiligen Einsatz sein. Als die Gasingenieure in den Werken vielfach die Erzeugung aufgeben mufsten, weil man sich an das Ferngasnetz anschloł, da hatten sie aus ihrer eigenen Erfahrung den Maf3stab, mit dem sie Forderungen bis zur letzten Ursache kritisch abwägen konnten. Jetzt kommen Lieferanten grof̧er, sehr grof̧er Gasmengen, die zwar Abfall sind, aber dennoch mehr oder weniger zugeschnitten für die Umwandlung abgeliefert werden müssen. Hier muł der Ingenieur im abnehmenden Werk die hilfreiche Kritik erst erlernen. Auch hierbei ist es ja nötig, dał in Rede und Gegenrede, in harmonischen gemeinsamen Überlegungen der Bestwert für beide gefunden wird. In der Gaswirtschaft müssen Männer zu finden sein, die in den Bedingungen der Ölverarbeitungsbetriebe zuhause sind. 
Das Gasfach steht vor Aufgaben, deren zwei nicht leicht richtig zu lösen sein werden. Es hat von sich aus die Pflicht, von dem schon gasförmigen Brennstoff möglichst viel zu übernehmen, zu sorgen, dał der Preis für die Raffinerie ein Anreiz bleibt, auch wenn in der Hausheizung dem Öl ein gewisser Absatz verioren geht. Andererseits bleibt neben der heute schon geübten, technisch beratenden Werbung für den Industrieabsatz als noch kaum angegriffener Absatz, der grołe Wärmebedarf der häuslichen Heizung. Dieser ist aber neben einigen in der Luft liegenden technischen Neuerungen mit verstärkter Aufklärung nur mit sehr ermäfigten Preisen gegenüber dem Gewohnten voll zu erschließ̧en. Hier muf̧ also genau abgewogen werden, wie weit man fordern, wie weit man nachgeben mufy. Dazu tritt aber noch eine zweite Klemme auf. Das Gasfach darf die Kohle als Hauptrohstoff nicht vernachlässigen. Denn mit dem energetisch gerechneten Verhältnis der Weltvorräte von Erdöl und Gas zur Kohle wie 1: 400 kann man ahnen, daf die Fülle des Erdölangebotes sich bald wieder abschwächen kann, und die Kohle wieder die Hauptquelle für Gas wird. Das sagt nicht, dał einzelne, besonders kleinere, Werke heute nicht gänzlich umgestellt werden sollten. Die groß̧en Werke werden aber ihre Ofen weiter betreiben müssen. England sieht zur Zeit die Lösung darin, neben dem Weiterbetrieb der in den letzten Jahren erbauten groß̧en Werke (meist mit Retorten!) jetzt durch Ausbau der Druckvergasungsanlagen der Kohle eine zusätzliche Abnahme zu schaffen. Die Lage ist allerdings anders als in Deutschland, weil in mehreren über das Land verteilten Bezirken reichliche Mengen schwachbackender billiger Kohlen anfallen. In Deutschland sind auch diese Sorten nicht reichlich und nur an der Ruhr und Saar vorhanden. Sie vertragen aber, wenn sie der Vergasung dienen sollen, keine Frachtaufschläge. Trotzdem muß die Aufgabe angepackt werden. Vielleicht stellt sich das Gleichgewicht zwischen neuen und alten Rohstoffen ein, wenn wir den in Holland angedeuteten Weg untersuchen, den Heizwert unseres Gases zu erhöhen. Als er von to Jahren festgelegt wurde, gab es nur die Vergasung vornehmlich zu Wassergas als Koks nicht liefernde Gaserzeugung.

Die deutschen Gaswerke müssen auch trotz $\mathrm{Ol}$ und Erdgas den Koksmarkt pflegen. Die Einfamilienhäuser werden zwar in den meisten Fällen den Koks allmählich aufgeben. Eine Parallele mit der Entwicklung in Schweden mag den Weg anze gen. Dort hatte man sich dem Öl eher zugewandt als bei uns, aber neuerdings sind viele der Häuser von $\mathrm{Ol}$ auf Gas umgestellt. Gas ist eben noch bequemer als $\mathrm{Ol}$ und verlangt keine empfindlichen und teuren Hilfseinrichtungen. Ausserdem ist das Abgas von Schwefelverbindungen trei. Wenn eine ganze Siedlung mit Öl beheizt wird, so macht sich bei diesigem Wetter ein unangenchmer Olduft in der Luft bemerkbar.

Groß̧e Heizanlagen in Bürohäusern, Verwaltungen, Schulen und Krankenhäuserı können mit den neuzeitigen automatischen Koksfeuerungen sauber und gleichmäfig beheizt werden. Städtische Werke haben bei den Heizämtern eine Möglichkeit, angehört zu werden. Das müssen sie ausnutzen. Die Zechen aber sollten, um der Kohlenlieferungen willen ihren Wunsch, hier im Wettbewerb mit Koks zu bleiben, zügeln und insbesondere nicht, sobald sich einmal in der Eisenindustrie eine Krise zeigt, in den behüteten Markt der Gaswerke einzubrechen suchen. Für alle diese Koks- und Gasfeuerungen kann der jetzt laut gewordene Ruf nach klarer reiner Luft ein Helfer sein. Bisher sind die Gaserzeuger in der 
Fachgruppe des Vereins deutscher Ingenieure reichlich stark in der Abwehr trotz ihrer Bemühungen, die Staub- und Rauchentwicklung in den Werken, insbesondere bei der Kammerfüllung zu vermindern. Das englische Gasfach ist demgegenüber in dieser Frage von jeher im Angriff gewesen. Begünstigt durch das diesige Klima und die verschwenderischen offenen Kamine, für die der züngelnden Flammen wegen die gasreichen Kohlen bevorzugt wurden, waren sie Hauptführer in der Rauchbekämpfungsbewegung ${ }^{5.255}$ ) (Vgl. Seite 302). Der Sieg gegen den Rauch wurde nach 6o Jahren mühevoller Aufklärung mit der Clean Air Act errungen. Aber schon haben die Werke handfeste Zahlen in der Hand, daß̧ der Aussto\} von Schwefeloxyden ebenso schädlich ist, wie der Rauch. Mediziner sind da heute die besten Verbündeten. Zu dieser Erkenntnis müssen die deutschen Gaswerke auch die Offentlichkeit führen. Das ist eine vordringliche Aufgabe $\left.{ }^{5.200}\right)$.

Die Ankunft des Öles und des Erdgases gibt also nicht nur Hoffnungen auf eine schnelle Entfaltung des Gasabsatzes. Sie stellt auch neue Aufgaben in noch undeutlichen Formen. Sie richtig zu sehen und zu lösen, wird dem Ingenieur und dem hoffentlich mit ihm eng zusammenarbeitenden Wirtschaftler zum mindesten Anregungen, hoffentlich aber einmal eine unbändige Freude bringen. Freudige, freie und ehrliche Zusammenarbeit aller, die mit dem Gasfach verbunden sind, wird die eine grof̧e Voraussetzung sein.

Das ist keineswegs neu. Das zu beweisen, war eine der Aufgaben dieses Geschichtsbildes.

\footnotetext{
\$.206) Gas Journal 308 (1961), Nr. 5118 S. 9

8.2min) 90 (1949), $574: 93$ (1952), 385; Gas Journal 287 (1956), Nr. 4856 S. 35; GWF 98 (1959). 590; Ges. Ing. 77 (1956), 236; GWF 101 (1960), 477; 68x
}

\section{SLUB}




\section{A NHANG I}

Ein Bericht über die Anwendung von Koblengas für wirtschaftliche Zwecke (An account of the application of the gas from coal to econocial purposes)

von W. Murdocb

In seinem Vortrag* führte Murdoch aus:

„Die Tatsachen und Ergebnisse sind begründet auf Beobachtungen dieses Winters in der Baumwollfabrik von Philipps \& Lee in Manchester, wo das Licht, das man aus der Verbrennung des Kohlengases erhält, in sehr grołem Maß̧e benutzt wird. Die Einrichtungen für die Erzeugung und Anwendung sind durch mich in der Fabrik von Boulton, Watt \& Co. in Soho entwickelt.

Sämtliche Räume dieser Baumwollspinnerei, die, wie ich glaube, die größ̧te des Vereinigten Königreiches ist, ferner die Verwaltungsräume und Lager sowie das anliegende Wohnhaus des Herrn Lee sind mit Kohlengas erleuchtet. Die Lichtmenge, die in den Betriebszeiten gebraucht wird, ist durch Schattenphotometrie als gleich der von 2500 Kerzen, sechs aufs Pfund, ermittelt...

... Die bewundernswerte Genauigkeit, mit der der Betrieb des Werkes geführt wird, gewährte eine ausgezeichnete Gelegenheit, Vergleichversuche anzustellen... ... Da die Versuche in grof̧em Małsstabe für längere Zeit geführt wurden, dürften sie als genügend guter Maß̧stab angesehen werden können, um die Vorteile des Gaslichtes unter günstigen Verhältnissen festzustellen ...

... Die Kohle wird in grofen eisernen Retorten entgast, die während des Winters mit Ausnahme der Ladezeiten dauernd im Betrieb sind. Das Gas, das daraus entsteht, wird durch eiserne Rohre zu groß̧en Behältern oder Gasometern geleitet, in denen es gewaschen und gereinigt wird, bevor es durch Hauptleitungen nach der Fabrik flief̧t. Diese Hauptleitungen teilen sich in eine Vielzahl von Abzweigungen (eine Gesamtlänge von mehreren Meilen ergebend) und werden im Durchmesser kleiner in dem Maf̧e, wie die Menge Gas, die hindurch muf, geringer wird. Die Brenner, in denen das Gas verbraucht wird, sind mit den Hauptleitungen und Rohren durch kurze Röhren verbunden. Jede von ihnen ist mit einem Hahn zur Regelung der Gaszufuhr zu jedem Brenner und zum völligen Abschluf versehen. Diese Abschaltung kann gleicherweise sofort und gleichzeitig für alle Brenner cines Raumes durch einen Hahn in der Hauptleitung geschehen...

... Als Brenner wurden 27r Argand- und 633 Cockspurbrenner eingebaut." (Bei letzteren treten 3 Flammen, die eine in der Mitte, nach oben, die beiden anderen seitlich, aus dem Brennerkopf).

Es folgt dann eine sehr genaue Wirtschaftlichkeitsberechnung, die Ersparnisse gegenüber den bisher gebrauchten Ollampen nachweist. Dann fährt Murdoch fort: „Die Einführung dieser Art Beleuchtung bei Philipps \& Lee ist schrittweise erfolgt. Man begann I8os mit zwei Fabrikräumen, dem Verwaltungsbüro und dem Wohnhaus. Dann wurde sie auf die ganze Fabrik ausgedehnt, so schnell, wie die Einrichtungen hergestellt werden konnten...

क) Philosophical Transactions. Teil I, 1808 S, 124/132. Nachgedruckt in Gas Times 81 (1954) Nr. 830 S. $49 / 36$. desgl. Appendix IV: The Rise of the Gas Industry in Britain. By Dean Chandler and A. Douglas Lacey. British Gàs Council, London 1949

614 
... Zunächst wurden Unzuträglichkeiten wegen des Geruches des unverbrannten oder unvollkommen gereinigten Gases wahrgenommen, denen größtenteils die schrittweisen Verbesserungen im Bau der Geräte, so wie die Installation fortschritt, zugeschrieben werden müssen. Aber seit der Fertigstellung und nachdem die Wärter mit dem Betrieb vertraut geworden sind, ist diese Unzuträglichkeit beseitigt, nicht nur in den Werkstätten sondern auch im Wohnhaus, das unter Ausschluf̧ jedes anderen künstlichen Lichtes glänzend beleuchtet ist....

Es folgt das Lob des Lichtes, die Freiheit von Funken und Schnäuzen der Kerzen und die Minderung der Feuersgefahr.

„Es sind nunmehr ungefähr 16 Jahre her, als ich Versuche zu Redruth in Cornwall über Menge und Güte des Gases anstellte, das ich durch Destillation von verschiedenen mineralischen und pflanzlichen Stoffen gewann. Ich war durch einige Beobachtungen, die ich vorher bei der Verbrennung von Kohlen gemacht hatte, angeregt, die Verbrennungseigenschaften von Gasen aus Kohle, Torf, Holz und anderen brennbaren Stoffen zu untersuchen. Beeindruckt von der groß̧en Menge Gas, die sie abgaben, und von dem Glanze des Lichtes und der Leichtigkeit seiner Erzeugung, machte ich mehrere Versuche, um die Kosten, die sich im Vergleich mit gleichen Lichtmengen aus Ol und Talg ergeben, festzustellen...

... Meine Anlage bestand aus einer Eisenretorte mit verzinnten Eisen- und Kupferrohren, durch die das Gas über eine beträchtliche Entfernung geleitet wurde... Die Versuche wurden mit Kohlen verschiedener Art angestellt, die ich aus entfernten Gegenden des Königreiches herangebracht habe, um festzustellen, welche die wirtschaftlichsten Ergebnisse zeitigten. Das Gas wurde auch mit Wasser gewaschen, und andere Mittel, es zu reinigen, wurden angewandt... ... Im Jahre $1798 \mathrm{kam}$ ich von Cornwall zu Boulton, Watt \& Co. zurück; dort erbaute ich eine Anlage in größzerem Małstabe, die während vieler aufeinanderfolgender Nächte für die Beleuchtung der Hauptgebäude eingesetzt wurde. Verschiedene neue Verfahren, das Gas zu reinigen und zu waschen, wurden angewandt...

... Die Versuche wurden mit einigen Unterbrechungen fortgesetzt bis zur Illumination der Fabrik beim Frieden von Amiens $1802 \ldots$

... Danach wurde die Anlage erweitert, um allen Hauptwerkstätten Licht zu geben. Diese ist dauernd im Betriebe unter Ausschluf jeder anderen Beleuchtung...

...Als ich meine Versuche begann, war mir völlig unbekannt, daf andere bereits festgestellt hatten, daf̧ Kohlengas benutzbar sei. Später habe ich gehört, daß Lord Dundonald oftmals das Gas aus seinen Teeröfen verbrannt hat, und ich finde (jetzt), daf3 Clayton schon 1739 experimentiert hat... Aber der Gedanke, das Gas als wirtschaftlichen Ersatz für Öl und Talg anzuwenden, scheint ihm nicht gekommen zu sein...

... Ich glaube, ich darf, ohne zuviel zu sagen, für mich beanspruchen, daf̧ ich sowohl den ersten Gedanken, es anzuwenden, hatte und auch die erste praktische Anwendung dieses Gases zu wirtschaftlichen Zwecken ausgeführt habe." 
A NHA NG 2

Der Brief Murdochs an ein Parlamentsmitglied von 1809.

„Nachdem ich in diesem Augenblick eine Veröffentlichung durchgesehen habe, die ein Ausschuf herausgegeben hat, um ein Gesetz im Parlament durchzubringen, das die Errichtung einer gewissen Gas-, Licht- und Koks-Gesellschaft bezweckt, fühle ich mich angerufen, die sehr unvornehme und unduldsame Aıt festzuhalten, mit der ich durch den ganzen Schriftsatz hindurch erwähnt bin... ... Ich wende mich an Sie, weil ich keine Zeit mehr habe, etwas anderes zu unternehmen ...

... Ich habe niemals behauptet, die Entzündbarkeit des Gases entdeckt zu haben. In meinem Vortrag ... I808 habe ich sie Dr. Clayton zugeschrieben...

... Ich gebe gern zu, daf3 die Frage nach der ersten Anwendung des Gases als einem wirtschaftlichen Ersatz für Öle und Talg in der Erzeugung von Licht für öffentliche und private Zwecke aufgeworfen ist. Das ist das, was ich für mich beanspruche und wofür ich mit der goldenen Madaille der Royal Society geehrt worden bin...

... Aber wie hat mich der Ausschuf meines Anspruches beraubt? Hat der Deutsche Diller durch seine philosophischen Feuerwerke im Lyzeum durch seine großen Kronen mit kleinen Flammen inmitten des Raumes die Anwendung des Gases für öffentlichen und privaten Nutzen gebracht, indem er, wie ich gehört habe, sein Verfahren mit alter händlerischer Vorsicht eines Taschenspielers geheimhielt? Kann der Gas-Ausschuß diese Cabaretunterhaltung gegen meıne praktische Verwendung in Soho und bei Philipps \& Lee halten? Ich überlasse dem Ausschuf, ob es ein vornchmes und anständiges Vorgehen ist, oder mit welcher Aufrichtigkeit er sich auf die behauptete wirtschaftliche Anwendung von Brenngasen beziehen kann, die, wie er sagt, einige Jahre nach Dillers Veranstaltung 1778 der königlichen Akademie der Wissenschaften in Paris mitgeteilt worden sei - ohne Angabe des Bandes oder Datums. Eine solche Nachricht habe ich niemals gehört, noch hat der Ausschuß uns mit Einzelheiten erfrcut. In seiner Bemühung. die Erfindung licber jeder anderen Quelle als mir zuzuschreiben, vergif̧t er, daf̧ es seine Pflicht ist zu zeigen, daf̧ irgendein praktisches Verfahren bezeichnet worden ist, sowie daf3 der Fortschritt daraus dargetan ist, früher als die Zeit, für die ich nachweisen kann, daf̧ diese Gesichtspunkte mir bekannt waren und meinen Freunden mitgeteilt sind. So ganz anders, als einen solchen Beweis gegen mich zu bringen, wurde die ganze Angelegenheit von Herrn Winsor und von seinen Freunden in mysteriöse Dunkelheit gehüllt, übertrieben und mit verführerischen Kalkulationen versehen. Das ganze würde noch in diesem Stadium sein, hätte ich nicht der Öffentlichkeit meine Entdeckungen und Versuche durch den etwähnten Vortrag unterbreitet." 
Aus einer der ersten phantastisch-tungebemmten Werbeschriften F. A. Winsors (1807) (Nach A. Fleck, Murdoch Memorial Lecture, London 1954, Institution of Gas Engineers s. II)

Eindeutige Fragen und Antworten, die jeden Widerstand gegen die wohltätige Einführung von Koks- und Gaslicht zurückweisen:

Frage: Nehmen Sie einen mit Gas angefüllten Raum an und Sie betreten ihn mit einer Kerze.

Antwort: Es wird sich niemals entzünden, weil es mit der Raumluft vermischt ist.

F. Aber ist es nicht der Atmung schädlich?

A. Nicht ein bif̧chen! Im Gegenteil, es ist unseren Lungen mehr angemessen als Sauerstoff, der eine zu starke Medizin ist, weil er nur zu einem Fünftel bis einem Viertel in der Atmosphäre enthalten ist; wohingegen entzündbare Luft zu mehr als zwei Dritteln in dem tierischen und vegetabilischen Reich, in allen Getränken und Lebensmitteln enthalten ist. Es ist ein Teil unseres Selbst.

F. Werden nicht Gasflammen mehr Sauerstoff oder den Lebensteil der Atmosphäre verzehren?

A. Wenn sie das tun, muß̧ es von der reineren Intensität der Flamme herrühren; selbstverständlich eine schnellere Umwälzung frischer Luft, die vom Stickstoff, verpesteter oder verbrannter Luft herkommen, weil sie so viel leichter sind als Sauerstoff oder Lebensluft! Im Verhältnis, wie verbrannte Luft aufwärts steigt, flief̧t die kalte, frische Luft, ringsherum von allen Seiten und ersetzt oder gleicht die Atmosphäre aus.

F. Ist es wohltätiger als der Kohlenrauch?

A. Unendlich so. Bei der ersten Einführung von Kohle in London 1273 glaubte man, dał der Rauch die Luft so sehr verunreinige, dał eine ernstliche Beratung abgehalten wurde und eine königliche Kundgebung von Eduard I. herauskam, die die Verwendung von Kohle gänzlich verbot. Rauch enthält schädliche Bestandteile in Lösung.

F. Warum ist dann der Verbrauch von Kohle fortgesetzt?

A. Brennholz wurde so teuer und knapp, daf die Verwendung von Kohle Brauch wurde, mehr durch die Nachsicht als durch Erlaubnis des Gesetzes. Dieses Gesetz ist jetzt hinfällig geworden mit manchen anderen, die die Regierung heute nicht mehr zu erzwingen wagt. 


\section{A NHANG 4}

Auszug aus Accums: Praktische Abbandlung über das Gaslicht nach der Ubersetzung von Lampadius. Weimar 1819 .

Accums Description. 1820 S. $239 \mathrm{ff}$.

\section{S. 139 Von den Hauptröbren und Nebenröbren}

Die Benennung Hauptröhren (mains) ist im strengen Sinne des Wortes, denjenigen zwei Zoll und darüber weiten, guß̧eisernen Gasröhren, welche unter der Erde das Gas in engere Röhren führen, gegeben worden; im ausgedehnteren Sinne heif̧en aber alle Röhren, welche mit kleineren Nebenröhren verbunden sind, Hauptröhren.

Alle Hauptröhren müssen vor dem Gebrauch sorgfältig geprüft werden, und zwar sollen sie 300 Fuf hoch Wasser halten, und zeigt sich hierbei der geringste Leck, so muf man sie zurücklegen. - Ein in dem Probieren der Röhren erfahrener Arbeiter wird mit einem bewundernswürdigen Grade von Sicherheit die Güte der Röhren nach ihrem Klange, durch einen Hammerschlag hervorgebracht, erkennen. (Es folgt die Beschreibung einer Flanschverbindung. Zwischen die Scheiben der zusammengeschraubten Röhren ist Eisenkitt eingestrichen. -

Dann kommt die Muffenverbindung.) - Diese Art der Zusammensetzung ist gewöhnlich bei den Hauptröhren. a heiß̧t das Zapfenstück (Muffe) und b der Zapfen. Die Höhlung zwischen beiden wird mit Kabel- oder Werggarn zum Teil ausgestopft. Die übrigbleibende Höhlung wird noch mit geschmolzenem Blei gefüllt und dieses durch Meiß̧cl und Hammer eingetrieben. -

- Alle Hauptröhren in öffentlichen Straf̧en müssen wenigstens 18 Zoll $(45 \mathrm{~cm})$ tief in der Erde liegen. -

- Der Zug aller Hauptröhren sollte geradlinig mit i Zoll Fall alle ro Fuf̧ ungefähr sein. -

- In allen breiten Straf̧en, in welchen an beiden Seiten Häuser Gaslicht bedürfen, ist es ratsamer, für jede Seite einen Zug Hauptröhren anzulegen, als beide Seiten aus einem Zuge weiterer Röhren zu versorgen. Da die Hauptröhren unter diesen Umständen enger zu sein brauchen und kürzere Nebenröhren erforderlich sind, so erspart man Kosten.

Alle, von einer Hauptröhrenleitung ausgehenden Nebenröhren müssen alle to Fuß̧ ungefähr I Zoll ansteigen, damit die sich etwa absetzende Flüssigkeit in die Hauptröhren zurückfließ̧en kann.

Alle kleinen, eisenblechernen Nebenröhren müssen, ehe man sie in die Erde verlegt, stark mit Steinkohlenteer überzogen werden; dieses geschieht, indem man die Röhrenstücke erhitzt und das siedende Teer mit einem Pinsel aufstreicht.

Auch jede einzelne Strecke der Nebenröhre muß man unter Wasser versuchen, ob sie völlig Luft hält. Die Schrauben, durch welche diese Röhren verbunden werden, tauche man in eine Mischung von Bleiweił und Leinöl vor dem $\mathrm{Zu}$ sammenschrauben ein.

618 
Trotz aller angewendeten Vorsicht kann es sich doch wohl ergeben, dafy ein kleines Leck an den gelegten Röhren entdeckt wird, weswegen man sie, ehe man das Gas einläf̧t, noch prüfen muf̧. Es kann am besten durch einen kleinen transportablen Gasbehälter, mit atmosphärischer Luft gefüllt, geschehen. Man setzt diesen durch ein Rohr mit der Röhrenleitung in Verbindung. Dieser Probegasbehälter kann so eingerichtet sein, dał er die Luft mit einem viermal stärkeren Drucke als der eigentliche Gasbehälter in die Röhren einpref̧t. Sind die Röhren luftdicht, so bleibt der Gassammler auf einerlei Höhe im Wasser, im Gegenteil sinkt er umso tiefer als die Rohre Luft auslassen.

Jede Viertelmeile (engl. $=400 \mathrm{~m}$ ) muß dieser Versuch unternommen werden.

- Um zu verhindern, dał sich keine Flüssigkeit in der Röhrenleitung anhäufen könne, muf̧ immer auf dem tiefsten Punkte, wo zwei oder mehrere Röhrenleitungen zusammentreffen, ein Verdichtungsgefäf, welches wir weiter oben unter dem Namen des Wasserreservoirs oder Hebers beschrieben haben, angebracht werden. (In der Kupferstichtafel II sind auch Wassertöpfe mit Absperrvorrichtung gezeigt.)

(Accum kommt dann auf den Einfluł der geodätischen Höhenunterschiede zu sprechen. Er empfiehlt richtig die Errichtung des Gaswerks an der tiefsten Stelle des Netzes, unverständlich bleibt aber ein Gedankengang, der zur folgenden Aussage führt):

- Befinden sich die Hauptröhren in einer höheren Lage, so dürfen sie weiter sein, liegen sie aber niedriger als das Niveau des Gasbehälters, so müssen sie enger genommen werden. -

(Die Länge der Rohre wird bei 2 und $2 \mathrm{r} / 2$ Zoll 1. W. mit $\mathrm{r}, 8 \mathrm{~m}$, darüber mit $2,7 \mathrm{~m}$ angegeben.)

S. ${ }_{153}$ Auszug aus: Anleitung für die Arbeiter, um Gasröbren im Innern der Häuser anzubringen

(In einer Einleitung wird beschrieben, in welcher Hinsicht die Aufgabe als zu leicht angesehen würde.)

Es scheint vielleicht unnötig zu erinnern, dał Gasröhren aus Substanzen, durch die Gasflamme schmelzbar, verfertigt, nicht in dem Inneren der Häuser angebracht werden sollten. - Daher sollten nie Röhren aus Zink, Blei (das Accum 1815 noch besprochen hat) oder Zinn in das Innere der Häuser gelegt werden. Kupferne und eiserne Röhren sind gewöhnlich im Gebrauch.

(Es folgen Angaben über die Rohrweiten, die aber nicht berechnet werden konnten.)

- Die Kupferröhren sollen gut eingefalzt und gelötet sein, auch müssen sie angeglüht werden, um sich leicht, ohne zu brechen, biegen zu lassen.

- Alle Nebenröhren müssen durch eine Handpumpe untersucht werden, ob sie luftdicht sind (unter Wasser). -

- Die verlöteten Fugen (Längsnähte) der Röhren müssen auß̧erhalb gekehrt werden. -

- Sind alle Röhren in einem Gebäude gelegt, so müssen sie mit äuß̧erster Sorgfalt geprüft werden, ob sie völlig luftdicht sind. Es geschieht am besten mit Hilfe einer Pumpe... Der schadhafte Fleck wird entdeckt, wenn die Röhre mit Stein- 
kohlengas gefüllt ist und man sie mit einer brennenden Lampe untersucht. (Bei Luftfüllung des Rohres wird die Flamme gestört!)

- Alle die verschiedenen Verbindungen zwischen Haupt- und Nebenröhren müssen durch Hilfe einzelner Röhrenstücke bewerkstelligt werden, damit man, wenn es nötig ist, diese leicht herausnehmen kann (gezeigt ist eine Verschraubung nach Art der Gasmesserverschraubung). -

- Zum Schluf folgen Angaben über den Gasverbrauch verschiedener Argandscher Lampen. Die Höhe des Glaszylinders darf nie geringer als s Zoll sein. -

\section{SLUB}




\section{A N H A NG ,}

Verbesserter Voranscblag über den Aufwand für den Bau eines Koblengaswerkes in Hannover.

2. Gasbehälter von 33 Fuf, ( $9900 \mathrm{~mm}$ ) Durchmesser und I6 Fuf3 \& $s$ d $(4800 \mathrm{~mm})$ tief, errichtet und vollständig mit Tasse von 67 Fuf 6 Zoll (20 $250 \mathrm{~mm}$ ) lang und 34 Fuf ( $10200 \mathrm{~mm}$ ) breit. Das Ganze mit Anstrich und zum Gebrauch fertig . . . . . . . 30 Retorten mit Mundstück und Einführungsrohren, acht Gruf̧feuer, Türgeschränke und Absperrung mit Hauptleitung vollständig . . . . . . . . . Kühler, Reiniger, Teer- und Ammoniakfässer . . . . . . ${ }_{25}$ Wassertöpfe, 17 Ventile für den Verbrauch in der Fabrik und in den Strafe $1600 \circ 0$ $1600 \mathrm{~m}$ s-zöllige Rohre zu II/3 pro Yard (0,914 m) 1600 m 4-zöllige Rohre zu 9/- pro Yard $1600 \mathrm{~m}$ 3-zöllige Rohre zu 6/7 pro Yard 4800 m 2-zöllige Rohre zu 5/- pro Yard Das Ganze verlegt und vollständig zu den obigen Preisen . . . 36310 Gebäude einschließ̧lich Ofenhaus, Direktorwohnhaus, Werkstatt usw.

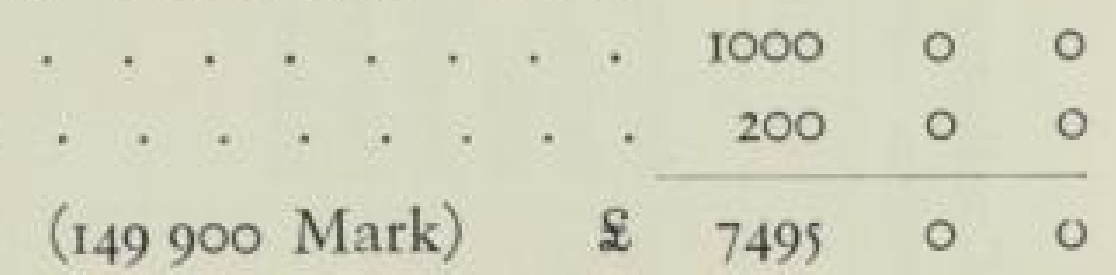

Hannover, 25. Februar 1825

gez. John Perks Ingenieur

\section{SLUB}


ลิ A NHANG 6

Städte und Vorstädte die ab 1825 von der Imperial Continental Gas Association (oder Tochtergesellschaften) versorgt wurden mit Daten des Baues, des Erwerbes oder der Beteiligung und des Geschäftsendes

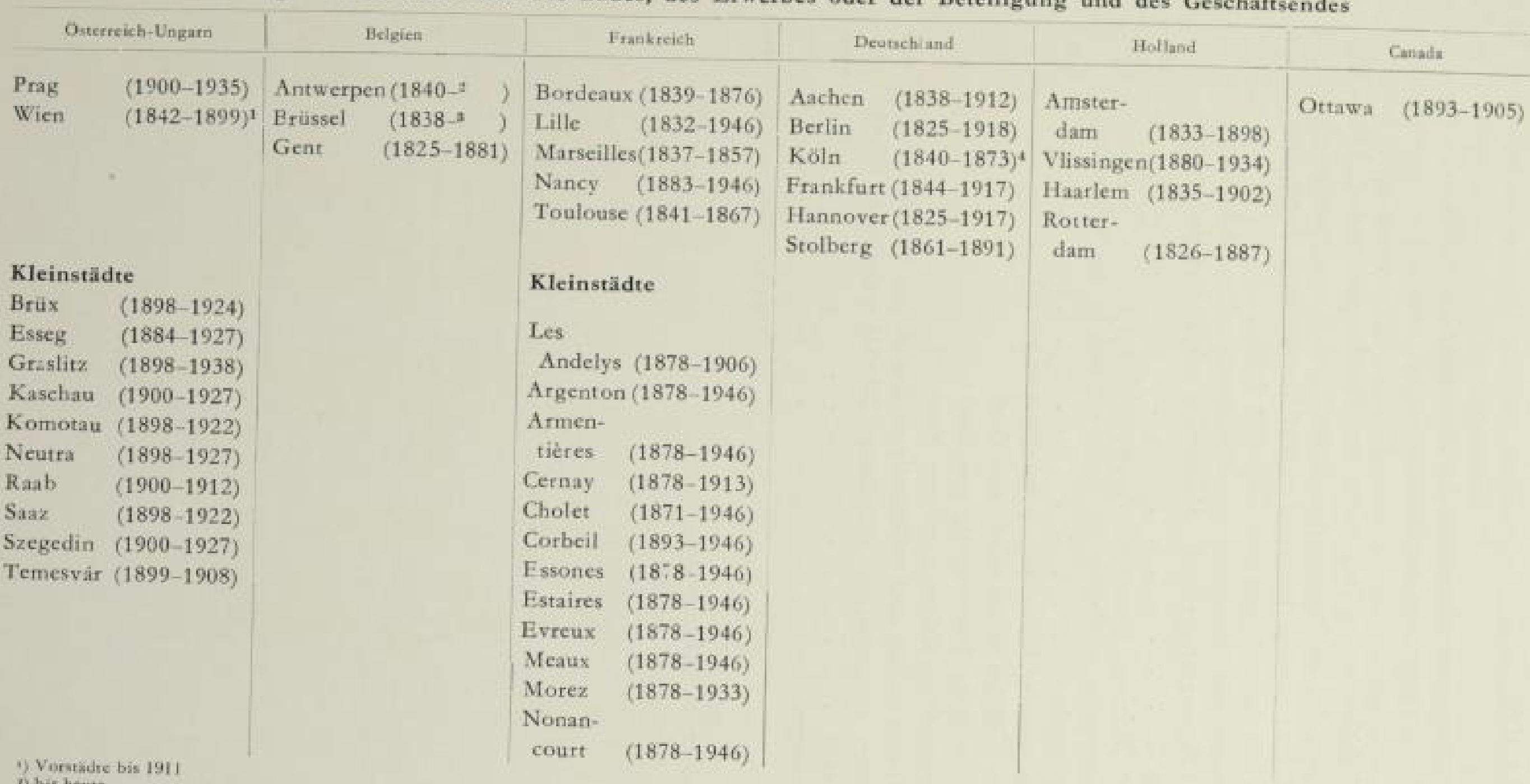

3) bis heute 1875 vorsadte bis beure
1. Fihrenfeld $1861-1899$

\begin{tabular}{|c|c|c|c|c|c|}
\hline Ostetreich-Ungata & Belgien & Frankreich & Deutscbland & Holland & Canada \\
\hline & & $\begin{array}{l}\text { Pont-à- } \\
\text { Mousson }(1887-1946) \\
\text { Quiévrain }(1878-1886) \\
\text { Romilly } \\
\text { S/S } \quad(1878-1946) \\
\text { Saintes }(1889-1946) \\
\text { St. Dié (1895-1946) } \\
\text { St. Jean d' } \\
\text { Angély (1889-1946) } \\
\text { St. Yrieux (1878-1880) } \\
\text { Thizy (1889-1946) } \\
\text { Uzés. (1889-1933) }\end{array}$ & & & \\
\hline
\end{tabular}

\section{SLUB}

Wir führen Wissen. 


\section{A NHANG 7}

Rudolf Sigismund Blocbmann

Quelle: Rudolf Sigismund Blochmann, der Begründer der deutschen Gastechnik, von Georg Friedrich Rudolf Blochmann. Schriftenreibe Arbeitsgemeinschaft für Technik, Geschichte des VDI, VDI-Verlag Berlin NW 7, 1939. Original in der Bibliothek der Technischen Hochschule Darmstadt.

Aus der Frübgescbichte der Gastechnik, vom gleichen Verfasser, München, Oldenbourg-Verlag 1942.

GMS. Blochmann. Journ. f. Gasbel. 36 (1893) S. 423

\section{E B E N S B I L D}

Rudolf Sigismund Blocbmann ist am 13. 12. 1784 als Sohn eines Pfarrers in Reichstädt bei Dippoldiswalde im Erzgebirge geboren. Die Familie Blochmanns stammte ursprünglich aus Böhmen, wohnte vorübergehend im Riesengebirge in der Gegend von Hirschberg und kam schließ̧lich nach der damals zum Kurfürstentum Sachsen gchörenden Oberlausitz.

Die Vorfahren Rudolf Blochmanns waren Kaufleute und Handelsherren, als solche waren deren zwei Bürgermeister in Lauban. Auch Verwandte der Nebenlinien sind in bürgerlichen Stellen gewesen.

Blochmann zeigte frühzeitig eine Vorliebe für Musik, vor allem aber zur Mechanik, d. h. wohl zum Basteln. Als er II Jahre alt war, holte der Vater einen Hauslehrer aber drei Jahre später, also 1798 starb der Vater plötzlich. Die Mutter, für die es eine Witwenversorgung nicht gab, zog in ihre Vaterstadt Dresden, wo sie durch Herstellung von künstlichen Blumen und Erteilung von französischem Sprachunterricht die Mittel zur Erziehung ihrer drei Söhne zu erringen suchte. Daß̧ dabei Entbehrungen und Überanstrengung den Körper geschwächt haben, ist verständlich. Im November 1813 , während der Belagerung der Festung Dresden, starb sie am Hungertyphus.

Die früh verwaisten Söhne sind indessen alle tüchtige Männer geworden. Der älteste Rudolf wurde zu einem tüchtigen Mechaniker in Dresden in die Lehre gegeben. Er hat aus eigenem Antrieb Naturwissenschaften studiert und war eifriger Besucher der Staatsbibliothek. Der Bibliothekar nahm sich des Jungen an und vermittelte ihm Kenntnisse in Mathematik, Phvsik und Chemie. Da kam im Jahre 1806 , also als Blochmann 22 Jahre alt und fertiger Mechaniker war, ein Angebot aus München, in das Mechanische Institut von Utzscbneider, Reichenbach und Fraunhofer in München als Mechaniker einzutreten. Das war die gröfte Entscheidung im Leben Rudolf Blochmanns.

In München hatte sich der der Kunst und Wissenschaft gegenüber aufgeschlossene Kurfürst Karl Theodor und sein Nachfolger auf dem Throne Max Joseph der Förderung des Gewerbefleiß̧es verschrieben. Dort wirkte als Kriegsminister der in England geborene Earl $R u m f o r d$, der in mehr als einer Hinsicht als Wissenschaftler Bedeutendes geleistet hat. Dort war also auch Georg Friedrich 
Reichenbach, geboren 1771 zu Durlach als hochwertig ausgebildeter Mechaniker in einem mit Liebherr 1804 gegründeten Mathematisch-Mechanischem Institut, in dem feine Mef̧instrumente gebaut wurden. Reıchenbach war aber äußzerst vielseitig. Seine grofze Tat auf menschlichem Gebiet ist es, daf3 er im Glasmacherlehrling Fraunhofer dessen erfolgversprechende wissenschaftliche Liebhabereien entdeckt hat und ihn in seine Werkstatt aufnahm.

In München war aber auch noch der Bergrat Baader, der ein begabter und erfindungsreicher Kopf war. Allerdings war er menschlich nicht einfach zu nehmen und viele seiner Gedanken sind deshalb als solche hängen geblieben, ohne ausgeführt zu werden. Da ist etwa seine Anregung vom Jahre 1815, eiserne Kunststraf̧en für Wagen mit Pferdebetrieb oder mit ortsfesten Dampftreidelmaschinen zu bauen. Baader reiste häufig nach England, um dort die technische Entwicklung zu beobachten. Als Reichenbach 20 Jahre alt war, durfte er auf Anregung von Lord Rumford auf Staatskosten Baader nach England begleiten. Beide sahen die berühmte Dampfmaschinenfabrik Boulton u. Watt.

Der Werkstatt Reichenbachs war eine zweite in Benediktbeuren als Optisches Institut für Fraunhofer angeschlossen worden. In diese kam Blochmann, der 1809 den mechanischen 'Teil als Ergänzung für Fraunhofer, der den optischen Teil leitete, ausführen sollte. Durch die wiederholten Besuche in England wurden Baader und Reichenbach auf die Leuchtgastechnik aufmerksam. 18r5 hatte Baader das Gaswerk der Gas Light and Coke Company in Peterstreet besichtigt. Baader entwarf Pläne zur Beleuchtung der königlichen Residenz. Eine kleine Versuchsanlage wurde in München im Jahre 1817 errichtet, aber nicht lange betrieben. Seine größten Pläne aber und auch ein weiterer Plan, den Reichenbach im Jahre 1818 zur Beleuchtung der Gänge und der Umgebung der königlichen Residenz ausarbeitete, wurden trotz einer günstigen Beurteilung von Mitgliedern der Akademie, nicht ausgeführt. In diese Arbeiten war auch Blochmann eingeführt worden. Blochmann entwarf eine Beleuchtungsanlage für das königliche Theater, die aber (Festschrift der Technischen Hochschule München aus dem Jahre 1906) infolge Blochmanns Weggangs von München nach Dresden nicht gebaut worden ist. Die Festschrift sagt, sicher wäre Blochmann imstande gewesen, diese Aufgabe zu lösen.

Er folgte aber gerne einem Ende $18 \mathrm{I} 8$ an ihn ergangenen ehrenvollen Ruf, in Dresden eine feste Stellung als Inspektor des königlichen Math.-Physik. Salons und der Kunstkammer, einer Sammlung astronomischer und mechanischer Geräte, anzunehmen. Blochmann errichtete seinerseits 1819 nach dem Vorbild von Bene. diktbeuren in Dresden in der Waisenhausstraf̧e ein mechanisches Atelier für optische und mechanische Mef̧instrumente. Diese Werkstatt beleuchtete er mit einer kleinen Gasanstalt. Er brachte auch am Hauseingang eine Gaslaterne an, was die Aufmerksamkeit der Dresdener Bürgerschaft erweckte.

Blochmann setzte nunmehr seine Vielseitigkeit lebhaft ein. Er beteiligte sich an der Errichtung einer von einem Dr. Struve geschaffenen Werkstatt zur Herstellung künstlicher Mineralwässer. 1823 erfand er eine Kugelprägemaschine zum Pressen von Gewehrkugeln. Als Mechaniker entwickelte er für die königliche Münze eine Maschine zum Justieren der Münzen am Münzrand. 1828-1830 beschäftigte er sich mit der Konstruktion von Strumpfwirk-Babinett-Webstühlen. Für die Dresden-Leipziger Eisenbahn (1836-1838) stellte er eine Vorrichtung 
zur gleichmäßjigen Herstellung der Einschnitte an die Schwellen her. Neben dieser Arbeit lief eine ganz andere Beschäftigung Blochmanns einher und das war sein Einsatz für die Errichtung einer technischen Bildungsanstalt, die am I. 5. 1828, also vier Tage nach der Inbetriebnahme der Leuchtgasanlage eröffnet worden ist. Blochmann, der in München bei Reichenbach und Fraunhofer wie an keiner anderen Stelle hatte sehen können, dał zur Bewältigung neuer technischer Aufgaben neben gut ausgebildeten Facharbeitern auch Ingenieure notwendig waren, hatte eine Denkschrift über die Ausrichtung einer solchen teclnischen Bildungsanstalt aufgesetzt. Vorbild war das $\mathrm{I} 8 \mathrm{Is}$ in Wien begründete Polytechnikum. Blochmann lehnte sich aber nicht völlig an Prechtl an, sondern folgte durchaus eigenen Gedanken. Man war auch bescheiden in den ersten Zielen und zunächst sollte das Polytechnische Institut nach dem Willen Blochmanns für 30 Schüler eingerichtet werden. Er unterschied drei Klassen; eine für das Theoretische und Theoretisch-praktische neben math. phys. Wissenschaften und neuen Sprachen in Verbindung mit der Ausübung und Vervollkommung in den reinen mechanischen Künsten (10 Schüler); 2. für eine Anzahl junger Leute für die reinen mechanischen Künste als Ausbilòung und praktische Vollkommenheit (Io Schüler); 3. um eine Anzahl schon ausübender Künstler und Handwerker zur höheren praktischen Vollkommenheit zu bilden. Daneben sollte das Institut nach außzen für die bestehende Bildung der mechanischen Künste gemeinnützig und fortschreitend durch Lehre und Beispiel wirken. Die Schüler der ersten beiden Abteilungen soliten mit $\mathrm{I}_{4}-\mathrm{Is}$ Jahren eintreten. Außjer der Fertigkeit im richtigen Lesen und gemeinen Spezies im Rechnen und einer guten korrekten Handschrift, wurden weitcre Kenntnisse nicht für unumgänglich nötig gehalten. Der Unterricht fand in dem „Pavillon“ auf der „Terrasse“ statt. Für den Werksunterricht stellte Blochmann seine mechanische Werkstatt zur Verfügung.

Seine Lebensarbeit entwickelte sich aber aus der kleinen Gaserzeugungsanlage seiner Werkstatt.

Der König von Sachsen hatte schon mehrere Jahre die Gasbeleuchtung Dresdner Strafjen ins Auge gefasst... Das mit der Bearbeitung beschäftigte Polizei-Kollegium holte Gutachten vom Ausland (Wien, Paris, Loodon) ein und forderte dann mehrere Projekte von verschiedenen Mechanikern, einem Chemiker und einem Orgelbauer an. Als 1824 die Imperial Continental Gas Association sich erbot, eine Gasbeleuchtung in Dresden zu errichten, griff man die alten eigenen Pläne wieder auf und veranlaf̧te Blochmann zu einem Entwurf für ein Gaswerk bis zu einer täglichen Leistung von to 000 Kubikfuł sächsisch, rund 230 Kubikmeter, von dem so Strafenlaternen versorgt werden sollten.

Blochmann fühlte sich aufgrund seiner eigenen bereits gelungenen Versuche wohl imstande ,diesen Zweig der Industrie auf heimatlichem Boden selbständig entwickeln zu helfen und erklärte seinen festen Willen, das ihm bisher in seinem Vaterland geschenkte Vertrauen gerade durch die Einführung der Gasbeleuchtung in seiner Mutterstadt Dresden dadurch zu rechtfertigen, dafy er den ihm bereits erteilten Auftrag ohne jegliche ausländische Hilfe auszuführen beabsiclitigte". Blochmann erhielt den Auftrag. Unter Zusicherung staatlicher Unterstützung ging er an die Arbeit, die Versuche im kleinen fortzusetzen und den Versuch im großen vorzubereiten. Die technischen Schwierigkeiten waren natürlich grof\}, da alles neu entwickelt werden mufte und die deutschen Werkleute und Werk- 
stätten erst für die neuartigen Arbeiten herangebildet werden muften. Besondere Schwierigkeiten bereiteten die Rohrleitungen mit denen Blochmann aber bei den Soleleitungen in Oberbayern Erfahrungen gesammelt hatte. Die Herstellung der ersten gufzeisernen Rohre wurde dem Graf Einsiedelschen Eisenwerk Lauchhammer übertragen. Blochmann zog das Fachschrifttum heran und das war ja damals die Arbeit von Accum, übersetzt durch Prof. Lampadius, das Buch Prechtls, sowie die Arbeit von T $a b o r$, die sehr ausführlich und kritisch gewissenhaft die verschiedenen Apparatcformen, wie sie in Versuchen entworfen und in der Praxis entwickelt worden waren, beschrieben. Der Bauplatz für das Gaswerk wurde mitten in der Stadt nahe dem Zwinger und dem Theater angeboten. Er reichte für die erste Anlage aus, aber nach to Jahren war er schon zu klein und Staub und Dünste wurden in der Stadt nicht gerade angenehm empfunden.

Zunächst aber wurde gebaut. Am 27. 4. 1828 bildeten die Gasflammen in den 36 zunächst aufgestellten Kandelabern den für das Publikum anziehendsten Teil einer Festbeleuchtung.

Im Gegensatz zu der englischen Gesellschaft, die sich der üblichen Holzmaste mit an diesen hochgeführten schmiedeeisernen Rohren bedient batte, nahm Blochmann nach damaliger Ansicht formschöne, d. h. mit Empireverzierungen versehene gufzeiserne Kandelaber, in deren innerem Hohlraum das Gas hochgeführt wurde. Das Gaswerk bewährte sich. Schon am 5. 4. 1828 bestätigt das Polizei-Kollegium, dał der Versuch mit der Gasbeleuchtung als gelungen anzusehen sei. Dabei hatte der erste Betriebswinter auf̧ergewöhnliche Kälte mit all ihren Schwierigkeiten für ein Gaswerk gebracht. Blochmann begegnete den Einfrierungen und Naphthalinverstopfungen mit Spiritus, ja er wandte mit der vollen Winterkälte die Tiefkühlung auf dem Werk an. Später hat Blochmann (1839) einen Waschapparat im Gaswerk erbaut, in dem er das Gas mit Spiritus und später mit leichtem Teeröl wusch. Blochmann griff auch die Staubentwicklung bei der Ladung der Retorten, die bei der Lage des Gaswerks besonders lästig war, durch Einführung von Bandeisenkörben an. Der Verschleiß̧ der Körbe war indessen so groł, dał diese Hilfseinrichtung nur in diesem Werke beibehalten wurde.

Infolge der politischen Entwicklung ging das staatliche Gaswerk 1833 in die Hände der Stadt über. Blochmann erhielt von der Stadtgemeinde 1830 für die technische Oberleitung jährlich Soo Taler. I 39 erbaute Blochmann ein neues Gaswerk für 5000 Flammen. 1840 wurden dann zum ersten Mal im Theater Zuschauerraum und Bühnenhaus mit 764 Flammen erleuchtet. Der Erfolg war so gut, dał nach seinen Plänen später auch Theater in Berlin, München, Darmstadt, Weimar, Koburg, Würzburg und Stettin eingerichtet wurden. Er hat dann viele kleine Verbesserungen ausgeführt. Genannt wird ein Sparhahn für Stıaf̧enleuchten nach II Uhr nachts, Laternen mit gufzeisernen Hauben ohne Seitenfassungen und „besonders schöne Aufsätze für Festbeleuchtungen “.

Wichtiger war sein Bemühen, die unangenehm riechende verbrauchte Kalkmilch mit Abhitze einzudämpfen und als Düngekalk zu verbrauchen. Blochmann hat seine Erfindungen nicht laut bekannt gemacht. Er lieł sie den von ihm beratenen Stellen allein zugute kommen, aber gab jedem, der es sehen wollte, geıne Auskunft. So kam 1834 der Antrag aus Leipzig, auch dort ein Gaswerk zu erbauen. Die Pläne waren im September 1835 fertig und er konnte einem Antrag, Portativ- 
gas zu wählen, entgegentreten. Am 30. 12. 1840 kam das Gaswerk in Betrieb. Der Preis des Gases war allerdings doppelt so hoch wie in Dresden, weil die Zwickauer Kohle auf Wagen herangeführt werden muf̧te, während in Dresden ein in der Nähe befindliches Kohlenvorkommen ausgebeutet wurde. Dafür war allerdings der Kokspreis in Leipzig sehr hoch. Der Verwertung des Ammoniakwassers wandte man sich in Leipzig zu. Blochmann wurde nun der anerkannte Fachmann und hat viele Städte und Unternehmer bei der Errichtung von Gaswerken beraten, I837 Magdeburg, I838 Braunschweig, I840 Frankfurt/M., Kassel und Breslau, I84i Gotha, 1844 Prag, 1845 Plauen, Kolberg, Weimar, Frankfurt/M., 1847 Darmstadt. In Aue 1834 und in Zwickau 1835 erbaute er die Gaswerke.

Seit 1836 war man in Berlin mit der englischen Gasgesellschaft nicht zufrieden und bereitete sich vor, den bis 1846 laufenden Vertrag nicht zu erneuern, sondern zwei eigene Gaswerke zu erbauen. Wieder wurde Blochmann herangezogen und nach langen Verhandlungen mit der englischen Gesellschaft begann man ${ }^{18} 41$ die Planung, die man Blochmann übertrug. Blochmann sah je ein Werk nördlich und südlich der Spree vor. Wieder muften bei den Ausführungsarbeiten Werkmeister und 'Techniker gesucht und ausgebildet werden, denn aus den Anstalten in Dresden und Leipzig konnte man keine Kräfte heranziehen. Deshalb richtete Blochmann für die tagsüber beschättigten Meister, Gesellen und Arbeiter in den Abendstunden Unterrichtskurse ein. Die vor allem an der Städt. Gasanstalt interessierten Fabriken, die Königliche Gief̧erei und die Gief̧erei E gells und Freund, die die Apparate lieferten, sowie der Gasbehälterbau bei Egells, Freund und $W$ öblert und in Lauchhammer wurde von Blochmann eingerichtet. Jedesmal wurden Probeausführungen angefertigt und geprüft, ehe die weiteren Aufträge erfolgten. Damit hat Blochmann die Berliner Fabriken dem Gasfach zugeführt, was in späterer Zeit zu weitgehenden Folgerungen führte, beispielsweise der Gründung der Deutschen Continental-Gas-Gesellschaft. Als am 31. 12. 1846 zum ersten Mal die Gaslampen des Städt. Werks in Berlin brannten, hörte ja die Arbeit in den Fabriken im grofen und ganzen auf und cs war selbstverständlich, dał̧ sie nunmehr Lieferungen für andere Städte zu übernehmen trachteten und dann auch wirklich übernahmen. Noch während der Berliner Arbeiten schuf Blochmann die Pläne für Breslau und Prag. Er hat viele technische Beratungen durchgeführt. Erhalten ist sein Projekt für das Gaswerk Bremen. Auch v. Unruh nahm seine Hilfe beim Bau des Magdeburger Gaswerks in Anspruch. Seine Mitarbeiter bei all diesen Arbeiten gingen zu verschiedenen Gaswerken als Leiter. Am bekanntesten ist wohl sein Schüler Wilhelm Kornbardt geworden, der als 30-jähriger von Blochmann beauftragt war, die Gasanstalt in Stettin zu errichten. Kornhardt wurde ein sehr rühriger Gasfachmann. Er hat allein 40 Gaswerke neben seiner Tätigkcit als Werksleiter gebaut. 1866 hat er mit Didier zusammen ein Patent auf einen Ofen erhalten. 1867 übernahm er dessen Schamottefabrik. Die Chronik nannte auch noch andere Namen, die nicht alle angegeben werden können. (Blume in Potsdam, Vierle in Breslau, Hartmann in Königsberg und Schwarzer in Görlitz. Die Fabrikanten R. W. Elsner, Berlin und S. Elster, Berlin). In Berlin war als Mitarbeiter Blochmanns vor allem sein Sohn, G. M. S. Blocbm an n, tätig.

Nachdem der Bau der Städt. Gasanstalten beendet war, kehrte I85i der Sohn Blochmanns nach Dresden zurück. Dort hatte der Vater eine Maschinenbau- 
anstalt errichtet, in der er Gasmesser herstellen lief, auf die 1950 ein Patent erteilt worden war. Später wurde die Firma als G. M. S. Blochmanns Maschinenfabrik und Eisengief̧erei weitergeführt. Sie beschäftigte sich mit der Ausführung vollständiger Gasbeleuchtungsanlagen für Private, namentlich für Theater und auch für Gemeinden mit Lieferung der Einzelteile. Auf̧erdem wurden aber noch Geräte zur Erzeugung künstlicher Mineralwässer und ganze W/armwasserheizungsanlagen erzeugt. Viele kleine Teile der Eisengief̧erei, vor allem Guf von Straf̧enlaternen, ergänzte das Programm.

Die politische Umwälzung im Jahre i $\$_{49}$ veranlałte die neugewählte Stadtverordnetenversammlung Blochmann die Jahresvergütung für die Mitarbeit beim Bau der Dresdner Gaswerke von 800 Taler zu kündigen, ihm wurde nahegelegt, selbst ein Abschiedsgesuch einzureichen. Blochmann tat dies wunschgemäf und widmete sich vor allen Dingen dem Bau einer Wasserversorgung, deren Rohrleitungen aus gebohrten Sandsteinrohren bestanden. Erst 20 Jahre später hat die Stadt Dresden dem 84 -jährigen Blochmann einen Ehrensold bis an sein Lebensende bewilligt.

Den Tag der Goldenen Hochzeit konnte er am 13. 6. 1860, nachdem er ein Jahr vorher auch die Oberleitung der Leipziger Gaswerke niedergelegt hatte, in voller geistiger und körperlicher Rüstigkeit im großen Kreise festlich begehen. Ein Jahr darauf wurde ihm seine Lebensgcfährtin genommen. Blochmann aber erfreute sich der Pflege seiner Verwandten und blieb auch in Berührung mit der Arbeit in der Fabrik, den alten Wirkungsstätten im Königlichen Theater, so daf̧ er einen ruhigen Lebensabend verbrachte. Am I8. 5. I87I verschied er ohne langes Krankenlager sanft in seinem Hause, nachdem er noch die Heimkehr seiner Enkel aus dem Felde erleben konnte.

Der Enkel als Geschichtsschreiber ist des Rühmens seines Grołvaters voll, und das hat auch seine Berechtigung. Was Samuel Clegg für das englische Gasfach war, ist Blochmann für das deutsche gewesen. Weit über die Arbeit seiner Vorgänger hinaus hat er unter Beachtung der damals bekannten wissenschaftlichen und physikalischen Grundlagen die technischen Anlagen der Gaswerke ausgebaut. In seiner „Relation“ an den Rat der Stadt Leipzig, vom 20. 8. 1835, führt er die Fortschritte, die er seit dem Bau des Dresdner Werkes gemacht hat, im einzelnen an. Da ist vor allem ein besonderes Verfahren, die Dichtigkeit der Gasröhren zu untersuchen, mehrere Röhren (die ja im einzelnen sehr kurz waren) vor dem Legen zusammenzudichtea und dann wieder zu untersuchen, womit er nachweislich $5 \%$ Gasverlust gegenüber der englischen Verlegungsweise, etwa in Berlin, erspart hat. Er verwies auf einen besonderen Gashahn mit Kleinstellung für die Nachtzeit, ferner auf seine Methode, eingefrorene Gasrohre wieder aufzutauen und die Einfriergefahr durch Kühlung überhaupt zu beseitigen. Besonders stolz ist er auch auf die Laternen mit widerstandsfähigem Gufjeisendach und ohne störende Seitenfassung. Etwas geheimnisvoll ungeklärt blieb die Einrichtung, wodurch bei einem größjeren Bedarf, als die projektierte Rohrleitung gewährt, noch 4 Mill. Kubikfuf̧ Gas für Leipzig abgegeben werden könnten. Vielleicht hat es sich um einen Verdichter gehandelt.

Wenn aber der Enkel, Blochmann mit Werner von Siemens als technischen Pionier in eine Reihe stelit, so ist das sicherlich etwas gewagt. Siemens hat wiederholt aufgrund physikalischer theoretischer Erwägungen ganze Industriezweige 
neu geschaffen. In der Schwachstromtechnik ist durch ihn die Telegrafie erst auf langen Strecken benutzbar geworden und das dynamo-elektrische Prinzip ist das Fundament der Starkstromtechnik gewesen. Ihm gegenüber hat Blochmann Vorbilder gehabt. Es gab auch schon gute Fachbücher über das Gaswesen, in denen nicht nur die theoretischen Grundlagen veröffentlicht, sondern auch Anweisungen über den Bau mit vielen zeichnerischen Darstellungen enthalten waren. Der Geschichtsschreiber selbst sagt, dał im Nachlaf, Blochmanns eine umfangreiche Bücherei über diese Dinge gefunden wäre. Bei dieser Abwägung gegenüber der Persönlichkeit Siemens soll die Leis'ung Blochmanns in keiner Weise herabgesetzt werden. Die ingenieurmäfjige konstruktive Vervollkommnung eines technischen Gerätes ist immer eine grołe Leistung eines schöpferisch veranlagten Ingenieurs. Aber gerade bei der immer in manchen Gemütern herrschenden Eifersucht zwischen Elektrizität und Gas ist es vielleicht gut, daf̧ auch von Gasseite aus der grundsätzliche Unterschied beider Männer betont wird.

Offenbar stark unter dem Eindruck der Ideologien im Jahre 1939-1942 hebt der Verfasser als besondere Grof̧tat den Einsatz für die kommunale Gasversorgung hervor. Dabei wird das Vorgehen der Engländer mit dem Schlagwort der Plutokraten offenbar sehr einseitig betrachtet.

Bei der Kapitalnot, die in Deutschland nach den Befreiungskriegen herrschte, war es für den Aufbau der Wirtschaft dringend notwendig, wo immer die Möglichkeit war, auch fremdes Kapital ins Land zu holen. Dafy das in dem damaligen Deutschland nicht leicht war, ist bereits auf Seite ros geschildert. So war die Hereinnahme des Kapitals für die Gaswerke, die eine sichere Rente zum mindesten nach einigen Jahren erwarten liefyen, damals nicht verwerflich, zumal wenn, wie in Hannover, die Berücksichtigung von einheimischen Lieferanten und die Benutzung hannoverscher Kohle zur Bedingung gemacht wurde, soweit nicht die Engländer unter Einbezug der Zölle billiger liefern konnten.

Die Schwierigkeiten, die mit den englischen Gasanstalten in Hannover und Berlin aufgetreten sind, liegen einmal ganz offensichtlich im Charakter der örtlichen Vertreter der Gesellschaft, dann aber auch, daßz die Geselischaft nicht nur mit der Stadt, sondern auch mit der Staaisverwaltung gleichzeitig zu rechnen hatte. In Berlin war man sehr böse, dał̧ der Staat mit Hilfe der Polizei, über die Köpfe der Stadt hinweg, vier Jahre vor der bürgerlichen Revolution die Konzession erteilt hatte. Es war so verständlich, dał man zur Kritik neigte, wo immer sie irgendwie berechtigt erschien und die Möglichkeit, grofzzügiger mit einer eigenen Gasanstalt zu arbeiten, 1846 aufgriff. In Dresden waren ja die Verhältnisse ganz ähnlich gewesen. Dort hatte, wie berichtet, der König d. h. der Staat das Gaswerk errichtet, was von der Kapitalbeschaffungsseite her für Blochmann ein groß̧es Glück gewesen ist. I833 übernahm die Stadt das Werk kos:enlos infolge der politischen Umstellung. Im gleichen Jahre setzte die englische Gesellschaft in Hannover den ersten deutschen Administrator ein und von da ab sind die Auscinandersetzungen zwischen englischer Gesellschaft und Stadt verstummt.

In den gleichen Gedankengängen betont auch der Verfasser, wie bescheiden die Ansprüche Blochmanns als Direktor des Gaswerks gewesen seien. Zunächst scheint dabei ein Irrtum in der Auffassung von der Amtsverpflichtung eines damaligen Direktors vorzuliegen. Man darf nicht vergessen, dafy in den 40 selbständigen Staaten ein einheitliches Verwaltungs- und Aktienrecht nicht bestan- 
den hat. Ganz offensichtlich spielt aber auch das Vorbild des englischen Aktienrechts dabei eine Rolle. Ein englischer Direktor gleicht zum Teil in seinen Rechten und Pflichten dem deutschen Aufsichtsrats-Mitglied und nicht dem deutschen Direktor. So konnte Blochmann gleichzeitig Direktor in Dresden und in Leipzig sein, und auch in Berlin so stark als Mitarbeiter auftreten, daf̧ er in der Denkschrift der Stadtwerke Bremen zum Ioo-jährigen Bestehen der Gaswerke auch für Berlin als Direktor bezeichnet wird. Sicherlich war Blochmann aber mehr ein beratender Ingenieur und es sind die Arbeiten, die sein Büro und seine Werkstatt - vermutlich nicht im einzelnen berechnet - für die Gaswerke leistete, sicherlich eingeschlossen. Immerhin ist vergleichsweise festzustellen, daf der erste Administrator in Hannover, dessen Tätigkeit man heute als Betriebsdirektor bezeichnen würde und der vollamtlich und ausschließ̧lich von morgens früh bis spät in die Nacht dienstlich gebunden war, 600 Taler jährlich Gehalt hatte, während Blochmann für seine Beratungstätigkeit in Dresden und gieichzeitig in Leipzig je 800 Taler bezog. Aus seiner Stellung als beratender Ingenieur erklärt sich auch zwanglos der Rücktritt i85o, der ohne weiteres möglich war und der einem Mann von der Vielseitigkeit Blochmanns nichts anhaben konnte, da er sofort andere nutzbringende Aufgaben angreifen konnte.

So sehen wir in Blochmann einen hervorragenden Ingenieur und Unternehmer, dessen Tätigkeit die Entwicklung des deutschen Gasfachs ungemein gefördert hat. Wir können ihm dankbar sein, auch wenn die in der Sprache des Nationalsozialismus hervorgebobenen Dinge nicht ganz zutreffend sind. 
ANNHANG 8 Eine Zusammenstellung der bestehenden Gaswerke in Deutschland nach W. Oechelhäuser, J. f. G. 2 (1859) S. 187/208

\begin{tabular}{|c|c|c|c|c|c|c|c|}
\hline Ont & Baujabr & Erthauer & Besitzet & Abgabe m4/fabr & Rohstoff & $\begin{array}{l}\text { Vertraes- } \\
\text { dauet Jahre }\end{array}$ & Anineskung \\
\hline $\begin{array}{l}\text { Altenburg } \\
\text { Altona } \\
\text { Anklam } \\
\text { Annaberg } \\
\text { Ansbach } \\
\text { Aschaffenburg } \\
\text { Augsburg } \\
\text { Aussig (Böhmen) } \\
\text { Baden-Baden } \\
\text { Bamberg } \\
\text { Barmen } \\
\text { Bayreuth } \\
\text { Bergedorf } \\
\text { b. Hamburg } \\
\text { Berlin } \\
\text { Berlin } \\
\text { Bicbrich } \\
\text { Bielefeld } \\
\text { Bingen } \\
\text { Bochum } \\
\text { Bonn } \\
\text { Braunschweig }\end{array}$ & $\begin{array}{l}1854^{*} \\
1856 \\
1846^{*} \\
1826^{\circ} \\
1856 \\
1857\end{array}$ & $\begin{array}{l}\text { P. Märier Wien } \\
\text { Riedinger }\end{array}$ & $\begin{array}{l}\text { Gasbeleuchtungs AG. Altenburg } \\
\text { Gas- und Wasserges. Altona } \\
\text { Justizrath a. D. Wallroth } \\
\text { Privatpersonen } \\
\text { E. Spreng, Nürnberg } \\
\text { Stadt: Pächter C.Knoblauch-Dietz,Fft/M } \\
\text { Gasbeleuchtungs AG. Augsburg } \\
\text { Osterr. Verein für chem. } \\
\text { u. metall. Produltion } \\
\text { J. B. Pollailon, Lyon } \\
\text { Aktiengesellschaft m. Bet, der Stadt } \\
\text { Barmer Gaserleucht Ges. Bet. Stadt } \\
\text { Aktiengesellschaft } \\
\text { Privatgesellschaft } \\
\text { Stadt } \\
\text { Imperial Cont. Gas Ass. } \\
\text { Chem, Fabrik v. D. Schmidt } \\
\text { Stadt } \\
\text { H. A. Klein, Bingen } \\
\text { Gemischtwirtschaftlich } \\
\text { A. Uster } \\
\text { Braunschweigische } \\
\text { Gasleleuchtungs Ges. }\end{array}$ & $\begin{array}{l}9,2 \text { Mio } \\
6,7 \text { Mio } \\
85000 \\
87000\end{array}$ & $\begin{array}{l}\text { St. K. } \\
\text { St, K. } \\
\text { St. K. } \\
\text { St. K. } \\
\text { St. K. } \\
\text { St, K. } \\
\text { St. K. } \\
\text { Mischgas }\end{array}$ & $\begin{array}{l}25 \\
40 \\
20 \\
30\end{array}$ & $\begin{array}{c}\text { aus Harz, Teer, Stein- } \\
\text { kohle-Leprince }\end{array}$ \\
\hline
\end{tabular}

\begin{tabular}{|c|c|c|c|c|c|c|c|}
\hline Bremen & $1854^{*}$ & & Stadt & 940000 & Mischgas & 25 & \\
\hline Breslau & 1845 & Blochmann* & Gasbel, AG, Breslau & 1, 8 Mio & & 25 & \\
\hline $\begin{array}{l}\text { Bricg } \\
\text { Bruchsal }\end{array}$ & & & Stadt & 97000 & St. K. & & \\
\hline Brünn & & & $\begin{array}{l}\text { Bad. Gasgesellschatt } \\
\text { Privatgesellschaft }\end{array}$ & 1 Mio & & & \\
\hline Bunzlau (Schles.) & & & Schles. Gasgesellschaft & & men & & \\
\hline Calbe & & & Allgem. Gas AG. Magdeb. & 40000 & St. K. & & \\
\hline $\begin{array}{l}\text { Cannstadt } \\
\text { Celle }\end{array}$ & $\begin{array}{l}1852 \\
1857\end{array}$ & Hack u. Bruns & K. Keil später J. G. Heinecken & & St. K. & 30 & \\
\hline Chemnitz & & & C. Pfalf u. R. Hösel & & St. K. & & \\
\hline $\begin{array}{l}\text { Crimmitschau } \\
\text { Danzig }\end{array}$ & 1856 & & $\begin{array}{l}\text { Aktien-Verein f. Gasbeleucht. } \\
\text { i. d. Stadt Cr. } \\
\text { Stadt }\end{array}$ & 800000 & St. $K$. & 40 & \\
\hline Darmstadt & 1854 & Riedinger & Darmstädter AG f. Gasbeleuchtung & 223000 & Holz & -1880 & \\
\hline Dessau & 1856 & D. C. G. G. & Deutsche Cont,-Gas-Ges. Dessau & 137000 & St $\mathbf{K}$, & $25+15$ & \\
\hline $\begin{array}{l}\text { Deutz } \\
\text { Dobeln }\end{array}$ & & & C. Schaurte & & St. K. & 45 & \\
\hline $\begin{array}{l}\text { Dobeln } \\
\text { Dortmund }\end{array}$ & 1857 & & $\begin{array}{l}\text { W. Smyers-Wiliguct } \\
\text { Aktiengesellschaft }\end{array}$ & & $\begin{array}{l}\text { St. } K \text {. } \\
\text { St. } K \text {. }\end{array}$ & 30 & \\
\hline Deresden & & & Stadt & & St. $K$. & & \\
\hline $\begin{array}{l}\text { Duren } \\
\text { Dusseldorf }\end{array}$ & 1858 & & Dürener AG. für Gasbel. & & St. K. & & \\
\hline Duisburg & & & Gesellschaft von Personen in Duisburg & & $\begin{array}{l}\text { Mischgas } \\
\text { St. K. }\end{array}$ & $\begin{array}{l}-1867 \\
25\end{array}$ & aus Harz A. St, K. \\
\hline $\begin{array}{l}\text { Elberfeld } \\
\text { Elbing }\end{array}$ & $\begin{array}{l}1839^{*} \\
1859\end{array}$ & im Bau & $\begin{array}{l}\text { H. G. v. d. Heydt \& Co, sei IBs: } \\
\text { durch die Stade }\end{array}$ & & & & \\
\hline Elmshorn & & & Elmsborner Gas $\mathrm{AG}$. & 46000 & St. K. & & \\
\hline $\begin{array}{l}\text { Erfurt } \\
\text { Erlangen }\end{array}$ & $\begin{array}{l}1857 \\
1858\end{array}$ & $\begin{array}{l}\text { D. C. G. G. } \\
\text { Riedinger }\end{array}$ & Deutsche Cont.-Gas.-Ges, Dessau & 210000 & St, $\mathrm{K}$. & 45 & \\
\hline & $\begin{array}{l}1858 \\
1856\end{array}$ & & $\begin{array}{l}\text { Ahtiengeselischaft, Stadt beteiligt } \\
\text { Essener Gas AG. }\end{array}$ & & $\begin{array}{l}\text { Holx } \\
\text { St. K. }\end{array}$ & $30+20$ & 59 nur zur Beleuch. \\
\hline Esslingen: & $1 \mathrm{as7} / 5 \mathrm{~s}$ & Aktiengeselisch & mit gemeindlicher Beteiligung & & St, $K$. & $30+20$ & tung von Fabriken \\
\hline Eupen & 1853 & & J.F. Richter & & St, $K$. & $20+35$ & \\
\hline Eutin & 1857 & & Terheyden \& Co, 4, L. Zietz & & & & \\
\hline
\end{tabular}




\begin{tabular}{|c|c|c|c|c|c|c|c|}
\hline Ott & Baujahr & Frthauer & Besitzer & Abgabe $m^{2} /$ Jaht & Rohstoff & $\begin{array}{l}\text { Vertrags } \\
\text { dauer Jabre }\end{array}$ & Anmerkung \\
\hline $\begin{array}{l}\text { Flensburg } \\
\text { Frankfurt/Main } \\
\text { Frankfurt/Oder } \\
\text { Freibe'g (Sa.) } \\
\text { Freiburg (Br.) } \\
\text { Fürstenwalde } \\
\text { Fürth (Bayern) } \\
\text { Gera } \\
\text { Giessen } \\
\text { Gl dbach-Rbeydt } \\
\text { Glauchau } \\
\text { Gleiwitz } \\
\text { Glogau } \\
\text { Glückstadt } \\
\text { Görlitz } \\
\text { Gotha } \\
\text { Griz (Steierm.) } \\
\text { Guben } \\
\text { Güstrow } \\
\text { Hagen (Westf.) } \\
\text { Halle/Saale } \\
\text { Hımburg } \\
\text { Hamm/Westf. } \\
\text { Hanau }\end{array}$ & $\begin{array}{l}1853 \\
1856 \\
1856 \\
1858 \\
1859 \\
1856 \\
1854\end{array}$ & $\begin{array}{l}\text { Danish Gas- } \\
\text { Deutsche Co } \\
\text { Stadt } \\
\text { Stadt u. } \\
\text { Riedinger } \\
\text { Riedinger, B } \\
\text { Deutsche Co } \\
\text { im Bau } \\
\text { Moore }\end{array}$ & $\begin{array}{l}\text { pany (engl. Besitz) } \\
\text { 1) Frankf. Gasbel. Ges. } \\
\text { 2) Imperial Cont. Gas Ass., London } \\
\text { Gas-Ges. Dessiu } \\
\text { Gasbel. Aktien Verein Freib-rg } \\
\text { Stadt. Verpachtet an Spreng u. Sonntag } \\
\text { Aktiengesellschaft mit } \\
\text { Vertrag für Riedinger } \\
\text { Gasbel. AG. Gera } \\
\text { eser u. Tebey } \\
\text { ental-Gas-Gcs. Dessau } \\
\text { Glauchauer Gas Bel. AG. } \\
\text { Schlesische Gas Ges. } \\
\text { H. Germershausen } \\
\text { J. H. Rede Erben } \\
\text { Stadt } \\
\text { Gothaer AG. f. Gasbel. Pacht. D.C.G.G } \\
\text { Germanische Gasbel. AG. } \\
\text { E. Lequerney \& Co. } \\
\text { O. Fehl ndt, Hamburg } \\
\text { ental-G.s-Gesellsch. Dessau } \\
\text { Stadt } \\
\text { Hamburg } \\
\text { AG. f. Gasbel. Hamm 1/3 Stadt } \\
\text { H. F. Ziegler }\end{array}$ & $\begin{array}{r}175000 \\
6,4 \text { Mio } \\
83000\end{array}$ & $\begin{array}{l}\text { St, K. } \\
\text { Oel u. Harz. } \\
\text { St. K. } \\
\text { St. K. } \\
\text { St. K. } \\
\text { St. K. } \\
\text { Holz } \\
\text { St. K. } \\
\text { St. K. } \\
\text { Holz } \\
\text { St. K. } \\
\text { St. K. } \\
\text { St. K. } \\
\text { St. K. } \\
\text { St. K. } \\
\text { St. K. } \\
\text { St. K. }\end{array}$ & $\begin{array}{c}25 \\
40 \\
15+15 \\
30 \\
40 \\
33 \\
25 \\
30 \\
30+20 \\
30 \\
30 \\
\\
40 \\
\\
20 \\
20 \\
30+20 \\
30 \\
20\end{array}$ & $\begin{array}{c}\text { von } 1858 \text {. St. K. } \\
\text { Harz und ÖI }\end{array}$ \\
\hline
\end{tabular}

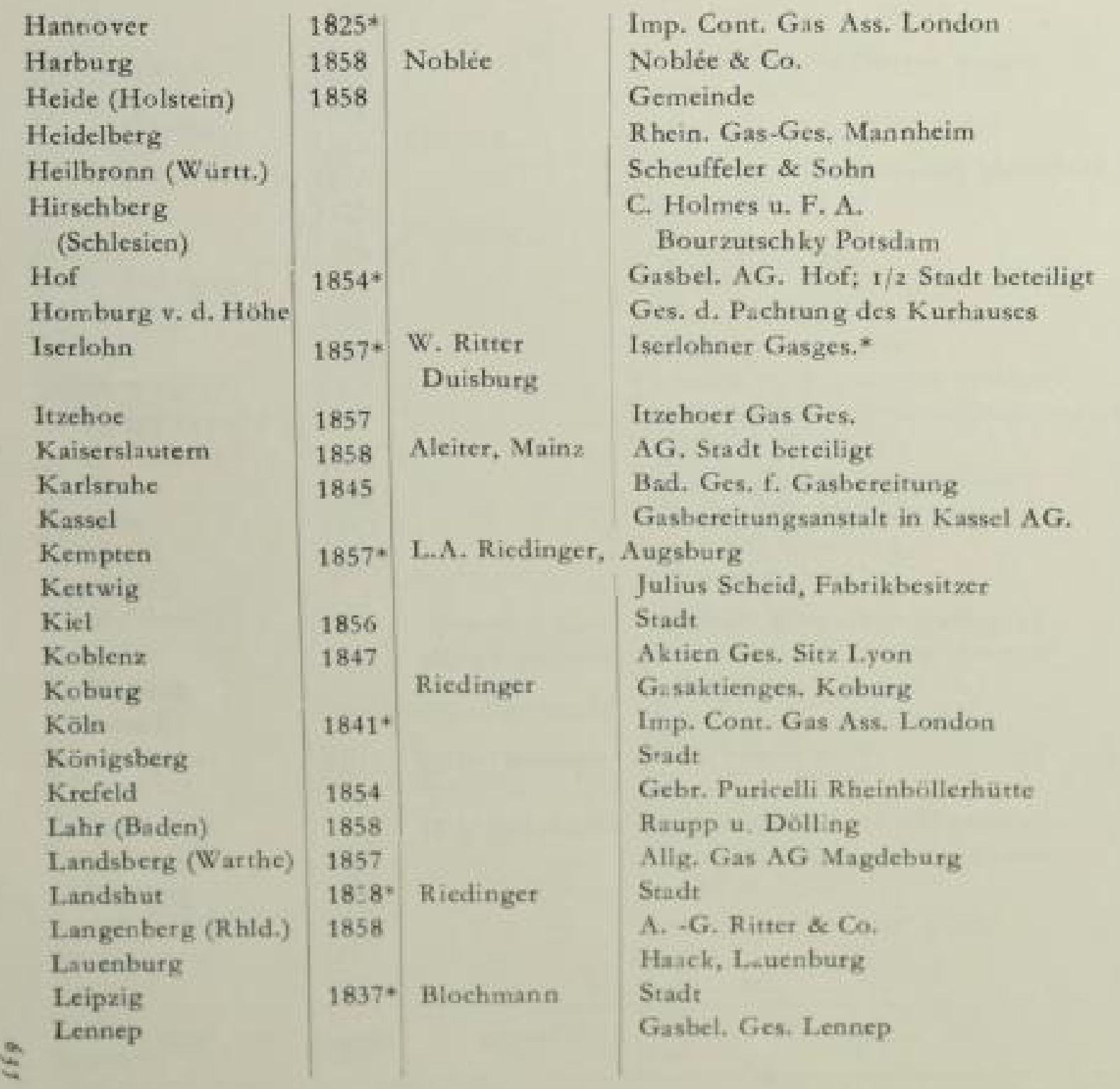

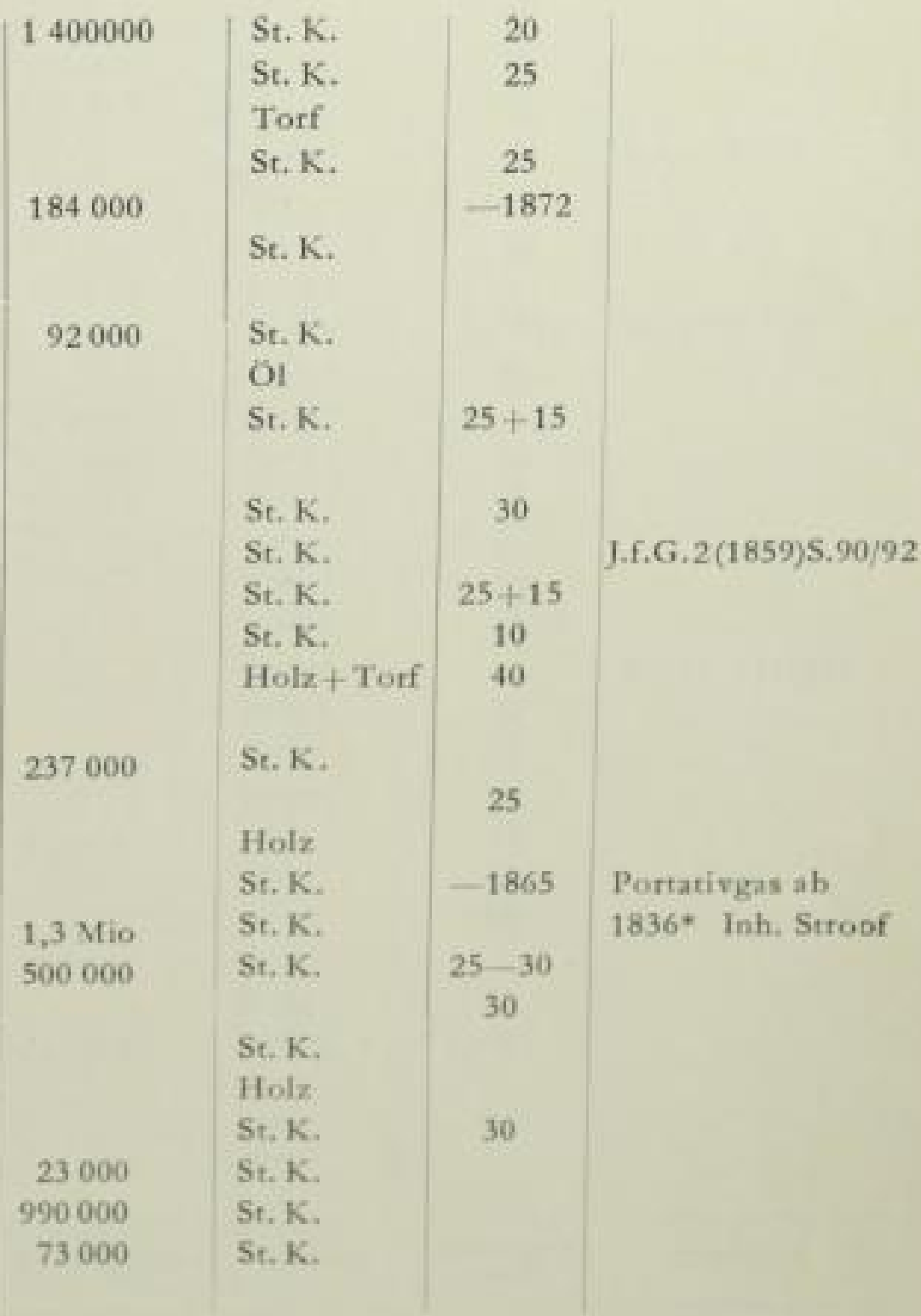




\begin{tabular}{|c|c|c|c|c|c|c|c|}
\hline On & Baujabr & Erbauer & Besitzet & Abgabe $m^{2} /$ Jaht & Rohutoif & $\begin{array}{l}\text { Vertrags. } \\
\text { dauer Jahre }\end{array}$ & Aometkupg \\
\hline $\begin{array}{l}\text { Liegnitz } \\
\text { Linz (Donau) } \\
\text { Löbau (Sa) } \\
\text { Luckeawalde } \\
\text { Ludwigsburg } \\
\text { Lübeck } \\
\text { Ludenscheid } \\
\text { Lüneburg } \\
\text { Magdeburg } \\
\text { Mainz } \\
\text { Mannheim } \\
\text { Meerane } \\
\text { Meissen } \\
\text { Minden } \\
\text { Mölln (Lauenb.) } \\
\text { Mühlheim (Rhein) } \\
\text { Mülheim (Ruhr) } \\
\text { München } \\
\text { Münster (Westf.) } \\
\text { Naumburg (Saale) } \\
\text { Neumünster } \\
\text { Neuss } \\
\text { Neustadt (Holst.) } \\
\text { Neustrelitz } \\
\text { Neuwied } \\
\text { Nordhausen }\end{array}$ & $\begin{array}{l}1856 \\
1857 \\
1853 \\
1855 \\
\\
1856 \\
1848 \\
1854 \\
1858 \\
1857 \\
1857 \\
1857 \\
1857 \\
1858 \\
1858\end{array}$ & $\begin{array}{l}\text { H. P. Stephenson, } \\
\text { Ritter, Iseriohn } \\
\text { Spreng, Sonntag } \\
\text { und Engelhorn }\end{array}$ & $\begin{array}{l}\text { Stadt } \\
\text { Allg. österr. Gas Ges. Triest } \\
\text { Stadt } \\
\text { Deutsche Cont,-Gas,-Ges. Dessau } \\
\text {, Stadt, verpachtet an Stephenson } \\
\text { Stadt } \\
\text { Ritter, Iserlohn } \\
\text { Allg. Gas AG. Magdeburg } \\
\text { Magdeburger Gas Ges. } \\
\text { Stadt verpachtet an Bad. Gas Ges. } \\
\text { Spreng, Sonntag u. Engelhorn } \\
\text { AG. } \\
\text { Aktienverein f. Gasbel. Meissen } \\
\text { Wolfers, Selberg und Homann } \\
\text { Elberling, Lauenbarg } \\
\text { AG. f. Gashel. Mühlheim, Stadt beteiligt } \\
\text { Deutsche Cont,-Gas-Ges. Dessau } \\
\text { Münch. Gas Bel. Ges. } \\
\text { Stadt. verpachtet } \\
\text { Vier Private, 25\% Stadtbeteiligung } \\
\text { Gemeinde } \\
\text { Gebr. P. u. L. Fels } \\
\text { Sander, Johannemann und Johannsen } \\
\text { Saelkow Anklam } \\
\text { Stadt } \\
\text { Deutsche Cont,-Gas-Ges. Dessau }\end{array}$ & $\begin{array}{r}113000 \\
620000 \\
1 \text { Mio } \\
\\
93000 \\
270000 \\
1 \text { Mio }\end{array}$ & $\begin{array}{l}\text { St. K. } \\
\text { Holz } \\
\text { St. K. } \\
\text { St. K. } \\
\text { St. K. } \\
\text { St. K. } \\
\text { St. K. } \\
\text { St. K. } \\
\text { St. K. } \\
\text { St. K. } \\
\text { St. K. } \\
\text { St. K. } \\
\text { St. K. } \\
\text { St. K. } \\
\text { St. K. } \\
\text { St. K. } \\
\text { St. K. } \\
\text { St. K. } \\
\text { St. K. } \\
\text { St. K. } \\
\text { St. K. } \\
\text { St. K. } \\
\text { St. K. } \\
\text { St. K. } \\
\text { St. K. } \\
\text { St. K. }\end{array}$ & $\begin{array}{c}30 \\
30 \\
25 \\
30 \\
30 \\
25 \\
30 \\
30 \\
\\
25 \\
25 \\
\\
30 \\
15+25 \\
25 \\
30+15 \\
25 \\
30 \\
20 \\
30\end{array}$ & J. f. G. $2(1859)$ \\
\hline
\end{tabular}

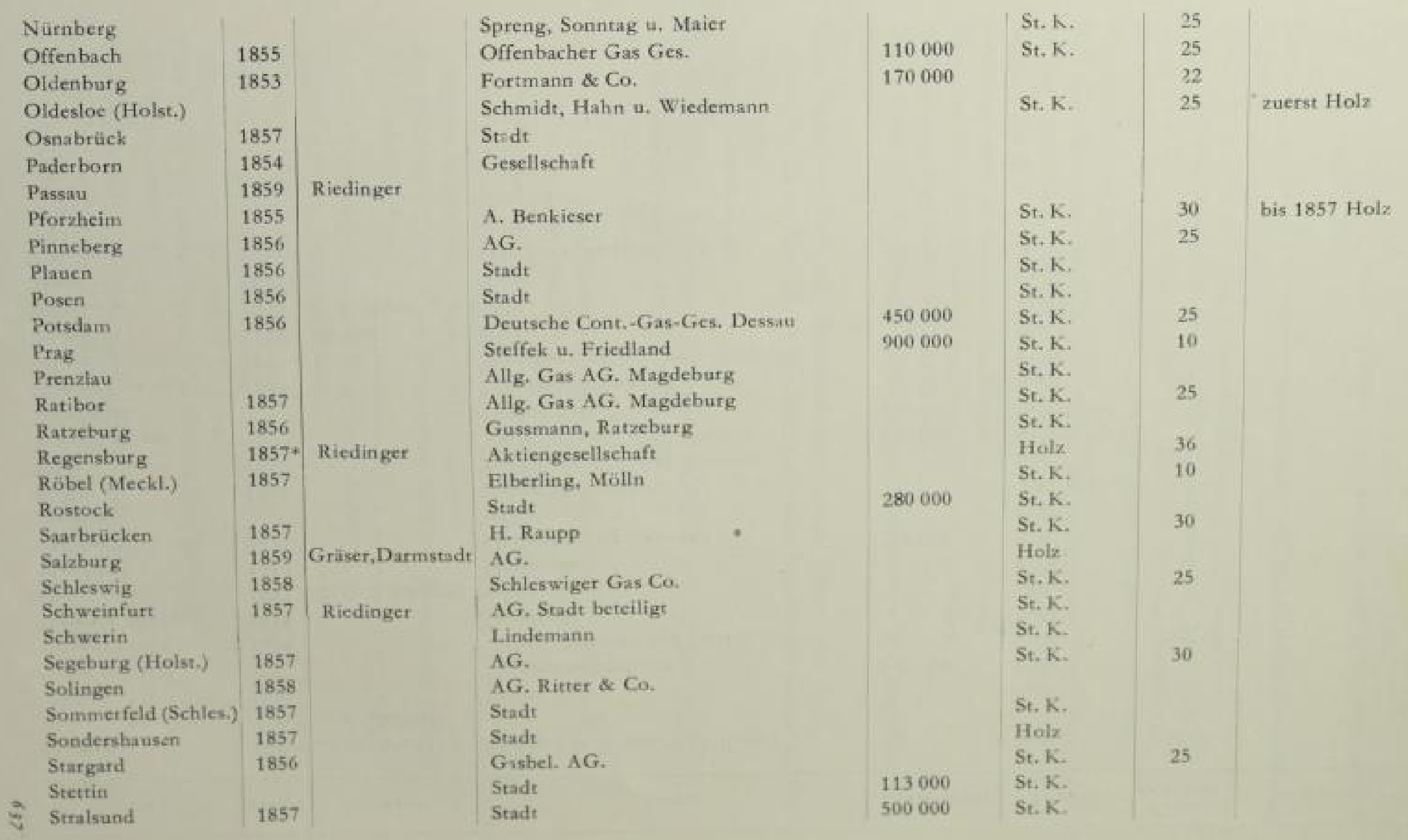




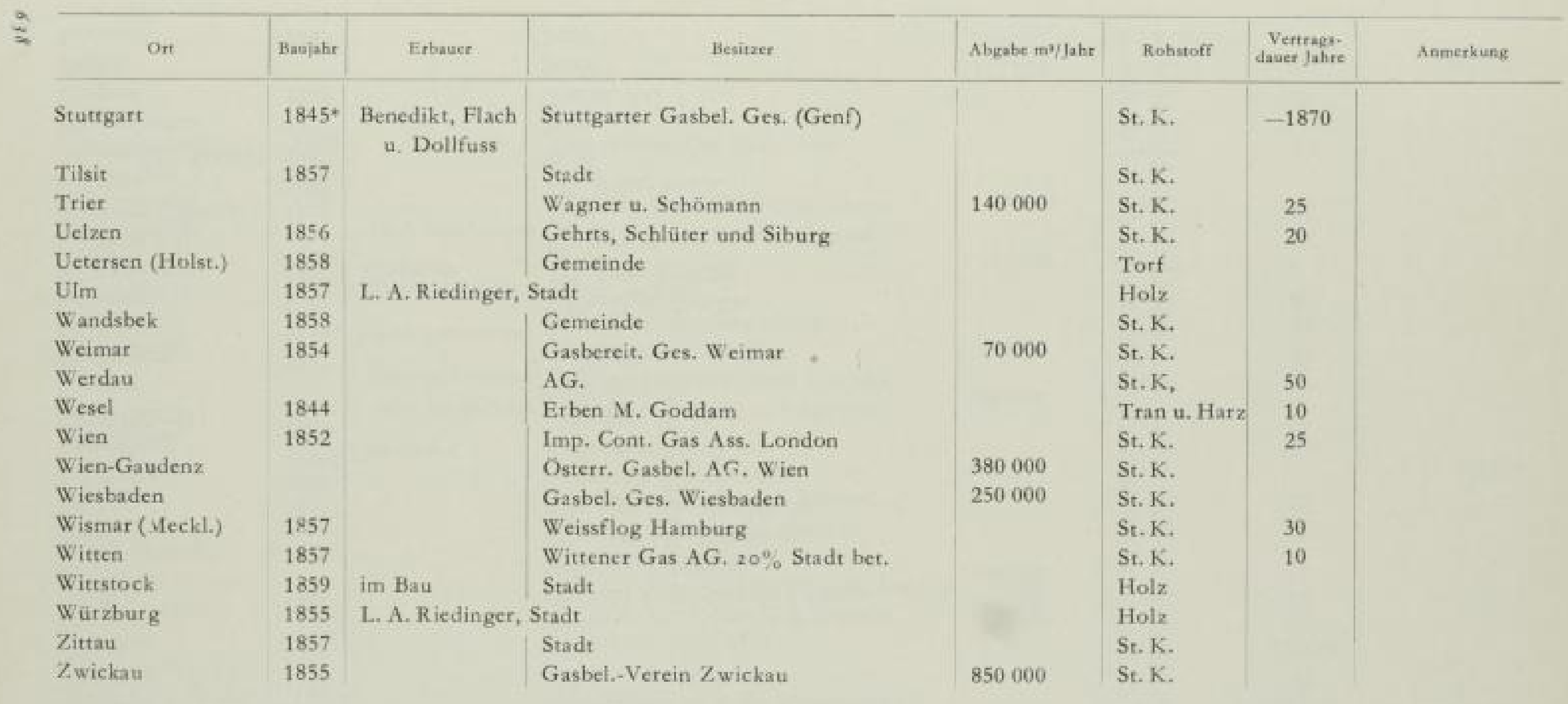

\section{SLUB}

Wir fohren Wissen. 


\section{A NHA NG 9}

Liste der Gründungen des Deutschen Vereins von Gas-und Wasserfachmännern und seiner Bezirksvereine

Gründung des Vereins deutscher Gasfachmänner und Bevollmächtigter deutscher Gasanstalten: 22. Mai 1859 .

Name ab 25. Mai 186r: Verein von Gasfachmännern Deutschlands.

ab 24. Mai 1870: Verein von Gas- und Wasserfachmännern Deutschlands

ab 19. Juni 1882: Deutscher Verein von Gas- und Wasserfachmännern

ab I8. Sept. 1903 unter gleichen Namen mit Zusatz: eingetragener Verein.

Wiederaufbau nach 1945 .

Juni 1945: Bezirksgruppe Gas- und Wasser für Nordrheinland und Westfalen.

29. Jan. 1946 Deutscher Verein von Gas- und Wasserfachmännern (nur für die britische Zone).

Gründung von Arbeitsgruppen des Vereins in Süddeutschland:

Bayern 23. Sept. 1948, Hessen 18. Jan. 1949, Württemberg-Baden

29. März 1949, Rheinland-Pfalz und Westberlin 9. Jan. 1950.

Damit hatte sich der Verein auf das ganze Bundesgebiet und Westberlin ausgebreitet.

Mittelrbeinischer Gas- und Wasserfachmännerverein (Name seit 1874)

gegründet am 15 . Mai 1864 in Neustadt a.d. Hardt (als Verein pfälzischer Gasfachmänner)

J. f. G. 7 (1864) S. 257.

Verein von Gas- und Wasserfachmännern Siblesiens und der Lausitz gegründet am 23. Mai 1867 in Görlitz

J. f. G. 16 (1873) S. 295.

Verein der Gas-, und Wasserfachmänner Rbeinlands und Westfalens gegründet am 5. Januar 1873 in Düsseldorf

J. f. G. 16 (I873) S. 296

Schweizerischer Verein von Gas- und Wasserfachmännern anfangs auch mit deutschen Mitgliedern aus dem Bodenseegebiete.

gegründet am 18. Mai 1873 in Bern (später nicht als Zweigverein geführt)

J. f. G. $16(1873)$ S. 296

Baltiscben Verein von Gas- und Wasserfachmännern

gegründet am 21. Juli $1 \delta 73$ in Elbing

J. f. G. I6 (1873) S. 295, 395

Märkiscber Verein von Gas- und Wasserfachmännern

gegründet am 5./6. Juli 1879 in Eberswaide

(als Verein der Gasfachmänner der Provinz Brandenburg)

J. f. G. 22 (1879) S. 557

Bayerischer Verein von Gas- und Wasserfachmännern gegründet am 14. Juni 1885 in Regensburg

J. f. G. 28 (1885) S. 558. 
Verein Sächsisch-Tbüringischer Gas- und Wasserfachmänner gegründet 1872

J. f. G. 52 (1909) S. 579

Niedersäcbsischer Verein von Gas- und Wasserfachmännern gegründet am i6. Juni 1899 in Hannover J. f. G. 42 (1899) S. 477

Die Bezirksvereine hatten zunächst organisatorisch keine Verbindung zum Hauptverein. 1883 wurden neue Satzungen des Vereins und der Name: Deutscher Verein von Gas- und Wasserfachmännern, um die Bezirksvereine einzugliedern, angenommen. Die Bezirksvereine entschlossen sich aber durchaus nicht sofort zum Beitritt. 1891 nahm der rheinische Verein den Namen: Verein der GasElektrizitäts- und Wasserfachmänner Rheinlands und Westfalens an. 1894 trat der sächsisch-thüringische Verein dem Hauptverein bei, 1896 der Bayerische Verein. 
Auszug aus den Verbandlungen der so. Jabresversammlung des deutschen Vereins von Gas- tund Wasserfaibmäniern in Frankfurt a. M. 1909.

Eröffnungsrede des Vorsitzenden.

\section{E. Körting, Berlin}

Meine Herren, den Schlüssel zum Verständnisse der guten alten Zeit hat mir ein Scherzwort gegeben, das vor 20 Jahren in Wien gang und gäbe war. Man nannte nämlich dort die Organisation der Gasfachmänner den österreichischen Gasschuster-Verein. Meine Herren, dieser Witz trifft den Nagel auf den Kopf. Die Gásindustrie der guten alten Zeit war eine handwerksmäfige. Die genialen Engländer, die im Anfange des vorigen Jahrhunderts die Gasbeleuchtung schufen, hatten für eine Reihe von Jahrzehnten alles wesentliche vorwegerfunden. Die jungen Gasingenieure lernten wie der Lehrling beim Meister die Handgriffe und Erfahrungen, auf die es ankam und vermehrten sie später durch neue, die sich aber nicht wesentlich über das Niveau der alten erhoben. Ganz im Geiste der damaligen Zeit ist folgende niedliche Geschichte, die vielleicht nicht allgemein bekannt ist. Eine grö̧zere deutsche Stadt lief̧ sich ein Gaswerk erbauen. Die Neuanlage kam in Betrieb, arbeitete auch ganz gut, aber nach 4 Wochen ging die Leistung der Öfen von Tag zu Tag mehr zurück. Man wufjte nicht mehr ein noch aus und rief schlief̧lich den Generaldirektor Oechelhäuser zur Hilfe. Der kam und sagte: „Ja, das Gasmachen ist eine Kunst, die gelernt sein will. Ich kann Thnen nur den Rat geben, das Werk schleunigst an meine Gesellschaft zu verpachten". Dies geschah denn auch und am selbigen Tage wurden die Retorten ausgraphitiert und lieferten bald ebensoviel Gas wie zuvor.

Grof3e Gasanstalten waren im Jahre 1858 und noch lange darüber hinaus in Deutschland überhaupt nicht vorhanden, hatten doch die Berliner städtischen Gaswerke vor 50 Jahren nur eine Gesamtgasproduktion von II Millionen cbm. In den 6oer Jahren genügte für die sämtlichen technischen und kaufmännischen Beamten der Gasanstalt Hannover ein ziemlich kleines Zimmer, und darin ging es so ruhig zu, daf3 ich dort gewöhnlich meine Schularbeiten anfertigen muffte. Maschinen gab es überhaupt nicht in den Gaswerken. Die Kohle wurde meist per Achse angefahren und mit Schiebkarren auf den Berg gekarrt. Im Retortenhaus herrschte der 6er und 7er Rostofen. Die Retorten wurden mit Schaufeln beschickt, entweder durch zwei Mann, einer links und einer rechts von dem Flur aus, oder durch einen Mann aus einer eisernen Karre. Der Koks wurde in Karren gezogen und unmittelbar vor dem Hause ausgekippt. Dann kamen Leute mit Hämmern und schlugen ihn klein. Die Kokskäufer standen dazw`schen herum und lief̧en sich die Waren einfüllen. Groł̧e technische Aufgaben traten an den Gasdirektor damals wenig heran, wenn ihm auch die vorkommenden bei der mangelhaften Entwicklung der technischen Methoden oft genug Kopfzerbrechen verursacht haben mögen. Aber er hatte auch gar keine Zeit dazu, denn er musste alles selbst machen. Mit Zeichnungen konnte er sich nicht viel abgeben. Es gehört zu meinen ersten Jugenderinnerungen, dał̧ mich mein Vater im Wagen 
mit zur Hannoverschen Eisengief̧erei nahm. Dort zeichnete er dem Meister mit Kreide die Gufsstücke auf, die er nötig hatte. Das stimmt genau mit einem bekannten Ausspruche des grofen englischen Gastechnikers Sir George Live se y überein: „I do not believe in drawings. I prefer a piece of chalk and a sheet of iron." Man sieht es auch den damaligen Zeichnungen an, wie wenig das Auge noch technisch geschult war. Alle Gegenstände wurden schattiert gezeichnet, damit sie durch den Eindruck der Körperlichkeit das Verständnis erleichterten. Man hatte damals auch keine Zeit, alle Rohrstränge usw. in den Fabriken zeichnerisch festzulegen und alle die wohldurchdachten Sicherheitsvorrichtungen anzuwenden, die heute üblich sind. Die Herren der Berufsgenossenschaft werden entsetzt sein, wenn sie hören, dał wir auf unserer Berliner Anstalt die Reinigertassen im Winter mit offenen Gasflammen zu erwärmen pflegten.

Es gab daher wohl damals im ganzen mehr Unfälle und Betriebsstörungen als jetzt, und diese lasteten schwer auf dem Herrn Direktor. Ich erinnere mich noch lebhaft an eine Damenrede, die mein Vater vor etwa 30 Jahren im Vereine gehalten hat. Alle Augenblick sturzte ein Arbeiter herein mit einer neuen Hiobsbotschaft. „Herr Direktor, eben sind die Nachreiniger in die Luft geflogen, Herr Direktor, wir haben nur noch einen halben Fuf̧ Gas im Behälter, Herr Direktor, das Hauptrohr ist voll Naphthalin wir kriegen kein Gas in die Stadt usw.". Das einzige, was dem unglücklichen Gasdirektor das Leben noch halbwegs erträglich machen konnte, war die treue Liebe seiner Gattin. Wenn diese Rede in späteren Jahrhunderten einmal ausgegraben werden sollte, so wird der betreffende Professor sicher daraus schliełzen, dał sich die Gasingenieure des 19. Jahrhunderts ungefähr in der gleichen Lage befunden haben müssen, wie die Verteidiger von Port Arthur im allerletzten Stadium.

Andererseits waren sie aber auch bei der Einfachheit des Betriebes in der Lage, zu Zeiten einen grofen Teil ihrer Pflichten auf einen Assistenten oder Meister abzuwälzen. Ein bekannter belgischer Gasfachmann war ein berühmter Landschaftsmaler. Der steckte einmal am Tage seinen Kopf aus dem Atelierfenster und rief: „Tommy, ist alles in Ordnung?” Nach dem obligaten: „Jawohl, Herr," hatte er dann seine Pflicht für den Tag getan. Jedenfalls fanden die Gasfachmänner vor Jahrzehnten häufig Mittel und Wege, sich mit Dingen von allgemeinem Interesse und idealen Zielen zu beschäftigen. Der alte Geheimrat Oechelhäuser war Shakespeare-Forscher und Politiker, Schililing ein feinsinniger Literat, mein Vater führte in Hannover das Schülerturnen ein, bildete sich zum Portraitmaler aus, gründete und leitete den Turnklub, war Schütze, Nationalvereinler, Freimaurer und hervorragendes Mitglied des Kunstvereines, Edward Drory, Photograph, Bootsbauser, Gärtner und Bienenzủchter. Die obengenannten Herren waren bekanntlich alle vortreffliche Fachmänner, erhöhten durch ihre Vielseitigkeit ihren persönlichen Wert und wurden so ihrer Stellung und ihrem Fache doppelt gerecht. Einigen ihrer Kollegen fehlte es aber entschieden an der nötigen ernsten Auffassung ihres Berufs. Ein alter Direktor wurde wiederholt von seinem Verwaltungsrate darauf hingewiesen, daf er zuviel Arbeiter habe, und tat dann foigenden klassischen Ausspruch:

„Zuerst klagt man, daf3 ich zuviel Brennerlohn ausgebe, da habe ich die Leute auf Kohle geschrieben, dann habe ich sie auf Koks gebucht, und nun fangen sie von zu hohen Kokslöhnen an. Ich schreibe den Herren niedrige Löhne auf jedes

642 
Konto, wo sie es wünschen, nur nicht für alle auf einmal, denn irgendwohin muf ich die Leute doch buchen".

In einem anderen Gaswerke wurde ein musterhaft sauberes Buch geführt über die Kosten aller Neubauten. Der Herr Direktor wollte aber niemals eingestehen, dał er mit irgendeinem Voranschlage nicht ausgekommen war. Es wurden daher die Überschüsse des einen Baues dazu verwendet, die Fehlbeträge des anderen zu decken, mit dem Ergebnisse, dał scillief̧lich sämtliche Zahlen falsch und unbrauchbar waren. Obige natürlich auch schon damals auffallenden Auffassungen sind deshalb so interessant, weil sie im vollen Gegensatze stehen zu der heutigen durch die harte Notwendigkeit diktierten Methode, sich über jede Kapitalsanlage genaueste Rechenschaft zu geben und den Betrieb bis in die kleinste Einzelheit hincin buchhalterisch zu durchleuchten. Im allgemeinen glaube ich, daf̧ vor Jahrzehnten die Zahl der Charakterköpfe und bedeutenden Männer in unserem Fache entschieden gröfzer war als in der Gegenwart, während uns jetzt bessere technische Bildung und wcit vollkommenere technische Hilfsmittel zur Verfügung stehen.

Ein typischer Vertreter der guten alten Zeit war für mich Herr L. G. D r o r y, der Vorgänger seines, erst vor wenigen Jahren verstorbenen Bruders Edward Drory in Berlin und längere Zeit der erste technische Beamte meiner Gesellschaft. Sein Name lebt fort in dem bekannten selbsttätigen Teerüberlauf der Vorlagen. Sonst ist er aber in der Offentlichkeit wenig hervorgetreten. L. G. Drory war ein Mann von starkem, cigenartigem Charakter, von grołem Gerechtigkeitsgefühl und von eiserner Pflichttreue. Sein Retortenhausbetrieb war musterhaft für die damalige Zeit. Er hatte frühzeitig erkannt, dał mit dem Rostofen nur bei ganz leichtem Einbau gute Vergasungsergebnisse erzielt werden können und duldete in seinen Ofen nur drei halbsteinstarke Pfeilerstellungen. Die Retorten hielten allerdings nur 200 bis 300 Feuertage. Dafür verlangte er aber auch, daß ein Ofen von 7 Fetorten in zwei Tagen fix und fertig gebaut wurde. Maurer, die das nicht leisten konnten,wurdei ohne Gnade entlassen.

L. G. Drory erzielte mit englischer Kohle schon vor 30 bis 40 Jahren $230 \mathrm{cbm}$ pro Tag und $300 \mathrm{cbm}$ pro Tonne und war damit seiner Zeit weit voraus. Berühmt war Drory auch durch die stramme Zucht, die er unter seinen zahlreichen Arbeitern aufrecht erhielt. Er liebte es, sich abends mit einem Glase Weif̧bier und einer Zigarre ins Retortenhaus zu setzen und seine Leute bei der Arbeit zu beobachten. Häufig verlieł̧ er auch die Fabrik ostentativ in seinem Wagen und kam im nächsten Augenblicke durch eine Hintertür zu Fufje zurück. Und wehe dem Arbeiter, den er dann faulenzend traf. Er wurde sofort entlassen. Die Arbeiter nannten infolgedessen ihren Chef den „Jäger“, seine Kollegen sprachen aber von ihm als dem besten Aufseher, den die Gesellschaft je besessen. Der eigentliche Aufseherstand war ja damals noch wenig entwickelt. Ein ehemaliger Chef von mir machte z. B. alte Brenner, die gebrechlich wurden, zu Retortenhausaufsehern. Die erhielten dann weniger Lohn als ihre Untergebenen mit der Begründung, dał sie ja doch nur faulenzten. Es blieb erst der neuen Zeit vorbehalten, junge intelligente Arbeiter theoretisch zu unterweisen, ihr Verantwortlichkeitsgefühl zu stärken und sie zu besser bezahlten Beamten aufsteigen zu lassen. So wurde der Stand der Ofenmeister gebildet, ohne den wir heute kaum in der I.age wären, unsere hochentwickelten Ófen zu betreiben. Dies nebenbei. Ein drit- 
ter Grundzug im Wesen L. G. Drorys war eine bis zum Äuf̧ersten gehende Sparsamkeit. Es wurde in der Fabrik niemals eine alte Anlage durch eine neue ersetzt, sondern immer noch etwas hinzugefügt, wo gerade Platz war.

Ebenso ging es mit dem Rohtsystem in der Stadt. Gas war ja damals eine Luxusbeleuchtung im vollsten Sinne des Wortes. Der Verbrauch pro Kopf der Bevölkerung war sehr klein, und die Rohre brauchten nur einen geringen Durchmesser zu erhalten. Drory achtete mit der größten Strenge darauf, daf, kein neues Rohr gelegt wurde, ehe es absolut notwendig war, und kein neuer Anschluf hergestellt wurde ohne absolute Sicherheit eines entsprechenden Verdienstes. Das Gesamtergebnis war ein auferordentlich niedriges Anlagekapital und ein sehr hoher Reingewinn. Man darf dabei natürlich nicht vergessen, daf3 Kohle und Löhne damals sehr niedrig im Preise standen, und dał der Koks bei dem geringen Umfange der Gaserzeugung zu hohen Preisen abgesetzt wurde. So ging es jahrzehntelang gut. Dann aber kam der Wettbewerb, das Petroleum von der einen, das elektrische Licht von der andern Seite und die gewaltige Steigerung der Arbeitslöhne und machten dem althergebrachten einträglichen Zustande ein jähes Ende. Eine neue Zeit mit neuen Anschauungen und Arbeitsmethoden zog herauf. Und wer, meine Herren, stand auf der Schwelle dieser neuen Zeit und war unser Wegweiser zum neuen Ziele? Kein anderer als der hervorragende Mann und Gelehrte, der noch heute als Generalsekretar an der Spitze unseres Vereins steht: Herr Geheimrat Dr. Hans Bunıe. Seine erste grofe Arbeit, die er im Vereine mit Schilling durchführte, die wissenschaftliche Untersuchung der Generatorfeuerung, war die erlösende Tat. Ich weif mich noch wohl zu erinnern, mit welchem Feuereifer die Vorgeschrittenen unter den Gasingenieuren sich auf diese neue Bahn warfen, mit welchen Schwierigkeiten sie aber auch zu kämpfen hatten, ehe Theorie und Praxis in Einklang gebracht waren. Aber, meine Herren, der Anfang war gemacht. Die Wissenschaft war an die Spitze der deu'schen Gasindustrie gestellt worden. (Bilder 134 bis 144 . J. f. G. 52 [1909] S. 560 ff.)

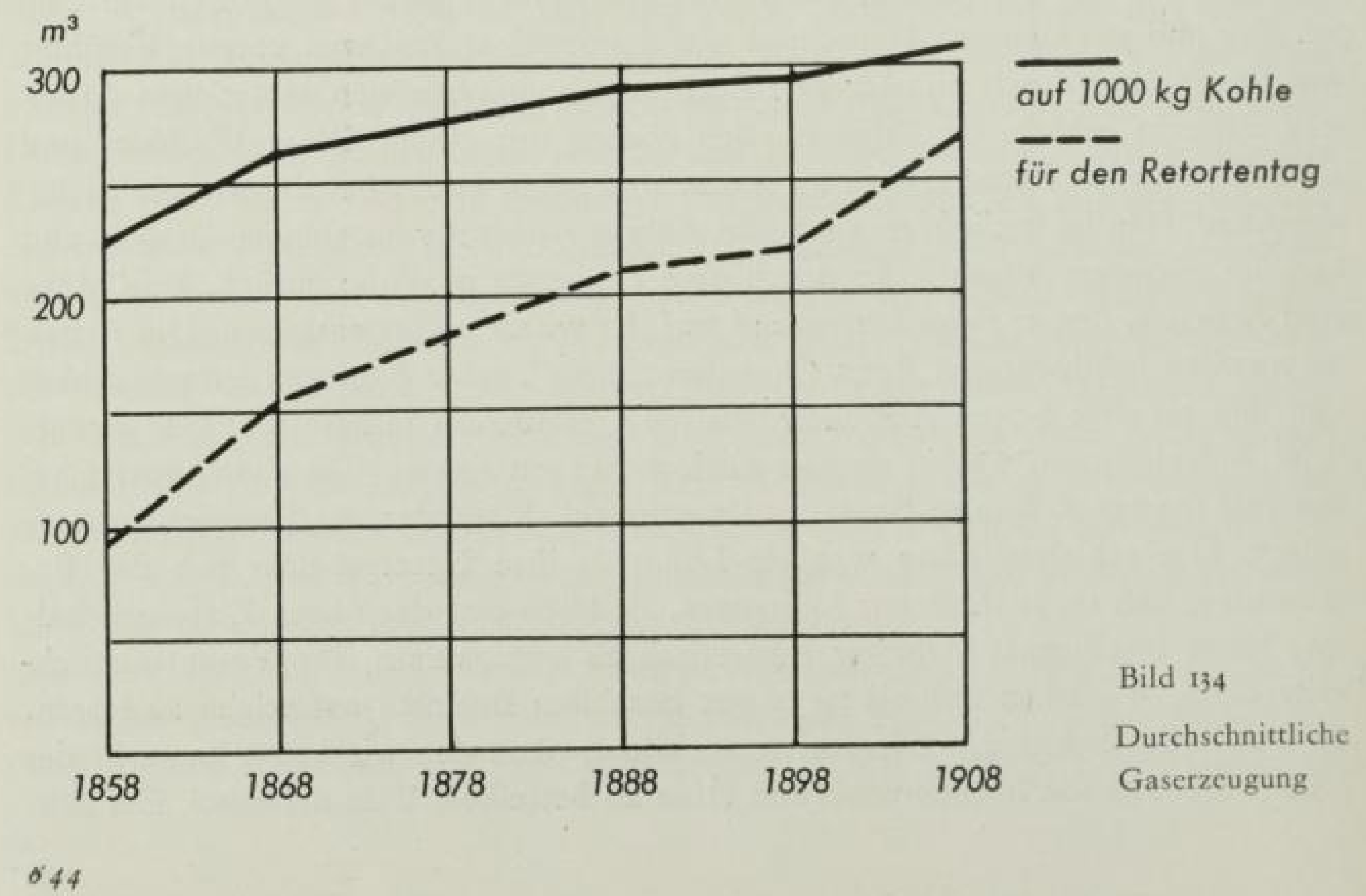

\section{SLUB}




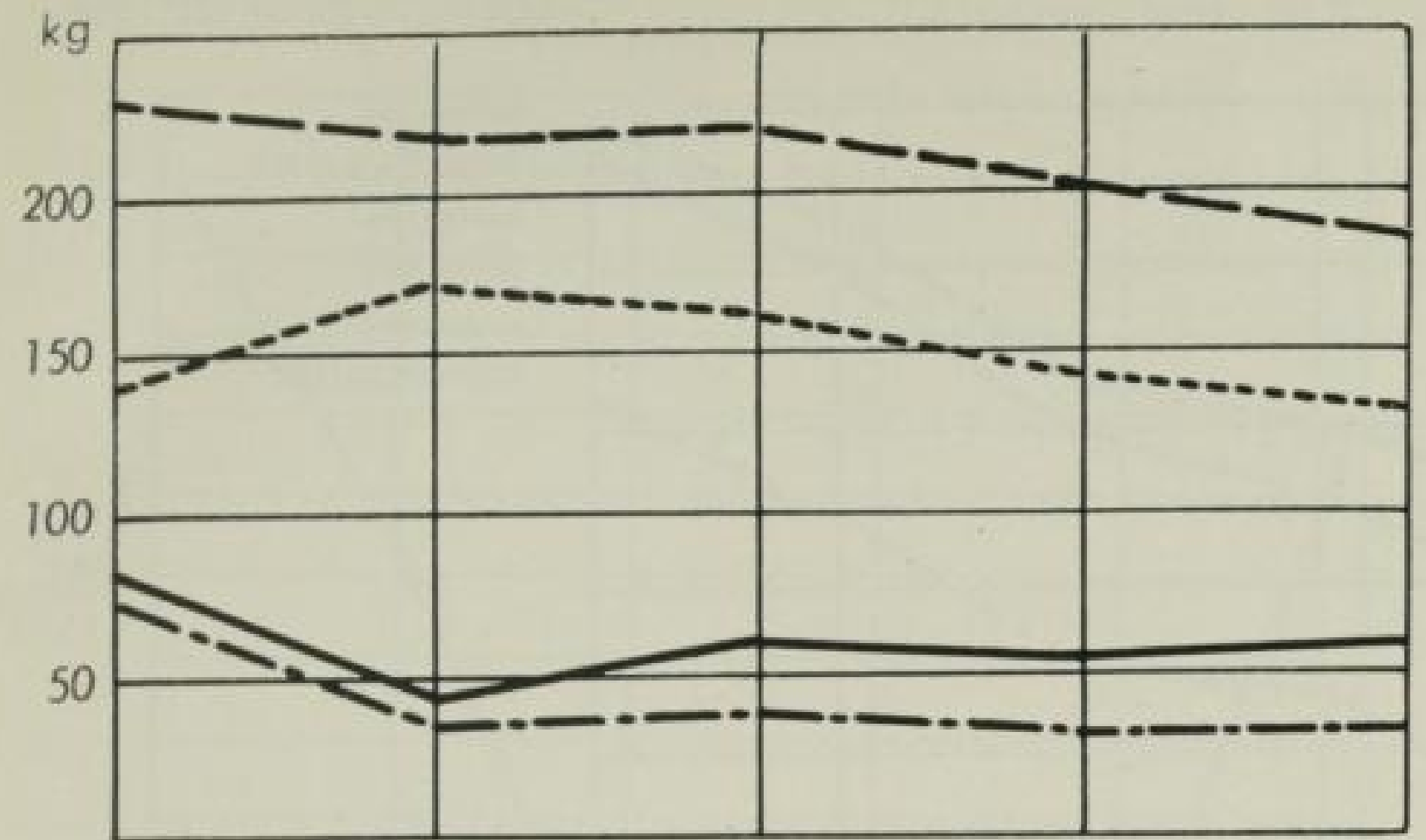

Kokserzeugung

Koksverkauf

Gesamtkoksverbrauch

Koksverbrauch

der Retortenöfen

Rostöfen

Generator-

öfen mit

Generator-

Cozeöfen

Vertikalöfen

Handarbeit

öfen mit Dreh- mech. Kohlen- nasses Verfahren

und Lade. $\quad$ und Koks.

maschine betrieb

Blauwasser

mech. Kohlen-und

gas

Koksbetrieb

Hochdruck-

fernversorgung

Auf $1000 \mathrm{~kg}$ Kohle:

$300 m^{3}$ Gas $320 m^{3}$ Gas $320 m^{3}$ Gas $350 m^{3}$ Gas $370 m^{3}$ Gas

Bild 135 Kokserzeugung, Koksverbrauch, Koksverkauf

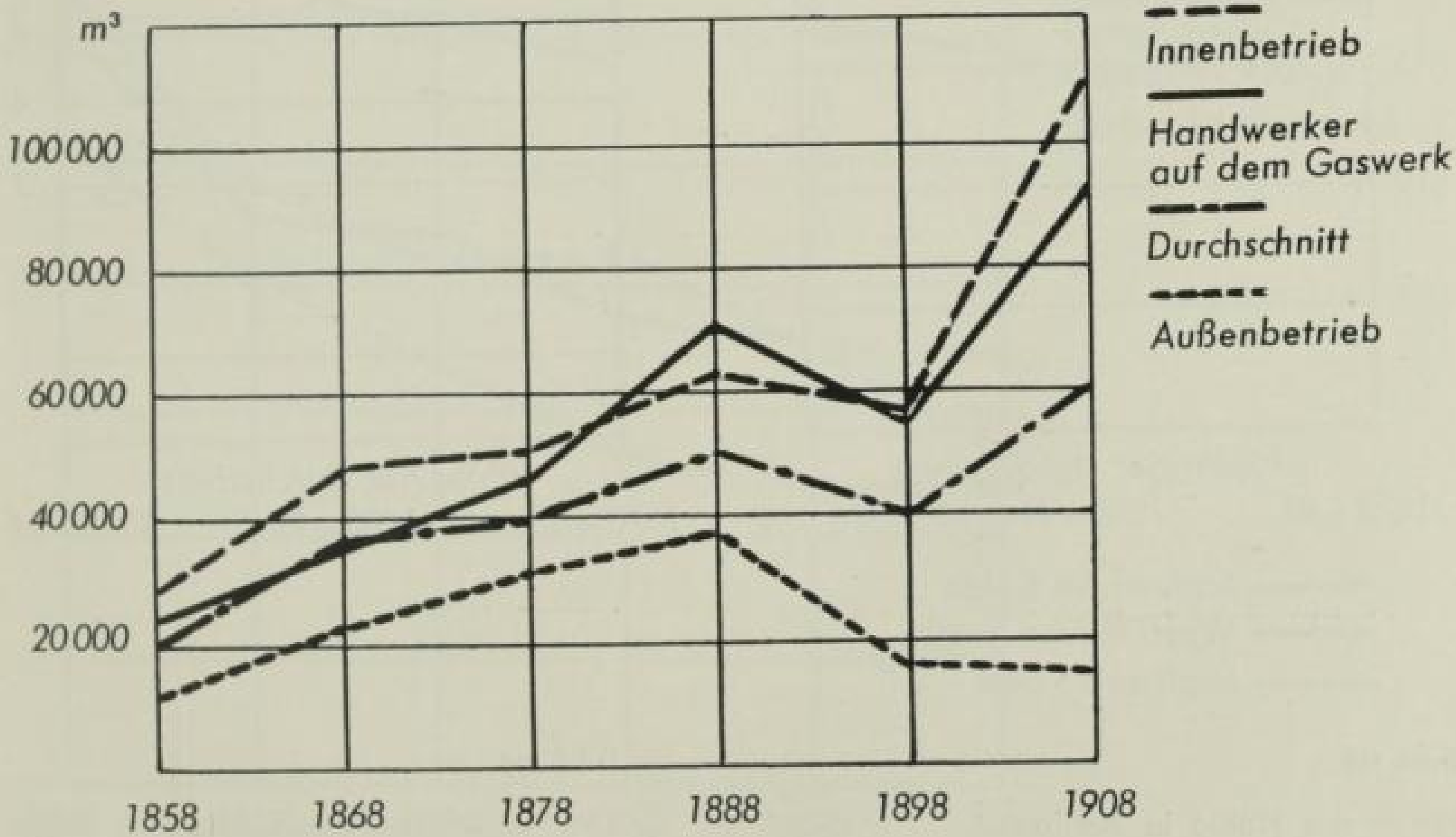

Bild 136 Gaserzeugung je Arbciter u. Jahr

\section{SLUB}




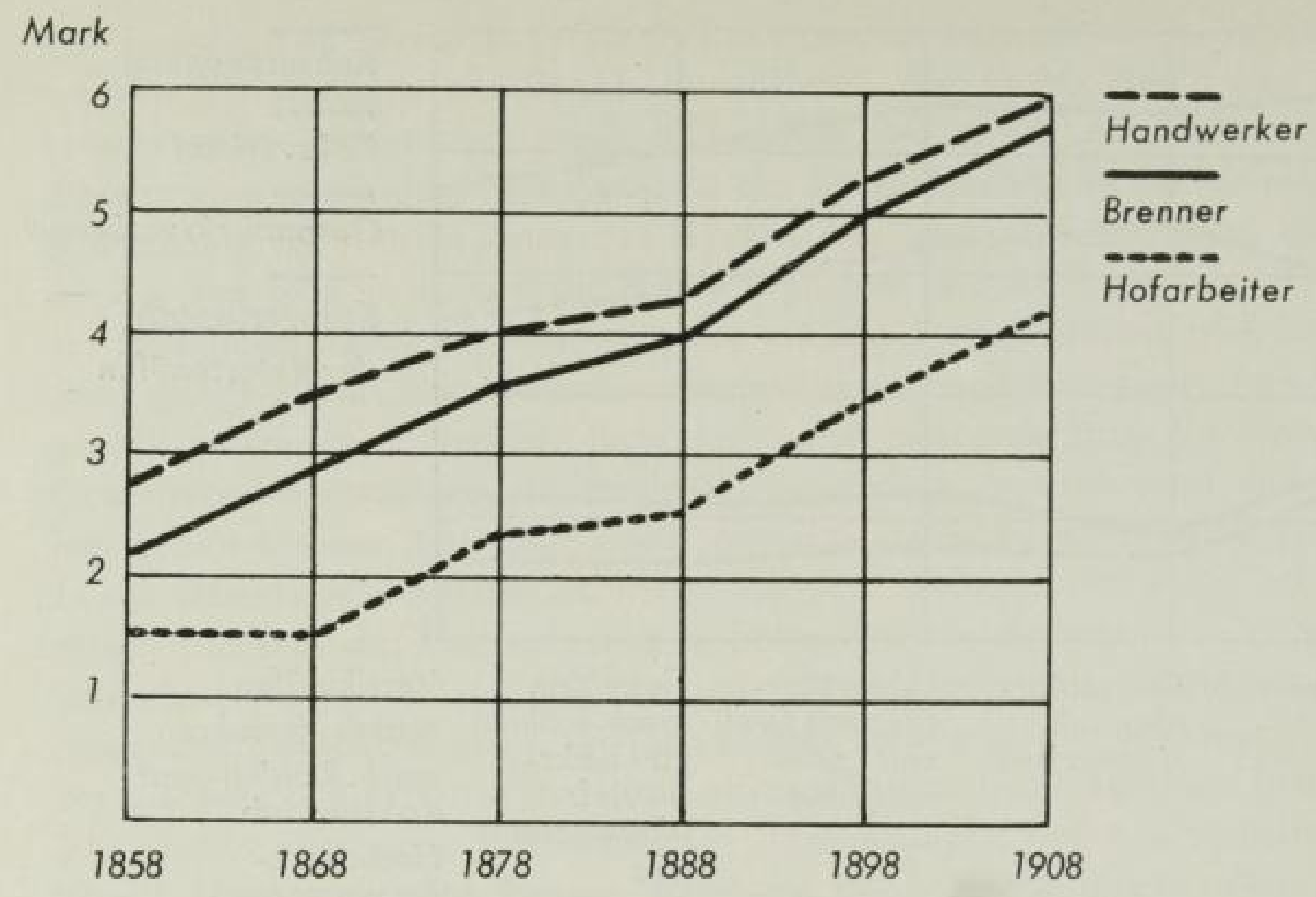

Bild 137 Lohnsätze je Tag in Mark

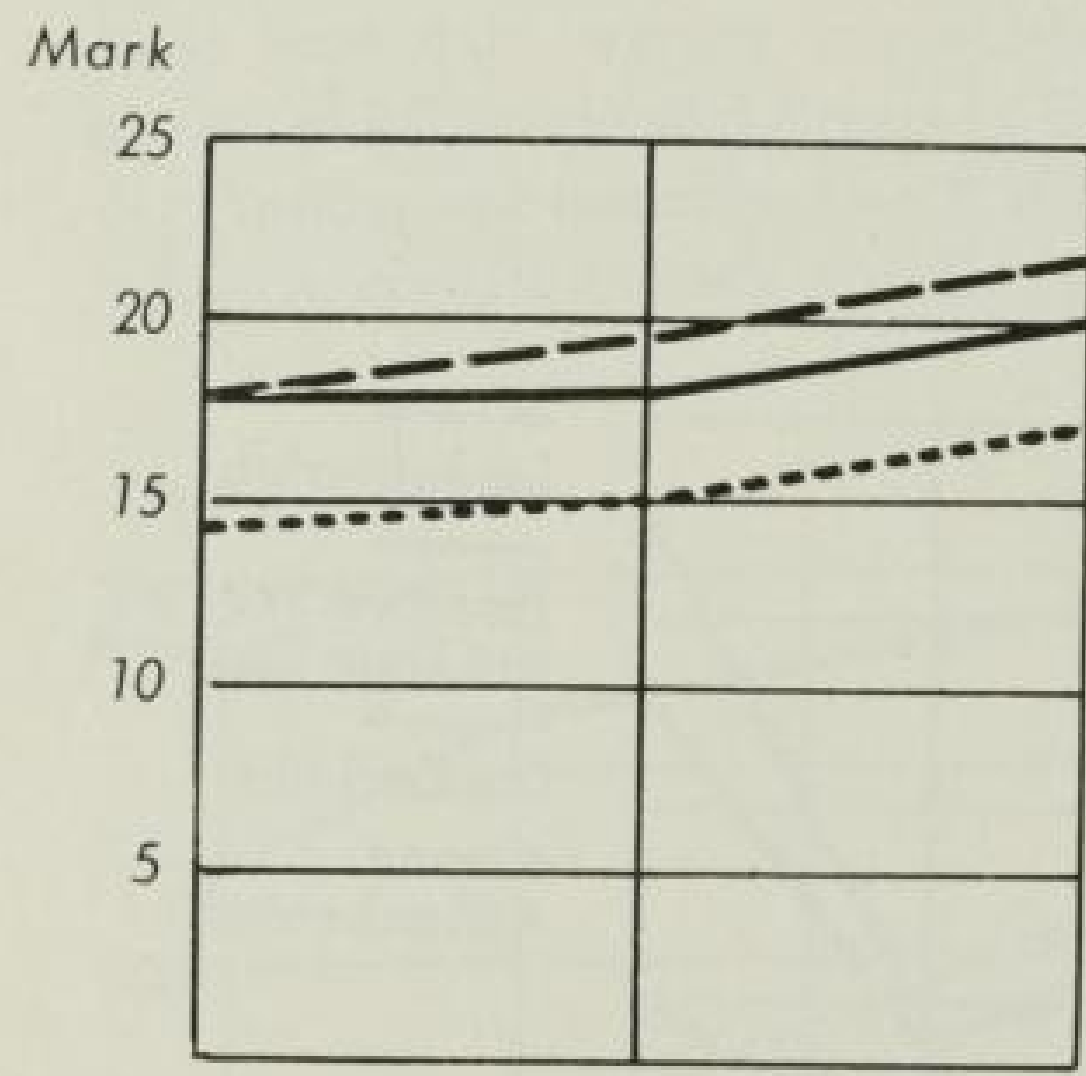

10iähriger Durchschnitt

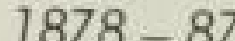

\section{- - Schlesische Kohle}

Westfälische Kohle

....... Englische Kohle

Bild 138

Preise der Kohle in Berlin

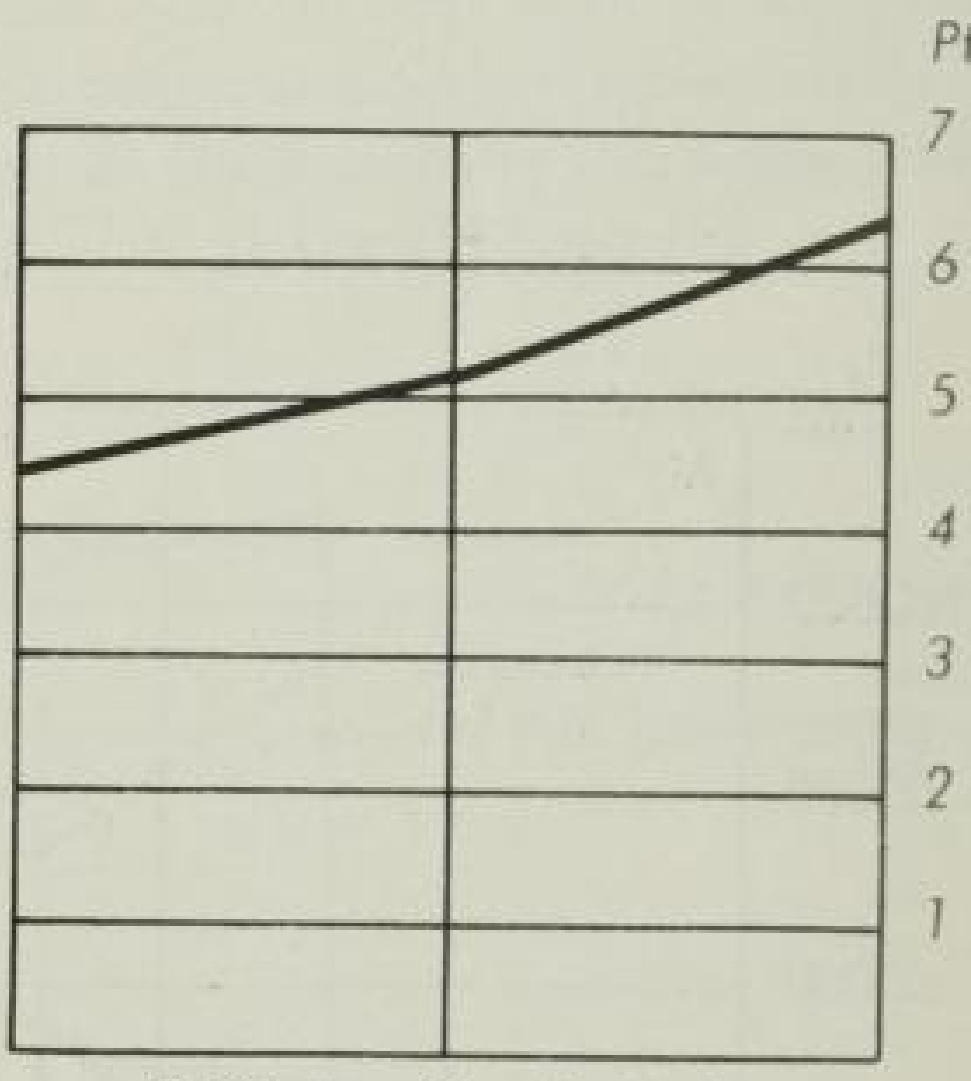

10jähriger Durchschnitt $\begin{array}{llll}1898-07 & 1878-87 & 1888-97 & 1898-07\end{array}$

Bild 139

Den städtischen Gasanstalten in Berlin kostete ausschlieflich Verzinsung und Amortisation d. Anlagekosten $1 \mathrm{~m}^{3}$ Gas

\section{SLUB}




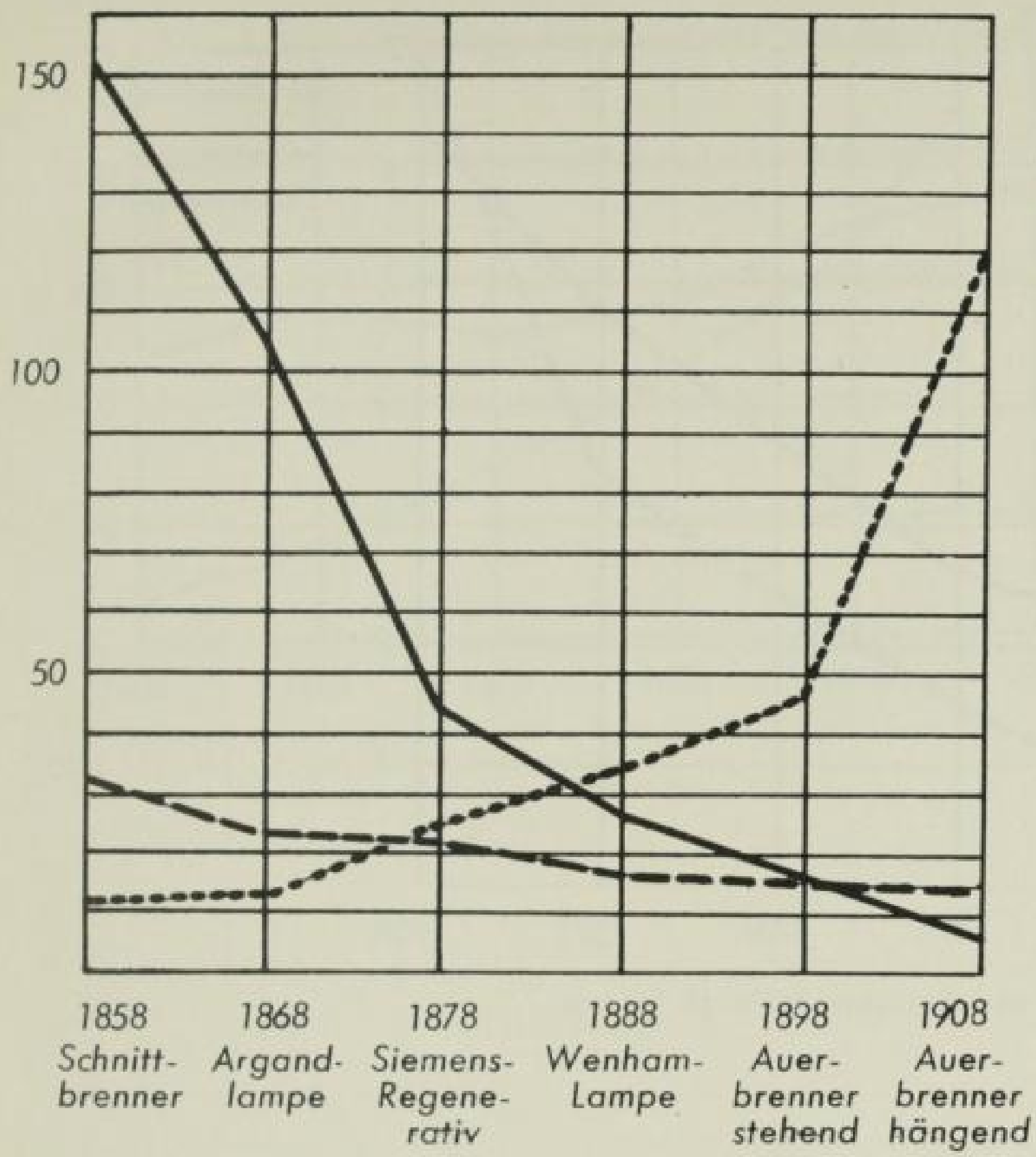

Preis

von 500 Std. H. K.

\section{Gaspreise}

$-\infty-\infty$

H. K. per 100 I

Bild 140 Einflufy der Brenner u. d. Gaspreise auf die Kosten der Beleuchtung

Pf

\section{5}

30

25

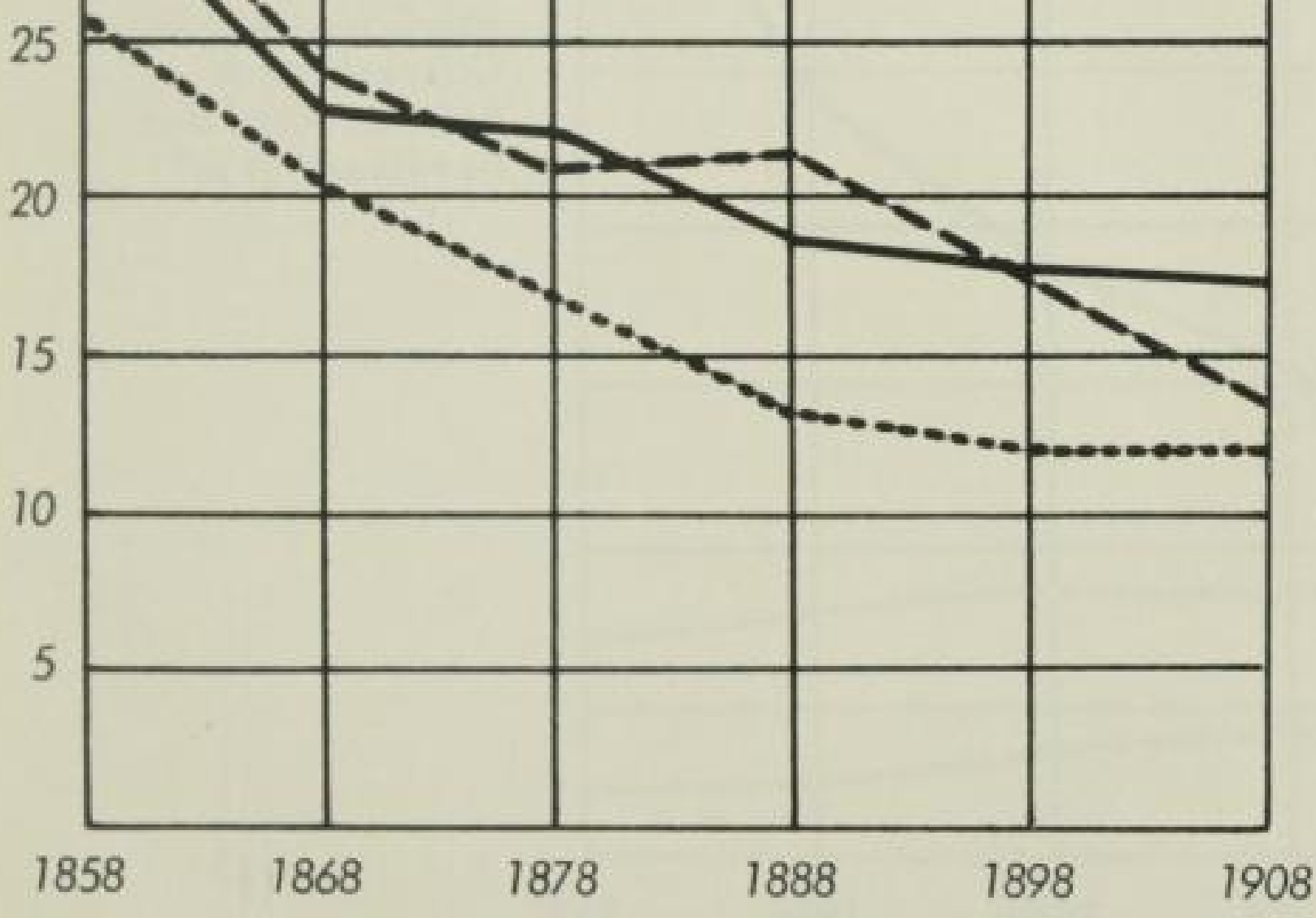

Leuchtgas

Einheitspreis

-.en...

Kraft-und Heizgas

Bild I4I Preise des Privatgases je $\mathrm{m}^{n}$ in 40 Stãdten Bilder $14 \mathrm{r}$ bis 144 sind statistisch bei 40 Städten ohne Rücksicht auf die Gröł̉e der Städte gewonnen 


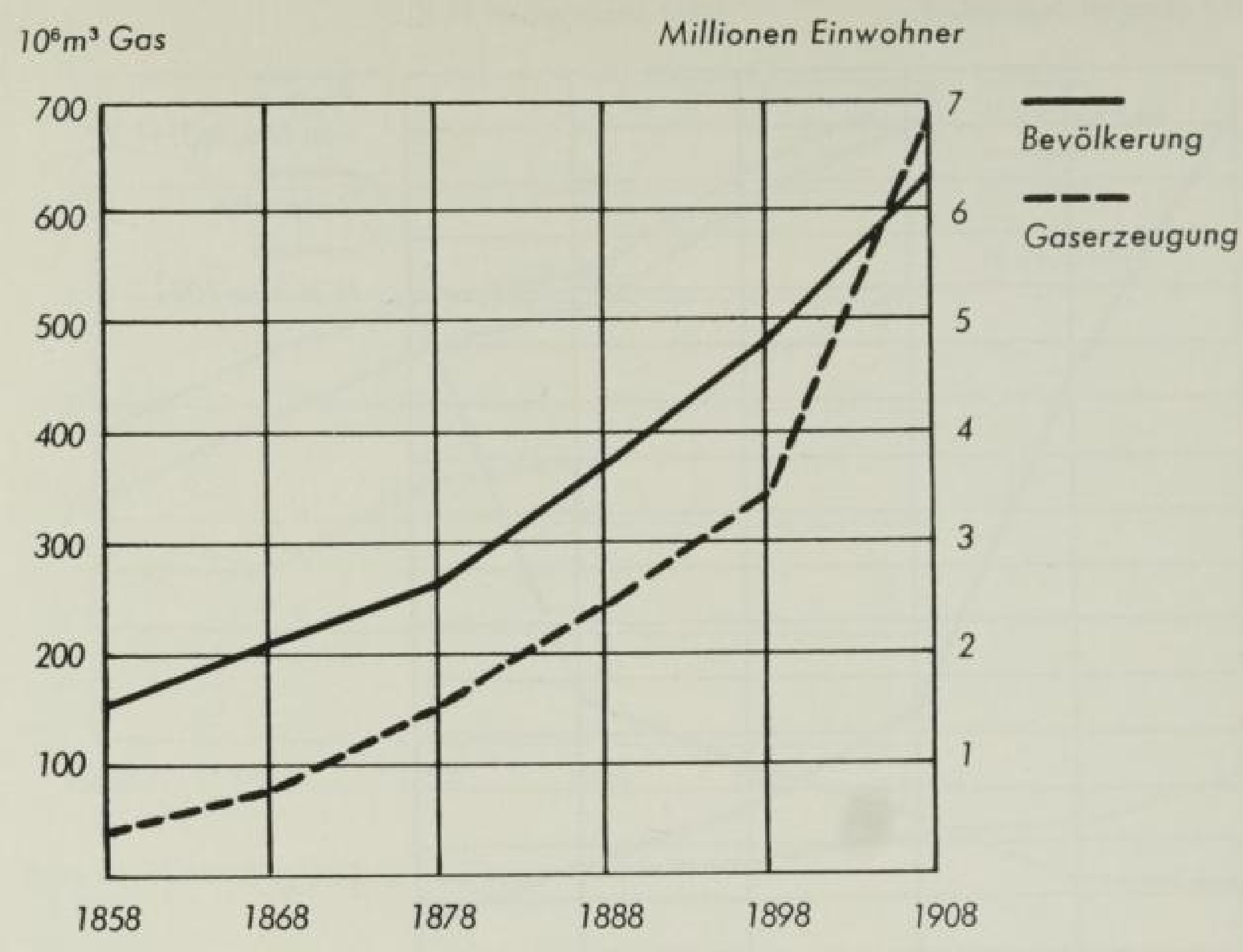

Bild 142 Gaserzeugung und Bevölkerung in 40 Städten

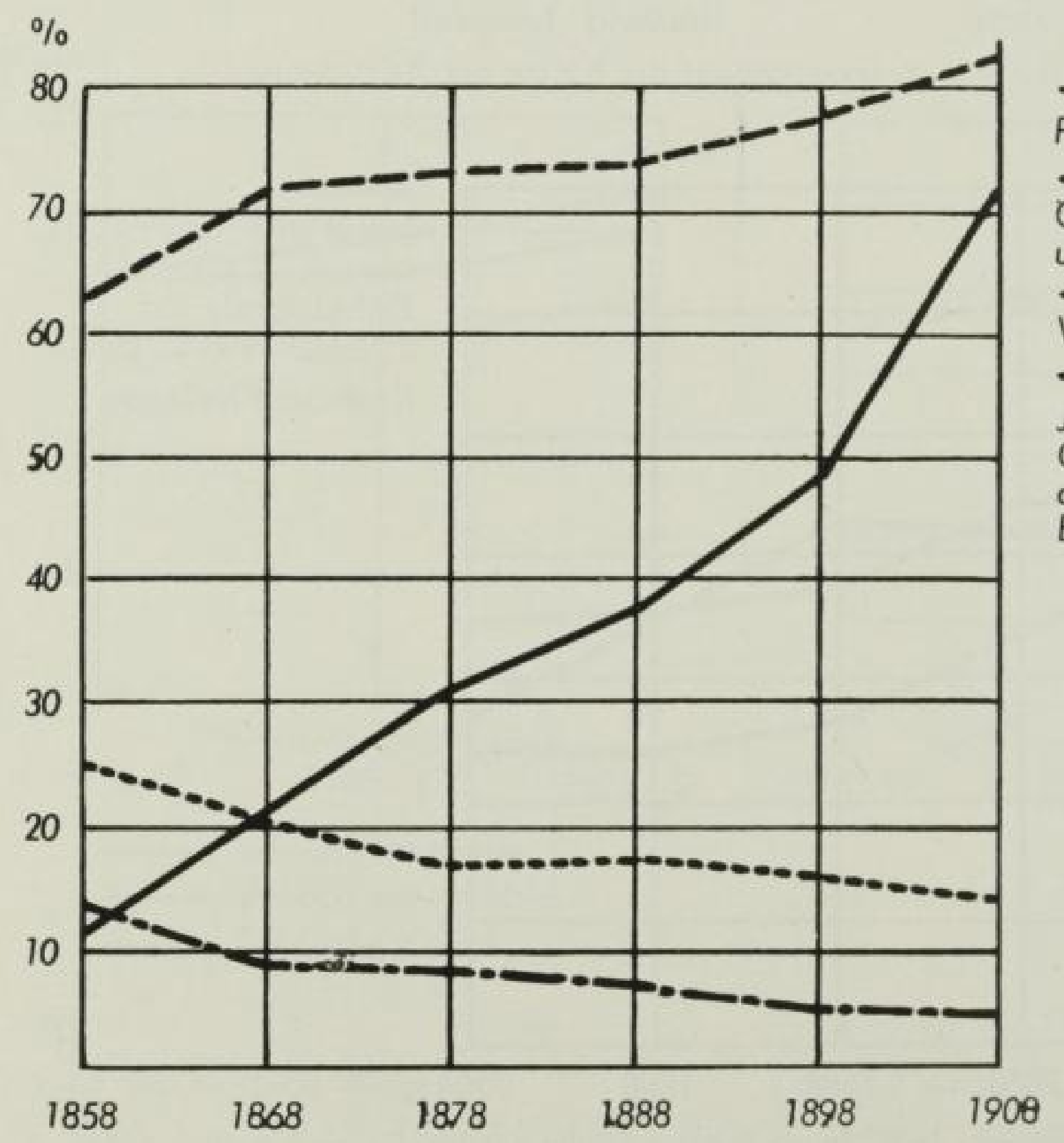

Privatverbrauch \% -on-s

Offentliche Beleuchtung und Selbstverbrauch Verlust \%

Jährlicher nutzbarer Gasverbrauch auf den Kopf der Bevölkerung $\mathrm{m}^{3}$

Bild 143 Verteilung der Gasabgabe in Prozenten des Gesamtverbrauches 


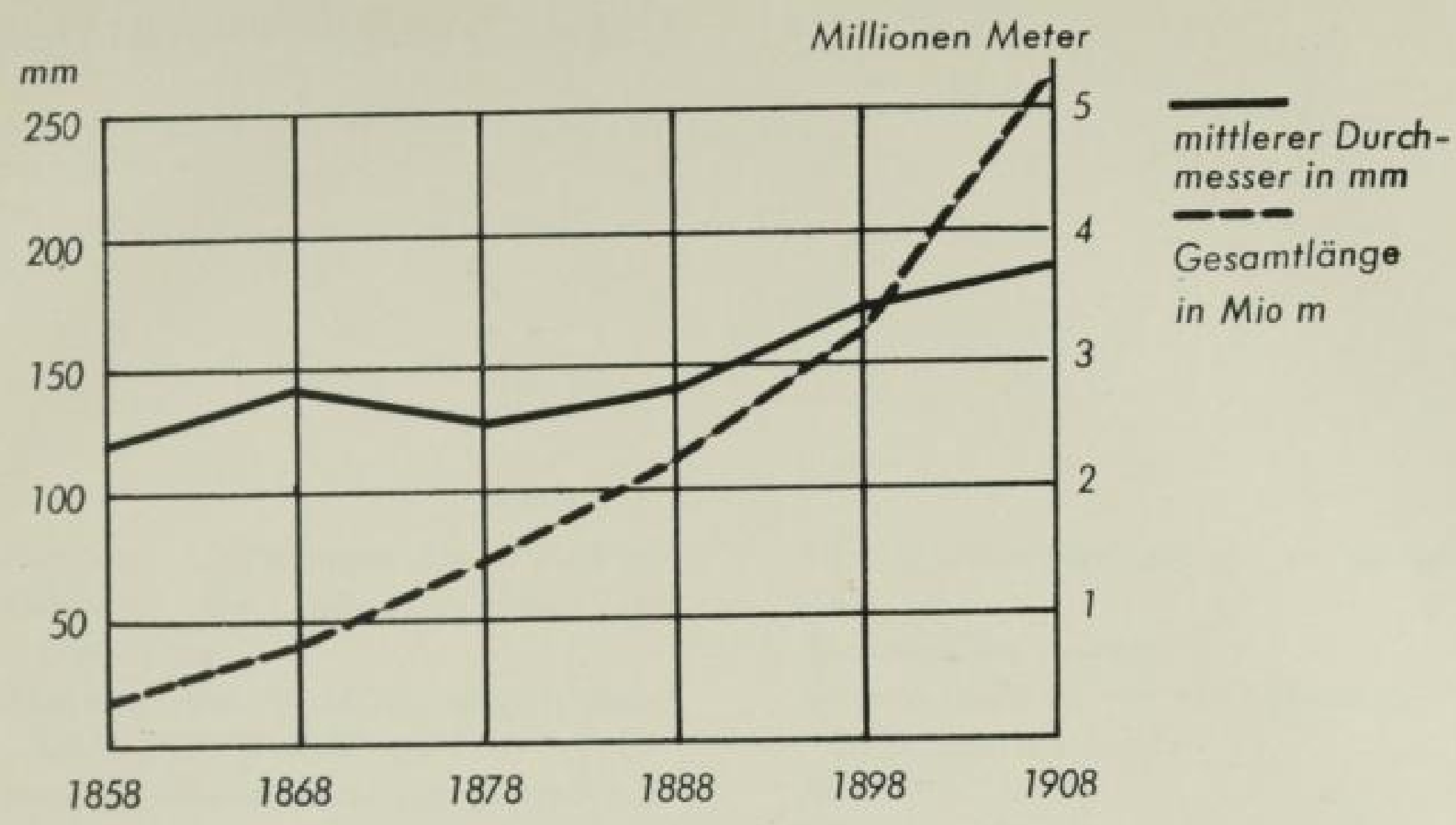

Bild 144 Länge der Hauptleitungen

\section{SLUB}

Wir führen Wissen. 
\$itso:

\section{SLUB}


Abteilung: Gaserzeugung des DVGW 521

Abtcilung: Gas, Wirtschaftsfragen des DVGW $\{23$

Abteilung: Gas Wirtschaft und Betriebsführung des DVGW 523

Abteilung: Wissenschaft und Unterricht des DVGW $\$ 21$

Accum, Friedrich 56, 58, 62, 63, 67 ff, 71. $73,74,77,78,79,80,82,83,84,85,86$.

$87,89,94,112,128,132,138,271,618$

Ackermann (Buchdrucker) 71, 72

Adolfshütte, Kaolin \& Chamottewerke. Crosta 434

Aerogen Gas Gesellschaft. Hannover 364

Aerzener Maschinenfabrik $\mathrm{GmbH}$,

Adolf Meyer Azrzen b/Hameln 201, 533 Aetna Iron Works 152, 156

Ahrens (Merseburg) 507, 576

Ahrens, F. (Berlin) 395

Aicher, Gustav 385, 433

Aktiengesellschaft für Eisenbahnbedarf, Berlin 119

Aktiengesellschaft der Städt. Elektrizitätswerke, Berlin $18 \mathrm{I}$

Aktiengesellschaft für automatische Zünd $\mathrm{u}$. Löschapparate, Zürich 398

Aktiengesellschaft für Gas und Elcktrizität, Köln 331, 337, 492

Aktiengesellschaft für Gas-, Wasser- und Elektrizitätsanlagen, Berlin (Agwea) 337 , $386,49 \mathrm{r}$

Aktiengesellschaft für Kohlenwertung (später Ruhrgas A.-G.), Essen 426, 456, 457 . $488 / 89,491,494,495,530$

Aktiengesellschaft für restlose Vergasung. Frankfurt a/M. 442, sio

Aktiengesellschaft für Selasbeleuchtung 392 Aktiengesellschaft für Stickstoffverwertung 374

Aktiengesellschaft Sächsische Werke $\$ 12$
Albrecht, Alexander 340, 359, 411, 452, 468,

$$
543.547
$$

Alexander der Grofye 18

Alexanderwerk A. von der Nahmer A.-G. Remscheid 466

Allen, A. L. 207

Allemagne, M. d.' 32

Allgemeine Deutsche Creditanstalt (Adca). Leipzig 537

Allgemeine Elektrizitäts Gesellschaft (AEG) Berlin $180,223,500$

Allgemeine Gas A. G., Magdeburg 122 . 179,229

Allgemeine Vergasungsgesellschaft, Berlin 506

Alliata G. 435, 525

Allner, Waldemar 371, 402, 413, 437

Althans 55

Altwill 212, 361

Aluminium Gesellschaft, Neuhausen 223

American Askania Corporation, Chicago 583

American Furnace Co 411

American Gas Association, New York 323. 442,525

Ammoniakverkaufsvereinigung $372,427,428$ Amt für deutsche Roh- und Werkstoffe 487 , 516

Amt für Technik 487

Anderson, George William 437, 519

Anderson, William 402

Andre 47

Andreac, B. 212

Arbeitsgemeinschaft der Verbände von Gas- und Wasserwerken. Wiesbaden (AVG) 604

Arbeitsgemeinschaft Forschungszwecke Ga: 487

Arbeitsgruppen des Deutschen Vereines von Gas- und Wasserfachmännern $4^{86}$ 
Arcet d' 142

Aremberg, Louis Engelbert v. 29

Arlande, d' 28

Armstrong, E. F. 87, 137, 511

Arnemann, C. 500,506

Arnold (Konstanz) 528

Askaniawerke A.-G., Dessau 428, 452, 458. $502,513,533,539,545,547,548,555,583$

Association des Gaziers Belges 323

Association of Gas Managers for Scotland 323

Attig, Walter $56 \mathrm{I}$

Auduin, Paul 234, 235, 275

Auer v. Welsbach, Carl 182, 283, 284, 339. 399, 6II

Aumund, H. 355

Auskunfts u. Beratungsstelle für Teerstrafenbau e. V., Essen 446

Australien Gas Light Co, Victoria 58I

Baader, Joseph v. $90,9 \mathrm{I}$

Badische Anilin- u. Sodafabrik, Ludwigshafen $236,360,373,568$

Badische Biographien 250

Badische Landesgewerbehalle (später: Bad. Landesgewerbeamt) 251, 315, 379

Bäcker, W. 188

Bähr, H. 426

Baltischer Verein von Gas- und Wasserfachmännern 639

Bamag, Berlin-Anhaltische Maschinenfabrik A.-G., Berlin 195, 202, 219, 238, 239, 258 . $259,260,332,344,359,378,387,388,398$. $402,410,415,434,447,452,527,533$

Bamag-Meguin A.-G., Berlin 510, 520 , 522

Bamberg Carl, Friedenau 428, 452

Banks, Sir Joseph 72

Bandsept 279

Barber, John 27

Barbier 32

Barlow, George 132

Barlow, James 63, 132

Barlow, Thomas Greaves 80, 124, 132, 173. 272,280

Barlow \& Co $n 6$

Barlow und Manby 170

Barking, Herbert 575

Barnes, R. is 8

Bauer, G. 521

Baum K. 503
Baumeister, L. 280, 315

Bausch, Herbert 36 ;

Bayerische Landesgewerbeanstalt, München 341

Bayerischer Verein von Gas- und Wasserfachmännern 639

Bayer \& Co, Leverkusen 236, 434, 446

Beale (Sauger) 144

Beale J. T. 235

Bebel, August 400

Becher, Joh. Joachim $24 \mathrm{ff}, 27,94$

Beck, Simon Adams 258

Becker, Christian 99

Becker, Julius 375

Beckmann, Ernst 471

Beckmann, Johann 26

Becquerel, E. 290

Behr (Kolberg) 404, 447

Behrens, Heinz $481,486,542$

Beischlag, R. 499

Bell, A. 221

Below, E. 200

Benckiser, August 280

Bengel \& Listard (Frankreich) 291

Benham \& Son 291

Benzolverband 428, 429

Berard, P. 275

Beratungsstelle für Rohrschutz 590

Berdenich, V. 224

Bergius, Friedrich 444

Berlin Anhaltische Maschinenfabrik A.-G. - siehe Bamag -

Bernheim, E., Düsseldorf 410

Bernt \& Cervenko, Prag 395

Bertelsmann, Wilhelm 376, 403, 451, 462, $4^{85}$

Berthelot, Marcellin P. E. 223, 224, 225, 228 , 270, 586

Berthollet, Claude Louis 69

Bertin, Lucien 28, 31, 32, 33

Bertrand 23

Berufsgenossenschaft für das Gas- und Wasserfach 320

Berufsverein für das Energie- und Wasserfach (vgl. Verein technischer Beamten u. s. w.)

Berzelius, Jöns Jacob 57

Besemfelder, Eduard R. 348, 358, 359, 36r, 440

Bessin. Max 266, 389, 459, $4^{82}$

Beumer, Dr. (Politiker) 331 


\section{Bihl, Ernst 47}

Bihl, J. G. 47

Biltz, Wilhelm 152, 154

Bindewald (Kaiserslautern) 371

Bischoff, Gottfried GmbH., Essen 518, 519 . 587

\section{Bisschop 311}

Black, Joseph 13

Blank 397

Blał, E. 214, 359

Blau, H. 364

Bloch, Dr. L. 432

Blochmann, G. F. Rudolf 47, 56, 90, III, 624

Blochmann, Rud. Sigismund 47, 56, 91, 109. $110,111,116,117,118,119,135,145,167,172$, $270,624 \mathrm{ff}$

Blochmann, Georg Moritz Sigismund 109. 112, 119, 150, 624, 628

Blochmann, Dr. Reinhold 270, 271

Blomquist (Höganäs) 432

Blum, Emil 360,402

Blume, Kurt (Bayreuth) 467, 477

Blume, (Potsdam) 628

Böhm, O. 306

Boetticher, A. 168

Bolstorff (Essen) Beigeordneter 427

Bolton, F. J. 242

Bolz, Christian 347

Bonc, W. A. 4 ro

Bonecourt Surface Combustion Ltd 410

Borchardt, Andreas 518

Borchardt, C. 359

Bormann, J. G. L. 363

Born, H. 171

Bornkessel $4 \mathrm{II}$

Bornschein, (Chemiker) 56

Bosch, Robert, Stuttgart 555

Bose, E. 328

Botley, E. 233

Botley, Charles Frederic 233

Boudouard, O. 219, 362

Boulanger, Georges Ernest 181

Boulton, Matthew 13, 51

Boulton \& Watt, Soho 38, 39, 51, 54, 55.

$$
\text { 70. } 614,615
$$

Bourdou 267

Bowditch, W. R. $81,143,276$

Boyden, Ulrich A. 267

Boyer 359

Boyle, Robert 21, 26
Brabant, M. $89,140,150,57^{8}$

Brabbée $44^{8}$

Brande (Hannover u. London) 67, 72, 143

Brandl, A. (Wien) 533

Brandt, H. 521

Brandt, Johannes 332, 333

Brauer, Eberhardt 374

Braunholtz, Walter T. K. 345

Braunkohlenschwelkraftwerk A.-G., Hessen 506/507

Braunkohlen- und Brikett-Industric A.-G. (Bubiag) 507, 576

Breckon, Robert 193

Bredig, G. 369, 370

Brehm, H. 197

Breisig (Wien) sto

Brender à Brandis, G. A. 520

Brennkrafttechnische Gesellschaft 508 Brennstoff-Technik G.m.b.H., Essen 508

Brinitzer, Carl 57

British Association of Gas Managers

(später: Institution of Gas Egineers) 323 British Commercial Gas Association 403

British Methan Limited, London 585

Brönner, T. 275

Brooman, R. A. 235

Brockhaus, (Lexikon) 44

Brownhill, R. W. 265

Brückner, Horst $501,518,526$

Brümmerhoff, W. 545

Brüning (Reichskanzler) 476

Bruhn (Rathenow) 435

Brunck, Franz 374

Brunklaus, Henri J. 99, 516, 528, 529

Brunton, John 137,138

Bucerius, Walter 379

Buderussche Eisenwerke, Wetzlar 99, 530

Bueb, Julius 233, 249, 255, 288, 344, 345, 346, $347,348,350,373,381$

Bucb, Wilhelm 504

Büchner, F. 373. $3^{80}$

Bünhe A. \& Co., Freiburg 385

Buhe, A. 250,356

Buhe, E. 356

Buhk 340

Buhle, M. 354

Buhlmann 396

Bundesbank 565

Bundesministerium für Wirtschaft 569

Bunsen, Robert Wilhelm 127, 128, 130, 131, $132,153,154,155,188,251,326$ 
Bunte, Hans 165, 183, 184, 188, 204, 210, 213. $214,218,220,224,228,233,242,249,252$, $270,272,273,292,293,306,318,321,322$. $325,326 \mathrm{ff}, 329,334,374,381,382,390,391$, $471,611,642$

Bunte, Karl 391, 406, 408, 426, 432, 435, 436, $439,443,446,449,450,451,464,471 \mathrm{H}$. $503,517,518,519,525,526,531,534$

Burgbacher, Fritz 542,573

Burgemeister, Fritz 385

Burkheiser, Karl 375, 376, 377, 381

Burns, James 58 ;

Busch, Bremen 364

Buss, Sombart \& Co., Magdeburg 311

Busse 349

Butzwerke A.-G., Berlin 54s

Caglievina (Wien) 306

Carcel 273

Carlisle, Sir Anthony 67

Carlyle, Thomas 562

Caro, Dr. N. $360,374,396$

Cerasoli, T. sII

Chamberlain 180

Chandler, Dean 18, 22, 23, 27, 61, 68, 70, 72, $74,77,81,82,87,106,124,143,156,157,614$ Chandler, S. 240

Chappuis, L. und Pignot 514

Chardonnet 396

Charles 28

Chaussenot 276

Chaussier, François 23

Chelton, Fr. H. 206

Chemische Werke, Hüls 586

Chemische Werke Rhenania, Nieder-Ingelheim $53 \mathrm{I}$

Chemisch-Technische Gesellschaft, Duisburg 500

Chem.-Techn. Prüfungs- u. Versuchsanstalt, Karlsruhe 273,328

Chemisch-Technische Reichsanstalt 556

Chevalet, L. 238

City of London Gas Co 138, 145

Clamond, Ch. 282, 315

Clark, L. J. 585

Clasen (Berlin) 460,465

Claude, G. 225

Claus, Carl Friedrich 247

Clayton, John 21, 22, 6r5, 616

Clegg, Samuel d. A. $38,61,63,68,69,70 \mathrm{ff}$, $78,81,82,83,84,85,139,230,318$
Clegg, Samuel d. J. 22, 54, 71, 75, 76, 79, 84 . $85,98,127,128,129,131,133,134,137,141$. I43, 145, 159

Cleland, W. (Liverpool) 245

Cliff, W. D. 196

Cobb, John W. 443

Cockerill, John 56, 109, 149

Coke and Gas 126, 581

Colladon, D. 233,240

Compagnie Francaise de l'Acéthylène dissous 226

Compagnic Parisienne de Gaz 125

Concordia (Zeche), Oberhausen 514

Condurier (Lens) 248

Constam, E, J. 378

Congreve, Sir William $72,86,105 f, 110$ Constok 585

Cook, Benjamin ss

Cooper 24I, 249

Cooper, Stanley G. 374

Covent Garden Theater 87

Cowan, Joseph \& Co 135

Cowan and Warner 263

Coze, André 183, 184, 191, 378

Creighton (Soho) 53

Creighton (Glasgow) ${ }^{142}$

Crell, Lorenz Friedr. v. 49

Croissant, H. 359

Croll, Alexander Angus 125, 143, 152, 185 Crompton 182

Crossley, Henry 76, 158, 267, 313

Cruikshank 283

Czakó, Emmerich 525

Daeves, Karl 474

Daimler, Gottlieb 309

d'Allemagne, H. 32

d'Arcet 142

Dalton, John $70,83,127,128,131$

Dampfkessel u. Gasometerfabrik vorm.

A. Wilke \& Co., Braunschweig 258 .

Danger, Hamburg 468

Daniell 87, 106, 114, 289

Danish Gascompany, London 126, 292

Davidson, G. 370

Davy, Sir Humphry 69, 127, 130, 131, 269 de Brouwer (Brügge) 195, 342, 344, 378 Debruck (Düsseldorf) 362

Deckert (Hamburg) 545

Defrics, England 158

Deliwick, C. 183, 217, 219 
Demag, Deutsche Maschinenfabrik A.-G., Duisburg 579

Demann, Walter $\$ 23$

Dempster, Robert \& Sons Ltd, Elland Yorks 54

Denayrouze, M. L. 285, 393

Denis, St. 291

Dent, Dr. F. J. 574

Deringer, Winterthur 588

Desaga, C. Heidelberg 154

Dessauer Vertikalofengesellschaft 347,350 , 434

Dettmar, G. 340

Deurag. Deutsche Raffinerie A.-G., Hannover 513

Deutsche Aucrlicht Gesellschaft, Berlin 392

Deutsche Continental-Gas-Gesellschaft, Dessau $110,117, \pi 18 \mathrm{ff}, 173,174,177,179,18 \mathrm{I}$, $187,203,220,221,240,254,258,263,266$. $267,291,292,293,312,313,314,328,329$, $330,337,345,346,371,387,401,404,413$, 429. $455,471,472,491,492,494,512,514$. 521

Deutsche Edison Gesellschaft, Berlin 180 . 181, 314

Deutsche Gasgesellschaft, Berlin 429

Deutsche Gasglühlicht Aktien-Gesellschaft. Berlin 332, 394, 396

Deutsche Gaszünderfabrik, Elberfeld $39^{8}$

Deutsche Gold-u. Silberscheideanstalt (Degussa) Frankfurt a/M., 316

Deutsche Mondgasgesellschaft 360

Deutscher Normenausschufy $4^{8} 4$

Deutscher Städtetag 489, 495

Deutscher Verein von Gas- u. Wasserfachmännern

(auch kurz „Verein“ genannt)

vgl. Verein der Gasfachmänner Deutschlands 121, 167, 184, 188, 190, 195, 200, 227. $240,261,292,322,330,335,336,352,357$. 363, 402, 408, 409, 416, 418, 420, 423, 424. $425,426,431,432,438,443,445,451,454$. $455,457,459,479,481,483,485,486,487$. $512,514,521,523,529,535,536,540,541 / 42$, $552,557,563,573,576,590,594,604,605$, 607,639

Deutsche Shakespeare-Gesellschaft 121, 330

Deutsche Stickstoff G.m.b.H. 374

Deutsche Wassergasgesellschaft DellwickFleischer, Essen 219
Deutsch-Luxemburgischer Bergwerksverein 447

Diaphragm and General Leather Co Ltd 152

Dickens, Charles 64

Didier, Friedr. Ferd. $131,504,628$

Diehm, Carl 35

Diesel, Rudolf $15,284,314$

Diesel, Eugen, 284

Dietz (Osnabrück) 452

Dillgardt, Just (Essen) $4^{87}$

Diller 27, 60, 616

Dinnendahl, Franz 55, 56

Dinsmore, J. 147, 204

Dirnsdale, Th. J. 205

Distrigaz, Brüssel 586

Dixon, Robert 193, 270

Döbereiner, Johann Wolfgang 35

Dölling. Louis d. Ä. $17 \mathrm{I}$

Dörr (Berlin) 432

Dolch, Paul $14^{8}$

Dolensky (Frankfurt) 439

Dollfuss 236

Dollinger, J. 502

Domann, Friedrich 574

Dommer, Otto 452

Dowson, J. 214, 215, 315

Drawe, Rudolf $443,479,495,501,511,512$, 574

Drehschmidt, Heinrich 248, 263, 376, 395

Drory, Edward 342, 642, 643

Drory, Lennard 107, 108, 172

Drory, Leonhard George 643, 644

Dubochet, Vincent 139, 144, 185

Dubois, Erich 503,528

Duckham, Arthur 348

Duckwitz, Arnold 120, 121

Dürer, Albrecht, 17

Duff 352

Dujardin \& Co.. P. F., Düsseldorf 411

Dumas, Jean Baptistc 149, 275, 316

Dundonald, Lord 27, 53, 6I, 6I5

Dux A.-G., Metallwarenfabrik deutscher

Gaswerke, Frankfurt a/M. 427, 428

Dwight, G. S. $2 \mathrm{II}$

Dworkowitsch 221

Eberle, Christian, Darmstadt 448

Eberle, Emil 460

Ece-Economic Commission for Europe 570 Eck, Fritz 574 
Edge 267

Edison, Thomas Alva $177,178,180$

Eduard, I., König von England 617

Edwards, David Oven 153, 154, 158

Egells, Franz Anton J., Giefjerei, Berlin II0, 628

Egestorff, Georg, 312

Ehlers, Bremen 116

Ehrich \& Gractz, Berlin 394, 395, 463

Eilender, W. 549

Einsiedel, Graf III

Eisele, W. 296, 386, 454

Eitle, C., Stuttgart 193, 343, 378, 379

Eitner, Paul 233, 328, 447

Elektra A.-G., Dresden 490

Elektrizitätswerk Westfalen, Dortmund 337

Elektrotechnische Zeitschrift 432

Ellisen, Robert 18, 27

Elsholtz, Johann Sigismund 21

Elsner, R, W. 153, 154, 158, 159, 160, 302, 628

Elster, Johannes 460

Elster, Stiegmar $167 f, 173,210,238,266$. $272,275,279,628$

Elster \& Co A. G., Mainz-Kastel 168, 264. 590

Eltgas G.m.b.H., Leipzig 537

Elvers, Hans 485

Enderle, (Ettlingen) 443

Endenthum 290

Energie A.-G., Oetsch-Mark-Kleeberg $49^{\circ}$

Engler, Carl 225. 327, 358, 471

Epplen, München 293

Erdmann, E. 363, 520

Erdmann, O. L. 172

Ericsson, John 186

Erlenmeyer, Emil 326

Erste Bruchsaler Herdfabrik 568

Erxleben 23

Eschebach \& Haussner, Dresden später: Eschebachwerke, Dresden 296. 298, 406

Escher, F. Zürich $460,465,4^{85}$

Essich, O. 469

Esso, Hamburg 581

Etzel, Franz 571

Europäische Gemeinschaft für Eisen und Stahl (Montanunion) $569,570,573$

Europäische Wassergasgesellschaft, Stockholm 211, 214
Everard, Stirling 63, 68, 83, 84, 85, 106, 125 . $138,145,148$

Ewart \& Son, Ltd. 295

Eymann, Constanz 575

Ezechiel (Rabbiner) 18

Faas, A. 319

Faber du Faur, Achilles Christian Wilhelm Friedrich 57

Fabrikantenvereinigung im Gas- und Wasserfach (Fagawa) 478, 482, 484, 509, 532, $538,540,557,605$

Faehndrich, G, 121, 182, 203, 284

Fafnierwerke, Aachen $4^{14}$

Fages, (Narbonne) 282

Fahlberg, Constantin 237

Fahnehjelm, O. 283

Falck (Detmold) $54 \mathrm{I}$

Faraday, Michael $88,127,152,153,154$

Farbwerke Höchst 586

Farçot 140

Farmer 212, 361

Faujas de Saint Fond 28

Favre, P. A. 131

Fehling, Hermann v. 326

Feld, Walther 373, 375, 376, 381, 587

Feldhaus, Franz Maria 84, 168

Fellner \& Ziegler, Frankfurt a/M., 438, 500 Ferbers, Wilhelm 451

Ferguson, John 21

Ferngasgesellschaft Saar m.b.H. 498, 499

Ferngas Schlesien A.-G. 492

Ferngas Sudetenland 560

Ferngasversorgung Rheinprovinz 491

Ferngaswerk Erfurt A.-G. 454

Fernversorgung Niederschlesien 491, 492

Fernversorgungsverband Hohenstein-Ernstthal 455

Ferrari, E. C. 149

Féry $3^{8} 3$

Figawa, Technische Vereinigung der Firmen im Gas- und Wasserfach, Dortmund 605

Fink, Dr. 412

Fischer, Emil 382, 471, 517

Fischer, Ferdinand 228, 24I, 242, 289, 327 ,

Fischer, Franz 382, 437, 588 382

Fischer, Paul 407, 459, 468

Flasshoff s5

Fleck, Alexander 21, 27, 617 
Fleck, H. 228

Fleischer, J. 183, 218, 233

Fleischhauer, R. $23^{8}$

Flesch 575

Fletscher, Thomas 297

Flürscheim, M, 256, 267, 275, 280, 315

Ford Motor Co., Dagenham 529

Förster, Hubert 368

Förtsch, (Ludwigshafen) 375

Fontana, Felix 35

Forster, W. 24I

Foulis, William 191, 198, 232, 242, 249

Francke, Carl (Bremen) 332, 344, 435

Frank'sche Eisenwerke, Niederscheld 448

Frank, A. 223, 360, 374, 396, 414, $43^{8}$

Frank, Fritz 500

Frank, M. (Dresden) 407

Franke, Georg (Delmenhorst) $44^{8}$

Franke, W. (Dortmund) 171

Franke, W. A. $4^{85}$

Frankenstein 283

Frankfurter Gasbereitungsgesellschaft auf Aktien $\mathrm{I}_{4}$

Frankfurter Gasgesellschaft (neue s. Neue Frankfurter Gasgesellschaft) 421, 428, 439. $466,480,493,506,518$

Frankfurter Wassergas-Syndikat System Dellwick-Fleischer 219, 359

Frankland, Edward 132, 270, 276

Frankland, Percy F. 248, 270, 271

Franklin, Benjamin 453

Fraunhofer, Joseph 91, 624, 625

Frei, Erwin 545,555

Freic Vereinigung Deutscher Installateure $34 \mathrm{I}$

Frenzel 47

Fremy, E. 316

Frerichs, G. und Normann, Bonn 468

Freund, Julius Conrad, Maschinenfabrik. Berlin no, 628

Freund, Fr. $33^{8}$

Friedleben, Th. 232, 275

Friedrich (Zerbst) 442

Froitzheim, E. 253

Frundsberg, Georg v. 17

Fuel Research Board 450, 505

Gabrielenhütte (Gräflich Bucquoische Eisenwerke) 58

Gadd u. Mason, Northwich 261

Gärtner, A. 300

42 Geschichte der deutschen Gasindustrie

\section{Galoszy 576}

Gareis, J. 201

Gasanstaltsbetriebsgesellschaft, Berlin 332 Gasbahngesellschaft, Dessau 313

Gasbetriebsgesellschaft, Berlin 429, 434, 459 . 547

Gasch, Robert 228, 249

Gas Council, London 575, 585, 614

Gasfernversorgung Saale, Halle/Saale 492

Gasgemeinschaft 402, 540

Gasinstitut, Karlsruhe (Lehr- u. Versuchsgasanstalt) $428,448,452,464,465,472$, $483,485,487,502,517,556,561,563,578$. $589,590,594$

Gas Integrale, Mailand 574

Gas Journal (s. a. Journ. of Gaslighting) $65,66,148,153,156,157,158,210,288,289$. 291, 295, 297, 298, 300, 301, 302, 303, 349. $580,581,585,597,602,613$

Gaskalender 238

Gaskokssyndikat 427, 429

Gaskoksvertriebsgesellschaft, Berlin 335 Gas Light and Coke Co., London 63, 67, $71,73,74,77,78,79,83,86,100,105,134$ 135, 145, I48, I5I, 186, 210. $215,217,246$. $258,259,348,407,422,505,532,577$

Gasmesserfabrik Mainz, Elster \& Co siehe Elster \& Co A. G. Mainz-Kastel

Gasmotorenfabrik Deutz 309, 311, 314

Gasmuseum Charlottenburg 402, 460

Gastaschenbuch 607

Gastechnik A.-G., Oberhausen (RId) 587

Gas- und Stromversorgung Mittelsachsen 492

Gasverbrauch, G.m.b.H. Der 427, 460, 485 , $486,537,540$

Gasverkauf, Der 6o5

Gasversorgung Magdeburg-Anhalt (Gamanag) Magdeburg 492, 494

Gasversorgung Rheingau 454

Gasversorgung Westsachsen A.-G. 455

Gaswärme (Zeitschrift) 607

Gaswärmeinstitut, Essen 487,607

Gas World 233

Gautier \& Co, Paris 3 II

Gaz de France 40, 41, 42, 564, 592

Gebr. Körting, Hannover 188, 236, 3II, 371, $4 \mathrm{I} 3$

Gebrüder Remy, Rasselstein bei Neuwied I05

Gebr. Sulzer, Winterthur $447,44^{8}$

\section{SLUB}


Geck, Werner 545

Geelen, Jacq 29

Gegi, Gaz à l'Eau et Gaz Industrielle 579. $58 \mathrm{I}$

Geiger, L. 36

Geilenkeuser, Hans 530

Geinitz 228

Geipert, Rudolf 362, 381, 419, 435, 442, 446, 524

Geith, I. R. 254

Gelsenkirchener Bergwerks A.-G. 254

Gemeinnützige Gasversorgungsgesellschaft m.b.H. im Saargebiet 490

Gengembre ${ }_{14} 8$

Gentsch 298

Georg III. v. England 38

Georg IV v. England 106

Geppert und Liese, Karlsruhe 388

Gerdes, Heinrich 357

Gerdes, H. Christian 485, 520, 521

Gerlach, G. Th. 242

Gesellschaft für Gasentgiftung, Berlin $\$ 20$. 521

Gesellschaft zur Förderung der Braunkohlengaserzeugung. Halle 492, 500, 507

Gesellschaft zur Wahrnehmung der Interessen an der Fernversorgung (Braunkohle) 494

Gesfürel-Ludwig Loewe, Berlin 491

Giersch 47

Giersen 212

Gieseking (Leipzig) 54I

Gillard, J. P. 282

Giroud, H. 271, 315

Gläser, Pforzheim 436

Glaser, W. $43^{8}$

Glasgow, Arthur G. 210, 218

Glover, Samuel 349

Glover, Thomas 152, 264, 350

Goddard, Ebeneser 156

Godesberger Badeapparatefabrik G.m.b.H 405, 406

Goebel, Bochum 435

Goehde, Richard 294

Göhrum, F. (Stuttgart) 338, 378, 391, 401, 413

Goethe, Joh. Aug. v. 34, 35, 36

Goethegesellschaft 330

Göttling 47

Goffin, E. $433,434,442,504$

Goldschmidt, F. so5
Goldschmidt, Karl 445

Gollmer, Walter $4^{88}$

Goos, G. 532

Gordon, David 88

Gosling, John 86

Gostkowsky (Lemberg) 313

Gouy 391

Gräfl. Einsiedelsches Eisenwerk Lauchhammer 110,112

Gräser, P. 172

Graf, Ernst G. 354, 508, 511, 520, 521, 576

Grafton, F. J. 134, 143

Grahn, Ernst 193, 194, 248

Grant, James Ludowic 63

Grashof, Franz 197

Great Central Gas Consumers Co., London 124,185

Greenwood, H. D. 563

Greineder, F. 401

Gridl, Jg., Wien 258

Griesheimer Autogen Verkaufs G.m.b.H., Frankfurt a/M. 553

Grimme, Natalis \& Co, Braunschweig 294

Grjimailo, G. 99

Grönegress, H. W. 553

Grosskinski, Otto 576

Grofygaserei Mitteldeutschland, Magdeburg $425,455,494,505$

Grothe, Theodor 360, 392

Gruber, M. 318

Gülich, Josef 504

Gümbel (Bruchsal) 541

Guglielminetti, Ernst 370

Guericke, Otto v. 20

Guillaume \& Co., Köln 265

Guldberg, Cato Maximilian 232

Gumz, Wilhelm 564, 575

Guner, St. Etienne 316

Guffrohrverband 453

Gutenberg, Johannes 17

GWF-System $\$ 24$

Gwynne. W. A. 206

Haas (Gasmesser) 264, 266

Haas, G. R. 538

Haber, Fritz 285, 294, 369, 374, 388, 449

Hack, Henry 193

Hadden \& Johnson 158

Hahn \& Kolb, Stuttgart 554

Halberger Hütte G.m.b.H., Brebach (Saar) 530 
Hales, Stephen 22

Hall 577

Hamilton, John 205

Hand, A. 373

Hannoversche Kolonisations- und Moorverwertungsgesellschaft, Osnabrück 360

Harcourt, V. 248, 295

Hardenberg, Karl August, Fürst v. 89

Hargreaves, James $6_{3}$

Harkort, Friedrich Wilhelm ss

Harlem, R. T. 443

Harlem Gas Light Co 126

Harris, G. W., 206, 207

Harries, Louis 443

Hartley, F. W. 288, 289, 291

Hartmann, Karl 409

Hartmann (Königsberg) 628

Hartmann, Richard $4^{87}$

Hase, Max 260, 368, 387, 420

Hase Dr. R., Hannover 383

Hasse, J. Theodor 230, 231, 347

Hassler, Fr. 122

Hastig 228

Haupt, C. 188

Haupt, Gera 403

Hauptgruppe Energieversorgung $485 / 4^{86}$

Heard, Edward 60, 61, 81, 249

Hecker, Eberhardt 595

Hefner-Alteneck, Friedrich v. 178, 272, 273

Hegener, August 188, 193, 283

Heike, Theodor 579

Heiligenstaedt, Werner 487, 549

Heim, Wien 252

Heinke (Petersburg) 242

Heintz, W. 129

Heintz, A. 289

Heinze, R. 505

Heise, Georg $4^{82}$

Heise, Johann Georg 91, 92

Heizkommission des Deutschen Vereines v. Gas- und Wasserfachmännern 335

Helfenstein 443

Helmholtz, Hermann v. 326

Helmholtz, Robert v. 270

Helmont, Johann Baptiste von 19

Hempel, Walther 204, 214, 219, 237, 382, 383

Henfrey 23

Henry, William 7I, 128, 129

Heräus, C. W., Hanau 290

Hermbstãdt, S. F. 49

Herning, Fritz 589
Herzberg, F. 431

Herzfeld, H. A. 538

Hef3, A. 225

Heł, Hermann Heinrich 131

Hessen-Nassauische Gas A.-G., Höchst 493 ..

Hessische Kommunale Gasfernversorgung (Hekoga) 493, 496

Heumann, K. 270

Hickey, R. G. 227

Hilgenstock, Gustav 367

Hillebrand 511,574

Hills, Frank Clark 143, 246

Himmel Aktiengesellschaft für Gasbeleuchtung. Tübingen 397, 399

Hinselmann Koksofenbaugesellschaft m.b.H., Essen 503

Hirzel, H. 222

Hodsman, H. J. 443

Hörder Bergwerks- und Hüttenverein 314

Hogg 282

Hoffmann (Berndorf) 437

Hoffmann, Gustav 366

Hoffmann, W. $4^{87}$

Hofmann, August Wilhelm v. 127, 236

Hofsäss, Max 390, 450

Hohtmann Frl. (Hannover) 294, 400

Holborn, Ludwig Friedrich Christian 383

Holl 313

Holzwarth, Hans 4I4

Homann Dr. (Norm. Eichungskommission) 264,287

Homann, Wilhelm, Vohwinkel 404, 465

Horn, Regensburg 26I

Horn, Gustav, Braunschweig 351

Horn, Wilhelm, (Bremen) 142, 188, 236, 25), 351

Horton 528

Houben, J. G., Sohn Carl, Aachen 295, 296, $299,303,305,404,406,407,466$

Hudler, J. 300

Hüssener, Albert 220

Hüttentechnische Vereinigung der deutschen Glasindustrie, Frankfurt a/M. 549

Hugershoff, Fritz 468

Hugon 3II

Hulett, D. 240

Hultmann, G. H. (Stockholm) 348

Humboldt, Alexander v. 57

Humboldt Maschinenbau A.-G., Köln-Kalk 447 
Humphreys, Alexander Crombie 209, 210

Humphreys, A. $4^{14}$

Humphreys u. Glasgow 210, 219

Hurdelbrink, F. 467

Hutchinson, Stephan 145

Huyghens, Christian 84

lbbetson, J. H. 87,148

Ibeg Industriebedarfs Gesellschaft, Innsbruck 574,579

Ibing, Hugo, Recklinghausen 581

Il Gas Integrale s. Gas Integrale

Imperial Continental Gas Association, London (I. C. G. A.) 100, $104 \mathrm{ff}, 110,112,114$. II), $116,118,126,159,167,181,258,262,264$. $267,322 / 23,342,346,376,378,410,427$. $622 \mathrm{f}$

Indugas 495

Institut für Kohlenvergasung, Wien $43^{8}$

Institution of Gas Engineers, London 323 . 325,411

Internationale Gas Union 485, 578, 588, 605 Internationale Wassergas Aktien-Gesellschaft Patent Strache 359

Intze, Otto 259, 260, 261

Investitionshilfe der Deutschen Industric 565

Irinyl 372

Jablochkoff 177

Jackson 301

Jacquet 302

Jahn, C.F.A. 275

Jars, M. 27

Jafyniger, Joh. Nep. 47

Jobard, M. 148

Jochum, P. 520

Joens, W. H., Düsseldorf 531

Johannsen, Otto 25

John, J. A. A.-G., Ilversgehoven 410

Jordi, F. 588

Joule, J. P. 131

Journal des Usines à Gaz 20, 43

Journal für Gasbeleuchtung (später: Gasu. Wasserfach) 163, 177, 187, 220, 222, 289. $312,326,405,421,471,472$

Journal Inst. Fuel $13 \mathrm{I}$

Journal of Gaslighting (später: Gas-Journal) $76,124,132,204,217,233,295,325$, $346,363,391,396,437,460$

Jungmann, K. 524
Junkers, Hugo 15, 288, 289, 298, 299, 314. $367,406,408,451,452,466,467,539$ Junkers \& Co $404,405,406,466,545,567$ Junker \& Ruh, Karlsruhe 294

Kahn, Richard A.-G., Berlin 465

Kaiser, Fritz ${ }_{467}$

Kaiser \& Schmidt, Berlin 290

Kaiser Wilhelminstitut für Heizstoffe und Krafterzeugung; später für Kohleforschung $382,437,586$

Kalle \& Co 236

Kaolin u. Schamottewerke, Adolfshütte 349

Karl August v. Weimar 35, 57

Karl II v. England 21, 26

Karl V, Deutscher Kaiser 18

Karle, W. 433

Karl Theodor, Kurfürst 624

Karmarsch, Karl 59, 60, 80, 85, 90, 127, 129. $132,133,142,145,173,289$

Kaf̧ner, H. 282

Kattwinkel, R. 426

Kaun, Heinrich 564

Kay, R. D. 235

Kayser, (München) 164

Kayser (Berlin) 447

Kellner, Otto 171, 249

Kemmer, Harald 520, 521

Kern, G. 336

Kerpely, Anton v. 353, 380

Kersten, O. 269,271

Kilchmann, Eduard 398

Killing, C. 395,463

Kindler, Fritz 468

King, Alfred is6

King, W. 238

Kirchhoff, Gustav Robert 326

Kirkham, Th, 140, 235, 240

Klass, Gert v. $4^{88}$

Klałmann sos

Klatte, Oskar 392

Klempt und Bonnet, Duisburg 380

Klingenberg, Georg $44^{8}$

Klinkerfues, Dr. 280

Klönne, August 188, 193, 195, 197, 238, 239. $242,254,259,347,352,433,434,527,529$ Kluge, Friedrich 19

Knapp, Friedrich Ludwig 321

Knoblauch, C. 252

Knoblauch, Johann Friedrich 112, 113, 252 Knoblauch, O. 467 
Knoch \& Co., Lauban 352, 360

Knoevenagel 375

Knorr, R. 299

Knublauch, Oskar 241, 247, 248, 249, 32I

Kobbert, Ernst 219, 359, 362, 406, 408, 455, 467

Köllner, Wilhelm 335, 605

Kölnische Maschinenbau A.-G., Köln-Bayenthal 258

Königliche Harzbergbauverwaltung 150

Königlich Sächsisches Amalgamierwerk

Halsbrücke bei Freiberg 59

Körner (Dresden) 402

Körting, Arnold s16

Körting, Ernst Friedrich Dietrich August 108

Körting, Ernst George Bernhard 325, 346, $362,378,387,402,406,416,420,426,433$. $449,451,641$

Körting, Ernst Gottlieb Waverley 20I, 311, 312

Körting, Johannes Friedrich Wilhelm 328, $382,474,482,547,54^{8}$

Körting, Leonhard 232, 236, 322, 343

Kohlenscheidungsgesellschaft 500

Kohlenveredelungs G.m.b.H.; später A.-G., Berlin 439, 500, 506

Kohlenwirtschaftsgruppe 478

Kolonialverein 530

Koning, B. 73, 91

Kontrollrat 563

Koop, H. 235, $43 \mathrm{I}$

Koppers, Heinrich, Essen 352, 353, 367, 374. $434,436,502,508,517,575,576,581,587$ Kordt, F. 368

Kornhardt, Wilhelm 135, 136, 140, 172, 628

Krämer, G. 204

Kractzer, A. 340

Krause, H. (Hamburg) 344

Krauss, Georg v. 205

Krautwurst, Franz $\$ 22$

Krecke, C. 508,536

Kretschmer od. Kretschmar 47, 73

Kridlo, V. A. 379

Krieger (Königsberg) 219

Kromschröder, G. 202, 263, 264, 266, 332, $360,452,459,468,555,590$

Krüss, H. 272, 273, 274

Krupp, Friedrich 219, 259, 268, 469, 505, 508. 509

Krupp-Grusonwerk, Magdeburg 314
Kuckuk, Friedrich 254, 375, 387, 404, 447, 540

Kudličz, J. 253, $379^{\circ}$

Küchler, Fr. 205

Kühlmann, Friedrich 374

Kühnell, C. August 135, 167, 176, 245, 278

Küppers, K. 389

Küppersbusch F, und Söhne, Gelsenkirchen 466

Kuhn, Gotthilf 200

Kunath, E. 232

Kunheim \& Co., Berlin 373

Kurlbaum, Ferdinand 383

Kutscher, R. Leipzig 302, 303, 406

Lacey, A. Douglas 18, 22, 23, 27, 61, 68, 70, $72,74,77,81,82,87,106,124,143,156,157$. 614

La lumière moderne, Paris 393

Laming, R. 143

Lampadius, Wilhelm August 13, 38, 47, 56 ff, $68,69,77,86,87,88,89,90,99$, 122, 156, 618

Landelektrizität Halle $\mathbf{4 9 2}$

Landesgasversorgung A.-G., Leipzig 490

Landesstelle für Gemeinwirtschaft (Sachsen) 426,455

Landesgasversorgung Süd-Niedersachsen 492 Langen, Arnold $3 \mathrm{HI}$

Langen, Eugen 308, 309, 310

Langer, Karl 242

Lapostolle, Alexandre 31, 32, 33, 49, $4 \mathrm{I} 4$

Lauchhammerwerk s. Gräfl. Einsiedelsches Eisenwerk Lauchhammer

Laurien, Helmut $580,584,606,607-610$

Lavoisier, Anton Laurent 13, 32, 33, 35, 37 . $47,48,68,83,84,130,148$

Layton, W. T. 21

Leblanc, Nicolaus 13

Lebon, Philippe $13,37,38,40 \mathrm{ff}, 47,48,50$, $51,52,56,60,61,64,66,81,94,122,156$

Le Chatelier, Henry 131, 270, 290, 328

Lechler, Paul, Stuttgart $45^{8}$

Lechner, A. 9I

Lee, George 54

Lee-Wilson 553

L.chmann, F. 259

Lehmann, Hermann H. A. 566

Lehr- und Versuchsgasanstalt, Karlsruhe (später: Gasinstitut) 389, 391, 471, 472

Leipziger Illustrierte 258,259 
Leipziger Neueste Nachrichten 35

Lempelius, Karl 402, 420, 427, 432, 459, 486, 501, 510,517

Lencauchez, A. 187

Lenoir, Jean Joseph Etienne 161, 179. 307. 308

Lenze, Franz 477, 518,519

Lenze, Philipp d. Å. 280, 397

Leprince $117,145,148,149,207$

Le Roux, A. 204

Lescombe, Edward 87

Leuna Werke, Merseburg 513

Lewes, Vivian B. 217, 218, 224, 270, 285, 358, 359

Lewis, J. 282

Ley, Francis 193

Leybold, W. $83,84,218,246,373,404$, 405

Leybold und Schmidt, Hamburg 373

Leykauff 254

Lichtenberg, Georg Christoph 34. 57

Liebig, Justus v, 127, 251

Lieckfeld, G. 312

Liegel, Georg 170, 188, 232, 236

Liese (Hamburg) 452

Limberg 500

Linde, Carl v. 363, 396, 511

Lindley, Sir William Heerlein 388

Lingens, Th. 486

Link Belt Co 198

List, Friedrich $64,65,66$

Livesey, Sir George Thomas 124, 185, 246, $262,275,396,642$

Livesey, Thomas d. Ä. 63

Lockemann, Georg 19, 49, 130, 131, 148, 154 , Is)

Lodge, H. 71

Ludwig Löwe, Berlin 360

London County Council 371

London-Greenwich Tramway 313

London Portable Gas Co 88

Loos, V. 363

Lorenz, Friedrich 318

Lorenzen, Gerhard $\$ 23$

Lother, Sir James 22

Lowe, George 123, 133, 134, 138, 145, 147, 148, I51, 159, 202, 271, 358

Lowe, T.S.C. 208, 211

Low Temperature Carbonisation Ltd., Lon ${ }^{-}$ don 506

Lubberger, F. $24 \mathrm{I}$
Lubszinsky, Ludwig 343

Lucas, Paul 392, 393

Ludwig, Bernhard 294, 425, 482, 534, 539

Ludwig der Heilige 18

Lüer (Essen) 445

Lührig 313

Luis, Jose 138

Lunardi 60

Lunge, Georg 214, 218

Lurgi Chemie Frankfurt a/M. 500, 508, 509. 522

Lurgi-Gesellschaft für Wärmetechnik,

Frankfurt a/M. 479, 495, 501, 512, 560, 575.576

Lux, Friedrich 231, 247, 248, 275, 290, 318, 382

Mac Adam, John, London 38

Macadam, St. 203

Macintosh (Glasgow) 316

Macintosh \& Co., London 254

Mackenzic 20s

Märkischer Verein von Gas- und Wasserfachmännern 432,639

Maffei, Peter Paul v, 91

Mahler, P. $183,228,288$

Maier-Kapferer 170

Main P. \& A. Ltd., Glasgow 291

Malam, John $75,77,78,82,83$

Malam (Dumfries) $23 \mathrm{I}$

Mallard, E. 131,270

Mallet, A. 153

Manhatten Gas Light Co 126

Mannesmann, Max 254, 394, 574

Mannesmann, Reinhard 254

Mannesmannwerke, Düsseldorf 517, 53 I

Maquenne 223

Marcus, Siegfried 202

Maréchal (Metz) 281

Marischka, Karl 352, 353, 354, 521, 533

Marshallplan s6s

Marti (Paris) 312

Martin (Mühlheim, Rhein) 249

Martini und Hünecke G.m.b.H., Berlin 531 Maschinenfabrik Augsburg-Nürnberg

(MAN) 371, 374, 457, 458, 527

Maschinenfabrik Oerlikon, Zürich 344

Maschinen- u. Bronzewarenfabrik L. A.

Riedinger, Augsburg 122, 123

Massachussets Technical Institute 443

Matschofy. Conrad 55, 56, 90, 140, 307, 311 
Matthews, William 52, 53, 55, 62, 68, 71, 74,

$$
\text { 77, } \mathbf{r}_{4} 6
$$

Maugham, W. 295

Maurach, H. 549

Mayer, Max 39r

Mayer, Robert 13r

Mazzas 369

Meeus-Van der Maelen P. J. 89, 126

Meguin 439, 44I

Meidinger, Johann Heinrich 103, 250, 304. 305, $406,407,408$

Meinert 47

Meister, Lucius \& Co., Höchst 236

Méker, Paris $4 \mathrm{II}$

Melan, Prof. 260

Melchinger 542

Menzel, F. 375

Menzel, H. 370, 391, 454

Merkens (Jnsterburg) $23 \mathrm{I}$

Merz, E. 400

Messinger, Fr. (Inspektor Berlin) 411, 4/2

Metherie, M. de la 23

Methven, John 144, 273

Metropolitan Railway, London 316

Meurer, Conrad auch C. Meurer A.-G. 340, 403, 407, 467, 546, 547

Meurer, Friedrich 406, 407

Meusnier 35

Mevissen, Gustav 258

Meyer, Adolf 201

Meyer, E. (Göttingen) 315

Meyer, Ernst (Dresden) 547

Meyer (Lexikon) 118

Meyer (Pintsch, Berlin) 380

Mezger, Robert 502, $510,519,520$

Micum, Mission interallié de controle des usines et des mines 424

Mile End Oil Gas Co 85, 145

Militärregierung 562

Miller, Oskar v. 556

Minckelers, Jan Pieter 29, 30, 31, 8I, 414

Minister für Volkswohlfahrt 546,547

Ministerium für Wirtschaft und Arbeit 516

Mitscherlich, Eilhardt 57

Mitteldeutsche Stahlwerke, Riesa 496

Mittelrheinischer Gas- und Wasserfachmännerverein 639

Mobil Oil A.-G., Bremen 48 r

Möllers, G. 372, 402

Mohr, A. 259

Mohr (Altenburg) 445
Mohrmann (Bremerhaven) 490

Moissan, H. 223

Moltrecht \& Co., H., Hamburg

Mond, Ludwig 215, 24I, 360

Mongruel, A. 202

Montanunion s. Europäische Gemeinschaft

Montgolfier, Jacques Etienne 28

Montgolfier, Joseph Michel 28

Morgenthaler 571, 572, 582

Morton, Henry 196

Morton, Robert

Morveau 23

Moser 47

Motorenfabrik Oberursel $4 \mathrm{I} 4$

Muchall, C. W. 276,28 ;

Müller, A., Charlottenburg 460

Müller, Emil 446

Müller, Hermann 293, 455, 485, 489, 503. 512,521

Müller u. Eichelbrenner, Paris 187

Müller u. Fichet, Paris 189

Müller und Korte, Berlin

Müller, W. J. (Wien) 520

Münchner Gasgesellschaft 163, 181

Münchner Kammerofengesellschaft 434

Muencke, Robert 317

Muizon, Houzeau 143

Muller, M. (Champignole) 202

Mundhenke, M. 107, 108

Munker, J. G. 200

Murdoch, William 13, 38, so ff, 56, 58, 61, $62,66,67,79,85,94,138,614 \mathrm{ff}$

Musäus, Johann August 34

Muspratt, James Sheridan 69, 82, 143, 144. $146,149,187,189,192,196,201,206,221$. $222,223,228,234,235,238,239,240,247$. $248,254,257,258,259,26 \mathrm{r}, 262,263,273$. 274,275

Nagel \& Co., Hamburg 267, 287

National Coal Gas Co 207

National Commercial Gas Association New York 4 oI

National Light and Heat Company 6r

Naumann, A. 212, 231, 440

Nebenprodukten Verwertungsgésellschaft deutscher Gaswerke, Frankfurt a/M 428 , 429

Neeff, Rico 410

Neff, Carl G.m.b.H., Bretten 568

\section{SLUB}


Nernst, Walther 328, 339.

Neilson, James Beaumont 73,85

Neuberg, E. $4^{13}$

Neue Deliwa Zeitschrift 605

Neue Frankfurter Gasgesellschaft 115, 166

Neue Gasgesellschaft Nolte \& Co., Berlin 173, 337

Neuffer, Wilhelm ${ }_{467}$

Neuman, F. A., Eschweiler 258, 529, 591

Neuwirth, Joseph 93

New York Gas Light Co 123

Nicholson, William 67

Niebaum \& Guterberg A.-G., Herford 512

Niederrheinische Licht- u. Kraftwerke A.-G., Rheydt 338

Niedersächsischer Verein von Gas- und

Wasserfachmännern 385,640

Niederschlesisch-Märkische Eisenbahn 169

Niederschlesische Gaswerks A.-G. 492

Niemann, M. 260

Niggemann, Herrmann sos

Noack, W. 571

Noll, Dr. (Hanau) 318

Nolte, Julius 338

Nolte, Wilhelm 173

Nordenscöld 47

Nordharzer Kraftwerke G.m.b.H., Goslar 454

Nübling, Richard 489,536

Nordharzer Kraftwerke G.móbóH., Goslar Nulandt, Louis 118,121

Nuf, Max 467

Oberschlesisches Kohlensyndikat $38 \mathrm{I}$

Oechelhäuser, Ph. O., Berlin 329

Oechelhäuser, Wilhelm d. Ä. 117, 119, $120 \mathrm{ff}$, $134,141,161,174,177,185,186,188,200$, 203, 234, 236, 238, 245, 256, 258, 264, 632, $64 \mathrm{I}, 642$

Oechelhaeuser, Wilhelm v. d. J. $184,267$. $284,288,307,314,315,320,322,326,328$, $329 \mathrm{ff}, 338,400,402,409,413,415,4^{18}$ OEEC Organisation for European Economic Cooperation 570. 571

Örlikon s. Maschinenfabrik Örlikon

Oest, Christian Ludwig 135

Österreichische A.-G. für Gasbeleuchtung. Wien 119,203

Osterreichische Auergesellschaft, Wien 339

Oest Wwe. \& Co., F. S., Berlin 135
Oldenbourg, Rudolf, auch R. Oldenbourg Verlag 78, 164, 165, 254, 267, 314, 395. 414, 4I5, 501, 503, 607

Onia, Office National Industrie de l'Azote 579, 581

Onslow, A. W. 408

Orsat, L. H. 290

Ortlieb (Berlin) 468

Ostwald, Walther 444

Ostwald, Wilhelm 232, 374

Ott, E. (Zürich) 407, 408, 444, 525

Otto Dr. C., Bochum 195, 243, 366, 367, 371, $374,435,504,508,574,575,584$

Otto, Nikolaus August 16r, 179, 307, $308 \mathrm{ff}$, 312,414

Paddon, J. B. 240

Palmer, Holsworthy 143

Papen v. (Reichskanzler) 478

Paracelsus Theophrastus Bombastus ab

Hohenheim 17, 18, 25

Parkinson \& Cowan, London 387

Paschke, Kurt 590

Passavant, Hermann 433

Pauwels, Antoine 89, 200, 261, 262

Pauwels u. Dubochet, Paris 139, 144, 185

Payer, Th. 510

Paziot 97

Peale, Rembrandt 126

Pease, E. Lloyd 261

Peckston, T. S. $77,80,83$

Peddinghaus, Paul Ferdinand, Gevelsberg 553

Peischer, O. 407,408

Pelouze, Eugène 234, 235

Pemberton, Josiah ss

Perissini, G. 247

Perkin, William Henry 127, 142, 234, 235

Perks, John 99, 106, 138, 139, 140, 141, 621

Permien, Martin 504

Perrott (Genf) 316

Perth, John Maiben ss

Peters, A. 352

Peters, Kurt 328

Peterson (Essen) 530

Pettenkoffer, Max v. 122, 130, 132, 146, 164. $165,172,318$

Pettit \& Smith, London 154, 156

Pfälzische Gas A.-G., Ludwigshafen $49^{8}$

Pfeifer, P. 260

Pfeiffer, E. G. 571 
Pfeiffer, O. 357, 382, 390

Pfleiderer Dr. Ing. 408

Pflug, Jena 35

Pharos-Licht, Klatte \& Co., Hamburg 392

Philipps (England) 291

Philipps, Joseph 28I

Philipps \& Lee, Manchester $52,54,85,614$. $6 \mathrm{r} 6$

Phillips, Reubon $82,83,143$

Phys.-Techn. Reichanstalt $382,460,484,510$, 533

Piatti, L. 523

Pichler, Helmut 586

Pickel, Johann Georg 23

Pictet, Raoul 225, 363, 437

Piger, Bos. 295

Pintsch-Bamag, Butzbach $168,169,258,287$, 587

Pintsch, Johann Christian 168

Pintsch, Julius $168 \mathrm{ff}, 219,222,283,287,288$, $347,353,395,396,434,439,440,442,443$. 458, 511, 522, 574

(auch J. Pintsch A.-G.)

Pintsch, Richard $169,170,284$

Pistor, F. 519

Pitt d. J., William 38

Plenz, Friedrich 444, 506, 521, 573

Plinius 18

Plutarch 18

Poggendorff (Lexikon) 128, 130

Pohling A., Köln 355

Pole Dr. 151, 387

Polenske, R. ${ }^{667}$

Ponsard 187

Popitz Dr. (Staatssekretär) 480

Popp, V. 282, 283

Porges C. A. 306

Pott, Alfred O. $427,438,439,456,457,4^{88}$

Power Gas Corporation 360

Prechtl, Joh. Jos. 56, 91, 93 ff, 97, 99, 127. 152

Preller, Ludwig 476

Prenger, Heinrich 402, 457

Prentice (Ipswich) 527

Preuf3 89

Preufyische Elektrizitäts A.-G. (Preag) 477 Preuffischer Minister für Volkswohlfahre 546

Preufyisch-Hessische Staatsbahn 395

Price, D. 235

Price, L. 280
Price, W. E. 352

Priestley, Joseph 47

Prince, A. 204

Pütsch, A. 257

Puricelli 166, 170

Quaglio, Julius v. 211, 212, 213, 283, 312

Rackhouse 80, 138

Radiant Heating Co Ltd., Leeds 4 ro

Raffloer 587

Ramsey, Sir William 363

Rankine, William John Macquorn 131

Rasch, G. 255

Raschig, Max 568

Raupp, August 171, 259

Raupp, H. 171, 280

Ravené (Berlin) I68

Redtenbacher, Ferdinand 104

Regnault, Henry Victor 275

Reichard, F. 267, 293, 296, 317, 406

Reichenbach, Georg Friedrich 90, 91, 624. 625

Reichenbach, (Chemiker) K. v. 142

Reichsarbeitsminister 556

Reichsfinanzminister $459,54^{2}$

Reichsgruppe Energiewirtschaft 498, 508 , 536,542

Reichsinnenminister 542

Reichskohlenrat 421, 423, 424

Reichskommissar für die Preisbildung $47^{8}$. 542

Reichskommissar für den Wohnungsbau 561 Rcichsstelle Gas 420

Reichsverband des Deutschen Gas- u. Wasserfaches $4^{85}$

Reichsverkehrsministerium $\$ 14$

Reichswerke Hermann Göring 498

Reichswirtschaftsminister $421,445,499,536$. 557

Reiher, H. 467

Reinecke, Josef Heinz, Physikalisches Laboratorium u. Apparatebau, Bochum 452, 502

Reinecker, Julius Eduard, Chemnitz 385

Reinhard (Hildesheim) 446

Reis 375

Reiset, Jules 130

Reisner, Essen 487

Reissig, W. 229, 290

Reissner (Berlin) 260 
Reparationskommission 422,424

Ress, Franz Michael 138, 140, 193, 195, 201, $238,241,283,353,501,518$

Retzius, Anders Johann 49

Reubold (Berlin) 378

Reutter, Carl 234

Rheinische Stahlwerke, Duisburg-Meiderich 445

Rheinisch-Westfälisches Elektrizitätswerk, Essen (RWE) $337,368,369,487,488$

Rheinisch-Westfälisches Institut für Wirtschaftsforschung 571

Rhein. Westf. Kohlensyndikat 362,381

Rheinisch-Westphälischer Verein der GasWasser- u. Elektrizitätsfachleute 32I, 454

Richter, Hugo 98, 531

Richter, Jeremias Benjamin 13

Ricks 148

Riebeck, A. 205, 577

Riebecksche Montanwerke A.-G., A., Halle 506

Riedinger, Ludwig August $122 f, 141,165$, $172,173,254,279,364$

Rieger, O. 590

Riepe, Eduard \& Co., Braunschweig 344. 351

Ries, Hans 243, 351

Riess, Dr. 489

Rietschel, Hermann 335, 536, 406, 408

Rincker \& Wolter 4IS

Ritter, E. R., Mannheim 340

Ritter, Wilhelm 171

Robb, J. 264

Robert 28

Robinson, Edinburg 153

Rodde, Ludwig 531, 547

Rodeck, F. 385

Roebuck, John so

Röhm, C, 459

Rössler, H, 316

Rogers, Samuel Baldwin 88

Rohland, Walter 552, 553, 595

Roots, Philander H. und Francis M. 201, 533

Rosenkranz (Riga) 380

Rosenthal, Hans 509

Roser Dr., (Mülheim Ruhr) 438

Rosier, Pilatre de 28

Ross, A. Q 193

Rostin Dr. 398, 517,521
Rothenbach, A. 398

Rother, R. 343

Rüdorff, Fr, 273

Ruhrgas Aktiengesellschaft, Essen 367, 427. $478,479,487,489,490,493,494,495,496$. $498,499,526,562,563,569,573,575,591$

Ruhrkohlenverband 424, 494, 512

Rumford, Graf 59, 79, 128, 130, 271, 624

Rummel, Kurt 549

Rummel, R. 575

Runge, Friedlieb Ferdinand 127, 142

Runge (Lademaschine) 193

Runkel, F. 446

Ruprecht von der Pfalz 25

Rutten, J. 249

Rutter, J. O. N. 157

Ruud, Hamburg 409

Saarferngas A.-G. (s. a, Ferngasgesellschaft Saar m.b.H.) 493

Sabatier, Paul 363, 519

Sackur, Dr. 319

Sächsisch-Thüringischer Verein von Gas-

u. Wasserfachmännern 455

Saint Denis (Frankreich) 291

Sainte Claire-Deville, Henri $76,228,390$

Samtleben, A, 286

Samuda 76

Sass, Friedrich 311

Saugeon, W. 509

Saunders 55

Sautter, L. 387

Schaak, Erich 525

Schack, Alfred 549

Schadeck 433

Schäffer, A. (Ingolstadt) 403, 544

Schäfer, Franz 89, 150, 225, 295, 313, 315, 340, $401,402,403,405,409,422,434,440,454$. 466

Schäfer, Hugo 526

Schäffer u. Walcker, Berlin 160, 204, 291, 293, 294, 302, 305

Schallenberg (Frankfurt a. M.) $43^{8}$

Schenk, M. (Wirling) 365

Schenk, Paul $57^{8}$

Schenzinger, Karl Alois 331

Scheuer (Landau) $44^{2}$

Schiele, C. 200

Schiele, J. G. R, 112, 113, 114, 115, 166

Schiele, Simon 115, 165, $166 f, 180,203,205$. $228,278,28 \mathrm{I}, 314,32 \mathrm{I}$ 
Schilling, Eugen 165, 220, 224, 228, 232, 303. $332,337,396,401,409$

Schilling, Nikolaus Heinrich 47, 78, 104. $115,124,127,128,129,132,133,136,139$. $14 \mathrm{I}, 142,143,151,159,163 \mathrm{ff}, 173,174,201$, $204,227,228,232,247,264,271,272,326$, 381,642

Schimming, G. 204

Schinz, C. 290

Schipke (Chemnitz) 435, 442

Schmidt, A. (Berlin) 480,490

Schmidt, Karl (Halle) 507

Schmidt-Giefjen 97

Schmidt-Hebbel 127

Schmiedt, Ernst 375, 447

Schmiedt, Hugo 391

Schnabel, Franz 64, 93

Schnabel, Rudolf 410

Schniewind, Friedrich Wilhelm Karl ${ }_{3} 66$

Schomburg, L. 451

Schreiber, Em. 290, 315

Schröter, M. 315

Sehroth, W. 510

Schüssl, Franz 574

Schulz, A., Spandau 528

Schulz, Knaudt \& Co., Essen 214, 253, 283 Schulz \& Sackur, Berlin 293

Schumacher, Ernst (Frankfurt) 451, 502, 503

Schumacher, Dr. Ernst (München) 544, 545

Schumann u. Küchler, Erfurt, 193, 222

Schuster, Dr. Fritz 35

Schwank, Günter 548, 594

Schwarz (Hamburg) 545

Schwarz, J. v. 226,288

Schwarzer, Görlitz 628

Schwedler (Berlin) 259, 260

Schweizerischer Verein von Gas- und

Wasserfachmännern 639

Scientific American 178

Scott, Sir Walter 88

Seebauer, G. 536

Seelbeck, Th. J. 290

Segas, South Eastern Gas Board 579. 581 Segelken, Lüder $580,584,606,607-610$

Seger, Hermann 289

Seidenschnur, F. 500,507

Selligue, A. F. $14^{8}$

Senderens, Jean Baptiste 363, 519

Senking. Hildesheim (Senkingwerk K.-G.)

291, 411

Sentke, Fritz 446
Servier 259

Seur 205

Sharp, James 156

Shirley, Thomas 20,21

Siebel, Hans 560

Siegener Maschinenfabrik A.-G. 120

Siemens, Friedrich 178, 182, 186, 212, $276 \mathrm{ff}$. 294, 301, 305, 306, 307, 397, 403, 406, 407. 597.601

Siemens-Schuckert Werke. Berlin $4^{14}$

Siemens und Halske, Berlin 223, 314

Siemens, Werner v. 15, 176, 177, 178, 182, $186,224,270,272,276,277,589,629$

Siemens, Wilhelm (Sir William) 186, 212. $256,257,276,290,302,315$

Silbermann, J. Th, i31

Simmersbach, O. 367

Simon, S. 3 II

Singer, Paul (Politiker) 252

Sinzendorf, Graf v. 25

Sinzig \& Co., Düsseldorf 149

Skelly Oil Co 513

Slaby, Adolf 288

Slocum, Frank L. 366

Smith \& Phillips 158

Snelling und Peterson, Pittsburg 36,

Société Anonyme d'Ougrée-Marinage 376

Société du Gaz de Paris 228, 514

Société française de l'Industrie du Gaz,

Paris 323

Söhren, C. H. 181, 229, 243

Solvay, Ernst 140,241

Somzée, L. 282

Sonntag, F. 167, 170, 272

South Eastern Gas Board s. Segas

South Metropolitan Gas Co., London 185 , $259,265,292,34 \mathrm{I}, 437,512,543$

Soyer, Aiexis 156

Spaleck, Paul 406, 407, 451, 454, 467, 482

Spedding 27

Spice, R. T. 249

Spielmann 27

Spinney, Thomas 134

Spittank, Friedrich Walter $\$ 66$

Spreng, Albert 171

Spreng, Carl Ludwig Emil 170

Spreng, J. N. 170

Stack, Baurat 878

Stadelmann, Jean 288

Standard Oil Co if New Jersey 365

Starke, Richard F. 456, 491 
Steffens, Henrik 57

Stein, Karl, Reichsfreiherr vom und zum 89

Stein, W. 129, 270

Steinbeis, Ferdinand 103,124

Steiner, Helmut 474

Steinle \& Hartung, Quedlinburg 290

Steinmüller, Gummersbach $44^{8}$

Sternberg, Graf v. 57

Stettiner Chamottefabrik (Didier) 191, 219. $332,342,507,576,579$

Stevens Institute of Technologic 210

Stickstoffsyndikat 429

Stief, Friedrich C. L. 521, 573, 574, 576 , 581

Still, Carl, Recklinghausen s05, 508

Stinnes, Hugo 367

Stockvis, W. J. 397

Stoof C. J. IIs

Stotz, A., Stuttgart 378

Strache, Hugo 217, 218, 219, 286, 348, 359 . $360,361,362,382,389,391,403,435,43^{8} f$. $440,442,450,451,452,510$

Strassmann, (Silamitwerke, Krefeld) 436

Straube, Hildegard 76, 432

Strölin, Stuttgart (Politiker) $4^{81}$

Stromeyer, Friedrich iss

Strong, M. H. 21I, 212

Struck, Paul 530, 531, 589

Struve, Dr., Dresden 621

Suchet 315

Südwestdeutsche Ferngas A.-G., Stuttgart 499

Südwestdeutsche Gas A.-G., (Süwega) 492, 493

Sugg, William T. 178, 275, 287, 295

Szombathy, Dr. v. 587

Tabor, Carl Wigand 26, 77, 80, 86, 89, $97 \mathrm{ff}$, $112,114,127,185$

Tait 85,145

Talbot 283

Tangerhütte 253

Tantesch, Düsseldorf 468

Tardin, Jean 20

Taschenbuch für Feuerungstechniker, Spamer $1908 \quad 382$

Tausz, J. 524

Taylor, John 86, 114

Taylor and Marthineau 86

Taylor, J. J. 204
Technische Vereinigung der Firmen im Gas- und Wasserfach (s. Figawa)

Technische Zentrale für Koksverwertung $3^{80}$

Teichmann 224

Teichmüller, Joachim 388

Tennessee Valley Corporation 556

Terhacrst, Rudolf $362,449,450$

Terres, Ernst 76, 432, 450, 473, 474, 587

Tessié du Motay 208, 212, 281, 282

Thau, Adolf 439, 445, 504, 505, 506, 508, 520,564

Thermotechnische G.m.b.H., Berlin 410

The Waverley Association of Gas Managers 323

Thiem \& Töwe, Halle 364

Theisejahns 297

Thomsen, Julius 131

Thomson, William (Lord Kelvin) 131

Thüringer Bezirksverein deutscher Ingenieure 385

Thüringer Gasgesellschaft, Leipzig 173, 179 . $182,237,331,352,415,416,434,454,490$, $491,492,493$

Thurgar 280

Thysbaert, J. F. ${ }^{1}$

Thyssen, August $367,438,478,500$

Thyssensche Gas- u. Wasserwerke, Hamborn $369,457,477,496,498,518,576$

Tieftrunck, Ferdinand 232, 243

Tiele-Winkler, Graf 372

Tiemessen, Johannes 475, 485, 486, 522

Tillmetz, Franz P. 428, 442, 450

Todt, Fritz 486

Tollens 459

Tormin, H. 248

Torricelli, Evangelista 20

Totzeck, Friedrich 561, 576

Townsend, J. 213

Traenckner, Kurt 575

Trautwein Dr., (Nürnberg) 362

Travers, M. W. 223

Tremus, Georg 413, 432

Trenkler, H. R. 353, 438, 444

Treska 307

Trevelyan, George Macauley 38

Trinks, W. 550

Tropsch 588

Tulpin 315

Turner, Cornelius I52

Tyndall, John 13 ! 
Ubbelohde, Leo 390

Ullmann Encyclopädic 35

Ullrich (Gasmeister) 24

United Coke \& Gas C, New York 366

United Gas Improvement Co, Philadelphia 209

Universal Gas Co., London 150

Unruh, Hans Viktor v. $I I \& \mathrm{f}, 144$

Uppenborn, F. 274

Uthe (Dresden) 56

Utzschneider, Joseph v. 91, 624

Vaillant, Johann, Remscheid 296, 404, 405, $406,545,595$

Valon, W. A. $24^{8}$

Van den Broeck, A. 29

Van de Velde, A. J. J. 20, 21, 23, 29

Van Helmont, Joh. Bapt. 19

van't Hoff, J. H. 232

Vater, Georg 442, 512

Verbände der Deutschen Gas- und Wasserwerke (VGW) 604

Verbände der Gas- und Wasserwerke 564 . 604

Verband der Armaturenfabriken 335

Verband der Gasmesserfabrikanten, Berlin 335

Verband der Gas- u. Wasserfachbeamten, Berlin 335

Verband deutscher Elektrotechniker (VDE) 388

Verband mittlerer technischer Beamten, Bezirkverein Bonn 335

Verein der Gasfachmänner Deutschlands später: Deutscher Verein von Gas- u. Wasserfachmännern 161, 165, 322

Verein der Gasfachmänner Rheinlands und Westfalens (später: Verein der Gas-, Wasser- u. Elektrizitätsfachmänner Rheinlands u. Westfalens) 368,639

Verein deutscher Chemiker 371

Verein deutscher Eisenhüttenleute 495, 549

Verein deutscher Gasbehälterfabrikanten $260,26 \mathrm{I}$

Verein deutscher Ingenicure 166, 167, 329. $330,385,43 \mathrm{I}, 448,613$

Verein deutscher Strafjen- u. Kleinbahnverwaltungen 388

Verein für Kommunalwirtschaft u. Kommunalpolitik 480

Vereinigte Elektrizitätswerke Westfalen
G.m.b.H. (VEW) 337, 493, 494

Vereinigte Glanzstoff-Fabriken, Elberfeld 396

Vereinigte Institute für Wärmetechnik, Essen 487

Vereinigte Stahlwerke, Gelsenkirchen ${ }^{888}$ 530

Vereinigung der Elektrizitätswerke 535

Vereinigung deutscher Gaskocher-Fabrikanten, Berlin 335

Vereinigung von Sächsisch-Thüringischen Gaswerken 335. 336

Vereinigung Württembergischer Gaswerke 335

Verein Pfälzischer Gasfachmänner 639

Verein Pfälzischer Gaswerke 335

Verein Sächsisch-Thüringischer Gas- u.

Wasserfachmänner 640

Verein technischer Beamten des Gas- und Wasserfaches (später: Verein der Licht-

u. Wasserfachbeamten, Deliwa) 335

Verein von Gas- und Wasserfachmännern Schlesiens und der Lausitz 639

Verein zur Beförderung des Gewerbefleisses, Berlin 402, 499

Verkaufsvereinigung für Teererzeugnisse,

Essen 428

Versuchsanstalt für Brennstoffe, Feuerungsanlagen und Gasbeleuchtung, Wien $43^{8}$ 439

Vial 282

Viag Vergasungs A.-G., Wien 574

Vieille 224, 225, 270

Vierle (Potsdam) 628

Vieweg, F. 93

Vincent, Ernst 34

Vinci, Leonardo da 18

Violle, J. 273

Vögler, Albert 457, 488

Volkmann, Dr. Dipl. Ing. 349

Volta, Alessandro 23

Von der Heydt 118

Vorster und Grüneberg, Kalk bei Köln 245

Voss, Conrad 292

Voß̧werke, Sarstedt 550, 551

Vulkan Verlag Dr. W. Classen, Essen 99. 249, 595, 598, 607

Vygen \& Co H. J., Duisburg 195

Waage. Peter 232

Waagner, R. Th., Wien 258 
Wagener, Georg 487

Wagner, J., Salzburg 47

Wagner, Paul 243

Wagner u. Drescher, Chemnitz 222

Wahl, Karl 359

Waller, George 195

Walter, Theo 107,108

Walter, W. (Leipzig) 532

Wanklyn, J. A. 242

Wanner, H. ${ }^{8} 83$

Warmbrunn, Quilitz \& Co., Berlin 412

Warsteiner Gruben- und Hüttenwerke 219, 406

Wassbein 293

Watson, Richard 22

Watt, Gilgory 51

Watt, James d. A. 13, 38, 39, 50, 51

Watt, James d. J. 52, 53, 54, 55

Weber, Leonhard 274

Wedgewood, Josiah 289

Wehrmann, Fritz $503,531,576$

Weigel, Kreisbaurat 454

Weiler \& Co 236

Weinberg (Braunschweig) 294

Weisbach, Julius 133, I51

Weifzenberger, G. 53I

Weittenhiller, Hellmuth 509,576

Wenham, Fr, 277

Wenzler, Joh. B. 47

Werner \& Pfleiderer, Stuttgart-Cannstatt 468,551

West, John 197, 343, 349

Westfälische Ferngas A.-G., Dortmund 493

Westharzer Kraftwerke A.-G., Osterode 454

Westinghouse, George 287, 389

Westphal, Carl 257, 435

Weyrich, Adam 502

Wheeler 437

W'hite, S, 149, 207

Wibel, H. 270

Wiebenga, J. G. 453

Wieland, Christoph Martin 34

Wien, W. 290

Wiener Gas-Industriegesellschaft s. Österreichische A.-G. für Gasbeleuchtung

Wiener Ringtheater 179

Wilberforce, Sir 61

Wild (Ludwigshafen) 520,521

Wilhelm, A. 442
Will, Heinrich 235

Wille, Rudolf und Fia 397

Williams, C. H. 235

Williams, J. 291

Willson, Thomas L. 223

Windel, Otto 4 II

Winkert, Edmund 414

Winkler, Clemens 212

Winkler, Fritz 575, 576, 587

Winkler, Ludwig $526,542,574$

Winsor (Winzer), Friedr. Albert 43, 44, 46, $54,60 \mathrm{ff}, 67,81,86,125,156,573,616,617$ Winsor d. J. 138

Winzler, Zach. Andreas $44 \mathrm{ff}, 64,66,8 \mathrm{I}, 94$

Wirth, Josepha 401,402

Wirtschaftsberatung deutscher Städte Versorgungs- u. Verkehrsunternehmen A.-G. 485

Wirtschaftsgruppe Gas- u. Wasserversorgung $484,485,486,508,542,551$

Wirtschaftsgruppe Kraftstoffindustrie 509

Wirtschaftliche Vereinigung deutscher Gaswerke $332,333,334 / 35,338,370,371,372$, $380,381,402,421,424,427,428,429,456$, $475,485,486,572,605$

Wislicenus, Johannes $47^{1}$

Witt, D. 524

Wittig 534

Wittig \& Hees 312

Witz, Aimé 288

Witzeck, R. 369, 403

Wobbe, Johann Gottfried 293, 302, 315, 392, $403,4 \circ 4,524$

Wobbe, Goffredo $524,525,589$

Wöhler, Friedrich 155, $47 \mathrm{I}$

Wöhlert, Johann Friedrich Ludwig, Maschinenfabrik, Berlin 110,628

Wolf, Franz 290

Wolff, C. 312

Wolff, Dr. Paul 395

Wolff, Werner $54^{\circ}$

Wolff, O. (Essen) 549

Wolff \& Co., Berlin 395

Wollheim, Cäsar 332

Wolpert (Kaiserslautern) 250

Woodall, Corbet 213

Woodall, Harold 347,348

Woodall-Duckham 349, 350, 362, 581

Wright \& Co, Alexander 288

Wright \& Co., John, Birmingham 29r, 295. 303 
Wright, L. T. 289

Wucherer, J. 522

Wunder, Georg $3^{81}$

Wunderlich, H. 447

Wunsch, Walter 530,533

Wurz, Fritz 577, 578

Wybauw, Pierre 265, 274, 303, 305, 306

Wyss 2I4

Yelin, Julius v. 114

Young, J. 142

Young, William 215, 221, 233, 360, 376

Young, W. M. 349

\section{Zahrtmann (Kopenhagen) 265}

Zankl, Wilhelm $563,57^{8}$

Zeidler, J. 36

Zeitschrift d. Osterr. Gas- u. Wasserfachmänner 46 , 50

Zeitschrift des Vereins d. Ingenieure 443

Zellstoff-Fabrik Waldhof, Mannheim 360
Zentrale für Asphalt- u. Teerforschung,

Charlottenburg 445

Zentrale für Gasverwendung, Frankfurt a/M. $568,604,605$

Zentrale für Gasverwertung e. V. 329, 402. $403,410,427,442,458,459,460,465,468$. $485,486,487,537,538,540,541,553$

Zentrale für Gas- und Wasserverwendung. Berlin $54 \mathrm{I}, 605$

Zentrale für Koksverwertung, Berlin 447

Zentrale Landesbank 562

Zentralwerkstatt Dessau 403, 404, 405, 406 , 409, 428

Zeppelin Graf Ferdinand v. 414, 513 Z f G W-Verlag, Frankfurt a/M. 605 Ziegler, Heinrich Friedrich 166, 254, 318

Zimmermann u. Jansen, Düren 22I

Ziurek 257

Zollikofer, H. 386

Zschintzsch, Wilhelm 536

Zschocke, Gottfried 238, 241, 369

zur Nedden, Franz 425, 486, 487, 536

Zweizonenverwaltung 563 


\section{ORTSLISTE}

Aachen $89,259,295,296,376,390,406,414$. $466,487,622,632$

Aalen (Wttbg) 499

Adolfshütte 349,434

Adorf 586

Aerzen bei Hameln 201, 533

Ahlen (Westf.) 494

Albion (Mich.) $\$ 29$

Alkmaar 73

Allenstein 544

Altenburg 392, 445, 632

Althaldensleben 56

Altona 175, 191, 250, 311, 312, 383, 421, 632 Altwasser (Schlesien) 368

Amiens 28, 31, 32, 39, 51, 125, 615

Amsterdam 89, 90, 106, 180, 346, 436, 622

Angoulème 4I

Anklam 632

Annaberg 632

Ansbach 200, 632

Antwerpen 31, 106, 148, 622

Arnheim (Holland) 397

Arnswalde 337

Aschaffenburg $347,375,447$

Asthon 21

Aue (Erzgebirge) 628

Augsburg 122, 123, 243, 259, 279, 364, 448, $454,457,566,632$

Aussig 434

Ayrshire (Schottland) so

Babelsberg b/Berlin 168

Baden-Baden 474, 577, 632

Baku 182

Baltimore 126

Bamberg 123, 591, 632

Barcelonahafen (N. Y.) 150

Barmen 369, 402, 632

Barr (Elsass) 387

Basel 588
Bath 88

Bautzen $3^{80}$

Bayreuth $123,254,467,522,632$

Beekesbourn (Kent) 22

Belfast 247

Benediktbeuren 91, 625

Bentheim 586

Bergedorf $337,340,360,362,439,632$

Bergen (Norwegen) $\$ 82$

Berlin 19, 47, 56, 70,88, 90, 99, 106, 108,

$109,110,116,118,119,120,135,138,140$,

$143,144,145,150,151,153,155,159,160$,

$16 \mathrm{I}, 167,168,173,174,176,180,181,182$,

$183,191,204,219,223,224,227,230,232$,

$245,252,256,257,258,259,260,264,265$,

$267,272,276,279,280,284,286,287,290$,

$291,292,294,302,311,313,314,320,329$.

$333,334,335,337,338,344,345,346,347$.

$349,352,357,360,363,368,370,373,378$,

$379,380,383,385,386,387,389,392,394$.

$395,396,397,400,401,402,403,404$.

$408,409,410,411,412,413,418,423,426$,

$429,431,432,433,438,439,442,443,446$,

$45 \mathrm{I}, 457,459,460,46 \mathrm{I}, 463,465,468,47 \mathrm{I}$,

$472,474,476,477,478,480,481,487,490$,

$492,495,497,499,500,501,503,505,506$.

$507,508,511,512,514,515,516,519,520$,

$521,523,526,531,532,537,539,545,547$,

$550,561,562,563,565,566,579,592,601$,

$605,622,624,627,628,629,630,631,632$,

$64 \mathrm{I}, 642,643,646$

Bermondsey 313,341

Bern 214, 398, 639

Bernau (Mark) 527

Bernburg 4Is

Berndorf 437

Bethune 514

Biebrich 632

Bielefeld 632

Bingen 340,632 
Birmingham 55, 88, 247, 256

Bischofsheim i. d. Rhön 93

Bitterfeld 415

Bochum 369, 402, 435, 452, 504, 523, 574, 632 Böhlen 479, 512

Bofzen bei Fürstenberg 57

Bologna 924

Bonn 18I, 229, 243, 335, 347, 447, 455, 468 . 497,632

Bordeaux 125, 622

Boston (Mass.) 210, 366

Bottrop so5

Boulogne 125

Bournemouth $34^{8}$

Brachay (Haute Marne) 40, 41

Bradford 256

Braunschweig 45, 46, 60,82, 93, 117,128 , 149, 155, 167, 258, 260, 294, 321, 344, 35I. $492,628,632$

Breda 434

Bremen 90, 103, 116, 117, 118, 120, 121, 142. $145,148,149,175,188,203,219,250,332$. $335,344,351,364,375,516,581,628,631$. 633

Bremerhaven 117,490

Brentford 191

Breslau 108, 118, 155, 227, 259, 287, 381, 420 . $469,490,491,508,628,633$

\section{Bretten 568}

Brieg 188, 633

Brighton 157

Bristol 87, 88

Bromberg 461

Brooklyn (N. Y.) 207

Bruay 508

Bruchsal $541,568,633$

Brünn 44, 45, 93, 363, 439, 444, 633

Brüssel 19, 20, 30, 31, 89, 140, 148, 265, 282. $303,306,577,586,595,622$

Brüx $560,561,622$

Budapest 224, 347, 356, 364, 374, 522

Budweis 188

Bückeburg 67, 434

Buenos Aires 127

Buffalo (N. Y.) 465

Bunzlau (Schlesien) 633

Burg bei Magdeburg 356

Butzbach (Hessen) 168

\section{Caēn 125}

Calbe 633
Calw 529

Cannstatt 172, 468, 633

Cardiff 89

Carmaux 508

Cartagena 585

Celle r18, 385, 422, 446, 633

Chalons sur Marne 40

Champignole 202

Charlottenburg $183 / 84,193,197,223,248$, $298,347,348,354,360,381,400,402,445$. $460,522,533$

Cheltenham 88

Chemnitz 171, 191, 222, 385, 435, 439, 442, 512, 521,633

Chester 88, 261

Chicago 260, 329, 527, 528, 583

Clausthal-Zellerfeld 454

Cleveland 585

Cleethorp 345

Clichy 354

Colchester 87

Como 380

Connersville 20I, 533

Cork 2I

Cossebaude bei Dresden 406, 467, 546, 547 Crimmitschau 633

Crosta 434

\section{Dagenham 529}

Dahlhausen 367,371

Danzig 108, 232, 425

Darmstadt $47,123,172,229,243,270,279$. $290,448,467,493,571,586,592,624,627$. 633

Delmenhorst $434,44^{8}$

Den Haag 90, 106, 249, 344, 519, 581

Dessau 73, 118, 119, 121, 150, 181, 184, 225, $233,249,250,255,259,260,289,313,314$. $322,329,344,346,347,350,356,371,402$, $403,406,409,413,415,428,434,466,47 \mathrm{I}$. $482,485,506,512,547,567,633$

Detmold $54 \mathrm{I}, 577$

Detroit 370, 603

Deutz bei Köln 309, 311, 313, 314, 315, 633

Diedenhofen 337,360

Diekirch 380

Dijon 23, 27, 148

Dippoldiswalde 624

Döbeln 633

Dorpat 97

Dorsten 576,586

\section{SLUB}


Donawitz 353

Dortmund 121, 171, 337, 493, 633

Dresden 47, 56, 58, 64, 90, 91, 99, 106, 109. 110, 111, 112, 129, 150, $168,174,188,191$. $214,228,242,255,275,276,296,298,313$. $335,349,397,402,406,407,434,480,490$, $507,510,538,547,624,625,626,627,628$, $629,630,631,633$

Dublin 193, 197, 205

Düren 221, 280, 397, 633

Dürkheim (Bad) 499

Düsseldorf $25,55,117,118,149,229,248$, $254,312,347,356,362,368,369,395,401$. $410,411,433,449,463,468,496,502,531$. $537,543,566,589,605,633,639$

Duisburg 121, 195, 312, 356, 380, 387, 401, $402,445,500,530,531 / 32,633$

Duisburg-Meiderich 445

Dunston 506

Durlach 91, 625

East Greenwich 383, 437

East Hull 375

Eberswalde 639

Edderitz bei Köthen 439, 500, 506

Edinburg 86, 87, 88, 134, 153, 203, 210, 355 . 375

\section{Edingen 455}

Eger 165

Eisenach 464

Ekbatana 18

Elberfeld $368,396,398,439,633$

Elbing 633, 639

Elizabeth (N. Y.) 206

Elland (Yorkshire) 54

Elmshorn 633

Elsterwerda 386

Eltville 454

Emmerich 280

Engelbostel bei Hannover 591

Erfurt 119, 193, 219, 222, 337, 454, 633

Erlangen $326,509,633$

Eschweiler 258, 529

Eskilstuna 579

Esseg 622

Essen 55, 99, 138, 140, 193, 214, 219, 220, $249,253,259,283,337,352,353,359,366$, $367,368,369,372,427,429,445,446,456$. $487,488,491,496,500,501,503,508,518$, $530,549,550,552,553,587,592,595,598$, $604,607,633$
Esslingen (Neckar) 47, 191

St. Etienne 316

Ettlingen (Baden) 443

Eupen 633

Eutin 633

Exeter 82, 88, I56

Fair Haven bei New Haven (Conn) 207 Falkenau 203, 206, s61

Falkirk $\$ 54$

Flensburg 126, 634

Frankenstein (Schlesien) 454

Frankenthal $\$ 86$

Frankfurt a. M. 35, 36, 80, 89, 97, 100, 106 , I12, H3, $114, \mathrm{H1}, \mathrm{I18}, 12 \mathrm{O}, 152,166,167,174$. $200,205,213,218,228,233,246,250,251$. $252,316,319,359,375,385,421,427,428$, $435,438,439,442,448,451,461,464,466$. $480,491,493,495,497,502,503,506,507$. $508,512,518,522,526,535,541,549,533$. $594,604,605,622,628,634,641$

Frankfurt/Oder 119, 471, 516, 634

Fredonia (N. Y.) 126

Freiberg (Sa) 56, 57, 58, 59, 98, 212, 500, 53I, 634

Freiburg i. Br. 65, 94, 170, 171, 371, 385, 434. 574,634

Friedenau (Berlin) 428, 452

Friedrichsfeld 455

Freudenstadt 434

Fürstenwalde 170, 227, 257, 634

Fürth 634

Gaggenau 256,

St. Gallen $123,147,386,400$

Geisenheim (Rhcingau) 340

Gelsenkirchen 369, 451, 453, 466, 530

Genf 316, 570, 573

Gent 106, 126, 622

Genua 347

Gera 434,634

St. Germain $44^{2}$

Germersheim 499

Gerthe 369

Gevelsberg 553

Giefen 97, 123, 124, 251, 493, 634

Glasgow 21, 73, 85, 86, 88, 142, $145,200$. $205,232,291,316,366$

Glatz 434

Glauchau 300, 634

Gleiwitz 22I, 634 
Glogau 634

Gloucester 89

Glückstadt 164, 634

Godesberg 405

Göppingen 499

Görlitz 263, 338, 628, 634, 639

Gottingen 34, 57, 155, 311, 315, 321

Goslar 454

Gotenburg 126

Gotha $34,122,173,628,634$

Graslitz 622

Graz 439, 440, 536, 590, 634

Greenwich 258, 313, 383

Greifswald 380,453

Grenoble 20

Griesheim 385, 415, 480, 553

Grünstadt (Pfalz) 499

Grund (Bad) 454

Guben 380, 634

Güstrow 164, 272, 359, 634

Gumbinnen 118

Gummersbach 455

Gustavsburg 457

Haag, Den s. Den Haag

Haarlem 622

Haddington 264

Hagen (Westf.) 119, 402, 634

Hagen-Eckesey 494

Hahnenklee 454

Halifax $54,71,366,442$

Halle (Saale) 171, 205, 260, 363, 364, 421, $445,480,492,500,506,507,520,535,634$ Halsbrücke 58

Hamborn (Duisburg) 367, 369, 457, 471, 518 Hamburg 50, 90, 92, 99, 159, 164, 165, 176 . 219, $253,259,267,270,272,274,286,293$. $300,302,311,344,347,366,373,376,381$, $384,385,392,399,400,409,452,453,464$. $468,478,489,503,511,521,531,555,566$. $569,573,574,581,592,634$

Hameln 344, 463, 520, 532, 533, 579

Hamm (Westf.) 374, 634

Hanau 166, 206, 254, 290, 318

Hannover 44, 67, 89, 106, 107, 108, 138, 143. $150,159,160,161,188,195,197,232,236$. $238,253,271,294,302,312,342,364,369$. $371,378,382,383,400,402,413,434,484$. 494, 495, 497, 513, 514, 515, 516, 591, 621. $622,630,631,635,640,641,642$

Harburg 206, 264, 635
Harzburg 460

Harzgerode 47

Hecklingen 492

Hedderheim (Frankfurt a. M.) 433, 448, 480

Hehlen a, d. Weser 57

Heide (Holstein) 510,635

Heidelberg 153, 155, 251, 280, 297, 311, 326. $386,387,493,635$

Heilbronn 131, 200/01, 254, 256, 259. 499 . 635

Helsingborg 126

Herford 512

Heringen bei Hamm (Westf.) 374

Herne 369

Herzenhalm 99

Yildesheim 291, 411, 446, 492, 514

Hirschberg (Schlesien) 313, 624, 635

Hirschfelde 512

Höchst 170, 462, 493, 586

Höganäs 432

Hörde (Dortmund) 314

Hof 243, 635

Hohenbostel (Deister) 112

Hohenstein-Ernstthal 455

Holzhausen (Nassau) 308

Holzminden Iss

Homburg (Saar) 490, 498, 519, 587

Homburg v. d. Höhe 635

Hüls 586

Hull 87,375

Ilsede 492, 514

Ilversgehoven 410

St. Ingbert (Saar) 112, 490, 498

Ingolstadt 403, 544

Innsbruck 352, 407/08, 574, 579

Insterburg 231, 413

Ipswich 527

Iserlohn 171, 219, 635

Itzehoe 164,635

Jena $35,259,300,504$

St. Johann (Saar) 248, 280, 400

\section{Kagrau bei Wien 249}

Kaiserslautern 206, 238, 250, 294, 312, 371. 379,4 OI, 635

Karlsbad 447, 561

Karlsruhe $104,170,171,172,175,184,197$. 233, $248,250,251,255,267,272,273,277$, 
$290,296,304,305,315,317,321,322,327$, $328,356,358,374,379,381,382,388,390$, $391,399,401,406,446,452,467,471,472$. $474,493,501,520,524,563,566,580,590$, 635

Kaschau 622

Kassel 155, 191, 215, 234, 400, 489, 507, 532 , $\{66,628,635$

Kempten 635

Kensal Green ro1

Kettenhot bei Wien so

Kettwig 635

Kidderminstce 88

Kiel 198, 435. $447,560,569,635$

Kildere 21

Kladno $56 \mathrm{I}$

Koblenz 99, 4);, 635

Koburg 254, 627, 635

Köln 55, 90, 92, 93, 115, 122, 173, 174, 176, $181,188,193,212,214,245,253,255,258$, $265,281,283,292,296,312,321,331,335$, $337,352,355,369,402,447,455,457,492$, $493,496,497,542,544,622,635$

Königsberg 108, 120, 167, 219, 270, 359, 362 . $375,376,378,389,406,408,431,467.508$. 628,635

Königshütte 454

Königslutter 294

Köslin 480

Köthen r19, 439

Kolberg $380,447,628$

Kolmar (Elsass) 313, 374

Komotau 360,622

Konstanz 171, 528

Kopenhagen 126, 131, 186, 265, 469

Korbach (Waldeck) 321

Krakau 119, 292, 434

Krefeld $166,297,312,343,356,368,433,434$. $436,495,552,553,635$

Krimmitschau 335

Krummhübel 450, 454, 526

La Butte aux Cailles 28

Ladenburg 455

Lahr 99, 635

Landau 400, 442

Landsberg (Warthe) 635

Landshut 583,635

Landskron 23

Langenberg Rhld. 171, 635

Langendreer 369
Langensalza 455

Langenschwalbach 308

Lankwitz (Berlin) 387

Lauban 352, 360, 624

Lauchhammer 110,627

Lauenburg 635

Lausanne 348,350

Lauterberg (Bad) 454

Leeds $85,88,145,216,410,512$

Leer (Ostfr.) 587

Lehrte 514

Leipzig 19, 20, 26, 34, 35, 44, 56, 64, 66, 90, 105, 106, 109, 110, 118, I22, I50, 171, 172 , $173,174,222,228,232,234,313,319,352$. $381,382,406,431,435,460,46 \mathrm{I}, 468,47 \mathrm{I}$, $490,492,532,537,538,541,547,552,625$, $627,628,629,630,631,635$

Leisnig 431

Leith 152

Lemberg 119,313

Lennep 635

Lens $24^{8}$

Leverkusen 434,446

Lichtenberg (Berlin) 414, 438, 506

Lichterfelde (Berlin) 387

Liegnitz $460,544,636$

I ille 622

Linden bei Hannover 197, 312, 494, 514

Linz a. Rhein 373,375

Linz (Donau) 586,636

Liverpool $86,88,147,152,185,204,245,265$. 348,434

Llandaff 22

Lecarno 435

Löbau 636

Locwen (Louvain) 18, 29, 30, 31, 150

London $18,20,21,22,25,27,44,45,51,52$, $54,55,60,62,63,64,67,69,70,73,74$. $77,78,79,82,84,86,87,8889,90,105,124$. 125. I35, 137, 138, 140, 142, 143, 145, 147. $150,152,154,156,157,159,1(-0,164,177$. $178,180,182,186,203,215,227,234,242$, $246,251,254,256,257,258,276,288,291$. $292,295,302,313,316,343,358,371,407$. $437,506,518,519,522,531,543,562,614$, 617,626

St. Louis 365

Luckenwalde 119,636

Ludwigsburg 636

Ludwigshafen 231, 236, 290, 359, 373, 382. $493,498,520,575,586$ 
Lübeck $319,355,368,369,387,455,479,561$, 636

Lüdenscheid 636

Lüncburg 636

Lünen 586

Lüttich 29, 89, 576

Luik (Belgien) 29, 149

Lussagnet 592

Lyon 27, 125, 344

Maastricht 29, 30, 149

Magdeburg 20, 118, 122, 144, 168, 179, 229, $286,312,332,347,357,368,382,390,425$, $442,455,492,494,496,628,636$

Mailand 23, 279, 574

Mainz 25, 167, 168, 170, 234, 264, 272, 493, $496,519,587,636$

Malmö 126

Manchester 53, 70, 71, 88, 131, 204, 469, 581, 614

Manlesfield 88

Mannheim 9I, 99, 170, 236, 434, 455, 493

Marburg (Lahn) 155

Marburg (Kroatien) sio

St. Margarethen 337, 386

Mariendorf (Berlin) 342, 346, 351, 359, 371, $378,379,387,434,566,579$

Marlay 43

Marseille 125, 131, 622

Massaua 257

Maubeuge 31

Meerane 636

Meissen 636

Menden (Westf.) 528

Meran 229

Merseburg 492, 507. 513

Metz 281, 386, 414

Michelstadt 492

Minden (Westf.) 434, 561, 636

Mölln 636

Mönchengladbach $119,312,337,347,380$ 634

Molsheim (Elsass) 387

Monte Carlo 370

Moskau 57,585

Mühlhausen (Thür.) 455

Mühlheim (Rhein) 249, 636

Mülheim (Ruhr) 119, 120, 121, 122, 124, 367. $368,382,437,438,530,636$

München $34,38,55,78,90,91, \mathrm{III}, \mathrm{II} 4,122$, 127. $153,164,165,172,177,181,184,188$,
$189,205,214,220,222,224,228,232,242$, $243,245,252,254,260,263,264,267,284$. $290,292,293,294,297,299,307,314,315$. $326,327,328,329,337,351,365,376,380$. $395,402,408,4 \mathrm{II}, 425,434,448,457,465$, $467,471,485,486,501,503,539,544,545$, $547,583,601,605,607,624,625,626,627$. 636

Münster (Westf.) 636

Mussy la Ville 307

Mutzig (Elsass) 387

Nancy 622

Nantes 125

Nantyglo 88

Narbonne 282

Naumburg (Saale) 636

Neuenburg (Schweiz) 313

Neudingen bei Donaueschingen 499

Neuengamma bei Hamburg 365,366

Neuhausen 223, 224

Neully s. Seine 285

Neumünster 636

Neunkirchen (Saar) 124, 527

Neuruppin 544

Neuf 258, 368, 636

Neustadt a. d. Hardt 639

Neustadt (Holstein) 636

Neustrelitz 636

Neutra 622

Neuwied 109, 636

Newark (N. Y.) 207

Newcastle 22, 117, 129

Newneaton 27

Newport 89

New York 126, 177, 178, 208, 210, 212, 291, $342,366,383,528$

Niederbarnim 454

Nieder-Ingelheim 531

Niederrad (Frankfurt a. M.) 113

Niederscheld 448

Niederwalluf 454

Nordhausen 119, 313, 491, 521, 636

Nordhorn 590

Norristown $(\mathrm{Pa}) 208$

Norrköping 579

Northwich 261

Norwich $87,280,350$

Nürnberg 170, 226, 245, 254, 259, 288, 341, $356,362,371,374,401,408,420,447,449$. 508,637

\section{SLUB}


Nufydorf $b / W$ ien so

Nyköbing 5I4

Oberbach 93

Oberhausen 453, 511

Oberursel 247, 414

Odenkirchen 337

Odense 126

Oetzsch-Markkleeberg 490

Offenbach $468,491,637$

Oldenburg 414, 583, 637

Oldesloe 164,637

Oppau 360, 520

Oppeln 313

Oranienburg 142,340

Oslo (Christiania) 435, 582

Osnabrück 202, 292, 360, 452, 459, 468, 555 . 586,637

Ostende $\$ 29$

Osterode (Harz) 454

Ostrowo 317

Ottawa 622

Paderborn 637

Parchim (Mecklbg) 434

Paris 18, 22, 23, 27, 28, 31, 32, 34, 40, 4I, 43 . $45.51,60,64,83,89,90,93,125,131,139$. $140,144,147,148,155,177,178,179,183$, $185,186,187,189,200,202,208,219,223$. $226,228,234,240,25 \mathrm{I}, 253,278,279,28 \mathrm{I}$. $282,284,288,291,292,307,309,31 \mathrm{I}, 312$, $315,323,333,362,389,393,397,398,406$, $411,463,469,485,514,517,522,561,563$. $564,566,592,601,616,626$

Pasing $385,433,453$

Passau 47, 637

Peebles 221, 360

Peine 331

St. Petersburg 126, 168, 242

Pforzheim 197, 280, 316, 357, 436, 493, 637

Philadelphia $(\mathrm{Pa})$ 202, 209

Phönixville 209

Pilsen 259

Pinneberg 637

Pisa $171,366,404,444$

Pittsburg 230, 365, 591

Plauen $511,628,637$

Podejuch bei Stettin 135

Pontypool 25

Posen 219, 457, 510, 637

Potsdam 118, 119, 434, 459, 521, 628, 637
Poughkeepsie (N. Y.) 207

Prag 44, 47, 289, 379, 393, 561, 622, 628, 637 Prenzlau 637

Preston 88

Quedlinburg 265, 290, 294, 312, 344, 400

Raab 622

Rapallo 410

Rathenow 435

Ratibor $515 / 16,522,637$

Ratzeburg 637

Reading (England) 585

Recklinghausen sos

Redruth (Cornwall) 51, 615

Regensburg 47, 26I, 637, 639

Reichhenbach (Schlesien) 454

Reichenberg (Böhmen) 561

Reichenhall 91, 337

Reims 184, 191

Reitbrook bei Hamburg 592

Remscheid 219, 296, 312, 359, 466, 595

Reutlingen 221, 499

Rheinfelden $4 \mathrm{IS}$

Rheydt $119,293,337,338,634$

Riesa (Sachsen) 496

Riga 168, 380

Rio de Janeiro 127

Röbel (Meckl.) 637

Rom SII, 588

Romford 58

Rostock 135, 380, 454, 504, 637

Rotterdam 89, 106, 126, 345, 352, 448, 573. 622

Rotthausen 369

Roudout (N. Y.) 207

Rouen 43, 195, 315

Ruhrort 335

Saarau 289

Saarbrücken $280,490,498,499,637$

Saaz 622

Salzbrunn (Schlesien) 368

Salzburg 47, 172, 322, 637

Sandersleben 47,73

Sarstedt 550, 551

Schaffhausen 26,171

Schleswig 637

Schmargendorf (Berlin) 387

Schönebeck $49^{2}$

Schöneberg (Berlin) 378, 383, 429, 434 
Schwaigern bei Heilbronn 122

Schweinfurt 637

Schwenningen 454

Schwerin 637

Seelbach bei Lahr 99

Segeburg (Holst.) 637

Seraing 149

Siegburg 435

Siegen $120,493,497,529$

Silberberg (Schlesien) 454

Sodingen 360

Soho 50, 52, 53, 54, 614, 616

Solingen 171,637

Solothurn 434

Sommerfeld (Schlesien) 637

Sondershausen 229, 637

Sorau (6chlesien) 380

Southampton 347

Spandau 343, 528

Speyer 24, 25, 499

Spray (N. Car) 223

Stargard 637

Stavanger 582

Steglitz (Berlin) 387

Stein am Rhein 528

Sterkrade 376

Stettin 116, 117, 135, 140, 148, 172, 191, 342 .

$431,502,529,531,547,627,637$

Stockholm 126, 283, 348, 400, 432, 444. 579

Stolberg 622

Stonyhurst 71

Stralsund 170, 188, 232, 637

Straf̧burg (Elsass) 27, 148, 317, 336, 338, 4 OI

Stuttgart 35, 36, 97, 130, 154, 155, 175, 193. $200,254,284,306,308,311,315,326,343$. $344,378,407,436,458,459,468,476,48 \mathrm{I}$, $491,499,502,503,510,514,516,520,527$. $531,536,545,551,554,555,564,567,571$, $578,579,638$

Swinemünde 454

Szegedin 622

Tangerhütte 253

Teddington 22

Tegel (Berlin) 345, 376, 380, 414

Temesvár 180,622

Teplitz 322, 560

Thorn 264

Tilburg 516, 528

Tilsit n8, 638
Titusville $(\mathrm{Pa})$ 16r

Toledo (Ohio) 554

Toulouse 622

Tournon 20

Travemünde 387,455

Trier 638

Triest 93

Troppau 293, 315

Tübingen $26,57,321,397,399,4^{88}$

Ulm $123,435,499,574,638$

Ülzen $63^{8}$

Urgan 2I

Ütersen (Holst.) 638

Utica (N. Y.) 207

Utrecht 4 Is

Valparaiso 127

Venedig 17

Verviers 149

Vierzon 574

Villingen 454

Virton (Belgien) 307

Vlissingen 622

Vohwinkel 465

Waldenburg (Schlesien) 368, 451, 554

Walsum (Ndrh) ${ }_{367}$

Wandsbek 433,638

Wanne 369

Waren (Westf.) s28

Warmbrunn 492

Warnemünde 454

Warschau 119

Warstein 218

Wasseralfingen 57

Wattenscheid $369,376,467$

Weimar 34, 56, 57, 58, 68, 106, 152, 290, 315 $476,618,627,628,638$

Weinheim (Bergstrafye) 455

Weißgenfels (Saale) 205, 219, 500

Werdau 638

Wernau (Neckar) 567

Wermelskirchen 312

Wesel 369,638

Wesseling 51I, 574, 575

West Bromwich 137

Westchester (N. Y.) 207

Westminster 2I, 7I

Weszprém 224

Wetter a. d. Ruhr ss

\section{SLUB}


Wetzlar 93, 530

Whitehaven 23, 27

Wien $25,44,45,46,47,49,50,56,90$, 91, 93, 94, 96, 97, $99119,155,158,179,18 \mathrm{r}$. 182, 191, 199, 202, 203, 212, 217, 224, 234 . $252,257,258,259,279,281,284,286,306$, $322,323,328,342,352,353,359,363,375$, $38 \mathrm{I}, 382,39 \mathrm{I}, 403,436,438,502,505,508$, $510,520,521,533,574,576,583,586,622$, $626,638,64 \mathrm{I}$

Wien-Gaudenz 638

Wiesbaden $\mathrm{II}_{4}, 285,400,455,480,522,587$, $60_{4}, 638$

Wigan 20, 21

Wildungen 574

Wilhelmsburg 4II

Wilmersdorf (Berlin) 429

Winterthur $349,447,588$

Wirling (Va) 385

Wismar 638

Witkowitz 2I4
Witten 369

Wittstock 638

Wittenberge 118

Wohlen 398

Woolwich 105, 408

Worms 433, 493

Würzburg 23, 93, 121, 123, 243, 310, 518; 519. $525,543,627,638$

Wunsiedel 326

Wunstorf 117

Zeit: 500

Zeit it $44^{2}$

Zinnowitz 454

Zittiu 442, 512,638

Znaim 44

Zorge 56

Zürich 123, 198, 214, 26I, 322, 342,344, 347. $378,381,382,398,407,415,4$ \%, 444, 447 . $453,460,465,485$

Zwickau 150, 439, 455, 462, 628, 638

\section{SLUB}

Wir führen Wissen. 


\section{SACHVERZEICHN IS}

Abgasabführung s. a. Rückstromsicherung. Schornstein, Unfälle durch Abgas 25I, $315 f, 336,405,408,464,466,467,546 f$. $593 \mathrm{f}$

- durch die Wand 336, 404, 593. 594

- fehlende 159, 299f, 303, 466

Absatzfinanzierung 461, 537

Absaugung der Retorten s. Retorten, Kammeröfen

Aktivkohle 446

Ammoniak Absatz 181, 145, 333f, $372 \mathrm{f}$

- Bestimmung 241, $32 \mathrm{~J}$

- erste Erwähnung 22

- Gewinnung 215, 232f, 237ff, 360, 373f, 575

- - mit Superphosphat 242, 243

- Sodaverfahren 140, 241, 242

- Synthese 237, 374

- Verwertung s. a. Ammoniak Absatz 68. 243, 445

Ammoniumkarbonat 68

Ammonsulfat $140,18 \mathrm{I}, 242,372,375 \mathrm{ff}, 445$

Analyse des Gases s. a. Zusammensetzung d. G. $94,155,290,589$

- Kohlendioxydgehalt $23,83,246$

- - im Abgase 132

Anbohrmaschine für Rohre 254

Anilinfarben $142,234 \mathrm{f}$

Ausbreitung des Gases 88ff, 99f, 170

- in fremden Ländern $124 \mathrm{ff}$

Ausstellungen $135,156,167,176,183,288,29 \mathrm{r}$, $309,323,397,402,404,459,537,539,543$ Azetylen s. a. Unfälle, Verbrennungslehre I85, 222ff, 444

- Brenner 226

- Entwickler $224 \mathrm{f}$

- Zerfall 224

Bäckerei mit Gas 317, 4II, 55of

Bandarbeit 539

Beale Sauger s. Retorten Absaugung
Becherwerke s. Fördereinrichtungen

Behördliche Eingriffe s. a. Kommunalisierung, Konzessionswesen 125, 245, 319. $419 f, 483$, $555 f$

Beleuchtung mit Gas s. a. Gasglühlicht, Prefggas, Pref̧luftbrenner, Leuchtbrenner, Straßenbeleuchtung, Zündeinrichtungen

$-27,31,35,59,169 f, 182,462 f$

- Anlagen roof, 168

- Einzelerzeuger 43, 45, 48f, 5Iff, 59, 60. $66,71,74,91,94,101,112, \pi 6$

- formschöne Körper 397

- Grofyerzeuger 48, 60, 97

- Theater 63, 91, 179, 317

- Verträge 107, 108, 119, 149

Benzol 142, 220f, 237, 32I, 446, 449, 534

- Entdeckung 88

- Gewinnung 446, 52Iff

Betricbsaufsicht s. a, Chemische Betriebskontrolle $332 \mathrm{f}$

- kaufmännische $\$ 23$

Bergius-Hydrierung 444, 447

Berufsgenossenschaft 320

Blaugas s. Flüssiggas

Bogheadkohlen II5, 117, 149, 166, 203, 206. 227

Braunkohlengas s. a, Schwelung 112,227 , 435, 499ff, 506f, 564

Brenneigenschaften des Gases s, a. Zündgrenzen $357,390,449 \mathrm{ff}, 524 \mathrm{ff}, 560,589$

- Wobbezahl $524 \mathrm{f}$

Brenner s. Leucht-, Bunsen-, Pref̧luft-, Pref̧gasbrenner

Brouwerrinne s. Koksbeseitigung

Bunsenbrenner s. a. Entleuchtung 153f, 593

Buntebürette 188,290

Burkheiserverfahren s. Schwefelreinigung 376

\section{SLUB}


Cannelkohlen 129, 148, 149, 203, 206, 216. 276

Chameroy-Rohre 150, 253

Chemische Betriebskontrolle 247, 320f, 381

Clausverfahren s. a. Schwefelwasserstoffreinigung, nasse 247

Dampfkessel mit Gas 300f, 153, 410, $54^{8}$

Dampfstrahlgebläse s. a. Retortenabsaugung 201

Doppelgas s. a. Schwelung $360,435,438 f$, $440 \mathrm{ff}, 510,574$

Dowsongas s. a. Wassergas $214 \mathrm{f}$

Druckautomat s, Warmwasserbereitung

Druckerhöhung $386 \mathrm{f}, 45 \mathrm{I}, 453 \mathrm{f}, 582$

- minderung 419

- regler s. Gasdruckregler

- vergasung 5. a. Sauerstoff 443, 501, 5H, 560,576

Eisenbahn Kohlentarif 124, 161, 227, 486

- Kokstarif $333 \mathrm{f}$

- Wagenbeleuchtung s. a. Ölgas $169 \mathrm{f}$, 286ff, 395

Elektrische Beheizung von Gaswerksöfen 435, 443

- Teerabscheidung s. Teer Abscheidung

- Zentralen mit Gasmotor 181, 314f, 360

Elektrizität im Gaswerk 342, 355

Wettbewerb $176 \mathrm{ff}, 180 \mathrm{ff}, 338,340 \mathrm{f}, 432 \mathrm{f}$, 535

Elektroentgasung als Energiespeicher 443

Energiewirtschaftsgesetz $42 \mathrm{I}$

Entgasung $95 \mathrm{ff}$

- erste Versuche 20, 2Iff, $37 \mathrm{ff}$

- Temperatur 95

- Rohstoffe, auf̧ergewöhnliche s. dort

- Vorgang 128f, 345f, 436

- zweiteilige 348,358

Entleuchtung des Gases 95, 153

Erdgas 18, 230, 256, 365f, 444, 561, $583 \mathrm{ff}$, 598 s. a. Sumpfgas, Grubengas

- Verflüssigung 585

Erdöl 161, 173f

Explosionen $71,84,457 f, 527 f$

Fachzeitschriften 164f, 40I, 564, 604ff

Fahrzeuggeneratoren 512

Feldverfahren 375,587

Ferngas $88 \mathrm{f}, 150,227,256,257,367 \mathrm{ff}, 426 \mathrm{f}$. $454 \mathrm{ff}, 474,478,488 \mathrm{ff}, 506,548,560,590$
Flammensicherung $75,76,317,452$

Flaschengas für permanentes Gas 88, 444. SI $4 \mathrm{ff}$

Fleischerei mit Gas 551

Flügelradgaszähler s. Gaszähler mit Schraubenrad

Flüssiggas $364 \mathrm{f}, 444,513$

Fördereinrichtungen im Gaswerk $197 \mathrm{ff}$, $353 \mathrm{ff}, 378 \mathrm{f}$

Gasabsatz 181f, 183, 415f, 419f, $477 f, 479$. 599, 606ff

- Kontingentierung der Abnehmer 419 . 420,423

Gasanalysen s. Analyse des Gases, Zusammensetzung

Gasanzünder für feste Brennstoffe 561

Gasbahn 313

Gasbehälter $46,53,73,84,257 \mathrm{ff}, \quad 383 \mathrm{ff}, 457 \mathrm{t}$ $526 \mathrm{ff}$

- Anstrich 83, 261, 458, $529 f$

- aus Gufjeisen 68

- Glockenführung und Statische Berechnung $84,145,259,260,26 \mathrm{r}, 383$

- Heizung 458, 467

- Hochdruck 259/60, $528 \mathrm{f}, 591$

- im Rohrnetz 150, 257, 261, 528, 592

- mit Gegengewichten 72, 84, 85, 145

- Schraubgeführter 383, 591

- Schweif3ung 458, 529

- Teleskopierung 85, 145,258

- trockene $46,457,527$

- umbaute 84f, 106, 145, 257, 259

- Vorschriften 84,260

- Zerknall 457, 527f, 591

Gasbeleuchtung s. Beleuchtung mit Gas

Gasbeschaffenheit Richtlinien 444, 45 of, 560

Gasbrenneigenschaften s. Brenneigenschaften des Gases

Gasdruckregler 73, 84, 151, 171, 200f, 287 , $293,388,452,590$

- für Leuchtbrenner 275

Gasentgiftung s. Kohlenmonoxydentfernung

Gaserzeugung gemeinsam mit Elektrizität s. Gaswerke Kupplung mit Elektrizitätswerken

Gasfortbildungskurse 322

Gasgemeinschalt $402,538,54 \circ$

Gasgesellschaftsgründung 6If, 64, $105,113 \mathrm{f}$, $118,122,123,173$ 
Gasglühlicht $282 \mathrm{ff}$

- Auerbrenner 182ff, 284

- Glühkörperverbesserung $\quad 284, \quad 286, \quad 392$. $395 \mathrm{f}$

- Hängelicht $390,393 \mathrm{ff}$

- mit Wassergas 283

- Prefggasleuchten 285, 286, 287, 392

Gasheizwert s. Heizwert des Gases

Gaskühlung s. Kühlung des Gases

Gasmangelsicherung 318

Gasmengenregler 275, 466

Gasmesser s. Gaszähler, Schwimmermesser, Strömungsmesser

Gasmotor 91, 182, 183, 307ff, 469

- erstes Patent 27

- Grofggasmaschinen 120, 329, $413 \mathrm{f}$

- in elektrischen Zentralen $180,181,314 f$

- Lenoir 161, 307

- Otto 16r, 179, 307ff

- Sonderpreise 312

Gasmuscum 402, 460

Gaspreise 5, a. Gasmotor, Gastarife no, 117, 125f, 175f, 292, 312, 399ff, 419, 422, 46 If, 54 If

- Verkauf nach Kalorien 450, 542

Gasreinigung s. Schwefelreinigung, Ammoniakgewinnung, Teer

Gasschlauch 404

Gassparer s. Sparbrennerschwindel

Gasspeicherung s. a. Gasbehälter

- Untergrund 591

Gasspürer 319, 453, 53I

Gasstecker 404, 593

Gastarife s. a. Gaspreise 401, 619, 54If

Gastrennung durch Fliehkraft $369 f$

Gasverkauf nach Heizwert s. a. Kilowärme 450,542

Gasverteilung s. Verteilung des Gases, Rohrnetz, Tragbares Gas

Gasverwendung s. a. Bäckerei, Kochen mit Gas, Luftschiffahrt, Raumheizung, Warmwasserbereitung

- erste Versuche 26,27

- erste Vorschläge 27, 28

- gewerbliche s. a. Bäckerei, Fleischerei. Wäscherei $89,315,409 \mathrm{ff}, 468,549 \mathrm{ff}$

- Industrie $409 \mathrm{ff}, 468,549 \mathrm{f}, 595 \mathrm{ff}$

- Eisen-und Stahlindustrie 316, 55Iff, 597

- - Gasmotoren s. dort

- - Glasindustrie 6oI
- - Keramische Industrie 554, 60If

- Metallindustrie 316, 602f

- - Regler 4I2, 550, 554

- - Schmiedeindustrie $598 \mathrm{f}$

- - Strahlungstrocknung s. dort

- - Umwälzungsöfen 551

Gaswaage 290, 382

Gaswasser Aufarbeitung 5. a. Ammoniak $68,83,423 \mathrm{f}$

- Düngung 423

Gaswerke Geräteverkauf 540

- Kupplung mit Elektrizitätswerken 380 . 425, 447f, 509, 536, 573

Gaswerksbauten 104ff, 164, 170ff, 332, 622f, $6{ }_{32} \mathrm{ff}$

- Berlin 108, 110

- Bremen ribff

- Dresden IIoff

- Frankfurt a. Main $112 \mathrm{ff}$

- Hannover 106

- Köln irsf

- Schwierigkeiten 245, 319

- Voranschlag v. 1825 62I

Gaswerksöfen s. a. Kammeröfen Retorten, Rekuperation und Regeneration, 8of, 98 . $132,185 \mathrm{ff}, 433 \mathrm{ff}$

- Garantie-und Abnahmebedingungen 436 . 444

Schieber $80,133,171,197$

- Silikasteine 436

- Unterer Abzug 80, 98f, 132, 185

Gaszähler s. a, Teilstromzähler $74,75,77$. 101, 106, 151, 167, 262ff, $388 \mathrm{ff}$.

- Drehkolben 533

- Eichung 262f, 389, 534, 535

- Einrohranschluf 590

- Gewindenormen 385, 389, 458

- Hochleistung 459, 533

- Membran 264, $388 \mathrm{f}$

- mit Belastungsschreiber 151, 590

- mit Doppelzählwerk 265

- mit Münzwerk 265f, 389, 399, 459, 534

- nasser Taumel- 533

- Schraubenrad 389, 590

- springendes Zählwerk 267, 389

- trockene 74, 75, 152, 263f, 534

- Ventilsteuerung 534

Gebläseförderung des Gases mit Dampfturbinen 356

Gemischtwirtschaftliche Unternehmen 112 . 173, 338, 429,479 
Generatorgasfeuerung s. a. Zentralgeneratoren $57,186 \mathrm{ff}, 342,534$

Goffinverfahren s. a. Retorten 433, 504

Grofjküche 156, 291, 404, 466, 544, 550

Grubengas 20, 2I, 22, $583 \mathrm{ff}$

Gruppengasversorgung s. a. Ferngas 386f, 425,45 of, 454 f, $490 \mathrm{off}$

Hängebahnen s. Fördereinrichtungen

Hängelicht s. Gasglühlicht

Harzgas 87, 114,129

Hausanschlüsse 99,254

Hausdruckregler 73, 396, 532

Heizwert des Gases 77, 153, 163, 195, 288. $39 \circ, 419,449 \mathrm{ff}, 456,524,526,563$

- des Kokses 68, 252, 379

Holzentgasung 39, 41ff, 58, $115,122 \mathrm{ff}, 130$, I46f, 165, 227, 229, 422, 444, 564

Horizontalretorten s. Retorten liegende

Hydrierung 444, 447, 560

Innenleitungen 99, 590, 619

Internationale Zusammenarbeit 325,485 , 565

- Gaskongref3 183, 200, 323

Kalklicht $\mathbf{2 8 2}$

Kalkmilch s. Schwefelreinigung

- Entfernung 69, 8I, 150

Kalkzusatz zur Kohle 8I, 24I, 249

Kalorimeter $\mathrm{I31}, 288$, 382, 4 If

Kalziumkarbid 189, 222

Kammeröfen 138, 184, 499, sorff

- Absaugeregler 436, 501, 502

- Horizontale 352, 435

- Innenabsaugung 505

- Klein- 504

- Schräge- 351f, 433, 435

- Starkgasbeheizung s. a, Unterfeuerung Verbund 502

- Vertikale 433f, 502

Kapitalsgesellschaftsform für Gaswerke s. a. Gemischtwirtschaftliche Unternehmen $62,66 \mathrm{f}, 100 \mathrm{f}, 114,118,125 \mathrm{f}, 150,173,431$. 480

Karburierung 95, 148f, 183, 202ff, 217, 219, $220,229,364,390,442 f, 570$

- Anlagen 206, 208ff

- Auto-358ff

Katalysator $242,363,571$

Kilowärme 542
Kirchenheizungen 159, 406

Kissengas s. Gasspeicherung Untergrund 591

Kochen mit Gas s. a. Grofjküche 69,88 , $152,153,156 \mathrm{ff}, 175,178,290 \mathrm{ff}, 403 \mathrm{f}, 464 \mathrm{ff}$. $543 \mathrm{f}, 593$

- Doppel (spar) brenner 292, 294, 403. 404

- Einbaubrenner $403 \mathrm{f}$

- Geschlossene Kochplatte 403

- Rippenplatte 293, 544

- Temperaturregler für Bratöfen 543

- Wäsche 544

Kocherprüfung 404

Kohlen amerikanische in Deutschland 422, $568 \mathrm{f}$

Kohlendioxydentfernung 130,143

Kohlen Kalkzusatz 81, 24I, 249

- Kokspreisverhältnis $177, \quad 332, \quad 362,390$. $418,421,520,569$

- Mahlen und Mischen 203, 249, 448f, 502 560

- Mangel 175, 228f, 252, 418, 420f, $567 \mathrm{ff}$

Kohlenmonoxydentfernung $\quad 217, \quad 242, \quad 318$ 363. $511,519 f f, 588$

Kohlen Ölzusatz 205f, $577 \mathrm{f}$

- Preise 78, 79, 419

- Selbstentzündung 229

- Sorten s. a. Boghead- und Cannelk. 129, 229, 421,426

- Staubvergasung 443, 575

- Untersuchung 165, 166, 225, $3^{82}$

- Vergasung s. Vergasung

- Wirtschaftsgesetz 421

Kokereigas s. a. Ferngas $366 \mathrm{ff}$

Kokereiöfen im Gaswerk s. a. Kammerōfen $138 / 39,184,185,566$

Koksabsatz 78, $117,148,149 \mathrm{f}, 175,249 \mathrm{ff}, 377$. 447, $475 \mathrm{f}$

- Aufbereitung am Ofen und Löschen 8r. 193, 195, 355, 378, 433, $44^{8}$

- Briketts 380, 447

- Dampfkesselfeuerung $44^{8}$

- Eigenschaften 250

- erste Erwähnung 22, $4^{8}$

- Grusfeuerung 252f, 379f, $44^{8}$

- Heizwert s. Heizwert des Kokses 68 252

- trockene Kühlung 436, $447^{f}$

- Zimmeröfen 250, 25 If, $44^{8}$

- Preisausschreiben 250, 252 
Kolbenexhaustor s. Retortenabsaugung

Kommunalisierung s. a. Streitigkeiten mit Behörden und Abnehmern 105. 112, 176. $337,479,4^{8 \mathrm{r}}$

Konkurse 172

Konzessionswesen 319

Kraftwagenbetrieb mit Stadt- und Klärgas s. Treibgas für Fahrzeuge

Kreiselgebläse s. Retorten Absaugung

Kriegsfolgen $417 \mathrm{ff}$

Kronleuchter 168, 178, 397

Kühlung des Gases s. a. Röhrenkühler 59. $71,97,99,369,519$

- Tiefkühlung 255

Laboratorium Vorentwicklung $17 \mathrm{ff}$

Lademaschinen s. Retorten

Lamingsche Masse 5 , Schwefelreinigung

Leichtsteine 468,549

Leuchtbrenner $4 \mathrm{I}, 48,73,85 \mathrm{f}, 152,274 \mathrm{ff}$, 614

- Azetylen 226

- Bandsept, Gasomultiplex s. a. Prefggas 279

- mit Luftvorwärmung $276 \mathrm{f}$

- mit Schornstein 286, 392, 393f

- Speckstein 288

- Wenham 277

- Zündeinrichtungen $279 \mathrm{f}$

Leuchtkraft des Gases s. a. Zusätze zur Verbesserung u. Mischgas 76, 77, 79, 83. $91,106,125,128 f, 132,134,147,166,170$, $174,182,184,195,204,206,269 f$

- Beanstandungen 147

- und Analyse 128, $269 f$

- und Dichteverhältnis 129

Lichtmef̧gröfen 274

- Kommission s. a. Photometer 167, 272 Luftgas s. a, Karburierung 202f, 364 Luftreinheit 50, 61, 214, 302, 378, 409, 613 Luftschiffahrt $28 \mathrm{ff}, 414 \mathrm{f}$

Mannesmannrohre $254,385,531$

Mengenumwerter für Drehkolbenzähler 533

Mischgas aus Steinkohlengas und Olgas $87,117,149$

- mit Wassergas $183,419,449 \mathrm{ff}$

Monazitsand 396

Münzgaszähler s. Gaszähler mit Münzwerk
Nachkriegsnotmafynahmen ab 191942 Iff

Nachwuchsförderung $320,322,402$

Naphthalin $147,203,232 \mathrm{f}, 531$

Nitrierhärtung 316

Normung s. Vorschriften, Vercinheitlichung

- Gaszähleranschlüsse 385, 458, 534

Oberflächenhärtung 316, 553

Oberflächenverbrennung $153,410,469,54^{8}$, 594

Olbeleuchtung als Vorgänger 90, 107, 115. 116

Ölgas 86, 106, 112, 115, 129, 145, 204f, 221. $286 f$

- aus Mineralölen und deren Produkten $577^{\mathrm{ff}}$

Olzusatz zur Kohle 205f, $577 \mathrm{f}$

Olspaltung 87, 357

Ofenatmosphäre $316,4 \mathrm{II}, 553 \mathrm{f}$

Ofenbau s. Gaswerksöfen

Organisation der Werke s. a. Kommunalisierung roof, $338,479 \mathrm{ff}$

- des Faches $427 \mathrm{ff}, 479 \mathrm{ff}, 604$

Orsatapparat 290

Ottzahl $\$ 25$

Paraffin 205

- Entdeckung im Teer $14^{2}$

Petroleum s. Erdöl

Phlogiston 25, 32, 47f

Photogen 173

Photometrie $59,68,79,130,168,270 \mathrm{ff}$

- Amylazetatkerze 273

- Vereinskerze 273

Portativgas s. tragbares Gas

Prefggas s. a. Oberflächenverbrennung 183. $463,466,551$

Preß̧luftbrenner 183,551

Prüfbrenner s. a. Ottzahl \$2s

Prüfzeichen 465,557

Pyrometer 289,383

Raffineriegas $565,580 \mathrm{ff}$

Rauchplage s. Luftreinheit, Reine-Luftbewegung

Raumheizung mit Gas s. a. Kirchenheizung 4 I, $69,88,153,158 f, 160,301,406 \mathrm{ff}, 466 \mathrm{ff}$, 594

- Abgasabführung durch die Wand 404. 594

- Abgasabsaugung 408, 457

\section{SLUB}


- Abzugslose Ofen 159, 299f, 302

- Gebläseluftheizung 548, 594

- Konvektionsöfen 303f, 305, 406, 407, 467. 546

- Preisausschreiben 306

- Reflektoröfen 302f, 305

- Raumtemperaturregler 306f, 452, 468

- Schulheizung 305

- Strahlheizer (Schwank) 548, 594

- Strahlheizofen 407, 467

- Uberdruckverbrennungskammer 408

- Untersuchung von Öfen 306, 407, 408

- Zentralheizung 409, 466f, $547 \mathrm{f}$, 595

Raumheizung mit Koks. s. Koks Zimmeröfen

Regler s. a. Raumheizung, Gasdruckregler, $262,412,550$

Reine-Luft-Bewegung s. Luftreinheit 48,61 , 214, 302, 378

Reinigung des Gases, Durchleiten durch Wasser 22, 30, 33, 4I

- durch Kalkmilch s. Schwefelreinigung, Schwefelwasserstoffreinigung

Rekuperation u. Regeneration $186 \mathrm{ff}, 342$

Retorten 73f, 79, 416

- Absaugung 134, 143f, $200 \mathrm{ff}$

- Bedienung (Lademaschinen) 137, 193, 194. 198, 345f, sos

- Deckel nach Morton 196

- Druck in Retorten 82, 232

Gleichmäfjige Beheizung 79f, 138, 191

- Keramische R. 81, 134ff, 195

- Kontinuierliche 73, 134, 137, $348 \mathrm{ff}$

- Liegende 42, 52, 8I, 133f, 185, 433, 434, 436

- Mechanisch gezogene 196

- Querschnitte 52, 79, 80

- Schrägliegende R, $\{2,183,184,191 f, 342$, 346,433

- Senkrechte $\{2,138,345 \mathrm{ff}, 433,434,437$

- Vereinheitlichung 195

Röhrenkühler 99, 140, 234, 369

Rohre 384

- Baustoffe 99, 150, 253, 254, 530

- - Beton 453

- - Blech geschweifyt 150, 253

- - Guf3 liegend gegossen 73, 99, 112. 150, 253,385

- - - geschleudert gegossen 530

_ _ - stehend gegossen 253

- Holz iso

- - Pappe 253, 453
- Stahl nahtlos gezogen 254, 385

- Chameroy 150, 253

- Dichtungen 114, 254, 256, 385, 386

- - Gummi 254, 385, 453

- Muffen 150, 254, 53 If

- Durchmesserberechnung 97f, 151, 387. 531

- Hausanschlüsse 254

- Verschweifyung 385. 453. 530

- Wandstärke 99, 253

Rohrnetz 114, 530f, 618

- Berechnung isif, s89f

- Betricb 530

- Blitzableiteranschlufy 255

- Düker 256, 455

- Druckerhöhung i. R. 261, 386, 451, 453f. 483,532

- Einfrierungen 107, 255

- Gefährdungen im Boden 25s

- Kathodischer Schutz 388, 531

- Korrosionen 255, 388, 531, 590

- Tetralineinspritzung 531

- Uberlagertes Mitteldrucknetz 256, 387

Rückstromsicherung s, a. Abgasabführung 277, $301,404,545$

Rootsgebläse s. a. Retorten Absaugung. Drehkolbengaszähler 533

Rohstoffe Auf̧ergewöhnliche (auß̧er Kohten. Holz, OI) 114, 117, 148, 227, 363, 444. $570 / 71$.

Ruhrkrieg 424

Sacharin 237

Salmiak 242, 243

Salpeterkrieg 243

Sauerstoff, Träger unwägbaren Wärmestoffes $47,69,128 \mathrm{f}$

- Verbrennungshilfe 281f, 396

- Vergasungsmittel 219, 443, 511f

Sauger s. Retorten Absaugung

Schieferentgasung $\mathbf{4 2 2}^{22}$

Schlackengenerator 575

Schlackenscheider und Schlackensteine 449

Schnellwasserheizer 293, 295, 298

Schornstein s. a. Abgasabführung 251, 546f

- am Gaswerksofen 133, 197

- Windeinflüsse 251, 547

Schrägretorten $s$. Retorten

Schutzgas s. Ofenatmosphäre 362

Schwefelreinigung s. a. Schwefelwasserstoffreinigung, Turmreiniger $77.8 \mathrm{Iff}, 245 \mathrm{ff}$. $375 \mathrm{ff}, 587 \mathrm{f}$ 
- Kalkmilch 46, 61, 71, 81ff, 99, 142

- Lamingsche Masse 143, 245

- Trockner Kalk 82

- Umschaltung, Tauchglocke $72,77,83,518$

Schwefelwasserstoffreinigung, Aufarbeitung der Masse 247,248

- Eisenfeilicht 143

- Eisenoxyde 99, 143, 517

- Nasse 143, 246f, $517 \mathrm{f}$

- Raseneisenerz, Reinigungsmasse 245, 247. 375

- Regeneration 248, 375, 518

Schwelung s. a. Doppelgas 173, 212, 215, 229. $358,437 f, 478,499 f, 505 f, 507 \mathrm{ff}, 560,564$. 574

- für Elektrizitätserke 437f, 439, 500, 506, $507,509,510$

- für Motore 219

- im Drehrohrofen 438, 439. 500

- von Olkreide und Torf sio

Schwenkbrenner 152

Schwimmermesser $267,45^{8}$

Selbständigkeit der Werkleitung 174, 175, $176,429,479 \mathrm{ff}$

Skrubber s. a. Teer Abscheidung, Ammoniak Gewinnung 14of, 238, 246

Solaröl 173

Soziale Fragen 101, 320, 342, 423, 476

Sozialer Wohnungsbau $56 \mathrm{I}$

Sozialisierung $421,426,455,489$

Sparbrennerschwindel 399, 462f, 464,544 Speckstein-Brenner 288

Speicherung des Gases s. a. Gasbehälter. Untergrund 529, 585, 591f, 594, 597

Spitzendeckung 221, 357, 435, 577, 579, 594

Stahlflaschen nahtlose 257, 516

Staubvergasung 443, 449, 56r, 575

Stehende Retorten s. Retorten senkrechte

Steigrohre am Ofen 81 189, 230, 232

Steinkohlengas s. Entgasung. Doppelgas

Stickoxyde 519

Stillegung v. Werken 42I, 422

Stofmaschine s. Retorten Bedienung

Strahlenschutz am Kokszimmerofen 251

Strahlrohrofen 553

Strahlungstrocknung mit Gas 564, 600, 603 Strafjenbeleuchtung $59,6 \mathrm{r}, 63,72,463,543$, 592

- Uberspannungen 397

Streiks 197, 216, 334, 370, 421, 422, 423, 424. 425,475
Streitigkeiten mit Behörden u. Abnehmern $107,109,116,125,149,167,170,172$

Streuströme s. Rohrnetz Korrosionen

Strömungsmesser $267 \mathrm{f}, 389 \mathrm{f}, 458,533$

Sumpfgas s. a. Grubengas, Erste Beobachtung 2 of

Syntheserestgas 560

Tauchverschluf3 72

Teer Absatz u. Preise 234, 236

- Abscheidung 7if, 83, I4of, 23off, 370, 445

- - elektrische 445

- als Endzweck der Gasung 26f, 43. $437 f$

- Aufarbeitung 68, 170, 234

- Dickteerbildung 189, $230 \mathrm{ff}$

- Erste Erwähnung 22, $25 f$

- Teeröl 142, 371, 445

- Urteer 73, 437f, 445

- Vergasung 147, 204, 236, 443,504

- Verwertung 59, 83, 95, 14If, 170, 236, 237. $358,371,445$

- Dieselmotor 349, 371, 413, 437

- Strafjenbau 236, 370f, $445 \mathrm{f}$

- Vorlage 81, 139, 230f

Teilstromzähler 215, 389, 533

Temperaturregler s, a. Raumheizung - für Bratöfen 54

Tetralineinspritzung s. a. Rohrnetz 531, 534

Theorie 47, 94f, 128, 131, 188, $269 \mathrm{f}$

- erste Versuche 47

Wassergas 211, 213, 218

Theaterbeleuchtung $87,148,179,278 \mathrm{f}$

Thermoelemente 290

Thermolampe $41,44,45,47,50,67,91,205$ Tieftemperaturteer $s$. Teer, Urteer

Torfgas s. a. Rohstoffe aufjergewöhnliche $229,360,422,444,510,562,564$

Tragbares Gas $87,88,114 \mathrm{ff}, 150,627$

Treibgas für Fahrzeuge 443, 469, 478, $514 \mathrm{ff}$. 561

Trigasverfahren - s. a. Schwelung 439,442

Turmreiniger $77,82,518$

Unfälle durch Abgas 30of, 464, 546f

- - Behandlung 318

- mit Azetylen 224f

- mit Gas 72, 88, 179f, 317, 404, 484, 591

- Statistik $317,320,340,464$

- Verhütung 317, 319, 555ff

Untergrundspeicherung s. Speicherung des Gases 
Unterfeuerung mit Kohle 48, 78, 79, 80

- mit Koks s. a. Generatorgasfeuerung 78 . $117,133,134,149,186,188,227,343,345 / 46$. $347,348,351,352,447,568$

- mit Teer I4If, 236

- Verbundöfen 212, 433, 502, 586

Untersuchungsmethoden s. a. Analyse des Gases 83, 589

Untertagevergasung $256,363,443,513,577$

Unterricht s. Nachwuchsförderung

Ursprung des Namens Gas 19

Verbrennungslehre s, a. Phlogiston 47, 69. $94,132,269,390$

Verbrennungswärme s. Heizwert

Vereinheitlichung Geräte 409, 543, 544. 557

- Retorten 195

- Rohre 253, 384/85

Vereinsarbeiten s. a. Vereinheitlichung. Vorschriften $482,4^{84}, 4^{86 f}$

Vereinsgründungen $101,161,165,167,322$, $335,485,604,639 f$

Vergasung s. a. Doppelgas, Generator, Staubverg,, Druckverg. 204ff, 257, 360f, 440,499 , 5roff, $566,573 \mathrm{ff}$

Verteilung des Gases - In Netzen s. a. Rohrnetz, Ferngas

- beschränkte Entfernungen 67,78

- Erste Forderung durch Winzler 48, 66

- In Behältern s. Tragbares Gas

Vertragungsgrundlagen 107, 108, 122, 125 . $147,165,174$

Verwendung des Gases zum Wärmen s. a.

Gasverwendung gewerbliche 55, 69

Voreingenommenheit gegen Gas 61, 71, 116. 157, 401

Vorentwicklung im Laboratorium $17 \mathrm{ff}$

Vorschriften für den Bau von Hausleitungen $85,99,619$

- und Richtlinien 253, 26I, $335 \mathrm{ff}, 483 \mathrm{f}, 516$, 523, 526, $528,529,530,534,540,557,560$. 594

Wärmetheorie s. a. Phlogiston $47,68 \mathrm{f}, 130$, I3I

Wärmeübergang 140

- im Gasgerät $297 \mathrm{ff}, 545$

Wäscher s. a. Ammoniakgewinnung 238, 369

- Standard 240

Wäscherei 410 , 551

Waggonkipfer s. Fördereinrichtungen
Warmwasserbereitung s. a. Schnellwasserheizer, Gasmengenregler 88, 158, $295 \mathrm{ff}$, $404 \mathrm{ff}, 466,544 \mathrm{ff}, 593$

- Abzugsloser Badeofen 258, 466

- Druckautomat 405, 545

- Durchlauferhitzer 295, 404f, 545

- Kochenwassergerät $544 \mathrm{f}$

- Nachwärmer 295, 546

- Schulbrausebäder 396

- Speichertherme 545

- Wärmewähler $545 f$

- Zapfhahnerhitzer $539 f, 544$

Wassergas $91,148,183,184 \mathrm{f}, 206 \mathrm{ff}, 346,348$. $35 \mathrm{I}, 353,356 \mathrm{ff}, 419,433,435,442,443,449$. $451,500,503 \mathrm{ff}, 511,526,560$

- erste Erwähnung 23, 35

- gesondert als Heizgas 212ff, 443

- Gleichgewicht 219, 362

- Karburierung 148f, 206ff, 351, 357, 502

- zur Beleuchtung 87, 283, 286

Wasserstoff, Bedeutung für das Gas 127 . I28, 132

- reiner aus Wassergas 511

Werbung für Gas 43, 61, 64ff, 10I, 292, 294 $399 \mathrm{ff}, 427,459 \mathrm{f}, 537 \mathrm{ff}, 617$

Wettbewerb s. a. Elektrizität, Azetylen. Erdöl 334, 338, 432, 535f

- mehrerer Werke untereinander 106, 109 $115,120,124 \mathrm{ff}, 147,151,167,174,175$

Wiederaufbau nach dem Kriege $420 \mathrm{ff}, 562 \mathrm{ff}$ Wirftschaftslage $183,331 \mathrm{ff}, 418,428,475 \mathrm{ff}$. $536,559 \mathrm{ff}, 562 \mathrm{ff}$

Wohnungsbau, sozialer 561

Xylol 233

Zapfhahnerhitzer s. Warmwasserbereitung Zementieren mit Gas 316, 554

Zentrale Landesbanken 562

Zentralgeneratoren 187, 193, 352, 353, 435, 439. 501, 502,504

Zündeinrichtungen $397 \mathrm{f}$

- Druckwellen 398

Zündgeschwindigkeit 156

Zündgrenzen 270, I55

Zündsicherung 452, 555

Zusätze zur Verbesserung der Leuchtkraft $147 \mathrm{ff}, 182,203 \mathrm{f}, 229$

Zusammensetzung des Gases 83, 94, $127 f$, 132,525

Zyanwasserstoff $248 \mathrm{f}, 375$ 


\section{03.75}

17 Mai 1377

25. $0 \mathrm{kt}$ ist?

3. D. Jan. 1978

'q 1. April 1979

Datum der Entleihung bitte hler einstempeln I

1 1. Juli 1979

23. April 1982

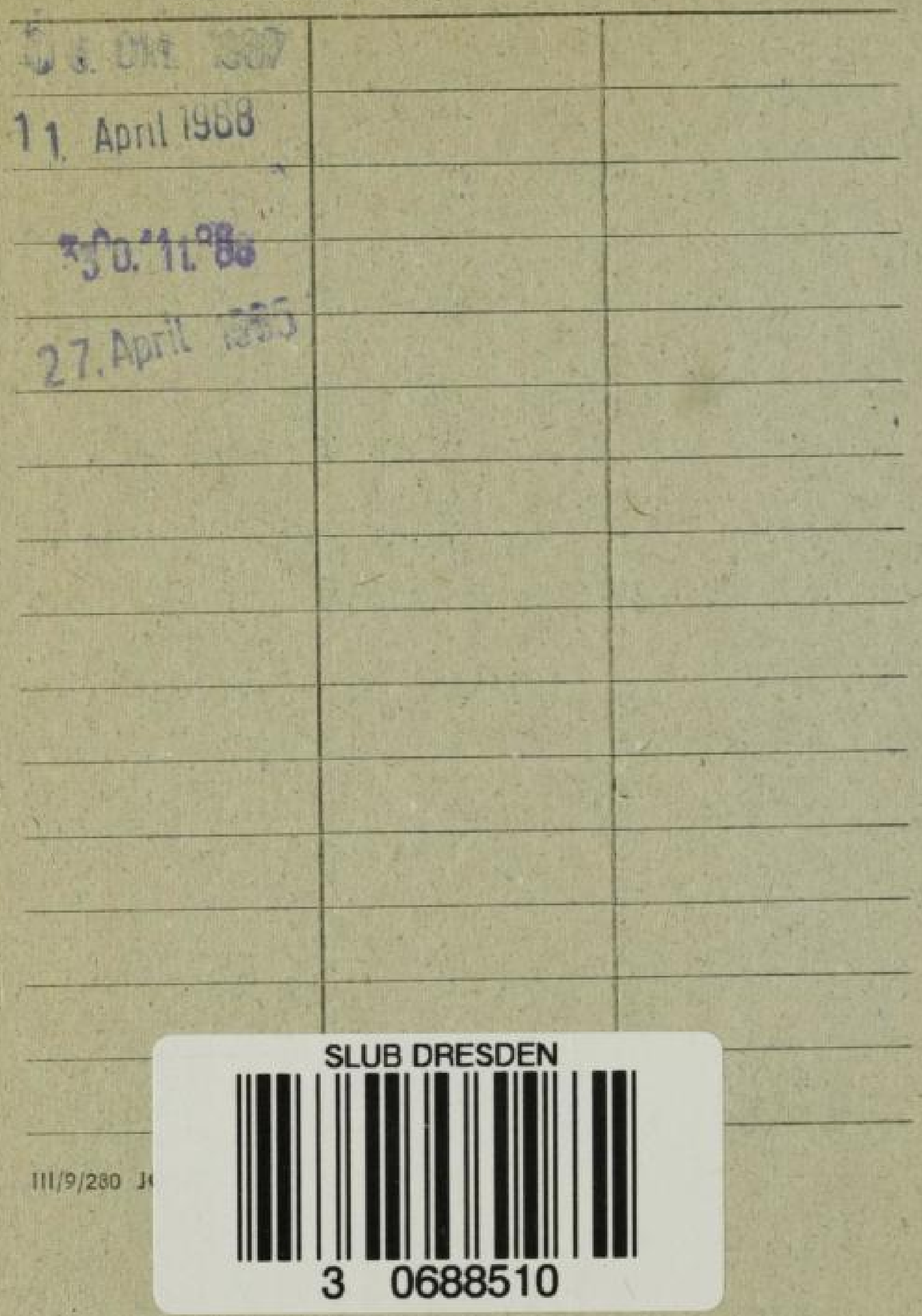

\section{SLUB}

Wir führen Wissen. 


\section{$84-$}

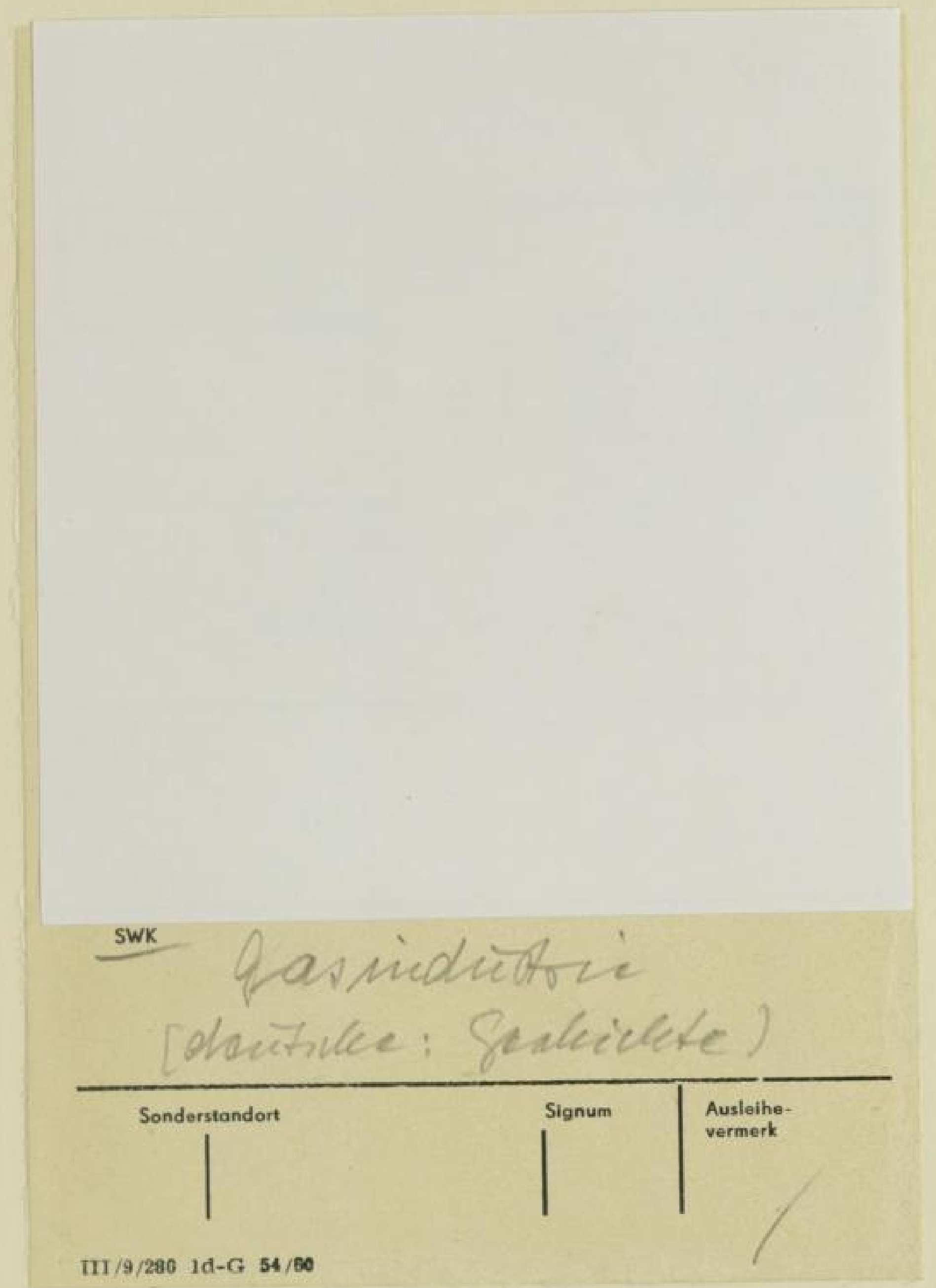

$39.8^{\circ} 2+55$

\section{SLUB}

Wir führen Wissen. 
